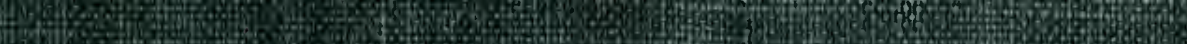

tofor 4 tas 320 20 9.8. s.7.

Wist.

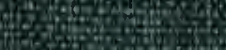
2030

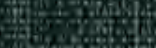

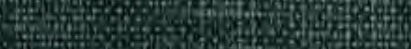
19. to 45. 8 .
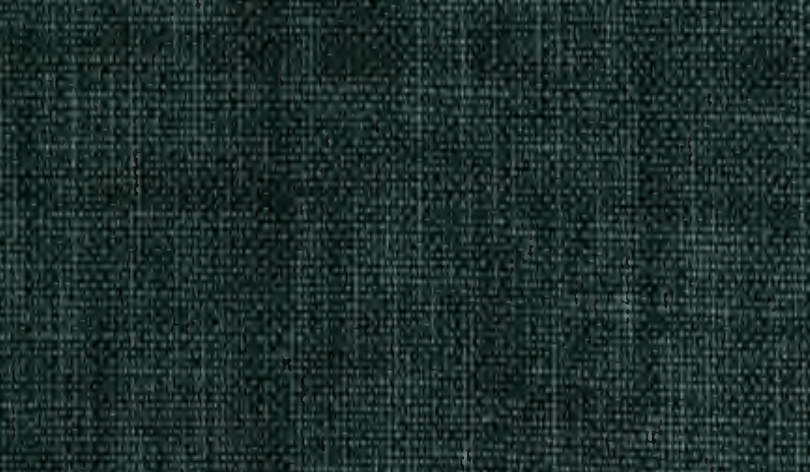

sites
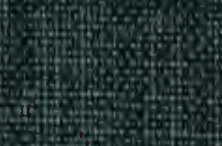

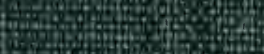

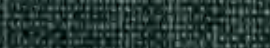
figetion

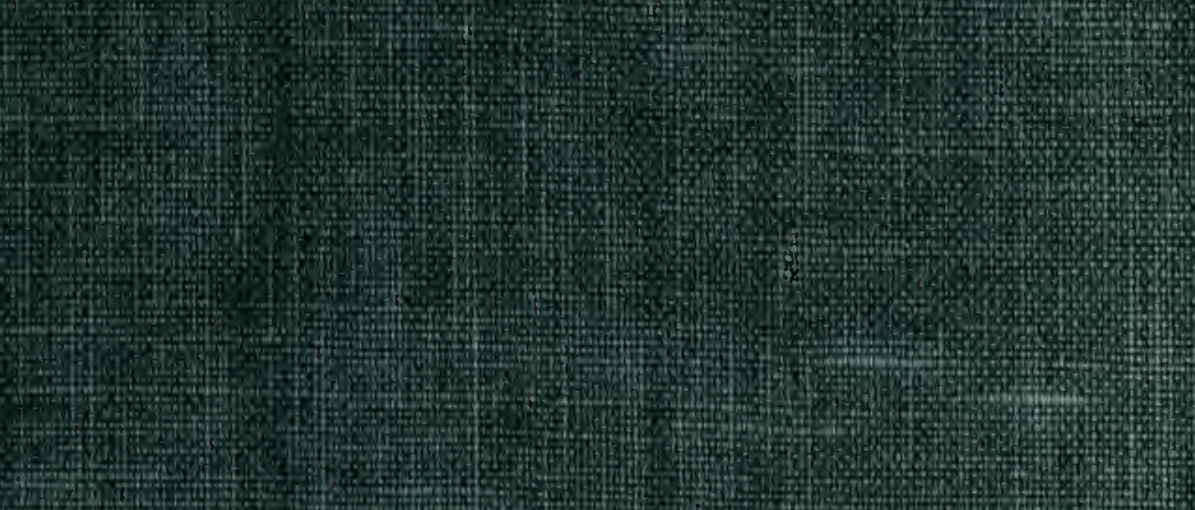

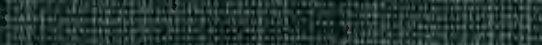

Q H. 7. L"

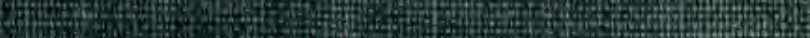
H. to Fin 14.0. 

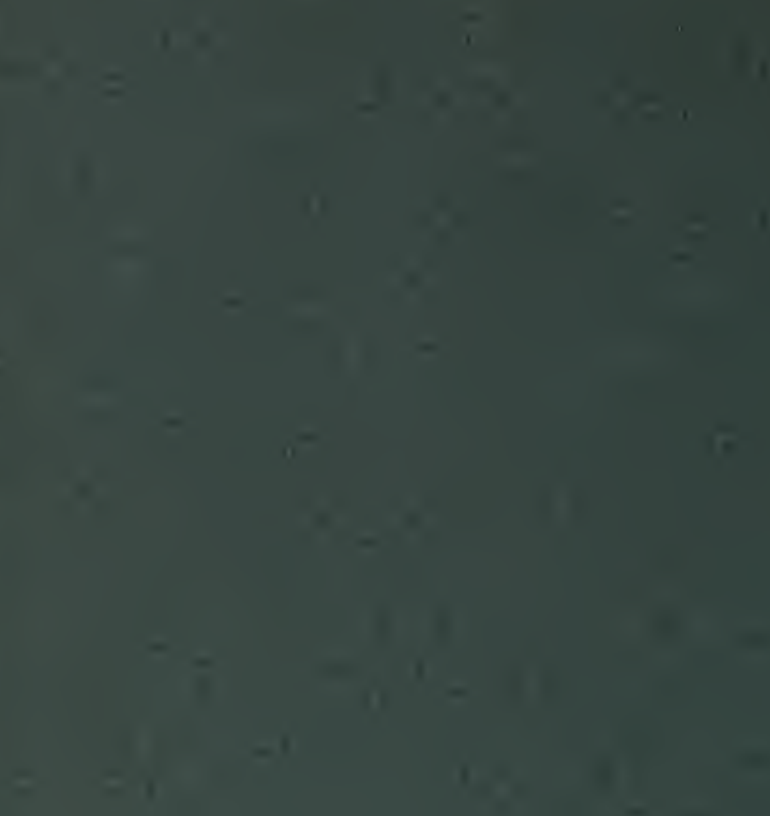

$+2$

E
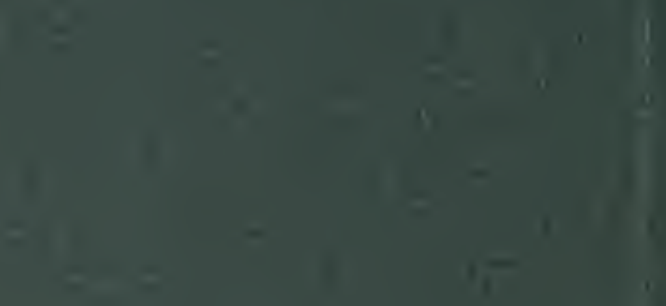

$1-1-1-$
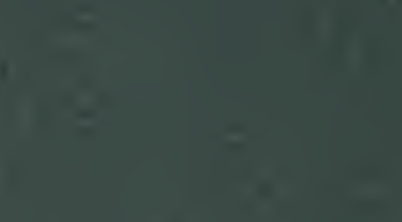


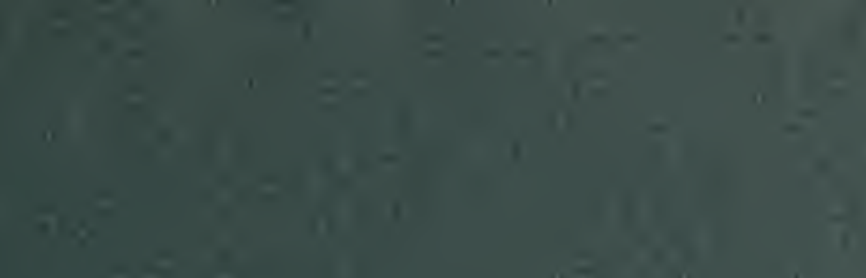

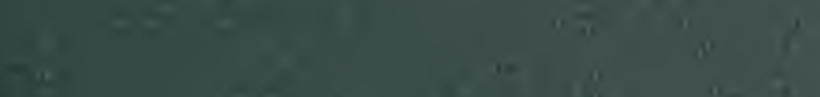

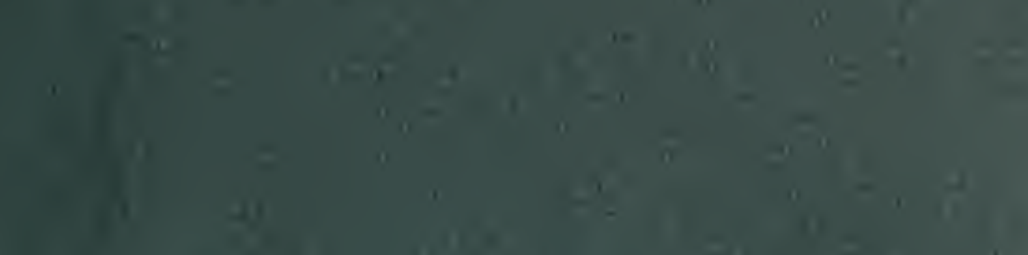

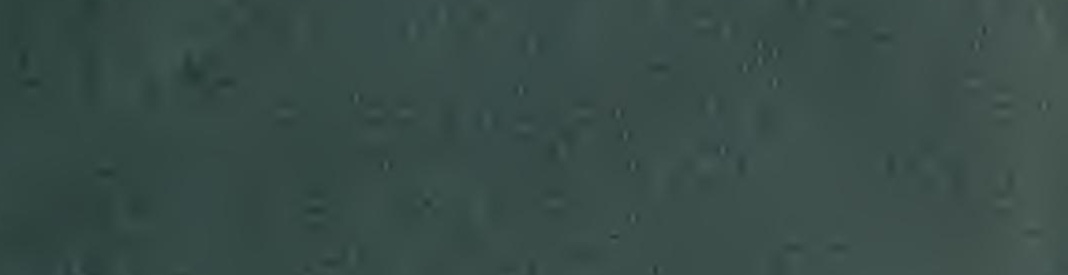

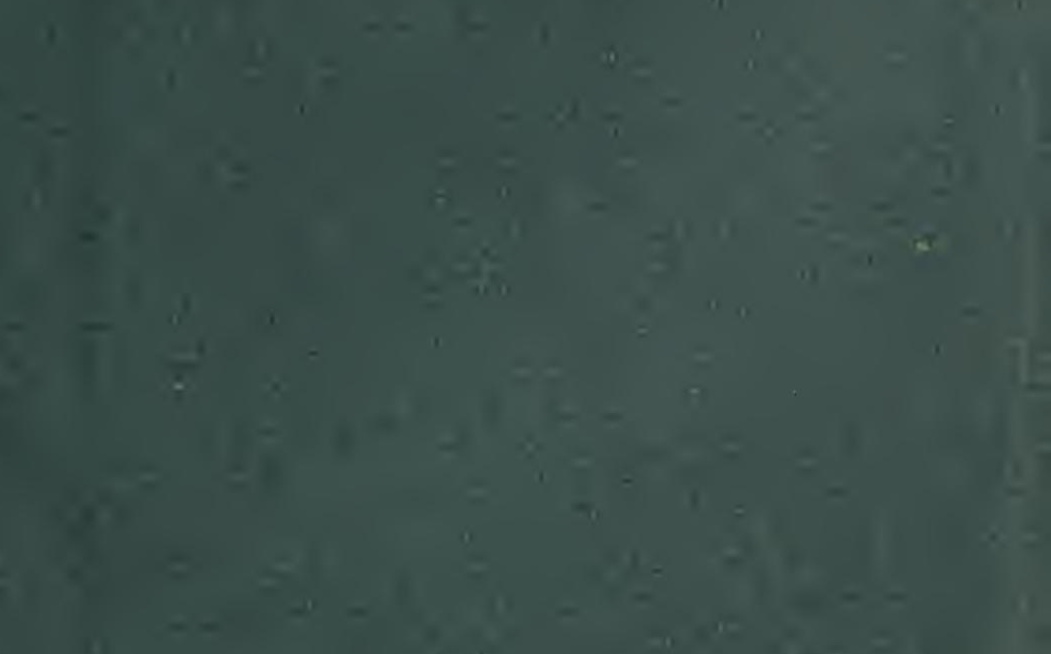




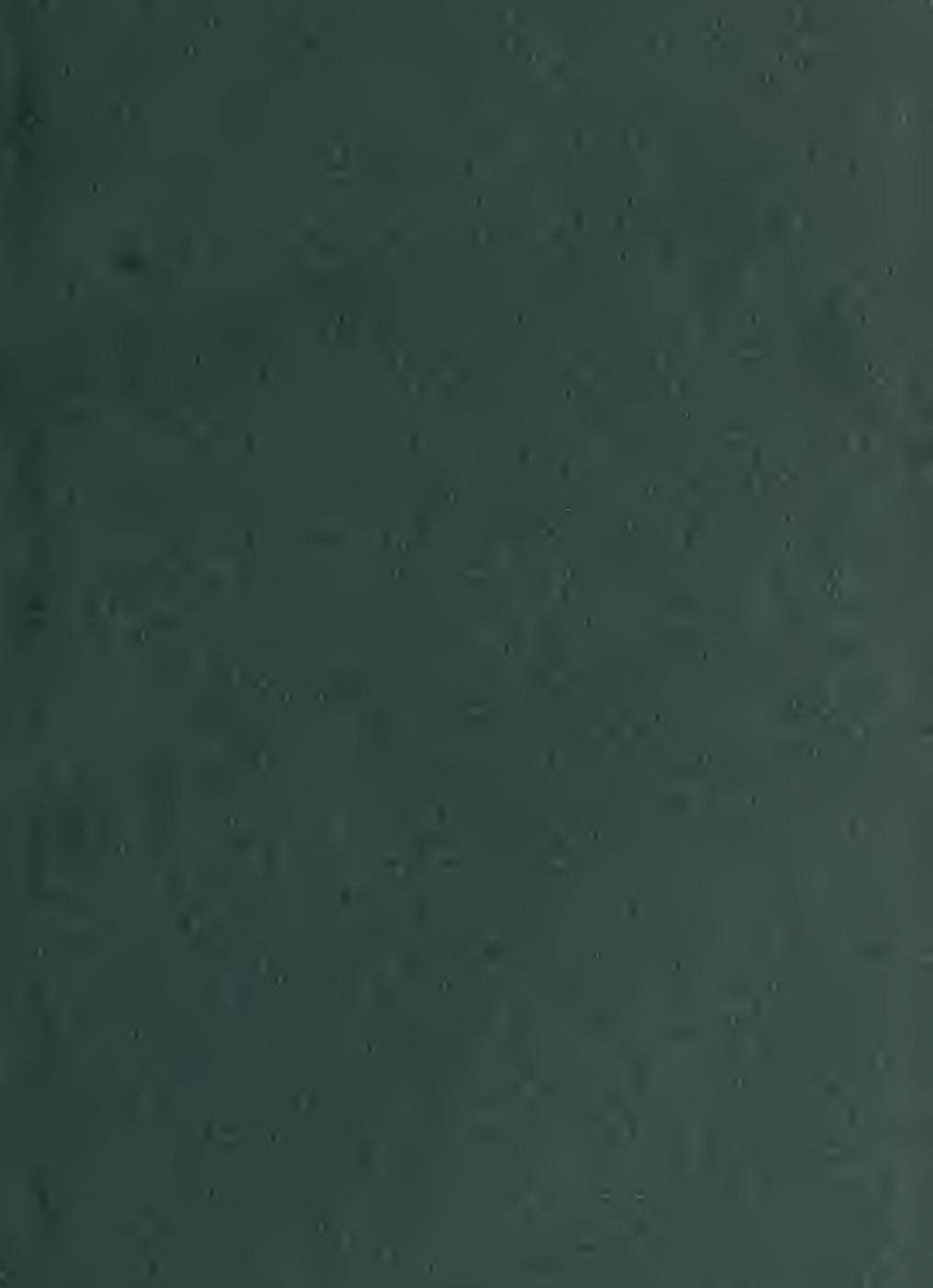


$-$

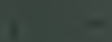

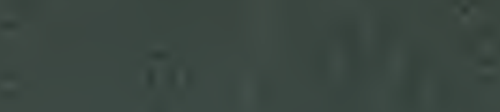

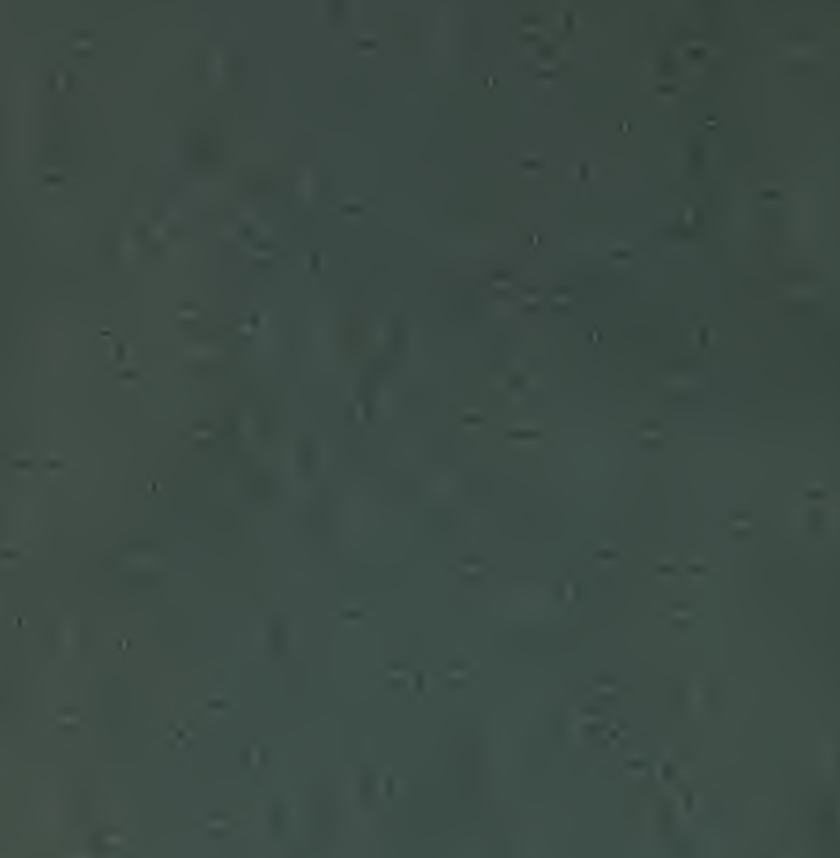

+1 


\section{H A A N D B 0 G}

\section{DEN DANSKE FLORA}

af

Joh. Lange.

LEBRARY

NEW YORK

BOTANTCA:

GakDES.

Tredie forøgede Udgave.

Kjobenhavn.

C. A. Reitzels Forlag.

1864. 


$$
\begin{aligned}
& Q K 287 \\
& i 23 \\
& 1864
\end{aligned}
$$

Bianco I unos Bugtygkeri ved F. S. Buhle. 


\section{RIBRARY \\ NEW YORK \\ Fortale til forste Udgave. Botanical GARUEN.}

I

det jeg herved overleverer mine Landsmænd nærværende Arbeide over den danske Flora, turde det maaskee være nødvendigt at ledsage samme med nogle Bemærkninger, i hvilke jeg skal gjore Rede, deels for de Grunde, som have foranlediget mig til at optræde som Forfatter, deels for Bogens Indretning.

De betydelige Fremskridt, som Botaniken, ogsaa dens beskrivende Deel, i de senere Aar har gjort, havde længe ladet denne Videnskabs Dyrkere her i Landet fole Savnet af en Haandbog, i hvilken man kunde finde hvad der fra ældre Tid var bekjendt om Danmarks Vegetation for gget med det i senere Tid lagttagne, og som altsaa ved paa eet Sted at samle det, der hidtil maatte soges paa mange, til en Tid kunde træde istedetfor de tidligere Arbeider i denne Retning. Efterat jeg i længere Tid med Forkjærlighed havde beskjæftiget mig med at iagttage mit Fædrelands Planter og deres Fordeling, blev jeg fra flere Sider opfordret til at udarbeide en Ilaandbog af den omtalte Beskaffenhed og jeg begyndte altsaa paa dette Arbeide, men jo længere dette rykkede frem, desto mere indsaae jeg de dermed forbundne Vanskeligheder, og hvis ikke Haab om velvillig Overbærelse fra det botaniske Publikums Side og den Tro, at det jeg vilde være istand til at levere, dog I livert Fald vilde kunne gjore nogen Nytte som Materiale, "hvormed der senere kunde bygges videre, havde bestyrket mig $\mathbf{i}$ at vedblive, vilde jeg maaskee ikke have lavt den 
fornodne Taalmodighed for at bringe det tilende, men forlængst have opgivet et Arbeide, som jeg ikke troede at kunne fuldfore paa en for mig selv eller Andre tilfredsstillende Maade. $O g$ de Vanskeligheder af forskjellig Art, som efterhaanden viste sig for mig, vare tilvisse ikke faa. Jeg vil ikke omtale det Vanskelige og næsten Umulige i at vedligeholde den til et mere omfattende Arbeide fornodne Ro under de sidste Aars politiske Bevægelser, (dette Tryk ville Alle, der i dette Tidsrum optraadte som Forfattere, have folt); jeg vil ikke opholde mig ved at udvikle videre, hvad Enhver let indseer, at Botanikens nærværende Standpunkt mere opfordrer til at anvende sin Tid paa physiologiske og morphologiske end paa floristiske Arbeider; men- jeg vil indskrænke mig til, med særligt Hensyn paa det foreliggende Skrift, at fremhæve nogle af de betydeligste Hindringer, som jeg har havt at kjæmpe imod, fordi jeg baaber, at mange Enkeltheder, som jeg selv hoiligen foler kunde og burde have været anderledes, derved maaskee, idetmindste tildeels, turde finde sin Undskyldning.

Skjondt næsten alle de i Bogen indeholdte Planter ere fortud vel kjendte $0 \mathrm{~g}$ for største Delen fortræffeligt beskrevne, ansaae jeg dog en Revision af Arterne i den levende Natur for aldeles nodvendig; thi foruden at der ofte ved Beskrivelserne af selv de bedst kjendte Arter kan være Et eller Andet at tilføie eller forandre, saa antage mange Planter i de forskjellige Lande et forskjelligt Præg, hvilket fordrer at Arterne skildres efter Exemplarer fra det Land selv, hvis Flora man vil beskrive. Jeg har sogt, saavidt muligt, at opfylde deane Fordring, men naar man erindrer, at Beskrivelserne ikke affattes efter Individer, men efter Masser, at det ikke er nok at iagttage Planten paa et enkelt Tidspunkt, men paa dens forskjellige Udviklingstrin, og naar det fremdeles tages i Betragtning, hvor vanskeligt det er at tilbagefore de ofte i det Uendelige varierende Former indenfor bestemte Grændser og at adskille de blot locale eller tilfældige Afændringer fra virkelig typiske Former, saa vil det let indsees, at det ikke er faa 
Aars Arbeide. Jeg har derfor ved enkelte Arters Beskrivelse maattet indskrænke mig til at jevnfore torrede Exemplarer $0 \underline{-}$ de bedre Afbildninger i Fl. Dan. med de allerede forhaanden værende Beskrivelser. Ved Behandlingen af nogle Slrgter, f. Ex. Calamagrostis, Callitriche, Atriplex, Rosa, har jeg isier levende folt det Onske, i længere Tid end der efter Omstandighederne stod mig til Raadiglied, at have knnnet indsamle lagttagelser over deres talrige og yderst foranderlige Former; blandt det lleget, som endnu staaer tilbage at iagttage angaaende de danske Planter, troer jeg fortrinsvis at burde anbefale disse Slægter til nærmere Provelse af Botanikere her i Landet.

Hvad Beskrivelsernes Form angaaer, da blev jeg snart enig med mig selv om at disse burde forfattes i det danske Sprog, navnlig fordi et ikke lidet Antal af Dem, jeg tænkte mig som Bogens Lisere, ikke uden Moie kunne benytte de latinske Beskrivelser; storre Vanskelighed foraarsagede det mig derimod at træffe den rette Middelvei mellem for lange og for korte Beskrivelser. De blotte D) iagnoser, som kun have til Opgave at adskille Arten fra de nærmest beslægtede, give, naar de slaae isolerede, paa Grund af deres Korthed, kun et megel ufuldstændigt Billede af den Plante, de skulle betegne, derimod kunne de aldeles fuldstiendige Beskrivelser af Planten fra nverst til nederst vistnoh være meget lærerige for Begyndere, men ikke at tale om at de optage en betydelig Plads, saa ere de trættende at gjennemlobe for den noget Viderekomne; ogsaa livve de, efter min Mening, kun deres Plads i specielle Monographier eller lıvor det gjælder om at beskrive nye Arter, men ikke hvor den omhandlede Plante allerede utallige Gange iforveien har været Gjenstand for Beskrivelse. Jer har i denne Henseende isier taget tif Monster Ko chs fortræffelige Synopsis; at jeg overalt skulde have været lieldig, tor jeg ikke haabe, men jeg troer, at Enhver, der har givet sig af med at affatte Beskrivelser af Naturgjenstande, vil have erfaret Vanskeligheden ved at affile disse saaledes, at de forene Tydelighed i Udtryk paa 
den ene Side med det passende Jevnmaal (hvor kun det Væsenlige fremhæves og det Tilfældige holdes borte) paa den anden Side. - De danske Benærnelser paa Plantedelenes Former ville i Almindelighed kunne forstaaes ved Hjælp af Drejers Terminologi; de enkelte Afvigelser herfra ere i Regelen forklarede ved Anmærkninger under Texten; at afvige betydelig fra denne Bog, hvortil jeg ofte var fristet, ansaae jeg ikke for rigtigt, saalænge intet nyere Arbeide foreligger, hvortil Forandringerne kunde stotte sig.

Valget af et passende Antal Citater og Synonymer blandt den uendelige llængde heraf, som enhver Art endnu stadigt maa slæbe omkring med sig, er ikke heller altid saa aldeles let; i et Arbeide som det nærværende ansaae jeg det dog for tilstrækkeligt at anfere de vigtigste af vore egne $0 \mathrm{~g}$ de fortrinligste $\mathrm{og}$ meest bekjendte af Nabolandenes floristiske Forfattere: af indenlandske Værker har jeg derfor i Regelen henviist til Hornemanns Plantelære og Drejers flora excursoria, ved enkelte Slægter tillige til Rafns og Schumachers Florer; af udenlandske til et eller andet af Fries's Værker og i Tilfælde af Navne-Ulighed til Kochs Synopsis. Ved enhver Art har jeg anfort hvor den findes afbildet i Flora Danica og i Reichenbachs nøiagtige Afbildninger; kun naar en Plante ikke findes optaget i noget af disse Billedværker, har jeg, for saavidt muligt at nævne en Figur for hver Art, citeret et eller andet let tilgængeligt Værk. Prof. Fries's Herbarium normale har jeg ogsaa stadigt næunt ved de Planter, som ere optagne i denne vigtige Kilde til Kundskab om vore nordiske Planter.

Det er nutildags temmelig almindeligt at lægge et eller andet naturligt System til Grund for Inddelingen af Planterne i floristiske Arbeider; det vil derfor maaskee af Flere blive lagt mig til Last, at jeg har ordnet Stoffet efter linnéiske Klasser. Jeg behover neppe at bemærke, at dette ikke har sin Grund i nogen Forkjærlighed for hiin Inddelingsmaade betragtet $\mathrm{i}$ og for sig, men derimod vil jeg ikke fragaae at være conservativ forsaavidt at jeg anseer 
den kunstige Inddelingsmaade for uden Sammenligning den beqvemmeste som Nogle til at opsoge Slægterne, og derfor troer at Begynderen lettest vil finde sig tilrette ved Hjælp af denne. Mange have vistnok med mig gjort den Erfaring, at Intet mere forstyrrer og afskrækker selv de dygtigste Begyndere ved Planternes Bestemmelse, end Mangel pila faste Regler og Kjendetegn; og hvorvel ogsaa den linnéiske Classification indeholder Undtagelser og Uregelmæssigheder, saa ere disse dog baade langt færre $0 g$ lettere at omgaae end i de naturlige Familier, hvor de forst finde deres Lesning ved at sees i Sammenhæng med det Hele. Men i en Haandbog som nærværende, der for en saa væsenlig Deel er beregnet paa at give Begynderen Midler ihænde til den enkelte Plantearts Bestemmelse, forekommer Lettelsen af det hermed forbundne Arbeide at være et ikke uvigtigt Hensyn; dette vilde jeg dog have sat tilside, hvis jeg lavde troet at derved en mindre videnskabelig Opfattelse kunde befrygtes; men skjondt de fleste Botanikere hidtil have gjort Begyndelse med at bestemme Planterne efter det linnéiske Systems mere schematiske Form, er der vel neppe Mange, som ville paastaae at have taget Skade paa deres senere botaniske Studier ved at være indforte i Videnskaben ad denne Vei. Derimod er der naturligviis ingen T'vivl om, at Enhver, som vil gaae ud over det Elementære, snart maa begynde med Øvelser $\mathrm{i}$ at henfore de bekjendte Planter til deres naturlige Slægtskab, hvortil da kan benyttes et eller andet Værk, som særligt omhandler de naturlige Familier. For at imidlertid ogsiaa de Læsere, som savne Adgang til slige fuldstæendigere systematiske Værker, kunne erholde en forelobig $\emptyset$ velse i at classificere de i vor Floras Omraade forekommende Planter efter naturlige Familier, har jeg anseet det for hensigtsmæssigt, som et Hjælpemiddel hertil at vedfeie ved enhver Slægt dens Plads i Systemet og i Begyndelsen af Bogen at give en kort Oversigt over de vigtigste Kjendetegn for hver Familie som er repræsenteret i vor Flora, med Indordning af de danske Slægter og Angivelser af disses Artsantal. 
Ved enhver Familie har jeg henviist til Mag. Anderss ons "Atlas öfver den Skand. Florans nat. Familjer", et Arbeide, der saavel paa Grund af de nøiagtige Tegninger, som paa Grund af dets Prisbillighed fortjener at være i Manges Hænder.

Hvad Planternes Udbredelse i Landet angaaer, da har jeg anvendt al den Omhu som var mig mulig paa at samle saa mange Data, at deraf kunde udbringes et Resultat til Oplysning om de enkelte Arters Grændser og Fordeling. Jeg skal her nævne de vigtigste Kilder, hvoraf jeg i denne Henseende har ost, for at Læserne lettere kunne sættes istand til at domme, hrorledes jeg har benyttet disse. Hovedværket til Kundskab' om de danske Planter er naturligviis endnu Hornemanns Plantelære, og naar man betænker, at den af Botanikens Studium her i Landet hoit fortjente Forfatter af hiint Værk har maattet samle saagodtsom forfra den betydelige Miengde Detail-Angivelser om Planternes Voxesteder, som indeholdes i samme, maa dette i høi Grad paaskjønnes, ikke alene som et for $\sin$ Tid yderst værdifuldt Arbeide, men ogsaa som et vigtigt Grundlag for senere Undersøgelser. Ogsaa Drejers F lora excursoria er et Arbeide, som har gjort megen Nytte især ved sin beqvemme Indretning, der gjor den særdeles brugbar ved Planternes forelobige Bestemmelse; 'ogsaa denne indeholder mange værdifulde Bidrag til Floraen, af hvilken den dog kun giver Oplysning om en liden Deel, idet den kun omhandler Sjællands Planter og tilmed det vestlige Sjælland dengang kun var ufuldstændigt undersegt. Men et ikke kort Tidsrum er allerede forløbet siden begge hine Værker bleve til, de i den mellenlliggende Tid stadigt fortsatte Undersøgelser over vore indenlandske Planter have baade forøget disses Tal betydeligt ${ }^{\star}$ ) $0 \mathrm{~g}$ modificeret de

*) Hornemann angiver i 1821 de danske Phanerogamers Tal til 1064 , medens næsten 1300 Arter nu ere kjendte herfra, og alene Sjællands Flora er i de 12 Aar, siden Drejers Flora udkom, idetmindste foroget med 50 Arter. 
dengang antagne Meninger om Fordelingen af et stort Antal blandt de tidligere bekjendte. Men livad der især bevirker, at de to nævnte Arbeider ofte maa benyttes med Varsomhed, er den Omstændighed, at den nuværende Tids Opfattelse af Artsbegrebet er anderledes end dengang, og at det altsaa i Tilfælde af at man har at gjore med en forhen collectiv Art, som nu er deelt i 2 eller flere, oftest er yderst vanskeligt at henfore de tidligere anforte Voxesteder til en bestemt af de nyere Arter. (Som Exempel blandt flere kunde anfores de forhen collective Navne Betula alba, Agrimonia Eupatoria, Montia fontana, Valeriana officinalis, Glyceria fluitans, flere Rubus- og Hieracium-Arter). De floristiske Arbeider af $R$ afn, Schumacher og Nolte, hvis vigtigste Udbytte er optaget i de 2 ovenfor nævnte Værker, har jeg dog stadigt raadspurgt i tvivlsomme Tilfælde, ogr naar hertil endnu foies nogle spredte Noticer, især bekjendtgjorte i Krøyers Naturhist. Tidsskrift, saa har jeg omtrent nævnt Alt, hvad der af trykte Materialier foreligger til Afbenyttelse. Af Locilflorer, et Materiale, hvorpaa Nabolandenes botaniske Litteratur er rig indtil Overflod, ere kun yderst faa tilstede hos os. Lige saa vigtige som imidlertid slige Angivelser over Planterne i en vis Egn, naar de ere fuldstiendige og noiagtige, ere som Forarbeider for den samlede Oversigt over Floraen, lige saa meget har jeg folt Sarnet deraf, fordi det derved blev vanskeligt at have nogen bestemt Mening om mangen Arts Forekomst eller Mangel $\mathrm{i}$ en vis Egn. Det var nemlig hidtil almindelig Brug i lubriken om Planternes geographiske Fordeling kun at angive Voxesteder for de Arter, som ansaaes for sjeldnere, og derimod om dem, der i Sjælland og især omkring Kjøbenhavn forekomme hyppigt, at bruge Udtrykket "almindelig", uden at angive om dette ogsaa er Tilfældet i Landets rige Egne. Derfor forekommer det Enhver, der kun har undersogt Jylland og Fyen, ligesaa forunderligt at see Planter som Plantago media, Carduus acanthoides, Helianthermum vulgare, Alopecurus pratensis o. ft. nævnte blandt de alınindelige, som det vilde undre Den, der kun har 
gjort Excursioner i Sjælland, om man kaldte Myrica, Genista tinctoria, Phyteuma, Arnica, Narthecium o. fl. almindelige, hvilket de $\operatorname{dog}$ i Virkeligheden kunne kaldes. med lige saa stor Ret som hine. Den omtalte Mangel paa Specialflorer er imidlertid for en stor Deel bleven mig erstattet ved talrige Bidrag af Planter og Noticer fra de forskjellige Egne af Landet, som ere komne til min Kundskab, deels gjennem den herværende botaniske Forening, deels. ad privat Vei ved flere Dyrkere af Botaniken saavel i Hovedstaden som i Provindserne og deels endelig ved egne Undersøgelser, hvilke jeg har været saa heldig at have kunnet fortsætte i en Række af Aar paa Reiser gjennem de fleste danske Provindser. Ved Ordningen af de saaledes indsamlede Angivelser om Planternes geographiske Udbredelse har jeg nu sædvanligviis fulgt den Regel, kun at betegne som almindelige uden videre Bemærkning de Planter, som jeg havde Grund til at ansee for omtrent ligeligt udbredte over hele Landet, for enhver Art derimod, der maatte antages at have en ueensartet Udbredelse, har jeg fremhævet de Egne, hvor samme synes at være sjelden eller aldeles at mangle. Specielle Voxesteder har jeg troet at burde anfore ikke alene for de strængt taget sjeldne Arter, men ogsaa for mange, som have en adspredt Forekomst, og kun naar der for slige sporadiske Planter var et saa stort Antal Voxesteder bekjendt, at Opregnelsen af dem alle vilde optage uforholdsmæssig stor Plads, har jeg undladt at nævne dem særskilt. Ved at ordne Provindserne og de enkelte Findesteder indenfor hver af disse i en bestemt Rækkefølge efter deres Beliggenhed, ved fremdeles at begynde med den Egn af Landet, hvor den omhandlede Plante synes at være meest udbredt, troer jeg at have lettet Oversigten for Dem, der ville benytte denne Deel af Bogen, og skjøndt visselig Meget endnu staaer tilbage, for vor Flora er saa vel undersøgt som det kunde onskes, haaber jeg dog, at en noget fuldstændigere Forestilling om Vegetationsforholdene i Danmark ved Hjælp af de her leverede Bidrag: efterhaanden skulde kunne erholdes. 
Det havde været mit Ønske at vedfoie en almindelig Skildring af Vegetationen i Danmark $0 \mathrm{~g}$ sammes afvigende Characteer i de forskjellige Egne: et Bilag, som jeg troer vilde have givet Bogen mere Værd, idet derved paa eet Sted kunde være sammenfattet hvad der nu maa søges i spredte Noticer for hver enkelt Plante, men da en slig Oversigt, for at have nogen Betydning, ikke kunde være aldeles kortlattet, har jeg, saavel al Hensyn til Forlægger og Kjobere af Bogen (idet denne allerede har overskredet det Arkeantal, livortil den forelobigt var anslaaet), som af Mangel psa tilstrækkelig Tid, da jeg er beskjæftiget med de fornodne Forberedelser til en Reise i Syden, opgivet dette. Nogle herhen horende Bemærkninger har jeg bekjendtgjort i "den naturhistoriske Forenings videnskabelige Meddelelser" 1849, p. 77; til disse saavelsom til Hornemanns "Bemærkninger angaaende Forskjelligheden af Vegetationen i Danmark" maa jeg altsaa her noies med at henvise.

Endnu staaer tilbage for mig den behagelige Pligt at udtale min anerkjendende Tak til de Mange, uden hvis Opmuntring, Raad og Medvirkning jeg ikke vilde have været istand til at udfore dette Arbeide. Jeg maa for'st bringe min varmeste Taksigelse til Hr. Etatsraad Schouw, hvis bekjendte Velvillie og virksomme Deeltagelse for de yngre Botanikere ogsaa i hoi Grad 'er kommet mig til Gode og paa mange Maader har bidraget til at fremme mine For'skninger i den danske Flora, og til IIr. Professor Fries, ikke alene fordi ethvert Blad i hans Skrifter over Skandinaviens Flora er en Guldgrube for alle senere Arbeider i denne Retning, men ogsaa for de værdifulde Oplysninger om mangen tvivlsom Form, som han har havt den Godhed at meddele mig af sin rige Erfaring over Arternes vexlende Skikkelser. Blandt de mange Andre, hvis Interesse for mit Arbeide har forskaffet mig saa mange vigtige Meddelelser om Planternes Udbredelse, maa jeg især nævne min mangeaarige Ven, Dr. Poulsen, hvis noie Kundskab til Halvøens og fornemlig Slesvigs Flora har havt stort Værd 
for mig; min Broder, Cand. theol. M. T. Lange, hvem jeg bl. A. skylder flere heldige Iagttagelser angaaende adskillige Arters Characteristik; mine Venner Apotheker Piper $\mathrm{og}$ Cand. pharm. Th. Schiotz, om hvis Ufortrodenhed i at efterforske vore indenlandske Planter næsten enhver Side i Bogen kan vidne; Godseier Hofman-Bang, som endnu i sin hoie Alderdom vedbliver med ungdommelig Iver at dyrke sin Yndlingsvidenskab; Froken Rosenberg, hvem jeg skylder en Mængde Oplysninger om Vegetationen i det nordlige Fyen; Professor Liebmann, som velvilligt har overladt mig sit danske Herbarium til Gjennemsyn; Dr. J. Vahl; Apotheker Steenberg; Bot. Gartner Weilbach; Pastor Fausboll; Cand. pharm. G. Jensen; Cand. theol. Vaupell; Cand. phil. E. Moller-Holst; Underlæge Meinert; Stud. polyt. Rostrup. Disse og mange Flere modtage herved min erkjendtligste Tak!

Og hermed anbefaler jeg min Haandbog til omhyggelig Provelse og velvillig Overbærelse af Botanikens Dyrkere i Fædrelandet.

Kjobenharn i December 1850.

Joh. Lange.

Fortale til anden og tredie Udgave.

Da jeg i Fortalen til forste Udgave har gjort Rede for Haandbogens Plan og Indretning, har jeg anseet det for hensigtsmæssigt at aftrykke demne uforandret. lím on de vigtigste i de senere Udgaver foretagne Forandringer skal jeg her tilfoie nogle Bemærkninger.

1. Det vil sees, at et ikke ubetydeligt Antal af Arter er tilkommet siden Bogen forst udkom, idet Totalsummen af de deri beskrevne Planter, som dengang kun belob sig til 1291, nu er voxet til 1378 (hvorunder dog er indbefattet 
22 Arter af Slægteme Charq og Nitella, som heelt og holdent ere tilfoiede i den nye Udgave). Dette Antal af over 80 for Danmark nye Planter indbefatter deels saadanne Arter, som tidligere vare bekjendte fra Nabolandene, men ikke fundne i Danmark eller idetmindste optagne med Tvivl (f. Ex. Agropyrum strictum og pungens, Poa bulbosa, Aira uliginosa, Setaria glauca, Carex maxima, Juncus tenuis, Potamogeton zosteraceus, flere Salices, Hieracium pratense og gothicum, Linnaa borealis, Orobanche Cirsii, Pedicularis Sceptrum carolinum, Camelina silvestris, Melilotus arvensis, hvortil endnu kan foies det mærkelige Fund af Nodderne af Trapa natans), deels nogle Arter, som enten ere beskrevne i de senere Aar, eller om hvis Ret som gode og holdbare Arter der tidligere var Tvivl, f. Ex. Ruppia brachypus, Allium Kochii, Atriplex Babingtonii, Polygonum nodosum, Hieracium integrifolium og anfractum, Bidens platycephala, Galium elongatum, Cuscuta Trifolii, Primula variabilis, Galeopsis angustifolia, Rubus Arrhenii, Polygala depressa o. $f$.). Denne ikke ubetydelige Tilvæxt skyldes især den Iver og Utrættelighed, hvormed flere Botanikere $\mathrm{i}$ de senere Aar have arbeidet 'for en noiere Undersogelse af Danmarks Vegetation; ogsaa har den Redebonhed, hvormed disse have meddeelt mig Udbyttet af deres Undersogelser, sat mig istand til at tilfoie mange nye Voxesteder for de sjeldnere Arter, livorved det for flere af disse er bleven muligt at pavise en mere bestemt begrændset Udbredelse. Jeg selv har i de senere Aar ikke havt Leilighed til at foretage mange længere Reiser indenfor Landets Grændser, og mine Undersogelser have fornemlig været indskrænkede til det nordlige og ostlige Sjælland. En Reise til det vestlige og nordlige Jylland, som jeg i Sommeren $18 j 8$ foretog for kongelig Regning som Ldgiver af Flora danica, bragte mig dog mange interessante Resultater om disse Egnes Vegetation og om enkelte sjeldnere Arters Forekomst.

2. Ved Revisionen af de tidligere i Haandbogen beskrevne Slægter og Arter har jeg bestræbt mig for ikke at 
foretage andre Forandringer end saadanne, som en nelre Prøvelse og sikkre lagttagelser gjorde fornødne; enten der var Spørgsmaal om at forøge eller om at formindske Slægternes og Arternes Antal har jeg derfor enten selv anstillet yderligere Undersøgelser eiler i tvivlsomme Tilfælde raadfort mig med de dygtigste Floristers Fremstilling. Læserne ville see, at kun yderst faa Slægter have faaet en forandret Begrændsning eller Benævnelse; i Henseende til Arterne ere Forandringerne vistnok flere, men jeg haaber dog ikke at skulle klive beskyldt for at have foretaget mange Forandringer uden Grund. Da jeg overhovedet anseer det for urigtigt at forandre Planternes Navne uden bydende Nødvendighed, har jeg kun foretaget Forandring al saadanne Navne, som enten ifolge de vedtagne Regler for Prioriteten eller paa Grund af en tidligere stedfunden Forvexling af Arter formeentlig ikke kunde beholdes.

3. I Henseende til Plantebeskrivelsernes Form og Omfang har jeg foretaget enkelte Modificationer, især sigtende til at gjore Beskrivelserne mere ensartede, og, hvor jeg ansaae det for hensigtsmæssigt, noget udforligere. Da det for Begyndere ofte kan være vanskeligt at finde sig tilrette med de aldeles kortfattede Beskrivelser, haaber jeg, at den derved bevirkede Forngelse af Bogens Omfang ikke vil blive misbilliget. Det er ligeledes fornemlig Hensyn til Begyndernes Tarv, som har bevæget mig til fremdeles at fastholde den tidligere Ordning efter det linnéiske system, og jeg henviser i denne Henseende til mine Yttringer i den tidligere Fortale, hvor villig jeg end er til at indromme, at den mere videnskabelige Ordning af Planterne efter et naturligt System vilde have gjort Bogen mere tiltalende for de mere ovede Botanikens Dyrkere og mere tilfredsstillende for mig selv. Det er mit Forsæt, hvis der forundes mig Helbred $0 \mathrm{~g}$ den fornødne Tid, senere at udarbeide et kort Compendium af den danske Flora, ordnet efter naturlige Familier og maaskee forfattet paa Latin, deels for at give en billigere og beqvemmere Haandbog til Brug paa Excursioner, deels for at bidrage til et noiere Be- 
kjendtskab, ogsaa udenfor Landets Grændser, med Danmarks Vegetation, som synes at være de fleste Botanikere i Udlandet saagodtsom ubekjendt.

4. Den systematiske Oversigt i Begyndelsen af Haandbogen er i tredie Udgave forøget ved Tilføielsen af FamilieKjendetegn og Slægtsnavne af de blomsterløse Planter (Alger, Lavarter og Mosser) samt en Angivelse af disses omtrentlige Artsantal i Danmark. Ved Udarbeidelsen af denne Oversigt, som var forbunden med ikke liden Vanskelighed, idet vi for de fleste af disse Familiers Vedkommende savne det onskelige Materiale til Oplysning om de i Danmark forekommende Arter, har jeg støttet mig deels paa værdifulde Oplysninger, der velvillig ere mig meddeelte af Froken Rosenberg, Dhrr. Branth, Th. Jensen, M. T. Lange og Rostrup, deels pala en Revision af de i min egen Samling indeholdte Cryptogamer.

5. Ligesom den anden Udgave blev foroget med en Anviisning for Begyndere til Haandbogens Brug ved Planters Bestemmelse, har jeg, ifølge Anmodning af Flere, i tredie Udgave tifføiet, ligeledes som et Hjælpemiddel for Begyndere, en alfabetisk ordnet Fortegnelse over de vigtigste i Haandbogen brugte Kunstord med en kort Forklaring over ethvert af disse.

Foruden de i forste Udgave næunte Hjælpemidler til Kundskab om Danmarks Flora har jeg af trykte Arbeider fornemlig afbenyttet folgende: H. P. G. Ko ch, "Falsters Vegetation"; M. T. Lange, "den sydfyenske Øgaards Vegetation" og "Tillæg til Danmarks Flora"; Th. Schiøtz, "Bidrag til Bornholms Flora" og "Beretning om en botanisk Reise i Slesvig og paa Vesterhavsøernen, fremdeles en Afhandling af F. Müller: i "Flora" 1853, som omhandler de i Eidersted og i Egnen om Husum fundne Planter. Desuden har jeg havt rigelig Understottelse af flere Botanikens Dyrkere, som med storste Forekommenhed og Velvillie have meddeelt mig liver fra sin Lgn deels Planter, deels haandskrevne Bemærhninger. Idet jeg fornyer min Tak til de Mange, som allerede understottede mig ved den forste Udgave, er 
det med Sorg jeg mindes, at flere af disse, og deriblandt saa udmærkede Bot:ınikere som Schouw, Hofman - Bang, J. Vahl, Liebmann og Vaupell, ere bortkaldte fra Videnskaben i de faa Aar, som siden den Tid ere forlobne. Blandt dem, som de 2 silste Udgaver især skylde saavel saare mange og værdifulde Bidrag af nye og sjeldne Planter som Berigtigelser og critiske Bemærkninger om enkelte Arter eller Grupper, maa jeg særligt nævne Dhrr. Kiammerraad Andresen, Bibliothekar Dr. Didrichsen, Professorerne Steenstrup og Ørsted, Seminarielærerne Mortensen, Th. Jensen og Rostrup; Dr. phil. Heiberg, Cand. theol. Branth, Cand. pharm. Schiøtz og Baggøe, Provst Koch, Sognepræsterne II. T. Lange, Jac obsen, Fausboll og Visby, Overretsprocurator Morville, Adjunkterne Feddersen, Grønlund, Hoff, Juel, Jørgensen, Knæckenborg, Lütken, d'Origny, Strøm og Thomsen, Baron Rosenorn Lehn, afd. Premierlieutenant Lund, Fuldmægtig Smith, Forstcandidat West, Stud. mag. E. Warming, Stud. med. Valløe, Landinspecteur J. Mørch, Skolelæreme Hjorth, P. Nielsen og V. Schmidt, Assessor pharm. Piper, Apothekene A abye og Benzon. Alle disse og flere Andre, som have meddeelt mig Bidrag og Oplysninger, bringer jeg herved min oprigtige Taksigelse.

Kjobenhavn, December 1864.

Joh. Lange. 


\section{Forklaring}

over

adskillige af de i Haandbogen hyppigst forekommende Tegn og Forkortninger.

Kyll. = P. Kylling, viridiarium danicum, Hafn. 1688.

Rafn. = C. G. Rafn, Danmarks og Holsteens Flora. Kbhavn. 1 D. 1796,2 D. 1800

Schum. = C. F. Schumacher, Enumeratio plantarum Sjællandix sept. \& orient., vol. 1-2. Hafn. 1802-3.

II. = Hornemanns oeconomiske Plantelære $3 \mathrm{Udg.,} 1$ Deel, 1821, H. II. - $2 \mathrm{Deel}, 1837$.

N., Nolt. = E. F. Nolte, Novitiæ Floræe holsaticæ, Kilon. 1826. - Bidrag til Fl. Dan.

Dr., Drej. = S. T. N. Drejer, flora excursoria Hafniensis 1838. - Bidrag til den danske Flora i Krøyers Tidsskrift.

Fr. Nov. = E. Fries, novitiæ flor. Suec. ed. II, 1828. - Mant., = mantissa I-III, 1832-42. - S. Veg. Sc. = Summa vegetabilium Scandinavia sect. $1-2,1845-49$.

Koch Syn. II. = W. D. I. Koch, Synopsis floræ germanicæ \& helvetica ed 2, vol. 1-3. Lipsia 1843-45.

F. D. = Flora Danica.

E. B. = English Botany.

Rchb. ic. fl. g. = Reichenbach, Icones floræ germanicæ \& helvetica, vol. I-XIX; Rchb. ic. crit. = iconographia botanica, cent. $\mathrm{I}-\mathrm{X}, 1823$ etc.

And. Atl. = N. J. Andersson, Atlas öfver den Skand. Flor. nat. Fam Stockh. 1849 - Cyp. Scand. = Cyperaceæ Scandinaviæ, Holm. 1849. - Gram. Scand. = Gramineæ Scandinaviæ, Holm. 1852.

H. $\mathbf{N}_{\text {. }}=$ E. Fries, Herbarium normale plantarum rariorum \& criticar. Suecice, fasc. $1-15$.

L. Ilerb. = Heıbarium for den landoeconomiske Botanik, udg. af Joh. Lange, 1-9 Hæfte.

$\odot=$ enaarig $\odot=$ toaarig $; \psi=$ vedvarende urteagtig; $\boldsymbol{\eta}=$ træ- eller buskagtig.

$\sigma^{*}=$ Stovblomst $;=$ Frugtblomst $; \not=$ Trekjonsblomst.

$\infty=$ ubestenit Antal.

$\dagger$ foran en Planteart (med . ii) betegner iudførte og nu alklimatiserede Planter.

Haandh. i den danske Flora. 


\section{XVIII}

$\dagger$ foran en Planteart (uden $N_{0}$ ) $=$ dyrkede eller tilfældigviis forvildede Arter.

$X=$ Arter, som tidligere have været fundne i Danmark, men nu synes at være forsvundne.

? = Tvivlsomme Arter for vor Flora.

* = (med No.) Sandsynligviis egne Arter.

* = (uden $N_{0}$.) Udmærkede Varieteter.

$==$ Bastardformer.

$D=$ Misdannelser.

Tegnene ved Slæegterne i Klassen Tetradynamia ere forklarede i Oversigten over de naturlige Familier (Fam. Cruciferæ).

Tallene efter Plantebeskrivelserne betegne de til de resp. Tal svarende Maaneder af Aaret, $\mathrm{i}$ hvilke Planten blomstrer, f. Ex. $5=$ Mai, $6=$ Juni o. s. v. $\frac{5}{2}-\frac{6}{1}=$ Blomstringstid fra Slutningen af Mai til Begyndelsen af Juni.
J. - Jylland.
Sl. - Slesvig.
F. - Fyen.
Falst. -. Falster.
Sj. - Sjælland.
Bornh. - Bornholm.

Loll. - Lolland.

Tegnet * med en Linie i forskjellig Retning, efter Artiklen om Planternes Forekomst. betegner den resp. Plantes Grændser mod Nabolandene, f. Ex. F Planter, som mangle i Norge, $*$ i England, *] i Sverige, 这 i Tydskland.

! efter et Voxested betegner at jeg selv har fundet Planten paa det angivne Voxested. Navnene i Parenthes efter Voxesteder betegne Finderne af den paagjældende Plante. De oftest nærnte blandt disse ere betegnede ved 'Tal, hvis Betydning nedenstaaende Fortegnelse angiver.

1. Den botan. Forening i Kbh.")

2. Fausboll, Præst.

3. Gotsche, Provst.

4. Hofman-Bang, N., Etatsraad.

5. Holst, E. Møller-, Caud. phil. Redacteur.

6. Hübertz, Cand. pharm.

7. Jensen, G., A potheker.

8. Jensen, Th., Seminarielæerer.

9. Kamphovener, Docent.

10. Kjærbølling, Dr. phil.

11. Liebmann, Professor.

12. Lange, M. T., Præst.

13. Meinert, Underlæge.

14. Mortensen, Seminarielærer.

15. Piper, Assessor pharm.

16. Poulsen, Dr. phil., Justitsraad.

17. Petit, praet. Læge.

18. Rosenberg, Frøken.

19. Rostrup, Seminarielærer.

20. Schiøtz, Cand. pharm., Fabrikant.

21. Steenberg, Apotheker.

22. Steenbuch, praet. Læge.

23. Steenstrup, Professor.

24. Strøm, V., Adjunkt.

25. Tuxen, Præst.

26. Tutein, Contoirchef.

27. Vahl, Dr. phil.

28. Vaupell, Dr. phil.

29. Westesen, Præst.

30. Warming, Stud. mag.

*) De til den bot. Forening indsendte Plaoter ere i Regelen betegnede med Indsenderens Numer, og Nr. 1 er deffor kun brugt naar det ikke er blevet optegnet fra bvem Planten er modtaget. 


\section{Kortfattet Anviisning}

til

Haandbogens Brug ved, Planternes Bestemmelse.

Mange af dem, som ville gjøre Brug af nærværende Haandbog til paa egen Haand at undersøge de danske Planter, kunde muligen ønske at erholde nogle Vink med Hensyn til den beqremmeste Maade, hrorpaa dette kan skee, og jeg skal derfor ledsage Bogen med en kort Veiledning til sammes Brug.

Undersøgelsen af den Plante, man ønsker at kjende, begynder man med at bestemme dens Plads i det linnéiske System efter den pag. XLVIII meddeelte Tabel. Classen finder man bedst ved at gjennemgaae Tabellen nedenfra, saaledes at man først forvisser sig om, hvorvidt Planten har tydelige eller utydelige Blomster, i første Tilfælde om Blomsterne ere særkjønnede eller tvekjønnede. Er Blomsten særkjønnet, da undersøger man om den er Enbo eller Tvebo, er den derimod tvekjønnet, da efterseer man, om en Sammenvoxning af Befrugtningsdelene finder Sted (og i saa Fald paa hvilken Maade) eller om Delene ere frie o.s. v. Har man ved denne Fremgangsmaade fundet Classen, da gaaer man videre til at bestemme Ordenen, hvilket skeer efter Tabellen pag. XLIX. Dersom man f. Ex. har valgt til Undersøgelse den almindelige Døvnælde (hvid Tretand), som har 2 lange og 2 korte Støvdragere og altsaa hører til 14de Classe, da finder man paa Ordenstabellen, at der $\mathrm{i}$ denne Classe ere 2 Ordener (Spaltefrugtede og Kapselfrugtede). Man bem:rker, at den Plante man har for sig, har 4 frie Nødder, og dan hører altsaa til 1 ste Orden (Spaltefrugtede). Nu gaaer man videre frem $\mathrm{i}$ Bogen, hvor en Oversigt over de til 14 de Cl. 1ste Ord. hørende 
Slagter er fremstillet S. 427. Denne Orden er, for at lette Bestemmelsen af de talrige Slægter, yderligere underafdeelt, og de til hinanden svarende (med ensartede Mærker betegnede) Underafdelinger maa nu stadigt sammenlignes, efterhaanden som Undersøgelsen rykker frem. Dersom f. Ex. den Plante, hvis Slægtsnavn jeg søger; har Frugten allerede før Modenheden deelt i 4 Nødder og Blomsterne tilsyneladende krandsstillede, da hører den til Afdelingen A, og denne er atter deelt i 3 Underafdelinger efter Bægerets Beskaffenhed, idet dette enten kan være titandet $(A A)$, regelmæssig femtandet $(B B)$ eller tolæbet (CC). Den Plante jeg har for mig, har et regelm. fémtandet Bæger, den hører altsaa til Underafd. BB, og jeg maa nu dernæst lægge Mærke til, om Støvłraadene ere parallele (a) eller efter Bestøvningen bøiede fra hinanden foroven (b). Paa denne Maade fortsættes saalænge der findes opstillet Underafdelinger, som ere betegnede ved Mærker der svare til hinanden indbyrdes. Har man ad denne analytiske Vei fundet, at den søgte Plante hører til $\beta \beta$, Underafdelingen *, da har man i denne kun 2 Slægter at sammenligne, nemlig Lamium og Galeobdolon, og ved at gjennemgaae de for hver af disse angivne særegne Kjendetegn, finder man, at disse passe paa den førstnævnte Slægt, som i Oversigten er betegnet med Nr. 6. Der staaer endnu tilbage at finde Navnet paa Arten, og dette skeer ved at opslaae den fundne Slægt (efter det angivne Numer), som indeholder flere Arter, der ere beskrevne S. 440. For at spare Gjennemlæsningen af de talrige Arters Beskrivelse ere disse atter fordeelte i Afdelinger, som ere betegnede med Bogstaver, der maa sammenlignes ligesom i Slægtsoversigten. Finder man, at Planten har tilspidsede Blade og er vedvarende (a), at dens Kronrør er krummet med en Haarkrands indvendig i Røret (aa), da er der i denne Afdeling kun 2 Arter at vælge imellem; ved nøiagtig at gjennemgaae de for disse Arter givne Beskrivelser findes at den forste, L. album, har udeelt Stængel, børsteformede Bægerflige, en skjæv Haarkrands i Kronrøret og hvide Kroner. Alle disse 
Kjendetegn, men derimod ikke de for den anden Art (L. maculatum) anførte, passe paa den Plante, jeg har til Undersøgelse, og jeg har saaledes fundet dens Navn. Foruden den egenlige Beskrivelse bør man ikke forsømme at lægge Mærke til de med mindre Tryk tilføiede Bemærkninger om Høiden, Blomstens Farve, Plantens Varighed, Blumstringstid o. s. v., livilke Angivelser ofte kunne være oplysende ved Plantens Bestemmelse. Adskillige af disse ere udtrykte ved Tegn, hvis Forklaring er meddeelt S. XVII-XVIII.

Den her beskrevne Fremgangsmaade vil ved nogen $\varnothing$ velse lette Arbeidet ved Planternes Undersøgelse betydeligt, idet man ved en nøiagtig Sammenligning af de hinanden modsatte Underafdelinger sparer den Uleilighed, som er forbunden med at gjennemlæse Beskrivelserne paa en stor Mængde Slægter eller Arter. Men ved enhiver Plantebestemmelse, og ikke mindst ved Brugen af det linnéiske System, udfordres en omhyggelig Undersøgelse af de enkelte Plantedele, især af Blomsten og Frugten, hvortil man bør være forsynet med en god Lupe*) og en skarp Kniv, samt nogle Naale. Det Exemplar, man vælger til Undersøgelse, bør være i god Tilstand, om muligt forsynet med Blomster og Frugter paa eengang, og man maa da ikke nøies med at undersøge en enkelt Blomst, men helst flere, deriblandt især nys udsprungne Blomster eller større Blomsterknopper, fordi de ælldre Blomster ofte tidligt tabe enkelte af de til Bestemmelsen væsenlige Dele. Frugten er altid vigtig og hos enkelte Slægter, f. Ex. Skjærmplanter, Rumex, Atriplex, aldeles nødvendig til Slægtens eller Artens Bestemmelse. Ofte er det ogsaa vigtigt at undersøge Roden og Rodbladene, og da de sidste stundom tidligt visne, bør man undersøge Planten i flere forskjellige Afsnit af dens Liv. Hos Treboplanter, f. Ex. Pileslægten, bør unan saavidt muligt søge at forskaffe sig begge Kjøn, og tillige de ældre Blade, da flere Arter blomstre førend Bladenes Udvikling.

*) De Kjendetegn, som i Haandbogen ere benyttede til Planternes Beskrivelse, ere i Regelen saadanne, som kunne sees med blot Øie eller med en stærk Lupeforstørrelse. 


\section{XXII}

Endnu bør omtales de enkelte Uregelmæssigheder, som finde Sted i det linnéiske System, og som stundom forvirre Begynderne. Hertil høre især de Tilfælde, da en Plante har Blomster med et forskjelligt Antal Støvdragere, endog paa samme Individ, f. Ex. Chrysosplenium, Adoxa, Polygonum o. A.; disse henføres da til den Classe, hvortil de ifølge Fleertallet af deres Blomster henhøre. Fremdeles kan en Slægt indeholde flere Arter, hvoraf nogle efter den kunstige Inddeling henhøre til en, andre til en anden Classe. Denne Uregelmæssighed er søgt afhjulpen derved, at Slægten er beskreven i den Classe, hvortil dens fleste Arter henhøre; men enhver af de afvigende Arter er novnt $\mathrm{i}$ den Classe og Orden, hvorhen man ifølge dens Befrugtningsdeles Antal eller andre Forhold matte sætte den, og naar man altsaa i Slægtsoversigten foran en Classe finder enkelte Arter nævnte særskilt uden Beskrivelse, maa man eftersee, om Kjendetegnene paa den Slægt, hvortil de høre, og hvis Plads i Systemet ved hver især er angivet, muligviis passe paa den Plante, man søger; f. Ex. i 22 de Classe 6te Orden anføres Rumex Acetosa og Acetosella, som ere TreboPlanter, medens de øvrige Arter af Slægten Rumex henhøre til 6te Classe 3die Orden.

For at erhverve sig nogen Øvelse $\mathrm{i}$ at bestemme Plantens Plads i det naturlige System bør man ikke forsømmo at benytte den Oversigt over de danske naturlige Familier, som findes foran i Bogen S. LII. Til Lettelse ved det hermed forbundne Arbeide er der i Slægtsoversigten foran hver Classe angivet den Familie, hvortil enhver Slægt hører, og ved at gjennemgaae de Familiers Kjendetegn, hvortil de undersøgte Slægter henhøre, vil man efterhaanden erhverve sig en foreløbig Kundskab om de vigtigste af disse. 


\section{Alfabetisk Fortegnelse}

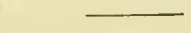

A.

Aarsskud (turio) en hos flere Buskvæxter (f. Ex. Rosa, Rubus) oftest fra Rodstokken udgarende Green, som i sit forste Aar er blod og urteagtig, barer Blade, men iklke Blomster.

Afbidt (præmorsus) kaldes den lodrette Rodstok hos Succisa pratensis, Primula Arter o. fl., der er i Spidsen ligesom afgnavet, idet de aldre Dele efterhaanden bortdoe nedenfia; den benævntes tidligere "afbidt Rod" paa Grund af dens Lighed med en Pælerod.

Ifsnit (segmentum) s. Snitdeelt.

Afrexleude (alternans), den Bladstilling, hvor der kun udgaaer eet Blad fra hvert Led, men Bladene ere reutede vexelviis til 2 forskjellige Sider af Strengelen, saa at det tredie Blad dwkker det første, det fjerde det andet o.s. v., (f. Ex. Ulmus).

Androgyn benærnes de sammensatte Ax hos Carex-Slægten o. fl., i hvilke nogle Blomster ere $\sigma$, andre $q$.

Antheridier eller Støvkolber ere oftest rundagtige eller kølleformede Legemer, som indenfor en Hinde indelıolde en Vædske med Sxdtraade af forskjellig Form; de fiudes hos Sporeplanterne og udfore idetmindste hos mange af disse Befrugtringen af Sporeme.

Ar (stigma), den øvre Deel af Støvveien, alm. beklædt med Haar eller Kirtler, som udsondre en klabrig Vædske, hvorved Arret opfanger og fastholder det tra Størknapperne nedfaldende Blomsterstov.

Avne (palea), skjælformede Dækblade f. Ex. ved Grunder af de enkelte

Smaablomster paa Blomsterleiet hos flere Kurvblomstrede, (f. Ex. Hypochoeris, Anthemis). Hos Græsarterne faae de Smaaaxet omgivende (oftest 2) i forskjellig Retning udgaaende Dækblade Navn af Yderazner (glumæ), det ene (ovre) udgaacnde lidet ovenfor det andet (nedre), hrorimod de hver enkelt Grasblomst omgivende og paa lignende Made stillede 2 Dækblade kaldes Inderavner (paleæ).

Ax (spica), en forlænget Blomsterstand med siddende Blomster. A. kan vare enkelt, med enligt stillede Blomster eller sammensat, naar det bærer mindre Blomsterstande (Krandse, Nogler eller Ax); i det sidste Tilfelde kaldes de mindre Blomsterstande Smaaax, f. Ex. hos flere Grosarter (Lolium, Elymus, Tritieım), los andre Gresarter ere . Smaaaxene sammenstillede i en Top (Bromus, Poa). 


\section{XXIV}

Axe (axis, rachis) kaldes Plantens Centralorgan i dets forskjellige Udviklingsformer (Rod, Rodstok, Stængel, Grene o. s. v.) Blonisterstandens Axe er særligt den Deel af Stængelen, som udgjør det fælles Udgangspunkt for flere nær ved hverandre samlede Blomster (s. Blomsterstand).

Axelblade (stipulæ) ere de ved Grunden af de egenlige Blade, oftest et ved hver Side af Bladstilken, siddende Blade af en fra selve Bladet forskjellig Form; de ere at ansee for en saregen Udviklingsform af Bladskeden, findes hos Fleertallet af Planter og ere snart vedblivende (endog tilvoxende), snart tidligt affaldende, stundom ere de saa smaae, at de kun med Vanskelighed iagttages. Smaaaxelblade eller Smaabillade (stipellæ) findes ved Grunden of et sammensat eller snitdeelt Blads Smaablade eller Afsnit (f. Ex. lios 'Thalictrum, Sanguisorba, Phaseolus).

Axelstillet (s. endestillet).

\section{B.}

Barktorn (aculeus), en fra Barklagets Overhud udgaaende spids, stikkende, tilsidst træagtig Fremragning hos Rosa, Rubus, Ribes Grossularia o. fl.

Bibager eller Yderbager (calyculus), en Kreds af bladagtige Dele ndenfor det egenlige Bxger, dannet enten af Dækblade eller af axelbladlignende Tilhængsler til Bægeret (f. Ex. Malvaceæ, Dipsaceæ, Potentilla).

BIkrone (parapetala). Herunder indbefattes deels de oftest kronbladagtigt farvede Ttlhæengsler af forskjellig Form, som hos adskillige Planter findes indenfor den egenlige Krone, og enten hidrore fra en ny Række Kronblade eller fra axelbladlignende Dele (f. Ex. Vincetoxicum, Agrostemma) deels indadrendte Ujævnheder i Form af Skjæel eller Tænder i Kronens Rør eller Svælg (f. Ex. hos Borrago, Symphytum, Myosotis).

Bistordragere (parastemones) omdunnede og golde Støvdragere (f. Ex. hos Parnassia, Scrophularia, Ajuga).

Blad (folium): Plantens Sideorganer. Et fuldstændigt B. bestaaer af Bladplade (lamina), Bladstilk (petiolus) og Bladskede (vagina). Enhver især af disse Dele kan mangle, og naar Bladet nævnes uden yderligere 'Tilføielse, er derved for det meste særlig at forstaao Bladpladen.

Bladagtlg (foliaceus) kaldes Plantedele af gron Farve og som forøvrigt besidde et normalt Blads Egenskaber, i Modsætning til Axedele og desuden deels til farvede (ikke grønne), deels til hjødfulde og deels til hindeagtige Plantedele.

Bladdusk (coma) en Samling af tomme Dækblade i Spidsen af en Blomsterstand (f. Ex. Melampyrum nemorosum, Mentha arvensis).

Bladknopper (gemmæ foliacea) kaldes de Knopper, af hvilke der senere udvikles bladbærende Grene, i Modsætning til Blomsterknopper (alabastra), som indeholde Blomstens Dele i uudviklet Tilstand.

\section{Bladplade \\ Bladskede $\}$ s. Blad. \\ Bladstilk}

Bloust (flos) dannes af en Axedeel (Frugtbunden) og bladagtige Dele, 
nemlig, forsaavidt Blomsten er fuldstondig, af 2 ydre Bladkredse som beskytte de indre og kaldes Blomsterdcekket (perigoniun ๑: Beger og Krone) og af 2 indre Bladkredse, som paa Grund af deres sarlige plysiologiske Bestemmelse kaldes Befrugtningsáele (genitalia) s. Støvdrager og Støvvei. En Blomst kaldes ufuldstcendig, nuar den mangler en eller flere Bladkredse.

Blomsterdække (perigonium), s. Blomst. Enkelt $B$. er et saadant, hvor enten den ene Kreds (Bæger eller Krone) mangler eller hvor begge disse ere hinanden aldeles lige indbyrdes i Form, Storrelse og Farve. Bladene i det enkelte Blomsterdakko kaldes Ferigonblade.

Blomsterknop (alabastrum) s. Bladknop.

Blousterkop (cyaminm) kaldes den for Slægten Enphorbia særegne Plonsterstand, i hvilken der i Midten findes en stilket Hunblomst, de $r^{\circ}$ omgives af en Kreds enblomstrede, nøgne, enhannede Hanblomster med særskilte Drkblade, og udenfor disse Dele et fælles sambladet Hylster (Kopdcelke).

Blousterkurv (calathium) s. p. 554.

Blomsterleie (anthoclinium) s. p. 554.

Blomsterskjæl (lodicula) Græsarternes Blomsterdække (indenfor Inderavuerne), dannet af $2-3$ smaae bindeagtig-gjennemsigtige, helo eller tofligede Skjæl.

Blousterstand (inflorescentia) en Samling af Blomster, som sidde i Nærheden af bverandre paa en fælles Axedeel (Blomsteraxen eller Blomsterstandens Axe). Efter dennes Beskaffenlied og Blomsternes Udvikling paa samme kaldes B. forlænget eller forkortet, begrændset eller ubegræendset, enkelt eller sammensat.

Blomsterstilk (pedunculus), den Forgrening af Blomsteraxen, som umiddelbart bærer Blomsten. Naar flere stilkede Blomster udgaae fra en fielles Blomsterstilk, kaldes de enkelte Blomsters Stilke Snaa. blomsterstille (pedicelli).

Blodpigge (murices, echini) ere stikkende, men urteagtige og temmelig bløde (ikke træagtige) Fremragninger af Overhuden (f. Ex. hos Kapselen af Esculus og Datura, Skaalen hos Fagus og Castanea).

Bractée s. Doekblad.

Bredvægget (latiseptus) s. pag. 471.

Buddike (theca, pyxidium), en paatværs opspringende Kapsel, ved hris Aabning et Laag (operculum) adskilles fra Kapselens nedre, vedblivende Deel (f. Ex. hos Hyoscyamus, Anagallis, Plantago, Bladmosser).

Budt (obtusus), kaldes en Plantedeel med liort og afstumpet, svagt afrundet Spidse.

Buenervet (converginervius), et Blad med ugrenede Nerver, som fjerne sig fra hverandre og danne Buer paa Midten, men lobe sammen mod Spidsen og Grunden (f. Ex. Convallaria majalis, Cephalanther

Bugflade (commissura), den mod Axen indadvendte Flade mellem den yderste Ribbe paa hver Side af Skjærmplanternes Smaafrugter.

Bugsom (sutura ventralis), s. Søm.

Bugtet (sinuatus) kaldes Indskjæringen i Randen af et Blad, naar denne i Dybde staaer omtrent midt imellem det tandede og lappede Blad (f. Ex. Datura Stranonium, Solanum nigrum og villosum). 
Bæger (calyx), Blomsterdæklkets ydre Kreds, hvis Blade kaldes Bagerblade (sepala), naar de ere fuldkomment adskilte fra hverandre (fribladet B.), ere de derimod mere eller mindre sammenvoxne (sambladet B.) faae de frie Dele af Bægeret Navn af Flige eller Tander.

Bælle eller Bælg (legumen), en enkelt, kapselagtig, enrmmmet Frugt, som aabner sig paalangs saavel i Bug- som Rygsømmen, med Frostolen langs Bugsømmen (f. Ex. Erteblomstrede).

Ballekapsel (folliculus), en oftest fleerfoldig, kapselagtig enrummet Frugt, som aabner sig paalangs i Bugsømmen, hvor ogsaa Frøstolen findes, men forbliver lnkket i Rygsømmen (f. Ex. Helleborus, Aquilegia, Sedum, Spirca).

Bær (bacca), en kjødfuld, nopspringende Frugt med oftest flere Frøe. Overscedige $B$. findes hos Convallaria, Asparagus, Solanum, underscedige hos Ribes, Sambucus, Vaccinium.

Barkogle (galbulus) kaldes den bærlignende Frngtstand hos Juniperus (en Art Kogle), i hvilken de nedre Kogleskjæl feilslaae og henvisne, medens de vre (alm. 3) efterhaanden voxe sammen og blive kjødfulde.

Bolget (undulatus) er Randen af et Blad (uden Hensyn til dets Indskjæring) med en ujævn og i flere Retninger foldet Flade (f. Ex. hos Prinula-Arter, Salix nudulata).

Borste (seta): 1, Frugtstilken hos Bladmosserne; 2, Haar, som ere langere og stivere end de sædvanlige, (f. Ex. hos Galeopsis versicolor, Papaver Argemone).

Borsteformet (setrcens) kaldes Blade eller Bladafsnit, som ere saa smale og stive, at de faae Lighed med Haar eller Børster (f. Ex. Bladene af Eleocharis acicnlaris, Potamogeton marinns. Bladafsnittene af Nyriophyllum, Blomsterdækket hos flere Halvgræarter, Avnerne paa Blomsterleiet hos flere Kurvblomstrede).

\section{C.}

Centrifugal (midtpunktfyende) kaldes en Blomsterstand, naar de indre (eller øvre) Blomster ndvikles for de ydre (eller nedre); den modsatte Orden i Blomsternes Udvikling kaldes centripetal (midtpunktsøgende).

D.

Dusk (thyrsus), en klaseformet Blomsterstand med korte Grene og derved sammentrængte Blomster (f. Ex. Ligustrum, Alopecurus, Psamma).

Duunhaaret (pubescens) kaldes Plantedelenes Beklædning, naar Haarene ere korte og meget bløde.

Drærggreen (brachyblastus), en Green med meget korte Ledstyliker og knippeformigt sammenhobede Blade (f. Ex. Larix, Pinus o. fl. Træer).

Da: blad (bractea), det støttende Blad ved Grunden af en Blomst eller Blomsterstand, som ofte har Lighed med Blomstens Dele, uagtet det ilkke egenlig henhorer til disse, og derimod i Form, Størrelse ng Farve afviger fra de alm. Blade. I en sammensat Blomsterstand faae de D., som udgaae nedenfor Smaablomsterstilkene og umiddelbart stotte de enkelte Blnmster, Navn af Smaadccliblade 
(bracteolæ). De i Regelen smaae, hindeagtige og skjællignende D. hos Halvgræasarterne kaldes Doekskjoel.

\section{E.}

Elliptisk (ellipticus) er en Plantedeel med bueformet Omrids, ontrent dobbelt saa langt som bredt, bredest paa Midten $\mathrm{og}$ spidst tillobende mod Grumden og Spidsen.

Eubo (monoecus) ere Srerkjønsplanter med Han- og Hunblomster paa samme Plante.

Endestillet (terminalis), et Organ, som afslutter en Axedeel. I Modsatuing hertil kaldes sidestillet (lateralis) ethvert Organ, der udgaater fra Siderne af Axedele, og sarligt axelstillet (axillaris), naar det udgaaer fra Bladvinkelen. Endestillede Blomster kunne stundom faae Udseende af at vare sidestillede, naar de boie sig til Siden og det stottende Blad derimod gaaer lige i Veiret ligesom en Fortsattelse af Axen, dette kaldes falsh sidestillet (f. Ex. Kolbeu hos Acorus, Qvasten hos Juncus effusus o.s. v.).

Ensidig (secundus) er deu Stilling af Blomster eller Blade, naar disse, selv om de udgaae fra flere Sider, dog alle ere vendte $\mathrm{i}$ een Retning (f. Ex. Blomsterne af Pyrola secunda, Epipactis atrorubens). Dut modsatte Forhold benæevnes alsidig.

Euskjonnet (homoganus) kaldes forste Orden i den 19de linnéiske Klasse (de Kurvblomstrede), hvor Kurvene indeholde lutter Tvekjønsblomster. Er der derimod T'vekjønsblomster i Skiven, men 1 eller flere Rækker Hunblomster i Randen af Kurven, kaldes denne forslijellighjomnet (heterogamus).

F.

Falsk fjernervet (s. fjernervet).

Falsk Frugt kaldes i Almindelighed enhver Frugt eller Frugtstand, i luvilken en betydelig Deel er dannet, ikke af Frggjemmet, men af andre Plantedele, og sarligt naar disse, Frugten ikke egenligt til. horende Dele ere starkt og iøinefaldende udviklede, f. Ex. Hybenog Ablefrugter, hvor Underbægeret, Morbær, hvor Blomsterdækkeme udvoxe og blive kjodfulde imod Modenheden.

Falsk sidestillet (s. endestillet).

Fane (vexillum), det overste, i Almindelighed større Blad i Firteblomsternes Krone, som i Knopleiet bedækler de øvrige Kronblade.

Fjerfliget (pinnatifidus), et fjernervet Blad med Indsuit mellem Sidenerverue, som naae over Halvveien af Afstanden melleın Randen og Midtnerven. (Kaldes ogsaa habvinnet.)

Fjernervet (penninervius), et Blad, i hvilkeit en stæerkere Nerve løber paralangs fra Bladets Grund til dets Spidse og deler Bladet i 2 Halrdele; fra deme Hoved- eller Midtnerve udgaae nindre og alm. yderligere forgrenede (Side-) Nerver. Falsk fjernervet (spurie p.) kaldes Bladet, naar den storre Nerve i Midten er dannet af flere ugrencde Nerver, som ved Grunden ere forenede, men efterliaanden bøie sig ud mod Bladranden (f. Ex. Calla). 
Fjersnitdeelt (pinnatisectus) er et fjernervet Blad med dybere Indsnit end det fjerfligede, som naae indtil eller henimod Midtnerven.

Filt (tomentum), hvoraf Benævnelsen filtet (tomentosus), en tæt, kort og blød Beklædning af Plantedelene, som derved alm. faae en graaagtig Farve, idet den tætte Haarbeklædning skjuler Overfladen af vedkommende Plantedeel.

Fingret eller fingerdeelt (digitatus), et haandnervet, sammensat Blad, hvis Smaablade ndgaae fra eet Punkt til flere Sider (f. Ex. Kløver, Potentil). Kaldes ogsaa koblet og betegnes noiere efter Antallet af Smaablade, f. Fx. trekoblet, femkoblet o.s. v.

Finnet (pinnatus), et fjernervet, sammensat Blad, hvis Smaablade udgaae fra forskjellige Punkter af den fælles Bladstilk (Midtnerven). Man skjelner mellem ligefinnet og uligefinnet, i forste Tilfielde ender Bladet med et Bladpar, i sidste med et umage Blad, og mellem modsatog afvexlende finnet, eftersom Smaabladene sidde parviis ligeoverfor hinanden eller afvexle.

Fladkravet (hypocrateriformis), en Krone med Kraven vaudret udstaraende fra det i Regelen temmelig lange og valseformede Rør (f. Ex. Primula grandiflora, Anchusa officinalis).

Fleerbo (polygamus) kaldes Planter, som bære baade Han-, Hun- og Tvekjonsblomster (f. Ex. Acer, Parietaria, Fraxinus).

Fleerfoldig (Fleerfoldfrugt), kaldes flere Frugter indenfor een Blomst, som fra Begyndelsen af ere fuldstendigt adskilte $i$ deres enkelte Frugtblade (f. Ex. Alisma, Aconitum, Anemone, Geum).

Fliget (laciniatus), et Blad med smale og temmelig dybe Indskjæringer mellem Nerverne, de saakaldte Indsnit (incisuræ); Bladets tilbageblevne Partier omkring Nerverne kaldes Flige (Iaciniæ).

Fnok (pappus), det oversædige Bæeger med haar- eller fjerformet,

- sjeldnere hindeagtig Krave (f. Ex. hos de Kurvblomstrede og Kartebollefamilien, s. p. $554 \mathrm{og}$ 106).

Fodıervet (pedinervius), Blad med en mindre, til begge Sider forgrenet Nerve i Midten og en større, kun opadtil forgrenet Nerve paa hver Side fra Grunden (f. Ex. Petasites, Asarum, Helleborus).

Forskjelligkjonnet (s. Enskjonnet).

Fremliggende (procumbens) eller nedliggende (decumbens), Stæengler, som $i$ hele deres Længde ere udstrakte langs Jordoverfladen, dog uden at slaae Rodder (f. Ex. Veronica hederæfolia, Jinaria Elatine).

Frlbladet (eleutherosepalus eller eleutheropetalus) kaldes Blomsterdækket (Bæger eller Krone), naar dets Blade i deres hele Længdeere indbyrdes adskilte.

Frugt (fructus), den til Modenhed udviklede Frugtknude. Hertil hører Frogjemmet (perispermium), bestaaende af et forskjelligt Antal Frugtblade (carpella) og de deri indesluttede Frøe (semina) o: de udviklede $\mathrm{Eg}$, tilligemed Frøstolen eller Egstolen (spermatophorum), den Deel hvorpaa Frøene ere befastede.

Frugtbund (torus, receptaculum) er Axedelen i den enkelte Blomst, fra hvilken saavel Blomsterdakke som Befrugtningsdele udgaae. Den kan være kegleformigt forlænget, fladt udbredt eller hunl o. s. v. Dersom Axedelen forlænges mellem 2 paa hinanden følgende af Blomstens Bladkredse (f. Ex. mellem Støvdragerne og Støvveien hos silene, Capparis), kaldes denne forlængede Deel af Frugtbunden 
Frugtholder (gynophorum); dersom den øvre Deel af Frugtbunden er forlænget og bærer talrige Fleerfoldfrugter, kaldes den særligt Frugtaxe (f. Ex. hos Myosurus, Batrachinm sceleratum), og i en Spaltefrugt bruges almindelig for den samme Axedeel Benævnelsen Frugtstol (carpophorum), f. Ex. hos Umbelliferæ, Geranium.

Frugtblad (s. Frugt).

Frugtblotist (s. Hunblomst).

Frugthob (sorus) s. p. 750 .

Frugtholder (s. Frigtbund).

Frugtknude (germen, ovarium) er den nederste og alm. tykkeste Deel af Støvveien, som senere udvikles til Frugt og indslutter Egstolen tilligemed Fgene.

Frugtstand er en Samling af flere Frugter, hidrørende fra et tilsvarende Antal Blomster, som have været samlede i en Blomsterstand (f. Ex. Naaletræernes Kogler, Morbær).

Frugtstol (s. Frugtbund).

Fryndset (fimbriatus), Randen eller Overfladen af et bladagtigt Organ, naar samme er deelt $\mathrm{i}$ fine Træoler (f. Ex. Kronen af Menyanthes trifoliata, Lychnis Flos cuculi).

Fro (semen), det fuldt ndvikede og modne $\mathbb{E g}$, bestaaende af Fr $\varnothing-$ skallen (Ágets Hinder) og Kjornen, der enten bestaaer alene af Kimen (embryo) eller tillige at en Frøhvide (albumen), som dannes under Frøets Udvikling enten indenfor Kimsækken (Endosperm) eller udenfor samme (Perisperm).

Froblad eller Kimblad (Cotyledon), den unge Plantes forste Blade, som allerede ere tilstede $\mathrm{i}$ det ndviklede Frø (før Spiringen), hvor de udgjore en betydelig Deel af Kimen. F. er enten udeelt (hos Entrobladplanterne), sjeldnere flere (maaskee rettest 2 til Grunden deelte) F., s. f. Ex. hos Gran, Fyr og Lærke).

Fregjerume (s. Frugt).

Frobile (cauda) kaldes den vedblivende og tilvoxende Griffel hos Pulsatilla, Clematis, Geum o. fl.

Frobud eller Frokappe (arillus) er et fra Frostræengens Udvidelse eller særegne Udvikling hidrorende Legeme, som omgiver en større eller mindre Deel af 'Skallens Overflade hos flere Frøe (f. Ex. Corydalis, Polygala, Euonymus).

Frolivide (albumen), s. Frø. Den kan være melet, kjødfuld, hornagtig o.s. v., og i Forhold til Kimen ligger den enten udenom (periferisk F.), ved Siden af (sideliggende F.) eller indenfor Kimen (central F.).

Frostol (s. Frugt).

Frould (desma), en nldagtig eller haarformet Udvidelse af Frøstrængen (f. Ex. hos Salix, Epilobium).

Fuldstandig kaldes en Blomst, i hvilken alle de 4 Bladkredse (Bæger og Kronblade, Støv- og Frugtblade) ere tilstede.

C.

Gabeude (ringens), en liwbedannet Krone, hvis 2 Laber ere fjernede fra linanden saaledes, at Svalget kommer tilsyue. 


\section{XXX}

Gane (palatum) kaldes en opadvendt Fold paa flere Maskeblomstredes Underlæbe, som tillukker Kronens Svælg (f. Ex. Linaria, Antirrhinum).

Gjennemvoxet Blad (eg. gjennemvoxende Stængel, caulis perfoliatus), et siddende, skjoldformet Blad, som til alle Sider omgiver Stængelen, der ligesom er voxet igjennem Bladpladen i sammes Midtpunkt (f. Ex. Bupleurum rotundifolium).

Glat (glaber) er en Plantedeel, som mangler enhver Slags Haarbeklaedning.

Guavet (erosus) kaldes Bladranden, naar denne er aldeles uregelmæssigt indskaaren, omtrent som om den var afbidt af Dyrenes Tænder.

Gold Blomst (flos neuter) eller kjonslos er en Blomst, indenfor hvis Blomsterdække der jkke findes Støvdragere eller Støvveie (f. Ex. Randblomsterne af Centaurea, Viburnum Opulus).

Green (ramus) kaldes i Almindelighed enhver Forgrening af Axen (Stængel eller Rod); lyppigt forstaaes herved Stængelens Grene, som i Regelen fremgaae ved Udvikling af Knopper i Bladhjornerne. Man skjelner mellem Hovedgrene (r. primarii), secundcere Grene (r. secundarii ell. ramuli) o. s. v.

Griffel (stylus), Støvveiens mellemste Deel, mellem Arret og Frugtknuden; den er oftest tynd og valseformet, med een eller flere Huulheder eller Gange (Griffelcanal) i det Indre. Fr G. nedentil stærkt opsvulmet ovenfor Frugtknuden, kaldes denne tykkere, stundom vedblivende Deel Griffelfod (stylopodium), f. Ex. hos flere Skjærmplanter.

Griffelstette (androstylium) s. p. 632.

Grubet (favosus, faveolatus), med afvexlende Ophoininger og Fordybninger ved Siden af hverandre (f. Ex. Blomsterleiet hos flere Kurvblomstrede, Frøstolen hos Anagallis, Frugterne los 'Teucrium).

Grundnervet (basinervius) er Bladet, naar Alere grenede Nerver udgaae fra Grunden af Pladen og danme Buer indtil de alle lobe sammen mod Spidsen (f. Ex Erythræa, Plantago major og media).

Grasfrugt (seminium), en nødagtig Frugt med tyndt og hindeagtigt. Frøgjemme, som er nøie sammenvoxet med Frøets Skal (f. Ex. Graminex). Denne Frugtform er i Regelen fri, men hos enkelte Græsslægter er Frugten yderligere sammenvoxet med Inderavnerne (f. Ex. Hordeum).

H.

Haandnervet (palminervius), et Blad med flere lige stærke, grenede Nerver udgaaende fra Bladpladens Grnnd (som hyppigt er opsvulmet til en Knude) og derfra ikke sammenløbende mod Spidsen, men udbredende sig til forskjellige Sider ud imod Bladranden (f. Ex. Malva, Acer, Ribes).

Ilaandlappet, haandfliget, haandsuitdeelt ere haandnervede Blade med forskjellig Dybde af Indskjæring mellem Nerverne (s. fjerfliget o. s. v.).

Haaret (pilosus) er enhver Plantedeel, som er beklædt med Haar (pili) ə: Celler eller Celleıækker, som rage udover Overhuden.

Ilaarformet (capillaceus) kaldes meget fine og slappe Bladflige (f. Ex. af Batrachium heterophyllum og trichophyllum). 
Hageborste (glochis) kaldes stive Haar, som i Spidsen ere tilbagebøiede eller forsynede med 2 eller flere Hager eller Kroge (f Ex. Bregeret af Myosotis, Frugterne at Galium Aparine, Cynoglossum officinale).

Ilalvbusk (suffrutex), en træagtig Væxt, hvis Stængler kun hæve sig ganske lidet over Jordoverfladen (f. Ex. Thymus, Calluna, Helianthemum).

IIalvfinnet (s. fjerfliget).

Ilalvkrands (semiverticillus) kaldes Blomsterstanden hos mange Græsarter, hvor flere Topgrene eller Smaax ere stillede i Krandsform paa den ene, men mangle paa den anden Side af Blomsteraxen. Oftest udgaae disse H..afvexlende i 2 eller 3 forskjellige Retuinger, saa at den samlede Blomsterstand bliver en alsidig og ikke en ensidig Top.

IIalroufattende (s. Omfattende.

Malvskjærm (corymbus), en klaseformet Blomsterstand, hvis nedre Blomsterstilke eller Grene naae omtrent ligesaa høit som de øvre, saa at alle Blomsterne, skjondt de udgaae fra forskjellige Punkter af Stængelen, ligge $\mathrm{i}$ en Flade foroven (f. Ex. Acer platanoides, Prunus Cerasus, de Korsblomstrede før Afblomstringen).

Illaublomst eller Støvblomst (flos masculus), en Særkjønsblomst, som indeholder Støvdragere, men ingen (eller kun ufuldstændige og golde) Størveie. Betegnes med Mærket $\sigma^{*}$.

Hase er et bladagtigt fliget Drkblad, som omgiver Hasselens og Arnbogens Hunblomst og tilvoxer med Frugtens Udvikling, saa at den skinler den største Deel af eller hele Nødden.

Ileelfrugt (holoearpium), en Frugt, som er fremgaaet af en enlig Frugtlinude i en Blomst og ved Modenheden enten forbliver lukket eller aabner sig i Klapper, der tydeligt udgjore Dele af et Hele (jvf. Spaltefrugt og Fleerfoldfrugt).

Heelrandet (integerrimus) er et Blad, hvis Rand er aldeles uden Indskjæering (f. Ex. Syringa, Græsarter og de fleste Enfrøbladplanter). Heelt (integer) kaldes Bladet, naar det er uden dybe Indskjæringer, selv om Bladranden er deelt i svage T'ænder ell. desl.

Ilindefrugt (utriculus), en nødlignende, en- eller faafrøet, men kapselagtig-opspringende Frugt med tyndt, oftest hindeagtigt Frogjemme (f. Ex. Amarantus, Smaafrugterne af Geranium).

Ijjelı (galea) kaldes (paa Grund af Formen) hos Aconitum det stgrre, umage, hættefornigt hvælvede og tarvede Bægerblad, lis Gjogeblomsterne de 5 Perigonblade (i Modsretning til Laelsen), som boie sig sammen med deres spidser i IIjelm- eller Hætteform.

Iljerteformet (cordatus) kaldes Bladpladen, naar den ved Grumden er bred og afruidet med et Indsnit for Bladstilken eller Tilhæitningspunktet og et rundagtigt Ore paa hver Side af dette, samt derpaa javint atsmalnende henimod Spidsen (f. Ex. Tilia, Viola silvatica).

Hjulformet (rotatus) er et sammensat skjoldformet Blad, hvis Smaablade udgaae fra et Midtpunlit til alle Sider (f. Ex. Asenlus, Lupinusj; hj. Krone en sanbladet Krone med meget kort Ror og vandret udstaaende Krave (f. Ex. Rorrago, Myosotis, solemum).

Homninggjemue (neetarium), Udsondring's. eller Opbevaringsstedet for den søde, honningagtige Vædske, som mange Blomster indeholde; de findes oftest ved Grunden af Kronbladene og fremtræde under 


\section{XXXII}

forskjellige Former, f. Ex. som en Honninggrube hos Fritillaria, en Honningfure hos Lilium, Honningkirtler hos Acer o. fl., men hyppigt udsondres Honningvadsken frit i Kronrøret uden særeget Gjemmested (f. Ex. hos Primula, Lonicera, Trifolium).

Hoved eller Blomsterhoved (capitulum), en Blomsterstand af rundagtig Form med forkortet eller til et enkelt Punkt sammentrængt Blomsteraxe og siddende eller yderst kortstilkede Blomster (f. Ex. Trifolium, Armeria, Eryngium).

Hunblomst eller Frugtblomst (flos foemineus), en Særkjønsblomst indeholdende Støvveie, men enten aldeles ingen eller golde Støvdragere. Betegues ved Mærket $q$.

Hybenfrugt kaldes Rosens Fleerfoldfrugt, som er dannet af et Antal Nodder, indsluttede $\mathrm{j}$ det vedblivende og ved Modenbeden kjødfuldt tilvoxende Underbæger.

Hylster (spatha), et Dælsblad, som er større end den Blomst eller Blomsterstand, ved hvis Grund det udgaaer, og som før. Udspringningen indhyller denne. H. er snart farvet, snart gront, hindeagtigt eller endog træagtigt (hos Palmerne), det er enbladet hos Arum, Calla, Narcissus, 2-3-bladet hos adskillige Løgarter, Mais o. s. v.

Hæfterod kaldes de fra Stængelens overjordiske Deel udgaaende Rodtrævler, som befæste Planten til fremmede Lcgemer, men ikke indsuge Næring af disse (f. Ex. Hedera Helix, flere Mosser og I Javarter).

Hovlformet (rumcinatus) kaldes et fjernervet-indskaaret (lappet, fliget eller snitdeelt) Blad, hvis Sidenerver ere rettede nedad og Indsnittene derfor vende opad (f. Ex. Crepis biennis, Taraxaeum offcinale).

Inderarne (s. Avne).

Indrullet (involutus) kaldes Randen af et Blad, naar samme danner en storre eller mindre Bue med Huulheden vendt indad mod Plantens Axe (f. Ex. Carex vulgaris, Agropyrum-Arter o.s.v.).

Indtrykt (retusus) er en Plantedeel med et meget svagt Indsnit $i$ den forøvrigt budte eller afrundede Spidse (med ligesom tilbagekrænget Spidse) f. Ex. Smaabladene af Melilotus officinalis, Medicago lupulina, Skulpen af Camelina foetida.

Jarn (lævis) er Overfladen af Plantedelene, forsaavidtsom Orerhudens Flade er ligelig, uden punktformede eller stribede Fremragninger.

\section{K.}

Kamdeeelt (pectinatus), et fjersnitdeelt Blad, hvis Bladkjød er saagodtsom forsvundet mellem Nerverne og de tilbageblevne Afsnit ere temmelig korte og stive (f. Ex. Myriophyllum vertieillatum, Hottonia palustris).

Kamformet (cristatus), omtrent af Form som en Hanekam (f. Ex. Drkbladene af Melampyrum cristatum).

Kapsel (capsula), en tos, opspringende og oftest fleerfrøet Frugt. Overscedig er K. hos Lilium, Datura, Linaria, undersaedig hos Iris, Campanula, Epilobium. 
Kileformet (euneatus), et Blad med smal og langagtig Plade, som fra en smal Basis jævnt udvides foroven og i Spidsen er afstumpet (t. Ex. hos Euphorbia helioscopia).

Kin (embryo) s. Frø.

Kirtelhaaret (glandulosus), beklædt med Kirtelhaar ग: Haar med en kngleformet Udvidelse i Spidsen, af luvilken der ofte ndsondres en klælbrig Vædske (f. Ex. Rosa rubiginosa, Rubus glandulosus og Radula, Sonchns arrensis).

Kjærneæble (s. LEblefrugt).

Kjol (carina) benæones de 2 nedre Blade af Erte-Kronen, som have adskilte Negle, men hvis Plader eru sammenvoxne saaledes, at de danne et baadformet, udadtil ofte skarplkjølet Legeme, der om. slutter Befrugtningsdelene.

Kjolformet (carinatus) ere Bladene f. Ex. hos flere Græs- og Halvgræsarter, hvor de 2 Sider af Bladpladen danne en Vinkel og Midtnerven en skarpt fremspringende Kant.

Kjonsles Blomst (s. gold).

Klase (racemus), en Blomsterstand med forlænget Blomsteraxe og stilkede Blomster, som udvikles i Ordenen franeden opefter. Den fæelles Blomsterstilk, som bærer Klasen, kaldes Klasestill (f. Ex. Prunus Padus, Veronica Chamædrys og Beccabunga!.

Klattrende (scandens) kaldes en Plante, som ikke ved Stængelens egen Slyngkraft, men ved egne Redskaber (Slyngtraade eller Hæfterodder) fasthæftes til freminede Gjenstande og derved holdes opreist.

Klokkeformet (campanulatus), et Blomsterdække (Bæger eller Krone, som er indsnøret paa Midten og udvidet saavel nedenfor Midten som foroven imod Kraven (f. Ex. Campanula, Atropa, Vaccinium Vitis idæa).

Knapbaand eller Støvknapbaand (connectivum) s. Støvdrager.

Knippe (fasciculus), en qvastformet Blomsterstand med korte Grene eller Blomsterstilke, livorved Blomsterne blive tæt sammenhobede (f. Ex. Dianthus Armeria og barbatıs, Juncus effusus). Knippestillede (fasciculati) kaldes de tæet sammentræugte Blade paa en Dværggreen (s. d. A.).

Knol (tuber), en underjordisk, opsvulmet, ofte kjødfuld Stængeldeel, som indeholder en eller flere Knopper (f. Ex. Orchis, Solanum tuberosum, Scirpns maritimus).

Knop (gemma) er den sammentrængte og endnu uudviklede Begyndelse til en Axedeel med tilhørende Blade, i livilken Bladene ligge sammenfoldede paa forskjellig Maade omkring den forkortede Axe. K. i Stængelens eller Grenenes Spidse kaldes Endeknop, hvorimod de gvrige K. (Sideknopper) i Regelen fremkomme i Bladhjørnerne, sjeldnere par tilfaldige Steder udenfor disse.

Knopskjæl (perulæ) benærnes de skjæltormede, hinde- eller læderagtige Bladskeder uden Plade, som omgive Knoppen og beskytte den om Vinteren, men falde af red Lovspringet.

Knudret (nodosus, tuberculatus) er en Plantedeel, som er ujærn af større eller mindre Knuder eller Vorter.

Kuaboiet (geniculatus) kaldes en Strengeldeel, som paa et eller flere Steder (ved Ledene) er bøiet saaledes, at det ene Ledstykke dauner en Vinkel med det nestfolgende (f. Ex. Alopecurus genicnlatus). 


\section{XXXIV}

Koblet (s. fingret).

Kogle (strobilus), Frugtstanden lios Naaletræerne, i hvilken flere, $\bar{x}$ Alm. ved Modenheden træ- eller læderagtige, aabne Frugtblade (Kogleskijocl) sidde axformigt ordnede omkring en fælles Blomsteraxe og indenfor hvert Skjæl alm. 2 eller flere nøgne Frøe.

Kolbe (spadix), en axformet Blomsterstand med kjødfuld Axe og smaae, ofte ufuldstændige Blomster alm. indsænkte i Axen (f. Ex. Arum, Calla, Acorus).

opdakke (s. Blomsterkop).

Korthaaret (hirtus) kaldes Plantedelenes Beklædning, naar Haarene ere korte og temmelig stive (f. Ex. Thrincia hirta, Ranunculus lanuginosus).

Krands (verticillus) kaldes en Samling af flere Blade (Bladkrands) eller Blomster (Blomsterkrands), stillede i samme Hoide men udgaaende fra forskjellige Sider af Stængelen, deraf Benævnelsen lkandsstillet (verticillatus), med Angivelse af, hrormange Blade (eller Blomster) der udgaae fra samme Punkt (f. Ex. 4 hos Galium boreale, 3 hos Juniperus). Falsk krandsstillede kaldes de modsatte Qvaster eller Nøgler hos flere Læbeblomstrede, som ved Blomsternes tætte Sammenhobning faae Udseende af at være krandsstillede.

Krave (limbus), den øverste, bredere og oftest tandede eller fligede Deel af et sambladet Blomsterdække.

Krone (corolla), den indre af Blomsterdækkets Kredse, som oftest farvet (sjeldnere gron). I den fribladede $\mathrm{K}$. kaldes de enkelte Blade Kronblade (petala), i den sambladede skjelnes mellem Kronroret og Kraven, den sidste er ofte mere eller mindre dybt deelt, og efter Indsnittenes Dybde benærnes Kravens frie Stykker mellem Indsnittene Kronflige eller Tænder.

Krukk eformet (urceolatus), en sambladet, regelret Krone med oppustet Rør og lille, indsuøret Krave (f. Ex. Erica Tetralix, Vaccinium nliginosum).

Krybende (repens) kaldes Strngelen, naar den er udstrakt langs henad Jordoverfladen og tillige skyder Rødder enten $\mathrm{i}$ hele sin Længde eller idetmindste ved Ledene.

Kræmmerhuus (ochrea), en Axelbladdanuelse hos Polygoneæ, dannende et enkelt, foroven fliget eller fryndset Rør indenfor Bladstilken og ikke sammenvoxet med denne, men ofte omfattende Stængelen.

hurvdække (periclinium) s. pag. 554.

Kolleformet (clavatus) kaldes Kronen, naar Røret er smalere forneden og bliver jwvnt tykkere opadtil, med en meget liden Krave (f. Ex. Symphytum officinale).

\section{L.}

Lancetformet (lanceolatus) er et bladagtigt Organ med omtrent 3 Gange større Længde end Brede, spidst udlobende foroven og forneden og par Siderne begrændset af Buer (f. Ex. Salix alba, lanceolața, acutifolia).

Lappet (Iobatus) kaldes et Blad, hvis Indskjæringer ere brede, men ikke dybe $\supset$ : omtrent naaende Bladpladens Midte. Indskjæringerne kaldes her Bugter (sinus) og de fremstaaende Stykker af Bladpladen Lapper (lobi). 
Ledballe (lomentum), en Bælle som er afdeelt ved Skillevægge paatværs mellem Froene og iklie aabner sig paalangs, men enten forbliver nopspringende eller adskilles i de enlselte Led efter Tværskilleværgene (f. Ex. Ornithopus, Hedysarum).

Ledskulpe (s. Skulpe).

Ledstykke (internodium) kaldes Afstanden mellem de 2 hinanden næermeste Led (nodi) af Stangelen. De ere forlcengede, naar Ledene ( $\mathrm{g}$ Bladene) ere fjernede fra hinanden, forkortede, naar Ledene og de fra samme udgaaende Blade ere saa tæt samlede, at deres indbyrdes Afstand er utydelig.

Ligefinnet (paripinnatus) s. finnet.

Linieformet (linearis) er et Blad, hvis Rande danne mere eller mindre rette og parallelt løbende Linier, saaledes at Bladet er næsten ligebredt overalt (f. Ex. Zostera, Potamogeton obtusifolius, Græsarterne).

Lyreformet (lyratus), et fjerfliget eller fjersnitdeelt Blad, hvis Endeflig eller Endeafsnit er meget større end Sidefligene (f. Ex. Geum rivale, Senecio Jacobæa).

Labe (labellum), det nedadvendte Perigonblad i den indre Kreds af Gjøgeblomsternes Blomsterdække, som i Form, Størrelse o. s. v. er forskjelligt fra Blomsterdækkets svrige Blade.

Læbedannet (labiatus) s. tolcebet.

Log (bulbus), en underjordisk Knop af oftest rundagtig Form, dannet af en kort, sammentrængt Axedeel (Lggkagen), og derfra udgaaende forneden Rodtrævler, foroven kjødfulde, enten taglagte eller coneentriske Blade (Logskjæl), f. Ex. Allium, Tulipa, Gagea.

Legknop eller Yngleknop (bulbillus) en over- eller nnderjordisk Knop, som ikke udvikles til en Green paa Moderplanten, men tidligt frigjøres og danner en ny Plante (f. Ex. Polygonum viviparnm, Dentaria bulbifera, Allium oleraceum, Saxifraga granulata).

Legknol (bulbotuber) er forskjellig fra Løget derved, at Axedelen (Løgkagen) er stærkere udviklet, kjødfuld eller meelstofholdig, Knoppen derimod lille og omgivet af de visnede eller optrævlede Løgskjæl (f. Ex. Crocus, Giladiolus).

Lov (frons) kaldes Brægnernes Blarle, som ere eiendommelige derved, at Sporehusene sidde i Frugthobe paa Bagsiden. L. (thallus) kaldes hos de lavere Sporeplanter en F'orening af Axen og Bladdele, af neget forskjellig Form og oftest af en ikke grøn Farve (f. Ex. Marchantia polymorpha, Alger og Lavarter).

\section{M.}

Maskeret (personatus) s. pag. 432.

Mellembrudt (interruptus) kaldes et $\mathbf{A x}$, naar Blomsteraxen ikke overalt bærer Blomster, men er nøgen i større eller mindre Mellemrum (f. Ex. Carex divulsa, Arnm maculatum); mellembrudt-fjersnitdeelt (interrupte pinnatisectus) er et Blad med afvexlende større og mindre Afsnit (t. Ex. Geuın rivale, Poterium, Potentilla anserina).

Mllemstok (s. Rodstok).

II Hoide af Strengelen (Spidsen af et Ledstykke), men vende til forskjellige Sider (f. Ex. Lonicera, Syringa, Læbeblomstrede). 
Muurskeeformet (deltoideus), et Blad, begræendset af rette Linier, skjævt firekantet i Omrids, med Firekantens korteste Sider mod Grunden, de læengste mod Spidsen (f. Ex. Atriplex hortensis, arenaria). (Staaer i Form omtrent midt imellem det rudeformede og spydformede Blad).

\section{N.}

Naaleborste (aciculus), stive, stiklkende Haar, som danne en Overgang fra de egenlige Haar til Barktorne og alm. forekomme blandede med disse sidste (f. Ex. hos Rosa spinosissima, Rubus hirtus, Radula o. s. v.).

Naaleformet (acicularis), Bladene los Pinus, Abies, Ulex o, fl, Bracteer og Svobblade hos Characeerne.

Naalehuus (vaginella), en Samling af vedblivende eller kun tildeels affaldende Knopskjæl, som i Form af en lille Skede omgive Drærggrenene af Larix, Pinus o f. Naaletraer.

Navle (hilum) kaldes det Sted paa Frots ydre Skal, hvor denne har været tilvoxet til Frøstrængen eller Frøstolen og ved Modenheden er losrevet derfra, kjendelig i Almindelighed ved en anden Farve end den ovrige Froskal; den er meget stor hos Asculus Hippocastanum.

Nedliggende (decumbens) s. fremliggende.

Nedlobende (decurrens) er et siddende Blạd, hvis Substans er forlienget nedad Stængelen (nedenfor Pladens Tilhæftuingspunkt), hvorved denne bliver vinget (f. Ex. Verbascum Thapsus, Symphytum officinale, Carduus crispus.

Negl (unguis) er den nederste, smalere og stilkformede Deel af et Bager- eller Kronblad.

Nikkende (nutans) kaldes en Blomst eller Blomsterstand, som paa Grand af at Blomsterstilken eller Stangelens øvre Deel er boiet i en Bue, vender nedad (f. Ex. Helianthus annuus, Cardnus nutans, Scliedonorus asper).

Nyreformet (reniformis), et Blad med større Brede end Længde, afrundet foroven og med 2 rundagtige Lapper ved Grunden samt imellem disse et Indsnit ved Bladstilkens Udgangspunkt (f. Ex. Asarum europæum, Viola palustris).

Næb (rostrum) kaldes den smalere Deel af flere Frugter, oftest dannet af Bagerrorets Forlangelse udover den undersædige Frugt (f. Ex. Taraxacum, Tragopogon, Anthriscus).

Nod (nux, caryopsis) en en- eller faafrøet, uopspringende Frugt med tørt Frøgjemme.

Nogen (nudus) kaldes: 1, Blomster som mangle Blomsterdække (f. Ex. Fraxinus excelsior, Salix, flere Halvgræesarter); 2, Blomsterdækket hos de Kurvblomstrede, naar dette manglex Avner (f. Ex. Bellis, Matricaria); 3, Bladenes Overflade, naar den mangler den for flere Arter eiendommelige Filt (f. Ex. nogle Arter af Hieracium).

Nogle (glomerulus), en qvastformet Blomsterstand med smaae og kortstilkede Blomster (f. Ex. Juncus conglomeratus, Beta vulgaris, Atriplex arenaria), Nøgleformet (glomeratus) kaldes en anden Blomsterstand, som har Liglied med et Nogle (f. Ex. Krandsene hos Rumex glomeratus). 


\section{XXXVII}

0.

Oliekaualer (vittæ) kaldes de rorformede Gange indenfor Frogjemmet hos de fleste Skjærmplanters Skalfrugter, i hvilke der indeholdes en retherisk Olie. De ere regelmassigt ordnede og i et bestemt Antal for hver Slegt eller Art, deels paa Skalfrugternes Bugflade, deels paa Ryggen mellem Ribberne.

Omfattende (amplectens) kaldes et siddende Blad med 2 Lapper eller Orer ved Grunden, hvormed det omgiver hele Strugelen (f. Ex. Brassica campestris, Turritis glabra). Hulvomfattende (semiamplectens), naar Blidets Ører kun omfatte Strengdlens halve Deel (f. Ex. Crepis tectorum, Hieracium boreale).

Omkringsædig (perigynus) er en Blomst, naar Kurvblade og Støvdragere ere forneden sammenvoxne med Bageret, som hrver sig op og dauner et Rør udenom den frie, ruen i Bagerrorets Huulhed indsankte Frugtknude (f. Ex. Prunus, Lythrum).

Ourendt hjerteformel (obcordatus) er et ved Grunden spidst, foroven efterhaanden bredere og i Spidsen i 2 afrundede Lapper deelt Blad (f. Ex. Smaabladene af Vicia sativa, Oxalis acetosella).

Omrendt ægformel (obovatus), en Plantedeel, som fra en smalere og spids Basis javnt udvides imod den budte eller afrundede Spidse (f. Ex. Bladene af Samolus Valerandi, Skulperne af Isatis tinetoria).

Opret (ereetus) er en Stængel, som fra Grunden af har en lodret Væxt (i Modsætning til den slyngende eller nedliggende Stængel).

Opstigende (adseendens) kaldes Stængelen, naar den fra Begyndelsen er svag og nedliggende, men efterhaanden hrever sig bueformigt i Veiret (f, Ex. Thymus Chamædrys, Juncus lamprocarpus).

Oral (ovalis), et bladagtigt Organ, som er omtrent dobbelt saa langt som bredt, budt eller afrundet ved Grunden og i Spidsen, og hris Sider ere begrandsede af Buer (f. Ex. Pyrus communis, Cotoneaster).

Overlabe (labium superius) s. tolcebet.

Oversadig Blomst (Hos superus, epigynus) er ved Bægerrørets Sammenvoxning ined Frugtknuden hævet op over Frugten, saaledes at Bægerflige, Kronblade og Støvdragere synes at udgaae fra Frugtens Spidse (t. Ex. Iris, Umbelliferæ, Pyrus).

\section{P.}

Parallelnervet (= retnervet).

Penselformet (penieillatus), en Plantedeel med mange Haar ndgaaiende fra eet Punkt (f. Ex. Arrene hos Rumex og mange Grasarter).

Perigonbiade (s. Filomsterdcclie).

Perigyuium, et sambladet, flaskeformet Blomsterdække, som løst omslutter Frugtkmuden og Nodden hos Carex, s. p. 671.

Piilformet (sagittatus) kaldes et Blad med 2 spidse Ører "ved Grunden, som danne en spids Vinkel med Bladstilken, en stump Vinkel med Midtnerven (f. Ex. Sagittaria, Rumex Aeetosa). Halvt piilformede ere Axelbladene hos flere Vieia- og Salix-Arter, idet det indadvendte Ore mangler og saaledes kun begge Axelbladene i Forening frembringe Piilformen.

Plade (s. Bladplade). 
Palerod eller pæleformet Bod er en saadan, hvor Rodens Hovedaxe uafbrudt vedbliver at fortsættes stærkere end Grenene, der udgaae fra samme.

\section{Q.}

Qvast (cyma), en Blomsterstand med begrændset (midtpunktflyende) Udvikling af Blomsterne, saaledes at den midterste eller i Hovedaxens Spidse stillede Blomst udvikles først og derpaa de i Spidsen af Hovedgrenene o. s. fr. Q. er oftest flad foroven, hyppigst deelt i 2, stundom i flere Grene, den er regelmassig hos Erythræa, Hypericum, Cerastium o. fl., ensidig hos de Rubladedes Familie, hvor bestandig kun den ene Green kommer til Udvikling, og Blomsterstanden derved faaer Lighed med en ensidig, forneden gaffeldeelt Klase eller Ax.

\section{R.}

Rakle (amentum), en axformet Blomsterstand med Særlijønsblomster (Han- eller Hunrakler) og alm. et meget ufuldstændigt Blomsterdakke eller nøgne Blomster, som derimod beskyttes af skjælformede Drkblade (Ralileskjael). R. er enten enbo (Birk, Al, Avnbøg) eller tvebo (Pors, Piil, Poppel), og nogle Planter have knn Hanblomsterne ordnede i Raliler, medens Hunblomsterme ere stillede $i$ en anden Blomsterstand (f. Ex. Corylus, Jnglans).

Randblomst (s. p. 554).

Randkrone. Kronen af Randblomsterne er ofte af forskjellig Form fra Skiveblomsternes, f. Ex. de udstraalende tungeformede Kroner lıos Aster, Chrysanthemum o. fl., hvis Skivekroner ere regelmæessig rørformede.

Randhaaret (ciliatus) er et fladt (alm. bladagtigt) Organ, naar samme i Randen er forsynet med Haar, medens den yvrige Flade enten er glat eller svagere haaret.

Ranke (sarmentum), overjordiske Sidegrene fra Rodstokken af Fragaria, Potentilla reptans o. fl., som ved Ledene ere bladbrende og rodslaaende, men forøvrigt bladløse.

Regelmæssig eller regelret (regularis) kaldes et Blomsterdække (Bæger eller Krone), hvis enkelte Dele ere lige i Form og Stgrrelse, ligesom ogsaa Mellemrummene mellem Bladene eller Fligene ëre ligestore. Ere Delene derimod ulige i Form eller Størrelse, kaldes Blomsten uregelmcessig (irregularis).

Retnervet (rectinervins) er et Blad med flere ngrenede Nerver, som lobe i en ret Linie og oftest parallelt fra Grunden til Spidsen (f. Ex. hos de fleste Græsarter).

Rlbbe (costa) kaldes en fremspringende Linie, oftest hidrørende fra Nerver eller sammenstødende Bladrande langs nedad en af sammenvoxne Blade dannet Plantedeel, f. Ex. Bæger, Frugt o. s. v. Paa Skjærmplanternes undersædige (med Bægerioret sammenvoxne) Frugter findes hos hver Slagt et bestemt Antal R., og man skjelner mellem Hovedribberne (alm. 5, dannede af Nerverne) og Biribberne (alm. 4, dannede af de nediøbende og sammenvoxne Bladraude.

Riflet (tesselatus) er en Plantedeel, som er forsynet med fremspringende Linier eller Længdenjævnheder, som i forskjellige Retninger krydse hverandre. 
Rod (radix), Plantens nedadvoxende, foroven alm. tykkere og forneden tilspidsede Axedeel. Fra Rodens Hovedaxe eller Rodhalsen udgaae Grene og finere Trævler, stundom meget fine Rodhaar.

Rodblade (folia radicalia), de nærmest ved Roden stillede, egenlig fra Strengelens nederste eller underjordiske Deel udgaaende Bíade, som i Regelen ere forskjellige fra de langs opad Strngelen siddende Blade.

Rodbals kaldes den ofte indsnørede Grændseflade mellem Stængelen og Roden.

Rodhatte (spongiola radicalis), en Overhuddannelse, som hos mange Planter mere eller mindre lost omgiver de yngste Spidser af Rodtrevlerne (f. Ex. hos Lemna).

Rodskud (turio), s. Aarsskud. Ogsaa hos de urteagtige vedvarende Planter kaldes de Knopper fra kodstokken, som efter Vinterhivilen udvikles og danne nye Stæugler, Rodskud.

Rodslaaende (radicans) $=$ krybende.

Rodstok eller Mellemstok (rhizoma) kaldes hos vedvarende Planter den under Jorden nedsænkte, vedblivende Deel af Stængelen, i Modsætning til deu overjordiske, aarligt bortdøende Stængeldeel. Den nedsender Rødder og bærer i Spidsen en eller flere Knopper (s. Rodskud), som udvikles til overjordiske Stængler.

Rodtravler (s. Rod).

Rosettestillede (rosulati) kaldes Blade, som, udgaaende fra en Strugeldeel med med meget forkortede Ledstykker, ere meget tret sammenhobede og udbrede sig i forskjellige Retninger. Oftest forekomme slige Bladrosetter ved Grunden af Stængelen (Rodblade).

Ru (scaber) er Overfladen af en Plantedeel, naar samme ved talrige korte og stive Børster eller Vorter viser sig meget ujærn ved Beroring.

Rudeformet (rhomboideus) er en Bladplade, som begrendses af 4 rette eller næsten rette Linier, der i Spidsen og ved Grunden danne spidse Vinkler, medens de 2 mellemliggende Vinkler ere stumpe (f. Ex. hos flere Atriplex-Arter).

Rumdelende (loculicidus) kaldes Opspringningen af Kapselfrugterne, naar disses Frugtblade halveres og adskille sig i Rygsømmene, medens Vægsømmene forblive sammenvoxne og Klapperne derfor hyppigt langs deres Midtlinie bære den fremspringende Plade af Skillevæggen, Vægsøınmens Fortsættelse (f. Ex. Syringa, Oenothera, Tulipa).

Rundbugtet (repandus) er Randen af et bladagtigt Organ, naar samme er begrændset af en Bolgelinie med meget svage, men brede Indsnit (f. Ex. Ajuga reptans, Blitum glancum).

Bundtakket (crenatus) kaldes Bladranden, naar den er afbrndt af korte, spidse Indsnit, og de derved frembragte udstaaende Takker ere afrundede.

Rygrsom (sutura dorsalis) s. Søm.

Ryuket (rugosus) er Overfladen af en Plantedeel, som er ujærn af fremspringende, bue- eller bolgeformede og alm. uregelmæssige Linier. (Ofte ere disse Linier frembragte ved Torring).

Ror (tubus) kaldes den nedre, sammenvoxne Deel af det sambladede * Bæger eller Krone, i Modsatning til den frie Deel (Kraven). 
Rorformet (tubnlosus) kaldes Blomsterdækket, naar Røret jærnt og uden kjendelig Indsnøring gaaer over i den alm. oprette eller kun lidet ndstaaende Krave (f. Ex. Primula officinalis, Skivekronerne hos flere Kurvblomstrede).

\section{S.}

Saftplet (gynizns), Arret hos Orchideæ i Form af en Plet eller Fordybning, som er uden Overhud og afsondrer en Vædske (f. Ex. stort hos Platanthera o. fl.).

Sambladet (gamopetalus eller -sepalus) kaldes Krone eller Bæger, naar deres Blade forneden ere sammenhængende og danne et Ror.

Saumensat Blad (folinm compositum) er et Blad, bestaaende af flere Smaablade, som ere tilleddede til en fælles Bladstilk, fra hvilken de løsnes og affalde naar Bladet visner. Smaabladene ere ofte forsynede med en særlig Smaabladstilk, deres Ordning paa den falles Bladstilk er forskjellig (s. fingret, finnet og hjuldannet). Dobbelt sammensat er Bladet, naar Smaabladene atter ere sammensatte (f. Ex. dobbelt finnede Blade hos Acacia lophantha).

Saugtakket (serratus) er Bladranden, naar de korte og ikke dybe Indsnit i samme ere spidse og de af Indsnittene begrændsede Takker ligeledes spidse og vende opad mod Bladets Spidse.

Seglformet (falcatus), jevnt brjet i en halvmaaneformet Bue (f. Ex. Dækbladene af Caliitriche hamulata, Bællerne af Medicago falcata).

Siddende eller stilkløs (sessilis) kaldes Bladene naar Bladstilken, og Blomsterne naar Blomsterstilken mangler.

Sideliggende kaldes Knopleiet, naar Bladenes Rande i Knoppen støde sammen uden at dække hinanden, og Kimen, naar denne i Forhold til Frohviden er saaledes beliggende, at de indtage en Plads ved Siden af hinanden.

Sidestillet (lateralis) s. endestillet.

Silkehaaret (sericeus), beklædt med bløde, korte og tiltrykte Haar, som give vedkommende Plantedeel en silkeagtig Glands.

Skaal (cupula) er den for en Deel af Rakletræerne eiendommelige Drkbladform, hvor en eller flere Nødfrugter ere enten ved Grunden eller heelt omgivne af en kopformet eller kapsellignende Udvidelse af Blomsterstilken, der bærer et storre Antal skjælformede Dækblade (f. Ex. Quercus, Fagus, Castanea).

Skaft (scapus), en Blomsterstængel uden Grene og oftest uden eller med ufuldkomne Blade (f. Ex. Taraxacum officinale, Narcissus, Allium).

Skal (testa), Egets Hinder, som ved Frøets Modenhed danne en tæt $\mathrm{og}$ fast, ofte haard Beklæedning omkring Kjærnen.

Skalfrugt (achæninm), en undersædig, nødagtig Frugt, som er beklædt med Bægerroret og ofte bærer en vedblivende Bægerkrave foroven.

Skede (vagina), Bladets nederste, ofte stærkt udvidede Deel, som sjeldnere er fladt udbredt, men hyppigere omgiver Stængelen enten heelt eller tildeels (f. Ex. Græsarter, Halvgræs og Skjærmplanter).

Skedehinde (ligula), et hindeagtigt Legeme mellem Skeden og Pladen af Græsarternes og Halvgræsarternes Blade; dens Form, Længde og: Retning er meget forskjellig og ofte af Betyduing for Arternes Bestemmelse. 
Sklllerag (dissepimentum), en Flade, som begrændser og adskiller til hinanden stødende Naborum, f. Ex. i Rodstokken af Cienta virosa, Bladene af Juncus lamprocarpus. Særligt betegues derved de Flader, som i Frugter med 2 eller flere Rum adskille disse indbyrdes. Sk. kumne være fuldstændige eller ufuldstændige (det sidste f. Ex. hos Papaver).

Skillevagbrydende (septifragus) kaldes Opspringningen af flere kapselagtige Frugter, hvor Klapperne (o: Frugtbladene) ved Modningen løsıe sig fra den vedblivende Skillevæg (f. Ex..hos Korsblomsterne).

Skillevægdeleude (septicidus) er den Opspringningsmaade, hvorved Frugtbladene ved Modningen adskille sig $\mathbf{j}$ deres naturlige Sammenføiningslinie, iclet de af 2 Nabofrugthlades Sammenvoxning opstaaede Skillevagge halveres (f. Ex. Digitalis).

\section{Skiveblomst}

Skirekrone $\}$ s. p. 564 .

Skjoldformet (peltatus) er et Blad, hvis Stilk er tilhæftet indenfor Randen, alm. henimod Midten af Pladen, hvorved dennes Omrids som oftest bliver kredsrundt (f. Ex. Hydrocotyle vulgaris, Tropæolum majus).

Skjæghaaret (barbatus) kaldes et Organ, som er beklædt med knippefornigt fra eet enkelt Punkt udgaaende Haar (f. Ex. Støvknapperne af Odontites, Griffelen af Vicia).

Skjal (squama): 1, Overhuddannelser, som beklæde Planten og nærmest ere at ansee for omdannede Haar (f. Ex. hos Hippophä̈ rhamnoides, flere Brregner); 2, skedeformede Blade uden Plade og oftest af en ikle gron Farve (f. Ex. hos Asparagus, Orobanche); 3, Drkbladene hos Carex, Rakletræer o.s. v.

Skjarm (umbella), en forkortet Blomsterstand med stilkede Blomster, som ndgaae fra eet Punkt og alın. naae lige høit. S. kan være enkelt eller sammensat, i sidste Tilfælle kaldes de secundrere ligeledes shjærmformede Blomsterstande Smaaskjorme (f. Ex. hos Umbelliferæe).

Skulpe (siliqua), en kapselagtig Frugt med 2 Rum, adskilte ved en hindeagtig Skillevæg, soin tilligemed de vægstillede Frystole bliver staaende tilbage naar Klapperne (Frugtbladene) ver Modningen adskille sig franeden paalangs og falde af. Smaaskulpe (silicula) er en Form af S. med omtrent lige stor Langde og Brede, hos Storsliulpen er Længden meget stgrre end Breden. Ledskulpen aabner sig ikke paalangs, men der dannes i denne Indsnøringer paatværs mellem de enkelte Froe (f. Ex. Raphınus Raphanistrum).

Skulpeformet (siliquæformis) kaldes Kapselen hos Chelidonium, som opspringer paa samme Maade som Skulpen, men mangler Skillevæg og som Følge deraf er enrummet.

Slyngende (volubilis), en Stængel, som snoer sig omkring fremmede Gjenstande og derved holder sig opreist uden særlige Redskaber (s. Klattrende), men ved Stængelens egen Spiralkraft, enten tilhøire (f. Ex. Humulus) eller tilvenstre (f. Ex. Phaseolus).

Slyngtraad (cirrhus), et spiralformig snoet Hrfteredskab, som tjener til at holde de klattrende Planter fast ved fremmede Gjenstande. Ifolge dens forskjellige Plads paa Planten kan Slyugtraaden snart udledes af en omdannet Green eller Blomsterstilk, snart af et Blad eller Axelblade (Vitis, Vieia, Bryonia). 
Slor (indusium) kaldes et hindeagtigt Legeme paa Underfladen at flere Brægners Løv, som løsrives fra Overhuden ved Grunden af Frugthobene (s. p. 750) og omgiver disse indtil Sporehusenes Modenhed, da de falde af. Nogle Brægner mangle S., hos andre erstattes det af Løvets tilbagebøiede Rand (falsk S.).

Smaaax (s. $A x$ ).

Smaaxelblade eller Smaabiblade (s. Axelblade).

Smaablad (foliolum) s. sammensat Blad.

Smaablousterstilk (s. Blomsterstilk).

Smaafrugter (carpidia, mericarpia) benævnes i en fleerfoldig Frugt eller Spaltefrugt de enkelte selvstiendige Frugter af forskjellig Art, som udvikles indenfor eet Blonsterdække (f. Ex. Aquilegia, Anemone, Acer, Skjærmplanter).

Smaaskjærm (s. Skjoerm).

Swalvagget (angustiseptus), s. p. 470.

Snitdeelt (sectus) kaldes Bladets Indskjæring naar denne naaer lige indtil eller næsten til Midtnerven (fjersnitdeelt) eller til Grunden (haand- eller fodsnitdeelt). De Stykker, hvori Bladet er deelt, kaldes Afsnit, disse blive ikke, naar Bladet visner, adskilte fra den fælles Bladstilk, men vedblive fastsiddende paa denue. Dobbelt eller fleerdobbelt $s$. ere Bladene, naar Afsnittene ere yderligere deelte paa denne Maade en eller flere Gange (f. Ex. hos flere Skjærmplanter).

Spadeformet eller Spatelformet (spathulatus), fra en smal og forlænget Basis jæevnt ndvidende sig til en budt eller afrundet Spidse (f. Ex. Bladene af Bellis perennis, Kronbladene af Rubus saxatilis).

Spaltefrugt (schizocarpium), en Frugt bestaaende af flere Frugtblade, som før Modenheden ere sammenhængende, men ved Modningen adskilles i lige saa mange selvstændige Frugter som der er Frugtblade tilstede. (S. er todelelig hos Acer, Mercurialis, tredelelig bos Euphorbia, firedelelig hos Labiatæ og Asperifoliæ, mangedelelig hos Malva).

Spore (calcar), en tilspidset, alm. kegleformet, ret eller bøiet 'Tilhængsel til et eller flere af Blomsterdækkets Blade (f. Ex. hos Bægeret af Delphinium, Kronen af Linaria, Blomsterdækket af Orchis).

Sporer (sporæ, sporidia) kaldes de encellede Formeringsorganer hos de saakaldte Sporeplanter; de ere enten frie eller indesluttede $\mathrm{i}$ et Gjemme, Sporelıuus (sporangium).

Spredte (sparsa) kaldes Blade eller Grene, naar der af disse kun ndgaaer eet fra hvert Led, i Modsætning til de modsatte eller krandsstillede Blade, hvor flere Blade udgaae i lige Høide fra samme Led. De spredte Blade ere hyppigst ordnede $\mathbf{i}$ et bestemt Talforhold, idet de enten ndgaae i $2(1 / 2), 3(1 / 3)$ eller $5\left({ }^{2} 5\right)$ sjeldnere i endnu flere forskjellige Retninger.

Spydformet (hastatus) er Bladet, naar fra dets Basis udgaaer 2 større fremspringende Lapper, en til hver Side, som danne en ret Vinkel med Bladets Midtnerve (f. Ex. Blitum bonus Henricus, Rumex Acetosella).

Stak (arista) er en lang og tynd, tilspidset og ofte stikkende Tilhængsel paa Blomstens forskjellige Dele eller Bladene; især er Stakken almindelig paa Græsarternes (nedre) Inderavne, hvor den 
enten danner en ligefrem Fortsæettelse af Avnens Spidse (Byg) eller træder ud nedenfor Spidsen, fra Midten eller fra Grunden (Bromus, Avena). Stakbcerende (aristatus) kaldes en med Stak forsynet Plantedeel, staklos (mnticus) en Plantedeel som mangler S.

Steenfrugt (drupa), en oftest enfroet, uopspringende Frugt med tynd Overhud, kjødfuldt og saftigt Mellemlag, hvis indre Parti er haardt og træagtigt (Stenen). S. er enkelt hos Prunus, Juglans, sammensat (fleerfoldig) hos Rubus.

Steenbær (pyrenium) kaldes Frngten hos Ilex n. fl., den er forskjellig fra Steenfrugten derved, at den har flere Froe og flere Rum med haarde, ofte træagtige Skillevægge.

Steenable (s. ZEblefrugt).

Stivharet (hispidus) kaldes Plantedelenes Beklædning, naar Haarene ere stive og udstaaende.

Stjernehaar kaldes Haar, som fra Grunden af ere forgrenede, med Grenene straaleformigt udgaaende til forskjellige Sider og alm. tiltrykte til den Plantedeel, de beklæde (f. Ex. Bladene af Potentilla incana, Malva Alcea).

Storskjærm s. Slijcernı.

Straa (culmus), Gresarternes Stængel, som har forlængede, indvendig hule Ledstykker, adskilte fra hinanden ved opsvulmede Led og med spredte, omskedende Blade.

Straaleblomster laaldes de Kurvblomstredes Randblomster, naar disse lave tungeformede Kroner, medens de indre (Skiveblomsterne) ere rorformede (Blomsterkurven kaldes i dette Tilfælde udstraalende).

Stæugel (caulis), Plantens opadvoxende Axedeel, som bærer Knopper, Blade og Blomster.

Stængelblade (s. Rodblade).

Stov eller Blomsterstøv (s. Støvdrager).

Storblomst (s. Hanblomst).

Stovdrager (stamen), det mandlige Befrugtningsorgan i Blomsten, bestaaende af Stovtraaden (filamentum) den nedre, smalere, ofte traadformede Deel, Støvknappen (anthera), den øvre, bredere Deel, oftest bestaaende af 2 Rum, som ved Bestøvningen aabne sig, og Støvknapbaandet (counectivum), en Fortsattelse af Støvtraaden igjennem Støvknappen, hvis Rum det adskiller. I det Indre af Rummene indeholdes Blonisterstovet (pollen), fine Korn af forskjellig Form, bestaaende af en enkelt Celle omgivet af 2 Hinder.

Stovholder (retinaculum) er en klsebrig Kirtel ved Grunden af Støvmasserne hos Orchideæ og Asclepiadeæ; ved denne fastklæbes Støvmasserne til Griffelstøtten.

Storkuap (s. Støvdrager).

Stovmasse (pollinium) kaldes Stóvet hos enkelte Familier (Gjøgeblomster og Svalerodsfamilien), naar dets enkelte Korn ikke ligge frie $o g$ indbyrdes adskilte, men ved et klæbrigt Stof ere forenede til en sammenhæugende, kornet eller voxagtig Masse.

Stortraad (s. Støvdrager).

Storvei (pistillum), Blomstens qvindelige Befrugtnirgsorgan, dannet af et eller flere Frugtblade og bestaaende af Frugtknude, Griffel og Ar (s. d. A.). 
Sralg (faux) er det Sted i det Indre af et sambladet Blomsterdakke, hvor Rør og Krave støde sammen.

Srælgkrands (coronula), en i Sṿælget befæstet krandsformet Bikrone (f. Ex. hos Narcissus).

Svardformet (ensiformis) er et overalt ligebredt (kun foroven spidst udløbende) Blad, der ikke, som Græsbladene, vender Fladerne opog nedad, men tilhøire og tilvenstre for Axen, som det omfatter med en tveægget skedeformet Basis. Imod Spidsen er det stundom boiet i Sabelform (f. Ex. Iris, Narthecium).

Srob (involucrum) kaldes en Samling af krandsstillede Drekblade (Svøbblade), som ongive en sammentrængt Blomsterstand (Skjærm eller Hoved, f. Ex. hos Primula, Jasione). Er Blomsterstanden sammensat, kaldes de ved Grunden af dens forste Forgrening stillede Sivobblade Storsvøb, de ved Grunden af Smaablomsterstandene stillede Smaasvøb (involucellnm) f. Ex. hos Skjærmplanterne.

Sylformet (subulatus) er et Blad, som er stivt og temmelig kort, begræendset af 2 rette Linier og fra en bredere Basis jævnt udløbende $\mathrm{i}$ en Spids (f. Ex. Juniperus).

Sarkjonnet (diclinis) er en Blomst, hvis Befrugtningsorganer (Støv: dragere og Støvveie) ikke ere samlede indenfor eet Blomsterdickke, men ere fordeelte $\mathrm{i}$ forslsjellige Blomster, enten paa een eller to Planter (s. Enbo og Tvebo).

Soun (sutura) kaldes fremspringende Linier paa Overfladen af Frugtknuden eller den modne Frugt, de gaae hyppigst paalangs og ere da enten opstaaede af Frugtbladenes Midtnerve (Rygsøm), af deres sammenstødende Rande (Bugsøm) eller af 2 til hinanden stødende Frngtblades Adskillelseslinje (Vagsøm).

\section{T.}

Tandet (dentatus) er et bladagctigt Organ med korte og brede Indskjæringer i Randen, hvorimod de mellem Indskjaringerne fremragende Stykker ere spidse (f. Ex. Bladene af 'Tussilago).

Tllbagerullet (revolutus) kaldes et Blad (i Modsætning til indrullet), naar den Bue, som Bladets Rande danne med dets Midtlinie, vender Hunlherlen hort fra Plantens Axe (f. Ex. Bladene af Vaccinium Oxycoccos, Carex stricta).

Tilhangsel (appendix). kaldes Udvidelser af forskjellig Form udenfor en Plantedeels normale Omkreds (f. Ex. Sporen hos Orchis, Viola, Skjæl i Kronroret af Symphytum, Lapper ved Grunden af Bægerbladene eller Bregerfligene hos Viola og Campanula).

Tilspidset (acuminatus) benærnes et Organ, som foroven udløber i en spids Vinkel med forlangede Sider, og som alm. er pludselig uddraget udover Organets Flade (f. Ex. Bladene af Salix cuspidata, Fagopyrum tataricum).

Tolabet (bilabius, labiatus) kaldes en særegen Form af det ureg lmæssige Blomsterdække (Bæger eller Krone), hvis Blade eller Fli o ere vendte i 2 hinanden modsatte Retninger, det ene opad (Overlaben), det andet nedad (Underlceben). Bruges fortrinsviis om Størstedelen af Planterne i Linnés 14de Classe (Læbe- og Maskeblomstrede). Den tolæbede Krone har alm. en tvedeelt Overlæbe, 
tredeelt Underlæbe, hvorimod det omvendte Forhold findes hos det labedannede Brger.

Tomagtig (didynamus) kaldes Stovdragerne, naar 2 ere læengere, 2 kortere (f. Ex. Lamium, Linaria).

Top (panicula), en Blomsterstand med forlænget Hovedaxe og lange, grenede, oftest mangeblomstrede Sideaxer, som aftage i Længde nedenfra opefter, hvorfor Blomsterstanden alm. bliver pyramideformet (f. Ex. Avena, Poa, Alisna).

Topskydende eller topspireude (prolifer) er en Plante, his Blomster heelt eller tildeels omdannes til Blade (hyppigt er det Folge af en Misdannelse, normalt er det Tilfældet hos Polygonum viviparum, Poa bulbosa var. vivipara).

Toradet (distichus) ere Blad- eller Blomsterdele, naar de ere regelmæssigt ordnede i 2 Rækker langs en Midtlinie (f. Ex. Smaaaxene hos Hordeum distichum, Bladene hos Taxus, Sporehusene hos Ophioglossum).

Tornet (spinosus v. aculeatus), s. Vedtorn og Barktorn. Tornløs (inermis) betegner Mangelen af Torne hos en Plante eller Plantedeel.

Tragtformet (infundibularis) kaldes en regelmæssig sambladet Krone, livis liør fra en snalere Basis gaaer jævnt og umærkeligt over i en udvidet Krave (f. Ex. Datura, Convolvulus).

Trekoblet (s. fingret).

Travlerod (radix fibrosa) er en af flere, omtrent ligestore Rodtrævler (Birødder) dannet Rod, som udgaaer fra Rodstokken, medens Rodens Hovedaxe ikke er udviklet.

Tueformet (cæspitosus) kaldes Planten, naar et stort Antal Stængler (og alm. tillige Rodblade) udgaae fra eet Punkt (f. Ex. Carex cæspitosa, stricta, Aira cæspitosa).

Tungeformet (lingulatus) er en sambladet uregelret Krone, hvis Krave el summenvoxet til eet Stykke nesten til Spidsen og udbredt, oftest vandret, til den ene Side (f. Ex. Smaablomsterne hos Cichoracer, Randblomsterne af Aster, Calendula o. fl.).

Trebo (dioecus), Særkjønsplanter med Han- og Hunblomsterne fordeelte paa 2 forskjellige Planter.

Trekjønnet (hermaphroditus) er Blomsten, naar Støvdragere og Støvveie tindes samlede indenfor eet Blomsterdække.

Trærskillevæg kaldes den Vag, som adskiller 'Trærrummene i de saakaldte Ledballer og Ledskulper (f. Ex. Ornithopus, Raphanus Raphanistrum).

Trærstillet (transversus, versifolius) er en Plantedeel, som er stillet paa en fra den sædvanlige Stilling afvigende Maade, idet den skarpe Kant vender i den ellers for Fladen almindelige Retning (f. Ex. Smaaxene hos Lolium, Bladene af Lactuca Scariola, Bladstilken i Forhold til Pladen hos Populus).

\section{U.}

Udlobere (stolones), underjordiske, mere eller mindre vidtkrybende Sidegrene fra Stængelens nedre Deel eller Rodstokken (f. Ex. Agropyrum repens, Epilobium palustre).

Udramdet (emarginatus) er en Plantedeel, som i den forøvrigt afrundede 


\section{LXVI}

Spidse har et oftest svagt Indsnit eller Indtryk (f. Ex. Skulpen hos Thlaspi arvense, Smaabladene af Vicia sativa).

Udstraalende (s. Straaleblomster).

Ufuldstandig (incompletus) kaldes en Blomst, naar enten et eller begge Blomsterdækker eller et eller begge Kjøn mangle.

Uldhaaret (lanatus, lanuginosus), beklædt med bløde og slappe, oftest meget krusede Haar.

Uligefinnet (s. finnet).

Underbager (hypanthium) kaldes i en oversædig eller omkringsædig Blomst den nedre Deel (Røret) af Bægeret, naar dette har lukket sig omkring og omslutter Frugtbladene, saa at det ved Modningen ofte synes at udgjøre en Deel af Frugten (f. Ex. Rosa, Pomaceæ).

Underlæbe (s. Tolocbet).

Undersædig (inferus) kaldes Blomsten, naar dens Dele sidde i deres naturlige Stilling, saaledes at Bageret er nederst (eller yderst), derpaa Krone, Støvdragere og overst (i Midten) Stovveien. Frugten lsaldes derimod n., naar det modsatte Forhold finder Sted (s. oversaedig Blomst).

Uregelmæssig (s. regelmcessig).

Urteagtig (herbaceus) s. bladagtig. Bruges desuden om Stængler (mods. træagtig) og betegner da, at Sfængelens Dele ere forholdsviis bløde $o g$ af kort Varighed.

V.

Vandgreen (flagellum), bladbærende og langs Jorden udstrakte, men ikke rodslaaende Sidegrene (f. Ex. af Ajuga reptans, Hieracium Pilosella).

Vedtorn (spina), en tilspidset, stikkende Green (f. Ex. hos Prunus spinosa, Cratrgus Oxyacantha), sjeldnere et i Form af en spids Torn omdannet Blad (f. Ex. Berberis, Ulex).

Vinger (alæ) kaldes de 2 midterste, indbyrdes eens og ligeoverfor hinanden stillede Kronblade $\mathrm{i}$ en Frteblomst.

Vingefrugt (samara), en nødagtig, oftest enfrøet Frugt med hindeagtigt eller læderagtigt Frogjemme, som er udvidet i Form af en Vinge til een eller flere Sider (f. Ex. Acer, Ulmus, Fraxinus).

Vinget (alatus) kaldes Stængelen, naar Bladene ere nedløbende og - derved danne en smalere eller bredere, fladt udbredt bladagtig Rand langs nedad Stængelen (f. Ex. Lathyrus silvestris, Onopordon Acanthium).

Vægstillet (parietalis) kaldes Frøstolen i en Frugt, naar den er beliggende $\mathrm{i}$ Frugtens Omkreds og ikke i dens Axe.

Vagsom (s. Søm).

Y.

Yderbæger (ealyculus) s. Bibager.

Yderavue (s. Avne).

A.

Eblefrugt (pomum), en undersædig Frugt med kjødfuldt, mod Frugtmodningen tilvoxende Underbæger, i hrilket Frugtbladene ere ind- 


\section{XLVII}

sænkte. Ere Frugtens Rum enfrøede, med træ- eller beenhaarde Vagge, kaldes den et Steenceble (f. Ex. Cratregns, Mespilus), ere de fleerfroede, med lseder- eller hindeagtige Vrgge, et Kjorneceble (f. Ex. Pyrus).

Eg (ovulum) er et i Frugtknudens Iudre par Agstolen udvoxende Legeme, dannet af en Agkjærne og 1 à 2 Aighinder; efter Befrugtningen udvikles $\mathbb{E}$. til Frøet.

Egformet (ovatus) kaldes en Plantedeel, som er afrundet ved Basis og spids foroven, med den storste Bredo nedenfor Midten (f. Ex. Bladene af Pulmonaria officinalis, Frugten af Castanea).

Ægstol (s. Frugt).

Egstrang (funiculus umbilicalis), en smal, oftest traadformet Stræng, ved hvilken Agene (eller Frøene) ere befaestede til Egstolen. Ertebloust (s. p. 456).

\section{B.}

Oret eller øreformet (auriculatus) kaldes et Blad, som foruden en større Endeflig eller Endeafsnit har 2 mindre Flige eller Afsnit (ligesom Orer) ved Grunden (f. Ex. Senecio aquaticus, Centaurea Jacea). 


\section{T a be 1}

over det linnéiske System.

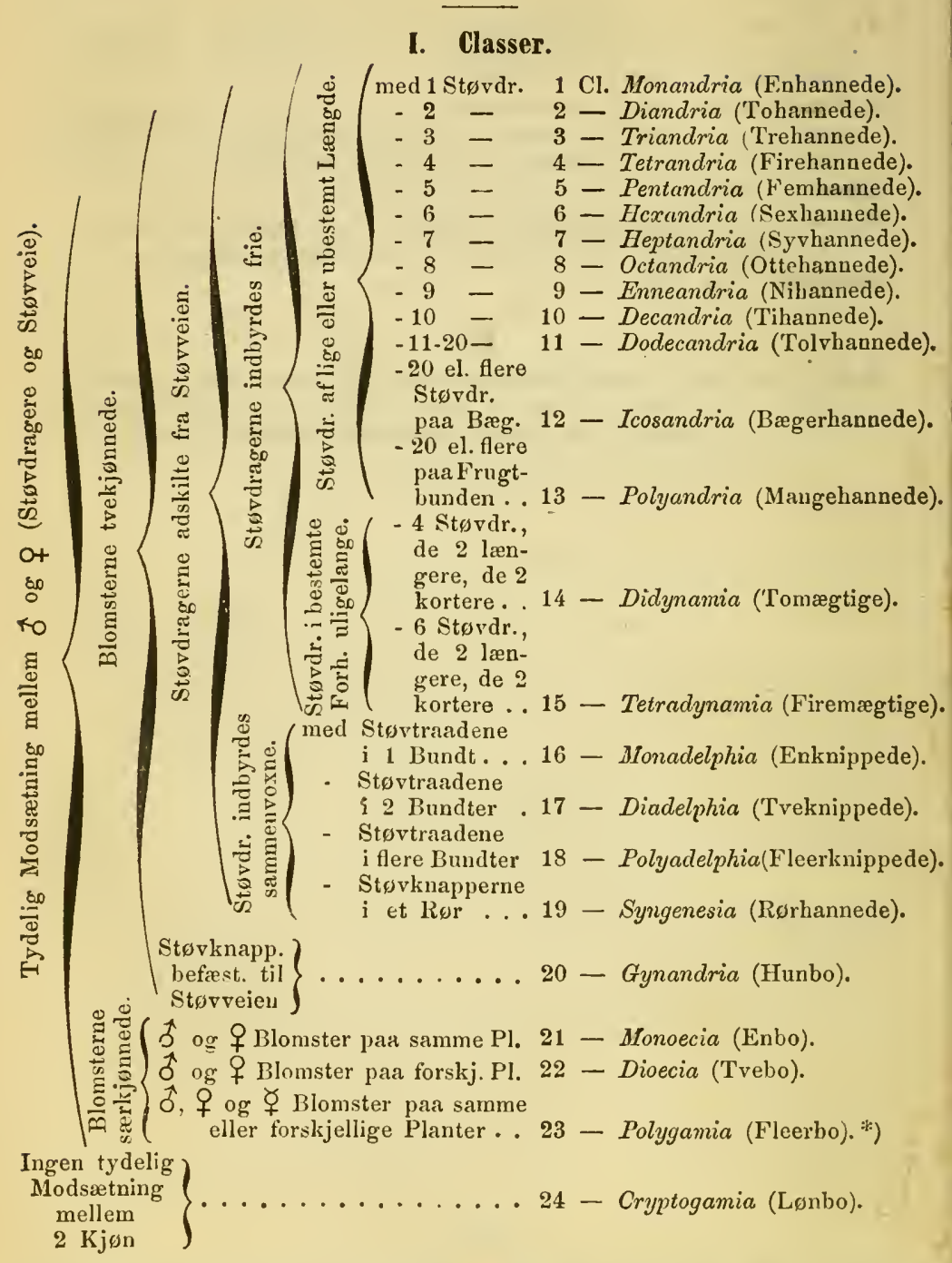

*) If horende slægter fordeelte $i$ andre Classer, hvorved Antaliet af linneiske Classer bliver 23 og ikke 24, som i Systemets oprindelige Skikkelse. 


\section{Ordener.}

1. I de første $\mathbf{1 3}$ Classer bestemmes Ordenen efter Storreienes Antal, saaledes at naar flere Frugtknuder med særskilte Grifler findes $\mathrm{i}$ en Blomst, angiver disses Tal Ordenen; er kun 1 Frugtknude tilstede; tælles Griflerne, og hvis Griflerne mangle, Arrene, f. Ex.

1. Orden: Monogynia (Enhunnede) med 1 Griffel.

2. - Digynia (Tohunnede) med 2 (Frugtknuder), Grifler (eller Ar).

n. - Polygynia (Mangeluunnede) med $\infty$ Grifler.

2. I $14 \mathrm{de}$ og $15 \mathrm{de}$ Classe bestemmes Ordenen efter Frugtens Beskaffenhed, enhver af disse Classer har 2 Ordener:

a) 14. Kl. 1 Orden: Gymnospermia (Spaltefrugtede) med 4, mod Modningen adskilte, enfrøede, uopspringende Smaafrugter.

- 2 - Angiospermia (Kapselfrugtede) med 1 fleerfrøet Kapsel.

b) 15. - 1 - Siliculosa (Smaaskulpede) Frugten (Skulpen) kort i Forhold til Breden.

- $\quad 2$ - Siliquosa (Langskulpede) 'Skulpens Læengde betydeligt storre end Breden.

3. I 16-18de Classe angiver Stovknappernes Antal Ordenen, f. Ex.:

Tetrandria (Firehannede) med 4 frie Støvknapper.

Hexandria (Sexhannede) med 6 frie Støvknapper.

Polyandria (Mangehannede) med $\infty$ frie Støvknapper.

4. I 19 de Classe bestemmes Ordenen efter Forholdet mellem Randog Skiveblomsterne. Folgende Ordener findes:

1. Orden: Syngenesia aqualis (Lige Sambo) med alle Blomsterne i Kurven ఫ.

2. - S. superflua (Overflødig Sambo). Skiveblomsterne $\Varangle$, Randblomsterne ?.

3. - S. frustranea (Unyttig Sambo) Skiveblomsterne $\not{\zeta}$; Randblomsterne kjønsløse.

4. - S. necessaria (Nødvendig Sambo). Skiveblomsterne $\hat{\sigma}$, Raudblomsteme $q$.

5. - S. segreguta (Sxrskilt Sambo). Flere enblomstrede Kurve (med $\Varangle$ Blomster) samlede til et Hoved.

6. - Monogamia (Srerbo). Blomsterne enlige (ilke i Blomsterkurv). 
5. I $20 \mathrm{de}$ til $22 \mathrm{de} \mathrm{Classe} \mathrm{tælles} \mathrm{Stovdragerne} \mathrm{(ligesom} \mathrm{i} \mathrm{16-18de}$ Cl.) for at angive Ordenen, f. Ex.:

1. Orden: Monandria (Enhannede), med 1 Størdrager.

2. - Diandria (Tohannede), med 2 St $\oint$ rdragere.

n. - Polyandria (Mangehannede), med $\infty$ Støvdragere.

6. I $23 \mathrm{de} \mathrm{Classe} \mathrm{ere} \mathrm{Ordenerne} \mathrm{følgende} \mathrm{naturlige} \mathrm{Familier:}$

1. Filices (Brægner).

2. Equisetacece (Padderokker).

3. Rhizocarpece (Rodfrugtræxter).

4. Isoëtece (Brasenurter).

5. Lycopodiacere (Ulvefødder).

6. Musci (Mosser).

7. Lichenes (Lavarter).

8. Algce (Alger, Vandtarer).

9. Fungi (Svampe). 


\section{Ta b e I}

over det naturlige Systems Hovedrækker.

\section{Thallophyta (Lovplanter).}

I Regelen ingen Karbundter mellem Cellevavet og ingen Modsætning mellem Stængel og Blade; Formeringsorganerne (Forplantningskorn, Sporer) bestaae kun af een enkelt Celle og mangle Kim. Hos de fleste findes desuden Antheridier med Sadtraade (eller dertil svarende Legemer).

A. Hysterophyta.

(Fungi. Svampe.)

B. Protophyta.

(Algre. Vandtarer.)

(Lichenes. Lavarter.)

II. Cormophyta (Stængelplanter).

Mere eller mindre fuldkomne Karbundter mellem Cellevævet; Bladene i Regelen tydeligt adskilte fra Stængelen.

A. Acrobrya (Bladsporeplanter). Voxe ved Tilsætning af nye Dele i Spidsen af Stængelen. Formeringsorganerne Sporer som hos de foregaaende og Støvkolber (Antheridier), som indeholde Sædtraade.

(Musci. Mosser.)

Lycopodiaceæ, Isoëteæ, Rhizocarpeæ, Filices, Equisetaceæ, Characeæ.

B. Amphibrya (Enfrobladplanter). Stangelen dannet af Cellevæv, som gjennemkrydses af Karbundter uden concentrisk Ordning; ingen Adskillelse mellem Bark og Marv; Bladenes Nerver alm. ugrenede; Bladstillingen i Regelen $1 / 3$ og Blomsten derfor alm. delelig med 3; Frøene udvikles efter forudgaaet Bestøvning ved Pollinarrør; Kimen med 1 udeelt Froblad.

* Frugten oversædig.

* Frugten undersædig.

C. Acramphibrya (Tofrøbladplanter). Stæengelens Ved dannet af Karbundter og Vedceller i concentriske Aarlag, som adskille det indre Cellevæv (Marren) fra det ydre (Barken); Bladene alm. med forgrenede Nerver, Bladstillingen typisk $1 / 2$ eller $2 / 5$ (og Blomstens Tal derfor alm. deleligt med 2 eller 5); Bestørning og Froe som foreg. men Kimen deelt i 2 Froblade.

* Gymnosperma (Nøgenfrøede).

** Apetalæ (Kronlose).

*** Gamopetalæ (Heelkronede).

***** Eleutlieropetalæ (Frikronbladede). 


\section{Oversigt}

over

de i den danske Flora fundne Planteslægter (med Undtagelse af Svampene), ordnede efter naturlige

Familier ${ }^{*}$.

\section{Thallophyta (Lövplanter).}

A. Hysterophyta (drage Næring af levende eller dode Organismer).

\section{(Fungi (Svampe)).}

B. Pr o t o p h y t a (drage Næring af Atmosphæren eller Vandet, ikke af levende eller dode Organismer).

*Alga (Alger eller Vandtarer) (J. G. Agardh, species, genera et ordines Algarum; Lyngbye, hydrophytologia danica; And. Atl. tab. 28) Salt- eller Færskvandsplanter, som spire uden forudgaaet Befrugtning eller ved Selvbefrugtning; Forplantningsorganet bestaaer af en enkelt Celle, enten fremkommen parthenogenisk som Produkt af en Celle eller ved flere Cellers Samvirken.

I. Diatomex. (Heiberg, consp. crit. Diat.) Alm. microscopiske Salt- eller Færskvands-Alger, hyppigt encellede, oftest levende i Colonier, samlede i en geleeagtig Masse eller i Traade, frie eller fastsiddende; Cellerne symmetriske, bestaaende af 2 Halvdele, der tilsidst adskilles, oftest incrusterede af Kiselsyre og omgivne af et Kiselhylster. Forplantningsorganet dannet ved flere Cellers Samvirken (Copulation).

*) Ved Opstillingen af Familierne er i det Væesenlige fulgt Lndlichers Genera plantarum. De i () indsluttede Kjendetegn ere i Regelen saadame, som kun gjælde for de $\mathrm{i}$ vor Flora forekommende Slægter, det i [] indsluttede betegner Forhold som kun finde Sted hos udenlandske Slægter. Tallene efter Slægterne angive disses Antal af Arter i Dammark. Saavel Familierne som Slægterne ere betegnede med fortløbende Tal (de forste med Romertal, de sidste med alm. Ciffre), men Numereringen er holdt særskilt for Lovplauterue og' de Bladsporeplanter, som ikke ere beskrevne i Haandbogen. 
1. Melosirn . . . 4. 4. 21. Pleurosigma ... 6 .

2. Lysigonium .... 1. 22. Amphiprora .... 3 .

3. Orthosira. . . . 6. 6. 23. Mastogloja . . . . 2.

4. Paralia ....... 1. 24. Gomphonema ... 6.

5. Aetinocyclus.... 1. 25. Coceoneis .... 2.

6. Biddulphia ..... 1. 26. Surirella ..... 3 .

7. Triceratium .... 1. 27. Campylodiseus ... 2.

8. Amphitetras .... 1. 28. Cymatopleura ... 2.

9. Diatoma ...... 5. 29. Novilla ...... 3 .

10. Fragilaria .... 7. 30. Epithemia .... 8 .

11. Synedra ..... 9. 31. Himantidium ... 3.

12. Meridion ..... 2. 32. Cymbella .... 4.

13. Asterionella .... 3. 33. Amphora. ..... 3 .

14. Rhabdonema. ... 2. 34. Nitzsehia. . . . 15.

15. Tabellaria .... 2. 35. Tryblionella .... 2.

16. Grammatophora .. 1. 36. Amphipleura.... 2.

17. Striatella ..... 2. 37. Aehnanthes .... 1.

18. Podosphenia .... 1. 38. Achnanthidium ... 4.

19. Navicula ..... 23. 39. Rhoicosphenia ... 1.

20. Stauroneis .... 7 .

II. Zygnemeæ. Grønne, ofte microseopiske (Færskvands-) Alger, levende samlede i Colonier, tildeels traadformede, med bløde, cylindriske, prismatiske, sphæriske eller stjerneformede Celler, Forplantningsorganet dannet ved flere Cellers Samvirken (Copulation).

a. Desmidiece. Hyppigst korte, runde eller stjerneformede, med udstaaende Spidser eller Takker, Cellerne symmetriske, bestaaende af 2 Halvdele, som tilsidst adskilles.

40. Euastrum...... 1. 42. Closterium ..... 1.

41. Cosmarium..... 1. 43. Desmidium..... 1.

b. Conjugatce. Oftest traadformede, uden fremstaaende Spidser, Cellerne cylindriske, efter Forlængelsen deelte i 2 Dele, almindeligt sammenhængende efter Delingen.

44. Zygnema ..... 5. 45. Mougeottia .... 1 .

III. Oscillatorinæ. Grønne, traadformede (Salt- eller Færskvands)-Alger, levende i Colonier indeni et geleeagtigt Hylster eller frit, alm. flere samlede, Cellerne (i en vis Periode) med Bevxgelsesevne, lange, uleddede med en Rad ringformede Celler indenfor en gjennemsigtig Hinde, af hvilken de, flere sammenhængende, glide ud og danne en ny Traad. 
a. Rivulariece. Traadene tilspidsede, i et rundagtigt, geleeagtigt Hylster forenede til begræendsede Colonier.

\section{Rivularia ..... 4.}

b. Oscillatoriece. Talrige cylindriske Traade samlede i Hobe eller frie hver for sig, stundom fastsiddende med den ene Ende.

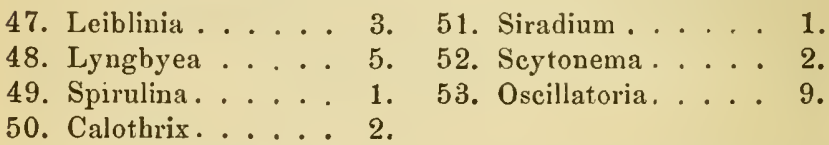

IV. Zoospermeæ. Alm. grøne (Salt og Færskvands)-Alger, levende sammen $i$ Colonier indenfor et geleeagtigt Hylster af rund Form eller frie, bestaaende af talrige Celler forenede til en Hinde eller oftere i Traade, ledede, undertiden encellede; Forplantningsorganerne Sværmsporer, dannede parthenogenisk indeni en Celle, eller tillige Coniocyster, der befrugtes ved Paavirkning af en anden Celle og derefter spire.

a. Nostochinece. Talrige rundagtige, frie eller sammenhrengende Celler forenede indeni et rundagtigt, geleeagtigt Hylster.
54. Protococcus .... 1. 56. Nostoc . . . . 9. 55. Falmella ..... 2.

b. Olvaceo. Afrundede eller kantede Celler forenede ved en mere eller mindre tydelig Intercellalærsubstans til en Hinde, som kan være flad eller rorformet.

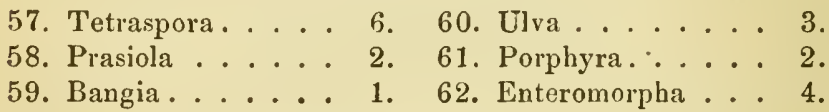

c. Hydrodictyece. Afrundet-cylindriske eller kantede Celler, forenedo ved Sammenvoxning (nætformigt) til en begrændset Coloni. Sværmsporerne ordnede til en ny Coloni indeni Modercellen.

63. Hydrodictyon... 1.

d. Confervece. Afrundede eller cylindriske Celler, som voxe ved Deling, sammenhwngende og danne en enkelt eller grenet Traad. Sværmsporerne udtrænge af Modercellen og spire uden Paavirkning af en anden Celle.
64. Mysonema ..... 2
2. 67. Conferva..... 30 .
65. Bulbochrte .... 1 .
66. Oedogonium .... 4 . 
e. Siphonec. En eller fleercellede, udeelte eller grenede, dannede af alm. lange, rorformede Celler.

69. Vaucheria .... 8. 70. Bryopsis ..... 1.

f. Draparnaldiece. Stwrkt forgrenede, cylindriske, ledede Traade, ligesom indsluttede $\mathrm{i}$ et geleeagtict Overtræk eller uden et saadant, men slibrige. Svirmsporeme stundom indsluttede i særegne Celler.

71. Chætophora ... 2. 73. Batrachospermum . 2.

72. Draparnaldia... 1.

g. Nodulariece. Rørformede, tilsyneladende leddede (knudrede) Traade, sammensatte af flere Rækker Cellevær. Forplantningsorgauerne i særegne Celler indeni Traadene.

74. Nodularia .... 1.

V. Fucoidex. Saltrands-Alger, alm, af olivengrøn eller bruun Farve og bestaaende af flere Cellelag; tydelige Vegetations. og Forplantningsorganer, disse ere: 1) Sværmsporer, 2) Sporer, enkelte eller flere $\mathrm{i}$ et Sporehuus, hos de høiere tillige Sædtraade i Antheridier; desuden forekomme hos nogle en Art Yngleknopper, som spire efterat være faldne hele fra Moderplanten.

$$
\text { a. Løvet leddet. }
$$

75. Elachista . . . . 3. 78. Chætopteris .... 1.

76. Ectocarpus. .... 5. 79. Cladostephus ... 2.

77. Sphacelaria ... 4.

b. Lovet bestaaende af en Axe og af leddede, fra denne udgaaende Traade.

80. Myrionema ..... 1. 84. Mesogloja ..... 2 .

81. Leathesia ..... 1. 85. Ralfsia ...... 1.

82. Myriocladia .... 1. 86. Chordaria .... 4.

83. Cladosiphon ..... 1.

c. Løvet bestaaende af flere Cellelag.

87. Punctaria ..... 2. 95. Lomentaria .... 1.

88. Asperococcus ... 2. 96. Laminaria .... 4.

89. Striaria...... 1. 97. Alaria...... 1.

90. Dictyosiphon .... 1. 98. Dichloria ..... 1 .

91. Sitosiphon ..... 1. 99. Desmarestia ... 1.

92. Stilophora .... 2. 100. Himanthalia.... 1 .

93́. Dictyota ...... 1. 101. Fucodium..... 1.

94. Chorda ...... 2. 102. Fucus...... 2.

VI. Corallineæ. Alm. røde Saltvands-Alger, Lovet mere 
eller mindre haardt af Kalk-Incrustation, oftest skjørt og sammensat af et dobbelt Cellelag; Vegetations- og ForplantningsOrganerne adskilte, de sidste bestaaende af 4 bælteformigt afsondrede Sporer i et Sporehuus.

\section{a. Lovet leddet.}

103. Corallina ..... 1.

\section{b. Løvet ikike leddet.}

104. Melobesia..... 1.

VII. Horidex. Alm. røde Saltvandsalger, sammensatte af flerc Cellelag. Vegetations- og Forplantnings-Organerne stedse adskilte, disse sidste ere deels Sporer, danncde $\mathbf{i}$ det peripheriske Cellelag ( 4 i eet Sporehuus), deels Antheridier med Sædtraade, deels Gemmidier ว: talrige Sporer i et Sporehuus, dannede i Central-Cellelaget.

a. Gongylospermece. Gemmidiernes Sporehuus omtrent kugleformet, nøgent eller indeni Løvet, sjeldent i en Kapsel, enkelt ell. sammensat af flere mindre, indesluttende talrige Gemmidier.

105. Callithamnion . 6 6. 112. Rhizophyllis ... 1 .

106. Griffithsia .... 1. 113. Cystoclonium... 1.

107. Ptilota ..... 1. 114. Ahnfeltia..... 1.

108. Ceramium .... 4. 115. Phyllophora ... 3.

109. Gloiosiphonia . . 1. 116. Dumontia .... 1.

110. Schizymenia ... 1. 117. Rhodymenia ... 2.

111. Furcellaria .... 1. 118. Wormskjoldia .. 1.

b. Desniospermece. Gemmidiernes Sporehuus nøgent, indeni Løvet eller i en (saakaldt) Kapsel, bestaaende af leddede Traade i Knipper. Gemmidierne ligge rækkevis langs Traadenes Led eller udvikles kun i det overste Led.

119. Helminthocladia . 1. 125. Polyides .... 1. 120. Nemalion. . . . 1. 126. Laurencia .... 1. 121. Cruoria ..... 1. 127. Rhodomela .... 1. 122. Erythroclathrus. . 1. 128. Odonthalia .... 1. 123. Gracilaria .... 1. 129. Polysiphonia . . 10. 124. Delesseria ... 2.

**Lichenes (Lavarter eller Landtarer) (E. Fries, Lichenogr. Europ.; W. Nylander, Lichenes Scandin.; And. Atl. tab. 28.) Langsomt voxende, hyppigst udviklende sig i Atmosphæren, med oftest centrifugalt, forskjelligformet (hinde- eller skorpeagtigt, seigt eller kalkagtigt-skjørt) Løv, bestaaende af et 
Barklag og et Marvlag samt et mellemliggende Gonidielag (eller frie Gonidier); Forplantningsorganet Sporer, oftest indsluttede i Sporesække, hvilke tilligemed Safttraade ere ordnede $\mathrm{i}$ et Frugtlag (Sporegjemme), som enten er indsænkt i Løvet eller træder frem paa dettes Overflade i Form af Skater, Skjolde eller Kugler o.s.v. I særegne Gjemmer (Sædhuse), som alm. ere vorteformede med en Aabning i Spidsen og nedsænkte i Løvet, findes desuden traadformede Legemer (sterigmata), som synes at repræsentere det andet Kjøn (Antheridier). Spire ved en af traadformede, grenede Celler dannet Forkim.

VIII. Collemacei (Slimlav) voxe paa fugtig Grund (nogle endog paa Stene i Vandet); Lovet geleeagtigt, ofte uden Barklag, sort, mørkebruunt eller olivenfarvet, med spredte eller halsbaandformigt sammenhængende Gonidier $\mathrm{i}$ det Indre.
130. Lichina.
1.
132. Leptogium ....
2.
131. Collema
7.

IX. Lichenacei. (Ægte Lavarter) Løvet fast, af forskjellig Form og Farve (kun undtagelsesviis sortagtigt), voxe udenfor Vandet (paa Stene, Jord eller Træbark).

a. Epiconiodei. Sporerne 8 i Sporesække, som hurtigt forsvinde, og Sporerne ligge derefter nøgne, i en Masse indenfor kugleformede, stilkede Sporegjemmer.

133. Sphinctrina. . . 1. 136. Trachylia ... . 3.

134. Calicium .... 10. 137. Sphærophoron .. 2.

135. Coniocy be .... 1.

b. Cladoniodei. Sporerne alm. 8, i Sporesække, indenfor alm. hvælvede, stilkede Sporegjemmer, Løvet alm. stærkt grenet, ofte med bladagtige Skjæl ved Grunden og hule eller tragtformede Frugtstilke.
138. Bæomyces .... 3
139. Cladonia .... 22.
140. Stereocaulon... 5 .

c. Ramalodei. Sporerne i Sporesække, Sporegjemmerne alm. skaalformede, Løvet bruskagtigt eller traadformig-grenet, uden Skjæl ved Grunden.

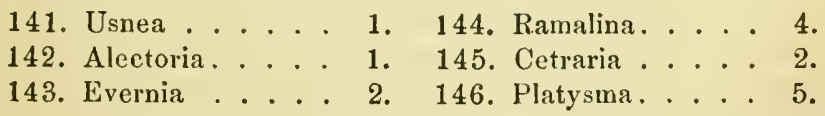
d. Phyllodei. Sporegjemmerne skjold- eller skaalformede (los nogle vorteformede med spiralformede Striber) Lovet fladt, bladagtigt, lappet eller fliget i Omkredsen, alm. med Hæftetraade paa Underfladen.

147. Nephroma .... 1. 148. Peltigera.... 5 . 
149. Solorina . . . 1. 153. Parmelia .... 11.

150. Stictina .... 1. 154. Physcia .... 8.

151. Sticta ..... 1. 155. Umbilicaria ... 2.

152. Ricasolia.... 2.

e. Placodei. Løvet skorpeformet eller kornet-vortet, alm. fast tilvoxet til Underlaget, uden Marvlag, Sporegjemmerne skaalformede eller hvælvede.

156. Psoroma ..... 1. 161. Urceolaria .... 1.

157. Pannaria .... 4. 162. Pertusaria .... 3.

158. Squamaria .... 1. 163. Phlyctis ..... 2.

159. Placodium .... 2. 164. Thelotrema.... 1.

160. Lecanora. . . . 21. 165. Lecidea .... 33.

f. Graphidei. Løvet svagt udviklet, ofte skjult under Træernes Bark, Sporegjemmerne stribeformede, aflange, linieformede eller i B $ø$ lgelinier, med alm. en Længdespalte i Midten af Skiven.

166. Graphis ..... 1. 168. Arthonia . . . 3. 167. Opegrapha. . . 4.

g. Pyrenocarpei. Løvet af forskjellig Form (stundom skjult under Træbarken eller 0); Sporegjemmerne indsænkte i Løvet eller Underlaget, vorteformede, lukkede eller med en punktformet Aabning i Spidsen, Sporesækkene i et alm. kugleformet Sporeleie indenfor Sporegjemmerne, hurtigt forsvindende, med eller uden Saftraade.

169. Endocarpon. . . 1. 170. Verrucaria .... 11.

\section{C ormophyta (Stængelplanter).}

\section{A. A crobrya (Bladsporeplanter).}

* Musci (Mosser). Oftest grønue, befæstede paa Jorden, Stene eller Træbark med eller uden traadformede Hæfterødder; Bladene dannede af et eller flere Lag kortere eller længere Celler (ingen egeulige Kar); Forplantningsorganerne 2 Slags: 1) Frugtanlag (archegonia) som udvikle sig til Sporehuse i Spidsen af en kortere eller længere Stilk, Børsten (seta) og 2) Stovkolber (antheridia), kugle- eller kølleformede Legemer, som indeholde Sædiraade. Sporerne udvikle en Forkim, hvoraf den unge Plante fremvoxer.

X. Hepatica (Levermosser) (And. Atl. t. 27) Stængelen med traadformede Hæfterødder, enten sammensmeltet med Bla- 
dene til et gaffeldeelt eller straaleformigt-lappet $L \phi v$, eller med tydeligt fra Stængelen adskilte Blade i 2 eller 4 Rader, med eller uden Biblade (amphigastria); Bladene dannes af eet Lag Parenchymeeller og mangle Nerve; Støvkolberne, siddende eller stilkede, indsænkte $\mathrm{i}$ eller siddende paa Overfladen af Løvet eller i Bladhjørnerne, Frugtanlægene bestaae af en Kjærne, omgivet af en hindeagtig Hætte; idet Kjærnen voxer ud til en stilket Kapsel, brister Hætten oftest i Spidsen; Kapselen skulpe-, kugle- eller ægformet, opspringende i 2 eller 4 Klapper, indeholdende talrige Sporer mellem Slyngere o: Traade med spiralformede Fortykningslag.

a. Ricciea. Løvet fladt, straaleformig-lappet, krybende eller svømmende; Kapselen indsænkt i Løvet, vedblivende omsluttet af Hætten.

Ingen Slyngere.

171. Riccia ..... 4 .

a. Anthocerotece. Løvet straaleformig-lappet; Kapselen skulpeformet, toklappet med haarformet Midtsøile.

172. Anthoceros.... 2.

c. Marchantieœ. Løvet gaffeldeelt-lappet med porøs Overhud, skjælagtige Smaablade paa Underfladen; Kapslerne næsten siddende, samlede paa Underfladen af en skjold- eller kegleformet, ofte straaleformet, stilket Frugtholder.

173. Preissia..... 1. 175. Marehantia. ... 1.

( ? Rebouillia .... 1) 176. Lunularia .... 1.

174. Fegatella.... 1.

d. Jungermanniea. Kapslerne, stillsede, opsringende i 4 Klapper, sidde enkeltviis.

aa, med Løv.

177. Metzgeria ... 1. 180. Pellia ..... 1.

178. Aneura ..... 3. 181. Blyttia..... 1.

179. Blasia ...... 1. 182. Fossombronia .. 1.

$\mathrm{bb}$, med adskilte Blade.

183. Lejeunia . . . . 1. 192. Chiloscyphus ... 2.

184. Radula ...... 1. 193. Lophocolea.... 4.

185. Frullania . . . 2. 194. Sphagnoecetis .. 1.

186. Madotbeca .... 4. 195. Jungermannia .. 24.

187. Ptilidium .... 1. 196. Seapania.... 6.

188. Trichoeolea ... 1. 197. Plagiochila .... 1.

189. Mastigobryum .. 1. 198. Alicularia .... 1.

190. Lepidozia .... 1. 199. Sarcoseyphus... 2.

191. Calypogeia .... 1. 
XI. Sphagnaceæ Endl. ('Tørvmosser). Bleggrønne, hyppigt rødlige eller næsten farveløse Mosser, uden Rodtraade; Stænglerne sammensatte af et tredobbelt Lag af forskjelligformede Celler, med knippestillede Grene, som ikke udgaae fra Bladhjornerne; Bladene taglagte, dannede af 2 Slags Celler, af hilke de indre ere tyndvæggede, forsynede med Porer og ringformede Afleiringslag; Blomsterstanden enbo eller tvebo, Støvkolberne axformigt samlede paa vandrette Smaagrene, stilkede, kugleformede, uden Safttraade; 1-5 Frugtanlæg (af hvilke kun 1 udvikles til Frugt) i Spidsen af sidestillede Frugtgrene fra Stængelens øvre Deel; Børsten kort eller utydelig, nedsænkt i en pæreformet Skede, som ved Frugtmodningen sprænges uregelmæssigt og ikke danner nogen egenlig Hætte; Kapselen tværsopspringende, uden Ring og Tænder i Ilundingen, Sporerne 2 Slags, nogle større, andre mindre, enten i samme eller forskjellige Kapsler. Forkimen flad, løvlignende.

200. Sphagnum ... 12.

XII. Bryacea Bartl.(Bladmosser) (T. Jensen, Bryol.dan., And. Atl. t. 27). Oftest grønne, med Rodtraade; Stængelens Celler langstrakte, mod Omkredsen tættere, intet Barklag, Bladene taglagte, alm. omfattende, bestaaende af eet eller flere Cellelag, uden porøse Celler, med eller uden Nerve (længere Celler) i Miditen og stundom med tykkere Rand; Blomsterstanden enbo eller tvebo; Støvkolberne alm. kølleformede, omgivne af Safttraade; Frugtanlægene alm. flere samlede (af hvilke 1 eller flere udvikles til Frugt) omgivne af Safttraade og af særegne Frugtsvøbblade, flaskeformede, indesluttende en Kjærne indenfor en Hinde, der, efterat Kjærnen udvoxer til en Kapsel, deler sig paatværs, den øvre Deel kaldes Hætten (calyptra); Kapselen paa en kortere eller længere Børste, opspringende ved Modningen paatværs (Buddike) alm. med 1 à 2 Rækker leddede Tænder af bestemt Antal (delelige med 4) i Mundingen og en leddet Ring nedenfor Laaget (operculum). Omkring en Midtsøile i Buddikens Indre dannes de ensartede Sporer. Forkimen traadformigt grenet.

a. Schizocarpe. Frugten en endestillet Kapsel, der aabner sig paalangs i 4 Klapper.

201. Andræa. ..... 1 . 
b. Acrocarpa. Frugten en endestillet Kapsel, som deles paatværs eller uregelmsessigt.

aa. Cleistocarpœ. Kapslen brister uregelmæssigt.

202. Ephemerum. ... 1. 205. Sphærangium ... 1.

203. Physcomitrella .. 1. 206: Phascum ..... 3.

204. Microbryum ... 1. 207. Pleuridium ... 3.

bb. Stegocarpce. Kapselen trærsopspringende (Buddike).

\section{a. Weisiacece.}

208. Systegium. .... 1. 213. Trematodon ... 1.

209. Gymuostomum .. 1. 214. Dicranella .... 6.

210. Weisia ..... 2. 215. Dicranum.... 9.

211. Cynodontium ... 1. 216. Campylopus ... 4.

212. Dichodontium .. 1.

ק. Leucobryacece.

217. Leucobryum ... 1.

$\gamma$. Fissidentacer.

218. Fissidens . . . 5 .

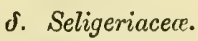

219. Seligeria . . . 1 .

ع. Pottiacer.

220. Pottia...... 4. 225. Ceratodon .... 1.

221. Anacalypta . . . 1. 226. Leptotrichum ... 3.

222. Didymodon .... 1. 227. Trichostomum .. 2.

223. Eucladium .... 1. 228. Barbula..... 11.

224. Distichium .... 2.

ל. Grimmiacece.

229. Cinclidotus .... 1. 235. Zygodon .... 2. 230. Grinmia .... 9. 236. Ulota ...... 4. 231. Racomitrium ... 8. 237. Orthotrichum ... 18. 232. Hedwigia .... 1. 238. Tetraphis.... 1. 233. Ptychomitrium .. 1. 239. Encalypta. ... 2. 234. Amphoridium ... 1.

$\eta$. Splachnacece.

240. Splachnum .... 1 .

ง. Funariacece.

241. Physcomitrium .. 1. 243. Funaria..... 1. 242. Entosthodon ... 2. 
¿. Bryacea.

244. Leptobryum ... 1. 250. Meesia . . . . 3. 245. Webera..... 5. 251. Paludella..... 1. 246. Bryum ..... 17. 252. Aulacomnion... 2. 247. Mnium ..... 9. 253. Bartramia .... 2. 248. Cinclidium .... 1. 254. Philonotis.... 3. 249. Amblyodon .... 1.

x. Polytrichacece.

255. Atrichum .... 2. 257. Polytrichum ... 7. 256. Pogonatum... 3.

ג. Buxbaumiacece.

258. Diphyscium. . . 1. 259. Buxbaumia.... 1.

c. Pleurocarpce. Frugten sidestillet, Kapselen tværsopspringende (Buddike).

«. Fontinaloidece.

260. Fontinalis ... 2 .

B. Neckeracea.

261. Cryphæa ..... 1. 264. Leucodon .... 1. 262. Neckera .... 3. 265. Antitrichia ... 1. 263. Homalia .... 1 .

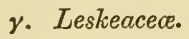

266. Myurella .... 1. 269. Heterocladium .. 1. 267. Leskea. . . . 2. 270. Thuidium ... 4. 268. Anomodon ... 2 .

\section{s. Hypnacece.}

271. Pterigynandrum . 1. 279. Eurhynchium ... 7. 272. Pterogonium ... 1. 280. Rhyncostegium . 5. 273. Climacium .... 1. 281. Thamnium .... 1. 274. Pylaisia .... 1. 282. Plagiothecium . 5. 275. Isothecium ... 1. 283. Amblystegium .. 4. 276. Homalothecium. . 1. 284. Hypnum .... 27. 277. Camptothecium . 2. 285. Hylocomium ... 5. 278. Brachythecium . 10. 
I. Characeæ Rich.*) (Krandsnaalvæxter). And. Atl. tab. 21. Vandplanter med leddede Strengler, fra Leddene udgaae krandsstillede Grene, som enten forgrene sig ensartet med Hovedstængelen eller i Spidsen opløses i Straaler; Forplantningsorganerne 2 Slags, som enten findes paa forskjellige Planter (Tvebo) eller paa cen Plante (Enbo), alm. ved Grenenes Led eller i Straalerne: Sporehusene ovale eller kugleformede, indeholdende 1 Spore, omgivet af spiralformigt snoede Celler, der i Spidsen ere frie og danne en Krone; Antheridierne kugleformede, alm. høirøde, indeholdende Spiraltraade. (Ofte indhyllede $i$ et Overtræk af Kalk og ildelugtende).

1. Nitella ..... 8. 2. Chara ..... 14.

II. Equisetaceæ DC. (Padderokker). And. Atl. t. 21. Stangelen leddet, med en tandet Skede ovenfor hvert Led, forøvrigt bladløs, uden eller med krandsstillede, leddede Grene; Sporehusene kredsformigt stillede paa Underfladen af stilkede, skjoldformede Forgreninger af en fælles forlænget Axe, ordnede til en endestillet, axformet Frugtstand.
3. Equisetum .... 8.

III. Filices (L.) (Brægner.) And. Atl. t. 26. Fra Rodstokken udgaae (oftest) grenede Løv; Sporehusene kapselagtige, tilligemed leddede Traade samlede i Frugthobe (sori) paa Bagsiden af Løvet, nøgne eller bedækkede enten af et hindeagtigt Skjæl (Sløret) eller af Løvets tilbagebøiede Rand.

a. Polypodiacece R. Br. Løvet i Knoptilstanden sneglehuusformigt indrullet; Sporehusene omgivne af en leddet Ring, opspringe paatværs.
4. Polypodium.... 3
3. 9. Seolopendrium... 1.
5. Aspidium ...... 1. 10. Pteris ...... 1.
6. Lastræa ..... 5. 11. Blechnum ..... 1.
7. Cystopteris .... 2. 12. Struthiopteris ... 1.
8. Asplenium .... 5 .

b. Osmundacece R. Br. Løvet som foreg., Sporehusene uden Ring, opspringende paalangs; (Bladkjødet forsvundet paa de med Frugthobe. beklædte Endegrene af Løvet).

13. Osununda .... 1.

*) De fleste Systematikere anvise denne Familie Plads nærmest ved Algerne. Uden at indlade mig paa dette Sporgsmaals Afgjørelse har jeg opfort Familien her, for paa eet Sted at samle alle de i Haandbogen beskrevne Planter. 


\section{XLIV}

c. Løvet i Knoptilstanden ret, Bladkjødet forsvundet fra de frugtbærende Grene; Sporehusene uden Ring, opspringende paatværs.

14. Botrychium ... 2. 15. Ophioglossum ... 1.

IV. Rhizocarpeæ Schleid. (Rodfrugtvæxter) And. t. 26. Fra Rodstokken udgaae (i Knoptilstanden sneglebuusformigt indrullede) Blade og ved Grunden af disse kugleformede (firerummede, ved Modenheden fireklappede) Frugtsamlinger, der indslutte talrige Sporehuse, hvoraf de nedre indeholde 1 større, de øvre flere smaa Sporer.

16. Pilularia...... 1.

V. Isoëteæ Bartl. (Brasenurter) And. t. 26. Fra en forkortet Rodstok udgaae udeelte, i Knoptilstanden rette Blade, som i deres udvidede Basis indslutte rundagtigt-ovale, af en uopspringende Hinde omgivne Sporehuse, af hvilke nogle (de ydre Rækker) indeholde større, kantede, andre (den indre Række) mindre, trindt-aflange Sporer, befæstede til tværstillede Traade.

17. Isoëtes ..... 2.

VI. Lycopodiaceæ DC. (Ulvefodsfamilien) And. t. 26. Stængelen beklædt med tạglagte Blade; Sporehusene i Bladhjørnerne eller samlede til Ax og omgivne af Drkblade, enten alle eensartede (indeholdende fine Sporer) eller af 2 Slags (nogle toklappede med fine Sporer, andre 3-4-klappede med faa, men større Sporer).

18. Lycopodium ... 6. 19. Selaginella ... 1.

B. Amphibrya (Monocotyledoneæ). Enfrobladplanter.

* Blomsten undersadig, Frugten fri.

VII. Graminea Juss. (Græsarter) And. t. 25. Stcongelen huul, leddet, Bladene med omskedende, paalangs spaltet Sleede og Skedehinde; Blomsterstanden sammensat (Ax, Klase eller Top), dens mindste Forgreninger (Smaaax) omgivne af alm. 2 Yderavner (glumx), der indslutte 1 -flere Blomster (alm. toradet-taglagte opad en fælles Axstilk); de enkelte Blomster bestaae af $1-2$ Inderavner (paleæ) og indenfor disse $2-3$ (stundom manglende) hindeagtige Blomsterskjal (lodiculæ); Støvdragerne i Regelen 3; 1 Frugtknude, 2 Grifler (undtagen hos Nr. 62); Frugten Nød 
med hindeagtigt, til Frøet fastvoxet Frøgjemme; Frøhviden stor, melet.

a. Locustiflora J. Ag. Den øvre Blomst i Smaaaxet fuldstændig, med 1 eller flere golde Blomster ved Grunden.

20. Setaria ..... 2. 24. Digraphis .... 1 .

21. Eehinochloa .... 1. 25. Hierochloa .... 1.

22. Digitaria .... 1. 26. Anthoxanthum... 1.

(Panieum.) 27. Leersia ..... 1.

23. Phalaris ..... 1.

b. Spiculiflorce J. Ag. Smaaaxet 1- eller fleerblomstret med alle Blomsterne fuldstændige eller den orre Blomst ufuldstæudig (gold) eller særkjønnet.

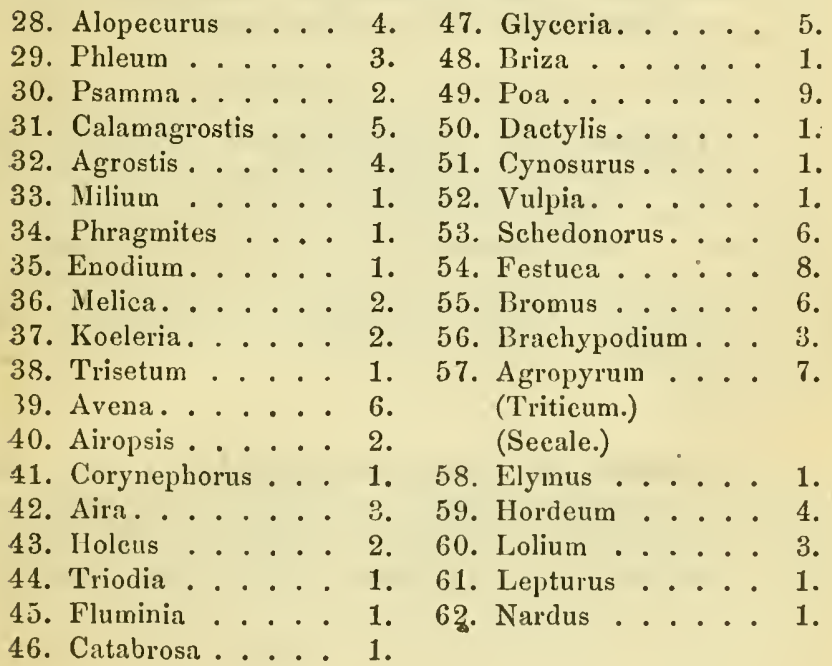

VIII. Cyperacex Juss. (Halvgræsarter) And. t. 24. Stcongeten heel; Bladene omskedende med heel Skede og mere eller mindre tydelig Skedchinde; Blomsterne i enlige, endestillede $\mathbf{A x}$ eller flere til en Blomsterstand samlede Smaaax, med adskilt eller samlet Kjøn; de enkelte Blomster omgirne af (alm. 1) Dækskjæl (palea); Blornsterdakket fribladet (borsteformet), sambladet (krukkeformet) eller 0; Stovdragerne alm. 3; 1 Frugtkmude, 2-3 Ar; Frugten nodagtig, ined et tort, til lroet ikke fastvoxet Frøgjemme.

Haandb. den danske Flora. 
a. Monoclines.

63. Cyperus...... 2. 67. Eleocharis .... 4. 64. Sehœnus .... 2. 68. Seirpus .... 14. 65. Cladium ..... 1. 69. Eriophorum ... 5. 66. Rbyneospora ... 2 .

\section{b. Diclines $\left.{ }^{*}\right)$.}

70. Carex ..... 54 .

IX. Typhaceæ Juss. (Duunhammerfamilien) And. t. 24. Blomsterne særkjønnede (enbo), i valseformede eller kugleformede Ax eller Hoveder, adskilte ved Mellemrum eller omskedende Blade ( $\widehat{o}$ ovenfor + ); Blomsterne af begge Kjøn omgivne af skjæl- eller børsteformede Perigonblade; Støvdragere 3; 1 Frugtknude med $1 \mathrm{Eg}, 1$ fladtrykt, tungeformet eller sylformet Ar; Frugten nød- eller steenfrugtagtig.

71. Typha...... 2. 72. Sparganium ... 3.

X. Lemmaceæ DC. (Andemadfamilien) Svømmende bladlose Vandplanter; fra den bladlignende Stcengel (Lovet) og dettes Forgreninger (Plader) udgaae Trævlerødder, forsynede med en Rodhrette; $\delta$ og $\$$ Blomster omgivne af et fælles hindeagtigt Hylster uden særegne Blomsterdækker; $\hat{\delta}: 1-2$ Støvdragere; 우 1 Frugtknude; Frugten 1-fleerfrøet, uopspringende eller tværsopspringende.

73. Lemna .... 4.

XI. Aroidex Juss. (Kolbeblomstrede) And. t. 24. Blomsterne $\mathrm{i}$ en endestillet eller falsk sidestillet, af et Hylster omgivet Kolbe, sær- eller trekjønnede, med eller uden Blomsterdckke; Støødragerne $6-\infty$; Frugt uopspringende, bær- eller kapselagtig, $1-\infty$-frøet.

74. Arum ..... 1. 76. Acorus ..... 1.

75. Calla ...... 1.

XII. Fluviales Vent. (Vandaxfamilien) And. t. 22 og 24. Vandplanter med nedentil omskedende Blade eller Axelblade; Blomsterne enlige, omgivne af Hylster eller samlede til Ax

*) Dr. Didrichsen har meddeelt mig den Iagttagelse, at der hos flere Carices, og normalt hos C. maxima, findes Trekjønsblomster ved Grunden af $q$ Axene. 
eller Kolber, særkjønnede eller tvekjønnede; $1-4$ Støvdra. gere; $1-4$ Frugtknuder; Frugten enfrøet.

77. Zostera ..... 2. 80. Ruppia ..... 3.

78. Najas ...... 1. 81. Potamogeton ... 23.

79. Zannichellia .... 3.

XIII. Alismacea R. Br. (Blomstersivene) And. t. 23. Sumpplanter med nedentil omskedende Blade; Blomsterdckket regelmæssigt, tredeleligt, med en ydre Kreds af alm. grønne Blade (Bæger) og en indre, oftest farvet (Krone); Støvdragere 6, 9 eller flere; Frugtbladene $3-\infty$; Frugten nod- eller kapselagtig.

a. Juncaginece. Bladene linieformede (Blomsterne i Klase), Blomsterdcekket grønt; Støvdragere 6; Frugtblade 3, fra Begyndelsen eller ved

Modningen sondrede; Frugterne enfrgede, uopspringende.

82. Triglochin .... 2. 83. Scheucbzeria ... 1.

b. Alismacece verce. Bladpladen med forgrenede Nerver (Blomsterne i krandsblomstret Top); Bcegerbladene gronne; Kronbladene farvede; Støvdragere $6-\infty$; Frugtbladene $\infty$, adskilte; Frugterne enfrøede, uopspringende.

84. Alisma .... 3. 85. Sagittaria .... 1 .

c. Butomece. Bladene linieformedo (Blomsterne i Skjærm); Bceger og Krone som foreg.; Stovdragere 9; Frugtblade 6 med talsige $\mathbb{A g}$, befæstede paa Klappernes indvendige Overflade; Frugt kapselagtig.

86. Butomus. ..... 1.

XIV. Colchicacer DC. (Tidløsfamilien) And.t. 23. Knolleformet Rodstok (ingen overjordisk Stængel); Blomsterdneliket farvet, sexdeelt; Støvdragere 6, tilvoxede til Blomsterdækket, med udadvendte Støvknapper; 3 Grifler; Frugten trerummet Kapsel med red Modenheden indbyrdes adskilte og i Bugsømmen opspringende Rum; Frøene befæstede til Bugsømmen.

87. Colchicum ..... 1. 88. Narthecium .... 1.

XV. Jnncaceæ DC. (Sivfarnilien) And. t. 23. Bladene omskedende; Blomsterne omgivne af Drkblade; Blomsterdakliket sexbladet, med oftest hindeagtige Perigonblade; Stovtragere 6 (sjeldent 3), med indadvendte Stovknapper; 1 Griffel; $3 \mathrm{Ar}$; Frugten treklappet, $3-\infty$-frøet Kapsel med rumdelende $\mathrm{O}_{\mathrm{p}}$ spriugning.

89. Juncus . . . 2 20.

90. Luzula . . . . 5. 


\section{LXVIII}

XVI. Liliacere Juss. (Liliefamilien) And. t. 23. Oftes: Løgvæxter; Blomsterdakket farvet, sexbladet eller sexdeelt; St $\downarrow v$ dragerne 6, med indadvendte Støvknapper; 1 Griffel og et tredeelt eller trekantet Ar; Frugten treklappet Kapsel med rumdelende Opspringning; Frøene talrige, befæstede til en midtstillet Frøstol.

(Lilium.)

91. Fritillaria .... 1.

92. Tulipa. ...... 1. 94. Ornithogalum ... 2.

93. Gagea....... 5. 95. Allium...... 7.

(Endymion).

96. Anthericum ... 2 .

XVII. Smilacex R. Br. (Konvalfamilien) And. t. 23. Blomsterdckket grønt eller farvet, sexbladet eller sexdeelt (sjeldnere fire- eller ottebladet); Stovdragerne i lige Antal med indadvendte Støvknapper; Frugten bæragtig, 3-4-rummet, uopspringende.

a. Asparagece. Blomsterdakket sexdeelt; 6 Støvdragere, 1 Griffel, $3 \mathrm{Ar} ;$ Frøenes Skal haard.

97. Asparagus..... 1.

b. Convallariece. Blomsterdcekket 4-6-deelt; Støvdragere 6, $1 \mathrm{Griffel}$, $3 \mathrm{Ar}$; Frøenes Skal hindeagtig.

98. Convallaria ... 4. 99. Majanthemum ... 1.

c. Paridece. (Blomsterdocliket ottebladet; de ydre Perigonblade stórre end de indre, Støvdragerne 8); Frøenes Skal hindeagtig.

100. Paris...... 1.

\section{** Frugten underscedig.}

XVIII. Narcissinex Juss. (Narcisfamilien) And. t. 22. Løgvæxter; Blomsterne tvckjønnede, enlige eller i Skjærm, omgivne af et Hylster; Blomsterdcklket sexdeelt, i 2 Kredse, farvet, med eller uden Bikrone; Støvdragere 6, med indadvendte St $\bullet$ knapper; 1 Griffel og udeelt Ar; Frugten trerummet, mangefrøet Kapsel med rumdelende Opspringning.

101. Galanthus .... 1. 103. Nareissus. . . . 2.

102. Leucojum .... 1 .

XIX. Iridex (Sværdlilier) And. t. 22. Rodstokken knolleformet; Blomsterdchliet farvet, sexdeelt, i 2 Kredse, den ydre Kreds ofte forskjellig fra den indre; Støvdragerne 3, ligefor de ydre Perigonblade, med udadvendte Stovknapper; 1 Griffel; 3 (kronbladagtige eller tragtformede) Ar; Frugten trerummet Kapsel med rumdelende Opspringning.

104. Iris...... 2. 105. Crocus..... 1. 
XX. Orchidere (Gjøgeblomster) And. t. 22. Bladene omskedende; (Blomsterne i Klase eller Ax); Blomsterdckket i 2 trebladede Kredse; Perigonbladene i den ydre Kreds omtrent ligeformede $\mathrm{og}$ oftest regelm. stillede; de 2 nedre (ved Blomstens Dreining opadvendte) i den indre Kreds ligeformede, det tredie (ovre, tilsyneladende nedadvendte), Løben, i Form og Størrelse afvigende fir de øvrige; 1 fuldkommen og 2 uudviklede Stovdragere, hiin siddende, tilvoxet til Arret og ved Foreningen med dette dannende en Griffelstotte; Stovet i Masser (1-2 i hvert af den torummede Støvknaps Rum); Frugten treklappet, enrummet Kapsel med vægstillede Frøstole og talrige smaae Fró. (Ofte Knoller fra Rodstokken).

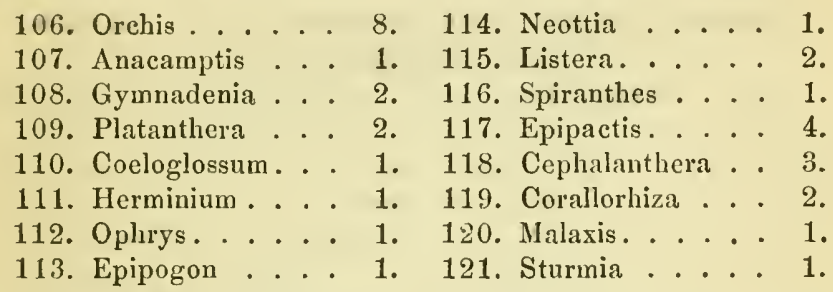

XXI. Ilydrocharideæ DC. (Frøbidfamilien) And. t. 23. Vandplanter; Blomsterne tvebo; Blomsterlcekkets Blade i 2 trebladede Kredse, de ydre (Brger) grønne, de indre kronbladagtige; Stovdragerne 9-12, ofte med flere Bistøvdragere; Griflerne 3-6, med todeelte Ar; Frugten fleerrummet, mangefrøet, kjødfuld, uopspringende.

122. Hydrocharis ... 1. 123. Stratiotes ... 1.

\section{Amphibrya (Dicotyledoneæ). Tofrobladplanter.}

* Gymosprermce (Nogenfreede). Fröene nogne, i aabne Frugtblade.

XXII. Coniferæ Juss. (Naaletræer) And. t. 20. Blomsterne særkjønnede, i Rakler, dannede af spiralformigt taglagte Dakblade; $\hat{f}$ : Blomsterne nogue, med bladagtigt Knapbaand og 1 eller flere Rum i Støvknappen; o: Frugtbladene i Vinklerne af Dækbladene, tilsidst læder-, træagtige eller kjødfulde, hvorved fremkommer en Kogle eller Barkogle; Frobladene stundom deelte til Grunden i flere Flige. - Træagtige Væxter med punkterede Vedeeller (ingen Kar), indeholde Harpix; Bladene naaleformede, oftest læderagtige og stedsegronne, spredte eller ved Grenens Sammendragning knippestillede og i sidste Tilfælde omgivne af et Naalehuus (॰: hindeagtige Knopskjæl). 


\section{LXX}

a. Abietince. Stovknapperne torummede; Kogleskijollene (Frugtblade) talrige, træ- eller læderagtige; Frøene oprette.
124. Pinus .
(Larix).
1. (Abies.)
(Picea.)

b. Cupressince. Støvknapperne fleerrummede; Kogleslijcellene faa (dannede af Dækblade, de nedre henvisnende, de øvre tilsidst kjødfulde), Frøene oprette.

125. Juniperus.... 1 .

c. Taxinea. Støvknapperne 3-8-rummede, skjoldformede; ingen Kogle, men et enkelt, opret, af en tilsidst kjødfuld Frøkappe omgivet $\mathbb{E g}$.

(Taxus.)

\section{** Apetalae (Kronlose). Froene Indesluttede 1 lukkede Frugtblade; Blomsterdækket enkelt eller 0.}

XXIII. Ceratophyllea Gray. (Hornbladfamilien) And. t. 21. Vandplanter med krandsstillede, fint deelte Blade, uden Axelblade; Blomsterne særkjønnede, siddende i Bladhjørnerue; $\hat{o}$ :

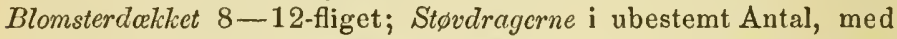
siddende, oventil braadspidsede Stovknapper; \&: Blomsterdoekket som hos $\delta ; 1$ fri Frugtinude med 1 Rum og 1 hængende AEg, braadspidset Griffel; Frugt nødagtig, ofte med udvoxende, tornspidsede Tilhængsler ved Grunden; Frøene uden Frøhvide med mangedeelte Frøblade.

126. Ceratophyllum .. 2.

XXIV. Callitrichineæ Link (Vandstjerner) And.t. 21. Vandplanter med modsatte, udeelte Blade uden Axelblade; Blomsterne $\mathrm{i}$ Bladhjørnerne, særkjønnede, alm. omgivne af 2 modsatte, hindeagtige Dxkblade; Blomsterdakke 0; 1 St $\phi v d r a g e r ;$ 1 firerummet Frugtknude med $1 \mathrm{Fg}$ i hvert Rum; 2 lange, siddende Ar; Frugten tilsidst deelt i 4 uopspringende, ofte vingede Smaafrugter; Kimen ret; Frøhviden hjodagtig.

127. Callitriche ... 4.

XXV. Myriceæ Rich. (Porsfamilien) And. t. 20. Buskvæxter med harpixholdige Punkter i Bladene; Blomsterne særkjønnede (tvebo), i Rakler; ô: Blomsterdaclice 0; 2-6 Stovdragere, befæstede til Grunden af Rakleskjællene; $q$ : hver Blomst omgivet af et 2-4-fliget, undersædigt Blomsterdokke, 1 Frugtknude med 2 Grifler; Frugt enfrøet, nødagtig, ved Grunden sammenvoxet med Blomsterdækket; Frøhvide 0.

128. Nyrica ..... 1.

XXVI. Betulinea Rich. (Birkefamilien) And. t. 20. Træagtige Væxter med affaldende Axelblade; Blomsterne særkjønnede (enbo), i Rakler; $\hat{\sigma}:$ Rakleskjollene med Biskjæl, indsluttende 3 enbladede eller firedeelte Blomsterdcekker ; 4 Stovdragere inden- 


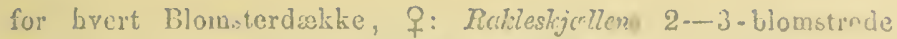
ened eller uden Biskjal; Blonsterdaktic $1 ; 1$ frugtinude med 2 Grifler; Frugien Nord eller Vingefrugt; Fo ptu ide 0.

$$
129 . \text { Betula ..... 2. 130. Aluns. . . . . } 2 .
$$

XXT1, Cupulifere Rich. (Skaalbxrere) And. t. 20. Treagtige Vaxter med affaldende Axelblade; Blonsterue snrkjonnede (enbo); os i Rakler; indenfor Rakleskjællene et 5-9-figet Blomster hicktie eller 2 Bistijat; Stordrayeme i lige cller robuclt Intal nod Blomsterdækkets Wlige (eller Biskjælleue); ;: Jlomsterne enligu eller flere samlede til Hoveder eller Rakler, bver Blomst især eller flere tilsamucn omgivne af et med Frugteu tilvoxende Hylster (Hase) eller af en kopformet eller knpselagtig Udvidelse af Blomst rstilken med fere taglagte (tom r.e) Durblade

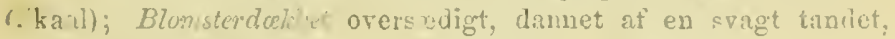
snart forsviudende Rand; 2-3 Ar og ligesaamange Ram i Frugtknuder, $1-2 \mathrm{E}$ o i hvert Rum; den modne Frugt turummet, enfrøet (uødagtig); Froluide 0.

131. Carpinus .... 1. 133. Fagus ..... 1.

132. Cory hus..... 1. 134. Quereus...... 2. (Castanea.)

Xxvilr. Vinacese Ag. (列lmefamilien) And.t. 19. Traek med a fvexlende, rue (ved Grunden ofte ikjare) Blade og affaidendo Axelblnde; Blonsterne i Hoved cller sikjorm paa Siderze af Grenene, tyekjomede; Hloinsterdakke gront eller farvet, 4-6-tandet; Stoidragerne raodsatte og i ligo Antal med Lilom. sterdækliets Flige; $1 \mathrm{fri}$, torummet Frugtlinude med $1 \mathrm{xg}$ i hvert Kuri; 2 Gifler; Hugten on ved Modenuedea exiroet Vingefrugt, med ret Kin uden Frghide.

135. Ulmus...... 3.

XYIX. Urticacen Juss. (Nældefamilien) And. t. 19. Urier med modsatte eller afvexlende Biude, bekledte med rus, of to brendende Haar, redblivende eller aftaldende Acclblad:; Bilunsterne sarkjunncde (sjeldent tvekjømede); 3 : Bionstcrulakiet regelin. 4-5-bladet; Stoudragere i samme Antal som og mod-

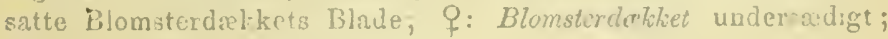
F'rugten cnfroet, hopspringende.

a. Urticece. $q$ : Blomsterdwikket 2-4-dcelt, f'xout opret, Jikill n $r$ t, omgivet af Frohvide.

136. Urtica. ...... 2. 137. Furictaria .... 1.

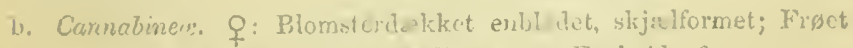
hrengead? Kimen spirallsrummit, Fuhvide 0.

135. Hunulus .... 1. (Camabis.) 


\section{LXXII}

c. Morea. 오 : Blomsterdækket firebladet; Frøet opstigende; Kimen (Morus). bøiet, omgivet af Frohvide.

XXX. Salicinea Rich. (Pilefamilien) And. t. 20. Træeller buskagtige Væxter med vedblivende (eller ingen) Axelblade; Blomsterne tvebo, i Rakler; Rakleskjallene uden Biskjæl, Blomsterdakke 0, $\mathrm{i}$ dets Sted en kirtelformet eller skaalformet Udvidelse af Frugtbunden; $\delta$ : Støvdragerne $2-\infty ;$; 1 Frugtknude; 2 Grifler eller 1 Griffel med 2-4 fligede Ar; Frugten toklappet Kapsel med talrige Froe, som ved Grunden ere om. givne af Frøuld; Kimen ret, Frohvide 0.

139. Salix..... 25. 140. Populus..... 7.

XXXI. Salsolacea Moq. (Salturter) And. t. 19. Urter eller Halvbuske med afvexlende Blade uden Axelblade; Blomsterne særkjønnede eller tvekjønnede; Blomsterdokket undersædigt, grønt, fembladet eller femtandet (sjeldnere 2-3-deelt); Støvdragere i bestemt Tal (typisk 5), modsatte Perigonbladene (sjeldent færre og aldrig flere end disse); Frugtknuden enkelt; enrummet og enfrøet; Grifler 2-4; Frugten Hindefrugt eller Nød, ofte omgivet af det vedblivende og tilvoxende Blomsterdække; Kimen krum eller spiralformet, uden eller med melet, midtliggende Frohvide. (Voxe hyppigt paa saltholdig Jordbund og indeholde ofte Salt, ofte ere de overtrukne af en løs melet Beklædning).

a. 141. Salicornia ... 2. 146. Blitum .... 5 .

b. 142. Chenopodina. . 1. 147. Beta..... 1.

143. Salsola..... 1. d. 148. Atriplex ... 7.

e. 144. Kochia..... 1. 149. Halymus ... 2.

145. Chenopodium . 7.

XXXII. Amarantacer Juss. (Amarantfamilien) And. t. 19. Urter med modsatte eller afvexlende Blade uden Axelblade; Blomsterne tvekjønnede eller særkjønnede, i Nøgler, Hoveder eller Ax; Blomsterdakket 3-5-deelt, hindeagtigt, ofte omgivet af et trebladet Biblomsterdække; Stovdragerne i lige Antal med Blomsterdxkkets Flige; Frugtknuden fri, enrummet, med 1-flere Frøe; Frugten uopspringende (Nød) eller opspringende [uregelm. eller paatværs: Hindefiugt].

150. Amarantus .... 1.

XXXIII. Polygonea Juss. (Syrefamilien) And.t. 17. '(Urteagtige) Væxter med afvexlende Blade og et hindeagtigt Axelblad (Kræmmerhuus) indenfor Bladstilken; Blomsterne tvekjønnede eller særkjønnede; Blomsterdakket undersædigt, farvet, 3-5-6-deelt (Perigonbladene i den indre Kreds ofte større); Stovdragerne i bestemt Tal, oftest lige med Perigonbladene (typisk 6); 1 Frugtknude; $2-3$ Grifler (eller 1 Griffel og $2-3$ 


\section{LXXIII}

Ar); Frugten enfrøet Nød (fladtrykt eller trekantet), ofte omgivet af det vedblivęude Blomsterdække; Frohviden stor, melet.

151. Polygonum .... 12. 153. Rumex ..... 15.

152. Fagopyrum ..... 1.

XXXIV. Santalacea R. Br. (Sandelfamilien). (Urteagtige) Væxter med afvexlende Blade uden Axelblade; Blomsterne med Dækblade (tilvoxede til Blomsterstilken), tvekjonnede; Blomsterdakket indvendig farvet, sambladet, med 3-5-deelt Krave; Støvdragerne $\mathrm{i}$ lige Antal med, tilvoxede til og modsatte Kravens Flige; Frugtknuden 1, undersædig; 1 Griffel; Frugten enfrøet, nød- eller steenfrugtagtig, beklædt med det vedblivende oversædige Blomsterdække; Frøene med Frøhvide.

154. Thesium ..... 1 .

XXXV. Thymelex Adans. (Kjælderhalsfamilien) And. t. 18. (Buskagtige) Væxter med ndeelte Blade uden Axelblade; Blomsterne tvekjønnede; Blomsterdcklket farvet, sambladet, med firefliget Krave; Stovdragerne befæstede til Røret af Blomsterdækket i [lige eller] dobbelt Antal mod dettes Flige; Frugtknuden 1, fri, enrummet (og enfrøet); Frugten Steenfrugt; Fro med ret Kim uden Frøhvide).

155. Daphne..... 1 .

XXXVI. Elaagnea R. Br. (Solvbladfamilien) And. t. 18. Buskvæxter (ofte med Vedtorne af tilspidsede Grene); Bladene bekliedte med solvglindsende, stjerneformede og skjoldformigt tilhaftede Skjæl; Blomsterne [tvekjonnede eller] særkjønnede; o : Blomsterne i korte $\mathrm{Ax}$, hver Blomst omgivet af et Drekblad; Blomsterdakket 2-4-bladet; 4 Stovdragere; $\$$ (og ఫ̧)-Blomsterne enlige eller faae samlede; Blomsterdcekket sambladet, 1 fri Frugtknude, 1 Griffel; Frugten enfrøet, nopspringende, omgivet af det vedblivende og kjødagtigt tilvoxende Blomsterdække (og derved falsk-bæragtig).

\section{Hippophä̈.... 1.}

XXXVII. Aristolochiese Juss. (Slangerodfamilien) And. t. 18. Urter (eller slyngende Buske) med afvexlende, brede, fod- eller haandnervede Blade; Blomsterne tvekjønnede; Blomsterclakkiet oversædigt (skjævt tragtformet eller regelm. tredeelt); Stovdragerne $6-12$, tilvoxede (med Støvtraaden) til en oversædig Skive eller (med Støvknapperne) til Arret; Frugtknuden 3-6-rummet med midtstillet Frøstol, 6 straaleformede Ar; Frugten kapselagtig med talrige Froe.

157. Asarum ...... 1. 158. Aristolochia.... 1. 


\section{LXXIV}

*** Cqunopetala (Ileelkronede). Blomsterdakket dobbelt, Kronen sambladet.

XXXVIII. Plantaginea Juss. (Veibredfamilien) And. t. 6. Urteagtige Vxxter; Blomsterne i Ax eller enlige, tvekjonnede eller særkjønnede; Bogeret firedeelt, redblivende; $K r o n$ is firefliget med hindeagtige Flige; 1 Frugthnude med 1-2 Kum og 1-2 Grifier; Frugten hos de sxrijonnede en enfroet Nød, hos de tveljonnede en torummet Buddike med en-flecrfoede Rum; Froene med Frøhride.

159. Plantago ..... 5. 160. Littore ${ }^{1}$....... 1.

XXXIX, Pumbarinere Juss. (Hindebrgerfamilien) Aad. t. 6. Tedvarende Uiter med udeelte Biade uden Arelblade; Blonsterne trekjonnede, i Hoved eller ensidige, grenede Ax; Lixgeret hindeagtigt, vedblivende, femtandet, foldet; Kronen femdeelt eller ftmblarlet; Stovdragerne 5, i forste Tilfilde bef:ostede til Frugtbunden, i sidste til Kronbladenes Basis; 1 tylisk femrummet Frugthrude; Griflerne (typisk) 5, (Fragten enfrget, uopspringende); Kinen ret, omgivet af Frøhride.

161. Statice ..... 2. 162. Armeria .... 2.

XI. Valrianea DC. (Baldrianfamilien) And. t. 2. Urter med modsatte Blade uden Axelblade; Blonsterne i gaffeldett, quastfornet Blomsterstand, tuldstrendige eller ufuldstendige; Bagerct oversædigt, hivdeagtigt eller haarformet med indrullet, zood Frugtmoduirgen nibredt Rand (Fook); Kronen ror-eller slagtformet, befastet til Bagerranden, med alm. femdeclt Frave; Stovdragerne 1-5 (hos de danke Arter 3); befiestede til kronrovet; Frugthnuden trerummet, de 2 Rum tomine og ofte til

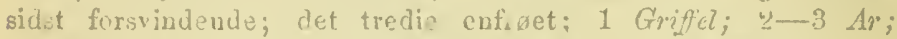
Frugten uol springende (Skalfrugt); Kinen ret, Frohride 0.

163 Valeriaua..... 3. 164. Valerianella ... 2.

ILI. Dipsncere DC. (Kartebollefamilien) And. t. 1. Urter med modsatie Blade uden Axelblade; Blomstirne samlede i Hoved (Blomsterkurv) og oungivne af et fælles Sivb (äu u-

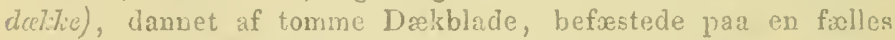
Blomsteraxe (Blu,nstcrleic), ofte med særegne 1)aliblndo (Avner) for bver enkelt Hlomst, tvekjonnede; Bageret dobk lt (et omkringsadigt $Y d e r \cdot b a g e r$ udenfor det egenlige, oversadige Bagrr), begge eller knn det indre haar eller børsteformede, bekledende Frugten i Form af Fock; Kronen regelua, cller uregelm.; Stovdragerne 4, frie, befostede til Fronroret; Frugthnuten enruminet, eufoet; 1 Griffel; $1-2 \mathrm{Ar} ;$ Frugten underadig iSkalfrugt); Froet med ret Iim, omgivet af kjodagtig Frohricle.

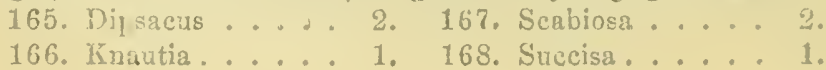


XLII. Synantherea Rich. (Kurvblomstrede) And. t. 1. Urter (eller Buskvæxter) uden Axelbladc; Blomsterne samlede til en Blomsterkurv, befæestede paa et Blomsterleie, omgivue af et Kurvdakke ( $\mathrm{s}$ : tomme Dækblade), de enkelte Blomster ofte af særlige Dækblade (Avner); Blomsterne tvekjønnede, særkjønnede eller kjønsløse; Bacgerets oversædige Krave (Fnok) fjer-, børsteeller haarformet, oftest mangestraalet, eller hindeagtig (sjeldnere 0 ) uden Yderbager; Kronen snart regelm. femtandet (rørformet), suart ensidigt udbredt og i Spidsen heel eller 2-5-tandet (tungeformet) eller uregelm. tragtformet [sjeldnere tolæbet], alle eens eller de ydre (Randkronerne) forskjellige fra de indre (Skivekronerne); Stovdragerne 5, befæstede til Kronrøret, med rørformigt sammenvoxede Stovknapper; Frugtknuden enkelt, undersædig; 1 Griffel, $2 A r$; Frugten enfrøet, nødagtig, beklædt med den vedblivende Fnok (Skalfrugt); Kimen ret, ingen Frøhvide.

a. Cichoracee Juss. (Løvetandsgruppen). Planten indeholder Mælkesaft, alle Blomsterne i Kurven $\Varangle$ med tungeformede Kroner.

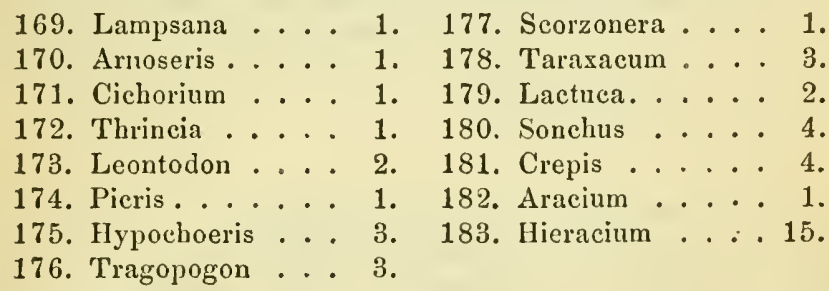

c. Cynaree Less. (Tidselgruppen). Griffelen hos Trekjønsblomsterne med en opsvulmet (ofte af en Haarkrands omgivet) Ring under Arrets Flige, Kurvdækket alm. kugleformet, med stive, ofte stikkende Blade.

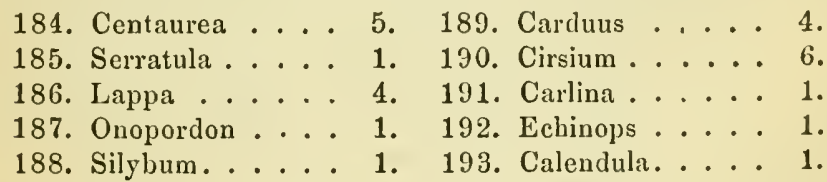

c. Eupatoriacea (Malurtgruppen). Kronerne rsprormede, i Skiven $\Varangle$, i Randen alm. $\$$; Griffelen uden opsvulmet Ring (Kurvdækket alm. valseformet, med urteagtige Blade).

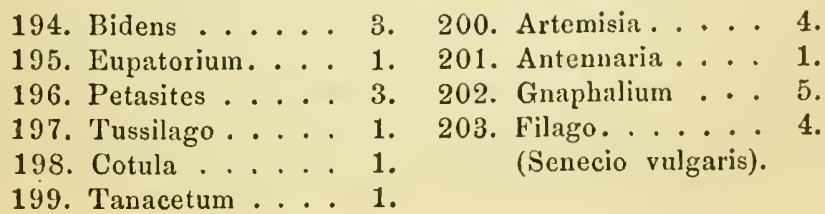


d. Radiatce (Straaleblomstrede). Kronerne-i Randen tungeformede ㅇ, i Skiven rørformiede, $\not$.

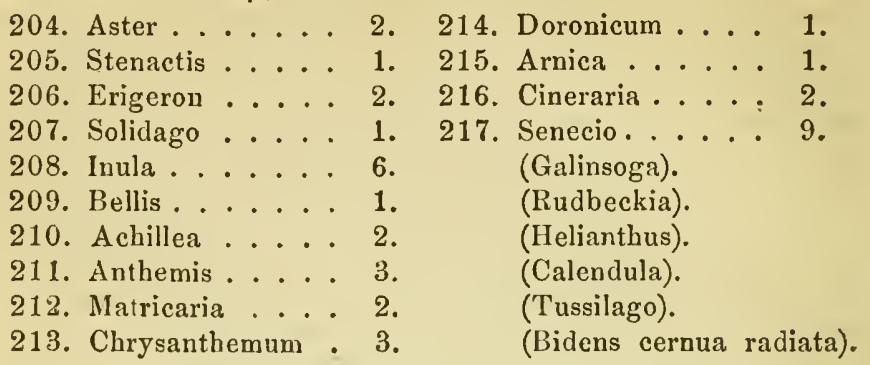

XLIII. Ambrosieæ Link (Braadfrøfamilien) And. t. 1. Enaarige Urter [eller. Halvbuske] med Særkjønsblomster; $\hat{o}^{\wedge}$ : Blomsterne i Hoved, omgivet af et mangebladet $S v \varnothing b$, de enkelte Blomster med Dækblade og et sambladet, femtandet Blomsterdakke; Støvdragerne 5 med (frie eller) sammenvoxede Støvtraade; ?: flere Blomster, hver med 1 Frugtknude og $2 A r$, indsluttede af et fxlles Svøb, der udvoxer og forhærdes oukring den modnende, nødagtige Frugt.

218. Xanthium ..... 1.

XLIV. Lobeliacen Juss. (Lobeliefamilien) And. t. 3. Urter [eller Halvbuske] med Mrlkesaft; Bladene afvexlende, uden Axelblade; Blomsterne fuldstændige, typisk uregelmæssige; $B c e-$ geret oversædigt eller halvt-oversædigt, regelm. eller uregelm. femfliget; Kronen befæstet til Bægerrorets øvre Rand, uregelm. og paa forskjellig Maade femdeelt (ofte med tolæbet Krave og ensidigt spaltet Rør); Støvdragerne 5, befæstede til Kronrøret eller en omkringsædig Skive; Støvknapperne rørformigt sammenvoxede; Frugtlcnuden 1, 2-3-rummet; 1 Griffel, 1 udeelt eller lappet, af en Haarkrands omgivet Ar; Frøstolene tilvoxede til Skillevæggene; Frugten uopspringende eller kapselagtig med rumdelende Opspringning.

219. Lobelia ...... 1.

XLV. Campanulacex Juss. (Klokkefamilien) And. t. 3. Urter med Mrlkesaft; Bladene afvexlende, uden Axelblade; Blomsterne med Dxkblade, fuldstændige, regelm. og typisk femdeelte; Bageret oversædigt eller halvt-oversædigt; Kronrøret tilbæftet til en oversædig Skive, Kraven mere eller mindre dybt

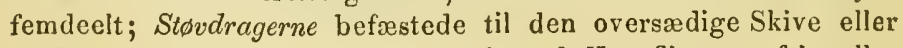
til Basis af Kronen, i lige Antal med Kronfligene, frie eller 
med tildecls sammenvoxede Stovknapper; (1 Griffel, 2-3 Ar); Frugtknuden (2-3-rummet) med fuldstændige Skillevægge og pladedannede 2 Egstole befæstede til Frugtbladenes i Midten samınenstødende Vinkler; Kapselen (2-3-rummet), mangefrøet, opspringende ved Huller paa Sirlerne, sjeldnere ved Klapper; Kimen ret, i Midten af den kjødede Frohvide.

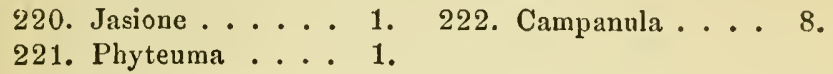

XLVI. Rubiaceæ DC. $\alpha$, Stellatæ (L.) (Kírapfamilien) And. t. 2. Urter med krandsstillede Blade, modsatte Grene; Blomsterstandens mindre Forgreninger oftest -gaffeldeelt-qvastformede; Blomsterne fuldstændige; Bageret oversædigt, 4-5-tandet, ofte utydeligt; Kronen tragt- eller hjulformet, 4-5-fliget; Stovdragerne befæstede til Kronrøret, i samme Antal som og afvexlende med Kravens Flige; Frugtknuden undersædig, dannet af 2 Frugtblade; 2 Grifler eller Ar; Frugten ved Modenheden todelelig Spaltefrugt, med uopspringende, enfrøede Smaafrugter (Nødder eller Steenfrugter); Kimen ret, omgivet af en hornagtig Frøhvide.

223. Sherardia.... 1. 225. Galium .... 12 .

224. Asperula .... 2. (Rubia).

XLVII. Caprifoliacere Juss. (Gedebladfamilien) And. t. 2. Buskvæxter med modsatte Blade; Blomsterne (parviis samlede eller i gaffeldeclt Qvast) fuldstændige eller nogle kjønsløse; Bageret femtandet, oversædigt; Kronen regelm. eller uregelm. femdeelt; Stovdragerne (5) befæstede til Kronrøret; Frugtknuden 2-5-rummet, undersædig; Frugten et undersædigt Bær; Frone med ret Kim og kjødet Frohvide.

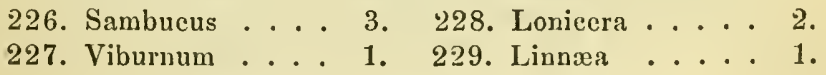

XLVIII. Oleinex Link. (Oliefamilien). Træer eller Buske med modsatte Blade uden Axelblade; Blomsterne fuldstandige eller ufuldstændige, regelmæssige; Bogcret firetandet (eller 0); Kronen fircfliget eller 0; Stovdragerne 2, befxstede til Kronreret eller til Frugtbunden; Frugtknuden 1, torummet, med 1-2 hængende Ey i hvert Rum; Arret todeelt eller udeclt; Frugten 1-2-rummet (Bær, Kapsel eller Vingefrugt).

230. Ligustrum .... 1. 232. Fraxinus .... 1.

231. Syringa .... 1 . 


\section{LXXVIII}

XLIX. Apocyneæ R. Br. (Snokronede) Contortæ And. t. 5. Halvbuske [eller Træer], indeholdende Mælkesaft; Bladene modsatte; Blomsterne fuldstændige, regelmæssige, typisk femdeelte; Kronens Krave i Knopleiet snoet; Støvdragerne befæstede til Kronrøret, i samme Tal som og afvexlende med Kravens Flige; Støvknapperne indadvendte, ofte med Tilhængsler; Frugtknuderne 2, adskilte eller sammenvoxede, 1-2-rummede; 1 fælles, ofte foroven (i Form af en flad Skive under Arret) udvidet Griffel; Frugterne 2 Bællekapsler [eller 1 toklappet Kapsel], Frone ofte omgivne af Frøuld.

233. Vinea...... 1 .

L. Asclepiadea R."Br. (Svalerodfamilien) Contortæ And. t. 5. Urter [eller Buske] med Mælkesaft; Bladene modsatte, Blomsterne fuldstændige, regelmæssig femdeelte; Kronens Flige i Knopleiet taglagt-snoede, med Bikronblade i Svælget; St $\emptyset v$ dragerne 5, befæstede ved Kronrørets Basis og afvexlendo med Kronfligene; Stovknapperne udadvendte, ofte med Tilhængsler og indbyrdes sammenvoxede; Stovet i parviis sammenhængende Masser (1 Masse fra hvert af de sammenstødende Støvknappers Naborum) og ved en Kirtel fasthæftede til Arrets Spidse eller Sider; Frugtknuderne 2, enrummede; Griflerne 2, forenede under det fælles, $5-\infty$-kantede Ar; Frugterne (typisk) 2 Bællekapsler; Frøene omgivne af Frøuld.

234. Vincetoxicum ... 1.

LI. Gentianeæ Juss. (Bitterbladfamilien). Urter, indeholdende et bittert Stof, uden Axelblade; Blomsterne fuldstændige, regelmæssigt 4-5-deelte; Bageret vedblivende; Stovdragerne i lige Tal og afvexlende med Kronfligene, befæstede til Kronrøret; Støvlonapperne indadvendte, ofte efter Bestøvningen snoede; 1 Frugtlknude og Griffel, todeelt Ar; Frugten toklappet, opspringende, med Froene befæstede paa Frugtbladenes indbøiede Rand.

a. G. verce (And. t. 5). Bladene modsatte; Kronen i Knopleiet snoet; Frugten med tort Mellemlag.

233. Gentiana .... 3. 237. Erythræa .... 3.

236. Cicendia .... 1.

b. Menyanthece Fr. (And. t. 4). Bladene afvexlende; Kronen med foldet Knopleie; Frugtens Mellemlag saftigt.

238. Menyanthes ... 1. (Limnanthemum). 
LII. Labiatx (L æbeblomstrede) Urter eller Halvbuske med firekantet Stangel, modsatte Blade uden Axelblade; Blomsterne i Qvaster eller Knipper, ved hvis Stilling i de modsatte Blades Hjørner ofte dannes (falske) Krandse, ofte, ved disses indbyrdes Tilnærmelse, Ax; Bageret femtandet, regelmæssigt eller tolæbet (Ovërlæben tre-, Underlæben tofliget); Kronen tolæbet (Overlæben todeelt eller udeelt, Underlæben trefliget); Støvdragerne 4, tomægtige, sjeldnere 2, befæstede til Kronrøret; Frugtknuden befæstet pąa en skiveformet Udvidelse af Frugtbunden, tobladet, firerummet, med $1 \mathscr{E g}$ i hvert Rum; Griffelen 1, midtstillet, med todeelt $A r ;$ Frugten firedelelig Spaltefiugt med nødagtige Smaafrugter; Fr $\varnothing$ uden eller med sparsom Frøhvide (Etheriske Olier i Kirtler under Overhuden give dem alm. en aromatisk Lugt).

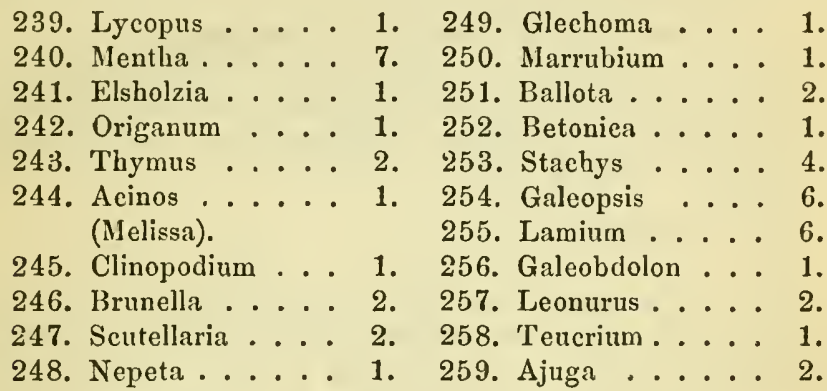

LIII. Yerbenaceß Juss. (Jernurtsfamilien) And. t..5. Urter [eller Buske] med hyppigt firekantet Stoengel og oftest modsatte Blade; Bageret regelmæssigt eller uregelmæssigt femdeelt; Kronen med en uregelm. femdeelt, næsten tolæbet Krave; Stovdragerne befæstede til Kronrøret, 4, tomægtige, de 2 ofte ufuldkomne, Frugten firerummet, med enfrøede [eller tofrøede] Rum, steenfrugtagtig, de enkelte Rum tilsidst som Smaafrugter indbyrdes adskilte; Frde uden Hvide.

260. Verbena .... 1 .

LIV. Asperifolia L. (Rubladede) (Borraginex Juss.) And. t. 3. (Urteagtige) alm. hvashaarede Væxter; Bladene udeelte, uden Axelblade; Blomsterstanden i Spidsen af Strengelen eller Grenene, ofte ved Grunden gaffeldeelt, ensidig og før Udspringningen sneglehuusformigt indrullet, Blomsterne fuldstændige; Bageret regelmæssig femdeelt; Kronen med regelmæssig eller sjeldent uregelmæssig femdeelt Krave og ofte Folder eller Tænder (den saakaldte Bikrone $0: 5$ indadvendte Sporer) i Svælget; 


\section{LXXX}

Støvdragerne 5, befæstede til Kronrøret; Frugien firedelelig Spaltefrugt med enfrøede Smaafrugter og midtstillet Griffel; Frölvide 0 eller liden.

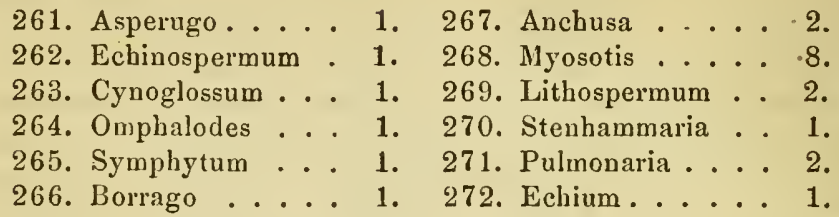

LV. Convolvulacea Juss. (Snerlefamilien) And. t. 3. (Urteagtige) slyngende Væxter med Mælkesaft; Bladene afvexlende, uden Axelblade; Blomsterne med Dakblade, fuldstandige; $B \propto$ geret regelm. fembladet, vedblivende; Kronen i Knopleiet snoet, mere eller mindre tydeligt femdeelt; Støvdragerne 5, befæstede ved Kronrørets Basis og afvexlende med Kronfligene; Frugten 2-4-rummet, kapselagtig med skillevægbrydende Opspringning; Frøenc hefiestede ved Grunden af Skillevæggen, med bøiet Kim og slimagtig Frohvide.

273. Convolvulus ... 2 .

LVI. Cuscutina Link. (Hørsilkefamilien) And, t. 3. Slyngende og ved Sugevorter snyltende bladløse Urter med Mælkesaft og uden grøn Farve; Blomsterne sammenhobede i Hoveder [eller Ax], fuldstændige, regelmæssigt 4-5-deelte; Kronen med eller uden Bikronskjæl i Svælget; Støvdragerne befæstede til Kronrøret, afvexlende med Kronfligene; Frugten faafrøet, tværsopspringende; Frøene med midtliggende, kjødagtig Frøhvide og spiralkrummet Kim uden tydelige Frøblade.

274. Cuscuta... 4.

$\dagger$ Polemoniacea Vent. Urter med spredte Blade (eller de nedre modsatte), Blomster i Qvast, Nogle eller Top, fuldstændige, regelmæssigt femdeelte; Kronen tragt- eller hjulformet (sjeldnere uregelmæssig), med taglagt, snoet Knopleie, Støvdragerne 5, befæstede i Kronrøret og afvexlende med Kronfligene; Frugtknuden ved Grunden omgivet af en undersædig Skive, med midtstillet Egstol, 1 Griffel med tredeelt $A r$; Frugten en trerummet Kapsel med rundelende Opspringning, Frøene 1 eller flere $\mathrm{i}$ hvert Rum, med slimet Froskal og ret Kim i Midten af en kjødagtig Frohvide.

(Polemonium). 
LVII. Solaneæ Juss. (Kartoffelfamilien) And. t. 6. (Urter eller Buske); Bladene afvexlende, uden Axelblade; Blomsterne uden Dækblade, fuldstændige; Bager og Krone typisk regelmæssigt femdeelte; Støvdragerne befæestede til Kronroret, afvexlende og i lige Antal med Kronfligene; Frugtknuden to. rummet med en tyk, midtstillet Egstol, ved hvis Udvidelse Frugten ofte bliver (falsk) firerummet; Bær eller Kapsel opspringende paalangs (skillevægdelende) eller paatværs; Frøe med kjødagtig Frøhvide og bøiet Kim. (Alm. giftige Væxter).

275. Lycium . . . . . 1

(Nicandra).

276. Solanum .... 5. 279. Datura ..... 1.

277. Physalis ..... 1. 280. Hyoscyamus ... 1.

278. Atropa ..... 1.

LVIII. Scrophulariaceæ Lindl. (Maskeblomstrede) And. t. 5. (Urteagtige Væxter) uden Axelblade; Blomsterne fuldstændige, uregelrette eller næsten regelrette; Bageret $4--5$-deelt; Kronen tolæbet, maskeret eller gabende, sjeldnere næsten regelmæssigt hjulformet, med eller uden Spore; Støvdragerne 4, tomægtige, sjeldnere 2 eller 5 uligelunge, befæstede til Kronrøret; Frugtknuden enkelt; 1 Griffel; Arret udeelt eller todeelt; Frugten torummet, med Frostolen paa Midten af Skillevæggen udvidet til en Plade eller Siøtte i begge Rummene, kapselformigt opspringende ved Huller eller i 2, ofte tredeelte Klapper; Froene talrige, med Frøhvide.

1. Verbascec. Støvdragerne 5 (eller 4 fuldkomne og 1 ufuldkommen), med Støvlnnapperne opspringende ved en Trærspalte.

281. Verbaseum .... 4. 282. Scrophularia ... 3.

b. Antirrhinea. Kronens Overlæbe dakker i Knopleiet Underlæben; St $\lesssim$ vdragerne 2 ellẹ 4 (tomægtige), Stovknapperne opspringe paalangs, uden Tilhængsler.

283. Limosella . . . . 1. 286. Digitalis ..... 1 .

284. Veronica .... 18. 287. Antirrhinum ... 1.

285. Gratiola ..... 1. 288. Linaria ..... 4.

(Mimulus).

c. Rhinanthaceœ. Kronens Underlæbe dækker i Knopleiet Overlæben. Støvdragerne 4 tomægtige, Støvknapperne med Længdeopspriugning, nedentil braadspidsede eller med Tilhrengsler.

289. Nelampyrum ... 5. 292. Odontites ... 2.

290. Pedicularis .... 3. 293. Euphrasia .... 3.

291. Rhinanthus ... 2.

Baandb. $i$ den danske Flora. 


\section{LXXXII}

LIX. Orobancheæ Juss. (Skjælrodfamilien) And. t. 5. Snyltevæxter med skjælformede Blade uden grøn Farve; Blomsterne (i Klaser eller $\mathrm{Ax}$ ) omgivne af Dækblade, fuldstændige, uregelmæssige; Bageret 4-5-deelt eller -tandet; Kronen tolæbet, Overlæben hvælvet, heel eller tolappet, Underlæben trelappet; Støvdragerne 4, tomægtige, befæstede til Kronrøret; 1 enkelt Frugtknude; 1 Griffel med todeelt eller udeelt Ar; Frugten kapselagtig, toklappet, enrummet med vægstillede Frøstole og talrige Frøe med Frøhvide.

294. Orobanche .... 4. 295. Lathræa .... 1.

LX. Lentibulariæ Rich. (Blærerodfamilien) And. t. 6. Vandeller Sumpplanter (ofte med Bladfligene tildeels omdannede til Blærer); Blomsterne fuldstændige, uregelmæssige; Bageret tobladet eller femdeelt, tolæbet; Kronen hurtigt affaldende, tolæbet eller maskeret, forsynet med en Spore; Stovdragere 2, befæstede til Grunden af Kronrøret, med enrummede Støvknapper; 1 Frugtknude, Griffelen kort eller 0; Arret tolæhet eller skjævt tragtformet; Frugten enrummet kapselagtig, toklappet eller uregelmæssigt opspringende, med fri, kugleformet Frøstol; Frøene uden Frøhvide.

\section{Utricularia ... 5. 297. Pinguicula ... 1.}

LXI. Primulacea Vent. (Kodriverfamilien) And. t. 6. Urter uden Axelblade; Blomsterne trekjønnede, regelmæssige, typisk femdeelte; Bcegerets og Kronens Flige i lige Antal og indbyrdes afvexlende; Stovdragerne i samme Antal, befæstede til Kronrøret og modsatte dettes Flige; 1 Frugtknude; 1 enkelt Griffel med udeelt $A r ;$ Frugten enrummet, opspringende paalangs, med Tænder af Kronfligenes Antal, eller paatværs; Frøene talrige, befæstede i Gruber paa den frie, midtstillede Frøstol.

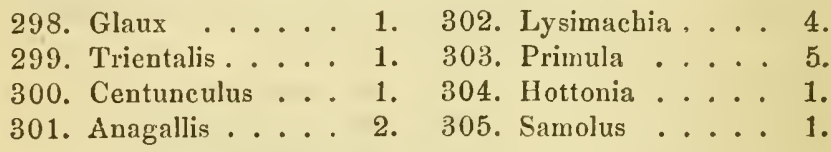

LXII. Ericinea Juss. (Lyngfamilien) And. t. 16. Buske eller Halvbuske, sjeldnere vedvarende Urter med alm. stedsegrønne Blade uden Axelblade; Blomsterne fuldstændige, regelrette, omgivne af Dækblade; Bageret 4-5-deelt eller -tandet, undersædigt eller tilvoxet til Frugtknuden; Kronen 4-5-bladet eller -tandet, i Knopleiet taglagt, befastet til Frugtbunden eller en oversædig Skive; Støvdragerne i [lige eller] dobbelt Antal, befæstede til Kronrørets Basis, til Frugtbunden eller til 
den oversædige Skive; Stovknapperne opspringe ved Huller i Spidsen [sjeldnere ved en Læugdespalte], ofte med horn-eller børsteformede Tilhængsler; Frugten fri eller undersædig, 4-5. rummet, bær- eller kapselagtig; $1-\infty$ Frde i hvert Rum med ret Kim, kjødet Frøhvide.

a. Vacciniece. Frugten undersiedig, bær- eller steenfrugtagtig. $\mathbf{\zeta}$. 306. Vaccinium .... 4 .

b. Ericea. Frugten fri, kapselagtig, med oftest rumdelende Opspringning, sjeldnere Steenfrugt; Kronen sambladet; Støvdragerne befæstede til en undersædig Skive. $\boldsymbol{\zeta}$.

307. Arctostaphylos .. 1. 309. Calluna .... 1.

308. Andromeda .... 1. 310. Erica ..... 1.

***** Eleutheropetalce (Frikronbladede). Blousterdækket dobbelt, Kroneu fribladet.

LXII. Umbelliferæ Juss. (Skjærmblomstrede) And. t. 8. Urter med leddet, ofte huul Stcengel, afvexlende, omskedende, alm. dybt deelte Blade; Blomsterne tvekjønnede, i enkelt elier sammensat Skjærm, ofte (saavel Storskjormen som Smaaskjormene) omgivne af Dækblade (Stor- og Smaasvob); Bagerets Krave femdeelt, ofte utydelig eller 0 ; Krohbladene 5 , regelmæssige eller uregelmæssige, ofte med tofliget, indrullet Spidse; Stovdragerne i lige Tal og afvexlende med Kronbladene samt tilligemed disse befæstede til en oversædig Skive, i Knopleiet indrullede; Frugtknuden undersædig, torummet, med 1 hængende $/ \mathrm{Eg}$ i hvert Rum; 2 Grifler med udeelte $A r$, forneden ndvidede og i Forbindelse med Skiven dannende en Griffelfod (stylopodium); Frugten en todelelig Spaltefrugt, de nødagtige Smaafrugter løsne sig fra neden og blive fastholdte ved den fra oven alm. todeelte Frugtstol (carpophorum), Frøgjemmet ofte udvendig beklædt med Ribber (Hoved- og Biribber), indvendig forsynet med Oliekanaler; Kimen liden, ret, i Spidsen af den kjødede eller hornagtige Frohvide.

a. Orthosperma. Frølividen paa den indadvendte Side (Bugfladen) plan.

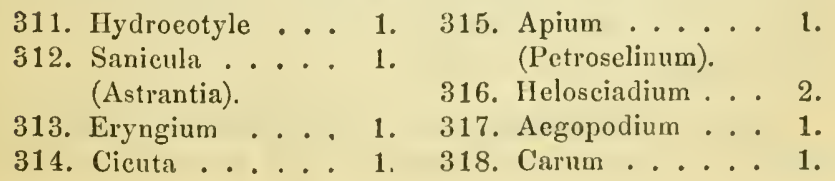




\section{LXXXIV}

319. Pimpinella ... 2. 329. Selinum..... 1.

320. Sium ...... 2. 330. Angelica ..... 1.

321. Falcaria .... 1. 331. Archangelica ... 1.

322. Bupleurum .... 2. 332. Peucedanum ... 2.

323. Oenanthe .... 3. 333. Imperatoria ... 1 .

324. Aethusa .... 1. 334. Anethum .... 1.

325. Libanotis ..... 1. 335. Pastinaca..... 1.

326. Cnidium .... 1. 336. Heracleum .... 2.

327. Haloscias ..... 1. 337. Laserpitium ... 1.

328. Levisticum .... 1. 338. Daucus .... 1.

b. Campylosperma. Frohviden paa Bugfladen indbøiet i Form af en Fold eller Fure.

339. Cancalis ..... 1. 343. Chærophyllum ... 1. 340. Torilis ..... 2. 344. Myrrhis ...... 1.

341. Scandix ..... 1. 345. Conium ...... 1 .

342. Anthriscus ... 3.

c. Coelosperma. Frøhviden fra Grunden til Spidsen krumbøiet.

346. Coriandrum ... 1.

LXIV. Araliaceæ Juss. (Vedbendefamilien) And. t. 7. Vedvarende Urter eller Buskvæxter; Blomsterne fuldstændige, regelmæssige; Blomsten oversædig eller halvt-oversædig, Bagerets Krave svagt 3-5-tandet; Kronbladene alm. 5; Støvdragerne i lige eller dobelt Tal, tilligemed Kronbladene befæstede til en oversædig Skive; Frugtknuden (femrummet) med 1 hængende AEg i hvert Rum, 1-5 Grifler med udeelte Ar; Frugten bæragtig; Kimen ret; Frøhviden kjødagtig.

347. Hedera .... 1: 348. Adoxa ..... 1.

LXV. Cornez DC. (Kornelfamilien) And. t. 7. Træer eller Buske med modsatte Blade; Blomsterne fuldstændige, regelmæssige, oversædige; Bagerkraven firetandet, oversædig; Kronbladene 4, affaldende, afvexlende meả Bægertænderne og tilvoxede til en oversædig Skive; Støvdragerne i lige Antal og afvexlende med Kronbladene; Frugtknuden 1-3-rummet, med 1 hængende $A g g$ i hvert Rum; 1 Griffel; Arret udeelt; Frugten 1-3-rummet med beenhaarde Vægye og saftigt Mellemlag; Kimen ret; Frøhviden kjødagtig.

349. Cornus ..... 2.

LXVI. Loranthaceæ Don. (Mistelfamilien) And. t. 2. Snyltende, stedsegrøune Buskvæxter med leddede, gaffeldeelte 
Grene og modsatte Blade; Blomsterne [tvekjønnede eller] særkjønnede; Blomsterclceliket enkelt eller dobbelt [eller 0], firedeelt; ô: Støvdragerne af lige Antal med Blomsterdækkets Flige og modsatte disse (tilvoxede til samme uden Støvtraade); + : Blomsten oversædig, en nøgen AEgkjarne (ofte med 2 Kime) indsluttet af den kjødfulde Frugtkunde; Frugten saftig.

350. Viseum ..... 1.

LXVII. Crassulaces DC. (Steenurtfamilien) And. t. 13. Urter med saftige Blade; Blomsterstanden alm. galfeldeelt; Blomsterne regelı. (trekjønnede); Bageret typisk femdeelt; Kronbladene $\mathrm{i}$ samme Antal som Bægerbladene og befæstede til Bægerets nedre Deel; Støvdragerne i lige eller dobbelt Antal, befæstede til Kronbladenes Basis; undersædige Skjal modsatte og af Tal med Frugtbladene, der ere krandsstillede, i samme Antal som Kronbladene, indbyrdes adskilte, enrummede; Frugterne Bællekapsler; Frøene talrige, befæstede til Bugsømmen, med kjødet Frøhvide og ret Kim.

351. Bulliarda ..... 1. 353. Sempervivum ... 1.

352. Sedum ..... 7 .

LXVIII. Saxifragaceæ Vent. (Steenbrækfamilien) And. t. 13. (Urteagtige Væxter), Blomsterne tvekjønnede, regelmæssige, $B a$ geret 4-5-deelt, undersædigt eller halvt oversædigt; Kronbladene i tilsvarende Antal og afvexlende med Bægerets Flige, befæstede tilligemed Støvdragerne til Bægerrøret; Støvdragerne i [samme eller] dobbelt Antal; Frugtknuden dannet af 2 Frugtblade, med talrige $L E g ; 2$ Grifler med udeelte $A r$; Frugten kapselagtig, 1-2-rummet, opspringende i Spidsen eller paalangs.

354. Saxifraga .... 3. 355. Chrysosplenium.. 2.

LXIX. Ribesiaceæ Rehb. (Ribsfamilien) And. t. 13. Buske med spredte, haandnervede Blade; Blomsterne regelmæssige, tvekjønnede eller særkjønnede; Bageret femdeelt; Kronbladene befæstede til en oversædig Skive i Bægerets Svælg, i tilsvarende Antal til og afvexlende med Begerfligene; 5 St $\phi v-$ dragere; Frugthnuden undersædig, tobladet, enrummet, med talrige $\mathscr{E} g$ befæestede til vægstillede Egstole; Griflerne 2, frie eller tildeels sammenvoxede, Frugten bæragtig, med det henvisnede Bæger i Spidsen, fleerfrøet; Froene ongivne af en geleeagtig Frøhud; Kimen ret.

356. Ribes ..... 4 . 


\section{LXXXVI}

LXX. Ranunculacea Juss. (Ranunfelfamilien) And. t. 9. Urter [eller Halvbuske] med oftest afvexlende, omskedende Blade uden Axelblade; Blomsterne tvekjønnede, regelrnæssige eller uregelmæssige, undersædige; Bogeret 3-6-bladet, grønt eller farvet; Kronbladene affaldende, i tilsvarende eller større Antal mod Brgerbladene, eller 0; Støvdragerne i ubestemt Antal, frie; Frugtknuderne [oftest] adskilte, i bestemt eller ubestemt Antal (sjeldnere 1), enrummede, med 1 -flere $A g$ befæstede til Bugsømmen; Griffel og $\mathrm{Ar}$ enkelte; Frugterne flere Nødder eller Bællekapsler (sjeldnere 1 Bær eller 1 fleerrummet Kapsel); Frone vandrette; Kimen ret, liden; Frøhvide hornagtig.

a. Anemonece. Bægeret farvet; Kronen 0; Fr. $\infty$ Nodder, ofte med vedblivende Griffel (Frohale).

357. Thalictrum .... 4. 359. Pulsatilla .... 2.

358. Anemone .... 3.

b. Ranunculece. Blomsterdækket dobbelt; Frugterne $\infty$ Nødder. 360. Myosurus ... 1. 362. Ranunculus ... 12. 361. Ficaria ..... 1. 363. Batrachium .... 9.

c. Helleborece. Bægeret farvet; Kronbladene 0 eller ufuldkomne; Frugterne krandsstillede Bællekapsler.

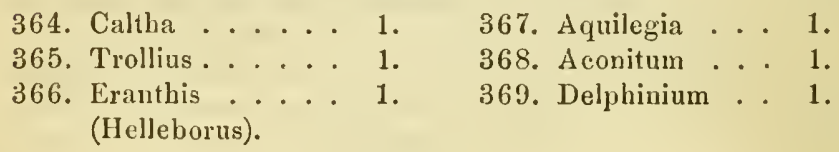

d. Prooniacece. Bægeret grønt; Kronbladene farvede eller 0; Støvknapperne indadvendte; Frngterne [Bællekapsler eller] Bær.

370. Actæa ..... 1.

LXXI. Berberideæ Vent. (Berberisfamilien) And. t. 9. Buske [eller Urter] med tornet-tandede Blade (de primære Blade ofte omdannede til Torne), og smaae affaldende Axelblade; Blomsterne tvekjønnede, regelmæssige, undersædige; Bageret farvet, 6 [3-4-9] -bladet, dets Blade i 2 Rækker; Kronbladene i tilsvarencle Antal i 2 Rækker, modsatte Bægerbladene (den ydre Rrkke af Kronbladene modsat den ydre Rrkke Brgerblade o. s. v.), ofte Kirtler ved Grunden af Kronbladene; Stovdragerne i samme Antal og modsatte Kronbladene; Stovknapperne elastisk opspringende ved Klapper; Frugtknuden enkelt, enrummet; Griffelen kort eller 0; Arret skjoldformet; Frugten 
(bæragtig) 1-faafroet; Froene med ret Kim og kjødagtig eller hornagtig Frohvide.

371. Berberis ..... 1.

LxXII. Papareracea DC. (Valmuefamilien) And. t. 9. (Urter) med (hvid eller guul) Mælkesaft; Bladene alm. spredte, uden Axelblade; Blomsterne tvekjønnede, regelmæssige, undersædige; Bageret tobladet, affaldende; Kronbladene (4) affaldeude; Stovdragerne frie, i ubestemt Antal ; Frugtlinuden 2-flecrbladet, ved de indbøiede Egstole ufuldstændigt 2-flerrummet; Arrene siddende, vedblivende, med Flige af Frugtbladenes Antal; Frugten kapselagtig, toklappet, opspringende paalangs eller ved de ufurdstænclige Skillevægge falsk fleerrummet, opspringende ved Huller i Spidsen under Arret; Frone med liden Kim, olieboldig Frohvide.

372. Papaver .... 4. 374. Chelidonium ... 1.

373. Glancium ..... 1.

LXXIII. Fumariacese DC. (Jordrøgfamiliea) And, t. 10. Urter med vandagtige Safter; Bladene dybt deelte uden Axelblade; Blomsterne tvekjønnede, undersædige, med Dækblade; Bregeret tobladet, affaldende (eller 0); Kronbladene 4, affaldende, de 2 ydre frie, ofte med en Spore, de 2 indre i Spidsen sammenhængende, uligestore med de ydre; Støvdragerne 6, med sammenvoxede Stovtraade i 2 Bundter (den midterste i hvert Bundt med torummet, de ydre med enrummede Stovknapper); Frugthnuden enkelt, med 1-flere Agg; Arret siddeude, heelt eller tofliget; Frugten enfrøet, nopspringende eller toklappet, kapselagtig med flere Frøe; liden Kim ved Grunden af Frohviden.

375. Fumaria .... 3. 376. Corydalis ... 5 .

LXXIV. Cruciferæ Juss. (Korsblomstrede) And. t. 10. Urter, alm. indeholdende skarpe Stoffer, med typisk afvexlende, fjernervede Blade, uden Axelblade; Blomsterne tvekjønnede, undersædige, i (først halvskjærmformede, senere) forlængecie Klaser, alm. uden Drekblade; Bageret firebladet, affaldende, de 2 ydre Bægerblade (ligefor Frugtens Klapper) undertiden bredere og med udvidet Basis; Kronbladene 4, med Negle, afvexlende med Brgerbladene; Stovdragerne 6, de 2 i den ydre Kreds kortere, ligefor de ydre Bægerblade, de 4 i den indre Kreds længere, ligefor Kronbladene; Kirtler paa Frugtbunden; Frugtknuden tobladet, torummet; 1 Griffel med mere eller mindre tydeligt todeelt Ar; Frugten 1 Skulpe, ved en hinde- 


\section{LXXXVIII}

agtig Skillevæg (den udvidede Frøstol) afdeelt paalangs i 2 Rum, med Frøene hefæstede i 2 Rækker paa hver Side af Skillevæggen; Klapperne opspringende fra neden (sjeldnere Ledskulper med flere Tværrum eller 1-faafrøet og uopspringende); Frøene uden Frøhvide, ined krum Kim og olieholdige Frøblade.

a. Pleurorrhizece $(0 \Rightarrow$ ) Frøbladene flade, Rodspidsen indbøiet mod deres sammenstødende Rand.

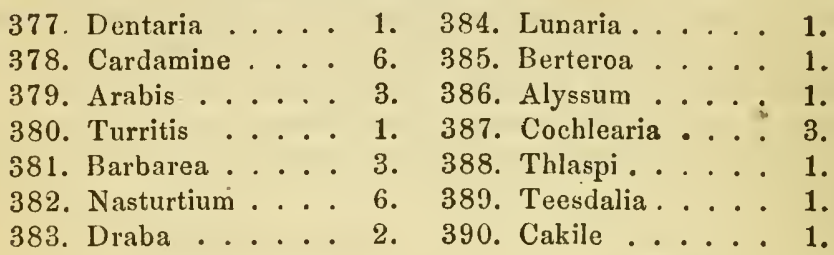

b. Notorrhizea. (0 \|) Frøbladene flade, Rodspidsen indbøiet mod deres Ryg.

391. Hesperis .... 1. 396. Capsella .... 1.

392. Sisymbrium . . 3. 397. Lepidium . . . . 4.

393. Alliaria .... 1. 398. Neslia ..... 1.

394. Erysimum ... 2. 399. Isatis ..... 1.

395. Camelina .... 3. 400. Senebiera ... 1.

c. Orthoplocece (ळ) Frobladene foldede paalangs, med Rodspidsen indbøiet mod Folden.

401. Brassica .... 5. 403. Raphanus ... 1.

402. Sinapis .... 2. 404. Subularia .... 1.

(Diplotaxis).

405. Crambe..... 1.

d. Spirolobece $\left(\begin{array}{ll}0 & \mathrm{cos}\end{array}\right)$ Frøbladene spiralformigt indrullede.

406. Bunias ..... 1.

LXXV. Resedacer DC. (Resedafamilien) And. t. 8. (Urter) med spredte Blade; Blomsterne i Klaser eller Ax, tvekjønnede, undersædige; Bageret 4-7-deelt, uregelmæssigt, vedblivende; Kronbladene i tilsvarende Antal, fligede (undertiden 0); Støv. dragerne 12-24, frie, befæstede til en skiveformet Udvidelse af Frugtbunden; Frugtknuden enrummet, aaben i Spidsen, dannet af 3-6 Frugtblade med et lige Antal korte Grifler; Frugten kapselagtig, med Undtagelse af den oprindelige Aabning i 


\section{LXXXIX}

Spidsen uopspringende, enrummet, 3-6-hjørnet, med Frøstole i Hjørnerne, talrige Frøe med krum Kim uden Frøhvide.

407. Reseda ..... 1 .

LXXVI. Nymphreacex DC. (Aakandefamilien) And. t. 9. Vandplanter med krybende Rodstok, hele, rundagtige, paa Vandfladen svøumende Blade med i Knoptilstanden indrullet Rand; Blomsterne enlige paa Blomsterstilkene, endestillede uden Dakblade, tvekjøunede, regelmressige; Bageret 4-5-bladet; Frugtbunden udvidet, tilleels omsluttende Frugtknuden og bærende Krone og Stovdragere; Kronbladene talrige, i flere Rækker;

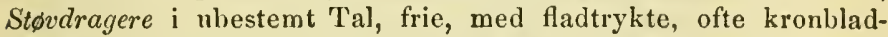
agtige Støvtraade og indadvendte Støvknapper; Frugtknuden mange. rummet, med talrige, vægstillede $E_{g} ;$ Griffelen kort, udvidet til et straaleformet, vedblivende Ar; Frugten uopspringende, ved den vedblivende, kjødfulde Frugtbund bæragtig; Frøene talrige, med ret Kim ved Grunden af Frohviden, som er deels melet (Perisperm), deels klar og gjennemsigtig (Endosperm).

408. Nuphar ..... 1. 409. Nymphæa .... 1.

LXXVII. Cistinex Juss. (Soløiefamilien) And. t. 11. Halvbuske med (modsatte) hele Blade, med [eller uden] Axelblade; Blomsterne tvekjønnede, regelmæssige, undersædige; Bageret fembladet, de 2 ydre Bxgerblade ofte mindre end de 3 indre [eller 0]; Kronbladene typisk 5, affaldende; Støvdragerne i ubesteint Antal, frie; Frugtknuden (trebladet), enrummet, med vægstillede Egstole; 1 Griffel; Frugten kapselagtig, opspringende fra oven i Klapper af Frugtbladenes lige eller dobbelte Antal; Froene (talrige) med melet Frøhvide og krum Kim.

410. Helianthemum . 1.

LXXVIII. Pyrolaces Lindl. (Vintergrønfamilien) And. t. 16. Vedvarende Urter med oftest stedsegrønne Blade; Blomsterne tvekjønnede, regelmæssige, undersædige; Bageret ferndeelt, vedblivende; Kronbladene 5, affaldende; Stovdragerne 10, frie; Stovknapperne opspringe ved Huller i Spidsen; Frugtlonuden femrumnet med 5 (vægstillede?, tilsyneladende miltstillede) Asgstole, 1 Griffel med rundagtigt lappet Ar; Frugten kapselagtig, femklappet med rumdelende Opspringning; Frøene talrige, smaae, omgivne af en løs Frøhud; Kimen ret, Frøhviden kjødagtig.

411. Pyrola ..... 6.

LXXIX. Monotropea Nutt. (Snylterodfamilien) And. t. 16. Snyltevæxter med skjælformede, ikke grønne Blade; Blomsterne 
tvekjønnede, undersædige, med regelret, 4-5-deelt Bager; Kronbladene 4-5, vedblivende; Støvdragerne i Kronbladenes dobbelte Antal, frie, med Tilhængsler ved Grunden af Støvtraadene; Støvknapperne enrummede, opspringende red Spalter paatværs (eller kalvkredsformigt); Frugten 4-5-rummet, med rumdelende Opspringning, 1 Griffel med fladt, rundtakket $A r$; Frone talrige, smaae, omgivne af en løs Frøhud; Frøhviden kjødagtig.

\section{Monotropa .... 2.}

LXXX. Droseracea DC. (Soldugfamilien) And. t. 12. Urter med Bladene samlede ved Grunden, alm. med kirtelbærende Haar og i Knoptilstanden spiralformigt indrullede; Blomsterne tvekjønnede, regelmæssige, undersædige; Bageret fembladet; Kronbladene i samme Tal og afvexlende med Bægerbladene (Støvdragere 5); Frugtknuden enrummet med $3-5$ vægstillede Egstole; Grifter eller Ar 3-5; Frugten kapselagtig, opspringende paalangs, med talrige Frøe paa Midten af Klapperne; Kimen ret; Frøhviden kjødagtig.

413. Drosera ..... 3. 414. Parnassia..... 1.

LXXXI. Violariea DC. (Violfamilien) And. t. 12. (Urter) med enkelte Blade og Axelblade; Blomsterne tvekjønnede, undersædige, med '2 Dakblade paa Blomsterstilkene; Bageret fembladet, uregelmæssigt; Kronbladene 5, uligestore eller uregelmæssige (det øvre ofte større, ved Blomsterstilkenes Dreining nedadvendt og forsynet med en Spore); Stgvdragere 5, med udvidede Støvtraade og indadvendte, sammenstødende eller sammenvoxede Støvknapper, Knapbaandet forlænget udenfor Rummene; Fragtknuden enkelt, trebladet, enrummet, med vægstillede AEgstole; 1 Griffel; Frugten kapselagtig, treklappet, opspringende paalangs, med talrige Eroe paa Midten af Klapperne; Kimen ret; Frohviden kjødagtig.

415. Viola ..... 11.

LXXXII. Cucurbitacese Juss. (Agurkfamilien) And. t. 13. Urter med saftrige, ved Hjælp af Slyngtraade klattrende Stongler; spredte, haandnervede, hvashaarede Blade; Blomsterne særkjønnede, regelmæssige, typisk femdeelte; $\hat{\sigma}$ : Støvdragerne befæstede til Kronrøret, 5, i 3 Bundter (de 4 parviis sammenvoxede, den femte fri) [eller alle i 1 Bundt]; $\$$ : Bageret femfliget; Kronbladene 5, afvexlende med Bægerfligene, frie eller forneden sammenvoxede indbyrdes og med Bægeret; Frugtknuden undersædig, 3 [ -5$]$-rummet, med tilbagebøiede Skillevægge og berved 
mere eller mindre fuldstændigt $6[-10]$-rummet; Aggene befæstede i flere Rækker til Skillevæggenes tilbagebøiede Rand; Frugten bæragtig, 3-5.tummet eller tilsidst enrummet; Kimen ret, Frohvide 0.

416. Bryonia .... 2.

LXXXIII. Portulacea Juss. (Portulakfamilien) And. t. 17. Urter med heelrandede, kjødfulde Blade; Blomsterne tvekjønnede; (Bageret tobladet) [eller 2-5-fliget]; Kronen 4-6-bladet (hos Montia femfliget) eller 0, befæstet til Bxgeret; Stovdragerne (3) [eller 5-20], befæstede til Bxgerroret eller Frugtbunden; Erugtinuden enrummet, med flere $\angle E g$ befæstede til en midtstillet ZEgstol; (3 Ar) [eller 1 Griffel med 1-8 Ar]; Frugten kapselagtig (treklappet); Frøene med krum Kim og melet Frohvide.

417. Montia ..... 2 .

LXXXIV. Paronychiex St. Hil. (Sandurter) And. t. 17. Urter med beelrandede, modsatte eller sjeldnere afvexlende Blade og typisk hindeagtige Axelblade; Blomsterne tvekjønnede, regelmæssige; Bageret typisk femdeelt; Kronbladene 5, befæstede til Bægerets nedre Deel (eller 0); Støvdragerne i tilsvarende eller dobbelt Antal (i sidste Tilfælde ofte hveranden gold); 1 fri, enrummet Frugtknude med 1-2 $2 \mathrm{Eg} ; 2$ Grifler eller Ar; Frugten enfrøet Hindefrugt eller Nød; Kimen krummet.

a) Scleranthece. Bladene modsatte, uden Axelblade; Frugten Nød, omsluttet af det vedbliveude Brger.

418. Seleranthus. . . . 2 .

b) Herniariece. Bladene afvexlende eller modsatte, med hindeagtige Axelblade; Fr. en fri Nod eller Hindefrugí.

419. Corrigiola .... 1. 421. Illecebrum .... 1 . 420. Herniaria . . . 2.

c) Spergulece. Bladene modsatte eller krandsstillede, med hindeagtige Axelblade; Fr. en fleerfrget Kapsel.

422. Lepigonum .... 4. 423. Spergula .... 3.

LXXXV. Alsinacese Bartl. (Fladstjernefamilien) And. t. 12. Urter [eller Halvbuske] med modsatte, heelrandede Blade, uden Axelblade; Blomsierne tvekjønnede, regelmæssige, undersædige, i qvastformet 13lomsterstand; Bageret dybt 4-5-deelt eller -bladet; Kronbladene med kort Negl, i tilsvarende Antal og afvexlende med Bxgerbladene (sjeldnere 0); Støvdragerne i dobbelt eller samme Antal; Frugthnuden siddende, enrumıei, 
Eggene befæstede til en fri, grund- eller midtstillet Egstol; 3-5 Grifler; Frugten kapselagtig, opspringende fra oven i Tænder eller Klapper af Griflernes lige eller dobbelte Antal; Frøene talrige, med krum eller spiraldreiet Kim og midtliggende, melet eller kjødagtig Frøhvide.

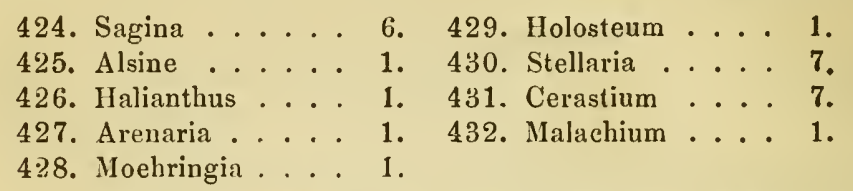

LXXXVI. Silenacer Braun. (Nellikefamilien) And. t. 12. Urter eller Halvbuske med modsatte, hele, ofte ved Grunden sammenvoxede Blade uden Axelblade; Blomsterne tvekjønnede, sjeldnere særkjønnede, regelmæssige, undersædige, i en alm. qvastformet Blomsterstand; Bageret sambladet, (5-) tandet; Kronblaclene (5) med tydelige Negle (og ofte Bikronblade), tilligemed de i Almindelighed i dobbelt Antal tilstedeværende Støvdragere befæstede til Frugtbunden, der ofte er forlænget til en Frugtholder (earpophorum) indenfor Bægeret; Frugtknuden enrummet eller ved Grunden ufuldstændigt 3-5-rummet, 2-5 Grifler; Frugten og Frotet som hos foreg. Fam.

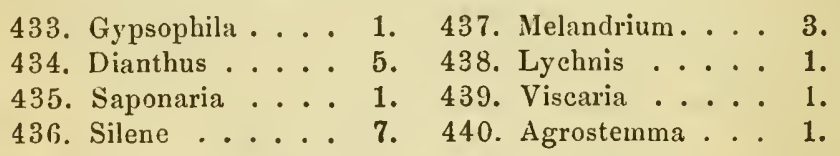

LXXXVII. Malvacere Juss. (Katostfamilien) And. t. 11. Urteagtige [eller træagtige] Væxter med afvexlende, oftest haandnervede Blade og (vedblivende) Axelblade; Blomsterne tvekjønnede, regelmæssige, undersædige; Bageret fembladet eller femdeelt, omgivet af et Yderbuger; Kronbladene 5, afvexlende med Bægerbladene, befæstede til Frugtbunden og med Neglene sammenvoxede med de til et Bundt forenede, talrige Støvtraade; Frugtknuderne flere samlede om en fælles Axe; flere forneden sammenvoxede Grifler; Frugten ved Modenheden en mangedelelig Spaltefrugt med enfrøede, uopspringende Smacfrugter omkring den vedblivende Griffelbasis [hos flere udenlandske Slægter er Fr. en mangefrøet Kapsel]; Frope med krum Kim og sparsom, kjødagtig eller slimet Frøhvide.

441. Malva ..... 5. 442. Althæa ...... 1.

LXXXVIII. Tiliacex (Lindefamilien) And. t. 11 . Træagtige Væxter med afvexlende, enkelte Blade og affaldende [eller vedblivende] Axelblade; Blomsterne tvekjønnede, regel- 
mæssige, undersædige, (med et til Blomsterstilken fastvoxet Drkblad); Bageret 4-.5-bladet; Kronbladene i tilsvarende Antal og afvexlende med Bxgerbladene, og, ligesom disse, affaldende; Stфvdragerne i ubestemt Antal, indbyrdes frie; Frugtknuden 2-10.rummet (hos Tilia femrummet med 2 A $\mathrm{Eg}$ i hvert Rum); Griffelen 1; Arret med Lapper af Frugtbladenes Antal; Frugten kapselagtig eller opspringende (hos 'Tilia enrummet, enfrøet, uopspringende); Kimen ret; Frohviden kjødagtig.

443. Tilia ..... 3.

LXXXIX. Hypericinese DC. (Perikonfamilien) And. t. 11. Urter [eller Buske og 'Træer] med modsatte, hele, fjernervede, af indsænkte Kirtler punkterede Blade nden Axelblade; Blomsterne tvekjønnede, regelmæssige, undersædige; Bageret fembladet, vedblivende; Kronbladene i tilsvarende Antal og afvexlende med Brgerbladene (gule); Støvdragerne i ubestemt Tal, tilligemed Kronbladene befæstede til Frugtbunden, forneden alm. forenede til Bundter; Frugtknuden $3[-5]$-bladet, ved de indbøiede Rande mere eller mindre fuldstændigt $3[-5]$-rummet; Grifler af Frugtbladenes Antal; Frugten kapselagtig, med skillevægdelende Opspringning fra oven, mangefrøet; Frøene uden Frøhvide.

444. 'Hypericum ... 7.

XC. Elatineæ Juss. (Bækarver) And. t. 12. Enaarige, urteagtige Vandplanter med modsatte Blade og Axelblade; Blomsterne tvekjønnede, regelmæsige, undersædige, i Bladhjørnerne; Bageret 3-5-deelt; Kronbladene i samme Antal, afvexlende med Bxgerbladene; Stovdragerne i tilsvarende eller dobbelt Antal, tilligemed Kronbladene befestede til Frugtbunden; Frugtbladene 3-5 med et tilsvarende Antal korte Grifer og hovedformede Ar; Frugten 3-5-klappet med talrige, [rette eller] bøiede Frøe uden Frøbvide.

445. Elatine ..... 2 .

XCI. Acerinese DC. (Valbịrkfamilien) And. t. 8. Træagtige Væxter med modsatte, oftest haandlappede Blade uden Axelblade; Blomsterne tvekjønnede eller særkjonnede, reggelmæssige, undersædige; Bageret 4-5-bladet, affaldende; Kronbladene i samme Antal og afvexlende med Bægerbladene (eller 0 ); Stovdragerne typisk i dobbelt Antal, befæstede tilligemed liron. bladene til en undersædig Skive; Frugtknuden torummet, med 2 hængende $\mathrm{Eg}$ i hvert Rum; 1 Griffel og et todeelt $A r$; Frugten todelelig Spaltefrugt; Smaafrugterne oftest enfrøede Vingefrugter fasthæftede ved den vedblivende, ofte tokløvede Frugtstol; Kimen med sammenfoldede Froblade, uden Frohvide.

446. Acer...... 3. 
XCII. Hippocastanex DC. (Hestekastaniefamilien). Træagtige Væxter med modsatte, (oftest) fingrede Blade uden Axelblade; Blomsterne tvekjonnede, uregelmæssige, undersædige; Bageret femdeelt; Kronbladene 4-5, uligestore; St $\varnothing v d r a g e r n e$ 6-9, med opstigende, indbyrdes adskilte Støvtraade; Frugtknuden trerummet, 2 Eg i hvert Rum, befæstede til Frugtbladenes i Midten sammenstødende Rande; 1 Griffel; Frugten treklappet Kapsel med rumdelende Opspringning og 1 -2-frøede Rum; Frøene store, med læderagtig Skal; Kimen krummet, med store, kjødagtige Frøblade, Frohvide 0.

447. Aeseulus ..... 1.

XCIII. Polygaleæ Juss. (Mælkurtfamilien) And. t. 10. Urter eller Halvbuske med spredte, udeelte Blade uden Axelblade; Blomsterne tvekjønnede, uregelmæssige, undersædige; Bageret fembladet, de 3 ydre Bægerblade mindre, de 2 indre større, farvede; Kronbladene $3-5$, forneden sammenvoxede med Støv. dragerne, det nedre (bageste) læbe- eller kjølformet; Støvdragerne 8; Støvtraadene sammenvoxede i 2 Bundter; Støvknapperne enrummede; Frugtknuden torummet, med 1 hængende $\mathbb{E g}$ i hvert Rum; 1 Griffel; (Frugten torummet Kapsel med rumdelende Opspringning; Frøene omgivne af Frøhud); Kimen ret.

448. Polygala .... 3.

XCIV. Frangulaceæ (Endl.) (Beenvedfamilien) And. t. 7. Buske eller Træeı med afvexlende eller modsatte, fjernervede Blade; Blomsterne tvekjønnede eller særkjønnede, regelmæssig 4-5-deelte; Bageret under- eller omkringsædigt; Kronbladene afvexlende med og i samme Tal som Bægerbladene, frie eller forneden sammenvoxede, befæstede til Bægeret eller en omkringsædig Skive (undertiden 0); Støvdragerne i samme Antal, afvexlende med eller modsatte Kronbladene og befæstede til disses nedre Deel eller den omkringsædige Skive; Frugtknuden fri, 2-5-rummet, med $1 \mathrm{Ag}$ i hvert Rum; Frugten bæragtig med forhærdede Skillevægge eller kapselagtig opspringende; Kimen ret; Frøhviden kjødagtig. .

a. Ilicinece. Kronen sambladet. Frugten bæragtig.

449. Ilex....... 1 .

b. Rhamnece. Kronen fribladet; Støvdragerne modsatte imod Kronbladene; Frugt bæragtig.

450. Rhamnus ..... 2 . 
c. Celastrinece. Kronen fribladet, afvexlende med Stovdr., Frugten kapselagtig, Froe med Frøhnd.

451. Euonymus .... 1.

XCV. Enpetrex Nutt. (Kræklingfamilien) And. t. 16. Buskvæxter med smale, læderagtige, stedsegrønne Blade; Blom. sterne treboe, enlige i Bladhjørnerne; Bøger og Krone trebladede; $\hat{\delta}$ : Støvdragerne 4, afvexlende med Kronbladene; $\$$ : 1 fri, 5-6-rummet Frugtinude med enfrøede Rum; 1 Griffel med straaleformet lappet $A r$; Frugten et Steenbær med $3-6$ Stene.

452. Empetrum ... 1.

XCVI. Euphorbiacea Juss. (Vortemællkfamilien) And. t. 16. Urter [i varmere Lande hyppigt 'Træer] ofte merl Mælkesaft; Blomsterne særkjønnede, (ố: Støvdragerne frie;) + : Blomsterdcekket undersædigt eller $0 ; 2-3$ Grifler; Frugtknuden 2-3-rummet, med 1-2 \&g i hvert Rum; Frugten ved Modningen 2-3-delelig Spaltefrugt (med toklappet opspringende enfrøede Smaafrugter); Kimen ret; Frøhviden kjødagtig.

a. Euphorbiece. o og $q$ Blomsterne samlede til en Blomsterkop o: omgivne af et falles fembladet Hylster (Kopdcekke); talrige, nogne, enhannede ơ Blomster paa en leddet Stilk, med særegne Dækblade ved Grunden; 1 midtstillet $q$ Blomst; uden eller med utydeligt Blomsterdække,

3 Grifler med tolappede eller udrandede $A r$; Frugten tredelelig.

453. Euphorbia ... 4.

b. Acalypheo. Trebo; o': Blomsterdcekket tredeelt; Stovdragere 9-12;

ㅇ: Blomsterdcelket tredeelt, 2 Grifler; todelelig Spaltefrugt.

454. Mereurialis ... 2.

+ (Juglandece DC. (Valnødfamilien) And. t. 20. Træer med finnede Blade; Blomsterne særkjønnede: $\widehat{\delta}$ Blomsterne i Rak-

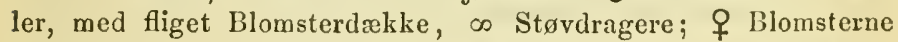
i Nøgler med firedeelt, oversædigt Bæger, Frugten undersædig Steenfrugt; Frøet uden Frøhvide, med store, lappede Frøblade).

(Juglans.)

XCVII. Geraniaces DC. (Storkenæbfamilien) And. t. 11. (Urter) med Bladene ofte forneden modsatte og Axelblade; Blomsterne tvekjonnede, undersædige, alm. parvise paa Blomsterstilkene eller i Skjærm, omgivne af Dokblade; Bagerel fembladet, vedblivende, Kronbladene afvexlende med og i samme Tal som Bæg., affaldende; Støvdragerne alm. dobbelt saa mange som 


\section{XCVI}

Kronbladene, og tilligemed disse befæstede til Frugtbunden; Støvtraadene stundom ved Grunden sammenvosede eller i den ydre Kreds golde; 5 Frugtknuder omkring en midtstillet Frugtstol, med hvis søileformede Forlængelse de 5 Grifler ere sammenhængende; Frugten femdelelig Spaltefrugt; Smaafrugterne enfrøede, i Bugsømmen opspringende Hindefrugter, der adskille sig fra Frugtstolen ved de nedenfra spiralformigt tilbagerullede Grifler; Kimen krum; Frøhvide 0.

455. Geranium ... 12. 456. Erodium .... 1 .

XCVIII. Lineæ DC. (Hørfamilien) And. t. 11. Urter [eller Halsbuske] med heelrandede Blade uden Axelblade; Blomsterne tvekjønnede, regelmæssige, undersædige; Brogeret vedblivende, 4-5-bladet; Støvdragerne i samme Antal (eller undertiden Spor til en anden Kreds i Form af tandformede Bistøvdragere), tilligemed de affaldende Kronblade befæstede til Frugtbunden; Frugtknuden 1-5rummet, med 2 Eg i hvert Rum; Griflerne 4-5; Frugten kapselagtig, 4-5-rummet med skillevægdelende Opspriugning eller ved en ufuldstændig Ryg-Skillevæg deelt $i$ et dobbelt Antal Rum; Frøene fladtrykte; Fr $\phi$ hvide 0 ; Kimen ret.

457. Linum ...... 1. 458. Radiola ..... 1.

XCIX. Oxalideæ DC. (Suurkløverfamilien) And. t. 11. (Urteagtige) Væxter med sammensatte, i Knoptilstanden spiralfornigt indrullede Blade; Blomsterne tvekjønnede, regelmæssige, undersædige; Bageret fembladet; Kronbladene 5, paa Frugtbunden, afvexlende med Bxgerbladene; Stovdragerne 10, ved Grunden sammenvoxede, de 5 (mindre) modsatte Kronbladene, de 5 (større) modsatte Bægerbladene; Frugtknuden femrummet; Grifler 5; Frugten femrummet Kapsel, opspringende ved Længderidser i Midten [eller uopspringende]; Frøene (omgivne af Frøhud) med kjødagtig Frøhvide.

459. Oxalis ..... 3 .

C. Balsamineæ A. Rich. (Balsaminefamilien) And. t. 10. Saftige Urter med fjernervede Blade uden Axelblade; Blomsterne tvekjønnede, typisk femdeelte; Brogeret uregelm., affaldende, det bageste Bægerblad forlænget til en Spore, de 2 forreste smaae eller 0; Kronen uregelret, dens Blade afvexlende med Bægerbld., det forreste størst,. de bageste og Sidebladene alle sammenvoxede, Lvorved Kronen synes trebladet); Stovdragerne 5 med i Randen sammenhxngende Støvknapper; Frugtknuden 5-rummet, 
fri, med siddende $A r$; (Frugten alm. kapselagtig, elastisk opspringende i 5 Klapper ined rumdelende Opspringning); Frostolen midtstillet; Frø med ret Kim uden Frøhvide.

460. Impatiens ... 1.

$\dagger$ (Philadelphece Don. Buske med modsatte Blade uden Axelblade, Blomsterne trekjønnede, regelm., modsatte i Bladhjørnerne eller i en endestillet Qvast, oversædige, Bagerets Krave firedeelt; 4 affaldende Kronblade afvexlende med Bregerfligene; St $ø$ dragere i ubestemt Antal; 1 Griffel med $4-5$ deelt Ar eller flere ved Grunden sammenvoxede Grifler, Frugtknuden 3-10rummet, undersædig, med vægstillede LEgstole; Frugten en i Spidsen opspringende Kapsel med talrige, smaae Froe omgivne af en løs hindeagtig Frøhud, Kimen ret i Midten af en kjødfuld Frohvide).

(Philadelphus).

CI. Onagrariex Juss. (Natlysfamilien) And. t. 14. (Urter) med fjernervede, spredte eller modsatte Blacle uden Axelblade; Blomsterne tvekjønnede, typisk regelrette, oversædige; Bageret to- eller firefliget; Kronbladene i samme Antal, afvexlende med og befrestede til Bægeret; Stovdragerne i samme eller dobbelt Tal paa Bægeret; Frugtknuden undersædig, flre-, sjeldnere torummet; Rummene $1-\infty$-frøede med midtstillet Ligstol; 1 Griffel med fliget $A r$; Frugten firerummet Kapsel, opspringende fraoven eller torummet uopspringende, Kim ret; Frohvide 0.

461. Epilobium .... 8. 463. Oenothera .... 1.

462. Chamænerium .. 1. 464. Cireæa..... 3.

CII. Ilalorrhagex R. Br. (Vandspirene) And. t. 14. Vandplanter med modsatte eller krandsstillede Blade uden Axelblade, Blomsterne krandsstillede (ufuldstændige); Bogerets Krave oversædig, typisk firedeelt, undertiden mangetandet, utydelig eller 0 ; Kronbladene 0 eller af Antal og afvexlende med Bægerfligene; Stovdragerne typisk af lige eller dobbelt Antal med Bægeret, sjeldent kun 1; Frugtknuden undersædig, 1-4-rummet, med 1 Agg i hvert Rum; Frugten nød- eller steenfrugtagtig, enfrøet eller ved Modenheden adskilt i 4, enfrøede Smaafrugter; Kimen ret, indsluttet af en kjødfuld Frohvide.

465. Myriophyllum. . 3. 466. Hippuris. . . 1.

CIII. Lythrariea Juss. (Kattehalerne) And. t. 13. (Urteagtige) Væxter med modsatte (heelrandede) Blade uden Axelblade; Blomsterne trekjønnede, regelmæssige; Bergeret oukring- 


\section{XGVIII}

sædigt, sambladet, deelt i 6 ydre og 6 indre Tænder; Kronbladene befæstede til Bægerets Svælg, af samme Antal som og afvexlende med dettes indre Tænder; Støvdragerne i lige eller dobbelt Antal mod Kronbladene, befæstede til Bægerrøret; Frugtknuden fri, 2- [-6-] rummet, med talrige $2 E g$ befæstede ti] en midtstillet, med Skillevæggen sammenvoxet LEstol; 1 Griffel, ucleelt $A r$; Frugten (torummet, toklappet) Kapsel omgivet af det vedblivende Bæger; Kimen ret; Frphvide 0.

\section{Peplis ...... 1. 468. Lythrum ..... 1.}

CIV. Pomacex Lindl. (Kjærnefrugtfamilien) And. t. 14. Træer eller Buske med afvexlende Blade og affaldende eller vedblivende Axelblade; Blomsterne tvekjønnede, regelmæssige, oversædige; Bogerets Krave femdeelt; Kronbladene i tilsvarende Antal og afvexlende med Bægerfligene, befæstede til disses Svælg og oversædige Ring; Stovdragerne (befæstede paa samme Maade) i ubestemt Antal; Frugtknuden 1-5-rummet, med midtstillet Egstol og 1 eller flere $2 \mathrm{Eg}$ i hvert Rum; Griflerne i samme Antal som Frugtknudens Rum; Frugten Eblefrugt o: Frøgjemmet med hindeagtige, bruskagtige eller beenhaarde Vægge, indsænkt i det kjødfulde, udlulede Bægerrør (Underbægeret); Froene med ret Kim uden Frohvide.

469. Cotoneaster ... 1. 472. Pyrus ..... 2.

470. Cratægus ... 2. 473. Cydonia ..... 1.

471. Sorbus..... 5 .

CV. Rosacex Juss. (part.) (Rosefamilien) And. t. 15. Urter eller Buske med afvexlende, oftest sammensatte eller dybt deelte Blade og vedblivende Axelblade; Blomsterne typisk tvekjønnede, regelmæssige; Bœgeret omkringsædigt eller undersædigt, typisk fembladet eller -fliget, ofte med et Yderbager af et tilsvarende Antal Flige; Kronbladene befæstede til Bægeret, af samme Antal som og afvexlende med Bægerfligene; Støvdragerne $\mathrm{i}$ ubestemt Antal, sjeldnere af lige Antal med Kronbladene, befæstede til Bægeret; Frugtknuderne oftest talrige, indbyrdes adskilte, sjeldnere $\mathrm{i}$ bestemt Antal; 1 Griffel for hver Frugtknude; Frugterne frie paa Frugtbunden eller indsluttede af Brgerrøret, alm. dannende en Fleerfoldfrugt, hvis enkelte Smaafrugter ere Nødder, Steenfrugter eller Bællekapsler; Frøene uden Frøhvide.

a. Sanguisorbece. Bageret firefliget; Frugtknuderne i bestemtTal; Fr. nødagtig, indsluttet af det forhærdede Underbager.

474. Poterium. .... 1. 476. Alchemilla .... 2. 475. Sanguisorba ... 1. 477. Agrimonia .... 2. 
b. Rosece. Bcegeret femfliget, Frugterne i ubestemt Antal, nødagtige, omgivne af det kjødfulde Underbager (Hyben). (Buske med Barktorne).

478. Rosa . . . . . 9.

c. Rubece. Bcegeret fembladet, undersædigt, Frugterne i ubestemt Antal, Steenfrugter paa den frie Fmigtbund. (Buske med Barktorne.)

479. Rubus .... 20.

d. Dryadece. Bregeret fembladet, undersædigt (med femfliget Yderbæger); Frugterne i ubestemt Antal, Nodder paa den frie Frugtbund (Urter).

480. Potentilla. . . . 12. 482. Comarum .... 1.

481. Fragaria .... 3. 483. Geum . . . . 3.

e. Spirceacece. Bcegeret femfliget, Frugterne frie, typisk 5 (sjeldent flere eller færre) Bællekapsler.

484. Spiræa . . . . 3.

CVI. Drupacex DC. (Steenfrugtfamilien) And.t. 14. Buske eller Træer med afvexlende, hele, fjernervede Blade og atfaldende Axelblade (Grenene ofte tilspidsede til Vedtorne); Blom. sterne trekjønnede, regelmæssige; Bageret omkringsæedigt, femfliget, tilligemed de i sammes Svælg befæstede 5 Kronblade og talrige Stovdragere affaldende; 1 enkelt, enrummet Frugthnude, med 1-2 hængende Eg; 1 Griffel; udeelt Ar; Frugten Steenfrugt med kjødagtigt Mellemlag og beenbaard Steen; 1 Fr med ret Kim nden Frøhvide. (Indebolde Blaasyre i Frøet, Barken og stundom i Bladene, og tillige Gummi).

485. Prunus . . . . 6.

CVII. Papilionacex L. (Ærteblomstrede) And. t. 15. (Urter eller Buske) med afvexlende, oftest sammensatte Blade og vedblivende Axelblade; Blomsterne tvekjønnede; Baggeret omkringsædigt, tolæbet eller uregelmæssigt femtandet; Kronbladene 5 uligestore; det øvre større (Fanen) i Knopleiet yderst, de 2 mellemste ligestore (Vingerne), de 2 nedre (Kjolen) mere eller mindre sammenvoxede; Støvdragerne (10, med Stovtraadene forenede til 1 eller $2(9+1)$ Bundter $)$ tilligemed Kronbladene befæstede til Grunden af Bægeret; 1 Frugtknude med oftest talrige $A g$ befæstede til Bugsømmen; 1 Griffel med udeelt Ar; Frugten enrummet, fleerfrøet (sjeldnere enfrøet) Bælle, opspringende paalangs i Bug- og Rygsømmen, sjeldnere afdeelt paatværs eller uopspringende; Froene med ingen eller liden Frøhvide; Frøbladene oftest kjødfulde. 
a. Lotece. Frøbladene bladagtige, ved Spiringen ovenfor Jorden; Bladene typisk fingrede, sjeldnere udeelte eller uligefinnede; Balien opspringer paalangs.

486. Ulex ...... 1. 493. Trigonella ... 1.

487. Sarothamnus . . 1. 494. Melilotus.... 4.

488. Genista . . . . 4. 495. Trifolium. . . . 13.

489. Cytisus. . . . . 1. 496. Lotus ..... . 3.

490. Ononis . . . . 3. 497. Tetragonolobus . 1.

491. Anthyllis . . . . 1. 498. Astragalus .... 3.

492. Medicago. . . 4 4. (Phaseolus).

b. Viciece. Frobladene kjødfulde, ved Spiringen under Jorden; Bladene typisk ligefinnede med Slyngtraade; Bollen opspringer paalangs.

499. Fisum ..... 1. 502. Lathyrus. . . . 7.

500. Ervum . . . . 2. 503. Orobus..... 3.

501. Vicia..... 11 .

c. Hedysarece. Bcellen uopspringende, enfroet eller afdeelt paatværs i eufroede Led (Bladene uligefinnede uden Slyngtraad).

504. Onobrychis ... 1. 505. Ornithopus.... 1.

Antallet af de naturlige Familier, som ere repræsenterede i den danske Flora er altsaa (med Undtagelse af de lavere Cryptogamer), fordeelt i 3 større Hovedrækker, følgende:

Tofrobladplanter. . . 86 Familier, 382 Slægter, 975 Arter. Enfrobladplanter. . . 15 - 104 - 339 Sporeplanter . . . . 6 - 6 - 19 - 64 -

Ialt . . 107 Familier, 505 Slægter, 1378 Arter.

Antallet af de lavere Cryptogamers Familier, Slægter og Arter (med Undtagelse af Svampene) er omtrent følgende:

Alger ......... 7 Familier, 129 Slægter, 371 Arter.

Lavarter . . . . . . . 2 - 41 - 193 -

Mosser........ 3 - $115-357-$

Ialt . . 12 Familier, 285 Slægter, 921 Arter. 
Ordnede efter deres Antal af Arter komme de danske Familier i følgende Orden:

\begin{tabular}{|c|c|c|}
\hline Familiens Navn. & $\begin{array}{l}\text { Antal af Arter } \\
\text { i Danmark. }\end{array}$ & $\begin{array}{c}\text { Torholdstal til } \\
\text { alle de her be- } \\
\text { shrevne daushe } \\
\text { Planter. }\end{array}$ \\
\hline 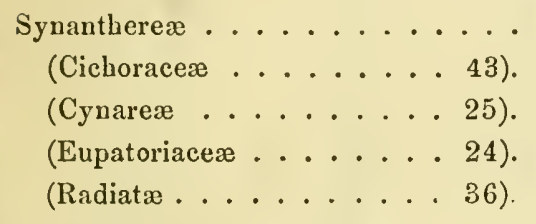 & 128 & 9,3 p. c. \\
\hline 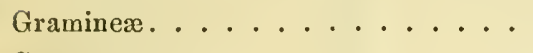 & 110 & 8,0 \\
\hline 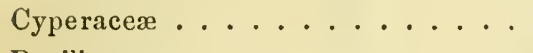 & 84 & 6,1 \\
\hline Papilionaceæ ........... & 66 & 4,8 \\
\hline 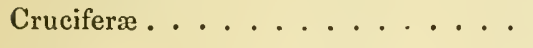 & 60 & 4,4 \\
\hline 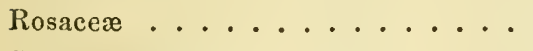 & 57 & 4,1 \\
\hline 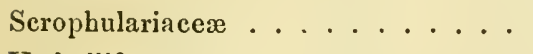 & 50 & 3,6 \\
\hline 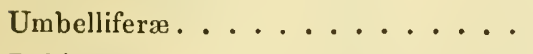 & 48 & 3,5 \\
\hline Labiatæ. . . . . . . . . . . . & 46 & 3,3 \\
\hline $\begin{array}{l}\text { Ranunculaceæ } \ldots \ldots \ldots \ldots \ldots \\
\text { Fluviales }\end{array}$ & 39 & 2,8 \\
\hline $\left.\begin{array}{l}\text { Orchideæ } \\
\text { Salicineæ }\end{array}\right\} \cdots \cdots \cdots \cdots$ & 32 & 2,3 \\
\hline 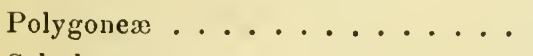 & 28 & 2,0 \\
\hline Salsolaceæ . . . . . . . . & 27 & 2,0 \\
\hline Alsinaceæ. . . . . . . . . & 26 & 1,9 \\
\hline Juncaceæ . . . . . . . . . & 25 & 1,8 \\
\hline Filices. . . . . . . . . & 24 & 1,8 \\
\hline $\left.\begin{array}{l}\text { Characeæ } \\
\text { Asperifoliæ }\end{array}\right\} \ldots \ldots \ldots$ & 22 & 1,6 \\
\hline Silenaceæ . . . . . . . . . . & 20 & 1,5 \\
\hline $\begin{array}{l}\text { Liliaceæ. . . . . . . . . } \\
\text { Primulaceæ) }\end{array}$ & 18 & 1,3 \\
\hline Rubiace $\left.{ }^{\prime}\right\} \cdots \cdots \cdots$ & 15 & 1,1 \\
\hline
\end{tabular}




\section{CII}

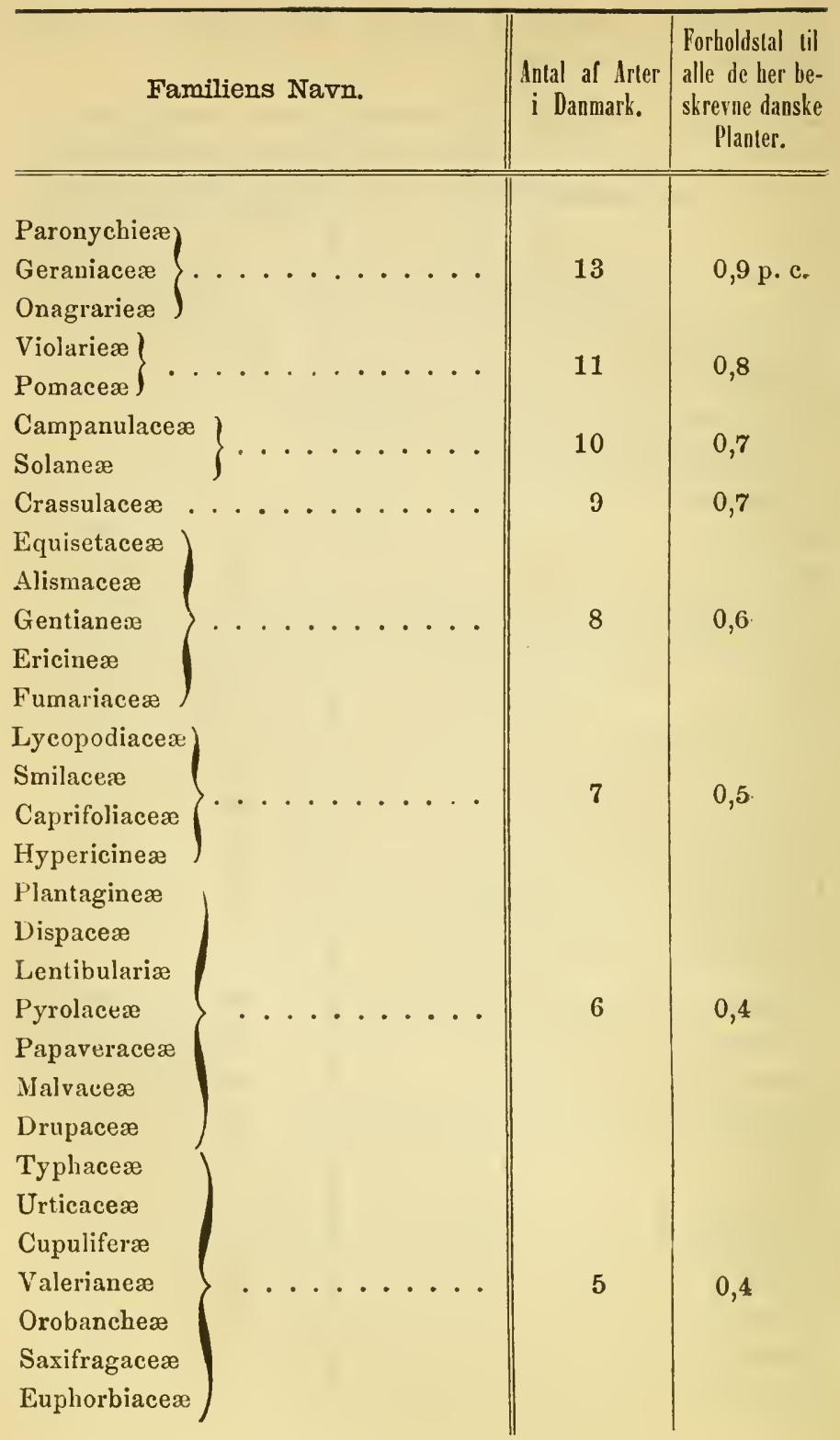




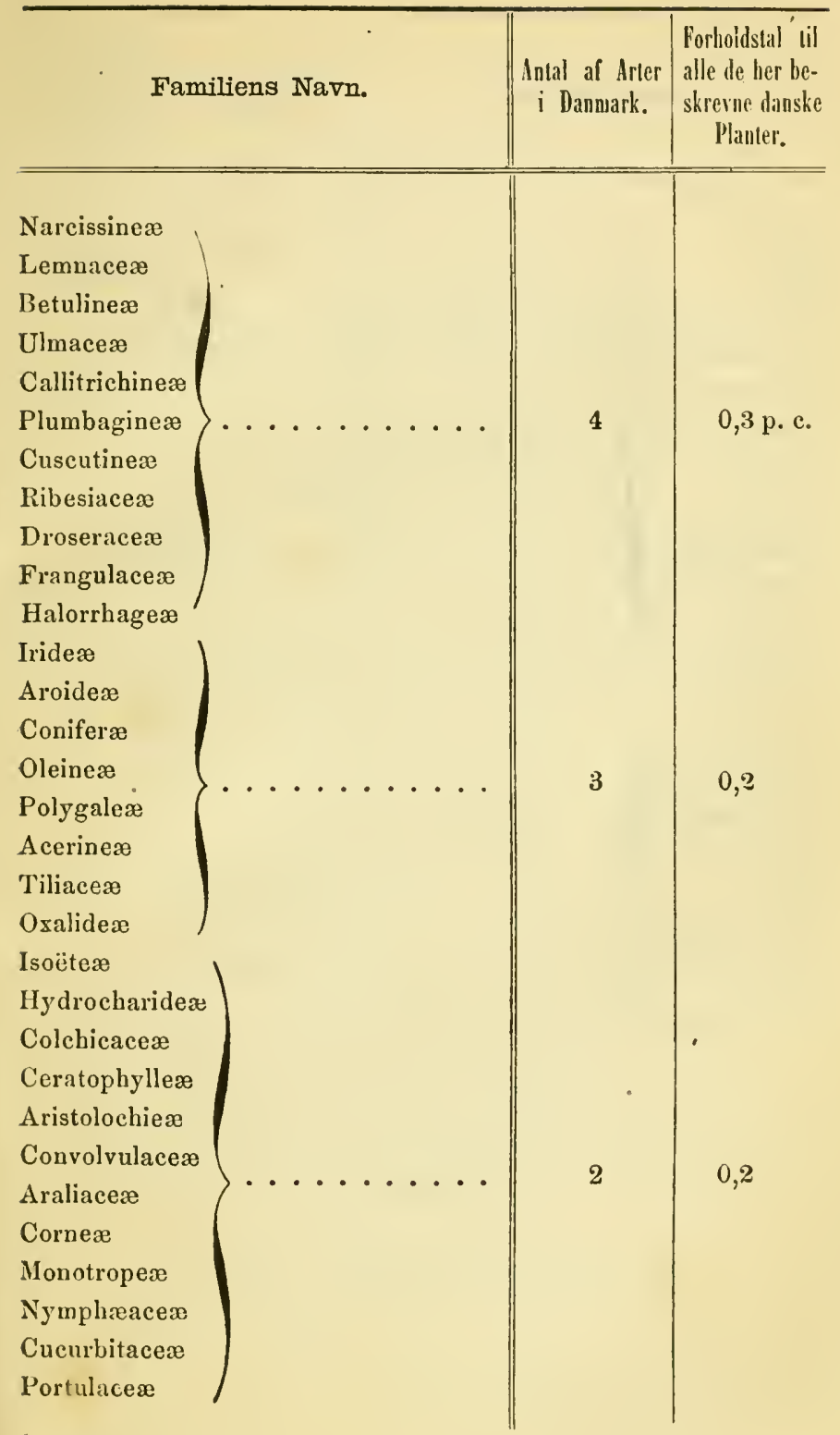




\section{CIV}

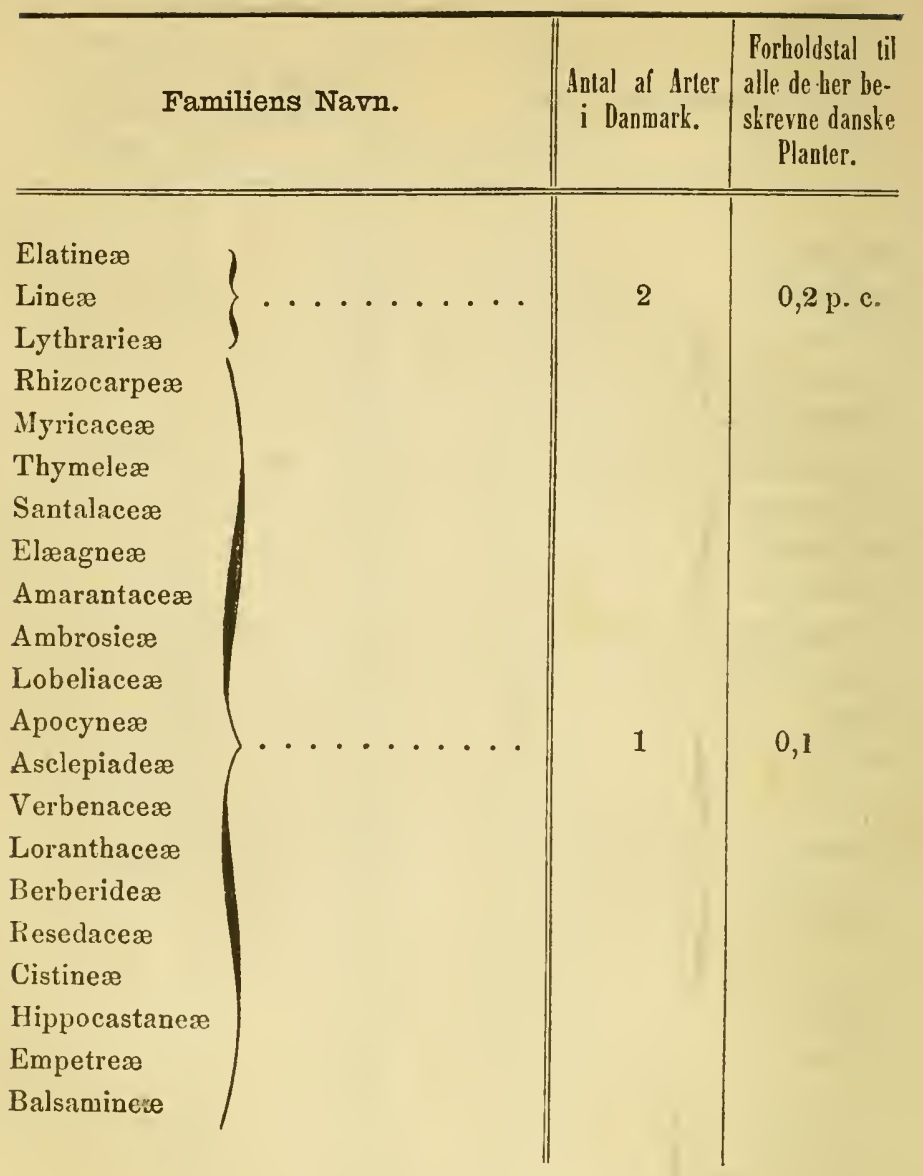




\section{1ste Klasse. Monandria (Enhannede).}

\section{Orden. Monogynia (Enhunnede).}

A. Blomsterne hylsterlose.

1. Ilippúris L. Stængelen bærer krandsstillede Blade; Bægeret oversædigt, i Form af en (utydelig) hindeagtig Rand; Krone 0; Arret sylformet, udeelt; Frugten nodagtig, beklædt af den vedblivende Brgerrand. (Naturl. Fam. Halorrhage x.)

Salicornia L. Stængelen leddet, bladløs; (2. 1). Alchemilla Aphanes L. $(4,1)$.

B. Blomsterne indsluttede af et IIylster.

Zostera L. Bladene flade, baandformede; Blomsterne nøgne, i ensidig, linieformet Kolhe. $(21,1)$.

Eriophorum alpinum L. $(3,1)$.

\section{Orden. Digynia (Tohunnede).}

Vulpia Gmel. Græsart med skjællignende Blomster; Frugten Græsfrugt. $(3,2)$.

Blitum capitatum og virgatum L. Frugten nodagtig, omgivet af det vedblivende, kjødfulde Blomsterdække. Blomster i Ax. $(5,2)$.

Callitriche L. Vandplante med Blomster i Bladlijømerne; Frugten 4-delelig Spaltefrugt. $(21,1)$.

\section{Orden. Tetragynia (Firehumede).}

Zanichellia L. (21, 1). 


\section{Honogynia. \\ 1. Illippuris. Vandspiir.}

1. II. vulgaris L. (Almindelig V.) H. p. 5; Drej. n. 1; F. D. t. 87 .

Stongelen rank, udeelt, leddet, porøs; Bladkrandsene 8-12-bladede; Bladene linieformede, med bruskagtig Spids; Blomsterne siddende i Bladhjørnerne.

1' høi. Støvdrageren mangler undertiden. 6-8. ข.

$\boldsymbol{\beta}$, fluitans Liljebl. Strengelen heelt nedsænkt under Vandskorpen; Bladene lange og slappe, ikke bruskagtige i Spidsen.

I Aaer og Bække, iklke sjelden i Danmark. $\boldsymbol{\beta}$, i dybere Vand, f. Ex. Sj. i Leersøen ved Kjøbenhavn! Jonstrup Mølleaa (14); Falst. i en Aa mellem Lidstrup og Tingsted (14); $\boldsymbol{F}$. ved Nakkebølle (12)。

\section{$2^{\text {den }}$ Klasse. Diandria (Tohannede). \\ 1. Orden. Monogynia (Enhunnede).}

A. Blomsterne ufuldstændige.

1. Fràxinus L. Træagtig; Blomsterne nøgne; Frugtknuden torummet, 1 Griffel med tokløvet Ar; Frugten enfrøet Vingefrugt. (N. F. Ole inex.)

2. Salicórnia L. Stængelen kjødfuld, leddet, bladløs; Blomsterne axformigt samlede i Stængelens og Grenenes øvre Led, 3 og 3 indsænkte $\mathrm{i}$ Gruber ovenfor Leddene, hver omgivet af et enbladet, kjødfuldt Blomsterdække; Arret kløvet; Frugten nødagtig. (N. F. S alsolaceæ.)

Lemna L. Strengelløs, svømmende Plante. (21, 2).

Cladium P. Br. Bladene i Randen og paa Kjølen hvast saugtakkede. $(3,1)$.

Rhyncospora Vahl. Bladene i Randen rne. $(3,1)$.

Scirpus setaceus L. Bladene glatte. $(3,1)$.

Lepidium ruderale L. Brgeret 4 -bladet (Krone 0); Frugten Skulpe. $(15,1)$.

B. Blomsterne fuldstændige.

a. Frugten undersædig.

3. Circáa L. Bæger og Krone tobladede, affaldende; Kronbladene dybt tokløvede; Frugten nødagtig, uopspringende 
1-2-rummet med enfrøede Rum, beklædt med Hagebørster. (Urter med krybende Udløbere og modsatte Blade.) (N. F. On a grarieæ.)

$$
\begin{aligned}
& \text { b. Frugten oversædig, } \\
& \text { a. firedelelig Spaltefrugt. } \% \text {. }
\end{aligned}
$$

4. Lýcopus L. Bægeret regelmæssig femtandet, vedblivende; Kronen budt-firekløvet, næsten læbedannet; Støvknappernes Rum parallele, tæt samlede, 2 golde Støvdragere; Smaafrugterne nødagtige. (N. F. L a bi a t æ.)

+ Salvia I. Bægeret tolæbet, vedblivende; Kronen læbedannet, med fladtrykt, hvælvet Overlæbe og trelappet Underlæbe; Støvknapbaandet traadformet, forlænget i en Bue, bvorved Rummene (det ene ofte goldt) fjernes fra hinanden; Fr. som foreg. (N. F. Labiatæ.)

$\boldsymbol{\beta}$. Frugten nopspringende Heelfrugt. $\boldsymbol{\zeta}$.

5. Ligústrum L. Bægeret svagt firetandet; Kronen tragtformet med firefliget Krave; Fr. et torummet, 2-4-fiøet Bær. (N. F. Oleineæ.)

$\gamma$. Frugten kapselagtig, opspringende.

* Kronen regelrel, Kapsclen torummet.

6. Syringa L. Bægeret firetandet; Kronen fladkravet, ined firefliget Krave; Kapselen toklappet med rumdelende Opspringning, faafrøet. (N. F. Ole ineæ.)

** Kroneu uregelrel, uden Spore, Kapselen torummet.

7. Verónica L. Kronen med kort Rør, firedeelt Kírave; den nedre Flig mindst; Arret udeelt.

8. Gratiola L. Kronen tolæbet $\left(\frac{2}{3}\right)$, merl langt Rør; 2-3 golde Støvdragere; Arret tokløvet. (7-8. N. F. Scrophulariner.)

*** Kronen labedaanel, med spore, Kapselen enrummel. 4 .

9. Pinguicula L. Brgeret femdeelt; líronen gabende; Støvknapperne aabue sig paatvaers; Kapselen opspringer paalangs fraoven. (Sumpplante med hele Blade.) 
10. Utriculíria L. Bægeret tobladet; Kronen maskeret, Støvknapperne aabne sig paalangs; Kapselen tværsopspringende. (Vandplante med fiindeelte Blade, der tildeels ere omdannede til Blærer forsynede med et Laag.) (9-10. N. F. Lentibulariæ.)

\section{Orden. Digynia (Tohunnede).}

Blitum L. $(5,2)$.

Anthoxanthum L. Græsart. Smaaxene enblomstrede med 2 Skjæl (ufuldstændige Blomster). (3, 2).

Hierochloa Gmel. Græsart. Smaaxene treblomstrede. (3, 2).

\section{Orden. Tetragynia (Firelunnede).}

Ruppia L. Blomsterdække 0; Frugterne 4 langstilkede Nødder. $(4,3)$.

\section{Ilonogynia.}

\section{Fraxinus. Ask.}

2. F. excelsior L. (Almindelig A.) H. 13; Drej. n. 3; F. D. 969 ; Rebb. ic. fl, germ. XVII, tab. 1072.

Bladene modsatte, uligefinnede med $3-6$ Par lancet. formede, saugtakkede Smaablade; Blomsterne i grenede Klaser, trekjønnede og særkjønnede enten paa samme eller forskjellige Planter; Vingefrugten oval, i Spidsen udrandet.

Hyit Træ med glat Bark; Knopperne tykke, omgivne af sorte Knopskjæl; Blomsterne udvikles før Bladene. 5. $\boldsymbol{h}$.

Almindelig som plantet Trae omkring beboede Steder; i Skove forekommer den sjeldnere, deels plantet, deels oprindelig vildvoxende, f. Ex. B or $n h$. ikke sjelden i Ostkystens Skove; $\boldsymbol{S} j$. Kulaas Skov i Odsherred! Skove ved Tiissø (28), Bognæs (20); Loll. ikke sjelden i Skovene $(1 \mathrm{~s}) ; \boldsymbol{F}$. Hofmansgave! Dalby paa Hindsholm, i det sydlige F. hyppig (12), Thorseng! Als hyppig (28); $S$ l. v. Aabenraa!

\section{Salicornia. Salturt.}

3. S. herbacea L. (Enaarig S.) H. 4; Drej. n. 2; F. D. 303 og 1621. 
Staengelen urteagtig, saftig; Grenene korsviis modsatte, oprette ( $\alpha$, erecta F. D. 303) eller aabent udstaaende ( $\beta$, patula F. D. 1621), ligesom Stængelen leddede; Axene valseformede; Arret svagt kløvet.

1/4-1' høi; var. opret og nedliggende, med 1 og 2 Støvdragere. 8-9. $\odot$.

Paa leret, dyndfuld Grund, som overskylles af Havet, almindelig i Danmark, isier paa nys inddammet Land og udenfor Digerne i Marskegnene paa Halvøens Vestkyst, sjeldnere paa saltholdige Steder inde i Landet, f. Ex. Saltkilde ved 'Toftegard i Vildmosen i Jy lland!

* 4. S. radicans [Sm. i E. B. 1691]. (Rodslaaende S.) H. II, 107 ; Nolt. nov. p. 1; S. biennis-radicans Fr. S. Veg. Se. p. 55 og 201.

Stangelen ved Grunden rodslaaende, næsten træagtig; Axene tykkere og mere budte end hos foregaaende; Arret dybt deelt.

Storre end foregaaende. 9. $\odot$ eller $\%$. Om den er en fra hiin virkelig adskilt Art, synes endnu ikke at viere tilstrakkeligt beviist. Jeg har ikke seet levende Exemplarer. (S. biemnis Afz., Fr. H. N. X, 58, som af $\mathrm{Fr}$. ansees for Hovedarten til denne, er ikke rodslaaende).

Strandbredder: $\boldsymbol{J}$. Ydre Bjerrum ved Ribe (16).

\section{Circaea. Steffensurt.}

5. C. alpina L. (Glat S.) H. 32 ; Drej.n. 8; F. D. 1321.

Bladene hjerteformede, kort tilspidsede, grovt-tandede, med vinget Bladstilk; Dokbladene smaae, sylformede; Blomsterstilkene glatte, efter Afblomstringen udstaaende, Bagerbladene glatte, hindeagtige, hvide, i Spidsen røde, Frugten aflang-kølleformet, enrummet, tilligemed Blomsterstilkene tidligt affaldende.

Strengelen saftig, rød, $3-8^{\prime \prime}$ høi, fra Gruuden grenet, de nedre Grene ere underjordiske, forlnengede, traadformede Udløbere, i hvis Spidse der om Eftersommeren dannes en aflang-kølleformet, kjødfuldt opsvulmet Knop med 2-4 Par korsviis stillede, skjælformede Blade; Bladene randhaarede, forøvrigt, ligesom Strengelen, glatte og glindsende; Kronbld. hvide, med tydelig Negl. 6-7. थ.

I Skove, især paa fugtige Steder ved randne Træstubber o.s. v.; sporadisk: paa $\boldsymbol{H}$ alvo en ikke sjelden; $\boldsymbol{F}$. Ravnholt Hesteliave (25), Brobygaard (24), Skjoldemose, Nielstrup (12); $S j$. hist og lier! Moens Klint (H); Falst. Donnemose (Rasm.), Corselitze og Hanenov Skove (14). 
6. C. intermedia [Ebrh. Beitr. 4, 42]. (Spidsbladet S.) Drej. n. 9 ; H. N. II, 47 ; C. alpina major H. 33 ; F. D. 256 (ikke god); C. lutetiana intermedia Wahlenb.

Bladene hjerteformede, langt tilspidsede og nedenfor Spidsen indknebue, grovt-tandede med rendet, uvinget Bladstilk; Dak . bladene smaae, sylformede; Blomsterstilkene næsten glatte, efter Afblomstringen udstaaende; Bagerbld. glatte, hindeagtige med rødlig Spidse; Frugten omvendt-ægformet.

8-12" høi. Udløbere som hos foreg., men ned større Endeknop og flere Par Skjælblade; Stængelen oventil samt Bladene i Randen og paa Nerverne duunhaarede, forøvrigt næsten glat. Kronbladene som hos foreg. 7-8. 4 .

I fugtige Skove, sporadisk og ilke almindelig: $\boldsymbol{S} j$. Helsingør (21), Hellebæk! Steenholts Mølle (27), Fredensborg (Weilbach), Frederiksborg (14), Folehaveskov v. Horsholm (7), Kulhuus (14), Dronninggaard (9), Hareskoven (Sehum.), Sparresholm (16); $\boldsymbol{F}$. Ulriksholm, Svendborg (H); J. Bangsho v. Fladstrand (H), Haven og Sabygaard i Vendsyssel (12), Volstrupgaard ved Struer (16), Skoven ved Klausholm, Silkeborg! Veile (15), Kolding (28); Sl. Gram (1), Gelting (16), Adserballe p. Als (10); Bornh. Tilleløj-ved Rønne (Hoff), Grodby Aa ved Boderne Hjorth), Røe, Klause Molle!

Anm. Ansees af flere Forff. for en Bastard, og forekornmer under 2 Former, den ene (C. alpino-lutetiana Mey. Chl. Hanov.), mere lig folgende, den anden (C. lutetiano-alpina Mey.), mere lig foregaaende. Ofte forekommer den dog livor ingen af de andre Arter findes i Narheden, og efter Prof. Fries's Meddelelse er den f. Ex. i deu nordamerikanske Stat Visconsin den eneste forekommende Art.

\section{C. Iutetiana L. (Dunet S.) H. 32; Drej. n. 10;}

F. D. $210 ;$ H. N. $1,44$.

Bladene xgformede eller xg-hjerteformede, langt, men jæunt tilspidsede, utydeligt tandede, med uvinget Bladstilk; Dokbladene 0 ;*) Blomsterstillene haarede, efter Afblomstringen nedbøiede; Bagerbladene paa Yderfladen svagthaarede, grønne, i Spidsen farvede; Frugten omvendt-ægformet, torummet.

$1 / 2-11 / 2$ ' høi. Udløberne tykkere end hos de 2 foregaaende, i Spidsen neppe opsvulmede. Hele Planten mere eller mindre duunhaaret; Bladene fastere og mindre gjennemsigtige og glindsende end de foregaaende Arters. Kronbladene hvide, uden Negl. 7-8. 4.

I Skove, almindelig udbredt.

*) Kun de nederste Blomster i Klasen have sylformede Dækblade (bracteæ), som hos foreg., men disse falde af for Udspringningen. Blomsterstilkene hos denue Art ere mere vedblivende end hos de foreg., hvor de falde meget tidligt af. 


\section{Lyeopus. Svartevald.}

8. L. curopaus L. (Almindelig S.) H. 31; Drej. 11. 11; F. D. 1081 ; Rchb. ic. f. germ. XVIll, tab. 1291.

Stungelen firekantet, furet; Bladene modsatte, xg-lancetformede eller elliptiske, saugtakket-fligede eller fjersnitdeelte; Blomsterne talrige, siddende og twt krandsformigt sanlede $\mathbf{i}$ Bladhjørnerne; Bagertanderne sylspidsede, randhaaret-1ue; Kronens Overlæbe udrandet, Underlæben trekløvet, den midterste Flig bredere end de ovrige.

1-2' høi. Var. mere eller mindre haret eller næsten glat, Bladones Indskjæringer aftage almindelig i Dybde fra Grunden mod Spidsen; de nederste, under Vandet eller Jordskorpen skjulte Blade kamformigt fjersnitdeelte med linie-borsteformede Afsnit, fra disse Blades Hjorner ndgaae Udløbere. Kr. hvid med rodprikket Svælg. 7-8. 4.

Ved Grøfter, Sø- og Aabredder, almindelig.

\section{$\dagger$ Salvia. Salvie.}

† S. pratensis L. (Eng-S.) Rehb. ic. XVIII, tab. 1252.

Stcengelen opret, Bladene ægformede eller ovale med hjerteformet Basis, rundtakkede, nætformigt ryukede, Rodbladene talrige, stilkede, Stængelbladene 1-2 Par, næsten siddende; Krandsene omtr. 6-blomstrede, de nedre adskilte, de gvre axformigt samlede; Dakblade og Bagertander sylspidsede, kirte]haarede; Kronens Overlæbe halvmaaneformigt hvælvet.

1-1 $1 \frac{1}{2^{\prime}}$ hoi. Bld. paa Underfladen duunhaarede. Kr. i Almindelighed mørkeblaa. 6-7. 4 .

Angivet fra Slesvig (Esmarch).

\section{Ligustrum. Liguster.}

† 9. L. vulgare L. (Almindelig L.) II. 11; F. D. 1141 ; Rehb. ic. fl. germ. XVII, tab. 1074.

Bladene modsatte, laneetformede, heelrandede, glatte; Blomsterstanden en tretblomstret Top i Spidsen af Grenene.

Kr. 1vide, have en sød Lugt. Har sort need violet $\mathrm{K} j ø d, 6-7 . \mathfrak{h}_{\text {. }}$

Ikke sjelden plantet ved, Gjarder, og opundelig indfort, men findes undertiden forvildet: $\boldsymbol{S} j$. mellem Helsingor og llcllcbrek (12), 
ved Lyngby $\mathbf{S} s(\mathbf{H}) ; \boldsymbol{F}$. Hofmansgave (1), mellem Svendborg og $\mathrm{Ny}-$ borg! $S i$. Augustenborg, Sundeved, Aabenraa (Rafn), hist og her ved Gjærder i Angel! Egernførde, Husum (H).

\section{Syringa. Siren.}

+ 10. S. vulgaris L. (Almindelig S.) H. 12 ; Rchb. ic. fl. germ. XVII, tab. 1073.

Bladene modsatte, æg-hjerteformede, heelrandede, glatte; Blomsterstanden en endestillet, pyramideformet Top.

$\mathrm{Kr}$. violet eller hvid, af behagelig Lugt. 5-6. そ.

Oprindelig fra Orienten, almindelig plantet som Siirbusk i Haver, forekommer hist og her forvildet, f. Ex. ved Gjærder i det østlige og sydlige Fyen! Sl. ved Gjæerder i Angel! Hnsum og Egernfórde (H).

\section{Veronica. AErenpriis $\left.{ }^{\star}\right)$.}

a. Cochliosperma Rchb. Blomsterne enlige i Bladhjørnerne. $\odot$.

(Frøene paa den ene Side hrælvede, paa den anden udhulede.)

aa. Bagerfigene spidse.

11. V. hederafolia L. (Vedbendbladet AE.) H. 23 ; Drej. n. 16 ; F. D. 428 (ikke god).

Stcongelen fremliggende; Bladene hjerteformet-nyreformede, haandnervet-3-5-lappede; Blomsterstilkene af Længde med eller kortere end Bladene, ensidigt haarede; Bagerfligene hjerteformede, randhaarede; Kapselen firelappet, næsten firekantet, i Spidsen indtrykt.

Kr. lila eller skident blegrød; St $₫$ dragerne blaae. Pai dyrkede Agre i god Jord har den storre og kjødfulde Blade, i Skygge blive Bladene mindre, Stængelen mere opret, Blomsterne mindre og Støvdragerne blegere ( $\beta$, umbrosa Mort.)! 4-5. $\odot$.

Almindeligt Ukrud i Haver og paa dyrkede Marker.

*) Det gjensidige Forhold mellem Blomsterstilke, Dækblade og Brger i denne Slægt er, (ligesom i Regelen i det Følgende, naar intet Andet udtrykkeligt er bemærket, bestemt under Blomstringen, mellem Frugten og de ovrige Dele derimod ved dennes fuldstæendige Udvikling. 
$\dagger$ 12. V. persica [Poir. ene. 8, 542] (Storkronet $\mathrm{E}$.) H. N. IV, 23; V. Buxbanmii Ten., H. II, 109; F. D. 1982 ; Rchb. ic. pl. crit. III, $430-31$.

Stcongelen fremliggende eller opstigende; Bladene æg-hjerteformede, dybt saugtakkede; Blomsterstilkene lengere end Bla. dene, alsidigt duunhaarede; Bageret ved Basis og i Randen Laaret, med æg-lancetformede, spidse Flige; Kapselen fladtrykt, omvendt-nyreformet, budt udrandet, med ophøiede, nætformede Aarer og langt fremragende Griffel.

Kr. himmelblaa, større end hos de øvrige Arter af samme Gruppe. 4-5. $\odot$.

Oprindelig indført, forekommer nu forvildet paa dyrkede Steder, f. Ex. $\boldsymbol{S}$. Ordrup! Lyngby, Kløvermark ved Gladsaxe (14), almindelig i Haver i Soro! Loll. Engestofte (Kherrinde Wichfeld); $\boldsymbol{F}$. Ollerup (12), Skaarup (19); $S l$. Rylskov i Augel! Slotshaven i Slesvig (16); B ornh. Røune (Hoff).

13. V. polita [Fr. nov. ed. 2 p. 1] (Glandsbladet $\mathbb{E}$.) Drej. n. 17; H. N. IV, 25; Rehb. ic. pl. crit. III , 304-5; V. agrestis F. D. 449.

Stcongelen fremliggende; Bladene fjernervede, æg-hjerteformede, dybt-saugtakkede; Blomsterstilliene omtrent af Læugde med Bladene, alsidigt haarede; Bagerfligene ægformede med puklede Tilhængsler ved Basis, randhaarede, spidse, tydeligt (3) nervede; Stovdragerne befæstede til den nedre Rand af Kronrøret; Kapselen omvendt-lijerteformet, spidst udrandet (med Griffelen fremragende af Indskjæringen), utydeligt aaret, opblæst, kirtelhaaret, Rummene omtrent 10 -frøede. $\left.{ }^{*}\right)$

Bladene noget kjødfulde, glindsende, svagthaarede og især paa

*) Baade denne og foregaaende Art forekomme hos os under 2 Former: a, gracilis, med smaae Blade, mange Gange kortere end Ledstykkerne, traadformede Blomsterstillke, (der hos 13 ere laengere end Bladene) og $\beta$, robustior, med storre Blade ( $1 / 2$ Gang kortere end Ledstykkerne). Reichenbach bemærker (Fl. exe. p. 365) at Høstformen af $V$. polita er mere laaret og derfor mindre glindsende end Vaarformen, livilket jeg ogsaa liar iagttaget i vor Flora. Den forste kan derfor ved overfadisk betragtning forvexles med V. opaea, fra hvilken den dog forovrigt er vel adskilt. 
Underfladen blaagrønne. Kr. himmelblaa, omtrent halvt saa stor som hos foregaaende. $4-5$ og $8-9$. $\odot$.

Paa dyrkede Steder, ikke sjelden paa Øerne (f. Ex. i Kjøbenhavus Omegn! ved Sorø) og sandsynligviis udbredt over hele Danmark (Jyll. v. Dybdals Kalkbakker (Dr.), Lyngby pr. Aarlus (16); Slesv. (16), men mindre hyppig end de 2 folgende Arter..

\section{bb. Bagerfligene budte.}

14. V. opaca [Fr. l. e. p. 3] (Matbladet $\mathbb{E}$. ) Drej. n. 19 ; H. N. II, 28; Rehb. ic. crit. III, 441 ; V. agrestis H. 32 (ifølge Beskr.).

Stcengelen fremliggende; Bladene rundagtigt-hjerteformede, grovt rundtakkede; Blomsterstilliene kortere end Bladene; Bugerfigene omtrent af Kronens Længde, ovale eller spatelformede (bredest i Midten), tæthaarede, tydeligt (3)-nervede; Støvdragerne befæstede til Svælget; Kapselen omvendt nyreformet, dybt og spidst udrandet (Griffelen ligelang med eller lidet længere end Indskjæringen), tret- og kruset-haaret, med 3-5-frøede Rum.

Hele Planten tæet haaret; Bladene af morkere og mattere Farve end hos foregaaende og folgende; Kr. himmelblaa. $4-5$ og 6-9. $\odot$.

Paa dyrkede Marker og i Haver, især i feed Muldjord, ikke sjelden $\mathrm{i}$ de danske Provindser. [*.

15. V. agrestis L. (Fr.!) (Fleerfarvet 死.) H. N. IV, 24; Rehb. ic. III. 440; V. versicolor (Fr.), Drej. n. 18; F. D. 2221.

Stangelen opstigende; Bladene bjerteformet-xgformede, ovale eller elliptiske, saugtakkede; Blomsterstilliene omtrent af Bladenes Længde; Bagerfigene ovale (bredest i Midten), af Længde med eller længere end Kronen, imod Frugtmodningen snoede, utydeligt (3) nervede, beklædte med faae lange Haar; Støvdragerne befæstede til Kronrørets Basis; Kapselen kirtelhaaret, opsvulmet, omvendt-hjerteformet, dybt og spidst udrandet (Griffelen kortere end Indskjæringen), Rummene 4-5-frøede.

Planten af en lysere gron Farve end de 2 foregaaende. Kr. blegrød eller mælkeblaa, den medre Flig lıvid. 4-5 og 8-9. $\odot$.

$\beta$, calycida Fr. Væxten finere og mindre, Brgeret ofte femfliget med indskaarne Flige.

Paa dyrket Jord i Mark og Have meget almindelig. $\beta$, træffes ofte mellem Hovedarten, især tidligt paa Foraaret. 
16. V. triphyllos L. (Trefliget A.) H. 24; Drej. n. 20 ; F. D. 627 ; H. N. IV, 22.

Stcengelen opret, med udspærrede eller opstigende Grene og Blomsterstilke; de nedre Blade xgformede, rundtakkede, Stangelbladene dybt haandfligede, Bladene ved Blomsterne hele eller trefingrede med linieformede Flige; Kapselen kirtelharet, omvendt-hjerteformet, udrandet, Griffelen længere end Indskjæringen.

Hele Planten kirtelhaaret, mørkfarvet, ved Tørring sort; Kr. mørkblaa. 4-5. $\odot$.

Paa tørre Marker mellem Vintersæden, sporadisk og ikke almindelig; forekommer $\mathbf{i}$ alle Provindser, men sjeldnere paa Halvøen end paa Øerne.

b. Veronicastrum Benth. Blomsterne i endestillede, spredtblomstrede Klaser (eller Ax); Kapselen fl ad trykt.

- (Kronroret meget kort, Frøene flade, skjoldformede.)

aa. Planten haaret. $\odot$.

17. Y. verua L. (Vaar-ÆE.) Il. 25; Drej. n. 27 ; F. D. 252.

Stcongel og Grene oprette; de nedre Blade agformede, saugtakkede, de øvre dybt 3-5-figede; Dakbladene lancetformede, af Bægerfligenes Længàe; Blomsterne tætsiddende; Blomsterstilkene oprette, kortere end Bxgeret; Kapselen fladtrykt, omvendt-nyreformet, overalt haaret, bredere end bægeret, Griffelen af Længde med Indskjæringen.

$1-4$ " høi. Kr. blaa, kortere end Bægeret. 4-5.

Paa tørre, udyrkede, isæer sandige Marker, forekonmer i alle danske Provindser, men sporadisk og ikke almindelig.

18. V. arrensis L. (Mark-Æi.) H. 23; Drej. n. 28; F. D. 515 (slet Fig.).

Stangel og Grene opstigende; Bladene xg-hjerteformede, rundtakkede; Dokbladene lancetformede, heelrandede eller svagt takkede, af Længde med eller længere end Bageret; Kapselen fladtrykt, omvendt-hjerteformet, raudhaaret, af Bugerets Brede, Griffelen af Læungde med Indskjæringen. 
1-6" høi. Kr. blaa (meget liden), kortere end Bægeret. Var. med heelrandede Blade (Drej.). 4-6.

Paa dyrkede og udyrkede Marker, ved Gjærder o. s. v. almindelig.

b6. Planten glat eller meget svagt haaret. 2.

+ 19. V. peregriua L. (Fremmed A.) H. 25; F. D. 407.

Stcengelen fra Grunden af grenet; de nedre Blade kortstilkede, elliptiske, svagt rundtakkede; Dckbladene siddende, smalt laneetformede, heelrandede, længere end Blomsterne; Kapselen næsten kredsrund, svagt udrandet, glat eller kirtelbaaret; Griffelen af Længde med Indskjæringen.

3-6" høi, glat eller svagt haaret; Bld. noget kjødfulde; $\mathrm{Kr}$. hvid eller blegblaa, kortere end Bægeret. 5-7. $\odot$.

En i Amerika oprindelig hjemmehørende Ukrudsplante. Angives med Tvivl fra Amager (Oeder); $\boldsymbol{S} \boldsymbol{j}$ all. uden Angivelse af Voxested (J. VahIs Herb.)! $\boldsymbol{S} l$. Coldenbüttel pr. Frederikstad (F. Müller i Flora 1853 p. 492).

20. V. serpyllifolia L. (Glat E.) H. 18; Drej. n. 29; F. D. 492 .

Stcengelen bueformigt opstigende, ved Grunden rodslaaende; Bladene modsatte, ovale, heelrandede eller utydeligt rundbugtede; Blomsterstillene oprette, kortere end de elliptisk-ovale Dolvblade, af Længde med Bogerets længste Flige; Kapselen randhaaret, omvendt-nyreformet, bredt, men svagt udrandet; Griffelen af lige Længde med Kapselen.

Bladene glatte, Strengelen (seet under Lupen) fiint- og tiltrylsthaaret. Kr. lysblaa. 5-7.

Paa grusede og lerede Steder, høie Enge, Gresmarker o.s.v. almindelig udbredt.

e. Pseudolysimachium Koeh. Blomsterne i endestillede, tretblomstrede Klaser (ellerAx). liapselen trind, svagt sammentrykt.

(Kronrørets Længde større end dets Tværsnit. భ.*))

21. V. spicata L. (Axblomstret AE.) H. 16; Drej. n. 30; F. D. 52 .

*) Bladene hos Arterne i denue Afdeling ere modsatte, almindelig aftagende i Storrelse nedenfra opad. Nogle have tillige Klaser fia 
Stangelen opstigende; Bladene modsatte, æg-lancetformede, elliptiske eller ovale, rundtakkede eller sangtakkede, i Spidsen og ved Grunden heelrandede; Blomsterstanden trtblomstret, axformet (Blomsterstilkene ntydelige); Dekbladene laneet-sylformede, længere end de indbyrdes omtrent ligestore Bægerflige; Stóvdragerne langere end Kronen; Kapselen rundagtig, udrandet, opblæst, flere Gange kortere end Griffelen.

$1 / 2-1$ ' høi. Kr. haa. 7-8. Var. betydeligt i Henseende til Bladenes Form, Indṣkæring og Beklædning (almindelig tæt- og tiltrykt-haarede, sjeldnere graafiltede eller næsten glatte), Bladstilkenes Lrengde o.s. v. De hos os forekommende Variationer synes mig dog ikke constante og afvigende nok for at kunne henfores til de talrige Eormer (eller egne Arter) som flere Forfattere have opstillet. Den meest iøinefaldende Form (- integrifolia) har alle Bladene lancetformede, spidse, heelrandede, meget kort- og svagthaarede, Stængelen kirtlet-dumuharet.

Paa torre Steder saavel med Kalk- som Granit-Underlag: Jyl $l$. i Kallsterrainet mod N.: Thorup, Logstør (12), Norbjerg i V. Hanherred (16), Aallborg, Daastrup (H), Gjedsted mellem Viborg og Løgstor (12), Hodal Molle ved Hobro (16), Boeslnm Strand ved Ebeltoft (Ørting); $S j$. i en Linie fra NV. mod SO.: Refsnas (21), Nykjøbing, Kongsøre, Adelersborg (H), Kalundborg (23), Jægerspriis, skulleløv, Selsø (15), Holmene i Isefjorden (H), Frederiksund (Sehnm.), Ledrehorg (Weilbach), ved gl. Kjøgekro og fra Pxambroen langs Stranden til Stevns Klint (H); Bornh. paa flere Steder i Granit-Terrainet, f. Ex. S. for Aakirkeby! Clemensker, Hammeren (Hjorth), St. Jons Kapel (Baagøe), Gudlijem (var.)!

22. V. Iongifolia L. (Langbladet A.) H. 15; H. N. III, 12 ; V. maritima F. D. 374.

Stangelen opret; Bladene krandsstillede (2-4 i Krandsene), fra bredere Basis lancetformede, tilspidsede, indtil Spidsen skarpt og ofte dobbelt saugtakkede; Blomsterne i tætblomstrede Klaser fra Enden af Strengleme og de øve Bladlijorner; Blomsterstilkene af Længde med eller kortere end de indbyrdes uligestore Brgerflige, kortere end de linie-sylformede Dokblade; Stovdragerne længere end Kronen; Kapselen opblæst, rundagtig, udrandet, af Længde med eller læugere end Bægerfligene, flere Gange kortere end Griffelen.

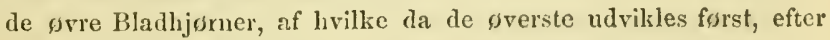
den begrandsede Strengels Typus. 
$2-3^{\prime}$ høi. Stgl. nedentil næsten glat, oventil dumhaaret; Bladenes Overflade næsten glat, Underfladen duunhaaret (Var. i Form og Indskjæring). Bliver sort ved Torring. Kr. blaa. 7-8.

Paa fugtige Steder sjelden; $\boldsymbol{J}$. Overklitgaards Mark ved Hjørring (Schjønning), Nørholm (H); $\boldsymbol{S} l$. Farrisbæk ved Rødding (20), Gjærder mellem Nykro og Huusby i Angel! Treya Holm ved Trenefloden: (16). [*.

d. Pleurobotrys Fr. Blomsterne i Klaser fra Bladhjørnerne.*)

aa. Bugeret femfliget. (Pentasepalce Ledeb.)

$+V$. latifolia L. (Bredbladet E.) V. pseudo-chamcedrys. Jacq. fl. austr. tab. 60 .

Stoengelen opret eller bueformigt opstigende; Bladene modsatte, siddende, ægformet-elliptiske, grovt saugtakkede eller halvfinnede; Klasestilkene mange Gange længere end Bladene; Blomsterstillkene oprette; Bagerfligene uligelange.

Kr. store, blaae med mørkere Striber. 6-7. 4 .

Forvildet i Charlottenlund! Fredriksdal (19).

\section{bb. Bcegeret firefliget.}

ж. Kapselen omvendt-hjerteformet, svagt ndrandet og nasten tresidet. Klasen mangeblomstret (Chamedrys).

23. V. officinalis L. (Læge-Æ.) H. 21; Drej. n. 26 ; F. D. 248 .

Stcongelen nedliggende eller opstigende, ved Grunden rodslaaende, alsidigt haaret; Bladene kortstilkede, elliptiske eller omvendt-ægformede, fiint saugtakkede ; Klaserne mangeblomstrede ; Blomsterstilliene oprette, kortere end de linie-lancetformede Dakblade og de budt-lancetformede Bagerflige; Kapselen fladtrykt, overalt klæbrig-haaret, længere end Brgeret, neppe saa lang. som Griffelen.

*) Arterne i denne Afdeling have modsatte Blade (almindelig aftagende i Storrelse ovenfra nedad) og derfor ogsaa typisk modsatte Klaser, men undertiden kommer kun Klasen i det ene Bladhjørne (alm. afvexlende) til Udvikling. Nr. 25 og 26 have saaledes hyppigst afvexlende Klaser. Da Strengelens Vaxt er ubegrændset, udvikles de nedre Klaser først. 
Var. mere eller mindre tæt haaret. Kr. lila eller blegblaa. 6-7. 4 .

$\boldsymbol{\beta}$, decolorans! Fr. S. Veg. Sc. p. 18. Stgl. meget grenet, med korte Ledstykker og sammentrængte Blade. Kronen guulgrøn med violette Aarer.

I Skove og par solaabne, tóre Steder, almindelig i Danmark. $\beta$, paa Lyngbakker ved Ilaraldslund i Jylland!

\section{Y. Chamadrys L. (Tveskjægget E.) H. 21; Drej.}

n. 24 ; F. D. 448 .

Rodstoliken krybende; Stangelen opret, tvesidigt haaret; Bladene æg-hjerteformede, dybt og grovt saugtakkede, de øvre siddende, de nedre kortstilkede; Blonsterstilkene oprette, efter Afblomstringen langere end de lancetformede Drkblade og de linie-lancetformede Bagerflige; Kapselen kortere end Bæageret og Griffelen.

Bladene rynkede, paa Underfladen dumhaarede; Kr. stor, mork himmelblaa (sjeldnere rødlig-lila), Støvdragerne hvide. 5-6. 4 .

$\beta$, parviflora! Bladene mindre, svagere haarede, Kronen liden, hvidagtig-blegblaa.

Paa høie Enge, ved Gjaerder, i Krat o.s. v. almindelig. $\beta$, en Skyggeform, funden i Sønderskoven ved Sorø! F alst. Nasgaard (14).

B. Kapselen omvendt-nyreformet, vinget-fladtrykt. Klasen fjernt- og faablomstret (Parmularia).

25. Y. montana L. (Bjerg-AE.) H. 22; Drej. n. 25 ; F. D. $1201 ;$ H. N. II, 29.

Rodstokken krybende, grenet; Stanglerne opstigende eller krybende, alsidigt langhaarede; Bladene xgformede, grovt saugtakkede, alle langstilkede; Blomsterstilliene længere end Dakbladene og de omvendt-xgformede Bagerflige; Kapselen i Randen bølget og haaret, længere end Bageret, omtrent af Laugde med Griffelen.

Kr. blegblaa eller lila med morkere Aarer, mindre end hos foreg. 5-7. 4 .

Paa fugtige Steder i Skove, forckommer i alle danske Provindser og i flere Egne ikke sjelden, men sporadisk. "म.

26. V. scutellata L. (Smalbladet A.) II. 20 ; Drej. n. 21; F. D. 209.

Stangelen svag, opstigende, med Udlobere fra Grunden; 
Bladene linie-lancetformede, spidse, heelrandede eller fjernt og utydeligt tandede, med nedadvendte Tænder; Blomsterstilliene udspærrede eller (imod Frugtmodningen) tilbagebøiede, omtrent dobbelt saa lange som de linieformede Dakblade, 3-4 Gange længere end de lancetformede Bagerflige; Kapselen dybt udrandet, længere end Bægeret, omtrent ligelang med Griffelen.

Hele Planten (hos Hovedarten) glat, $\mathrm{Kr}$. hvid med lysblaa eller blegrøde Aarer. 6-7. 4.

$\beta$, villosa (Schum.) F. D. 1561 ; V. parmularia Poit. \& Turp. Alm. mindre og finere end Hovedarten; Stgl. og Bld. duunhaarede.

Paa vaade og oversvommede Steder ikke sjelden. $\beta$, paa lignende Steder som Hovedarten, især paa Tørvgrund, f. Ex. hist og her i Nordsjælland!

$\gamma$. Kapselen kredsrnnd, svagt udrandet, noget opblæst. Klasen mangeblomstret (Beccabunga Grisebach).

27. V. Anagallis L. (Lancetbladet $\mathbb{A}$. .) H. 19 ; Drej. n. 22 ; F. D. 903 .

Stcongelen opret; Bladene alle stilkløse, lancetformede, spidse, med halvomfattende Basis, saugtakkede; Klaserne forlængede, mangeblomstrede; Blomsterstilkene efter Afblomstringen udstaaende eller opstigende, længere end de linie-lancetformede Dakblade og de lancetformede Bargerflige; Kapselen af Længde med Bageret og længere end Griffelen.

Hele Planten glat. Var. med næsten heelrandede Blade. $\mathrm{Kr}$. blegblaa eller blegrød. 6-8. 2. (eller $\odot$ ).

I Moser, Grøfter og Bække, almindelig udbredt.

28. V. Beccabunga L. (Tykbladet AE.) H. 19; Drej. n. 23 ; F. D. 511.

Stcengelen opstigende, ved Grunden rodslaaende; alle Bladene kortstilkede, ægformet-ovale, budte, svagt saugtakkede; Blomsterstillkene efter Afblomstringen udstaaende, omtrent ligelange med de linie-lancetformede Drkblade, længere end Bogeret; Kapselen omtrent af Længde med Bægeret, lidet længere end Griffelen.

Hele Planten glat, Bladene kjødfulde, var. næsten heelrandede. Kr. morkblaa. 6-8. ข.

I Dynd, ved Kildevæld og paa andre fugtige Steder almindelig. 


\section{Tratiola. Naadesurt.}

29. G. officinalis L. (Lancetbladet N.) H. 26; F. D. 363.

Rodstokken horizontal, leddet; Stangelen opstigende, foroven, tilligemed Grenene, firekantet; Bladene modsatte, trenervede, linie-lancetformede med afrundet, halvt-omfattende Basis, fra Midten til Spidsen saugtakikede; Blomsterstilkene enblounstrede i Bladhjornerne; Bxgeret femdeelt med 2 Dakblade ved Grunden.

$1 / 2,-1 \frac{1}{1} 2^{\prime}$ hsi. $\mathrm{Kr}$. hvide eller blegrode med guult, indvendig haaret Ror. 7-8. 4.

Ved Flodbredder og paa fugtige Enge. Opbevares i Heerfortlıs Lolland-falsterske Herbarium, men uden Angivelse af Voxestedet; $\boldsymbol{J}$. Ribe (6).

\section{Pinguicula. Vibefedt.}

30. P. rulgaris L. (Almindelig V.) H. 27 ; Drej. n. 12; F. D. 93 ; Rehb. ic. fl. germ. XX, tab. 1819.

Alle Bladene samlede ved Roden og tiltrykte til Jorden, xgformet-ovale, budte, i Randen indrullede; Blomsterstillene 1 eller flere fra Grunden, bladløse, enblomstrede; Blomsten nikkende; Sporen sylformet; Kapselen rgformet.

Hele Planten fedtagtig af klebrige Kirtler. Kr. violet med hvide Haar i Svalget. 5-6. 4 .

I fugtige Enge og Torvmoser, almindelig i de fleste Egne af Danmark (paa Loll. sjelden og kun bemærket ved Engestofte 19).

\section{Utricularia. Blaererod *).}

a. Bladene gjentaget-kamdeelte, med haarformede Flige.

31. U. vulgaris L. (Almindelig B.) H. 29;.Drej. n. 13 ; F. D. 138 ; Relıb. ie. fl. germ. XX, tab. 1822-23.

Bladenes Flige med fjerntsiddende, fine Smaapigge i Randen og Blxrer ved Basis; Klasen 6-10-blomstret; Blomsterstillene

*) Arterne i denne Slagt overvintre ved kugleformede kinnlper med tret sammenhobede Blade, som ndvikles $\mathrm{i}$ Spirlsen af lloveraxen og tilsidst losrives fra Moderplanten. De svommende, bladbaerende Stangler udskyde opaitil et blomstrende Skaft. Alle ere forsynede med Blærer, som enten findes mellem Bladfligene eller paa særegne, bladlyse Grene.

llaandb. i den danshe filora. 
efter Afblonstringeu tilbagebøiede eller udstaaende; Ganen oppustet, omtrent af den heelrandede Overlabes Længde; Sporen budt, kegleformet, noget udstaaende fra Underlceben og lige lang med eller lidet kortere end denne; "Stovknapperne sammenhængende".

Skaftet bruunagtigt. Kraftigere af Vext $\mathrm{og}$ med stgrre Blærer end de folgende. Kr. æggeguul med mørkere Striber paa Ganen. $6-8$. ข.

I Kjær og Tørvgrave almindelig, især paa Øerne. I flere Egne af Halvøen er deı sjeldnere end følgende Art.

32. U. neglecta [Lehm. ind. schol. Hamburg. 1828]. H. II , 11; F. D. 1981; H. N. VIII, 11; U. major Sehmid., Rehb. 1. c. tab. 1824, fig. 1-3.

Bladene som foregaaende, men fjernere fra hinanden og med finere Flige; Klasen 5-8-blomstret; Blomsterstilkene opretudstaaende; Ganen oppustet, halvt saa lang som den heelrandede Overlobs; Sporen budt-kegleformet, noget bøiet, tiltrykt til Underlaben og af denues halve Længde; "Støvknapperne frie".

Af Hgide med foreg., men noget finere, Bægeret og Blærerne mindre. Kronens Farve lidt lysere guul end hos foreg. 7-8. 4.

Paa samme Localiteter som foreg., bemærket flere Steder paa den jydske Halvø, livor den synes at vere alm. udbredt, f. Ex. J. Eveldrup Præstegaard (Dr.), Randers (7), Tolstrup og Brøndsted v. Fredericia! Kolding (2S), V. for Varde almindelig (30); Sl. Aabenraa (N.), Satrup Mose i Angel! Lyrskov v. Slesvig (Jessen), Seemühle og Carlshütte v. Rendsburg! B ornh. Aamyre Mose i Almindingen (Hjorth), Vallensgaards Mose! (Paa de andre Øer er det mig ikke bekjendt at den er funden). Fis

b. Bladene gjentaget-tredeelte, med børsteformettilspidsede, noget fladtrykte Flige.

33. U. intermedia [Hayne i Sehrad. Journ. 1, p. 18] (Storlæbet B.) H. 30; Drej. n. 14; F. D. 1262.

Blaclenes Flige med Midtnerve og talrige Smaapigge i Randen, uden Blærer; de blærebærende Grene bladløse; Klasen 3-4-blomstret; Blomsterstilkene efter Afblomstringen opadrettede; Ganen oppustet, halvt saa lang som den heelrandede Overlobe; Sporen ret, spidst kegleformet, tiltrykt til og omtrent halvt saa lang som den brede, nyreformede, fladtrykte Underlabe. 
Hele Planten grøn, noget mindre og finere end de foreg. Vinterknopperne, som findes i Spidsen af saavel de blarlbarende som de blærubærende Axer, ere omtrent af en Arts Storrelse. Kr. forboldsviis stor, svorlguul med rode Striber paa Gane og Overlabe. 6-7. 4.

Paa samme Steder som de foregaaende, sporadisk; $\mathbf{S}$. mellem Birkerød og Rudergaard (Schum.), Lyngby Mose! Holmegaardsmosen (16); J. Gravens Mose i V. Hauherred (16), Viborg (Feddersen), Skjern Aa ved Lønborg og Petersminde! i Egnen omkring Varde alm., Bxkbolling (30), Ribo (16); $S l$. Aabeuraa o. fl. St. (16); Bornh. Vallensgaards Mose!

34. U. Bremii [Heer Fl. der Schweitz. p. 984]. (Bruunstribet B.) Koch Syn. II, p. 666 ; Rehb. ic. fl. germ. XX, tab. 1826, fig. 2 ; U. pulchella C. A. Lehm., Fr. S. Veg. Sc. p. 20.

Bladenes Flige uden Midtnerve og Sinaapigge, med fatae (eller ingen) Blærer, de blærebærende Grene bladlose; Klasen 3-5blomstret, Blomsterstilkene efter Afblomstringen tilbagebøiede; "Bagerbladene rundagtigt-nyreformede med en kort Spids"; Ganen nedtrykt, af Længde med den udrandede Overlabe; Sporen meget kort, budt; Underlaben næsten kredsrund, fladtrykt.

Fïn som følgende, men med større, lys-svovlguul Krone og bruunstribet Gane. 7-8. 4.

Voxested som de Steder: $\boldsymbol{S}$. Lyngby Mose! J. Søerne ved Bordrup Sande pr. Varde $(30)$. 原

35. U. minor L. (Liden B.) H. 30 ; Drej. n. 15; F. D. 128 ; Rebb. l. c. fig. 1 .

Bladenes Flige uden Midtuerve og Smaapigge, med Blwer ved Basis; Klasen 3-6-blomstret, Blomsterstilkene efter Afblomstringen tilbagebøiede; Bagerbladene xgformet-ovale; $G a$ nen nedtrykt, af Længde med den udrandede Overlabe; Sporen meget kort, budt; Underloben ægformet med tilbagerullet Raud.

Liden og spæd, Knopperne meget smaae. Kr. liden, skidentblegguul. $6-8$. 4 .

Voxested som foreg., bemærket i alle Provindser, men sporadisk. Da denne Art og foreg. let kunne forvexles, maa de enkelte for denue Art angivne Voxesteder paany eftersees, ligesom overhovedet disse 2 Arter maa anbefales til næermere Undersggelse. 


\section{3die Klasse. Triandria (Trehannede).}

\section{Orden. MIonogynia (Enhunnede).}

A. Blomsterdækket dobbelt.

1. Valeriaiıa L. Bægerets Rør sammenvoxet med Frugtknuden, dets Krave under Blomstringen indrullet; Kronen tragtformet, uregelm. femfliget, ved Grunden puklet; Frugten enrummet Skalfrugt, oventil beklædt med fjeret Fnok (den tilsidst udfoldede Bægerkrave).

2. Valerianélla Poll. Bægeret sammenvoxet med Frugtknuden, dets Krave 3-4-tandet eller 0; Kronen tragtformet, regelm. femfliget, ikke puklet; Fr. trerummet Skalfrugt (med to tomme Rum), oventil beklædt med den vedblivende, hindeagtige Bægerkrave. (1-2. Bladene modsatte, Blomsterne i Qvast. N. F. V alerianex.)

3. Móntia L. Bægeret undersædigt, tobladet; Kronen tragtformet med kløvet Rør og uregelm. femfliget Krave; Fr. treklappet, trefrøet Kapsel. (Lave, glatte Sumpplanter med kjødfulde, modsatte Blade, N. F. Portulaeaceæ.)

Asperula tinctoria $(4,1)$.

\section{B. Blomsterdækket enkeit eller 0,}

a. oversadigt, kronbladagtigt-farvet. (Frugten kapselagtig).

4. Crocus L. Blomsterdækket med langt Rør og regelret sexdeelt, klokkeformet Krave; Griffelen forlænget, Arret trefliget med tragtformede, i Spidsen tandede eller fryndsede Flige; Kapselen treklappet. (Urt med Løgknol og linieformede Blade. N. F. Iride $x$ ).

5. Iris L. Blomsterdækket med kort Rør og sexdeelt Krave, hvis ydre Flige ere tilbagebøiede og af anden Form end de indre, oprette; Griffelen kort, med 3 kronbladagtige Ar; Kapselen treklappet. (Urter med knolleformigt forgrenet Rodstok og sværdformede Blade. N. F. Irideæ.) 
b. Blomsterdækket undersædigt, børsteformet

$$
\text { eller } 0 \text {. (Fr. uødagtig). }
$$

(Græslignende Væxter med omskedende Blade og heel Bladskede; Blomsterne i enlige Ax eller flere, til en sammensat begrendset Blomsterstand forenede, Smaax; de enkelte Blomster omgivne af [oftest] 1 Drekskjæl [gluma]; Arret 2-3-deelt. 6-12. N. F. Cyperaceæ, a).

\section{aa. Smaaaxene med toradede Dakskjol.}

6. Cypérus L. Smaaasene fladtrykte, mangeblomstrede; alle Drkskjallene blomsterbærende, ligestore eller de nedre størst; Blomsterdækket 0 . (Smaaxiene sammenhobede til en hoved- eller skjærmformet, endestillet Blomsterqvast, omgivet af 5 uligelange Svøbblade).

7. Schoenus L. Smaaxene med 5-6 Drkskjæl, hvoraf de $3-4$ nederste (mindre) ere blomsterløse; Blomsterdækket børsteformet eller 0 . (Blomsterstanden et Hoved, omgivet af 1 - 2 Svobblade).

\section{bb. Dakshjwllene alsidigt taglagte.}

$\boldsymbol{\alpha}$. Griffelen tilleddet, dens nedre Deel vedblivende.

8. Rhyncóspora Vahl. Smaaxene flere, faablomstrede, samlede til ax- eller hovedformede Nogler; de nedre $3-4$ Dækskjæl mindre og blomsterløse; Blomsterdækket dannet af $3-12$ Børster.

9. Eleócharis R. Br. Eet mangeblomstret Endeax; de nedre 1-2 Dakskjiel bredere og blomsterløse; Blomsterdakket $5-6$ Børster.

B. Griffelen ikke tilleddet til Frugtknuden.

10. Scirpus L. Eet eller flere endestillede (stundom falsk sidestillede) Smaax; de nedre $1-2$ Dakskjal bredere 0 g (med Undtagelse af Nr. 57) blomsterløse; Blomsterdakket 0 eller borsteformet, kortere end Dækskjællene.

11. Erióphorum L. Eet eller flere endestillede Smaax; de nedre 1-2 Diekskjal bredere og blomsterløse; Blomster- 
dxkket haarformet, tilvoxende efter Afblomstringen, under Frugtmodningen meget længere end Drkskjællene.

12. Cládium P. Browne. Blomsterstanden en Top, dannet af sammensatte Qvaster, i Spidsen af Stængelen og Grenene; Smaaaxene faablomstrede, de 3 nedre Diekskjæl nindre og blomsterløse; 2 Stovdragere; Blomsterdække 0; Frøgjemmet baardt og skjørt, løst omsluttende Frøet.

Nardus L. Blomsterne i ensidige Ax. $(3,2)$.

Juncus sp. $(6,1)$.

\section{Orden. Digynia (Tohunnede).}

(Græsarter med omskedende Blade og kløvet Bladskede; Blomsterstanden dannet af flere [til sammensat Ax eller Top samlede] Smaaax, omgivne af [oftest] 2 Yderavner [glumæ], hver Blomst af 1-2 Inderavner [paleæ], af hvilke den nedre ofte har Stak, den øvre sædvanligt lindeagtig, tonervet, i Spidsen totandet*). Frugten en Grcesfmigt.) (13-58. N. F. Graminere.)

A. Blomsterstanden et sammensat Ax. ${ }^{\star \star}$ )

a. Eet Smaaxi hvert af Axens Led.

aa. Eet Ar, som udtrader $i$ Blomstens Spidse.

13. Narilus L. Axet ensidigt; Smaaxene enblomstrede, omgivne af en meget liden, totandet (eller ingen) Yderavne; Inderavnerne 2, uligelange; Arret forlænget.

bb. To Ar, som udtrade ved Grunden af Blomsten.

$\alpha$. Smaaaxene enblomstrede, indsænkte i Fordybninger af Axen.

14. Lepturus R. Br. Smaaaxene omgivne af $1-2$ læderagtige Yderavner; Inderavnerne hindeagtige; Griflerne korte, Arrene fjerede.

$\beta$. Smaaaxene fleerblomstrede, fritsiddende.

15. Lólium L. Smaaxene fladtrykte, vende Ryggen (den smale Side) mod Axen, 3-mangeblomstrede; 1 Yder-

*) Naar i det Folgende Inderavnerne nævnes uden særskilt Angivelse af hvilken der menes, er dette sædvanligt den nedre.

**) Et ægte Ax er lettest kjendeligt paa den regelmæssigt leddede Axe, i hris Led 1 eller flere Smaax ere befrestede. 
avne (undtagen i Endesmaaxet, som har 2 Yderarner); Frugten tilvoxet til den orre Inderavne.

16. Brachypólium Beauv. Smaaxene mangeblomstrede, kortstilkede, for Blomstringen næsten trinde, vende Fladen mod Axen; 2 nligestore Yderavner; Frugten ikke tilvoxet til Inderavnerne.

17. Agropýrunı Beauv. Smaaaxene 3-mangeblomstrede, fladtrykte, vende Fladen mod Axen; Yderavnerne 2, lancet. formede, omtrent ligestore, 5-mangenervede; Frugten tilvoxet til Inderavnerne.

† 18. Triticum L. (part.) Smaaaxene hvælvede, $3-5^{-}$ blomstrede (de ovre Blomster ofte $\stackrel{\star}{\sigma}$ eller golde), vende Fladen mod Axen; Yderavnerne 2, ægformede, bugformigt hvælvede, fleernervede; Frugten fri eller tilvoxet til Inderavnerne.

† 19. Secale L. Smaaxene toblomstrede med Ansats til en tredie Blomst foroven, vende Fladen mod Axen; Yderavnerne 2, sylformede, 1-nervede; Frugten fri.

b. Flere Smaar i hvert af Axens Led.

20. Ilirdium L. Smaaxene (3 i hvert Led) enblounstrede med eller uden Ansats til en anden Blomst; Yderavnerne tilspidsede $\mathrm{i}$ en lang Stak.

21. Élymus L. Smaaaxene $(2-3$ i livert Led) 3 -fleerblomstrede (eller toblomstrede med Ansats til en tredie Blomst); Yderavnerne sylspidsede.

B. Blomsterstanden en Dusk*) eller Top.

a. Smaaxene enblomstrede eller med Ansats til en anden Blomst.

aa. Yderarner 0 .

22. Léersia Soland. Inderavnerne 2, pergamentagtige, fladtrykt-kjolformede.

*) Naar Blomsterstanden er en Dusk, ere Blomsterne ofte saa kortstilkede, at de synes at danne et Ax, men kjendes da par den ikke regelmassigt leddere Axe. 


\section{bb. 1-2 Yderavner.}

«. Blomsten under Blomstringen lukket, Griflerne forlængede, Arreno udtræde i Blomstens Top.

«↔. Ved Grunden af den frugtborende 1 gold Blonst (dannet af 1-2 Inderavner).

23. Setária Beaurv. Smaaaxene med et borsteformet Svøb ved Grunden, samlede til en alsidig Dusk; Yderavnerne uligestore: den nedre liden, dein øvre af Smaaaxets Længde, stakløs, 5-7-nervet; den golde Blomst (stundom ठ) dannet af 1--2 stakløse Inderavner, der ere ligelange med Smaaaxet.

24. Digitíria Scop. Smaanene uden Svøb, samlede til en fingerformet Halvskjærm, dannet af ensidige Ax; Yderavnerne uligestore: den nedre liden eller 0 , den øvre trenervet, stakløs, kortere end Smaaaxet; den golde Blomst dannet af 1 stakløs Inderavne af Smaaaxets Længde.

† 25. Pánícum L. (part.) Smaaaxene uden Svøb, samlede til en alsidig Top med forlængede Grene; Yderavnerne tilspidsede $\mathbf{i}$ en kort Braad, uligestore: den nedre kortere end Smaaxet, femnervet, den øvre af Smaarxets Længde, 9-11. nervet; den golde Blomst danmet af 2 Inderavner, af hilke den nedre er tilspidset, omtrent ligelang med den øvre Yderavne.

26. Echinóchloa Beauv. Smaaaxene uden Svøb, samlede til en Top, dannet af ensidige Ax; Yderavnerne uligestore: den nedre kortere end Smaaaxet, den gvre af Smaaaxets Længde, femnervet, endende i en Stak eller Braad; den golde Blomst dannet af 2 Inderavner, af hvilke den nedre er ligelang med Smaaaxet, stakbxrende.

$\beta \beta$. Blomsten paa hver Side omgivet af et hindeagtigt Slijol (०: 2 ufuldkonne, golde Blomster).

27. Digráphis Trinius. Smaaaxene paa begge Sider hvælvede; Yderavnerne omtrent ligestore, paa Ryggen kjolformede, uvingede; de golde Blomster skjæghaarede, lsortere end den frugtb.; Inderavnerne 2 , læderagtige, kortere end Yderavnerne. (Blomsterstanden en sammentrængt Top.) 
† 28. Philaris L. Smaaxene udadtil hvælvede, indadtil hule, Yderavnerne omtr. ligestore, paa Ryggen vingede; de golde Blomster ikke skjæggede, kortere end den frugtb.; Inderavnerne som foreg. (Blomsterstanden et rundagtigt Hoved.)

29. Inthoxinthum L. Yderavnerne uligestore: den nedre kortere, den øvre læugere end Blomsterne, paa Ryggen uvingede; de golde Blomster stakbxrende, haarede, læugere end den frugtb.; Inderavnerne 2, stakløse, hindeagtige; 2 Støvdragere. (Blomsterstanden en aflang Dusk.)

$\gamma \gamma$. Ingen golde Blomster ved Grunden af de frugtbcerende. (Blomsterstanden en valseformet Dusk).

30. Alopeciris L. 2 nedentil sammenvoxne, omtrent ligestore Yderavner uden Stak; 1 Inderavne med en nedenfor Midten befiestet Stak.

31. Phleum L. 2 frie, omtrent ligestore, i en Stak eller Braad tilspidsede Yderavner; 2 Inderavner uden Stak.

$\boldsymbol{\beta}$. Blomsten under Blomstringen aaben, Griflerne korte, Arrene ndtræde ved Girunden af Blomsten.

«a. Inderavnerne ved Grunden omgione af' lange Haar.

32. Psamma Beanv. Blomsterstanden sammenkueben, duskformet; Yderavnerne længere end de læderagtige, kort stakbærende Inderavner, den nedre Y'deravne mindre, ennervet, den øvre større, trenervet (eller indbyrdes ligelange).

33. Calamagróstis Adans. Blomsterne i en Top; Yderavnerne længere end de hindeagtige, med en korterc eller læugere Stak forsynede Inderavner; den nedre Yderavne længere end den øvre.

Phragmites communis $\beta$, repens. (Nr. 47).

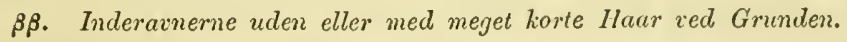

34. Igróstis L. Yderavnerne kjolformigt sammentrykte, længere end Blomsten og indibyrdes lidt uligelange; Inderavnerne $(1-2)$ hindeagtige. (Blomsterstanden en 'Top.) 
35. Milium L. Yderavnerne bugformigt hrælvede, indbyrdes ligelange og af Længde med Blomsten; Inderavnerne tilsidst læderagtige. (Blomsterstanden en Top.)

Helica uniflora. (Nr. 36).

Catabrosa aquatica $\beta$, subtilis. (Nr. 50).

b. Smaaxene med 2 eller flere fuldt udviklede Blomster.

aa. Yderavnerne (idetmindste den ene) langere ond eller ligelange med Smaaaxet.

ж. Nogle af Blomsterne sarkjønnede eller golde

36. Mlélica L. Smaarene 2-fleerblomstrede, de nedre (1-2) Blomster tvekjønnede, den øvre gold, alle stakløse; Yderavnerne hvælvede, omtrent af Blomsternes Lingde; Arrene udtræde ved Grunden af Blomsten.

37. llipríchloa Gmelin. Smaaxene treblomstrede, de 2 nedre Blomster $\hat{\sigma}$ trehannede, den øvre $\not{q}$ tohannet, alle stakløse (eller med en kort Stak); Yderavnerne kjølformigt sammentrykte, omtrent af Blomsternes Læængde; Arrene udtræde i Spidsen af Blomsten.

38. Holcus L. Smaaaxene toblomstrede, den nedre Blomst $\not{q}$ stakløs, den øvre $\widehat{o}$ med en Stak fra Ryggen; Yderavnerne kjølformigt sammentrykte, længere end Blomsterne; Arrene udtræde ved Grunden af Blomsten.

Avena elatior. (Nr. 46).

Setaria glauca. (Nr. 23).

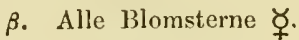

39. Huminia Fr. Yderavnerne bugformigt hvælvede, den nedre 3-, den øvre 5-nervet; Inderavnerne ved Grunden omgivne af Haar, den nedre 5-nervet, i Spidsen trefliget, stakløs; Frugtknuden i Spidsen haaret.

40. Triódia R. Br. Yderavnerne bugformigt hvalvede, begge ved Grunden 5-nervede; den nedre Inderavne læderagtig, 7-nervet, ved Grunden og i Randen haret, i Spidsen tretandet, 
(eller totandet med en kort Braad i Indskjaeringen); Frugtknuden glat.

41. Kopléria Pers. Yderavnerne kjølformigt sammentrykte, den nedre 1-, den øvre 3-ncrvet; den nedre Inderavne udeelt, stakløs eller med en kort Braad fra Spidsen; Frugtknuden glat, fri. (Blomsterne i Dusk.)

42. Aira I. (part.) Yderavnerne kjolformigt sammentrykte; Inderavnerne ined Haar ved Grunden, den nedre i Spidsen udrandet eller gnavet, med en Stak udgaaende fra Ryggen eller Grunden; Frugtknuden glat, fri, uden Laugdefure. (Blomsterstanden en Top.)

43. Corynéphorus Beauv. Yderavnerne kjølformigt sammentrykte; Inderavnerne med Haar ved Grunden, den nedre udeelt, spids, med en Stak udgaaende fra Grunden; Stakken paa Midten leddet og ved Leddet baaret, dens øvre Ledstykke opadtil kølleformet; Frugtknuden glat, med en Langdefure paa den indre Side.

44. Airópsis Desv. (Fr. mant. 3). Yderavnerne kjølformede; den nedre Inderavne trind, ntydeligt 3-5-nervet, i Spidsen tokløvet med en knæbgiet Stak fra Ryggen; Frugten glat, tilvoxet til Inderavnen.

45. Trisétum Pers. (Fr. mant. 3). Yderavnerne kjølformede; den nedre Inderavne bindeagtig, i Spidsen tobørstet, $\mathbf{3}-\mathbf{5}-$ nervet med en kjølformet Midtnerve og en knoboiet Stak fra Ryggen; Frugten glat (eller i Spidsen skjægget), fri, nden Læengdefure.

46. Aréna L. (part.) Yderavnerne bugformede; den nedre Inderavne ved Grunden læderagtig, 5-11-nervet, paa Ryggen trind med tokløvet eller tandet Spidse og en knabøiet eller snoet Stak fra Ryggen; Frugten i Spidsen eller overalt baaret, fri, med en Længdefure paa den indre Side.

Holcus L. (n. 38). 
bb. Yderavnerne kortere end Smaaaxet (af Langde med eller lortere end den nedre Blomsts Inderavner).

$\boldsymbol{\alpha}$. En af Blomsterne i Smaaaxet of eller gold.

47. Phragmites Trin. Blomsterne 2-7, ved Grunden omgivne af lange Haar (den nedre, $\hat{\sigma}$ eller golde Blomst undtageu); Yderavnerne uligelange (den øvre størst); den nedre Inderavne sylspidset, trenervet, dan øvre meget kortere.

48. Enódium Gaudin. Smaaaxene ægformet-aflange, 2-3blomstrede; Blomsterne uden Haar ved Grunden, den ørre gold; Yderavnerne uligelange (den øvre størst); den nedre Inderavne spids, æg-laneetformet, femnervet, stakløs. (Straaet har kun eet enkelt Led ved Grunden).

Melica nutans (den ovre Blomst gold, Nr. 36).

$\beta$ Alle Blomsterne fuldt udviklede.

ac. Den nedre Inderavne stakiløs, med parallele, $i$ Spidsen ilike sammenlobende Nerver,

* bugformigt bralret.

49. Briza I. Smaaaxene for Blomstringen bredt-ægformede, efter samme hjerteformede, 6-10-blomstrede, Blomsterne toradet-taglagte; Yderavnerne ligelange; Inderavnerne i Spidsen afrundede, den nedre ved Grunden hjerteformet-øret, svagt 7-9-nervet.

50. Catabrósa Beauv. (Fr. mant. 3). Smaaaxene ægformede, 1-3-blomstrede; Yderavnerne uligelange (den øvre størst); den nedre Inderavne tværhugget, budt, i Spidsen gnavet, trenervet.

51. Glycéria R. Br. (Fr. mant. 2, 3). Smaaaxene linieformede eller aflange, 4-12-blomstrede; Yderavnerne uligelange (den øvre størst); den nedre Inderavue 5-7-nervet, i Spidsen hindeagtig.

* Den nedre laderarne hjollormigt sammentrght.

52. Poa I. Smaaxene rgformede eller elliptiske, fladtrykte, 2-8-blomstrede; Blomsterne tat taglagte, ved Grunden frie eller løst sammenhængende formedelst en tiin, kruset Uld. 


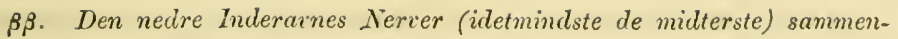
lobende $i$ Spidsen, Midtnerven (som oftest) $i$ eller nedenfor Spidsen udlobende $i$ en Stak.

- Smaanseac uden Hylster red firusden.

+ Inderavnerne bugformigt-hurclvede.

53. Festúca L. (part.) Yderavnerne uligelange (den nedre ennervet, over lialvt saa lang som den $3-5$-nervede ovre) eller næsten ligelange; den nedre Inderavne 3-5-nervet, staklos eller med Midtnerven udløbende i en Stak fra Spidsen, den øvre fiut-randhaaret; Griflerne befæstede i Spidsen af Frugtknuden. (Bladskeden heelt kløvet.)

54. Vúlpia Gmel. Yderavnerne uligelange: deu nedre meget kort (ikke halvt saa lang som den øvre) eller 0 ; den nedre Inderavue femnervet, med en lang Stak befrestet i Spidsen, den ovre fint-randhaaret; Griflerne befastede i Spidsen af Frugtknuden (Blomsterstanden sammentrængt; Bladskederne heelt kløvede; Smaagrenene imod Grunden af Smaarene kølleformede; Støvdragerne ofte 1.)

55. Bromus L. (part.) Yderavnerne uligelange: den nedre 3-5.nervet, over halvt saa lang som den ovre $5-\infty$ nervede); den nedre Inderavne 5-7-nervet, med en Stak befæstet nedenfor den tokløvede Spidse, den øvre i Randen kamformigt-børstchaaret; Griflerne befæestede paa Siden (ovenfor Midten) af den harede Frugtknude. (Bladskederne neppe i deres halve L,ængde kløvede.)

† Inderatnerne sammentrykte, med kjölformet Midtmerre.

56. Schelonórus lieauv. (Fr. bot. not. 1843). Yderavnerne ligesidede, uligelange: den nedre emnervet, over halvt saa lang som den øvre, trenervede; den nedre Inderavne femnervet, med en Stak i eller lidet nedenfor Spilsen; Griflerne befæstede paa Siden (ovenfor Midten) af den haarede Frugtkuude; Bladskederne neppe $\mathrm{i}$ deres halve Langde klovede.

57. Dáctylis I. Yderavnerne uligresidede, den ene (bredere) Side hvalvet, den auden flad eller indtrykt, uligelange: den nedre kortere, ennervet, den ovre trenervet; den nedre 
Inderavne femnervet med stivt-randhaaret Kjøl og en kort Stak lidet nedenfor Spidsen; Griflerne endestillede, Frugtknuden glat. (Bladskederne kløvede i næsten hele deres Længde; Smaaaxene sammenhobede til eensidige Nøgler.)

** Sanaasene red Graaden omgirae af el kamfornigt-figel Ifglster (et uudriklet Soraar).

58. Cynosírus L. Blomsterstanden en Dusk, dannet af toradet stillede, ensidigt vendte Nøgler; Smaaaxene 2-5.blomstrede.

\section{Orden. Trigyinia (Trehunnede).}

59. Holósteum L. Bæger og Krone fembladede; Kronbladene i Spidsen tandede; Frugten en med 6 Tænder opspringende, mangefrøet Kapsel. Frøene skjoldformede (Støvdragerne undertiden 4 eller 5). (Enaarig Urt med modsatte: Blade. N. F. Alsinaceæ.)

Montia L. $(3,1)$.

Stellaria media. $(10,3)$.

\section{I o nogynia.}

\section{Valeriana. Baldrian.}

a. Stængelen firekantet med stribede Sider.

Blomsterne trebo.

36. V. dioeca L. (Tvebo-B.) H. 42 ; Drej. n. 31 ; F. D. 687 ; Rehb. ic. fl. germ. XII, 1428.

Bladene paa Rodstokken og de overjordiske Vandgrene heelrandede, ægformet-ovale; Stcengelbladene lyreformet-snitdeelte med linieformet-ovale, budte, næsten heelrandede Afsnit.

$1 / 2-1^{\prime}$ høi. of Planten lavere og spædere end $q$, men med større, kjødfarvede, sjeldnere hvide Kroner og mere udspredt Qvast; \& Kr. smaae, hvide. 5. (6-7. fr.) 4 .

I fugtige Enge, hyppig paa Oerne; i Halveens sydlige Deel. bemærket paa flere Steder, mod N. sjeldnere eller maaskee aldeles forsvindende (mangler f. Ex. i Egnen ved Randers (7) og Haraldslund!): 
b. Stængelen furet. Blomsterne $\Varangle$.

37. V. sambucifolia Mikan [Pohl. fl. boëm. I, 41] Hyldbladet B.) Rehb. ic. fl. germ. XII, 1431; Fr. mant. 3, p. 1; H. N. XI, 16.

Alle Bladene fjersnitdeelte, ned 3-5 Par lancetformede eller elliptiske, grovt og fjernt-tandede Afsuit; Rodstokken skyder over- eller underjordiske Udløbere.

Qvasten efter Afblomstringen meget udspredt med fjerntsiddende Blomster. Skalfrugterne omtrent dobbelt saa store som hos folg.; Kr. hvid eller kjødfarvet. Blomstringstid hos os mindst 8-14 Dage tidligere end følg. 6-7.

Anm. Synes at vare en naturlig og vel adskilt Art, om der end kunde gnskes mere bestemte Charaeterer for at begrunde Adskillelsen. Dyrket i meget tor Jord, liar den i 6 Aar vedligeholdt sine Udløbere og sæeregne Habitus (12). De til hver Art hyrende Afrendringsformer maa narmere iagttages.

Ved Randen af Brkke og Grofter og paa andre sumpige Steder isar $\mathbf{i}$ Skove, almindeligt udbredt over hele Landet.

38. V. officiualis L. (I æage-B.) H. 43 ; Drej. n. 32 (undt. Voxest.) F. D. 570! Rehb. ic. fl. germ. XII, 1432.

Alle Bladene fjersnitdeelte, med 6-9 Par lancetformede, heelrandede eller tandet-saıgtakkede Afsnit; Rodstokken med eller aden underjordiske Udløbere.

Qvasten med talrige og mere tretsiddende Blomster, Kr. blegrod, kjødfarvet eller hvid, Roden stwrktlugtende (som hos den foreg.) 7. 2.

$\beta$, angustifolia (V. angustifolia Tausch, Rehb. fl. germ. XII, 1433); H. N. XI, 15; V. off. $\not \beta$, minor Koch Syn. II, 369.) Bladafsnittene linie-lancetformede, næsten alle beelrandede.

Anm. Denne Form forekommer hyppigt med Udlobere, hvis Mangel eller Næerværelse fortrinsviis turie rette sig efter Voxestedet. Var. desuden i Henseende til Bekliedningen, Stængclens Hoide o.s. v. (Adskillelsen mellem $\boldsymbol{\alpha}$, major og $\boldsymbol{\beta}$, minor, saaledes som den er fremstillet hos Koch, forekounmer mig ikke begrundet i Naturen, da Staengelens Hoide og Bladenes Indskjaring neppe staae i Afhæungighedsforhold til hinanden).

I Grofter, paa Enge, mellem Krat, ikke sjelden, inen mindre hyppig end foreg., meest udmerket og i stor Mangde har jeg fundet den par Kalkgrund (Møens Klint! Mlindelille!) 


\section{Valerianella. Krop.}

39. Y. olitoria [Poll. palat. 1, p. 30]. (Tandfri K.) Rehb. ic. f. germ. XII, 1398; H. N. XIIr, 33; Fedia Vahl, H. 44; Drej. n. 33 ; F. D. 1681 ; Valeriana Locusta $\alpha$ olitoria L.

Stcengelen kantet-furet, paa Kanterne svaghaaret af nedadvendte Haar; Sttengelbladene lancetformede, i Spidsen og ved Grunden afrundede; Deekbladene udstaaende, omvendt ægformetlaneetformede, budte, randhaaret-rue; Skalfrugten oftest glat, ægformet-rundagtig, fladtrykt fra Siderne, trerummet, de 2 tomme Rum større end det frøbærende, adskilte ved en ufuldstændig Skillevæg; den oversædige Bagerkrave utydeligt 2-3tandet.

Plantens Farve blaagrøn, Rodbladene omvendt-ægformede, de ovre Stængelblade ved Grunden ofte svagt-tandede. $\mathrm{Kr}$. blegblaa, næsten hvid. Froggjemmet paa Ryggen af det frobærende Rum tykt, svampagtigt. 5. (6 fr.) $\odot$.

$\beta$, lasiocarpa Rehb. ic. erit. I, tab. 60 . Skalfrugten duunhaaret.

Paa Diger og dyrkede, især tørre, Marker ikke sjelden, og bemærket $\mathrm{i}$ alle danske Provindser, men paa Halvoen mindre hyppig. $\boldsymbol{\beta}$, paa lignende Steder, men mindre hyppig end Hovedarten, f. Ex. $\boldsymbol{S} \boldsymbol{j}$. Sorø! J. Hjarbæk ved Viborg (Feddersen)! Bor $n \boldsymbol{h}$. (20)!

40. V. Morisonii [(DC.) Koch Syn. 1, p. 446]. (Tandbægret K.) V. dentata Poll. l. c. (part.), Lge. Haandb. 2 Udg. p. 29, Rehb. fl. germ. XII, 1402; Fedia dentata Wallr., H. 44; Drej. n. 34 ; H. N. IV, 8; Valeriana olitoria F. D. 738.

Stongelen (især under Leddene) ru; Stangelbladene linielancetformede; Dcekbladene tiltrykte, linie-lancetformede, spidse, randhaarede; Slialfrugten ægformet-kegleformet, fladtrykt fra Ryggen, enrummet med Spor til 2 tomme liun i Form af linieformede Striber, indsluttende et xgformet Mellemrum; det oversædige Bager omtrent $1 / 1$ af Skalfrugtens Langde, skraat afskaaret, faatandet, med uligestore, nerveløse Tænder.

Rodbladene spadeformede, Kr. blegrød eller hvid. 6-7. $\odot$.

$\alpha$, lejocarpa Koch; Rchb. 1. e. f. 1402. Frugten glat.

$\beta$, dasycarpa Rehb. 1. c. f. 1403. Frugten beklædt af ndstaaende, i Spidsen indbøsiede Haar. 
Paa dyrkede Marker som Ukrud i Vintersaden, især paa de sydlige Aer: Bornholm, Møen, Falster, Lolland og Langeland; i det sydlige Fyen alın. (12), Odense (19); $\mathbf{S}$. v. Hovdingsmaard og Prasto (Dr.)! Stubberup og Sipperup v. Skjelskør (Nielsen), mellem Stillinge og Kjeldstrup; $\boldsymbol{S} l$. Dyttebol ved Gelting (Lund). I de nordligere Egne ikke bemrerket.

Anm. Navnet $V$. dentata, som af flere Forff. tillægges denne Art, er mindre heldigt, da efter Amanuensis Krolis Undersogelser Linnés Valeriana Locusta $\delta$, dentata betegner $V$. Auricula DC.

$\dagger$ V. eriocarpa (Desv. journ. bot. 2 p. 314 t. 11, f. 2.) Fedia Rehb. ic. crit. I, f. 132. Det oversædige Bæger ountrent Jigelangt med Skalfrugten, 5-6-tandet med skraat afskaarne, uligestore, nætformigt-nervede Tænder, de tomme Rum indslutte et ovalt Hellemrum, forøvigt som foreg.

Forvildet i Rosendals Have paa Østerbro, og tidligere paa Pladsen ved Thorvaldsens Museum!

\section{Montia. Vandarve.}

41. H. rivularis [Gmel. Fl. bad. I, p. 302] (Stor V.) Koch Syn. II, 445; H. N. XIV, 58; M. fontana major F. D. 1926 ; M. lamprosperma Chamisso (Linnæa VI, p. 564 t. 7.).

Stcengelen langstrakt (2-8" høi), flydende; Bladene omvendt-ægformede; Blomsterne i faablomstrede Qvaster fra Hjørnerne af de modsatte Blade; Blomsterstilkene efter Afblomstringen nikkende; Frøene med fint punkteret, glindsende skal.

Bladene af en frisk grøn Farve, saftrige, Kr. livide, kun aabne i Solskin. 7-8. 4 .

I Kildevield og Bække, almindelig paa Halveen, synes at væere mindre hyppig paa Øerue: $\boldsymbol{S} \boldsymbol{j}$. Strandmollen $(15)$, Nymølle! $\boldsymbol{F}$. Kirkeby; Thur乡 (12); Bornh. v. Sandvig! Snogebæk (Balagoe).

42. H. minor [Gmel. l. e. p. 301] (Liden V.) Koch syn. II, 445; M. fontana L., Cham. (1. c.); F. D. 131 (?)

Stangelen (1/2-2" hoi) opret eller opstigende; Bladene elliptiske eller oinvendt-ægformede; Blomsterne i fleerblomstret, endestillet Qvast eller paa enblomstrede, efter Afblomstringen nikkende Blomsterstilke fra Hjørnerne af de modsatte Blade; Froenes Skal grovt punkteret, glandsløs.

Bladene mere guulgronne, mindre saftige. $\mathrm{Kr}$. som foreg. 5-6 og 9. $\odot$.

Ved Bredderne af stillestaaende Vand; paa fugtig, af og til oversvommet, især sandig Grund: i Sjall. og pai B ornh. ikke sjelden,

Hasndb. $\mathbf{i}$ den danske Flora. 
og, som det synes, ogsaa udbredt over de andre danske Øer (jeg har seet Expl. fra Møen, Falster, Lolland, Fyen); paa Halvøen er den sjeldnere: $\boldsymbol{J}$. Dronninglund i Vendsyssel (12), Harboøre (Andresen), Agger, Lemvig! Hansted Mose (2), Hjortlund ved Ribe (12); $S l$. Rosendal, Østerhısum (F. Müll.).

\section{Crocus. Safran.}

43. C. vernus L. (Vaar-S.) H. II, 112; F. D. 2042 ; Rchb. ic. fl. germ. IX, tab. 355 .

Hovedaxen en fladtrykt-kugleformet Knol, beklædt med brune, trævlede Hinder (det foreg. Aars henvisnede Bladskeder); Bladene smalt-linieformede, mørkgrønne med hvid Midtnerve og tilbagerullet Rand, ved Grunden omgivne af $4-5$ hvide Bladskeder uden Plade, Blomsterstilken af et enbladet Hylster.

$1 / 2^{\prime}$ høi. Blomsterne blaae, aabne sig kun i Solskin. Frugtknuden under Blomstringen skjult langt nede i Hylsteret. 3-4. 4.

Paa Enge, meget sjelden og lidtil kun funden i Slesvig: Hammelmark NO. for Egernforde $(\mathrm{N})$, Nyværk ved Slesvig, Slotsengen ved Husum (16).

\section{Iris. Svardlilie.}

44. 1. Pseudacorus L. (Guul S.) H. 45 ; Drej. n. 35 ; F. D. 494 ; Rehb. ic. fl. germ. IX, tab. 344.

Bladene sværdformede, af Stængelens Længde; Dækbladene af Længde med eller længere end Blomsterne; Blomsterdakkets ydre Flige store, elliptiske, gule med brune Striber ved Basis, de indre lancetformede med bredere, foldet Basis, mindre end Arrets Flige; Kapselen trekantet.

2-3' høi. Blomsterne gule. 6-7. 4.

I Kjær, ved Aa- og Søbredder, almindeligt udbredt i Danmark.

45. I. spuria L. (Blaa S.) H. 46 ; Drej. n. 36 ; F. D. 734 ; Rehb. I. c. IX, tab. 345 ; H. N. XII, 70.

Bladene sværdformede, kortere end Stæugelen; Dakbladene kortere end Blomsterne; Blomsterdckkets ydre Flige med agformet, blaa Plade og smalere, rødstribet, Negl, de indre omvenut-ægformede, lila, længere eud Arrets Flige; Kapselen sexkantet.

1-2' høi. Blomsterne blase. 6. 4. 
Ved Strandbredder af Øer i. Oresundet og Østersøen: hyppig ved Nordkysten af Saltholm (!), i Nakskov Fjord paa Oerne Steensø! Stubbeland (19) og Dueholm (9), Iholm mellem Fyen og Thorseng (Bredsdorff 1778, nu forsvunden, 12). 网

Anm. I. germanica L., som af Kylling angives fra Lolland, er ikke funden der senere, og hvis Citatet forøvrigt er rigtigt, maa den vel antages at have varet forvildet fra Haver, eller ialtfald forlengst ophort at vaere vildvoxeude i vor Flora. Fries (Bot. not. 1845 p. 123) antager forøvrigt, at de ældre Angivelser om denne sigte til I. squalens.

\section{f. Cyperus. Fladax.}

46. C. fuscus L. (Bruunt F.) H. 50; Drej. n. 38; F. D. 179 ; And. Cyp. Scand. t. I, f. 2 ; Rehb. ic. fl. g. VIII, tab. 280 ; H. N. XII, 79.

Stangelen skarpt-trekantet, med hule Sider; Smaaaxene fladtrykte, linieformede, med taglagte, tilsidst udspærrede Dxkskjæ]; 3 Ar; Frugten elliptisk, skarpt trekantet.

Smaaxene samlede til 1 eller (hos kraftigere Expl.) flere, $\mathrm{i}$ en halvskjærmformet Qvast stillede Hoveder i Enden af Stængelen, omgivne af oftest 3 Svobblade, der ere længere end Blomsterstanden; Dækskjællene sortbrune, med grøn, i en kort Spids ndløbende Midtnerve. 7-8. $\odot$. (Synes ikke i ethvert Aar at liomme til Udvikling.)

I ndtørrede Søer og paa fugtige, af og til oversvømmede Steder, ikke almindelig: $S j$. Hellebæk (12), Skjæremollen ved Fredensborg (Dr.), Frederiksborg, Lyngby, Frue Skov ved Bagsvard, Fortunen (H), Ermelund (26), mellem Cluristiansholm og Bellevue (Dr.); F alst. Horbelov (Koch); Loll. ved Steensgaard (19), Thorseng i en Skov mellem Lundby og Thaersminde!

47. C. flavescens L. (Guult F.) H. 50; F. D. 1682 ; And. 1. c. I, 1; Rehb. VIII, tab. 278.

Stungelen budt-trekantet, Smaaaxene linie-lancetformede, Aladtrykte, med taglagte, tiltrykte, budte Dækskjæl; $2 A r^{*}$; Frugten rundagtig, fladtrykt.

Blomsterstand og Svøbblade som hos foregaaende. Darksjallene guulbrune med gron Midtnerve. 7-8. $\odot$ (4? I Frankerig har jeg fundet Expl. med i Spidsen knolleformigt fortykkede Udlobere. Maa nærmere undersøges).

Paa fugtige Steder. Efter $H$. funden i Slesvig af Lelimamn. 网

\section{Schoenus. Skjane.}

48. S. ferrugincus L. (Rustfarvet S.) H. 47 ; Drej. n. 37 ; F. D. 1503; And. I, 3; H. N. I, 72 ; Chrtospora Rehb. VIII, tab. 285. 
Stanglerne tueformigt samlede, mange Gange længere end Bladene; Smaaaxene 2-4, samlede i et elliptisk, endestillet Hoved; det ydre Svobblad opret, lidet længere end Hovedet; Dokskjallene glatte; Blomsterdakket dannet af 3-5 Børster.

${ }^{1 / 2} \mathbf{2}^{\prime}$ ' høi. Dækskjællene og Bladskederne glindsende og sortagtigt kastaniebrune. 6. भ.

I Tørrmoser, sjelden i Danmark: $\boldsymbol{S}$. Bidstrupgaards Mose (!) og Svogerslev Mose (20) ved Roeskilde; Me en i Enggrofterne ved Grønsund (11); J. Bjørnsholm, Vissegaards Mose ved Aalborg (23), Moser $\emptyset$. for S. Tranders (12). F

49. S. nigricans L. (Sortagtig S.) H. 47; F. D. 2281; And. I, 4; Rehb. VIII, tab. $286 ;$ H. N. IV, 89.

Stconglerne og Rodbladene tueformigt samlede; Bladene omtrent halvt saa lange som Stænglerne; Smaaaxiene 5-8, samlede $\mathbf{i}$ et rundagtigt, endestillet Hoved; det ydre Svobblad skraat opstigende, meget længere end Hovedet; Doekskjollenes Rygnerve ru; Borster 0 (eller 6).

${ }^{\circ} 1-1{ }^{1} / 2^{\circ}$ høi. Dækskjællene og Bladskederne glindsende sortbrune. 6. 4 .

I Tørvmoser, meget sjelden og kun bemærket paa Halvøen: J. Gravens Mose i V. Hanherred (Dr.), Fjerritslev i V. Hauherred, Østerild! Jensby og Hillerslev Moser i Thy (Dr.), Vildsted pr. Løgstør (8)!

\section{Rhyncospora. Nabfre.}

50. R. fusca [Roem. \& Schult. Syst. II, 88]. (Bruun N.) And. I, 7; Rehb. VIII, 285; H. N. XIV, 80; Schoenus L., H. 49 ; F. D. 1562.

Rodstokken krybende; den blomsterbærende Stangel opret, med (i Spidsen af Stængelen og fra de øvre Bladhjørner) Smaaxene sammenhobede til elliptiske, axformede Nøgler, der ere meget kortere end det ydre Svøbblad; Blomsterdakkets Børster 3, dobbelt saa lange som Frugten; Støvdragere 3; Arrene 2, længere end Griffelen.

$1 / 4-1 / 2^{4}$ høi. Bladene guulgrønne, Dækskjællene brune. 7-8. 4.

I Torrmoser paa Hedegrund, kun funden paa Halvoen: J. Vildsted red Løgstør (8)! Viborg (H.), Stokbolm Mose V. for Skive (16); $S l$. Oxager i Angel (28); i Vesteregnene almindelig (H.)! 
51. R. alba [Vahl Eusm. II, 236] (Hvid N.) Drej. u. 39 ; And. I, 6 ; Rehb. VIII, 285; Schoenus L., H. 49; F. D. 320 ; L. Herb. IV, 71.

Stconglerne tueformigt samlede, opstigende, med (i Spidsen af Stængelen og fra de øvre Bladhjørner) Smaaaxene sammenhobede til rundagtige, halvskjærmformede Nøgler, omtrent af det ydre Svøbblads Længde; Blomsterdakkets Børster omtrent 10, af Længde med Frugten; Stovdragere 2; Arrene 2, kortere end Griffelen.

$1 / 2-1^{\prime}$ høi. Bladene mere blaagrønne, Drekskjæellene lividgule, imod Frugtmodningen blegbrune. 6-8. \%.

I Kjær og Hedemoser, især i Hængedynd: paa Halve en alm. især $\mathrm{i}$ den midterste og vestlige Deel; sjeldnere paa Øerne: $\boldsymbol{F}$. Langensø (13), Rødskebølle (12); Loll. Karleby verl Nysted (19); Falst. i Horreby Lyng! $\boldsymbol{S} \boldsymbol{j}$. Holmegaardsmosen, Tepri og Lyngby Mose $\left(\mathrm{H}_{.}\right)$ Erlandscus Molle ved Hillerød (7), Helsingør (H.), Bornh. i Høilyngen $(8)$.

\section{Eleocharis. Sumpstraa.}

a. Frugten jævn.

52. E. palustris [R. Br. prodr. fl. nov. holl. I, 80.] (Almindeligt S.) Drej. n. 43 ; Scirpus L., H. 51; F. D. 273 ; And. II, 22; Rchb. VIII, 297; H. N. II, 68; L. Herb. VII, 137.

Rodstokken krybende; Stcengelen trind, noget fladtrykt, med to lige afskaarne, bladløse Skeder ved Basis; Axet linielancetformet eller ovalt; Dakskjallene næsten spidse, de 2 nedre (blomsterløse) budte, omfattende hver Halvdelen af Axet; 2 Ar; Frugten omvendt-ægformet, noget fladtrykt med afrundet Rand.

Var. efter Voxestedet i Hoide $\left(1 / 3-1^{\prime}\right)$, Axets Form o.s. v. 6-8. 4 .

Almindelig paa fugtige Enge, i Moser, ved Søbredder og i selve Vandet (alm. den storre Form).

53. E. uniglumis [Link i Jahrb. d. Gew. K. I, 3, 77] (Enskjællet S.) Scirpus Fr. mant. 2, 45; Rchb. VIII, 296; And. II, 23 ; H. N. II, 69 ; S. palustris $\beta$, minor H. 51 ; S. acicularis F. D. 167 (?)

Stangelen trind; Axet xg-lancetformet; det nedre (blomsterløse) Dakishijol rundagtig-xgformet, heelt ornfattende Axet, (forøvrigt som foreg.) 
Ansees af Mange for en Form af foreg., fra hvilken den, foruden de angivne Kjendetegn, er forskjellig ved mere glindsende, morkrødbrune Bladskeder og finere Stængler. 6-8. 4.

Paa Enge og andre fugtige Steder, især ved Strandkanterne, forekommer $\mathrm{i}$ alle Provindser, men ikke saa hyppig som foreg.

54. E. multicaulis [Smith fl. britt. I, 48. Scirpus] (Mangestænglet S.) H. II, 113; F. D. 1923; Rehb. VIII, 296; And. II, 24 ; Fr. mant. I, 3; H. N. II, 67.

Stcenglerne tueformigt-samlede, trinde, med to bladløse, skraat afskaarne Skeder ved Grunden; Axet æg-lancetformet eller ovalt; Dakskjocllene budte, det nedre udrandet, heelt omfattende Axet; 3 Ar; Frugten omvendt-ægformet, skarpt trekantet.

De nederste Blomster i Axet ere stundom topskydende; Bladskederne blegbrune. Hos Rchb. (anf. St.) er den afbildet med 2 Ar, og maaskee altsaa disses Antal er forskjelligt; paa alle de af mig undersogte Expl. har jeg fundet 3 Ar. 6-8. 4.

Ved Søbredder og paa oversvømmet, sandig Grund, hidtil kun bekjendt fra $\boldsymbol{H}$ alve e $n$ : J. Karlsmærsk Hede ved Blaavandshuk (30!); $S l$. Huusby (28) og Oxager i Angel (16), Lak (Heiberg); Romø (N.) i smaa Sumper udenfor den vestlige Klitrække (16).

b. Frugten stribet.

55. E. acicularis [R. Br. l. c.] (Naaleformet S.) Drej. 1. 44 ; Scirpus L., H. 53; F. D. 287; Rehb. VIII, 294; Aud. II, 26 ; H. N. XV. 90.

Stcengelen traadformet, furet-firekantet; Axet ægformet-ellip1isk, faablomstret; Doekskjollene æxgformede; 3 Ar; Frugten omvendt-ægformet, med omtrent 8 Striber paalangs.

Rodstokken alm. krybende, stundom sammentrængt, med taeformigt samlede Stgl. Hele Planten meget spædere og finere end de foreg. 6-8. $\odot$ (efter Koch), y (Horn. o. Fl.)

Ved S s-og Aabredder, 'paa sandig og leret Bund) alm. i Sjælland og paa Bornholm og savnes neppe i nogen af de danske Provindser (fra Fyen har jeg ikke endnu seet Expl.) 


\section{Scirpus. Kogleax.}

a. Baothryon N. E. Eet endestillet enkelt Ax, 6 Børster i Blomsterdækket, 3 Ar.

56. S. parvulus [R. \& S. Syst. Veg. II, 124.] (Lav K.) F. D. 2161; Rebb. VIII, 299; And. I, 20; H. N. X, 68; S. nanus Spreng., H. II, 113.

Stanglerne trinde, med indvendige Tværrum, ved Grunden omgivne af tyndhindede Bladskeder uden Plade; Dokskjollene ovale, budte; hveranden af Børsterne læugere end den trekantede, jærne Frugt.

Rodstokken krybende, udsender traadfine Udløbere med en opsvulmet Knop i Spidsen; Planten liden som Eleocharis acicularis, men mere robust. $7-8$. $\psi$.

Ved S $\boldsymbol{s - o g ~ F l o d b r e d d e r : ~} \boldsymbol{S} l$. ved Bredderne af Slien i Mrengde (16), Halvmaanen ved Husun (F. Müll., 20!); Loll. i stor Mængde paa inddæmmede Strækninger af Nakskov Fjord, f. Ex. ved Holeby (19). Maa nærmere eftersøges, da dens Lighed med foreg. let kan skjule den for en flygtig Betragtning.

57. S. pauciflorus [Lightf. fl. Scot. p. 1078.] (Faablomstret K.) F. D. 1862 (høire Fig.); Rehb. VIII, 299; And. I, 21; S. Bæothryon Ehrh., H. 52; H. N. II, 66; Heleocharis Bæothryon Drej. n. 45.

Stcrnglerne tueformigt samlede, trinde, ved Grunden omgivne af Bladskeder uden Plade; Axene rundagtigt-xgformede, 4-6-blomstrede; Dakskjallene agformede, budte, alle blomsterbærende, det nedre større og omfattende, kortere end Axet, Borsterne lidt kortere end den trekantede, paalangs stribede Frugt.

4-8" høi. 6-8. 4.

$\beta$, minor (Blytt) F. D. 1862 (venstre Fig.) Straaene lavere (omtr. 2 " høie), opstigende.

I Hedemoser, ved Søbredder og paa fugtige Overdrev, alus. udbredt paa Halveen, mindre hyppig og kum sporadisk pai $\theta$ erne. $\beta$, paa mere tor Grund, f. Ex. Amager Felled! Vaalse Vig paa F'alster (Koch)! Hullebæk (14)! J. Overdrev ved Størringgaard i Jyllaud! 
58. S. caspitosus L. (Tue-K.) H. 52; F. D. 1861 ; Rehb. VIII, 300; And. I, 19; H. N. XV, 89; Limnochloa cæspitosa Drej. n. 47.

Stonglerne tueformigt samlede, trinde, stribede, ved Grunden omgivne af tæt-taglagte Bladskeder, af hvilke de øvre ende $\mathbf{i}$ en kort, sylformet Plade; Axet 3-5-blomstret; Dakskjollene ægformede, budte, det nedre tomt, af Længde med og omfattende Axet, tilspidset $i$ en tyk, bladagtig Braad; Børsterne længere end den trekantede, jævne Frugt.

$2-8 "$ høi. Straaene meget stive og tret sammenhobede. Skederne glindsende og løst onsluttende. 5-7. 4.

I Lyngmoser, almindelig i Halvo ens Hedeegne, paa Øerne ikke alm.; $F$. i Mrengde paa Hals Overdrev v. Hofmansgave (18); Langel. ved Tranekjær (19); Falst. Horreby Lyng (14); $S j$. Gurre (14), gl. Kjggekro (H.), Holmegaardsmosen! B or $n h$. i Høilyngen alm.!

b. Heleogiton Link. Stængelen flydende, leddet, fra Leddene (Bladhjørnerne) udgaae Blomsterstilke med eet enkelt, endestillet Ax. Børster 0. Ar 2.

59. S. fluitans L. (Flydende K.) H. 54; F. D. 1082 ; Rchb. VIII, 298; And. I, 18; H. N. II, 70; Dichostylis Beauv., Drej. n. 46 .

Stcengelen grenet, ved Grunden rodslaaende; Bladenes Plade linieformet, længere end Skeden; Axene faablomstrede; Frugten tveægget-fladtrykt.

De meget tynde, flydende Strengler ere eensbetydende med beslægtede Arters krybende Rodstok, de fra Bladhjørnerne udgaaende Blomsterstilke med hines overjordiske "Stængler “. Dækskjællene lysgrønne, i Randen hindeagtigt blegbrune. 7-8. 4.

I rindende og stillestaaende Vand: paa Halveen hist og her: Koustrup i Thy (Dr.), Hasselholt mellem Skive og Struer (16), Aarslev ved Aarhuus, Lille og Store Ring ved Skanderborg (H.), Borris! Henne! Tange (3 Mile N. O. for Ribe, 30) og derfra mod S. i Slesv. ikke sjelden (N.), Amrom (herb. Drej.); paa $\theta$ erne kun angivet fra (Sj.) en Dam i Hareskoven og (Bornh.) ved Vallensgaarden (H.). $\bar{*}$ 
c. Blomsterstanden tilsyneladende sidestillet, idet det større Svøbblad udvikler sig i Retuing af Stæagelen og ligner en Fortsættelse af denne. Smanaxene alm. 2 eller flere, i siddende eller til en sammensat, halvskjærmformet Qvast forenede Nøgler.

aa. Isolepis R. Br. Dakskjallene $i$ Spidsen hele, med en Braad. Borster 0.

60. S. setaceus L. (Børsteformet K.) H. 55; Drej. u. 53; F. D. 311 ; Rehb. VIII, 301; And. 1, 17; H. N. I, 74.

Stcengelen trind, ved Grunden beklædt med Bladskeder, af hvilke de øvre have Plade; Axene 1-3, siddende, ægformede, kortere end det tilsidst tilbagebøiede Svøbblad; 3 Ar; Frugten omvendt-ægformet, noget fladtrykt, stribet paalangs.

$1-6^{\prime \prime}$ høi. Var. med krybende eller tueformigt sammentrængt Rodstok, Stæænglerne oprette eller bueformet nedbøiede, med kortere eller længere Svøbblad, 2 og 3 Støvdr.; Bladskederne rødlige. 7-8. $\odot$.

Ved Søbredder, paa fugtige Overdrev, især paa sandig eller torvholdig Bund, sporadisk og ikke almindelig, men bemærket i alle danske Provindser, hyppigst par Halvøen og i Nordsjællaud. $\bar{\sharp}$

bb. Schoenoplectus Rchb. Dakiskjollene fryndset-randhaarede, $i$ Spidsen udrandede med en Braad i Indskjoringen. Blomsterdacket borsteformet.

\%. Straaet trindt.

61. S. lacustris L. (Sø-K.) H. 54 ; Drej. n. 54 ; F. D. 1142 ; Rehb. VIII, 306; And. 1, 13.

Stcengelen ved Grunden med Bladskeder uden eller med en kort Plade; Blomsterstandens Grene uddrague; Dalkskjolls.ze jærne; Støvknapperne i Spidsen haarede; 3 Ar; Frugten budttrekantet.

Stgl. 3-6 høi, af grøn Farve. (En Form i rindende Vaud med forlængede Bladplader anfores fra Sydeuropa og maa eftersøges los os.) $6-7.4$.

I Bække, Aaer og Indsøer, alm. ndbredt i Danmark.

62. S. Tabernamontani [Gmel. Fl. Bad. p. 101.] (Blaagrøn K.) Rehb. VIII, 307; S. glaueus Sm., H. II, 114; Drej. 
11. 55 ; F. D. 1922 og 454 (S. Holoschoenus); H. N. II, 65; S. lacustris $\beta$ glaucus Fr. nov. p. 6; And. 1, 13.

Blomsterstandens Grene korte; Dcelskijallene rødbrunagtigtpunkterede; Støvlenapperne alm. glatte; 2 Ar; Frugten i Gjennemsnit fladtrykt-halvtrind (mere bvælvet udad- end indadtil), forøvrigt som foreg., men lavere (omtr. $2^{\prime}$ høi) og mere blaagrøn. 6-7. 4 .

Flere Forfattere antage denne paa Grund af Overgangsformer og flere af de angivne Kjendetegns Foranderlighed for en Afart af foreg., frembragt ved Forskjellighed af Voxested; men saavel paa Grund af de anforte Kjendetegn som et særeget Habitus, forekommer mig dog Adskillelsen af denne $\mathrm{og}$ foreg. ligesaa naturlig som flere andre almindeligt antagne Arter.

Ved Bredderne af Salt- og Brakvand, ikke sjelden, bemærket i alle Provindser, især hyppig ved Halvøens Fjorde og Marskenge.

\section{B. Straaet tresidigt.}

63. S. carinatus [Sm. i E. B. 1983.] (Budtkantet K.) H. N. XII, 81 ; And. 1, 14; S. Duvalii Hopp., H. II, 114; F. D. 1743 ; Rehb. 724 ; S. trigonus Nolt. nov. p. 9.

Stoengelen forneden trind, fra Midten opad budt-trekantet (med 2 hvælvede og 1 flad Side); Smaaaxene samlede $\mathrm{i}$ flere, stilkede eller siddende Nøgler; Dwkskjallene spidst-udrandede; Stovknapperne glatte; 2 Ar; Blomsterdcekkets Børster ligelange med den fladtrykte, paa Ryggen hvælvede Frugt.

Stgl. 2-4' høi, af grøn Farve, ved Grunden tyk og opblæst, de øvre Bladskeder med længere Plade, Svøbbladet længere og mere opret end hos foreg. 6-7. 4 .

Ved Flodbredder, kun funden ved Bredderne af Eideren (N.)! 7

64. S. triqueter L. (Trekantet K.) H. 56; F. D. 1983; Rehb. 719 ; And. I, 15; H. N. XII, 82; S. Pollichii Godr. \& Gr.

Stcengelen overalt skarpt-trekantet; det øvre Blad med en Plade kortere end Skeden; Smaaaxene samlede i eet siddende eller flere kortstilkede Nogler; Dakskjallene budt-udrandede; Støvknapperne glatte; 2 Ar; Børsterne soin foreg.; Frugten trekantet, paa Ryggen hrælvet. 
2-4' høi, frisk grøn (ogsaa i tørret Tilstand); Bladpladen bred, trekantet, Svobbladet opret, læengere og bredere end hos foreg. 7-8. 4 .

Ved Bredderne af Eideren (N.)! 用

65. S. pungens Vahl [ms., herb! enum. II, 255.] (Stikkende K.) H. II, 114; Nolt. nov. p. 9; And. I, 16; H. N. XIII, 79; S. Rothii Hopp., Rchb. 717-18; S. triqueter F. D. 1563 .

Stangelen overalt skarpt trekantet; de 2 ovre Blade med Plade længere end Skeden; Smaaaxene enlige eller flere samIede til et siddende Nogle; Drekshjollene spidst-udrandede; Stovknapperne i Spidsen raudluarede; 2 Ar; Borsterne neppe halvt saa lange som den budt-trekantede, paa Ryggen hvælvede Frugt.

$1 / 2-1 \frac{1}{2}{ }^{\prime}$ høi. Bliver guulbrum ved 'Tørring. Bladpladerne $o g$ det oprette, sylspidsede Svøbblad omtr. dobbelt saa lange, men meget smalere og finere end hos foreg. Var. med 3 Ar (Vahls Her's. og Mscr., Exemplarer fra Frankerig!). 7-8. 4.

Paa lignende Steder som de to foreg. Arter, og ligesom disse, hidtil kun funden iSlesvig: ved Slien (Jessen), Ulsnas (16), St. Peter i Eidersted (F. Müll.). 网

d. Phyllanthela Fr. Blomsterstanden endestillet, med flere starkt udviklede Svøbblade. (3 Ar.)

66. S. maritimus L. (Strand-K.) H. 56 ; Drej. 1. 56 ; F. D. 937 ; Rehb. 726-28; And. I, 11; L. Herb. IX, 164.

Stcengelen overalt skarpt trekantet, mangebladet; Smaaaxene samlede i eet siddende og flere stilkede Nøgler; Dakskijallene spidst udrandede med en Braad i Indskjæringen; Blomsterdakkets Borster 3-6, kortere end Frugten; Stovlnapperne i Spidsen randbaarede; Frugten omvendt-ægformet, budt-trekantet, i Gjennemsnit næsten halvtrind.

1-3 høi. Rodstokken krybende, ofte knolleformigt opsvulmet. Dselsskjællene kastaniebrune. Var. med 2 Ar. 7-8. \%.

$\beta$, monostachys, med eet enkelt rundagtigt-ovalt Ax.

$\gamma$, macrostachys Koeb. Smaaaxene lancetformede, næsten 1 " lange.

d, sphuerostachys! Smaaaxene xg-kugleformede. 
Ved Strandbredier, meget alm. Formerne paa samme Steder, men sjeldnere: $\boldsymbol{\beta}, \boldsymbol{S}$ j. Kalındborg Fjordenge (Baagøe!); $\boldsymbol{F}$. Hofmansgave (4); Vresen i Storebælt (19); Loll. ved Bjerremark (19), Falst. Kippinge Nor, Vaalse (14), Hesnæs (Koch); $S \boldsymbol{l}$. v. Haderslev Fjord (Grønlund!), Flensborg Fjord! $\gamma$, Marienborg paa $\boldsymbol{M} \boldsymbol{\theta}$ en (9), L oll. ved Torpe $(19) ; \boldsymbol{F}$. mellem Nyborg og Holkenhavn (Lund); $\delta$, Torvmoser paa Lyø (12).

67. S. silraticus L. (Skov-K.) H. 57; Drej. n. 57; E. D. 307; Rchb. 731; And. I, 10.

Stcengelen forneden budt-, foroven skarpt-trekantet, mangebladet; Blomsterstanden flere Gange sammensat, qvastformet, med forlængede Smaagrene; Dakskjcllene budte med en kort Braad; Borsterne 3-6, længere end den trekantede Frugt.

2-3' høi. Hele Planten frisk grøn, Bld. brede; Dækskjællene sortgrønne med bleggron Midtnerve. Smaaaxene mange Gange mindre end hos foreg. 6-7. 4 .

Par sumpige Steder i Slkove, ved Grøfter, Vandhuller o. s. v., torekommer $\mathrm{i}$ alle Provindser, men $\mathrm{i}$ enkelte Egne sparsom (f. Ex. i det sydvestl. Sjoll. (17), paa Lolland og i det nordl. Jyll.; ikke beunærket i $\nabla$. Hanherred (12)).

e. Blysmus (Panzer). Smaaxene toradet ordnede til et sammensat, endestillet Ax. (2 Ar).

68. S. Caricis [Retz. Prodr. ed. II, p. 16.] (Fladtrykt K.) Schoenus compressus L., H. 48; F. D. 1622 ; Blysmus compr. Panz., Drej. n. 4 I; Rehb. 693 ; And. I, 9.

Stcengelen utydeligt og budt-trekantet; Bladene flade med kjølformet Midtnerve paa Underfladen; Smaaaxene 6-8-blonstrede; Blomsterdakikets Børster med nedadvendte Smaatorne, vedblivende, længere end den lindseformet-fladtrykte, glindsende Frugt; Støvknapperne i Spidsen randhaarede.

Svobbladet oftest længere end Axet. Dækskjællene lys-kastaniebrune. 6-7. 4 .

Paa Enge (saarel Færskvands- som Strandenge) alm. ndbredt.

69. S. rufus [Schrad. fl. germ. I, 133.] (Rødbrun K.) Sehoenus Huds., H. 48; F. D. 1504; Blysmus Link., Drej. n. 42 ; Rehb. 694 ; And. I, 8 ; H. N. XII, 80 ; L. Herb. VII, 139 . 
Stangelen trind; Bladene halvtrinde, paa Overfladen rendede; Smaaaxene 2-5-blomstrede; Borsterne 0 eller hurtig; affaldende, "med opadrettede Smaatorne", kortere end den fladtrykt-halvtrinde, glandsløse Frugt.

Svøbbladet ofte kortere, sjeldent længere end Axet; Drekskjællene mørkere og mere rødligt-kastaniebrune, Frngterne større end hos foreg. $6-7$. $\psi$.

* _ bifolius (S. bifolius Wallr. Sehed. erit. p. 27; S. Tabernæmontani $\beta$, monostachys Lge. Haandb. 1 Udg. p. 38), med høiere og kraftigere Stængler, bredere Blade af glindsende mørkgrøn Farve; Axet omgivet af 2 Svøbblade, det ene omtrent af Axets Længde, det andet meget længere. Bliver ikke guul ved Tørring som Hovedarten og blomstrer senere $\left(\frac{7}{2}-8\right)$.

Paa Syltenge og Strandfælleder, sporadisk og ikke almindelig: $\boldsymbol{S}$. Holbæk (15), Jægerspriis (19), Bosernp (20), Saltholm (!) Vesterfielled, Kjøge (Dr.); Moen v. Grønsund (14), Ulfsliale (17); Falst. v. Hesnæe (14), Ulslov Sø (Koch), Gronsund (9); Loll. Stroguxs (5); $\boldsymbol{F}$. Hofnansgave (4), Knudshoved (19), Rodkilde, Lyo (12), 'Thuro (19); J. mellem Fjerritslev og Klim i V. Hanherred, Agger i 'Thy (Dr.), Fjaltring! Mariager Fjord (7); $\boldsymbol{S}$. Flensborg Fjord, Slien ved Slesvig (16), Sylt (N.). * $\boldsymbol{S} j$. Strandenge ved Flaskekroen (19); $J$. indenfor Klitterne ved Fjaltring (i Selskab med Hovedarten)! $\boldsymbol{S} l$. St. Peter i Eidersted (F. Müll.).

Anm. Formen * er i Udseende meget forskjellig fra Hovedarten og ligner ved flygtig Betragtning langt mere $S$. pungens, saa at jeg ilkke vilde betænke mig paa at ansee den for en egen Art, dersom den ikke $\mathrm{i}$ de væenligere Kjendetegn stemte aldeles overeens ined S. rufus. Den anbefales til nærmere Undersøgelse!

\section{Eriophorum. Kjaeruld.}

a. Polystachya. Smaaxene flere $(3-10)$, i halvskjærmformet Qvast, omgivne af Svøbblade; det indre Smaar siddende, de ydre stilkede, paa tilsidst nikkende Axstilke.

70. E. gracile [Koch i Roth. Cat. bot. 2. p. 259.] (Fiin K.) H. 61; Drej. n. 52; Rchb. 687-88; And. II, 29; L. Herb. III, 51; H. N. XIV, 79; E. triquetrum Hopp., F. D. 1441 ; E. polystachyon $\gamma$, L. fl. Suec. 
Rodstokiten med Udløbere; Stongelen budt-trekantet; Blotdene overalt trekantede, det øvre Stængelblad naaer ikke Blomsterstanden; Axstilkene duunhaaret-rue; Dokskijollene budte; Støvknapperne kortere end Støvtraadene.

Finere og med smalere Blade end de 2 folgende; Ulden (det haarformede Blomsterdække) kortere og finere, bestaaende af $1-2$ Cellerækker, (hos de 2 folgende af flere, omtr. 7 Cellerækker (12). $5-6$. 4 .

I Hængedynd eg dybe Moser, sporadisk og ikke almindelig: $\boldsymbol{S} \boldsymbol{j}$. Bagsvard (H.), Dronninggaard (Puerary), Frederiksdal (14), Lyngby Mose (!) $\circ g$ Viintappergaarden (Dr.), Lundehuusmosen! $\boldsymbol{F}$. Hofmansgave (H.), Norup Mose (18), Ollerup, Nielstrup, Egense (12), J. Moser Ø. for Tostum S 9 , Hobro (16), Karlslund ved Randers (7), Bredstrup ved Fredericia (12); $S l$. Haderslev (16), Aabenraa (Rafn), Huusby i Angel (16).

71. E. latifoliun [Hoppe Tascheub. 1800, p. 108.] (Fladbladet K.) Drej. n. 50; Rehb. 691-92; And. II, 28 ; L. Herb. I11, 50; E. polystachyon $\beta$, L. A. Suec., F. D. 1381; H. 59 .

Rodstokken uden Udløbere; Stangelen oventil budt-trekantet; Bladene flade med kjølformet Midtnerve paa Underfladen, i Spidsen trekantede, det øvre Strugelblad ikke naaende Blomsterstandeu; Axstilkene rue; Dokskjollene spidse; Støvknapperne kortere end Støvtraadene.

Frisk grøn, Bld. aftage jævnt i Brede mod Spidsen, de øvre have alm. en sort Plet ved Grunden; Ulden kortere end hos den følgende. 5-6. 4 .

Paa fugtige Enge, i alle Provindser, men ikke saa almindeligt udbredt som folgende og som oftest ikke i Selskab med denne. I enkelte Egne mangler den aldeles, f. Ex. ikke bemærket paa Lolland (19).

72. E. angustifolium [Roth. tent. 1, 24.] (Smalbladet K.) H. 60 ; Drej. n. 51 ; F. D. 1442 ; And. II, 27 ; L. Herb. VII, 138 ; E. polystachyon a, L. fl. Suec., Rchb. 689-90.

Rodstokken med Udløbere; Stcongelen trind; Bladene rendeformede, omtrent fra Midten til Spidsen trekantede, læugere end Ledstykkerne (det øverste Stængelblad naaer under Blomstringen op over Blomsterstanden); Axstilkene jævne og glatte; Deekskjallene spidse; Støvknapperne længere end Støvtraadene. 
Bladene blaagronne, mere ligebrede overalt end hos foreg, var. iøvrigt i Henseende til Bladenes Brede, Stæugelens Hoide, Axenes Antal o. s. v. Ulden meget lang. 4-5. y.

I Snmper, Kjæ1 og Grofter overalt i de danske Provindser.

b. Monostachya. Eet enkelt, endestillet Ax.

73. E. vagiuatum L. (Skedestraaet K.) H. 58; Drej. n. 49 ; F. D. 236 ; Rchb. 686 ; And. II, 30 ; L. Herb. III, 52.

Stcengelen glat, oventil budt-trekantet, med 1-2 bladløse, opblaste Skeder; Rodbladene lange, børsteformede, i Randen rue; Borsterne talrige, forlængede til en ret Uld.

$1 / 2-1^{1} / 2^{\prime}$ høi, Rodstokken sammentræengt, damner tæette Tuer, omgivne af Trævlenæet (de ældre Bladskeders Rester). 4-5. य.

I Torv-og Hedemoser, alm. paa Halvøen og i Sjælland, sjeldnere i Fyen og paa Lolland.

74. E. alpiumm L. (Liden K.) H. 59; F. D. 620 ; Rchb. 683-84; And. II, 33; L. Herb. V, 89; Limnochloa alpina Drej. n. 48.

Rodstokken skjævt krybende, udsender med korte Mellemrum flere, 6-8" lange, trekantede, rue Stongler, som kun ved Grunden ere forsynede med Blade, af hilke de øvre have en meget kort, i Randen ru, de nedre ingen Plade; Borsterne $4-6$, forlængede til en kruset Uld.

Hele Planten, og især Axene, meget mindre end foreg., Dækskjællene guulbrune med gron Rygnerve. (Ligner under Blomstringen meget Scirpus crespitosus). 4-6. भ,

I Moser, især med Hangedynd, sporadisk og hidtil bemærket hyppigere i Sjælland end i de andre Provindser: Sj. Jonstrup Vang, Ruderhegn (14), Dronninggaard, Tepri og Lyugby Noser (H.), Viintappermosen (Dr.), Holmegaardsmosen (H.)! Kongsted Moso (9), Soro (Hoffmeyer), Antvorskov (H.); Woen (H.); F. Langeskovs Kro (16); J. Vildmosen (16), Svenstrup Eng ved Aalborg (Branth), Stokholm Mose mellem Skive og Struer (16), Fusing Vasehuus (7), Kalbygaard! Gjedved, Satrup, Riis Mose (2), Kolding (28); $S l$. Broager (28).

\section{Cladium. Avnknippe.}

75. C. Mariscus [R. Br. Prodr. fl. N. Holl. I, 92.] (Hvasbladet A.) Drej. 11. 40; Rehb. 682 ; And. I, 5; H. N. IV, 
88; C. germanicum Schrad., H. 33; Schoenus Mariseus L., F. D. 1202 .

Stangelen trind, glat, mangebladet; Bladene i Randen og paa den kjølformede Rygnerve hvast-saugtakkede; Smaaaxene knippefornigt aamlede i stilkede, qvastformede Blomsterstande i Spidsen af Stængelen og Grene fra de øvre Bladhjørner.

Stgl. 3-4' høi og stiv, med tydelige Led. 7-8. భ.

I dybe Kjær og Torrgrave ikke almindelig: $\boldsymbol{S} \boldsymbol{j}$. Slangerup (H.), Øtholm (20), Nymølle, Lyngby Mose (H.)! Langholmsmosen ved Dronninggaard (14), Leerbæks Mose ved Roeskilde! Holmegaardsmosen (Dr.), Munkeljergby (Lund); Falst. Liselund v. Stubbekjøbing (Rasm.), Borup Sø (14); Langeland i Freimose (H.); F. Schelenborg! Øxemose ved Hofmansgave (18); J. Skanderborg (H.); Sl. Langsø ved Midsunde (16).

\section{Nardus. Katteskjag.}

76. N. stricta L. (Stivt K.) H. 61; Drej. n. 143; F. D. 1022 ; Rchb. ic. Al. germ. I, tab. 110; And. Gramin. Scand. XII, 141.

Straaene og de stive Bladknipper tæt tueformigt sammenhobede; Smaaaxene indsænkte i Axen; den nedre Inderavne læderagtig, sylformet, randhaaret-ru; Griffelen traadformet, Arret forlænget udenfor Blomstens Spidse.

6-8" høi, blaagraa. 6-7. 4.

Paa slette Enge og Lyngheder, almindelig i Landets magrere Egne, sjeldnere i de frugtbare (f. Ex. ikke bemærket paa Lolland (19), sjelden paa Falster (Koch).

\section{Digynia.}

\section{Lepturus. Spidshale.}

77. L. filiformis [Trin. Fund. agrost. 121] (Traadstænglet S.) Rehb. ic. fl. g. I, tab. 2; And. Gram. I, 12 ; H. N. XI, 94; L. Herb. VI, 112; (L. incurvatus Drej. n. 142 og Rottboellia incurvata H. 125 tildeels: efter Voxestederne); Rottboellia filiformis Rotb Cat. bot. 1, p. 21.

Straaet fra Grunden af grenet, med knæbøiet-opstigende Grene; Axet ret eller svagt bøiet, efter Afblomstringen fjernet fra det øvre Stængelblad; Axen skjør. 
4-10" høi, blaagrøn. 6-7. $\odot$. Forekommer under 2 Former: $\alpha$, strictus I.ge. Haandb. 2 Udg. p. 44 (Rottboellia incurvata $E . B$, tab. 760). Axene stivt oprette.

$\boldsymbol{\beta}$, subcurvatus Lge. I. c. (R. incurvata F. D. 938 ; H. og Drej. tildeels; Lepturus incurvatus (?) Lge. Haandb. 1. Udg. p. 42). Asene i Spidsen noget bøiede.

Paa Strandenge og Strandfalleder, sjelden og sporadisk: $\mathbf{S}$. Vesterfælled (Blytt), Reersg (13); Mren p. Gronsund Eng (14); F. Hofmansgave (H.); J. Limfjorden V. for Aalborg (H.); Sl. Gelting (Stisgaard!), Beenslıallig (N.). $\boldsymbol{\beta}$, Amager ved Limfabriken (Sehum., F. D.); Loll. hyplig paa Øerne og det inddxemmede Land ved Nakskov Fjord (19); Sylt (Spicker), Amrom (N.).

Anm. Den i Sydeuropa (f. Ex. ved Kysterne af Middelhavet og paa Spaniens Saltstepper) voxende L. incurvatus (Trin.) Koeh. Syn. II, p. 958; Rehb. fl. germ. I, tab. 2 (Rottboellia ineurvata Cav. ic. 3, ta's. 213!) er i Udseende saare forskjellig fra vor Art og adskilles let red lavere Vaext, nedliggende Grene, Axet under og efter Blomstrir gen stærkt seglformigt indbøiet, dets nedre Deel indsluttet i det øvre Stængelblad, hvis Plade er bredere og kortere. (Det fra Inder-og Yderamemes gjensidige Længde hentede Kjendetegn forekommer mig foranderligt). Til denne havde jeg tidligere med Tvivl henført Formen $\beta$, som da kun var mig bekjendt fra F. D. og et Expl. fra Nolte i Poulsens Herb., men efterat jeg hat samlet og sammenlignet begge Arter i Sydeuropa, og efterat Prof. Nolte har havt den Godhed at meddele mig den Bemærkning, at efter hans Anskuelse Alt hvad her i Landet forekommer, liører til een Art, har jeg udslettet L. incurvatus af Haandbogen. Sandsynligviis er den fra Skåne angivne L. incurvatus (Fr. mant. 2, And. Gram. Scand. p. 10) og overhovedet den af flere Forff, under dette Narn anforte Plante ligeledes den her angivne L. filiformis $\beta$. - Rottboellia inenrvata L. fil. ( Egilops incurvata L. Sp.) syues efter Beskr. og Citater at indbefatte begge Arter.

\section{Lolium. Raigraes.}

78. L. perenne L. (Almindeligt R.) H. 133; Drej. n. 136; F. D. 747 ; Rchb. ic. Al. germ. I, tab. 6; And. Gram. II, 15; L. Herb. III, 49.

Fra Roden udgaae saavel blomsterbærende Straa som blomsterløse Bladknipper; Bladene glatte, de yngre foldede; Smaaaxene under Blomstringen tiltrykte til Axen eller kun lidet ndstaaende; Yderavnen omtrent af Smaaxets halve Længde; Inderavnerne stakløse, hindeagtige, den nedre bredere end den ørre.

Straaene glatte, ved Grunden knæboiet-opstigende. 6-8. 4. 
$\alpha$, vulgare. Smaaaxene 6-9-blomstrede.

$\beta$, tenue H. 1. c. (L. tenue L.) Smaaaxene 3-4-blomstrede, Straa og Blade finere.

$\gamma$, aristatum (Schum. p. 36). Yderavnerne stakbærende.

Paa Græsmarker, høie Enge, ved Veigrøfter o.s.v., meget alm. $\boldsymbol{\beta}$, paa torre Steder, dyrkes ofte paa kunstige Græsplainer; $\boldsymbol{\gamma}$, anføres af Schum. som sjællandsk. Desuden forekomme folgende Misdannelser: - 1, (adbreviatum) med kort Ax (sammentrængt Axe), 2, (ramosum) med grenede og 3, (viviparum) med topskydende Smaax.

† L. italicum [A. Braun, Flora 1834 p. 241] (Italiensk R.) L. Bouchéanum Kth., Rchb. ic. fl. germ. VII, 238-39.

De yngre Blade indrullede i Randen, tilligemed Bladskederne lidet rue; Smaaaxene under Blomstringen stærkt udspærrede; den nedre Inderavne med en kort Stak nedenfor Spidsen; forøvrigt som foreg. (-) eller 4.

Dyrkes i de senere Aar hist og her som Fodervaxt og forekommer stundom forvildet, f. Ex. $\boldsymbol{S} j$ ved Jagtveien udenfor Kjøbenhavn! Rolighedsveien; F alst. Stubbekjøbing; Loll. Nakskov; F. Nyborg, Klingstrup (19).

79. L. Jinicola Sonder [Koch syn.II, 957] (Hør-R.) And.II, 14; L. arvense H. 134 ; F. D. 1864 ; Rehb. ic. fl. germ. I, tab. 4, f. $1337-39$; H. N. II, 78; L. Herb. II, 33 (ikke Wither).

Straaene oprette, glatte eller foroven lidet rue, ingen blomsterløse Bladknipper; Yderavnen lidet kortere end Smaaaxet; den nedre Inderavne nedenfor Midten læderagtig, uden eller med en bøiet, affaldende Stak; den фvre Inderavne naaer (ved Frugtmodningen) med Randen udenfor den nedre.

Finere end de øvrige Arter. Smaaaxene alm. 5-8-blomstrede, sjeldnere forekommer den med færre $(2-5)$ Blomster i Smaaaxet $(\beta$, minus Koch, Falst. Veg., L. Halleri Gmel.) eller med flere (10-11) Blomster i Smaaaxet ( $y$, majus Koch 1. c.). 7. $\odot$.

Almindeligt Ukrud i Hoprseden, og har udbredt sig med Hørculturen, som det synes, til alle Egne af Landet. $\beta$, Lommeløv, $\gamma$, Riserup p. Falst. (Koch)!

80. L. temulentum L. (Svingel-R.) H. 134; Drej. n. 137; F. D. 160 ; Rehb. I, tab. 5, fig. 1342-44; And. II, 13; L. Herb. II, 32 . 
Straaene oprette, rue, ingen blomsterløse Bladknipper; Yderavnen af Længde med eller længere end Smaaxet; den nedre Inderaune nedenfor Midten læderagtig, med en $3-4^{\prime \prime \prime}$ lang, oftest ret Stak; den ovre Inderavne naaer (ved Frugtmodningen) med Randen udenfor den nedre.

Kraftigere end foreg., Smaaaxstilken skjør og Blomsterne derfor (med Undtagelse af Yderavnen) hurtigt affaldende. Var. med en meget kort og noget bgiet Stak, Yderavnerne alm. større, Smaaaxene 6-8blomstrede $(\beta$, leptochoeton A. Br.) En Form med jæevnt Straa $(\gamma$, speciosum Koch Syn., L., arvense With.) har jeg ikke bemærket i vor Flora. $6-7 . \odot$.

Ikke sjelden paa dyrkede Marker, især blandt Vaarsæden. I enkelte Eqne (f. Ex. i Fyen) sparsom. Formen $\beta$, paa Ryddepladser og ved Mløddinger, sjeldnere end Hovedarten, f. Ex. Kjøbenhavn, Svendborg (19).

\section{Brachypodiun. Stilkax.}

a. Inderavnerne stakløse, den øvre i Randen fiinharet.

81. B. loliaceum [Fr. mant. 3, p. 15] (Raigræasagtig S.) And. II, 16; H. N. VIII, 96; Lolium festucaceum Link, Rchb. I, tab. 6; Festuca loliacea Huds. fl. angl. 38; Koch. Syn. II, 443 ; Glyceria lol. Godr. A. Lorr. 3, 168.

Bladene linieformede, slappe, glatte, paa Underfladen rue; Axet nikkende; Smaaaxene fladtrykte, de nedre kortstilkede, de øvre siddende; den nedre Inderavne stakløs.

Væxten ligner Festuca pratensis, Blomsterstanden Lolium perenne, men den er let kjendelig fra den forste ved det toradede $\Lambda x$, fra den sidste ved Smaaaxenes Stilling og 2 Yderavner. De tidligere for Festuca loliacea anforte danske Voxesteder (F. D., Drej.) høre ikke til denne Art, men til $F$. pratensis $\beta$, pseudololiacea (sml. Lange i Kroy. Tidsskr. IV, 462)。 6-7. 4 .

Paa høie Enge og ved Veigrofter, sporadisk og sjelden: $\boldsymbol{S} \boldsymbol{j}$. Bredderne af Peblingesøen ved Kjøbenhavn (i Mængde 1841-42)! Skovsborg (15); J. Sporring og Haldum ved Aarhus! 可

b. Den nedre Inderavne stakbærende, den øre i Randen stivharet.

82. B. gracile [Beauv. agrostogr. p. 101] (Langstakket S.) Drej. n. 129 ; Rehb. 1. c. tab. 16, f. 1373- 55 ; L. Herb. Vl, 108; 
B. silvaticum R. \& S., And. II, 17; H. N. XII, 94; Festuca gracilis Moench, H. 120 ; Bromus pinnatus $\beta$, L. sp., F. D. 164 ; B. silvaticus Juss., Rafn. I, 560; Schum. 39.

Rodstokken sammentrængt, ikke krybende; Bladene linielancetformede, slappe, tilligemed Bladskederne haarede og paa begge Flader rue; Axet nikkonde, med fjerntsiddende Smaaax; Stakken af Længde med eller længere end Inderavnerne.

Plantens Farve frisk grøn. 7-8. $\psi$.

$\beta$, majus! (B. pinnatum $\beta$, Rchb. 1376?) Smaaaxene tættere samlede, 10-12-blomstrede, omtr. 1" lange. Planten større.

I Skove og Krat, ikke sjelden i de danske Provindser. $\beta$, paa mere aabne Steder: Falst. Guldborg (Koch); Loll. Lungholm! F. Dyrupgaard! J. Nebbegaard! Riis Skov ved Aarhuus!

83. B. pinnatum [Beauv, l. c.] (Kortstakket S.) Drej. n. 130 ; F. D. 2525 ; Rehb. 1. c. tab. 17, fig. 1377-78; And. II, 18; H. N. XII, 93; L. Herb. VI, 107; Bromus L., Festuca Moench, H. 121; Bromus gracilis Schum. 39.

Rodstokken krybende; Bladene lancet-linieformede, stive, paa begge Flader rue og haarede, Axet opret, med tætsiddende Smaaax; Stakken kortere end Inderavnerne.

Af mere guulgron Farve end foreg. Bladskederne alm. glatte. De nedre Smaaax komme ofte ikke til Udvikling. Var. med grenede Smaaax. 6-7. $\%$.

I Kratskove, paa Bakker og Skrænter, sporadisk og ikke almindelig: $S j$. Fuglevad Mølle (Dr.), Bagsvierd (Schum.), Hareskoven mod Ballerup (H.), Frederiksdal (9), Jonstrup Vang (14), Enrum ved Vedbæk (19), Boserup Skov (20), Kjøge Aas (9)! Magleby Dyrehave paa Sterns (Visby)! Alindelille Fredskov! Moen (Dr.); J. Dybdals Bakke v. Aalborg (Dr.)

\section{Agropyrum. Qvik.}

a. Nerverne paa Bladenes Overflade beklædte med flere Kækker af fine Børster*).

84. A. junceum [Beauv. 1. c. p. 102] (Sivbladet Q.)

*) Til at erkjende denne Forskjel er en temmelig stærk Forstørrelse med Lupen nødvendig. 
Drej. n. 135; Rchb. I, tab. 22, f. 1394; Triticum L., H. 139; F. D. 916 ; And. I, 1 ; H. N. VI, 91 ; L. Herb. II, 30.

Rodstolken krybende; Bladene stive, tilsidst sammenrullede, paa Overfladen blødt-fløielshaarede; Axen skjør, glat; Smaaaxene fjerntsiddende, 5-8-blomstrede; Yderavnerne budte, $9-$ 11-nervede, omtrent af Længde med Halvdelen af Smaaaxet; Inderavnerne budte, glatte.

Hele Planten blegt blaagraa, lavere, men mere robust end $\mathrm{Nr}$. $86-87$, fra hvilke den strax kjendes ved den meget skjøre Axe. Fra den følgende Art adskilles den let ved glatte Inderavner og ikke rn Axe. Saavel denne som alle de folgende Arter af Qvik forekomme under 2 Former, som synes at vare afhængige af Voxestedet: $\alpha, m i$ crostachyum og $\beta$, macrostachyum (Fr.). 6-7. 2 .

Paa den yngre Havstok, iklie sjelden i Danmark og bemærket i alle Provindser. $\%$

85. A. strictum [Dethard, consp. fl. Megapol. p. 11, under Triticum], (Stiv Q.) Rehb. 1. c. tab. 23, f. 1395.

Rodstokken krybende; Bladene paa Overfladen flgielshaarede, stive, forboldsviis smale, tilsidst sammenrullede, med stikkende Spidse og store bugformede Bladskeder; Axen noget skjør, ru; Smaaaxene fjerntsiddende, 4-5-blomstrede, Yderavnerne spidse, glatte, femuervede, over $2 / 3$ af Smaaaxets Længde; den nedre Inderavne budt, fra Grunden til Midten duunharet.

Straaet tykt, stivt opret, høiere end foreg. 6-7. 4 .

Sandige Strandkyster. Ourehoved paa Are (12).

86. A. obtusiusculum Lge. Haandb. 2 Udgave (1856). (Budtklappet Q.) Triticum acutum Fr. S. veg. Sc. p. 249; H. N. VI, 94 (forma macrostachya) And. I, 2; Rehb. l. c. tab. 22, f. 1393; Lge. Haandb. 1 Udg. S. 46; A. adfine (3) Drej. p. 49 ? F. D. 1986 ? Triticum hebestachyum Fr. Bot. not. 1857 p. 69 og 1858 p. 129.

Radstokken krybende, Bladene stive, kjølformede, tilsidst sammenrullede, paa Overfladen fløielsharede, rue; Axet opret, med lidet skjør Axe; Smaaaxene tætsiddende, 4-7-blomstrede; Yderavrerne budte, 5-7-nervede, mere end halvt saa lange som Sinaaaxet; Inderavnerne budte med en kort Braad. 
Blaagrøn. Axen alm. glat, sjeldnere haaret. 6-7. 4.

Ved Strandbredder, meget sjeldnere end den følgende; jeg har kun seet Expl. fra Halvoens Vestkyst, f. Ex. Øen Langlig Bjerge i Hjerting Bugt, Ballum, Hoier (16), Wyk paa Fohr $(20)$, og Loll. Strandbredder mellem Rødby og Nakskor, Vresen i Storebxit (19), som aldeles stemme overeens med Beskr. hos Fries og Fig. hos Rehb. 席

87. A. acutum [DC. cat. hort. monsp. p. 153 (under Triticum)] (Slapbladet Q.) Gren. \& Godr. f. Fr. III, p. 605; L. Herb. VI, 109; A. adfine Dethard. consp. fl. Megap. p. 11, (Triticum); Lge. Haandb. 1 Udg. p. 46 ; Drej. n. 13+(1-2!); Rehb. 1. c. tab. 21, f. 1391; Triticum laxum Fr. mant. 3, p. 13 ; H. N. VI, 94.

Rodstokken krybende; Bladene slappe, flade, paa Overfladen rue; Axet i Spidsen bøiet, med seig, glat eller i Randen ru Axe; Smaaaxene fjerntsiddende, 4-7-blomstrede; Yderavnerne 7-nervede, spidse, $2 / 3$ af Smaaaxets Længde; Inderavnerne spidse.

Var. mere eller mindre blaagron. Fra Rodstokken udgaae talrige Bladknipper. 6-7.

$\boldsymbol{\alpha}$, microstachyum (Fr. m. 3; T. acutum DC. herb.!). Axet kort, med mindre Smaaax, Bladene paa de blomsterløse Stængler indrullede.

$\beta$, megastachyum (Fr. 1. c.: A. adfine Deth. i Rchb. fl. g. exs. n. 403). Axet forlænget, Smaaaxene større, alle Bladene flade.

Ved Strandbredderne i Sandet, begge Former ikke sjeldne ved de danske Kyster: $\alpha$, paa den yngre, $\beta$, paa den ældre Havstok. $\overline{\bar{*}}$

Anm. Grenier og Godron (l.c.) have gjort opmærksom paa, hvad der ogsaa belkreftes ved Decandolles Original-Expl. i Pariser-Musæet), at den ved Montpellier voxende og af DC. beskrevne Triticum acutum er den samme som af Rchb. er afbildet under Narn af Agropyrum adfine og af Fries benærnt T. luxum. Decandolles Narn maa altsaa, som det wldste, beholdes for denne Art, til hvilken det ogsia passer bedre end tıl foregaaende, hvor saavel Ydes- som Inderavner ere budte. Af Formen $\boldsymbol{\beta}$, har jeg ved Lappesteen pr. Helsinggr fundet Exemplarer med frisk grøn Farve og stakbærende Smaaax. Trit. littoreum Schum. F. D. 1863 er vistnok kun et meget nngt Exemplar af samme Form. 
b. Nerverne paa Bladenes Overflade beklædte med en enkelt Rakke af 13 ğster eller langere Haar.

88. A. pungens [Roem. \& Sch. Syst. II, p. 753 ex part.] (Stikkende Q.) Gren. \& Godr. fl. Fr. III, p. 606.

Rodstokken krybende; Bladene blaagraa, paa Overfladen rue, $\mathrm{i}$ Randen indrullede med stikkende Spidse; Axet opret, med glat eller ru Axe; Smaaaxene tætsiddende, 3-4 Gange langere end Ledstykkerne, fladtrykte, skjævt tiltrykte til Axen, 6-10-blomstrede, under Blomstringen lancetformede; Yderavnerne outrent af Smaaxets halve Lxengde, 5-7-nervede, spidst laneetformede med kjølformet $\mathrm{Ry}_{\mathrm{g}} \mathrm{og}$ smal hindeagtig Rand; Inderavnerne spidse eller budte med en Braad.

Ved Strandbredder: Beenshallig (Nolte i Kamphøv. Herb.) $\mathbf{S}$. Rødvig Skandse paa Sterns (Visby!). ⿷匚⿱一⿻上丨巨大

Anm. Expl. fra Beenshallig ere mindre af Væxt, have glat Axe og 6-7-blomstrede Smaax, de fia Rødvig ere hoiere og kraftigere, ned ru Axe og bredere, S-10-blomstrede Smaax, hiin minder on A. obtusiusculum, denne om Former af $A$. repens, men forgvigt ere de ved flere Eiendommeligheder (f. Ex. den blatagraa Farve, stikkende Blade, meget fladtrykte, tæet- og skjævtsiddende Smaax o. s. v.) saa noie forbundne med hinanden og forskjellige fra de ovrige Arter, at jeg maa antage dem for at hore sammen til een Art. Den af Godr. og Gren. (fl. Fr. III, 606) beskrevne A. pycnanthum stemmer i flere Kjendetegn overeens med vor Art, men efter Beskrivelsen formaaer jeg ikke at skjelne denne tilstrækkeligt fia A. pungens. Jeg har paa dyrkede Expl. i botanisk Have (fra Stevus) stedse fundet Frugterne golde.

89. A. repens [Beauv. ]. c.] (Almindelig Q.) Drej. n. 132 ; Rehb. 1. c. tab. 20, f. 1383-88; Triticum L., H. 140; F. D. 748; And. 1, 4; L. Herb. IX, 163.

Rodstokken krybende; Bladene flade, paa Overfladen haarede og rue; Axet opret, med ru Axe, Smaaaxene txtsiddende, orntrent femblomstrede; Yderavnerne tilspidsede, femnervede, med bred hindeagtig Rand; Inderavnerne tilspidsede eller budte med en Braad.

Stakken paa Inderavnerne var. betydeligt i Læengde; ogsaa Yderavnerne forekomme stakbxrende. 6-8.

Anm. Af de talrige Former, hvorunder denne i Henseende til Storrelse, Farve, Bekludning o. s, v. yderst foranderlige Art ogsia i vor Flora fremtræder, maa nævues son de ineest ndmarkede: 
$\beta$, arundinaceum (Fr. S. Veg. Sc. p. 250). Høi og kraftig (omtrent $2{ }^{\prime}$ ); Bladene brede, glatte, rue; Axen glat med rue Kanter; Smaaasene omtrent 30, tæt forenede til et næsten 1/2' langt Ax; Yderavnerne 7-9-nervede, stakbærende.

$\gamma$, firmum (Presl ?, Rchb. 1383). Som foreg., men med haarede Blade, færre, men større (7-9-blornstrede) Smaaax, 7-nervede Yderavuer.

$\delta$, littorale Bab. man. p. 400. Stængelen lavere og finere, tilligemed de smale, i Randen indrullede og jævne Blade blaagraa; Smaaaxene faa- $(3-5)$ blomstrede. A. littoreum Drej. n. 133 (efter Beskr., ikke F. D.); T. rep. $\beta$, maritimun Koch Syn. II, p. 953.

Et almindeligt og besværligt Ukrud i Haver, Marker, ved Gjærder o.s.v. $\beta, S j$. Frederiksverk (herb. Drej.); Falst. Grønsund, Ulsløv (Koch); $\boldsymbol{F}$. St. Jørgensgaard (12); Sl. i Strandsandet ved Frederiksort i Slesvig (16), $\gamma, S_{j}$. Helsingor (herb. Drej.); J. Strandbredder ved Aarhus! $\delta$, ved Bredderne af Tiissø i Sjilland! Avernakø (12).

90. A. caninum [Roem. \& S. Syst. II, 756] (Hunde-Q.) Drej. n. 131; Rehb. 1. c. tab. 19, f. 1381; Triticum Sclireb., H. 141 ; F. J. 1447 ; And. I, 5; H. N. Vl, 97 ; L. Herb. VI, 110 ; Elymus L., Schum. p. 44.

Rodstokken sammentrængt, uden Udløbere; Bladene pą begge Flader rne og haarede; Axet nikkende, med ru Axe; Smaaaxene 3-5-blomstrede; Yderavnerne tilspidsede, 3-5nervede; Inderavnerne tilspidsede, kortere end den rue og noget bøiede Stak.

Mørk og frisk grøn. 6-8. 4.

$\boldsymbol{\beta}$, gracilius (cfr. Fr. S. Veg. Sc. p. 250). Finere, med smalere Blade, toblomstrede Smaaax.

I Skove, især paa Muldjord, ikke sjelden og forekommer $\mathrm{i}$ alle danske Provindser. $\boldsymbol{\beta}$, med Hovedarten, f. Ex. i Skovene ved Sorø!

\section{Triticum. Ilvede.}

$\dagger$ T. vulgare Vill., Metzger Cereal. tab. 1-2. Axet firekantet, med tret taglagte, omtrent fireblomstrede Smaax; Yder- 
avnerne hvælvede, med fremstaaende Rygnerve i Spidseu. 6-7. $\odot \operatorname{og} \odot$.

$\alpha$, astivum (Vaar-H.) T. astivum I. Inderavnerne stakbærende.

$\boldsymbol{\beta}$, hibernum (Vinter-H.) T. hibernum L. Inderavnerne uden Stak.

Dyrkes almindeligt i Landets frugtbare Egne.

Anm. De fra Stakken hentede Skjelnemierker mellenı de to Forner, saaledes som de af Limé ere angivne, ere ikke bestandige, idet f. Ex. Vinterhveden, som hos os hyppigst dyrkes, findes saavel med som uden Stak.

† T. turgidum L. (Engelsk H.) Metzg. 1. e. tab. 3. Axet firekantet, med tæt taglagte, omtrent fireblomstrede Smaaax; Yderavnerne længere, med en kjølformet, vinget Ryguerve, som naaer fra Grunden til Spidsen. 6-7. $\odot$ og $\odot$.

Dyrkes sjeldnere end foregaaende.

\section{Secale. Rug.}

† S. cereale L., Metzger, 1. c. t. 9. Smaaaxene tæet taglagte, længere end Yderavnerne; Inderavnerne kamformigtrandharede, tilspidsede $\mathrm{i}$ en lang Stak. $6 . \odot$.

Dyrkes overalt i Landet, som vor vigtigste Kornsort.

\section{Hordeum. Byg.}

a. Crithe Doell, Fl. Bad. p. 118 . Alle Smaaxene enblomstrede, med langstakkede Trekjønsblomster, eller Side-Sinaaxene med stakløse ô Blomster. Axen seig.

$\dagger$ H. polystichum Doell, 1. c. p. 119. Axet mere eller mindre tydeligt sextandet; alle Smaaaxene $\not{q}$, stakbærende.

- $\alpha$, vulgare Doell (H. vulgare L.) (Alm. Byg.) Axet nikkende; Smaaxene imod Modningen stillede i 6 Rader, de to midterste Rader mindre fremragende end de ovrige. $\odot$ og $\odot$.

Dyrket. 
- $\beta$, hexastichon Doell (H. hexastichon L.) (Sexradet B.) Axet opret; Smaaaxene $\zeta$, imod Modningen regelmæssigt ordnede i 6 Rader. $\odot$.

Dyrket.

$\dagger H$. distichon L. (Toradet B.) De midterste Smaaax $\Varangle$, Side-Smaaaxene $\hat{\sigma}$ stakløse (Axet toradet-fladtrykt). $\odot$.

Den hyppigst dyrkede Bygart i Danmark.

b. Hordeastrum Doell, l. c. p. 117. Alle Smaaxene enblomstrede, stakbærende, de midterste $\not$, de ydre $\widehat{o}$ eller kjønsløse. Axen skjør.

91. Il. maritimum [Wither. arr. 172] (Strand-B.) H. 139; F. D. 1632 ; Rehb. I, tab. 11, fig. 1364 ; And. I, 11 ; H. N. XII, 95; L. Herb. VII, 135.

Bladene haarede paa begge Flader; med glatte, bugformigt oppustede Skeder; Yderavnerne alle børsteformede, rue, de indre i Side-Smaaxene indadtil vingede; Sideblomsterne $\hat{\delta}$.

4-8" høi. Straaene talrige, ved alle Ledene knæbøiede, det øverste Blads Skede meget langere end sammes Plade, af Længde med eller lidet kortere end Ledstykket ovenfor: Asen mindre skjør end hos de følgende. 6-7. $\odot$.

Paa Digerne ved Vesterhavet i Slesvig: Dagebøl, Juliane-Marieskoog (H.), Hnsum! Pellworm (N.). *

92. II. pratense [Huds. fl. angl. ed. 2, p. 56] (Eng-B.) Rehb. l. e. fig. 1363 ; H. secalinum Schreb., H. 138; Drej. n. 141 ; And. I, 10 ; H. N. VI, 98; L. Herb. I, 14; H. maritimum F. D. 630.

Bladene haarede paa begge Flader; Skederne ikke oppustede, de øvre glatte, de nedre haarede; Yderavnerne $\mathrm{i}$ alle Smaaaxene børsteformede, rue; Sideblomsterne kjønsløse.

Straaene $1-1^{1} / 2^{\prime}$ høie, opstigende, ved de nedre Led knæbøiede, det 6-7. 4 .

Paa Strandenge, kun bemarket (og ikke almindelig) i den sydligere Deel af Landet, meest ndbredt paa de sydlige Øer: $\boldsymbol{M}_{\boldsymbol{\theta}}$ en (Dr.), Falster og Lolland! Ero (10), Stryng, Lyg (12), og i Marskegnene ved Vesterhavet, sjeldnere mod $\mathrm{N}$. ved Bixlterne og Katte- 
gattet, f. Ex. J. Horsens Fjord Norrestrand (2), Kolding (28); F. Hofmansgave (18), Nyborg (Jorgensen), Svendborg! Sj. Helsingør (Dr.), mellen Vedbxk og Kjobenhavn, Amager (Schnm.), Avedore (Broager), Vordingborg (2), Stubberup v. Skjelskor (Nielsen), Korsor (Drej.); Bornh. Skibsbroen ved Rønne (8). $\$$

93. II. murimum L. (Gold B.) H. 138; Drej. n. 140; F. D. 629 ; Rehb. I. c. fig. 1362 ; And. I, 9; L. Herb. I, 13. Bladene haarede paa begge Flader, med glatte, bugformigt oppustede Skeder; Yderavnerne af det midterste Smaaax linielancetformede, randhaarede, den indre i Side-Smaaxene linieformet, mod Basis randhaaret, den ydre børsteformet, uden Randhaar; Sideblomsterne $\hat{o}$ eller kjønsløse.

$1 / 2-1^{\prime}$ høi. Straaene ved Grunden knæbøiet-opstigende. 7-8. $\odot$.

Ved Mure og Veie, især omkring Kjøbstæder: i Kjøbenhavus Omegn meget almindelig og forekommer ved de fleste andre Kjøbstader paa Oerne. Paa II lvoen sjeldnere: Aarlus! Skanderborg, Fredericia (12), Slesvig! Husum (16).

c. Pseudelymus! Alle Smaaxene stakbærende, de yderste $\not{q}$, de midterste ofte golde. Axen seig.

(Elymus L.).

94. Il. silvaticum [Huds. l. c. p. 57] (Skov-B.) Elymus europæus L., H. 137; Drej. n. 138; F. D. 1631; Rchb. I. c. tab. 9, fig. 1359; And. I, 8; H. N. IV, 99; L. Herb. VII, 136.

Bladene glatte (eller paa Overfladen svagthaarede), paa begge Flader rue, med haarede Skeder; Yderavnerne linie-sylformede, rue, stakbærende; den nedre Inderavne med en Stak, dobbelt saa lang som Avnen.

$1^{1 / 2}-3^{\prime}$ høi og stiv, frisk grøn. Det midterste (ofte golde) Smaaax har kortere og smalere Yderavner end de øvrige. Smaaaxene hyppigst enblomstrede med en borsteformet Ansats til den anden Blomst. Da saaledes ingen viesenlig Characteer adskiller den fra Slægten Hordeum, med hvilken den i Habitus har samegen Lighed, synes den rigtigere at finde $\sin$ Plads $\mathrm{i}$ denne end $\mathrm{i}$ folgende Slægt, til hvilker de Fleste benfore den). 6-7. 4 .

I hojtliggende, skyggefulde Lovskove, hist og her paa Halvoens Ostkyst; $\boldsymbol{F}$. sjelden: Kjerteminde (Heiberg), Nishlyhoved Skov (13), Hvidkilde, Faaborg (12); Loll. Uglelsolt, Nobbslle (19); F alst. i Hanenov, Oustrup og Bangsebro Skove (14), Ravnstrup Skov (Koch), $\boldsymbol{S} j$. sporadisk og isier i den sydlige og vestlige Deel; ikke bemærket paa Bornh. 


\section{Elymus. Marehalm.}

95. E. arenarius L. (Sand-M.) H. 136; Drej.n. 139; F. D. 847 (slet); Rchb. I, tab. 10, f. 1360 ; And. I, 7; L. Herb. VI, 111.

Bladene brede, stive og spidse, tilsidst indrullede; Smaaaxene 3-4-blomstrede; Yderavnerne lancet-sylformede, paa Ryggen kamformigt-haarede, omtrent af Længde med Smaaaxet; Inderavnerne duunhaarede; 2 spidse, randhaarede Blomsterslijcel*).

Stort (3-4' høit) Græs af blaagraa Farve, Axet ${ }^{1 / 2}-\mathbf{1}^{\prime}$ langt. 6-8. ข.

$\beta$, minor! Straaet lavere (omtr. $1^{\prime}$ ), ved Grunden knæbøiet; Bladene meget smale; Axet kort (3").

Ved sandige Strandbredder, i Flyvesandsklitter, almindelig udbredt, sjeldnere ved Bredden af Færskvand, f. Ex. S $j$. den østlige Bred af Tiisss! $J$. Tange ved Gudenaa (16). $\beta$, Bredderne af Øresund ved Vedbæk!

\section{Léersia. Riisgraes.}

96. L. oryzoiles [Sw. fl. ind. occ. I, 132] (Vand-R.) H. 63 ; F. D. 1744 ; Rchb. I, tab. 52 , fig. 1495 ; And. X, 116; Phalaris L.; Asprella Lam., Rafn I, 504.

Den øvre Deel af Toppen udbredt med bølgede Grene, den nedre indsluttet i Bladskcden ${ }^{* *}$ ); Inderavnerne (altid lukkede) ovale, stakløse, i Randen og paa den kjølformede Rygnerve stivt-randhaarede (med ofte ved Grunden grenede Haar).

1-2 h hi. Topgrenene og Bladene meget rue; Skedehinden meget kort. Kommer ikke i alle Sommere til Udvikling. 8-9. 4.

Paa fugtige Steder, ved Bredder af Søer og Aaer, meget sjelden. $S j$. Hellehæk ved Hammerdammen, Umacks Dam o. fl. St. (12)!; $S l$. ved Eideren paa den slesvigske Side (16). 可

×) Ved Blomsterskjæl (lodieulæ) forstaues Blomsterdækket hos Gresarterne, som dannes af $2-3$ hindeagtige, fine, for det blotte Oie ofte usynlige Skjæl indenfor Inderavnerne og udenfor Støvdragerne.

**) Dette gjælder dog kun for vort Clima, hvor den blomstrer saa seent paa Aaret, at 'Toppen i Regelen ikke nazer sin fulde IJvikling. Den bærer heller ikke moden Frugt hos os. 


\section{Setaria. Skjaermax.}

97. S. viridis [Beauv. 1. e. 52] (Grønt S.) Drej. n. 58 ; Rehb. I, tab. 47, fig. 1467; And. XI, 123; H. N. XV, 92; L. Herb. II, 28 ; Panicum L., H. 65 ; F. D. 852.

Straaet jævnt, Bladene i Randen rue; Skedehinden dannet af en Haarkrands; Dusken valseformet; Svøbets Børster med opadvendte Smaatorne; Blomsterne glatte; Tvekjonsblomstens Inderavner jævne, af Længde med den øvre Yderavne.

Hele Planten (ogsaa Blomsterne) grøn, var. med bruunviolette Borster. 7-8. $\odot$.

Paa dyrkede, tørre, især sandige Marker, funden i alle Provindser, men sporadisk og ikke almindelig.

$\dagger$ S. verticillata [Beauv, l. c. 51] (Krandsblomstret S.) Panicum rerticillatum L.; H. II, 116; F. D. 2163.

Straaet foroven og Bladene rue; Dusken forneden afbrudt ved Mellemrum mellem de halvkrandsstillede Smaaax; Svgbets Børster kortere, med nedadvendte Smaatorne, hrorved Dusken bliver meget ru naar man stryger opad; forøvrigt som foreg. 7-8. $\odot$.

Forvildet ved Ollerup i Fyen.

98. S. glaicea [Beauv. l. c. 51] (Blaagraat S.) F. D. 2162, Rcbb. I. c. fig. 1466; Panicum glaucum L., H. II, 117 (Blaagraa Hirse).

Hele Planten blaagrøn, Svøbets Borster brandgule; Tvekjonsblomstens Inderavner paatværs rynkede, dobbelt saa lange som den øvre Yderavne, forøvrigt som Nr. 97, men Smaaaxene dobbelt saa store som hos hiin.

(De her i Landet fundne Expl. have (2) Støvdragere i den ufrugtbare Blomst.) 7-8. $\odot$.

Paa lignende Steder som foreg., men hidtil kun funden paa faa Steder: Horagre ved N. Orslev og i en Havremark ved S. Kirkeby paa Falster (Koch)! Fyen? (Brnun). 可

\section{Digitaria. Fingerax.}

99. D. glabra (Fremliggende F.) D. humifusa Pers., H. 66 ; And. XI, 120 ; H. N. I, 76 ; L. Herb. IV, 68; D. filiformis Koel., Rchb. I, tab. 27, fig. 1406; Panicum sangvinale Poll. (ikke L.), 
F. D. 388 (slet) og 2641 ; P. glabrum Gaud., Lge. Haandb. 1 Udg. S. 51.

Blade og Skeder glatte; Skedehinden kort; Axene linieformede, 3-4 fingerformigt sammenhobede; Smaaaxene wgformede, alm. 2 samlede, det ene siddende, det andet kortstilket; Blomsterne stakløse, duunhaarede; den øvre Yderavne korthaaret, næsten af Længde med Smaaaxet; Inderavnerne af Tvekjonsblomsten budte, glatte, glindsende.

Straaene oftest fremliggende, rode. Blst. bruunagtige. 7-9. $\odot$.

Paa sandige Marker og Veie, temmelig sjelden i Danmark: $\boldsymbol{S}$ j. Hellebæk! Fredensborg Slotsgaard (12), Stiftsbjergby (Weilbach); Falst. alm. (14); F. Dalby paa Hindsholm! $S l$. Bommerlund (16), Handeved Skovkro! Isted (16), i det sydlige (f. Ex. ved Rendsborg!) hyppigere. $\overline{ }$

$\dagger$ D. sanguinalis [Scop. Carn. I, p. 52] (Blodhirse). Rchb. I, tab. 27, fig. 1407-8; Panicum sangvinale L.

Blade og Skeder stivhaarede; Axene 5-7 fingerformigt sammenhobede, længere end hos foreg., Smaaaxene elliptiske, forøvrigt som foreg. men Straaene høiere og kraftigere, oprette eller opstigende; Blomsterne stærkt rødviolet anløbne. 7-9. $\odot$.

$\alpha$, genuina. Den golde Blomsts Inderavne i Randen svagt duunhaaret.

$\beta$, ciliaris Gren. \& Godr. (D. ciliaris Koel., Panicum ciliare Retz.) H. N. XIII, 88. Den golde Blomsts Inderavne paa Sidenerverne langt randhaaret.

Indført med fremmed Sæd: $\boldsymbol{S} \boldsymbol{j}$. Snedkersteen ved Helsingør (Heiberg, $\beta$ ), Ukrud i Haver ved Jonstrup $(14, \alpha$ !).

\section{Panicum. Ilirse.}

$\dagger P$. miliaceum L., Metzg. Cereal. t. 18 (Hirse).

Bladene linie-lancetformede, tilligemed Bladskederne stivbaarede; Skedehinden kort, langhaaret-fryndset; Toppen rigtblomstret, med oprette, imod Frugtmodningen nikkende Grene; Smaaxene $x$ gformede, glatte; Inderavnerne af Trekjønsblomsten budte, glatte, glindsende.

Straaene oprette. Toppen alm. rødigt anløben. 7. $\odot$. 
Oprindelig fra Orienten, dyrkes hyppigt i Sydeuropa, sjeldent i Danmark. Funden forvildet paa en Horager ved N. Orslev paa Falster (Koch).

\section{Echinochloa. IIanespore.}

100. E. crus galli [Beauv. agr. 53] (Kantet H.) Rehb. I, tab. 29, fig. 1411--12; L. Herb. IV, 69; Panicum L., H. 65; F. D. 1564 ; And. XI, $119 ;$ H. N. I, 75.

Bladene rue, uden Skedehinde; Axen forlænget, femkantet; Yderavnerne og den nedre Inderavne $i$ den golde Blomst stivhaarede; Inderavnerne af den tvelijonnede Blomst glatte, glindsende.

Straaene snart opstigende, snart fremliggende, Blomsterne oftest rødligt auløbne, var. med kortere eller langere Stak. 7-8. $\odot$.

Paa dyrket, saavel sandig som leret Jord, sporadisk: $\mathbf{S} \boldsymbol{j}$. Karise (Kyll.); Falst. Moseby (14); Loll. Søholt (H.), Maribo (5); Als (H.); $S i$. Bredsted (16).

\section{Digraphis. Rorgras.}

101. D. arundinacea [Trin. Fund. agr. p. 127] (Almindeligt R.) Drej. n. 66; And. XII, 135; L. Herb. VII, 122; Phalaris L., H. 64 ; F. D. 259 (slet); Baldingera Dumort., Rchb. I, tab. 52, fig. 1494.

Toppen med korte, under Blomstringen aabne Grene og knippeformigt sammenhobede Smaaax; Yderavnerne tilspidsede; Blomsterne stakløse, de golde meget smaae; Bladene brede, rue; Skedehinden forlænget.

$3-5^{\prime}$ høit, stivit Græs. Yderavnerne alm. rødviolette med grønne Nerver. Frugten tret omgivet af de glatte, glindsende Inderavner. 6-7. 4.

Ved Bredderne af Søer, Aaer og Bække, alm. udbredt i Danmark.

\section{Phalaris. Glandsfro.}

$\uparrow$ 102. P. canariensis L. (Kanariegræs). H. 63 ; Drej.p. 25 ; Rehb. I, tab. 52, fig. 1492; And. XII, 134; L. H. II, 26.

De øvre Blades Skeder bugformigt oppustede; Skedehinden lang; Dusken axformigt sammentrengt, oval; Smaaaxene omvendtægformede; Yderavnerne spidse, udadtil med en bred, bue- 
formet, grøn Nerve indenfor den hvidvingede Kjøl, indadtil med en ret Nerve, parallel med de næsten ret afskaarne Rande; de golde Blomster af Trekjønsblomstens halve Længde. 7-8. $\odot$.

Dyrkes paa flere Steder og forekommer hist og her forvildet paa Marker og ved Veie.

\section{Anthoxanthum. Guulax.}

103. A. odoratum L. (Vellugtende G.) H. 34 ; Drej. n. 79 ; F. D. 666 ; Rehb. I, tab. 106 , fig. 1722-25;And. XII, 136; L. Herb. II, 27.

Skedehinden forlænget, forneden skjæghaaret; Dusken lancetformet, før og efter Blomstringen axformigt sammentrængt; Yderavnerne spidse; de golde Blomster beklædte med (alm.) brune Haar, den ene med en ret, den anden med en længere, knæbøiet Stak.

Ved Torringen vellugtende Græs, som tidligt antager en guul Farve. Var. efter Voxestedet i Henseende til Størrelse, Beklædning, Bladenes Brede, Blomsterstanden o.s. v. 5-6. 4 .

Folgende Former kunne særligt fremhæves:

$\alpha$, vulgare, lavere af Væxt $\left(6-8^{\prime \prime}\right.$ høi), ofte mangestænglet, Dusken tætblomstret, bred-lancetformet eller elliptisk, Blomsterne alm. bruunligt anløbne.

$\beta$, majus! (Rchb. l. c. fig. 1724), høi og kraftig (1/1/2-2' høi), Dusken rigblomstret, tæt eller forneden mellembrudt, forlænget, næsten pyramideformet; Bladene bredere.

$\gamma$, laxiforum! Stænglerne faa, langstrakte $\left(1-1^{1} / 2^{\prime}\right.$ bøie) men meget fine, Bladene meget smale, Dusken smalt lancetformet, alm. grøn, Smaaaxene færre og fjernere fra hinanden, nogle stundom golde.

Paa Græsmarker, Enge, i Skove meget almindelig. Formen c forekommer især paa solaabne Steder, $\gamma$, i Skygge; $\beta$, sjeldnere, f.Ex. Brøndsted i Jylland! 


\section{Alopecurus. Havehale.}

a. Yderavnerne spidse, indtil Midten sammenvoxne. Straat opret (ellerkun med et Kuæ ved det nedre L,ed).

104. A. pratensis L. (Eng-R.) H. 69 ; Drej. n. 62 ; F. D. 1985 ; Rehb. I, 1479 ; And. XI, 127; H. N. X, 88.

Straaet jævnt; Dusken valseformet, foroven og forneden afrundet, med $4-5$ Smaax paa hver Green; Yderavnerne tæt og stivt haarede, længere end Inderavnen.

$1^{1} / 2-3^{\prime}$ høi. Stakken ret, var. i Længde. Blomsterne snart grønne, snart farvede. $5-6$. 4 .

Paa Enge og lavtliggende Græsmarker, ved Veigrøfter, i de ostlige Egne af $S \boldsymbol{j}$ a $l l$. alm., sjeldnere $\bmod \mathrm{V}$; $\boldsymbol{F}$. sporadisk: Holstenshuus, Rodkilde, Ollerup, Svendborg! Bornh. Rønne, Hasle (20); synes at mangle paa de gvrige Øer samt i de fleste Egne af $\boldsymbol{H}$ alv. oen; de eneste mig belsjendte Voxesteder, ere: J. Hurup Kirkegaard (Andresen), Rydhave ved Holstebro (Sehmidt), Veile, Kolding (7), Ribe (6); $S l$. Haderslev (7), Syderhøft i Eidersted (F. Müll.).

Anm. A. nigricans I., som adskilles ved krybende Udløbere og kortere, tilsidst sortagtig Dusk, er endnu ikke funden i vor Flora.

105. A. agrestis L. (Ager-R.) H. 70 ; Drej. n. 61 ; F.D. 697 ; Rekb. I, tab. 49, fig. 1473 ; And. XI, 125; H. N. IV, 85 ; L. Herb. I, 12.

Slraaet oventil ru; Dusken valseformet, i begge Ender tilspidset, med 1-2 Smaax paa hver Green; Yderavnerne svagt randhaarede, lidet kortere end Inderavnen.

1-2' høi. Stakken bøiet, udgaaer nærved Grunden af Inderavnen og er dobbelt saa lang som denne. 7-8. $\odot$.

Paa dyrkede Marker, isier mellem Sæden og hyppigst paa Leergrund: $S \boldsymbol{l}$. hyppig mellem Rapssæeden i Marskegnene (H.) samt ved Veie og i Agerrene i Eidersted (N.), Schauendal (16); Als (19); paa Loll. et alm. Ukrud i Vaarsaden omkring Maribo (14), Rødby og Nakskov! Falst. Ourupgard (Koch), Nasgaard; Moen Stege (14); $S j$. Farimagsveien ved Kjobenhavn! Amager ved Kastrup o. Al. St.! (I mange Egne af Landet (isier mod N.) forekommer den aldeles ikke. 读

b. Yderavnerne budte, ved Grunden sammeuvoxne. Straaet knabøiet, ved Grunden nedliggende.

106. A. geniculatus L. (Kineboiet R.) H. 71; Drej. Haandb, i den danske Flora. 
n. 60 ; F. D. 861 ; Rehb. I, tab. 49, fig. 147i; And. XI, 128 ; H. N. X, 89; L. Herb. III, 47.

Yderavnerne randhaarede; Inderavnerne med en bøiet Stak: befxstet nedenfor Midten og ragende udenfor Smaaaxet, (omtrent af Yderavnernes dobbelte Lxngde).

Smaaaxene mørkviolet anløbne, Støvknapperne violette eller skidenbrune. 5-8. $\odot$.

Paa fugtige, oversvommede Steder ilmindelig udbredt.

107. A. fulvus [Sm. Engl. Bot. 1467] (Guul R.) H. II, 117; Drej. 1. 59; F. D. 1804 ; Rehb. I, tab. 49, fig. 1476 ; And. XI, 129; H. N. X, 90 ; L. Herb. III, 48.

Yderavnerne randhaarede; Inderavnerne paa Midten stakbærende; Stakken ret, af Længde med Y deravnerne og indsluttet i Smaaaxet.

Planten har en mere blaagron Farve end foreg., Smaaaxenegrønne, Støvknapperne brandgule. 5-8. $\odot$.

Paa lignende Steder som foreg., bemærket $\mathrm{i}$ alle Provindser, men mindre hyppig.

\section{Phleum. Rottehale.}

a. Yderavnerne afstumpede med en Braad, intet Spor til en anden Blomst i Smaaxet. (Phleum Beauv.).

108. P. pratense L. (Eng.R.) H. 67; Drej. n. 63 ; F. D. 1984 ; Rehb. I, tab. 50, fig. 1483; And. XI, 130; L. Herb. V, 98.

Dusken foroven og forneden afrundet; Smaaaxene stilkløse; Yderavnerne paa Ryggen randhaarede, 3 Gange længere end den $\mathrm{i}$ Spidsen befiestede Braad.

$1-3^{\prime}$ høj. Stratat stribet. $6-9 . \odot$.

$\boldsymbol{\beta}$, nodosum (P. nodosum L., F. D. 380). Straaet ved Grunden knolleformigt opsvulmet; Dusken kortere.

Faa Enge og Græsmarker almindelig vildvoxende og dyrket (underNavn af Timotheigr(es). $\beta$, pan tørrere Steder. 
b. Yderavnerne tilspidsede, Ansats til en anden Blounst. (Chilochloa Beauv.)

109. P. Borhmeri [Wib. fl. Werth. p. 125] (Glat R.) H. 68 ; Drej. n. 64 ; L. Herb. I, 11 ; Chilochloa Beauv., Rehb. I, tab. 51, fig. 1488; Phalaris phleoides L., F. D. 531 ; Phleum phalaroides Koel., And. XII, 132; H. N. XI, 84.

Dusken foroven noget tilspidset; Smaaaxene stilkede, paa halvt.krandsstillede, tiltrykte Grene; Yderavnerne paa Ryggen rue eller svagt randhaarede.

$1 / 2-11 / 2^{4}$ høi. Frembringer blomsterløse Bladknipper fra Rodstokken; Straaet glat, glindsende, svagt stribet, ofte rødagtigt. Let kjendelig ved den smale, og naar den boies, tydeligt grenede Dusk. 6-7. 4 .

Paa torre, sandige eller kalkholdige Bakker, sporadisk $\mathrm{i}$ det nordlige og nordestlige $\boldsymbol{J} y l l$. (til Aarhus); i Nordsjalland! paa Moen (Dr.); B ornh. ved Hammershuus (20). (I Fyen, Lolland og Falster er den hidtil ikke bemærket.)

110. P. arenarium L. (Sand-R.) H. 69 ; Drej. n. 65 ; F. D. 915 ; Rehb. I, tab. 50, fig. 1482; And. XII, 133; II. N. II, 72 ; L. Herb. III, 46.

De øvre Bladskeder oppustede; Dusken valseformet eller omvendt-ægformet, forneden smalere; Smaaaxene stilkløse; Yderavnerne lancetformede, paa Ryggen stivt randharede.

2-6" høi. Stænglerne talrige; ingen golde Bladknipper. Dusken almindelig kort. 5-6. $\psi$.

Paa Havstokken og sandige Overdrev nær Havet: paa II alveen alm. i kiliterne mod V. (H.) og paa Øerne i Vesterhavet, f. Ex. Fanø, Romø (16); paa Oerne sporadisk: $S j$. Kongsøre i Odsherred (15), Adserbo Overdrev! Frederiksværk (H.), Lappesteen ved Helsingør (21), Havstokken S. for Kjøge! Feddet ved Lindersvold; M $\boldsymbol{M}_{\theta}$ en: Ulfshale (II.) og Budsemark (9); Falst. Gronsund (9); Loll. Kramnitze (H.) o. fl. St. paa Havstokken mellem Rødby og Nakskov Fjord; Langeland v. Spodsbjerg (19); B ornh. ved Hammershuus (2).

\section{Psamma. IJjelme.}

111. P. arenaria [R. \& S. syst. 2 p. 845] (Sand-H.) Ammophila Link; Drej. n. 76 ; Lge. Haandb. 1. Udg. p. 55; Rehb. I, tab. 44, fig. 1454 ; L. Herb. V, 81; Arundo L., 
H. 85 ; F. D. 917 ; Calamagrostis Roth, And. VIII, 92 ; H. N. XIII, 90 .

Dusken valseformet, foroven tilspidset; Yderavnerne lancetformede, spidse; den nedre Inderavne over dobbelt saa lang som Haarene, med en kort sylformet Braad nedenfor den tokløvede Spidse.

$2-3^{\prime}$ høj. Hele Planten, Dusken indbefattet, blegt blaagraa. Bladene indrullede, med forlænget, spids Skedehinde. 7-8. 4.

Paa Flyresand ved Havet, almindelig, især paa Halvøen og i Nordsjelland; sjeldnere paa sandige Bakker inde i Landet (f. Ex. Ø. Nykirke i Jyll.; Rendsborg!)

112. P. baltica [R. \& S. l. c.] (Østersøisk H.) Ammophila Link; Lge. Haandb. 1. Udg. p. 56 ; Rchb. l. c. fig. 1455; Arundo Flügge, H. 86; F. D. 1684 (ikke god); Calamagrostis Hartm., And. VIII, 93; Fr. H. N. I, 74.

Dusken smalere og mere tilspidset, med længere Grene og derved lappet; Yderavnerne sylspidsede; den nedre Inderavne neppe dobbelt saa lang som Haarene, i Spidsen fiint tokløvet, med en haarformet Stak nedenfor Spidsen, af Længde med eller lidet længere end Indskjæringen.

$2-3^{\prime}$ høi, mindre blaagraa; Dusken rødviolet; Bladene tilsidst indrullede, forøvrigt som foreg. 7-8. $थ$.

Paa sandige Strandbredder ved Kysterne af Vesterhavet og Østersøen: $\boldsymbol{S} l$. Klitterne ved Eidersted (N.), Frederiksort, Bieverør, Holdnæs (16); Als (N.); Langelands Østkyst (19); Loll. Bredfjed (5); F alst. Tromnæs! Grønsund (14), Bøtø (5); S j. Harstokken (Jædderen) N. for Kjøge (9); Bornh. Nebberodde ved Rønne! Hasle (11). (I Kattegatpartiet forekommer den neppe.) [F

\section{Calamagrostis. Ror.}

a. Yderavnerne læderagtige; Haarene længere end Inderavnerne; Stakken ret. (Stive, bredbladede Græsser: Orophila Fr.)

113. C. Epigejos [Roth tent. Al. germ. 1, 34] (Bjerg-R.) Drej. n. 73; Rchb. I, tab. 43, fig. (1451 og) 53; And. VIII, 85, H. N. VIII, 85, Arundo L., H. 81; F. D. 2165.

Toppen stivt opret, sammenhobet-lappet; Yderavnerne lan- 
cetformede, sylspidsede, efter Blomstringen lukkede; Stakken be fæstet paa Midten af den i Spidsen tokløvede Inderavne; kortere end Haarene.

1-3' høi. Straae og Blade rue. Toppen paa aabne Steder rødviolet; i Skygge mere gron. Var. (efter Fr.) med Stakken befæestet i Indskjæringen. 7-8. 4 .

ק, glauca (Blytt, Norsk Fl. p. 134; Rehb. 1. c. fig. 1452; C. glauca M. Bieb.) Blaagrøn, med læengere og mere aabne Topgrene, Stakken længere end hos Hovedarten.

Ikke sjelden paa lerede og sandige Skrænter ved Strandbredder, mindre hyppig i Skove; $\beta$, paa mere fugtig Grund, men sjeldnere: Folehave Skov ved Horsholm, Kjobenhavns Omegn! Flyng (8), Magleby Dyrehave p. Stevns (Visby), Stokkebjerg Skov (Weilbach); F a lst. Guldborg (Koch); F. Hofmansgave (18).

b. Yderavnerne hindeagtige, Stakken ret, indsluttet i Smaaret (Straaet tilsidst grenet:

$$
\text { Helophila Fr.) }
$$

114. C. Langstortii [Trin. diss, de Gram. 1824 p. 225]? H. N. XIII, 89; C. phragmitoides Lge. Haandb. 1 Udg. (ikke Hartm.); C. rubicunda Blytt., Norges Fl. p. 91 (?); C. nutans Saut., Rchb. I, tab. 40, fig. 1446 (?) en større Form; Arundo Ps eudophragmites Nolt. nov. p. 11.

Toppen opret eller noget nikkende, med under Blomstringen udbredte, senere oprette Grene; Yderavnerne under Blomstringen aabue, lancetformet-tilspidsede; Stakken ountrent ligelang med og befæstet ovenfor Midten af Inderavnen; Haarene omtrent af lige Længde med Inderavnen.

$2-3^{\prime}$ høi; Bladene $3-5^{\prime \prime \prime}$ brede, Skedehinden forlænget. Toppen hos mit Expl. blaagron med svagt rodligt Anstrøg. 7. 4.

Paa fugtige Steder, i Skove: $\boldsymbol{S} \boldsymbol{j}$. Sjæl-S $\boldsymbol{\rho}(7) ; \boldsymbol{J}$. Vesterengene og Twihuushaven ved Randers (7). [ [

Anm. Det Expl. jeg har for mig til Beskrivelse, meddeelt af Apotheker Jensen under Navn af $C$. Halleriana, afviger fra $C . p h r a g m i t o i d e s$ His. ved en bleggron Top, mindre stive Blade og Inderavnen litugere end Haarene. Fra Expl. af $C$. gracilescens Blytt (C. Halleriana Fr. i H. N. VIII, $85 \mathrm{og} \mathrm{X}, 93$ ) afviger den mere ved Toppens Form og Bladenes Brede. C. Pseudophragmites (Schrad.) Rehb. synes forskjellig fra vor Art ved koltere, tversafskaaren Skedehinde, inørkere (violet) 
Top, større Smaaax og Haarene længere end Inderavnen. Bedst stemmer den overeens med saavel Beskrivelse som Afbildning af C. Langsdorfi, hvortil jeg derfor troer at maatte henføre den. Expl. i H. N. fra St. Petersborg ere aldeles lignende det jydske, med Undtagelse af at Haarene hos hiin ere noget længere elld hos denne. Blytt (l. e.) antager imidlertid ikke den i H. N. VIII fremstillede Plante for den ægte C. Langsdorfii Trin., men henfsrer saavel H. N. XIII, 89 som C. nutans Saut. med Tvivl til sin C. rubicunda. Da Stakkens Tilhæftningspunkt og relative Længde til Inderavnen og Haarene varierer hos denne og nærstaannde Arter, er det vanskeligt at henfore et tørret Exemplar med Bestemthed til nogen af de talrige Arter, der ere opstillede $i$ denne Slægt, og af hville endeel synes endnu ikke at være aldeles fast begrundede. En ngiagtig Undersygelse af de danske Calamagrostis-Arter maa særdeles anbefales Botanikerne, og vigtige Hjælpemidler hertil ville findes hos Fries (mant. 3, S. Veg. Sc., H. N.) og Blytt (l. c.)

115. C. lanceolata Roth. [l. c.] (Eng-R.) Drej. n. 72; Blytt, Norg. Fl. p. 93; Rchb. 1. c. fig. 1448; And. IX, 96; H. N. X, 92; Arundo Calamagrostis L., H. 82 ; F. D. 280 (slet), 1624.

Toppen noget nikkende, med udbredte Grene; Yderavnerne sinalt laneetformede, tilspidsede, efter Blomstringen aabne; Stakken meget kort, befæstet i Spidsen af den udrandede Inderavne; Haarene længere end Inderavnerne og nxsten ligelange med Yderavnerne.

$3-4^{\prime}$ høi. Straaet jævnt, Skederne jævne eller oventil rue. Bladene smalere end hos foreg., Toppen alm. rodt anløben, men var. efter Voxestedet mere grøn. 6-7. $\psi$.

Anm. Stakken alm. lidet længere end Indsnittet, men var. i Lengde (C. gracilis Schum. I, 35; H. 85; Drej. n. 71, er kun en spæd Form af denue Art med ingen eller meget utydelig Stak).

Paa Enge mellem Krat, i Skove, ikke sjelden i Danmark. (Formen gracilis paa Strandklinterne mellem Taarbak og Springforbi, Sclium.)

116. C. neglecta [Ehrh. Beitr. 6, 137 under Arundo] (Stivtoppet R.) And. IX, 100; H. N. VIII, 87; Arundo stricta Timm, H. 83 ; F. 1). 1803 ; L. H. IV, 62 ; Calamagrostis str. Hartm., Drej. n. 74; Blytt, Norges Fl. p. 85 ; Rchb. I, tab. 37, fig. 1439; Agrostis coarctata Schum. I, p. 24.

Toppen stivt opret, med korte, under Blomstringen aabne, før og efter samme smalt sammenknebne Grene; Yderavnerne æg-lancetformede, spidse, efter Blomstringen lukkede; den nedre 
Inderavne længere end Haarene, med en Stak. som udgaaer lidet nedenfor eller orenfor Nidten og naaer omtrent til Spidsen; Ansats til en anden Blomst (i Form af et fint Haarknippe ved Grunden af den øvre Inderavne).

1-3' høit, stivt Græs med jævne eller lidet me Skeder, kort Skedelinde; Bladene paa Grenene indrullede. Toppen i yngre Tilstand morkviolet, blaagraat anløben. 6-8. 4 .

$\beta$, geniculata Fr. H. N. VIII, 88. Straaene ved Grunden knæbøiet-opstigende.

I Moser og paa fugtige Skovenge, hidtil kun funden paa Halvsen $\circ \mathrm{g}$ i Nordsjalland og ikke almindelig: $\boldsymbol{S} \boldsymbol{j}$. Adserbo Overdrev! Lille Vierløse, Hesttangs Mrslle (Dr.), Lundelnumsmosen! Boserup (20), Dronninggaards store Mose (9), Jonstrnp Vang (15); J. Gravens Mose i V. Hanherred (16), Fjerritslev (Gronluud), Skjørring Hovkjær, 'J'andrup i Thy, Kjærs Molle ved Aabborg (Dr.), Ranum ved Logstor' (8), Hornbak (16) og Vesterengene ved Randers (7); Sle svig (Rchb.). $\delta$, med Hovedarten i Lundehunsmosen!

c. Ugrenede Græsser med knæbøiet Stak ragende udenfor de hindeagtige Yderavner.

$$
\text { (Nemophile Fr.) }
$$

117. C. arundinacea [Roth. fl. germ. II, 1, p. 89] (Skov-R.) Blytt, Norg. Fl. p. 82; C. silvatica DC., Drej. n. 75; Rehb. I, tab. 38, fig. 1440; And. IX, 104; H. N. VIII, 90; Arundo Schrad., H. 84 ; F. D. 1683 ; L. Herb. V. 82 ; Agrostis arundinacer L.

Toxpen opret, med korte, stivhaarede, under Blomstringen aabne, for og efter denne sammenknebne Grene; Yderavnerne lancetformede, tilspidsede, efter Blomstringen lukkede, den avre neppe liengere end Inderavnerne; Stakikn nedenfor linæ. boiningen snoet, udgaaende fra Grunden af den nedrẹ Inderavne og næsten dobbelt saa lang som denne; Harene meget korte ( $1 / 4$ af Blomstens Længde); Ansats til en anden Blomst.

1-4' høi, stiv; Skederne jrevne eller lidet rue, de nedre ofte haarede! Skedehinden forlinget. 7-8. 4 .

I hoitliggende Skove og paa Baklker mellem Krat, forekommer par mager Jordbund: i Jyllands Hedeegne hist og her; sjelden paa Derne: $\boldsymbol{S} j$. Marienlyst ved Helsingør! Niesgatard ved Dronningaard 
(14), Naaleskoven i Gjelskov mod Søllerød! Bisserup ved Skjelskør (Nielsen); Bornh. i Almindingen (H.). [*

\section{Agrostis. IIvene.}

a. Apera Adans. Den nedre Yderavne mindst, Inderavner, den uedre med en forlænget Stak; Ausats til en anden Blomst.

118. A. Spica renti L. (Langstakket H.) H. 73; F. D. 853; And. X, 108; Apera Beauv., Drej. «. 70; Rchb. I, tab. 32, fig. 1421 ; L. Herb. II, 22.

Toppen pyramideformet, med talrige udspærrede Grene, før Blomstringen nikkende, under og efter samme opret; Stakken lige eller svagt bøiet, fæstet tæt under Spidsen af Inderavnen og 3-4 Gange længere end deune.

$1-3^{\prime}$ høi. Toppen grøn eller violet anloben. 6-7. $\odot$.

Paa dyrkede Marker, saavel paa leret som sandig Grund, ikize. sjelden, men forekommer ikke i alle Egne, hyppigst (og et besværligt Ukrud mellem Sxden) paa Bornholm, Lolland og Falster samt i flere Egne af Jylland.

b. Trichodium Michaux. Den nedre Yderavne størst; 1 Inderavne med en knæbøiet Stak.

Ingen Ansats til en anden Blomst.

119. A. canina L. (Hunde-H.) H. $75 ;$ Drej. n. $67 ;$ F. D. 1443 ; Rehb. I. c. fig. 1424 ; And. X, 112; H. N. IX, 87 ; L. Herb. II, 21; A. rubra H. 74 (efter de danske Voresteder).

Rodstokken sammentrængt, udskyder tueformigt samlede Straa og golde Bladknipper eller tillige krybende Udlobere;: Rodbladene børsteformede; Stcongelbladene flade; Skedehinden aflang; Toppen under Blonstringen aaben, for og efter samme sammenkneben; Stakken befastet nedenfor Midten af Inderarnen, (almindelig fremirgende udenfor Smaaxet).

Toppen mørk violet-rødbruun, undertiden af blegere, endog straaguul Farre ( $\beta$, pallida Relıb. 1425). Var. desuden med kortere eller langere, tæt- eller faablomstrede 'Topgrene, bredere eller smalereStrengelblade og med kort eller aldeles ingen Stak. 6-8. $\psi$. 
Paa torvholdige Enge, i Hedemoser, ikke sjelden, især hyppig paa Halvøen og i Nordsjælland. $\beta$, Strandbredden ved V. Skjerninge i Fyen!

Anm. Fig. i F. D. viser ikke de borsteformede Rodblade.

c. Vilfa Beauv. Yderavnerne omtrent ligestore eller den nedre storst, 2 Inderavner uden (eller med meget kort) Stak. Ingen Ansats til en anden Blomst.

120. A. Valgaris [With. arr.p. 132] (Almindelig H.) H. 76; Drej. n. 68 ; Rchb. l. c. fig. 1427; And. X, 110; H. N. XI, 83 ; L. Herb. VII, 123; A. capillaris F. D. 163; Rafn I, 523.

Alle Bladene flade; Skedehinden kort, afstumpet; Toppen i Omkreds pyramideformet eller ægformet, med under og efter Blomstringen udspærrede Grene.

Smaaaxene fine, rødagtige, sjeldnere grønne. 6-8. थ.

$\boldsymbol{\beta}$, stolonifera (A. stolonifera $\alpha$, L.) ned Udløbere og fremliggende Bladknipper.

$\gamma$, tenella (A. tenella Hoffm.) Topgrenene haarfine, Smaaaxene bleggrønne, meget sinaae.

$\delta$, pumila F. D. 1902 (A. pumila L.) Dværgform (1-2" høi) med rundagtige Smaaax (er en ved Brandsvampe i Blomsten frembragt sygelig Form).

$\varepsilon$, vivipara Schrad. (Rehb. 1429) med topspirende Smaax (den nedre Inderavne grøı, 5-nervet, dobbelt saa lang som Yderavnerne).

Paa Græsmarker, høie Enge, ved Veie, i Skove o. s. v. meget alm. over hele Landet: $\beta$, paa frugtbar Jord, $\boldsymbol{\gamma}$, i Skove, $\delta$, paa torre, sandige Bakker, $\boldsymbol{\varepsilon}, \boldsymbol{S} \boldsymbol{j}$. Skjelskor (Nielsen); $\boldsymbol{J}$. paa Skovenge ved Brondsted!

121. A. alba L. (KKrybende H.) H. 79 ; Rafn I, 529; F. D. 1623 ; A. stolonifera Drej. n. 69; H. 77, Rehb. l. c. fig. 1430 ; And. X, 109, L. Herb. IV, 61.

Alle Bladene flade; Skedehinden aflang; Toppen langagtigoval, med efter Blomstringen sammenknebne Grene.

Smaaxene større end hos foreg., grønne eller blege, sjeldnere rodligt anløbne; har undertiden en kort, ret Stak nedenfor Spidsen 
af Inderavnerne, Rodstokken udsender alm. vidtkrybende Udløbere og opstigende Bladknipper. 7-8. 4 .

Anm. Af de talrige Former, hvorunder denne Art efter Voxestedets Forskjellighed fremtræder, nævnes som de meest udmærkede:

$\beta$, coarctata Blytt. 149; (A. flava F. D. 751 ; Rafn I, 525) Toppen forlænget, med korte Grene, Smaaaxene ofte bleggule.

$\gamma$, maritima Mey. Chl. han. (A. maritima Lam., Rehb. 1. c. fig. 1436 ; A. stolonif. $\beta$, L. sp., F. D. 564 ? (slet). A. stol. decumbens Rafn. I, 522). Bladene stive, blaagrønne, Toppen axformigt sammentrengt.

$\delta$, gigantea Rchb. I. c. fig. 1433; I. Herb. VII, 124; (A. gigantea Roth) $2-3^{\prime}$ høi, med talrige, lange og mangeblomstrede Grene.

$\varepsilon$, vivipara Rchb. I. c. fig. 1434 (A. silvatica L., Rafn. I, 524; A. alba silvatica H. 71)? Smaaaxene topspirende.

Meget almindelig i Danmark, forekommer baade paa torre og funtige, skyggefulde og aabue Steder. $\beta$, ved Strandbredder, f. Ex. i det sydlige Lolland, Nlat $₫$ (Koch); $S l$. Dyttebsl Strand ved Gelting (Lund); $\gamma$, i Flyvesandet f. Ex. Vendsyssel (26), Thy (7), alm. i Klitterne V. for Lemvig! Blaarands Huk (28), Sl. Eidersted (F. Müll.); $\mathcal{d}$, ikke sjelden paa fugtig Leergrund; $\boldsymbol{\varepsilon}$, (efter Hornem.) i Skove. (Saavel denne som foreg. benævnes alm. Fioringrces).

\section{Miliun. Miliegraes.}

122. II. Pffusum L. (Udspredt M.) H. 72; Drej. n. 77; F. D. 1143 ; Rchb. I, tab. 45 , fig. 1456 ; And. X, 115; L. Herb. VII, 121.

Topgrenene haarfine, under Blornstringen horizontalt udspærrede, efter samme nedhængende; Smaaaxene xgformede; Inderavncrne stakløse.

2-3' høit, glat, lysgrønt Græs med brede, slappe Blade, lang Skedehinde. 6. 4 .

Paa Muldjord i Løvskove almindelig.

\section{Melica. Flittcrax.}

123. M. unillora [Retz. obs. I, 10] (Enblomstret F.) H. 98 ; Drej. n. 96 ; F. D. 1144 ; Rchb. I, tab. 72, fig. 1576; And. VIII, 89 ; H. N. XIV, 89 ; L. Herb. VII, 125. 
Skedehinden spids, hindeagtig med grøn Midtnerve, modsat Bladet; Toppen ensidigt grenet med oprette, toblomstrede Smaaax; den nedre Blomst tvekjønnet, den ovre ufuldkommen.

Skeder og Straae jævie, Topgrenene med 1-4 Smaaax, Yderarnerne ungrkrode. 5-6. थ.

I skyggefulde Skove paa Muldjord almindelig i Danmark.

124. I. nutans I. (Nikkende F.) H. 98; Drej. n. 97; F. D. 962 ; Rehb. I. e. fig. 1577 ; And. VIII, 90; L. Herb. IV, 63 .

Sliedehinden utydelig; Toppen klaseformigt sammentrængt, ensidig, med korte Grene og nikkende, treblomstrede Smaaax; de 2 nedre Blomster ఫ, den ovre ufuldkommen. .

Straaet oventil firekantet, tilligemed Skederne rue, Topgrenene alm. med 1 Smakax, Yderavnerne som foreg. 5-6. 4 .

I Kratskove, isier paa fugtig Grund, sporadisk paa Halveens Ostlyst, i Sjalland og paa Bornholm; i Fyen sjeldnere: Langeskors Kro (16). Voxesteder fra Lolland og Falster ere mig lidtil ikke bekjendte).

\section{Hierochloa. Festgries.}

125. II. borealis [R. \& S. syst. II, 513] (Vellugtende F.) Drej. n. 80; Rchb. I, tab. 107, fig. 1728; And. XII, 137; H. N. VIII, 92; L. Herb. III, 41; Holeus odoratus L., H. 96; F. D. 963 .

Rodstokiken krybende; Straaet med meget faa (1-2) Led ved Grunden; Straabladenes Plade kort; Toppen udbredt, med glatte Grene; Smaaaxene bredt ægformede; den nedre Inderavne tæt randhaaret.

Vellugtende Græs, med brune, glindsende Smaaax. $0^{x}$ Blomsterne have undertiden en meget kort Stak. 4-5. 4.

I Enge og Moser, hist og her i Nordsjalland, sjeldnere paa de andre Der og paa II alvoen: $S$ j. ved Ladegaatrdsaen udenfor Kjobenhavn (19), Lundehunsmosen, Ordrup Mose! Jonstrup Vang (20), Leerbæks Mose ved Koeskilde! mellem Hove ng Vexo (14), Tiis S Munkebjergby (Lund); Thorseng ved Bukkeliave (12); J. Kjolbygaard og Tandrup i Thy (Carst.), Rantm v. Logstor (8), Hobro Skov (16), Grenaa (Meyer), Moesgaard ved Aarlus (2), Horsens (16), Stenderup S. for Kolding (Andersen), Engene ved Lonborg (16); Sl. Cluesriis ved Flensborg (12) og Kobbermolleskoven (16), Quellentlal ved Lyksborg, Klensby Eng red Slesvig, Molledammen red Husum (16). 


\section{Ilolcus. Hestegraes.}

126. Il. lanatus L. (Uldbladet H., Fløielsgræs). H. 95 ; Drej. n. 81; F. D. 1I8I; Rchb. I, tab. 105, fig. 1718-20; And. VIII, 85; L. Herb. VII, 126.

Straa og Blade fløielshaarede; Toppen under og efter Blomstringen aaben; den nedre Yderavne budt med en kort Braad; $\hat{0}$ Blomsten med en tilsidst hageformigt indbøiet, i Smaaaxet indsluttet Stak.

Hele Planten, formedelst den fløielshaarede Beklædning, graaagtig; Smaaaxene rødligt-anløbne, var. (argenteus R. \& S.), med sølvhvide Smaaax.

Paa Enge og i Skove meget almindelig. 6-7. $\%$

127. Il. mollis I. (Blødt H.) H. 96 ; Drej. n. $82 ;$ F. D。 1059; Rehb. l. c. fig. $172 \mathrm{I}$; And. VIII, 86 ; H. N. XIII, 91 ; L. Herb. V, 84.

Rodstokken krybende; Straaet og de øvre Bladskeder glatte, de nedre Skeder og Bladpladerne duunhaarede; Toppen under Blomstringen aaben, senere sammentrængt; den nedre Yderavne tilspidset; $\hat{\sigma}$ Blomsten med en knæbøiet, udenfor Smaaaxet fremragende Stak.

Blaagrøn; Smaaaxene oftest guulbrune. Var. med begge Blomster $\not{\zeta}$, den nedre stakløs, den øvre med en langt udtræedende, snoet, ikke knæbøiet, Stak. 7-8. 4.

I Kratskove, paa dyrkede, især sandige Marker ikke sjelden. Var. i Rudehegn (F. Schmidt), Hellebæk, Nakkehoved (Heiberg).

\section{Fluminia. Rorsvingel.}

128. F. arundiuacea [Fr. S. Veg. Sc. I, p. 247] (Vand-R.) And. VI, 66; Festuca Liljebl.; Glyceria Fr. mant. 2, p. 8; H. N. III, 93; Festuca borealis M. \& K.; Scolochloa festucacea Link, Rchb. I, tab. 71 , fig. 1573.

Rodstokiken ved Leddene rodslaaende; Toppen i Spidsen nikkende, med forlængede, opret-aabne, rue Grene; Smaaaxene 3-5-blomstrede; den nedre Inderavne 5-nervet, med 3 spidse Tænder. 
Hoit (omtr. 4') og stærkt Græs, de nedre Ledstykker nedsænkte i Vandet og udsendende krandsstillede Rodtrævler. Skedehinden forlaenget, en bruun Plet ved Grunden af Bladpladen. 6-7. 4 .

Ved Flodhredder, hidtil kun fundet i $S l$. ved Steinschleuse $\varnothing$. for Süderstapel (N.). 夙

\section{0. 'Triodia. Tandbalg.}

129. T. decumbens [Beauv. agr. p. 76] (Nedliggende T.) Drej. n. 95 ; Rehb. I, tab. 71, fig. 1572 ; And. VI, 67; H. N. IX, 97 (var.); I. Herb. VI, 101; Poa Scop., H. 112; Festuca L., F. D. 172 .

Straaene ved Grunden knæbøiede, nedliggende, under Blomstringen opstigende; Blade og Skeder haarede, en Haarkrands i Skedehindens Sted; Blomsterstanden klaseformet, med korte, 1-3-blomstrede, før og efter Blomstringen opret-tiltrykte Grene; Smaaaxene 3-5-blomstrede; Inderavnerne læderagtige, den nedre 7--9-nervet, ved Grunden og i Randen haaret.

$1 / 2-1 '$ høit, stivt Græs. 6-7. 4 .

Paa hoie Enge, Bakker, Lyngheder og aabne Steder i Skove, almindelig, især i Jylland, Nordsjalland, Lolland-Falster og paa Bornholm.

\section{Koeleria. Kambunke.}

130. K. cristata [Pers. syn. I, 97] (Randhaaret K.) Drej. n. 94 ; F. D. 2223 ; Rehb. I, tab. 93, fig. 1668-70; And. VII, 82; H. N. XIV, 88; L. Herb. II, 29 ; Aira L., Il. 87.

Bladene (især de nedre) i Randen og undertiden overalt langhaarede, jævne eller i Randen og paa Overfladens Nerver rue af en enkelt Række korte Børster; Skedehinden utydelig; den nedre Inderavne tilspidset.

Var. i Høide, Bladenes Brede, Smaaxenes Farve o. s. v. 6-7. य.

Paa torre Bakker, sjelden: $\boldsymbol{S} \boldsymbol{j}$. en lyngklædt Bakke ved Jagerspriis $(9) ; J$. ved Veien over Objergbakker fra Langsted Kro (Beek), Dybdals Bakker! og Sandgraven ved Aalborg (Dr.), Godtlatab ved Aalborg (Strandgaard).

131. K. glauca (DC. hort. monsp. 116] (Blaagron K.) Rehb. 1. c. fig. 1672 ; And. VII, 83; H. N. I, 72 ; L. Herb. IV, 70; Aira Schrad., H. 88; F. D. 1566. 
Blade og Skeder overalt fiint fløielshaarede (Overfladens Nerver med flere Rækker af meget fine Haar); Skedehinder kort afskaaren; den nedre Inderavne budt, stakløs eller med en kort Braad.

Tueformet, ved Grunden omgivet af de henvisnede, men vedblivende Skeder. Bladene red Tørring indrullede. Hele Planten paa Grund af Reklædningen blaagrøn. 6-7. 4 .

I Sandklitter, hidtil kun bemærlset i Klitterne mod Vesterhavet paa Halveen og de vestlige Øer (Horne (Dr.) ng. Tornby i Vendsyssel (12); Thorsted pr. Ringkjøbing! Blaavand, Fanø (H.), Romø (16). [F

\section{Aira. Bunke.}

132. A. Alexuosa L. (Bølgestæenglet B.) H. 89; And. VI, 71; F. D. 157 (slet); Rchb. I, tab. 95, fig. 1678-79; Avenella Bluff, Drej. n. 91; Avena M. K, L. Herb. VI, 106.

Bladene smale, børsteformede; Skedehinden toøret, paa de nedre Blade budt, paa de øvre spids; Toppen uảbredt, nikkende, med bølgeformigt bugtet Axe og Grene; Smaaaxene toblomstrede; Yderavnerne uligelange; de 2 Blomster i Smaaxet tæt samlede, omtrent ligelange med den ovre Yderavne, flere Gange længere end Haarkrandsen ved Grunden af Inderavnerne; Stakken knæbøiet, udgaaende ovenfor Grunden af Inderavnerne og fremragende udenfor Smaaaxet.

Var. paa forskjellige Voxesteder i Henseende til Smaaxenes Farve og Størrelse o. s.v. $1-1 \frac{1}{1 / 2}{ }^{\prime}$ høi. 6-7. 4 .

Paa Lyngheder, Bakker, i aabne Skove meget almindelig.

133. A. uliginosa [Whe. i Boenningh. fl. Monast. p. 25, (Sump-B.) F. D. Suppl. tab. 3 ; Rehb. 1. c. fig. 1681; Deschampsia Thuillieri Godr. \& Gren. fl. Fr. III, 508.

Rodbladene i tætte Tuer, meget fine, næsten baarformede; Skedehinden forlanget, tilspidset; Toppen opret, med haarfine, kun lidet bølgede og efter Blomstringen iklke udspærrede Grene; Yderavnerne næsten ligelange; Smaaxets øvre Ledstykke forlanget og den ovre Blomst derved fjernet fra den nedre; Stakken noget længere, Smaaxene mindre, forøvrigt som foreg. 7-8. 4.

I Hedemoser og klitsumper: synes at væere ndbredt over hele den nordlige og vestlige Deel af Halvøen, f. E. $\boldsymbol{J}$. Hjallerup i Vend- 
syssel, Fjerritslev i V. Hanherred; Agger og Blissø i Thy, Thorsted pr. Ringljobing, Neiberg i Hammerumlerred! Karlsmarsk Hede i Oxby Sogu (30), Hjortlund (12); Sl. Syderhøft i Eidersted (F. Müll.).

134. A. caspitosa L. (Mose-B.) H. 89; Drej. n. 92; F. D. 240 ; Rchb. 1. c. fig. 1682 ; And. VI, 69 ; L. Herb. VII, 133; Deschampsia Beauv.

Bladene flade, paa Overfladen og i Randen rue; Shedehinden forlænget; Toppen under Blomstringen udbredt, pyramideformet, opret; Smaaaxene toblomstrede med Ansats til en tredie Blomst; Inderavnerne med Haar af Blomsternes halve Længde; en knæbøiet eller næsten ret Stak ovenfor Grunden omtrent af Inderavnens Læengde, indsluttet $i$ Smaaxet.

Yderavnerne violette med brumnglindsende Rand, hvorved Smaaaxet faaer et broget Udseende. 2' høi, damer tætte Tuer. 6-7. 4 .

$\beta$, pallida Koch. (ochrolenca Rchb. l. c. fig. 1685). Yderavnerne uligelange; lividgule med grøn Rygnerve, Inderavnerne blege (solv-eller guldglindsende), Stakken ragende udenfor Smaaaxet.

$\gamma$, vivipara, med topspirende Smaar.

$\delta$, stolonifera, med Udløbere fra Rodstokken, Yderavnerne meget kortere end Smaaxet.

Paa Enge $n g$ ved Grofter meget almindelig. $\beta$, (en meget afvigende Form) Sj. Hellebrek! Liselund paa Moen! J. Srbygaards Skov (8), Vestervig (Andresen), $\gamma$, Søllested p. Lolland (19); $\delta$, Ollerup i Fyen (12).

$A n m$. Den ved Elbbredden udenfor Altona forekommende $A$. Wibeliana Sonder, F. D. 2461, som afviger ved Udløbere fra Rodstokken, mindre rue Blade, storre Smaaax af guulagtig Farve, tidligere Blomstringstid o. s. v. maı eftersøges $\mathrm{i}$ vor Flora, hor den sandsynligviis forekommer ved Bredderne af de storre Aaer.

\section{Corynephorus. Sandskjag.}

135: C. canescens [Beauv. agr. p. 90] (Graat S.) Drej. n. 93 ; Rehb. I, tab. 94, fig. 1674 ; And. VIII, 84 ; L. Herb. III, 45; Aira L., H. 92 ; F. D. 1023 ; H. N. I, 77.

Roden fiinttravlet; Straaene talrige, tueformigt samlede; Bladene stive, børsteformigt sammenrullede; Toppen med korte, uncler Blomstringen aabne Grene. 
4-8" hyit, stivt Græs af blaagraa Farve, Toppen violetagtigt anløben, sjeldnere bleg. 7-8. .

$\beta$, maritimus Gren. \& Godr. fl. Fr. III, 502. Straaene lavere, knæbøiede og mere udbredte, Toppen mindre.

Paa tørre, sandige Marker, i de magrere Enge af Landet almindelig og i Mængde. $\beta$, Strandbredder mellem Rødby og Nakskov Fjord (19).

\section{Airopsis. Dvargbunke.}

136. A. pracox [Fr. mant. 3, 180] (Tidlig D.) And. VII, 78; Aira L., H. 93; F. D. 383 ; H. N. II, 75; Rehb. I, tab. 94, fig. 1675; Avena Beauv., Drej. n. 90; L. Herb. IV, 67.

Bladene børsteformede; Toppen sammenkneben, oval eller elliptisk, kortgrenet; Smaaaxene sammenhobede; Yderavnerne omtrent af lige Længde med Inderavnerne.

1-4" høi. Smaaaxene bruunglindsende. 4-6. $\odot$.

Paa tørre, især sandige Marker, Bakker og İyngheder almindelig ndbredt.

137. A. caryophyllea [Fr. ]. c.] (Udspærret D.) And. VII, 77; Aira L., H. 93; F. D. 382; Rchb. l. c. fig. 1676; H. N. II. 74; Aveua Web., Drej. u. 89 ; I. Herb. III, 44.

Bladene børsteformede; Toppen under og efter Blomstringen pyramideformet, med længere, udspærrede Grene; Smaaaxene adskiIte; Inderavnerne kortere end Yderavneme.

4-10" høi. Smaaaxene sølvglindsende, Straaet og Skederne forneden violette. $5-6 . \odot$.

Paa lignende Localiteter som foreg., ikke sjelden. $\bar{\star}$

\section{Trisetum. Guldhavre.}

138. T. flavescens [Beauv, agr. 88] (Glindsende G.) And. VII, 79; Avena L., H. 132; Drej. n. 88; F.D. 1507; Rchb. I, tab. 99, fig. 1694-96; H. N. III, 91; L. Herb. V, 87.

Bladene flade, med kort Skedehinde; Toppen under Blom. stringen udspredt; $2-3$ fuldkomne og 1 gold Blomst i hvert 
Smaaax; den ovre Yderavne dobbelt saa lang som den nedre; Stakken af Smaaaxets dobbelte Længde.

$1-1^{1} \frac{1}{2^{\prime}}$ h $\varphi$ i. Bladene og de nedre Skeder haarede; Smaaaxene guldglindsende, var. $\mathrm{i}$ Henseende til Størrelsen, men altid mindre end hos Arterne af følg. Slregt, som den iøvrigt ligner. 6-8. 4 .

Paa Græsmarker og ved Veie, sporadisk og ikke alm.: $\boldsymbol{S} \boldsymbol{j}$. i Kjobenharns Omegn bemarket paa flere Steder, f. Ex. bag Kastellet, ved Leerswen, Ordrup, Sorgenfri, Dronninggaard, Jonstrup! Sparresholm (Lund), hist ng her i Egnen on Skjelskgr (Nielsen); Hesseloen (Lgby); F. Sørup (12)! Jyll. Tøilhuushaven ved Randers (7)!

\section{Avena. Ilavre.}

a. Avenas. s. Alle Blomsterne $\not$, Smaaxene nedhangende, Yderavnerne 5-9-nervede.

aa. (Agrestes Coss. \& DR.) Blomsterne tilleddede til Blomsteraxen og ved Modenheden affaldende.

139. A. fatua L. (Flyve-H.) H. $129 ;$ Drej. n. $85 ;$ F. D. 1629 ; Relıb. I, tab. 103, fig. 1712 ; And. VII, 72; L. Herb. II, 25.

Toppen alsidig; Smaaaxene alm. treblomstrede; Yderavnerne længere end Blomsterne, Axen skjør, haaret, Blomsterne stakbærende; den nedre Inderavne ved Grunden stivhaaret, i Spidsen tofliget, med hindeagtige Flige.

Inderavnernes Haar rødbrune. 7-8.

I flere Egue et almindeligt Ulsud mellem Vaarsæden, især paa Bornholm.

* 140. A. hybrila [Peterm. i Rehb. fl. saron. p. 17] Koch Syn. II, 917 ; F. D. 2642; (A. intermedia Lindgr. Bot. not. 1841 ; H. N. VII, 89.)

Toppen alsidig; Smaaaxene 2(-3)-blomstrede; Yderavnerne længere end Blomsterne, begge Blomsterne stakbærende; den nedre Inderavne glat, i Spidsen hindeagtigt tofliget, Bloinsteraxen skjor, haaret.

Ukrud mellem Sæden: $\boldsymbol{S} \boldsymbol{j}$. mellem Valdby og Flaskekroen hyppig (med A. fatua)! Utterslev (19); $S l$. ved Tonder (Koch).

Anm. De af mig i Sj:elland samlede Expl. stemme overeens med den af Lindgr. (l. e) beskrevne Art. Da jeg ikke liar seet Expl. af A. hybrida, er det kun af den hos Koch givne Beskrivelse at jeg har 
troet at kunne antage denne for at vare den samme som den svenske Art. Muligviis er denne kun en Var. af foreg. Art.

bb. (Sative Coss. \& DR.) Blomsterne fastsiddende paa Axen, ikke affaldende.

$\dagger$ A. sativa L. (Almindelig H.) Metzg. Cereal. t. 12. Toppen alsidig, med aabne Grene, Smaaxene aabne, alm. toblomstrede, Yderavneme længere end Blomsterne, den nedre Inderavne glat, i Spidsen hindeagtigt tofliget, den ovre Blomst stakløs, Blomsteraxen seig, glat.

Var. med alle Blomsterne stakløse, og med hvide og sorte Inderavner. $7-8$.

Dyrkes almindeligt i flere Afarter.

$\dagger$ A. orientalis [Schreb. Spicil. 52] (Sværd-H.) Metzg. 1. c. tab. 12. Toppen ensidig, med oprette Grene, Smaaxene alm. toblomstrede, lukkede; Inderavnerne alm. bruunagtige, forøvrigt som foreg. $7-8$.

Dyrkes mindre alm. end foreg.

141. A. strigosa [Schreb. spicil. 52] (Pur-H.) H. 129 ; Drej. 1. 84 ; F. D. 2528; And. VII, 73; Relıb. 1. c. fig. 1710 ; H. N. II, 76 .

Toppen ensidig; Smaaaxene toblomstrede; begge Blomsterne stakbærende; Yderavnerne af Langde med Smaaxet; den nedre Inderavne glat, i Spidsen tofliget, med stakformigt tilspidsede Flige.

Stakken og Inderavnerne imod Modenheden sorte. Undertiden Ansats til en tredie Blomst. 7-8.

Forekommer hist og her forvildet mellem Vaarsaden, dyrkes i de magre Egne af II alvoen under Navu af sort Havre.

b. (Avenastrum Koch.) Alle Blomsterne $\not$, Smaaaxene oprette, Y deravnerne 1-3-nervede. ข.

142. A. pratensis L. (Eng-H.) H. 131; Drej. n. 87; F. D. 1083 ; Rchb. l. c. tab. 99, fig. 1697; And. VII, 76; L. Herb. I, 10 .

Bladene stive, glatte, smale, paa Overfladen og Skederne 
rue; Toppen klaseformigt sammentrængt med meget korte Grene (1-2 i hver Krands); Smaaaxene 4-5-blomstrede; begge Idevavnerne trenervede.

Rodbladene ofte sammenrullede. Smaaxene oventil sølvglindsende. $6-7$.

Paa løjie Fnge og graesklædte Bakker, i mange Egne af Landet (f. Ex. Moen, Nordsjalland, det nordl. Jylland) aln. I andre E'gne sjeldnere og sporadisk, eller (f. Ex. det syảlige Fyen), ikke tilstede.

143. A. pubescens L. (Dunet H.) H. 131 ; Drej. n. 86 ; F. D. 1203 ; Rchb. l. e. tab. 100, fig. 1700 ; And. VII, 75 ; L. Herb. I, 9 .

Bladene slappe, tilligemed de nedre Skeder harede; Toppen aaben, med langere Greue $(4-5$ i de nedre Kraudse); Smacaxene 2-3-blomstrede; den nedre Yderavne alm. 1-nervet, den ovre større, trenervet.

Bladene bredere, alle flade, Smaanxene sølvglindsende. 5-6.

Pala Enge og Griesmarker, alm. udbredt.

c. (Arrhenatherum Beauv.) Den nedre Blomst $\hat{o}$ stakbarende, den øvre $\not$ stakløs. 4.

144. A. elatior L. (Høi H.) F. D. 165 ; Fr. mant. 3, p. 4; And. VII, 74; H. N. IX, 88; Arrhenatherum elatius M. \& K.; Drej. n. 83 ; L. Herb. I, 8; A. avenaceum Beauv., Rehb. 1.c. tab. 104, fig. 1715 ; Holcus avenaceus Scop., H. 94.

Bladene flade, rue; Toppen alsidig, udbredt; den ovre Yderaine trenervet, dobbelt saa lang som den nedre (1-nervede), den ovie Blomst haaret.

$2-3^{\prime}$ hoi. Den øvre Blomst har undertiden en kort, ret Stak. I den nedre Blomst findes alm. en uudviklet Frugtknude uden Grifler. $6-7$.

$\alpha$, vulgaris. Smaaaxene toblomstrede, den nedre (ठ̋) Blomst med, den øvre (ఫ) uden Stak.

$\boldsymbol{\beta}$, typica Fr. (hermaphrodita). F. D. 2643, Smaaaxene 2-3-blomstrede, alle Blomsterne trekjønnede.

Paa Enge mellem Buske, ved Veie, i Krat, alm. udbredt. Formen $\boldsymbol{\beta}$, er meget sjelden: $\boldsymbol{S} \boldsymbol{j}$. Klinterne ved Taarbæk! 


\section{Phragmites. Tagror.}

145. P. communis [Trin. fund. agrost. p. 134] (Almindeligt T.) Drej. n. 78; F. D. 2464 ; Rehb. I, tab. 108, fig. 1729 ; And. VIII, 91; L. Herb. V, 83; Arundo Phragmites L., H. 80 .

Bladene brede, næsten lancetformede; Skedehinden randhaaret; Toppen rigtblomstret, udbredt; Smaaaxene 4-5.blomstrede.

Det største danske Græs $\left(4-6^{\prime}\right)$, Rodstok ng Udløbere tykke; Smaaaxene mørkt violetbrune, efter Blomstringen formedelst de lange Haar sølvglindsende. 8-9. ข.

$\beta$, repens Mey. Chl. banov.; F. D. 2164. Lav, med talrige, nedliggende og krybende Grene, 1-2-blomstrede Smaaax.

$\gamma$, flavescens Cust. i Gaud. fl. helv. 6, p. 341. Smaaaxene guulbrune, 3-fleerblomstrede.

Ved Søbredder og i Kjær hyppig. $\beta$, i Strandsandet, f. Ex. J. ved Harboøre (H.), meget alm. i Klitterne fra Agger til Fjaltring! Handbjerg Strand (Schmidt); Sl. ved Aabenraa Fjord! Dyttebøl ved Gelting (Lund); Avernakø (12); F. Nyborg; Falst. (Koch); Sj. Bekkeskov v. Præstø (Lund). $\gamma$, Stadsgravene ved Kjøbenhavn og Christianshavns Voldgrave, med Hovedarten, men tydeligt adskilt fra denne!

\section{Enodium. Blaatop.}

146. E. coeruleum [Gaud. agr. I, 145] (Almindelig B.) And. V, 55; Aira L. sp., F. D. 239; Melica L. mant., H. 99; Molinia Moench, Drej. n. 117; Rehb. I, tab. 78, fig. 1606; L. Herb. VII, 131 .

Roden stærkt- og langtrævlet; Straaene ved Grunden tykke, 1-2-leddede, foroven uleddede; Bladene brede, langt tilspidsede; paa Overfladen haarede; Skedehinden dannet af en Haarkrands; Topgrenene korte, opret-tiltrykte.

Smaaaxene og Støvknapperne mørk-violette. 7-8. ข.

$\boldsymbol{\beta}$, altissima Link. (Molinia littoralis Host, Rchb. 1607). Høiere, med længere Topgrene, svagere farvede Smaaax.

$\gamma$, vivipara, med topspirende Smaaax. 
Paa torvholdige Enge, i høie. Skove og mellem Krat, alm. især paa Halvoen og Boruholm. $\beta$, paa skyggefulde Steder; $\gamma, \boldsymbol{L}$ oll. ved Maribo S $\emptyset$ (19).

\section{Briza. Bavregraes.}

147. B. media L. (Almindeligt B.) H. 112; Drej. n. 98; F. D. 258 ; Rchb. I, tab. 92, fig. 1665 ; And. V, 52; L. Herb. VII, 127.

Toppen alsidigt udbredt; med haarfine Topgrene; Smaaaxene hængende; Skedehinden kort, afstumpet.

Yder- og Inderavnerne violetbrune, med hvid, hindeagtig Rand. Let kjendelig ved de hjerteformede Smaaax med taglagte A vner. 6-7. 4 .

Paa Enge og Græsmarker alm. udbredt.

\section{Catabrosa. Tappegras.}

148. C. aquatica [Beauv. agr. 97] (Dynd-T.) Fr. mant. 3, 174 ; Drej. n. 112 ; And. VI, 64; H. N. IX, 89; Aira aqu. L., H. 86 ; F. D. 381 (slet); Glyceria aqu. Presl; G. airoides Rehb. I, tab. 78, fig. 1608; G. Catabrosa Kl. \& R., I. Herb. I, 2.

Rodstokken krybende og forsynet med Udløbere; Bladene korte og budte; Skedehinden forlænget og afrundet; Toppen alsidigt udbredt, med talrige og fine Grene i Halvkrandsene; Yderavnerne budte, gnavede eller udrandede.

Blødt, aldeles glat Græs. Yderavnerne violette, Inderavnerne brune med hrid hindeagtig Rand, Støvknapperne hvidgule, hrorved Toppen farer et broget Udseende. (Former med indtil 5 Blomster i Smaaaxet, som angives af $\mathrm{H}$. og Rafn, har jeg ikke fundet; den forekommer hyppigst toblomstret, undertiden med Ansats til en tredie Blomst). 6-7. 4 .

$\beta$, subtilis Hook. Liden, med enblomstrede Smaaax.

I Dynd, ved Kildevæld og par oversvømmede Steder ikke sjelden og forekommer $\mathrm{i}$ alle danske Provindser. $\beta$, paa fugtig Sandgrund; f. Ex. Falst. ved Øverup (14); Sl. Seemülile ved Rendsborg!

\section{Glyceria. Sodgraes.}

a. Inderavnerne utydeligt 5-nervede. (Halophila Duval-Jouve.)

149. G. maritima (M. \& K. D. Fl. I, 588] (Strand-S.) 
Irej. n. 116 ; Rchb. I, tab. 79, fig. 1612; And. VI, 60; H. N. V. 94 ; L. Herb. I, 4; Poa Huds., H. 103.

Rodstokken udsender krybende Udløbere og nedliggende, forlængede Bladknipper; Rodbladene tilsidst sammenrullede; Straaet opstigende; Topgrenene i de nedre Halvkrandse alm. 2, under Blomstringen udstaaende, efter samme opret-tiltrykte; Smaaaxene 5-8-blomstrede (meget større end hos den følgende). $6-7$. 4 .

$\boldsymbol{\beta}$, anomala! Alm. lavere end Hovedarten, med enlige, meget kortstilkede, større, stundom topskydende Smaaax, forlænget-tilspidsede Inderavner.

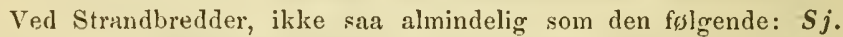
Helsingør, Vesterfeelled, Saltholm, Bognæs ved Roeskilde! Eskildsø i Isefjorden (14), Bisserup ved Skjelskør! Korsør (H.), Veirhøi! Falst. Gronsunds Nor (Koch); Loll. Nebbelunde (5), Nakskor Fjord, Ravnsby (19); F. Hofmansgave! St. Jørgensgaard o. fl. St. mod S.; Drejø, Strynø (12); J. Saltkilde ved Toftegaard i Vildmosen! Agger (herb. Drej.), Limfjorden $\nabla$. Aalborg (9), Randers Fjord (7), Kalss, Hobro (16). I Marskeguene danner den, uden at blomstre, Hovedbestanddelen af Græsviexten paa Forlandene, men ikke indenfor Digerne (Bruun). Formen $\beta$ (som maaskee rettest er at betragte som en Misdannelse) er funden ved Vaarsaa Strand i Vendsyssel (12)! Ribe (Hornem. Herb.)! Amrom (Nolt.!).

Anm. F. D. 1626 , som benævnes Poa maritima, hører ikke til denne Art. Blomsterstanden ligner meest den folgende, Plantens nedre Deel er aldeles som foreg. Prof. Nolte har meddeelt mig den Bemærkuing, at den er tegnet efter et stort Expl. af Catabrosa aquatica, men Tegningen er $i$ ethvert Tilfxlde saa slet at den ikke kan tjene til Oplysning om nogen Arts typiske Udseende.

150. G. distans [Wahlenb. fl. upsal.p. 36] (Udspærret S.) F. D. 251 (Poa maritima) og 2222; Rehb. l. c. fig. 1609; And. VI, 62; H. N. VI, 87; L. Herb. I, 3; Poa distans L., H. 103; Heleochloa Drej. n. 113.

Straaene talrige, tueformigt samlede, knæbøiet-opstigende, ingen krybende Udløbere; Bladene flade; Topgrenene i de nedre Halrkrandse alm. 5, efter Blomstringen udspilede eller tilbagebøiede; Smaaaxene 3-7-blomstrede, dets Blomster tidligt affaldende.

Var. meget i Henseende til Topgrenenes Antal og Retning, Antallet af Blomster i Smaaaxet og dettes Farve 0. s. v. 6-7. ข. 
$\beta$, pulvinata Fr. mant. 3 ; H. N. V, 90. Straaene fine, danne trtte Tuer, de nedre Topgrene 2, korte og mindre udspærrede.

-Ved Strandbredder, især paa leret, af Havet ofte overskyllet Grund, sjeldnere inde i Laudet paa Gader ved Rendestene (f. Ex. Ringsted!) $\beta$, 'T'mmerpladserne paa Christianslıavn, Bredderne af Tïissø! J. Ottesnud paa Thyholm!

Anm. Poa arenaria Rafn I, 540, synes efter Beskrivelsen at hore til foregaande, efter Synonymerne til denne Art.

b. Inderavaerne tydeligt 7-nervede. (Hydrochloa H artm.)

151. G. spectabilis [M. \& K. D. f. I, 586] (Høit S.) L. Herb. IX, 161; Foa aquatica L., H. 100; F. D. 920; Glyceria aqu. Wahlb., Rehb. l. c. tab. 80 , fig. 1614; H. N. IX, 91; Heleochloa aqu. Fr. fl. scan., Drej. n. 114.

Rodstoklien krybende; Stracet opret; Skedehinden kort, afskaaren; Toppen rigtblomstret, under Blomstringen udbredt, tilligemed Axen ru; Grenene oprette, $6-10$ i de nedre Halvkrandse; Smaaaxene æg-lancetformede, 6-9-blomstrede (meget mindre end hos de følgende).

4-6' hoit, bredbladet Græs, Blomsterne fastsiddende længe efter Modningen. 7-8. ४.

Ved Rinden af Søer og Aaer, findes $\mathrm{i}$ alle de danske Provindser, men ikke overalt lige hyppig, f. Ex. meget sjelden i det sydlige Fyen og paa Øerne S. for Fyen (12), samt paa Lolland (19).

152. (4. plicata [Fr. mant. 2, p. 7] (Foldbladet S.) H. N. V. 91 ; Rehb. Suppl. Agr. f. 381 ; And. V, 55; F. D. 237 (Festuca fluitans L.)? og 2465; G. fluitans $\delta$, obtusifora Sond. fl. hamburg. p. 57.

Rodstokken tyk, krybende; Straaet ved Grunden nedliggende; Skedehinden kort; Toppen næsten alsidig, med jævn Axe og ensidigt rue, under Blomstringen vandret udspilede Grene, alm. $4-5$ i de nedre Halvkrandse; Smaaaxene linieformede, 7--12-blomstrede; Blomsterne tret taglagte; don nedre Inderavne budt afrundet. 
De ældre Bladskeder opløses i et trævlet Næt; Støvknapperne (oftest) gule. 6-7. 4 .

$\beta$, triticea (M. Lange). Toppen sammenkneben, med enlige, korte Grene.

I flydende og stillestaaende Vand, bemærket $\mathrm{i}$ alle danske Provindser, og som det synus, ligesaa hyppig som følgende. $\boldsymbol{\beta}$, ved Nielstrup i Fyen (12).

153. G. fluitans [R. Br. prodr. I, 179] (Manna-S.) Drej. n. 115 ; F. D. 2403 ; Rchb. J. c. tab. 80 , fig. 1615 ; And. V, 54 ; L. Herb. VII, 130 ; G. fluitans $\alpha$, acutiflora 1)oell, Fl. Bad. p. 170; Festuca fluitans L., Poa Scop., H. 101.

Rodstokken krybende; Straaet ved Grunden nedliggende; Skcdehinden forlænget; Toppen ensidig, med jævn Axe og eusidigt rue, under Blomstringen vandret udspilede Grene, 1--3 i de vedre Halvkrandse; Smaaaxene linieformede, 7-12-blomstrede, med løst taglagte Blomster; den nedre Inderavne spids.

Støvknapperne længere end hos foreg., violette, tilsidst bleggule. Blomsterne større end hos hiin, hvorved Smaaxene blive langere. Hos begge de sidste Arter affalde Blomsterne hurtigt efter Blomstringen. $6-7.4$.

$\beta$, triticea Fr. (H. N. V, 92). Toppen axformigt sammenkneben, med enlige, meget korte Grene.

Paa lignende Voxesteder som den foreg., alm. i Danmark. $\beta$, paa mere tør Grund end Hovedarten, f. Ex. Sj. Leersøen! Birkerød! Sorø! F. Hofmansgave $(18)$; J. Eveldrup (Dr.)

Anm. De 2 sidstnæunte Arter forekomme mig vel adskilte ved flere væsenlige Kjendetegn, om end enkelte Former kunne være vanskelige at bestemme, hvorfor flere Forfattere ansee dem for at henhore til een Art. Det fia de unge Blade hentede Mærke, hvorefter disse sliulde være flere Gange foldede hos Glyceria plicata, (deraf Navnet) har imidlertid ikke viist sig holdbart.

\section{Poa. Rapgraes.}

a. Enaarige, med imod Frugtmodningen nedbøiede T opgrene.

154. P. annua L. (Enaarigt R.) H. 111 ; Drej. n. 99 ; And. V, 51; F. D. 1686 ; Rchb. I, tub. 82 , fig. 1621 ; L. Herb. II, 23. 
Straaet fladtrykt; Bladene kjølformigt sammenlagte, paatværs bølgede; de øvre Skedehinder forlængede, de nedre kortere, afstumpede; Topgrenene alm. 2 i hver Halvkrands; Smaaaxene 3-7-blomstrede; Inderavnernes Nerver tydelige.

$4-8$ " høi, frisk grøn, danner tætte Tuer. De frugtbærende Topgrene forekomme undtagelsesviis vandret-udstaaende eller opret-aabne(ikke tilbagebøiede). 4-9 (eller i frostfrie Aar hele Vinteren igjennem).

Paa dyrket Jord, f. Ex. i Haver, paa Veie og Gader et yderst almindeligt Ukrud.

b. Vedvarende, med efter Blomstringen oprette eller udstaaende Topgrene.

aa. Caspitosa Fr. Rodstokien uden Udløbere. Inderavnerne $i$ Randen og paa Ryggen duunhaarede, utydeligt (ikke ophøiet) nervede.

155. P. nemoralis L. (Lund-R.) JI. 109; Drej. n. 100; And. IV , 46; F. D. 749 og 750 (P. palustris, slet); Rehb. l. c. tab. 86 , flg. $1638-43$; L. Herb. VII, 129.

Straaet trindt, jærnt; Bladskederne kortere end de tilsvarende Ledstykker, den øverste kortere end sin Bladplade; Skedehinden kort, afstumpet; Toppen smal, med rue, efter Blomstringen oprette Grene $(3-5$ i de nedre Halvkrandse); Smaaaxene 2-5-blomstrede; Inderavnerne spidse.

Straaene fine, alm. tueformigt samlede, Leddene brune, Bladpladen red Grunden togret. Var. i Henseende til Smaaxenes Form og Antal af Blomster, Farven o. s. v. 7-8. थ.

$\beta$, subuniflora Rehb. l. c. fig. 1638 ( $\alpha$, vulgaris Koeh Syn.) Hele Planten grøn, Straaene fine, slappe, Smaaaxene 1-2. blomstrede, meget smaae.

$\gamma$, firmula Gaud. Rehb. 1. e. fig. 1643. Straaet stivt, Smaaaxene 3-5-blomstrede.

Alm. i Skove og Krat, ved Gjærder o.s.v. $\beta$, i Skygge, $\boldsymbol{\gamma}$, paa solaabne Steder.

156. P. fertilis [Host. gram. 3, t. 14] (Stortoppet R.) Drej. n. 101; L. Herb. III, 42; P. serotina Ebrb., H. 108; 
And. IV, 45; F. D. 2166 , H. N. VI, 83 ; P. angustifolia L. Fr. fl. hall. p. 26 ; Rclib. 1. e. fig. $1645-47$; P. palustris Rotb, Sclum. p. 32.

Straaet trindt, jævnt; Bladskederne ligelange med Ledstykkerne, den øverste af lige Lingde med sin Plade; Skedehinden forlanget; Toppen udbredt, med rue, efter Blomstringen oprette Grene, (omtreut 5 i Halvkrandsene); Smaaaxene 2-5blomstrede; Inderavnerne budte.

Stosre og mere rigblomstret end foreg., Stranet ofte forneden grenet, Bladpladen ved Gruuden togret, Inderavnerne i Spidsen bruunplettede, ofte violet-anløbne. 7-8. 4.

I fugtige Enge og Moser, sporadisk og ikle almindelig: $\mathbf{S j}$. ved et Kjæer S. for Horsholm! ved Søerne i Rudehegn! Bagsværd, Lundehuset (Schum.), Vesterfæelled (19); L oll Sollested, Stensgaard, Søliolt (19); $\boldsymbol{F}$. Abel $\phi$, Hofmansgave (1); $S l$. Oxager i Angel (16). li*

Anm. P. adspersa [1)rej. n. 202], som beskrives med "Skeder kortere end Ledstyklkerne og Bladpladerne, forlwnget Skedehinde, efter Blomstringeu udstaaende Topgrene og spidse, tydeligt nervede Inderavner", er neppe nogen serskilt Art, men (efter de Expl. jeg har seet i Drejers Herbarium og den derefter til Fl. dan. af Liebmann tegnede Figur) kun en local Form af foregatende, hos livilken Nerverne $\mathrm{i}$ tørret Tilstand ogsaa ofte træde tydeligt frem.

bb. Subbulbosa Fr. Flere Straae og golde Bladknipper tat og tueformigt samlede; ingen Udlobere, Straaene ved Grunden logformigt opsvulmede, tat omgivne af de henvisnede Blades

Skeder.

157. P. bulbosa L. (Løgbærende R.) Rehb. l. c. tab. 81, fig. 1619 ; F. D. 2606 ; And. V, 50; H. N. II, 77.

Bladene korte, smalt linieformede, med stærkt udviklede Skeder og spidse, forlængede Skedehinder; Toppen kort og sammentrængt, med 1-3 opret-aabne, rue Grene i hver Halvkrands; Smaaaxene xgformede, 4-6-blomstrede; Inderavnerre (i frisk Tilstand utydeligt, tørrede tydeligt) femnervede, paa Ryggen og i Randen duunhaarede, ved Grunden omgivne af lang, kruset Uld.

6-8" høi. Efter Afblomstringen hurtigt henvisnende. 5-6. 4.

$\beta$, vivipara L., Rchb.l. c. fig. 1620 ; Smaaaxene topspirende 
med forlænget-tilspidsede, ved. Grunden og i Rauden glatte Inderavner.

Hovedarten er ikke funden i Danmark. Var. $\beta$, Bornh. Klippestien V. for Hammershuns og ved Hammeren (8), Havegjaerder ved Ronne (Hjorth), Listed Fiskerleie (Baagøe). ד

ce. Fasciculifera Fr. Rodstokken sudskyder golde Bladlnipper, men ingen Udlobcre, Inderavnerne $i$ Randen glatte, med tydelige (ophoiede) Nerver.

158. P. trivialis L. (Almindeligt R.) H. 106 ; Drej. n. 103; F. D. 1685; Relıb. l. c. tab. 89, fig. 1653-54; And. IV, 44 ; H. N. VII, 92 (var.); L. Herb. IV, 64.

Straaet og Topgrenene oventil rue; Skederne noget fladtrykte, rue; Skedehinden forlænget, spids; Toppen aaben, udbredt; Sinaaaxene ægformede, omtrent treblomstrede; Inderavnerne spidse, paa Ryggen forneden randhaarede, ved Grunden omgivne af kruset Uld. 6-7. $\%$.

$\beta$, multiflora Rchb. 1. c. fig. 1655. Bladene bredere, tilligemed Skederne haarede, Topgrenene $7-9$ i de nedre Halvkrandse, Smaanene femblomstrede.

I Grofter, paa Enge og andre fugtige Steder alm. $\beta$, paa frodig Havejord mellem Buske ved V. Skjerninge i Fyen!

159. P. sudetica [Hänke Sudet. 120] (Sudetisk R.) H. II, 120; F. D. 1924; P. (sudetica) * remota Fr. nov. ed. 2 p. 11; H. N. VI, 83; And. IV, 43; Lge. Haandb. 2 Udg. S. 81; P. hybrida (Gand.?) Koch Syn. ed. 1, Rchb. 1. c. tab. 90, fig. 1656.

Bladskederne tveægget-fladtrykte, de øvre rue; Bladene fra bred Basis efterhaanden smalere og langt tilspidsede, kjolformigt sammenlagte, med kappeformigt sammendragen Spidse; Skedchinden kort; Topgrenene rue, lange og ved Grunden uตgne, i Spidsen nikkende, Idbredte (alm. 5 i de nedre Ilalvkrandse); Smaaaxene ægformet-elliptiske, $3-5$-blomstrede; Inderavnerne lancetformede, spidse, glatte, ved Grunden ongivne af los Uld.

$2-4^{\prime}$ høi. Let kjendelig fra foreg. ved de haarfine, et langt Stykke nøgne Topgrene, tverggede Bladskeder o.s.v. Ved langere 
Stæengelblade, en større, pyramideformet Top med længere Ledstykker, mindre Smaaax og finere, længere, tilsidst nikkende Topgrene er den forskjellig fra $P$. Chaixi Vill. Fl. delph. p. 7; (P. sudetica Schrad., Koch etc., non Hänke, Rchb. l. c. fig. 1657). Jeg finder ingen Kjendetegn, hvorved vore Expl. afvige fra Besks. af P. hybrida Gaud., men da jeg hverken har seet Afbildning eller Expl. af denne Art, og da den hos os fundne Form er aldeles lig den i Sverige og Norge forekommende Art, som efter Fries (bot. not. 1858 p. 130) er den ægte P. sudetica Hänke, har jeg beloldt dette Navn. For den sydeuropæiske Art, som af de fleste Forff. benævnes P. sudetica, vil det da være rigtigst at gjenoptage Villars's i 1785 givne Navn P. Chaixi (cf. Bull. Soc. bot. Fr. X, 77). 6-7.

I fugtige Skove: $\boldsymbol{S} \boldsymbol{j}$. ved Rungsted (11), Lunden ved Flakkebjerg pr. Skjelskør (Nielsen); J. Rydhave ved Holstebro (Schmidt); andre Voxesteder ere mig hidtil ikke bekjendte (Holsteen N.). lit

dd. Stolonifera Fr. Rodstokken krybende, med forlangede Udlobere.

160. P. pratensis L. (Eng-R.) H. 107; Drej. n. 104 ; Rchb. I. c. tab. 88, fig. 1648-52; And. IV, 40 ; L. Herb. VII, 128 ; P. trivialis F. D. 1444.

Straaet trindt; tilligemed Bladskederne jævnt; Skedehinden kort afskarren; Toppen udbrcdt, alsidig, med $3-5$ Grene i de nedre Halvkrandse; Smaaaxene ægformede; 3 -5-blomstrede; Inderavnerne tydeligt femnervede, med kruset Uld paa Ryggen og ved Grunden. $5-6$. 4 .

Aum. Var. betydeligt paa forskjellige Voxesteder i Henseende til Bladenes Brede, Smaaxenes Størrelse og Farve, Plantens Høide o. S. $\nabla$. De meest afvigende Former ere:

$\beta$, humilis Rchb. J. c. fig. $1651 ;$ H. N. IX, 91. Alle Bladene korte og brede, Smaaraxene violet anlobne og tilligemed hele Planten af en blaagron Farve.

$\gamma$, angustifolia Rchb. 1. c. fig. 1648. Rodbladene meget lange, traadsmale og sammenrullede, Plantens Farve grøn.

Paa Enge, Gresmarker og verl Veie meget alm. $\beta$, paa tor (leret eller gruset) Jordbund; $\gamma$, paa Bakker og aabne Steder i Skove.

* 161. P. costata [Schum. enum. p. 38] (Klapribbet R.) Drej. n. 105 ; F. D. 2402. 
Straaet trindt, tilligemed Bladskederne jæunt; Skedehinden kort afskaaren; Toppen kort, efter Blomstringen sammenkneben, med meget korte Grene (alm. 2 i de nedre Halvkrandse); Smaaaxene ægformet-elliptiske, omtrent treblomstrede; Yderavnerne og Inderuvnerne ophoiet-nervede, tilspidsede og imod Spidsen indbøiede.

Omtrent $1^{\prime}$ høi, blaagrøn. 6-7. 4 .

Paa Strandbredden mellem Springforbi og Papirmgllen (Schnm.) gjenfunden af G. Jensen 1843; en Skuv ved Bagsværd! Nyrup Hegn ved Helsingar (Heiberg), Hellebæk!

Anm. Hornem. anseer den for en Var. af folgende, fra hvilken den dog er vel adskilt; langt nermere staaer den ved foreg., til hvilken den af Fries henføres, men hvorfra den dog ved de angivne Kjendetegn og et eiendommeligt Habitus er ikke lidet forskjellig.

162. P. compressa L. (Fladstraaet R.) H. 110 ; Drej. n. 106 ; F. D. $74 \%$; Rehb. l. e. tab. 85, fig. 1636; And. IV, 42 ; H. N. XIII, 98, L. Herb. I, 1.

Straaet fladtrykt, ved Ledene knæbøiet, jævnt; Skedehinden kort, afrundet; Toppen noget ensidigt sammentrykt med 2-5 efter Blomstringen tiltrykte Grene i de nedre Halvkrandse; Smaaaxene elliptiske, 3-7-blomstrede, med tæt taglagte Blomster; Inderavnerne budte, med utydelige Nerver, paa Ryggen og i Randen duunhaarede.

$1 / 2-1^{\prime}$ høi, mat- og blaaggtig-grøn; Inderarnerne i Spidsen bruunplettede. $7-8$. 4 .

Paa tørre, især lerede Marker, forekommer i alle danske Provindser, hyppigst paa Lolland-Falster, sjeldnere i Jylland.

\section{Festuca. Svingel.}

a. Ovina Fr. Rodbladene borsteformigt sammenrullede, Skedehinden toøret.

163. F. ovina L. (Faare-S.) H. 115; Drej. n. 118; F. D. 2462 ; Rchb. I, tab. 61 , fig. 1530 ; And. III, 27 ; H. N. VIII, 93; L. Herb. III, 43.

Roden fintrævlet; Straaene talrige, tueformigt samlede, jævne og glatte, foroven firekantede; alle Bladene traadformigt sammenrullede; Toppen smal, ensidigt sammenkueben, med 
korte, under Blomstringen udspærrede eller opret-aabne Grene; Smaaaxene 4-6-blomstrede; Blomsterne stakbærende. 5-6. 4.

$\beta$, tenuifolia (F. tenuifolia Sibth.; Rchb. I. c. fig. 1532). Bladene frisk grønne, haarfine, Stakken kort eller 0.

$\gamma$, glauca Fr. nov. p. 13. Bladene blaagraae.

Paa Bakker, Lyngheder og andre magre Steder alm., $\beta$, i Skove, $\gamma$, paa aabne Steder med Hovedarten.

Anm. Var. $\gamma$, maa iklke forvexles med $F$. glauca Lam. !Fr. nov. p. 14, mant. 3, p. 6; H. N. V, 96), en Art, som Fries (skjondt ikke uden Tvivl) adskiller fra foreg. red Straaene, som ikke ere samlede i en Tue, men tilligemed de samme omgirende Blade og brede Bladskeder adskilte i flere Smaatuer. On dens Forekomst i vor Flora kan jeg Intet angive ined Sikkerlied.

164. I. duriuscula L. [Fr. nov. p. 12 ; mant. 3 p. 9] (Stivbladet S.) H. 117; Rehb. 1. c. tab. 62, fig. 1538; And. III, 26 ; H. N. VIII, 94.

Roden trævlet; Straaene talrige, tueformigt samlede, trinde; Stcongelbladene smale, rendede (snart indrullede): Toppen opret, under Blomstringen udspærret, noget ensidig; Smaaaxene 3-5blomstrede, stakbærende; den nedre Inderavnes Nerver utydelige.

Straaene forneden tret omgirne af de visne Bladskeder. Det nederste Stxngelblads Skede ofte liaaret. Smaaaxene st 5 rre end hos foreg., rodligt anløbne. 6. 4.

$\beta$, casia Fr., F. rubra-cæsia H. N. V, 98 ; med blaagraae, tykke og haarde, ofte krummede Blade.

Paa Enge og Græsmarker, ikke sjelden.

Anm. Starer i Kjendetegn og Udseende midt imellem foreg. og følg. Art; Voxemaaden og Toppens Form ligner meest liiin, Bladene, Straaet og Smanaxenes Storrelse meest denne. Mfellenformer ere ofte vanskelige at bestemme, men de typiske Former synes vel adskilte.

I65. F. rubra L. (Rød S.) H. 118; Drej. n. 119 (tildeels); Rehb. l. c. tab. 67, fig. 1557; And. III, 25; H. N. XII, 92 (var.); L. Herb. VI, 102.

Rodstokken udskyder Udløbere; Straaene trinde, med flade Stangelblade, af hvilke det øvre er langt korterc end Ledstykket 
ovenfor; Toppen under Blomstringen udbredt, næsten alsidig, med 5-7-blomstrede, (hos Hovedarten) glatte Smaaax; den nedre Inderavne dobbelt saa lang som den i sammes Spidse befæstede Stak, dens Nerver tydelige.

Siranene paa Grund af den krybende Rodstok fjernede fra hinanden; Toppen ofte lidet nikkende, var. med rodlige eller blegere Smaarx. $6-7$.

$\alpha$, genuina, Udløberne nuderjordiske, alle Bladene flade, Toppen rigtblomstret, udbredt.

$\beta$, dumetorum (L.) Fr. mant. 3 p. 7 ; H. N. V, 97 ; Rod. stokken forgrenet i flere, overjordiske Rodskud, Stringelbladene flade og rendede eller indrullede, Toppen smal, under Blomstringen aaben.

1, - nemorum Fr., hoi og bleggron, Toppen nikkende. (F. nemorum Leyss., Rehb. 1558)?

2, - scopulorum Fr. Lavere, blaagrøn, Toppen opret. (F. glauea F. D. 1628.)*)

Par Enge, ved Veigrofter o. s. v., meget alm. $\beta$, (1) i Skove og paa Skovenge, (2) Klipper ved Stranden mellem Allinge og Sandvig paa Bornholm (H).

* 166. I. arenaria [Osbeck i Retz. Suppl. 1 fl. Scand. p. 4] (Sand-S.) F. hirsuta F. D. 1627 ; F. sabulicola L. Duf.; F. dumetorum Rafn I, 349 ; F. rubra $\beta$, arenaria Fr. fl. Hall. p. 28 ; Drej. n. $119 \gamma$; L.ge. Haandb. 1 Ulg. p. 77.

Rodstoliten krybende, forgrenet $\mathrm{i}$ lange og stærke Udløbere; de nedre Bladskeder store, bugede, violetbrune; Straaene

*) Jeg lıar søgt i Korthed at gjengive de vigtigste af Prof. Fries angivne Kjendetegn mellem de ovenstaaende, i hoi Grad foranderlige Arter (og Former) som vistuok alle forekomme i vor Flora, men hvis rette Begrandsning jeg hidtil forgjaves har sggt $i$ alle enkelte Tilfxelde at erkjende. En nøiagtig Undersøgelse af levende Planter og Iagttagelse af de analoge Udviklingsrakker, under livilke enhver Art efter Voxestedet fremtreder, mal høilig anbefales de danske Botanikere, og den bedste Veileduing hertil vil findes indeholdt $\mathbf{i}$ den ovenanforte beromte Forfatters critiske Behandling af disse Arter. 
knæbøiede; Bladene tilsidst indrullede, det øvre Stængelblad næsten ligelangt med Ledstykket ovenfor, Toppen noget ensidig; Smaaaxene større end hos foreg., graaagtige, oftest tæt duunhaarede, 7-9 blomstrede, den nedre Inderavne svagt nervet; forøvrigt som foreg. $6-7$. 4 .

Sandige Strandbredder og Klitter: hyppig $\mathbf{i}$ det nordlige og vestlige Jylland (H., Drej.!) Bornh. ved Rønne (8), Boderne! S j. Hornbæks Plantage!

b. Bovince Fr. Alle Bladene flade, Skedehinden afstumpet eller aflang, (ikke toøret).

aa. Stakken ret, kortere end Inderavnen (eller 0).

167. F. pratensis [Huds. fl. angl. ed. I, p. 37] (Eng.S.) H. 119 ; Drej. n. 121; F. D. 1323 (slet, hører snarere til følg.); Rchb. l. c. tab. 80, fig. 1565; And. II, 24; I. Herb. V, $86 ;$ F. elatior L. (tildeels).

Rodstokken udskyder opstigende Straae og Bladknipper; Bladene bredt linieformede, med meget kort Skedehinde: Toppen noget ensidig, sammenkneben, under Blomstringen aaben, med 2 Grene fra hver Halvkrands, den ene længere, med flere, den anden meget kort, med kun et enkelt Smaaax; Smaaaxene linie-lancetformede, 5-10-blomstrede; den nedre Inderavne jævn, staklos eller med en kort, ret Stak; Frugtknuden glat.

1-2' høi. 6-7. 4.

$\beta$, pseudololiacea Fr. (F. loliacea F. D. 1925; Drej. 1. 120 ; Rehb. 1. c. fig. 1566). Grenene korte, med faa Smaaax, de øvre næsten siddende.

Paa Enge, ved Randen af Veie o.s. v., meget alm., $\beta$, en paa mager Jordbund ikke sjeldent forekommende Form (som ikke inaa forvexles med $\mathrm{F}$. loliacea Huds. 0: Brachypodium Fr.).

168. F. littorea Wahlenb. [Bromus Retz. prodr.] (StrandS.) H. N. IX, 94; F. arundinacea Schreb., Drej. n. 122; And. II, 23; F. D. 2163 ; Rehb. l. c. fig. 1568; L. Herb. VI, 103; F. elatior Sm., H. 119.

Rodstokken udskyder krybende Udløbere; Bladene bredtlinieformede, med meget kort Skedehinde; Toppen alsidig, i 
Spidsen nikkende, med parvise, under og efter Blomstringen udstaaende, næsten ligelange Grene, begge med flere, æglancetformede, 4-5-blomstrede Smaaax; den nedre Inderavne jævn, stakløs eller med en kort, ret Stak; Frugtknuden glat.

$2-5^{\prime}$ høi. Smaaxene ofte bruunagtige; var. med en Stak halvt saa lang som Inderavnen ( $\beta$, pauciflora Hartm.) $6-8$.

Paa Strandenge og Skrænter i Nærheden af Havet, sporadisk og sjeldnere end foreg., findes sjeldent paa Enge inde i Landet (Raavaddam! Lundehuset! Flakkebjerg ved Skjelskøør (Nielsen). $\beta$, Marselisborg ved Aarhus!

Anm. Af de talrige Navne, som ere blevne denne Plante tildeel, forekommer det valgte mig heldigst for at betegne dens Forskjellighed i Forekomst fra foreg. Det Schreberske Navn er vel ældre, men har af Liljeblad været anvendt paa Fluminia arundinacea.

169. N: silvatica [Vill. delph. II, 105] (Skov-S.) H. 120; Rehb. I, tab. 68, fig. 1562; And. II, 22; H. N. IX, 95; L. Herb. IV, 65 ; Poa silvatica Poll., F. D. 1145.

Straae og Bladknipper stivt oprette, forneden beklædte med bladløse Skeder; Bladene brede; langt tilspidsede, paa Overfladen blegere, paa Underfladen mørkere grønne, glatte, i Randen rue; Skedehinden forlænget; Toppen opret, med udspærrede Grene (2-4 i de nedre Halvkrandse); Smaaaxene 3-5.blomstrede; den nedre Inderavne tilspidset, stakløs, korthaaret-ru; Frugtknuden i Spidsen haaret.

2-3' høi. De bladløse Skeder bugformigt oppustede, glindsende, glatte, de bladbierende punkteret-rue. 6-7. (Blomsterne meget hurtigt affaldende). 4 .

I Skove: Sj. "den dybe Rende " i Hresede Skov ved Gisselfeld! forgrrigt kun bemarket paa Ilalvoen, især i de ostlige Skove: J. Saltum 2 Mile fra Silkeborg (16), Kollerup Skov (2), Veile! S l. hyppigere, f. Ex. Torning Slov ved Haderslev (Gronlund), Hjelm red Aabenraa! Kobbermolleskoven ved Flensborg! Dyrehaven ved Slesvig (20).

bb. Stakken bolget, dobbelt saa lang som Inderavnen.

170. F. gigantea [Vill. delph. Il, 110] (Kjæmpe-S.) Drej. n. 125; And. 11, 21 ; L. Herb. VI, 105; Bromus L., H. 126 ; F. D. 1630 ; Rchb. I, tab. 76, fig. 1602 . 
Bladskederne glatte, stribede, foroven tilligemed de brede, mørkgrønne Blades Rand og Overflade lidet rue; Skedehinden meget kort; Toppen alsidigt udbredt, med lange, i Spidsen nikkende, under og efter Blomstringen udspærrede Grene; Smaaaxene 5-8.blomstrede; Stakken befæstet lidet nedenfor Inderavnernes Spidse; Frugtknuden glat.

3-4' høi, næsten aldeles glat. Blomsterne kortharet-rue, Bladene ved Grunden toørede. Paa Grund af Stakkens Tilhæftningdanner denne Art et Mellemled til Slægten Sehedonorus. 7. 2 .

$\beta$, triflora (B. triflorus L., F. D. 440). Smaaaxene treblomstrede.

Alm. i Skove og Krat, især paa Muldjord eller fugtig Grund, $\boldsymbol{\beta}$, med Hovedarten, sjelduere.

\section{Vulpia. Vaselhale.}

171. V. sciuroides [Gmel. Bad. I, p. 8] (Langstakket V.) Drej. n. 127; Festuea Roth, And. III, 28; H. N. XIII, 93; F. bromoides Sm., H. 116 ; F. D. 1445; Vulpia bromoides Link., Rehb. 1, tab. 60, fig. 1529.

Straaene tueformigt samlede, ingen golde Bladknipper; Bladene smale, det øvre fjernet fra Blomsterstanden; Skedehinden toøret; Toppen ensidig, axformigt sammenkneben, opret; Grenene under Blomstringen opret-aabne, de nedre $1 / 2-$ mange Gange kortere end Toppen; den øvre Yderavne langt tilspidset; Inderavnerne kortere end Stakken.

4-12" høi. De nedre Grene ofte meget korte, med eet enkelt Smaaax. 6-7. $\odot$.

Paa tørre, saavel sandige som lerede Marker og Rakker, sporadisk og ilke almindelig, men bemærket $i$ alle Provindser, hyppigst paa Bornholm. 可

Anm. V. Myurus Gmel. (V. pseudomyurns Willem., Rehb. l. e. fig. 1525), som er meget nær beslægtet micd foreg. og adskilles ved en mere forlænget, nikkende Top, tæt omskedet af det ovre Blad, er funden i Holsteen (Web., N.), og muligviis hore ogsia nogle af de danske Voxesteder herhid. Den maa søges paa lignende Localiteter som foreg. 


\section{Bromus. Ileire.}

a. Den nedre Inderavne ligelang med den ørre, længere end den balgede Stak, Blomsterne imod Modningen i Randen indrullede (og derved fjernede fra binanden).

172. B. secalinus I. (Almindelig H.) H. 121 ; Drej. n. 108 ; F. D. 29.3 (B. arvensis) og 1446 (?), Rchb. I, tab. 75, fig. 1600; And. III, 35; L. Herb. VII, 132.

Straa og Bladskeder glatte; Bladene paa Overfladen haarede og rue; Topgrenene under Blomstringen udbredte; efter samme nikkende; Smaaaxene aflange, glatte.

Smaaaxene grønne, var. i Henseende til Størrelse og Stakkens Langde (ofte aldeles staklyse). 6-7. (-)

Almindeligt Ukrud i Vintersaden.

Anm. F. D. 1446 er ikke heldig, og det er endogsaa triplsomt om den hører til denne Ait eller om den ikke snarere skal forestille den folgende. 'Iil B. commutatus, hvortil Horn. henfører den, hører den neppe.

b. Den nedre Inderavne ligelang med den øvre, kortere end den rette Stak, Blomsterneimod Modenheden taglagte.

173. B. arrensis L. (Ager.H.) H. 124; Drej. n. 111 ; F. D. 2527 ; And. III, 34 ; Rchb. I, tab. 74, fig. 1587 ; H. N. VI, 88; L. Herb. I, 7.

Bladene paa Underfladen rue, tilligemed de nedre Skeder haarede; Toppen udbredt, efter Afblomstringen nikkende, med lange og slappe Grene; Smaaaxene fladtrylkte; lancetformede, glatte, med opret-aabne Blomster; den nedre Inderavne ligelang ned Afstanden fra sammes Spidse til Spidsen af den tredie Blomst paa samme Side.

Smaaaxene alm. bruunviolette med hvid hindeagtig Rand. 6-7. $\odot$.

Paa dyrkede Marker, ved Veie og Grofter, sporadisk og ikke alm., men benærket $\mathrm{i}$ alle Pıovindser og som det synes hyppigere i de senere Aar, da den paa enkelte Steder har veret dyrket (meest udbredt har jeg fundet den paa Lolland). [* 
c. Den nedre Inderavne længere end den øvre, ligelang med Stakken, (forøvigt som b.)

aa. Toppen efter Blomstringen nilkende.

174. B. commutatus [Schrad. fl. germ. I, 353] Mangeblomstret H.) H. 123 (undt. Cit. af F. 1).); Drej. n. 109; F. D. 2526; And. IV, 37; Rehb. I. c. fig. 1589; L. Herb. I', 5; Br. pratensis (Ehrh.) Fr. mant. 3, p. 9; H. N. VI, 89 .

Bladene og de nedre Skeder haarede; Topgrenene slappe; Smaaaxene 9-11.blomstrede, lancetformede, trindt-fladtrykte, glatte, uled taglagt-tiltrykte Blomster; den nedre Inderavne ligelang med Afstanden fra sammes Spidse til Spidsen af den tredie Blomst, dens Rand danner ovenfor Midten en stump Vinkel.

Var. i Henseende til Topgrenenes Antal og Længde (alm. ere disse dog meget kortere end hos foreg.). Smaaxene almindelig matgrønne. $5-6$.

Paa tørre Steder, f. Ex. Diger, Agre, funden i alle de danske Provindser, men sporadisk. (Da jeg intetsteds har bemærket den paa Enge, livor derimod den folgende almindeligst forekommer, synes Ehrlarts Navn for Danmarks Vedkommende at vaere mindre passende $o g$ at kunne bevirke Forvexling).

\section{b6. Toppen efter Blomstringen opret, sammentrcengt.}

175. B. racemosus L. (Klaseblonstret H.) H. 123; F. D. 2644 ; Rehb. I. c. fig. 1590 ; And. IV, 36; H. N. I, 79; L. Herb. II, 24.

Bladene og de nedre Skeder haarede; Toppen klaseformet, med k orte, under Blomstringen aabne Grene; Smaaaxene glatte, æg-lancetformede, noget triude, 7-9-blomstrede med taglagttiltrykte Blomster; den nedre Inderavne ligelang med Afstanden fra sammes Spidse til Spidsen af den fjerde Blomst paa samme Side, dens Rand afrundet (danner en Bue).

Straaene ofte rødagtigt anløbne; Inderavuerne i Spidsen tilligemed Stakkeı alm. brune. 6. (-).

Paa fugtige Enge, ikke alm., men bemærket i alle Provindser. 
176. B. mollis L. (Blød H.) H. 122; Drej. n. 110; F. D. 1324; Rehb. I. e. fig. 1591-92; And. IV, 38; H. N. VII, 96 ; L. Herb. I, 6.

Straaet opret; Blade og Skeder duunhaarede; Toppen under Blomstringen udbredt; Smaaaxene haarede, glandsløse, aglancetformede, 7-9-blomstrede, med taglagt-tiltrykte Blomster; den nedre Inderavne ligelang med Afstanden fra sammes Spidse til Spidsen af den fjerde Blomst paa samme Side, dens Rand danner ovenfor Midten en stump Vinkel.

$1 / 2-1^{1 / 2} 2^{\prime}$ høi. Var. i Henseende til Topgrenenes Længde, Straaets og Smaaaxenes Bekladning. 6-7. $\odot$.

$\beta$, lejostachys M. \& K.; H. N. VIII, 95. Smaaaxene glatte eller lidet rue af meget korte Haar.

$\gamma$, pygmaus (B. nanus Weig.) Dværgform med alm. 1 enkelt Ax.

Paa Græsmarker, høie Enge, ved Veie o. s. v. meget alm. $\boldsymbol{\beta}$, mellen Hovedarten, sjeldnere: $\boldsymbol{S} \boldsymbol{j}$. Jagtveien ved Kbh.! Sorø! Kjoge! $\boldsymbol{F}$. Nyborg (Lund); J. Livg i Limfjorden (8), Randers (7); $\gamma$, paa mager Jordbund.

177. B. hordeaceus L. [Wahlenb. fl. ups. p. 40] (Strand-H.) Fr. mant. 3, p. 11; And. IV, 39; H. N. VII, 97; B. arenarius Thomine.

Straacne tæet samlede i Tuer, oftest nedliggende, 2-6" høie; Toppen under Blomstringen axformigt sammenkneben, med meget korte Grene; Smaaaxene elliptiske, glatte, glindsende, forørigt som foreg. $5-6$. $\odot$.

Paa Strandenge, Overdrev, ved Sobredder, mangler neppe i nogen af de danske Provindser, isar hyppig langs Reeskilde Fjord, paa flere Steder ved Øresundet (f Ex. Saltholu, Kjøge Strand!), langs Sydvestkysten af Lolland (19), langs Storebelt paa Østkysten af Fyen og paa Snaaserne S. for Fyen (12), samt pai Bovbjerg i Jyll.l 


\section{Schedonorus $\left.{ }^{\star}\right)$. Ileiresvingel.}

a. Vulpioidei Fr. Smaaxene efter Blomstringen bredest mod Spidsen, den øvreInderavne i Randen kamformigt stivhaaret. $\odot$ eller $\odot$.

178. S. sterilis [Fr. Bot. not. 1843, p. 131] (Gold H.) And. III, 32; Bromus L., H. 127; Drej. n. 107; F. D. 1325 ; Rchb. I, tab. 73, fig. 1583 ; H. N. I, 80; L. Herb. IV, 66.

Straaet glat; Bladene og de nedre Skeder fint- og tiltryktduunhaarede; Toppen alsidigt udbredt, med lange, i Spidsen nikkende Grene; Smaaaxene linic-lancetformede, rue, med en Stale som er meget længere end Inderavnen.

\section{1-2' høi. 5-8. $\odot$.}

Ved Byer, Gjærder og Mure ikke alm., men bemarket i alle Provindser og, hvor den forelsommer (især ved Kjøbstæder), ofte $\mathbf{i}$ stor Mængde; hyppigere paa Øerne end paa Halvøen.

179. S. tectorum [Fr. l. e.] (Tag-H.) And. III, 33; Bromus L., H. 128 ; F. D. 1806 ; Relbb. I. e. fig. 1582 ; II. N. $\mathrm{XI}, 91$.

Straact foroven, ligesom Blade og Skeder, duunhaaret; Toppen noget ensidig, nikkende, med slıppe, nedhæugende Grene; Smaaaxene linieformede, tæt duunhaarede, med en Stak omtrent af Inderavnens Læengde.

${ }^{1} / 2-1^{1 / 1} 2^{\prime}$ høi. Lavere og finere end foreg., Smaaaxene mindre, ofte rødligt anløbne. $6-8 . \odot$.

Den anføres som dansk allerede af Schum. og Hornem., dog uden Angivelse af Voxesteder. Den er meget sjelden her i Landet paa lignende Steder som foreg., og de eneste mig bckjendte danske Voxesteder ere: $\boldsymbol{S} j$. Storelsedinge (Visby)! $\boldsymbol{F}$. Hofmansgave (A. Meyer), Faborg (12). |t

*) Narnet Sehedonorus skyldes Pal. Beauv. (Agrost. p. 99), dets her antagne Begrændsning Fries. Orthographien Schenodorus (hidrørende fra en Trykfeil i Registret hos Beauv.) og Schoenodorus (sic!) er falsk. 
b. Festucacei Fr. Smaaxene bredest i Midten, deu ovre Inderavne i Randen ru af meget korte Børster. ข.

180. S. asper [Fr. I. e.] (Ru H.) And. III, 30 ; Bromus Murr., H. 126 ; F. D. 1382; Rehb. I, tab. 76, fig. 1603; H. N. IV, 97; Festuca aspera M. K., Drej. n. 123.

Bladene paa begge Flader rue, tilligemed de nedre Bladslieder stivbaarede (Haarene paa Bladskederne nedadvendte), de ovre Skeder glatte; Toppen med lange, tiltrykte Grene (alm. $2-4$ i de nedre Ilalvkrandse); Smaaxene 7-10-blomstrede; rue; den ovre Yderavne langs Sidenerverne langhaaret, den nedre Inderavne haaret til Spidsen, af Stakkens Langde eller lidet liengere.

3-5' høit og stivt Græes. 6-7.

I Skove, især para fugtig Grund; ikke sjelden paa II alvoens $\emptyset_{\text {st- }}$ kyst, i Fyen, paa $\theta$ crne og i Vest.Sjalland, sjeldnere mod $\emptyset$. (f. Ex. Vedhek! Ordrups Mose (H.), Dronninggaard (Dr.), Jonstrup Vang (15), Boserup!)

* 181. S. serotinus Rostr. (Sildigblomstrende H.) Bromus serotinus Beneken, Bot. Zeit. 1845, p. 724 .

Alle Bladskederne langharede; Tuppen nikkende, de nedre Topgrene parviis stillede, udsprelte; den ovre Yderavne kortere og windre tilspidset, glat; den nedre Inderavne i Spidsen glat, forovigt som forey., men blomstrer 2 i 3 Uger senere. 4 .

Temmelig almindelig i Skove par Lolland (19)! Findes sandsynligviis ogsaa $i$ andre Egne af Landet, men har hidtil ikke været sondret fra foreg. og maa derfor nirmere iagttages.

182. S. erectus [Fr. l. e.] (Opret H.) And. III, 31; Bromus Huds., H. 125 ; F. D. 1383 ; Rchb. I, tab. 77, fig. 1604; H. N. IX, 96; Festuea Wallr., Drej. n. 124; L. Herb. $\mathrm{VI}, 104$.

De nedre Skeder baarede, med udstanende Haar; Bladene randhaarede; Toppen opret, alsidig, med kortere, opret-aabne, efter Afblomstringen tiltrykte Grene (alm. $3-4$ i de nedre Halvkrandse); Smaaaxene 5-9-blomstrede; den nedre Inderavne 2-3 Gange længere end Stakken. 
11/2-3' høi. Fra Rodstokken udgaae flere golde Bladknipper: Bladene smalere end hos foreg., og kun paa Overfladen rue. 6.

Paa tørre Steder, f. Ex. ved Randen af Marker og Veie sjelden: $S j$. Birkerød (Schum.), Dronninggaard, Lundehuset (H.), Jægersborg Allee ved Bernstorf! Strandmarkerne udfor Charlottenlund (Dr.).

183. S. inermis [Fr. l. e.] (Stakløs H.) And. III, 29; Bromus inermis Leyss.; H. I, 125; Rehb. I, tab. 70, fig.1569-70; H. N. VII, 94; Festuea speciosa F. D. 1805.

Bladene bredere end hos foreg., tilligemed Bladskederne glatte; krybende Udlobere fra Rodstokken; Toppen opret, alsidig, med fine, efter Afblornstringen udstaaende Grene (alm. 5-7 i de nedre Halvkrandse); Smaaaxene lancetformede, 610-blomstrede; den nedre Inderavne stakløs eller med en kort Stak (mange Gange kortere end Inderavnen).

1-1 $12^{\prime}$ høi. $7-8$.

Enge og Gjaerder mellem Ballastbroen og Kielseng paa Sydsiden af Flensborg Fjord! $\sqrt{x}$

\section{Dactylis. IIundegraes.}

184. D. glomerata L. (Hvas H.) H. 113; Drej. n. 126; F. D. 743; Rehb. I, tab. 59, fig. 1523; And. II, 20; L. Herb. $\mathrm{V}, 85$.

Rodstokken sammentrængt, med Bladknipper, men uden Udløbere; Bladene rendede, rue; Skedehinden lang, tofliget; Toppen ensidig; med under Blomstringen udspærrede Grene og nøgleformigt sammenhobede Smaaax.

6-7. ข. Forekommer efter det forskjellige Voxested under flere afvigende Former:

$\beta$, adbreviata Drej. (D. adbreviata Bernh., Rehb. 1. e. fig. 1522). Topgrenene meget korte, fra Grunden af besatte med $5-7 \cdot$ blomstrede Smaaax.

$\gamma$, lobata Drej. Topgrenene ved Grunden et langt Stykke nøgne, Smaaaxene omtrent treblomstrede, Inderavnerne paa Ryggen svagt rue eller næsten jævne.

Paa Græsmarker, ved Gjwerder o.s.v. meget alm. $\beta$, paa torre. og solaabne Steder, f. Ex. J. Strandbredder N. for Aarhus; F. Øxnebjerg 
ved Svendborg! Langelands Ostkyst (19); Loll. Bredfjed i Rødby Fjord (14); Falst. Gronsund, Ulslov Straud (Koch); $\gamma$, i skove: Sj. Skoven ved Kongens Moller (27), Alindelille Fredskov! Boserup, Sorgenfri (20), Sparresholm (Lund); Hoens Klinteskov! Falst alı. (Kocls); Loll. Kyllingskoven ved Juellinge (19); J. Haraldslund! $S$ l. Nyvierk ved Slesvig!

\section{Cynosurus. Kamgraes.}

185. C. cristatus L. (Almindelig K.) H. 114; Drej. n. 128; F. D. 238; Rehb. I, tab. 7, fig. 1351-52; And. II, 19 ; L. Herb. VII, 134.

Dustien linieformet, opret (1-2" lang), ensidig; Noglerne afvexlende, meget kortstilkede; Yder-og Inderavnerne tilspidsede $\mathrm{i}$ en Braad; Skedehinden kort afskaaren. 6.4.

Paa Enge, Grxsmarker og ved Randen af Veie alm.

\section{Trigynia.}

\section{Holosteum. Spidsgab.}

186. II. umbellatum L. (Skjærmblomstret S.) H. 143 ; Drej. n. 145 ; F. D. 1204 ; Rchb. I. c. V, fig. 4901 ; H. N. I, 40 .

Bladene modsatte, lanectformede eller elliptiske, spidse, glatte; Blomsterne i Skjærm; Blomsterstilliene efter Afblomstringen nedhængende.

Stængelen oventil klæbrig. Kronbladene hride. Ligner en Cerastium. $3-5$. $\odot$.

Paa torre Marker, Steengjæerder, ikke almindelig: $\boldsymbol{S} \boldsymbol{j}$. et Tanggjar de ved Sophieuberg (21), Horsholm (Dr.), Frydenlund, Dronninggnard, Sorgenfri (H.), Aagerup (14), Hvedstmp red Roeskilde (8); paa Moen ikke sjelden; Batagø; Falst. ved Moseby og Veiringe (14); L oll. Ostofte (H.); B ornh. paa Slirenterne fra Pythuset til Amager (20). 


\section{$4^{\text {de }}$ Klasse. Tetrandria (Firehannede).}

\section{Orden. Monogynia (Enhunnede).}

A. Blomsterdækket dobbelt.

a. Kronen sambladet.

aa. Frugten underscedig.

*. Blomsterne ordnede til en Blomsterkurv, Frugten en med en dobbelt Fnok*) beklædt Skalfrugt. Bladene modsatte.

$$
(1-4 \text {. N. F. Dipsaiee }) \text {. }
$$

ar. Blomsterleiet beklcedt med Børster.

1. Knáutia L. (Coulter). Deu ydre Fnok utydeligt firetandet, den indre mange-(8-10-) straalet; Kronen firedeelt; Skalfrugten sammentrykt, med 4 skarpe Kanter, uden Furer, men med 4 svage Gruber foroven.

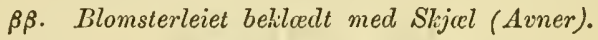

2. Scabiósa L. Den ydre Fnok hindeagtig, udeelt, med tandet Rand, den indre fernstraalet; Kronen femdeelt; Skalfrugten valseformet, furet.

*3. Succísa M. \& K. Den ydre Fnok firekløvet, kort, urteagtig, den indre femstraalet; Kronen firedeelt; Skalfrugten furet.

4. Dipsacus L. Kronen firedeelt; den ydre Fnok utydelig, hindeagtig, den indre hindeagtig, affaldende; Skalfrugten firekantet, furet (Avnerne stikkende, Blomsterleiet kegleformet). $\boldsymbol{\beta}, \quad$ Frugt todelelig Spaltefrugt (Skalfr. eller Steenfrugter) uden Fnok eller beklædte med en enkelt Bægerrand). Bladene krandsstillede.

$$
\text { (5-8. N. F. Rubiaceæ a, Stellatæ). }
$$

5. Sherárdia L. Kronen tragtformet, (violet); Skalfrugten beklædt af et sextandet $\mathrm{Bæger}$.

6. Aspérula L. Kronen tragtformet (hvid); Bægerranden utydelig; Skalfrugt.

*) Den indre Fnok hos Planterne i denne Afdeling er dannet af det egenlige (oversædige) Bager, den ydre af et Yderbæger. 
7. Gảlium L. Kronen hjulformet (hvid eller guul), Bægerranden utydelig; Skalfrugt.

8. Rúbia L. Kronen hjulformet (grønguul); Bægerranden utydelig; Frugterne saftige; steenfrugtagtige.

\section{bb. Frugten fri.}

9. Plantágo L. Blomsterstanden axformet; Bægeret firedeelt; Kronen regelm. firefliget; Kravens Flige tilbagebøiede; Støvdragerne afvexlende med Kronfligene og længere end disse. Frugten opspringende paatværs (Buddike), 2-4-rummet. (N. F. Plantaginea).

Anm. Hos alle danske Arter af denne Slregt ere Bladene samlede red Grunden, Skafteme bladløse.

10. Centunculus L. Blomsterne enlige i Bladhjørnerne; Biegeret dybt firedeelt; Kronen firefliget, med udstaaende Krave; Støvdragerne ligefor Kronfligene; kortere end disse; Frngten opspringende patværs, enrummet. (N. F. Primulaeeæ.)

11. Cicéndia Adans. Blomsterne enlige, endestillede eller i Vinklerne af gaffeldeelte Grene; Bægeret firetandet; Kronen firedeelt. med oprette Flige og Støvdragerne afvexlende med disse; Frugt 1-2-rummet, opspringende paa langs. (N. F. Gentianex.)

Gentiana Amarella og campestris $(5,1$.

Limosella 0 . Al. af de Tomrgtige $(14,1 \mathrm{og} 2$.

\section{b. Kronen fribladet.}

12. Cornus I. Blonst oversædig; Bægeret firedeelt; Kronblade 4, tilligemed Støvdragerne befæstede til en overssedig Skive; Fr. Steenfrugt med $2(1-3)$ Rum. (N. F. Corneæ.)

13. Euónymus L. Blomst undersædig; Bægeret 4-5deelt; Kronblade 4-5; Støvdragerne befæstede til en omkringsædig Skive; Fr. 3-5-rummet Kiapsel, i hvert Rum 1 Frø, omgivet af Frøhud. (N. F. Frangulaceæ, e.)

$X$ Trapa L. Blomsten oversædig; Bægerflige og Kronblade 4 , de sidste tilligemed Støvdragerne befæstede til en Skive omkring den foroven frie Frugtknude; Frugten en en- 
frøet Nød, tæt omgivet af det efterhaanden forhærdede Bægerrør og beklædt paa Siderne af de tilsidst bornformigt tilspidsede Bægerflige. (N. F. Halorrbage æ).

Rhamnus. Fr. Bær eller Steenfrugt $(5,1$.)

Cardamine hirsuta. Skulpefrugt $(15,2$.

\section{B. Blomsterdækket enkelt.}

14. Majánthemum Web. Blomsterdækket firedeelt, undersædigt, alle Blomsterne $\Varangle ;$ Griffelen endestillet; Frugten et Bær. (Urt med buenervede Blade og Blomsterne i endestillet Klase. N. F. Smilaceæ.)

15. Parictária L. Blomsterue enbo eller fleerbo; $\Varangle$ og f Blomsterdækket undersadigt, firedeelt (grønt), $†$ Blomsterdrkket klokkeformet, i Spidsen indsnøret, firetandet; Arret penselformet; Frugt nødagtig. (Urt med fjernervede Blade og Blomster i Nøgler fra Bladhjørnerne. N. F. Urtica ceæ.)

16. Alchenilla L. Alle Blomsterne $\Varangle ;$ Blomsterdækket omkringsædigt, ottedeelt, (hveranden Flig mindre)*), grønt; 1 Griffel udgaaende fra Frugtknudens Basis, med hovedformet Ar; Frugten Nød, omsluttet af det vedblivende Underbæger. (Urt med haandlappede Blade og Blomster i en grenet Qvast. (N. F. Ros a ce a $\alpha$.)

17. Sanguisórba L. Blomster $\Varangle$ (eller fleerbo); Blomsterdækket oversædigt, firedeelt, farvet; Griffelen endestillet, med tolappet, kirtellaaret Ar; Frugt som hos foreg. (Urt med fjersnitdeelte Blade og Blomsterne i Ax. N. F. Rosaceæ $\alpha$.)

Thesium. $\Varangle$ Blomsterdæklke oversædigt, 4-5-deelt, (udvendig grønt, indvendig hvidt). $(5,1$.

\section{Orden. Digynia (Tohunnede).}

Cuscuta. Frugt Buddike (Snylteplante) $(5,2$.

Gentiana. Fr. torummet Kapsel $(5,1$.

*) Blomsterdæklket hos denne Slægt kan let antages for dobbelt, naar de 4 ydre (og mindre) Flige, som staae ligefor Støvdragerne, ansees for Bregerblade, men disse maa, i Lighed med andre Arter af samme Familie, f. Ex. Potentilla, ansees for et Yderbeger. 
Herniaria Hindefrugt $(5, .1$.

Ulmus. Vingefrugt $\left(\boldsymbol{\zeta}_{\mathbf{2}}\right)(5,2$.

Alchemilla. Nodfrugt $(4,1$.

Galium og Asperula. Todelelig Skalfrugt $(4,1$.

\section{Orden. Trigynia (Trehunnede).}

Holosteum. $\quad(3,3$.

Ilex $(4,4$.

\section{Orden. Tetragynia (Firehunnede).}

A. Blomsterdækket dobbelt.

18. Ilex L. Bæger og Krone firedeelte; Griffel 0, 4 (3-5) Ar; Frugten et Bær med 3-5 enfrøede Rum og beenhaarde Skillevægge. $\zeta$. (Bladene stedsegrønne, tornede $\mathrm{i}$ Randen. N. F. Frangulaceæ, a.)

19. Radiola Dill. Brger firedeelt, med 2-3-fligede Afsnit; Krone firebladet; Fr. en firerummet Kapsel (hvert Rum deelt i 2 ufuldstændige, toklappede og tofrøede Rum). (N. F. Lineæ.)

20. Bulliárda DC. Bxger firedeelt; Krone firebladet; Fr. 4 fleerfrøede Bællekapsler. (N. F. Crassulaceæ.)

Sagina (a). Fr. enrummet, fireklappet Kapsel $(10,4$.

Cerastium tetrandrum $(10,4$.

B. Blomsterdækket enkelt.

21. Potamogéton L. Blomsterdækket firedeelt; Støvdragerne siddende paa Blomsterdækkets Flige; Frugterne 4 stilkløse Nødder eller Steenfrugter. (Vandplante med Blornsterne i Ax.)

22. Rúppia I. Vandplante med alm. toblomstrede Blomsterstilke; Blomsterdække 0 ; Støvdragerne 4, enrummede, siddende parviis paa 2 korte Skjæl (eller 2, torummede med skjælformede Støvtraade); Frugterne 4 ved Modningen langstilkede Nødder. (21-22. N. F. Fluviales c.) 


\section{Monogynia.}

\section{Knautia. Blaahat.}

187. K. arrensis [Coult. Dips. p. 29] (Almindelig B.) Scabiosa L., H. 152; Drej. n. 158; F. D. 447 ; Rehb. ic. A. germ. XII, tab. 680, fig. 1353; Trichera Schrad.

Stangelen stivliaaret; Rodbladene grovt-takkede; Stangelbladene fjersnitdeelte eller halvfinnede, med heelrandede, linielancetformede Flige og en større Endeflig; Randkronerne uregelrette, større end de regelrette Skivekroner.

$1^{1 / 2}-3^{\prime}$ høi. Var. i Henseende til Dybden af Bladenes Indskjæring og Kronens Farve (blaa, violet, hvid). 6-7. 4.

$\boldsymbol{\beta}$, campestris Koch. Alle Kronerne regelrette.

Alm. paa dyrkede og udgrkede Marker, ved Veie o.s.v. $\beta$, med Hovedarten.

\section{Scabiosa. Skabiose.}

188. S. Columbaria L. (Due-S.) H. 152; Drej. n. 159; F. D. 314 ; Asterocephalus Wallr., Rchb. 1. c. XII, tab. 693, fig. 1378.

Stcongelen næsten glat; Bladene paa de golde Bladknipper elliptiske, rundtakkede eller, tilligemed de nedre Stængelblade, lyreformet-halvfinnede eller -snitdeelte med tandede eller indskaarne Flige; de øvre Slungelhlade fjersnitdeelte med smalt linieformede Afsnit; Straalerne i deu indre Fnok 3-4 Gange længere end den ydre Fnoks Krave; Randkronerne uregelrette; Skivekronerne regelrette.

1-1 $1^{1} / 2^{4}$ høi. Kronerne violette. 7-9. $\psi$.

Paa torre Bakker sporadisk: i det østlige og nordlige $\mathbf{S}$. hist og her, sjeldnere mod V. (Veirhøi! Tiissø! Nestved (H.); Meens Klint alm.! Falst. ved Grousunds Færge! o. fl St. (Koch); Loll. Nysted (5); $S l$. Haderslev, Midsunde N. for Fargestedet (16); paa Bornh., i Jyll. og F. ikke bemærket.

189. S. suaveolens [Desf. cat. hort. par. 110] (Vellugtende S.) H. II, 127; Dŕej. n. 160; Asterocephalus Wallr., Rehb. XII, tab. 690, fig. 1372 ; H. N. I, 9 ; Scabiosa canescens W. \& K., F. D. 2282. 
Stangelen tret graafiltet; Bladene paa de golde Bladknipper lancetformede, heelrandede (sjeldnere tandede); Stangelbladene fjersnitdeelte med smalt linieformede, heelrandede Afsnit; Straalerne i den indre Fnok dobbelt saa lange som Kraven af den ydre; Randkronerne uregelrette; Skivelironerne regelrette.

Lavere end foreg. $\left(1 / 2-1^{1} \frac{1}{\prime} h\right.$ h $\left.\oint i\right)$, Blomsterne have en ikke stærk, men belıagelig Lugt, lila Kroner. 7-9.

Paa sandige Marker og Bakker, hidtil kun funden i Nordsjalland: ved Nordbredden af 'Tiissø paa Skræuterne tæt O. for Beks Kro (27)! Kjeldby Banke ved 'Tømmerup pr. Kalundborg (Baagøe). Fi

\section{Succisa. Djaevelsbid.}

190. S. pratensis [Moeneh meth. 499] (Eng-D.) Rehb. XII, tab. 698, fig. 1385; Scabiosa Succisa L., H. 151; Drej. n. 161 ; F. D. 279.

Rodstokken lodret, den nedre Deel afstumpet ("afbidt Rod (I), med talrige, stærke Rodtrævler; Stcengelen duunharet; Rodbladene elliptiske eller omvendt-ægformede, heelrandede; Stcongelbladene lancetformede, heelrandede eller utydeligt tandede; Blomsterkurven kalvkugleformet; alle Kronerne regelrette.

$1-1^{1} \frac{1}{2} 2^{\prime}$ høi. Kronerne blaae, sjeldnere lysrøde eller livide. 8-9. ข.

Paa lıøie Enge (især paa Torrgrund) alm. udbredt. En Var. med blegrode Blomster og femkløvede Randkroner er funden paa I. oll. ved Hellinge (19), $S_{j}$. Boserup Overdrev (Lund).

\section{Dipsacus. Kartebolle.}

191. D. pilosus L. (Haaret K.) H. 150; Drej. n. 157; F. D. 1448; Rehb. XII, tab. 704, fig. 1393; H. N. II, 18; Cephalaria pilosa Gren. \& Godr. fl. Fr. II, 69.

Bladene stilkede, ved Grunden orede, svagt haarede; Kurvbladene nedhængende, ligelange med eller kortere end den kugleformede Blomsterkurv; Avnerne tæet og børsteformigt-randhaarede.

Stængel og Grene, især oventil, beklæedte med Pigge. Kronerne hvide. 7-8. $\odot$.

I Skove sjelden: $\boldsymbol{S}$ j. Sorgenfri (19), Herlufsholm, Vordingborg (H.); Falst. Næsgaard, Corselitze (14); Loll. Kuntlienborg (H.), 
Bremersvold (5), Vesterborg, Østofte (19), Græshave (14) o. fl. St. (19); F. Lundsgard ved Kjerteminde (Heiberg), Aalykkeskoven ved Udense (H.)! Veistrup (19), Nielstrup (12), Hallenskov v. Svendborg (H.); $\boldsymbol{A}$ ls $\boldsymbol{s}$. Sonderborg (14); $\boldsymbol{S}$ l. Udmark i Angel (1), Röest v. Slesvig (16). $\bar{*}$

192. D. silvestris [Mill. dict. n. 2] (Almindelig K.) H. 149; Drej. n. 156 ; F. D. 965 ; Rchb. XII, tab. 707, fig. 1397.

Stangelbladene siddende, ved Grunden noget sammenvoxne, fra bredere Basis lancetformede, tilspidsede, rundtakket-saugtakkede; Kurvbladene bueformigt opstigende, de ydre liengere end den ægformede Kurv; Avnerne tæt duunhaarede og i Randen beklædte med fjerutstaaende Figge.

$3-5^{\prime}$ h $\phi$ i. Stængel, Rodblade og Kurvblade beklædte med Pigge, Kronerne violette, de midterste Blomster udspringe forst. 7-9. ().

Paa Marker, ved Veie og Gjærder: $\boldsymbol{S} \boldsymbol{j}$. Refsnæes (21), Kalundborg (Baagøe), N. Jernløse (Leth), Korsør, Munkebjergby (Lund), Jydernp (Dr.), Soderup (H.), Gjentofte (19), Pesthuset ved Kjøbenhavn! i Sydvest-Sjæll., paa Moen, Falst (mod N. V.) og Loll. alm.; Langeland v. Faareveile (H.); Stryno (12); F. Ulriksholm, Skovsbo (H.), Rørbæk! Kongslıøi Aa (19), St. Jorgensgaard, Hvirlkilde! Fe mern (H.); $S l$. Frederiksstad, Syderstapel (16); J. Barritskov (16), Rosenvold (15). ( 1 den nordlige Deel af Jylland synes den at mangle). 周

\section{Sherardia. Blaastjerne.}

193. S. arrensis L. (Ager-B.) H. 153; Drej. n. 162; F. D. 439 ; Rehb. 1. c. XVII, tab. 1183.

Bladere krandsstillede (ty pisk $1 / 6$ ), omvendt-æg formet-lancetformede, stivharede, især i Randen; Blomsterne i Hoveder i Spidsen af Grenene, omgivne af et alm. sexbladet, ved Grunden sammenvoxet $S v \phi b$.

Stængelen svag, nedliggende, firekantet, ru af nedadvendte Smaatorne. Kronerne violette. 6-8. $\odot$.

Paa dyrkede Agre mellem Sxden, især paa Leergrund, ikke sjelden i de fleste Egne af Danmark.

\section{Asperula. Mysike.}

194. A. odorata L. (Bokar, Skovmærke) H. 154; Drej. n. 163 ; F. D. 562 ; Relib. XVII, tab. 1178. 
Rodstoklien krybende; Bladene krandsstillede (de nedre alm. $1 / 6$, de ovre 1/8), laneetformede, glatte, i Randen og paa Rygnerven rue; Skalfrugterne stivhaarede af hagekrummede Børster.

Bladene have, isæer tørrede, en stæerk og behagelig Lugt ("gronne Krandse"); Kronerne hvide, ved Torring sorte. 5-6. 4.

I Skove par los Muldjord og i Skygge, alm. udbredt.

195. A. tinctoria L. (Farve-M.) H. 155; Rchb. XVII, tab. 1180 ; H. N. III, 6.

Rodstoliken krybende, Bladene krandsstillede (de nedre $1 / 6$, de øvre 1,4), linieformede, glatte, i Randen lidet rue, Skalfrugterne glatte.

Rodstokken løoirød*), Kronerne hvide, alm. med trefliget Krave. 6-8. थ. (Beck). 店

Paı Bakker og Lyngheder: i Danmark kun funden ved Aalborg

\section{Galium. Snerre.}

a. Bladene trenervede, budte, uden Braad;

Stæugelen jævn. (Platygalium DC.)

196. G. bornale L. (Trenervet S.) H. 160; Drej. n. 164; F. I). 1024 ; Relbb. XVII, tab. $1186 ;$ H. N. XV, 15.

Stangelen opret, fint duunhaaret eller glat; Bladene linielaneetformede eller $æ g$-lancetformede, alm. 4 i Krandsene; Griffelen spaltet nxsten til Grunden; Frugterne stivhaarede af hagekrummede Børster.

1-1 $1 / 2^{\prime}$ høi. Rodstokken alm. høirød. Kronerne hvide. 7-8. 4.

$\beta$, latifolium! Bladene bredere, de ovre agformede, femnervede.

$\gamma$, hyssopifolium Koch, Frugterne glatte, Bladene bredt lancetformede.

Paa hoie Fnge og Bakker mellem Krat: alm. i Hanherred (12), nordl. og østl. Sjall. og især paa Bornh.! sjeldnere og sporadisk

*) Flere af de til disse Slagter (5-S) henhorende Arter have en hoirød Rod og Rodstok. Hos nogle Arter er Griffelen tikGrunden tredeelt, hvorfor de søges under Digynia.

Haandb. $\mathbf{i}$ den danske Flora. 
i de ørige Provindser, mangler f. Ex. i det sydlige Fyen (12). $\beta$, ved Helsingor (11); Bornh. Seiersgaard ved Rønne (Baagøe); $\boldsymbol{\gamma}, \boldsymbol{L}$ oll. Vindeby Skov (19)!

b. Bladene ennervede, med en Braad. Stængelen jævn. (Eugalium D C., Koch).

197. G. silvaticum L. (Skov-S.) H. 159, Rehb. XVII, tab. 1189 ; H. N. XIII, 34 ; G. glaucum F. D. 609.

Stcengelen opret, trind, utydeligt fireribbet; Bladene 6-8 i Krandsene, oval--lancetformede, med en kort Braad, i Randen rue, forøvigt glatte, paa Underfladen blaagrønne; Blomsterstanden starkt forgrenet; Blomsterstillens harfine, før Blomstringen nikkende, efter samme aabne; Krunfligene med en kort Spids; Frugterne glatte, svagt rynkede.

$1^{1}{ }_{2}-2^{\prime}$ høi. Rodstokken høirød. Kronerne hride. 6. 7. य.

I Skove og Krat. S $t$. i Skoven ved Wittensee (16), i de andre danske Provindser ikke lemærket (De af Drejer l. c. angivne sjæe]landske Voxesteder høre ikke herhid, men til en Form af følgende). 周

198. G. Mollugo L. (part.) (Bredbladet S.) H. 159; Drej. n. 170 ; F. D. 455 ; G. elatum Thuill.; Gren. \& Godr. fl. Fr. 2 , p. 22 ; Rchb. XVII, tab. $1187-88$.

Stcongelen opret eller fremliggende, firekantet; Bladene alm. 8 i Krandsene, linie-lancetformede, i Randen rue; Topgrenene udbredt-aabne; Blomsterstilkene efter Blomstringen udspærrede; Kronfigene tilspidsede; Frugterne glatte, svagt ryukede.

Stængel og Blade var. glatte eller duunhaarede. Kronerue hvide. 6-8. 4.

$\beta$, ochroleucum H. N. II, 20 ; Kronerne bleggule.

$\gamma$, umbrosum (G. insubricum Gaud., Rchb. XVII, tab.1188-89 ; G. silvaticum Drej. n. 171.) Stængelen svag, nedliggende; Bladene bredere, tyude, med tydeligt Aarenat; Toppen udspærret, med haarfine Grene; Kronerne smaae.

Ved Gjæerder, i Udkanten af Skove o.s. v., ikke sjelden i Danmark, især meget alm. paa Loll.-Falsler og i det sydl. Fyen! (ikke bemarket i det nordlige Jyll. og paa Bornh.!). $\beta$, med Hovedarten. $\quad \boldsymbol{y}$, i Skove, sjeldnere : $\boldsymbol{S} \boldsymbol{j}$. Hammermolleskoven ved Helsingør (11), mellem Springforbı og Fapirmollen (Schum.); J. Ødstedgaard! 
199. G. crectum [Huds. fl. Angl. p. 68] (Opret S.) Gren. \& Godr. Al. Fr. 2, p. 23; Rehb. VII, tab. 1188; G. Mollugo L. (part.)

Stcengelen opret, dens Ledstykker ved Grunden mindre opsvulmede end hos foreg.; Toppen mere sammentrængt og med kortere Grene; Blomsterstilkene opret-aabne (ikke vandret udspilede); Bladene bredere mod Spidsen, kort braadspidsede; Frugterne storre, forøvrigt som foreg. $6-7$.

$\beta$, rigidum Gren. \& Godr. Bladene smalt linieformede, glindsende, Pl. lavere.

I Lundehuusmosen ved Kbh. har jeg for flere Aar siden fundet et aldeles æogte Expl. af denne Art. Fra Ringsted findes Expl. i Drejers Herbarium, den angives fremdeles fra Horreby Lyng paa Falst; Ravusby og Godsø) p. Lull. (19), og uden Trivl vil den findes par flere Steder (Fra Holsteen laar jeg seet Expl. samlede ved Viehburg pr. Kiel. 18). $\beta, S j$. mellem Sorø og Pedersborg! $J$. Hjortlund Kirkegaard (12).

Ann. Denne Art, som almindelig adskilles af de nyere Forfattere, har ikke tidligere med Bestentlied varet angivet for Norden. Dens Adskilielse fra foreg. er unrgtelig ikke meget skarp, og skjøndt den lıar et ret eiendommeligt Udseende, kunde man let fristes til at ansee den for en magrere form af liin, og som saadan er den utvivlsomt indbefattet under Linnés og flere senere Forfatteres G. Mollugo. Da jeg ved Sammenligning med forskjellige Exemplarer fra Sydeuropa, ogsaa fra England (Babington), har overbeviist mig om, on at den rette G. erectum findes her, anforer jeg den, for at dens Udbredelse her i Landet og dens Berettigelse som sxerskilt Art yderligere kan blive undersøgt.

200. G. verum L. (Guul S.) H. 158 ; Drej.n. 169; F.D. 1146 ; Relıb. XVII, tab. 1187.

Stcrngelen opret eller opstigende, med 4 Ribber, duunhaaret; Bladene 6-12 i Krandsene, smalt linieformede med tilbagebøiet Rand, glatte eller paa Underfaden duunhaarede; Blomsterne i en tæet sammentrengt Top med korte, efter Blomstringen horizontalt ndbredte Grene; Kronfligene budte med en meget kort Braad; Frugten glat.

Rodstokken ofte høirød. Kronerue gule. 6-8. 2 .

$\boldsymbol{\beta}$, effusum (ochroleucum H. N. II, 21); G. decolorans Gren. 
\& Godr. fl. Fr. II, p. 19. Kronerne bleggule, Toppen mere udbredt, med længere Grene. Bliver ikke sort ved Tørring.

$\gamma$, altissimum Leeog \& Lamotte; (G. eminens Gren. \& Godr. l. e.) Kronerne bleggule, næsten dobbelt saa store som Hovedartens; Toppen forlænget, udbredt, med mere fjerntblomstrede Grene; de nedre Blade bredere. Bliver sort ved Tørring.

$\delta$, littorale! Rodstokken krybende, Stænglerne nedliggende eller opstigende, med korte Ledstykker, Toppen meget sammenkneben, Kronerne mørkgule.

Ved Gjaerder og Veie, paa Bakker, forekommer $\mathrm{i}$ alle danske Provindser, især i Sandegne (endog i Flyvesandsstrækninger) og er derfor sparsommere i de frugtbare Egne af Landet. $\beta$, forekommer ikke sjeldent med Hovedarten. $\gamma, S l$. ved Bülk (18); $\delta$, alm. i det vestlige Jyllands Sandklitter; Bornholm! F. Ostercen ved Nyborg (Lund).

201. G. silvestre [Poll. palat. 151] (Liden S.) Rehb. XVII, tab. 1193 ; H. N. IV , 10; H. 157 (undt. Voxest.); G. pusillum Sm., H. II, 128; F. D. 1866 (ikke L.).

Stconglerne talrige, opstigende, firekantede, glatte eller duunharede; Bladene omtrent 8 i Krandsene, linie-laneetformede, tilspidsede; Blomsterne i en halvskjærmformet Top med opret-aabne Grene; Kronfigene spidse; Frugterne utydeligt punkterede.

$4-10^{\prime \prime}$ bgi. Kronerne hvide. 6-7. 4.

$\alpha$, glabrum Schrad. (G. læve Thuill.) Stængel og Blade, endog i Randen, glatte.

$\boldsymbol{\beta}$, hirtum Koch (G. Bocconi All.) Stængelen forneden og Bladene korthaarede af udstaaende Haar, Bladene i Randen rue.

* supinum Gaud. (Koch Syn. p. 367). Mangestænglet og tueformet, med finere, nedliggende Stængler, kortere Ledstykker og bredere Blade end Hovedarten, Blomsterstanden meget kort (kun 1-2 Gange gaffeldeelt-grenet).

Paa Lyngbakleer og Heder: paa Ilalvoen hist og her, f. Ex. ikke sjelden i Thy! Neufling Mose S. for Aalborg (Gronlund), Dybdal v. Aalborg, Eveldrup (Dr.), Randers (7), Haraldslund! Ø. Nykirke (12), Nebbegaard! Veile (28), Rødding (16), paa de vestlige Øer fra Fanø 
til Sylt (N.). $\boldsymbol{\beta}$, sjeldnere end $\boldsymbol{\alpha}$, .f. Ex. Eveldrup (Dr.). * Kalkbakker paa Hanstholm og ver Blissg i Thy! Paa Oerne er denne Art ikke hidtil bemærket.

202. G. saxatile L. (Lyng-S.) H. 157; Drej. n. 168; F. D. 1633; Rchb. XVII, tab. 1194; H. N. II, 19; G. her. eynicum Weig.

Stanglerne talrige, svage, nedliggende eller opstigende, firekantede, glatte; Bladene 4-6 i Krandsene, omvendt-rgformede, budte ined en Braad (de øvre bredt lancetformede), glatte, i Randen rue; Blomsterne i en halvskjærmformet Top med opret-aabne Grene; Kronfligene spidse; Frugterne tydeligt punkteret-rue.

4-10" høi. Bliver sort ved Tørring; Bladsubstansen tyndere end hos de foreg. Arter. Kronerne hivide. 6-7. थ.

I Hedemoser og paa tos Grund mellem Lyng og Stene: hyppig i Halvoens og Nurdsjallands Hedeegne; sjeldnere i Sydsjalland, fyen og paa de mindre Øer, f. Ex. ikke bemærket pait Falst. (14) eller paa Loll. (19).

c. Bladene ennervede, Stængelen ru af nedad. vendte Smatorne.

aa. Blomsterstanden en halvsijarmformet Iop, dannet af langstillede, endestillede Qvaster fra Hovedstongelen og de qvre Grene.

ข. (Aparinoides Jord.)

203. (4. palustre L. (Kjær-S.) H. 155; Drej. n. 165; Rehb. XVII, tab. 1195.

Stcongelen svag, firekantet; Bladene $3-5$ i Krandsene, uligestore, lancetformede, foroven bredere (eller omvendt-ægformede), budte, uden Braad, i Randen rue; Blomsterne i halvskjærmformet Top med udspærrede, mod Frugtmodningen tilbageboiede Grene; Blomsterstilliene mod Frugtmodningen vandret udspilede; Frugterne grubet-marmorerede.

$1 / 2-1^{\prime} \mathrm{k} \Leftrightarrow \mathrm{i}$. Bliver sort ved 'Tørring. Kronerne hvide. 6-7. 4. I Kjær og Vandgrofter alm. udbredt.

* 204. G. elongatum [Presl. fl. Sie. I, p. 59] (Mlose-S. Gren. \& Godr. fl. Fr. 2, p. 39 ; Rehb. XVII, tab. 1195 ; (x) palustre F. D. 423. 
Rodstokken langstrakt-krybende; Stconglerne langstrakte, opstigende, mindre tæt samlede i Tuer end hos foregaaende; Bladene 4-6 i Krandsene, linie-laneetforınede (ueppe bredere imod Spidsen), med mere fremtrædende Nerve; Blomsterstanden mere rigtblomstret, med opret-aabne eller vandret udspilede (ikke tilbagebøiede) Grene; Blomster og Frugter næsten dobbelt saa store som hos foreg., med luvilken den forøvrigt er meget nær beslægtet. $7-8$.

I Moser og Kj:er, synes at være udbredt over hele Landet, og i de fleste Egne lige saa almindelig som foreg. Art.

Anm. Ved de angivne Kjendetegn, ved dobbelt saa store Dimensioner af alle Plantens Dele og sildigere Blomstringstid er denne Art let kjendelig fra foreg., men af de fleste aldre Forff. er den ikke adskilt fra hiin, og det turde ogsaa vare tvivlsont, om den skal betragtes som en virkelig Art eller kun som en ndmerket Form af foreg. I hvert Fald er den ristnok medindbefattet under Linnés G. palnstre, skjondt Udtrykket "fol. obovata" synes at sigte til denne. (Anbefales til nærmere Undersøgelse).

205. G. uliginosum L. (Sump-S.) H. 156; Drej. n. 167; F. D. 1509 ; Rehb. XVII, tab. 1193 ; II. N. XV, 17.

Stangelen svag, firekantet; Blodene omtrent 6 i Krandsene, smalt lancetformede, braadspidsede, i Randen og paa Ryggen rue af nedadiendte Smaatorne; Toppen forlxnget, ined opretaabne Blomstcrstille; Frugterne punkteret rue.

$1 / 2-1$ ' høj. Bliver ikke sort ved 'T $\emptyset$ rring. Kronerne hvide. 6-7. ข.

I fugtige Enge og Moser alm.

bb. Blomsterstanden en forlanget Top, dannet af qvastformede Forgreninger $i$ Bladlijornerne, nosten fra Grunden af Stangelen. $\odot$. (Aparine Gren. \& Godr.).

206. G. Aparine L. (Burre-S.) H. 161; Drej. n. 166; F. D. 495 ; Rehb. XVII, tab. 1197.

Stongelen svag, firekantet, meget $\mathrm{ru} ;$ Bladene $6-9$ i Krandsene, lancetformede, foroven bredere (eller linie-lancetformede), i Randen og paa Rygnerven rue af nedadvendte Smaatorne; de blomsterborende Grene modsatte i Bladhjørnerne; 
de frugtbærende Blomsterstilke, rette, udspærrede; Frugterne tæt beklædte med Kirtler, hvorfra udgaae Hageborster.

Stgl. klattrende ved Iljæelp af dens rue Beklæedning. Kronerne livide eller gutlgrønne. 6-9. $\odot$. Var. i Henseende til Høiden, Bladenes Form o.s.v. Af de mange Former fremhæves:

$\beta$, tenerum (G. ten̉erum Schleich.) Rehb. XVII, tab. 1197. Stangelen nedliggende, Bladene omvendt-ægformede, Frugterne forholdsviis smaae.

$\gamma$, confertum Westerlund i bot. not. 1863 p. 139 (G. Aparine-marinum Fr. nov. p. 24 ?) Stinglerne udstrakte, med korte Isedstykker; Blarlene kortere og bredere, kjødfulde; Grenene korte, enblomstrede, med tilsidst hagekrummede Blomsterstilke.

Paa dyrket Jord, ved Gjerder og i Krat, meget alm. $\beta, S j$. i aahne Naaleskove ver Sors! $\boldsymbol{F}$. Granskor ved Skjoldemose (12); $\boldsymbol{\gamma}$, Strandbredder: $\boldsymbol{S} \boldsymbol{j}$. Vedbæk; $\boldsymbol{J}$. Damgaard!

Anm. Formen $\gamma$, kan ikke forvexles med G. tricorne With. paa Grund af Frugtens Bekleedning. Den æote $G$. tricome (Blomsterstilkene treblomstrede, hagekrummede, Fugterne beklxdte med kmudrede Vorter) angives som dansk af Fr. (S. Veg. Se. 1, p. 10. Jeg har iklie seet danske Expl. af demne, men muligviis forekommer den i Slesvig, da den er funden i Holsteen (Web.).

207. G. spurium L. [Fr.] (Hør-S.) F. D. 2530; Rehb. XVII, tab. 1197; H. N. II, 22 ; G. Aparine $\gamma$, Koeh Syn. II, 363 .

De blomsterborende Grene gjentaget 2-3-deelte; Bladene smalt linie-laneetformede; Kronerne meget smaae, grøngule; Frugterne glatte, glindsende og kjødfulde, neppe mere end halvt saa store, forøvrigt som foreg. 6-7. $\odot$.

$\beta$, Vaillantii Rchb. XVII, tab. 1197 (G. Aparine $\gamma$, infestum Lge. Haandb. 1 Udg. S. 95 ; G. infestum W. Kit., G. Vaillantii DC.) Frugteme bekledte med stive, korte Haar uden Kirtler ved Grunden.

Ukrud i Hørseden: Falst. ved Øverup (19), Tunderup (Rasmussen) og Kraghave! $\boldsymbol{L}$ oll. Refihale ved Maribo So (19). $\beta$, inellem Sxeden, hist og her, f. Ex. S $j$. 'Tryggerod, Faxø, Pedersborg ved Sorø!

Anm. Frugterne hos denne Art bar jeg stedse fundet meget nindre end hos foreg., livorimod de af flere Forff. angives at være storre end hos denne, af hvilken der ogsaa skal forekonme en Form 
med glatte Frugter (G. Aparine lejospermum Wallr. (cf. Westerlund 1. c.) som dog ilke er bemærket i vor Flora. At $G$. Vaillantii DC. snarere loorer til $G$. spurium end til $G$. Aparine, er.jeg fremdeles overbevist om paa Grund af dens Characterer og Habitus; jeg har altid funden den som Ukrud blandt Sxden, dog ikke, som Hovedformen, udelukkende i Hørsæd.

\section{Rubia. Krap.}

$\dagger$. tinctorum L. (Farve-K.) Drej. p. 61; Rehb. XVII, tab. 1184.

Stcengelen firekantet, tilligemed Bladenes Rand og Rygnerve ru af nedadvendte Smaatorne; Bladene $4-6$ i Krandsene, elliptiske; Kronfligene tilspidsede, grongule.

6-7. 2.

Dyrkes og forekommer stundom forvildet, t. Ex. ved St. Jørgens Sø udenfor Kjobenhavn (Schum.).

\section{Plantago. Veibred.}

a. Buddiken ved en tovinget Frostol deelt i 2 Rum (Bladene hele).

aa. Kronroret glat.

208. P. major L. (Glat V.-Kjæmper) H. 164; Drej. ฉ. 150 ; F. D. 461 ; Rehb. XVII, tab. 1128.

Bladene 5-9-nervede, xgformede, glatte eller med faa spredte Haar, ssmmendragne til en rendet Bladstilk omtrent af Hladens Længde; Skaftet trindt, utydeligt stribet; Axet forlænget, valseformet; Kronens Krave guulbuuu hindeagtig; Støvknapperne rodbrune; Buddiken ottefrøet.

6-8. 4. Var. i Henseende til Styrrelsen, Axets Læengde $\left(1-8^{\prime \prime}\right)$, Bladenes Rand (heelrandede eller tandede), Nervernes Antal o. s. v. En Misdannclse med bladet $A x, 0$ : stærkt udviklede Drekblade $(\triangle$ rosea Dene.) forekommer hist $\mathrm{og}$ her.

$\beta$, minima (DC.) $1-2^{\prime \prime}$ høi, Bladene trenervede, længere end Bladstilken, Axet forkortet, xgformet.

* intermedia (P. intermedia Gilib., Gren. \& Godr., fl. Fr. II, 720; P. major $\gamma$ pubeseens Lge. Haandb. $2 \mathrm{Udg}$. p. 107). Bladene blødere og tyndere (ikke læderagtige), duunhaarede, ved Grunden mere eller mindre dybt tandede, agformet- 
elliptiske, jævnt afsualnede .i Bladstilken; Skaftet bueformigt opstigende; Axet kortere og noget afrundet foroven, forøvigt som Hovedarten.

Ved Veic, par Marker, Strandenge o.s. v. alm. $\quad \boldsymbol{\beta}$, paa sandig og tørvholdir Grund ikke sjelden; * (som manskee er en egen Art) voxer paa sandig Jord, Overdrev, især paa Steder, som af og til oversvømmes: $\boldsymbol{S} \boldsymbol{j}$. Helsingor (Heiberg), Rostganrds Dan ved Hellebæk! Selchousdal (Lund), Skjolden ved Soro! Loll. Hamborgerskoven (14); Bornh. Rønne, Kanegaard, Aarsdale (1 Ijorth); J. fugtıge Pletter mellem Klitterne ved Agger!

209. P. media L. (Dunet V.) H. 164; Drej. n. 151; F. D. 581 ; Rehb. XVII, tab. 1137.

Bladene 5-7-nervede, agformede, dumnhaarede; Bladstilken fladtrykt, flere Gange kortere end Pladen; Skaftet trindt, utydeligt stribet; Axet kegleformet, efter Afblomstringen valseformet (kortere end hos foreg.); Kronens Krave bvid hindeagtig; Stovknapperne hvide paa rosenrøde Støvtraade; Buddiken tofrøet.

Bladene fladt udbredte paa Jorden, meget kortere end Skafterne. 5-7. 4 .

Ved Veie og paa torre, lerede Marker: meget alm. i Sje ll. og det nordostlige $\boldsymbol{J} y / l$. til Horsens; $\boldsymbol{F}$. paa Hindsholm alm.! Odense, Holkenharn (19); Loll. Aalholm (3), Nakskov Volde (19); Falst. Latndeveien mellem Gaabense og Nykjobing, Corselitze, Gjedsernddo Fyrtaarn (14), N. Kirkeby (Kocli); Moen (14); fra de gvrige Egne af Landet ere ingen Yoxesteder mig bekjendte.

210. P. lauceolata L. (Lancetbladet V.) H. 165; Drej. n. 152 ; F. D. 437 ; Rehb. XVII, tab. 1130; L. Herb. VIII, 157.

Bladene 3-6-nervede, lancetformede eller elliptiske, glatte eller duunhaarede, Bladstilken kortere end Pladen; Skaftet kantet og furet; Axet ægformet eller kngleformet (efter Afblomstringen alm. valseformet, men kortere end hos de foreg.); de 2 Bagerfige paa Ryggen kjølformigt vingede; Kronens Krave bruun bindeagtig; Stovknapperne og Støvtraadene guulhvide; Buddiken tofrøct; Froene med en Langdefure paa Inderfladen.

Var. i Henseende til Bladenes Brede og Bekladning, Skafternes Læengde $\left(1 / 2-2^{\prime}\right)$ Axets Form o. s. v. (En Misdannelse med grenet Ax er ikke sjelden). 5-7. $ข$.

$\beta$, criophylla Dene. i DC. prodr. XIII, 715. Axene kugleformede, Bladene tilligemed de korte Skafter, især ved Grunden, tæt silkehaarede. 
Paa Græsmarker, høie Enge o. s. v. meget alm. $\beta$, paa sandig Grund, f. Fx. F. ved Hofmansgave (18); Lo ll. Albuen ved Nakskov (19); Bornh. Sandvig! Gudhjem! Ronne!

\section{bb. Kronrøret haaret.}

211. P. maritima L. (Strand-V.) IJ. 166 ; Drej. n. 153; F. D. 243 og 691 ; Rehb. XVII, tab. 1132 ; L. Herb. V, 99.

Bladene linieformede, i Spidsen og ved Grunden smalere, kjødfulde, trenervede; Skaftet trindt, tiltrykthaaret (sjeldnere glat); Axet valseformet, forlenget; Dcelcbladene xgformede, spidse, af Bægerets Længde; Buddiken tofrøet; Frøene med en ruudagtig Grube paa Inderfladen.

7-9. 4. Bladene ofte bruunprikkede, alm. glatte og paa den hindeagtige Bladskede duunharede, var. desuden:

$\boldsymbol{\beta}$, dentata (F. D. 1634). Bladene fjernttandede.

$\gamma$, pygmcea! Skafterne meget korte $\left(1-2^{\prime \prime}\right)$, udstralste, Axet faablomstret, næsten kugleformet.

Ved Strandbredder, isæer paa Syltenge alm., forekommer desuden ved sandige Veie i det Indre af Landet (f. Ex. i Halvouns Hedeegne). $\boldsymbol{\beta}$, med Hovedarten ikke sjelden, $\gamma$, paa Flyvesandsmarker mellem Allinge og Sandvig paa Bornh.!

b. Buddiken ved en firevinget Frøstol deelt i 4 Rum. (Bladene fligede).

212. P. Coronopus L. (Fligbladet V.) H. 167; Drej. 11. 154: F. D. 272; Rehb. XVII, tab. 1130 ; H. N. I, 23.

Bladene fjerfligede med linieformede, tilspidsede Flige, graafiltede; Skaftet trindt, tætlaaret; Axet valseformet; Dakbladene ved Grunden xgformede, sylformigt tilspidsede; de 2 Bagerflige paa Ryggen kjolformigt vingede; Kronroret fiinlaaret; Buddiken firefrøet; Frøene med en rundagtig Grube paa Inderfladen. 7-8. $\odot$.

$\boldsymbol{\beta}$, pygmoa! Bladene med færre Haar og svagere Flige, Axet forkortet (næsten kugleformet) og faablomstret.

Paa Strandenge og ved sandige Havluredder, ikke sjelden i Danmark, men mindre hyppig end foreg. $\beta$, Bornh. paa Sandgrund ved Allinge! Svanike (Hjorth); Christianso (Didrichsen); Falst. Vaalse Vig (Koch); Jyll. (herb. Drej.). 


\section{Centunculus. Centunkel.}

213. C. miumus L. (Liden C.) H. 168; Drej. n. 155; F. D. 177 ; Rehb. XVII, tab. 1082 ; H. N. I, 22.

Stangelen grenet, ofte nedliggende; Bludene xgformede, spidse; de wedre modsatte, de ovre afvexlende; Blomsterne næsten siddende i Bladbjørnerne.

1-2" høi. Kronerne hvide eller lysrøde. 6-8. $\odot$.

$\beta$, simplex (C. simplex Horuem. 168; F. D. 1567). Stængelen udeelt, opret, Bladene smalere.

Paa Strandfaelleder og Overdrev paa Torv- eller Hedegrund, ikke sjelden, især paa Halvoen. $\beta$, Frederikshavn (herb. Drej.), paa en Eng ved Grenaa (11.), Nebbegaard og Brondsted i Jyll.!

\section{Cicendia. Bitterblad.}

214. C. filiformis [Rchb. f. exc. p. 421 ] (Traadstænglet B.) H. N. XIII, 36 ; Gentiana L., F. D. 324 ; Exacum Willd., H. 163; Microcala Link, Rehb. XVII, tab. 1045.

Stangelen traadfiin, flere Gange gaffeldeelt, med langstilkede Blomster i Gaffeldelingerue; Bladene modsatte, siddende, linielancetformede.

1-3" høi. (Smaae Expl. ere ofte aldeles ugrenede). Kronen guul. 7-8. $\odot$.

I Hedemoser og par sandige Overdrev, hidtil kum bemærket i den sydlige Deel af $\boldsymbol{H}$ alvo en : Ribe (Oeder), Ostenfeldt (Didr.), Husum (Forchhammer), ved 'iolker og Tolkwade S $\rho$ i Slesvig (16). 计

\section{Cornus. Kornel.}

215. C. succica L. (Hønsebær). H. 171; Drej. n. 172; F. D. 5 ; H. N. II, 34 .

Stcongelen urteagtig; Bladene modsatte, siddende, ægformede med 2 nærved Grunden udgaaende Sidenerver paa hver Side af Midtnerven; Blomsterstanden en Skjærm, omgivet af et firebladet Svob, som er længere end Blomsterne.

$1 / 2^{\prime}$ høj. Svgbet hvidt; Blomsterne smane, sortrøde; Steenfrugten rod. $5-6$. 24.

I fugtige Skove og Hedemoser: i Vendsyssel alm. (H.) og derfra sporadisk gjennem Jyll. og Slesv.; paa Øerne sjeldnere; kun be- 
mærket i de nordlige Egne af $\boldsymbol{F}$ yen (Einsiedelsborg, Hals ved Hofmansgave (H.) og $\mathbf{S} \boldsymbol{j}$. (Helsingor (21), Krogenberg, Danstrup og Ravnsholt Hegn (14), Marianelund v. Gurre! Gribs Skov! Frederiksborg (16)) samt paa Moen ved Ulfshale (H.).

216. C. sanguinea I. (Rød K.) H. 172; Drej. n. 173; F. D. 481 ; H. N. II, 35 .

Buskagtig, med i yngre Tilstand tiltrykt-haarede, senere glatte Grene; Bladene modsatte, stilkede, ægformede, tilspidsede, 3-5 Sidenerver paa hver Side af Midtuerven, udgaaende fra dennes nederste Halvdeel; Blomsterstanden en foroven fladtrykt Qvast uden Svøb.

Grenene have ofte rod Bark. Kronerne livide, Steenfrugterne sortblaa. 6-7. Ђ.

I Kratskove og ved Gjærder, ikke sjelden i Danmark, især hyppig i Fyen, Lolland-Falster, paa Bornlıolm og i Angel.

\section{Euonymus. Beenved.}

217. E. europreus L. (Almindelig B.) H. 271; Drej. n. 174 ; F. D. 1089 ; Rehb. ic. fl. germ. VI, tab. 309, fig. 5134 ; H. N. II. 36 .

Buskagtig med firekantede, glatte Grene; Bladene modsatte, elliptiske, fiint saugtakkede; Blomsterne i langstilkede, faablomstrede Qvaster fra Bladhjørnerne; Kronbladene aflange, grøngule; Kapselen fireklappet, budt firekantet-lappet, rosenrød; Frdene hvide, heelt omgivne af en brandguul Frohud.

Veddet smukt lysguult; den yngre Bark grown, Blomsten 4- (sjeldnere 5-) delelig. 5-6. .

I Kratskove og ved Gjærder, temmelig alm. udbredt $\mathrm{i}$ de danskeProviudser.

\section{Trapa. Hornnød.}

X T. natans L. (Svømmende H.) H. II, 130; Sehk. Handb. t. 25.

Vandplante; Stconglerne langstrakte, de svommende Blade ægformet-rudeformede, skarpt tandede, kortere end de ovenfor Nidten tilsidst ofte bugformigt opblæste Bladstilke; de nedscenkte Blade haarformig-kamdeelte; Blomsterne enlige i Blad- 
hjørnerue; Nodden sortbrumn (omtr. af en Kastanies Størrelse) med storst Brede paa Nidten og med 4 korstillede Horn af de forthrodede lixgerflige.

Nodder af deme Plante, som voxer i Moser og Søer i det sydligere Europa, men ikke hirltil har varet funden vildvoxende hos os, ere samlede i Mrengde i Torvmoser par Lolland (Galdemosen ved Steensgaard) af IIr. Rostrup, og den maa derfor nævnes som en fordum i den danske Flora hjenmehorende, men mu sandsyuligviis aldeles forsvinden Plante. (Hornemann anforer den som efter Opgivende funden ved Lavenburg, men efter Rimelighed er den ogsaa derfra forsvunden).

\section{Majanthemum. Maiblomst.}

218. M. bifolinm [DC. fl. fr. 3, p. 177] (Tobladet M.) Drej. n. 146; Relib. ic. fl. germ. X, tab. 436, fig. 967; M. Convallaria Weber; Convallaria bifolia L., H. 378; F. D. 291.

Stengelen tobladet (sjeldnere en- eller trebladet); Bladene afvexlende, stilkede, hjerteformede; Blomsterne parvise $\mathrm{i}$ en endestillet Klase.

$6-8^{\prime \prime}$ h hsi. Blomsterne hvide. Bæarrene for Moduingen grsngule med rrsdbrune Prikker, i moden Tilstand rode. 5-6. భ.

I Skove, især paa fingtig Grund, almindelig.

\section{Parietaria. Springknap.}

219. P. crecta [M. \& K. D. Fl. 1, p. 825] (Opret S.) Drej. n. 149 ; P. officinalis L. (for en Deel); H. 172; F. D. 521 ; Rchb. I. c. XII. tab. 651, fig. 1317; II. N. 1, 58.

Stcongelen opret; Bladene afvexlende, stilkede, elliptiske, tilspidsede, heelrandede, haarede og ru-punkterede; Blomsterne nøgleformigt sammenhobede i Bladhjøruerne.

Støvtraadene leddede paatværs; Støvkı apperne rulle sig ved Blomstens Udspringning elastisk op. Blomsterne grenlige. 6-8. ข.

Ved Gjærder og Mure, især omkring Kjøhstreder, sporadisk og ikke alm. Sj. Kastellet ved Kjobenhavm (Schum)! Kjøge (9), St. Ibs Kirke ved Roeskilde, Holsteinborg! Noen r. Stege omkring Ilavegjaerder ved Straudbredden (Dr.); F alst. Hullebrek (14), Nylkjølıing(H.)! Loll. Naliskov (19); Als ved Sonderborg Kirke (14), Slesvig!

\section{Alchemilla. Lovefod.}

220. A. rulgarís L. (Almindelig L.) H. 173; Drej. n. 147 ; F. D. 693 ; L. Herb. III, 58. 
Bladene baandlappede, med afrundede, saugtakkede, i Randen tiltrykt-haarede Lapper; Rodbladene langstilkede, nyreformede, 7-9-lappede, Stcengelbladene 3-5-lappede, med store, saugtakkede, indbyrdes til et fladkravet Rør sammenvoxne Axelblade; Blomsterne guulgrønne, qvastformigt samlede i Spidsen af Stængelen og Grenene. 5-7. थ.

$\beta$, subsericea Koch (A. montana Willd., H. 164). Stængel og Blade duunbaarede.

Alm. paa høje Enge og Græsmarker. $\beta$, paa mere tørre Steder og noget sjeldnere end Hovedarten.

221. A. Aphanes [Leers fl. herb. 54] (Liden L.) H. 175; Jrej. n. 148; Aphanes arvensis L., F. D. 973; Alchemilla arvensis Scop.

Stonglerne nedliggende; Bladene haandformigt trefligede, Fligene kileformede, i Spidsen 2-4-tandede, Axelbladene sammenvoxne, i Spidsen sangtakket-fligede, Blomsterne grønlige, nøgleformigt sammenhobede i Bladhjørnerne.

Blomsterne meget smaae, de mindre Bægerflige ofte utydelige. 5-8. $\odot$.

Paa dyrkede og hvilende Marker almindelig.

\section{Sangvisorba. Qvaesurt.}

222. S. officiualis L. (Læge-Q.) H. 169; F. D. 97; H. N. VI, 51.

Bladene uligefinnede; Smaabladene stilkede, æg-hjerteformede eller lancetformede med hjerteformet Basis, saugtakkede, tiltagende i Størrelse mod Spidsen; Axet ovalt; Dakbladene randhaarede.

Var. med eller nden Smaabiblade ved Grunden af Smaabladene. Blomsterne mørkrøde. 6-8. ข.

Paa Enge, sjelden: Sl. Bredderne af Trenen ved Hollingsted (Didr.), i Miengde paa Strandenge ved Klensby Nor og Steksvig ved Slien (20), Stampemollen ved Slesvig, Eiderbredden mellem Rendsborg og Syderstapel (16), Rantrum ved Husum, Syderhöft i Eidersted (F. Müill.). 


\section{Tetragyia.}

\section{Ilex. Christtorn.}

223. I. Aquifolium L. (Almindelig C.) H. 177; F. D. 508 ; Rehb. ie. fl. germ. XVII, tab. 1080 ; H. N. X, 17.

Busk (eller 'Træ) med stedsegronne, læderagtige, glindsende, ægformet-elliptiske, i Kanden tornet-tandede Blade; Blomsterne i Skjærm f:a Bladhjornerne.

Kronerne hvide. Bier røde. 6. h.

$\beta$, integrifolia. Bladene nxesten heelrandede.

I Skove og Krat: i den ostlige Deel af Halvoen fra Grenaa mod $\mathrm{S}$. ikke sjelden, sparsommere $\mathrm{i}$ det Indre $\mathrm{og} \bmod \mathrm{V}_{.}, \mathrm{f}$. Ex. Silkeborg (16), Himmelbjerget (ํ), Skanderborg, Fohl Skov ved Ribe, Husum (16); L cese (Kamploøv. Herb.); F . sjelden: Gribsvad (18), Abels ved Bogense, Einsiedelsborg (H.), Juelsberg og 'Teglvarksskoven ved Nyhorg (Lund), Faaborg (H.), Thorseng (Kyll.); Seiere (60 à 70 Traer samlede, Baagve); Moun ved Ulfshale (17, Kph. Herb.). I Sjælland, paa Lolland-Falster og Bornholm mangler den; par flere af de fyenske Voxesteder findes den neppe mere (12). $\beta$, mellem Hovedarten. *]

\section{Radiola. Tusindfro.}

224. R. millegrana [Sm. A. brit. p. 202] (Liden T.) H. 189; Drej. n. 194; Rchb. ic. fl. germ. VI, tab. 625, fig. 5152 ; R. linoides Gmel., H. N. XIV, 37; Linum Radiola L., F. D. 178.

Stangelen opret, med gjentaget-gaffeldeelte, udstaaende, haarfine Grene; stilkede Blomster i Gaffeldelingerne; Bladene modsatte, siddende, agformede, heelrandede; Bogerbladene tandede; Kronbladene heclrandede.

${ }^{1 / 2}-2^{\prime \prime}$ høi, Kronerne hivide, meget smaae. 7-9. $\odot$.

Oversvømmede Steder, isser par Sand- og Hedegrund, ikke sjelden, og ofte i Sulskab med Centuneulus minimus.

\section{Bulliarda.}

225. B. aquatica [DC. bull. philom. n. 49 p. 1] Drej. n. 195 ; H. N. IX, 42 ; Tilliea L., H. 188; T. prostrata Sehk., F. D. 1510 . 
Bladene modsatte, linieformede; Blomsterne næsten siddende, i Bladhjørnerne.

$3 / 2-1^{\prime \prime}$ høi; Stængelen i Vand opret, ovenfor Vandet oftest udstrakt, Kronerne blegrøde. 7-8. $\odot$.

I Vand og udtørrede Vandhuller, ved Søbredder: $\boldsymbol{S} \boldsymbol{j}$. i en udtorret Dam (Rostgaards Dam) ved Hellebxk i stor Mrengde 1862! Tidligere er den, efter Hornemans Angivelse, funden i Sjæelland af M. Vall, men det specielle Voxested ikke angivet. [*

\section{Potamogeton. Vandax.}

a. Plantaginifolii Fr. Bladene (idetmindste nogIe) paa Midten eller nedenfor samme bredere.

aa. De nedre Blade afvexlende, de ovre (ncermest Blomsterstillkene) modsatte. Blomsterne $i$ Ax.

«. Bladene forskjelligformede, alle stilkede.

226. P. natans L. (Svømmende V.) H. 179; Rafn 1, 679; Drej. n. 193 ; F. D. 1025 ; Rchb. ic. A. g. VII, tab. 50, fig. 89 ; H. N. V, 73.

Stangelen ugrenet; alle Bladene stilkede; de nedscenkte lancetformede (uden Plade) eller linieformede, de svommende lang stilkede, ovale med hjerteformet Basis, læderagtige, heelrandede; Blomsterstilkene lige tykke overalt; Frugterne store, omvendt-ægformede, sammentrykte, i frisk Tilstand paa Ryggen budte, i tørret Tilstand skarpkjølede.

Planten bliver ved 'Tørring bruun, Bladene foranderlige i Formen : de nedsænkte ere enten linieformede uden Plade eller i yngre Tilstand med lancetformet, tilsidst forraadnende Plade, lovorved Stilken bliver ene tilbage. $6-8$. 4 .

$\boldsymbol{\beta}$, fluviatilis (Fr. Nov. p. $28 ; \boldsymbol{\beta}$, prolixus Koch Syn. II, 775). Bladene fjerntsiddende, spidst-lancetformede med afrundet (ikke hjerteformet) Basis, Axstilkene udgaae fra de nedre Bladhjørner.

I Søer og Damme meget alm. i Dannark, sjeldnere i rindende Vand. $\beta$, i Grofter ved Eveldrup i Jyll. (Dr.).

227. P. fluitans [Roth. tent. fl. germ. I, 72, II, 202] (Flydende V.) H. II, 132; Nolte nov. p. 16; F. D. 2105 ; Rchb. I. c. fig. 88 ; H. N. IX, 72. 
Strengelen enkelt eller lidet grenet; alle Bladene stilkede, de nedscente vedblivende, hindeagtige, langstrakt-lancetformede, de svommende laneetformede cller elliptiske (med tilspidset eller afrundet, ikke hjerteformet-indskaaren Basis), læderagtige, heelrandede, Bladstilkene paa Overfladen convexe; Axelbladene med en dobbelt Kjøl paa Ryggen; Blomsterstilkene tykkere og oppustede foroven, tykkere end Stæengelen; Frugterne sammensrykte, med skarpkjolet Ryg. $7-8$. 4 .

$\beta$, rivularis! Stænglerne meget lange og grenede, de nedsænkte Blade linieformede, forlængede (indtil $1^{\prime}$ lange, og lignende Bladene af Zostera marina), de svømmende smalt laneetformede.

I Aaer og Bække, sjelden i Danmark: J. Varde Aa S. for Byen! Kongeaaen ved Hjortlund (12); $\boldsymbol{S} \boldsymbol{l}$. i Eideren (N.); $\boldsymbol{\beta}, \boldsymbol{F}$. i Odense Aa ved Munke Molle og Fruens Bøge! J. Mosbjerg Aa i Vendsyssel (23)? 居

Anm. Den under $\beta$, anførte Form, som jeg tidligere henførte til P. sparganifolius Lastad. (efter Beskrivelsen i Fr. Mant. 1, p. 9), maa jeg nu efter Undersøgelse af mange Expl. (dog kun faa blomstrende og ingen frugtborende) ansee for en Form af P. fluitans, frembragt ligesom den af foreg. ved Forekomst i starkt strømmende Vand. Om den fra Jyll. af Drej. (Krøy. 'Tidsskr. II, 160) med 'Tvivl som P. sparganifolius angivne Art ogsaa hører herhid, kan jeg paa Grund af Mangel paa Expl. ikke afgjøre.

228. P. polygonifolius [Pourr. Chlor. narb. in act. Toul, 3, p. 325] (Aflangbladet V.) Rchb. 1. c. tab. 44, ficr. 7981 ; P. oblongus Viv., Fr. nov. p. 29 ; Ige. Haandb. 1 Udg. S. 103 ; H. N. V, 74 og 75 (var.).

Stangelen enkelt eller lidet grenet; alle Bladene langstilkede, de nedsankte vedblivende, bredere eller smalere laneetformede, de svømmende tyndt læderagtige, heelrandede, elliptiske eller agformede (med eller uden hjerteformet Basis); Blomsterstilkene lige tykke overalt, tyndere end Stængele.., bueformigt nikkende; Frugterne smare, sammentrykt-trindryggede.

Bladene ved Tørring brune, deres Form 'meget forskjellig. Let kjendelig fra $P$. natans ved de smaae, i torret Tilstand rodbrune Frugter. 6-8. 4. Blandt de talrige Former udheves: 
$\alpha$, angustifolius (Fr. nov. p. 30) Stængelen langstrakt, alle Bladene smalt lancetformede.

$\beta$, amphibius (Fr. 1. c.; P. parnassirefolius Schrad.) Rodstokken krybende, med korte Grene, ingen nedsænkte Blade, de svømmende bredt ægformede, ved Basis afrundede eller hjerteformede.

I Kjær, Hedemoser o. s. $\nabla$, hist og her paa Halveen og Bornholm; paa de øvrige Øer sjelden, f. Ex. $\boldsymbol{F}$. Vængemose ved Skaarup (19). $\quad \beta$, ikke sjelden i de $j y d s k e$ og slesvigske Hedemoser, især i Kildevald paa Sandgrund; $\alpha$, sjeldnere: jeg har kun fundet den i Vandhuller ved Hammeren paa Bornholm (i Salt- eller Brakvand).

229. P. coloratus [Hornem. i F. D. 1449 (1818)]; (Veibredbladet V.) Fr. S. Veg. Sc. p. 68 (ef. p. 219); H. N. XIII, 77; H. 181; Nolte nov. p. 18; P. plantagineus Ducroz.: Rehb. l. c. fig. 82-84; P. Hornemanni Mey. Chl. Hanov.

Stcenglerne enkelte eller lidet grenede; alle Bladene (kort-) stilkede, tynde, gjennemsigtige, med talrige og tydelige Træraarer, i Randen bolgede, de nedscnkte ovale eller elliptiske, de фvre bredt-ægformede; Blonsterstilkene lange, lige tykke overalt og tyndere end Stængelen, rette eller buekrummede; Axet tætblomstret, Blomsterne meget smaae; Frugterne smaae, sammentrykt-trindryggede, omvendt-ægformede.

Bladene i torret Tilstand oftest grønne, sjeldnere rødbrune (det sidste er Tilfæeldet med Fig. i F. D.). Frugterne endnu mindre end hos foreg. 6-8. थ.

I stillestaaende Vand, f. Ex. Grøfter, Moser, sjelden og sporadisk: $\boldsymbol{S}$. Grøfter ved Leersøen udenfor Kjøbenhavn! en Dam ved Bognæsgaard pr. Roeskilde! Svogerslev Mose (20) og Ladegaardsmgllen ved Roeskilde (15); Falst. ved Ourupgaard (Koch) og Hullebæk (14); F. Hofmansgave (Vahl, Hofman Bang!); J. Gravens Mose i V. Hanherred, Jensby Eng i Thy (Dr.); $S l$. Wanderup S. for Flensborg (16). 可

Anm. Rehb. (l. c.) fører P. coloratus F. D. som Synonym til foreg., men Expl. meddeelte af Hr. Hofman Bang fra det Vahlske Findested (Hofmansgave), hvor P. oblongus ikke findes, bekræfte tilstrækkelig, hvad ogsaa Figuren udviser, at F. D. 1449 og P. plantagineus hos Rchb. ere identiske. 
B. Bladene (typisk) forskjelligformede, de nedre (nedsænkte) stilkløse.

230. P. rufescens [Schrad, in Cham, adnot. ad Kth. A. berol. p. 5. (Rustfarvet V.) H. II, 133; I, 180 og 182 (P. fluitans og P. lucens angustifolius); Drej. n. 192; Schum. n. 159-60 (P. fluitans og P. serratum); F. D. 1450 (P. fluitans) og 1635 (P. lucens var.); Rchb. l. c. fig. 56 ; H. N. V, 76.

Stcongelen enkelt; de nedsconkte Blade forlænget-lancetformede, tindeagtige, gjennemsigtige, de svommende omvendtægformede eller elliptiske, budte, noget liederagtige, heelrandede, kortstilkede; Axelbladene store, tidligt henvisnende; Blomsterstillkene af Stængelens Tykkelse og lige tykke overalt; Frugterne sammentrykte, paa Ryggen skarpkjølede, udspærrede, tilspidsede i den vedblivende Griffel.

Plantens Farve i frisk Tilstand mat grøn, i tørret stærk rødbruun. Fra Bladenes Midtnerve udgaae til begge Sider et taet Nat af Tværaarer. $7-8$. 4 . Landet.

I flydende og stillestarende Vand, almindelig i de fleste Egne af

231. P. nitens [Web. suppl. fl. hols. n. 11] (Kírumbladet V.) F. D. 1807 ; Rehb. I. e. fig. 60-62; P. curvifolins Hartm., H. II. 133 ; Drej. n. 191.

Stcongelen grenet; de nedre Blade halvt-omfattende, lancetformede, spidse, gjennemsigtige, i Randen rue, de фvre kortstilkede, bredt lancetformede, i begge Ender tilspidsede, læderagtige; Blomsterstilkene tykkere foroven; Frugterne halvt-kredsrunde, sammentrykte, med en budt Kjøl paa Ryggen.

Bladenes Form forskjellig; de svgmmende Blade mangle hyppigt aldeles, endog hos Formen $\beta$. 6-8. $\psi$.

$\alpha$, salicifolius (Fr. nov. p. 34.) De nedsænkte Blade linie-laneetformede, rette, Ledstykkerne og Blomsterstilkene forlængede, de sidste udgaae fra alle de øvie Led.

$\beta$, heterophyllus (Fr. 1. c., H. N. VIII, 67, P. curvifolits.) De nedsænkte Blade kortere, bueformigt-tilbagebøiede.

I swer og Bække, sjelden, ( $\kappa$, især i stæerkt strømmende Vand): Moen v. Landsled (Holst), Lo ll. Maribo So (5); J. Vaarsaa (12) og 
Vang i Vendsyssel, Ore S $\emptyset$ i Thy (Dr.), Flade Sø ved Agger! Aalborg (Strandgaard, $\varsigma$ ), Skjern Aa ved Lønborg og Petersminde! $(\alpha)$; Søgaard Sq ved Aabenraa (28). [*

Anm. Paa Exemplarer af denne Art, som jeg samlede ved Stockholm Sept. 1849, har jeg fundet en eiendommelig Forgreningsmaade, som jeg ikke tidligere har seet omtalt for dens Vedkommende. Fra alle de nedsenkte Blades Hjorner udgaae 2 Grene, den indre (imod Axen vendte) kortere, opadrettet med temmelig tætsiddende Blade, den ydre, vendt imod det støttende Blad) langstrakt, nedstigende, med meget forlængede Ledstykker og skjælformede Blade, fra hvis Vinkler der udgaae opadtil nye Grene, uedadtil Rodtrævler. I Spidsen ere disse forlængede G'rene opsvulmede til en Knop, som synes bestemt til at overvintre og maaskee frigjores fra Moderplanten. Det fortjener at unders $\emptyset \mathrm{ges}$, om denne Forgreningsmaade, som senere er iagttaget hos P. pectinatus og synes at liave Lighed med den af $J$. Gay hos P. trichoides beskrevne, er almindelig hos disse Arter ogsaa i vor Flora, og om ikke muligviis flere Arter af denne Slægt ved Undersøgelse om Efteraaret maatte fremvise lignende Forhold.

232. P. gramineus L. (Græsbladet T.) Fr. nov. p. 36 ; S. Veg. p. 244 ; H. N. V, 77 ; Drej. 1. 190 ; P. heterophyllus Sehreb., H. 180; Schum. n. 163 ; F. D. 1263; Rehb. 1. c. fig. $73-75$.

Stangelen grenet; de nedre Blade i begge Euder tilspidsede, linie-lancetformede eller elliptiske, gjennemsigtige, i Randen bølget-rue, de orre svommende, stilkede, agformede eller elliptiske, læderagtige, heelrandede; Blomsterstilkene tykkere foroven; Frugterne sammentrykte, balv-kredsrunde, med budt Ryg.

6-8. 4. Var. i Henseende til Ledstykkernes Længde, Bladenes Form o.s. v. De vigtigste Former ere:

$\alpha$, graminifolius (Fr. nov. p. 36; Koch Syn. II, 777; P. gramincus Schum. n. 166 (?); H. 184; Rehb. l. c. fig. 71; F. D. 222). Bladene slappe, alle linie-laneetformede (ingen svømmende).

$\boldsymbol{\beta}$, heterophyllus (Fr. 1. e., H. N. XII, 75), de nedsænkte Blade kortere, bredere, udstaaende eller krumbøiede (de svømmende stedse tilstede).

Temmelig hyppig $\mathrm{i}$ alle danske Provindser, saavel i flydende som stillestaaende $V$ and. $\beta$, den almindeligste Form; $\alpha$, sjeldnere, f. Ex. $S j$. Gurre S $\emptyset$ (14), Uttersløv Mose (7), Grofter i Flommen ved Sorø! Orsløv ved Skjelskør (Nielsen); Falst. ved Ourupgaard (14); Loll. hist og ler (19); Olene paa Bornholm (Oeder, 19). I udtorrede 'Tørvmoser og andre dyndfulde Steder forekommer undertiden eu Form med lutter laederagtige og stilkede Blade (f. terrestris Fr. l.c.) 
$\boldsymbol{\gamma}$, Bladene ensformede, hindeagtige, stilkløse eller kortstilkede.

* 233. P. Zizii [M. \& K.] (Langstilket V.) Rehb. 1. c. fig. $66-67$; P. gramineus $\gamma$, Zizii Koch Syn. II, 778; P. lucens $\beta$, minor Nolte, P. luc. $\beta$, heterophyllus Fr. 1. c.

Stangelen grenet; alle Bladene elliptisk-lancetformede, kort braadspidsede, gjennemsigtige, i Randen bølget-1ue; de nedre kort, de фvre tydeligt stilkede; Blomsterstilkene tykkere foroven, længere end Bladene; Frugterne omvendt-ægformet-rundagtige, med en budt Kjøl paa Ryggen.

De af mig samlede Exemplarer blive sorte ved Torring. Afviger forøvrigt fra folg. fornemlig kun ved de lange Blomsterstilke og hele Plantens mindre Dimensioner (ogsaa Frugterne ere mindre), og staaer langt nærmere ved denne end ved foreg., til hvilken Koch henforer den.

Sjeldnere end foreg. og folg. $\boldsymbol{S}$. en Dam ved Hellebæk (12); $\boldsymbol{J}$. en Aa mellem Fiils $\emptyset$ og Vesterhavet (ved Henne Molle)! $S \boldsymbol{l}$. Molledammen ved Husum (16).

234. P. lucens L. (Glindsende V.) H. 181; Drej. n. 189 ; F. D. 195 ; Schum. n. 161 ; Rchb. 1. c. fig. 64.

Stangelen grenet; alle Bladene ovale eller elliptiske, kortstilkede, gjennemsigtige, i Randen bølget-rue; Axclbladene med en dobbelt Kjøl paa Ryggen; Blomsterstilkene tykkere foroven, længere end det tætblomstrede $A x$, kortere end Bladene; Frugterne storo, sammentrykte, paa Ryggen budt trekjølede.

Vedligeholder ved Tørring en smuk grøn Farve. 7-8. 4. Bladene var. afrundede, braadspidsede og

$\beta$, acuminatus Rchb. 1. c. fig. $69--70$; P. acuminatum Schum. n. 162 ; F. D. 1384). Bladene forlæenget-lancetformede, langt tilspidsede af den udløbende Midtnerve (Spidsen ofte af Pladens Langde, undertiden er Nerven alene tilbage).

I flydende og stillestaaende Vand, ikke sjelden og ndbredt i alle danske Provindser. $\boldsymbol{\beta}$, med Hovedarten f. Ex. Sj. Sorg Sø! Farum So, Fuglevad (14); L oll. Maribo S $\phi(14)$; J. Randers (Selner), Kongeaaen ved Ribe (16); $\boldsymbol{S}$ l. Lyksborg Mglledam, Trenetloden v. Treyaholm (16), Eideren ved Rendsborg!

? 235. P. decipiens [Nolte i Rehb. fl. germ. exs. n. 1603] Rehb. 1. c. fig. 63 ; Koch. Syn. II, 779; H. N. XIV, 76. 
Stcengelen grenet, med knæbøiede Ledstykker; alle Bladene stilkløse, med afrundet Basis, elliptiske eller ovale, budte med en meget kort Spids, heelrandede, hindeagtige, gjennemsigtige; Blomsterstilkene lige tykke overalt, tykkere end Stængelen, længere end det tætblomstrede Ax; Frugterne med en budt Kjøl paa Ryggen.

I Characterer nærmer den sig P. prælongus, i Udseende staaer den mellem P. lucens og nitens. 7-8. 4 .

Af Prof. Fries (S. Veg. Sc.) optaget blandt de danske Planter; funden af Prof. Nolte i Holsteen (f. Ex. ved Kiel); om den ogsaa findes i Slesvig, er mig ubekjendt). $\sqrt{x}$

236. P. praclongus [Wulfen i Röm. Arch. III, 331] (Langstrakt V.) H. II, 134; Drej. n. 188; F. D. 1687; Rchb. l. c. fig. $59 ;$ H. N. IX, 74 .

Stongelen grenet, med knæbøiede Ledstykker; alle Bladene stilklose, fra en bred, halvt-omfattende Basis æg-lancetformede, budte, med en hætteformigt sammentrukken Spidse, hindeagtige, gjennemsigtige; Blomsterstilliene af Stængelens Tykkelse og lige tykke overalt, efter Afblomstringen meget længere end Bladet og det ikke tætblomstrede $A x ;$ Frugterne store, balvkredsrunde, sammentrykte, i tørret Tilstand med en skarp, vingeformet Kjøl paa Ryggen.

Blomsterstilkene $1 / 2-1^{\prime}$ lange, Bladene meget lange, heelrandede eller mod Spidsen bolgede; var. fra næsten ljerteformede til linielancetformede, vedligeholde ved Tørring en gron Farve. 7-8. ข.

I Aaer og Søer, sporadisk og ikke alm. $\boldsymbol{S} \boldsymbol{j}$. Esrum Sø, Sortesø (Dr.), Sorø Sø (M. Vahl); F. Odense Aa ved Munke Molle! Bramstrup (18), Ollerup $\mathrm{S} \emptyset(12) ; J$. Ove Sø og Aakjærs Aa i Thy, Ridemands Mølle ved Aalborg (Dr.), Vaarsaa mellem Hjørring og Sæby (Branth); $\boldsymbol{S} l$. Jels Sø $(28)$, Gram Aa og Mølledam $(8,16)$ o. fl. St. (N.).

\section{P. perfoliatus L. (Hjertebladet V.) H. 182; Drej.} n. 187 ; Schum. n. 164 ; F. D. 196 ; Rchb. 1. c. fig. $53-54$.

Stangelen grenet; alle Bladene stilkløse, fra en hjerteformet, omfattende Basis ægformede eller æg-lancetformede, budte, hindeagtigt gjennemsigtige, i Randen bølgede; Axelbladene korte, ægformede, hurtigt henvismende; Blomsterstilkene lige tykke overalt; Axet tætblomstret; Frugterne sammentrykte, 
budt trekjølede, med et kort Næb (af den vedblivende Griffel).

Farven i frisk Tilstand olivengrøn, i torret bruun. 6-8. 4 .

I Søer, meget alm. i de fleste Egne af Danmark (ikke bemærket paa Falst. (14).

238. P. crispus L. (Kruset V.) H. 183; Drej. n. 186; Schun. 1. 165 ; F. D. 927 ; Rehb. l. e. fig. 50 ; H. N. VIII, 68.

Stangelen fladtrykt, grenet; alle Bladene stilkløse, fra en xgformet, halvt-omfattende Basis bredt linieformede eller ovallancetformede, budte, i Randen saugtakket rue og bølgede, gjennemsigtige; Axelbladene korte; Blomsterstilkene lige tykke overalt; Axet faa- og fjernblomstret; Frugterne sammentrykte, halv-kredsrunde, med langt $\mathrm{Næb}$ (af den vedblivende, alm. tilbagebøiede Griffel).

I tørret Tilstand rødbrun. 6-8. थ.

I flydende og stillestaaende Vand hyppig.

Anm. Forekommer undertiden i yngre, blomsterløse Expl. med smalere, linieformede, svagt saugtaklsede, men iklke bolgede Blade (Rehb. 52; P. serrulatus Schrad.), og en Misdannelse med Axene omdamede til Bladknipper med brede og korte, nedentil bruskagtige Blade ( $\beta$, gemmifer Rclib. 51, cfr. Nolte nov. p. 22).

b6. Alle Bladene modsatte, Blomsterne $i$ et 2-3-blomstret Hoved. (Antiphyllogeton Rchb.)

239. P. densus L. (Tætbladet V.) H. 182; F. D. 1264 ; Rehb. 1. c. fig. $46-49$; H. N. X, 67 .

Stangelen oventil gaffeldeelt-grenet, med korte Ledstykker og tætsiddende, hindeagtigt gjeunemsigtige, ægformet- eller elliptisk-lancetformede, spidse Blade; Axclbladene korte, omvendt. ægformede; Blomsterstilkene korte, i Stængelens Gaffeldelinger, under Blomstringen ovenfor Vandet, efter samme tilbagebøiede; Frugterne sammentrykte, i tørret Tilstand paa Ryggen vingeformigt-kjolede, med krumt Næb, Frøgjemmet tyudt; Kimen spiralformet (med 2 Vindinger).

Plantens Farve i tørret Tilstand olivenbrum. Bladene var, i Formen fra bredt ægformede til linie-lancetformede. 7-9. 4 . 
I flydende og især stillestarende Vand (f. Ex. Marskgrøfter); hidtil kun funden paa Halveen: Nebel Sø j Thy (Dr.), Hoe, Bramminge, Villebøl (30!), Kongeaaen ved Hjortlund (12), Nibsaaen og Grøfter ved Ribe (6), Høyer (28), 'Tønder (H.), Rødding (16), Wittensee, Rendsborg (20), Syderstapel (F. Miill.), og paa Als i Adserballe Aa (10). 雨.

b. Graminifoliifr. Alle Bladene overalt ligebrede.

aa. Axelbladene frie $i$ Bladhjornerne (Chloëgeton Rchb.).

240. P. zosteræfolius [Schum. ]. c. n. 168] (Bændelbladet V.) H. 184; Drej. n. 185 ; F. D. 1865 og 2046 (P. acutitol.); Rehb. l. c. fig. 45 ; P. compressus (L.) Fr. nov. p. 44; H. N. $\mathrm{V}, 78$.

Stcengelen grenet, vinget-fladtrykt; Bladene baandformede, budte med en Braad, mangenervede, med $3-5$ stærkere Nerver; Blomsterstillene 2-flere Gange længere end det 10-12. blomstrede valseformede $A x$; Frugterne omvendt-ægformede, med budt Kjøl.

Bladene meget lange, og ligne Bladene af Zostera marina. 6-8. 4 .

I Biekke og Aaer, ikke sjelden paa IIalveen og i Sjalland. (Fra de øvrige Øer er den mig ikke bekjendt.)

241. P. acutifolius [Link i Röm. \& Sch. syst. veg. III, 513] (Spidsbladet V.) H. II, 135; Drej. n. 184; F. D. 1747 ; Rehb. 1. c. fig. 44 ; H. N. V, 79.

Stangelen grenet, vinget-fladtrykt; Bladene linieformede, kort tilspidsede, mangenervede, med 3 stærkere Nerver; Blomsterstilkene neppe 1/9", af Længde med eller lidet længere end det 4-6-blomstrede, i Frugttilstanden rundagtige $A x ;$ Frugterne sammentrykte, skjævt omvendt-ægformede, med kjølformet vortet Ryg.

I de fleste Blomster kommer kun een Frugtknnde til Udvikling. Fra foreg. adskilles den let red de mere tilspidsede Blade og de kortstilkede, faablomstrede Ax. 7-8. 4 .

I Syer og Vandgrøfter, sjeldnere end foreg.: $\boldsymbol{S} \boldsymbol{j}$. Fredensborg, Fortunen (20), Mose ved Ordrup (17), Frederiksdal ved Sneglebakken, Dammen ved Ladegaarden (9), Utterslev Mose (19), mellem Værebro Mølle og Gundsømagle, Thorslunde (15); Loll. ved Birket og Grønnegade (Rasmuss.); F. O. Skjerninge; Thorseng (12); J. mellem Bramminge og Aalbæk Mølle, Villebøl ved Kongeaaen (30)! $S l$. Aabenraa! Huusby (28); B o rnh. ved Nexø (20). 
242. P. obtusifolius [M.\& Koch D. Fl. I, 855] (Budtbladet V.) H. II, 135; Drej. n. 183 (undt. Cit. af H. og Schum.); F. D. 2107 ; Rehb. l. c. fig. 43 ; H. N. V, 80.

Stcengelen grenet, traadformet, trind-fladtrykt; Bladene linieformede, ved Grunden smalere og tokirtlede, budte, med en kort Braad, 3-5-nervede, Midtnerven stærkere end Sidenerverue og dannet af flere tæt samlede Karbundter; Blomsterstillene lige tykke overalt, omtrent af Længde med det 1 æt 6-8-blomstrede $A x$; Frugterne skjært ovale eller halv-kredsrunde, sammentrykte, paa Ryggen budt trekjølede, ujævne.

Midtnerven af en blegere Farve end det øvrige Blad. 7-8. $\psi$

I Torvmoser og Søer, ikke sjelden i Sjalland og paa Halvoen; Bornh. Vallensgaards Mose! F. ved Svaninge (12); Loll. Gronnegade (Rasmuss.); Falst. Moseby (14).

243. P. mucrouatus [Schrad. i R. \& Sch. syst. III, 517] (Braadbladet V.) F. compressus Oed. i F. D. 203; Rehb. l. c. fig. 42 ; Schum. n. 167 ; H. 184 ; P. pusillus major Fr. nov. p. 48 ; P. Friesii Rupr.

Stcengelen grenet, firekantet-fladtrykt (ikke vinget); Bladene linieformede, budte, med en Braad, femnervede, med 2 Lirtler ved Grunden; Blomsterstillene tykkere foroven, 1-3 Gange liængere end det faa- og fjernblomstrede $A x$; Frugterne skjært elliptiske, med en budt trekjølet Ryg. 7-8. 4.

I Søer og Aaer, f. Ex. S j. Aaerne ved Tiissø (11)! Papirmøllen, St. Hans Hospital (H.), Nestved (Oed.); F. Hvedholm (H.); J. Vaarsaa i Vendsyssel (12), Aalborg (Strandg.)! Vildsted Sø (herb. Drej.); Randers Fjord (3), mellem Kjeldst og Broeng V. for Varde (30!), alm. i Kongeaaen ved Hjortlund (12), Ribe (6); Sl. Marskgrofter ved Hoyer (16); Bornh. (H.). $\overline{\$}$

Anm. 1. Maaskee høre ikke alle de Hornemannske Voxesteder herlid. At den af Hornem. og Sehum. beskrevne P. compressus horer til P. pusillus major Fr. forekommer mig imidlertid af Beskrivelserne og Cit. af F. D. utvivlsomt, denne næermer sig ligesaameget P. obtusifolius som P. pusillus, og er ved den mere fladtrykte Strengel forskjellig fra begge, hvorfor jeg har anseet dens Adskillelse som egen Art (hos Rehb. o. fl. Forf.) for vel begrundet.

Anm. 2. P. mutilus Wolfg. (Rehb. 1. c. fig. 40-41; H. N. XV, 74; P. cæespitosus Nolt. i Hans. Herb. n. 1007), som ndmærker sig bl. A. ved stivere, i Tuer voxende Stcengler, nasten toradede, trenervede Blade, som tilligemed Axelbladene ere langt tilspidsede, i ældre Tilstand af en rodig Farve, er optaget som dansk af Fr. (S. 
Veg. Sc.), men jeg finder intetsteds omtalt, om 'den af Prof. Nolte, som har fundet den i Holsteen, ogsaa er bemærket i Slesvig.

244. P. pusillus L. (Liden V.) H. 185; Drej. n. 182 ; F2. nov. p. 48 (undtagen $\alpha$, major); Schum. u. 169; F. D. 1451 ; Rehb. l. c. fig. $38-39$; H. N. XII, 76.

Stungelen grenet, traadformet, trind-sammentrykt; Bladene smalt-linieformede, trenervede, braadspidsede, med 1-2 Kirtler ved Grunden; Blomsterstilkene lige tykke overalt, 2-- flere Gange længere end det 4-8-blomstrede, mellembrudte $A x ;$ Frugterne (i Regelen alle udviklede) skjævt elliptiske, opblæste, jævne, paa Ryggen budt trekjølede.

Forekommer under flere Former, som dog alle ere finere og spædere end de foreg. 6-9. $\psi$.

$\alpha$, vulgaris Fr. nov. p. 49 . Bladene trenervede, spidse, $1 / q^{\prime \prime \prime}$ brede.

$\beta$, tenuissimus M. \& K. (Rchb. 1. c. fig. 39). Bladene trenervede, ined utydelige Sidenerver, tilspidsede, $1 / 5^{\prime \prime \prime}$ brede.

I Aaer og Søer alm. $\alpha$, den hyppigste Form; $\boldsymbol{\beta}, \boldsymbol{S} j$. Dragerup ved Holbæks Fjord (21); F. Ollerup (12); Falst. Oustrup (14); S l. Marskgrøfter ved Husum!

Anm. P. gracilis Fr. nov. p. 50, som foreg., men med ennervede Blade, kugleformet-elliptiske, trindryggede Frugter (Planten ved Torring sort), kunde muligviis findes i vor Flora, men turde let forvexles med var. $\beta$ af foreg., hvis Sidenerver ere meget utydelige.

245. P. trichoides [Cham. \& Schldl. in Linnæa II, 176] (Haarfiin V.) Rchb. I. c. fig. 34; P. monogynus J. Gay, (Coss. \& Germ. Atl. fl. Par. tab. 33, fig. 4-6).

Stcengelen traadfin, trind, meget grenet, med 1-4 Grene fra Bladhjørnerne; Bladene linie-børsteformede, trenervede med utydelige Sidenerver, tilspidsede; Blomsterstilkene lige tykke overalt. oftest nikkende, flere Gange længere end det 4-6blomstrede, mellembrudte $A x$; Frugterne halv-kredsrunde, større end bos foreg., med en Tand ved Grunden paa den indadvendte Side, paa Ryggen vortet-rundtakkede. (Kun een Frugt kommer til Udviling i hver Blomst).

Let kjendelig fra foreg. ved Frugterne og ved den eiendommelige Forgreningsmaade (ef. J. Gay i Bull. soc. bot. de Fr. 1854 Juill.). 7-8. ข. 
Paa lignende Steder som foreg., men meget sjeldnere: Falst. Stubberup (14); $\boldsymbol{S} l$. Vilstrup ved Haderslev (8).

\section{bb. Axelbladene tilvoxne til Bladenes Basis i Form af en toфret Sliede (Coleogeton Rchb.).}

\section{P. zosteraceus [Fr. nov. p. 51] (Nangegrenet V.)} Fr. S. Veg. Se. p. 216 ; Rehb. l. e. fig. 33 .

Stcengelen meget langstrakt og grenet, med forneden fladtrykte, foroven tykkere Ledstykker; Bladene linieformede, flade, kort tilspidsede, de øvre tre-, de nedre femnervede, med tydelige 'Tværaarer; Blomsterstillene meget lange, med langt Hellemrum mellem Blomsterkrandsene; Blomsterdakkets Blade omvendtægformede med indbøiet Spidse; "Frugterne næsten kugleformede, paa Ryggen trekjølede".

I Havet og i Aaer med stærk Strøm, sjelden: J. i Mængde i Kongeaaen mellem Hjortlund og Skodborg (12!); Lyø (12)?

Anm. I Henseende til Bladene ligner den $P$. zostercefolius, i Henseende til Blomsterstanden $P$. nuarinus; i Forgreningsmaaden og dens hele Habitus staaer den narmest $P$. pectinatus. Den af mig (efter et sterilt Exemplar) som $P$. pectinatus $\gamma$, flabellatus med Tvivl anforte Form (Haandb. 2 Udg. p. 124) hører sandsynligviis herhen, hvorimod $P$. flabellatus Bab. efter Expl. fra Forf. staaer saa nær ved $P$. pectinatus, at jeg ikke kan antage den for andet end en bredbladet Form af denne.

247. P. pectimatus L. (Børstebladet V.) H. 185; Sehum. n. 171-72 (P. peetinatum og P. marinum); Drej. n. 181; Fr. nov. p. 52; F. D. 186 (P. marinum) og 1746; Rehb. l. c. fig. $30-32$; H. N. V, 82 .

Stangelen grenet, langstrakt, traadformet; Bladene linieformet-borsteformede, svagt indrullede, tilspidsede, ennervede; Bladskedens Ører oprette; Blomsterstilkene lange; Axet mellembrudt; Blomsterdakkets Blade nyreformet-rundagtige; Frugterne halv-kredsrunde, opblæste, i tørret Tilstand budt trekjølede.

Strenglerne alm. meget lange; var. med txet- og fjernblomstrede Ax, smalere og bredere Blade o.s.v. 6-8. $\psi$.

$\beta$, scoparius Wallr. (Rehb. 32). Bladene haarfine, knippeformigt samlede.

I flydende og stillestanende, saavel Frersk-, som oftere Salt- og Brakvand; alm. i Dammark, især i Mængde i Fjordene paa Halvøens 
Østkyst. $\boldsymbol{\beta}$, med Ilovedarten, især i Brakvand paa Leergrund, f. Ex. F alst. hist og her (Koch); $\boldsymbol{F}$. Hofmansgave (18), i Brakvand N. for Nyborg (Lund); Gravensteens Nor paa $\boldsymbol{E} r \theta(10) ; J$. Lillestrand ved $\emptyset$ dstedgaard!

248. P. marinus L. (Traadformet V.) Fr. nov. p. 54; H. N. III, 65; Rchb. l. c. fig. 27-29; P. filiformis Pers., H. II, 136; Drej. n. 180 ; F. D. 2106 ; Nolte nov. p. 20 ; P. setaeeum Schum. n. 170 (ikke L.).

Stunglerne enkelte eller kortgrenede, med tæt sammentræugte Ledstykker; Bladene haurfine, ennervede, trindt-fladtrykte, paa Grund af de korte Ledstykker knippeformigt samlede; Bladskedernes Ører udstaaende; Blomsterstilkene meget lange, haarfine, enlige paa Strenglerne; Axene rned 3-4 fjerne; alm. toblomstrede Krandse; Blomsterdcekkets Blade spadeformede; Frugterne omvendt-ægformet-kugleformede, sammentrykte, paa Ryggen budte, i tørret Tilstand rynkede.

Finere og meget lavere end foreg., Frugterne neppe halvt saa store som hos hiin. Disse 2 Arter adskilles desuden let ved et aldeles forskjelligt Udseende. 6--8. 4.

$\beta$, fasciculatus (Rchb. 1. c. fig. 28-29; P. fasciculatus Wolfg.), Blomsterstilkene af Længde med eller kortere end Bladene.

Medens den i Sverige, saaledes som Navnet antyder, oftest findes i Saltvand, er den hos os udelukkende bemærket i Færskvandssøer, og sjeldnere end foreg.; $\boldsymbol{S}$. Tiissø, Sorø Sø! Haraldsted $\mathbf{S} \emptyset(11)$, Fuursøen ved Frederiksdals Mølle (Dr.), Gurre Sø (14); Loll. Maribo S $\emptyset$ ved Engestofte $(19) ; \boldsymbol{F}$. S $ø$ rup $\mathrm{S} \emptyset(12) ; \boldsymbol{J}$. Vandet S $\emptyset$ i Thy (herb. Drej.), Gudenaa ved Randers (7), Skanderborg $\mathrm{S}_{\wp}$ (Aabye); $\boldsymbol{S} l_{\text {. }}$ (N.). $\beta, S j$. Gyrstinge $\mathbf{S} \emptyset(12)$.

\section{Ruppia. Havgraes.}

249. R. spiralis [L. adnot. in herb. suo, ef. C. Hartm. Anteckn. i Vet. Akad. Handl. 1849 p. 191] (Langstilket H.) Dnmort. fl. Belg., J. Gay i Coss. pl. crit. 1848; R. maritima L. (ex part.) H. 186; Drej. n. 179; Lge. Haandb. 1 Udg. S. 112 ; E. D. 364 ; Relıb. l. c. fig. 26 ; H. N. XII, 77.

Bladene børsteformede, ved Grunden omskedende; Skeden foroven kantet; Blomsterstilkene under Nodenheden meget lange, alm. spiralformigt snoede; Støvknappernes Rum ovale; Frugterne 
mange Gange kortere end Frugtstilkene, ægformede, skjævt oprette (Griffel og Ar staae ligefor Frugtstilken), 7-9. 2.

I Salt- og Brakvand, i Vandhuller, som overskylles af Havet, alm. udbredt.

Anm. Ruppia maritima L. er uden Tvivl et collectivt Navn, som indbefatter baade denne og følgende Art. If liandling af Mag. C. Hartman er det endog R. rostellata, som under hiint Navn findes opbevaret i Limés Herbarinm, medens den almindelig saakaldte $R$. maritima der benævnes $R$. spiralis. Da dette sidste Navn tillige betegner en af Plantens meest fremtræedende Characterer, kan det med god Grund foretrækkes for det seldre, som desuden med lige god Ret kan anvendes paa enhver af Arterne.

250. R. rostellata [Koch i Rehb. ic. crit. 2, f. 306] (Skjævfrugtet H.) Drej. n. 178; Rchb. ic. fl. germ. VII, fig. 25 ; H. N. VI, 6s; R. maritima Linn. Herb. ex C. Hartm. I. c.

Bladene som foreg.; Skeden mindre og ikke kantet; Blomsterstilkene under Modenheden langt kortere end hos foreg. (ikke snoede); Stovknappernes Rum næsten kugleformede; Frugterne flere Gange kortere end Frugtstilken, fra en ægformet Basis halvinaaneformigt opstigende, tværsstillede (Griffelen falder ikke i Linie med Frugtstilken); Frøgjemmet bruskagtigt.

Ifølge J. Gay (Gren. \& Godr. fl. Fr. III, 324) er Frugtens Form foranderlig og kan iklke med Sikkerhed benyttes som Kjendetegn fra foreg. $-7-9$. $\psi$.

Paa samme Steder som foreg., ikke sjelden og bemærket ved Kysterne af alle danske Provindser.

251. R. brachypus [J. Gay i Coss. not. crit. 1848 p. 10] (Kortstilket H.).

Bladene som hos foreg., Bladskederne bredere og mere oppustede; Blomstcrstilkene meget korte (1-4"' lange); Stovknapperncs Rum agformet-kugleformede; Frugtstillene omtrent af Frugternes Længde (lidet kortere eller længere end samme); Frogjemmet beenhaardt. 8-9. 4.

Paa lignende Steder som de foreganende Arter, men sjeldnere. S $j$. Oresund udfor Classens Have (26)! Loll. Lienlund ved Nakskor $(19)$ ! 


\section{$5^{\text {te }}$ Klasse. Pentandria (Femhannede).}

\section{Orden. Monogynia (Enhunnede).}

A. Blomsterdækket dobbelt.

a. Kronen sambladet, undersædig.

aa. Frugterne 4 Nodder med en midtstillet Griffel. /Blomsterne $i$ ensidige, for Udspringningen spiralformigt sammenrullede Klaser eller $\left.A x .^{*}\right)$ Bladene oftest rue. (1-12. N. F. Asperifolic.)

๘. Kronens Svælg uden Bikrone.

1. Échium L. Biegeret femdeelt; Kronen uregelm. tragtformet, næsten tolæbet; Støvdragerne uligelange; Smaafrugterne ved Grunden flade.

2. Lithospérmum L. Bægeret femdeelt; Kronen regelm. tragtformet; Svælget indsnøret af 5 indvendig haurede Længdefolder; Smaafrugterne beenhaarde, ved Grunden flade.

3. Stenhammária Rehb. Bægeret femdeelt; Kronen regelm. tragtformet; Svælget i Nidten sammenkuebet, glat; Smaafrugterne trekantede, ved Grundeu puklede, furede, uden Ring; Frøgjemmet hindeagtig-opblæst.

4. Pulmonária L. Bægeret femtandet; Kronen regelm. tragtformet med en Haarkrands i Svælget; Smaafrugterne glindsende, fladtrykt-convexe, ved Grunden udhulede og omgivne af en Ring.

ק. Kronens Svælg indsnøret af skjæl- eller tandformede (indvendig hule) Tilhængsler (den saakaldte "Bikrone").

ce. Smaafrugterne tilvoxne til (og sammenhcengende med) Griffelen.

5. Asperúgo L. Bægeret først femfliget med todeelte Tænder mellem F ligene, tilsidst dybt todeelt, fladtrylkt og tæt

*) Blomsterstandens forste Forgrening er i Regelen gaffeldeelt, stundom med en Blomst i Gaffeldelingen efter den qvastformede Typus. Den yderligere Forgrening i saakaldte ensidige Klaser eller Ax er vistnok rettest at forklare som en Qvast, hvor bestandigt kun den ene Side kommer til Udvikling. 
omgivende den modne Frugt; Smaafrugterne sammentrykte, med den smalere Side tilvoxne til Griffelen, tret og fint vortetpunkterede.

6. Cynoglóssum L. Bægeret regelm. femdeelt; Smaa. frugterne fladtrykte, med den brede Side (henimod Spidsen) tilvoxne til Griffelen, overalt beklæedte med Hagebørster.

$\dagger 7$. Omphalódes Tournef. Bægeret regelm. femdeelt; Smaafrugterne hindeagtige, fladtrykte, mod Spidsen baadformigt sammendragne med indrullet Rind, med den brede Side tilvoxne til Griffelen, uden Hagebørster.

8. Echinospérnum Sw. Bægeret regelm. femdeelt; Smaafrugterne trekantede, med 2 Rækker Hagebørster i Randen, med den brede Side tilvoxne til Griffelen.

Bß. Smaafrugterne tilvoxne til Frugtbunden (eller en underscedig Slive),

- ved Grunden flade.

9. Myosótis L. Kronen hjulformet eller fladkravet; Svælget lukket af 5 vorteformede Tilhæugsler; Smaafrugterne jærne, glindsende.

** Smaafrugterne red Gronden udbulede og omgirne af en Ring.

10. Borrigo L. Kronen hjulformet, med korte, budte eller udrandede, skjælformede Tilhængsler i Svælget; Støvtraadene tokløvede; Støvknappen befæstet paa den indadvendte Tand; Smaafrugterne rynkede.

11. Anchusa L. Kronen tragtformet eller fladkravet; Svælgets Tilhængsler hvid-randhaarede, budte; Støvdragerne uden Tilhængsler; Støvtraadenes frie Deel kortere end Støvknapperne; Smaafrugterne rynkede.

12. Sýmphytum L. Kronen kølleformet; Svælgets Tilhængsler sylspidsede, tillukkende Røret; Støvdragerne uden Tilbængsler; Støvtraadene omtrent af Længde med Støvknapperne; Smaafrugterne jævne. 
b6. Frugten Heelfrugt med endestillet Griffel,

$\alpha$, bæragtig.

13. Átropa L. Bægeret grønt, femfliget med udstaaende Flige, længere end Frugten; Kronen klokkeformet; Støvknapperne aabne sig paalangs (Urt med enlige Blomster).

14. Phýsalis L. Bægeret femtandet, tilvoxende efter Afblomstringen, under Frugtens Modenhed farvet, blæreformigt omsluttende Bærret; Kronen hjulformet; Støvknapperne aabne sig paalangs (Urt med enlige Blomster fra Bladhjørnerne).

† Nicandra Adans. Bægeret femfliget, med ægformede, oprette Flige og piilformede Ører ved Grunden, efter Afblomstringen blæreformigt opblæst og omsluttende Frugten; Kronen klokkeformet; Støvknapperne opspringe paalangs, Bærret saftløst.

15. Solánum L. Bægeret grønt, femdeelt, kortere end Frugten; Kronen hjulformet; Størknapperne opspringe ved Huller i Spidsen (Urter eller Halvbuske med Blomster i uregelm. skjærmformet Qvast, oftest udgaaende fra Midten af Ledstykkerne).

16. Lýcium L. Bægeret grant, tolæbet, meget kortere end Frugten; Kronen fladkravet eller tragtformet; Støvknapperne opspringe paalangs (Buske med tornede Grene, enlige eller knippestillede Blomster fra Bladhjørnerne).

\section{B. Frugten 2-4-ruminet Kapsel.}

17. Hyoscýamus $L$. Kronen femlappet, uregelm. tragtformet; Kapselen tværopspringende, torummet, tæt omgivet af det vedblivende, femtandede Bæger; Arret udeelt, rundagtigfladtrykt.

18. Datira L. Kronen fentandet, regelı. tragtformet; Bxgeret femtandet, tilsidst omkringskaret; dets ovre Deel affaldende, den nedre veảblivende; tilbagebøiet; Arret tolappet; Kapselen furerummet, fireklappet, opspringende paalangs. (Nr. 13-18. N. F. Solaneæ).

19. Verbáscum L. Brgeret femdeelt, vedblivende; Kronen 
femdeelt; uregelm. hjulformet; Støvdragerne uligelange (Støvtraadene, alle eller nogle, beklædte med Uld); Kapselen toklappet, opspringende paalangs, maugefrøet, med smaae Frøe. (N. F. Scrophularineæ $\alpha$ ).

20. Couvólrulus L. Brgeret fembladet; Kronen regelm. tragtformet, svagt femtandet, i Knopleiet snoet; Støvdragerue ligelange; Kapselen faafiøet med store Froe; $2 \mathrm{Ar}$. (Slyngende Urter med Mælkesaft. N. F. Convolvulaceæ).

$\uparrow$ Polemónium L. Bægeret femdeelt; Kronen dybt fenfliget, hjulformet-klokkeformet, med snoet Knopleie; Arret tredeelt; Kapselen trerummet og treklappet med rumdelende Opspringning, indeholdende 6-9 kantede Frøe. (N. F. Folemoniacex).

21. Erythráa Pers. Bægeret femdeelt; Kronen regelm. tragtformet, femfliget, i Knopleiet snoet; Støvknapperne efter Bestøvningen spiraldreiede; Kapselen ufuldstændigt torummet, mangefrøet; Frøene smaae, befæstede paa Frugtbladenes indbøiede Rande. (N. F. Gentianer).

$\gamma$. Frugten enrummet med vægstillede Frgstole.

22. Gentiána L. Bægeret 2-5-deelt; Kronen tragtformet eller fladkravet, 4-5-fliget, med snoet Knopleie; Kapselen toklappet, med talrige smaae Frøe paa Klappernes indboiede Rande. (Bladene heelrandede, modsatte).

23. Menyinthes L. Bægeret femdeclt; Kronen tragtformet, med foldet Knopleie og femfliget, indrendig fryndset Krave; Frøgjemmet saftigt, tilsidst uregelmæssig opspringende paalangs; Frøene store. (Sumpplante med trekoblede, afvexlende Blade). (21-23. N. F. Gentianex).

† Limnanthemum Gmel. Bægeret dybt femdeelt; Kronen hjulformet, femlappet, med randhaarede Lapper og fryudset Svælg; Frogjemmet uopspringende; Frøene fladtrykte, randhaarede. (Vandplante med heelrandede, kredsrundt-nyreformede Blade. N. F. Gentianeæ).

s. Frngten enrummet med miltstillet Frøstol.

24. Prímula L. Bægeret femtandet; Kronen tragtformet eller fladkravet; Arret kugleformet; Kapselen opspringende i 
Spidsen med $(5-10)$ Tænder. (Eng-eller Skovplanter med hele, rundtakkede Blade, alle samlede ved Grunden).

25. Hottónia L. Bageret dybt femdeelt; Kronen flad. kravet, med kort Rør; Arret rundagtig-flydtrykt; Kapselen femklappet med i Spidsen sammenhængende Klapper. (Vandplante med kamdeelte, rosettestillede Blade).

26. Iysimichia L. Bægeret femdeelt; Kronen hjulformet; Arret tværhugget; Kapselen femklappet, opspringende paalangs. (Bladene heelrandede, modsatte).

27. Anagállis [. Bægeret femdeelt; Kronen hjulformet; Arret kuglerundt; Kapselen træropspringende. (Bladene som hos foreg.) $-24-27$. N. F. Primulaceæ).

cc. Frugten flerfoldig (2 Bollekapsler).

28. Vinca L. Bægeret femdeelt; Kronen fladkravet, i Knopleiet snoet; Støvknapperne sammenstølende ovenfor Arret; 2 Frugtkuuder med en fielles Griffel udvidet til et saftfuldt, i Spidsen skjægget Ar. (N. F. A pocyneæ).

b. Kronen sambladet, oversedig.

aa. Frugten kapselagtig, $\alpha$, opspringende ved Klapper.

29. Símolus L. Bægeret halvt-oversædigt, femdeelt; Kronen regelm. femdeelt med fem tandformede Tilhængsler (golde Støvdragere) mellem Fligene; Støvdragerne frie; Kapselen enrummet, femklappet. (N. F. Primulaceæ).

30. Lobélia L. Bægeret femdeelt, oversædigt; Kronen uregelret, Røret spaltet $\mathrm{i}$ den ene Side; Støvknapperne sammenvoxne; Kapselen 2-3-ruminet, 2-3-klappet. (N. F. Lobeli a e e $)$.

$\beta$. Kapselen opspringende ved Huller. (31-33. Urter med Mælkesaft. N. F. Campanulacer).

31. Campánula L. Kronen klokkeformet; Støvdragerne frie; Arret trefliget; Kapselen 2-3-rummet, opspringende ved Huller paa Siden (Blomsterne enlige eller i Klaser). 
32. Phyteuma L. Kronen med 5 i Begyndelsen foroven sammenhængende, tilsidst stjerneformigt udbredte Flige; Støv. dragerne frie; Arret trefliget; Kapselen trerummet, opspringende i Huller ved Grunden eller paa Midten (Blomsterne i Ax).

33. Jasioue L. Kronen som foreg., med til Grunden deelt Krave; Støvknapperne ved Grunden sammenvoxue; Arret kolleformet, tilsidst tolappet; Kapselen torummet, opspringende ved Huller i Spidsen (Blomsterne i Blomsterkurv med mangebladet Kurvdække).

\section{bb. Frugten baragtig.}

34. Lonicéra L. Kronen uregelret; Støvdragerne frie; Arret næsten kugleformet; Bærret 2-3-rummet. (Buskviexter med modsatte Blade). (N. F. Caprifoliacex).

Sambucus. Kronen regelret, hjulformet, Frugt trefrøet Steenfrugt $(5,3)$.

Viburnum. Kronen regelret, hjulformet, Frugt enfrset Steenfrugt $(5,3)$.

Rubia. Kronen regelret, hjnlformet, to enfrøede Steenfrugter $(4,1)$.

$$
\text { c. Kronen fribladet. }
$$

aa. Kronen uregclret (hos 35-36), Frugten kapselagtig.

35. Viola L. Bægeret fembladet, med Tilbængsler ved Grunden; Kronen uregelm. fembladet, det større Kronblad med en Spore; Støvlnnapperne sammenhængende, de 2 nedre med Spore, Knapbaandet forlænget udenfor Rummene; Kapselen opspringer fra Spidsen til Grunden i 3 Klapper; Frostolene vagstillede. (N. F. Violariex).

36. Impátiens L. Bæger og Krone trebladede, uregelm., det uparrede Bregerblad stort, farvet, forlænget $i$ en Spore; Støvknapperne sammenhængende; Kapselen elastisk opspringende i 5 Klapper fra Grunden; Frostolen midtstillet. (N. F. Balsamine $æ$ ).

Erodium. Blomst undersædig, femdelelig Spaltefrugt $(10,1)$.

Geranium rotundifolium. $(10,1)$.

Euonymus. Bieger og Krone regelm. 4-5-bladede $(4,1)$. 


\section{bb. Kronen regelret, Frugten bceragtig.}

37. Rhamuus L. Blomsten undersædig eller omkringsædig; Bæger og Krone 4-5-bladede; Bærret 2-4-rummet, med ligesaamange Frøe. (Buske med fjernervede hele Blade). (N. F. Frangulace $x$ ).

38. Ribes L. Blomsten oversædig, femdeelt; Arret todeelt; Bærret enrummet, med 2 vægstillede Frøstole, mangefrøet. (Buske med handlappede Blade). (N. F. Ribesiacex).

39. Ilédera L. Blomsten oversædig eller halvt-oversædig, femdeelt; Arret udeelt; Bærret femrummet, femfrøet. (Klattrende Busk med haandlappede, stedsegrønne Blade). (N. F. A rali a c e $æ$ ).

\section{B. Blomsterdækket enkelt,} a, undersædigt.

40. Glaux L. Bægeret farvet, klokkeformet; Krone 0; Frugten femklappet, enrummet, 5-10-frøet Kapsel. (Strandplante ned modsatte Blade uden Axelblade). 4. (N. F. Frimulace æ).

41. Illecébrum L. Blomsterdækket hindeagtigt, fembladet, med hætteformede, i en lang Spids endende Flige; Støvdragerne 10, de 5 golde; Frugt femklappet, enfrøet. (Enaarig Urt med modsatte Blade og hindeagtige Axelblade). (N. F. Paronyehiex).

Polygonum. Blomsterdækket farvet, 4-5-bladet, Støvdragerne $5-8$, Frugten nødagtig $(6,3)$.

Herniaria. Blomsterdækket grønt, femdeelt (5, 2).

b. Blomsterdækket oversadigt.

42. Thésium I. Blomsterdxkket 4-5-deelt, udvendig grønt, indvendig farvet (hvidt); Støvdragerne befæstede til og modsatte Blomsterdækkets Flige, med et Kinippe af Haar ved Grumcien udadtil; Frugten enfrøet, uopspringende (Skalfrugt). (N. F. Santalace ). 


\section{Orden. Digynia (Tolunnede).}

A. Blomsterdækket enkelt.

a. Frugt enfrøet (Nød eller II indefrugt) indsluttet i det vedblivende Blomsterdxke. (Urteagtige

$$
\mathrm{V} a \mathrm{x} \text { te } \mathrm{r} \text { ). }
$$

aa. Bladene flade, med hindeagtige Axelblade.

43. Herniária L. Blomsterdxkket gront, feindeelt, Fligene budte: Stovdragerne 10, de 5 golde; 2 siddende, meget korte Ar. (N. F. Paronychie $x$ ).

Illecebrum. Blomsterdæklket hiadeagtigt, Fligene sylspidsede $(5,1)$. Polygonum amphibium. $(6,3)$.

bb. Bladene fade, uden Axelblade.

44. Beta L. Frugten tilvoxen til det vedblivende, femdeelte, kjød- eller bruskagtigt tilvoxende Slomsterdække; Frøet vandret, med hindeagtig Skal.

45. Chenopódium I. Blousterdækket grønt, femdeelt; Frugten fri; Froet vandret med hornagtig Skal.

46. Blitum L. (C. A. Mey.) Støvdragerne 1-5; Frugten fri i det vedblivende, femdeelte, ofte farvede ( $\mathrm{og}$ kjødfulde) Bloinsterdække. Frøet lodret (eller undtagelsesviis vandret) med hornagtig Skal.

Atriplex. Frugt fri, Frøet lodret, med liomagtig Skal, $q$ Blomsterdækket tobladet $(21,5)$.

Halymus. $q$ Blomsterdæklset tofliget, tæt omsluttende Frugten, Frget lodret, med hindeagtig Skal $(21,5)$.

cc. Bladene trinde eller halvtrinde, kjodfulde.

47. Chenopodina Noq. Blomsterdakket femdeelt, uden Tilhængsler; Frøets Skal hornagtig; Kimen spiraldreiet, Frohvide 0. (Bladene uden 'Torne).

48. Sálsola L. Blomsterdækket fembladet, efter Afblomstringen med vingeformede, paatværs tilvoxne Tilhæugsler; Frøets Skal hindeagtig; Kimen spiraldreiet; Frohvide 0 (Bladene i Spidsen toruede). 
49. Kóchia Roth. Blomsterdækket femdeelt, ned efter Afblomstringen paatvars tilvoxne Tilhængsler; Frøets Skal hindeagtig; Kimen ringformigt ongivende den midtliggende Frøhvide. (Bladene uden Torne). 44-49. (N. F. Salsola ceæ).

Scleranthus. 10 Støvdragere (de 5 ofte golde), Bladene sylformede $(10,2)$.

b. Frugten (Vingefrugt) længere end Blomster. dækket. দุ.

50. Ulmus L. Blomsterdækket 4-6-deelt, klokkeformet; Støvdragerne 4--8; Frugten enrummet, enfrøet, med et paa alle Sider af Frøet hindeagtigt udvidet, fladtrykt Frogjemme. (Træer med afvexlende, ved Grunden skjæve Blade, Blomsterne i sidestillede Hoveder eller Skjærme, udvikles for Bladene). (N. F. Ulin a ce $x$ ).

B. Blomsterdækket dobbelt.

a. Krouen undersædig, sambladet, Frugten kapselagtig.

51. Vincetóxicum Noench. Bægeret dybt femdeelt; Kronen hjulformet, med femlappet Bikrone; Støvknapperne sammenhængende, ved deres Knapbaands hindeagtige Forlængelse dannende et Tag over det skjoldformede, for begge Grifler fælles Ar; Stovet i Masser. Frugterne 2 (sjeldnere 1) Bællekapsler; Frøene med Frøuld. (N. F. Aselepiadeæ).

52. Cuscuita L. Bægeret 4-5-deelt; Kronen 4-5-fliget, klokke- eller kugleformet, med skjælformet Bikrone; Støvdragerne frie; Frugten en torummet Buddike; Frøene nden Frøuld; Kimen spiralkrummet, Frøhviden midtliggende. (Bladløs Snylteplante med Sugevorter, Blomsterne i kugleformede Hoveder). (N. F. Cusentinæ).

Gentiana. Kronen tragtformet eller fiadkravet, Støvdragerne frie, Kapselen toklappet, opspringende paalangs $(5,1)$. 
b. Kronen oversædig, fribladet*), Frugt todelelig Spaltefrugt, Sma afrugterne nødatige, Frøgjemmet ofte udvendig forsynet med Ribber, indrendig med Oliekanaler; Blomster i enkelt eller sammensat Skjarm, ofte med Stor-og Smaasvøb. (53-88. N. F. Umbellifere).

aa. Slijormen hovedformet (Blomsterne siddende),

a, enkelt.

53. Hylrocótyle L. Bregerkraven utydelig; Kronbladene bele, spidse; Frugten fladtrykt fra Siden; Smaafrugierne feuribbede (de 3 Ribber ofte utydelige). (Bladene skjoldformede).

54. Erýngium L. Bægerkraven femtandet; Kronbladene i Spidsen indbøiede og derved tofligede; trugten trind, Smaafrugterne uribbede, beklædte med Skjæl. (Bladene tornettandede.)

\section{$\boldsymbol{\beta}$. Skjærmen sammensat.}

55. Sanicula L. Bægerkraven femtandet; Kronbladene med indbøiet Spidse og derved udrandede; Frugten trind, Smaafrugterne uribbede, beklædte med Hagebørster. (Bladene haandsnitdeelte).

\section{bb. Blomsterne $i$ egenlig Skjarm (stilkede).}

a. Smaafrugternes Bugflade med flad eller convex Frohride.

(Orthosperma).

«. Hovedribberne 5, Biribberne 0.

$\boldsymbol{c}^{\prime}$. Skjærmen enkelt.

$\dagger$ Astríntia L. Blomsterne omgivne af et mangebladet Srøb; Bægerkraven femtandet; Hovedribberne tykke, beklædte med 2 Rader brede og buite, tandformede Skj:el, Mellemrummene uden Oliekanaler.

*) Hos mange Slægter i denne Afdeling er den oversædige Bregerkrave saa svigt udviklet, at den indskrankes til en utydelig Rand eller synes at mangle, hvorved Blomsterdakket farer Udseende af at vare enkelt. 


\section{$\beta^{\prime}$. Skjærmen sammensat.}

- Frugten sammenlrykl fra Siden.

†ronbladene i Spidsen udeelte.

56. Bupleurum L. Brgerkraven utydelig; Kronbladene budte, med indbøiet Spidse; Ribberne vingeformigt fremstaaende, Mellemrummene uden Oliekanaler. (Bladene hele, Kronerne gule).

57. Heloscídium Koch. Brgerkraven utydelig eller svagt fentanclet ; Kronbladene spidse, indbøiede; Ribberne traadformigt fremstaaende, 1 Oliekanal i hvert Mellemrum (Bladene suitdeelte, Kronerne hvide).

58. Apium L. Stor- og Smaasvob 0; Bægerkraven utydelig; Kronbladene i Spidsen afruudede og indbøiede; Ribberne traadformigt fremstaaende, 2 Oliekanaler i hvert Mellemrum; Frugtstolen udeelt. (Bladene snitdeelte; Kronbladene bvide.)

$\dagger$ Petroselínum Hoffm. Svøbet faabladet; Frugtstolen todeelt; 1 Oliekanal i hvert Mellemrum, forøvrigt som foreg.

t+ Kronbladenc ved Spidsens Indböining udrandede eller omvendt-hjerteformede.

1. Bagerkraven utydelig.

59. Aegopódium L. Frugten ægformet, uden Oliekanaler; Stor- og Sinaasvob 0.

60. Varum L. Frugten elliptisk, 1 Oliekanal i hvert Mellemrum, 2 paa Bugfladen; Storsvøbet faabladet, Smaasvob 0 .

61. Pimpiuélla L. Frugten agformet eller oval, flere Oliekanaler i hvert Mellemrum og paa Bugfladen; Stor- og Smaasvob 0.

2. Bagerkraven tydeligt femtandet.

62. Cicita L. Smaafrugterne uæsten kuglerunde, med hvælvet Bugflade; 1 Oliekanal i hvert Mellemrum; Storsvøbet 0 , Smaasvøbet fleerbladet.

63. Palcária Host. Frugten aflang; Bugfladen plau; 1 Oliekanal i livert Meilemrum; Stor-og Smaasvøb fleerbladede. 64. Siım L. Frugten elliptisk eller ægformet; Bugfladen 
plan; flere Oliekanaler i hvert Mellemrum; Stor. og Sinaasvøb fleerbladede.

" Frugten sammentrikt fra Riggero (eller triad).

+ Smaafrugternes Sideribber sammenslultende.

1. Frugtens Gjennemsnit trindt eller svagt sammentrykt.

1. Brgerkrasen tydeligt fentandet.

65. Denánthe L. Bægertænderne og de oprette Grifler vedblivende; Frugten glat, omvendt-kegleformet eller elliptisk, trind eller kantet, med budt-afrundede Ribber, 1 Oliekanal i hvert Mellemrum; Frugtstolen tilvoxet til Frugten; Froet fastvoxet til Frøgjemmet.

66. Libauótis Crantz. Bægertæenderne afialdende; Griflerne tilsidst tilbagebøiede; Frugten haaret, oval, trind eller noget sammentrykt, med tykke, budte Ribber, 1 Oliekanal i hvert Mellemrum, 4 paa Bngfladen; Frugtstolen fri; Frøet fastvoxet til Frøgjemmet.

67. Ilalóscias Fr. Bægertınderne meget smaae; Griffelen tilbagebøiet; Frugten glat, elliptisk, noget sammentrykt, med 5 skarptvingede Ribber; flere Oliekanaler i hvert Mellernium, 6 par Bugfladen; Frugtstolen fri; Frøet løst i Frøgjemmet.

2. Bxgcrliraren utydelig.

68. Aethisa L. Frugten trind, ægfornet-kugleformet, med tykke, skarpt kjølformede Ribber (Sideribberne bredere); 1 Oliekanal i hvert Hellemrum, 2 paa Bugfladen; Frugtstolen fri; Storsvøbet 0 ; Smaasvobets Blade linieformede, nedhrengende.

69. Cuílium Cusson. Frugten trind, oval; Ribberne lindeagtigt vingede; alle ligebrede; Stor- og Smaasvobbladene børsteformede, udstaaende, forøvrigt som foregaaende.

2. Frugten lindseformigt nadtrykt, Sideribberne med en ndvidet Rand, (hvorved Frugten bliver tovinget).

1'. Eronerne hride eller rodlize.

70. Peucédanum L. Bægerkraven tydelig fentandet; Alle Ribber $\mathrm{i}$ lige Afstand fra hinanden; de 3 midterste Ribber traad- 
formede (Sideribberne svagere), Oliekanalerne (1 i hvert Mlellemrum)"nedløbende til Basis af Frugten, 2 paa Bugfladen.

† 71. Imperatória L. Bægerkraven utydelig; Kronbladene omvendt-hjerteformede, med indbøiet Spidse; alle Ribberne i lige Afstand fra hinanden; Midtribberne skarpt kjølformede; Oliekanalerne som hos foreg.

72. Meracléum L. Bægerkraven tydelig femtandet; de 3 midterste Ribber traadformede, $i$ lige Afstand fra hinanden, men fjernede fra Sideribberne; Oliekanalerne 1 i hvert Mellemrum, forsvindende ovenfor Basis, 2 paa Bugfladen, kølleformigt udvidede nedentil og ophørende ovenfor Midten.

2' Eronbladene gule.

73. Pastináca L. Bægerkraven utydelig; Kronbladene rundagtige, udrandede med indrullet Spidse; de 3 midterste Ribber traadformede, fjernede fra Sideribberne; Oliekanalerne (1 i hvert Mellemrum) ophørende nedenfor Midten.

† 74. Anéthum L. Bægerkraven utydelig; Kronbladene tværsafskaarne, med indrullet Spidse; alle Ribberne i lige dfstand fra hinanden; Midtribberne skarpt kjølformede; Oliekanalerne naae til Grunden af Mellemrummene.

+ Smaafrugternes Sideribber frastaaende (Fruglen firevingel).

1. Bægerkraven utydelig, Frget fastvoxet til Frogjemmet, 1 oliekanal i hvert Mellemrum.

75. Levísticum Kocb. Kronbladene afrundede med indbøiet Spidse (gule); Midtribberne vingede, smalere end Sideribberne; Storsvøb og Smaasvøb mangebladede.

76. Selinum L. Kronbladene i Spidsen udrandede, om. vendt-hjerteformede, med indbøiet Spidse (hvide); Nidtribberue vingede, smalere end Sideribberne; Storsvøb 0 eller faabladet, Smaasvøbet mangebladet.

77. Angélica L. Kronbladene hele, spidse, lidet indbøiede (hvide eller røde); Midtribberne traadformede, flere Gange smalere end Sideribberne; Storsvob 0 eller faabladet, Smaasvobet mangebladet. 
2. Bægerkraven femtandet, Frøet frit (lost i Fragjemmet), beklædl med talrlge oliekanaler.

78. Archangélica Hoffin. Kronbladene hele, spidse, med indrullet Spidse; Midtribberne skarpt kjølformede, flere Gange sınalere end de vingerle Sirleribber.

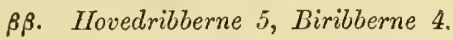

79. Laserpitium L. Bægerkraven femtandet; Kronbladene udrandede, omvendt-hjerteformede; Hovedribberne traarlformede; Biribberne hindeagtigt vingede, uden Burster eller Torne. Storsvobets Blade udeelte.

80. Daucus L. Bægerkraven femtandet; Kronbladene udrandede, omvendt-hjerteformede; Hovedribberne traadformede (de 3 midterste beklædte med Børster, Sideribberne udgaae fra Bugfladen), Biribberne vingede, med en enkelt Rad Torne. Storsvobets Blade fjersnitdeelte.

$\boldsymbol{\beta}$. Smanfugterue med en Liengdefure paa Bugfladen, dannet af Fro. hridens indbøiede Rande (Campylosperma).

ace. Bagerkraven femtandet, Hovedribberne 5, Biribberne 4, bellcedte med Pigge og Børster.

81. Caucalis L. Hovedribberne traadformede, beklædte med Børster; Biribberne med en enkelt Rrkke af Pigge.

82. Tórilis Adans. Hovedribberne beklædte med Burster, Biribberne med flere Rækker af Pigge.

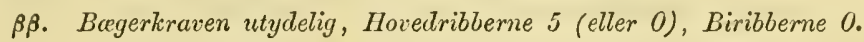

* Smaalfuglerne ende $i$ et Nab.

83. Anthriscus Hoffm. Smaafrugterne uribbede; Næbet femribbet, kortere end Frugten.

84. Scandix L. (excl, sp.) Smaafrugterne med 5 budte Ribber; Næbet uribbet, af Frugtens dobbelte Længde.

** Smaafrugterue nden Nid.

85. Chærophýllum L. (excl. sp.) Smaafrugterne lancetformede (eller linieformede), med budte Ribber; 1 Olickanal i bvert Rum; Storsvob 0. 
86. Myrrhis Seop. Smaafrugterne lancetformede; Frøgjemmet med en dobbelt Hinde, den indre tæt beklædende Frøet, den ydre løs, med ophøiede, skarpe, hule Ribber; Oliekanaler og Storsvøb 0.

87. Conium L. Frugten ægformet, med ophøiede, bølgettandede Ribber; Oliekanaler 0; Storsvøbet mangebladet.

$\boldsymbol{y}$. Frøhviden udhulet, foroven og forneden sammenbyiet. (Coelospermæ).

$\dagger$ 88. Coriándrum L. Bæegeret femtandet, Kronbladene ved deu indbøiede Spidse omvendt-hjerteformede, (paa Straaleblomsterne dybt todeelte); Frugten kugleformet, med sammenhængende Smaafrugter og svagt ophøiede, bølgede Ribber.

\section{Orden. Trigynia (Trehunnede).}

a. Blomsterdækket dobbelt, oversadigt.

89. Vibúrnum L. De ydre (ndstraalende) Kroner større, hjulformede, de indre klokkeformet-rørformede; Frugten enfrøet Steenfrugt. (Busk med lappede Blade).

90. Sambucus L. Alle Frronerne hjulformede; Frugten trefrøet (bæragtig) Steenfrugt. (Bladene fjersnitdeelte). (91-92. N. F. Caprifoliace $æ$ ).

b. Blomsterdækket dobbelt, undersædigt.

91. Corrigiola L. Bæger og Krone femdeelte; Frugten en enfrøet, uopspringende Hindefrugt eller Nød (Bladene med hindeagtige Axelblade). (N. F. P aronyehieæ).

92. Drósera L. Bægeret femdeelt, 5 Kronblade; Griflerne 3 (sjeldnere $4-5$ ), oftest indtil henimod Grunden tvedeclte, med hele eller i Spidsen tolappede Flige; Frugten en enrumınet, treklappet, mangefrøet Kapsel med vægstillede Frøstole (Bladene alle samlede ved Grunden, tæt beklædte med klæbrige, stilkede Kirtler). (N. F. Droseraceæ).

Stellaria media. Frugten kapselagtig, opspringende med Tænder. $(10,3)$.

Holosteum. Frngten kapselagtig, opspringende med Tænder i Spidsen $(3,3)$. 
c. Blomsterdxkket enkelt.

Polygonum aviculare $(6,3)$.

\section{Orden. Tetragynia (Firehunnede).}

93. Parnássia L. Bæger og Krone fembladede; 5 kirtletrandhaarede Bikronblade; Frugten enrummet, fireklappet Kapsel med rægstillede Frøstole. (N. F. Droseraeeæ).

Drosera. Ingen Bikronblade; Kapselen treklappet. $(5,3)$.

\section{Orden. Pentagynia (Femhunnede).}

a. Brgeret urteagtigt.

Drosera $(5,3)$.

Linum. Brgeret fembladet, Frugt tirummet, tifrøet Kapsel.

Cerastium semidecandrum $(10,5)$.

Spergula vernalis $(10,4)$.

b. Bægeret hindeagtigt.

94. Státice L. (excl. sp.). Bægeret femnervet og femtandet; Kronbladene 5, ved Grunden sammenvoxne med Støvdragerne; Frugt enfrøet, uopspringende; Blomsterne i gaffeldeelt grenede, ensidige $A x$.

95. Arméria Willd. Blomsterne i Hoved med taglagt Srøb, de ydre Svøbblade red Grunden forlængede i et nedadrettet, hindeagtigt Ror; forøvrigt som foreg. (94-95. N. F. Plumbagine $x$ ).

\section{Orden. Polygynia (Mangehunnede).}

Myosurus. Stovdrageme $5-\infty$, Frugterne talrige, nodagtige, paa en keglefermigt forlænget Frugtbund. $(13,3)$. 


\section{Monogynia.}

\section{Echium. Slangehoved.}

252. E. vulgare L. (Almindelig S.) H. 219; Drej. n. 196; F. D. 445 ; Rchb. ie. fl. germ. XVIII, tab. 1298, fig. 2.

Stcengelen rank-opret, tilligemed de linie-laneetformede Blade stivhaaret-ru; Blomsterstanden pyramideformet, sammensat af ensidige, før Udspringningen tilbagerullede $A x$ fra Bladhjørnerne.

1-3' høi. Krouen bla:*), sjeldnere blegrød eller hvid. 6-7. (-).

Ved Veje og paa Græsmarker, meget alm. paa Bornholm, i Sjælland, Møen og den nordlige Deel af Falster og Lolland; i Fyens nordostlige Deel ikke sjelden (hyppigst paa Hindsholm), mod S. og V. sporadisk: Nyborg, V. Skjerninge! Skaarup (19), Svaninge, Mynderup; Lyo (12); paa flalvoen alm. i V. Hanherred (12) og omkring Aalhorg (Branth), S. for Limfjorden sjelden og sporadisk: Nibe (8), Hvidbjerg ved Slive (Funch), Loistrupgaard ved Randers (16), Mariager (7), Holme ved Aarhuus (2), Horsens (Jørgens.), Norup ved Veile (Warming), Estrup mellem Kolding og Ribe (28), Ribe (Fabr. Müller), Haderslev (Grønlund), Volmerstoft, Flensborg (16).

\section{Lithospermum, Steinfry.}

253. L. officinale L. (Læge-S.) H. 210; Drej. n. 197; F. D. 1084 ; Rehb. ie. fl. germ. XVIII, tab. 1313, fig. 1.

Bladene laneetformede, tilspidsede, tiltrykt-korthaarede, med ophøiede Sideaarer paa Underfladen; Kronens Svælg fempuklet, Kronrøret (under Blomstringen) af Længde med Bægerfligene; Nodderne jærne, glindsende, hvide.

*) Alle Arter af Familien Asperifolise (Nr. 252-73), hvis Krone i ældre Tilstand har en blaa eller violet Farve, have umiddelbart efter Udspringningen rode Kroner. Kun hos enkelte Arter og undtagelsesviis vedligeholder den rode Farve sig under hele Blomstringen. Naar Kronens Farve i det Folgende uden yderligere Bemarkninger angives, er den bestemt efter den xldre Tilstand. Om Blomsterstandens Forlold i Knoptilstanden see ovenfor (i Slægts-Oversigten). Hos flere Arter af Familien forekommer Blomsten under en dobbelt Form: deels (O) med stærkt udviklet Griffel (længere end Bregeret) og korte Støvdragere, deels $\left(\sigma^{7}\right)$ med kort (i Bægeret indsluttet) Griffel og stærkere urviklet Krone og St $\varphi$ rdragere. 
Kronerne Ividgule. Kun $2-3$ ! Frugter komme til Udvikling i hver Blomst. 6-7. 2 .

Faa Skrænter, stenede og grusede Pladser, i Kratskove: paa Oerne sporadisk og i enkelte Figne (f. Ex. Bornholm, Møens Klint, Roeskilde og Fredriksvark) hyppig; paa Halvoen sjeldnere: J. Kalo SIot (13); $S l$. Ballastbakken ved Flensborg, Nyværk ved Slesvig (16).

254. L. arrense L. (Rynket S.) H. 211; Drej. n. 198 ; F. D. 456 ; Rehb. l. c. tab. 1314 , fig. 5-6.

Bladene oval-lancetformede, de nedre budte, de øvre næsten spidse, kortharet-rue, Sidearerne utydelige; Kronens Svalg foldet; Bagerfligene under Blomstringen læugere end Kronrøret, efter Blomstringen linieformet-forlængede; Nodderne rynket-ujævne, brune.

Kronerne hvide med sortgrønt Rør, større end hos foreg. Roden rødviolet. 5-6. $\odot$.

Ulkrud i Vintersæden, aIm. udbredt paa Oerne; paa Halveen sjeldnere: Hansted og Korso i Thy (Carst.), pat Aagaards Kalkbakker og ved N. Sundby (12), Solngaardsholm (Juel), Ranum v. Løgstør (8), Horsens (Jørg.); Haderslev (Gronlund).

\section{Stenhammaria. Ilestetunge.}

255. S. maritima [Rehb. fl. excurs. I, p. 387] (StrandH.) Yulmonaria L., H. 215 ; F. D. 25 ; H. N. V, 5 ; Hippoglossum Hartm. Skand. fl. 4. Uppl.; Mertensia maritima Don, Rchb. 1. c. tab. 1317, fig. 1 .

Stangelen meget grenet, nedliggende; Bladene elliptiske eller oinvendt-æagformede, kjødfulde, blaagraae, paa Overfladen (i torret Tilstand) rue af talrige vorteformede Punkter, forøvigt glatte.

Kronerne lysblaa eller lili. 6-7. $\%$.

Ved Strandbredder, meget sjelden, og lsun funden i den nordvestlige Deel af Jylland: Hirtshals i Hjorring Amt (Juel), Svineklov ved den gromne Strand i V. Hanherred (16), Klitmoller ved Thisted (28), Hansted paa Hanstholmen i Thy (7)! Bovljerg (Khr. Wichfeld). *

\section{Pulmonaria. Lungeurt.}

256. P. officinalis L. (Almindelig L.) H. 214 ; Drej. n. 199; F. D. 482 (slet); Rehb. 1. c. XVIII, tab. 1317, fig. 2 . 
Rodbladene ægformede eller æg-hjerteformede, med en smalvinget Bladstill; Stangelbladene ægformede elle: elliptiske, siddende eller kortstilkede; Stængelens Haar udstaaende eller nogle nedadrettede, blandede med Kirtelbaar.

Bladene ofte plettede. Var. med smalere, elliptiske Rodblade og Iancetformede Stængelblade (P. angustifolia H. 214, F. D. 483). Kronerne violet-blaa. Undertiden mangler Haarkrandsen i Svælget. $4-5$. $\%$.

I Skove og Krat meget alm.

257. P. angustifolia [L. Fl. Suec. ed. 2, p. 58] (Himmelblaa L.) Drej. n. 200 ; F. D. 2344; H. N. I, 14; P. azurea Bess., Lge. Haandb. 2 Udg. S. 143; Rchb. l. c. tab. 1319, fig. $1-2$.

Rodbladene lancetformede, nedløbende i en bredvinget Bladstilk; Stckngelbladene smalt lancetformede, i Randen noget tilbagerullede, halvt-omfattende og lidet nedløbende; Stangelens Haar nedadrettede, ingen (eller ganske faa) kirtelbærende.

Bladene med talrigere, men kortere og blødere Haar end foreg. Kronerne himmelblaa (var. med hvide Kr. -14 ). 4-5. ฯ.

I aabne Skove sjelden: $\boldsymbol{S}$. Jonstrup Vang imod Seminariet (i Mrengde)! [:*

\section{Asperugo. River.}

258. A. procumbens L. (Fremliggende R.) H. 218 ; Drej. n. 201 ; F. D. 552 ; Rebb. 1. c. XVIII, tab. 1327.

Stcengelen kantet, ru af nedadvendte Børster, gaffeldeelt; Bladene lancetformede, budte, heelrandede eller utydeligt tandede, rue, ved Forgreningerne modsatte; Blomsterne enlige eller parvise i Gaffeldelingerne eller Bladhjørnerne; Bageret tiltagende i Størrelse efter Afblomstringen.

Holder sig fast red Hjælp af den rne Beklædning. Kronerne mørkviolette. $5-7 . \odot$.

Ved Gjærder, især omkring Byer, alm. i $S j \propto l l$. og paa de østligere og sydligere Oer, sparsommere i Fyen (Hindsholm, Odense (12), Nyborg (Lund), Aunslev (16), V. Skjerninge, Svendborg! Skaarupor, Stryno (12); Samso (2); paa Ilalvoen sjolden: Broust i $\emptyset$. Hanherred (16), Mariager Kloster (7), Ebeltoft (Orting), Jægergaarden ved Aarhus (16), Horsens (Jørg.), Fredericia (12), Ribe (Andresen), Flensborg (16). 


\section{Cynoglossum. IIndetunge.}

259. C. officinale L. (Læge-H.) H. 213; Drej. n. 203; F. D. 1147 ; Rehb. 1. c. XVIII, tab. 1330.

Stangelen opret; Bladene lancetformede, de nedre stilkede, de ovre halvt-omfattende; Blomsterstanden en Top; Frugterne fladtrykte, omgivme af en fremstaaende Rand.

1-3' høi. Hele Planten graatiltet. Frugterne hænge fast i Klæderne ved de hagekrummede Børster. Har en ubehagelig (museagtig) Lugt. Kronerne skident mørkrøde. 6-7. $\odot$.

Ved Gjærder og Veigrøfter omkring beboede Steder hist og her.

\section{Onphalodes. Vaarforglemmigei.}

+260 . 0. rerna [Moench. meth. p. 420] (Hjertebladet V.) Rehb. 1. c. XVIII, tab. 1326, fig. 2; Cynoglossum Omphalodes L., H. II, 140.

Rodbladene langstilkede, æg-hjerteformede, Stongelbladene æg.lancetformede, kortstilkede; Blomsterne i gaffeldeelt, faablomstret Kilase.

Svagt- og korthaaret, Kronen himmelblaa (ligner de større Myosotis-Arter). 4-5. 4 .

Dyrkes i Haver og forekommer derfra undertiden forvildet, f. Ex. Pulverholz og Nyverk ved Slesvig( (16).

\section{Echinospermum. Pigfrø.}

261. E. Lappula [Lehm. asperif. 121] (Tvehaget P.) Drej. n. 202 ; Rehb. l. c. XVIII, tab. 1329 , fig. 2 ; II. N. IX, 9; Myosotis L., F. D. 692; H. 209; Cynoglossum Wallr.

Stangelen opret, foroven grenet; Bladene lancetformede; Blomsterstillicne efter Afblomstringen oprette; Bageret dybt, næsten til Grunden, femkløvet, med linie-lancetformede Flige; Frugterne vortet-punkterede, med 2 Rækker af 2-3-hagede Børster i Randen.

Stængel og Blade tæet og tiltrylkt haarede, rue. Kronen himmelblaa. Ligner under Blomstringen Myosotis, under Frugtmodningen Cynoglossum. 6-7. $\odot$.

Paa tørre, grusede Steder omlsring Byer sjelden: Bornh. red Hammershuus (19), Nexø og Ronne (H.); Moen (16); S $j$. Stevns 
Klint (9), udenfor Øster- og Amager-Port ved Kbhvn. (П., Dr.), Helsingør (27); $\boldsymbol{F}$. Odense (H.). (Paa flere af de nævnte Voxesteder synes den nu at vare forsvunden).

\section{Myosotis. Forglemmigei.}

a. Bægerets nedre Deel beklædt med udstaaende, hagekrummede $\mathrm{Ha}$ ar.

aa. Fugaces Fr. Tidligt blomstrende og hurtigt henvisnende. $\odot$.

ж. Bægeret under Frugtmodningen lukket, længere end Blomsterstilken.

262. II. versicolor [Pers. Syn. I, p. 156] (Forskjelligfarvet F.) H. 209; Drej. n. 213 ; Fr. nov. 67; F. D. 583 (høire Fig.) og 2285 b.; Rchb. l. c. XVIII, tab. 1325, fig. 1; H. N. I, 12.

Stanglerne oventil gaffeldeelte; Bladene lancetformede, spidse, ved Stængelens Forgreninger ofte modsatte; Blomsterne i nedentil bladløse Klaser; Blomsterstilkene (efter Afblomstringen) ndstaaende; Bugeret dybt femfliget; Griffelen lidet længere end Nødderne.

4-8" høi. Bladene stærkere randhaarede end følg., med udstaaende Haar. Kronen først guul, siden blaa eller violet. 5-6.

Paa tørre, især dyrkede Marker, alm. udbredt.

263. II. stricta [Link Enum. hort. berol. I, 164] (Rank F.) Drej. n. 214 ; Fr. nov. p. 67 ; F. D. 2285 a.; Rchb. 1. c. tab. 1324, fig. 2 ; H. N. I, 13.

Stconglerne stivt oprette, fra Grunden af grenede; alle Bladene spredte, oval-lancetformede, budte; Klaserne forneden bladbærende (undertiden Blomster fra de nederste Bladhjørner); Blomsterstillene meget korte, opret-tiltrykte; Bageret dybt femfliget; Griffelen af Længde med eller kortere end Nodderne.

2-6" høi; med trettere, men kortere og blødere (ofte indbøiede) Haar end foreg. Kronen blaa, meget liden. 4-5.

Paa sandige Marker alm. l:* 
ß. Brgeret af Langde med eller kortere end Blomsterstilken, dets Flige under Frugtmoduingen opret-udstaaende.

264. II. collina [Hoffm. D. Fl. ed. 1, p. 61] (Bjerg-F.) Fr. nov. p. 66 ; H. N. I, 11 ; M. hispida Schldl., Drej. n. 212 ; F. D. 2284 ; Rehb. l. c. tab. 1323 , fig. $2-3$.

Bladene omvendt-æg-laneetformede, budte eller (de ovre) spidse, alle spredte; Klaserne forneden bladløse; Blomsterstillene udstaaende, omtrent af Bægerets Længde; Griffelen af Længde med Nodderne, meget kortere end det til lidet nedenfor Midten femfligede Bæger.

2-6" høi, tret- og stivhaaret, med udstaaende Haar. Kronen blaa, meget liden. $4-5$.

Paa torre Marker og Bakker, meget alm.

265. II. sparsiflora [Pohl i Hopp. Taschenb. 1807 p. 123] (Fjernblomstret F.) H. 206; Drej. n. 211 ; F. D. 1688; Rehb. 1. c. tab. 1324 , fig. 3 ; H. N. X, 14.

Stcengelen svag, gjentagne Gange grenet; Bladene elliptiske, de nedre omvendt-ægformede, budte; Blomsterne enlige ved Stængelens Forgreninger og i fjernblomstrede, forueden bladbærende Klaser; Blomsterstilkene efter Afblomstringen nedboiede, 2-4 Gange længere end det dybt femdeelte Bager (Bægerfligene næsten dobbelt saa lange som Røret); Griffelen kortere end Nødderne.

Haarene fjerne, korte og indbøjet tiltrykte. Kronen blegblad. 5-6.

Forekonmer forvildet $\mathrm{j}$ og omkring Haver (oprindelig indført), f. Ex. Marienlyst ved Helsingor (21); Classens o. fl. Haver ved Kj $\boldsymbol{\text { G }}$ benhavn! 阅

bb. Persistentes Fr. Sildigere blomstrende og langere vedvarende. (Bageret under Frugtmodningen kortere end Blomsterstilliene). (-) eller 4.

266. II. arrensis [Roth fl. germ. H, p. 222] (Nark.F.) M. interınedia Link, H. II, 140; Drej. n. 210 ; Lge. Haandb. 1 Udg. n. 258; Fr. nov. p. 65 ; Rehb. l. c. tab. 1323, fig. 1 ; H. N. X, 13; M. scorpioides $\alpha$, arvensis L.

Bladene oval-lancetformede, de nedre omvendt-ægformede, budte; Klaserne bladløse; Blomsterstilliene imod Frugtmodningen udstaaende, dobbelt saa lange som det dybt femdeelte Bager; 
Bagerfigene sammenstødende; Kronens Krave huul; Griffelen omtrent af Nøddernes Længde, flere Gange kortere end Bægeret. $1 / 2-11 / 2^{\prime}$ høi, graaagtig af den tætte Haarbeklæedning. Kronen blaa. 5-7. $\odot$.

Paa dyrket Jord i Mark og Have, i Udkanten af Skove o. s. v. alm.

267. II. silvatica [Hoffm. D. Fl. ed. 2, p. 85] (Skov-F.) H. 207; Drej. n. 209; Fr. nov. p. 64; F. D. 583 (venstre Fig.); Rchb. l. e. tab. 1322, fig. 1.

Bladene laneetformede, budte eller spidse, de nedre ovale eller elliptiske, stilkede; Klaserne bladløse; Blomsterstitkene af Læugde med eller lidet længere end Bageret, som er dybt femdeelt, med opret-aabne Flige; Kronens Krave flad; Griffelen over halvt saa lang som Bregeret.

$1 / 2-11^{1} / 2^{\prime} h ø i$, friskere gron og iklse saa tæethaaret som foreg. Kronen dobbelt saa stor, blaa, sjeldnere livid eller blegrød. 5-6. ข.

I Skove og Krat ikke sjelden.

b. B $x$ geret overalt tiltrykt-haaret (under Frugtmoduingen kortere end Blomsterstilkene).

268. I1. lingulata [Schultz i Lehm. Asperifol. I, p. 110] (Sump-F.) Fr. nov. p. 64 ; Rehb. 1. e. tab. 1321, fig. 1 ; H. N. IV, 11; M. cæspitosa Schultz, H. II, 139; Drej. n. 208; F. D. 2283 .

Rodstokken sammentrængt, lodret; Stangelen trind; Bladene lancetformede, budte; Klaserne forneden blaủbærende; Boggeret meget kortere end Blomsterstilken, dybt femdeelt med udstaaende Flige; Kronfligene afrundede; Griffelen meget kort.

Stængleme alm. talrige fra Rodstokken, tiltrylkt-haarede, ved Grunden rodlige; ingen Udlobere. Kronen mindre end hos folgende, blaa. $6-8 . \odot$.

$\beta$, radicans! Stænglerue langstrakte, meget grenede, opstigende og ved Grunden rodslaaende; noget kantede; Bægeret deelt omtrent til Midten.

I Tørv- og Hedemoser, paa sumpige Steder i Skove, ikke sjelden og bemarket $i$ alle danske Provindser. $\boldsymbol{\beta}, \boldsymbol{F}$. Slsaarup (19)! Sl. Haderslev (Grøulund)! 
269. I. palustris [With. arr. of brit. pl. 2, 225] (EngF.) H. 207; Drej. n. 207; Fr. nov. p. 63; F. D. 1988; Rchb. I. c. tab. 1320 ; M. seorpioides $\beta$, palustris L.

Rodstokken forlænget, krybende; Stcengelen kantet; Bladene lancetformede, Stængelbladene spidse; Klaserne bladløse; Bageret kortere end Blomsterstilken, femtandet med udstaaende Tænder; Kronfigene svagt udrandede; Griffelen af Brgerets Længde.

Hoiere og med storre Kroner (blaa) end de øvrige Arter. Har ofte, is ar Formen $\gamma$, Udløbere fra Rodstokken. 6-8. 2 .

$\alpha$; genuina Rchb. l. c. tab. 1320 , fig. 1. Stængelen med udstaaende Haar.

$\beta$, laxifora (M. laxiflora Rchb. 1. e. fig. 4), Stængelens Haar tiltrykte, Grenenes udstaaende, Kronerne store.

$\gamma$, strigulosa (M. strigulosa Rchb. l. c. fig. 3), Stængelens og Grenenes Haar tiltrykte. Lavere og spædere end Hovedarten, Kronen mindre. (Ofte Udløbere fra Rodstokken).

Paa Enge, ved Randen af Bække og Søer, alm. ndbredt. $\gamma$, (en udmarket Form) ved Sandbjerg pr. Horsholm! Fidt-Mose ved Hjortespring! Soro! Selehousdal (Lund); F. Ollerup (12).

Anm. M. repens Don (E. B. 2703) horer, efter Expl. fra Babington (og Beskrivelsen i Sammes Man. of Brit. bot.) ikke herhen, forskjellig ved nedentil bladbærende Klaser, liengere og efter Afblomstringen strerkt tilbagebøiede Blomsterstilke, dybere deelt Bagger, kortere Griffel, blegblaa Kroner og Stengelen stivhaaret af udstaaeude Haar. Denne maa eftersgges $i$ vor Flora.

\section{Borrago. IJjulkrone.}

† 270. B. officinalis L. (Blaa H.) Drej. p. 75; Rafn p. 48 ; Rchb. I. e. XVIII, tab. 1302.

Bladene elliptiske, stilkede, tilligemed Stcengelen og det dybt femdeelte Bager tæt beklædte af hvide, stikkende Haar. Kronen himmelblaa. $6-7$. $\odot$.

Forekommer forvildet omkring Haver, f. Ex. Sj. Rungsted (Dr.), Bidstrupgaard (14), Maglekilde ved Roeskilde (Thomsen); Moen red Mlarienborg (9); Loll. Stokkemarke, Aunede (19); J. Sindal i Vendsyssel (Juel), Staby pr. Holstebro! Charlottenlund ved Kolding (30), Sl. Aarøsund (Nielsen); Stampemollen ved Slesvig, Fredriksort (16). 


\section{Anchusa. Oxetunge.}

271. A. arvensis [I. Bieberst. fl. taur. cauc. 1, 123] (Krumhals). Drej. n. 205; Rehb. l. c. XVIII, tab. 1310, fig. 1; Lycopsis L., H. 218 ; F. D. 435 (slet).

Bladene lancetformede, rundbugtet-tandede; Kronens $R \phi r$ bøiet; Bageret næsten til Grunden femkløvet.

$1 / 2-1$ ' høi. Hele Planten stivhaaret og meget ru. Kronen himmelblaa. 5-7. $\odot$.

Paa dyrkede Marker alm.

272. A. officinalis I. (Læge-O.) H. 212; Drej. n. 204; F. D. 572 ; Rehb. 1. c. XVIII, tab. 1309 ; H. N. VII, 6.

Bladene lancetformede, heelrandede eller utydeligt tandede; Bageret til lidet nedenfor Midten femdeelt; Kronroret ret.

1-2 høi, stivhaaret-ru, Kronen først rødagtigt-, senere blaaviolet, sjeldnere hvid. 6-7. 4 eller $\odot$.

Var. i Henseende til Bekladningen, Bregerfligenes Retning o.s. v. Den hvide Form har efter Premierlieut. Lunds Iagttagelse, smalere Blade, bredest paa Midten (hos Hovedarten ere de bredest ved Grunden!.

Ved Veie og paa Marker, hyppig i Sjæll. og paa $\theta$ erne (Bornholm indbef.), paa Hindsholm og i Jyllands nordlige Deel; sjeldnere og sporadisk i det vestlige Lolland, Langeland og det sydlige Fyen (Nyborg! Hvidkilde (Jørgens.), Horup, Steenstrup (12), Faaborg!) og Halveens sydlige Deel (Skanderborg, Horsens (12), Rødding, Husum (16), Flensborg (12).

\section{Symphytum. Kulsukker.}

273. S. officinale L. (Læge-K.) H. 216 ; Drej. n. 206; F. D. 664 og $1569 ;$ Rehb. l. c. XVIII, tab. 1303, fig. 1; H. N. V, 3; L. Herb. III, 60.

Stangelen vinget af de nedløbende Blade; de nedre Blade rg-lancetformede, stilkede, de фvre lancetformede, tilspidsede, nedlabende; Bagcret dybt femdeelt; Kronens Krave svagt femtaudet, med tilbagebøiede Tænder; Stovknapperne længere end Støvtraadene.

1-2' høi; stivhaaret-ru; Kronen violet, sjeldnere rosenrød ell. hvid. 6-8. 4 . 
Var. med liengere cller kortere Griffel og Bikronskjæl; Bægert:enderne oprette eller udstaaende (den sidste Form S. patens Sibth.).

Ved Ssbredder og andre fugtige Steder, især omkring Byer, hist og her, men ikke almindelig, i alle danske Provindser.

$\dagger$ S. orientale I. H. N. V, 4. Stcengelen ikke eller kun ved Bladenes Basis vinget. mere ru end hos foreg.; de nedre Blade ag-hjerteformede, de øvre svagt eller aldeles ikke nedlobende; Støvknapper og Støvtraade ligelange. lironen rød eller violet. $6 \ldots 8$.

Forvildet ved Veistrup i Fyen (19)!

\section{Atropa. Galnebaer.}

274. A. Belladonua L. (Giftig G.) H. 260; F. D. 758 ; Rchb. 1. c. XX, tab. 1629 .

Bladene (alm. 2 sammen, det ene mindre) elliptisk-ægformede, heelrandede; Blomsterne enlige i Bladhjornerne, nikkencie; Blomsterstilke og Bager klabrig-haarede.

2-3' høi. Kronen skident violet med brune Aarer. Barret sort. Rod og Blade have en bedøvende Lingt. Giftig. 7. 4.

Ved Gjurder omkring beboede Steder, sjelden (og maaskee fra aldre Tider indfyrt): $\boldsymbol{J}$. Mggelkjær (H.), ved 'Teglovnen N. for Kolding! og Bellevue S. for Kolding, (30); $\boldsymbol{F}$. Middelfart (H.), L angeland ved Hou, L.oll. v. Christianssade og Aalholm (H.). S $j$. Maglekilde ved Roeskilde ('T'homsen), Sparresholm (Lund);

\section{Physalis. Blaerebager.}

† 275. P. Alkekengi L. (Jødekirsebær). H. 261; F. D. 1636 ; Rehb. 1. e. XX, tab. 1630.

Bladene modsatte, stilkede, $x g$-hjerteformede eller $x g$ formede med indsnøret Basis, heelrandede eller svagt tandede; Blomsterne enlige i Bladhjørnerne, nikkende.

1' høi. Kronen guulhvid, Bregeret forst grønt, siden tilvoxende og opbliest, tilligemed Bærret ligirgdt. 6-7. \%.

Omkring Byer og andre dyrkede Steder (oprindelig indfort): Lo ll. ved Saxkjobing (19), Hnnseby (5), Norreballe, Hillested, ciodsted (H.); F als $\boldsymbol{t}$. ved Bregninge, Horbeløv, Taademp (1+1); $\boldsymbol{S} \boldsymbol{j}$. Vemmetofte (Sünckenberg). 网 


\section{$\uparrow$ Nicandra.}

$\dagger$ N. physaloides [Gärtn. de fruct. II, p. 237, tab. 131] Rehb. 1. c. XX, tab. 1626, fig. 2 ; Atropa physaloides L.

Glat; Stcengelen opret med kantet-furede Grene; Bladene ægformede eller elliptiske, bugtet-tandede, med vinget Bladstilk; Blomsterne store, enlige, Bageret femkantet-vinget, gjennemsigtig-bleggrønt (imod Modenheden blegbrunt), med stærkt fremtrædende Aarenæt; Kronen blegblaa eller lila. 7-8. $\odot$.

Oprindelig fra Sydamerika, dyrket i Haver og derfra forvildet: $S j$. Sarsløv ved Holbæk (Leth), Jonstrup (14), Søllerød (Petersen)! Fatst. Horbel $ø \mathrm{v}(\mathrm{Koch}) ; \boldsymbol{B}$ or $n h$. langs Stranden ved Rønne søudre Baadeliavn (Baagøe)!

\section{Solanum. Natskygge.}

a. Stængelen urteagtig, opret.

aa. Underjordiske Knoller paa Rodstokkens Grene. 4.

$\dagger$ S. tuberosum L. (Kartoffel). Rafn II, p. 156; Rehb. 1. c. $\mathrm{XX}$, tab. 1633 , fig. $3-4$.

Bladene mellembrudt-fjersnitdeelte med agformede eller ovale Afsnit; Blomsterne i Skjærm eller Qvast fra de øvre Bladhjørner; Blomsterstilkene ovenfor Nidten leddede; Kronen femkuntet.

Var. meget i Henseende til Kronens Farve (violet, blaa, hvid) og Knollernes Storrelse, Form og Farve. 6-7.

Dyrkes alm. overalt i Landet (oprindelig indført fra Amerika).

bb. Roden pceleformet, grenet, ingen Knoller. $\odot$.

276. S. nigrum L. (Sort N.) H. 263; Drej. 11. 239; F. D. 460 ; Rehb. l. c. XX, tab. 1631, fig. 1-2.

Stcengelen med fremstaaende, knudrede Kanter; Bladene rudeformet-ægformede, heelrandede eller rundbugtet-tandede, tilligemed Stængelen svagt dutuhaarede; Blomsterstanden skjærmformet, modsat Bladet eller fra ubestemte Steder af Stængelen; Blomsterstilkene i Spidsen tykkere, tilsidst nedbaiede; Barret kugleformet, sort-violet. 
Kronen hvid, undertiden med violette Spidser eller Underflade. Stovkapperne gule. 8-10.

Paa dyrket Jorl, især i Haver, et almindeligt Ukrud, dog ikke overalt, f. Ex. sjelden i det nordlige Jyll. (Branth).

277. S. humile [Bernh. i Willd. Enum. hort. ber. I, 236] (Glat N.) Drej. n. 238 ; F. D. 2345 ; S. nigrum-lunmile Rehb. I. c. XX, tab. 1632, fig. 2 ; H. N. IX, 14.

Stcngelen med utydeligt vortede Kanter, tilligemed Bladene nxsten glatte; Barrene guulgrønne, forøvigt som foreg. $8-10$.

Ved Gjærder og paa dyrket Jord med foreg., men sjeldnere: $\boldsymbol{S} \boldsymbol{j}$. Charlottenlund, Anager (Drej.), Farimagsveien! Sors (12), Kaluud. borg (15); Falst. ved Moseby og Taaderup (14); Thorseng ved Lindby! $\boldsymbol{F}$. Hofmansgave (18), i det sydlige alm. (12); Bornh. Rønne (14), Terkels Mølle (Zahrtmann). Fis

278. S. villosum [Lam. dict. 4, p. 289] (Haaret N.) H. II, 147; Drej. p. 88 ; H. N. XV, 22; S. nigrum-villosum Rehb. I. c. XX, tab. 1632, fig. 1 .

Bladene ægformede, bugtet-tandede, tilligemed Stangelen fint-udbaarede; Bcrrene voxgule, forøvrigt som foreg. $8-10$. Med de foreg., sjelden: Helsingør (Rafn)?, Amager (27). 涝

279. S. miniatum [Bernt. l. c.] (Høirøu N.) Drej. n. 240 ; H. N. XV, 21 ; S. nigrum-miniatum Rchb. 1. c. tab. 1632 , fig. 3 ; S. nigrum villosum F. D. 1927 .

Stcengelen ned fremstaaende, stærkt knudret-vortede Kanter, tilligemed de rudeformet-ægformede, rundtakket-fjerlappede Blade duunhaarede; Barrene hoirøde, forøvrigt som foreg. $8-10$.

Paa Ryddepladser, omliring Byer o.s. v. ikke alm. Amager ved Porten og Götchens Batteri (Dr.)! Hellested, Tryggevalde (9); F alst. Stubbekjobing (19); L oll. Lindholm (19).

b. Stxngelen buskagtig, bøietog noget slyngende.

280. S. Dulcanıara L. (Bittersød N.) H. ¿62; Drej. n. 237 ; F. D. 607 ; Relıb. 1. c. XX, tab. 1633, fig. 1-2.

Bladene ag-hjerteformede, ofte spydforınt-orede ved Grunden; Barrene aflange. 
Kronerne violette med 2 grønne, hvidrandede Pletter ved Grunden af hver Flig. Bar røde. 6-7. h.

Var. i Bladenes Form, Beklædningen o.s.v.

$\beta$, tomentosum Koch Syn. II, p. 584, med duunharede Stængler og Blade.

$\gamma$, marinum Bab. man. ed. 3, p. 225. Stængelen fremliggende, meget grenet, med kortere Ledstykker og tætsiddende, hele eller ørede Blade, som tilligemed de unge Grene ere kjødfulde.

$\delta$, laciniatum Dun. (DC. prodr. XIII, 78). Alle Bladene ørede, de nedre og midterste lyreformede, med 2-3 Par Flige ved Grunden.

Paa fugtige Steder i Kratskove alm. udhredt. $\boldsymbol{\beta}$, sjeldnere og par solaabne Steder; $\gamma$, ved Strandbredder i Sandet: $\boldsymbol{S} \boldsymbol{j}$. Nykjøbing (27), Helsingør (Heiberg); Loll. ved Bredfjed! o. fl. St. langs Ostersøen mellem Rødby og Nakskov Fjord (19); Ere (10)! o, Loll. ved Maibølle (5)!

Anm. Fra den los os forekommende Strandform afviger den af Babington beskrevne $\gamma$, marinum red hjerteformerle og ikke grede Blade.

\section{Lycium. Bukketorn.}

† 281. L. vulgare [Dun. i DC. prodr. XIII, 509] (Gjærde-B.) L. barbarum L. ex part., Rchb. I. c. XX, tab. 1635, fig. 1 (L. afrum).

Stcongelen buskagtig, mnd bueformigt-hængende Grene; Bladene lancetformede; Blomsterne enlige eller 2-3 samlede, omgivne af Bladknipper fordeelte langs op ad Stængelen. Kronens Rør og Krave ligelange.

Kronen violet, Bær rode. 6-7. h.

Plantes alm. ved Hegn og udbreder sig med Lethed, hvorfor den forekommer forvildet, især i det sydvestl. Sjæll. og Fyen.

\section{Ilyoscyamus. Bulmeurt.}

282. II. niger L. (Almindelig B.) H. 259; Drej. n. 236 ; F. D. 1452 ; Rehb. 1. c. XX, tab. 1623.

Stangelen opret, de nedre Blade stilkede, halvfinnede, de øvre halvtomfattende, bugtet-tandede eller halvfinnede; Blomsterne kortstilkede, ensidige, fra de ørre Bladhjørner. 
Klabrig-haaret, har en ubehagelig, bedovende Lugt og er giftig. Kronens Krave gulgraa med morkviolette Aarer, Roret indvendigt morkviolet. $6-7$. $\odot$.

$\beta$, agrestis Fr. (H. agrestis W. \& K.) H. N. VIII, 8. Lavere, med gule lironer.

Paa grusede Steder omkring Byer ikke sjelden. $\beta$, paa dyrkede Marker, sjeldnere: J. Ribe (d'Origny)! Bornh. Klemensker (Zahrtmanil).

\section{Datura. Pigable.}

283. D. Stramonium L. (Giftig P.) H. 258; Drej. n. 235 ; F. D. 436 ; Rehb. 1. c. XX, tab. 1624.

Stcengelen oventil gaffeldeelt, med Blomsterne enlige, kortstilkede i Greenvinklerne; Bladene regformede, grovt og uregelmassigt bugtet-taudede; Kapselen beklædt med Blødpigge.

Gron, næsten aldeles glat, giftig. Kronen hvid. 7-9. $\odot$.

Ved Strandbredder og paa grusede Steder omkring Byer, ikke alm. S $j$. Snedkersteen! Vedbrk (15), Straudmollen (Dr.), Skovshored, Farnm (H.), Amager ved Götchens Batteri! Nastved (II.); Bornh. ved Ronne (H.)! Falst. Idestrup (5), Lo ll. Maribo, Hunseby, Sumlby (H.), Nebbelunde (5); J. Skovbakken ved Aalborg (Juel); Sl. Hvidding S. for Kongearen (16), Gram (1), Vonsbak (Nielsen), Als v. Stolbro $(10)$.

\section{Verbascum. Kongelys.}

a. Thapsus. Bladene tret beklædte af en hvidguul Filt, mere eller mindre nedløbende. Støvdragerue nligelange; de længere med nedløbende Støvknapper. Kapselen aflang.

+ V. phlomoides L. Relib. 1. c. XX, tab. 1639-41. Bladene xgformet-elliptiske, rundtakkede, de nedre stilkede, de midterste kort nedlobende i 2 brede, korte, afrumdede Vinger, de ovre Blade ikke nedlabende; Klasen forneden mellembrudt, sje!dent grenet; forøvigt som følg., men ikke saa stærkt filtet. $7-8$. $\odot$.

Forvildet paa Gijerrler ved Hasmark pr. Hofmansgave (1S)! og i Loll. ved Nakskov (19), para livilket Sted den dog senere er forsvunden. Den fra Moens Klint af IJomem. antorte tilhorer maaskee en Form af folg. 
284. V. thapsiforme [Sehrad, monogr. Verb. I, p. 21] (Uldbladet K.) Fr. nov. p. 68; Rebb. I. c. XX, tab. 1638; H. N. IV, 19; V. płlomoides Drej. n. 232; H. 256 (og 254: V. Thapsus tildeels).

Bladene nedlobende, rundtakkede, de nedre elliptiske, de øvre xgformede, tilspidsede, udstaaende; Klasen txtblomstret; Blomsterstilkene (under Blomstringen) kortere end Bægeret; Kronen uregelm. hjulformet, den ene Flig mindre end de øvrige; de 3 (kortere) Støvdragere tæt hviduldede, de 2 (længere) med oventil svagthaarede Støvtraade, $1^{1 / 9-2}$ Gange liengere end de aflange, paa den ene Side nedløbende Støvknapper.

Hele Planten tat beklædt af en uldagtig, gnulhvid Filt, dannet af grenede Haar, Kronen guul, sjeldent hvid. (Klasen ofte ved Grunden grenet). 7-9. $\odot$.

$\beta$, cuspidatum [Schrad.]. H. II, 145; F. D. 1810 ; H. N. IV, 20. Klasen forneden afbrudt; de øvre Blade og Drk. bladene langt tilspidsede.

Paa torre Marker, ved Gjærder: i Sjöll. meget alm., især i den vestlige Deel; Loll. og Falst. hist og her $(19,14) ; J$. sjelden: Fredencia! Kolding (1), fra de mig bekjendt. $\beta$, hist og her med Hovedarten. $\bar{\sharp}$

285. V. Thapsus L. (Filtbladet K.) H. 254 (iildeels); Drej. n. 234; F. D. 631; V. Schraderi Mey., Koch. Syn. II, 586 ; Rehb. 1. e. XX, tab. 1637.

Bladene nedløbende, utydeligt rundtakkede, de nedre omvendt-ægformet-lancetformade, budte, de øvre elliptiske, spidse, opret-tiltrykte; Klasen tætblomstret; Blomsterstilkene kortere end Bægeret; Kronen tragtformet, næsten regelret (den ene Flig ubetydeligt større end de øvrige); de 3 kortere Støvdragere tæt hviduldede, de 2 langere med svagt haarede eller glatte Støvtraale, der omtrent ere 4 Gange længere end de paa begge Sider nedløbende Støvknapper.

Beklædningen som hos foreg. og ligesom denne, has store Expl. med nedentil grenet Klase. Kronen guul, sjeldnere hvid. 7-8. @.

Paa tørre, meest lerede Steder, ved Veie og paa Skræenter, især i Strandegue, knn sjeldent i Selskab med foreg. (ved Sors!); ineget alm. paa Bornholm, Møen, Falster og Lolland, i $\mathbf{S j}$. sporadisk og 
meget sjeldnere end foreg., i Fyen ikke sjelden (12), paa $\Pi$ alv $\boldsymbol{l}$ ens Østkyst hist og her.

Anm. Synonymien hos Drej. (fl. excurs.) er bleven indviklet paa Grund af at han har beskreven V. thapsiforme under Narn af V.phlomoides L., som ikke findes egenlig vildvoxende i den danske Flora. Nr. 233 og 234 Drej. 1. c. høre vistuok begge til V. Thapsus, men Beskrivelserne synes at være affattede efter enkelte Exemplarer.

b. Lychnitis Benth. Bladene ikke nedlobende, glatte eller kortfiltede, Støvdrageroe ligelange, med ikke nedløbende Støvknapper, Kapselen aflang.

286. V. nigrun L. (Mørk K.) H. 257; Drej. n. 230; F. D. 1088 ; Rehb. l. c. XX, tab. 1649.

Bladene ægformet-elliptiske med hjerteformet Basis, rundtakkede, paa Overfladen glatte eller svagthaarede, paa Underfladen tyndt filtede, de nedre langstillede, de øvre siddende eller kortstilkede; Klasen forlænget; Blomsterstilkene dobbelt saa lange som Bægeret; Støvdragerne alle violet-uldede.

Kronen guul med violette Pletter i Svælget, sjeldnere hvid. 7-8. $\odot$.

$\beta$, thyrsoideum (Host.) Bladene paa begge Flader tætfiltede, Blomsterstilkene længere.

I Kratskove, ved Veie og Gjærder alm. udbredt. $\boldsymbol{\beta}$, sjeldnere, f. Ex. Sj. red Helsingør (27); Lotl. Pederstrup (19); J. Kolding!

287. V. Lychnitis L. (Smaablomstret K.) H. 256 ; Drej. p. 85 ; F. D. 586 ; liehb. I. c. XX, tab. 1648.

Bladene elliptiske, rundtakkede, paa Overfladen næsten glatte, paa Underfladen kort hvidfiltede, de nedre kortstilkede, de ovre siddende, Blomsterstanden en Top eller greuet Klase (dannet af indbyrdes adskilte, længere eller kortere stilkede Knipper fra Bladlijorneme); Støvtraadene hviduldede.

Stangelen foroven tilligemed Blomsterstilke og Bæger støvethvidfiltede. Kronen hvid eller blegguul. 7-8. $\odot$.

Ved Gjærder, onkring Byer o. a. dyrkede Steder, sjelden or maaskee oprindelig udkommen fra Haver: $\boldsymbol{S} j$. Hørsholms Kirkegard (Dr.)! Frederiksdal (H.)! J. Bjømsholm (A. Jange), Orsted (H.); $S l$. Slotsgravene ved Husum, Slesvig (16), Egernförde (H.). F 
c. Blattaria. Bladene glatte, ikke nedløbende; Støvdragerne uligelange, de liengere med nedløbende Støvknapper. Kapselen kugleformet.

$\dagger$ V. Blattaria L. (Enligblomstret K.) Rehb. l. c. XX, tab. 1653.

Stcngelen glat, dens gvre Deel kirtelhaaret, Bladene glatte, bngtet-rundtakkede, siddende, de øvre halvt omfattende, Blomsterne $\mathrm{i}$ en fjernblomstret Klase, dannet af enlige Blomster $\mathrm{i}$ Bladhjørnerne, Blomsterstilkene kirtelhaarede, længere end Bægeret og omtrent af Læugde med Dækbladene; Stovlraadene røduldede. $7-8 . \odot$.

Forrildet fra Haver: $\boldsymbol{S} \boldsymbol{j}$. Bognæs (Kyll.). ikke funden i senere Tid; Falst. Nykjøbing (19)! Brarup, Skjerne (Koch)! Loll. Christianssæde (2);Sl. Egernförde (H.). 席

d. Bastardformer, frembragte ved Krydsuing mellem de foreg. Arter.

(Forekomme i Regelen knn i enkelte Exemplarer og bære sjelden spiredygtigt Fro. Benævnelsen er hentet fra de Arter, fra hvilke de antages at nedstamme).

$\asymp$ V. thapsiformi-nigrum [Schiede, pl. hybr. 36]; Rehb. 1. c. XX, tab. 1663 ; V. adulterinum Koch Syn. II, 591.

Mindre filtet, Bladene halvt nedløbende, de ørre hjerteformede; Klasen forneden afbrudt; Blomsterstillkene af Bxgerets Længde; Støvtraadene røduldede, forøvrigt som V. thapsiforme.

Forekommer sporadisk i Selskab med V. thapsiforme og nigrum, af livilke den ansees for en Bastardform: $\boldsymbol{S} \boldsymbol{j}$. Sorg Akrdemilave! Lundbygaard (Arbo)! Buddinge (9), Strandmolien (15), Frederiksdal (14); J. Kolding (30).

$\asymp$ V. Thapso-nigrum [Schiede, pl. hybr. 32] V. collinum Schrad. monogr. tab. 5, fig. 1; H. II, 146; Drej. n. 231 ; F. D. 181.1; Rchb. 1. c. XX, tab. 1639, fig. 1.

Bladene ægformet-elliptiske, rundtakkede, halvt eller næsten ikke nedløbende, paa Overfladen svagt, paa Underfladen tætfiltede; Klasen forlæuget, forneden afbrurlt; Blomsterstilkene neppe saa lange som Bægeret; Støvtraadene røduldede; Stovknapperne ikke nedløbende. 
Forekommer enkeltviis med foreg. og V. nigrum, af livilke den er en Bastardform; $\boldsymbol{S} \boldsymbol{j}$. Vedbak! mellen Taarbak og Straudmollen (Drej.), Lundtofte (14), Bidstrup (19), Tappernøie! Falst. N. Vedby (Koeh), Nykjobing Slots Ruiner! Lo ll. Bregneholt (19), Ourebygard (H.); $\boldsymbol{F}$. Christiansminde og Orkilds Slotsbakke ved Svendborg!

\section{$\asymp$ V. nigro-Thapsus [Fr. S. Veg. Sc. p. 192]?}

Stangelen svagt-, Bladene tæt-filtede, de nedre stilkede, de mellemste og øvre siddende (ikke nedløbende), forøvigt som V. Thapsus.

En Form, (funden ved Strandmøllen af $\mathrm{Hr}$. Piper) som kun ved de ikke nedløbende Blade adskiller sig fra V. Thapsus, maa jeg ogsaa formode at vare en Bastard, og da Beskrivelsen hos Fr. (l. c.) ikke strider derimod, har jeg troet at kunne henfore den til denne, af hvilken jeg dog ikke har seet Expl.

$\asymp$ V. nigro-Lychnitis [Schiede l. c. 40] Rehb. 1. c. XX, tab. 1664; V. Schiedeanum Koch Syn. II, 592.

Bladene elliptiske, tilspidsede, dybt-rundtakkede; Blomsterstilke, Boger og den øvre Deel af Stængelen støvet-hvidfiltede; Stovtraadene røduldede.

Med Hovedarterne i Sorø Akademihave! og ved Frederiksdal (14).

\section{Convolvulus. Snerle.}

288. C. arrensis L. (Ager-S.) H. 235; Drej. n. 228; F. D. 459 ; Rchb. ic. fl. germ. XVIII, tab. 1337.

Bladene spydformede (sjeldnere nxsten piilformede), med spidse, heelrandede Lapper ved Grunden; Dakbladene linieformede, fiint randhaarede, fjernede fra Bægeret.

Var. glat og dunnhauret, med 1-og 2-blomstrede Blomsterstilke. Kronen hvid eller blegrod, med 5 rosenrøde Striber, aabne i Solskin, vellugtende (omtrent som Mandler). 6-8, 4 .

Paa dyrkede og hvilende Marker, Grøftevolde, meget alm. og et besværligt Ulsrud.

289. C. sepium L. (Gjærde-S.) H. 235; Drej. n. 229 ; F. D. 458; Calystegia R. Br.; Rehb. l. c. tab. 1340 og 1341 fig. 1 .

Bladene piilformede med budte, bugtet-tandede Lapper ved Grunden; Dokbladene hjerteformede, glatte, tæt omgivende 
Bægeret og længere end dette; Blomsterstilkene firekantede, enblomstrede.

Hele Planten glat. Kronen hvid, storre end hos foreg. 7-9. 2.

$\beta$, coloratus! Stængelen og Bladnerverne paa Underfladen morkrøde. Kronerne rosenrøde.

Ved Gjærder og i Kratskove, især paa fugtig Grund: i enkelte Egne sjelden, f. Ex. i det nordlige Jylland (Aalborg 16), i det østlige $S j a$ ll. ikke alm., i de fleste Egne af Danmark temmelig hyppig. $\boldsymbol{\beta}, \boldsymbol{J}$. ved Damgaard! F. Nyborg (Lund)! Svendborg! Loll. ved S $g$ holt (19); $S j$. Stillinge (Lund).

\section{$\dagger$ Polemonium. Flok.}

$+P$. coeruleum L. (Jacobs Stige). H. 236 ; F. 1). 255.

Stangelen opret, bladet; Bladene fjersnitdeelte, med lancetformede, heelrandede Afsnit; Blomsterstanden en Top eller Halvskjxrm; Kronen omtrent dobbelt saa lang som Bægeret.

Glat eller foroven duunhaaret, Kr. blaa, sjeldnere hvid. 5-6.

Dyrkes som Siirplante og forekommer hist og her forvildet, f. Ex. $\mathrm{i}$ en Mose mellem Dronningaard og Kaningaarden (19).

\section{Erythraea. Tusindgylden.}

290. E. pulchella [ $\mathrm{Fr}$. nov. ed. 1, p. 30] (Liden T.) H. 265 ; Drej. n. 247 ; F. D. 1637 ; H. N. III, 16 ; E. ramosis sima Pers., Rehb. 1. c. XVII, tab. 1061; Centaurium inapertum Rafn II, p. 77; Gentiana Centaurium b. L. (Fl. Suec.).

Stcongelen skarpt firekantet, med smalvingede Kanter; Bladene ægformede; Blomsterne i den gaffeldeelte Stængels Vinkler paa Blomstcrstillie næsten af Længde med Bægeret; Bagerfligene (ved Blomstens Udspringning) kortere end Kronrøret; Kronens Flige elliptiske, budte.

Stængelen gjentagne Gange, ofte fra Grunden af, gaffeldeelt. Smaae Expl. (Gentiana pulehella Sw.) have stundom enblomstret, aldeles udeelt Strengel. Kronen rosenrød, mindre end lros de følg., lukker sig ved Middagstid. 1-6" hoi. 7-10. $\odot$.

Paa Strandenge og sandige Overdrev i Nrerheden af Stranden forekommer den iklse sjeldent $\mathrm{i}$ alle danske Provindser, sjeldnere ved Fxrskvandssger, f. Ex. $S j$. ved Tïs $S g$ (Lund), Smørumuedre (14),

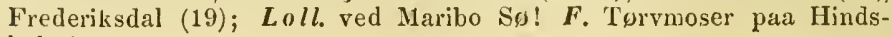
holm! 
291. F. Centaurium [Pers. Syn. I, 283] (Almindelig T.) H. 264 ; Drej.n. 245; Rehb. I. c. tab. 1061 , fig. 1; H. N. II, 31 ; Gentiana L. (Sp. pl.), F. D. 617 ; Centaurium Erythrea Rafn l. c. 75.

Stangelen skarpt firekantet; Bladene elliptiske eller ovale, budte eller noget spidse; Blomsterstilkene meget korte, med 2 Dakblade ved Grunden; Bagerfigene omtrent halvt saa lange som den nys udsprungne Krones Rør; Kronfligene ovale.

4-10" høi. Strengelen forneden udeelt, Blomsterne i tret Qvast fra Enden af Stængelen og de $\mathbf{i}$ de øvre Bladhjørner modsatte Grene. Kronen rosenrød, sjeldnere hvir.

Paa Græsmarker og høie Enge, ikke sjelden. $\bar{\nabla}$

292. E. linarifolia [Pers. I. e.] (Sinalbladet T.) Drej. n. 246 ; Rehb. l. c. 1061 , fig. 2 ; E. littoralis Fr. nov. ed. I, p. 29 ; H. 265 ; F. D. 1814 ; H. N. V, 9; Gentiana Centaurium $\alpha$ L. (Fl. Suec.); Centaurium vulgare Rafn 1. e. 73 .

Stongelen budt firekantet, de 2 Flader bredere, convexe; Bladene budte, de nedre omvendt-ægformede, de ovre linieformede; Blomsterstilkene meget korte, med 2 Dwkblade ved Grunden; Bagerfigene næsten af Længde med den nys udsprungne Krones Rør; Kronfligene ovale, budte.

$2-8^{\prime \prime}$ høi. Stanglerne (ofte flere fra samme Rodstok) forneden udeelte, oventil gaffeldeelte, dannende en fjerublomstret Qvast. Kronen rosenrød, sjeldnere hvid. $7-10 . \odot$.

$\beta$, minor Hartm., lavere $(1-3 "$ høi), med vedblivende og $\mathrm{i}$ en Rosette samlede Rodblade; Blomsterne samlede $\mathrm{i}$ en tat sammentrængt Qvast.

Paa Strandfælleder og Syltenge, ikke alm., men bemærket $\mathrm{i}$ alle Pro-indser, forekommer (ligesom 290) sjeldnere inde i Landet paa El r eller ved Færskvandssøer. $\beta$, paa lignende Steder som Hovedartes; men sjeldnere: Loll. Øerne i Maribo Sø! J. Aaby i Vendorast l (Gronlund)! Euge indenfor Klitterne ved Fjaltring!

\section{Gentiana. Entian.}

a. Endotricha Fröl. . Kronens Svælg beklædt med fryndset-mangedeelte Skjæl af Kronfligenes

Antal.

293. G. Amarella L. (Smalbægret E.) H. 299; Drej. n. 243 ; F. D. 328 ; Rehb. l. c. XVIl, tab. 1046 ; H. N. VI, 15. 
Stangelbladene siddende, fra en xgformet Basis smalt lancetformede; Bageret næsten regelret femfliget med linieformede, spidse Flige; Kronen femtandet.

Rodbladene omrendt-ægformede, kortstilkede; Kronen skident blaa eller violet. 8-9. $\odot$.

Var. $\alpha$, med korte Blomsterstilke (G. Amarella Willd.), $\beta$, med Blomsterne længere end Stængelens Ledstykker samt ved Grunden afsmalnede Stængelblade ( $G$. uliginosa Willd.) og $\gamma$, med budte, næsten tunge formede, Strengellblade (G. lingulata Ag., H. N. VI, 14). Blomsten pai smare Expl. undertiden, isar hos $\beta$, firedeelt; Kapselen var. siddende $\mathrm{og}$ kortstilket.

Paa Enge, Overdrer og Fælleder, især i Nærleden af Havet, bemærket $\mathrm{i}$ alle danske Provindser, men $\mathrm{i}$ enkelte Egne sjelden, f. Ex. $i$ det sydlige Fyen og den sydlige Deel af $\boldsymbol{J} y \boldsymbol{l l}$.

Ann. G. germanica Willd. (F. D. Suppl. ined. tab. 67), som adskilles fra foreg. ved større Kroner og tilspidsede Bregerflige, fra følg. ved ligestore Bagerflige, kunde muligviis forekomme $\mathrm{i}$ ror Flora. Expl. sendte under dette Navn fra Aalborg (Juel) høre til en Form af G. Amarella, med tydelig stilket Kapsel. Dette Forhold er ogsaa foranderligt loos $\mathrm{G}$. germanica.

294. G. campestris L. (Bredbægret E.) H. 300 ; Drej. n. 244 ; F. D. 367 ; Rehb. XVII, tab. 1046 ; H. N. VIII, 10.

Stangelbladene siddende, $x g$-lancetformede, Bageret dybt firedeelt, de 2 ydre Flige xgformede, de indre meget mindre, lancetformede, tilspidsede; Kronen firetandet; Kapselen meget kortstilket.

Rodbladene som hos foreg. Forekommer ogsaa med femdeelt Blomst. Kronen ureen blaa eller violet, sjeldnere hvid. 8-10. $\odot$.

Paa Strandenge, Overdrev og Lyngbakker, alm. paa Halvoen; ligesaa i det østlige og uordlige $\boldsymbol{S} j \boldsymbol{a} \boldsymbol{l l}$.; sjelden i Vestsjælland, Fyen og paa Loll.-Falst.

\section{b. Coelanthe Fröl. Kronens Svælg nøgent.}

295. (i. Pnemmonanthe L. (Smalbladet E.) H. 297; Drej. n. 242 ; F. D. 269 ; Rehb. XVII, tab. 1051 ; H. N. $\mathrm{XIV}, 15$.

Bladene linieformede, med tilbagerullet Rand; Bogeret regelm. femfliget med linieformede Flige; Kronen femtandet, tragtformet; Støvknapperne sammenklæbede. 
De nedre Stængelblade smaae, skjælformede, Blomsterne enlige i Spidsen af Strengelen eller flere, kortstilkede i de ørre Bladhjørner. Kronen stor og smukt ultramarinblaa, indvendig med grønne Puukter, sjeldent hvid (Grimstrup ved Varde, 14). 8-9. ข.

I Hedemoser og torvholdige Enge, paa II alvoen meget alm. i den vestlige Deel, sjeldnere $\bmod O$., paa $\boldsymbol{\theta}$ erne sjelden: $\boldsymbol{S} \boldsymbol{j}$. Annebjerggand, Kalnndborg, Svenstrup, Roeskilde, Gilleleie, Kronborg Overdrev, Udsholt, Kjoge (H.), Vallensbreks Mose (15); $\boldsymbol{L} \circ$ oll. ved Hunseby (H.).

\section{Menyanthes. Bukkeblad.}

296. II. trifoliata L. (Almindelig B.) H. 226; Drej. n. 241 ; F. D. 541 ; Rehb. XVII, tab. 1043.

Stcengelen opstigende; Bladene omskedende, stilkede, trekoblede, med omvendt-ægformede eller ovale Smaablade; Blomsterne i Klase.

Kronen indrendig hvid, med tæt og sirligt trævlet-fryndset Krave, udvendig rosenrød. Undertiden findes en Misdannelse med grøn, bagerlignende Krone ( $\neg$ paradoxa Fr.) 5-6.

I dybe Moser og Kjær, Hængedynd, alm. udbredt. $\triangleleft$ i en Mose ved Bagsværd!

\section{† Limnanthemum.}

† L. nymphoides [Hffg. et Lk. fl. port. I, p. 344.] Rehb. 1. e. XVII, tab. 1042; Menyanthes L., F.D. 339; Waldsehmidia Web. (Wiggers) primit. p. 20, H. 228; Villarsia Vent.

Stangclen nedsænkt under Vandet, ved Ledene rodslaaende; Bladene langstilkede og ved Grunden omskedende, kredsrundtnyreformede, næsten heelrandede, læderagtige, paa Underfladen punkterede; Blomsterstilkene langstrakte, tilsidst bøiede, $1-4$ udgaaende fra Bladhjørnerne.

Hele Plauten glat. Kronerne store, smukt gule. Ligner i Bladformen Nymphxa og Hydroeharis. 7-8. 4.

Findes vildroxende i Marskgrgfter og Aaer i Iolsteen, men neppe i det egenlige Danmark. I Kronborgs Frestningsgrave, hvor den i flere Aar har voxet og udbredt sig, er den oprindelig indplantet (21), ligeledes sandsynligviis i Søerne ved Hørsholm, hvor den 1863 er funden af Apotheker Piper. 


\section{Primula. Kodriver.}

a. Bladene glatte, paa Underfladen melede, Kronen rød eller lila.

297. P. farinosa L. (Melet K.) H. 224 ; Drej. n. 215 ; F. D. 125 ; Rebb. 1. c. XVII, tab. 1092 ; H. N. XIII, 38.

Bladene omvendt-ægformet-lancetformede, rundtakkede; Skaftet bladlust; Svøbbladene sylformede, ved Grunden sækformigt udvidede; Blomsterne kortstilkede, i en tæt Skjærm; Bagertanderne linieformede, budte; Kronens Flige omvendthjerteformede; Svalget med korte, gule Kirtler.

$3-10^{\prime \prime}$ høi. (En af vore smukkeste vildvoxende Planter). 5-6. ฯ.

I Moser og vaade Enge paa tørvholdig Bund, forekommer alm. paa Bornh. (20) og ikke sjeldent i et Brite gjennem det midtersto Sjælland (ikke bemærket i Egnen af Helsingør eller i sydvest-Sjælland/; i de andre Provindser sjelden: $\boldsymbol{J}$. Skanderborg Dyrehave, Horsens paa Enge ved Fjorden (16); $\boldsymbol{F}$. ved V. Skjerninge (H.); Thorseng (Lund). Paa de 2 sidstnrevnte Steder er den sandsynligviis nu forsvunden.

b. Bladene duubarede, rynkede, ikke melede. Kronen guul.

298. P. officinalis [Jacq. misc. I, 158] (Huulkravet K.) H. 222; Drej. n. 218 ; Rchb. 1. c. XVII, tab. 1090; P. veris $\alpha$, L., F. D. 433.

Bladene med rgforınet Flade, pludseligt overgaaende $\mathbf{i}$ en vinget, uregelm. bolget-rundtakket Bladstilk; Blomsterne i alsidig Skjarm med sylformede Svøbblade; Bageret ensfarvet, kort- og hvidagtig duunhaaret, lidet langere eller sortere end de tat- og korthaarede Blomsterstilke, klokkeformet, opblæst, skarpt femkantet, med 5 korte, spidse, ægformede Tænder, omtr. ${ }^{1 / 3}$ af Bægerrørets Lxngde; Kronen tragtformet; Kronens Flige omvendt-hjerteformede, hvælvede; Svcelget indsnøret ved en Krands af vorteformede Fremragninger.

Skaftet 4-8" hoit, tilligemed Blomsterstilke og Bæger fløielshaaret. Kronen citronguul med 5 orangefarvede Pletter i Svælget, sjeldnere høirød. Blomsterne af behagelig, men ikke stærk Lugt. $4-5$. 4 . 
Var. (ligesom de øvrige Arter i Slagten) $q$, med mindre Kroner, kortere Støvdragere indsluttede i Kronroret, (som derved faaer en sækformet Udvidelse paa Midten) og stærkt ndviklet Griffel (af Liengde med Bregeret) og $\widetilde{\delta}$, med større Kroner, længere Støvdragere (som naae til Kronrørets øvre Deel, der har en sækformet Udvidelse umiddelbart under Kraven) og tilbagetrangt Griffel (kortere end Bægeret). En Var. med enblomstrede, fra Rodstokken udgaaende Blomsterstilke og Dxkblade ved Grunden ( $\beta$, subacaulis Doell.) er funden i Fyen ved St. Jorgensgaard (12)!

Paa høje Enge og Bakker mellem Krat alm., sjeldnere i Skove.

* P. unicolor [Nolt. i Hans, Herb. Nr. 1159] P. Tornmasinii Gren. \& Godr. fl. Fr. II. p. 499, Rchb. l. c. XVII, tab. 1102 (?); P. officinali-elatior Muret i Reut. pl. vasc. de Genève p. 143; P. elatior $\beta$, macrocarpa Personnat, Bull. soc. bot. Fr. I, p. 160 ; P. elatior $\beta$, decipiens Sond. fl. Hamb. p. 113.

Adskilles fra foreg. ved ensidig Skjærm, ikke ensfarvet Bæger (Tænderne og Nerverne granlige, Mellemrummene hvidagtige), ved større og mere flade Kroner, som mangle de orangefarvede Pletter i Svalget, fra følg. ved klokkeformigopblæst Bæger (omtr. af Krronrorets Læugde) med kortere og bredere Flige, ved mørkere Kroner med hvælvede Flige samt ved mindre klæbrige Blomsterstilke. 4-5. 4.

Funden i Steenskoven paa Lolland (19)! og ved Borreby i Sjall. (Nielsen)!

Anm. Ansees af de fleste Forff. for en Bastard af P. off. og elatior, men dette synes at modsiges af den Kjendsgjerning, at den rgte P. elatior ikke fudes i Omegnen af Skjelskør, hvor denne Plante er funden. (Personnat (l. c) bemærker ligeledes, at denne er den eneste Form som foreknmmer ved St. Flour i Frankrig). Jeg ex derfor snarere tilboielig til at ansee den enten for en storblomstret Form af $P$. officinalis eller for en Afart af $P$. elatior.

299. P. elatior [Jaeq. l. c.] (Fladkravet K.) H. 223; Drej. n. 217 ; Rehb. 1. c. XVII, 1090; H. N. II, 32 ; P. veris $\beta$, L., F. D. 434 .

Bladene som hos de 2 foreg., men med talrige Sidenerver, lodrette paa Midtnerven; Blomsterne i noget ensidig Skjærm med sylformede Srobblade; Bogeret omtrent af Langde ined Blomsterstilken, tragt- eller valseformet, med ag-lancetformede, pludseligt tilspidsede Tænder, omtr. halvt saa lange som Bæger- 
røret (Tænderue og de fremstaaende Nerver grønlige, Mellemrummene hvidagtig-gjennemsigtige); Kronen fladkravet, med svagt udrandede Flige, svovlguul med citronguult, ikke indsnøret Svcllg.

Skaftet $1 / 2-1^{\prime}$ høit, tilligemed Blomsterstilke og Bæger klæbrigduunhaaret, Blomsterne uden eller med svag Lugt. Blomsterstilkenes Haar krusede, omtr. af Længde med Blomsterstilkens Gjennemsnit. 4-5 (omtr. 8-14 Dage tidligere end P. officinalis). 4.

I Skove: i det østlige $\boldsymbol{S} \boldsymbol{j}$. alm., sjeldnere $\bmod \mathrm{V}$. (Ringsted! Tase Mølle! Forslov!), i de andre Provindser sporadisk og som oftest mindre alm. end foreg. (Dyrles tilligemed de 2 følgende som Siirplante i forskjellige Varieteter).

* 300. P. variabilis [Goupil ann. soc. Linn. Paris 1825 p. 294] (Langstilket K.) Gren. \& Godr. Fl. Fr. II, 448; P. brevistyla DC., Rchb. l. c. XVII, 1103; P. grandiflora $\beta$, caulescens autt. (Lge. Haandb. 1-2 Udg.).

Bladene jæunt afsmalnede $\mathbf{i}$ en vinget Bladstilk, Sidenerverne fjernere og mindre lodrette paa Midtnerveu end hos foreg.; Skjormen alsidig; Blomsterstilkene længere end Bægeret (meget længere end hos foreg.); Bageret opblxst tragtformet, dets Tænder lancetformede, jævnt tilspidsede, omtrent af Bægerrørets halve Længde; Kronen fladkravet, med omvendt-hjerteformede Flige; forøvrigt som foreg.

Ansees af nogle Forff. for en Bastardform af P. officinalis og graudiflora. 5. $\psi$.

I Skove hist og her: $\boldsymbol{S} \boldsymbol{j}$. Asnæs Nordstrand (Smith); Moens Kiint! F. Holkenhavn (Lund)! Langeskov Kro (16), Tidselholt, Skaarup, Klingstrup o. fl. St. i det sydøstl. Fyen $(12,19)$; J. Haslund Krat ved Randers (Selmer)! Holme (2), Boller (13); Sl. Haderslev, Halk (Gronlund)! Bornh. (20)!

301. P. grandiflora [Lam. A. fr. 2, 248] (Storblomstret K.) P. acaulis Jacq., H. 223 ; Drej. n. 216 ; P. elatior $\beta$, acaulis H. N. II, 33; P. veris $\gamma$, L., F. D. 194 ; P. vulgaris Huds.; P. silvestris Scop., Rchb. l. c. XVII, 1091.

Bladene omvendt-ægformede, jævnt afsmalnede til en vinget Bladstilk, bølget-rundtakkede; Blomsterstilliene enblomstrede, ud. gaaende fra Rodstokkeu; Bageret skarpt femkantet, tragtformet, med linie-lancetformede, tilspidsede Tæuder omtr. af Bægerrørets Længde; Kronen fladkravet, med omvendt-hjerteformede Flige; Svcelget svagt indsnøret ved en Krands af Vorter. 
Blomsterstilke og Bager uldhaarede. Kronen større end hos de foreg. og blegere guul, med en morkere Ring ved Svalget, har en behagelig, men svag Lugt. 4-5. 4 .

I Skove, ikke sjelden paa I alvoens Ostkyst, sjeldnere i det Indre af Landet $\mathrm{og} \bmod V$. (f. Ex. Rimmen pr. Lemrig! Kalbygaard! Gram (1), Hnsum (16), derfira mod 0 . sjeldnere: hist og lier i det sydlige Fyen og paa oerne indtil Moens Klint; $\mathbf{S} j$. alm. i Asnas Skov red Kalunilborg (Baagge, Smith)! Bornh. ved Nexg (20). (Varieteter med rode og hvide Kroner ved Hammelev pr. Haderslev (Grønlund), med brumrode Kroner ved Magaard i Fyen (19).

\section{Ilottonia. Vandrollike.}

302. Il. palustris L. (Almindelig V.) H. 228 ; Drej. n. 219 ; F. D. 487 og 1867 (var.); Rehb. l. c. XVII, 1081.

Bladene kamformigt fjersnitdeelte; med linieformede Afsnit; Skaftet bladløst, med krandsstillede Blomster foroven, dannende en fjernblomstret klase; Blomsterstilkene mod Frugt. modningen tilbagebøiede; Dolibladene linieformede, af Længde med eller kortere end Blomsterstilkene.

$1 / 2-1$ ' høi. Kronen hvidagtig-kjødfarvet, med brandguult Svælg, sjeldnere rosenrød. $5-6$. 4 .

I Kjær, Grofter o. a. stillestaaende Vand, alm. udbredt.

\section{Lysimachia. Fredlos.}

a. Naumburgia Mönch. Kronen dybt femdeelt med 5 Tænder mellem Fligene.

303. L. thyrsillora L. (Gulddusk). I1. 230; F. D. 517; Rehb. 1. c. XVII, 1085; Naumburgia Drej. n. 225.

Stcengelen opret; Bladcne modsatte, sjeldnere krandsstillede $(1 / 3$ eller $1 / 4)$, siddende, sinalt laneetformede; Klaserne stilkede i Bladhjørnerne, tætblomstrede, ovale; Kronfigene linieformede; Støvdragerne sammenvoxne til en kort Ring.

Klaserne udvikles kun fra de midterste Blade paa Stængelen. Bladene punkterede, Kronen guul. Har stundom 7-10 Stovdragere. $6-7$. 2 .

I Kjar, ved Bredderne af Aaer og Søer, alm. i Sjall. og paa II alvoen (især dens vestlige Lgne), sjeldnere paa Oerne; i det sydlige Fyen ikke funden (12!), paa Bornh. kun ved Kleven i Clemensker Sogn (Hjorth). 
b. Lysimastrum Duby. Kronen uden Tænder mellem Fligene.

aa. Støvdragerne ved Grunden sammenvoxne.

304. L. rulgaris L. (Almindelig F.) H. 229; Drej. n. 222 ; F. D. 689 ; Rehb. 1. c. XVII, 1086.

Stcengelen opret; Bladene modsatte eller krandsstillede $(1 / 3-1 / 3)$, meget kortstilkede, fjernervede, elliptiske eller lancetformede, paa Underfladen duunhaarede; Blomsterstanden en Top, dannet af Halvskjærme fra de øvre Blades Hjørner; Bagerfigene æg-lancetformede, omgivne af en mørkere Rand.

Var. i Henseende til Bladenes Brede og Antal i Krandsen, samt Beklædningen og Blomsterstilkenes Længde. Kronen guul. 6-8. ข. udbredt.

Ved Søbredder, paa Enge mellem Krat, i Moser o. s. v., alm.

† L. punctata [Jacq. Fl. austr. I, 366].

Stcongelen opret; Bladene krandsstillede $\left({ }^{1} / 3\right)$, sjeldnere modsatte, elliptisk-ægformede; Blomsterne enlige i Bladhjørnerne, kortstilkede og kortere end Bladene; Bagerfigene linie-lancetformede, haarede og besatte med sorte Punkter (ligesom Bladene undertiden). Kronen guul. 7-8. ข.

Hjemmehørende i Sydenropa, dyrkes hist og her i Haver og forekommer stundom forvildet, f. Ex. $S j$. Kirkehelsinge (Baagøo!), Gurre i Mængde i Anlæget ved Skovriderboligen! Sl. Angel (7).

\section{bb. Støvdragerne frie.}

305. L. numnularia L. (Pengebladet F.) H. 231 ; Drej. ı. 223 ; F. D. 493 ; Rehb. 1. c. XVII, 1084.

Stangelen krybende; Bladene modsatte, kortstilkede, fjernervede, hjerteformet-kredsrunde eller ovale, budte, glatte; Bagerfigene hjerteformede, spidse.

Kronen guul, tilligemed Bladene med mere eller mindre talrige (under Lupen synlige) blodrøde Punkter. Blomsterstilkene snart kortere, snart længere end Bladene. 6-7. थ.

Paa Enge, ved Randen af Veie og i fugtige Skove, iklke sjelden, især meget hyppig i det sydl. Sjall. og Fyen samt paa $\theta e r n e$. 
306. L. nemorum L. (Arveagtig F.) H. 231; Drej. n. 224 ; F. D. 174 ; Rchb. l. c. XVII, 1084; H. N. I, 21.

Stcengelen svag, udstrakt eller opstigende; Bladene modsatte, kortstilkede, grundnervede, ægformede, spidse, glatte; Bagerfligene lancet-£ylformede, tilspidsede.

Blomsterstilkene fine, oftest længere end Bladene, mod Frugtmodningen tilbageboiede; Kronen neppe halvt sar stor som foreg., guul. Ligner Anagallis arvensis. 7-8. 4 .

I fugtige, skyggefulde Løvskove, paa II alveen og i Fyen ikke sjelden, men sporadisk; i $\boldsymbol{S}$ a $(\boldsymbol{l}$. sjelden: Stokkebjerg Skov (Weilbach), Frederiksborg, Sparresholm (H.). Hæsede Skov ved Gisselfeld! Langebak og Steensbøg Skove (West); ligesaa paa de mindre Øer: L angel. v. Tranekjær (12); Loll. Stokkemarke (19); Moens Klinteskov! B ornh. Hammershuus, Røe (8)! Almindingen, Svanike (F. D.).

\section{Anagallis. Arve.}

307. A. arrensis L. (Kød A.) H. 232; Drej. n. 220; F. D. 88 ; Rehb. 1. c. XVII, 1082.

Stcengelen udstrakt; Bladene modsatte (sjeldnere krandsstillede), siddende, ægformede; Blomsterstilkene enlige i Bladhjornerne, efter Afblomstringen nedbøiede; Bagerfligene sylformede, tilspidsede; Kronfligene kirtlet-randhaarede.

Kronen høirød eller kjødfarvet, sjeldnere lila. 6-8. $\odot$.

Par dyrkede Agre mellem Sæden, alm. udbredt, især i stor Mængde paa Bornholm!

* 308. A. coerulea [Schreb. spicil. fl. lips. p. 5] (Blaa A.) Drej. n. 221 ; F. D. 1570 ; A. arvensis coerulea H. 232 .

Stcengelen udstrakt eller opstigende; Bladene modsatte eller krandsstillede $(1 / 3-1 / 4)$, siddende, ag-lancetformede; Bogerfigene sylformede, under Lupen saugtakkede; Kronfligene rundtakkede.

Kronen blaa. Ansees af Flere for en Afart af foreg. 6-8. $\odot$.

Paa dyrkede Agre: $\boldsymbol{S}$ j. paa Markerne ved Lyngby So (Lehm., gjenfunden 1861, Wahlstedt), Kongelunden paa Amager (19), Langebreks Molle (Rosenørn-Lehn), Petersgaard, Viemose (West); Falst. Eget, Horbeløv (Hansen), Horreby, S. Kirkeby (Koch); Loll. Bollesminde (Galschiott); $\boldsymbol{F}$. Hofmansgave (N. E. Hofm.-Bg.). 


\section{Vinca. Singron.}

† 309. V. minor L. (Liden S.) H. II, 147; F. D. 1813 ; Rehb. 1. c. XVII, 1062.

Stcongelen fremliggende eller krybende; Bladene modsatte, elliptiske, læderagtige og stedsegrønne; Bagerfigene spidse, kortere end Kronrøret, glatte.

Var. med xgformede eller lancetformede Blade. Kronen blaa, sjeldnere hvid. 5.2 .

I Skove og ved Gjærder: $S j$. Frydenlund (H.), Dronninggaard (19), Søndermarken! Fulst. red et Gjarde paa Nykjøbing Mark (Koch); angives ogsaa fra $\boldsymbol{J} y l l$. (uden Voxested) (H.); $S l$. Papirmollebakken ved Flensborg, Nyværk ved Slesvig (16). Paa alle disse Steder er den dog sandsynligviis forvildet fra Haver, hvor den dyrkes som Siirplante.

\section{Samolus. Samel.}

310. S. Valeramdi L. (Strand-S.) H. 266 ; Drej. n. 226 ; F. D. 198 ; Rehb. l. c. XVII, 1083; H. N. XV, 24.

Stangelen opret; Bladene omvendt- ægformede, budte; Blomsterne i Klaser i Enden af Stængelen og fra de øvre Bladlijørner; Blomstcrstilkene udstaaende, ovenfor Midten knæbøiede med et Dækblad ved Bøiningen; Kapselen kugleformet.

$1 / 2-1$ ' lıøi. Kronerne hvide. 7-8. 4.

Paa Strandenge, sporadisk og ikke alm., men bemærket i alle danske Provindser, hyppigst paa $\boldsymbol{\theta}$ erne og i Fyen, sjeldnere i Sjalland. Forekommer ogsaa, men sjeldent, ved Bredderne af Færskvandssøer (f. Ex. Skarritsø! Snserup! Lindede red Kjøge (9), Kattinge $\mathrm{S} \emptyset$ ved Roeskilde (Dr.).

\section{Lobelia. Lobelie.}

311. L. Dortmanna L. (Tvepibet L.) H. 247; Drej. n. 248 ; F. D. 39 ; Rehb. l. c. XIX, tab. 1618 ; H. N. VIII, 7.

Bladcne tæt samlede ved Roden, linieformede, seglformigt tilbagebøiede, torummede paalangs; Skaftet faabladet; Blomsterne $\mathrm{i}$ en fjernblomstret Klase, efter Afblomstringen nedhængende.

Roden hvidtrævlet. $1 / 2-1^{1 / 2}$ hoi. Bladene $\operatorname{og}$ Stæengelens nedre Deel under Vandet. Kronerne blegt blaaggtigt-hride. 7-9. 4. 
I Søer og red Sobredier paa Gruus- eller Sandbund, paa H a lv o en bist og her $\mathrm{i}$ Søerne $\mathrm{i}$ Hede- og Klitstrækningeme, iscer mod V.; paa Oerne meget sjelden: L a so (H.); Sj. Gurre Sø ved Helsingør (21)!

\section{Campanula. Klokke.}

a. Blomsterne stilkede, i Klase eller Top. aa. Kapselen opspringende ved Huller $i$ Midten eller Spidsen (nedenfor Bagerfligene).

312. C. persicafolia L. (Smalbladet K.) H. 240; Drej. n. 254 ; F. D. 1087 ; Rehb. l. c. XIX, tab. 1613.

Slangelen opret; Bladene fjernt og svagt saugtakkede; Rodbladene omvendt-ægformet-lancetformede, stilkede; Stangelbladene lancet-linieformede, siddende; Klasen faablomstret; Bagerfigene lancet-sylformede, neppe halvt saa lange som Kronen; Kapselen glat eller stivhaaret.

Blade og Brgerflige alm. glatte, sjeldnere haarede. Kronen blaa. 6-7. 4 .

$\beta$, calycida! De nedre Blade omvendt-ægformede, Strengelen enblomstret; Brgerfligene elliptiske, over halvt saa lange som Kronen.

Paa Bakker, især mellem Krat: paa Bornholm, Meen og Falster samt i det ostlige og sydlige $\boldsymbol{S} j a l l$. list og her, $\mathrm{i}$ de ovijge Provindser sjelden og sporadisk: Loll. Ravnsby (19), Christianssade (2); F. Ulriksholin (H.), Holkenhavn (25); J. Aagaard og Norbjerg i V. Hanherred (16), Dybdal ved Aalborg (12), Ellitshoi S. for Aalborg (Il.), Vaar Skov ved Logstor (Andresen), Monsted ved Viborg (7), Hodal Mglle ved Hobro (16); Arnage Bakke ved Ebeltoft (H.), Boeslum Strand (Orting), Aarhus, Veile; Sl. Haderslev (7). I det sydlige Fyen ikke funden. $\beta$, Bornholm (11).

313. C. Rapunculus L. (Rapuntsel-K.) H. 239; Drej. n. 253 ; F. D. 1326 ; Relıb. I. c. XIX, tab. 1613.

Roden tapformet, kjødfuld; Bladene bølget-saugtakkede, de nedre stilkede, elliptiske eller omvendt-rgformede, de ovre siddende, laneetformede; Toppen klaseformet forlænget; Bagerfigene sylformede, over halvt saa lange som lironen; Kronfligene oprette.

$2-3^{\prime}$ hoi. Var. glat og haaret. Kronen blaa. 7-8. $\odot$. 
I Krat og ved Gjærder, sporadisk, men paa de fleste Steder sandsynligviis forvildet fra Dyrkning i ældre Tid: $\boldsymbol{S} \boldsymbol{j}$. Udby, Slangerup, Jægerbakken ved Frederiksborg, Bregentved (H.), alm. Ukrud i Sorø A kademihave (12)! F alst. Bonnet, Veiringe, Aastrup (14); L oll. Sæbyholm! Juellinge (19), Aaliolm (H.); $\boldsymbol{F}$. Hverringe (Heiberg); $\boldsymbol{J}$. Thyrsbak (H.); Sonderborg paa $\boldsymbol{A} l \mathbf{s}(20) ; \boldsymbol{S}$. Haderslev, Flensborg, Nyværk ved Slesvig, Slotsengen ved Husum (16). $\overline{\#}$

314. C. patula L. (Aabenbsegret K.) H. 239; Drej. n. 252 ; F. D. 373 ; Rehb. 1. c. XIX, tab. 1614 ; H. N. VIII, 6.

Roden tynd; Bladene rundtakkede; Toppen halvskjærmformet, med aabne, i Spidsen deelte Grene; Bagerfligene kor tere end den halve Krone; Kronfligene udbøiede, forørigt som foregaaende, hvilken den meget ligner.

1-2' høi. Var. som foreg. i Henseende til Belslædningen. Kronen blaa. $7-8$. $\odot$.

Ved Gjærder, paa Marker og Bakker, meget sjelden: $\mathbf{S} \boldsymbol{j}$. Brinker ved Aaen mellem Nymolle og Dyrehaven (9), Brankebakken ved Frederiksdal (O. F. Miiller); i haandskrevne Anmæerkn. af Rafn angives den fra Sønderborg. Sl. Husum (F. Müll.). $\quad$

bb. Kapselen opspringende i Huller ved Grunden, r, glat.

315. C. rotundifolia L. (Rundbladet K.) H. $238 ;$ Drej. ๖. 251 ; F. D. 1086 ; Rehb. l. c. XIX, tab. 1603.

Roduladene langstilkede, nyreformede eller rundagtigt-ægformede, rundtakkede; Stangelbladene lancetformede, de øvre linieformede, heelrandede; Blomsterne nikkende; Bagerfigene sylformede, udstauende, ikke halvt saa lange som Kronen.

$1 / 2-1^{1 / 2} 2^{\prime}$ hoi. Rodbladene ere alm. henvisnede naar Blomstringen begynder. Kronen blaa (sjeldnere hvid). 7-8. 4.

$\beta$, stricta Schum. (C. Rapunculus F. D. 855). Stængelen stivt opret, hoj og mangegrenet, Rodbladene wgformet-elliptiske.

$\gamma$, parviflora! Stængelen Jav; Bladene næsteu børsteformede; Kronerne meget smaae, blege.

$\delta$, calycida! Enblomstret, Bægerfligene linie-laneetformede, af Læunde med Kronen.

Ved Gjwrder og i Kratskove, paa aabne Marker og Lyngheder alm. udbredt. $\boldsymbol{\beta}$, i Skove: $\boldsymbol{S}$. Lyngby (14); $\boldsymbol{F}$. Rødskebolle ved 
Svendborg (12); J. Ødstedgaard! $\boldsymbol{\gamma}$, i Sandklitter: $\boldsymbol{S} \boldsymbol{j}$. Tibirke Baklker! $\boldsymbol{J}$. Nebbegatard! Sl. Rendsborg! $\delta, S j$. Grevinge i Odsherred (9); F. V. Skjerninge!

316. C. Iatifolia L. (Bredbladet K.) H. 241 ; Drej. n. 255 ; F. D. 85 (var.) og 782 ; Rchb. l. c. XIX, tab. 1599.

Stcongelen opret, udeelt, svagt kantet; Bladene dobbelt saugtakkede, harede, de nedre ægformede, tilspidsede, med en vinget Bladstilk, de фvre æg-lancetformede, næsten siddende; Klasen udeelt, med enblomstrede, tilsidst nikkende Blomsterstilke; Bagerfligene lancetformede, udstaaende.

3-4' høi. Kronerne store, blaae, sjeldnere hvide. 7-8. 4.

I Skove: paa Halvoens Østkyst, i det sydlige Fyen, Sydvestsjalland og par Derne ikke sjelden; sparsommere i Sjallands ostlige og nordlige Egne: Sophieuberg (H.), Vedbæk! Stıandmøllen (Dr.), Charlottenlund (15), Jonstrup Vang (14)', Boserup! Alindelille!

\section{$\beta$. Kapselen haaret.}

317. C. Trachelium L. (Nx]debladet K.) H. 242; Drej. n. 256 ; F. D. 1026 og 2167 (var.); Rehb. l. c. XlX, tab. 1600 .

Stongelen opret, skarpt kantet; Bladene stivhaarede, grovt og dobbelt saugtakkede, tilspidsede, de nedre hjerteformede, stilkede, de фvre æg-lancetformede, næsten siddende; Blomsterne i Klase eller Top, med 1-3-blomstrede, lidet nikkende Blomsterstilke; Brgerfligene æg-lancetformede, oprette; Kapselen stivhaaret af udstaaende Haar.

2-3' høi. Rodstoklsen uden Udlobere. Var, i Henseende til Bladenes Indskjwring, Blomsterstandens Forgrening og Bxgerets Beklædning. Kronen mørkblaa, sjeldent hvid. 7-8. 4 .

I Skove og Krat, alm. udbredt.

318. C. rapunculoiles L. (Ensidig K.) H. 241; Drej. n. 257 ; F. D. 13.77 ; Rclib. 1. c. XIX, tab. 1600.

Rodstokken krybende; Stcengelen opret, budt-kantet; Bladene rue, grovt og dobbelt saugtakkede, spidse, de nedre hjerteformede, langstilkede, de ovre ag-laneetformede, siddentle; Blomsterne i ensidig lilase, med enblomstrede, nilkende Blomsterstilke; Bagerfigene linie-lancetformede, tilbagebøiede; Kapselen korthaaret af nedadrettede Haar. 
1-2' høi. Kroven blaa. 7-8. 4.

Omkring Haver og Byer, ikke sjelden i Danmark, og ofte et besværligt Ukrud i Haverne paa Grund af de vidtforgrenede Udløbere; sjeldnere paa Marker mellem Sæden, f. Ex. J. Ø. for Aalborg (12); L angel. ved Rudkjobing (19); Bornh!

b. Blomsterne stilkløse, nøgleformigt samlede i Enden af Stængelen og de øvre Bladhjørner.

319. C. glomerata L. (Nøgleblomstret K.) H. 245 ; Drej. n. 250 ; F. D. 1328 ; Rchb. 1. c. XIX, tab. 1596.

Bladene fiint rundtakkede, duunhaarede, de nedre langstilkede, æg-lancetformede med hjerteformet Basis; de ovre siddende og halvt omfattende, ægformede; Bagerfigene oprette.

$1 / 2-1^{1} / 2^{\prime}$ høi. Var. i Henseende til Bladenes Brede, Beklædningen og Kronens Størrelse. Kronen blaa eller violet. 7-8. 4.

Ved Gjærder og i Kratskove, bemærket i alle danske Provindser (undtagen Bornholm), men i de fleste Egne sporadisk og ikke alm., hyppigst forekommer den i et Parti af det østlige Jylla $n d$ (omtrent fra Hobro til Horsens!), i det nordøstlige Fyen og Egnen om Roeskilde. $\approx$

Anm. 1. Angivelsen af C. Cervicaria L. fra Lolland (Miill. i F. D. 787) beroer uden 'Tvivl paa en Feiltagelse. Paa det angivne Voxested (ved Rødby) findes C. glomerata i Mangde.

Anm. 2. Wahlenbergia hederacea Rchb. I. c. tab. 1617 (Lge. Hdb. 1 Udg. n. 303; Campanula F. D. 330) er angivet af Horn. (1, 245) at vare funden paa Sylt og Fohr, men er ikke senere gjenfunden. De Expl., hvorefter Tegningen i F.D. er gjort, ere samlede i Hertugdømmet Oldenburg (sml. Horn. II , 144), hvorfor denne Plante indil videre bliver at udstryge af den danske Flora.

\section{Phyteuma. Rapuntsel.}

320. P. spicatum L. (Axbærende R.) H. 245 ; Drej. p. 93 ; F. D. 362 ; Rehb. 1. c. X1X, tab. 1586.

Bladene dobbelt saugtakkede, de nedre langstilkede, æghjerteformede, de ovre linie-lancetformede, siddende; Blomsterne i et endestillet, under Blomstringen ovalt, imod Frugtmodningen valseformet $\mathrm{Ax}$.

1-2' høi. Kronerne guulhvide, med grønlige Spidser; Støvtraadene randhaarede. $6-7$. 4 .

I Skove, alm. i den ostlige Deel af Halvoen, sporadisk mod V. (f. Ex. Nørholm N. for Varde! Kloby og Lundager Krat ved Ribe (6), Fjedsted Slkov v. Ribe (Fabr. Müller) og i Fy en (aftagende mod 
Ø.); paa de øvrige Oer mangler den, km i $\boldsymbol{S}$ j. er den funden ved Sorgenfri, formodenlig forvildet (Drej., 19!).

\section{Jasione. Munke.}

321. J. montana L. (Blaa M.) H. 246; Drej. n. 249; F. D. 319 ; Relib. 1. c. XIX, tab. 1578.

Roden udeelt; Stanglerne enlige eller flere fra Rodhovedet, nedentil tætbladede, foroven nøgne, furede; Bladene linieformede, bredere imod Spidsen, bølget-tandede, stivhaarede; Blomsterkurvene enlige i Enden af Stænglerne.

Kronerne blaa, sjeldnere hvide. 6-8. $\odot$.

$\beta$, iittoralis Fr. nov. ed. 2 , p. 269 ; Rchb. 1. c. XIX, tab. 1578, fig. 2; H. N. VI, 12. Mangestæulet, med flere, nedliggende eller i Spidsen opstigende Stangler og mindre Blomsterkurve. (Denne Form har jeg fundet med glatte Blade).

Torre Marker og Bakker, almindelig. $\beta$, ved sandige Strandbredder og paa Sandbakker: Sj. Tibirke $(27) ;$ Thorseng paa Breguinge Bakke (12); F. Knudshoved (19); Bornholm alm. i Sanditrakningerne, især omkring Rønne! $\boldsymbol{J}$. hist og her i Klitterne ved Vesterhavet, f. Ex. Agger, Fjaltring, Thorsted! Blaavand, Bakbølling (30)! Sl. Eidersted (F. Müller).

\section{Lonicera. Gedeblad.}

322. L. Periclymenum L. (Almindelig G.) H. 267; Drej. n. 258; F. D. 908; Rehb. 1. e. XVII, 1172.

Stongelen slyngende; Bladene elliptiske eller ovale; Blomsterne i et endestillet, mangeblomstret Hoved; Bagerets Krave vedblivende (i Spidsen af Frugten).

Blomsterskaft, Bager og Krone udvendig kirtlet-duumhaarede; Bladene var. glatte eller paa Underfladen duunhaarede, heelrandede eller bugtet-fjerlappede ( $\beta$, quercifolia). Kronen vellugtende, lysguul, udvendig rodagtig (især naar den voxer paa aabue Steder). Bærrene høirøde: 7-8. h.

I Krat og red Gjærder, alm. udbred;, ogsaa i de magre Egne. $\boldsymbol{\beta}, \boldsymbol{S} j$. Lundtofte $(19$, Sorgenfri! Loll. Steensgatard, Ravnsby; $\boldsymbol{F}$. Skaarup (19); hyppigst paa Ryddepladser i Skove.

323. L. Xylosteum L. (Dunet G.) H. 268; Drej. n. 259; F. D. 808 ; Rehb. 1. c. XVII, 1174. 
Stcengelen opret; Bladene ægformet-elliptiske eller ovale; Blomsterstilkene modsatte i Bladhjornerne, toblomstrede med ved Grunden sammenvoxne Blomster; Bagerets Krave affaldende.

Hele Planten duunhaaret, Kronen hvidguul; Bærrene mørkrøde. De 2 Blomster ere i yngre Tilstand indbyrdes frie, omgivne yderst af to bladagtige, spidse, og indenfor disse af 2 budte, skaalformede Dækblade. De sidste omgive tæet Frugtknuderne, og voxe tilsidst sammen med disse. 5-6. h..

I Slkove og Krat, sporadisk, hyppig i det østlige Sjall., Me en og især Bornholm. I Landets vestligere Egne er den sjeldnere og maaskee aldeles ikke tilstede.

\section{Viola. Viol.}

a. Nomimium Ging. De 2 mellemste Kronblade udstaaende til Siderne, Griffelen ved Grunden lidet bøiet, foroven ret eller under Arret hagekrummet. (4).

aa. Bagerbladene budte. Ingen overjordisk Stangel, men Rodstok eller krybende Udløbere.

ж. Blomsterstilkene efter Blomstringen oprette. Griffelen oventil puklet, med skjævt endestillet Ar. Kapselen budt trekantet.

324. V. palustris L. (Eng-V.) H. 250; Drej. n. 263; F. D. 83 ; Rchb. ic. fl. germ. III, fig. 4491; H. N. VIII, 31.

Bladene nyreformede (eller nyre-hjerteformede), med utydelige Sideaarer; Axelbladene ægformede, frie; Blomsterstillene (under Blomstringen) længere end Bladene, med 2 Dockblade nedenfor Midten; Bagerbladene budt-ægformede, med afrundede Tilhængsler af Længde med den næsten rette Spore; Støvknappernes Rum parallele, de 2 nedre med en kort, tyk, afrnndet Spore.

Rodstokken krybende; Bladene glatte eller før Udviklingen svagt duunhaarede; Kronen blegt lila med violette eller mørkrøde Aarer. 5.

I Moser (mellem Sphagnum) og fugtige Enge alm. udbredt.

325. V. epipsila [Ledeb. ind. sem. hort. dorp. 1820] (Tørv-V.) F. D. 2405; Fr. S. Veg. Sc. II, 556; V. scanica H. N. VIII, 32 . 
Bladene nyreformet-hjerteformede, med tydeligt og stærkt forgrenet Aarenæt; Axelbladene ægformede, frie; Blomsterstilkene (under Blomstringen) af Langde med Bladene, med 2 Dakblade ovenfor Midten; Bagerbladene ovale med afskaarne Tilhængsler, der ere kortere end den bøiede Spore; Støvknappernes Rum parallele, de 2 nedre med en kegleformet, bøiet Spore af Længde med Støvkuapperne.

Rodstokken krybende, meget skjør; Bladene paa Underfladen duunhaarede, tilsidst næesten glatte. Kronen blaaagtigt lila, ned mørkere Striber, næsten dobbelt saa stor som foreg. 5 (noget senere end foreg.).

I Moser paa torvholdig Bund, især ved raadne Træstød, lidtil kun funden sporadisk: $\boldsymbol{S} j a$ ll.: Tryggerød, Ordrup- og LundehuusMoserne! Bloustrød! Jonstrup Vang, Særløse ved Roeskilde, Brofelde red Holbek (15), Sorø! Falst. Horreby Lyng (Benzon), F. Ollerup! J. Haven i Vendsyssel (8), Urup (2); Sl. Veesriis ved Rylskov!

326. V. uliginosa [Schrad. n. journ. IV, 80] (Sump-V.) Fr. mant. 2, 51; Rehb. l. c. fig. 4492 ; H. N. V, 27.

Bladene aflang-hjerteformede, rundtakket-saugtakkede; Axelbladene lancetformede, kirtlet-tandede, indtil ovenfor Midten sammenhængende med den vingede Bladstill; Blomsterstillkene med Dækblade ovenfor Midten; Bagerbladene budte, med afskaarne Tilhængsler, der ere meget kortere end den budtkegleformede Spore.

Kronbladene store, lysviolette. 5-6.

I Torvmoser, meget sjelden: Bornh. i Vallensgaards Mose (20)! Echodalen i Almindingen (Hoff)! $F_{*}^{*}$

$\beta$, Griffelen under Arret liagekrummet, Blomsterstilkeue efter Afblomstringen udstrakte; Kapselen kugleformet.

327. V. hirta L. (Korthaaret V.) II. 249; Drej. n. 264; F. D. 618 ; Rehb. l. c. fig. 4493 ; H. N. VIII, 30.

Rodstokken lodret eller skjæv, uden Udløbere; Bladene æg-lijerteformede, paa begge Flader haarede; Axelbladene smalt Iancetformede, grønne, randhaarede; Blomsterstilkene med Dakblade (alm.) nedenfor Midten; Kapselen haaret; Støvknappernes Rum forneden frastaaende. 
Bladene og især Bladstilkene forstørres betydeligt efter Blomstringen; Kronen lugtløs, blegblaa eller lila, sjeldnere hvid (paa de senere Blomster 0 ). $4-5$.

I aabne Skove og paa Bakker mellem Krat, hyppig i de fleste Egne af Danmark, men paa enkelte Steder (f. Ex. omkring Sorø) ikke bemærket.

328. V. odorata L. (Marts-V.) H. 249; Drej. n. 265; F. D. 309 ; Rchb. 1. c. fig. 4498; H. N. IV, 41.

Rodstokken med krybende Udløbere; Bladene nyreformethjerteformede, rundtakkede, glatte eller før Udviklingen svagt haarede ; Axelbladene æg-lancetformede, hindeagtige, randhaarede; Blomsterstilkene med Dokblade ovenfor Midten; Kapselen som: foreg.; Stovknappernes Rum forneden frastaaende.

Bladene alm. glindsende; Kronen mork violet, vellugtende. 4.

$\beta$, alba. Blomsterstilkene duunhaarede, Kronbladene hvide med violet Spore.

I Udkanten af Skove, paa Græspletter og ved Gjærder i Nærheden af Byer, ikke sjelden. $\boldsymbol{\beta}, \boldsymbol{S} \boldsymbol{j}$. Grøfter udfor Slukefter! Falst. S. Kirkeby (Koch); F. mellem Skaarup og Skaarupor (19), mellem. Svendborg og St. Jørgensgaard (12).

b6. Den overjordiske Stangel udviklet, Bagerbladene spidse; Kapselen trekantet.

$\boldsymbol{\alpha}$. Stængelen eensidigt haaret.

329. V. mirabilis L. (Forskjelligblomstret V.) H. 252; Drej. n. 266 ; F. D. 1045 ; Rehb. l. e. fig. 4504.

Stcengelen opret; de nedre Blade nyreformede, de øvre bredt. hjerteformede, kort tilspidsede, svagt haarede, især langs Nerverne og Bladstilkene paa Ryggen; Axelbladene*) lancetformede, tilspidsede, heelrandede (de hos Rodbladene sammenhængende med Bladstilken); Dakbladene nærved Blomsten; Bagerbladene spidse; Sporen budt, omtrent dobbelt saa lang som de afrundede Biegertilbængsler.

*) Ved Undersøgelsen af Axelbladene hos Violarterne med overjordisk Strengel maa man benytte dem, der sidde paa Midten af Stængelen, som de fuldkomnest udviklede og mindst foranderlige. 
De furst udviklede Blomster udgaae fra Rodstokken, ere fuldstændige, men frembringe kun sjeldent Frugt, de senere fra Stængelen frugtbærende, oftest med meget ufuldstiendige eller ingen Kronblade. Kronen vellugtende, violet. $4-5$.

I Skove og Krat sporadisk: J. Haslund Krat (Selmer), Haraldslund! $\boldsymbol{S} \boldsymbol{j}$. Alindelille Fredskov! Borreveile (II.), Ledreborg! Boserup (Albrechit)! Jonstrup Vang (15), Krattet ved Ordrups Kongekilde! Kjøge Aas (9), Basnæs Skov (Nielsen). I de andre Provindser ikke bemærket. |*

B. Strengelen glat eller alsidigt haaret.

330. V. silvatica [Er. fl. hall. p. 64] (Skov-V.) Fr. mant. 3 , p. 121 ; H. N. VI, 26; V. canina silvatica H. 251; V. silvestris Kit.; Drej. n. 268; Rchb. I. c. fig. 4503; V. canina F. D. 1453 (?):

Rodstokken udskyder bloinsterløse Bladknipper og opstigende Blomsterstængler; Bladene hjerteformede, de ovre kort tilspidsede, de nedre budte; Bladstilliene uvingede, flere Gange længere end de lancetformede, tilspidsede, fryndiset-saugtakkede Axelblade; Sporen budt, udrandet, 2-3 Gange lengere end Bægertilhængslerne, eeusfarvet med Kronen; Griffelen i Spidsen bøiet, med en svag Haarkrands ved Bøiningen og et lidet sidestillet $A r$; Kapselen spids.

Kronen blaaagtig-lila, lugtløs. (De tidligst udspringende Blomster frembringe hyppigt ikke moden Frugt og de sildigste mangle ofte Kronblade, ligesom hos flere af Slregten og typisk hos Nr. 329.) 5.

$\beta$, macrantha Fr. (V. Riviniana Rchb. l. c. fig. 4502). Kronen større, det uparrede Kronblad svagt udrandet, Sporen dobbelt saa lang som Bægertilhængslerne, hvidagtig.

I Skove og Krat alm. udbredt. $\beta$, med Hovedarten.

Anm. V. arenaria DC., som adskilles ved lavere og finere Stængler, som tilligemed Bladene ere duunhaarede, fløielshaaret Kapsel, er, saavidt mig bekjendt, ikke lidtil funden i Danmark, livor den dog muligviis kunde findes par sandige Bakker. Expl. samlede mellem Bramstedt og Ulzburg i Holsteen (Lehm.) findes i Hornemanns Herbarium.

331. V. canina L. (Mark-V.) H. 251, II, 144; F. D. 2646 ; H. N. IV , 42 ; V. ericetorum Schrad., Drej. n. 267 ; Rchb. 1. c. fig. $4501 \gamma$. 
Stanglerne udstrakte eller opstigende, ingen blomsterløse Bladknipper; Bladene aflang-ægformede, med hjerteformet Basis, budte, Bladstilkene uvingede, flere Gange længere end de lancetformede, tilspidsede, fryndset-saugtakkede Axelblade; Sporen fladtrykt, budt eller udrandet, dobbelt saa lang som Bægertilbængslerne, guulhvid; Griffel og $A r$ som hos foreg.; Kapselen budt.

Kronen blaa eller lila. 5-6.

$\beta$, lucorum Fr., Rehb. 1. c. fig. $4501 \delta$. Stænglerne langstrakte, Sporen grønlighvid.

$\gamma$, minor. Ingen overjordisk Stængel, Bladene bredere, Bladstilken lidet længere end Axelbladene. 1-3" høi. (V. flavicornis Sin.; V. canina $\beta$, sabulosa Rchb. 1. c. fig. $4501 \alpha$ ).

Paa Bakker, udyrkede, tørre Marker og i Udkanten af Skove meget alm.; $\boldsymbol{\beta}$, i Skove; $\gamma$, paa Lyngheder og tørre Fælleder.

Anm. V. lancifolia Thore, Rchb. l. c. fig. 4506 (V. pumila Fr. mant. 3, p. 123, V. lactea Sm., E. B. 445), forskjellig ved liengere, æg-lancetformede Blade, som ved Grunden ere afrundede eller afsmalnede $i$ en oventil vinget Bladstilk, lange og tynde Rlomsterstilke, smalere og blegere Kronblade, spids Kapsel, kunde muligviis findes her, da den er funden ved Hamborg (Sonder). Den ansees af Flere for en Var. af V. canina.

332. V. stricta [Hornem. oec. Pl. II, 145] (Rank V.) Fr. mant. 3, p. 124 ; Drej. n. 269; F. D. 1812; V. nemoralis Kütz.; V. lactea Nolt. nov.; Hans. Herb. Nr. 1163 (ikke Sm.); V. Ruppii Rchb. 1. c. fig. 4505 og V. lactea fig. 4507.

Stanglen opret, trekantet, med Udløbere fra Rodstokken; Bladene fra en $æ$ g-hjerteformet Basis forlænget-lancetformede, nedløbende $\mathrm{i}$ den oventil vingede Bladstillk; de mellemste Axelblade balvt saa lange som Bladstilken, de øvre ligelange med denne, lancetformede, tilspidsede, fryndset-saugtakkede; Blomsterstilkene meget længere end Bladene; Sporen lidet længere end Bægertilbængslerne.

Planten bleggrøn, Kronen lys mællsblaa med bleg grønguul Spore. 5-6.

$\beta$, humilis Wimm., Fr. mant. 3, p. 124, lavere, med mere nedliggeude Stængler. 
Paa høie Enge og Strandfælleder, i Kratskove, sjelden: $\boldsymbol{S} \boldsymbol{j}$. Vesterfæelled (Schlichtkrull), Stillinge pr. Korsør (Lund), Torvmose ved Flakkebjerg (Nielsen)! Skjorringe Eng ved Storehedinge (Visby)! $\boldsymbol{F}$. Oxemose red Hofnansgave og Kratskor ved Lunde pr Odense $(4,18)$ ! L oll. ved Darket (5)! Stokkemarke (19), Bornh. (Hjorth)! $\boldsymbol{\beta}, \boldsymbol{F}$. Lunde (med Hovedarten (18)! l*

Anm. De Expl. jeg liar seet fra de angivne Voxesteder, stemme vel overeens med Fig. i F. D. og Beskrivelsen (cfr. Koch Syn. II, 93). Fra de glandske Expl. af V. persicafolia Sehreb., Fr. H. N. IV, 43, som beskrives med kortere Spore, mindre nedlobende Bladstilk, formaaer jeg dog ikke tilstraklseligt at adskille vore. De med V. stricta beslegtede Arter staae hinanden meget naer, ere i høi Grad foranderlige $\mathrm{og}$ derfor vanskelige at bestemme. Ogsaa har Hornem. indbefattet flere Arter under $\sin$ V. strieta, og som Hovedkilden til denne bør derfor citeres Fl. dan. 1812.

? 333. V. pratensis [Mert. \& Koch D. Fl. II, 267] (Lavstænglet V.) Fr. mant. 3 , p. 125; H. N. IV, 44; Rehb. l. c. fig. 4507 b; V. pumila Vill., Gren. \& Godr. fl. Fr. I, 1 So.

Stcenglerne glatte, oprette eller opstigende, med Udløbere fra Rodstokken; Bladene bredt laneetformede, ved Grunden afrundede eller nedløbende $\mathrm{i}$ en vinget Bladstilk; Axelbladene bladagtige, de mellemste af Længde med eller længere end Bladstilken; Blomsterstilkene meget fine, længere end Bladene; Sporen omtrent af Længde med Bægertilhængslerne.

Lavere og finere end foreg. Den paa Bornh. fundne Plante er maaskee kun en spæd Form af foreg. Blonsterne smaae, med blegblate Kroner. $5-6$.

Bornh. paa fugtige Pletter imellem Lyngen (Blemmelyng) i Knudsker Sogn (8)! 'Tjæreby, Vallensgaards Mose (Hoff, Hjorth)!

b. Melanium DC. De 4 ovre Kronblade opadrettede. Griffelen opstigende, med stort, krukkeformet Ar. (๑).

334. V. tricolor L. (Stedmodersblomst). H. 253; Drej. n. 262 ; F. D. 623 ; Rchb. I. c. fig. 4517.

Stcongelen opstigende eller opret, grenet; Bladene ægformede eller æg-hjerteformede, (de øve elliptiske), rundtakkede; Axelbladene lyreformet.fjersnitdeelte, med rundtakket Endeafsnit; Sporen længere end Bægertilhængslerne; Kapselen budt. 
4-10*). En i Henseende til Bladenes Form, Kronens Farve o. s. $\nabla$. meget foranderlig Plante. De i vor Flora forekommende Former ere:

$\alpha$, vulgaris. Kronbladene længere end Bægeret, lysblaa, det nedre ved Basis guult med sorte Striber.

$\beta$, angustifolia! Stængelen langstrakt, opret, Bladene linielancetformede, Axelbladene store, med linieformede, heelrandede Afsnit, Kronbladene som hos $\alpha$.

$\boldsymbol{\gamma}$, hortensis. Kronbladene længere end Bægeret, mørkviolette og var. med forskjellige Farver.

$\delta$, arenaria Sond. Hamb. Fl. p. 137, F. D. 2647 ; V. sabulosa Boreau (Puel \& Maill. herb. loc. Fr. Nr. 213)? Stænglerne meget grenede, udstrakte, Bladene linie-lancetformede, Axelbladene nasten haandsnitdeelte, med meget smale Sideafsnit, Sporen lang og tynd, Kronen trefarvet, omtr. af Længde med Bægeret. ( $\mathrm{Er}$ maaskee en egen Art).

$\boldsymbol{\varepsilon}$, arvensis (V. arvensis Murr., H. 254; F. D. 1748, usædvanligt stort Expl.). Kronbladene kortere end Bægeret, hvide, det nedre ved Grunden guult med sorte Striber.

$\zeta$, syrtica. Kronen som foreg., Bladene kjødfulde.

Paa tørre Marker og Bakker alm. udbredt. $\varkappa$, især paa Sandgrund og udyrket Mark; $\beta$, Borød red Sorø! Jylland (5)! $\gamma$, dyrkes i Haver og forekommer derfra forvildet; $\delta$, Klitter ved Skagen (Drej.), ved Rahr og Agger i Thy! Sj. Hellebæk! Bornh. Dueodden (Hjorth). $\varepsilon$, ogsaa paa Leerjord (især som Ukrud mellem Sæden); $\zeta$, ved sandige Strandbredder.

\section{Impatiens. Springfro.}

335. I. Noli tangere L. (Springbalsamin). H. 248 ; Drej. n. 270; F. D. 582 ; Rchb. ic. fl. germ. V, 4483.

Stangelen opret med opsvulmede Led; Bladene ægformetelliptiske, rundtakkede; Blomsterstilkene 1-4-blomstrede, kortere

*) Denne Art kan i Grunden rigtigst angives at blomstre hele Aaret; i milde Vintre finder man den hyppigt i Blomster indtil Nytaar eller læengere; ja Hr. Rostrup har hele Vinteren igjennem, endog under Sneen, fundet kronløse Blomster, som tidligt paa Foraaret frembragte modne Frugter. 
end Bladene; Blomsterne hæengende; Sporen i Spidsen tilbagebøiet; Frøene mørkbrune, ovale, fladtrykte med 4 skarpe Kanter og faae bølgeformede, ophøiet-rynkede Striber mellem Kanterne.

Stængelen skjør, meget saftig, Blomsterne lysgule med rodligbrune Punkter. De tidligst frugtbærende Blomster ere alm. mindre og ufuldstændigt udviklede (mangle det uparrede Bægerblad).

Paa fugtig og løs Skovjord, ikke sjelden i Danmark.

† I. parviflora [DC. prodr. I, 687] (Smaablomstret S.) Ledeb. ic. ross. I, t. 89.

Bladene saugtakkede: Blomsterstilkene oprette, 3-5-blomstrede, længere end Bladene, Kronen blegere guul og mange Gange inindre end hos foreg., med kort, ret Spore; Frøene graabrune, ovale, trindt-fladtrykte uden Kanter, men overalt tæt og fint stribede, forøvigt som foreg. 8-9. $\odot$.

Oprindelig fra Siberien, funden forvildet i stor Mængde ved Nebbegaard pr. Horsholm (15)!

\section{Rhamnus. Vrietorn.}

336. R. catharticus L. (Tvebo-V.) H. 269 ; Drej.n. 260 ; F. D. 850 ; H. N. II, 36 .

Grenene modsatte, ende ofte $\mathrm{i}$ en Vedtorn; Bladene $æ \mathrm{~g}$ formede, ovale eller elliptiske, fint saugtakkede, med 3 Sidenerver paa hver Side af Midtnerven; Blomsterne tvebo; 4 Støvdragere, Arret firekløvet.

Bladene modsatte (paa de forkortede Grene knippestillede), ofte dumuharede, Kronen grøn, hos $0^{\pi}$ bruun hindeagtig; $q$ Blomsten lar 4 golde Støvdragere. $5-6$. 万. $^{2}$

I fugtige Kratskove ikke sjelden.

3ิ37. R. Frangula L. (Tvekjønnet V., Tørstetræ). H. 270; Drej. n. 261 ; F. D. ¿78.

Grenene tornløse, ligesom Bladene spredte; Bladene ovale eller ægformet-elliptiske, budte ined en kort Spids, beelrandede, med flere Nerver paa hver Side af Midtnerven; Blomsterne trekjønnede; 5 Støvdragere; Arret udeelt.

Kronen hvidagtig. 6. h.

I Skove og Krat, især paa fugtig, torvholdig Grund, alm. 


\section{Ribes. Ribs.}

a. Grossularia DC. Bladene stottede af enkelte eller 2-3-grenede Barktorne. Blomsterstilkene $1-3$-blomstrede.

338. R. Grossularia L. (Stikkelsbær). H. 275; Drej. n. 271 ; R. Uva crispa F. D. 546.

Tornene enkelte eller tregrenede; Bageret klokkeformet, med ovale, skident røde Flige; Kronbladene omvendt-ægformede, rødlig-bleggrønue.

Bladene mindre end hos de følgende Arter; Bladstilkene randhaarede af grenede, i Spidsen kittelbarende Hiar. Bierrene hos den vilde Plante lysgrønne eller gule, sjeldnere rode. (Foruden de Bladene stottende Torne findes undertiden flere eller færre og større eller mindro Torne langs opad Grenene). 5. h.

$\alpha$, pubescens (R. Uva crispa L.) Frugtknuden svagt haaret, den modne Frugt glat.

$\boldsymbol{\beta}$, glandulosum (R. Grossularia L.) Frugtknuden og den modne Frugt beklædt med Kirtelhaar.

I Kratskove og ved Gjæerder alm. Forskjellige Former dyrkes i Haver paa Grund af de velsmagende Frugter.

b. Ribesia DC. Stængelen tornløs. Blomsterne i Klaser.

aa. Klaserne hangende. Dakbladene kortere end Blomsterstilkene. $\Varangle$.

339. R. nigrum L. (Solbær). H. 275, Drej. n. 274; F. D. 556 .

Bladene 3-5-lappede, paa Underfladen kirtlet-punkterede; Dakbladene sylformede; Bageret duunbaaret med ovale Flige; Kronbladene ovale eller omvendt-agformede.

Har en temmelig stærk og ikke ubehagelig Lugt. Blomsterne gronne, indvendig violette, Bær sorte (af krydret Smag). 5-6. $\boldsymbol{\zeta}_{\text {. }}$

I fugtige Skove, ved Bredderne af Bække og Aaer, sporadisk og ikke meget alm., hyppigst i det nordøstlige Sjæll. Dyrkes alm. i Haver. 
340. R. rubrum L. (Ribs). H. 272; Drej. n. 273; F. D. 967 ; H. N. IV, 57 (var.).

Bladene 3-5-lappede, paa Underfaden duunhaarede eller tilsidst glatte; Dokbladene ægformede; Bageret glat, dets Flige tilligemed Kronbladene spadeformede.

Blomsterne groune, Bar rode (syrlige), sjeldnere hvide $(\beta$, leucocarpon!). 5-6. $\boldsymbol{h}_{\text {. }}$.

Paa lignende Steder som den foreg., men mere alm. udbredt. $\beta$, ved Rugtred i Vendsyssel (12). Dyrkes alm. i Haver under forskjellige Former i Henseende til Bærrenes Størrelse og Farve.

bb. Klaserne oprette, Dakbladene langere end Blomsterstilkene. Tvebo.

341. R. alpinum L. (Fjeld-R.) H. 274; Drej. n. 272; F. D. 968 ; H. N. XIII, 56.

Bladene trefligede med dybt og dobbelt saugtakkede Flige, paa Overfladen tiltrykt-haarede; Klasestilkene og de lancetformede Dakblade i Randen kirtelhaarede; Bageret glat, med ægformede Flige; Kronbladene spadeformede.

o K Klasen alm. faablomstret, med 5 golde Støvdragere, $\sigma$ Klasen mangeblomstret, med golde St $\rho v v e i e$. Blomsterne grongule, Bar røde (smagløse). 5-6. 万.

I hoitliggende Skove, sjelden: paa Moens Klint i Mrugde! F alst. i Krat ved S. Alslev (Kocls), Bornh. (H), ved Blykobbeaaen i Knudsker Sogn (Baagøe); forekommer desuden paa enkelte Steder i Kratskove (nuligviis forvildet fra Haver, hvor den stundom dyrkes), f. Ex. $\boldsymbol{S} j$. 'Tryggerød Slrov! $\boldsymbol{F}$. paa flere Steder i det sydlige (19); J. Randers, Veile (7); Sl. Haderslev, Munkbra up i Angel (16).

\section{Iledera. Vedbende.}

342. II. Helix L. (Almindelig V.) H. 277; Drej. n. 275; F. D. 1027 ; H. N. XIII, 39.

Stangelen txt besat med Hafterødder og derved klattrende; Bladene haandnervede, 3-5.fligede eller lappede, paa de blomsterbærende Grene ægformet-elliptiske, tilspidsede, heelrandede; Blomsterne i Skj:erm; Blomsterstille og Bager duunhaarede.

Bladene lrederagtige, mørkgrønne med hvide Aarer, glindsende. Blomsterne groune, Bær sorte $(9-10$. Frugten modnes i det paafølgende Foraar). $\boldsymbol{h}_{2}$. 
I Skove og ved Gjærder ikke sjelden, især hyppig i det østlige $\boldsymbol{S} l$. samt paa Lolland-Falster og Bornholm. Kun de aldre, op til Mure eller 'Træer $t$ astheftede Individer frembringe Blomster. De paa Skovbunden krybende Expl. blomstre ikke.

\section{Glaux. Sandkryb.}

343. G. maritima L. (Almindelig S.) H. 279; Drej. n. 227 ; F. D. 548; Rehb. ic. fl. germ. XVII, tab. 1127; I. Herb. VIII, 160.

Bladtne modsatte, ovale eller elliptiske, heelrandede, glatte; Blomsterne siddende i Bladhjøruerne, ned rosenrøde Kroner.

2-6" høi. Den afblomstrede Stængel udskyder ved Grunden traadformede, i Sandet krybende Udløbere, der ved hvert Led have 4 traadformede (Arbeids-) Rødder. På Udløberne findes en eller flere Vinterknopper, der hver ex forsynet med 4 mægtige, tapformede (Amme-) Rodder (Meddeelt af Doc. Didrichsen). 6-7. 4 .

Ved Strandbredder, saavel paa Havstokken som paa Syltenge, alm. udbredt.

\section{Illecebrum. Bruskbager.}

344. I. rerticillatum L. (Krandsblomstret B.) H. 278; F. D. 335 ; H. N. XII, 60 .

Stconglerne fremliggende; Bladene modsatte, omvendt ægformet-kredsrunde, heelrandede; Blomsterne krandsstillede, siddende i Bladhjørnerne (hvide). 7-8. 0.

Paa sandige Veie og Overdrev, tørvholdig Bund, kun bemærket i de sydlige Egne af Landet: $S l$. sporadisk, f. Ex. mellem $\emptyset$. Vedsted og Lystrup ved Ribe (6), Løgumliloster (28), Wanderup ved Flenshorg! Ø. Orsted, Bilskov og Lyrskov mellem Flensborg og Slesvig, Rendsborg (16), mellem Hornp og Læk (20), Lund ved Husum! Falst. ved Nykjgbing (H.). 7.

\section{Thesium. Naalebager.}

345. T. ebracteatum [Hayne i Schrad. journ. 1800, I, p. 33] (Hørbladet N.) Drej. n. 277; Rehb. ic. Al. germ. XI, 1168 ; H. N. XI, 56; T. pratense H. 279; F. D. 1205.

Stangelen fra en vandret, grenet Rodstok opstigende eller opret; Bladene linieformede, spredte; Blomsterne i Klase; Blomsterstilkene enbloinstrede mad et enkelt Dakblad under Blomsten, de øverste tomme Dakblade danine en Bladdusk; Blomster- 
dækket tragtformet, ved dets smalere Basis tilleddet til Blomsterstilken og det vedblivende Dækblad, dets Flige under Blomstringen aabne, efter samme med indbøiet Spidse; et bruskagtigt Korn ved Grunden af hvert Indsnit.

Rodtrævlerne forsynede med smaae vorteformede Udvæxter, ved hvilke den nærer sig som Snylteplante paa andre Planters Rødder. 6-7. 4 .

$\beta$, subbracteatum J. Vahl i Fr. S. Veg. Se. p. 52; T. pratense Drej. n. 278. 2-3 Dækblade under Blorristen.

Paa græsklædte Bakker, sjelden og hidtil kun bemærket i Sjœ ll.: Brede Bakker! Jonstrup Vang (14)! Ballerup Mark ved Hareskoven (H.), Jægerspriis $(9,14) ! \beta$, paa Brede Bakker med Hovedarten (27). 周

\section{Digynia.}

\section{IIerniaria. Bridurt.}

346. Il. glabra L. (Almindelig B.) H. 281; Drej. n. 275 (bis); F. D. 529.

Stconglerne fremliggende; Bladene elliptiske eller ovale, ined hindeagtige Axelblade, de nedre modsatte, de øvre, ligesom Grenene, afvexlende; Blomsterne smaae, danne trette Nøgler i Bladhjornerne; Blomsterdokket (hos Hovedarten) glat.

Stænglerne ofte rodslaaende, beklædte med meget korte, nedad. rettede Haar; Bladene glatte; Blomsterne grønne. 6-9. ข.

$\beta$, subciliata (Babington man. p. 121). Bladene fiint randbaarede, Blomsterdakket udvendig haaret.

Paa tørre, især sandige Marker og Bakker, alm. udbredt. $\boldsymbol{\beta}, \boldsymbol{S} \boldsymbol{j}$. ved Bredderne af Tjustrup $\$ \emptyset !$ Falst. ved Bregninge (14); Søby paa Ere (10)!

? 347. II. hirsuta L. (Stivbaaret B.) H. 282 ; Drej. n. 276.

Stconglerne fremliggende, tæt duunbaarede af udstaaende Haar; Bladene omvendt-ægformede, tilligemed Blomsterdakket stivbaarede, forøvigt som foreg. 7-9.

Paa tørre Marker, angives af $H$. som funden paa Hastrup Mark ved Præstø (Badstüber), men muligviis beroer denue Angivelse paa en Forrexling med Afarten af foreg. 


\section{Beta. Bede.}

348. B. maritima L. (Strand-B.) H. 292; Drej. w. 297 ; F. D. $1571 ;$ H. N. XIII, 67 .

Stanglerne flere, fremliggende; Rodbladene ægformet-rudeformede, nedløbende i Bladstilken, i Randen bølgede, Stongelbladene lancetformede; Blomsterne i Ax, dannede af tæt samlede og forneden sammenvoxne, 2-3-blomstrede Nøgler, der ere kortere end Dakbladene; Arrene lancetformede. 7-8. 4.

Ved Strandbredder, sporadisk og temmelig sjelden: J. paa Vestkanten (Beck), Tyvholm og Græsholm red Frederikshavn (Dr.), Aarhus! $\boldsymbol{F}$. Langø red Hindsholm! $\boldsymbol{S} j$. Reersø (Dr.), Korsør! Vresen mellem Nyborg og Langeland, Fre ved Ourehoved (H.), Halen ved Marstal (Bredsdorff). 用

$\dagger$ B. vulgaris L. (Rødbede). Enstænglet, Stangelen opret; Rodbladene budt ægformet-lijerteformede; Stcengelbladene ægformet-rudeformede; Blomsterstanden som foreg., Arrene ægformede. $\odot$ eller $\odot$.

$\alpha$, Cicla (B. Cicla L.) Roden cylindrisk eller omvendtkegleformet, Bladstilkene tykke.

$\beta$, rapacea Koch (Runkelroe). Roden kjødfuld, roeformet (rød, guul eller hvid).

Dyrkes alm. i Haver $(\alpha)$ og i Marker $(\beta)$.

\section{Chenopodium. Gaasefod.}

a. Frøene glandsløse.

349. C. hybridum L. (Hjertebladet G.) H. 284; Drej. n. 292 ; F. D. 2049 .

Stangelen opret; Bladene hjerteformede, bugtet-tandede eller lappede, med tilspidsede Tænder; Blomsterstanden en oventil bladløs Top, dannet af udspærrede, quastblomstrede Grene; Frøene grubet-punkterede.

Bladene alm. uden Meel. 7-8. $\odot$.

Paa dyrket, løs Jord, f. Ex. onkring Byer, i Haver o. s. v. ikke sjelden, men sporadisk. 
350. C. urbicum L. (Rank G.) H. 283; Drej. n. 291; F. D. 1148.

Strengelen rank opret; Bladene triangelformede, ved Grunden lidet nedløbende i Bladstilken, grovt tandede; Blomsterstanden en forlæuget, oventil bladløs Dusk, sammensat af tiltrykte, axblomstrede Grene; Frøene meget fint punkterede; med budt Rand.

Bladene melede. 7-9. $\odot$.

$\boldsymbol{\beta}$, intermedium K̋och (C. rhombifolium Mühlenb., Drej. n. 290). Bladene bugtet-taudede, med tilspidsede Tænder.

Ved Gjærder, omkring Byer o. a. dyrlsede Steder, sporadisk, men forekommer i alle Provindser. $\beta$, paa Ryddepladser, sjeldnere. Exemplarer fra Helsingor (11), efter hvilke Beskrivelsen hos Drej. er affattet, forekomme mig tvivlsomme og synes snarere at benhøre til Blitum rubrum ifølge dens Habitus og de glindsende Frøe.

351. C. murale L. (Muur-G.) H. 284; Drej. n. 289; F. D. 2048 ; H. N. XV, 59.

Stangelen opstigende; Bladene ægformet-rudeformede, grovt og skarpt tandet-saugtakkede, med tilspidsede Tænder; Blomsterstanden en Top, sammensat af udspærrede, qvastblomstrede Grene med Blade til Spidsen; Frøene ophøiet punkterede, med skarpkjølet Rand.

Bladene melede. 7-9. $\odot$.

Ved Mure og omkring Byer, iklse almindelig: $\boldsymbol{S} j$. Lyıgby Kirkegaard! udenfor Norre Port! Dragor paa Amager! Herløv, Jyllinge o. ft. St. i Nordajælland (19), Roeskilde (15), Soro! Havrebjerg ved Slagelse (12), Korsør! i Omegnen af Skjelskør alm. (Nielsen); $\boldsymbol{F}$. Hofmansgave (18)! Svendborg! Sl. Gelting, Husum (16), Loll. ikke. sjelden (19)! Falst. Nyljjøbing! o. fl. St. (14), Bornh. Rønne!

\section{b. Frnene glindsende.}

aa. De aldre Blade bugtet-tandede eller lappede.

352. C. album L. (Hvidmelet G.) H. 285; Drej. n. 286.

Stangelen opret; Bladene xgformet-rudeformede, bugtettandede, de ovre elliptiske, næsten heelrandede; Blomsterstanden en Top, sammensat af ax- eller quastblomstrede, oventil bladløse Grene; Froene jævne. 
6-9. $\odot$. Var. betydeligt i Henseen e til Bladformen, Blomster standen o.s.v.

$\alpha$, album. Bladene stærkt melede; Blomsterne i Ax.

$\beta$, viride (C. viride L., Drej. n. 275 ; F. D. 1150). Bladene lidet melede, svagt tandede eller næsten heelrandede; Blomsterne i Qvast.

$\gamma$, glomerulosum Hartm. (C. opulifolium Drej. n. 288). Bladene tyndere, rundagtigt-ægformede, skarptandede, næsten trelappede; Blomsterstanden en Top med forlængede Grene og smaae, spredte Nogler.

Omkring Byer, paa Gjødningspladser, i Haver o. a. dyrkede. Steder, meget alm. $(\alpha \circ \mathrm{og} \beta) ; \gamma$, sjeldnere.

Anm. Om den ægte C. opulifolium Schrad. (H. N. XIV, 62) forekommer i Danmark, er mig ikke bekjendt. Den under dette Navn af Drej. beskrevne er neppe andet end en Form af foreg.

353. C. ficifolium [Sm. Fl. brit. I, 276] (Figenbladet G.) Drej. n. 287.

Stangelen opret; Bladene fra en kileformet Basis spydformet-trelappede, den midterste Lap forlænget, budt, bugtettandet, de øvre Blade linie-lancetformede, næsten heelrandede; Blomsterstanden som foreg., med quastblomstrede Grene; Frøene fint grubet-punkterede, mindre end bos foreg. 7-9. $\odot$.

Paa lignende Steder som foreg., sjelden: Dæmningen red St. Jørgens Sø og Kastellet ved Kjøbenhavu!

† Ch. Botrys L. (Egebladet G.) N. E. Fl. germ. IV, 56.

Stangelen opret; Bladene ovale eller omvendt-ægformede, budte eller udrandede, fjerlappede, med paa Underfladen stærkt fremstaaende Nerver; Blomsterstanden en forlænget, indtil Spidsen bladbærende Top, sammensat af quastformede Grene fia Bladhjornerne; Frøene jævne, lindseformet-fladtrykte, mindre end hos de foreg.

Hele Flanten beklædt med korte, kirtelbærende Haar eller siddende Kirtler, af stærk aromatisk, ikke ubehagelig Lugt. 7-8. $\odot$.

Forvildet omkring Haver o. a. dyrkede Steder: $S \boldsymbol{j}$. Snedinge Mølle (Nielsen); $\boldsymbol{F}$. Østrupgaard N. for Odense, bvor den i flere Aar har voxet i Mængde (Møller)! 
bb. Alle Bladene heetrandede.
354
C. polyspermum
L. (Tætfrøet
G.)
H. 287 ; Drej.

n. 283 ; F. D. 1153 .

Stcengelen opret eller fremliggende, med udspærrede Grene fra Grunden af; Bladene elliptisk-ægformede eller ovalc, budte eller spidse; Blomsterne nøgleformigt samlede $\mathrm{i}$ tæt- eller fjerntblomstrede, quastformede Grene fra Bladhjornerne; Blomsterdakket ved Frugtens Modenhed aabent; Froene punkterede.

Bladene uden Meel. 7-9. $\odot$.

$\boldsymbol{\beta}$, acutifolium (Sm.) Bladene spidse, Grenene tætblomstrede, næsten axformede.

Omkring Byer og andre fugtige Steder, især paa fugtig Grund: i de fleste Egne af Danmark ikke sjelden, hyppigst i det sydøstlige Jylland, Fyen og paa Oerne. $\boldsymbol{\beta}$, med Hovedarten.

355. C. Vulraria L. (Stinkende G.) H. 286; Drej. n. 284 ; F. D. 1152 ; C. olidum Curt.

Stungelen nedliggende eller opret, med vandret udstaaende Grene fra Grunden af; Bladene agformet-rudeformede, budte; Blomsterne nøgleformigt samlede $\mathrm{i}$ tatblomstrede Grene fra de øvre Bladhjørner; Blomsterdakket ved Frugtens Modenhed lukket; Froene fiint punkterede.

Har en stærk og meget ubehagelig Lugt. Hele Planten graaagtig af et melet Overtræk. Froene større og mere løst omsluttede at Frogjemmet end foreg. 7-9. $\odot$.

Paa dyrkede Steder, ved Møddinger og Ryddepladser, sjelden: $S j$. Charlottenlund, Nørreport og Salpetervarket udenfor Østerport (H.), Jagtveien (17), Amager ved Götchens Batteri! F. Ryslinge (H.); Bornh. Nexø (11).

\section{Blitum. Andefod.}

a. B lomsterdakket ved Frugtmodningen kjødfulät, farvet (hvorved Noglerne faae Lighed med Bær).

1 Stovdrager.

X 356. B. capitatum L. (Jordbærspinat). H. 8; Drej. p. 104.

Bladene spydformede, tandede; Blomsterne i rundagtige 
Nøgler, samlede i et oventil bladløst. Ax; Blomsterdokket ved Modenheden purpurrødt. $6-8$. $\odot$.

Forvildet omkring Haver og dyrkede Steder, f. Ex. $\boldsymbol{S} \boldsymbol{j}$. Bagsværd (H.), Valdby (Dr.); $J$. Randers (7). Har maaskee tidligere været hyppigere, da den angives som alm. af Kylling. [a

$\dagger$ B. virgatum L. (Axelblomstret A.) Drej. p. 104; H. N. VIII, 52.

Bladene spydformede, dybt tandede; Blomsterne i rundagtige Nøgler med Dækblade indtil Spidsen af Stængelen; Blomsterdakket ved Modenheden høirødt. 6-8. $\odot$.

Som foreg. forvildet, f. Ex. Gram i Slesvig (1); Næshy paa Falster (Benzon).

b. Blomsterdækket kortere end den modne Frugt, tørt (grønt eller farvet). 5 Støvdragere*).

aa. Arrene korte. $\odot$.

357. B. rubrum [Rehb. fl. exe. p. 582] (Rød A.) Drej. n. 294; Chenopodium L., H. 282; F. 1149.

Stangelen opret; Bladene triangelformet-rudeformede eller spydformede, bugtet-tandede, de øvre lancetformede, spidse, ofte heelrandede; Blomsterstanden Ax eller Dusk (med Dækblade til Spidsen), sammensat af aflange, txtblomstrede Nogler; Frøene smaae, glindsende, budtkjølede i Randen.

Var. meget i Henseende til Bladenes Form og Indskjæringer. Har alm. en rød Farve, især paa Stængelen. 7-9.

Paa dyrkede Steder og ved Strandbredder (især i stærkt leret eller gjødet Jordbund), alm. udbredt.

358. B. botryoilles [Drej. fl. exe. p. 295 (undt. Voxest.)] (Drueblomstret A.) Chenopodium Sm., E. B. 2247 ; Nolt. nov. p. 24 ; Chenopod. rubrum $\delta$, glomeratum og $\varepsilon$, crassifolium Moq. (DC. prodr. XIII, 2, p. 84).

*) Denne Afdeling horer hos L. og flere nyere Forff. til Chenopodium', fra hvilken Slægt den dog synes naturligt adskilt, skjøndt den vanskeligt kan sondres ved kunstige Kjendetegn. Med Fries og Koch har jeg belıoldt den Meyerske Slægtsbegrændsning. 
Stcrngelsn opret eller opstigende, med lange, udspærrede Grene nedadtil; Bladene spydformet-triangelformede, budte, beelrandede eller med faae, korte Tænder; Blomsterne i en oventil bladløs Dusk, sammensat af forlængede, fjernblomstrede Nøgler; Frøene som hos foreg., men næsten dobbelt saa store. $8-9$.

Ved Strandbredder i Dynd, udtørrede Marskgrøfter: Falst. ved Gjedsergaard (14); Loll. Nakskov; Vresen i Storebrelt (19); $\boldsymbol{F}$. Langø ved Hindsholm! Øxemose ved Hofmansgave (27)! Lyø, A vernak $\emptyset$ (12)! Ere (N.); Brandsø og Aarø i Lille Belt $(28,7)$ ! Fohr (N.).

Anm. Exemplarerne fra de angivne Voxesteder, efter hvilke Beskrivelsen er affattet, afvige ved de anførte Kjendetegn og isar ved Blomsterstanden altfor meget fra foreg. til at kunne være en Afart af denne, saaledes som flere Forff., og deriblandt Moquin-Tandon (1. c.) antage. Angivés ogsaa fra Flaskekroen (Drej.), men de Expl., som jeg har seet derfra, synes at tilhøre en mindre Form af B. rubrum.

\section{B. glaucum [Koch D. Fl. Suppl.] (Rundbugtet A.)} Drej. n. 296; Chenopodium L., H. 286; F. D. 1151.

Stangelen opret eller nedliggende, med udspilede Grene; Bladene elliptiske eller lancetformede, fjernt og dybt rundbugtettandede, paa Underfladen blaagraae; Blomsterne i sammensatte, foroven bladløse $A x$, dannede af korte, rundagtige, tætblomstrede Nøgler; Frøene jævne, glindsende (dobbelt saa store som hos de 2 foreg.), deels vandrette, deels lodrette. 7-9.

Ved Randen af Damme o. a. fugtige Steder, især omkring Landsbyer, alm. udbredt, sjeldnere ved Strandbredderne.

\section{bb. Arrene forlcengede. 4.}

360. B. Bonus llenricus [C. A. Mey. i Ledeb. fl. alt. I, p. 11] (Stolt Henrik). Drej. n. 293; Chenopodium L., H. 282 ; F. D. 579.

Stcongelen opret; Bladene spydformede, heelrandede; Blomsterne $\mathrm{i}$ et sammensat, oventil bladløst $\mathrm{Ax}$, dannet af tætsiddende og tætblomstrede, aflange Nogler; Frøene jævne, glindsende.

Hele Planten, især i ung Tilstand, beklædt med Meel. 5-7.

Ved Gj:erder og omkring Byer meget almindelig.

Uaandb. $i$ den danske Flora. 


\section{Chenopodina. Strandgaasefod.}

361. C. maritima [Moq.-Tand. i DC. prodr. XIII, 2, 161]. Chenopodium L., H. 287; F. D. 489; Schoberia C. A. Mey., Drej. n. 281 ; H. N. IV, 50; Suæda Dumort.

Stcrngelen opret eller opstigende, fra Grunden af grenet; Bladene spredte, halvt-valseformede, kjødfulde; Blomsterne i rundagtige, faablomstrede Nøgler i Bladhjørnerne fra Grunden. af Stængelen og Grenene; Frøene glindsende.

$\alpha$, vulgaris Moq. Stængelen udstrakt eller opstigende, fra Grunden af grenet, Frøene større.

$\beta$, erecta Moq. Stængelen opret, nedentil oftest ugrenet; Frøene mindre.

$1 / 2-1^{\prime}$ høi, blaagraa (især $\alpha$ ), ofre rødligt anløben (især $\beta$ ). 7-9. $\odot$. De 2 Former, som begge forekomme i vor Flora, afvige fra hinanden i Udseende, ogsaa i dyrket Tilstand, og maa nærmereundersøges, da de muligviis ere 2 adskilte Arter.

Ved Strandbredderne, i leret Marskbund alm.

\section{Kochia. Tangurt.}

362. K. hirsuta [Nolte nov. fl. hols. p. 24] (Laaden T.) Drej. n. 282 ; H. N. IV, 49; Salsola L., H. 293; F. D. 187; Echinopsilon Moq.

Stcengelen opstigende, fra Grunden af grenet; Bladene spredte, linieformede, budte, kjødfulde, haarede; Blomsterne parviis i Bladbjørnerne; Blomsterdakkets Tilhængsler kegleformede; Frøene glandsløse. 7-9. $\odot$.

Ved Strandbredderne paa Marskenge, i raaden Tang o. s. $\nabla$. , sjeldnere end foreg. Sj. ved Lammefjorden alm.! Skjelskør (H.); $\boldsymbol{F}$. mellem Nyborg og Holkenhavn (H.); Hatve en: Ydre Bjerrum ved Ribe (6), Romø, Amrom, Beenshallig (N.), Fohr (20), Skovbol ved Husum (16), Aarø, Femern, Erø (N.), Drejø (12), Langelands Østkyst (19); L oll. ved Bredfjed! Falst. ved Boto (5), Vaalse Nor (14)! [₹*

\section{Salsola. Sodaurt.}

363. S. Kali L. (Tornet S.) H. 292; Drej. n. 280; F. D. 818 . 
Stcengelen med udspærrede Grene fra Grunden af; Bladene naaleformede, tornspidsede, kjødfulde (de nedre modsatte); Blomsterne enlige i Bladhjørnerne; Blomsterdakket under Blomstringen hindeagtigt, ved Frugtmodningen bruskagtigt med tilspidsede Flige og afrundede Tilhcengsler.

Var. glat eller korthaaret. 7-8. $\odot$.

Ved sandige Strandbredder hist og her.

\section{Ulmus. AEIm.}

364. U. montana [Sm. Fl. brit. I, p. 281] (Storbladet \&., Ypern). Fr. mant. 3, 19; F. D. 632 (U. eampestris) og 2532; Rebb. ic. fl. germ. XII, tab. 1332; H. N. XII, 63; U. campestris H. 294 ; Drej. n. 279.

Bladene ægformet-elliptiske eller omvendt-ægformede, tilspidsede, ved Grunden skjæve, grovt og dobbelt saugtakkede, rue; Blomsterne nxsten siddende, $\mathrm{i}$ et Hoved eller meget forkortet Halvskjærm; Stovdragere 5-6; Vingefrugterne glatte, ovale, i Spidsen svagt udrandede, Indskjæringen fortsættes i en Griffelkanal af Frøets Længde.

Bladenes Tænder alm. grovere og i Spidsen mere indbøiede end hos de følgende Arter. Blomsterne liyppigst rødlige. 4. (6 fr.)

Et hyppigt 'Trae i Plantager og omkring Byer, mindre alm. vildvoxende i Skove, f. E.x. B or $n h$. alm. paa Ostkysten (i Granit-Terrainet); Sj. Boserup Skov (20), Borreveile (H.), Kulaas Skov i Odsherred! Falst. hist $\mathrm{ng}$ her (Koch); Loll. temmelig alm. i Skovene (19); F. Keirup (H.) og fl. St. i det sydlige (12).

+ 365. U. campestris [Sm. Fl. brit. I, p. 281] (Smaabladet E.) Fr. mant. 3, 18; F. D. 2531; Rehb. I. c. tab. 1331.

Bladene ægformet elliptiske, tilspidsede, ved Grunden skjæve, dobbelt-saugtakkede, rue eller næsten jævne; Blomsterstanden som hos foreg.; Støvdragere 4--5; Vingefrugterne glatte, omvendt-hjerteformet-kredsrunde, dybt indskaarue; med Frøet umiddelbart under Indskjæringen.

Grenene spædere, Bladknopperne og Bladene mindre end hos foreg., Griflerne alm. mere udspærrede. Blomsterne bruunagtigtgronne. $\frac{1}{2}-\frac{5}{1}$. (6. fr.) h. 
I Plantager omkring beboede Steder, hist og her, men sjeldnere end foreg. og neppe oprindelig vildvoxende, f. Ex. flere Steder omkring Kjøbenhavn!

* 366. U. suberosa [Ehrh. Beitr. VI, p. 87] (Kork-ÆE.) Schum. p. 84; Rafn 258; Rchb. l. c. tab. 1333; U. campestris $\beta$, suberosa Fr. mant. 3 , p. 18 , H. N. IV, 80.

Barken paa Grenene korkagtig, vingeformigt udstaaende; Bladene meget mindre; Blomsterdcekket alm. firedeelt, 4 Støvdragere, forøvrigt som foreg.

Ved Gjærder og omkring beboede Steder, sjeldnere end de foreg., f. Ex.Sj. Kaningaarden ved Fuurs $\emptyset$ en (Schum.), Glacierne mellem Øster-og Nørre-Port, Kjøbenhavns Vold ligefor Nørregade, Tivoli, gamle Kongevei (19), Bülowsveien mellem Ladegaarden og Falkoneeralleen! Basnæs Skov (Nielsen); $S l$. Dybbol (12).

Anm. Mange Forfattere ansee denne Art for en Form af U. campestris, men da den har et meget forskjelligt og eiendommeligt Udseende og da desuden, efter hvad Hartig (forstl. Culturpfl.p 458) har gjort opmærksom paa, dens Ved er forskjelligt fra de 2 foregaaende Arters, har jeg troet at maatte opfore den som en egen Art. Det af ham frembævede Kjendemærke, at Axelbladenes Ar foroven ere omgivne af en Række Haar, har jeg dog ikke kunnet finde bekræeftet paa de af mig undersøgte Exemplarer.

$\dagger$ 367. U. effusa [Willd. prodr. Al. berol. n. 296] (Skjærmblomstret Æ.) Drej. p. 100; Rchb. I. c. tab. 1337; H. N. IV, 81 ; U. pedunculata Foug.

Bladene som hos foreg., men duunhaarede paa Underfladen og jævne (ikke rue); Blomsterne stilkede (i Skjærm); Støvdragerne 6-8; Vingefrugterne randhaarede, elliptiske, dybt indskaarne; Frøet umiddelbart under Indskjæringen.

Foruden de angivne Kjendetegn adskilles den fra de foreg. ved endnu mere skjære Blade og mindre Frugter. 4-5 (fr. 6).

Forekommer hist og her omkring Byer og Gaarde (oprindelig indført), f. Ex. Sj. Helsingor (21)! mellem Lundehuset og Bernstorf! Vesterbro (10), Alleen S. for Bidstrupgaard (14)! Loll. Borgø i Maribo S $\emptyset$ (Kherre Wichfeld); Bornh. Rabeklkegaard i Knudsker Sogn (Hjorth); $S l$. Hollingsted i Angel (Hansen), Husum (F. Müll.).

\section{Vincetoxicum. Svalerod.}

368. V. officinale [Moench method. 717] (Hvidblomstret S.) Rehb. I. c. XVII, tab. 1067; Asclepias Vincetoxicum L., H. 280 ; F. D. 849 ; Cynanchum R. Br.; Drej. n. 306. 
Stangelen opret; Bladene modsatte, æg-hjerteformede, tilspidsede; Blomsterne i Qvaster fra Bladhjørnerne, Blomsterstilkene kortere end Bladene; Kronens Flige æegformede; Bikronen femlappet med budte Lapper.

Indeholder Mælkesaft. Kronen hvid med lysguul Bikrone. 6-7. $\odot$.

I hoitliggende Kratskove, paa Brinker: paa Bornh. og i det nordlige og nordøstlige $\boldsymbol{S} j a l l$. hist $\mathrm{og}$ her, sparsommere mod S., f. Ex. Kjøge, Prambroen i Stevns Herred (9), Færø (H.); i de ovrige Provindser sjelden: $\boldsymbol{F}$. Romsø ved Hofmansgave, Nyborg (H.), Holkenhavn (Lund); J. Buderupholm (H.). l*

\section{Cuscuta. Horsilke.}

a. Epilinella Pfeiffer. Bægeret næsten til Grunden femdeelt, Arrene kølleformede.

369. C. Epilinum [Whe. Arch. der Apoth. Verein 8. p. 51] (Ager-H.) H. II, 131; Drej. n. 176; F. D. 1987; H. N. XII, 29 ; C. densiflora Soy. Will., Rehb. l. e. XVIII, tab. 1342, fig. 3 .

Stcengelen enkelt eller svagt grenet; Kronrøret kugleformet, dobbelt saa langt soin Kraven, omtrent af Længde med Bægerfligene; Bikronens Skjæl oprette; tiltrykte til Kronrøret, med nedentil afrundede Mellemrum; Kapselen forneden torummet.

Stængelen og Blomsterne bleggule, Hovederne med færre, men større Blomster end folg. 7-8. $\odot$.

Snyltende Ukrud i Horren, hist og her paa $\theta$ erne, men ikke alm. ng hidtil ikke bemærket i stor Mrengde. Paa Halvoen sjelden: Hatting ved Horsens (16); Rosgaardo (12) og Loitmark i Angel (16).

b. Cuscuta Pfeiff. Bægeret 4-5-lappet (eller-fliget). Arrene traadformede. Kapselen heelt torummet.

370. C. europaa L. (Gjærde-H.) H. 176; Drej. n. 177 ; F. D. 199; C. major DC.; Rchb. l. c. tab. 1342, fig. 4.

Stcengelen grenet; Kronrorct valseformet, af Læugde med Kraven, meget længere end Bægerfligene; Bikronens Skjæl oprette, tiltrykte til Kronrøret, tokløvede med nedentil afrundede Mlellemrum. 
Stæengelen traadformet, tilligemed Bægeret rødigt anløben. Krouen blegguul. $6-7 . \odot$.

$\beta$, nefrens Fr. (C. Schkuhriana Pfeiff. i Bot. Zeit. 1846 p. 20?) Kronrøret uden Skjæl.

Snylteplante paa Urtica dioeca, Humulus, Salix og andre vedvarende og buskagtige Væxter ved Gjærder og i Kratskove, ikke sjelden, især hyppig i Sydsjælland, Fyen og paa Øerne.

$A n m$. Formen $\beta$, som efter Fries findes paa $V i c i a$ sativa, er maaskee en egen Art, som fortjener nøiere Undersøgelse. Da Pfeiffer (l. c.) citerer F. D. 199 til C. Schkuhriana, har jeg anført denne Form her, skjøndt det ikke er mig bekjendt at den er funden i Danmark, og Mangelen af Skjæl paa Fig. i F. D. muligviis kunde hidrøre fra en Unøiagtighed ved Tegningen. En nærstaaende Art, C. Ligustri F. W. Areschoug, som er funden i det vestlige Sverige, især paa Liguster, kunde muligviis findes ogsaa her i Landet.

371. C. Epithymum [Murr. i L. syst. veg. ed. 15 p. 173] (Lyng-H.) Drej. n. 175; H. 177; F. D. 427 (slet); Rchb. 1. c. tab. 1343 , fig. $3,5,6$, H. N. XII, 31 ; C. minor DC.

Stcongelen grenet; Bagerfigene kortere end Kronen; Kronroret valseformet, af Længde med Kraven og imed Bilkronens Skjæl, som ere sammenstødende i Spidsen og tillukkende Svælget, fryndsede, med smale, spidse Mellemrum forneden; Støvknapperne fremragende.

Stænglerne baarfine, rødlige; Blomsterne mindre end hos foreg., Bægeret rødligt, Kronerne hvide. 7-8. $\odot$.

Snylteplante paa Calluna, Genista, Thymus, Helianthemum, ikke sjelden i Halvoens Hedeegne, især i den sydlige Deel, sjelden paa Øerne: $\boldsymbol{S} j$. Veirhøi i Odsherred! Tiisvilde, Ledreborg (H.), Sonnerup (Feddersen), Roeskilde (Rohde i Schlichtkrulls Herb.). F

372. C. Trifolii [Babingt. man. 2 ed. p. 216] (Kløver-H.) E. B. Suppl. 2898; C. Fpithymum $\beta$, Trifolii Choisy, Rehb. l. e. tab. 1343 , fig. 4 .

Hovederne større og mere tætblomstrede, Bikronskjollene smale, halvt saa lange som Kronrøret, ined afrundede Mellemrum forneden; Bagerfigene af Kronrørets Lxngde, forøvrigt som foreg., men hele Planten af blegere Farve. 7-8. $\odot$.

Snylteplante paa Græsmarler og især paa Kløver, i hvilken den danner rundagtige Pletter, er først iagttaget her i Landet for omtrent $20 \mathrm{Aar}$ siden, men har siden den 'I'id udbredt sig stærkt og er bemæerket i alle Provindser, paa enkelte Steder et besværligt Ukrud i Kløvermarkerne. 


\section{Iydrocotyle. Vandnavle.}

373. II. rulgaris L. (Almindelig V.). H. 304; Drej. n. 339 ; F. D. 90 ; Rehb. l. c. XXI, tab. 1842.

Stongelen krybende; Bladene skjoldformede, kredsrunde, rundtakket-lappede, læugere end Blomsterstilkene; Skjormen hovedformet, 4-6-blomstret, ofte flere Skjærme paa samme Skaft, krandsformigt fjernede fra hinanden; Frugterne ud. randede $\mathrm{i}$ Spidsen og ved Grunden.

Bladstilkene nærved Pladen langhaarede, Planten forøvrigt næsten glat. Bladene var. i Storrelse; Blomsterne meget smaae, kortstilkede eller næsten siddende. 7-9. $\%$.

I Tørvmoser, ved Søbredder og paa fugtige Enge, ikke sjelden i Danmark.

\section{Eryngium. Mandstro.}

374. E. maritimum L. (Strand-MI.) H. 302; Drej. n. 341 ; F. D. 875 ; Rehb. l. c. XXI, tab. 1849 ; H. N. XIV, 23.

Bladene haandlappede med tornet-tandede Lapper, de nedre nyreformede, stilkede, de фvre omfattende; Svøbbladene bredt kileformede, 3-5-tornet-lappede, lidet lengere end det rundagtigt-ægformede Hoved, de enkelte Blomster omgivne af tornetfligede Dwkblade.

Hele Planten glat, blaagraa, Svøbbladene violet anløbne, Blomsterne blaae. 7. 4.

Ved sandige Strandbredder (paa Havstokken), forekommer i alle Provindser, i Jyll. hyppigere paa Øst- end Vestkysten.

375. E. campestre L. (Bjerg-M.) H. 304 ; F. D. 554; Rehb. l. e. XXI, tab. 1852.

Bladene dobbelt- eller tredobbelt fjersnitdeelte, med tornettandede Afsnit; Rodbladene stilkede; Stongelbladene med en øreformet, tornet Skede omfattende; Svøbbladene linie-lancetformede, tornspidsede, meget længere end det rundagtige Hoved; Dakbladene ved Blomsterne udeelte; Bageret langere end Kronen.

Hele Planten glat, graagrøn, Blomsterne skident-hvide. 7-8. ฟ.

Sandige Bakker, meget sjelden: $\boldsymbol{J}$. i Vendsyssel of ved Viborg

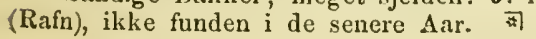




\section{Sanicula. Sanikel.}

376. S. Puroprea L. (Skov-S.) H. 305 ; Drej. n. 340 ; F. D. 283 ; Rehb. 1. c. XXI, tab. 1847.

Bladene haandsnitdeelte med saugtakkede, i Spidsen trelappede Afsnit; Skjormen dobbelt sammensat, med uligelange Straaler; Smaaskjormene danne et rundagtigt Hoved.

1' høi. Kronen rødlig-hvid. 6-7. ข.

I Skove almindelig, sjeldnere i det nordl. Jyll. (efter H.).

Astrantia. Stjerneskjarm.

† A. major L. (Stor S.) Rchb. 1. c. XXI, tab. 1843.

Rodstokken beklædt med trævlede Rester af visne Bladskeder; Bladene, især de nedre, langstilkede, dybt haandfligede med grovt og dobbelt saugtakkede, i Spidsen uregelmæssig 2-3-deelte Flige; een endestillet Skjærm og modsatte sidestillede Grene (som ende med en Skjærm og ofte have modsatte Sideskjærme); Svøbbladene talrige, under Blomstringen stjerneformigt udbredte, lancetformede; Bagerfligene braadspidsede, længere end Kronbladene.

1- $1^{1} \frac{1}{2}{ }^{\prime}$ høi, glat. Svøbbladene nætformigt aarede, hvide eller rødlige med grøn Spidse; Blomsterne og Frugternes Skjæl hvide. De sidestillede Skjærme ofte ufrugtbare. 6-8. .

Dyrkes i Haver og forekommer hist og her forvildet, f. Ex. Sj. Dronninggaard, Humletofte (9)! Aldershvile (19), Krattet ved Lundehuset! Moen v. Liselund (14).

\section{Bupleurum. Ilaregre.}

377. B. tenuissimum L. (Smalbladet H.) H. 306 ; Drej. n. 323 ; F. D. 1090 ; Rchb. 1. c. tab. 1891, fig. 2 ; H. N. I, 27.

Stcongelen grenet fra Grunden af, med opstigende eller nedliggende Grene; Bladene linie-lancetformede, tilspidsede, heelrandede; de endestillede Skjorme alm. trestraalede, de sidestillede ufuldstændige; Smaaskjarmene $3-5$ blomstrede; Blomsterne siddende, kortere end de sylformede Svøbblade; Frugten kornet-ru. 
Stænglerne traadformede, 2-8" lange. Kronbladene gule. 7-8. 4.

Paa Syltenge og Strandfielleder sporadisk og ikke alm., men bemærket $\mathrm{i}$ alle danske Provindser; sjeldnere $\mathrm{i}$ det Indre af Landet, f. Ex. $\boldsymbol{F}$. ved Skjoldemose (12).

378. B. rotundifolium L. (Rundbladet H.) H. 306 ; F. D. 2408 ; Rchb. 1. c. tab. 1880 , fig. 2 .

Stangelen opret, oventil grenct; de ovre Blade xgformede, gjennemvoxne af Stængelen, de nedre ovale, omfattende; Skjormen mangestraalet; Storsvøb 0; Smaasvøbets Blade ægformede, braadspidsede; efter Blomstringen sammensluttende omkring Frugterne; Frugten med ophøiede Striber mellem Ribberne.

$1 / 2-1^{\prime}$ høi. Kronbladene gule. 6-7. $\odot$.

Ukrud i Haver paa Ero (10); ligesaa i Haver og Marker ved Christianshavn (Visby)! Angives desuden som Ulkrud mellem Sæden fra Moen (Kyll.); Falst. ved Korselitze (H.), men er ikke funden paa disse Steder $\mathrm{i}$ de senere Aar. 可

\section{Ilelosciadium. Skjarmlille.}

379. I1. inundatum [Koch Umb. p. 126] (Svømmende S.) Drej. n. 324 ; H. N. I, 26 ; Sison L., H. 325 ; F. D. 89 ; Apium Rchb. l. c. XXI, tab. 1855, fig. 1.

De nedscenkte Blade dobbelt kamdeelte, med haarformede Flige, de ovre fjersnitdeelte med kileformede, 3-5-tligede Afsnit; Skjormene modsatte Bladene, tostraalede uden Storsvøb; Smaasvøbet faabladet.

Naar den voxer paa tor Grund er Stængelen heelt krybende og nden haardeelte Blade, i Vand bliver Stængelen forlænget, svømmende og alle Blade haardeelte ( $\beta$, fluitans Fr. H. N. VIII, 18; Rehb. 1. c. fig. 2). Kronbladene hvide. 6-8. \%.

I Torvgrave, Hedemoser $\mathrm{hg}$ red Randen af Gadekjær eller Søer : paa Øerne sporadisk, hyppigere paa II alvoen (især i den midterste og vestlige Deel og par Bornholm. $\beta$, S $j$. Hellebæk (Heiberg)! Bornh. Rønne (Hjorth); J. i A aer ved Thorsted pr. Ringkjøbing (2)! 'l'orvgrave ved Skodborg V. f. Kolding!

380. H. repens [Koch 1. c.] (Krybende S.) H. N. XIII, 42 ; Sium Jacq., H. 324; F. D. 1514; A pium Rehb. l. c. tab.. 1855, fig. 2.

Stangelen krybende; Bladene fjersnitdeelte, med rudeformet- 
ægformede, uregelmæssigt tandet-lappede Afsnit ; Skjcermen 4-7straalet med 3-5-bladet Storsvøb og fleerbladet Smaasvøb.

Kronbladene hvide. 7-8. $थ$.

I Sumpe og Torvmoser, hidtil kun funden i Fyen ved Midskor paa Hindsholm (4)!

\section{Apium. Selleri.}

381. A. graveolens L. (Have-S.) .H. 341 ; Drej. n. 325 ; F. D. 790 ; Rehb. l. c. XXI, tab. 1854.

Bladene fjersnitdeelte, de øvre enkelt eller dobbelt haandsnitdeelte; Afsnittene rudeformede eller kileformede, i Spidsen tandet-lappede; Skjormen kortstilket, dens Straaler 6-12 eller flere.

Bladene glatte, glindsende, mørkgrønne, Kronbladene hvide. Planten har en stark Lugt, som i torret Tilstand længe vedligeholder sig. 7-9. ๑.

Ved Strandbredder mellem Tang og i feed Marskbund, sporadisk og ikke alm., forekommer i alle danske Provindser, især i Sydsjœlland, Fyen og paa Oerne. Dyrkes i Haver for Rodens og Bladenes Skyld.

\section{Petroselinum. Persille.}

$\dagger$ P. sativum [Hoffm. Umb. 177] (Have-P.) E. B. Suppl. tab. 2793; P. hortense Rehb. J. c. XXI, tab. 1856; Apium Petroselinum L.

Bladene 2-3-dobbelt fjersnitdeelte, Afsnittene smalt-laneetformede, (paa Rodbladene kileformede) hele eller fligede; Skjcermen mangestraalet; Kisonbladene guulgrønne. 6-7. $\odot$.

Dyrkes alm. i Kjøkkenhaver.

\section{Aggopodium. Sqvalderkaal.}

382. A. Podagraria L. (Almindelig S.) H. 342; Drej. n. 326 ; F. D. 670 ; Rehb. 1. c. XXI, tab. 1861 .

Rodstokken med krybende Udløbere; de nedre Blade 2-3. dobbelt, de фvre enkelt haandsnitdeelte; Hoved- og Smaaafsnittene 3, stilkede, de sidste ægformede med skjæv Basis, tilspidsede, saugtakkede; Slijarmene 12-20-straalede, den midterste frugtbærende, de øvrige golde. 
Kronbladene hvide. 6-7. 4 .

$\beta$, subsimplex. Alle Bladene enkelt haandsnitdeelte, med æg-hjerteformede Afsnit.

I Skove og ved Gjærder, især i Haver et almindeligt og besvierligt Ukrud. $\beta$, Fredensborg Slotshave!

\section{Carum. Konmen.}

383. C. Carvi L. (Almindelig K.) H. 337; Drej. n. 327; F. D. 1091 ; Bunium Carvi M. B., Rehb. l. e. XXI, tab. 1872.

Bladene dobbelt fjersnitdeelte, Afsnittene fligede eller snitdeelte med smalt linieformede Afsnit; Storsvobet enbladet eller 0 , Smaasvobene 0.

Frugterne krydrede. Kronbladene hvide. Ved Grunden af Bladskederne findes i Regelen 2 haandsnitdeelte Ører med traadformetlinieformede Afsnit. 5-6. $\odot$.

$\beta$, atrorubens! Krone og de øvre Bladskeder purpurrøde.

Paa Enge, Græsgange og ved Gjærder alm. Dyrkes som Haudelsplante. $\boldsymbol{\beta}$, ved Ladegaardsaaen udenfor Kjøbenhavn (5)! Ordrups Mose!

\section{Pimpinella. Pimpinelle.}

384. P. magna L. (Stor P.) H. 340 ; Drej. n. 328; F. D. 1155 ; Relbb. l. e. XXI, tab. 1868 ; H. N. II, 41.

Stangelen kantet, furet, fleerbladet; Bladene fjersnitdeelte; Afsnittene $x$-hjerteformede, saugtakkede eller fligede; Griflerne længere end Frugtknuden og af Læengde med den ovale Frugt.

$1^{1} / 2-2^{\prime}$ høi. Kronbladene hvide, var. ( $\beta$, rosea Koch) med rosenrøde Kroner. 6-7.

Paa Enge og i fugtige Kratskove: i det nordvestlige Sjall. ikke sjelden, mod S. ved Nestved (H); Falst. Gaabense! Loll. alm. (14); $\boldsymbol{F}$. Bogense; J. Ebeltoft (H.); Als alm.! St. Hoyer, Kappel, Klapskov ved Slesvig (16); $\beta$, med Hovedarten, f. Ex. Enge ved Leersøen! -

385. P. Saxifraga L. (Almindelig P.) H. 338; Drej. n. 329 ; F. D. 669 ; Rehb. l. c. tab. 1869.

Stangelen trind, stribet, med bladløse Skeder foroven; Rodbladene fjersnitdeelte, med xgformede, saugtakkede eller 
fligede Afsnit, Stcongelbladene dobbelt fjersnitdeelte; Griflerne kortere end Frugtknuden og den ægformede Frugt.

$1 / 2-11^{\prime}$ høi. Skjærmene for Udspringningen nikkende. Kronbladene livide (var. ros. ligesom foreg.) 7-8. $\psi$.

$\boldsymbol{\beta}$, dissectifolia Wallr.; Rehb. 1. c. fig. 4. Bladene fjersnitdeelte, med linieformede Afsnit.

Paa Groftevolde, Græsmarker og Balkker, alm. udbredt. $\beta$, med Hovedarten.

Anm. P. nigra Willd. (H. 340) med tæt duunhaarede Blade, Grene og Blomsterstilke, Roden tyk, indeholdende en ved at udsæettes for Luftens Paavirkning blaaagtig Saft, er angivet fra Immingsted pr. Husum (F. Müll.) og med 'Tvivl fra Erø (Bendtsen, 12). - Jeg har ikke seet danske Expl. af denne Art, men da den findes saavel i Skåne som i Holsteen, er det rimeligt at den ogsaa forekommer her, og den anbefales derfor til nøiere Eftersøgning.

\section{Cicuta. Giftyde.}

386. C. virosa L. (Vand-G.) H. 328 ; Drej. n. 330 ; F. D. 208; Rchb. l. c. XXI, tab. 1853.

Rodstokken afdeelt ved Tværskillerum; Rodtrcelerne traadformede; Bladene 2-3-dobbelt fjersnitdeelte; Afsnittene linielancetformede, saugtakkede; Storsvølet 0 eller faabladet; Smaasvobbladene talrige, sylformede.

Stængelen tyk, huul, 2-4' høi. Kronbladene hvide. Giftig。 7-8. 2.

I Moser, ved Sø- og Aabredder ikke sjelden.

\section{Falcaria. Seglblad.}

387. F. Rivini [Host, fl. austr. I, 381] (Langfinnet S.) Rehb. l. c. XXI, tab. 1862 ; Sium Falcaria L., H. 324 ; F. D. 1749 ; H. N. II, 40; Critamus Falcaria Rehb.

Bladene haandsnitdeelte, det midterste Afsnit tredeelt, Sideafsnittene 2-3-deelte, med langstrakt-linieformede, fint og skarpt saugtakkede Afsnit, nedløbende i den vingede Smanbladstilk; Stor-og Smaasvob fleerbladede.

Kronblatene hvide. 7-8. 4 .

Paa Marker mellem Sæden, sjelden: $\boldsymbol{S}$ j. Skove mellem Jonstrup og Roeskilde (14)! Loll. mellem Vesterborg og Vedby, Rubjergmark 
ved Juellinge (19)! Bor $n h$. en Fng meliem Vallensgaards Mose og Almindingen (Baagøe)! (Angives af $\mathrm{H}$. fra Frergegaarden ved FemernSund, muligviis i Holsteen og ikke paa den slesvigske $\emptyset$ Femern). "

\section{Sium. Marke.}

388. S. latifolium L. (Bredbladet M.) H. 322 ; Drej. n. 331 ; F. D. 246 ; Rehb. 1. c. XXI, tab. 1877.

Rodstokken krybende; de nedre Blade langstilkede, 2-3dobbelt fjersnitdeelte; Smaaafsnittene linieformede, de gvre Blade stilkløse, enkelt fjersnitdeelte med lancetformede, skarpt og ligeligt saugtakkede Afsnit; Stor- og Smaasvøbene fleerbladede, ined lancetformede, hele Blade; Frugtens Sideribber randstillede; Oliekanalerne tydelige udenpaa Frøgjemmet.

$3-5^{\prime}$ høj. Bladstilkene paa de nedsænkte Blade leddede. Kronbladene bvide. $7-8$. 4 .

Ved Bredderne af Søer, Aaer og Kjær, alm. udbredt.

389. S. angustifolium L. (Smalbladet M.) H. 322 ; H. N. I, 25; Berula Koch, Drej. n. 332; Rchb. 1. c. tab. 1878; Sium nodiflorum F. D. 247 (ikke L.).

Rodstokken krybende; Bladene fjersnitdeelte; Afsnittene ægformet-elliptiske, dybt og uregelmæssigt saugtakkede (ved Grunden ofte fligede); Skjarmene kortstilkede, modsatte Bladene; Svobene fleerbladede, med lancetformede, i Storsvøbet alm. indskaarne Blade; Frugten med svage Ribber, Sideribberne indenfor Randen; Oliekanalerne ikke tydelige udenpaa Frø. gjemmet.

1-3' høi. Kronbladene hvide. 7-8. ข.

Ved Grøfter, Bakke og Kilder alm. ndbredt. $\bar{\square}$

\section{Oenanthe. Klaseskijarm.}

a. Roden dannet af knippestillede, kjødfulde

Trævler; Frugten bredest oventil.

390. Oe. fistulosa L. (Vand-K.) H. 325; Drej. n. 335; F. D. 846 ; Rehb. I. c. tab. 1898 ; H. N. II, 39.

Rodtravlerne kølleformet-aflange eller traadformede; Rod- 
stokken med Udløbere; Rodbladene 2-3-dobbelt fjersnitdeelte; Stcongelbladene enkelt fjersnitdeelte med linieformede, budte Afsnit, Udløbernes Blade dobbelt fjersnitdeelte med omvendt-ægformede, 2-3-lappede Afsnit; Bladstillen opblæst huul, længere end Fladen; den først udviklede Skjorm 2-3-straalet med frugtbare Blomster, (Smaaskjærmene i Frugttilstanden kugleformede), de senere 4-10-straalede med ufrugtbare Blomster; Frugten kantet, ouvendt-kegleformet, kortere end de vedblivende Grifler.

Planten af en blaagrøn Farve. Kronbladene rødlig-hride. 7-8, 4 .

I og red Randen af Aaer, Grøfter og Kjær, alm. udbredt.

391. Oe. Lachenalii [Gmel. fl. bad. I, p. 678] (Eng-K.) Drej. n. 336 ; Rehb. l. c. tab. 1892 ; H. N. XV, 25; Oe. pimpinelloides Sm., H. 325; F. D. 1454 (ikke L.)

Rodtravlerne forlænget-kølleformede (og nogle traadformede); Rodbladene dobbelt fjersnitdeelte med aflange eller kileformede, budt 2-3-lappede Afsnit, de nedre Stcengelblade 2-3-dobbelt, de øvre enkelt fjersnitdeelte, med smalt linieformede, spidse Afsnit; Bladstilken kortere end Pladen; Skjormene 6-12-straalede, de ydre Blomster i Smaaskjærmene langstilkede, ufrugtbare, de indre frugtbare, næsten siddende (Smaaskj:rmene $\mathbf{i}$ Frugttilstanden balvkugleformede); Frugten omvendt-ægformet, længere end de vedblivende Grifler.

Rodbladene henvisne meget tidligt. Kronbladene rødlig-hvide. 7-8. 4 .

Paa Enge, især i Nærheden af Stranden, sjelden: $\boldsymbol{S} \boldsymbol{j}$. Tappernøie, Evenet red Præstø, Gaunø, Kongebroen ved Korsør (H.); Falst. (Kyll.), Nøisomhed ved Nykjøbing (14)! Thorseng ved Stioul (9); F. Svendborg (11), Holkenhavn (Lund), Langø ved Hindsholm! J. Palsgaard (H.); S l. Sverdrup ved Haderslev Fjord (Grønlund), Gjenner (28)! Aabenraa (N.), Bæverør ved Gelting (16), Husum (H.). *

b. Roden dannet af krandsstillede, traadformede Trævler. Frugten smalere oventil.

392. Oe. Phellandrium [Lam. fl. fr. 3, p. 432] (BilleboK.) Drej. n. 337; Rchb. l. c. tab. 1896; Phellandrium aquaticum L., H. 327 ; F. D. 1154.

Rodstokken med Udløbere; Stcengelen grenet; Grenene ud- 
spærrede; Bladene 2-3-dobbelt fjersnitdeelte; Afsnittene udspilede, omvendt-ægformede eller elliptiske, dybt fligede, med lancetformede Flige, de uedsænkte Blade med haarformede Afsnit; Skjormen inangestraalet; alle Blomsterne i Smaaskjærmene stilkede; Frugten xgformet-elliptisk.

2-3' høi. Giftig. Kronbladene hvide. 7-8. $\odot$ eller $\psi$.

I Søer, Damme og Tørvgrave alm. udbredt.

Anm. 1. Blade, samlede i Varde Ar (30)! synes at tilhøre Oe. fluviatilis Colem. (Bab. man. brit. bot. ed. 3 p. 140, E. Bot. Suppl. 2944), som udmærker sig ved de under Vandet nedsæenk te Blade, hvis Afsnit ere meget forlængede, parallele, linieformede eller linie-kileformede, hvorimod Bladene ovenfor Vandet have bredere Afsnit end Oe. Phellandrium, af hvilken den dog muligviis kun er en Afart. Maa yderligere eftersøges i rindende Vand.

Anm. 2. At eftersøge Oe. conioides (Phellandrium conioides Nolt. i Hansens Herb. N. 215), hvis noiere Beskrivelse af Forf. (Index sem. hort. Kilon. ?) er mig ubekjendt. Den ligner i Udseende endeel Conium maculatum og synes især forskjellig fra foreg. ved storre Blade med bredere og grovere Flige, samt ved dobbelt saa store, lancetformede Frugter. Den er funden i Holsteen (Nolt.) og findos muligviis ogsaa i det egenlige Danmark. (Frugter af Expl. fra Ollerup i Fyen (12), synes at hore berhen).

\section{Libanotis. Iljorterod.}

393. L. montana [All. fl. ped. 2, p. 30] (Laaden H.) H. N. XII , 45; L. vulgaris DC., Drej. n. 338; Athamanta Libanotis L., H. 314 ; F. D. 754.

Stcengelen kantet, furet; Bladene dobbelt fjersnitdeelte; Afsnittene halvfinnede med clliptiske, braadspidsede Flige; det nedre Par Afsnit tiltrykte til Bladstilken; Stor- og Smaasi $\sigma b$ fleerbladede.

Hele Planten, især Frugter og Blomsterstilke, duunhaarede; Rodhalsen beklædt med de trævleformede Rester at henvisnede Bladskeder. 1-3' høi. Kronbladene hvide eller rødlige. 7-8. 4.

Paa Strandskrænter, sandige Bakker, sjelden og sporadisk: $\boldsymbol{S} \boldsymbol{j}$. Jægersborg, Valdbygaard (H.), Korsør (14)! Reersø (Dr.), Seierø (Baagøe), Nexelø, Odsherred mellem Overby og Ebbelykke (H.), Refsnæs (15); nordl. Samse (Jaeobsen); F. Fyenshoved (H.)! $S l$. Gram (16), Svanskilde (H.); Loll. Gottesgabe (19), Kramnitze Odde ved Rødby Fjord!

\section{Ilaloscias. Lostilk.}

394. II. scoticum [Fr. S. Veg. Sc. p. 180] (Skotsk L.) H. N. XI, 28; Ligusticum L., H. 319; F. D. 207. 
Bladene dobbelt trekoblede; Afsnittene rudeformet-elliptiske, foroven grovt og uregelmæssigt saugtakkede (Sideafsnittene skjæve); Stor - og Smaasvøbbladene 5-7, uligestore, tiltrykte.

Stængelen stribet, nedentil rødlig, 1-2' høi, hele Planten glat, Bladene glindsende. Kronbladene hvide. 7. 4.

Ved Strandbredder meget sjelden: $J$. Tyvholm og Græsholm ved Frederikshavn(Dr.), Lokken (H.), Ørum Klit i Thy (Andresen)! L oll. ved Rødby (F.D.)? \#

\section{Athusa. Ilalvsvob.}

395. A. Cynapium L. (Vild Persille). H. 329; Drej. n. 334 ; F. D. 1991 ; Rehb. 1. c. tab. 1901.

Bladene 2-3-dobbelt fjersnitdeelte; Afsnittene halvfinnedo med lancetformede Flige; Storsvøbet 0, Smaasvøbbladene alm. 3 , linieformede, nedhængende, ensidige, længere end Smaaskjærmene; Bugfladens Oliekanaler foroven sammenstødende, nedentil (ovenfor Basis) bueformigt nærmede til hinanden (ikke sammenlobende).

Giftig. 1-2' høi. Bladene glatte, mørkgrønne, af en svag, men ubehagelig Lugt. Kronbladene hvide. 6-9. $\odot$.

$\beta$, pygmcea Koch (ÆE. segetalis Boenn.) 2-6" høi; de nedre Blade trekoblede, med budte Flige, Smaasvøbene korte, Blomsterstilkene lidet længere end Frugten.

Almindeligt Ukrud i Haver, $\beta$, mellem Sæden.

\section{Cnidium. Braendeskjarm.}

396. C. renosum [Koch Umb. 199] (Fiinbladet B.) Drej. n. 333 ; H. N. IV , 30; Selinum lineare Schum. p. 95; H. 314 ; F. D. 1330 ; Selinum silvestre L. sp.

Stcengelen trind, stribet; Bladene dobbelt fjersnitdeelte, med forlængede Bladskeder (ingen Bladstilk paa Stængelbladene); Afsnittene linieformede, spidse, med ophøiet Midtnerve paa Underfladen; Svobbladene børsteformede, Smaasvøbet af Smaaskjærmens Længde.

1-2' høi. Kronbladene hvide. 7-9. 4.

Paa høie Enge, ved Gjærder, mellem Krat, meget sjelden; S joll. 
Sundbyvester (19) og Kongelunden paa Amager! Vesterfalled og Flaskekroen! Lille Virolgse Overdrev (Mort.); $\boldsymbol{F}$. Strandbredder ved Svendborg (H.); J. Bjørum Skov (Beck). $\sqrt{x}$

\section{Peucedanum. Svovlrod.}

397. P. palustro [Moench meth. 82] (Kjær-S.) Drej. n. 317 ; Selinum L., H. 312 ; F. D. 257 og 412 (S. silvestre); Thysselinum Hoffm., Koch. Syn. II, 336.

Stungelen furet; Bladene 2-3-dobbelt fjersnitdeelte; Smaaafsnittene bele eller dybt deelte, med linie-laneetformede, braadspidsede Flige; Stor- og Smaasvobbladene talrige, laneetformede, nedbriede; i Randen hindeagtige; Skjormens Straaler eensidigt duunhaaret rue; Oliekanalerne paa Bugfladen ikke synlige udenpaa Frøgjemmet.

$3-5^{\prime \prime}$ høi. Bladenes Flige og især Svøbbladene i Randen rue, forøvrigt glat. Kronbladene hvide. 7-8. 4 .

I Tørvmoser, paa fugtige Enge, mellem Krat, alm. udbredt.

398. P. Oreoselinum [Moench meth. 82] (Udspilet S.) H. N. II, 38; Athamanta L., H. 315 ; F. D. 1750.

Stungelen trind, stribet; Bladene tredobbelt fjersnitdeelte, med langstilkede, stivt udspilede eller næsten tilbagebøiede Afsnit; Smaaafsnittene elliptiske, indskaaret-tandede; Stor-og Smaasvøbene mangebladede, med linieformede, nedbøiede Blade; Oliekanalerne paa Bugfladen synlige udenpaa Frøgjemmet.

1-3' høi. Kronbladene hvide. 7-8. 4.

Paa Bakker, høie Enge: i det egenlige Danmark kun funden paa Bornh.: Duebjerggaard i Almindingen (8)! Kleven (Feddersen), Almegaard nar Ronne (20)! Splitsgaard (14) o. H. St. i det nordvestlige Bornh. (Baagøe). (I Jolsteen, Nolte.)

\section{r1. Inperatoria. Storskjarm.}

X 399. I. Ostruthium L. (Mesterrod). H. 335 ; H. N. V, 13; Peucedanum Koeh.

Stcengelen trind, stribet; Bladene trekoblede; Afsnittene dybt todeelte, med ægformede eller elliptiske, skarpt og dobbelt saugtakkede Afsnit; Bladskederne stole; Storsvob 0; Smaasvob- 
bladene børsteformede, hurtigt affaldende; Frugterne kredsrunde.

2-4' høi, glat, med store, mangestraalede Skjærme.

Angives af Kylling fra Bornholm, hvor den endnu dyrkes Bønderhaver (20), og muligviis aldrig har været vildvoxende.

\section{Ileracleum. Bjørneklo.}

400. II. Sphondylium L. (Almindelig B.) H. 317; Drej. n. 319 ; F. D. 2406 (H. sibiricum * australe Hartm.).

Stcongelen furet; Bladene enkelt eller dobbelt fjersnitdeelte; Afsnittene snitdeelte, balvfinnede eller lappede med uregelmæssigt tandet-saugtakkede Lapper (eller Flige), Smaaskjormene flade, de ydre Kroner større; Frugtknuden duunhaaret; Frugten oval, svagt udrandet, tilsidst glat.

$3-5^{\prime}$ h $₫ \mathrm{j}$, stivhaaret-ru. Kronbladene hvide eller rødlige. $6-8$. ().

Var. betydeligt i Henseende til Smaabladenes Form og Indskjæringer. Den meest afvigende Form er:

$\beta$, elegans Koch. Bladene dobbelt fjersnitdeelte, med forlænget-lancetformede, langt tilspidsede Afsuit.

Paa Enge, ved Gjærder og i Udkanten af Skove, meget alm. $\beta$, sjeldncre, f. Ex. Sj. ved Sorø! Bakkerne ved Ørholm og Brede (H.), Bornh. ved Helligdommen i Rø Sogn (19).

* 401. II. sibiricum L. (Sibirisk B.) Fr. mant. 2, 16; H. N. IV, 29; Drej. i Krøy. Tidsskr. III, 414.

Smadskjormene hvælvede; Kronerne omtrent ligestore, grøngule; Frugthnuderne og de rundagtigt-ovale, dybt udrandede Frugter glatte, forøvigt som foreg.

Var. ligesom foreg. i Henseende til Bladene. 6-8. $\odot$.

Paa lignende Steder som den foregaaende Art. Jeg har ofte: fundet Former, som svare til Beskrivelsen hos Fr., men byppigere saadanne, der syntes at danne en Overgang til $\mathrm{H}$. Sphondylium. (Saa udmærket som den forekommer $\mathrm{i}$ den nordsvenske Flora har jeg aldrig seet den hos os. Dens Fordeling og bestemtere Begræendsning fra foreg. bor nærmere iagttages). |*

\section{Pastinaca. Pastinak.}

402. P. sativa L. (Almindelig F.) H. 335 ; Drej. n. 318 ; F. D. 1206 ; L. Herb. VI, 120. 
Stcengelen kantet, furet; Bladene fjersnitdeelte, de nedre ofte dobbelt fjersnitdeelte; Afsnittene rg-laneetformede; grovt saugtakket-lappede, glindsende, glatte eller paa Underfladen svagt duunhaarede; Svoh 0; Frugterne kredsrund-ovale.

2-3' høi. Roden (i det forste Aar) spiselig. Kronbladene gule. 7-8. $\odot$.

$\boldsymbol{\beta}$, silvestris. Bladene paa begge Flader duunharede.

Ved Veie, omkring Byer, paa høie Enge o. s. v. alm. udbredt i S jall. (især omkring Kjobenhavn) og paa $\boldsymbol{H}_{\boldsymbol{\theta}}$ en; i mange Egne sparsom, synes f. Ex. at mangle paa Boruholm, og ofte kun forvildet, da den dyrkes i Haver. $\beta$, med Hovedarten, f. Ex. ved Pesthuset udenfor Kjøbenhavn!

\section{Anethum. Dild.}

† 403. A. graveolens L. (Have-D.) H. 336; F. D. 1572.

Stcengelen trind, stribet; Bladene dobbelt fjersnitdeelte, med linieformet-traadformede $A f s n i t$; $s v \propto b 0$.

$1-3^{\prime}$ høi, glat, blaagrøn. Kronbladene gnle. Har en stærk krydret Lugt. 7-8. $\odot$.

Dyrkes i Haver og forekommer derfra hist og her forvildet.

75. Levisticum. Lovstikke.

† 404. L. officinale [Koch Umb. p. 101] (Almindelig L.) Drej. p. 114; Ligustieum Levisticum L., H. 318; Hayne Arzn. I, 82 e. tab.

Stungelen trind, stribet; Bladene dobbelt fjersnitdeelte; Afsnittene kileformet-rudeformede, i Spidsen tandet-lappede; Svobbladene laneetformede; Blomsterstilliene meget korte.

$4-5^{\circ}$ høi; Stængelen blaadugget, Bladene glindsende, Kronbladene gule. Har en stærk og gjennemtrængende Lugt, omtrent som Selleri. 7-8. .

Dyrkes hist og her i B gnderhaver og forckommer forvildet, f. Ex. Sj. i Hammermolleskoven ved Helsingor! F. Lykkesholms Skov; J. V. Haldne i Vadun Sogn (Vendsyssei)! ved Norre Tranders (H.); Bornh. Allinge (Hjorth). Fa

\section{ร6. Selinum. Seline.}

405. S. Carvifolia L. (Kommenbladet S.) H. 313; Drej. n. 322 ; F. D. 667. 
Stongelen furet, vinget-kantet; Bladene 2-3-dobbelt fjersnitdeelte; Afsnittene indskaarne, med lancetformede, braadspidsede, i Randen rue Flige; Bladskederne korte; Smaasvøbbladene traadiformede.

2-3' høi. Kronbladene hvide. 7-8. 4.

I Tørv- og Hedemoser, paa høie Enge mellem Krat, ikke sjelden men sporadisk, hyppigere paa Halvøen end paa Øerne. ॠ

\section{Angelica. Angelik.}

406. A. silvestris L. (Skov-A.) H. 321 ; Drej. n. 320 ; F. D. 1639 .

Stcongelen trind, stribet, foroven tilligemed Skjormens Straaler fløielsagtigt duunbaaret; Bladene 2-3-dobbelt fjersnitdeelte; Afsnittene ægformet-elliptiske, fint og skarpt saugtakkede ; Bladskederne store, opblæste; Storsvobet faabladet, affaldende; Smaasvøbbladene flere, traadformede.

3-5' høi. Stængelen huul, tyk, blaadugget. Kronerne hvide eller rodlige. $7-8$. 4 .

I fugtige Skove og paa Enge mellem Krat, alm. udbredt.

\section{Archangelica. Qvan.}

407. A. littoralis [Fr. S. Veg. Sc. p. 181] (Vand-Q.) H. N. X, 23; Angelica Fr. fl. Hall. p. 51; Drej. n. 321 ; F. D. 2407; Angeliea Arehangelica $\alpha$, L., H. 320 (tildeels, med Undtagelse af flere Synonymer og Voxestederne fra de nordlige Lande).

Stongelen trind, furet, glat; Slijormens Straaler duunhaarede; Bladene 2-3-dobbelt fjersnitdeelte; Afsnittene skjævtægformede, grovt og skarpt-saugtakkede, Endeafsnittet trefliget; Bladskederne store, opblæste; Storsvobet mangebladet, med linieformede Blade; Smaasvobbladene flere, linieformede; Smaaskjormene hvælvede efter Afblomstringen.

4-6' høi. Stængelen tyk, huul, rødlig, Bladene blaagrønne, Kronbladene bleggrønne. 7-8. 4.

Ved Bredderne af Bække og Aaer, som den ofte følger i lange 
Strækninger: bemærket i alle Frovindser; ogsaa, men sjeldnere, ved Strandbredder: f. Ex. ved flere Fjorde paa Halvøens Ostside (7).

Anm. A. officinalis Hofjm. (Angelica Areliangelica $\beta$, L.) er ikke funden i Danmark.

\section{Laserpitium. Foldfre.}

408. L. latifolium L. (Bredbladet F.) H. 316 ; Drej. n. 316 ; F. D. 1513.

Stangelen trind, stribet; Bladene 2-3-dobbelt fjersnitTeelte; Afsnittene hjerteformede, saugtakkede; den indadvendte Side af Skjormens Straaler ru; Storsvobet mangebladet, med lancet-sylformede Blade.

$3-5^{\prime}$ høi. Kronbladene hvide. 7-8. 4. Bladene paa Underfladen blaagrønne, alm. glatte, var.

$\boldsymbol{\beta}$, asperum (Crantz). Bladstilke og Smaablade i Randen og paa Underfladen rue.

$\gamma$, tenuisectum, Bladenes Afsnit linie-laneetformede, heelrandede.

I Skove, meget sjelden og kun funden i Sjw ll.: Slangerup, Jonstrup Vang, Hareskoven (H.), Ballerup, Kirkeværløse, ved Søndersøen S. for lille Værløse, Hesttaugs Mølle (14)。 $\gamma$, i Jonstrup Vang (14).

\section{Daucus. Gulerod.}

409. D. Carota L. (Almindelig G.) H. 308; Drej. n. 315 ; F. D. 723.

Stcengelen furet, stivhaaret-ru; Bladene dobbelt fjersnitdeelte; Afsnittene mere eller mindre dybt halvfinnede, med lancetformede, tilspidsede Flige; Storsvøbets Blade kamdeelte, sjeldnere tredeelte, med linieformede Afsnit, ved Udspringningen omtrent af Skjærmens Længde; Biribbernes Torne af Længde med Frugtens Trærsnit.

1-2' høi. Roden hos den vilde Plante hvidagtig, hos den dyrkede brandguul, Skjærmen efter Afblomstringen huul (ved de ydre Straalers Sammentrækning), Kronbladene hvide eller rødlige, de midterste Blomster i Skjæermen ofte morkrode, golde. 7-8. $\odot$.

Ved Gjærder of paa Narker, alm., isæer meget hypig i Fyen og paa Loll. - Falst.l Dyrkes i Haver formedelst dens spiselige Rod. 


\section{Caucalis. Fodangel.}

410. C. daucoilles L. (Faastraalet F.) H. 307; Drej. n. 307 ; F. D. 2346 .

Stcongelen kantet, furet; Bladene 2-3-dobbelt fjersnitdeelte; Afsnittene fjersnitdeelte eller halvfinnede, med linie-laneetformede, spidse Flige; Storsvobet 0 eller enbladet; Skjormen faa- (omtr. tre-)straalet; Smaasvobbladene 3-5, laneetformede, med hindeagtig Rand og randhaarede; Smaaskjormene fleerblomstrede, men kun med $2-3$ frugtbare Blomster; Frugten elliptisk, $B$ ribbernes Pigge hagekrummede, af Længde med Frugtens Tværsnit.

$1 / 2-1^{\prime}$ høi. Bladene og Stængelens Led haarede; Kronbladene rødlige. $6-7 . \odot$.

Paa dyrkede Marker, mellem Sæden, meget sjelden: $\boldsymbol{M} \theta$ en ved Sømark (H.), Graaryg (9), Fruerstuefaldet (14)! $S l$. i Egnen af Husum (Ferd. Müll.). ॠ

\section{Torilis. Randfro.}

411. T. Anthriscus [Gmel. fl. bad. I, p. 615] (Hvashaaret R.) Drej. n. 308; Tordylium L., F. D. 919; Caucalis H. 307.

Stcongelen opret, ru, foroven furet; Bladene dobbelt fjersnitdeelte; Afsnittene elliptiske, halvfinnede eller saugtakkede; Skjormene langskaftede; Storsvøbet fleerbladet med linieformede Blade; Biribbernes Pigge sylformede, spidse, bøiede (ikke hagekrummede).

1-3' høi. Kronbladene rodlige eller hvide. 6-7. $\odot$.

Ved Gjærder og Veie, i Krat o.s. v. alm. udbredt.

412. T. nodosa [Gärtn. fruct. I, p. 82] (Knudret R.) H. N. XII, 44; Tordylium L.; Canealis Seop., H. 308; F. D. 1990.

Strongelen opstigende eller nedliggende, trind, stribet; Bladene dobbelt (de øvre enkelt) fjersnitdeelte; Afsnittene mere eller mindre dybt halvfinnede; Shjormene kortskaftede, modsatte Bladene, tætblomstrede (Blomsterne næsten siddende), 
mod Frugtmodningen kugleformede; Storsvobet fleerbladet, med linieformede Blade; de ylre Frugter beklædte med hagekrummede Pjgge, de indre med rue Vorter.

$1 / 2-1^{1} / 2^{\prime}$ høi. Kronbladene hvide. 6-8. $\odot$.

Paa Diger og tørre Marker; i vor Flora kun funden paa Marskdigerne i det vestlige Slesvig: Dagebøl, Husum(H.!), Eidersted (N.). $\rightarrow$

\section{Anthriscus. Korvel.}

a. Frugterne beklædte med krogede Smatorne.

413. A. Vulgaris [Pers. Syn. I, 320] (Gjærde-K.) Drej. n. 311 ; Seandis Anthriscus L., H. 332; Cauealis seandicina Roth, F. D. 863 .

Stangelen glat, trind, stribet; Bladene 2-3-dobbelt fjersnitdeelte; Afsnittene mere eller mindre dybt halvfinnede; Bladskederne randhaarede; Bladstille og Nerver, især paa Underfladen, haarede; Skjormene kortskaftede, modsatte Bladene; Smaasvobet 2-3-bladet, med laneet-sylformede, randhaarede Blade; Nobet ${ }_{1 / 3}$ af de ægformede Frugters Længde.

'1/2-2' høi. Kronbladene lıvide. 5-6. $\odot$.

Ved Gjærder, især omkring Byer: i Sjall., paa Bornh. og de gvrige sydlige Oer ikke sjelden; sparsommere i Fyen; paa II alveen sjelden: J. Aarhus (Aagaard), Braband (16), Horsens (13); Sl. Rødding, Husum (16), Owschlag, Nybel ved Rendsborg (20).

b. Frugterne glatte.

$\dagger$ 414. A. Cerefolium [Hoffm. Umb. p. 41] (Have-K.) Drej. p. 111; Scandix L., 11. 331; Chærophyllum sativum Gärtn., F. D. 1640; Cerefolium sativum Bess.

Stangeten trind, stribet, Ledstykkerne ved Grunden duunhaarede; Bladene tredobbelt fjersnitdeelte; Afsnittene halvfinnede ; Bladskederne randharede, Bladstilke og Nerver spredt-haarede; Skjormene endestillede, paa kortere eller liengere Skaft, eller sidestillede (modsatte Bladene), siddende; Smaasvobet 2-3bladet, med lancetformede, randhaarede Blade; Nobet $1 / 3$ af den linieformede Frugts Længde. 
1-3' høi. Har en stærk og behagelig Lugt. Kronbladene hvide. $5-6$. $\odot$.

Ved Gjærder og omkring Byer, oprindelig forvildet fra Haver, hvor den dyrkes.

415. A. silvestris [Hoffm. Umb. p. 40] (Vild K.) Drej. n. 310 ; Chærophyllum L., H. 333 ; F. D. 2050.

Stungelen furet, forneden haaret, foroven glat; Bladene 2-3dobbelt fjersnitdeelte; Afsnittene mere eller mindre dybt halvfinnede, glatte eller paa Underfladen fjerut-haarede; Skjormene endestillede, langskaftede, før Udspringningen nikkende; Smaasvobet omtrent fembladet, med ægformede, tilspidsede, hule Blade; Nobet ${ }^{1 / 5}$ af den xg-lancetformede Frugts Længde.

2-3' hoi. Bladskederne og Bladstillene ved Grunden af Af: snittene haarede. Kronbladene hvide, udstraalende. 5-6. ข.

Paa Enge, ved Gjærder og i Skove meget alm.

\section{Scandix. Langnab.}

416. S. Pecten Veneris L. (Kamformet L.) H. 331; Drej. n. 309 ; F. D. 844 ; H. N. IV, 28.

Bladene dobbelt fjersnitdeelte; Afsnittene haandsnitdeelte, med linieformede Afsnit; Smaasiobbladene randhaarede, hele eller i Spidsen 2-3-fligede; Nobet fladtrykt fra Ryggen, i Randen tilligemed Frugtens Ribber ru; Griflerne oprette.

$1 / 2-1^{\prime}$ høi. Kronbladene hvide, udstraalende. Griffelfoden mørkrød. 6-7. $\odot$.

Paa Marker mellem Sæden, sjelden i den nordlige Deel af Landet: J. Aalborg (Dr.); $\boldsymbol{S} j$. udfor Tuborg (26)! Vordingborg (Koblse); alm. Ukrud paa Mloen, Falster, Lolland (!) og Femern (H.).

\section{Chaerophyllum. Huulsvob.}

417. C. temulum L. (linudret H.) H. 334 ; Drej. n. 312 ; F. D. 918 .

Stongelen trind, stribet, under Ledene opsvulmet, forneden stivhaaret ru, foroven haaret; Bladene haarede, dobbelt fjersnitdeelte; Afsnittene germede, halvfinnet-lappede med rundtakketsaugtakkede Lapper; Slijormene endestillede, før Udspringningeu 
nikkende; Smaasvobet 5-8-bladet med xg-lancetformede, tilspidsede, randhaarede Blade; Ribberne glatte.

1-2' høi. Stængelen nedentil rødplettet. Kronbladene hvide. 6-7. $\odot$.

Ved Gjærder og i Kratskove alm. udbredt.

\section{Myrrhis. Sodskjarm.}

418. II. odorata [Scop. fl. carn. p. 207] (Spansk Kørvel). Drej. n. 313 ; F. D. 1928; Scandix L., H. 330.

Stangelen trind, furet; Bladene haarede, 2-3-dobbelt fjersnitdeelte med $x$ g-lancetformede, halvfinnede Afsnit; Skjoermene endestillede; Smaasvobbladene lancetformede, langt tilspidsede, haarede, nedhængende; Griflerne tilbagebøiede.

$2-3^{\prime}$ høi. Stærklugtende (omtr. som Anthriseus Cerefolium). Kronbladene hvide; den modne Frugt mørkbruun, glindsende $\left(1 / 2{ }^{\prime \prime}\right.$ lang). 5-6. 4 .

Omkring Haver, Byer o. a. beboede Steder, sporadisk i alle Provindser, (formodenlig forvildet fra en tidligere Tids Havekultur, skjøndt den nu ikke langere dyrkes).

\section{Conium. Skarntyde.}

419. C. maculatum L. (Plettet S.) H. 311 ; Drej. в. 314 ; F. D. 2168 .

Stcengelen glat, trind, oventil furet; Bladene tredobbelt fjersnitdeelte, med lancetformede, halvfinnede Afsnit; Storsvobet 6-7-bladet; Smaasrolet 3-4-bladet, ensidigt, med $x$-lancetformede, glatte Blade.

$2-4^{\prime}$ høi, glat, glindsende; Stængelen rødplettet. Giftig. Kronbladene hvide. $6-7$. $\odot$.

Ved Gjærder og Veigrøfter, især omkring Byer o. a. dyrkede Steder, ikke sjelden: mindre hyppig $\mathrm{i}$ Kjøhenhavns Omegn end $\mathrm{i}$ de fleste andre Egne af Landet og ilke bemærket paa Bornholm (Hoff).

\section{Coriandrum. Koriander.}

† 420. C. satirum L. (Have-K.) H. II, 158; F. D. 1989.

Stcengelen trind, stribet, glat; Bladene 2-3-dobbelt fjer- 
snitdeelte; Afsnittene fjersnitdeelte eller halvfinnede, med linieformede Flige (Rodbladene ligesaa, men med bredere Flige); Smaasvøbbladene ensidige, linieformede.

1-2' høi. Kronbladene hvide eller rødlige, udstraalende. Frugterne krydrede. 6-7. $\odot$.

Dyrkes undertiden, dog sjeldent, i Haver, og forekommer forvildet: Sj. Kjøbenhavn ved Farimagsveien! Kjøge (9); Fre (N.); J. Horsens $(2) ; S l$. Aabenraa (H.). *

\section{Trigynia.}

\section{Viburnum. Qvalkved.}

421. V. Opulus L. (Sneebolletræ). H. 343 ; Drej.n. 342 ; F. D. 661 ; Rehb. ic. fl. germ. XVII, tab. 1171.

Bladene handnervede, 3-5-lappede, med tilspidsede, tandede Lapper; Bladstilken foroven tokirtlet; $2-4$ linieformede Axelblade ved Grunden af hvert Blad; Blomsterne i mangegrenet og mangeblomstret Qvast, Straaleblomsterne golde, med hjulformede Kroner; Borret kugleformet; Frøet Aladtrykt.

Kronerne hvide. Straaleblomsterne have ofte 5 rode Kirtler (feilslaaede Støvdragere) i Svælget. Bær røde. 6. 亿.

I fugtige Kratskove, ved Gjærder, alm. udbredt. (I Haver dyrkes en Afart $\beta$, roseum R. \&. S., med lutter golde Blonster og store hjulformede Kroner).

\section{Sambucus. Hyld.}

422. S. nigra L. (Almindelig H.) H. 345 ; Drej. n. 344 ; F. D. 545 ; Rehb. l. c. XII, tab. 730 .

Bladene fjersnitdeelte med 2 Par elliptiske, saugtakkede Afsnit og et uparret Endeafsnit; Axelbladene linie-børsteformede (eller 0), Qvasterne samlede til en feungrenet Skjærm.

Bladene have en stærk, ubehagelig, Blomsterne en vammel-sødagtig Lugt. Kronerne hvide, Støvdragerne gule, Bær sorte. $\frac{6}{2}-\frac{7}{1}$. $\boldsymbol{Z}_{2}$.

$\beta$, laciniata (Mill.). F. D. 2169 ; Bladene dobbelt fjersnitdeelte, med fligede Afsnit. 
Ved Gjærder, i Kratskove og onkring Byer, meget alm. $\boldsymbol{\beta}$, sjeldnere: Sl. Sommersted (16), Gram (1), Nisvraa i Angel (Jessen); Ero (H.); F. Naaleskov ved Veistrupgaard (19); $\boldsymbol{S} j$. Petersmindo red Kalundborg (Baagøe), Sundbyvester paa Amager (19).

† 423. S. racemosa L. (Klaseblomstret H.) Rehb. l. c. XII, tab. 731 .

Bladene som foreg.; Axelbladene vorteformede; Qvasterne samlede til en ægformet Klase.

Blomsterne guulhvide, med tilbagebøiede Kronflige; Bær røde; Blomsterstilkene ved Frugtmodningen violette. 5. (Fr. 7). .

Dyrkes hist og her i Plantager og forekommer derfia forvildet, f. Ex. $S j$. Folehaveskov ved Rungsted! Ordrups Krat mellem Skovloberhuset og Ordrupsdal! Aldershvile (14), Brede, Ravneholms Skov (Petersen), Dronninggaard, Sondermarken, Vesterfælled (19), Philosophgangen ved Sorø! J. Hjorring (Juel); $\boldsymbol{S} l$. Fattigcolonien ved Husum (16); Loll. Soholt (5); Bornh. red Romersdal! Echodalen (20). 周

424. S. Ebulus L. (Sornmer-H.) H. 344 ; Drej. n. 343 ; F. D. 1156 ; Rehb. 1. c. XII, tab. 729; H. N. IV, 7.

Afsnittene laneetformede med afrundet Basis, saugtakkede, 3-4 Par og et uparret Endeafsnit; Axelbladene bladagtige, ægformede; Qvasterne samlede til en tregrenet Sljærm.

$3-4^{\prime}$ høi. Blomsterne rødlig-hvide (starktlugtende); Støvdragerne morkrode; Bar sorte. 7-8. 4.

Ved Gjærder, sjelden : $\boldsymbol{S} \boldsymbol{j}$. Jrgerspriis (H.), Rolighed ved Sorø! Falst. ved Nykjøbing (H.); Loll. Kjettinge! Taars ved Saxkjøbing (5); J. Fredericia (H.); Sl. Christiansfeld (28), Sonderborg (16), Digerue i Marsken (H.). ॠ

\section{Corrigiola. Skorem.}

425. C. littoralis L. (Sand-S.) H. 348 ; F. D. 334; H. N. XII, 59.

Fleerstænglet, med udstrakte, traadformede Stcngler; Bladene omvendt-xgformet-linieformede, med hindeagtige Axelblade; Blomsterne stilkede, i Nøgler fra de øvre Bladhjørner; Bageret vedblivende.

Kronerne smaae, hride. $7-8 . \odot$.

Sandige Veie og Over 'rev; mangler paa Øerne; J. sjelden: Rye (12); hyppigere i $S$ l. f. Ex. Bommerlund, Bilskov ved Flensborg, Schuby ved Slesvig (16), Sonderbrarup (Frol.), Rendsborg! 


\section{Drosera. Soldug.}

426. D. rotundifolia L. (Rundbladet S.) H. 354 ; Drej: n. 352 ; F. D. 1028 ; Rehb. ic. fl. germ. III, fig. 4522.

Bladene*) næsten kredsrunde (Breden større end Længden), Bladstillene haarede; Skaftet opret, omtrent 3 Gange længereend Bladene; Dcekbladene linieformet-traadformede; Frøene omgivne af en hindeagtig, linieformet Frøhud.

$2-6^{\prime \prime}$ høi. Kronblade og Støvdragere hvide, Arrenes Flige hvide kølleformede, alm. udeelte. 7. 4 .

$\boldsymbol{\beta}$, bracteata (Lyngby). Blomsterne i en gaffeldeelt Qvast; Dckbladene omvendt-ægformede, kirtelhaarede.

I Tørv- og Hedemoser mellem Sphagnum, alm. udbredt. $\beta, \mathrm{i}$ Mæugde paa Hals ved Hofinansgave (Lgb.)!

427. D. longifolia L. (Langbladet S.) H. 355 ; Drej. n. 353 ; F. 1). 1093 ; Rcbb. l. c. fig. 4524 ; H. N. V, 30; D. anglica Huds.

Bladene linieformet-tungeformede, budte, med glat Bladstilk; Skaftet opret, omtrent dobbelt saa langt som Bladene; Dakbladene linieformet-sylformede, af Længde med Blomsterstilkene, hurtigt affaldende; Frøene som foreg.

$3-8^{\prime \prime}$ høi, Kronerne hvide, Støvtraadene hvide med gule Støvknapper, Arrets Fhge kolleformede, hele eller udrandede, hvide med røde Spidser.

$\beta$, obovata Koch (D. obovata M. \& K., Rchb. 1. c. fig. 4525). Bladene omvendt-ægformede.

I Hiengedynd og Moser mellem Sphagnum, sporadisk og mindre hyppig end foreg. $\mathbf{S} j$. Adserbo Overdrev! Juul Sø i Rudehegn (13), Birkerod, Lyngby, Raavaddan! Ordrup (H.), Kongsted Mose (13); $\boldsymbol{L}$ oll. Musse (Rasmussen), Nysted (5); F. Langeskov Kro (16). Hals ved Hofmansgave (4); J. Gravens Mose i V. Hanherred (16), Klitter i Thy (Andresen)! Ferslev ved Aalborg (Brantlı), Stokholm Mose og Hasselholt V. for Skive (16), Ranum ved Logstgr (8)! Viborg (Morville), Maabjerg ved Holstebro, Hjerting (16); $S l$. Huusby i Angel, Tolkwade Sis ved Slesvig (16). $\boldsymbol{\beta}$, med Hovedarten, sjeldnere: $\boldsymbol{S} j$. Lyngby Míose (14)! J. Ferslev ved Aalborg (Branth).

*) Bladene hos alle Arter i denne Slægt ere rosetformigt samlede ved Grunden, Skaftet bladløst. 
428. D. intermedia [Hayne i Schrad. Journ. 1801, p. 37] (Liden S.) H. II, 160; Drej. n. 352 b; F. D. 2108; Rchb. 1. c. fig. 4523 ; H. N. V, 32 .

Bladene omvendt-ægformede, budte, med glat Bladstilk; Skaftet opstigende, af Længde med eller lidet længere end Bladene; Dakbladene sylformede, vedblivende; Froene trinde, ovale, kirtlet-vortede, uden Frøhud.

$1-3^{\prime \prime}$ hoi. Kronerne hvide; Støvtraadene gule; Arrets Flige udrandede eller toklørede, rødlige. 7-8. ข.

Hedemoser og Klitsumpe, sandige Overdrev: paa Halvoen, især den midterste og vestlige Deel, ilke sjelden; $\boldsymbol{F}$. Rødskebølle (12); S j. Rorvig (Feddersen), Grevinge (Weilbach), Adserbo Overdrev! Soborg (Lgh.), Gurre (1).

\section{Tetragyuia.}

\section{Parnassia. Leverurt.}

429. P. palustris L. (Hvid L.) H. 349 ; Drej. и. 345 ; F. D. 584 .

Stangelen med eet Blad nedenfor Midten og een endestillet Blomst; Bladene hjerteformede, Rodbladene stilkede, Stangelbladct siddende og omfattende; Bikronbladene med 9-13 kirtlede Fryndser.

1/2-1' høi. Bladene glatte, med rodgule Punkter; Kronerne hvide med gjennemsigtige Aarer; Bikronbladene guulgrønne. 8-9. 4.

Fugtige Enge, især paa torvholdig Grund, ikke sjelden, dog mindre hyppig paa Bornholm og Lolland-Falster!

\section{Pentagynia.}

\section{Statice. Illindebager.}

430. S. Behen [Drej. fl. exc. n. 350] (Tætblomstret H.) F. D. 2409 ; Rehb. ic. fl. germ. XVII, tab. 1140 ; H. N. X, 21 ; S. Limonium L. (tildeels), Koch Syn. I, 684. 
Bladene omvendt-ægformet-elliptiske, braadspidsede, med tydelige Sidenerver paa begge Flader; Axene halrskjærm. formigt samlede, efter Blomstringen tilbagebøiede, Smaagrenene korte, med tretsiddende, taglagte Blomster; Dakbladene tilspidsede, de nedre paa Smaagrenene tomme.

Bladene paa Underfladen sort-punkterede. Dækbladene (i Randen) og Bægeret hvid-hindeagtige. Kronen blaa. 8-9. ข.

Paa Syltenge: ved Kysterne af Nordsøen paa Halveen fra Hjerting til Husum og de vestlige Øer; onlkring Østersøen, især mod V. Femern (N.); AEre (10); Stryne, Dreje (12); F. Bjørnemose (Jorgensen); Thorseng ved Stioul (Rafu); Langel. ved Fakkebjerg (Ørsted); Loll. Nakskov, Øerne i Rødby Fjord! $\boldsymbol{S}$. Basnæs, Ørsløv, Stigsnæs (Nielsen), Holsteinbor. Ormø, Reersø (Dr.); paa Egholm i Limfjorden (Mørch)! Mangler attegat-Partiet!

Anm. S. Limonium H. 352, som indbefatter baade denne og følgende, angives ogsaa fra Saltholm og paa Nrsset ved Assens (Kyll.), hrilke Voxesteder sandsynligviis begge hore til S. Behen.

431. S. rarillora [Drej. 1. c. n. 349] (Fjernblomstret H.) F. D. 2410 og 315 (slet: S. Limonium); S. bahusiensis Fr. mant. 1, 10; Rehb. I. c. XVII, tab. 1140.

Bladene omvendt-ægformet-lancetformede, braadspidsede, med især paa Overfladen svage Sidenerver; Blomsterstanden halvskjærmformet, med udspærrede eller opstigende Grene, Smaagrenene (Axene) forlængede med tydeligt adskilte Blomster, paa de ydre Grene ensidige, paa de indre afvexlende; Dakbladene budte, paa Smaagrenene alle blomsterbærende.

Dækbladene og Bægerets Nerver røde, i Randen hvidhindede. Kronen blaaagtig-lila. 8-9. $\%$. Forekommer under 2 Former:

$\alpha$, danica Fr. S. Veg. Sc. I p. 200. (S. rariflora Drej., H. N. XI, 26); Bladene flade med en Braad fra Spidsen, Axene oprette; Væxten lavere $\left(3-6^{\prime \prime}\right.$ høi).

$\beta$, borealis Fr. 1. c. (S. bahusiensis Fr. mant. 1 ; H. N. III, 18), Bladene bredere, i Randen bølgede, med en Braad nedenfor Spidsen; Axene noget indbøiede. $1-2^{\prime}$ høi.

Paa Syltenge, i Danmark fornemlig i Kattegat-Partiet: $\alpha, \boldsymbol{S} j$. ved Roeskilde Fjord paa mange Steder, f. Ex. ved Frederikssund (Dr.), mellem Jatgerspriis og Nedre Draaby (21)! Saltbæk N. for Kalundborg (Rafn); J. Mariager Fjord (23); $\boldsymbol{\beta}$, sjelduere: $\boldsymbol{S} \boldsymbol{j}$. Ourø (15)! Hesselgen (Lgb.); F. ved Hofmansgave (4)! Falst. paa Strandenge ved Noisomhed (14). 兰 
Anm. Skjøndt det af Prof. Fries givne Navn er aldre end Drejers, har jeg beholdt dette sidste fordi det betegner den mest iøinefaldende Forskjel mellem de to Arter og fordi Navnet "bahusiensis" navnlig betegner den støre Form, der har sit Centrum i Bahuslän, medens den mindre synes at være den fremherskende i Danmark.

\section{Armeria. Faareleger.}

432. A. vulgaris [Willd. Enum. hort. Berol. I, 333] (A]mindelig F.) Rehb. ic. fl. germ. XVII, tab. 1149; F. D. 2585; A. maritima H. 351 (ikke Willd); A. elongata Lge. Haandb. 1 Udg. n. 421 ; H. N. VIII, 15.

Bladene smalt linieformede, glatte eller randhaarede, samlede $\mathrm{i}$ flere Rosetter fra Spidsen af Rodstokken; Skafterne alm. glatte, flere Gange længere end Bladene; de 3-4 ydre Svobblade tilspidsede af den udløbende bladagtige Midtnerve, de indre budte; Bagerroret haaret paa de 5 ophøiede Nerver, i Furerne glat, owtr. af Længde med Smaablomsterstilkene; Kronbladene budte eller svagt indtrykte.

1/2-1' høi. Kronen rosenrød. 5-9. ข. Var.

$\alpha$, elongata (Statice elongata Hffm.; S. Armeria F. D. 1092 ; A. campestris $\gamma$, Hoffmanui Wallr.; A. elongata Drej. n. 348). Skafterne langstrakte, de ydre Svøbblade længere tilspidsede.

$\beta$, purpurea Rebb. 1. e. tab. 1148 (Armeria purpurea Koeb; Drej. n. 347 ; A. campestris $\beta$, Kochii Wallr.) Svøbbladene mere budte, Kronbladene mørk-rosenrøde.

$\gamma$, humilis Mey. Chl. hanov. (Rehb. l. c. tab. 1148) Lavere, med smalere, ofte randhaarede Blade.

Ved Strandbredder: i enkelte Egne, f. Ex. omkring Kjøge, meget alm., sjeldnere paa sandige Marker og Bakker iude i Landet. $\beta$, paa Enge, sjeldnere. I*

433. A. maritima [Willd. I. c.] (Engelskgræs). F. D. 2584; Rchb. 1. c. tab. 1148 ; Drej. n. 346 ; H. N. V, 12; A. vulgaris H. 351 (tildeels).

Bladene smalt linieformede, budte; Skafterne duunhaarede, omtr. dobbelt saa lange som Bladene; Svobbladene kortere og 
mere budte; Bagerroret overalt haaret; Kronbladene udrandede, forøvrigt som foreg.

$3-6^{\prime \prime}$ høi. Kronen rødagtig.lila. 6-8. 4.

Ved Strandbredder, især paa Syltenge, sjeldnere end foreg. $\boldsymbol{J}$. Tornby i Vendsyssel, Østergaard ved Løgstør (12), paa Steenrevler ved Limfjorden paa begge Sider af Ottesunds Færge! $\boldsymbol{F}$. Langø ved Hindsholm! Schelenborg (12), Østerøen ved Nyborg (Lund); $\boldsymbol{S}$. Reersø (Baagøe), Kongsøre Nebbe i Odsherred (9), Veirhøi! Roeskildo Fjord paa flere Steder $(19,21 !)$. Dyrkes alm. i Haver til Indfatning af Blomsterbede.

Anm. Arterne i denne paa Former rige Slægt (Statice Armeria L.) trænge til en nøiere Undersøgelse og skarpere Begrændsning.

\section{6 te Klasse. Ilexandria (Sexhannede).}

1. Orden. Monogynia (Enhunnede).

A. Blomsterdækket dobbelt.

1. Bérberis L. Bæger og Krone sexbladede; Kronbladene med 2 Kirtler ved Grunden; Støvknapperne opspringe ved Klapper; Arret siddende, skjoldformet; Frugten 1-2-frøet Bær. 万. (N. F. Berberidex).

2. Peplis L. Bægeret tolvtandet, de 6 Tænder mindre; Kronen sexbladet (hurtigt affaldende, ofte 0); Frugt torummet, mangefrøet Kapsel. $\odot$. (N. F. Ly thrarieæ).

Trientalis. Bægeret og Kronen syvdeelte; Frugt enrummet Kapsel. 4. $(7,1)$.

Subularia o. fl. Firepmægtige $(15,1-2){ }^{2}$

\section{B. Blomsterdækket enkelt.}

a. Frugten undersædig, kapselagtig (Løgbærende $\mathrm{V} x \mathrm{xter}$ ).

3. Galánthus L. Blomsten omgivet af et Hylster; Blomsterdækket sexbladet, dets 3 ydre Blade større, de 3 indre mindre, i Spidsen udrandede; Støvknapperne sylformigt tilspidsede, opspringende i Spidsen.

4. Leucójum L. Blomsterne omgivne af et Hylster; 
Blomsterdækket sexbladet, alle dets Blade af lige Længde; Støvknapperne budte, opspringende i Spidsen.

5. Narcissus L. Blomsterne omgivne af et Hylster; Blomsterdækket sexbladet, dets Blade alle ligestore og udbredte; en sambladet, krands- eller rørfornet Bikrone befæstet til Svælget; Støvknapperne budte, opspringende ved Længdespalter $(3-5$. N. F. Narcisinex).

b. Frugten oversædig, bæragtig (Urter uden Løg).

6. Aspáragıs L. Blomsterdækket sexdeelt, klokkeformet, med meget smalt Rør ved Grunden (hvorved Blomsterstilken faaer Udseende af at være leddet paa Midten); Griffelen deelt i $3 \mathrm{Ar}$ ('Trebo).

7. Convallária L. Blomsterdækket sexfliget eller tandet; Griffelen udeelt, med trekantet Ar. (6-7. N. F. Smilace æ).

c. Frugten oversædig, kapsehigtig. á. Blomsterdakket 'Kronbladagtigt farvet,

'ce, sambladet.

† MIuscári Tournef. Blomsterdækket kugle- eller krukkeformet, sextandet med indsnøret Svælg; Kapselen skarpt sexkantet. (N. F. Liliace æ).

$\dagger$ Endymion Dumort. Blomsterdækket klokkeformet, næsten til Grunden sexdeelt; Fligene i Spidsen tilbagebøiede; Kapselen budt trekantet. (N. F. Lilia ce æ).

\section{B. Blomsterdækket fribladet,}

$\alpha \boldsymbol{\alpha}$. med Honninggjemmer.

8. Tritillária L. Perigonbladene med Honninggrube ved Grunden, Griffelen med trespaltet Ar; Frøene flade. (Lograxt).

9. Lilium I. Perigonbladene med Honningfure langs Midtlinien (forneden); Arret udeelt, trekantet; Frøene flade (Løg. $\nabla æ x t)$.

$\beta \beta$. Blomsterdceliket uden IIonninggjemmer.

- Stovknapperse befustede med Basis til slorlradeue.

10. Túlipa L. Griffel 0; Arret trelappet; Frøene flade (Løgvæxt, med enkelt endestillet Blomst uden Svøb). 
11. Gágea Salisb. Griffelen med afstumpet, udeelt eller utydeligt trelappet Ar; Frøene rundagtige (Logvæxt med Blomsterne i Skjærm, omgivne af et Svøb).

** Storknapperne befrstrde med Ryggen til Stortraadene.

+ Blomster i Shjarm, omgivne af et falles hindeagtigt Hylster.

12. Állium i. Stovdragerne tilvoxne til Perigonbladene ved Grunden sammenhængende; Griffelen udeelt; Frøene kantede (Løgvæxt, med en stærk og eiendommelig Lugt).

" tf Blomster i Klase uden falles Hylster.

13. Ornithógalum L. Støvtraadene hindeagtigt udvidede, glatte; Frøene runde (eller kantede), uden Tilhængsler (Blomsterstilken uleddet. Løgvæxt).

14. Anthéricum L. Støvtraadene traadformet-sylformede, glatte; Frøene kantede, uden Tilhængsler. (Blomsterne tilleddede til Blomsterstilken. Rodstok med Trævlerødder. Intet. Løg.) - (8-14. N. F. Li]iaceæ).

15. Narthécium Moehr. Støvtraadene traadformede, uldhaarede; Frøene omgivne af traadformede Tilhængsler (Frøkappe). Krybende Rodstok med Trævlerødder; intet Løg. (N. F. Colchicace æ).

bb. Blomsterdakket hindeagtigt eller bladagtigt (bruunt ell. gront).

«. Blomsterne i Qvast eller Nøgler*).

16. Juncus L. Kapselen trerummet, treklappet, mangefrøet. (Bladene skedeformede, trinde eller sammenrullede).

17. Lüzula DC. Kapselen enrummet, treklappet, trefrøet; (Bladene flade). (16-17. N. F. Juncaceæ).

*) Typisk forekommer hos disse 2 Slægter en af qrast- eller nøgleformede Blomsterstande 1 eller flere Gange sammensat Halvskjærm, hvis Grene paa den temmelig korte Blomsteraxe udvikle sig fra oven nedad, men derimod aftage i Langde franeden opad. 
B. Blomsterstanden en Kolbe.

18. Ácorus L. Kolben falsk-sidestillet*); Kapselen trerummet, uopspringende. (Bladene svierdformede). (N. F. A roide $\mathfrak{x})$.

d. Frugten oversædig, nødagtig.

Polygonum $(6,3)$.

\section{Blomsterdækket 0 .}

19. Calla L. Blomsterne i Kolbe, omgivet af et kræmmerhuusformet, i Spidsen tilbagebøiet Hylster, der er længere end Kolben; Frugten Bær. (Støvdragerne ofte i ubestemt Antal). (N. F. Aroideæ).

\section{Orden. Digynia (Tohunnede).}

Polygonum. Fr. Nød $(6,3)$.

Ulmus. Fr. Vingefrugt $(5,2)$.

\section{Orden. Trigynia (Trehunnede).}

A. I Frugtknude, 3 Grifler (eller 1 Griffel med 3 Ar).

$$
\text { a. Frugt nødagtig. }
$$

20. Polýgonum L. Blomsterdækket farvet, dybt femdeelt med ligestore Flige; Frugt en trekantet eller fladtrykt Nød; Arrene hovedformede.

21. Rumex L. Blomsterdækket (alm.) gront, sexblaret, dets 3 yure Blade (Begerblade) udstaaende, de 3 indre (Kronblade) større, ved Modenheden sammensluttende omkring den trekantede Nød; Arrene penselformede. (20-21. N. F. P olygonea).

*) Stængelens bladagtige Forlængelse ovenfor Kolben er at ansee som et Hylsterblad, tilsvarende til det som findes hos Calla. 
b. Frugt kapselagtig.

22. Cólchicum L. Blomsterdækket sambladet, regelm. sexdeelt med langt Rør; Støvdragerne tilvoxne til Røret. Frugten spalter sig ved Modenheden til 3 Bællekapsler. (N. F. Colchicace æ).

\section{B. 3 Frugtknuder, siddende Ar.}

23. Scheuchzéria L. Arret skjævt tilvoxet til Spidsen af Frugtknuden (tilsyneladende sidestillet); Frugterne (Fleerfoldfrugt) 3 samlede ved Grunden, frastaaende i Spidsen, uden fælles Frugtaxe, toklappet-opspringende, 1-2.froede.

24. Triglóchin L. Arret endestillet; Frugterne $3-6$ enfrøede Spaltefrugter, befæstede omkring en fælles Frugtaxe og tilsidst løsrivende sig fra neden. (23-24. N. F. Alismace

\section{Orden. Hexagynia (Sexhunnede).}

Triglochin maritimum $(6,3)$.

\section{Orden. Polygynia (Mangehunnede).}

25. Alísma L. Blomsterdækket sexbladet, dets 3 ydre Blade (Bægerblade) grønne, de 3 indre (Kronblade) farvede. Frugterne talrige Nødder (Fleerfoldfrugt). (N. F. Alismace æ, b.).

\section{Nonogynia.}

\section{Berberis. Berberisse.}

434. B. vulgaris L. (Almindelig B.) H. 397 ; Drej. n. 393 ; F. D. 904 ; Rchb. ic. fl. germ. III, tab. 18, fig. 4486.

Bladene omvendt-ægformede, tornet-saugtakkede, knippeformigt samlede (i Dværggrene) fra Hjørnerne af en enkelt 
eller tregrenet Vedtorn (et omdannet Blad); Blomsterne i nikkende Klaser; Barrene ovale.

Blomsterne gule, lugte sødt; Bær røde (af syrlig Smag), Støvdragerne bøie sig ved Berøring elastisk henimod Støvveien. 5-6. r̨.

Ikke sjelden ved Gjærder, hvor den, især i tidligere Tid, ofte har været plantet. I enkelte Egne forekommer den vildvoxende i Skove, f. Ex. Bornh. liyppig i Almiudingen! Sj. Odsherred, Tryggerød (H.), Skovsborg! Falst. ved Nykjøbing (H.).

\section{Peplis. Vandkryber.}

435. P. portula L. (Portulak-V.) H. 399 ; Drej. n. 394 ; F. D. 64 .

Stcongelen udstrakt eller krybende, med modsatte Blade og Grene; Bladene omvendt-ægformede, stilkede, heelrandede; Blomsterne enlige, næsten siddende, i Bladhjornerne.

Var. (efter det forskjellige Voxested) i Henseende til Plantens Farve (oftest rødagtigt anløben), Ledstykkernes Længde og Bladenes Størrelse. 6-9. $\odot$.

Paa fugtige Steder, f. Ex. Overdrev, Veigrofter, Moser, baade paa Leer-, Sand- og Torvgrund: alm. paa Halveen og Bornh.; i de ovrige Provindser sjeldnere: $\mathbf{S} j$ sporadisk $\bmod$ N. O., mod $\mathbf{S}$. sjelden: Kjøgekro (9); ligesaa i $\boldsymbol{F}$. Ulriksholm, Hindsholm (N. E. Hofm. Bang), Filstrup! Heldagergaard (12) og paa de sydlige Øer: Falst. i Horreby Lyng (H.), Byskov, Bregninge (14); Loll. ved Ravusby (19); Thorseng paa flere Steder (12).

\section{Galanthus. Vintergjak.}

$\uparrow$ 436. G. nivalis L. (Almindelig V.) H. 361; Drej. p. 133; F. D. 1641 ; Rehb. ic. fl. germ. IX, 807.

Bladene linieformede, paa Ryggen kjolede; Skaftet enblomstret; Hylsteret i Spidsen tokløvet; Blomsterne nikkende; Blomsterdckikets ydre Blade omvendt-ægformede, hule (hvide), de indre omvendt-hjerteformede (indvendig grøntstribede, udvendig hvide med en grøn Plet foroven).

Løgvæxt. 3-5" høi. 3-4. 4.

Paa Enge og i hrat, oprindelig forvildet fra Haver, hvor den dyrkes: $\boldsymbol{S}$ j. Orsholt (11), Kongens Have i Fredriksborg (Knæekenborg), Charlottenlund (15), Berustorf, Antvorskov (H.); Falst. Horbeløv, Nykjøbing (Koeh); F. St. Jørgensgaarrl (12); J. Bjorusholm (8), 
Oust Mølle ved Randers (16); $S l$. Slotsengen ved Husum, Nyværk ved Slesvig (16).

\section{Leucojum. IIvidblomme.}

437. L. æstivum L. (Sommer-H.) H. 361 ; F. D. 1265 ; Rehb. l. c. IX, fig. 805 .

Bladene linieformede; Skaftet treægget, 2-4-blomstret med nikkende Blomster; Hylsteret budt; alle Pcrigonbladene elliptiske (hvide med en grøn Plet nod Spidsen).

Løgvæxt. 1-1 $1 \frac{1}{2} 2^{\prime}$ høj. 5-6. ข.

Par Enge mellem Krat, sjelden og muligviis forvildet ligesom foreg.: J. Aalborg (16), Taglijær ved Aarslev (H.), langs Braband Søes sydlige Enge fra Constantinsborg til Viby (2); Loll. i en Ellemose ved Ulriksdal (Kmberre Wichfeld). 落

\section{Narcissus. Narcis.}

$\dagger$ 438. N. poëticus L. (Pindselilie). Drej. p. 133; Rchb. l. c. IX, fig. 808 .

Bladene linieformede, svagt rendede, budtkjølede; Bikronen rundtakket, hjulformet, meget kortere end Perigonbladene.

Lggvæxt. Blomsterne hvide, med guul, i Randen brandguul Bikrone. 5. ข.

I Kratskove, forvildet fra Haver, hvor den dyrkes som Siirplante: Sj. mellem Orsholt og Gurre (21), Esrom (Dr.), Flommen ved Sorø (12); Falst. S. Kirkeby, Riserup, Gaabense (Koch); Sl. Fruenhof i Angel (16). $\%$

439. N. Pseudonarcissus L. (Paaskelilie). H. II, 164; Drej. p. 133 ; F. D. 2170 ; Rchb. I. c. IX, fig. 816 .

Bladene linieformede, flade med en svag Kjøl; Bikronen tragtformet, i Rauden bølget-rundtakket, af Læugde med Perigonbladene.

Løgvæxt. Perigonbladene bleggule, Bikronen mørkere guul. 4-5. ช.

I Kratskove, sandsynligviis oprindelig forvildet (da den ligesom foreg. dyrkes som Siirplante): $\boldsymbol{S} j$. Soborg ved Slotsruinerne (Lgby), Esrom (Dr.); L oll. Juellinge (19); F. Rødkilde! J. Bjørnsholm (8), Kjergaard Skov ved Ribe (d'Origny); Sl Eisbøl Slotsbanke ved Haderslev (Gronlund), Fruenhof i Angel, Nyværk ved Slesvig, Slotsengen red Husum (16). $\overline{\#}$ 


\section{Asparagus. Asparges.}

440. A. officinalis L. (Almindelig A.) H. 373 ; F. D. 805 ; Rehb. l. e. X, fig. 967 .

Stangelen glat; de primare Blade skjælformede, spredte langs opad Stæengelen og Grenene; de secundare Blade (eller golde Blomsterstilke) børsteformede, 2-5 knippeformigt samlede i Hjornerne af Grenenes Skjæl; fra Iljørnerne af Stængelens øvre og Grenenes nedre Skjæl (Blade) udgaae $1-3$ stilkede Blomster.

1-3' hoi. Alm. ere i nogle Blomster fortrinsviis Støvreien, i andre Støvdrageme udviklede og Planten bliver da tvebo, uden at dog det andet Kjøn aldeles feilslaaer. - Kronen skident guulgrøn; Bær røde. De unge Strengler spiselige. 6-7. ๆ.

Ved Strandbredder: $S j$. Kalundborg (16), paa flere Steder ved Kysterne af lsefjorden, f. Ex. Ouros, Hammerbakken ved Vellerup (15), Oxholm (9) og Ehorn i Roeskildefjord (Albrecht), Hersløv ved Roeskilde! Amager (H.): S evedo (17); Falst. hist og her ved Strandkanterne (Kech): Flalo i Guldborgsund! Loll. Kramnitze Odde (H.) o. fl. St. (5); L angel. ved Faareveile (12), Hjorto, Avernalio, Ero (H.); F. paa Oerne i Odense Fjord (H.), Ijjgrnemose (Jørgensen); J. Dagnæs ved Horsens Fjord (16). Forekommer desuden forvildet fra Haver, hvor den dyrkes som Kjgkkenvæxt.

\section{Convallaria. Konval.}

a. Coeloerinonkoch. Blomsterd kket klokkeformet, Støvdragerne befæstede ved Grunden af Røret.

(Blomsterne i Klase).

441. C. majalis L. (Lilie-K.) H. 375 ; Drej. n. 376; F. D. 854 ; Rehb. l. c. X, fig. 960 .

Hovedaxen med 2-3 laneetformede eller elliptiske Blade, som tilligemed det bladløse, halvtrinde Blomstershaft (Biaxen) omgives af 5-6 hindeagtige Slecler; Klasen ensidig; Blomsterstilkene nikkende, længere end Diekbladene.

6-8" høi. Bladene i Knoptilstanden kræmmerhuusformigt indrullede, Blomsterne lrvide, vellugtende; Bær rgde. 5-6. ฯ.

I skove, alm. udbredt. 
b. Polygonatum Tournef. Blomsterdækket valseeller kølleformet, Støvdragerne befæstede i Midten af Røret (Blomsterne i Bladhjørnerne).

aa. Bladene krandsstillede, Bar rode.

442. C. verticillata L. (Krandshladet K.) H. 376 ; F. D. 86 ; Rchb. I. c. fig. 966 ; Polygonatum Moench, Drej. n. 377.

Stongelen svagtkantet; Bladene linie-lancetformede, $3-7$ i hver Krands; Blomsterstilkene alm. toblonstrede; Støvtraadene glatte.

Stængelen $1-1^{1} / 2^{\prime} h ø i$, forneden rødplettet. Blomsterne hvide, i Spidsen af Fligene gronne. 6. 4.

I fugtige Skove og Krat: i Halveens ystlige Skove ikke sjelden, især i Strækningen mellem Randers og Veile, sparsommere i det Indre af Landet mellem Krat paa Heden, f. Ex. Haraldslund: Fresenhagener Skov ved Lak (16); paa Øerne meget sjeldnere: $\boldsymbol{F}$. mod N. V. (7), Sanderumgaard (H.); Sj. Egebæksvang (21), Dumpedals Molle ved Birkerød (H.), mellem Ermelund og Ordrups Mose! Charlottenlund (Weilbach).

\section{bb. Bladene spredte, Bar blaaagtige.}

443. C. multiflora L. (Salomons Segl). H. 377; F. D. 152; Rchb. 1. c. fig. 961 ; Polygonatum Noench, Drej. n. 379.

Stcongelen trind; Bladene ægformet-elliptiske, halvt omfattende; Blomsterstilkene 3-5-blomstrede; Stovtraadene haarede.

$1^{1} / 2-2^{\prime}$ høi. Rodstokken randret, hrid, leddet, Stængelen i Knoptilstanden nikkende; Blomsterne hvide med gronspidsede Flige. (Spædere Former have stundom enblomstrede Blomsterstilke). 5-6. భ.

I Skove, alm. udbredt.

444. C. Polygonatum L. (Kantet K.) H. 376 ; F. D. 377 ; Rchb. l. c. fig. 964 ; Polygonatum anceps Noench, Drej. n. 378 .

Stcengelen kantet; Bladene elliptisk-ægformede, halvt omfattende; Blomsterstilkene 1-2-blomstrede; Støvtraadene glatte.

$1-1^{1 /} 2^{\prime}$ høi. Rodstokken som hos foreg., men med fjernere Led. Blomsterne stgrre. 5-6. $\%$.

I hoitliggende Skove, paa Brinker mellem Krat: paa Bornholm og $M \theta$ ens Klint aln.; i det nordøstlige $S j$. ikke sjelden, men sporadisk; sparsommere mod V.: Refsnæs (15), Niesbyholm (H.), Egholm 
i Storebelt (17) og i de ovrige Provindser; Falst. ved Gronsund! Ulsløv (Koch); Thorseng (Lund); F. Hofmansgave (4), ved Ladegaardssben pr. Nyborg (Lund); J. Aagzard i V. Hanherred (16), Dybdal ved Aalborg (Braith). Lundbykrat (H.), Ingerslev Bjerge (Selmer), Horseus (Jørg.), Ribe (Warming); $\mathbf{S} l$. Haderslev, Kobbermølleskoven ved Flensborg, Immingsted og Süderholz ved Husum (16).

\section{Muscari.}

$\dagger$ M. botryoides DC. (Sukkertop). Drej. p. 134; Rchb. l. e. fig. 998; Hyacintbus L., H. II, 168.

Bladene linie-lancetformede, ved Grunden meget smale; Skaftet bladløst, med Blomster i en tæt, endestillet, opret Klase; Blomsterne nikkende, de øvre golde, oprette.

Logvæxt. Blomsterne morkblaa. 5. ฯ.

Forvildet fra Haver, sjelden, f. Ex. F. Marker ved Skaarup (19); L oll. Eugestofte (Kherrinde Wichfeld).

\section{Endymion.}

$\dagger$ E. nutans Dumort. (Klokkehyacinth). Agraphis nutans Link, Rehb. 1. c. fig. 1008; Hyacinthus non scriptus L.

Bladene lancet-linieformede, rendede; Skaftet bladløst, med Blomster i en ensidig, nikkende Klase, Blomsterne hængende, blaae.

Løgvæxt. $5-6$. 4 .

Hist og her forvildet $\mathrm{i}$ og omkring Haver.

\section{Fritillaria. Keiserkrone.}

445. H. Meleagris L. (Vibeæg). H. 366 ; Drej. p. 134 ; F. D. 972 ; Rehb. l. e. fig. 974 .

Skaftet bladbxrende; Bladene spredte, linieformede, rendede, Blomsten enlig, endestillet, nikkeude, med klokkeformet Blomsterdække; Perigonbladene lancetformede (kjødfarvet- og morkrødt-tarnede, sjeldnere guulhvide), nedenfor Midten udvendig puklede, indvendig med en aflang Honninggrube.

Logvext. 5. น.

I Kratskove, formodenlig forvildet fra Haver, sjelden: $\boldsymbol{S} \boldsymbol{j}$. Charlottenlund paa en Eng bag Slottet, Sneeslov i Flakkeljerg Herred (H.); $\boldsymbol{F}$. Hverringe paa Hindsholm (A. Lange); $\boldsymbol{S} l$. Nyvierk ved Slesvig (16). 


\section{Liliun. Lilie.}

$\dagger$ L. bulbiferum L. (Løgbærende L.) H. II, 165; Rchb. l. c. fig. 995 .

Bladene spredte $(\mathbf{1} / \mathbf{3})$, linie-lancetformede, med Logknopper i Bladhjornerne; Blomsterne oprette, i en endestillet, faablomstret Skjærm; Blomsterdakket klokkeformet, med rette, indvendig ruvortede Perigonblade.

Løget med taglagte Skjæl. Blomsterne brandgule med rødbrune Pletter. 6-7. भ. (H.)

Forvildet fra Haver, sjelden: $\boldsymbol{S} \boldsymbol{j}$. Kjøge; $\boldsymbol{J}$. Aalborg; $\boldsymbol{S} \boldsymbol{l}$. Gottorp

† L. Martagon L. (Krandsbladet L.) H. II, 165; Rchb. l. c. fig. 989 .

Bladene krandsstillede, elliptisk-lancetformede, uden Løgknopper; Blomsterne i Klase, nikkende; Blomsterdak̋ket med tilbagerullede, indvendig haarede Perigonblade.

Løget med gule, taglagte Skjæl. Blomsterne rosenrøde med morkrode Pletter. 6-7. ข.

Forvild et: $S j$. Vodrofgaard (19), Skjoldnæsholm (9); F alst. Rise-

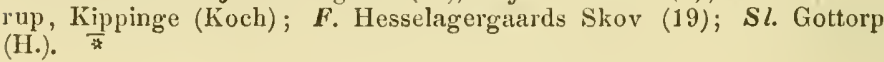

\section{Tulipa. Tulipan.}

446. T. silvestris L. (Vild T.) H. 367 ; Drej. n. 380; F. D. 375 ; Rehb. l. c. fig. 983.

Bladene (2-3) spredte, langstrakt og smalt lancetformede; Blomsten enlig, endestillet, lidet nikkende; de indre Perigonblade og Støvdragerne ved Grunden skjæghaarede.

Løget omgivet af brune Hinder. Blomsterne gule, vellugtende. $5-6$. ข.

I Kratskove omkring beboede Steder: muligviis forvildet fra Dyrkning i ældre Tider, bemærket i alle Provindser og i enkelte Egne i Mrengde, f. Ex. omkring Kjøbenhavn!

\section{Gagea. Guldstjerne.}

a. 2-3 Rodblade ved Grunden af Blomsterskaftet.

447. G. spathacea [Schult. Syst. Veg. 7, p. 541] (Hylsterbladet G.) Drej. n. 382; Rchb. l. c. fig. 1039; 
Ornithogalum Hayne, H. 367 ; H. N. I, 67 ; O. minimum F. D. 612 (ikke L.).

Et storre og mange smaae $L \phi g$ indsluttede af en fælles Hinde; Rodbladene traadformede, halvtrinde, ikke rendede; 1 lancetformet, ved Grunden huult, i Spidsen trindt, langttilspidset Blad hylsterformigt omgivende den 2-4-blomstrede, ved en fælles Blomsterstilk fra Hylsteret fjernede Skjarm; Smaablomsterstillene glatte (trinde), med 2--4 laneet-sylformede Dakblade ved Grunden; Perigonbladene budte, laneetformet-ovale; Stovdragerne meget kortere end Griffelen; Frugtknuden budt og utydeligt sexkantet.

Blomsterne gule, til-idst med rodligt Anstrøg. 5. 4.

I Skove, is:er paa fugtig Gruud, sporadisk, men ikke sjelden og bemærket i alle Provindser. [F

448. G. arreusis [Schult. 1. e. 547] (Ager-G.) Drej. n. 383 ; Rehb. 1. c. fig. $1049-50$; H. N. XV, 69; Ornitho. galum Pers., H. II, 167; F. D. 1869.

To rundagtige $L \emptyset g$ indslnttede af eu frlles Hinde; Rodbladené smalt linieformede, rendede; tilbagebøiede; 2 større Svobblade tæt omgivende den mangeblomstrede, med flere mindre Drkblade forsynede Skjorm; Smaablomsterstilkene og de lancetformede, spidse Perigonblade paa Yderfladen duunhaarede.

Blomsterne gule. Ilar ofte Løgknopper ved Grunden af Sinaablomsterstilkene. $4-5$. 4 .

Paa Agre o. a. dyrkede Steder i Landets sydlicere Fgne, sjellen: f. Ex. Sl. ved Egemførde (N); Lolland i Mæugde ved Nakskov (14); F alster i det gstl. aln. (14)! Hoen i Haver (Dr.); Bornh. Romne, ved Byaaen (Hoff)! 同

\section{b. 1 Rodblad ved Grunden af Blomsterskaftet.}

449. G. minima [Sehult. 1. c. 539] (Liden G.) Drej. n. 381 ; Rehb. 1. c. fig. 1040; H. N. XII, 71; Ornithogalum minimum L., H. 369 ; F. D. 1331.

Et starre og et mindre Log omgive af en fælles Hinde (eller det mindre udenfor samme); Rodbladet smalt linieformet, fladt, paa Ryggen stribet; 1 laneetformet, tilspidset Svobblad 
hylsterformigt omfattende den 2-6-blomstrede, ved en fælles Blomsterstilk fra Hylsteret fjernede Skjarm; Smaablomsterstilkene traadformede, glatte, med linieformede Dcklblade ved Grunden; Blomsterdakket ved Grunden stumpt afskaret, med linie-lancetformede, tilspidsede Perigonblade; Frugtinuden trekantet.

Finere og spædere (men ikke lavere) og med mindre Løg end de øvrige. Blade og Skaft ved Grunden haarfine; Blomsterne gule. $4-5.4$.

I Skove og Krat, sporadisk og ikke alm., fra Slesvig er mig intet Voxested bekjendt, forøvrigt bemærket $\mathrm{i}$ alle Provindser.

450. G. Iutea [Schult. l. c. 538] (Alunindelig G.) Drej. n. 384 ; Rehb. l. e. fig. 1045 ; H. N. XIV, 72; Ornithogaluin L., H. 368 ; F. D. 378.

Eet enkelt, regformet $L \phi g$ omgivet af Hinder; Rodbladet opret, linie-lancetformet, fladt eller rendet, paa Ryggen skarpkjolet, stribet, i Spidsen kappeformet; $2-3$ Svøbblade (det ydre størst) ved Grunden af den 2-8-blomstrede Slijcerm; falles Blomsterstill 0 eller meget kort; Smaablomsterstilkene glatte, uden Dækblade ved Grunden; Blomsterdaklet med afsmalnet Basis, dets Blade lancet-linieformede, budte; Frugtknuden trekantet.

Svobbladene alm. dunet-randhaarede. Ofte findes flere Smaaløg ved Grunden af det større $\mathrm{L} \omega \mathrm{g}$, men udenfor dettes Hinder. Var. med Blade af blaagron Farve. Blomsterne gule. 4. 4.

I Skove, Haver, ved Gjærder o. s. v., meget alm.

451. G. stenopetala [Rehb. FI. exc. p. 107] (Eng.G.) Ornithogalum Fr. fl. Hall., p. 58; H. N. II, 64; O. pratense H. II, 166 ; F. D. 2225 ; Rehb. l. c. fig. 1033-37.

Tre $L \phi g$ : det ene hindedækket, udskydende Blad og Blom sterskaft, de 2 øvrige nøgne (det ene større, vandret, det andet mindre, lodret); Bladene flade; Skjormen 2--4.blomstret, med 1-2 Dakblade ved Grunden af Smaablomsterstilkene; Perigonbladene langstrakt oval-linieformede, budte; forøvrigt som foreg., med hvilken den har megen Lighed.

Blomsterne gule. 4-5. (Lidet sildigere end foreg.). 4 . 
$\beta$, bifolia Koch Falst. Veget., med 2 Rodblade.

Paa Groftevolde og Agre, hrie Enge og i Krat: Slesvig (Nolte); Sa $\boldsymbol{m} \boldsymbol{s} \boldsymbol{\theta}$ (Jacobsen); $\boldsymbol{F}$. Dalby Klint paa Hindsholm (A. Lange), Ostercen ved Nyborg (Lumd); Loll. Nakskov (19); Falst. alm. (14); $\boldsymbol{S} j$. Lillehedinge i Stevns, Kirsebrergangene ved Kjøbenhavn (12)! Charlottenlund (Lütken), Bognes ved Roeskilde (20)! Bornh. lyyppig omkring Ronne (Hjorth), Arnager (20). $\quad \beta, F a l s t$. S. Kirlieby, S. Alsløv (Koch). Forekommer sandsynligviis paa mange flere Steder, men hidtil overseet paa Grund af de overjordiske Deles store Lighed med foreg. F

\section{Allium. Log.}

a. De 3 (indre) Strvdrageretretandede, den midterste Tand støvknapbærende (Bladene ligebrede).

\section{aa. Bladene flade.}

452. A. Scorodoprasum L. (Skov-L.) H. 362 ; Drej. $n$. 388 ; F. D. 1455 ; Rehb. ic. fl. germ. X, tab. 490 , fig. 1073.

Bladene i Randen rue; Skederne tveæggede; Skjormen faablomstret, med talrige Løgknopper ved Grunden af Blomsterne; Hylsteret 'enbladet, kort-tilspidset; Støvdragerne kortere end eller af Længde med Blomsterdækket, Tænderne sylspidsede, den midterste med Støvknappen halvt saa lang som Stovtraaden.

$2-3^{\prime}$ høi; Bladene indtil $1 / 2^{\prime \prime}$ brede. Flere, ofte stilkede SmaaIog ved Grunden af Hovedløget. Logknopperne rundagtige eller omvendt-ægformede, morkviolette; Blomsterne violetrøde. 6-7. 2 .

$\beta$, minus Fr. (A. arenarium Sm., Rehb. 1. c. fig. 1074 ; A. Scorodoprasum F. D. 290). Mindre og spadere, med smalere Blade, triude Bladskeder.

I Kratskove, ved Gjærder og paa hoie Enge, ikke sjelden, bemarket i alle Provindser og i enkelte Egne hyppig, f. Ex. paa $\boldsymbol{B}$ ornh., ved Helsingør og Kjøbenhavn. $\boldsymbol{\beta}, \boldsymbol{S} \boldsymbol{j}$. ved Kjøge (9), Vemmetofte (H.); Noen; Flatg i Guldborgsund; Loll. Lienlund ved Nakskov (19); F. Nyborg; J. Aarlıus, Palsgaard (H.).

† A. Porrum L. (Porre-L.) Rebb. ]. c. tab. 489, fig. 1071. Bladene bredt linieformede, rendede; Shijarmen tætblomstret, kugleformet, uden Logknopper; Hylsteret enbladet, langt-tilspidset; Blomsterdakket hvicit med røde Striber.

Dyrkes i Kjokkenhaver. 
† A. sativum L. (Hvid L.) Rchb. I. c. tab. 488, fig. 1069. Bladene linieformede, flade; Skjormen faablomstret, med Løgknopper; Hylsteret enbladet, langt tilspidset, affaldende; Blomsterdakket skident hvidt eller rødligt; Smaaløg ved Grunden af Hovedløget.

Dyrkes som foreg.

b6. Bladene hule, trinde eller halvtrinde.

453. A. vineale L. (Strand-I.) H. II, 162 ; Drej. $n_{\text {。 }}$ 389 (undtagen Synon.); F. D. 1870 (slet) og 2227; Rchb. 1. c. fig. 1075 ; A. arenarium Fr. nov. p. 84 ; H. N. VIII, 69.

Bladene halvtrinde, paa Overfladen svagt furede; Hylsteret enbladet, langt tilspidset; Skjcermen med Løgknopper ved Grunden af Blomsterne; Perigonbladene budte; St $₫$ vdragerne længere end Blomsterdækket, Tænderne sylspidsede, den midterste med Støvknappen længere end Støvtraaden.

$1 / 2-2^{\prime}$ hตi. Bladene smale, alm. henvisnede naar Blomsterne udspringe; Smaaløg ved Grunden af Hovedloget. Løgknopperne omvendt-ægformede, budte med en kort Spids; Blomsterne rosenrøde eller gunlgrønne med Anstrøg af Rødt, var. grønne (viridiflorum Drej. F. D. 2227). 6-7. औ.

$\alpha$, capsuliferum Koch. Skjærmen mangeblomstret, med faae Løgknopper.

$\beta$, compactum Thuill. Løgknopperne danne et kugleformet Hoved; Blomsterne 0 eller meget faae.

Ikke sjelden i Nærheden af Kysterne i alle Provindser, f. Ex. paa Havstokken, Brinker mod Stranden; sjeldnere inde i Landet ved Gjarder og i Krat. ( $\beta$, er los os den hyppigste Form.)

454. A. Kochii [Lge., Fl. dan. ined.] (Mangeblomstret L.; A. vineale $\boldsymbol{\beta}$, purpureum Koch, Falst. Veg. p. 39.

Bladene halvtrinde, $\mathrm{i}$ den nedre $\% / 3$ af deres Længde rendede, foroven trinde, sylspidsede; Skjormen mangeblomstret med talrige Løgknopper; Perigonbladene spidse, mørkt carmoisinrøde, i Randen lysere, længere end de tandløse og af Længde med eller lidet kortere end de tandede Støvdragere; forøvrigt som foreg. 
Høiere $\left(1^{1} / 2-2^{1} / 2^{\prime}\right)$ og med storre $\operatorname{Lgg}$ end foreg. 7. 4.

I Mængde ved en Gruusgrav udenfor Nykjobing paa Falster (Koch)! (Har vedligeholdt sit Udseende og Characterer ved fleeraarig Dyrkning i den botaniske Have.)

Anm. Denme smnkke Logart, som jeg bar benærnt efter Finderen, den utrettelige Botaniker Provst Koch, staaer ifølge Charactererne nærmest ved $A$. vineale, fra livilken den dog synes mig tilstrækkelig adskilt, hvorimod den i Udseende, fornemlig ved de talrige og smukt morkrøde Blomster, har mest Lighed med $A$. sphcerocephalum $\mathrm{L}$. (H. II, 16:2, F. D. 2111, Rehb. 1. c. 1080). Denue er imidlertid meget forskjellig ved hule, trinde, ved Grunilen fladtrykte Blade, tobladet Srgb, kugleformet Skjærm med kortere Blomsterstilke og uden Logknopper. Den er funden i Holsteen (Nolte), men hidtil ikke, saavidt mig bekjendt, $\mathrm{i}$ vor Flora, thi paa det Kyllingske Voxested, (Løghøien ved Ribe), som citeres til deme, findes den neppe mere, og det turde vel endog ansees for tvivlsomt, om den af $K y l l$. angivne Plante med Rette er henfort til A. sphærocephalum.

† A. Cepa L. (Rød L.) Rehb. 1. c. tab. 494, fig. 1083. Loget stort, enligt; Stongelen nedentor Midten bugformigt opblæst; Bladene trinde, rorformede; Skjarmen kugleformet, mange blomstret, uden Løgknopper; Støidragerne meget langere end Blomsteruxkket, med korte 'Tæender.

Dyrkes i Kjøkkenhaver.

$\dagger$ A. ascalonicum L. (Skalot-L) Rehb. 1. c. tab. 491, fig. 1076. Logene smaae, flere samlecie; Stangelen ligetyk overalt; Bladene trinde, rørformede; Skjarmen med eller uden Løgknopper; Hylsleret tobladet; Stovdragerne lidet længere end Blomsterdækket, med korte Truder.

Dyrkes i Kjøkkenhaver, men blomstrer neppe hos os.

b. Alle Støvdragerne uden Tilhængsler.

aa. Bladene ligebrede, uden Sideaarer; Blomsterne rode eller rodlig-grønne.

ж. Loget ruudagtigt, dannet af kjodfulde Løgskjæl uden Plade;

Logknopper ved Grunden af Blomsterne.

455. A. oleraceum L. (Vild L.) H. 363 ; Drej. n. 390 ; F. D. 1456 ; Rchb. 1. c. tab. 487, tig. 1067.

Bladene rue, forneden halvtrinde, mod Spidsen flade, paa Overfladen furede, paa Underfladen mangestribede; Hylsteret 
tobladet, med langt tilspidsede Blade, (det ene meget længere end det andet); Shjormen faablomstret; Blomsterstilkene lange; Blomsterdakkets Biade budte, af Længde med Støvdragerne.

1-2' høi. Løgknopperne elliptiske, tilspidsede; Blomsterne hvideller guulgrønne, rødt anløbne eller blegt rosenrøde med brune Striber. 7. ข.

$\beta$, canaliculatum Fr. Høiere af Væxt; Bladene brede, rendede; Blomsterne bruunagtigt grønne.

I Skove og Krat, ved Gjærder o. s. v., alm. udbredt. $\beta$, med Hovedarten, f. Ex. Bastionerne ved Kjøbenhavn!

456. A. carinatum L. (Kjølet L.) H. II , 161; F. D. 2109 ; Rchb. l. c. tab. 482, fig. 1057; H. N. VI, 64.

Bladene smalt linieformede, rendede, mod Spidsen flade, med 3-5 fremstaaende Striber; Hylsteret som foreg.; Skjarmen mangeblomstret; Blomsterstilkene lange; Blomsterdakket trekantet; Perigonbladene budte, med indrullet Spidse, kortere end Støvdragerne.

1' høi. Blomsterne lila-rosenrøde, Bladene henvisnede i Blomstringstiden. 7. ข.

I hoitliggende Krat: $\boldsymbol{S} l$. ved Aabenraa (Bargum efter N.); $\boldsymbol{F}$. Hofmansgave (18)! B ornh. Rønne (Hjorth), Rabekkegaard (Hamann). Angives af Kyll. fra Stevns og Assens. Fix

$\beta$. Løget aflang-valseformet, dannet af de henvisnede Blades Skeder; Logknopper 0 .

$\dagger$ A. Schoenoprasum L. (Pur-L.) H. 365; F. D. 971; Rchb. I. c. tab. 496, fig. 1085.

Bladene trinde, rørformede; Skjcermen kugleformet, noget længere end det 2-3-bladede Hylster; Perigonbladene lancetformede, spidse, længere cud Stovdragerne.

$6-10^{\prime \prime}$ høi. Blomsterne violet-røde. 6-7.

Dyrkes i Kjøkkenhaver. Angives af O. F. Müller (i F. D.) fra Hindsgavl i Fyen, hvilket formodenlig hidrorer fra en Feiltagelse, hvis den ikke der tilfældigviis har været forvildet.

457. A. montanum [Schmidt. Fl. boëm. IV, p. 28] (Kantet L.) Fr. mant. 2, p. 18; Rchb. 1. c. tab. 500, fig. 1094; 
A. angulosum L. (ex part.), Nolt. nov. p. 33 (?); II. II, 163 (?); F. D. 2110 ; A. fallax R. \& S., H. N. V, 70.

Logene udgaae fra en forlænget, næsten vandret Rodstok; Bladene smalt linieformede, flade, omtrent femnervede; Slcaftet oventil skarpkantet; Hylsteret 2-3-bladet, af den hvrelvede, mangeblomstrede Skjorms halve Længde; Støvdragerne længere end Blomsterdakket.

$1 / 2-1^{\prime}$ høi. Blomsterne rosenrøde, brune Støvdr. (Fr.). 7. भ.

Paa Lyngbakker og Heder, kun bemærket i Slesvig: Gelting Birk, Hedebakker ved Læk, Egekrat ved Königsmark pr. Husun (16), mellem Sehauendal og Olderup (N.). $\sqrt{*}$

Anm. Saavel Fig. i F. D. som de slesvigske Exemplarer jeg har seet (fra Gelting) stemme bedst overeens med A. montanum hos Rehb. (l. c.). Nolte (l. c.) angiver fremdeles A. senescens som funden i Sl. (mellem Enge og Læk). Da jeg ikke har seet Expl. fra dette Voxested og ingen Synonymer ere anførte, er jeg uvis om hvorhen denne hører; muligviis til $A$. acutangulum Sehrad., (Rchb. 1095; A. fallax ${ }^{*}$ serotinum Fr. l. e.), som adskilles ved høiere og mere kantet Stiengel, langere og bredere Blade med tydeligere Midtnerve samt indsluttede Stovdragere. Af samme Grund er jeg ikke sikker paa, om de frá N. og H. anførte Synonymer ere rigtigt anvendte, saa meget mindre som Synonymiken af de 2 Arter er meget forviklet. Disse ere dog manskee kun 2 Former af samme Art (Irmisch, Zwiebelgew. p. 17 erklærer Charactererne fra Bladnerverne og Støvdragerne for valklende), frembragte ved Forekomst pai forskjellige Localiteter (A. acutangulum angives at voxe par Enge).

\section{bb. Bladene lancetformede, med Sideaarer, Blomsterne hvide.}

458. A. ursinum L. (Rams-L.) H. 364; Drej. n. 387; F. D. 757 ; Rehb. 1. e. tab. 507, fig. 1109 ; H. N. II, 61 .

Løget aflang-laneetformet, solidt; 3 Blade: det ydre hindeagtigt uden Plade, de 2 ovrige langstilkede, med flad Plade; det yderste af disse med en hindeagtig Skede omfattende det trekantede, paa Underfladen coneave Skaft og det inderste Blads kjødfulde Skede; Hylsteret dybt 2-3-deelt, af Lingde med den flade, faa- (8-20)-blomstrede Skjarm; Logknopper 0; Støvdragerne kortere end Blomsterdxkket.

Bladpladerne vende Underfladen opad; Loget dannes af det inderste Blads kjodfulde Skededecl, som i Aarets L $ø b$ fortæres med Undtagelse af le som krandsstillede Trævler vedblivende karbundter. Hylsteret hurtigt affaldende. $5-6 . \%$.

Par skyggefilde, især noget fngtige Steder i Skove, oftest i

Haandh. den danstre Flora. 
Strandegne; ikke alm., men bemrerket i alle Provindser, og hvor den voxer, (oftest under Egefræer), udbreder den sig stærkt og findes alnz. i stor Mrengde.

\section{Ornithogalum. Fuglemaelk.}

† 459. 0. nutans L. (Nikkende F.) H. 370 ; Drej. n. 386 ; F. D. 912; Albucea Rchb. I. c. X, tab. 473, fig. 1031.

Blomsterne (efter Afblomstringen) nikkende, i ensidig Klase; Blomsterstilkene kortere end Dakbladene og Blomsterdakket; Støvtraadene hindeagtige, de 3 indre længere, linieformede, trekløvede (den midterste Flig kortere, støvknapbærende), de ydre mindre, oval-lancetformede, hele eller udrandede; Frugtknuder rundagtig, i Spidsen indtrykt, under Blomstringen kortere end. Griffelen.

Blomsterne indvendig hvide, udvendig grønne. 4-5. 4.

Ved Gjærder og paa skyggefulde Steder omkring Byer og Haver, funden $\mathrm{i}$ alle Provindser, men ikke overalt. Synes oprindelig at være: udvandret fra Haver.

$\dagger$ 460. 0. umbellatum L. (Halvskjærmblomstret F.) H. 369 ; Drej. n. 385 ; F. D. 1266 ; Rchb. l. c. tab. 467, fig. 1019.

Blomsterne i Halvskjærm, Blomsterstilkene udspærrede eller opstigende, længere end Dakbladene og Blomsterdakket; Støvtraadene lancetformede, udeelte; Frugtknuden oval, under Blomstringen læugere end Griffelen.

Bladene morkgronne med hrid Midtnerve; Blomsterne indvendig hvide, udvendig grønne. 5. 4.

Paa lignende Steder som foreg., men sjeldnere, og ligesom hiin: oprindelig indfort.

\section{Anthericum. Edderkopurt.}

461. A. ramosum L. (Grenet E.) H. 371 ; Drej. n. 391 ; F. D. 1157 ; Rchb. l. c. tab. 511 , fig. $1114 ;$ H. N. VI, 65.

Stcengelen oventil grenet (dannende en Top); Bladene linieformede, noget rendede; Dakbladene flere Gange kortere end Blomsterstilkene; Griffclen ret.

Blomsterne hvide. 7.4 . 
$\boldsymbol{\beta}$, Pseudo-Liliago! Strengelen ugrenet, Blomsterne i Klase.

Paa Bakker, mellem Krat, sjelden: $\boldsymbol{S}$ j. Jægerspriis (21), Frederikssund (Feddersen), Veile Viig i Voldborg Herred, Leire (Kyll.), Bidstrupgaard, Slangerup, Søllerød, Ørholm (H.), Brede Bakker ! $\beta$, (som i Udseende ligner folg.) ved Brede med Hovedarten, og i enkelte Aar fremherskende fremfor deune (F. Schmidt), Nymglle (14). lik

\section{A. Liliago L. (Ugrenet E.) H. 372; Drej. n. 392;} F. D. 616 ; Rehb. l. c. fig. $1115 ;$ H. N. VI, 65 .

Stcongelen ugrenet; Blomsterne i Klase; Bladene linieformede, rendede; Dakbladene af Blomsterstilkenes halve Længde; Griffelen opstigende.

Blomsterne hvide, storre end hos foreg. 6-7. $\psi$.

I Kratskove, sjelden: $\boldsymbol{S} \boldsymbol{j}$. Jægerspriis (9), mellem Bidstrup og Roeskilde, Fortunen (H.); $S l$. mellem Schauendal og Olderup (N.), Egekrat ved Engelsborg pr. Husum (16). F

Anm. Jeg har ikke seet sjellandske Expl. af denne Art, og maaskee henhore de fra $\boldsymbol{S} j$. anførte Voxesteder til var. $\boldsymbol{\beta}$ af foreg., idetmindste synes dette at være Tilfældet med den af $O$. F. Müll. (F. D. l. c.) omtalte Form fra Kobbermollen (?). Fig. i F. D. fremstiller $\operatorname{dog}$ den ægte $A$. Liliago, hrortil ogsaa de slesvigske Expl. henhøre.

\section{Narthecium. Beenbraek.}

463. N. ossifragum [Huds. Fl. angl. 145] (Sværdbladet B.) H. 372 ; Rebb. l. c. tab. 421 , fig. 936 ; H. N. XIV, 73; Anthericum L., F. D. 42.

Rodstokken krybende (beklædt med Trævler af de henvisnede Blades Karbundter); Rodbladene linieformet-sværdformede; Stangelbladene skedeformigt omfattende; Blomsterne i Klase; Blomsterstilkene med et Dakblad ved Grunden og et ovenfor Nidten; Perigonbladene længere end Støvdragerne, kortere end den spidse Kapsel.

\section{$1 / 2-1^{\prime}$ høi. Blomsterne gule. 7-8. 4.}

I 'Tørv- og Hedemoser, kun bemærket paa Halvoen, i hvis vestlige og midterste Egne den ikke er sjelden; sparsommere mod Ø., f. Ex. J. Kanders (7), Riis Mose mellem Horsens og Skanderborg (2), Brøndsted ved Fredericia! $\boldsymbol{S l}$. Aabenraa (Grønlund), Flensborg! Oxager i Angel (14). 


\section{Juncus. Siv.}

a. Froene med en til begge Sider udvidet Frøhud.

464. J. maritimus [Lam. Dict. 3, 264] (Strand-S.) H. 383 ; Drej. n. 360 ; F. D. 1689 ; Rchb. ic. Al. germ. IX, tab. 402, fig. 895 ; H. N. IX, 69.

Rodstokken vandret; de nedre Blade skedeformede, uden Plade; de фvre nedentil omskedende, oventil ligesom de blomsterbærende og blomsterløse (nøgne) Stcengler trinde, uleddede, sylspidset-stikkende; Blomsterstanden en dobbelt sainmensat, falsksidestillet*) Qvast med oprette Grene; de ydre Perigonblade spidse, de indre budte med en Braad, alle af Længde med den elliptiske, braadspidsede Kapsel.

1-2' høi og meget stiv. $8-9$. 4.

Paa Strandenge, især i lerede Huller, som Vandet af og til overskyller: Sj. Kalundborg (H.), Jægerspriis (28), Saltholm (9), Holmene ved Præst $\emptyset$, Voldingborg (H.), Holsteinborg (17) o. fl. St. i Egnen af Skjelskør; $\boldsymbol{F}$. Lang $\emptyset$ ved Hindsholm! Østerøen ved Nyborg (Lund), Aastrup, V. Skjerninge; Thorseng, Langeland (12); L oll. Nakskov, Bjerremark, Kjeldernas; Falst. mellem Stubbekjøbing og Gronsund (19), Nøisomhed, Klodskov, Vennerslund (14); J. Nebbegaard ved Lillestrand! Aars i Lillebelt (8); Als (H.); $S l$. ikke sjelden paa Østkysten fra Aabenraa mod S., Femern (N.).

b. Frøene uden (eller med en utydelig) Frøhud.

aa. Blomsterbcrende og blomsterløse Stcengler nøgne, med bladløse Skeder ved Grunden (Blomsterstanden falsk-sidestillet).

465. J. conglomeratus L. (Knop-S.) H. 380 ; Drej. ฉ. 361 ; F. D. 1094 ; Rehb. 1. c. IX. fig. $912-13$.

Tueformet; Stangelen fiint stribet, med sammenhængende Marv; Blomsterstanden dobbelt sammensat af kortstilkede Nøgler; Perigonbladene lancetformede, tilspidsede; Støvdragerne 3 ; Kapselen omvendt-ægformet, trekantet, indtrykt, med Griffelens vorteformede Basis i Indskjæringen.

*) Falsk-sidestillet kaldes 13lomsterstanden fordi den forlængede Spids, fra hris Side den synes at frembryde, maa ansees som et Hylsterblad og ikke som en Fortsættclse af Strengelen. 
De bladlose Skeder lysbrune. Blomsterstanden tæt, nasten kugleformet. Var. med længere Grene og Nggleme derved fjernede fra hinandeu. (En saadan Form med blegere og mindre Blomster er J. subuliflorus Drej. 11. 362). 6-7. 4.

Paa fugtig Leerjord, ved Grsfter og paa Overdrev, forelsommer $i$ alle Provindser, sjeldnere i det nordlige $\boldsymbol{J} y l l$. (Drej.). $\beta$, en Skyggeform: $\boldsymbol{S} j$. ved Fuursøen (Dr.); J. Sæebygaards Skov i Vendsyssel (12); $S l$. Aabenraa!

466. J. effusus L. (Lyse-S.) H. 381 ; Drej. n. 363 ; F. D. 1096 ; Rehb. l. e. fig. 920 ; H. N. 1X, 70.

'Tueformet; Stængelen jævn, ved Tørring meget fint stribet, med sammenhængende Marv; Blomsterstanden dobbelt sammensat, wed forlangede Blomsterstilke; Perigonbladene lancetformede, tilspidsede; Støvdragerne 3 eller 6; Kapselen ouvendt-ægformet, trekantet, indtrykt, med forkortet Griffel udgaaende fra Indskjæringen.

De bladlose Skeder lysbrume. Blomsterstanden alm. en fjernblomstret Qvast, var. ( $\beta$, compactus Leight.) med sammentræengt Blomsterstand og desuden forekommer en Afundring med de $y$ dre Grene i Qvasten topskydende. $(\gamma$, prolifer Sond.). 6-7. $\psi$.

Paa lignende Localiteter som foreg., i de fleste Egne liyppigere end liiin. $\beta, \boldsymbol{L}$ oll. Torrig Skov (19); anferes ogsaa af Drej. (Krøy. Tidskr. III, 415); $\gamma$, Falst. ved Gronsund (19).

Anm. Pala Grund af Afændringsformer kan den ofte forvexles med foreg., og forenes af Flere med denne; (J. communis Mey.); dog syues de typiske Former af begge vel adskilte $i$ Naturen, om end vanskelige at begræundse ved bestemte Kjendetegn.

467. J. glaucus [Ehrb. Beitr. 6, 83] (Blaagraa S.) H. 382 ; Drej. n. 364 ; F. D. 1159 ; Rehb. I. e. fig. 922 ; H. N. I, 69 .

Rodstokken sammentrængt, tueformet; Stcengelen dybt stribet, blaagraa, med afbrudt Marv; Blomsterstanden dobbelt eller flere Gange sammensat, quastformet, med spredte, forlængede Grene og Blomsterstilke; Perigonbladene lancetformede, tilspidsede, de $y d r e$ lidet lengere, de indre kortere end den ovale eller elliptiske, budte, af den vedblivende Griffelbasis braadspidsede Kapsel.

2-3' høi. De bladløse Skeder mork-kastaniebrune. 7-8. भ. 
Ved Sø- og Aabredder, fugtige Steder paa Gruus- og Leergrund, isæor i Strandegne, bemærket i alle Provindser sporadisk, men ikke sjelden (f. Ex. meget hyppig paa Bornbolm!)

Anm. J. diffusus Hoppe, som adskilles fra denne ved en mere grøn Farve og sammenhangende Marv, fra de 2 foreg., ved rødbrune Skeder og 6 Støvdragere, kunde muligviis findes i vor Flora.

468. J. balticus [Willd. Berl. Mag. 1809, p. 288] (KlitS.) H. 381 ; Drej. n. 365 ; Rchb. I. c. fig. 917 ; H. N. I, 68 .

Rodstokken vandret krybende; Stuengelen jævn, i tørret Tilstand stribet, med sammenhængende Marv; Blomsterstanden enkelt eller dobbelt sammensat; Perigonbladene æg-lancetformede, de ydre spidse, de indre kortere, budte med en kort Braad; Kapselen elliptisk, braadspidset af den vedblivende Griffelbasis, af Længde med eller længere end de ydre Perigonblade.

Lavere $\left(1 / 2-1^{1} / 2^{\prime} h ø i\right)$, men mere robust end foreg., Kapselen næsten dobbelt saa stor; de bladløse Skeder lysbrune. 7-8. थ.

* inundatus (J. inundatus Drej.; F. D. 2287; Rchb. l. c. fig. 916). Strengelen lavere og meget finere, Blomsterstanden enkelt, forøvrigt som Hovedarten.

I Sandklitter: ikke sjelden i den nordvestlige Deel af Jylland fra Skagen til Holstebro (Drej., Poulsen)! B ornh. ved Frydenlund N. for Rønne! Flyvesand $\emptyset$. for Boderne! * med Hovedarten; J. Tranum Strand (Dr.), Hjortdal (16)! Kollerup, Bulbjerg, Nors Klit (Dr.)!

469. J. filiformis L. (Traadstæuglet S.) H. 382 ; Drej. n. 366 ; F. D. 1207 ; Rchb. l. c. fig. 919.

Rodstokken vandret krybende; Stcenglerne i Spidsen bøiede, jævne, ved Tørring stribede, med sammenhængende Marv; Blomsterstanden en enkelt, faablomstret Qvast omtrent paa Midten af Stængelen; Perigonbladene lancetformede, spidse ; Kapselen næsten kugleformet, budt med en meget kort Griffel.

Stænglerne $1 / 4-1^{\prime}$ høie, traadformede; de bladløse Skeder lysbrune. $7-8$. 4 .

I Torv- og Hedemoser, alm. i Halveens Hedeegne og paa Bornh!! i Sjall. sporadisk i den nordlige Deel, sjeldnere mod S. og paa de andre Øer: F alst. ved Bøto(5); Thorseng red Bregninge! AEO (10). 
b3. Alle Stcnglerne bladbarende (Blomsterne endestillede, $i$ Nogler eller oftere $i$ en af talrige Nogler enkelt eller dobbelt sammensat Qvast).

a. Rladene afdeelte red Led paatværs.

470. J. obtusillorus [Ehrh. Beitr. 6, 83] (Budtblomstret S.) H. 384 ; Drej. n. 371 ; F. D. 1872 ; Rehb. 1. e. fig. 901 ; H. N. I, 70; J. retroflexus Rafn II, 486.

Rodstokken vandret; Stanglerne oprette, 2-3-bladede, tilligemed Blade og Bladskeder trinde; Blomsterstanden en dobbelt sammensat Qvast med efter Blomstringen tilbagebøiede Smaagrene; Perigonbladene ligelange, budte, lidet kortere end den ægformede, tilspidsede, trekantede Kapsel.

1-2' høj. Dxkblade og Perigonblade rødligt anløbne, i Randen hıvidhindede. 7-9. ข.

I Hængedynd og paa vaade Enge, sporadisk og ikke hyppig, men funden $\mathrm{i}$ alle Provindser (undtagen Borul.).

471. J. acutillorus [Ehrh. Beitr. 6, 82] (Spidsblomstret S.) H. 385 ; Drej. n. 368 ; F. D. 2112 ; Rehb. l. e. fig. 906-7; J. silvatieus Reichard.

Rodstokken vandret; Stcenglerne oprette, $3-4$-bladede, tilligemed Blade og Bladskeder trindt-sammentrykte, Bladenes Tværskillevægge tydelige, ingen Striber paalang; ; Blomsterstanden en dobbelt sammensat Qvast, med korte, udspærrede Smaagrene; Perigonbladene sylspidsede, de indre længere, i Spidsen tilbagebøiede, alle kortere end den ægformede, langt-tilspidsede Kapsel.

$1^{1 / 2}-3^{\prime}$ høi. Planten større og kraftigere, Blomsterne mindre end hos de folgende Arter af samme Afdeling. 7-8. 4 .

$\boldsymbol{\beta}$, macrocephalus Koch. Noglerne dobbelt saa store, paa længere Grene.

I 'Tørrmoser og paa fugtige Enge, ikke alm. og hidtil, saavidt mig bekjendt, kun funden paa Halvo en: Borre S $q$ ved Silkeborg (7)! Østbirk (2)! mellem Ribe og Medolden (16)! Hjortlund (12), Papirmollen ved Flensborg! Pulverholz Eng ved Slesvig (16), Husum, Rendsborg! $\beta$, med Hovedarten ved Flensborg, Brøndsted i Jy Il.!

Anm. Det i H. N. VII, 71 indeholdte Expl. under Navn af $J$. acutiflorus fra Stoekholm (Nyman), tilhører en Form af J. alpinus. 
472. J. lamprocarpos [Ehrh. Calam. n. 126] (Glandskapslet S.) 1) jej. n. 369 ; Rchb. l. c. fig. $902-4$; J. articulatus $(\alpha)$ L., F. D. 1097 ; H. N. V, 71.

Tueformet; Stcenglerne opstigende, 3-6-bladede, tilligemed Blade og Bladskeder trindt-fladtrykte, Bladenes Skillevagge tydelige, Mellemrummene (ved Torring) fint stribede; Blomsterstanden en dobbelt sammensat Qvast med udspærrede Grene; Perigonbladene ligelange, de ydre spidse, de indre budte med en Braad, alle kortere end den trekantede, æg-lancetformede, braadspidsede Kapsel.

$1 / 2-11^{1} 2^{\prime}$ høi. Kapselen glindsende sort eller mørkbruun. Nøglerne storre end hos de 2 foreg. 7-8. 4.

$\beta$, repens (J. repens Nolt. nov.) Stængelen krybende (eller i Vand flydende), rodslaaende.

$\gamma$, pauciflorus Sond. A. Hamb. p. 193 (J. nigritellus D. Don, Bab. man.; J. articulatus $\beta$, subatratus H. N. Xll, 72). Qvastens Grene færre og mere oprette, færre Blomster i Nøglerne.

$\delta$, multiflorus! Nøglerne større, mangeblomstrede; de nedre Grene paa Stængelen udgaae nedenfor Bladet.

I Torvmoser, paa Enge og ved Grofter alm. udbredt. $\beta$, ved sandige Sobredder eller i selve Vandet; $\gamma$, med Hovedarten paa magrere Grund; $\delta$, paa fugtige Steder, sjeldnere, f. Ex. J. Skagen (Drej.), Toftegaard i Store Vildmose, Rørbek $S \emptyset$ red 0 . Nykirke! Sl. mellem Limsig og Scliwabstedt (Didr.); $\boldsymbol{S}$. Flommen ved Soro (12). Denne sidste svarer ontrent til Bekr. af $J$. lagenarius Laharp., Gren. \& Godr. fl. Fr. IlI, 346; (J. repens Req.), men forekommer mig ikke tilstrækkelig adskilt fra J. lamprocarpos.

473. J. atricapillus [Drej. i Krøy. Tidsskr. 11, 182] (Sorthoved-S.) J. atratus H. N. XI, 68 (ikke Krock.).

Rodstokken vaudret; Stunglcrne oprette, 2-3-bladede, svagt fladtrykte; Bladskederne paa liyggen kjølede; Bladene med tydelige Shillevagge, ved Torring fiut stribede paalangs; Blomsterstanden en dobbelt sammensat Qvast med oprette Grene; de indre Perigonblade budte, de ydre lidet længere, spidse, kortere end den ag-laneetformede, braadspidsede Kapsel.

$1-1^{1 / 2^{\prime}}$ høi. Nærmest beslagtet med folgende, fra hvilken den dog er let lijendelig ved Perigonbladene og et aldeles forskjelligt Ha- 
bitus, ikke ulig rigblomstrede Former af J. compressus. Blomster og Kapsel morkbrune. 8-9 (meget senere end de beslægtede Arter). 4.

\section{Forekommer under 2 Eormer:}

$\alpha$, congestus! Lavere; Qvasten kortgrenet og tætblomstret, med stor'e Nogler.

$\beta$, sparsiflorus! (J. anceps Laharp., Gren. \& Godr. Fl. fr. III, 347; J. nigricans Rehb. 911), høiere af V:ext, med langere og finere Grene, farre Blomster i Noglerue.

I Halveens Sandklitter langs Vesterhavet ikke sjelden fra Skagen (Drej.) til Eidersted (16), samt paa de vestlige Øer: Romø (16), Amrom (20)! Sild (28)! folger paa enkelte Steder Sandstrækningerne længere ind i Landet: Oland, Holstebro (16), Varde! De 2 Former synes hos os at viere lige hyppige. (Fra Vestfrankrigs sandige Kyster har jeg Expl. under Nıvn af J. anceps Laharp.? (Letourneux), som aldeles svare til Formen $\beta$ ). [同]

Anm. J. atratus Krock., Fr. mant. 3, p. 23, Rehb. 909-10, med $\Sigma-3^{\prime}$ hoie, opstigende Stængler, tydeligt og i torret 'l'ilstand dybt stribede Blade, Perigonbladene braadspidsede (de indre læengere), omtr. ligelange med den agformede, braadspidsede Kapsel, kunde muligviis findes i vor Flora. Den synes (efter Beskr. og Afbildn. hos Rehb.) at vare nermere beslagtet med J. acutiflorus og lamprocarpos end med foreg.

474. J. alpinus [Vill. Dauph. II, p. 233] (Sodfarvet S.) H. II, 169; F. D. 2171 ; Rehb. l. e. fig. $896-900 ;$ H. N. VI, 66 og VIl, $71 \%$ acutiflorus); J. ustulatus $H_{p p}$, Drej. n. 370 ; Lge. Hndb. 1 Udg. n. 461.

Rodstoliken vandret; Stcenglerne oprette eller opstigende, 2-3-bladede, nasten trinde; Bladskederne paa Ryggen kjølede; Bladene ved Torring fiint stribede paalangs; Blomsterne i enkelt eller sammensat Qvast med oprette Grene; Perigonbladene budte, de ydre med en Braad nedenfor Spidsen, ligelange, kortere end den æg-lancetformede, braadspidsede Kapsel.

$1 / 2-1^{\prime}$ hgi, finere end de foreg., Perigonbladene sodfarvede, Kapslerne glindsende sortbrune. 7-8. ข.

$\beta$, rariflorus Hartm. (H. N. VII, 72). Qvasten fjernblomstret, med 2-5-blomstrede Nøgler og blegere Blomster.

I fugtige Enge og Klitmoser: i H alvoens vestlige og nordlige Deel paa flere Steder (Drej., N.), Als (10); $\boldsymbol{S} j$. sjelduere: Bidstrupgaard (N.), Fuursøen ved Kaningaarden (9), Moseu mellen Ermelund 
og Ordrups Krat! (Fra de andre Øer er den mig iklke bekjendt). $\boldsymbol{\beta}$, ved Gurre $\mathbf{S} \emptyset(8)$ ! [*

475. J. supinus [Moench Pl. hass. n. 296] (Liden S.) H. 386 ; F. D. 1099 ; Rchb. l. e. fig. $882-86$; H. N. V, 72; J. bulbosus L. Sp. ed. 1; J. uliginosus Roth, Drej. u. 367.

Tueformet, med sammentræugt, ofte knollet Rodstok, Bladene traadsmale, paa Overfladen rendede, utydeligt leddede paatværs; Blomsterstanden en enkelt eller sammensat Qvast med faae og fjerntsiddende Nøgler; de ydre Perigonblade spidse, de indre budte, alle ligelange og lidet kortere end den budte, braadspidsede Kapsel; $3-6$ Stovdragere; Stovknapperne af Længde med Støvtraadene.

2-8" høi. Stænglerne traadformede. 7-8. 2. En meget foranderlig Plante i Henseende til Stængelens Retning, Blomsterstanden, Noglernes Størrelse, Blomsternes Farve o. s. v. De vigtigste Former ere :

$\boldsymbol{\alpha}$, terrestris. Stænglerne oprette eller opstigende; Blomsterne bruunagtige.

$\beta$, repens. Stængelen krybende.

$\gamma$, fuitans (J. subverticillatus Wulf., F. D. 817 ; H. N. II, 64). Stængelen flydende, med forlængede Blomsterstilke; Nøglerne omgivne af Bladknipper; Blomsterne grønlige.

Alm. udbredt $\mathrm{i}$ alle Provindser: $\alpha$, paa fugtig Hedejord, torvholdige Enge; $\beta$, par oversvommede Steder; $\gamma, i$ selve Vandet, især i Tørrmoser.

\section{ß. Bladene uden Tværskillevægge.}

ra. Perigonbladene af Langde med eller kortere end Fapselen.

476. J. squarrosus L. (Børstebladet S.) H. 383; Drej. n. 372 ; F. D. 430 ; Rchb. l. c. fig. 893 ; H. N. XV, 72.

Tueformet; Rodbladene talrige, stive, børsteformede, rendede, de ældre udspærrede eller opstigende; Stanglerne oprette, fladtrykte eller svagt kantede, ved Grunden enbladede, forøvigt bladløse; Blomsterstanden en sammensat Qvast, med eneller faablomstrede Blomsterstilke; Perigonbladene budte, af Lsengde med den omvendt-rgformede eller ovale, budte, braadspidsede Kapsel; Støvknapperne 4 Gange længere end Støvtraadene. 
${ }^{1 / 2}-\mathbf{1}^{\prime}$ høi. Kapsel og Perigonblade glindsende graabrune, de sidste, ligesom de rodlige Drkblade, i Rauden hvidhindede. 6-8. 4.

I Tørv- og Hedemoser, paa tørre og magre Enge, alm. udbredt, især hyppig i Halveens Hedeegne og par Bornholm; sjeldnere i Fyenlog paa Falst. (14), ikke funden i Loll. (19).

477. J. compressus [Jacq. Enum. stirp. agr. vind. p. 60] (Fladstraaet S.) Drej. u. 373 ; Rehb. 1. e. fig. 890-92; J. bulbosus L. Sp., ed. 2; H. 387; F. 1). 431 ; H. N. IX, 71.

Rodstolken krybende eller sammentrængt; Stcenglerne trindtfladtrykte, med 1 Blad omtrent paa Midten; Bladene linieformede, rendede; Blomsterstanden en enkelt eller sammensat Qvast med oprette Grene; Perigonbladene budte, omtrent halvt saa lange som den næsten kugleformede, kort braadspidsede Kapsel; Griffelen halvt saa lang som Frugtknuden.

$1 / 4-1^{\prime}$ høi. Stænglerne ofte forneden knolleformigt opsvulmede. Perigonbladene brune med hindeagtig Raıd og grønguul Midtnerve. 7-8. 4.

Paa Enge saavel i Nærheden af Havet som inde i Landet, alm.

478. J. Gerardi [Lois. Not. p. 60] (Botnisk S.) Rchb. 1. c. fig. $888-89$; H. N. X, 63; J. bottnicus Wahlenb., Drej. n. 374 ; F. D. 2411 ; J. bulbosus maritimus H. 387.

Stcenglerne næsten trinde, oventil trekantede; Perigonbladene budte, næsten af Længde med den ovale, svagt trekantede Kapsel; Griffelen af Frugtkuudens Længde, forøvrigt som foreg., hvilken den meget ligner, og af bvilken Mange ansee den for en Afart. 7-8. 4.

Paa Strandenge ikke sjelden, især hyppig paa Øerne og ved Fjordene paa Halvøens Ostkyst.

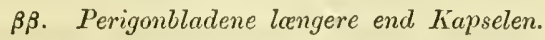

479. J. tenuis [Willd. Sp. pl. II, p. 214] (Tue-S.) F. D. 2468 ; Rchb. I. c. fig. 887.

Rodstollien sammentræugt, tueformet, Stanglerne flere, oprette, fine, kun forneden bladbærende; Bladene linie-traladformede, rendede, oprette; Blomsterstanden en kortgrenet Qvast omgivet af $2-3$ lange Dxkblade ved Grunden og med $3-5$ tret 
sammenbobede Blomster paa Grenene; Perigonbladene ligelange, lancetformede, tilspidsede, trenervede, lidet længere end den ægformet-ovale Kapsel.

6-10" høi, med talrige Blade fra Rodstokken. Ferigonbladene: guulgronue med hvidhindet Rand; Kapselen blegbruun. 7-8. 4.

Expl. fra mager Jord paa AEr (10) findes i J. Vahls Herbarium. Da den ogsaa voxer i Holsteen, kunde den maaskee findes paa flere Steder i Landet. 7

Anm. Fra J. bufonius fasciculatus kjendes den ved en vedvarende Rodstok og kortgrenet Qvast, fra yngre Former af J. compressus ved de tilspidsede Perigoublade, som ere længere end Kapselen.

480. J. Tenageja [Ehrh. Beitr. 4, 148] (Tyndstænglet S.) H. 388 ; F. D. 1160 ; Tenageja Vaillantii Thuill., Rchb. l. c. fig. 923 .

Stanglerne trinde, 1-2-bladede; Bladene børsteformede, forneden rendede; Blomsterstanden qvastformet, med udstaaende Grene og spredte, enlige Blomster (paa tydelige Blomsterstilke); Perigonbladene æg-lancetformede, sylspidsede, de indre af Længde med de ydre, længere end den budte, næsten kugleformede Kapsel.

2-8" høi; fleerstæunglet, med traadfine Stængler; Kapsler og Perigonblade brune, de sidste med gron Midtnerve. 6-8. $\odot$.

Tørv- og Hedemoser, sandige Overdrev, kun funden paa Halvøen: Fra $\boldsymbol{J} y l l$. (livorfra den angives af H.) er mig intet Voxested bekjendt; $S l$. Rødemis ved Husum, Wittensee (16).

481. J. bufonius L. (Tudse-S.) H. 388 ; Drej. n. 375 ; F. 1. 1098 ; Rchb. 1. c. fig. $872-76$.

Stcengelen trind, en-fleerbladet; Bladene børsteformede, forneden rendede; Blomsterstanden en Qvast med oprette Grene og enlige, spredte Blomster (siddende eller meget kortstilkede i Vinklerne og langs 'Siderne af Grenene); Perigonbladene lancet-sylformede, tilspidsede (de ydre læugst), alle længere end den omvendt-ægformede, budte Kapsel.

$4-8^{\prime \prime}$ høi, fleerstienglet og fleerblomstret; Perigonbladene hvidhindede med gron Midtuerve. 6-8. $\odot$.

$\beta$, fasciculatus Koch, H. N. VII, 73; (J. insularis Viv., 
Rehb. l. e. fig. $877-81$ ). 1-4" høi, Blomsterne $2-3$ samlede $\mathrm{i}$ Nogler.

Paa fugtig Grund meget alm.; $\beta$, ved Soj- og Aabredder: $S j$. Damhuussøen (27), Flaskekroen! $\boldsymbol{F}$. Nartofte pai Hindsholm! $\boldsymbol{J}$. Skjern Aa ved Lønborg! Rørbæk $S \emptyset$ ! Nebbegaard! Ornsø ved Ribe (12); Sl. Seemïhle ved Rendsborg! St. Peter i Eidersted (16).

482. J. pyğmaus [Thuill. Fl. par. 178] (Dværg-S.) H. II, 171 ; F. D. 1871 ; H. N. XI, 69; J. triandrus Rehb. 1. e. fig. 864 .

Stangelen opret; Bladene børsteformede, rendede, samlede red Roden; Blomsterne i'3-4-blomstrede Nøgler, som sidde enlige eller $2-3$ samlede $i$ Enden af Stængelen (det ene stilket, det andet siddende); Perigonhladene laneet-sylformede, lidet langere end den trekantede, pyramideformede Kapsel; 3 Støvdragere.

1-3" høi. En-fleerstænglet. 7-8. $\odot$.

Paa fingtig Sandjord i Klitterne mod Vesterhavet paa Halve en: Thy (Dr.), Løkken (7), Langslade Rende ved Blaavandshuk (30)! S l. List paa Sild, Eidersted (N.). 医

483. J. capitatus [Weig. Obs. bot. p. 28] (Fiinbladet S.) H. 389 ; F. D. 1690 ; Rehb. l. e. fig. 862 ; H. N. I, 71 .

Stcengelen opret, traadformet, bladløs, ved Grunden omgivet af børsteformet-haarformede, rendede Blade, som ere kortere end Stængelen; Blonsterne $3-6$ samlede i $1-2$ endestillede Nøgler (det ene stilket, det andet siddende); de indre Perigonblade ægformede, spidse, lidet kortere end de ydre (langt tilspidsede), næsten dobbelt saa lange som den budte, xgformede Kapsel; 3 Støvdragere.

$1-6^{\prime \prime}$ høi. En-fleerstæenglet, Perigonbladene rødbrume med hindeagtig Rand og gron Rygnerve. 6-8. $\odot$.

'Sandige Overdrev og fingtige Steder mellem Klitterne sarut ved Veie i Hedeegnene; hist og her i Ilalvoens Sandstrekninger, paa Øerne sjelden: $\boldsymbol{S} j$. Adserbo Overdrev ved Frederikswark! Bornh. ved Veie N. for Rønne og mellem Ronne og Pythiset!

Anm. J. triandrus Gouan (J. pygmeus Rchb. l. c. 863) adskilles efter Koch vasenligt kun ved udstaaende Dakblad og hele Plantens rodbrune Farve. Denne findes muligen ogsai $i$ vor Flora, men el neppe en fra foreg. adskilt Art. 


\section{Luzula. Frytle.}

a. Blomsterne i Halrskjærm med enblomstrede eller quastformet 2-3-blomstrede Blomsterstilke.

Frøene med en seglformet Frøhud i Spidsen.

484. L. pilosa [Willd. En, hort. berol. I, 393] (Haaret F.) H. 395 ; Drej. n. 359 ; F. D. 2533 ; Rehb. l. c. fig. 848-49; L. Herb. VIII, 145; Juncus pilosus L.; L. vernalis DC.

Bladene linie-lancetformede, langhaarede; Blomsterstilkene efter Afblonstringen tilbagebøiede; Perigonbladene ligelange; Kapselen trekantet, pyramideformet, budt med en Braad.

$1 / 2-1^{\prime}$ høj. Perigonbladene sortbrune, glindsende, med hindeagtig Rand. 4-5. 4. Var.

$\beta$, simplex Sonder Fl, Hamburg. p. 199. Rodbladene næsten linieformede, Blomsterstilkene oprette (ved den bøiede Frøhud forskjellig fra L. Forsteri DC., som den noget ligner).

Almindelig i Løvskove. $\beta$, Haven Skov i Vendsyssel (12).

Anm. L. Forsteri DC., som adskilles ved linieformede Rodblade, Blomsterstilkene efter Afblomstringen oprette, Frøhuden ret, kunde muligviis forekomme i vor Flora. (Den er funden af Prof. Nolte i Holsteen).

b. Blomsterne i faa- (3-5-) blomstrede Nøgler, samledetilen 2-3-dobbelt sammensat Halvskjærm, Frøene uden eller med ensvag, vorteformet Frøhud i Spidsen.

485. L. maxima [DC. Fl. fr. III, p. 160] (Stor F.) H. 396 ; H. N. XIV, 74 ; L. silvatica Gaud., Rchb. l. c. fig. 861 ; Juncus pilosus $\delta$, L., F. D. 441.

Bladene bredt-linieformede, i Randen langhaarede; Stcongelbladene kortere end Ledstykket ovenfor samme; Dokbladene kortere end Blomsterstanden; Perigonbladene ligelange, tilspidsede, omtrent af Længde med den ægformede, braadspidsede Kapsel.

$1-2^{\imath}$ høi. Perigonbladene mørkbrune, med blegere hindeagtig Rand. 5-6. 4 .

I høitliggende Bøgeskove, forekommer kun $\mathrm{i}$ den vestlige Deel 
af Landet og synes her at luave sin Østgrændse: J. Hald Bøgeskov ved Viborg (H.), Kalbygaard (12), Himmelbjerget, Silkeborg! og derfra mod S. ikke sjelden i Skovene paa Halvøens Østkyst; $\boldsymbol{F}$. Strand-

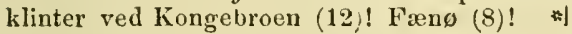

486. L. albida [DC. 1. c. p. 159] (Blegblomstret F.) H. 395 ; Drej. n. 358 ; F. D. 2467; Rehb. l. c. fig. 854 ; H. N. XII, 74 .

Bladene linieformede, langhaarede; Stungelbladene længere end Ledstykkerne; Dakbladene lengere end Blomsterstanden, hvis nederste Green er langt fjernet fra de øvre; Perigonbladeneæg-lancetformede, spidse (de ydre kortere), alle lidet længere end den trekantede, spidse Kapsel.

$1-1^{1 / 1} 2^{\prime}$ høi. Perigonbladene hvide eller i Midten kjødfarvetblegbrune. 6-7. 4 .

I Skove, meget sjelden i Danmark: $\boldsymbol{S} j$. Gjels Skov (9)! $\boldsymbol{S} \boldsymbol{l}$. Schwabstedter Holz (16). 周

c. Blomsterne $i$ mangeblomstrede (axformede) Nøgler, samlede til en Halvskjærm. Frøene med en kegleformet Frøhud ved Grunden.

487. L. multiflora [Lejeune Fl. de Spa. I, 169] (Mangeblomstret F.) Rehb. I. c. fig. 838 ; L. Herb. III, 54 ; L. erecta Desv., Drej. n. 357; L. campestris erecta H. II, 172; Juncus campestris F. D. 1333.

Rodstokken forkortet, med tueformet samlede Stcengler, uden Udløbere; Bladene linieformede, i Randen, især ved Grunden, langhaarede, tilsidst glatte; Noglerne oftest talrige, det ovre siddende, de фvrige stilkede, med oprette Stilke; Perigonbladene tilspidsede, længere end den afrundede, braadspidsede Kapsel; Stovdragerne omtr. halvt saa lange som Kapselen, Støvknap og. Støvtraad ligelange; Griffelen tidligt affaldende, neppe halvt. saa lang som Arrene.

$1 / 2-1^{\prime}$ høi. 5-7.

$\boldsymbol{\beta}$, pallescens (Hopp.) H. N. VI, 67 ; L. campestris palleseenz H. 393; Blomsterne blegere, Nøglerne mindre.

$\gamma$, congesta Fr. (L. congesta Lejeune, II. 394; F. D. 1692). 
Nøglerne kortstilkede eller næsten siddende (samlede til et tæt Hoved).

Paa Enge og i Skove alm. udbredt; $\beta$, i Skygge, mindre hyppig; $\gamma$, Hedemoser og Klitter: $\boldsymbol{S} \boldsymbol{j}$. omkring Søndersøen ved Jonstrup (14); J. Klitter ved Henne! S l. Hedemoser mellem Flensborg og Lyksborg (H.); Husum (F. Müll.), Schulendamm ved Rendsborg (20).

488. L. campestris [DC. 1. c. p. 161] (Mark-F.) H. 392, Drej. n. 356 ; F. D. 1386 (var.), Rchb. l. e. fig. 831-33, H. N. XII, 73, L. Herb. III, 53; Juncus eampestris L.

Rodstokken krybende; Noglerne $3-5$ samlede $\mathbf{i}$ en Halvskjærm paa tilsidst nikkende Blomsterstille; Støvdragerne omtr. af Kapselens Liengde, Støvknapperne længere end Størtraadene ; Griffelen vedblivende, lidet kortere end de langt fremragende $A r$.

3-8" høi, 4-5 (har næsten fuldvoxne Frugter naar foreg. begynder at blomstre). ข.

Paa Græsmarker, Fælleder og høie Enge meget alm.

\section{Acorus. Kalmus.}

489. A. Calamus L. (Almindelig K.) H. 378; Drej. u. 355 ; F. D. 1158 ; Rehb. I. c. X, 956.

Rodstokken krybende; Bladene sværdformede; Stcengelen fladtrykt-vinget, med et linieformet, opret Hylsterblad ovenfor Kolben.

Hele Planten har en behagelig og stærkt krydret Lugt, Bladene paa Midten paatværs bølgede. 6-7. $ข$.

Ved S 6 - og Aabredder, ikke sjelden $i$ de fleste Egne af Danmark, dog ikke overalt (f. Ex. sjelden i Kolding-Egnen (28) og paa Lolland-Falster! ikke funden paa Bornholm (Hoff).

\section{Calla. Mysse.}

490. C. palustris L. (Kjær-M.) H. 902; Drej. n. 876 ; F. D. 422 ; Rehb. I. e. VII, 13.

Rodstokken skjævt opstigende, leddet; Blaclene falsk-fjernervede, hjerteformede, tilspidsede, stilkede og omskedende med en i den øvre Halvdeel fri Skede; Kolben overalt beklædt med Blomster.

Hylsteret udvendig grønt, indvendig hvidt, Bær røde. 6-7. ข. 
I Torvmoser og Sumper; i flere Egne hyppig, f. Ex. det nordøstlige Sjall. og vestlige Jyll. fra Ringkjøbing til Ribe, forøvrigt sporadisk og i enkelte Egne (f. Ex. det sydvestlige Sj., F. og Øerne) sjelden! ikke bemærket paa Bornh. (Hoff.) (*

\section{Trigynia.}

\section{Polygonum. Skedeknao.}

a. Bistorta Tournef. 1 enkelt Ax eller axformet Klase i Spidsen af den udeelte Stængel. Kræmmerhusene valseformede, heelt omfattende Stængelen, 3 Grifler, Nød trekantet. 4.

491. P. viviparum L. (Topspirende S.) H. 442 ; F. D. 13.

Rodstokken vanclret; Bladene laneetformede eller linie-lancetformede, med tilbagerullet Rand; Bladstilken uringet; Axet smalt, linieformet, med Løgknopper i de nedre og Blomster i de øvre Dækblades Hjørner; Støvdragere 8, længere end Blomsterdakket.

4-8" høi. Blomsterne hvide eller hlegrøde, Støvknapperne violette, Løgknopperne spire ofte medens de endnu sidde paa Planten. $6-7$.

I Moser mellem S. Tranders og Romdrup ved Aalborg (H.), mellem N. Tranders og Gudumlund (16), Neufling Mose S. for Aalborg (Juel), Aalborg Exerceerplads (Branth)! de eneste bekjendte Voxesteder i Danmark.

492. P. Bistorta I. (Tvevreden S.) H. 441; F. D. 421 ; H. N. XI, 52.

Rodstokken vandret, krumbøiet; Bladene aflang-hjerteformede, de ovre siddende, de nedre stilkede med vinget Bladstilk; Klasen tætblomstret, elliptisk eller valseformet; Stovdragere 8, længere end Blomsterdoliket.

1-1 $1 / 2^{\prime}$ høi. Blomsterne blegrøde. Støvknapperne hvide. $6-7$.

Paa Enge, sjelden i Dammark: J. Podeluuset ved Aalborg (H.), Boller Skov (16), Haraldskjæer (12); S l. en Eng ved Flensborg (25), Nyvark ved Slesvig, Slotsengen og Süderholz red Husum (16). Paa Øerne angives den fra flere Steder, bvor den enten senere er forsvunden eller maaskee udvandret fra Haver (f. Ex. Sj. Gurre Vang 
(Heiberg), Dronninggaard (H.), Leersøen (19), Vedbæk, Roeskilde ; Loll. (Kylling); Fals $\boldsymbol{l}$. paa en Eng ved Kirkeby (14).

b. Persicaria Tournef. Stængelen grenet, med Ax fra Bladhjørnerne; Kræmmerhusene valseformede, heelt omfattende Stængelen; Nød trekantet eller fladtrykt.

aa. Axene tatblomstrede, valseformede. a. 5 Støvdragere. $\psi$.

493. P. anıhibium L. (Tveformet S.) H. 438; Drej. n. 399 ; F. D. 282.

Rodstokken krybende; Bladene bredt lancetformede, med afrumdet eller hjerteformet Basis; Axene oval-valseformede, oftest enlige (tilsyneladende endestillede), Griflerne 2, i 1/3 af deres Længde sammenvoxne.

Blomsterne rosenrøde. 7-9. Var. efter Voxestedet, især under 2 Fiormer:

$\boldsymbol{\alpha}$, terrestre Leers. Stængelen opret, Bladene kortstilkede, overalt haarede og rue; Kræmmerhusene tiltrykt-stivhaarede.

$\boldsymbol{\beta}$, natans Moench. Stængelen flydende; Bladene langstilkede, i Randen rue, forøvrigt tilligemed Kræmmerhusene glatte; Axene kortere og mere afrundede.

Alm. udbredt: $\alpha$, paa dyrket Jord, især fugtig Leerjord, ved Randen af Grøfter, $\beta$, i Damme og Søer.

\section{B. 6-8 Støvdragere. $\odot$.}

494. P. lapathifolium L. (Blegbladet L.) H." 439; Drei. n. 398 ; H. N. IV, 69 ; Rchb. ic. crit. V, 688.

Stangelen opret eller nedliggende; Bladene elliptiske eller lancetformede; Krommerhusene kort-randhaarede, forøvigt næsten glatte; Axene valseformet-ovale (foroven afrundede); Blomsterstilke og Blomsterdakke beklædte med Kirtler; Griflerne 2, næsten til Grunden adskilte; Nodden fladtrykt med concave Sider.

Bladene grønne eller hvidgraae af tiltrykte Haar, med eller uden en trekantet Plet paa Midten. Var. med hride, blegrøde eller skiden- 
gule Blomster. 7-9. Blandt de talrige Former ere de meest udmærkede:

$\beta$, pallidum Fr. mant. 2 p. 24; (P. pallidum With., F. D. 2412 ; H. N. IV, 70). Axene tykke og korte, Endeaxet ovalt, Sideaxene kugleformede, siddende. Hele Planten bleggrøn. Blomsterne oftest hvide.

$\gamma$, incanum Koch (P. incanum DC., Fr. H. N. IV, 73; P. lapathifolium $\delta$, procumbens Sond.). Bladene lancetformede, især paa Underfladen hvidfiltede; Stængelen fra Grunden af grenet, med nedliggende Grene.

Paa dyrkede, især fugtige Agre et meget almindeligt Ukrud (den hvidgraa Form især paa tor Grund); $\beta$, med Hovedarten temmelig almindelig; $\gamma$, ikke sjelden og par lignende Steder som Hovedarten.

* 495. P. nodosum [Pers. Enchir. I, p. 440] (Ophovnet S.) Meisn. i DC. prodr. XIV, p. 118; Fr. nov. mant. 2, p. 25 ; F. D. 2648 ; Rehb. ic. crit. V, 686 og 689 ; P. laxum E. B. 2822 ; P. lapathifolium $\gamma$, nodosum (autt. plur.) Lge. Haandb. 1 Udg. S. 221.

Stcengelen opret, med opsvulmede Led og udspærrede Grene; Axene linie-valseformede, foroven tilspidsede, talrige og mere tæt samlede; Griflerne som hos foreg., med tilbagebøiede Grene, Dahbladene bredt ægformede, oftest glatte, forøvrigt som foreg., men hoiere, med ofte stærkt rødplettet Stængel og smukt rosenrøde Blomster.

Alm. høiere end foreg. Art. Var. med flere eller færre Kirtler eller næsten glat. 7-9.

Ved Randen af Grøfter og Vandløb hist og her, f. Ex. i Kjøbenhavns Omegn paa mange Steder, Tryggerøl Mose! Jonstrup (14); F. Osterøen ved Nylorg (Lund); B or $n h$. Vsegerne ved Runne (Hjorth).

Anm. Ligner i Udseende P. Persicaria, i Characterer P. lapathifolium, og har af forskjellige Forff. væeret lenført snart til demne, snart til hiin. Maaskee er den kun en ved Voxestedet frembragt Form af P. lapathifol., men par Grund af dens eiendommelige Udseende har jeg iklie taget i Betæenkning med Meisner i det eiterede monographiske Arbeide (DC. prodr.) at opstille den særskilt.

496. P. Persicaria L. (Færskenbladet S.) H. 438; Drej. n. 397 ; F. D. 702 ; Rehb. 1. c. 684 ; H. N. IV, 74 . 
Krommerhusene tiltrykt-haarede og langt randhaarede; Axene valseformet-ovale, foroven afrundede; Blomsterstilke og Blomsterdakke uden Kirtler; Griflerne 2, til Midten sammenvoxne; Nodderne fladtrykt-convexe med en hvælvet og en flad Side eller budt-trekantede; forøvrigt som de foreg., og var., ligesom hine, i Henseende til Blomsternes og Bladenes Farve, Beklædning og Form. 7-9.

$\beta$, biforme (Wahlenb.) Fr. m. 2, p. 28 ; H. N. X, 57. Opret; Bladene grønne; Axene i Begyndelsen tæt samlede, alle Dækbladene randhaarede; Blomsterdækket utydeligt nervet.

Paa dyrkede Marker et alm. Ukrud mellem Sæden. $\beta$, paa mere fugtige Steder.

b6. Axene traadformede, afbrudte ved Mellemrum mellem Blomsterne.

497. P. strictum [All. Fl. ped. II, 207] (Liden S.) Fr. mant. 2, p. 32 ; H. N. XI, 53.

Stangelen tynd; Bladene linie-lancetformede, kortstilkede eller næsten siddende; Krammerhusene stivhaarede og langt randhaarede; Axene mod Frugtmodningen oprette; Blomsterstilkene af Længde med eller kortere end de randhaarede Dokblade; Blomsterdakket glat; Støvdragere $5-6 ; 2-3$ til Midten sammenvoxne Grifler; Nødderne smaae, glindsende, trekantede eller fladtrykte med convexe Sider. 7-9. $\odot$.

$\alpha$, elatum Fr. I. e. (P. minus Rchb. I. c. 686; P. mite nonn. autt., H. N. VII, 53). Opret, $1-1^{1} / 2^{\prime}$ høi, oventil grenet; Blomsterne hvide eller blegrøde.

$\beta$, pusillum Fr. (P. pusillum Lam., P. minus H. 440 ; Drej. n. 396 ; F. D. 2230 ; H. N. IV, 75 og (P. mite) IV, 76?). Lavere $\left(3-8^{\prime \prime}\right)$, fra Grunden af grenet, med nedliggende eller opstigende Grene; Blomsterne rosenrøde.

Paa fugtig og tor Jordbund; $\boldsymbol{\beta}$, forekommer hist og her i alle danske Provindser, især paa Torvgrund; $\alpha$, sjelden og især paa skyggefulde Steder: $\boldsymbol{S} \boldsymbol{j}$. Nyrup Hegn ved Helsingør (Heiberg), Frederiksborg (12), Rudersdal (1), Vedbæk! Pedersborg ved Sorø! Falst. ved S. Kirkeby (Koch), N. Vedby (19); Loll. ved Juellinge og Solle- 
sted (19); F. Ollerup Kohave! J. Rydhave ved Holstebro (Schmidt!), Eveldrup (herb. Drej.); $\boldsymbol{S} l$. Flensborg!

498. P. laxiflorum [Whe. i Flora 1826 p. 746] (Fjernblomstret S.) Fr. 1. c. p. 3 L; P. mite Pers., Koch.; P. dubium Stein; P. intermedium Ehrh., Hansens Herb. Nr. 1219.

Stangelen opret, Bladene lancetformede, kortstilkede eller næsten siddende; Krommerhusene tiltrykt haarede og langt randhaarede; Axene fjernblomstrede, nikkende; Blomsterstilkene omtrent af Længde med de randhaarede Dakblade, Blomsterdakket glat; Støvdragere 6--8, Griffelen 2-3-deelt, Nodderne glindsende, trekantede eller plan-convexe.

Fra den større Form af foreg. kjendes den ved tykkere Stængel, nikkende $\mathrm{Ax}$ og større Frugter. I Udseende ligner den mere den folgende, men adslilles let ved de anforte Kjendetegn og mangler desuden den bidende Smag. Blomsterne rosenrøde. 7-9. $\odot$.

Paa fugtige Steder, sjelden: $\boldsymbol{S} \boldsymbol{j}$. Ledreborg (Weilbach)! $\boldsymbol{F}$. Rødskebølle (12); $S \boldsymbol{l}$. Hollingsted (Didr.)! (I Holsteen har jeg fundet den ved Glïekstadt).

Anm. Navnene P. mite Schrank og P. minus Huds. ere af forskjellige Forfattere tillagte forskjellige Arter, og derfor tvivlsomme. Af de talrige Bastardformer mellem denne og de ovrige Arter af Gruppen Persicaria, som anfores (sml. Gren. \& Godr. fl. Fr. III, p. 49-50) har jeg ingen bemærket $i$ vor Flora.

499. P. Hydropiper L. (Bidende S.) H. 440 ; Drej. ni 395 ; F. D. 1576 ; Rchb. l. c. 687.

Stangelen opret eller opstigende; Bladene lancetformede, næsten siddende; Krommerhusene kort-randbaarede, forøvigt glatte; Axene fjerntblomstrede, nikkende; Blomsterstilkene ved Frugtmodningen fremragende udenfor de ikke randhaarede $D c k$ blade; Blomsterdakket kirtlet-punkteret; Stovdragere 6; Griffelen næsten til Grunden todeelt; Nodderne glandsløse, trekantede eller fladtrykte med convexe Sider.

Bladene og Frugterne have en skarp Smag. Blomsterne hridgronne med rødt Anstrøg. 7-9. $\odot$.

Paa fugtige Steder almindelig. 
c. Avicularia Meisn. Stangelengrenet med spredte Blomster i Bladhjornerne; Kræmmerhusene-tvedeelte eller uregelm. fligede; 8 Støvdragere; 3 Grifler med hovedformede Ar; Nødden trekantet.

500. P. aviculare L. (Udstrakt S.) H. 443; F. D. 803 ; Centinodium Rehb.; Drej. n. 434.

Bladene lancetformede eller elliptiske; Blomsterne 1-3 i Bladhjørnerne; Krcmmerhusets Flige tilspidsede, tilsidst lasetmangedeelte; Nødderne glandsløse, fint stribede, omtrent af Blomsterdækkets Længde.

Blomsterne blegrøde med grøn Rygnerve, sjeldnere hvide eller mørkrøde. 7-9. $\odot$. En yderst forauderlig Plante; dens vigtigste Former ere:

$\alpha$, prostratum. ( $\varepsilon$, depressun Meisn.) Stænglerne talrige, meget grenede, tiltrykte til Jorden; Bladene linie-lancetformede.

$\beta$, littorale. Stængelen med korte Ledstykker; Bladene brede, saftige.

$\gamma$, erectum (latifolium). Strngelen opret, Bladene bredt lancetformede eller elliptiske, noget budte.

$\delta$, angustissimum Meisn. Stænglerne nedliggende eller op. stigende, tynde, med forlængede Ledstykker, Bladene linieformede, Kræmmerhusene længere, Blomsterne faae og fjerntsiddende.

En meget almindelig Ukrudsplante, $\alpha$, paa Gader og Veie; $\beta$, ved Strandbredder; $\gamma$, paa dyrkede Marker; $\delta$, mellem Sæden, især paa Sandgrund.

d. Tiniaria Meisn. Stængelen slyngende; Blomsterne i mellembrudte Klaser; Kræmmerbusene korte, skraat afskarne; 8 Støvdragere; I Griffel med 3 hovedformede Ar; Nød trekantet.

501. P. Convolvulus L. (Snerle-S.) H. 445; F. D. 744; Tiniaria Drej. n. 435.

Stcengelen kantet furet; Bladene piilformet-hjerteformede, tilspidsede; Blomsterstilkene kortere end Blomsten og tilleddede 
til denne tret nedenfor sammes Basis; Blomsterdakkets 3 ydre Flige budt-kjølede efter Afblomstringen; Nodderne glandsløse, fiint punkterede.

Hele Planten svagt beklædt af et melet-dunet Overtræk. Blomsterne rødlig-grønne, indvendig og i Randen hvide. 7-8. $\odot$.

Almindelig paa dyrket Jord, isæer mellem Sreden.

502. P. dumetorum L. (Vingebrgeret S.) H. 446 ; F. D. 756 ; H. N. XIII, 68, Tiniaria Drej. n. 436.

Stungelen trind, stribet; Bladene som hos foreg.; Blomsterdackiets 3 ydre Flige med tilsidst brede, hindeagtige Vinger paa Ryggen, nedløbende $i$ en Blomsterstilk omtrent af Blomsterdækkets Længde; Nodderne glindsende, jævue.

Glat. Blomsternes Farve som foreg. De tidligst udsprungne Blomster have stundom uvinget Blomsterdække (23)! 7-9. $\odot$.

I Udkanten af Slove og Krat, ved Gjærder, forekommer i alle danske Provindser, men sporadisk, hyppigst i Fyen og paa Thorseng!

\section{Rumex. Skrappe. $\left.{ }^{*}\right)$}

a. Lapathum Tournef. Blomsterne trekjønnede (eller enbo), (Skræpper).

aa. Hydrolapathum Fr. Krandsene tat samlede, $i$ Spidsen bladlose; Kronbladene brede, nasten hjerteformede, heelrandede eller svagt takkede.

503. R. Hylrolapathum [Huds. Fl. angl. p. 154] (Vand-S.) H. 401 ; Drej. n. 409 ; F. D. 2348 ; H. N. VI, 52.

*) Arterne af denne Slægt maa undersøges henimod Frugtens Modenhed, da Blomsterdæklsets indre Blade (Kronbladene), som afgive vigtige Kjendetegn, forst paa denne Tid have naaet deres fuldkomne Udvikling, idet de hos alle Arter, undtagen $\mathrm{Nr}$. 517, tiltage i Storrelse og forandres i Form efter Afblomstringen. Ogsaa de modne Nodder have Betydning for Artens Bestemmelse. Til Kundskaben om de nordiske Arter af demne vanskelige Slagt ero de vigtigste Kilder: E. Fries, Nov. ed. 2, p. 94, mant. 3, p. 24, S. Veg. Sc. p. 202 , Hartm. Skand. Fl. 8 Uppl. p. 93 og F. W. Areschoug, adnot. crit. de Rnm. (i Öfvers. af K. Vet. Acad. Förhandl. 1862 p. 57). 
Bladene lancetformede, tilspidsede, bølget-rundtakkede; "Bladstilkene paa Overfladen flade uden Rand"; Kronbladene trekantet-ægformede, alle bruskbærende, heelrandede eller forneden svagt tandede; Noddernes Sider elliptiske, med kort Spids.

3--5' høi. Rodbladene meget lange, paa Underfladen ofte blaagronne. De nedre Krandse ofte langt adskilte. 7-8. 4.

I Aaer og Bække, dybe Tørvgrave og Moser alm. udbredt.

504. R. maximus [Schreb. i Schweigg. \& Kört. fl. Erlang. I, 152] (Stor S.) Drej. n. 408; F. D. 2347; H. N. VI, 53; R. heterophyllus Schultz.

Rodbladene og de nedre Stangelblade forlænget-ægformede med hjerteformet Basis; de øvre Stcengelblade æg-lancetformede, alle Bladene spidse, fiint bølget-rundtakkede; "Bladstilkene paa Overfladen rendede eller flade med en fremstaaende Rand paa liver Side"; Kronbladene trekantet-hjerteformede, heelrandede eller forneden svagt tandede, alle bruskbærende; Nodderne støre, men af samme Form som hos foreg.

$3-6^{\prime}$ høi. $7-8$. 2 .

Ved Aa- og Sobredder sjeiden: $\boldsymbol{J}$. Bonderup og Ferslev ved Aalborg (Branth), Ormholt (12)! Volstrup (8)! Faurholt (Gronlund)! Hjermeslevgaard og Hgoholt i Vendsyssel, Simested Aa (Dr.); $\boldsymbol{S l}$. Syderhøft ved Trenefloden (F. Muill.); $S j$. Paulinelyst ved Helsingor (21), mellem Rudersdal og Birkersd! B ornh. Nexo (11). 绦

505. R. Hippolapathum [Fr. Mant. 3, p. 28] (Dynd-S.) Areschoug, Öfvers. K. Vet. Acad. förh. 1862, p. 61, H. N. V, 55 .

Rodbladene flade, vedblivende, frisk grønne, ægformeteller triangelformet-hjerteformede, budte; Bladstilkene sammentrykte fra Siden eller trinde, foroven rendede; Kronbladene xgformede med næsten lige afskaaren Basis, heelrandede, uden Bruskkorn; Nфddens Sider elliptiske.

3-5’ høi. Bladstilke og Nerver ofte mørkrøde. 7. थ. 
* Helolapathum (R. Helolapathum Drej. i Kroy. Tidssis II, 183 ; Lge. Haandb. 1-2 Udg., F. D. z288; R. aquaticus $\beta$ Drejeri Sond. fl. hamb. p. 207; M. Lange i Naturh. Foren. vid. Medd. 1861, p. 5).

Bladene smalere, aflang-ægformede med hjerteformet Basis, Bladstilkene ved Grunden flade, foroven med en svag Rand af den nedløbende Bladplade, Kronbladene muurskeformet-xgformede, meget budte, mindre end hos Hovedarten.

I Sumpe, kun funden i det nordlige $\boldsymbol{J} y l l$ : : Estrup (12)! og mellem Sulsted og Ø. Brøudersløv i Vendsyssel (Drej.). * Hjermesløvgaard og Hammelmose, ved Grøfter mod Vildmosen (Drej.)! Hørby (Gronlund)! og Haven i Vendsyssel (12)!

Anm. R. Melolapathum Drej. er vistuok ikke lidet forskjellig i Habitus fra den typiske (svenske) R. Hippolapathum Fr., navnlig udmærker denne sig fremfor de jydske Expl. ved lumiere Væxt, bredere Blade og støre, mere uddragne Kronblade, men Charactererne ere deels af underordnet Værdi, deels neppe tilstrækkelige til at begrunde en virkelig Artsforskjel, saameget mindre som Kronbladenes Form (efter M. Langes Iagttagelse) variere, endog paa samme Individ, og hos flere Expl. nærme sig mere den typiske Form. Jeg er derfor nu tilbøielig til med flere Forff. at forene disse under een Art.

506. R. domesticus [Hartm. Sk. Fl. 1 Uppl. p. 148] (By-S.) Drej. n. 419 ; F. J. 2349 ; H. N. VII, 55.

Rodbladene længe vedblivende, tilligemed de nedre Stangelblade bredt oval-lancetformede med afrundet eller hjerteformet Basis, næsten heelrandede, bolgerle; "Bladstilliene halvt valseformede, paa Overfladen flade med en svagt ophoiet Rand paa hver Side"; Kronbladene nyreformede eller bredt hjerteformede, heelrandede eller svagt rundtakkede, alle uden Brusk; Noddernes Sider bredt elliptiske, med kort Spids.

$1-1 / 2^{\prime}$ høi. Bladene frisk og lys grønne. Blomsterstanden tæt $\mathrm{og}$ rigtblomstret. Undtagelsesviis findes Kronbladene nudertiden bruskbærende $\mathrm{og}$ de nedre Krandse langt fjernede fra liverandre (F. D. 2350). $7-8$. $\psi$.

$\beta$, latifolius Hartm. (aquaticus Fr.) Høi af Væxt, med bredere, ved Grunden hjerteformede, næsten ikke bolgede Blade. 
Paa Græsmarker og ved Veic, især i Nærheden af beboede Steder : paa Halvoen alm. udbredt fra Skagen (Drej.) saavel i de ostlige frugtbare Egne som mod V. (Skjern! Ribe, Rødding, Fanø, Sild (16); i $S j$. ikke sjelden i den nordø-tlige Deel, f. Ex. Hellebak, Helsingør! Donze (23), Rungsted! Kjøbenhavns Omegn! mod $S$ og paa de øvrige Oer ikke iagttaget. $-\beta$, i det nordlige $\boldsymbol{J} y \boldsymbol{l}$ t. (Dr.), Lundehuusmosen!

Anm. Meisner (DC. prodr. XIV, p. 44) forener denne Art med R. Hippolapathum Fr. under Navn af $R$. longifolius DC. En slig Forening kan jeg ingenlunde antage for rigtig. $R$. domesticus forekommer mig at have langt mere Lighed med $R$. Patientia end med $R$. Hippo. lapathum, og denne sidste er desuden en Vandplante.

? 507. R. propinquus [J. E. Areschoug, Bot. not. 1840 p. 22] F. W. Aresch. 1. c. p. 69.

Bladene mørkgrønne, bølget-krusede, Rodbladene aflange eller elliptiske, tidligt henvisnende, de nedre Stangelblade laneetformede med hjerteformet Basis, Bladstilkene sammentrykte fra Siden, foroven flade; Kronbladene nyreformet-hjerteformede, budte eller med en kort afstumpet Spidse svagt-bølgeformetrundtakkede, med eller uden Bruskkorn; Nøddernes Sider kort og bredt elliptiske, med kort Spids. Have!

I Nærheden af Øresundet mellem Kalkbrænderierne og Classens

Anm. Den af mig samlede Plante, bestemt af Adj. Areschoug, stemmer ikke aldeles overeens med Beskrivelsen, men endnu mindre med nogen af de audre her forekommende Arter. Den staaer omtrent midt imellem R. domesticus, crispus og conspersus, men jeg kan neppe antage den for en Hybridform, da den er rigeligt frugtbærende og alle Nødderne fuldmodne.

508. R. crispus L. (Kruset S.) H. 401 ; Drej. n. 407; F. D. 1334 ; Rehb. ic. erit. VI, 783; H. N. VII, 56.

Bladene lancetformede, spidse, bølget-krusede, Rodbladene idligt henvisnende; "Bladstillene halvtrinde, paa Overfladen flade uden Rand, foroven vingede af den nedløbende Plade"; Kronbladene bredt hjerteformede, budte, heelrandede eller svagt tandede, alle bruskbærende (Bruskiornene agformede, det ene større end de øvrige); N $N_{\phi} d d e r n e s$ Sider kort og bredt elliptiskægformede, med kort Spids.

$1^{1 / 2}-2^{\prime}$ høi. Bladene mat- og mørkgrønne. Undertiden ere de 
2 Kronblade uden Brusk, undertiden ere Kornene hos dem alle ligestore. 7-8. $\psi$.

Ved Gjærder, paa Grasmarker og omkring Byer, meget alm.

509. R. conspersus [Hartm. Sk. Fl. 3 uppl. p. 85] (Rødbroget S.) Fr. m. 3, p. 26; H. N. VII, 54.

Bladene aflang-agformede med hjerteformet Basis; "Bladstilkene forneden halvtrinde, foroven sammentrykte fra Siden og rendede"; Kronbladene bredt hjerteformede, fiint tandede, det ene fortrinsviis, de andre svagt bruskbærende; Noddernes Sider elliptiske, med lang Spids.

Stængelen 2-3' høi, tilligemed Blomsterne rødligt anløben; Toppen stor med tretblomstrede Grene. 7-8. 4 .

Ved Søbredder sjelden: Sj. Hellebak (12), udenfor Kjøbenharns Norreport mellem Farimagsveien og Sorte Sø! J. Horby og Estrup i Vendsysse] (12), Fjaltring ved Lemvig! Eveldrup (Drej. herb.) ${ }_{\text {[* }}$

bb. Oxylapathum Fr. Krandsene, idetmindste de nederste, adskilte, Kronbladene (typisk) forlonget-tilspidsede.

$\alpha$, Rodbladene med afrundet eller hjerteformet Basis. (Kronbladenes Bruskkorn rundagtige).

$\alpha \alpha$, Kronbladene under Blomstringen heelrandede, imod Frugtmodningen tandede.

510. R. acutus L. [Fr. S. Veg. Sc. p. 52] (Spidsblariet S.) R. pratensis M. \& K., Drej. n. 405, H. N. IX, 58; R. cristatus IVallr., H. II, 173.

De nedre Blade tidligt henvisnende, aflange med hjerteformet Basis, spidse; "Bladstilkene balvtrinde, foroven svagt furede med ophøiet Midtnerve"; Blomsterstandens Grene oprette, forlængede, med mangeblomstrede Krandse; Kronbladene trekantet hjerteformede, nxtformigt arede, ved Grunden kort sylspidset-tandede, det ydre (større) fortriusviis, de andre svagt bruskbærende; Noddernes Sider elliptiske (bredest paa Midten), med kort Spids.

$3-5^{\prime}$ høi. Stængelen huul, tilligemed Blomsterne ofte rødligt anl,ben; Bladene morkgrønne. 7-8. భ.

Paa Græsmarker og ved Gjærder, sporadisk: $\mathbf{S}$. Helsingør (Dr.); Hørsholm ved Forstplantagen! Donze (23), Søllerød (Petersen), Kjø- 
benhavns Omegn alm.! Falst. Gaabense! Loll. hist og her (19); F. Ørkilds Slotsbakke ved Svendborg! o. fl. St. mod S. (12); J. Hjermeslevgaard, Hammelmose og Aalbæk i Vendsyssel, Viborg udenfor Skottenborg Port, Eveldrup (Dr.), Randers ved Hvidemølleport (7), Aarhus (Dr.).

511. R. oltusifolius L. (Budtbladet S.) Drcj. n. 404 ; F. D. 1335 (ikke god); H. N. V, 54 og X, 56; R. acutus H. 402 (?) R. silvestris Wallr., Sturm D. Fl. 73, 10-11.

De nedre Blade længe vedblivende, æg-hjerteformede eller afrundet-ovale med hjerteformet Basis; "Bladstilkene sammentrykte fra Siden, foroven flade med en nedløbende Rand"; Grenene opret-aabne med tæt- og mangeblomstrede Krandse; Kronbladene nætformigt aarede, ægformet-triangelformede med heelrandet Spidse, ved Grunden tandede af sylformede Tænder, alle (eller fortrinsviis det ene) bruskbærende; Noddernes Sider ægformede (bredest nedenfor Midten), med lang Spids.

$\boldsymbol{\beta}$, divaricatus (R. divaricatus Fr. mant. 3, H. N. VII, 57; Lge. Hdb. 1 Udg. n. 494 (ikke L.); R. obtusifolius Wallr., R. Friesii Gren. \& Godr.). Grenene mere udspærrede, Kronbladene bredere, med mere forlænget Spidse og længere 'Tænder.

$1^{1 / 2}-3^{\prime}$ høi. Var. glat eller duunhaaret, frisk grøn ( $\kappa$, concolor) eller med mørkrøde Blomster og Bladnerver ( $\boldsymbol{\beta}$, discolor Wallr.). Nodderne som oftest kun halvt saa store som hos foreg. 7-8. 4 .

Onkking Byer og ved Gjæerder alm. udbredt.

Anm. Afarten formaaer jeg ikke med Sikkerhed at adskille fra Hovedarten. Grenenes Retning og Kronbladenes Form og Storrelse forekomme mig yderst foranderlige; jeg har derfor ikke troet at burde beholde den som egen Art. (Min Trivl i denne Henseende er senere bekræftet ved F. W. Areschougs Undersøgelse (l. c. p. 58), ifølge hvilke $R$. divaricatus Fr. kun er en af de mange Former, hvorunder $\mathrm{R}$ obtusifolius L. optræder). Navnet $R$. divaricatus er i hvert Fald ikke heldigt, da det af Linné ngsaa har været anvendt paa en Afart. af den sydeuropæiske R. pulcher.

$\beta \beta$, Kronlladene heelrandede.

512. R. conglomeratus [Murr. Prodr. fl. Goett. p. 52] (Nøgleblonstret S.) Drej. p. 142 ; F. D. 2228 ; Rchb. ic. erit. IV, 551 ; H. N. IX, 57; R. Nemolapathum Ehrh.; R. nernorosus H. 400 (tildeels). 
Bladene i Randen bolgede, de nedre lancetformede, med ægformet Basis; Grenene udspærrede eller opstigerde; Krandsene rigtblomstrede, alle adskilte og med Dækblade; Kronbladene aflang-linieformede, budte, alle bruskbærende; Nødderne skarpkantede, med lang Spids og ægformet-elliptiske Sider.

\section{$1^{1 / 2}-2^{\prime}$ høi. 7-8. 4 .}

Ved Grøfter, Søbredder og paa fugtige Steder i Udkanten af Skove: $\boldsymbol{J}$. Ølands Skov (16), fra Veile af mod S. ikke sjelden i Østkystens Skovegne; i Fy en og par de mindre Øer (Bornh. indbefattet) hist og her; sparsommere i $\mathbf{S} \boldsymbol{j}$.: Hammermølleskoven! Raavaddam! red Fuursøen (19), Frederiksberg Allee! Sorø! Brokeskov (Lund), Basnæs, Skjelskør (Nielsen).

513. R. nemorosus [Sehrad. i Willd. hort. berol. I, 397] (Skov-S.) H. 400 (tildeels); R. Nemolapathum Wallr., H. 400; Drej. n. 406 ; F. D. 2229 ; Rehb. ic. IV, 552 ; H. N. I, 53.

De nedre Blade aflange med hjerteformet Basis (ofte ovenfor Basis indsnørede) de фvre æg-laneetformede; Grenene opretaabne; Krandsene faablomstrede, alle adskilte, kun de nedre med Dækblade; Kronbladene aflang-linieformede, budte, kun det ene bruskbærende; Nødderne mindre end hos foreg., budtkantede, forøvrigt af samme Form.

$1^{1 / 2}-2^{\prime}$ høi. 7-8. ข. - Var. med udeelt Stængel og desuden: $\alpha$, viridis Sm. Hele Planten grøn.

$\beta$, sanguineus (R. sanguineus L.) Stængel og Bladnerver røde.

I Skove paa fugtige, skyggefulde Steder alm. udbredt. $\beta$, paa mere solaabne Pladser, sjeldnere.

$\beta$, Rodbladene med afsmalnet Basis. (Kronbladene allerede under Blomstringen tandede, med smale og oventil spidse Bruskkorn).

514. R. palustris [Sm. FI. brit. p. 394] (Sump.S.) H. 404 (undtagen Voxestederne); Drej. n. 403; F. D. 1873; H. N. II, 52.

Bladene forlænget-lancetformede, de gvre næsten linieformede; Krandsene adskilte, alle med Dakblade; Kronbladene ægformet-elliptiske, alle bruskbærende, i Spidsen heelrandede, ved Grunden med (oftest) 3 børsteformede Tonder, der ere 
kortere end selve Kronbladene; Nødderne større end hos følgende, med rgformede Sider.

Lettest kjendelig fra fsilg., som den meget ligner, ved de kortere og bredere Tænder paa Kronbladene og næsten dobbelt saa store Nodder. De nedre Krandse stedse langt adskilte fra hinanden, de פverste stundom samlede. 7-9. $)$ eller 4 .

Paa fugtige Steder, f. Ex. Randen af Søer og Grøfter, meget sjeldnere end følg.: $\boldsymbol{S}$ j. Skovshoved (12), Valdby! St. Jørgens S $ø$, gl. Pesthuus, Classens Have og Kastellet ved Kbhvn! Moen ved Stege (12); F a lst. Stubbekjøbing (19); Loll. Errindlev (5)! Sørup (Rasmussen); $\boldsymbol{F}$. mellem Nyborg og Sophienberg (Lund); $\boldsymbol{J}$. Ødstedgaard! Sl. Heilsbugt (28)! Haderslev (7), Aabenraa! Gelting (16), Egernforde (18). De hos Horn. angivne Voxesteder høre sandsynligviis til folg.). *

515. R. maritinus L. (Strand-S.) H. 404 ; Drej. n. 402 ; F. D. 1208 ; H. N. I, 54 .

Bladene linie-lancetformede, de фvre linieformede; alle Krandsene (med Undtagelse af de nederste) tæt samlede, alle med Dækblade; Kronbladene ægformet-rudeformede, alle bruskbærende, i Spidsen beelrandede, ved Grunden med (oftest) 2 børsteformede Tænder, der ere længere end Kronbladene; Nodderne smaae, med elliptiske Sider.

Planten guulgron; Bladene ofte i Randen krusede. 6-9. () eller 4.

Bemærket $\mathrm{i}$ alle danske Provindser og ikke sjelden, men sporadisk; forekommer saavel ved Strandbredder som ved Randen af Søer og Moser inde i Landet.

b. Acetosa Tournef. Blomsterne trebo (Syrer).

516. R. Acetosa L. (Syre). H. 405; Drej. n. 401; F. D. 2534 ; H. N. XI, 54 ; L. Herb. VI, 119.

Bladene æg-lancetformede med piilformet Basis; Krcemmerhusene fliget-tandede, bruunt hindeagtige; $q$ Bagerbladene tilbagebøiede; Kronbladene rundagtigt-nyreformede, beelrandede eller bølgede, med et meget lidet, nedbøiet, skjælformet Bruskkorn ved Grunden.

$1-1{ }^{1} / 2^{\prime}$ høi. Bladene have en behagelig syrlig Smag; Blomsterne ofte smukt røde. Var. i Henseende til Bladformen. 5-7. 2.

Paa Græsmarker, Enge, ved Veigrøfier o. s. v. alm. 
517. R. Acetosella L. (Rødknæ). H. 406; Drej. n. 400; F. D. 1161 .

Bladene linie-lancetformede, med spydformet Basis og tilbagerullet Rand; Krammerhusene forlængede, lasede, hvid-hindeagtige; + Bagerbladene tiltrykte; Kronbladene ægformede, heelrandede, uden Bruskkorn.

$1 / 2-1$ ' hoi ; Rodstolkken ofte krybende, med Udløbere. Strenglerne og Blomsterne mørkrode. Kronbladene forstørres ikke mærkeligt efter Blomstringen. Bladene mangle ofte de spydformede Lapper ved Grunden. 6-7. 4 .

Paa udyrkede, især tørre og sandige Marker, alm. udbredt.

\section{Colchicum. Tidlos.}

518. C. autumnale L. (Høst-T.) H. 410 ; F. D. 1642; Rchb. ic. fl. germ. X, 949-50.

Rodstokken knolleformet, omgivet af bruunt-hindeagtige Bladskeder; Bladene lancetformede; Blomsterdokket trag!formet; Kravens Flige budt-lancetformede, meget kortere end Røret.

Blomsterne lila eller hvide, udgaae uniddelbart fra Rodstokken (8-10); Bladene udvikles tilligemed Frugterne i det paafolgende Foraar (6). 2 .

Paa Enge og forvildet omkring beboede Steder, sjelden: $\boldsymbol{J}$. Eng ved Barritskov (H.); $S l$. Nyværk ved Slesvig (16), Egernførde (H.); Loll. ved Thiersted (H.), Christianssæde (2).

\section{Scheuchzeria.}

519. S. palustris L. (Kjær-S.) H. 408; Drej. n. 414; F. D. 76 ; Rehb. ic. fl. germ. X, 927-29; H. N. XV, 71 .

Stcengelen opret, tilligemed den vandrette Rodstok leddet; Bladene omskedende, linieformede, halvtrinde, noget kjødfulde, indadtil rendede, med en Pore $\mathrm{i}$ Spidsen og en budt Skedehinde ved Grunden af Pladen; Blomsterne $\mathrm{i}$ en faablomstret Klase; Smaafrugterne skjævt ægformet-kegleformede, oppustede.

6-8" høi. Blomsterne gronlig-brune. 6. ข.

I dybe Torvmoser og Hæugedynd mellem Sphagnum: i det østlige Sjall. hist og her, f. Ex. Ramlose (H.), N. f. Helsingor (21), Joustrup (14), Ruderhegn, Birkerød, Dronninggaard, Bagsværd (H.), 
Lyngby Mose! Søholm i Stevns (9). I de andre Provindser er det mig ikke bekjendt at den er funden.

\section{Triglochin. Trehage.}

520. T. palustre L. (Kjær-T.) H. 409; Drej. n. 412; F. D. 490 ; Rehb. ic. Al germ. VII, 90--91; L. Herb. VIII, 158.

Bladene traadformet-linieformede, halvtrinde, paa Overfladen svagt rendede; Arrene 3, fryndset-haarede, udstaaende eller oprette; Frugten kantet, linieformet, tredelelig, paa en til Axen tiltrykt Blomsterstilk.

$1 / 2-1^{\prime}$ høi. Blomsterne grønlige. 6-7.

Paa Enge og i Tørvmoser alm.

521. T. maritimum L. (Strand-T.) H. 409; Drej. n. 413 ; F. D. 306 ; Rchb. l. c. $92-93$; L. Herb. V, 100.

Bladene linieformede, halvtrinde, paa Overfladen næsten plane; Arrene 6, tilbagebøiede; Frugten agformet, kantet, sexdelelig, paa en efter Afblomstringen udstaaende Blomsterstilk.

1-1 $1 \frac{1}{1} 2^{\prime}$ høi. Klasen mere tretblomstret end hos foreg. Blomsterne grønlige. 6-9. 2 .

Paa Strandenge ved alle Danmarks Kyster, især meget hyppig i det vestlige Slesvig, hvor den er en af de vigtigste Planter paa den nye (udendigs) Marsk (16), sjeldnere ved Indsøer og paa Færskvandsenge inde $\mathrm{i}$ Landet, f. Ex. Tiissø! Sorø! Leersøen!

\section{Polygynia.}

\section{Alisma. Skeeblad.}

522. A. Plantago L. (Veibredbladet S.) H. 411; Drej. n. 416 ; F. D. 561 ; Rehb. I. c. VII, 100.

Bladene (alle ved Grunden) 5-7-nervede, bjerteformetægformede; Skaftet opret, budt trekantet; Blomsterstanden en Top, sammensat af flere Rækker krandsstillede Skjærme; Frugt- 
samlingen budt trekantet, med fladtrykte, afrundede, paa Ryggen 1-2. furede Smaafrugter.

1-3' høi. Kronbladene hvide eller blegt lila. 6-8. Var. især i Henseende til Bladformen. Nedenstaaende Former ere de mærkeligste:

$\beta$, lanceolatum With., Rehb. 1. c. 101. Bladene laneetformede.

$\gamma$, graminifolium Elırh., Rehb. 1. e. 102. Bladene linieformede (fladtrykte Bladstilke uden Plader).

$\delta$, latifolium! meget høi, Bladene bredere end hos Hovedarten, 9-11-vervede.

Ved Bredderne af Søer, Bække og Grøfter, alm. udbredt. $\beta$, sjeldnere $o g$ især ved sandige Søbredder, f. Ex. S $j$. Kiær paa Nordsiden af Amager! Hoie Sandbjerg! Damhuussoen (12); Tiisso (11; F. Fæatningsgravene ved Nyborg (Lund); $\boldsymbol{J}$. Staby ved Nissum Fjord! $\boldsymbol{S} l$. Bistensee $(2()) ; \gamma$, i selve Vandet: $J$ Flade $\mathrm{S} \emptyset$ red Agger i Thy! $\boldsymbol{S}$ l. Eideren ved Rendsborg! $\delta, \boldsymbol{F}$. Vindinge ved Nyborg (Lund).

523. A. ranunculoides L. (Smalbladet S.) H. 413 ; Drej. n. 415 ; F. D. 122 ; Rehb. 1. e. 97 ; H. N. IV, 87.

Bladene (alle ved Grunden) trenervede, linie-laneetformede; Skaftet opret eller opstigende; Blomsterne i enkelt Skjærm eller 2. ovenfor hinanden stillede Krandse; Frugtsamlingen kugleformet, med elliptiske, spidse, femkantede, furede Smaafrugter.

4-10" høi. Kronbladene lila eller blegrøde, større end hos foreg. $6-7$. ข.

$\beta$, repens. Rehb. 1. c. 98 ; A. repens Cav. Skaftet nedliggende, ved Skjærmen rodslaaende.

Ved Bredderne af Søer og Tørvmoser, sporadisk, men bemærket $i$ alle danske Provindser; $\beta$, ved grusede og lerede, af og til oversvonimede Søbredder, f. Ex. Maribo \$ø !

524. A. matans L. (Svømmende S.) H. 412 ; F. D. 1573 ; Rehb. I. e. 95 .

Rodbladene linieformede (Bladstilke uden Plade); Stongelen flydende, ved Leddene udskydende Røduler og langstilkede Blade med trenervet, oval Plade; Blomsterne langstilkede, krandsstillede eller enlige fra Leddene; Frugtsamlingen næsten kugle- 
formet, med omvendt-ægformede; budte, af den vedblivende: Griffel braadspidsede, mangestribede Smaafrugter.

Kronbladene hvide. 6-8. 2.

I Aaer og Grøfter, kun bemærket i Halvøens vestlige Egne: J. mellem Skjermbro og Ringkjøbing, ved Stauning (H.), Hee og Thim pr. Ringkjøbing (2), Skjern Aa ved Lønborg! S. Vium!

\section{gde Klasse. Ileptandria (Syvhanned(').}

\section{Orden. Monogynia (Enhunnede).}

1. Ásculus L. Bægeret uregelret femdeelt; Kronen uregelret 4-5-bladet; Støvdragerne opstigende; Frugten en pigget, trerummet, oftest enfrøet Kapsel med rumdelende Opspringning. そ. (N. F. Ilippoeastaneæ).

2. Triputilis L. Bæger og Krone regelmæssigt syvdeelte (Kronen hjulformet); Frugten en enrummet, mangefrøet Kapsel med 5-7 hurtigt affaldende Kilapper. 4 . (N. F. Primulace ).

\section{Ilonogynia.}

\section{Esculus. Ilestekastanie.}

$\dagger$ 525. W. Hippocastaurm L. (Almindelig H.) Rehb. ic. fl. germ. V, 4822 .

Bladene modsatte, 5- 7 -koblede, med omvendt-ægformede, tilspidsede, dobbelt saugtakkede Smaablade; Blomsterne i oprette, pyramideformede Klaser.

Høit Træ; Kronbladene hvide, randhaarede, med en guul, tilsidst rød Plet ved Grunden af Pladen; Støvknapperne rustfarvede; Frøet stort, brunt med hvid Navle. $\frac{5}{2}-\frac{6}{1}$.

Oprindelig indført fra Asien, alm. plantet i Alleer og Lystskove, og nu at betragte som acclimatiseret. 


\section{Trientalis. Skovstjerne.}

526. T. europara L. (Almindelig S.) H. 414; Drej. n. 417; F. D. 84; Rchb. ic. fl. germ. XVII, tab. 1083.

Bladene (oftest $6-7$ ) næsten krandsstillede, i Spidsen af Stængelen, elliptiske, utydeligt tandede eller næsten heelrandede; Blomsterne 1-3, paa fine Blomsterstilke fra de ydre Bladhjorner.

$3-6^{\prime \prime}$ høi. Kronen hvid med en grønlig eller guul Ring ved Grunden. (Var. med 6-8-deelt Blomst). 6. 4.

Paa Lyngheder og i Skove, saavel Løv- som Naaleskove, hyppig paa $H$ alvoen og i det nordøstlige Sjall., sjeldnere i det sydvestlige Sj., i Fyen (f. Ex. Hals red Hofmansgave, Nyborg $(\mathrm{H})$, Skaarup 119), og de mindre Øer: Falst. i Horreby Lyng (5), Hanenov Skov (14); B o rnh. i Almindingen!

\section{8de Klasse. Octandria (0ttehannede).}

\section{Orden. Monogynia (Enhunnede).}

A. Kronen fribladet.

a. Frugten undersædig.

1. Chamænérium Scop. Bægerrøret ikke forlænget ovenfor Frugten; Lronbladene 4, lidet uregelmæssige; Stovdragerne nedbøiede; Griffelen hagekrummet; Frugten en firekantet, linieformet, firerummet, fireklappet Kapsel med rumdelende Opspringning; Froene med Frould.

2. Epilóbium L. Bægerrørets Forlængelse 0 eller meget kort; Kronbladene regelmæssige; Støvdragerne oprette; Griffelen ret; Frugt og Frø som foregaaende.

3. Oenothéra L. Bægerrørets Forlængelse ovenfor Frugten længere end Bægerfligene; Krone, Størdragere og Griffel som foregaaende; Kapselen budtkantet, ved Grunden bredere, forørrigt som foreg.; Frø uden Frøuld. (1-3. N. F. On agrarieæ). 
b. Frugten oversædig.

4. Acer L. Bægeret regelret fembladet; Kronbladene 5, befæstede tilligemed Støvdragerne paa en undersædig Skive; Frugten en todelelig Spaltefrugt, Smaafrugterne Vingefrugter, befæstede til en fælles, todelelig Frugtaxe. (Træer med modsatte, haandnervede Blade; Blomsterne ofte særkjønnede). (N. F. A cerineæ).

5. Monótropa L. Bæger og Krone regelm. 4-5-bladede; Støvdragerne $8-10$, befæstede paa Frugtbunden, hveranden med en hesteskoformet Kirtel ved Grunden; Frugten en 4-5klappet, mangefrøet Kapsel. (Snyltende Urter med skjælformede, bruungule Blade). (N. F. Monotropeæ).

(Vaccinium Oxycoccos).

B. Kronen sambladet. Stø̈knapperne opspringe ved Huller i Spidsen. (Lave Halıbuske).

a. Frugten oversædig, kapselagtig (Støvknapperne ved Grunden tohornede).

6. Erica L. Bægeret urteagtigt, kortere end den krukkeformede Krone; Kapselen med rumdelende Opspringning.

7. Calluna Salisb. Bægeret farvet, længere end den klokkeformede Krone; Kapselen med skillevægbrydende Opspringning. $(6-7$. N. F. Ericinex, b.).

b. Frugten undersædig, bæragtig (Støvknapperne i Spidsen tohornede).

8. Vaccínium L. Bæger og Krone 4-5.deelte; Støvdragerne befæstede paa Randen af en oversædig Skive; Bærret kugleformet. (N. F. Ericineæ, a.).

C. Blomsterdækket enkelt, sambladet. (Busk).

9. Daphue L. Blomsterdækket farvet, med firedeelt Krave; Støvdragerne tilvoxne til Røret (4 kortere, 4 længere); Frugten oversædig, cnfrøet Stcenfrugt. (N. F. T'hymeleæ). 


\section{Orden. Digynia (Tohunnede).}

10. Chrysosplénium L. Blomsterdækket enkelt, firedeelt, halvt-oversædigt, udvendig grønt, indvendig guult; Støvknapperne enrummede; Frugten en toklappet, mangefrøet Kapsel*). (Saftige Uiter med Blomster i Qvast. N. F. S.axifrag a eeæ).

Scleranthus. Blomsterdækket femdeelt, omkringsædigt; Frugten nødagtig $(10,2)$.

Ulmus effusa $(5,2)$.

Polygonum. Blomsterdækket femdeelt, undersædigt; Frugten Nød $(6,3)$.

Acer. Bæger- og Kronblade 5, undersædige; Frugten Vingefrugt $(8,1)$.

\section{Orden. Trigynia (Trehunnede).}

11. Fagopýrum Moench. Blomsterdækket enkelt, dybt femdeelt; de 3 indre Støvdragere ned Kirtler ved Grunden; 3 Grifler med hovedformede Ar; Frugten trekantet Nød med midtliggende Kin og sammenfoldede Froblade. (N. F. Poly-

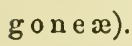

Polygonum. Kimen sideliggende, Frøbladene flade $(6-3)$.

\section{Orden. Tetragynia (Firehunnede).}

12. Paris L. Bæger og Krone firebladede; Frugten et firerummet, oversædigt Bær. (Blomsten enlig, endestillet). (N. F. Smilace $æ$, c.).

13. Adóxa L. Bægeret 2-3-deelt; Frugten et 4-5rummet $B \rightsquigarrow r$, beklædt med det halvt-oversædige Bæger. Blomsterne $i$ et endestillet, femblomstret Hoved; Endeblomsterne med 4 Kronblade og Grifler, 8 Støvdragere; Sideblomsterne femdelelige. (N. F. Araliaceæ).

14. Elatine L. Bægeret firedeelt; Kronen firebladet;

*) Forekommer undertiden med femdeelt Blomsterdække og 10 Stevdragere. 
Frugten firerummet, oversædig Kapsel med flere valseformede, mere eller mindre buekrummede Frøe i hvert Rum. Blomsterne i Bladhjørnerne*). (N. F. Elatineæ).

\section{Ilonogynia.}

\section{Chamanerium. Gederams.}

527. C. angustifolium [Scop. Fl. carn. I, p. 271] (Smalbladet G.) Drej. n. 424 ; Epilobium L., H. 419; F. D. 289.

Bladene spredte, (sjeldnere krandsstillede), lancetformede, heelrandede eller utydeligt tandede; Blomsterne i Klase; Kronbladene omvendt-ægformede, med Negl.

$3-4$ ' høi. Kronbladene smulst violet-røde. 7-8. 4.

I Skove, især paa aabne Pladser efter Bortrydning, ved Gjærder o. s. v., ikke sjelden, og i eukelte Egne i Mængde, f. Ex. Almindingen paa Bornholm!

\section{Epilobium. Dueurt.}

a. Blomsterknopperne før Udspringningen nikkende.

aa. Stangelen ned 2-4 ophøiede Linier (af den nedløbende Bladsubstans).

528. E. roseum [Schreb. Spic. fl. lips. 147] (Rosenbladet D.) H. 423 ; Drej. n. 430 ; F. D. 1815 ; Rehb. ic. crit. II, 329 ; H. N. III, 34 ; E. nudum Schum. n. 360 .

Rodstokken (om Efteraaret) med kugleformede Bladknopper**), dannede af kjødfulde, taglagt-tiltrykte Blade; Støngelen oventil

*) Til denne Slægt høre Arter med tredeelt Blomst og 6 Støvdragere, af hvilke dog ingen er funden i vor Flora.

**) Knopperne, som hos Arterne i denne Slægt afgive gode Kjendetegn, maa undersoges i det sildige Efteraar, naar de have opnaaet den Form og Størrelse, de under Vintertilstanden skulle beholde. Uagtet samtlige Arter angives som vedvarende, er 
duunharet; Bladene elliptiske, tret og skarpt tandet-sangtakkede, alle tydeligt stilkede, de nedre modsatte; Bagerfligene kort tilspidsede; Arrene (oftest) kolleformigt sammenklæbede; Frøene næsten jævne, omvendt-ægformede.

$1-2^{\prime}$ høi. Stængelen alm. stærkt grenet; Bladene frisk grønne (ofte rødligt anløbne); Kroubladene rosenrøde eller blegrode. 8-9. 4.

Ved Grøfter, Randen af Damme o. a. fugtige Steder ikke sjelden.

6b. Stcongelen trind (uden ophøiede Linier).

529. E. montanum L. (Glatbladet D.) H. 423; Drej. D. 427 ; F. D. 922 ; Rehb. ic. erit. II, 328.

Rodstoliken med Bladrosetter af langstrakt-oval Form; Stcengelen, især oventil, duunhaaret; Bladene xgformede eller æglancetformede, tret og skarpt tandet-saugtakkede, de nedre mod-

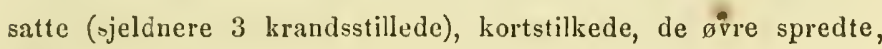
stilk]øse; Bagerfigene budte; Arret tilsidst firekløvet; Frøene (under Lupen) fint kornet-vortede, ovale.

1-2' hoi; Stængelen oftest grenet; Bladene graagrønne, i Randen og paa Nerverne duunhaarede, Kronbladene rosenrode eller lila. Var. i Henseende til Bladenes Brede, Behaaringen, Kronbladenes Storrelse og Farve. 7-8. 4 .

Ved Gjærder og i Skove, meget alm.

530. E. palustre L. (Kjær-D.) II. 424; Drej. n. 428; F. D. 1574 .

dette ikke strængt Tilfældet, idet Moderplanten hos flere bortdoer naar den har frembragt Knopper eller Bladrosetter. Især er dette Tilfaldet med E. palustre, som kun fortsattes ved loglignende Knopper. Denne Forskjellighed hos Vinterknopperne kan ret vel benyttes som Inddelingsgrund ved Arternes Opstilling, og jeg har forsogt dette $\mathrm{i}$ en tidligere Afhandling (Vidensk. Medd. af Naturhist. Foren. 1849 S. 97), men da en Haandbog, som for en stor Deel benyttes af Begyndere, formeentlig bor undgaae at benytte til Arternes Gruppering Forhold, som kun undtagelsesviis kunne erkjendes par den 'Tid, da Planterne sædvanligt undersøges, har jeg kun opfort de fra Knopperne lientede Kjendetegn ved Beskrivelsen af de enkelte Arter, men ikke benyttet dem til Slægtens Inddeling. 
Rodstokken udskyder traadfine Udløbere med meget smaae Blade og forlængede Ledstylker, $i$ hvis Spidse dannes en kugleformet-oval Knop med fireradet-taglagte, kjødfulde, skjælformede Blade; Stcongelen duunhaaret; Bladene linieformede eller laneetformede, heelrandede cller fjernt og svagt tandede, stilklose, indtil ovenfor Midten af Stængelen modsatte; Bagerfigene budte; Arrets Flige kolleformigt sammenklæbede; Frøene jævne, langagtige, forneden tilspidsede, foroven afsmalnede.

$1 / 2-11^{1} / 2^{\prime}$ høi; Stængelen mere eller mindre grenet; Bladene oftest glatte, paa Underfaden glindsende. Kronbladene blegrøde eller lila. 7-8. ข.

I Tørvmoser og Kjær, især i Hængedynd mellem Sphagnum, alm.

b. De uudsprungne Blomster oprette.

aa. Stangelen kantet of $2-4$ nedlobende Linier.

531. E. virgatum [Fr. Nov. p. 113] (Riisdannet D.) H. II, 175 ; Drej. p. 149 ; F. D. 2528 ; H. N. X, 46; E. tetragonum F. D. 1029 (?)

Stangclen ved Grunden opstigende og udskydende traad. formede Udlobere med udviklede Blade og forlangede Ledstykker; de oploicde Linicr 4 (af de nedlobende Bladrande); Bladene stilkløse, lancetformede med bredere, afrundet Basis, fjernt og svagt tandede, fra Grunden til ovenfor Midten af Stængelen modsatte; Bagerfigene budte; Arrets Flige kølleformigt sammenklæbede; Frugthnuden tæt duunhanret; Frdene kornet-vortede, omvendt.ægformede, ved Grunden spidse.

1-2' hoi; Strngelen grenet; Bladene glandsløse, glatte eller paa Underfladens Nerver svagt duunhaarede. Kronbladene rødagtiglila. $7-8$. 4 .

Ved Randen af Torvgrave, Hedemoser og Grofter: paa Halvo en, især dens midterste Deel alm., sjeldnere paa Øerne: $\boldsymbol{F}$. Søbo (ㄴ), Ollerup! Fgense, St. Jorgensgaard 1:), Skaarup (19); Thorseng ved Bregninge! L a ngel ved llenninge (19); I alst Liselund (Koch); Sj. Hell bæks Vang, Høie Sandbjerg! Vedbæk! Skjoldeu ved Sorø (12); Bornh. ved Rønne o. fl. St.!

Anm. Denne Art har af flere, især tydske Botanikere været anfægtet, men sikkert med Uret; den adskilles let fra foreg. foruden de angivne Kjendetegn ved et aldeles forskjelligt Udseende; fra følg. 
afviger den saavel ved Bladene som ved aldeles forskjelligt Voxested og Voxemaade. Om deu, ligesom E. palustre, overvintier ved løgformede Knopper, frigjorte fra Moderplanten, livilket synes rimeligt paa Grund af Udlobernes Lighed, har jeg ikke med Vished kunnet udfinde.

532. E. tetragoum L. (Firekantet D.) H. 424; Drej. n. 429 ; Rchb. ic. crit. II, 340 ; H. N. VIII, 41.

Rodstokken med toetbladede Bladrosetter; Stcrngelen kantet af 4 ophøiede Linier; Bladene stilklose (de midterste nedløbende), lancetformede med smalere Basis, tæt saugtakket-tandede, de nedre modsatte; Bogerfligene tilspidsede; Arrets Flige sammen. klæbede; Frugtknuden svagt duunhaaret; Frøene kornet vortede, omvendt-ægformede, ved Grunden budte.

1-2' høi. Stængelen stærkt grenet; Bladene glindsende, næsten glatte; Rosetternes Blade om Efteraaret fuldt udviklede. Kronbladene som foreg. 7-9. .

$\beta$, obscurum Schreb. (F. D. 1267; H. N. VIII, 42). Stængelen høiere, Bladene bredere, glandsløse og duunhaarede.

Ved Grofter og lignende fugtige Steder, især i Strandegne: lyyppig paa de sydlige Øer, sporadisk $\mathrm{i} \boldsymbol{S} \boldsymbol{j}$. og $\boldsymbol{F} . /$ paa $\boldsymbol{H}$ alvoen sjeldnere: mellem Rye og S. Vissing! Husum (16); $\beta$, paa Bornholm ved Hammershuus (H.).

533. E. purpureum [Fr. Fl. hall. p. 65] (Rødstæuglet D.) Fr. mant. 3, 18j; S. Veg. Sc. 178.

Rodstokiken med tatbladede Roseiter af langstrakt Form; Stcengelen med 2 nedløbende Linier af Bladnervens Fortsættelse; Bladene bredt lancetformede, med smalere Basis, saugtakkede, stilkløse, modsatte, de ørre afvexlende; Bagerfigene tilspidsede; Arret udeelt eller firekløvet; Frugtknuden duunhaaret; Frøene fiint kornet-vortede, omvendt-xgformede, ved Grunden budte.

Stængelen 1-3' høi, stærkt grenet, tilligemed Bladene fint dnunhaaret $\mathrm{og}$ ofte rodagtig. $7-8$. $\psi$.

Ved Gjærder udenfor Kolding! Hidtil ikke funden andensteds i Danmark. 㔷

Anm. Arret er paa alle de af mig samlede Expl. firekløvet, hvorimod det beskrives ndeelt paa de svenske Expl. af Trof. Fries. Vor l'lante mangler aldeles Kronblade. Sonder (fl. hamburg.) anseer denne Art for en Form af E. montanum, meu ved de oprette Bloinster- 
knopper, tilspidsede Bægerflige og Stæugelens nedløbende Linier forekommer den mig tilstrækkeligt adskilt fra denne. Paa Grund af dens Sjeldenhed kunde inan fristes til at antage den for en Bastardform (f. Ex. af E. montanum $\circ \mathrm{g}$ tetragonım), men den sidstnævnte Art findes neppe i Egnen om Kolding. Jeg har desuden fundet Froene fuldt udviklede og modne.

\section{bb. Stongelen trind (uden ophøiede Linier).}

534. E. pubescens [Roth Tent. I, p. 167] (Dunet D.) H. 422 ; Drej. n. 426 ; F. D. 347 ; H. N. VIII, 43 ; E. parviflorum Schreb.; E. Lirsutum $\beta$, L.

Vinterknopperne danne tatbladede Rosetter; Stcengelen duunhaaret; Bladene stilkløse, lancetformede, fjernt og svagt tandede; de nedre modsatte, kortstilkede; Bagerfigene budte; Arret firekløvet; Frøene fiint kornet-vortede, omvendt-ægformede, ved Grunden budte.

1-3' høi. Kronbladene lila, alm. af Længde med Bægerfligene, Bladene par Rosetterue om Efteraaret fuldt udviklede, paa Underfladen violotte. $7-8$. 4 .

$\beta$, subglabrum Koch (E. rivulare Wahlenb., Rebb. ic. crit. 301 ; H. N. V, 40.) Strengel og Blade glatte eller svagt haarede.

I Moser, Grøfter, ved Aa- og Søbredder, alm. udbredt. $\beta$, Thaersminde paa Thorseng!

535. E. hirsutum L. (Laaden D.) H. 421; Drej. n. 425 ; F. D. $326 ;$ H. N. V, 39 .

Rodstolkken udskyder underjordiske Udlobere med forlængede Ledstyliker og ufuldstændige, skjælformede Blade; Stongelen haaret af længere Haar og kortere Kirtelhaar; Bladene stíkløse og omfattende med lidet nedløbende Basis, elliptiske eller æg-lancetformede, tandet-saugtakkede, modsatte, de øvre afvexlende; Bagerfligene kort braadspidsede, Arret firekløvet; Frøene fint kornet-vortede, omvendt-ægformede, ved Grunden spidse.

Stængelen 3-5' høi, grenet, Ledstykkerne undertiden oventil med svage Linier af de nedlobende Bladrande. Kronbladene store, 2-3 Gange længere end Bægerfligene, smukt røde, sjeldent hvide 
(Sj. Kongens Moller, Lund). 7-8. 4. Var. i Henseende til Beklædningen o.s. v.

$\beta$, micranthum! Stængel og Blade tæt fløielshaarede; Blomsterne mindre, Kronbladene neppe $1 / 2$ Gang længere end Bægerfligene.

Ved Sø- og Aabredder, i Tørvmoser, alm. udbredt. $\boldsymbol{\beta}$, ved Bredderne af Sorø $\mathrm{S} \emptyset ! \mp$

$\asymp$ E. roseo-pubescens! Bastardform af E. roseum og E. pubeseens. Forskjellig fra førstnæunte ved oprette Blomsterknopper, fra Grunden til Spidsen duunhaaret Stængel og større Blomster, fra sidstnævnte ved stilkede, skarpt saugtakkede Blade, tilspidsede Bægerflige og nedentil svagt kantet Stængel. Alle Expl. nied golde Frøe.

Mellem Stamarterne paa fugtige Steder i St. Jørgens Præste gaards Have!

\section{Oenothera. Naflys.}

† 536. Oe. bicnnis L. (Toaarig N.) H. 418; Drej. p. $150 ;$ F. D. 446 .

Bladene spredte, utydeligt tandede; Rodbladene (det første Aars) elliptiske, langstilkede; Stangelbladene (det andet Aars) elliptiske eller bredt lancetformede, kortstilkede; Kronbladene længere end Bægerfligene og Støvdragerue, omtrent halvt saa lange som Bægerrøret.

Stængelen 2-3' høi, svagt haaret og ru af Haarenes udvidede, vedblivende Basis; Kronbladene store, lysgule, kun aabne om Natten. 6-8. $\odot$.

Oprindelig indført som Siirplante, forekommer uu som Ukrud i og omkring Haver og stundom liengere fra dyrkede Steder, f. Ex. Nexelo (Baagde); Falst. i straudsandet ved Hesnas! Lanyel. ved Hou (H.).

† Oe. muricata L. (Rødstænglet N.) H. II, 175; F. D. 1752.

Stcengelen mere baaret og ru, rødt anløben; Bladene smalere, mere tydeligt tandede; Krombladene mindre, $1 / 3$ af Brgerrørets Læugde, ligelange med Støvdragerne, forøvigt som foreg. 
Oprindelig indvandret fra Nordamerika; forvildet ved Gjærder imod Stranden ved Hellebæk!

\section{Acer. Lan.}

537. A. Pseudoplatauus L. (सretræ, Valbirk). H. 435; Drej. n. 431 ; F. D. 1575 ; Rehb. ic. f. germ. V, 4829.

Bladene femfligede, med grovt og uregelmæssigt budttandede Flige; Blomsterne i hængende Klaser; Frugtknuden udvendig duunharet, indvendig silkehaaret, med opstigende Vinger; Støvdragerne omtrent af Kronens dobbelte Længde.

Smukt og høit Træ med glat Bark, Bladene paa Underfladen glandsløse, blaagrønne og (i yngre Tilstand langs Nerverne) duunhaarede, udvikles for Blomsterne. 5. h.

Forekommer alm. plantet i Alleer og Lystskove, udbreder sig med Lethed og angives allerede af Kyll. som voxende $\mathrm{i}$ Skove, men sandsynligviis er den ikke oprindelig indenlandsk: $S \boldsymbol{j}$. ved Herlufsholm; Loll. i Skovene hist og her alm.; $\boldsymbol{F}$. Skjoldemose og Hundstrup (H) og fl. St. i det sydlige (12); $\boldsymbol{A} l s ; S l$. Aabenraa, Sundeved, Flensborg o. fl. St. $(12,28$ !).

\section{A. platanoides L. (Tandbladet L.) H. 436; Drej.} n. 432 ; F. D. 2586 ; Rehb. l. c. 4828 .

Bladene femlappede med afrundede Bugter mellem de dybt og spidst 3-5-tandede Lapper; Blomsterne i opret Halvskjærm; Støvdragerne af Længde med Kronen; Frugtknuden udvendig og indvendig glat, med udspærrede Vinger.

Smukt Træe, alm. af lavere Væxt end foreg.; Bladene glindsende, paa begge Sider frisk grønne og glatte; Blomsterne guulgrønne, udvikles forend eller samtidigt med Bladene. 5.

Vildvoxende i Skovene paa Østkysten af Bornholm; (i GranitTerrainet)! sjelden i de øvrige Provindser: $S j$. Kulaas Skov i Odsherred! Nexelø (Baague), Svenstrup, Bregentved (28); J. Haraldslund! Estrup mellem Kolding og Ribe (28). Forekommer desuden, ligesom foreg., meu sjeldnere, plantet. |*

539. A. campestre L. (Naur). H. 437; Drej. n. 433; F. D. 1288 ; Rehb. I. c. 4825 ; H. N. I, 37.

Bladene 3-5-lappede; Lapperne budte, hele eller trelappede; Blomsterne i opret Halvskjærm; Stovdragerne i $\widehat{\delta}$ Blomsten lidt længere, i $\Varangle$ kortere end Kronen; Frugtknuden udvendig duunhaaret, indvendig glat, med vaudret udspilede, ved Grunden ikke indtrykte Vinger. 
Busk eller lavt Træ; de ældre Grene kantede, med remet, korkagtig Bark; Bladene paa Underfladen mat-grønne og, idetmindste langs Nerverne, duunhaarede; Blomsterne grønne, udvikles efter Bld. Var. med glat Frugtknude. $\frac{5}{2}-\frac{6}{1}$. $\quad \boldsymbol{h}$.

I Skove, alm. i de sydlige Egne af Landet, f. Ex. Sydsjælland, Fyen, Øerne fra Moen til Als! I de nordligere Egne sjeldnere, f. Ex. Mariager (28), Randers (7), Haraldslund! Skanderborg (7) Mangler paa Bornholm! $\bar{\varpi}$

\section{Monotropa. Snylterod.}

540. M. hirsuta [Hornem. oec. Pl. II, p. 179] (Haaret S.) Drej. n. 443 ; M. Hypopitys L., Wallr., F. D. 232 ; M. Hypopitys $\alpha$, birsuta Nolt. nov, p. 43, Rehb. ic. f. germ. XVII, tab. 1152.

Stangelen opret, udeelt, tæt beklædt med skjælformede Blade; Klasen før Udspringningen nikkende; Bageret i Randen, Krone, Støvdragere og Støvvei haarede; Frugtknuden oval; Griffelen forlænget.

6-8" høi; hele Planten saftrig, bleg-bruunguul, red Tørring sortbruun. $6-7.4$.

I skyggefulde Løvskove, især Bøgeskove, snyltende paa Trærødder mellem Løvet; ikke sjelden, men sporadisk og hyppigst i fugtige Sommere.

\section{II. glabra [Bernh.] (Glat S.) H. II, 179; Drej.} n. 444 ; M. Hypopitys $\beta$, glabra Roth, Nolte l. e., F. D. 2051 ; Rehb. l. c. XVII, 1152; M. Hypophegea Wallr., Rchb. ic. crit. V, 675 .

$3-6^{\prime \prime}$ høi; Klasen opret eller nikkende, faablomstret; Blomstens Dele, undtagen Støvtraadene og Arret, glatte; Frugtknuden kugleformet; Griffelen kort (omtr. halvt saa lang som Frugtknuden), forøvrigt som foreg., af hvilken flere Forfattere ansee den for en Afart.

Alm. lavere end foreg. 7. (4. $\odot$ ?).

I Skove, især Naaleskove, sjeldnere end foreg.: $\mathbf{S} \boldsymbol{j}$. Sørup Hegn red Fredensborg (Jørg.), Hesttangs Mølle (Wroblevsky), Ledreborg Dyrehave (15), Alindelille (1), Sonderskoven ved Soro (12), Asnæs Skov ved Kalundliorg (Buagøe); Heen ved Dronningstolen (9); F alst. ved Kringelborg (14); I. oll. ved Vesterborg, Steensgaard (19), 
Erikstrup (Krebs); J. Lilleø i Juul Sø ved Silkeborg (16); $\boldsymbol{S} l$. Kobbermølleskoven ved Flensborg (Stisgaard).

\section{Erica. Lyng.}

542. E. Tetralix L. (Klokke-L.) H. 432; Drej. n. 419; F. D. 81 ; Rehb. ic. fl. germ. XVII, tab. 1163.

Bladene krandsstillede, linieformede med tilbagerullet, stiv. haaret Rand, paa Overfladen og Midtnerven af Underfladen duunhaarede; Blomsterne nikkende, samlede til en tætblomstret Skjarm i Enden af Grenene.

Lav Halvbusk med oftest 4 Blade i Krandsene. Kronerne smnkt rosenrøde, sjeldnere hvide, efter Afblomstringen henvisnende. 7-8. $\mathfrak{h}$.

I Hedemoser, hyppig paa Halvoen, især dens midterste Deel, i Nordsjalland og paa IBornholm; sjeldnere i Sydsjall. (Holmegaard! Fedet ved Lindersvold (H.), Kongsted (9)) og paa de ovrige Øer: F. Hofmanggave! V. Hæsinge! Steenstrup (H.); Loll. Engestofte; Falst. Horreby Lyng (H., ikke bemærket i de senere Aar).

\section{Calluna. Iledelyng.}

543. C. rulgaris [Salisb. i Linn. trans. VI, p. 317] (AImindelig H.) Drej. n. 418 ; Rchb. I. c. XVII, tab. 1162; Erica L., H. 430 ; F. D. 677.

Bladene korsviis-modsatte, tæt taglagte, linic-sylformede, med piilformet Basis; Blomsterne i ensidig Klase paa Siden af Grenene.

Halvbusk med talrige, af de tætsiddende Blade firekantede Grene; Kronerne rødviolette, sjeldnere hvide, efter Afblomstringen vedblivende uforandrede. $8-9 . \quad$ h.

$\boldsymbol{\beta}$, pubescens lioch. Bladene tæt duunhaarede.

I Skove og Tørvmoser, men især paa tørre Heder, af hvilke den selv danner den væsenligste Bestanddeel; bar sin største Udbredelse paa Høideryggen i Midten af Halvøen, det nordøstlige Sjall. og Hoilyngen paa $\boldsymbol{B}$ or $n h$., men forekommer hist og ber i de Provindser, hvor en mager og ufrugthar Jordbuud eller Mangel paa Dyrkning begunstiger dens Fremtiæden; sjeldnest paa Lolland Falster! $\boldsymbol{\beta}$, i Hedemoser ved Orsholt i Sjall. (9), Hellebreks Vang! Teglstrup Hegn, Humletofte (Heiberg); F alst. Horreby Lyng; L oll. Karleby Mose pr. Nysted (19); $F$. Skatrup (19). 


\section{Vaccinium. Bolle.}

a. Myrtillus. Bladene affaldende; Kronen krukkeeller kugleformet, Stovknapperne med 2 born-

formede 'Tilhængsler ved Grunden.

544. V. Myrtillus L. (Blaabær). H. 426 ; F. D. 974 ; Rchb. l. c. XVII, tab. 1169; Myrtillus silvaticus Drej. n. 420.

Grenene kantede; Bladene xgformede, fiint saugtakkede, paa begge Flader grønne; Blomsterne nikkende, enlige i Bladhjornerne; Bagerranden smal, udeelt; Kronen kugleformet.

1/2-1' høi. Kronen grønlig med kjødfarvet Anstrøg. Bær sorte med blaa Dug, indvendig røde. 5. $\boldsymbol{\zeta}_{2}$.

Paa Lyngbakker og i høitliggende Skove, alm. paa Halvoen, i Sjall. og par Bornh., sjeldnere i Fyen: Assens, Steenstrup (H.), Hoibjerg (12), Holsteenshuus, Søbo (24), og paa de mindre Oer: Loll. Fyrrevænget ved Saxkjøbing (5), Bøllesminde (19); Falst. i Horreby Lyng (Rasm.); Meen!

545. V. uliginosum L. (Mose-B.) H. 427 ; F. D. 231 ; Rehb. 1. e. tab. 1168 ; Myrtillus uliginosus Drej. n. 421.

Grenene trinde; Bladene omvendt-ægformede, heelrandede, paa Underfladen blaagraae; Blonsterne nikkende, sammenhobedes Bageret budt firetandet; Kronen krukkeformet.

$1 / 2-3^{\prime}$ høi ; Kronen hvid eller voxguul med rødligt Anstrøg. Bær som foreg., men indvendig hvide. 5-6.

$\beta$, macrocarpum Drej., F. D. 2469. Bærrene oval-pæreformede, alm. større end hos Hovedarten.

I Tørv- og Hedemoser: i Halve ens nordlige Egne alm., sjeldnere nod S.: Varde! Vonsild, Dravitskov ved Lygumkloster (28), Gram (1), Rødding (16), Amrom (Jessen); i Nordsjalland ikke sjelden, sparsommere i Sydsjall. og paa de ovrige Øer. $\beta, S . j$. Tiisvilde (Drej.), Store Hareskov (14).

b. Vitis idea. Bladene stedsegrønne; Kronen klokkeformet, Støvkapperne uden eller med utydelige Tilhængsler ved Grunden.

546. V Vitis idaa L. (Tyttebær). H. 428; Drej. n. 422 ; F. D. 40 ; Rehb. 1. c. tab. 1168. 
Bladene omvendt-ægformede, med tilbagebøiet, utydeligt rundtakket Rand; paa Underfladen punkterede; Blomsterne i nikkende Klaser fra Enden af Grenene; Bagerfligene ægformede.

6-8" høi. Bladene paa Overfladen mørkgrønne, glindsende; Kronen hvid eller blegrød; Bærret høirødt. 6--7. Ђ.

Paa Lyngheder og i Hedemoser; alm. i de Egne af Halvøen, Bornholm og Nordsjælland, hvor Lyngen spiller Hovedrollen, i de andre Egne sporadisk: $\mathbf{S} j$. Frederiksdals Skov! Særløse Overdrev (14), Fedet ved Lindersvold! Aamosen (15); F als t. Horreby Lyng (14); F. Assens, Steenstrup ( $\mathrm{H}_{\text {. }}$.

c. Oxycoccos. Bladene stedsegrønne; Kronen hjulformet; Støvknapperne uden Tilhængsler ved Grunden.

547. V. Oxycoccos L. (Tranebær). F. D. 80; Oxycoceos palustris Pers., H. 429; Drej. n. 423; Rchb. l. c. tab. 1169.

Stcongelen traadformet, krybende; Bladene ægformede, heelrandede med tilbagerullet Rand, paa Underfladen blaagraae; Blomsterne langstilkede, enlige eller samlede til en faablomstret Halvskjarm i Enden af Grenene; Bagerfigene nyreformede; Kronfligene tilbagebøiede.

Kronerne rosenrøde, Støvknapperne brandgule. Bær carmoisin. 6.-7. h.

I Tørr- og Hedemoser, især mellem Sphagnum, alm. udbredt.

\section{Daphne. Kjalderhals.}

548. D. Mezereum L. (Pebertræ). H. 434; F. D. 268; Rehb. l. c. XI, 556 .

Bladene lancetformede, med størst Brede ovenfor Midten, heelrandede; Blomsterne i afbrudte $A x$, dannede af 2-3.blomstrede Nøgler langs opad de aargamle Grene; Blomsterdakket med udvendig haaret Rør og ægformede Flige.

En lav Busk med rosenrøde, vellugtende Blomster, som udspringe for de i Spidsen af Grenene fremkommende Blade. Frugten høirød. 3-4. Ђุ.

Er neppe oprindelig vildroxende i Danmark, men dyrkes alm. i Haver, fra hvilke den stundom forekommer forvildet: $S j$. Frydenlund (H.); Loll. Knuthenborg Skov (Holten), Bollesminde (19); F. St. Jørgensgaard! J. Enge mellem Krat ved Kjærsholm S. for Viborg (7), 
Kolding (H.); $\boldsymbol{S} l$. Eibøl Slotsbanke ved Haderslev (Grønlund), Ballastbakken ved Flensborg (16).

\section{Digynia.}

\section{Chrysosplenium. Milturt.}

549. C. alternifolium L. (Almindelig M.) H. 467; Drej. n. 453 ; F. D. 366 .

Stongelen opret, udeelt; Bladene nyreformede, rundtakketlappede; Rodbladene langstilkede; Stongclbladene kortstilkede, afvexlende; Blonisterstanden en endestillet, fladirykt Qvast.

4-5" høi. Blomsterne og de dem omgivende Blade gule. 4-5. 4.

I fugtige Skove, især ved Kildevæeld, alm.

550. C. oppositifolium L. (Smaabladet M.) H. 467; Drej. n. 452 ; F. D. 365 ; H. N. XIV, 47.

Stangelen opstigende, ved Grunden rodslaaende, ofte grenet; alle Bladene modsatte, ægformet-kredsrunde, ved Grunden afsmalnede til en kort Bladstilk, rundbugtede; Blomsterstanden en endestillet, fladtrykt Qvast.

4-6" høi. Bladene mindre end hos foreg.; Blomsterne grongule. 5. 4 .

Paa lignende Steder som foreg., men mindre hyppig: i Halvoens ystlige Skove ikke sjelden, sparsommere $\bmod V$.; $\boldsymbol{F}$. sporadisk: Vissenberg (H.), Nyborg (4), Caroline-Amalielund ved Svendborg! Ollerup Kohave! o. fl. St. mod S. (12); i $S j$. sjelden: Gisselfeldt (H.), Hæsede! Steensby Skov (Rosenørn-Lehn), Langebæk (Knæckenborg).

\section{Trigynia.}

\section{Fagopyrum. Boghvede.}

551. H. tataricum [Gärtn. fruet. II, p. 182, t. 119] (Tatarisk B.) Drej. p. 152; F. D. 2649; Polygonum L.

Bladene hjerteformet-piilformecie, tilspidsede; Blomstcrne i tætte lilaser; Frugten spids, trekantet med bugtet-udrandede Kanter og graangtig, rynket Overbud.

Haandb, $i$ den danske Flora. 
Blomsterne grønlig-hvide. 7-8. $\odot$.

Ukrud mellem Boghvede og anden Sad, sjeldnere paa Øerne end paa Halvøen, hvor den tillige undertiden dyrkes. [*

$\dagger F$. esculentum [Woench. Meth. p. 290] (Almindelig B.) Drej. p. 152 ; Polygonum Fagopyrum L., H. 444.

Bladene langt-tilspidsede; Frugten tilspidset, trekantet, med beelrandede Kanter og jævn, sort, ofte glindsende Overhud; forøvrigt som foreg.

Blomsterne hvide eller rosenrøde. 6-7. $\odot$. vildet.

Dyrkes alm., især i sandige Egne, og forekommer af og til for-

\section{Tetragynia.}

\section{Paris. Fireblad.}

552. P. quadrifolia L. (Almindelig F.) H. 447; Drej. n. 439 ; F. D. 139 ; Rehb. ic. fl. germ. X, 957 .

Rodstokken vandret; Skaftet opret, bladløst med Undtagelse af $4 \mathrm{krandsstillede,} \mathrm{grundnervede,} \mathrm{elliptiske,} \mathrm{heelrandede} \mathrm{Blade;}$ Blomsten enlig, endestillet; Bogerbladene lancetformede, længere end de traadformede Kronblade.

${ }^{1 / 2}-1^{\prime}$ høi. Blomsterne grønne, med mørkrød Frugtknude og Grifler. Bær blanagtig-sort. Var. med 3-6 Blade og Blomstens Dele i tilsvarende Antal. 5. 4.

I Skove, alm. udbredt.

\section{Adoxa. Desmerurt.}

553. A. moschatellina L. (Almindelig D.) H. 448; Drej. n. 438 ; F. D. 94 ; Rebb. ic. fl. germ. XVII, tab. 1172.

Rodstokken med hvide, tandformede Skjæl og udskydende Udløbere; Bladene dobbelt haandsnitdeelte, med lappede Afsnit; Stangelen opret, udeelt, med 1 Par modsatte Blade ovenfor Midten; Blomsterhovedet kantet. 
3-4" høi. Blomster og Bær gronne. Hele Planten lugter af Moskus. 4-5.

I Skove og Krat alm., især i løs og fugtig Muldjord.

\section{Elatine. Bakarve.}

554. E. Hylropiper L. (Bidende B.) H. 448; Drej. n. 437 ; F. D. 156.

Stcrngelen krybende eller rodslaaende, med oprette Grene; Bladene modsatte, ovale eller onvendt-ægformede, Pladen kortere end Stilken; Blomsterne afvexlende, siddende eller meget kortstilkede.

$1-2^{\prime}$ høi, under Vandet grøn, ovenfor samme rodlig. Var. nied Bladpladen liengere end Bladstilken. Kronbladene rosenrøde. 6-9. $\odot$.

$\alpha$, gyrosperma (Düb. i Bot. not. 1839). H. N. IX, 41. Kapselen fladtrykt, Frøene kredsformigt eller hesteskoformigt bøiede.

$\beta$, orthosperma (Düb. 1. c.) Kapselen afrundet; Frøene bøiede $i$ en svag Bue.

I rindende Vand og ved Randen af Søer, hyppigst under, sjeldnere orenfor Vandet, iklke alm., skjøndt ofte overseet paa Grund af dens Lidenhed. $\alpha$, den almindeligere Form: $\boldsymbol{S} \boldsymbol{j}$. II ved 13agsverd, Frederiksdal, Frederiksberg (F. D.), Damhuussøen (Drej.)! $S l$. Seemühle ved Rendsborg! $\beta$, forekommer i Slesvig (16), f. Ex. i Eıderslikken mellem Rendsborg og Süderstapel.

\section{$X$ 555. E. Alsinastrum L. (Krandsbladet B.) H. 449;} Drej. p. 153 ; F. D. 2239 ; H. N. XIII, 55.

Stcengelen opret eller upstigende; Bladene krandsstillede, siddende, de nedre (under Vandet) ennervede, linieformede, 8-10 i Krandsen, de øvre (ovenfor Vandet) 3-5-nervede, lancetformede, $3-5$ i Krandsen; Blomsterne krandsstillede, siddende eller kortstilkede; Frøene meget svagt bøiede.

4-6" høi. Kronbladene hvide. 6-9. 4.

Et Exemplar i Schumachers Herbarium angives at være samlet i en Sø ved Frederiksberg. Senere er den hverken funden der eller andetsteds $\mathrm{i}$ det egenlige Danmark. 网 


\section{9de Klasse. Enneandria (Nihannede).}

\section{Orden. Hexagynia (Sexhunnede).}

1. Bútomus L. Blomsterdækket farvet, sexbladet, dets Blade i 2 Rækker; Frugterne 6 ved Grunden forenede Bællekapsler med talrige, vægstillede Frøe. (N. F. A lismaceæ).

\section{Illexagynia.}

\section{Butomus. Brudelys.}

556. B. umbellatus L. (Skjærmblomstret B.) H. 451; Drej. n. 440 ; F. D. 604 ; Rchb. ic. fl. germ. VII, 103.

Bladene talrige fra den forkortede Rodstok, linieformede, trekantede; Skaftet bladløst med en af et trebladet Svøb omgivet mangeblomstret Skjorm i Spidsen.

2-3' høi. Blomsterne rosenrøde. 6-7. 4.

Ved Bredderne af Aaer og Søer, funden i alle danske Provindser, men ikke lige alm. overalt: f. Ex. sjelden i Halveens nordlige og østlige Egne: J. S. Tranders, Gistrup (H), Als ved Mariager Fjord (Brantli), Aarhus! Østbirk (2); Horsens (Jø)g.), Fredericia (1); Sl. Hoptrup (Gronlund), Aabenraa (Hempel), Flensborg Mølledam (16) og i det sydlige Fyen: (Søbo! Lydinge Molle (12), hyppigst i Marskegnene og langs Aaerne paa Halvøens Vestkyst samt paa Loll.Falster.

\section{0 $0^{\text {de }}$ Klasse. Decandria (Tihannede).}

1. Orden. Monogynia (Enhunnede).

A. Kronen fribladet.

1. Geránium L. Bæger og Krone fembladede; 10 knapbærende Støvdragere (hos G. rotundifolium de 5 golde); Griffelens Strænge ved Modenheden nedenfra sneglehuusformigt tilbagerullede, Frugten femdelelig Spaltefrugt, Smaafrugterne enfrøede, indrendig glatte Hindefrugter (Blomsterstilkene 1-2blomstrede). 
2. Erjdium L'Herit. Bæger og Krone fembladede; $\mathbf{5}$ knapbærende Størdragere og 5 golde Bistøvdragere; Griffelens Strænge ved Modenheden spiralformigt snoede; Frugten som foreg., med indvendig haarede Smaafrugter (Blomsterne $i$ Skjærm). (1-2. N. F. Geraniaceæ)*).

3. Pýrola L. Bxgeret fendeelt; Kronen fembladet, regelret; Støvknapperne opspringe ved Huller i Spidsen; Frugt femrummet, mangefrøet Kapsel med rumdelende Opspringning. (N. F. Pyrolace $\mathfrak{x}$ ).

Monotropa $(8,1)$.

\section{B. Kronen sambladet.}

4. Andrómeda L. Blomsten undersædig; Størknapperne med hornformede Tilhængsler og opspringende ved Huller i Spidsen; Frugt femrummet, femklappet, mangefrøet Kapsel med rumdelende Opspringning.

5. Arctostiphylos Adans. Blomsten undersædig; Støvknapperne som foreg.; Frugten et Steenbær med 5-7 en. froede Stene. (4-5. N. F. Ericineæ, b.).

Vaccinium. Blomst oversædig, Frugten et Bær. $(8,1)$.

Lysimachia thyrsiflora. Blomsten undersædig. Frugten Kapsel. $(5,1)$.

\section{Orden. Digynia (Tohunnede).}

A. Blomsterdækket enkelt.

6. Scleránthus I. Bægeret femdeelt, omkringsædigt; Krone 0; Frugten en Nød, tæt omsluttet af det vedblivende Bæger. (N. F, Paronychie $x$ ).

*) Slægterne Geranium og Erodium henregnes af de Fleste (ogsaa af L.) til Klassen Monadelphia, men lıos de danske Arter, som jeg har undersøgt, har jeg fundet Støvdragerne enten aldeles jkke eller kun saa svagt sammenvoxne, at man, uden iforveien at være underrettet derom, iklse let falder pau at soge dem jblandt de Enknippede. Jeg har henført disse Slægter efter Støvdragernes Antal til Decandria. 
Herniaria. $\}$ Blomsten undersædig, 5 frugtbærende og 5 golde Illecebrum. $\}$ St

Chrysosplenium. Blomsten halvt oversædig. Frugten torummet Kapsel. $(8,2)$.

B. Blomsterdækket dobbelt.

7. Saxifraga L. Bægeret femdeelt, undersædigt eller halvoversædigt; Kronblade 5; Frugten torummet Kapsel med 2 Horn i Spidsen (de vedblivende Grifler), og opspringende ved et Hul mellem disse. (N. F. Saxifragace æ).

8. Gypsóphila L. Bægeret tragt- eller klokkeformet, uden Bibæger; Krovbladene uden Bikrone; Frugten enrummet, fireklappet Kapsel med midtstillet Frøstol.

9. Saponária L. Bægeret rørformet, uden Bibæger; Kronbladene med skjælformede Bikronblade i Svælget; Frugt som foreg.

10. Diànthus L. Bægeret rørformet, med Bibæger; Kronbladene uden Bikrone, ofte med Haar i Svælget; Frugt som foreg. (8-10. N. F. Silenaceæ)*).

\section{Orden. Trigynia (Trehunnede).}

A. Bægeret sambladet, Kronbladene med lange Negle.

11. Siléne L. Bægeret femtandet eller femfliget, uden Bibæger; Kronbladene hele eller indskaarne, med eller uden Bikrone; Kapselen sextandet, ved Grunden trerummet. (N. F. Sile na e æ).

Melandrium noctiflorum Fr. $(10,4)$.

*) Slægterne 8-25, som høre til de naturlige Familier Silenaceæ, Alsinaceæ og Paronychieæ, have alle modsatte (eller krandsstillede), hele Blade samt en ved Tænder eller Klapper opspringende Kapsel med midtstillet Frostol. 
B. Bægeret fribladet, Kronbladene med korte eller ingen Negle.

a. Bladene med hindeagtige Axelblade (Kronbladene røde eller rødlig-hvide).

12. Lepigonum Fr. Kronbladene udeelte; Kapselen treklappet. (N. F. Paronyehiex).

b. Bladene uden Axelblade (Kronbladene hride.

$$
\begin{gathered}
\text { 13-17. N. F. Alsinace }) \text {. } \\
\text { aa. Kapselen trelclappet. }
\end{gathered}
$$

13. Alsine Wahlenb. Kronbladene udeelte eller svagt udrandede; Støvdragernes ydre Kreds med srage Honningkirtler ved Grunden; Frøene talrige, smaae.

14. Llalianthus Fr. Kronbladene hele; Støvdragernes ydre Kreds med (10) tydelige Honningkirtler ved Grunden; Frøene faae og store.

bb. Kapselen sexklappet.

15. Areuária L. (part.) Kronbladene udeelte; Frøene nyreformede, uden Frøhud.

16. Hochringia (L.) Kronbladene udeelte (eller svagt udrandede); Frøene nyreformede, omgivne af en Frøhud ved Grunden.

17. Stellária L. Kroubladene i Spidsen tokløvede; Frøene nyreformede (uden Frohud).

Holosteum. Frøene skjoldformede $(3,3)$.

\section{Orden. Pentagynia (Femhunnede).}

A. 1 Frugtknude, 5 Grifler; Frugten en Kapsel. a. Bægeret sambladet. (18-21. N. F. Silenaeeæ).

18. Agrostémma L. Bægeret læderagtigt, femfliget; Fligene længere end Kronen; Kronbladene udrandede, uden Bikrone, Kapsclen enrummet, feutandet.

19. Melándrium Roehling. Bægeret femtandet; Kron- 
bladene tokløvede, med Bikronblade i Svælget; Kapselen op springende ved Tænder af Griflernes dobbelte Antal.

20. Lychnis L. (part.) Bægeret femtandet, Tænderne kortere end Kronen; Kronbladene dybt fligede, med Bikronblade i Svælget; Kapselen enrummet, opspringende red Tænder af Griflernes Antal.

21. Viscária Roehl. Bægeret femtandet, Tænderne kortere end Kronen; Kronbladene udrandede, med tokløvet Bikrone i Svælget; Kapselen ved Grunden femrummet, opspringende ved 'Tænder af Griflernes Antal.

b. Bægeret fribladet. (22-24. N. F. Alsinaceæ).

aa. Kronbladene $i$ Spidsen udrandede cller tofligede.

22. Cerástium L. Blomsten 4-5-delelig; Kronbladene udrandede eller til Midten tofligede; Kapselen titandet.

23. Haláchium Fr. Blomsten femdelelig; Kronbladene dybt todeelte; Kapselen femklappet med totandede Klapper.

\section{bb. Kronbladene $i$ Spidsen hele.}

24. Sagína L. Blomsten 4-5-delelig; Kapselen 4-5klappet; Frøene nyreformede, uvingede. (Bladene modsatte, uden Axelblade; Kronbladene mangle undertiden).

25. Spérgula L. (part.) Blomsten femdelelig; Kapselen femklappet; Frøene kugleformet-lindseformede, vingede (Bladene krandsstillede, med hindeagtige Axelblade. - N.F.P a r o n y c h i e æ).

Oxalis. Støvdragerne ved Grunden sammenvoxne $(16,2)$.

B. I Frugtknude, 5 Grifler, Frugten et Bær. Adoxa. Bregeret 2-3-bladet, halvt oversædigt $(8,4)$.

C. 5 Frugtknuder, Frugterne 5 Bællekapsler.

26. Srdum I. Bæger og Krone fembladede; 5 Skjæl ved Grunden af Frugtknuden (Saftrige Urter. N. F. Crassu] a c e $\mathfrak{x )}$. 


\section{Ho nogynia.}

\section{Geranium. Storkenab.}

a. Batrachium koch. Rodstokken tyk, vandret eller skjæv, snoet, knudret, foroven skjældxkt. ข.

aa. Smaafrugternes Klapper (Frøgjemmet) javne.

$\alpha$, Blomsterstilkene enblomstrede.

557. G. sanguiucum L. (Blodrød S.) H. 740 ; Drej. n. 682 ; F. D. 1107 ; Rehb. ic. fl. germ. V, fig. 4884.

Bladene kredsrundt-nyreformede, dybt haandfligede eller -snitdeelte, med omtrent 7,3-5-fligede Afsnit; Bogerbladene trenervede, ægformede, hule, braadspidsede, halvt saa lange som de omvendt-hjerteformede, udrandede Kronblade; St $\emptyset v$ traadene med udvidet Basis, randhaarede; Frogjemmerne kirtletduunharede, oventil langhaarede; Fr $\phi e n e$ fint-punkterede.

Stængler og Blomsterstilke stivhairede af vandret ndstaaende Haar. Kronbladene mørk-rosenrøde, ovenfor Neglen skjæghaarede. 6-8. 4 .

Paa Bakker og Skrænter, især mellem Krat: i enkelte Egne ikke sjelden, f. Ex. det nordl. Jyll. (til Aarhus), Nordsjalland og Bornh; i de andre Egne sparsommere: Falst. Gaabense! Loll. (5); F. Hofmansgave (H.), Kjerteminde (Heiberg); S l. Gelting Birk, Kö. nigsmark og mellem Schauendal og Olderup ved Husum (16).

$\boldsymbol{\beta}$, Blomsterstilkene toblomstrede.

558. G. palustre L. (Kjær-S.) H. 736 ; Drej. n. 694 ; F. D. 596 ; Rehb. 1. c. fig. 4892 .

Stcengelen udstrakt eller opstigende, med udspilede Grene tilligemed Blomsterstilkene stivhaarede af nedadvendte Haar; Bladene haandformigt fernfligede med indskaaret-saugtakkede Flige; Axelbladene urteagtige; Blomsterstilkene efter Afblomstringen tilbagebøicde; Bagerbladene femnervede, ægformet-ovale, braadspidsede, halvt saa lange som de omvendt.xgformede Kronblade; Støvtraadene ved Grunden udvidede, randhaarede; Frøgjemmerne og Nabet tiltrykt-haarede, uden Kirtler; Froene fint punkterede.

Kronbladene mørk rosenrøde eller rødviolette, ovenfor Neglen skjægharede. 7 . 
Paa Enge mellem Buske, i fugtige Kratskove: i Sja ll. (især mod S. V.) samt paa $L$ oll . F alster ikke sjelden; $\boldsymbol{E} r \boldsymbol{\theta}(10) ; \boldsymbol{S}$. Ensted ved Aabenraa, mellem Teesbæk og Bommerlund, mellem Kappel og Egernforde. Selker Mose (16), Enge ved Gottorp Slot! (I Jyll. og Fyen er det mig ikke bekjendt at den er funden). F

559. G. pratense L. (Eng-S.) H. 737 ; Drej. n. 693 ; Rchb. I. c. fig. 4883 .

Stangelen opret, med opret-aabne, foroven, tilligemed Blomsterstilkene, kirtlet-duunhaarede Grene; Bladene haandsnitdeelte, med omtrent 7 dobbelt fjerfligede Afsnit; Axelbladene hindeagtige; Blomsterstilkene efter Afblornstringen tilbagebøiede; Bagerbladene trenervede, ægformet-ovale, langstakkede, halvt saa lange som de onvendt-ægformede Kronblade; Støvtraadene ved Grunden brede, randhaarede; Frøgjemmerne og Nobet kirtelhaarede; Fr.øene fint punkterede.

Hele Planten større end foreg. og følg., Kronbladene blaaagtigviolette, ovenfor Neglen randhaarede. $7-8$.

I Krat og ved Gjærder, sjelden: $\boldsymbol{S} \boldsymbol{j}$. Brede (H.)? F alst. mellem Horbeløv og Meelse (14), Stubbekjøbing (19); $\boldsymbol{F}$. Kratskov mellem V. Hæsinge og Torringe! Svendborg (H.); J. Skjærup! Findes desuden forvildet omkring Haver og Byer, f. Ex. $S \boldsymbol{j}$. paa flere Steder i Kjøbenharns Omegn, L otl. ved Pederstrup (19); F. ved Landsbyer hist og her (19); J. Ødstedgaard! Sl. Husum, Tønning (F. Müll.), mellem Knoop og Holtenau!

560. G. silraticum L. (Skov-S.) H. 736 ; Drej. n. 692 ; F. D. 124 ; Rehb. 1. c. fig. 4882.

Stangelen opret, med opret-aabne, tilligemed Blomsterstilkene kirtlet-duunhaarede Grene; Bladene dybt haandfigede, med omtrent 7 saugtakket-indskaarne (ofte trelappede) Flige; Axelbladene hindeagtige; Blomsterstilkene efter Afblomsíringen oprette; Bagerbladene trenervede, ovale, braadspidsede, halvt saa lange som de omvendt.ægformede Kronblade; Frogjemmerne og Nabet kirtelhaarede; Frøene fint punkterede.

Mindre end foreg., Kronbladene rødviolette, ovenfor Neglen skjæghaarede. $6-7$.

I Skove og Krat: i det østl. Jyll. (især fra Aarhus til Veile) ikke sjelden, sparsommere mod S. (fra Slesv. er mig intet Voxested bekjendt); paa $\theta$ e rne sporadisk: $\boldsymbol{F}$. Krat ved Lunde pr. Odense (18), Smallehave ved V. Skjerninge! $\boldsymbol{S} j$. Boserup, Ledreborg! Bernstorf (H.), Ørholm! Brede! Paa Bornholm alm.! 
bb. Smaafrugternes Klapper paatvars rynkede.

† 561. G. phæum L. (Bølgekronet S.) H. 735 ; Drej. n. 685 ; F. D. 987 ; Rehb. l. c. fig. 4891 ; H. N. IX, 33.

Stangelen opret, især ved Leddene tilligemed Blomsterstilkene stivhaaret af udstaaende Haar; Bladene haandfligede eller -lappede, med omtrent 7 indskaaret-saugtakkede Lapper; Kronbladene rundagtige med kort Negl, bølget-rundtakkede, fladt udbredte, lidet længere end de femnervede, orale eller elliptiske, kort braadspidsede Bogerblade; Frøgjemmerne tiltrykt-haarede; Frøene fiut stribede.

Stgl. alm. rødprikket, Kronbladene mørlst violetbrune. 6-7.

$\beta$, lividum Koch (G. lividum L'Herit.), Haarene blødere, Krombladene skident lila.

I Skove og Krat, isar omkring beboede Steder, sandsynligviis oprindelig forvildet fra Haver, hvor den dog nu ikke mere dyrkes: $\mathbf{s} \boldsymbol{j}$. Sorgenfri i Krattet ved Aaen! Rosenborg Have, Soro (H); Falst. Moseby Prastegaards Have (14), Hanenov (19); F. Bramstrup (18); $J$. Lyngbygaard ved Aarhus (16), Ødstedgaard! $S l$. Bommerlund (16), Huusby (12) og Grumtoft i Angel, Nyvark ved Slesvig (16), Ascheffel (20). $\beta$, Et Gjærde ved "Lygten " udenfor Kjobenhavn (12). \$

b. Batrachioides Koeh. Rodeu tapformet, ingen Rodstok. 4 .

562. G. pyrenaicum L. (Pyrenæisk S.) Drej. n. 688; F. D. 2240 ; Rehb. 1. c. fig. 4881 ; H. N. 1X, 34.

Stongelen opret, duunhaaret; Bladene nyreformede, haandfligede, (de nedre 7-9-, de øvre femfligede), Fligene rund. takket-lappede; Blomsterstilkene efter Afblomstringen tilbagebøiede; Kronbladene omvendt-hjerteformede, tokløvede, ovenfor den korte Negl skjæghaarede, næsten dobbelt saa lange som de randhaarede, kort braadspidsede Bagerblade; Frogjernmerne jævne, tiltrykt-duunhaarede; Nobet kirtelhaaret; Frøene jxevne.

Kronbladene rosenrød-lila eller hvide. 7-9.

Ved Gjærder, omkring Haver og Byer, ikke alm. og paa de flesto Steder, som det synes, oprindelig forvildet: $\boldsymbol{S} \boldsymbol{j}$. Helsingør (21), Søllerod (Petersen), Dronninggaard, Sophienholm ved Frederiksdal, Roeskilde, Bidstrup! Ledreborg (24), Sorø! Bregentved, Nysø(9); F. Svendborg (12), Langeskors Kro (16), Hofmansgave (18); J. Veile! S l. Ha- 
derslev (Grønlınd), Vonsbæk (Nielsen), Hesteberger Schützenkoppel red Slesvig (16).

c. Columbinum Koch. Roden tynd, pæleformet, ingen Rodstok. $\odot$.

aa. Smaafrugternes Frøgjemme jaevnt. $\alpha$, Frøene jævne.

563. G. rotundifolium [L. Fl. Suec., Fr. Nov. p. 212] (Rundbladet S.); H. N. XIV, 35; G. pusillum H. 734; Drej. n. 687 ; F. D. 1994 ; Relıb. I. c. fig. 4877.

Bladene kredsundt-nyreformede, haandfigede, med 5-9, trelappede Flige; Blomsterstilkene efter Afblomstringen tilbagebøiede; Kronbladene omvendthjerteformede, udrandede, med svagt randhaaret $\mathrm{Negl}$, ligelange med de kort-braadspidsede Bagerblade, de 5 Støvdragere golde; Frogjemmet tiltrykt-haaret.

Hele Planten meget fint duunhaaret af udstaaende Haar, Blomsterstilkene kirtelhaarede, Kronbladene lila ell. skidenrøde. 6-8.

$\beta$, minus Fr. 1. c. (G. pusillum L. sp.) Lavere og med mere spidst-lappede Blade.

Ved Gjærder, paa Marker o. a. dyrkede Steder meget alm. $\beta$, med Hovedarten, paa magrere Jord.

$\boldsymbol{\beta}$, Frøene grubet-punkterede.

? G. viscidulum [Fr. Nov. p. 216] (Klæbrig S.) G. rotundifolium L. Sp., H. 739 (undt. Voxest.); Drej. n. 689; Rchb. l. c. fig. 4878 ; H. N. XII, 52.

Bladene nyreformede, haandfligede, med $5-7$ rundtakkettrelappede Flige; Blomsterstilkene som hos foreg. (kortere end Bladene); Kronbladene omvendt-ægformede, beelrandede, med glat Negl, lidet længere end de kirtelhaarede, braadspidsede Bægerblade; Frøgjemmet duunbaaret af udstaaende Haar.

Stængler og Blomsterstilke kirtelhaarede, Kronbladene lysrøde. $6-8$.

Ved Gjærder og Mure. Angives af Hornem. som forekommende hist $\mathrm{ng}$ her, hvilket vel beroer par en Forvexling med den storre Form af foreg. Det er mig ikke bekjendt at den er funden i Danmark, men da den forekonmer saavel i Skăne som i Tydskland og Fngland, kunde den muligviis ogsaa findes her, og snbefales derfor til nærmere Eftersøgning. 
564. G. dissctum L. (Kløftbladet S.) H. 739; Drej. n. 691 ; F. D. 936 ; Rehb. l. e. fig. 4876 ; H. N. XIV, 36.

Bladene nyreformede, de nedre 5-7-fligede med trelappede Flige, de ovre haandsnitdeelte med $3-5$ dybt trefligede Afsnit (Fligene linieformede); Blomsterstilkene som hos foreg., kortere end Bladene; Kronbladene omvendt-hjerteformede, udrandede, med svagt randhaaret Negl, ligelange med de langt braadspidsede Bogerblade; Frøgjemmerne tilligemed Bæger og Blomsterstilke beklædte med udstaaende Kirtelhaar.

Stængelen med nedadvendte Haar. Kronbladene carmoisin- eller mørk-rosenrøde. 6-7.

Paa dyrkede Marker, Grøftevolde o. s. v., ikke sjelden.

565. G. columbinum L. (Storbægret S.) H. 740; Drej. n. 690 ; F. D. 1222 ; Rchb. l. c. fig. 4875 ; H. N. XV, 37.

Bladene haandsnitdeelte, Afsnittene 5-7, dybt 3-5. tigede, med linieformede Flige; den falles Blomsterstill længere end Bladene, med efter Afblomstringen tilbagebøiede Smaablomsterstilke; Bageret femkantet; Kronbladene omvendt-hjerteformede, med randhaaret Negl, ligelange med de langstakkede Bægerblade; Frøgjemmerue fjernt- og tiltrykt-baarede (eller næsten glatte).

Stængelen svagthaaret af nedad tiltrykte Haar; Blomsterne større end hos de andre Arter af Afdelingen c., Kronbladene lila-rosenrøde.

Paa dyrket Jord, red Gjærder, i aabne Kratskove, ikke sjelden.

b6. Smaafrugternes Klappcr paatvars rynkede.

566. G. molle L. (Blød S.) H. 738; Drej. n. 686; F. D. 679 ; Rehb. I. c. fig. 4879 ; H. N. I, 36 .

Stangelen opstigende; Bladene kredsrundt-nyreformede, haandfligede; Fligene $7-9$, budt trelappede; Blomstcrstilkene som foreg.; Kronbladene omvendt-hjerteformede, udrandede, med randhaaret Negl, længere end de kort braadspidsede Bagerblade; Frogjemmerne glatte; Frøene jævne.

Hele Planten blødt-duunhaaret af udstaaende Haar. Kronbladeno smukt røde. $5-8$.

Paa tørre Marker, Grøftevolde og Diger meget alm. 
567. G. lucidum L. (Skinnende S.) H. 738; Drej. D. 684 ; F. D. 218 ; Rehb. l. e. fig. 4872.

Stcengelen opret, tilligemed Blomsterstilkene ensidigt haaret, forøvrigt glat; Bladene fjernt-haarede eller næsten glatte, kredsrundt nyreformede, haandfligede, Fligene $5-7$, rundtakketlappede, med budte, braadspidsede Lapper; Blomsterstilkene som foreg.; Bageret femkantet, med paatværs rynkede, braadspidsede Bægerblade, lidet kortere end Kronen; Kronbladenes Plade oinvendt-ægformet, heelrandet, kortere end den glatte $\mathrm{Negl}$; Frøgjemmerne stribede paalangs, foroven duunhaarede; Frøene jævne.

Hele Planten glindsende, ofte rødligt anløben. Kronbladene rosenrøde. $6-8$.

I Skove og Krat, sjelden: Sj. Helsingør (H.)? Tjustrup red Soro! mellem Taarnholm og Dyrehovedgaard ved Korsør (29); B or $n h$. ved Ruinerne af Gamleborg (H.) og Lilleborg, Lindholmsklipperne i Røe Sogn (19), Randkleven (8), Ringbjerget (21).

568. Q. robertianum L. (Stinkende S.) H. 737; Drej. n. 683 ; F. D. 694 ; Rehb. l. e. fig. 4871.

Stcengelen opret eller opstigende, tilligemed Blomsterstilkene langhaaret af udstaaende, glindsende Haar; Bladene til Grunden haandsnitdeelte, Afsnittene $3-5$, fjersnitdeelte med saugtakketfligede Afsnit; Blomsterstilkene som foreg.; Bogeret tikantetstribet, med langstakkede Bægerblade; Kronbladene som foreg.; Frøgjemmerne svagt duunhaarede; Frøene jævne.

Stængelen alm. rødligt anløben. Hele Planten har en stærk, ikke behagelig Lugt. Kronbladene rosenrøde. 7-8. Var. i Henseende til Beklædningen, Bladenes Indskjæringer o.s. v. En afvigende Form er:

$\beta$, rubricaule Hornem. (b. purpureum Rchb. l, e. fig. 4871). Stængelen nedliggende, meget grenet, mørkrød; Bladene mindre, med finere Flige; Frøgjemmerne glatte, mere rynkede.

I fugtige Skove og omkring dyrkede Steder alm. $\beta$, ved Strandlredder millem Sand og Stene paa Havstoklen: $\boldsymbol{S} j$ Strandbredder S. for Kjøge! Bredderne af Kattegattet ved Veirhøi! Nykjøbing i Odsherred $(9)$; Sains $\theta$ (2); F. Havstokken $\emptyset$. for Hersnap paa Hindsholm! Avernakø (12); Søby Batteri paa $\boldsymbol{E}_{r \theta}(10)$; Moen red Kapellet (14); J. Boeslum Strand ved Ebeltoft (Ørting). 


\section{Erodium. Tranchals.}

569. E. cicutarium [L'Herit. i Ait. h. kew. ed. 1, II, 414] (Almindelig T.) Drej. n. 690; Rehb. l. e. fig. 4864; Geranium eicutariun L., H. 733; F. D. 986.

Bladene dobbelt-fjersnitdeelte, med saugtakket fligede Afsnit; Frobladene 3--5.lappede; Bagerbladene hule, budte med en Braad nedenfor Spidsen, langs Nerverne stivhaarede, i Randen finthaarede; Kronbladene uligestore, længere end Bægeret, omvendt-ægformede med skjæghaaret Negl; Stovdragerne glatte, de 5 frugtbare nedentil udvidede, med en mørkrød Kirtel ved Grunden; Nabet tiltrykt-haaret.

Stængel og Blade stivbaarede af ndstaaende Haar. Kronbladene rosenrøde, de 2 kortere med en hvid, sortprikket Plet ved Grunden. Var. i Henseende til Bladenes Indskjæring. 4-7. $\odot$.

Paa torre Steder, f. Ex. sandige Marker, Groftevolde, Mure, alm.

Anm. E. pimpinellaefolium Willd. (Drej. n. 681; Rchb. 4865), som beskrives med udeelte Froblade og Kroublade af Bregerets Larngde, er en tvivlsom Form og maaskee neppe andet end en Afrendring af foreg. Den angives fra Baarse og Lundbygaard ved Prast $ø$.

\section{Pyrola. Vintergren.}

a. Moneses Salisb. Stængelen enblomstret; Kronbladene horizontalt udbredte, Kapselen opspringende ovenfra, uden 'Tr rlenæt mellem Sømmene.

570. P. unillora L. (Enblomstret V.) H. 466 ; Drej. n. 445 ; F. D. 8 ; Rehb. l. c. XVII, tab. 1156 ; Chimaphila Fr. Bot. not. 1840 p. 37 ; Moneses grandiflora Salisb.

Rodbladene omvendt-ægformet-kredsrunde, saugtakkede; Skaftet bladlest eller uned et Dækblad ovenfor Midten; Blomsterne nikkende; Støvdragerne opstigende og tiltrykte til Kronen; Arret straaleformet, Griffelen ret, omtrent af Langde med den ved Modenheden oprette Frugt.

2-6" høj. Blomsterne hvide, vellngtende. 6-7. 4 .

I Naaleskove, sjelden: $\boldsymbol{S}$ j. Hornbæks Plantage (17!), Rungsted (Fru Pingel), Rudergaard (Frisenette), Rudersdals Skov (14), Bagsværd ved 'Teglgaarden (9), Frederiksdal (15); J. Skyum Krat, Skjsorping (H.). 
b. Pyrola genuina. Blomsterne i Klase, Kronblade og Støvdragere opadrettede; Kapselen opspringendo nedenfra, med Trærlenæt mellem Sømmene.

aa. Pyrola Alefeld, Linnca 1856 p. 18. Klasen ensidig; Støvknapperne fremragende, 2 Kirtler ved Grunden af hvert af Kronbladene.

571. P. secunda L. (Ensidig V.) H. 465; Drej. n. 446 ; F. D. $402 ;$ Rchb. XVII, tab. 1155.

Bladene ægformet-elliptiske, spidse, saugtakkede; Bagerfigene ægformede, afrundede; Kronbladene sammensluttende; Griffelen fremragende og længere end Kapselen; Arret femlappet uden Ring forveden.

4-6" høi. Kronbladene grønlig-hvide. 7. 4.

I høitliggende Skove, funden i alle Landets Provindser, men sporadisk og ikke alm.

bb. Amelia Alef. l. c. Klasen alsidig; Støvknapperne indsluttede, ingen Kirtler ved Grunden af Kroubladene, Griffelen ret, smalere end det skiveformede $A r$.

572. P. minor L. (Liden V.) H. 464; Drej. n. 447; F. D. 55; Rechb. XVII, tab. 1155; Amelia minor Alef. 1. c. p. 25.

Bladene ovale eller elliptiske, rundtakkede; Bagerfigene ægformede, tilspidsede; Kronbladene under Blomstringen sammensluttende; Griffelen indsluttet i Kronen og kortere end Kapselen, Arret femlappet, uden Ring forneden.

$1 / 2-1$ ' høi. Kronerne rosenrøde eller hvide. 7. 4.

I høitliggende Løvskove hist og her i alle danske Provindser, sjeldnere i T'grvmoser, f. Ex. Estrup i Vendsyssel (12) og paa Sandgrund, f. Ex. J. Klitter ved Blaavandshuk $(30) ;$ B or $n h$. Frydenlund ved Rønne!

573. P. media [Sw. Vet. ac. handl. 1804 p. 257, t. 7] (Klokkeblomstret V.) H. 464 ; Rehb. XVII, tab. 1154; H.N. IX, 56; P. rotundifolia F. D. 110 ; Amelia media Alef. 1. c. p. 30 .

Bladene ovalt-kredsrunde, utydeligt rundtakkede; Bager. 
Aigene ægformede, spidse; Kronhladene under Blomstringen tilsluttende, Griffelen fremragende udenfor Kronen og længere end Kapselen; fra hvilken den udgaaer i en skraa Retning, Arret femlappet, udvidet forneden til en Ring.

$1 / 2-1^{\prime}$ høi. Kronbladene rødlig-hvide, meget større end hos foreg. 6-7. 2.

I Skove og paa Bakker mellem Krat, meget sjelden: Bornh. i Almindingen! J. Bonderup Bakker (Branth), i Krattet Skatskov ved Eveldrup (Dr.).

cc. Thelaia Alef. l. c. Griffelen fra en nedbøiet Basis bueformigt opsigende, tykkere end Arret, forovrigt som foreg.

574. P. rotundifolia L. (Aabenblomstret V.) H. 463; Drej. n. 449 ; F. D. 1816 ; Rchb. l. c. XVII, tab. 1153, fig. 1; Thelaia rotundifolia Alef. 1. c.

Bladene budt-ægformede eller kredsrundt-ovale, heelrandede eller utydeligt rundtakkede; Bagerfigene lancetformede, spidse, af Kronbladenes halve Længde; Kronen under Blomstringen aaben; Griffelen længere end Kronbladene og Kapselen, foroven udvidet til en Ring, der er bredere end det opretfemlappede Ar.

6-9" høi. Kronbladene hvide. 6-7. भ.

$\beta$, arenaria Koch, Rchb. l. c. fig. 2 (Thelaia intermedia Alef. 1. c.) Lavere, med talrige, brede og budte Skjæl paa Blomsterskaftet, budte Bægerflige, kortere og mindre boiet Griffel.

I Hængedynd og Hedemoser, ikke alm.: S $\boldsymbol{j}$. Tibirke Mose! Jonstrup Vang (14), Lyugby Mose! Heder ved Kjøge Bugt (15); J. Hjesbæk Molle S. f. Aalborg (Dr.), Svenstrup (Branth), Fusing Vasehuus, Klausholm (7), Boller (Jørg.); $\boldsymbol{S} l$. Gremmerup Kjær i Angel (16), Olderup ved Husum (F. Muill.); Bornh. Hasle (11), Rytterknagten (20). $\beta$, paa fugtig Sandgrund, f. Ex. Adserbo Overdrev ved Frederiksจærk!

575. P. chlorantha [Sw. Vet. ac. handl. 1810, p. 190] (Grønblomstret V.) H. 464 ; Drej. n. 448; F. D. 1693 ; Rchb. l.c. XVII, tab. 1154; H. N. XIII, 65; Thelaia chlorantha Alef. l. c.

Bladene kredsrunde eller ovale (ofte med større Brede end Længde), i Spidsen afrundede eller svagt udrandede, heelrandede eller utydeligt rundbugtede; Bagerfigene ægformede 
med en kort Spids, $1 / 4$ af Kronbladenes Længde; Kronen under Blomstringen aaben; Støvknapperne rørformigt forlængede; Griffelen som foreg.

$1 / 2^{4}$ høi. Bladstilkene rødbrune. Kronen bleggrøn (Blomsterknopperne til det folgende Aar ere allerede tydelige i Blomstringstiden). $6-7$. $ข$.

I Naaleskove meget sjelden: $\boldsymbol{S}$. Hornbæks Plantage (Heiberg)! Granskov ved Bagsværd Sø (27!). |

\section{Andromeda. Rosmarinlyng.}

576. A. polifolia L. (Vild Rosmarin) H. 461; Drej. n. 441 ; F. D. 54 ; Rchb. 1. c. XVIl, tab. 1161.

Bladene linie-lancetformede, heelrandede med tilbagerullet Rand, glatte og paa Underfladen hvidgraae; Blomsterne langstilkede, skjærmformigt samlede i Spidsen af Grenene; Kronen ægformet-krukkeformet.

$1 / 2-1^{\prime}$ høi. Halvbusk med stedsegrønne Blade. Kronen blegrød. 6-7.

I Hedemoser: ikke sjelden paa Halveen; i Sjall. sporadisk, paa de orrige Øer sparsom: Falst. Horreby Lyng! Lidstrup Lyng (Koch); Loil. Karleby ved Nysted (19), Soholt (5); Langel. ved 'Tranekjær (H.); F. Steenstrup, Fyenshoved (H.).

\section{Arctostaphylos. Meelbarriis.}

577. A. Ura ursi [Spr. Syst. II, pag. 287] (Stedsegrøn M.) Arbutus Uva ursi L., H. 462; F. D. 33; Aretostaphylos officinalis W. \& Gr., Drej. n. 442; Rehb. 1. c. XVII, tab. 1167.

Stcongelen nedliggende, stærkt grenet; Bladene omvendtægformede, heelrandede, glindsende, stedsegrønne, nætformigtaarede; Blomsterne i sammentrængte, kortstilkede Klaser fra Spidsen af Grenene.

Kronen rosenrød ell. hvid med rod Krave. Bærret høirødt. Bladene ligne 'I'yttebærblade. $5-6$. $\boldsymbol{\zeta}$.

Paa Lyngheder: alm. paa Halvoen fra Hederyggen mod V., sjeldnere $\varnothing$. for samme; paa $\boldsymbol{\theta}$ erne meget sjelden: $\boldsymbol{S}$ a m $s \boldsymbol{\theta}$ (Jacobsen), $\boldsymbol{S} j$. Tiisvilde (H.). 


\section{Digynia.}

\section{Scleranthus. Knavel.}

578. S. annuus L. (Enaarig K.) H. 479 ; Drej. n. 450; F. D. 504 .

Stcengelen leddet, gaffeldeelt-grenet; Bladene sylformede, alsidigt vendte, modsatte, med knippestillede Blade (forkortede Grene) fra Bladhjørnerne; Bægerfligene ægformede, spidse, grønne med en smal hindeagtig Rand, mod Frugtmodningen aabne.

Hele Planten grøn. 5-7. $\odot$. Var. med mere eller mindre grenet Stængel og

$\beta$, biennis Fr. (Fl. Sean. p. 118; H. N. XII, 61). Bægeret mod Frugtmodningen aabent. $\odot$.

Faa dyrkede Marker, et alm. Ukrud. $\beta$, paa tørre Bakker: L oll. ved Grønnegade (5).

579. S. perennis L. (Fleeraarig K.) H. 479; Drej. n. 451 ; F. D. 563 ; H. N. XII, 62.

Bladene ensidigt vendte; Bagerfigene ovale, budte, med bred, hindeagtig Rand og grøn Midtnerve, mod Frugtmodningen lukkede, forøvrigt som foreg.

Stængelen ofte rødlig. Forekommer hyppigst med korte Ledstykker og tæet sammentrængt, knippeformet Blomsterstand, men var., som foreg., med forlængede Ledstykker og stærkt forgrenet Qvast. 6-8. 4 .

Paa udyrkede, sandige Marker og Bakker, ikke sjelden paa Halvøen, i det vestlige Fyen, Nordsjalland og Bornholm; i de øvrige Egne, især paa de mindre Øer, sparsom.

\section{Saxifraga. Steenbrak.}

a. Hirculus Tausch. Bægeret undersædigt, med tilbagebøiedeFlige; Kronbladene gule. (Bladene heelrandede; overvintrer ved bladbærende Rodskud).

580. S. llirculus L. (Filtstænglet S.) H. 472 ; Drej. n. 454 ; F. D. 200 ; H. N. I, 45. 
Stcongelen opret, i Spidsen beklædt med rustfarvet Filt, tilligemed de fremliggende eller opstigende Rodskud tætbladet; Bladene laneetformede; Blomsterne 1-3 i Spidsen af Stængelen; Bagerfligene budte, randbaarede; Kronbladene omvendt-ægformede, med 2 bruskagtige Punkter (og flere brandgule Prikker) ved Grunden.

$4-8$ " høi. 7-9. 4.

I Hængedynd, fugtige Enge, ikke alm. og kun bemærket $\mathrm{i}$ Nordsjælland og paa Halvøen: $\mathbf{S}$. Lovenborg, Slangerup (H.), Skjæremøllen ved Fredensborg (9), Tryggerød Mose! Terkelskov! Gjeddevad Mose red Farum (14), Jonstrup, Langholmsmosen ved Dronninggaard (H.), Lyngby Mose (14), mellem Ermelund og Kongekilden! $\boldsymbol{J}$. Estrup og Haven i Vendsyssel, Vildmosen, Gravens Mose (12), Ferslev og Gravlev ved Aalborg (Branth), Ravnstrup Mose mellem Viborg og Skive, Tange (16), Dalsgaard, Taastrup i Rindsherred (Dr.), fl. St. ved Viborg (Morville), Thorsted (2), Ringkjøbing (H.), Torslev, V. Velling (Dr.), Haraldslund, Kalbygaard! Norup N. V. for Veile (30); Sl. Pulverholz ved Slesvig (16).

b. Nephrophyllum Gaud. Bægeret halvt-oversædigt, med opretteFlige; Kronbladene bride ell. rødlige;

(Bladene indskaarne; ingen Rodskud).

581. S. granulata L. (Kornet S.) H. 473 ; Drej. n. 455 ; F. D. 514 .

Rodstokken med kugleformede, duunhaarede Løgknopper; Stangelen opret, faabladet; Rodbladene langstilkede, nyreformede, rundtakket-haandlappede; Stangelbladene næsten siddende, 3-5lappede; Blomsterstanden qvastformet; Kronbladene omvendt-ægformede, $2-3$ Gange længere end Bægeret.

Hele Planten kirtelhaaret, $1 / 2-1^{\prime}$ høi. Kronbladene hvide. 5-6. 4 .

Paa høie Enge, Bakker og mellem Krat, meget alm.

582. S. tridactylites L. (Trekløvet S.) H. 476 ; Drej. n. 456 ; F. D. 1517 ; 11. N. XIII, 58.

Stangelen opret, udeelt eller fra Grunden af grenet; Bladene omvendt-ægformede eller kileformede, trefligede (eller -lappede); Dakbladene parvise, lancetformede, beclrandede; Blomsterstilkene spredte, enblomstrede, 3-4 Gange læugere end den fuldroxne Frugt. 
2-4" høi. Hele Planten rodagtig, klæbrig-kirtelhaaret, Kronbladene smaae, hvide. Var. (paa smaae Expl.) med alle Bladene heelrandede ( $\beta$, exilis Gaud.). $\frac{4}{2}-\frac{6}{1}$. $\odot$.

Paa tørre, sandige Marker og Bakker. Fra Slesvig har jeg ikke seet Expl., forovrigt forekommer den i alle Provindserne, men sporadisk og ikke i alle Egne; hyppigst i det nordl. Jyll. og Nordsjalland.

\section{Gypsophila. Gipsurt.}

583. G. muralis L. (Muur-G.) H. 480; Drej. n. 461; F. D. 1268 ; Rchb. ic. fl. germ. VI, tab. 239 , fig. 4997 (og G. serotina 4998); H. N. XV, 40.

Stangelen fra Grunden af gaffeldeelt-grenet; Bladene linieformede; Blomsterne enlige, paa haarfine Blomsterstilke i Gaffeldelingerue; Bageret femtandet, med afrundede Tænder; Kronbladene rundtakkede eller udrandede.

2-6" høi. Kronbladene rosenrøde. 7-8. $\odot$.

Paa Marker og Steengjærder sjelden: $\boldsymbol{S} \boldsymbol{j}$. Kronborg (H.). Hestkjøbgaarden ved Birkerød (Schum.), Kollekolle, Rudersdal (H.), Lyngbygaard ved Skjelskor (West); Loll. Nebbelunde (H.). (Er sandsynligviis paa flere af de angivne Steder nu forsvunden). [*

$\dagger$ G. Vaccaria [Sibth. et Sm. fl. græc. I, 279]; Saponaria Vaccaria L. Vacearia pyramidata Fl. Wett., Rehb. l. c. VI, tab. 245 .

Stangelen foroven gaffeldeelt-grenet; Bladene æg-lancetformede, spidse, ved Grunden sammenvoxne; Blomsterne langstilkede, i fjerntblomstret Qvast; Bageret opblæst, kantet-vinget med tilspidsede Tænder; Kronbladene i Spidsen uregelmæssigt tandede.

$1-1^{1} \frac{1}{2^{\prime}}$ høi. Kronbladene rosenrøde. 7-8. $\odot$.

Ukrud mellem Hør ved Jonstrup (14), indvandret fra det sydlige Enropa.

\section{Saponaria. Sabeurt.}

584. S. officinalis L. (Læge-S.) H. 481; Drej. p. 160; F. D. 543; Rebb. l. c. VI, 4995; Silene Saponaria Fr. bot. not. 1842 p. 10.

Stcengelen opret, udeelt eller i Spidsen greuet; Bladene 
elliptiske eller lancetformede, spidse, trenervede; Blomsterne i Knipper fra Spidsen af Stængelen og Grenene, samlede til en Halvskjærm eller Top; Kronbladene omvendt-ægformede, ofte udrandede i Spidsen.

1-2' høi. Hele Planten glat ell. oventil duunhaaret; Kronbladene bleg-rosenrøde eller hvide. 7-8. 4 .

Ved Gjærder, især omkring Byer, ikke sjelden, men sandsynligviis i ældre 'Tider udvandret fra Haver, hvorom det ogsaa synes at vidne, at den hyppigst forekommer med fyldte Blomster.

\section{Dianthus. Nellike.}

a. Kohlrauschia Kth. Bægeret femkantet, med vingeformigt fremstaaende Kanter.

585. D. prolifer L. (Knop-N.) H. 482; Drej. n. 457; F. D. 221 ; Rehb. I. c. fig. 5009 ; H. N. II, 44 ; Tunica Scop.

Stcongelen oventil firekantet, glat, udeelt eller grenet; Bladene linieformede; Blomsterne i tæt Hoved, omgivet af (alm.) 3 Par hindeagtige Svøbblade, af hvilke det ydre Par ere korte, braadspidsede, de indre budte, af Længde med eller længere end Blomsterne; Bibogeret af Form med de indre Svøbblade; Eronbladene udrandede.

1/2-1 $1 / 2^{\prime}$ høi; hele Planten glat; Hylsterbladene blegbrune; Kronbladene smaae, blegrode (I hvert Hoved udspringer kun 1 Blomst ad Gangen). 7-8. $\odot$.

Paa sandige Bakker og Skrænter, sjelden i Danmark: Bornh. v. Hammershuus (8), Sorthat ved Hasle (Hjorth), paa Skrænterne mod Havet fra Boderne til Pythuset! $S j$. Refsnæs (15); Moen v. Kjelby! Magleby og Ulfshale (Dr.): $\boldsymbol{F}$. mellem Hessum og Gjerskov red Hofmansgave (4), Samso ved Maarup (2); J. Arnage Hoi mellem Grenaa og Ebeltoft (H.).

b. Caryophyllum Endl. Bægeret trindt, stribet.

aa. Blomsterne knippeformigt sammenhobede.

586. D. Armeria L. (Knippeblomstret N.) H. 482; Drej. n. 458 ; F. D. 230 ; Rehb. 1. c. 5011.

Stongelen trind, duunhaaret, i Spidsen grenet; de nedre Blade lancetformede med smalere Basis, de фvre linieformede, budte, ved Grunden sammenvorne til et kort, ligesaa bredt 
som langt Rør; Blomsterne, i Kinjpper fra Spidsen af Stængelen og Grenene; Bibagerbladene lancetformede, sylspidsede, tæthaarede, næsten af Længde med Bægerrøret, tilligemed de ydre kortere Svøbblade bladagtige; Kronbladene i Spidsen tandede, Pladen omtrent halvt saa lang som Neglen.

$1-1^{1 / 1} 2^{\prime}$ høi. Bladeue (idetmindste de haarede. Kronbladene morkrode med hvide Pletter, kun aabne i Solskin. 7-9. $\odot$.

Paa Bakker, tørre Marker og i Udkanten af Kratskove, alm. i de sydligere Egne af Landet, især i det sydl. Fyen og paa $\theta$ erne i Ostersøen (Bornh. indbefattet), i de nordlige Egne af $\boldsymbol{S} \boldsymbol{j}$. og $\boldsymbol{F}$. sjeldnere og kun sporadisk; Samse ved Nordby (2), i J. meget sjelden: Kalø (16), Palsgaard (H.).

587. I. Carthusianorum L. (Kartheuser-N.) H. 481; F. D. 1694 ; Rehb. l. c. fig. 5019.

Blomsterløse Bladknipper fra Rodstokken; Stangelen firekantet, glat, udeelt eller i Spidsen kortgrenet; Bladene smalt og spidst linieformede, ved Grunden sammenvoxne til et forlænget Rør; Blomsterne i tætte Knipper fra Spidsen af Stængelen; Bibagerbladene omvendt-xgformede, pludseligt tilspidsede i en sylformet Braad, halvt saa lange som Brgerrøret, tilligemed Svobbladene (1-2 Par) bruunt-hindeagtige; Kronbladene saugtakkede, Pladen og Neglen omtrent ligelange.

$1 / 2-1^{1 / 2} / 2^{\prime}$ høi. Hele Planten glat; Brger og Svobblade i Spidsen randhaaret rue; Kronbladene rode. 6-8. 4.

Ved Diger og Veikanter paa Amrom (Nolt., Sehiøtz!). 啉

† D. barbatus L. (Busk-N.) Rehb. I. e. fig. 5013.

Rodstokken udskyder talrige blomstrende og blomsterløse trinde Stængler; Bladene lancetformede; Blomsterknipperne tætog mangeblomstrede, hovedformede, omgivne af lange, tilspidsede Drkblade, Bibagerladene og Bagerfigene sylformet tilspidsede, bladagtige; Kronbladenes Plade rundtakket, kortere end Neglen.

Kironbladene lysere eller mørkere røde, hvide med rode Punkter o. s. v. 7-8. ข.

Dyrkes alm. i Haver som Siirplante, og forekommer hist og her 
forvildet: $\boldsymbol{S}$. Nasgaard ved Dronninggaard; Falst. Hanenov (14); $\boldsymbol{F}$. hist og her i det sydlige (19); J. Venneberg, Aalborg (Grønlund)!

bb. Blomsterstanden fjerntblomstret med tydeligt stilkede Blomster $i$ Qvast eller Top.

588. D. deltoides L. (Rundtakket N.) H. 483; Drej. n. 453 ; F. D. 577 ; Rchb. 1. c. fig. 5040 .

Rodstokken med blomsterløse Rodskud og (alm.) flere opstigende, grenede, duunhaaret-rue blomsterbærende Stængler; Bladene linieformede, de nedre budte, paa Rodskuddene linielancetformede; Grenene gaffeldeelte, en- eller faa- og fjerntblomstrede; Bibagerbladene oftest eet Par (uden Svøbblade), ægformet-elliptiske, sylformet tilspidsede, halvt saa lange som Bægerrøret; Kronbladene med omvendt-ægformet, tandet-rundtakket Plade kortere end Neglen.

1/2-1' høi. Bladene frisk gronne, i Randen og paa Rygnerven fiint haaret-rue. Kronbladene rosenrøde med en mørkere Plet (i Form af en Vinkel) ved Grunden. 6-8. 4.

$\beta$, glaucus. H. N. VII, 31 (D. glaneus L., Relsb. ic. erit. VI, 748). Mangestæuglet, med kortere og mere tætbladede Stængler; Bladene budte, blaagraae; 2 Par Bibægerblade; Krombladene hvide eller blegrøde, med en mørkere Plet.

Paa torre, isæer saudige Marker og Bakker, alm. udbredt. $\beta$, sjeldnere: $\boldsymbol{S} j$. Sandmarker N. for Tiissø ved Halleby! Næstved, Kjøge (Dr.); Moen paa Mannehoiene (16); Loll. (5); F. Signenæs. ved Horne (12); Bornh. ved Boderne (Rafn).

589. D. superbus L. (Strand-N.) H. 484 ; Drej. n. 460 ; F. D. 578 ; Rehb. 1. c. fig. 5032 .

Rodstokken med flere blomsterløse Rodskud og alm. 1 opstigende, grenet, glat Blomsterstængel; Bladene lancet-linieformede, tilspidsede; Grenene oprette, gaffeldeelte, 2-5blomstrede, danne en Top eller Qvast; Bibcegerbladene 2 Par, de indre omvendt-æg formede, budte, kort braadspidsede, 1/t af Bægerrørets Længde; Kronbladenes Plade indtil nedenfor Midten deelt i mange traadformede Flige, omtrent lige lang med Neglen. 
${ }^{1} / 2-1^{1} / 2^{4}$ høi. Blomsterne vellugtende; Kronbladene rod-lila, i Svælget guulgrøune med mørkrøde Haar. 7-9. 4. Var. med Grene nxsten fra Gruuden af $\mathrm{og}$ med fae, i Spidsen samlede Grene, samt $\beta$, coespitosus Drej. (1. e.) Finere; Bladene smalere; Kronbladene hvide.

$\gamma$, micropetalus! Kronbladene smaae (Neglen 2-3 Gange længere end Pladen).

Paa Bakker, Græsmarker og Fælleder, især i Nærheden af Stranden, funden i alle dauske Provindser (undtagen Bornh.), men ikke alm., sjeldnest par Halvgen: J. Vissegaard ved Aalborg (Branth), Skinnersbro (H.), Bakker mellem Randers og Riis Mølle (7); S $l$. Hedebakker ved Liek pr. Husum (16). - $\beta$, ved Flaskekroen med Hovedarten (16); $\gamma$, Ulfshale paa Mgen (Holst). l*

\section{Trigynia. \\ 11. Silene. Liim urt.}

a. Bægeret blæreformigt opblæst, med talrige $(20-30)$ Striber.

* Behen Moench. Blomsterne $i$ regelmassig Qvast (eller enlige $i$ Spidsen of Stangelen).

590. S. inflata [Sm. Fl. brit. 5,467 ] (Blære-Smelle) Drej. n. 464 ; Rehb. l. c. fig. 5120; Cucubalus Behen L., H. 485 ; F. D. 914 .

Stangelen opret eller opstigende, grenet; Bladene lancetformede; Blomsterne nikkende, i en alm. mangeblomstret Qvast; Blomsterstilkene længere end eller af Længde med det under Blomstringen ovale, ved Grunden navleformigt indtrykte, mod Frugtmodningen ægformet-kugleformede Bæger; Bagertanderne spidse, trekantet-ægformede: Kronbladene med kileformigt udvidet Negl, dybt tokløvet Plade og utydelig, topuklet Bikrone; Kapselen ægformet-kugleformet, omtrent $2 / 3$ langere end Frugtholderen*).

*) Ved Frugtholderen forstaaes den hos flere Arter i denne Familie forekommende, mere eller mindre forlangede Frugtbund, som har Form af en Stilk, ved hvilken Kapselen er fjernet fra Bægeret- 
1-2' høi. Planten glat, blaagrøn; Bægeret blegt (ofte rødagtigt) med mørkere Aarenæt; Kronbladene hvide. 6-8. 4.

$\boldsymbol{\beta}$, pctrca Fr.! (Cucubalus Behen-petræus Fr. fl. Scan., H. N. IV , 51). Stænglerue talrige, nedliggende eller opstigende; en-, sjeldnere 2-3-blomstrede; Bladene korte, linielancetformede.

Ved Veie, paa torre Enge, Marker og Bakker, alm. (I det sydlige Fyen og det vestlige Lolland meget sjelden; paa Smaaøerne Syd for F. ikke bemærket (12). $\quad \beta$, Møens Klint nedenfor Sommerspiret (14); Hammeren paa Bornholm (Baagge).

Ann. St $ø$ vdragerne alm. fremragende, omtr. af Lrengde med Griflerue; en Form med mindre Kronbld. og indsluttede Støvdr. meget kortere end Bægeret, er funden paa Kjøbenhavns Volde!

591. S. maritima [With. Bot. arr. II, 414] (Strand-L.) Rchb. I. c. fig. 5119; Cucubalus Lam., H. 486; H. N. IV, 52 ; Cucub. Behen $\beta$, L. F. D. 857.

Stanglerne (talrige, saavel blomsterbærende som blomsterløse, fra Rodstokken) ved Grunden nedliggende, tilsidst træagtige, med vedblivende, smalt lancetformede, i Spidsen tilbagebøiede, kjødfulde Blade; Blomsterne i faablomstret Qvast (eller enlige), oprette; Kronbladene mindre dybt kløvede, med tydelig, totandet Bikrone; Kapselen næsten kugleformet, omtrent dobbelt saa lang som Frugtholderen, forøvrigt som foreg.

$1 / 2-1$ ' høi. Kronbladene livide. Var. med utydelig Bikrone (Hartm.). 6-8. 4.

Paa Strandklinter, især paa Kalk, sjelden og kun bemærket red de nordlige Kyster af Vesterhavet, Liimfjorden og Kattegattet: $\boldsymbol{J}$. Bulbjerg (Fangel)! Lgkken, Hirtslıolmen, Frederikshavn (H.), Agger, Ottesund paa Thyholm! Løgstør, Bjørnsholm (12); Hesseløen (Brix i Kamphøv. Herb.). $\#$.

b. Brgeret valseformet eller tragtformet, 10 -stribet.

** Atocion Fr. Blomsterne $i$ regelret Qvast $i$ Spidsen af Stcengelen.

† 592. S. Armeria L. (Kinippeblomstret L.) H. 489 ; Drej. p. 161 ; F. D. 559 ; Rchb. 1. c. fig. 5079 ; H. N. X, 39. Stangelen opret; Bladene ægformede eller ovale; Qvasten 
tætblomstret, med oprette Blomster, der alle naae omtrent lige høit; Bageret forlænget-valseformet, mod Frugtmodningen tragteller kolleformet, med korte og budte Tæuder; Kronbladene udrandede, med 2 sylformede Bikronblade; Frugitholderen af Længde med eller læugere end Kapselen.

Hele Planten glat, blaagron; Stængelen under de øvre Led klæbrig; Bægeret blegrødt med mørkere Striber, Kronbladene rosenrode, Støvknapperne violette. 7-8. $\odot$.

Ukrud i Haver og paa Marker, sjelden og neppe oprindelig indenlandsk, men tilfældigt forvildet: $S \boldsymbol{j}$. Frederilssborg (Kyll.), Tryggerød, Taarbæk (19), Flaskekroen (H.), Boserup (Albrecht), Valo (Kyll.); Falst. S. Kirkeby (Koch); Loll. (Kyll. og Heerfortlı Herb.!), Svinsbjerg o. fl. St. (19).

**** Otites Fr. Blomsterne $i$ Klase eller Top, dannet af modsatte, quastblomstrede Grene.

593. S. Otites [Sm. Fl.. brit. 469] (Smaakronet L.) Rehb. 1. c. fig. 5094 ; H. N. X1, 40 ; Cucubalus L., H. 487 ; F. D. 518.

Stangelen opret, med korte, blomsterløse Bladknipper ved Grunden; de nedre Blade onvendt-ægformede, langstilkede, de pvre linie-lancetformede; Blomsterstanden alsidigt klaseformet, med forkortede Grene og derved tilsyneladende krandsblomstret (med mange Blomster i hrandsene), eller de nedre Grene forlængede, oprette; Blomsterne oprette, oftest tvebo; Bageret tragtformet-klokkeformet, med budte Tændex; Kronbladene hele, uden Bikrone; Frugtholderen meget kort eller 0.

1/2-1' høi. Stængelen, fornemlig i Midten, klæbrig, forøvrigt glat eller fiint haaret; Bladene, især Dækbladene, randhaarede; Blomster og Frugter meget mindre end hos de to f 6 lg. Kroubladene guulgronne, Støvdragerne bleggule, 6-7. 4 .

I Klitter og paa sandige Marker sjelden og kun bemærket i Halvgens vestlige Egne: $J$. fra Nymindegab til Skallingen (H.), Bordrup Sande (30), Varde (10), Ribe (6); Fanø, Romø, Sylt, Amrom $(\mathrm{N} ., 16)$. 雨

594. S. nutans L. (Nikkende L.) H. 488 ; Drej. n. 463 ; F. D. 242 ; Rebb. l. c. fig. 5108.

Stangelen opret, med korte Bladknipper ved Grunden; 
Bladene omvendt-ægformede eller. lancetformede med størst Brede ovenfor Midten; Blomsterstanden ensidigt klaseformet, med udstaaende, 3-5-blomstrede (paa fattige Expl. ofte enblomstrede) Grene; Blonsterne nikkende under Blomstringen; Bageret kølleformet, mod Modenheden tragtformet, med spidse Tænder; Kronbladene tokløvede, med 2 sylformede Bikronblade; Frugtholderen $1 / 2-1 / 3$ af Kapselens Længde.

$1-1^{1} / 2^{\prime}$ høi. Duunhaaret, oventil klæbrig. Bageret gronliglividt med violette Striber. Kronbladene guulhvide, (aabne sig om Aftenen), Støvdragerne violette. 6-7. $\%$.

Paa Bakker, Skræenter og j høitliggende Kratskove, bemærket i alle danske Provindser, men iklke overalt; lyyppigst i Nordsjælland, paa Sterns og Møens Klint samt Bornholm!

Anm. Den glatbladede Form (S. infracta W. K., H. N. IV, 50; Rehb. l. c. fig. 5109) er, saavidt mig belijendt, ikke funden i Danmark.

595. S. viscosa [Pers. Syn. 1, 497] (Klæbrig L.) Drej. n. 462 ; Rehb. I. c. fig. 5099 ; H. N. XIII, 53; Cucubalus L., H. 487 ; F. D. 1209.

Stcengelen opret; Bladene lancetformede eller elliptiske, med bredere Basis, i Randen bølgede; Blomsterstanden alsidig, med 1-5-blomstrede, oprette Grene; Blomsterne oprette; Bageret valseformet, mod Modenheden indsnøret i Spidsen, med budte Tænder; Kronbladene tokløvede, uden Bikrone; Frugtholderen $\mathbf{1}_{12}-1 / 3$ af Kapselens Længde.

$1-1^{1 / 1} 2^{\prime}$ høi, hele Planten klæbrig-haaret. Bladene, især de øvre, var. fra linie-lancetformedo til bredt-ægformede. Kronbladene hvide. 6-7. $\odot$.

Ved sandige Strandbredder, sjelden: $\boldsymbol{S} \boldsymbol{j}$. Oxholm i Isefjorden (H.); L oll. Hyldekrog (5), Bredfjed (H.!); F. Fyenshoved, Romsø ved Hofmansgave (4)! J. Øerne i Horsens F jord, Palsgaard (H.) (de vestligste. bekjendte Voxesteder i Europa). 店

*** Viscago Fr. Blomsterne enlige, afvexlende, danne fjerntblomstrede Klaser.

596. S. anglica L. (Engelsk L.) H. 488; F. D. 1643 ; Rehb. I. c. fig. 5056 ; H. N. VII, 32. (S. gallica og quinquevulnera L. og S. silvestris Schott (Rchb. 5054-55) høre tił samme Art). 
Stangelen opret eller opstigende, (ofte gaffeldeelt-grenet med enlige Blomster i Gaffeldelingerne; Bladene lancetformede, de nedre omvendt-ægformede; Bugeret med sylformede Flige, ralseformet, mod Frugtmodningen ægformet, af Længde med eller lidet længere end de til samme Tid forlængede og udstaaende Blomsterstilke; Kronbladene omvendt-ægformede, heelrandede, tandede eller udrandede, med Bikrone.

$1 / 2-1 \frac{1}{2}$ høi. Hele Planten, især oventil, klæbrig-duunhaaret; Bægeret grønstribet, Kronbladene smaae, hvide, sjeldnere rosenrøde. 7-8. $\odot$.

Ukrud mellem Sæden, sjelden: $S j$. Svenstrup ved Kalnndborg (Baagøe)! Kartoffelagre S. V. for Magleby paa A mager! og paa Amager Fælled (19).

\section{Lepigonum. Ilindekna. *)}

a. Frøene ru-punkterede.**)

597. L. rubrum [Fr. Mant. 3, p. 33] (Mark-H.) Arenaria rubra $\alpha$, L., Alsinella rubra Sw., H. 197; Alsine Wahlenb., Drej. n. 472 ; Spergularia Pers.

Stanglerne talrige, nedliggende eller opstigende, i Gjennem. snit trinde; Bladene traadformet-linieformede, flade, kort-braad-

*) De meget foranderlige Arter i denne Slægt trænge endnu til fortsat Opmærksomhed og Undersøgelse. Jeg har indtil videre i det Væesenlige fulgt Kindbergs "synoptisk framställning af växtslägtet Lepigonuma $1856 \mathrm{og}$ det senere Værk af samme Forf., "Monographia generis Lepigonorum" Upsalia 1863.

**) Om Frøenes jærne eller 1ue Overflade, som Kindberg antager for Hovedsagen ved Arternes Adskillelse, er et virkelig eonstant Kjendetegn, forekommer mig tvivlsomt. Undersøgelsen af flere Arter fra Sydeuropa foranledige mig til at troe, at Frøene kume variere $\mathrm{i}$ denne Henseende ligesaavelsom $\mathrm{i}$ Henseende til den vingede eller uvingede Rand, og i saa Fald vilde man f. Ex. neppe være istand til at adskille L. neglectum og L. leiospermum. (Forekomsten af jævne og rue Frøe hos en og samme Art uden andre vasenlige Forskjelligheder er ogsaa bemærket hos andro Slægter, f. Ex. Linaria). Jeg er imidlertid ikke istand til at fremfore mere end en Formodning i denne Henseende og har derfor indtil videre beholdt den tidligere Opstilling af Arterne. 
spidsede; Axelbladene solvglindsende, ægformede, tilspidsede, indbyrdes frie og i Spidsen alm. kløvede; Blomsterstilkene længere end Bægeret, efter Afblomstringen tilbagebøiede; Bagerbladene lancetformede, budte, omgivne af en smal hindeagtig Rand, omtrent af Længde med Kapselen; Frøene meget smaae, pæreformede, hvælvede, med ophøiet Rand, men uden Hindekant.

Bladene paa Grund af forkortede Grene i Bladhjørnerne tilsyneladende krandsstillede, alm. blaaggtig-grønne. Var. i Henseende til Beklædningen (glat eller kirtelhaaret), Ledstykkernes og Blomsterstilkenes Længde o. s. v. Kronbladene rød-lila. 5-7. $\odot$ eller $\odot$ Følgende Former kunne adskilles:

$\alpha$, campestre (Fenzl.) Bladene kortere end Ledstykkerne, Stænglerne langstrakte, Qvastens Grene fjerntblomstrede, foroven klaseformede.

$\beta$, radicans (Presl.) Kdbg. (Arenaria media F. D. 2232 ; L. rubrum $\beta$, arenarium Lge. Haandb. 2 Udg. p. 301). Lavere, nedliggende og stundom rodslaaende; Ledstykkerne meget korte (kortere end Bladene), Axelbladene stærkt udviklede, Qvasten kort og mere tætblomstret, Blomsterne mindre.

$\alpha$, paa tørre Marker, Overdrev og ved Veie alm., $\beta$, paa mager Sandjord, især ved Strandbredder.

* 598. L. neglectum [Kindb. Bot. not. 1857 p. 84] (Kjødbladet H.) H. N. XV, 46; L. salinum (Presl.) Kindb. Monogr. p. 36 ; Spergularia rubra $\beta$, pinguis Gren. \& Godr. Fl. Fr. I, 275 ; Lepigon. rubr. $\beta$, pingue Lge. Haandb. 1 Udg. p. 268 (excl. Syn. L. medium Fr.); Alsinella marina F. D. 2231.

Bladene halvtrinde, kjødfulde, Axelbladene korte, bredt ægformede, mindre glindsende; Kronbladene blegrøde ell. hvide, Støvdragerne ofte 5; Kapselen længere end Bægeret, forøvrigt som foreg.

Ved Strandbredder, sjeldnere end de ørrige Arter, f. Ex. $\boldsymbol{S}$. Flaskekroen (Didrichsen)! $\boldsymbol{L}$ oll. paa inddæmmede Steder ved Nakskov og Rødby Fjorde (19)! Bornh. S. O. for Ronne (14).

Anm. Denne Art danner et Overgangsled fra foreg., som den ligner i Froenes Bygning, til den følgende, som den i Habitus og de fleste øvrige Kjendetegn nærmer sig. Muligviis ere denne og folgende kun 2 Former af samme Art, for livilkeu da Navnet L. salinum maatte beholdes, skjøndt dette Navn ikke er heldigt, da det passer for de 
fleste Arter. Jeg har beholdt det æeldre kindbergske Navn for deme Art, som han nu henforer til L. salinum (Presl) Fr., men saavidt jeg kan skjønne liar Fries, idetmindste for en Deel, under sin L. salinum havt folgende Art, der er saa liyppig ved de nordiske Strandbredder, for Øie. L. medium Fr. (mant. 3, 34; H. N. VIII, 37) som jeg tidligere urigtig henforte hertil, adskilles efter Fr. og Kindb. (l. c.) ved en vedvarende Rod, trinde Stangler, ikke tilbageboiede Blomsterstilke omtrent af Bægerets Længde, jævne Fro. Denne findes muligen ogsaa hos os, men jeg er ikke istand til at angive noget bestemt Voxested.

b. Frgene jævne.

599. L. leiospermum [Kindb. Monogr. p. 23] (Glatfrøet H.) L. salinum Fr. ex p., H. N. XIV, 42; Kindb. l. c. p. 43 ; Arenaria marina F. D. 740 (ikke god).

Stcengelen enlig, ved Grunden udeelt og opret, eller flere fra Grunden og nedliggende, i Gjennemsnit fladtrykt; Bladene kjødfulde, trindt-fladtrykte, linieformede; Axelbladene forneden sammenvoxne, med bredt triangelformede, spidse Flige; Blomsterstilkene lidet længere end Bægeret, efter Afblomstringen tilbagebøiede; Bagerbladene ovale, budte, $1 / 3$ kortere end den budt trekantede Kapsel; Frøene omvendt-ægformede, med ophøiet Rand (af den bøiede Kim), alle (eller de fleste) uden Hindekant.

Frøene større end hos Nr. 597, mindre end hos følg. De unge Bladknipper i Bladhjørnerne faabladede eller 0. Var. desuden, ligesom de ørrige Arter, glat og kirtlet-duunhaaret. Kronbladene blegrode. 7-9. $\odot$. De vigtigste Former af denne mangeformede Art ere folgende:

$\alpha$, cymosum! Blomsterstanden med indtil Spidsen blad. bærende Grene.

1, apterum. Alle Frgene uvingede.

2, heterospermum. Vingede og uvingede Frøe (endog i samme Kapsel) blandede indbyrdes.

3 , alatum. Alle Frgene vingede.

$\boldsymbol{\beta}$, racemosum! Qvastens Grene forlænget-klaseformede, i Spidsen bladløse.

Alm. ved Harkysterne paa feed Leer- eller Marskbund. Formen a 1 , er den meest udbredte, 2, sjeldnere, 3, ved Dragor! Formen $\beta$ har jeg kun seet fra Flaskekroen (Didr.); den er ogsaa funden i $\boldsymbol{L} o l l$. ved Nébbelunde (19). 
600. L. marinum [Wahlb. Fl. gothob. p. 47] (Vingefrøet H.) Fr. I. c. p. 35 ; H. N. VIII, 38 ; Arenaria rubra $\beta$, marina L., A. marina E. B. 958 ; Alsine Drej. n. 473; Alsinella H. 497 (indbefatter tillige foreg.); Aren. marginata DC.

Stoenglerne talrige (udgaaende fra en tyk og kjødfuld Pælerod), udstrakte eller opstigende, i Gjennemsnit fladtrykte; Bladene halvtrinde, kjødfulde, linieformede; Axelbladene forneden sammenvoxne, med bredt-triangelformede, spidse Flige; Qvastens Grene foroven bladløse; Blomsterstilkene udvidede under Bægeret og længere end dette, efter Afblomstringen tilbagebøiede; Bagerbladene ægformet-elliptiske, halvt saa lange som den trindtægformede, opblæste Kapsel; Frøene rundagtige, med svagere ophøiet Rand, alle (elller de fleste) med en (under Lupen) stribet-tandet Hindekant.

Er i alle Dele større og kraftigere end de foreg. Hele Planten glat med Undtagelse af Blomsterstanden, som var. mere eller mindre kirtelhaaret. Kronbladene blegresde. 7-9. 4.

$\beta$, fasciculare (L. fasciculare Lönnroth, Observ. crit., Ups. 1854 , p. 13) med tæt og tueformigt samlede Stængler, mere sammentrængt Blomsterstand, opretle, mod Frugtmodningen vandret udspærrede (ikke tilbagebøiede) Blomsterstilke, Kapselen neppe 1/2 Gang længere end Bægeret, Frøene omvendt-ægformede, med ophøiet Rand og uden Hindekant.

Paa lignende Steder som (og i Selskab med) foreg., ikke sjelden, især hyppig i Marskegnene paa Halvøens Vestkyst. $\beta$, Marskenge paa Føhr (20)!

Anm. Den under $\beta$, beskrevne Form er i Udseende og flere Characterer væsenlig forskjellig fra Hovedarten, og de paa $\mathrm{F} \wp \mathrm{hr}$ samlede Exemplarer staae navnlig saa nær ved $L$. azoricum Kindb., at kun de jævne (ikke ru-punkterede) Froe synes at adskille dem fra denne. Ved Udsædsforsog i botanisk Have med Frøe, samlede paa det nævnte Voxested, har den imidlertid tabt flere af de Eiendommeligheder, som adskilte den vildvoxende Plante fra L. marinum, og jeg maa altsaa antage den for en blot Localform af denne, hvilket ogsaa Fries og Kindberg (Monogr. p. 21) antage. Saafremt den af mig fremsatte Formodning om Uholdbarheden af en skarp Adskillelse mellem Arterne med jævne cg rn-punkterede Frøe skulde bekrafte sig, antager jeg at $L$. azoricum Kindb. ogsaa maa forenes med L. marinum. 


\section{Alsine. Norel.}

601. A. viscosa [Schreb. Spieil. p. 30] (Klæbrig N.) H. N. I, 41; A. tenuifolia $\beta$, viscosa Koch Syn. 125; Alsinella Hartm. Sk. Fl. 1 Uppl. p. 176, H. 498; F. D. 389 (Arenaria tenuifolia) og 1754 ; Sabulina Rchb. ic. fl. g. V, fig. 4917.

Stcrngelen enkelt, næsten fra Grunden af gaffeldeelt-grenet og dannende en spredtblomstret Qvast; Bladene sylformede; Blomsterstilkene i Gaffeldelingerne, traadfine, oprette, mod Frugtmodningen længere end Bladene og 2-3 Gange længere end Bægeret; Bagerbladene lancet-sylformede, trenervede, længere end Kronbladene, af Længde med eller længere end den valseformede Kapsel.

$1-3^{\prime \prime}$ høi. Blomsterstilke og Brger kirtelhaarede; Kronbladene hvide, meget smaae. $6-7 . \odot$.

Paa torre Marker og Bakker, sjelden: Moen mellem Aborrebjerget og Liselund! Steengaard (20); Sl. (N.)? Hovedarten (A. tenuifolia Wahlenb.), som er glat og alm. større af Væxt, med Kapselen oftest længere end Bægeret, er ikke funden i Danmark.

\section{Ialianthus. Strandarve.}

602. II. peploides [Fr. Fl. Hall. p. 75] (Tykbladet S.) Drej. n. 474; Arenaria L., H. 500; F. D. 624; Honkenya Ehrh., Rchb. l. c. fig. 3670 .

Stcengelen udstrakt, modsat-grenet (den ene Green mindre); Bladene tætsiddende, korsviis-modsatte, ægformet.elliptiske, kjødfulde med en bruskagtig Rand; Blomsterne i faablomstret Qvast i Spidsen af Stængelen og Grenene; Bagerbladene ovale, budte, enuervede; Kapselen kugleformet.

Hele Planten glat $o g$ glindsende. Kronbladene hvide, var. uden Kronblade ( $\beta$, apetalum Rostr.).

Alm. ved Strandkysterne paa den yngre sandige Havstok. $\beta$, ved Skaarupor i Fyen (19).

\section{Arenaria. Sandvaaner.}

603. A. serpyllifolia L. (Smaakronct S.) H. 502; Drej. „. 475 ; F. D. 977 ; Rchb. l. c. fig. 4941 . 
Mangestænglet, med opstigende, oventil gaffeldeelte Stcongler; Blomsterstanden qvastformet; Bladene stilkløse, ægformede, spidse, i tørret Tilstand fleernervede; Blomsterstilkene $1 / 2$ Gang længere end Bægeret; Bagerbladene lancetformede, tilspidsede, trenervede, længere end Kronen og af Længde med eller lidet længere end Kapselen.

6-8. $\odot$. Var. betydeligt i Henseende til Beklædningen, Stænglernes og Ledstykkernes Længde 0 . s. v. De meest iøinefaldende Former ere:

$\alpha$, scabra Fenzl. Graaagtig af meget korte og fine Haar.

* tenuior Koch. 4-6" høi; Ledstyklerne mange Gange længere end Bladene, Stængel og Blomsterstilke meget fine; Qvasten fjerntog mangeblomstret.

** condensata! 1-2" høi; Bladene bredt-ægformede, længere end Ledstykkerne og derved taglagte; Stænglerne nedliggende, 1-3blomstrede.

$\beta$, glutinosa Koch. Blomsterstilke og Bæger beklædte med kirtelbærende Haar.

Alm. paa Græsmarker, Bakker o. s. $\nabla$. $\alpha$, den hyppigere Form, $\boldsymbol{\beta}$, sjeldnere, f. Ex. ved Sorø! ** paa tørre Sandmarker: $\mathbf{S j}$. Veirhøi! Bornh. ved Ronne!

\section{Moehringia. Skovarve.}

604. H. trinervia [Clairv. Man. herb. 150] (Trenervet S.) Rchb. 1. c. fig. 4943 ; Arenaria L., H. 501 ; Drej. n. 476 ; F. D. 429 .

Mangestænglet, med opstigende, oventil gaffeldeelt-grenede Stcongler; Bladene ægformet-elliptiske, trenervede, de nedre stilkede; Blomsterstilkene i Spidsen nikkende, 2-3 Gange længere end Bægeret; Bagerbladene længere end Kronen og Kapselen, lancetformede, spidse, trenervede, med stærkere og randhaaret Midtnerve.

Bladene randhaarede, forøvrigt er Planten mere eller mindre beklædt med korte Haar eller glat. 5-6.

I fugtige Kratskove, ved Gjærder o.s. v. alm. udbredt. 


\section{Stellaria. Fladstjerne.}

a. Bladene siddende, Stængelen glat.

aa. De narmeste Blade ved Blomsterne urteagtige.

605. S. Holostea L. (Skarpbladet F.) H. 491; Drej. n. 470 ; F. D. 2650 ; Rchb. l. c. fig. 4908.

Stcongelen nedliggende, med opstigende, skarpt firekantede Grene; Bladene lancet-linieformede, fra en bredere Basis efterhaanden tilspidsede, i Randen og paa Rygnerven rue; Blomsterne i Qvast fra Spidsen af Grenene; Bcegerbladene lancetformede, nerveløse, halvt saa lange som de til Midten kløvede Kronblade; Kapselen kugleformet, opblæst, omtrent af Længde med Bigeret.

Stæengel (og Grene) meget skjør, forneden beklædt med vedblivende, henvisnede Blade $\mathrm{og}$ alm. skjult under Løvet, Blomsterne store. 5-6. $\psi$.

I Skove, Krat og ved Gjærder, alm. udbredt.

Anm. Den i F. D. tab. 598 under Navn af Stellaria Holostea afbildede Plante horer neppe hertil, men suarere til St. graminea eller palustris, og er forøvrigt for slet til med Sikkerhed at kunne bestemmes.

606. S. crassifolia [Ehrh. Beitr. 3, p. 60] (Tykbladet F.) H. 494 ; Drej. n. 466 ; F. D. 2114.

Stungelen firekantet, oventil gaffeldeelt-grenet; Bladene noget kjødfulde, linie-lancetformede eller elliptiske, med smalere Basis; Blomsterne enlige i Gaffeldelingerne; Blomsterstilkene under Bægeret udvidede og dannende en undersædig Skive, flere Gange længere end de lancetformede, i tørret Tilstand svagt trenervede Brogerblade; Kronbladene næsten til Grunden todeelte, lidet længere end Bægeret; Kapselen ægformet, 1/2 Gang længere end Bægeret.

6-8. 4. Var.

$\alpha$, elodes (M. Bieb.) Rchb. l. e. fig. 4909. Udløbere fra Grunden, Stængclen opret eller opstigende, oventil grenet, med forlængede Ledstykker og mindre kjødfulde Blade.

$\boldsymbol{\beta}$, brevifolia [Rafn II, p. 763] H. N. V, 33; S. graminea e, F. D. 415 ; S. erassifolia Rehb. l. c. fig. 3667 . Stængelen fra 
Grunden af grenet, med nedliggende Grene og forkortede Ledstykker.

Sporadisk og ikke alm., men bemærket i alle Provindserne (hyppigst i det $ø$ stl. $S j(2 l l): \alpha$, i Moser og fugtige Enge, $\boldsymbol{\beta}$, paa Strandenge og ved Strandbredder mellem fugtig Tang. I*

\section{bb. Bladene ved Blomsterne hindeagtige.}

607. S. uliginosa [Murr. Prodr. stirp. goett. p. 55] (SumpF.) H. 494 ; Drej. n. 467 ; F. D. 2535 ; Rchb. l. c. fig. 3669 ; H. N. III, 32 .

Mangestænglet, med firekantede, svage, opstigende eller udspredte Stcengler; Bladene lancetformede, ved Grunden svagt randhaarede; Blomsterne i Qvast fra Green- eller Bladvinklerne; Dakbladene glatte, Blomsterstilkene udspærrede, under Bægeret udvidede; Bagerbladene lancetformede, trenervede, meget længere end de næsten til Grunden todeelte Kronblade; Støvdragerne omkringsædige; Kapselen ægformet, af Længde med Bægeret.

Bladene mat-blaagrønne, ofte bølgede, Kronbladene meget smaae. 5-7. $\odot$.

Ved Kildevæld og paa sumpige Steder ikke sjelden.

608. S. palustris [Retz. Prodr. p. 106] (Kjær-F.) Drej. n. 468 ; H. N. V1I, 33 ; S. glauca With., H. 493; F. D. 2115 ; Rchb. l. c. fig. 4909.

Stcongelen firekantet, fra Grunden af grenet, med oprette Grene; Bladene smalt- eller lancet-linieformede, med tilbagebøiet Rand, tilligemed Dakbladene glatte; Blomsterne 1-2 fra Spidsen af Grenene eller flere quastformigt samlede i Green. eller Bladvinklerne, Blomsterstilkene efter Afblomstringen udspærrede; Bagcrbladene æg-lancetformede, tilspidsede, svagt trenervede, kortere end de næsten til Grunden tokløvede Kronblade; Kapselen oval, omtrent af Længde med Bægeret.

6-7. भ. Kronbladene snart dobbelt saa lange, snart kun lidet længere end Bægeret. Var. desuden:

$\alpha$, glauca. Hele Planten blaagrøn.

$\beta$, viridis. Bladene frisk-grønne. 

end $\beta$ ).

I Hængedynd, Torvmoser og fugtige Lnge alm. ( $\propto$, hyppigere

609. S. graminea L. (Græesbladet F.) H. 492 ; Drej. n. 469 ; F. D. 2116 ; Rehb. 1. c. fig. 4911.

Stongelen firekantet, fra Grunden af grenet, med svage, opstigende eller udstrakte Grene; Bladene lancetformede eller linieformede, tilligemed Drkbladene ved Grunden ofte randbaarede; Blomsterne $\mathrm{i}$ endestillet, fjernt- og mangeblomstret Qvast med efter Blomstringen udspærrede Blomsterstilke; Bagerbladene lancetformede, trenervede, af Længde med eller kortere end de nxsten til Grunden kløvede Kronblade; Kapselen elliptisk eller oval, lidet længere end Bægeret.

Bladene mørkgrønne, glindsende. 6-8. భ. Var.

$\alpha$, grandiflora $(\hat{\delta})$. Blomsterne større; Kronbladene næsten dobbelt saa lange som Bægeret; Støvdragerne lidet kortere end Kronbladene, med rødt Støv.

$\beta$, parviflora (Q). Blomsterne mindre; Kronbladene omtrent af Længde med Bægeret, Støvdragerne kortere end Frugtknuden, med guult Støv; Griflerne næsten ligelange med Kronbladene.

$\gamma$, spathulata Rchb. l. c. fig. 4910 . Bladene paa de blomsterløse Rodskud omvendt-ægformet-elliptiske, kortstilkede.

Paa Græsmarker, høie Enge og ved Gjarder, alm. udbredt ( $\boldsymbol{c}, \mathrm{og}$ $\beta) ; \gamma, S j$. i en Groft ved Flaskekroen! $\boldsymbol{F}$. Ø. Aaby (19).

b. Bladene stilkede, med ved Grunden afrundet Bladplade; Stængelen (idetmindste for en Deel) ha a re t.

610. S. media [Vill. delph. 3, 615] (Fuglegræs). Drej. n. 465 ; Rehb. l. c. fig. 4904 ; Alsine L., H. 348 ; F. D. 525.

Mangestænglet; Stcenglerne opstigende eller udstrakte, trinde,

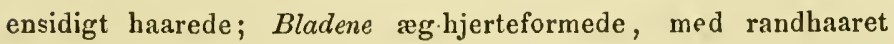
Bladstilk, forøvrigt glatte, de øverste (1-3 Par) stilkløse, elliptiake; Blomsterstanden qvastformet; Blomsterstilkene ensidigt haarede, efter Afblomstringen tilbagebøiede; Bagerbladene budte, 
elliptiske eller ovale, længere end de til Grunden kløvede Kronblade, kortere end den ovale Kapsel.

Stængelen meget skjør. Blomstrer hele Aaret igjennem. $\odot$. Var. $\alpha$, vulgaris. Stængelen fin, Støvdragere $3-5$; Kronbladene alm. kortere end Brgeret.

$\boldsymbol{\beta}$, neglecta Koch; (S. neglecta Whe., Rebb. l. c. fig. 4905; Alsine media decastemon H. 349 ; F. D. 438). Høiere og kraftigere, med noget kjødfulde Blade; Kronbladene næsten af Længde med Bægerbladene; 10 Støvdragere.

$\gamma$, apetala! uden Kronblade.

Alm. Ukrud overalt paa løs, især dyrket Jord; $\beta$, især paa fugtige Steder i Skove; $\gamma$, Juellinge paa Lolland, Vresen i Storebælt (19); B ornh. Fævagten ved Rønne (Zahrtmann).

611. S. nemorum L. (Skov-F.) H. 491; Drej. n. 471; F. D. 271 ; Rehb. l. c. fig. 4906 ; H. N. VI, 28.

Stangelen fra en krybende Rodstok opret, alsidigt haaret (idetmindste foroven); Bladene hjerteformede eller ægformede, tilligemed Bladstilken randhaarede, de øverste Par stilkløse; Blomsterne i endestillet Qvast; Blomsterstilkene duunhaarede, før Blomstringen nikkende, efter samme udspærrede; Bladene ved Blomsterne grønne; Bagerbladene elliptiske, halvt saa lange som de næsten til Grunden kløvede Kronblade, kortere end Kapselen.

Bladene meget tyude. Var. med glat eller ensidigt haaret Stængel og glatte Blomsterstilke (Heiberg)! $\frac{6}{2}-\frac{7}{1}$. 4 . vindser.

I Lørskove sporadisk, men ikke sjelden, bemærket i alle Pro-

\section{Pentagynia.}

\section{Agrostemma. Klinte.}

612. A. Githago L. (Almindelig K.) H. 511 ; Drej. n. 480 ; F. D. 576 ; Githago segetum Desf., Rchb. l. c. fig. 5132.

Bladene og Bagerfligene linieformede, de sidste dobbelt saa lange som det ægformede, tinervede Bagerr $\phi r$. 
$1^{1 / 2}-2^{1 / 2} 2^{1}$ hoi, med store, fjerntsiddende Blomster. (Kxpl. paa mager Jord lavere, $1 / 2-1$ ' hoie, ofte enblomstrede og med mindre Blomster). Hele Planten, især Bageret, langhaaret. Kronbladene violetrøde med blaaagtige Striber. Froene store, knudret-rue. 6-7. $\odot$.

Alm. Ukrud i Vintersæedeu.

\section{Melandrium. Pragtstjerne.}

a. Stovtraadene ved Grunden harede; 5 Grifler, Blomsterne trebo.

613. M. diurumm [Er., Lyehnis Sibth. Fl. oxon. p. 145] (Dag-P.) Rehb. l. e. fig. 5126; Lychnis silvestris Rafn II, 790; H. 513 ; Drej. n. 484 ; F. D. 2172 ; L. dioeca $\alpha$, L.

De nedre Ijlade omvendt-rgformede eller elliptiske, langstilkede, de øv'e agformede eller elliptiske, stilkløse; Blomstor. standen en endestillet Qvast; + Bageret ægformet eller elliptisk, med laneet-triangelformede 'Tænder; Kapselen ægformet-oval, med tilbagerullede Tænder; Frugtholderen meget kort eller 0 .

Hele Planten langhaaret, Haarene uden Kirtler; Kronen mørkrosenrød, aaben om Dagen og uden Lngt. $5-6$. 4 .

$\beta$, expallens. Kronbladene blegrøde eller hvide.

Ved Aabredder, i fugtige liratskove, ikke sjelden (yderst almindelig ved levende Hegn i Angel! mindre hyppig i det sydlige og vestlige Sjæll.). $\quad \beta, S j$. Ordrup! Jonstrup (14); F alst. Hallerup Skov (Koch); Lo ll. Nakskov (19); J. Veile!

614. II. respertinum [Fr., Sibth. l. e.] (Aften-P.) Lychnis pratensis Rafn 792 ; H. 514 ; Drej. n. 483 ; L. dioeea $\beta$, L., F. D. 792 ; Rehb. J. e. fig. 5125.

Bladene elliptiske eller laneetformede, de nedre kortstilkede, de øvre stilkløse; Blomsterstanden en endestillet, fjerntblomstret Qvast; $\hat{\delta}$ Bageret ovalt, $q$ Bageret opblast agformet, med forlænget-linieformede Truder; Kapselen kugleformet-ægformet, med oprette, i Spidsen svagt udbøiede Tæuder; Frugtholderen 0.

Stængler og Blade korthaarede, Blomsterstilke og lBæger kirtelhaarede; Blomsterne storre end hos foreg., udspringe om Aftenen, og have en svag, men behagelig Lugt. Kronblarlene hvide. 6-9. भ.

$\beta$, laciniatum! Kronbladene dobbelt tokløvede.

$\gamma$, coloratum Rostr. Irronbladene blegrøde. 
Ved Gjærder, paa Græsmarker og høie Enge alm. $\boldsymbol{\beta}, \boldsymbol{B}$ or $\boldsymbol{n}$ : ved Ø. Larsker (Baagøe)! $\gamma, \boldsymbol{F}$. Skaarupør; L oll. Steensgaard (19)

b. Stovtraadene glatte; 3 Grifler; Blomsterne $\not$.

615. H. noctiflorum [Fr. Bot. rot. 1842 p. 170] (Nat-P.) H. N. IX, 37 ; Silene L., F. D. 2470 ; Rehb. 1. c. fig. 5063.

De nedre Blade omvendt-ægformede, kortstilkede, de ovre lancetformede eller elliptiske, stilkløse; Blomsterne i endestillet, fjerntblomstret Qvast; Bugeret før Udspringningen valseformet, mod Frugtmodningeu elliptisk, med forlænget-sylformede T'ænder; Kapselen ægformet med tilbagebøiede Tænder, 6-8 Gange læugere end Frugtholderen.

Hele Planten klaebrig-kirtelhaaret; Kronen blegt-kjødfarvet, vellugtende, aabner sig on Aftenen. 7-9. $\odot$.

Ukrud mellem Sæden, ikke alm. og oprindelig indfort: $S j$. Hillerod Ladegaard (A. Rafn), Taarbæk (15)! Marker mellem Svanemøllen. og Kalkbrænderiet! Bakkehuset! Amager paa fl. St., f. Ex. Sundbyvester, Kastrup! Falst. N. Ørsløv, Øverup (14), Karleby (Koch): B ornh. Ronne (14); J. Aalborg (Gronlund)!

\section{Lychnis. Travlekrone.}

616. L. Hos cuculi L. (Eng-T.) H. 512; Drej. n. 482; F. D. 590 ; Rehb. 1. c. fig. 5129 .

Stangelen furet; Bladene smalt-lancetformede; Blomsterstanden. qvastformet i Spidsen af Stængelen og de modsatte Grene; Bageret klokkeformet, med korte, spidst triangelformede Tænder; Kronbladene dybt haandformigt kløvede i 4 linieformede Flige; Bikronbladene sylformede, hindeagtige; Kapselen oval-kugleformet; Frugtholderen meget kort eller 0.

1-2' høi. Stængelen ru og beklædt med fjerne, nedadvendteHaar. Kronbladene rosenrøde, sjeldnere hvide. 6-7. 4.

Alm. paa Enge.

\section{Viscaria. Tjarenellike.}

617. V. purpurea [Wimm. Fl. v. Schles. p. 67] (AImindelig T.) Lychnis Viscaria L., H. 512; Drej. n. 481 ; F. D. 1032 ; Rchb. l. c. fig. 5131 . 
Stungelen opret, jævn, under Ledene mørkrød-klæbrig, med mangebladede Bladkuipper ved Grunden; Bladene lancet-linieformede; Blomsterstanden klaseformigt forlænget, dannet af modsatte, kortstilkede, 3-5-blomstrede Ḱnipper; Bcegeret tragtformet, med korte, spidst triangelformede Tænder; Kapselen oval, 1/9 Gang lengere end Frugtholderen.

1' høi, glat. Stæengelbladene ved Grunden uldet-randhaarede. Kronbladene rosenrode, sjeldnere hvide. 5-6. 4.

Paa torre Marker og Bakker, især paa sandig Grund, ikke sjelden $\mathrm{og}$ bemrrket $\mathrm{i}$ alle Provindser, $\operatorname{dog}$ sjeldnere $\mathrm{i}$ det sydlige $\boldsymbol{F}$ yen, Loll. og Falst. end i de andre Egne.

\section{Cerastium. Honsetarm.}

(Kronbladene hos alle Arterne hvide).

a. Enarige. Hele Planten døer efter Frugt. modningen.

618. C. tetrandrum [Curt. Fl. lond. fasc. 6 t. 31] (Firehannet H.) H. II, 187; F. D. 2117; H. N. XV, 44; Lindeberg Novit. fl. Scand. I, p. 8 ; Esmarchia cerastoides Rchb. l. c. fig. 4954 .

De nedre Blade spadeformede, de ovre ovale eller omvendtægformede, budte; Dokbladene heelt grønne, bredt ægformede; Blornsterstilkene 2-4 Gange saa lange som Bageret, efter Afblomstringen lidet bøiede, mod Frugtmodningen aldeles oprette; Støvdragere og øvrige Blomsterdele 4; Kapselen ret, lidet længere end Bægeret.

Klæbrig-kirtelhaaret, guulgrøn; Bladene kjødfulde, aftage i Størrelse fra Strengelens forste Gaffeldeling nedefter.

I Sandklitterne paa Manø og List (N.). \#

619. C. pumilum [Curt. ]. c. t. 30] (Lav H.) Rehb. 1. c. fig. 4969 .

Bladene ægformet-ovale; Blomsterstilkene først nikkende, efter Afblomstringen udstaaende eller oftest oprette, lidet lwngere end Bægeret; de øvre Dakblade og Bxgerbladene smalt hindekantede; Kronbladene neppe halvt saa lange som Bæger- 
bladene; Støvdragere $5-10$; Kapselen dobbelt saa laug som Brgeret, ret eller i Spidsen svagt bøiet.

Stængelen lav (1-2" høi), var. nedliggende eller opret, overalt tilligemed Bægeret korthaaret og mere eller mindre kirtelhaaret. 5-7.

$\beta$, abortivum! Blomsterstilkene meget korte, Blomsterue golde.

Sjelden i Danmark: Bornh. paa sandige Marker mellem Pythuset og Stampen! Rønne (14), Nexø (20), Christiansø (Didr.); Saltholm (Hoffmeyer)! $\beta$, Kongelunden paa Amager (19)!

Anm. Efter Leetor Lindebergs nøiagtige Undersøgelser (1. e. p. 8) om denue og foreg. Art synes det yderligere at bekræeftes, hrad jeg ogsaa (Haandb. 2 Udg. p. 311) fornodede, at denne Art ikke, som Gren. (fl. Fr. I, 269) antager, bor forenes med C. tetrandrum Curt., men derimod med C. glutinosum Fr. (nov. p. 132, H. N. IV, 54; F.D. 2537 ; C. obseurum Chanb., C. varians $\beta$, obscurum Coss. \& Germ. atl. tab. V). Denne Form, som adskilles ved kraftigere, mere klæbrige Stængler, Dækbladene aldeles uden Hindekant og Kronbladene alm. større, forekommer paa enkelte Steder i Sverige og er hyppig i Sydeuropa, men hidtil ikke bemærket i vor Flora. Fra folg. er den let kjendelig ved en meget mere sammentrængt Qvast;, kortere og efter Afblomstringen oprette Blomsterstilke og smalere Hinder paa Bægerog Dækblade. Fra foreg. Art adskilles den let ved sildigere Blomstringstid, femdelelige Blomster, meget kortere Blomsterstilke og længere Kapsel m. m.

620. C. semidecandrum L. (Femhannet H.) Fr, nov. p. 134 ; H. 517; Drej. n. 490 ; F. D. 1212; Rebb. l. c. fig. 4968.

Stcongelen fiin; Bladene ovale eller elliptiske med kort Spids, de nedre omvendt-ægformede, kortstilkede; Blomsterstillene efter Afblomstringen tilbagebøiede, efter Frøspredningen oprette, 2-4 Gange længere end Bægeret; Dakbladene med en bred hrid hindeagtig Rand; Bagerbladene længere end Kronbladene, med en bred, hindeagtig, i Spidsen gnavet-tandet, glat Rand; Støvdragere alm. 5; Kapselen ret eller i Spidsen svagt bøiet, neppe dobbelt saa lang som Bægeret.

5-6. En meget foranderlig Art i Henseende til Beklædningen, Bladformen, Blomsterstanden, Støvdragernes Antal (indtil 10) o. s. $\nabla$.

$\alpha$, vulgare. Hele Planten graaagtig-duunhaaret.

$\beta$, viscidum Fr., H. N. I, 39; C. viscosum H. 516; F. D. 1211 , C. glutinosum Rchb. l. c. (ikke Fr.) Planten, især Blomsterstilke og Bæger, klæbrig-kirtelhaarede. 
Alm. paa torre Marker, Steengjærder o. s. v. (saavel $\boldsymbol{\alpha} \operatorname{som} \boldsymbol{\beta}$ ).

Anm. Den glatte Form - macilentum, Fr. nov. p. 135 (C. maciJentum Aspegr.) er mig ikke bekjendt at være funden i Danmark. (Arterne at demne Afdeling i vor Flora fortjene en nermere Eftersøgning og Undersøgelse).

621. C. viscosum L. (Opret H.) Fr. Nov. p. 128; F. D. 1931; H. N. XlV, 41; C. ovale Pers., H. 516; C. glomeratum Thuill, Drej. n. 487; C. vulgatum Sm. (Linn. Herb.), Rchb. l. c. fig. 4970 .

Stcengelen opret eller opstigende; Bladene rundagtigt-ovale med en meget kort Spids, de nedre omvendt-ægformede; Blomsterne i sammentrængt Qvast; Blomsterstilliene kortere end eller af Længde med Brgeret, efter Afblomstringen udstaaende, tilsidst oprette; Dakbladene heelt gronne; Bcegerbladene paa Ryggen og i Spidsen haarede, med hindeagtig liand, omtrent af Længde med de ved Grunden randharede Kronblade; Kapselen buekrummet, neppe dobbelt saa lang som Bægeret.

Hele Planten bleggrøn, senere gunlgrøn, beklædt med lange, udstaaende Haar (eglandulosum Koch), undertiden, især oventil, med Kirtelhaar. Kapselen glindsende straaguul. 5-8. $\odot$ eller $\odot$.

Paa dyrket Jord i Mark og Have, saavel paa aabne som skyggefulde Steder, ikke sjelden og funden i alle Provindser, men sporadisk. (Den haarede Form er hos os meget liyppigere end den kirtelbærende).

622. C. strigosum [Fr. Fl. hall. p. 78] (Stivhaaret H.) Fr. nov. p. 131 ; H. 517 ; F. D. 2536 ; H. N. I, 38; C. braclyypetalum Desport., Drej. n. 488; Rchb. l. e. fig. 4971.

Stongelen opret, fra Grunden af grenet eller udeelt; Bladene elliptiske eller ovale med en kort Spids; Qvasten fjern. blomstret; Blomsterstilliene (ved Frugtmodningen) 2-3 Gange længere end Bægeret, i Spidsen nikkende; Dakbladene heelt grønne, tilligemed de smalt hindekantede Bagerblade i Spidsen skjæghaarede; Kronbladene kortere end Bægeret; Kapselen valseformet, næsten ret, lidet længere end Bægeret.

Hele Planten graaagtig og stivharet af tiltrykte Haar. 5-6. O. Paa torre Marker og Bakker, meget sjelden i Danmark: M $\boldsymbol{M}_{\text {en }}$ (H.), Bornh. ved Hammershuus Fyrtaarn (Hjorth), Krat ved Lind- 
holms-Klipperne i Røe Sogn (20)! mellem Allinge og Gudhjem, Randkleven (8). 陪

b. Vedvarende ( $\odot$ eller 4$)$.

623. C. vulgatum L. Sp. (Almindelig H.) Fr. Nov. p. 125 ; H. 515 ; F. D. 1645 ; H. N. X, 40 ; C. triviale Link, Drej. n. 489 ; Rchb. 1. c. fig. 4972 ; C. viscosum Sm. (Linn. Herb.).

Mangestænglet; Stanglerne fra en nedliggende og ofte rodslaaende Basis knæbøiet-opstigende; Bladene elliptiske eller lancetformede, de nedre omvendt-ægformede; Blomsterstilkene efter Afblomstringen udstaaende, omtrent dobbelt saa lange som Brgeret; Dcekbladene og de indre Brogerblade i Randen og Spidsen hindekantede (uden Rand- eller Skjæghaar); Kronbladene af Længde med eller lidet længere end Bægeret; Kapselen buekrummet, lidet længere end Bægeret.

Stænglerne forneden alm. mørkrøde, Planten trethaaret, Stængelens Haar udstaaende, Bladenes tiltrykte. 5-9. 4 (eller sjeldnere $(9)$ ). Forekommer under mange Former, af hvilke den meest afvigende er:

$\boldsymbol{\beta}$, holosteoides Fr. 1. c.; H. N. XV, 42. Stængelen (afvexlende) ensidigt haaret; hele Planten forøvrigt glat.

Meget alm. paa Græsmarker, Enge, ved Grøfter o. s. v. $\beta$, paa Strandenge, sjelden: $\boldsymbol{S} \boldsymbol{j}$. Svinninge Veile ved Lammefjorden! Amager Fælled ved Kongelunden (19); Loll. Lidsø ved Rødby! J. Agger og Ottesund i Thy!

624. C. arrense L. (Storblomstret H.) H. 518; Drej. n. 486 ; F. D. 626 ; Rehb. 1. c. fig. 4980 ; H. N. XV, 41 .

Stonglerne nedliggende eller krybende, med oprette eller opstigende Grene og tætbladede, blomsterløse Rodskud; Bladene. linie-lancetformede; Qvasten fjerntblomstret; Blomsterstilkene efter Afblomstringen oprette, i Spidsen nikkende; Dakbladene randhaarede, tilligemed Bagerbladene bredt-hindekantede; Kronbladene dobbelt saa lange soin Bægeret; Kapselen svagt bøiet, lidet længere end Bægeret.

Stængelen alm. korthaaret; J3ladene var. duunhaarede, randhaarede eller aldeles glatte; i Stængelbladenes Hjorner ofte knippe- 
stillede Blade af en undviklet Green. (Ved den store Krone let kjendelig fra de øvrige Arter). 5-8. $\psi$.

Ved Gjærder og Randen af Veie, paa lerede Marker: $\mathbf{S} \boldsymbol{j}$. i det ustlige iklie sjelden, sparsommere mod V., f. Ex. Kongens Møller, Strædet ved Sorø! Faardrup ved Skjelskor (Nielsen); i de øvrige Provindser sjelden: Falst. Ourupgaard, Hallerup (Koch); F. Vindinge ved $\mathrm{Ny}$ borg! Dalum ved Odense, V. Hæsinge (24!), Qverndrup, Rorlkilde, Ollerup (12); J. Aalborg (Juel), Gudumlund! Søndermolle ved Viborg (Feddersen), Tarp (16), Norup pr. Veile (30); $S l$. Gram (1), Taarnum, Agerskov (12), Haderslev, Cosel ved Slesvig (16), Rendsborg! Bornh. ved Ronne!

\section{Malachium. Klovkrone.}

625. I. aquaticum [Fr. Fl. hall. p. 77] (Vand-K.) Drej. n. 485 ; Rehb. l. c. fig. 4967 ; H. N. VI, 27; Cerastium L., H. 520 ; F. D. 1337.

Stangelen foroven trind, forneden firekantet, nedliggende eller opstigende, ved Grunden rodslaaende; Bladene æg-hjerteformede, tilspidsede, stilkløse, de nedre kortstilkede; Blomsterne i en fjerntblomstret, udspærret Qvast; Blomsterstilkene efter Afblomstringen vandret udstaaende eller nedbøiede, i Spidsen nikkende; Bagerbladene lidet kortere end Kronbladene og den femkantet-ægformede Kapsel.

Stængelen skjør, foroven tilligemed Blomsterstilkene og Bægerbladene kirtelharet; Biadene ofte i Randen bølgede. 6-7. $\psi$.

$\boldsymbol{\beta}$, saxatile Fr. Stængelen firekantet, med korte Ledstykker, Bladene mindre og smalere, næsten alle stilkede, med randbaaret Stilk, forøvrigt glatte, Qvasten faablomstret.

Ved Grufter og Bække, paa fugtige Enge o. s. v. hist og her. $\beta$, ved Bredderne af Tiissø (paa Gruus)!

\section{Sagina. Fiirling.}

a. Bæger og Kronblade, Støvdragere og Kapselens Klapper 4. (Sagina L.)

aa. Ingen midtstillede Bladrosetter. $\odot$.

626. S. stricta [Fr. Nov. ed. I, p. 47] (Rank F.) H. 187; Drej. n. 494 ; H. N. I, 43 ; S. maritima Rebb. I. c. fig. 4960 ; F. D. 2104. 
Stangelen udeelt, opret eller fra Grunden af grenet med knæbøiet-opstigende, opadtil ranke Grene; Bladene kjødfulde, glatte, linieformede, budte (i tørret Tilstand med en kort Braad); Blomsterstilkene under og efter Blomstringen oprette; Bagerbladene ovale, afrundede, udhulede; Kronblade 0.

Stængelen, især nedentil, mørk-violetbruun. 5-8.

$\beta$, maritima Fr. 1. c. (H. N. X, 42 ; S. maritima Don, S. erecta F. D. 845). Stængelen spædere, af mere grøn Farve, ofte nedliggende, senere Blomstringstid. vindser.

Paa Strandenge, ikke sjelden og forekommer i alle danske Pro-

627. S. ciliata [Fr. l. c.] (Randhaaret F.) Relb. 1. c. fig. 4956 ; H. N. I, 42 ; S. apetala $\beta$, decumbens F. D. 2102 (nederste Fig.).

Mangestænglet; Stcenglerne nedliggende eller bueformigt opstigende; Bladene linie-sylformede, braadspidsede, ved Grunden randhaarede; Blomsterstilkene efter Afblomstringen i Spidsen krummede, efter Frøspredningen rette; Bægerbladene af Længde med og tiltrykte til den modne Kapsel, de 2 ydre lancetformede, braadspidsede, de 2 indre budte, ovale; Kronbladene meget smaac, hurtigt affaldende.

Stængleme rødlige, finere, Blomsterne mindre end hos foreg. Var. (S. depressa Schultz) med Blade uden Randhaar. 6-7.

Paa torre Marker og ved Veie, saavel paa Sand- som Leergrund: Bornh. ved Gudhjem og Vældensby! Sj. Jersie ved Kjøge, Lindholm (15), Sors paa Marker mellem Parnas og Skjelskørveien! Mocns Klint ved Aborrebjerget (var.)! Falst. Stubbekjøbing (Rasm.), Meelse (14); Loll. Steensgaard (19); Thorseng ved Bregninge; $\boldsymbol{F}$. Hofmansgave (18), Nyborg (Lund), Ollerup o. fl. St. i det sydlige (12); J. Agre ved Apotheket i Hanherred (16), Bjergets Kro i V. Hanherred! Løgstør (A. Lange)! Braband, Gjellerup, Gjeding (16), Thyrsbæk (15), Brøndsted! Taulov!

628. S. apetala L. (Kronløs F.) H. II, 136; F. D. 2102 (øverste Fig.); Rchb. 1. c. fig. 4958; H. N. XIII, 54.

Mangestænglet; Stconglerne opstigende eller oprette; Bladene linie-sylformede, braadspidsede, randhaarede; Blomsterstilkene for og efter Frøspredningen rette; Bogerbladene kortere end 
og udstaaende fra den modne Kapsel, ægformet-ovale, budte, udhulede, de 2 ydre med en kort, indadbøiet Braad; Kronbladene meget smaae eller 0.

Fiin som foreg, mere gron. 7-8.

Paa torre Marker i dyrket Jord: $\boldsymbol{S}$ j. Soderup og Øde-Hastrup ved Roeskilde (15), Lillehedinge i Stevns! Falst. og L oll. almindelig; $\boldsymbol{F}$. Hofmansgave (18), Nyborg (Lund), Ollerup (12), Kogtved ved Svendborg! Lyo (12); Sl. Dybbøl, Husum (16).

bb. Stanglerne udgaae fra Grunden af en midtstillet Bladrosette (den forkortede Hovedstangel). 4.

629. S. procumbens L. (Fremliggende F.) H. 187; Drej. n. 495 ; F. D. 2103 ; Rehb. I. c. fig. 4959.

Stconglerne nedliggende, rodslaaende; Bladene smalt linieformede, braadspidsede, glatte; Blomsterstilkene efter Afblomstringen i Spidsen nikkende, efter Frøspredningen oprette; Bagerbladene $x$ gformede, budte, lidet kortere end og udstaaende fra den modne Kapsel; Kronbladene neppe halvt saa lange som Bægeret, ofte 0 .

$\beta$, crassifolia Nolte (maritima Fr.), F. D. 2103 n. 3. Bladene saftige, uden Braad.

$\gamma$, spinosa Gibson (Bab. man. p. 47). Bladene randhaarede.

Var. desuden med femdelelige Blomster, kortere og længere Blomsterstilke o. s. v. $5-8$.

Dyrkede og udyrkede Marker, saavel paa Sand- som Leergrund alm. $\beta$, ved Strandbredder; $\gamma$, en tosrvholdig Eng ved Bagsværd! Knudsbølle paa Thorseng, Avernak $₫$ (12).

b. Bæger, Krone og Kapsel femdelelige, Støvdragere 10. (Spergella Rchb.)

630. S. subulata [Torr. an\%. Gray Fl. of N. Am. I, 178] (Sylbladet F.) Spergula Sw., H. 523; H. N. IV, 56; Spergella Rchb. l. c. fig. 4963; Drej. n. 492; Spergula laricina F. D. 858 .

Stconglerne udstrakte eller tueformigt sammentrængte; Bladene linie-sylformede, langt braadspidsede, kirtlet-randhaarede; 
Blnmsterstilkene meget lange, efter Afblomstringen nikkende, efter Frøspredningen oprette; Bagerbladene ægformede, budte med en indbøiet Braad, omtrent ligelange med de budte Kronblade, kortere end Kapselen.

Blomsterstilke og Bægerblade kirtelhaarede. Kronbladene hvide. 6-8. 4 .

Sandige Marker og Klitter paa Halveen: Klitter i Thy (Dr.), Agger, Thorsted! Provstlund (13), Tange (16), Raavad ved Kolding (28), Obbekjær ved Ribe (6), Hjortlund (12), Romø (16), alm. paa Sylt, Føhr og Amrom (N.), Torreskov (16), Lygumkloster (28), Hyttener Bjerge (Jessen), Mielberg S. for Slesvig, St. Peter i Eidersted (16), Immingsted ved Husum (F. Müll.); $\boldsymbol{F}$. Nyfæste (16). (Angives ogsaa fra Flaskekroen af $\mathrm{H}$., men er ikke senere gjenfunden, og forøvrigt ikke bemærket i Sjælland og de sydlige Øer).

631. S. nodosa [Torr. and Gray l. c.] (Knudret F.) Spergula I., H. 522 ; F. D. 96 ; Spergella Rebb. 1. c. fig. 4965 ; Drej. n. 493.

Stanglerne talrige, fra Grunden af et midtstillet Bladknippe opstigende; Bladene linieformet-traadformede, halvtrinde, tilsyneladende krandsstillede (især oventil) paa Grund af forkortede Grene i Bladhjørnerne; Blomsterstilkene oprette, enlige; Bagerbladene $æ$ gformede, budte, $2-3$ Gange kortere end Kronbladene, omtrent af Længde med Kapselen.

Bladene aftage i Længde nedenfra opad. Kronbladene hvide. 7-8. భ. Stænglerne var. enkelte eller grenede, glatte eller (især oventil) kirtelhaarede ( $\beta$, glandulosa Bess.) og desuden:

$\beta$, moniliformis! Stænglerne udstrakte, med meget forkortede Ledstykker, Bladene paa de forkortede Grene i Bladhjørnerne og de øvre Stængelblade korte og kjødfulde, rundagtig-xgformede.

I fugtige Enge og Torrmoser alm., sjelden paa høitliggende sandige Steder, f. Ex. Møens Klint! $\beta, J$. Sandklitter ved Henne nær Vesterhavet!

\section{Spergula. Spergel.}

632. S. arrensis L. (Almindelig S.) H. 520; Drej. n. 491 ; F. D. 1033.

Bladene linieformet-traadformede, paa Overfladen hralvede, paa Underfladen furede; Blomsterne i Qvast, det øverste Led- 
stykke nedenfor Blomsterstandeu neppe læugere eud de øvrige; Blomsterstilkene efter Afblomstringen tilbagebøiede; Stovdragerne oftest 10; Frøene kugleformet-lindseformede, vortet-rue, omgivme af en sinal hindeagtig Rand.

Planten mørkgrøn, klæbrig-kirtelhaaret, ${ }^{1 / 2}-1^{\prime}$ høi. Kroubladene hvide. $\odot$. Var.

$\boldsymbol{\alpha}$, vulgaris (Boenn., Rchb. ic. crit. VI, 705). Frøene beklædte med hvidagtige, opbøiede Vorter.

$\beta$, sativa (Boenu.; S. arvensis Rchb. ic. crit. VI, 704). Frøene sorte, fint punkterede.

Paa twrre, sandige Marker, alm. udbredt, især i Halvøens magrere Egne; $\boldsymbol{\beta}$, dyrkes hyppig som Fodervæxt $\mathrm{og}$ forekommer stundom forvildet.

* 633. S. maxima [Whe. i Boenn. Prodr. fl. Monast. n. 570] (Stor S.) Nolt. nov. p. 46; Rehb. ic. erit. VI, 706; Hausens Herb. No. 674.

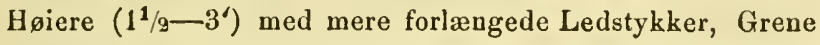
og Blomsterstilke; hele Planten glat eller kun foroven svagt haaret; Frøene 2-3 Gange større end hos foreg., tæt beklædte med hvide, ophøiede Vorter, forøvigt som foreg.

Ukrud i Hørsseden: $S l$. Schauendal ved Husum (F. Müll.); Bornh. ved Vester Mariæ Skole (Hamann), Enesgaard i Ruthsker Sogn (Hjorth)! F. Skaarup (19, en Form med svagere, iklse hvide Vorter paa Frøene)!

634. S. rermalis [Willd. Prodr. fl. Berol. p. 158] (Femhannet S.) S. Morisonii Boreau, Rev. bot. p. 123, Lge. D. Fl. 2 Udg., p. 318; S. pentandra H. 521; F. D. 1930; H. N. IV, 55 .

Bladene kortere, næsten trinde, uden Fure paa Underfladeu; Stcengelens øverste Ledstykke uedenfor Qvasten flere Gange længere end de øvrige; Kronbladene ovale, budte; St $\emptyset v$ dragerne oftest 5; Frøene fladtrykt-kredsrunde med en ru-punkteret Rand og udenfor samme omgivne af en bred, straaleformigt stribet, lysbruun Hinde; forøvrigt som foreg., wen af mere blaagrøn Farve. 
3-6" høi. Var. glat eller kirtelhaaret. Kronbladene hvide. 5-7. $\odot$.

Paa sandige Marker, sjelden: Bornh. paa Klipperne ved Hammershuus Fyrtaarn! Sl. Brinker paa N. O. Siden af Wittensee (20), Sorgwohld N. for Rendsborg (16). I*

Anm. Willdenows Navn S. vernalis, som efter Vidnesbyrd af A. Braun og Ascherson (Bot. Zeit. 1859, p 291) hører til S. Morisonii, bør, som det wldste (allerede givet 1787), gjenoptages for denne Art. Den ægte $S$. pentandra L. (Bor. l. c.), adskilles ved lancetformede, spidse Kronblade og jærne Frøe med en bredere, sølvhvid-glindsende Rand. Denne Art er ikke funden hos os, den forekommer sparsomt i Nord- og Mellemtydskland, hyppigere i Sydeuropa.

\section{Sedum. Steenurt.}

a. Bladene trinde, heelrandede, Planten overvintrer ved bladbærende overjordiske Rodskud.

aa. Kronbladene hvide.

635. S. album L. (Hvid S.) H. 507; Drej. p. 164; F. D. 66 .

Stcengelen krybende, de blomsterbærende og bladbærende Grene oprette eller opstigende; Bladene spredte, udsparrede, valseformede, paa Underfladen lidet fladtrykte, budte; Blomsterne $\mathrm{i}$ mangeblomstret og flere Gange gaffeldeelt Qvast; Kronbladene lancetformede, budte, 2-3 Gange længere end Bægeret.

Hele Planten glat, Stængel og Blade rødprikkede, Kronbladene hvide med røde Punkter, Støvdragerne mørkrøde. 7-8. 4.

Klipperne ved Gudlijem paa Bornholm (H.)! I de andre danske Provindser er den neppe vildvoxende, men forekommer flere Steder plantet eller tilfældigt forvildet, f. Ex. paa Møens Klint og i Mængde ved Strandveien o. Al. Veie N. for Kjøbenhavn!

† S. cruciatum [Desf. Cat. b. par. 162; S. monregalense Balb., Rchb. ic. crit. III, 438] Bladene krandsstillede (1/4); Qvasten faablomstret, dens Grene kirtelhaarede; Kronbladene æglancetformede, tilspidsede, forøvrigt soin foreg.

Forvildet eller plantet ved Dyrehavegjærdet mod Ordrup Mose (Heiberg) og tidligere i Frederiksdals Skov ved Kilden! 


\section{bb. Kronbladene gule.}

636. S. acre L. (Bidende S.) H. 505; Drej. n. 477 ; F. D. 1457 .

Stcenglerne krybende, meget grenede; de blomsterbærende og golde Grene opstigende; Bladene trtsiddende og taglagttiltrykte, uregelm. spredte (paa de golde Rodskud i 4-6 Rader), ægformede, budte, med plan Overflade, ved Grunden nedenfor Tilbæftningspunktet afrundede; Blomsterne i Qvast med $2-3$, under Blomstringen tilbagekrummede Grene, hver Green med 2-5 næsten siddende Blomster; Brogerbladene ægformede, budte, nedenfor Basis forlængede; Kronbladene lancetformede, spidse, udspilede, dobbelt saa lange som Bægeret; Ballekapslerne udspærrede.

\section{6-7. 4. Var.}

$\alpha$, genuinum Godr. Bladene spredte, af bidende Smag.

$\beta$, sexangulare Godr. (S. sexangulare L. Sp.) Bladene tæt taglagte, paa de golde Stængler i $5-6$ Rader, Blomsterne færre og mindre, Planten af mindre bidende Smag.

Meget alm. paa sandige Marker, hist og her paa Straatage og især paa Steengjærder, som den ofte beklæder i store Tuer. $\boldsymbol{\beta}, \boldsymbol{S} \boldsymbol{j}$. ved sandige Bredder af Tiiss $\emptyset ! \boldsymbol{F}$. Ballen (12); J. paa Kalkgrund ved Aalborg (12).

637. S. boloniense (Lois. Not. p. 71] (Sexkantet S.) Gren. \& Godr. fl. Fr. 626; Koch. Syn. II, 1024; Rehb. ic. crit. IX, p. 18 ; S. Forsterianum ib. f. 1135 ; S. sexangulare DC. fl. fr., H. 506 ; Drej. p. 164 ; F. D. 1644 ; H. N. IX, 43.

Stcenglerne krybende, med opstigende, fæerre og mere spredte Grene; Bladene tætsiddende i 6 Rader, linieformede, budte, med en spids Forlængelse ved Grunden; Qvasten som hos foreg., men med 6-10-blomstrede Grene; Bcegerbladene lancetformede, budte, ved Grunden ikke forlængede, balvt saa lange som Kronbladene; Ballekapslerne udspærrede.

Smagen ikke bidende. 7. (Blomstrer omtrent 14 Dage senere end foreg.). $\%$.

Paa torre Marker og Skrænter, sjelden: Falst. ved Grønsunds 
Færgested! Græsskrænter ved Næsgaard! Abelvig (14), Gaabense (H.); Sl. Nyværk (16). i*

Anm. Da den linneiske Beskrivelse af S. sexangulare (fol. subovata, flor. in corymbo 2 จ. 3) ikke passer paa denne Art, som alm. gaaer under Navnet S. sexangulare, har jeg efter Godron forandret dens hidtil almindelige Benærnelse. I Linnés Herb. findes ogsaa (ifølge C. Hartm.), under Navn af S. sexangulare, en Form af S. acre. Expl. i Hornemanns Herbarium, meddeelte af Roth under Navn af S. sexangulare L. (samlede ved Vegesack) tilbøre ogsaa denne Form (S. acre $\boldsymbol{\beta}$, ) og ikke S. boloniense.

638. S. rupestre L. (Bjerg-S.) H. 509; Rchb. ic. crit. III, 439; H. N. IV, 58; S. reflexum F. D. 113.

Stcongelen krybende, de golde og blomsterbærende Grene spredte, opstigende; Bladene spredte, paa de golde Grene tætsiddende, udstaaende eller tilbagebøiede, trindt-sylformede, spidse, med en sporeformet Forlængelse ved Grunden; Qvasten 3-5.grenet, med tilbagebøiede, ofte todeelte Grene; Blomsterne kortstilkede; Bcegerfigene lancetformede, spidse, ved Grunden ikke forlængede, halvt saa lange som Kronbladene; Bollekapslerne oprette.

7-9. 2. Var.

$\alpha$, glaucum Koch (S. rupestre L., Fr.), Bladene blaagrønne.

$\boldsymbol{\beta}$, viride Koch (S. reflexum L., H. 508; F. D. 1818). Større, med mere grønne Blade.

Angives fra Als (Fr. S. veg. Sc. p. 254); forekommer forøvrigt forvildet paa Steengjærder og omkring Haver, livor den stundom dyrkes.

b. Telephium Kocb. Bladene flade, tandet.rundtakkede; Roden knollet, overvintrer ved underjordiske Knopper.

639. S. Telephium L. (Fr.) (St. Hansurt). H. 504 ; F. D. 2174 ; S. maximum Suter, Drej. n. 479 ; Rchb. ic. crit. VIII, 969.

Bladene modsatte eller krandsstillede (1/2-1/3), ægformetovale med hjerteformigt omfattende Basis, fra Grunden af saugtakket-tandede; Blomsterne i bladet, twt og mangeblomstret 
Qvast; Kronbladene udstaaende, nærved Basis sammenvoxne med de ydre Støvdragere.

Planten alm. større, med længere Ledstykker og mere grøn end følgende. Kronbladene hvidgule eller gunlgrønne. 8-9. (Senere end følg.). $\psi$.

Ved Gjærder og i Kratskove alm., især meget hyppig i GranitTerrainet paa Bornholm.

*640. S. purpurascens [Koch Syn. II, 284] (Rødstænglet S.) S. Telephium Drej. p. 322 ; Rchb. ic. crit. VIII, 968.

Bladene spredte (eller de nedre modsatte), omvendt-ægformede eller ovale, med afrundet Basis, fra Grunden af saugtakket-tandede; Blomsterne i bladløs, tæt- og mangeblomstret Qrast; Kronbladene ovenfor Midten udbøiede, $\mathrm{i} / 3-1 / 6$ af deres Længde forneden sammenvoxne med Støvdragerne.

Stængelen mørkrød, Kronbladene bleggule med rødligt Anstrøg (aldeles røde har jeg ikke fundet dem i vor Flora). Støvdragerne røde. $7-8.4$.

Paa tørre Marker ved Ordrup og Charlottenlund! Stevns! sydlige Fyen (12), sandsynligviis vil den ved nærmere Undersøgelse findes paa flere Steder.

Anm. De af mig samlede Expl. stemme aldeles overeens med Fig. hos Rehb., som af Koch (1. e.) henfores til denne Art, og da de fleste Kjendetegn tillige svare til Kochs Beskrivelse (med Undtagelse af Kronbladene, som hos den sydeuropæiske Plante ere skidenrøde med blegere Midtnerve), har jeg her indtil videre beholdt den som egen Art. Flere af de hos Koch angivne Kjendetegn (f. Ex. de udhulede Blomsterknopper og hvælvede Frugtknuder hos S. Telephium, plane Blomsterknopper og furede Frugtknuder hos S. purpuraseens) ere neppe ennstante. Fra folg. er den meget forskjellig.

\section{$\dagger$ 641. S. lividum [Willd. Enum. supp]. p. 24 ?] (Blaggraa} S.) Drej. n. 478 ; S. Telephium $\beta$, purpureum F. D. 686.

Bladene spredte, omvendt-ægformet-ovale, ved Grunden smalere, heelrandede, fra nedenfor Midten til Spidzen tandetrundbugtede; Blomsterne i bladet, mangeblomstret Qvast; Kronbladene udstaaende, $\mathrm{i} \mathbf{1} / \mathbf{3}$ af deres Lxingde nedentil sammenvoxne med Støvdragerne.

Bladene blaagronne, Qvasten med mere spredte Blomster og oprette Grene end de foreg., Stængelen fint rødprikket.' Kronbladene mørk-rosenrøde. 8-9. 4 . 
Meget sjelden: $\boldsymbol{S} \boldsymbol{j}$. mellem Gurre og Helsingør (Heiberg), mellem Hillerød og Fredensborg (Münster), Asminderød (Hoff), Egelund! en Mose ved Dumpedals Mølle! Kobbermgllen (?) ved Kjøbenhavn (O. F. Müll.), Louisenborg Skov o. fl. St. ved Storehedinge (Visby)! Sophiehøi ved Gisselfeld (Lund), Snoldeløv (14); F. Strandbredder ved Kjerteminde (O. F. Müll.); Fohr ved Alkersum (20). Maaskee ikke oprindelig indenlandsk. Findes ofte som Siirplante i Haver.

Anm. Navnet S. lividum er brugt af Drej. og her beholdt som passende for Planten skjondt det er uvist om Willdenows Navn skal betegne denne. Fra S. Fabaria Koch (Syn. II, 258), H. N. XIV, 48 adskilles den ved at Planten er mindre, Bladene smalere hos sidstnævnte end hos vor, og at denne blomstrer seent paa Efteraaret, medens Koch angiver Blomstringstiden for S. Fab. til Juni.

\section{$11^{\text {te }}$ Klasse. Dodecandria (Tolvhannede).}

\section{Orden. Monogynia (Enhunnede).}

1. Asarum L. Blomsterdækket enkelt, trekløvet, oversædigt, farvet; Støvknapperne med et $i$ en Spids udenfor Rummene forlænget Knapbaand; 6 Ar; Kapselen sexrummet. (N. F. Aristolochieæ).

2. Lythrum L. Bægeret tolvtandet (hveranden Tand kortere), omkringsædigt; Kronbladene 6, farvede, befæstede til Bægerrøret; Arret hovedformet; Kapselen torummet, omgivet af det vedblivende Bæger, (N. F. Lythrarieæ).

\section{Orden. Digynia (Tohunnede).}

3. Agrimónia L. Bægeret omsluttende Frugtknuden, beklædt med Hagebørster nedenfor den femfligede Krave; Kronbladene 5, tilligemed Støvdragerne befæstede paa Bægerranden; Frugten 1-2-rummet, tæt omgivet af Bægerrøret. (N. F. Rosaceæ, a).

\section{Orden. Trigynia (Trehunnede).}

4. Reséda L. Bægeret 4 (-6)-bladet; Kronbladene uligestore, fligede; Støvdragerne befæstede til en udvidet 
Skive ovenfor Kronbladene; Frugten en (før Modenheden) i Spidsen aaben Kapsel. (N. F. Resedaceæ).

Euphorbia. Blomsterne nøgne (i Blomsterkop), tredelelig Spaltefrugt $(21,1)$.

\section{Orden. Dodecagynia (Tolvhunnede).}

5. Sempervírum L. Bæger- og Kronblade 12; Frugterne ligesaamange Bællekapsler; undersædige Skjæl ved Grunden af Frugtknuderne. (N. F. Crassula ceæ).

\section{Monogynia.}

\section{Asarum. Treblad.}

642. A. europæum L. (Europæisk T.) H. 525; Drej. p. 171 ; F. D. 633 ; Rchb. ic. fl. g. XII, fig. 4339 ; H. N. $\mathrm{XI}, 55$.

Rodstokken krybende, grenet, paa bver Green 2-3 nyreformede, heelrandede Blade og 1 før Udspringningen nikkende Blomst; Blomsterstilken kortere end Bladene; Blomsterdakket klokkeformet (udvendig bruunlig-grønt, indvendig mørkrødt, haaret).

Bladene langs Nerverne fiinthaarede, forgvrigt glatte og glindsende. 5. 4.

Paa skyggefulde Steder, meget sjelden: Forhen i Rosenborg Have (H.); J. Gjøl i Limfjorden (Mortens. Herb.), Kidholm i Kolding Fjord (H., nu forsvunden: 28); Sl. Slotsvolden ved Gelting i Angel (16), Mörel (Seehusen), Nyværk ved Slesvig (Esmarch).

\section{Lythrum. Kattehale.}

643. L. Salicaria L. (Pilebladet K.) H. 526; Drej. n. 496 ; F. D. 671.

Stangelen opret, firekantet; Bladene korsviis-modsatte $(1 / 9-1 / 4)$, lancetformede med hjerteformet Basis; Blomsterne falskt krandsstillede i Bladhjørnerne; de øvre Krandse tæt samlede og derved dannende et Ax; Bagerets indre Tænder 
triangulære, flere Gange kortere end de ydre, sylformede; de 6 Støvdragere kortere, de 6 længere.

$2-4^{\prime}$ høi, var. glat eller duunhaaret, Kronbladene purpurrøde. 7-8. 2.

$\beta$, triphyllum. Stængelen sexkantet; Bladene krandsstillede $(1 / 3)$.

$\gamma$, tetraphyllum. Stængelen firekantet; Bladene krandsstillede $(1 / 4)$.

Ved Bredderne af Søer, Grofter og Aaer alm. udbredt.

\section{Digynia.}

\section{Agrimonia. Agermane.}

644. A. Eupatoria L. (Almindelig A.) H. 527; Drej. n. 497 ; F. D. 588 ; H. N. XI, 44.

Bladene mellembrudt- og uparret-fjersnitdeelte, med lancetformede eller elliptiske, dybt saugtakkede Afsnit; Axelbladene halvmaaneformede, fligede; Blomsterne i forlængede Klaser, paa korte, under Blomstringen oprette, mod Frugtmodningen nikkende Blomsterstille; de ydre Hagebørster udstaaende; Bagerrøret (ved Modenheden) omvendt-kegleformet, med Længdefurer til Grunden.

1-2' høi, stivhaaret, især paa Stængelen og Bladenes Underflade. Blade og Blomster vellugtende. Kronbladene gule. 7-8. 4. Ved Gjærder og paa solaabne Steder alm. ndbredt.

645. A. odorata [Mill. Dict. n. 2] (Vellugtende A.) F. D. 2471 ; H. N. XIV, 51; A. procera Wallr.

Bagerrøret klokkeformet, kun foroven, omtrent til Midten, furet; de ydre Hagebørster tilbagebøiede, forøvigt som foreg., men alm. høiere $\left(2-3^{\prime}\right)$; Bladenes Afsnit længere tilspidsede; Stangelen mere ru, men (tilligemed Bladene) med svagere Haarbeklædning, hvoriblandt Kirtelhaar, som give Bladene en stærk Lugt. 
Hos denne Art har jeg hyppigst fundet 2, hos foreg. kun 1 Frugt indsluttet i Bægerøøret. 7-8. 4 .

Ved Gjærder og i Kratskove hist og her, bemærket $\mathrm{i}$ alle Provindserne, og i enkelte Egne alm., f. Ex. i I.olland og det sydlige Fyen.

\section{Trigynia.}

\section{Reseda. Vau.}

646. R. luteola L. (Farve-V.) H. 528; Drej. n. 498; F. D. 864 ; Rebb. ie. fl. germ. II, fig. 4442 ; H. N. I, 32.

Stcongelen rank-opret; Bladene spredte, lancetformede, heelrandede; Blomsterne i forlængede, tætblomstrede Klaser; Blomsterstilkene omtrent af Længde med det firebladede Boger; Kronbladene alm. 3-4, det øvre (større) 4-7-fliget; de mellemste 2-3-fligede, det nedre udeelt; Kapselen klokkeformet, 3-4-kantet, rynket paatværs.

1-2' høi, glat, Kronbladene bleggule. 7-8. $\odot$.

Ved Veie, især omkring Byer, paa Marker og Bakker, sporadisk, men forekommer $i$ alle Provindser, hyppigst paa Bornholm! $\bar{*}$

\section{Dodecagynia.}

\section{Sempervivum. Iluusleg.}

647. S. tectorum L. (Tag.H.) H. 532; Drej. n. 499; F. D. 601 .

Rodskuddene med rosetteformigt samlede, tykke og saftrige, elliptiske eller omvendt-ægformede, braadspidsede, randhaarede Blade; Stcengelen opret, med spredte, lancetformede eller elliptiske Blade, oventil deelt i en qrastformet Blomsterstand med eensidige Blomster paa Grenene; Kronbladene stjerneformigt ndbredte, lancetformede, spidse, dobbelt saa lange som Bægeret; de undersadige Skjal sunaae, kirtelformede. 
Stængelen $1-1^{1} /_{2}{ }^{\prime}$ h $\phi i$, oventil kirtelhaaret. Kronbladene rosenrøde. De indre Størdragere omdannes ofte til Frugtblade. 7-8. 4 .

Paa Straatage i Landsbyer, ikke sjelden.

\section{$12^{\text {te }}$ Klasse. Icosandria (Bægerhannede).}

\section{Orden. Monogynia (Enhunnede).}

1. Prunus L. Bægeret omkringsædigt, femfliget, Kronbladene $5^{*}$ ), Frugten fri, en saftig Steenfrugt. (Træer eller Buske med spredte Blade. N. F. Drupacex).

$\dagger$ Philadélphus L. Bægerrøret sammenvoxet med Frugtknuden, Bægerets Krave firefliget, Kronbladene 4, Frugten en undersædig, firerummet Kapsel. (Busk med modsatte Blade. N. F. Philadelpheæ).

Cratcegus monogyna $(12,2)$.

\section{Orden. Di-Pentagynia (To-Femhunnede).}

A. Blomsten oversædig eller halvt oversædig, Frugterne uopspringende, mere eller mindre omgivne af det kjødfulde "Underbæger" $(0$ : det mod Frugtmodningen tilvoxende Bægerror). (2-6. N. F. P o m a c æ ).

a. Frøgjemmets $V æ g g e$ beenbaarde (Steenfrugt).

2. Cratǽgus L. (part.) Blomsten oversædig; Frugt Steenæble med 1-5 Stene ( 0 : Frugtknudens Rum 1-5, enfrøede og heelt omsluttede af Underbægeret).

3. Cotoneảster Lindl. Bægeret halvt oversædigt; Frugtknudens Rum 3-4, enfrøede, foroven frie, nedentil sammenvoxne med det tilsidst kjødfulde Underbæger.

*) De Slægter i denne Klasse, som høre til Familierne Drupaceæ, Pomaceæ og Rosaceæ, have alle femdeelt Bæger og 5 Kronblade. 
b. Frøgjemmets Vægge hindeagtige eller bruskagtige (Kjærnefrugt).

4. Sorbus L. Bægerfligene henvisnende; Frugten et bærformigt Kjærneæble med 5 enfrøede Rum, omgivne af Frøgjemmets hindeagtige Vægge og heelt omsluttede af Underbægeret.

5. Pyrus L. Bægerfligene henvisnende; Frugten et paa Overfladen glat Kjærneæble med 5, 1-2-frøede Rum, omgivne af læderagtige Vægge og beelt indsænkte i Underbægeret.

† 6. Cylonia Tourn. Bægerfligene grønne (vedblivende uforandrede); Frugten et paa Overfladen filtet-duunhaaret Kjærneæble med 5 fleerfrøede Rum, omgivne af bruskagtige Vægge og heelt indsænkte i Underbægeret.

Poterium L. $(21,6)$.

B. Blomsten omkringsædig, Frugterne opspringende, frie.

7. Spiræa L. Frugterne 5 eller flere, 2--6-frøede Bællekapsier. (N. F. Rosaceæ, e).

\section{Orden. Polygynia (Mangehunnede).}

A. Bægeret fembladet eller femdeelt, uden Yderbæger; (Buske med Barktorne).

8. Rosa L. Frugterne mange Nødder, omsluttede af det kjødfulde, bægerformigt udhulede Underbæger (Hybenfrugt). Bægerfligene vedblivende eller affaldende, hele eller fligede. (N. F. Rosaceæ, b).

9. Rubus L. Frugterne mange Steenfrugter, tilhæftede udenpaa den kegleformede Frugtbund; Bægeret vedblivende. (N. F. Rosace æ, c).

Spircea $(12,2)$. 
B. Bægeret fembladet, dets Blade afvexlende med et fembladet Yderbæger. (Urter uden Barktorne).

$$
\text { (9-12. N. F. Ros a c æ, d). }
$$

10. Fragária L. Griffelen affaldende; Frugterne Nødder, befæstede paa den kjødfulde, ved Modningen affaldende Frugtbund. (Kronbladene hvide).

11. Potentilla L. Griffelen affaldende; Frugterne Nødder, befæstede paa den torre, vedblivende Frugtbund. (Kronbladene gule eller hvide).

12. Cómarum L. Griffelen affaldende; Frugterne Nødder, befæstede paa den svampagtigt opsvulmede, vedblivende Frugtbund. (Kronbladene bruunrøde).

13. Geum L. Griffelen vedblivende i Spidsen af Nødderne og tilvoxende mod Modningen under Navn af Frøhale; Frugterne befæstede paa den tørre, vedblivende Frugtbund.

\section{Monogynia.}

\section{Prunus. Krage.}

a. Prunus s. s. Blomsterne enlige eller parvise, udvikles før eller samtidigt med Bladene; Frugtens

Overhud beklædt med Dug; Stenen fladtrykt.

648. P. spinosa L. (Slaaentorn). H. 541; Drej. n. 500; F. D. 926 .

De unge Grene duunhaarede; Bladene lancetformede eller elliptiske, saugtakkede, paa begge Flader glatte; Blomsterne enlige; Blomsterstilkene glatte; Frugterne kuglerunde, oprette.

En lav Busk med talrige og stærke Vedtorne; de yngre Blade duunhaarede; Kronbladene hvide; Blomsterne udvikles for Bladene. Frugten blaadugget, dens Smag sammensnærpende. 4-5. $\boldsymbol{h}$.

$\beta$, coctanea W. \& Gr. F. D. 2590 ; P. fruticans Whe.; P. insititia Drej. n. 501 (efter Voxestedet), Blade og Blomster 
udvikles samtidigt, Stammen høiere end hos Hovedarten; Blomsterne større, ofte parvise.

I Krat og ved Gjærder, udbredt overalt i Danmark. $\boldsymbol{\beta}$, sjeldnere: $\boldsymbol{S} \boldsymbol{j}$. et Gjærde mellem Helsingør og Egebæksvang (21), Frederiksdals Skov (14), Sundbyøster paa Amager (19), Pliilosophgangen ved Soro! Falst. S. Kirkeby, Korselitze (Koch); Bornh. Rønne Vang (Hjorth); $\mathbf{S} l$. Haderslev (Gronlund), Flensborg (16).

649. P. insititia L. (Almindelig K.) H. 540; Drej. n. 501 (undt. Voxest.); F. D. 2651 ; H. N. V, 48.

De unge Grene fløielshaarede; Bladene omvendt-xgformetelliptiske, saugtakkede, paa Underfladen duunhaarede; Blomsterne parvise, med finthaarede Blomsterstilke; Frugterne kuglerunde, nikkende.

En større Busk med færre Vedtorne; Kronbladene hvide; Frugten større end hos foreg., dens Smag sød eller syrlig. (Er ifølge Koch Stamarten til de ruude Blommer). 4-5. দৃ.

Ved Gjærder og i Kratskove, i vild Tilstand sjelden: $\boldsymbol{S}$. Frydenlund (Frk. Rieffestahl)! mellem Grøndal og Brøndshøi, Amager (19); i det sydl. Fyen hist og her (12), Langeland (H.); Falster alın. (Koch); Hasseløen ved Nykjøbing p. F.! J. Ødstedgaard! Dyrkes hyppigt i flere Afændringer.

$\dagger$ 650. P. domestica L. (Blommetræ). H. 539; Drej. p. 173 ; Sv. bot. t. 193.

De unge Grene glatte; Bladene omvendt-xgformet-elliptiske, saugtakkede, paa Underfladen duunbaarede; Blomsterne parvise med duunhaarede Blomsterstilke; Frugterne aflange, nikkende.

En høi Busk eller Træ, uden Vedtorne; Kronbladene guulagtigthvide; Frugten af sød Smag (Stamart til de aflunge Blommer, f. Ex. Svedsker). 5. そ. (Var. med glatte Blomsterstilke).

Dyrkes alm. og forekommer hist og her forvildet: Langeland, Als (H.); S j. Bernstorfsveien ved Lundehuset (Dr.), Roeskilde (19!).

b. Cerasus DC. Blomsterne i eu sammentrængt Halvskjærm, udvikles samtidigt med Bladene; Steenfrugten uden Dug, Stenen kugleformigt opblæst (Ingen Vedtorne).

$\dagger$ 651. P. Cerasus L. (Kirsebærtræ). H. 536; Cerasus Caproniaua DC., Drej. p. 172. 
Bladene elliptisk·ægformede, saugtakkede, glatte, jærne, uden Kirtler; de indre Knopskjol bladbærende. Underjordiske Udløbere.

Træ af Middelstørrelse. Kronbladene hvide. Frugtens Smag syrlig (de sure Kirsebær nedstamme fra denne Art). 5. h.

Dyrkes alm. og forekommer hist og her forvildet: $\boldsymbol{S} \boldsymbol{j}$. ved Bernstorfsveien, hvor Teglovnen har været (Schum.), Kaningaarden ved Fuursø (14), Fægangsveien ved Sorø! F alst. en Høi V. for Stubbekjøbing (Benzon); $\boldsymbol{F}$. Skrænt ved Ladegaardsøen ved Nyborg (Lund); Sl. Vonsbæk (Nielsen).

652. P. avium L. (Fuglekirsebærtræ). H. 538; F. D. 1647 ; Cerasus DC., Drej. n. 503.

Ingen Udløbere; Bladene elliptisk-ægformede, dobbeltsaugtakkede, paa Underfladen duunhaarede, med 2 Kirtler ved Grunden af Pladen; alle Knopskjoellene bladløse.

Høit Træ. Kronbladene hvide. Frugterne af sød Smag (fiere dyrkede søde Kirsebær nedstamme fra denne Art). 5.

Forekommer hist og her vildvoxende i Skove, i nogle Egne hyppig, f. Ex. paa Bornh.! Moens Storeklint! Langeland, sydlige Fyen (12); J. ved Ødstedgaard!

c. Padus Koch. Blomsterne i Klase, udvikles efter Bladene. Frugt som foreg. (Ingen Vedtorne).

653. P. Padus L. (Hægebærtræ). H. 535; F. D. 205; Cerasus DC., Drej. n. 502.

Bladene elliptiske, fiint saugtakkede, rynkede, med 2 Kirtler ved Grunden af Bladpladen; Klaserne hængende; Kronbladene tandede.

Et Træ af Middelstorrelse. Kronbladene hvide; Frugterne smaae, sorte, af sammensnæerpende Smag. 5. h.

I Skove, alm. i Fyen og paa Østkysten af $\boldsymbol{H}$ alvoen, sjelden i det Indre og mod V., f. Ex. Bølling, Estrup (28), Rødding, Husum (16). I $S j a l l$. og paa de øvrige Øer sporadisk og ikke hyppig.

\section{$\dagger$ Philadelphus. Pibeved.}

$\dagger$ Ph. coronarius L. (Falsk Jasmin). Schk. Handb. t. 121.

Bladene ægformet-elliptiske, tandet-saugtakkede, tilspidsede; Blomsterne i en kort, klaseformet Qvast; Bagerfigene tilspidsede; 
Griffelen til henimod Grunden firedeelt. Kronbladene hvide. 6. 万ุ.

Dyrkes i Haver paa Grund af dens stærke Lugt, og forekommer hist og her forvildet, f. Ex. i $\boldsymbol{F}$. hyppig omkring Gudme og Hesselager (19).

\section{Di - Pentagynia.}

\section{Cratregus. IIvidtorn.}

654. C. monogyna [Jacq. Fl. austr. t. 292, f. 1] (Engriflet H.) Drej. n. 507; F. D. 1162; Mespilus Willd., H. 547; C. Oxyacantha (I $)$ Fr. H. N. IX, 45.

Bladene fjeruervet-3-5-fligede; de nedre Sidenerver udadbøiede fra Hovednerven; Blomsterne i Halvskjærm, med duunhaarede Blomsterstilke; 1 Griffel og 1 Steen i Frugten; Bagerfigene tilbagebøiede.

Kronbladene hvide. (En rødblomstret Afart, den saakaldte Rødtjørn, dyrkes alm. i Haver). Bladfligene heelrandede eller fjernt saugtakkede. 6. (omtrent 14 Dage senere end følg.). ḩ.

$\boldsymbol{\beta}$, denudata Sehum. Enum. p. 155. Blade og Bladstilke dunede, Blomsterstilkene glatte.

I Kratskove og ved Gjærder, bemærket $\mathrm{i}$ alle Provindser og ikke sjelden, dog mindre hyppig end følg. $\beta$, anfores af Schum. uden Angivelse af Yoxested.

655. C. Oxyacantha [Jacq. 1. c. f. 2] (Almindelig 11.) Drej. n. 506; F. D. 634 ; Mespilus Gärtn., H. 545 ; M. oxyacanthoides Thuill.

Bladene fjernervet-3-5-lappede; de nedre Sidenerver indbøiede mod Hovednerven; Blomsterne i Halvskjærm, med glatte Blomsterstilke; 2-5 Grifler og ligesaamange Stene; Bagerfligene opret-udstaaende, i Spidsen tilbageboiede.

Kronbladene hvide. Bladets Lapper saugtakkede. Antallet af Støvveie var., undertiden er ved Reduction kun 1 tilstede, men er dog stedse en fra foreg. ved de mindre indskaarne Blade, Nervernes Retning og den forskjellige Blomstringstid vel adskilt Art. $\frac{5}{2}-\frac{6}{1} \cdot \boldsymbol{h}_{2}$.

I Krat og ved Gjærder, alm. udbredt i Danmark. Sædv, busk- 
agtig, men undertiden, f. Ex. paa Dyrehavesletten ved Eremitagen og paa Bornholm forekommer den som høit Træ med udeelt Stamme og tæet Krone.

$†$ C. punctata Ait. Bladene omvendt-ægformet rudeformede, skarpt- og dobbelt-saugtakkede, forekommer forvildet ved et Gjærde mellem Jægersborg og Lyngby og i Philosophgangen ved Sorø!

\section{Cotoneaster. Mispel.}

656. C. vulgaris [Lindl. Trans. linn. soc. 13 p. 101] (Smaabladet M.) Mespilus Cotoueaster L., H. 517; F. D. 112.

Bladene ægformet-ovale, heelrandede, paa Underfladen (ligesom de unge Grene) hvidfiltede; Blomsterstilkene 1-3blomstrede, fra Bladhjørnerne, tilligemed Bagerranden duunhaarede.

Lav Busk. Bladene var. spidse, budte med en Braad eller udrandede. Kronbladene hvide eller blegrøde; Frugterne rode. 5. (7-8-fr.). h.

Paa Klipper. I Danmark kun funden paa Bornholm i GranitTerrainet paa Østkysten fra Hammershuus til Svanike.

\section{Sorbus. Ren.}

a. Bladene saugtakkede eller lappede.

657. S. torminalis [Crantz Austr. fasc. 2 p. 45] (Tarmvrid-R.) Drej. n. 511 ; Cratægus L., F. D. 798; Pyrus Ehrh., H. 551 .

Bladene æg-hjerteformede, 5-7-lappet-fligede, Fligene saugtakkede, spidse, det nedre Par større, udstaaende; Underbogeret, Blomsterstilkene og de yngre Blade paa Underfladen duuet-graafiltede.

Blomsterne i Halvskjærm (ligesom hos de øvrige Arter). Kronbladene hvide, Frugterue mørkrøde. 6. $\boldsymbol{h}$.

I Kratskove, meget sjelden i Danmark: Bor $n \boldsymbol{h}$. Helligdommen ved Røe (8), paa Lindholms-Klipperne ved Bobbeaaen (20)! Moen ved Ulfshale $(9) ; L$ oll. (Viborg). 献

658. S. Aria [Crantz. l. c. fasc. 2 p. 46] (Axelbær-R.) 
H. 544; H. N. VI, 38; Cratægus Aria $\beta$, L. ․ Suec., F. D. 302 .

Bladene omvendt-ægformede eller ovale, dobbelt saugtakkede med nedadtil efterhaanden svagere Takker, ved Grunden heelrandede, paa Underfladen ligesom Blomsterstilkene og Underbageret sølvhvid-filtede.

Buskagtig. Kronbladene hvide, Frugterne røde, af sød Smag. 5-6. h.

Paa Klippegrund: i Danmark kun vildvoxende paa Bornh. Hammershuus (11)! Helligdommen i Rg Sogn! ved Bobbeaaen og Lindholmsklipperne (Baagøe). Plantet og forvildet omkring Byer, f. Ex. Farumgaard (H.).

659. S. scandica [Fr. Fl. hall. p. 83] (Selje-R.) Fr. nov. p. 138 , H. N. VI, 39 ; S. intermedia H. 544; Cratægus Aria $\alpha$, L. f. Suec.

Bladene ægformet-ovale, fjerlappede (Lapperne saugtakkede, Indsnittenc tiltage $\mathrm{i}$ Dybde nedad mod Grunden af Bladet), paa Underfladen graafiltede.

Større Træ. Kronbladene hvide. Frugterne som foreg., men mindre. 5-6. 5 .

I Skove paa Klippegrund: alm. i Skovene paa Bornholm! I de $ø$ vrige Provindser er den ikke vildvoxende, men forekommer stundom i Plantager.

Anm. Dette Træ findes i Bursers Herbarium, under Navn af Sorbus Herloviana, fra Herlufsholins Skoles Have, med den Bemærkning at Ingen veed hrorfra det er kommet eller livorlænge det har voxet der.

$\dagger$ 660. S. fennica [Kalm Fl. fenn.; Fr. S. Veg. Se. p. 42] (Blandet'R.) H. N. VI, 40; S. hybrida L. fil., H. 543, Cratægus Aria F. D. 301.

Forskjellig fra foreg. ved de foroven fjerfligede, forneden fjersnitdeelte Blade med (især i Spidsen) saugtakkede Flige, Frugterne af syrlig Smag.

Angives fra Bornh. (F. D., H.), men er forgjeves eftersggt der af Alle som senere have besøgt Oen, saa at Angivelsen muligviis turde lidiore fia en Forrexling med foreg. Findes, ligesom de toreg., undertiden plantet omkring beboede Steder.

Haandb, i den danske Flors. 
b. Bladene uligefinnede.

661. S. aucuparia L. (Almindelig R.) H. 542; Drej. n. 510 ; F. D. 1034.

Smaabladene (6-8 Par) oval lancetformede, saugtakkede, paa Underfladen duunhaarede, i ældre Tilstand næsten glatte; Knopperne filtede.

Træ af Middelstørrelse. Kronbladene hvide. Frugterne røde, mindre end hos de foreg., af syrlig Smag. $\frac{5}{2}-\frac{6}{1}$. $h$.

$\beta$, integerrima! Smaabladene heelrandede.

I Skore, ikke sjeldent vildroxende i Danm.; hyppigt plantet i Skove og Haver. $\beta, B$ or $u h$, ved Helligdommen i Rø Sogn (Baagøe).

\section{Pyrus. Abild.}

662. P. communis L. (Pæretræ). H. 548; Drej. n. 509; F. D. 2118 .

Bladene ægformede eller ovale, budte eller kort tilspidsede, heelrandede eller fiint saugtakkede, med ligelang Stilk og Plade; Blomsterne i Halvskjærm; Griflerne frie.

I vild Tilstand ofte buskagtig med Vedtorne; i dyrket Tilstand et anseeligt Træ uden Vedtorne. Frugten ved Grunden afsmalnet $(\alpha$, Achras Wallr.) eller afrundet $(\beta$, Pyraster Wallr.), ikke indtrykt; mellem de saftige Celler findes Korn (o: saftløse Celler med stærkt fortykkede Vægge). Blomsterstilke, Underbægeret og Bladene i Randen og paa Underfladens Nerver duunhaarede. Kronbladene hvide. $\frac{5}{2}-\frac{6}{1}$. (fr. 8-9). h.

I Skove og Krat sporadisk ng ikke alm.: $\boldsymbol{S j}$. Kjøbenhavns Glacier (12), Eremitagen (25), Ermelusdsslsoven (Schum.), Bognæs Vesterskov (20), Kjøge (9), Herlufsholm (H.), Sorø (12), Holsteinborg Strandskov (Nielsen); Mloens Storeklint ved Taleren! Falst. Nøisomhed (14), Gaabense! Loll. Bjerremark (5), i stor Mrugde paa Veilø i Nakskov Fjord (19); F. St. Jørgensgaard! ILindskov, Skjoldemose, Lyø (12); J. Mariager (7); S l. Rylskov i Angel (12), Hadeby red Slesvig (16). Paa de fleste af disse Steder synes den at være virkelig vildvoxende. Dyrkes desuden i Haver under mange Afændringer. $\bar{\varpi}$

663. P. Malus L. (Æbletræ). H. 549; F. D. 1101; Malus silvestris Hoench, Drej. n. 508.

Bladene ægformet-ovale, tilspidsede eller afrundede, saugtakkede, Stilken halvt saa lang som Pladen; Blomsterne i Skjærm; 
Grifterne ved Grunden sammenvoxne; Frugten ved Grundeu navleformigt indtrykt.

Høit Træ, i vild Tilstand stundom med Vedtorne. Kronbladene lysrode eller hvide. $\frac{5}{2}-\frac{\hbar}{1}$. (fr. $8-9$ ). Ђ. Var.

$\alpha$, austera Wallr. (P. aeerba DC.) Bladene og Underbægeret glatte; Frugten af sammensnærpende Smag.

$\beta$, mitis Wallr. De yngre Blade og Underbægeret duunhaarede; Frugtens Smag sød eller syrlig.

I Sknve, Krat og red Gjarder, alm.; $\beta$, sjeldnere, f. Ex. Sj. Charlottenlund! Krat ved Sundbyøster paa Amager (19); $\boldsymbol{F}$. Nyborg Vold (Lund). Dyrkes i mange Afendringer.

\section{Cydonia. Qviede.}

† 664. C. vulgaris [Pers. Syn. II, p. 40] (Alm. Q.) Pyrus Cydonia L., Jacq. Fl. austr. t. 342.

Bladene ovale eller budt-ægformede, heelrandede, paa Overfladen glatte, paa Underfladen guulhvid-filtede; Blomsterne enlige, kortstilkede; Bagerfligene kirtlet-tandede, Kronbladene indvendig, ligesom Grifler og Støvdrayere, ved Grunden filtede; Frugten pæreformet.

Træ af Middelstşrrelse. Kronbladene hvide ell. blegrøde. Frugtens Smag sammensnærpende. 5. (fr. 9). $\boldsymbol{\zeta}$.

Dyrkes undertiden i Haver (oprindelig indført fra Asien), og forekommer forvildet, f. Ex. Horbeløv og Bøunit paa Falst. (Koch)!

\section{Spiraea. Mjodurt.}

a. Urteagtige, med tandede Axelblade. Blomsterstanden quastformet.

665. S. filipendula L. (Knollet M.) H. 552; Drej. n. 504 ; F. D. 635 .

Roden trævlet, Trævlerne hist og her knolleformigt op: svulmede; Bladene paa begge Flader glatte, mellembrudt-fjersnitdeelte, Afsnittene bredere eller smaleri: lancetformede, fjerfligede (Endeafsnittet lige stort med de ovrige); Frugterne krandsstillede, haarede, rette Bællekapsler. 
1-1 $1^{1 / 2^{*}}$ høi. 5-7. Kronbladene hvide, i Knoptilstanden rødlige (da den røde Farve forsvinder efter Udspringningen, er Navnet "rødblonstret", som Hornem. har tillagt den, mindre passende).

Paa Bakker og høie Enge, funden i alle danske Provindser, og i enkelte Egne alm., f. Ex. paa Bornh., i Sj. omkring Roeskilde! og Skjelskør (Nielsen); J. i Hanlıerrederne (16) og Aalborg-Egnen (Branth); i andre Egne sjelden, f. Ex. i den sydlige Deel af Halvøen; ved Helsingør ikke bemærket (21).

666. S. ulmaria L. (Almindelig M.) H. 553; Drej. n. 505 ; F. D. 547 .

Rodtrcelerne ikke opsvulmede; Bladene mellembrudt-fjersnitdeelte, Afsnittene elliptisk-ægformede, uregelm. og dobbeltsaugtakkede (Endeafsnittet trelappet, større end de øvrige); Frugterne glatte, krandsstillede, snoede Bællekapsler.

$2-3^{\prime}$ Fod høi. Kronbladene mindre end hos foreg, hvide (ogsaa i Knoptilstanden), vellugtende; bele Plantẹn har en stærk krydret Lugt naar den gnides. 6-7.

$\alpha$, discolor Koch. Bladene paa Overfladen glatte, paa Underfladen tæt hvidfiltede.

$\beta$, concolor! (S. denudata Hayne). Bladene paa begge Flader grønne og næsten glatte.

Paa Enge og i fugtige Skove alm. udbredt. Formen $\alpha$, er den hyppigste; $\boldsymbol{\beta}$, sjeldnere, f. Ex. Sj. Hellebak! L oll. Steensgaard o. fl. St.; F. Odense, Skaarup alm. (19); nordl. Jyll. (Drej.); Sl. Husum (F. Müll.).

b. Buskagtige, uden Axelblade. Blomsterstanden $\mathrm{klas}$ eformet.

+ 667. S. salicifolia L. (Pilebladet M.) Engl. bot. t. 1468.

Bladene lancetformede, skarpt saugtakkede, glatte; Blomsterstanden en sammensat Klase med korte Grene.

Kronbladene hvide eller lysrode. Var. med Blomster i pyramideformet Top ( $\beta$, paniculata Willd.). 7-8. 々.

Oprindelig indfort som Siirbusk, men forekommer hist og her forvildet i Skove og ved Gjærder, f. Ex. Sj Ruderhegn! Mose S. for Dronninggaard, Jonstrup Vang (14), Gamle Mose ved Lyngby (20); Falst. Nykjøbing (Koeh); Loll. Holmegaard (19); F. Tvede, Dongshoirup, Ollerup, Rødkilde (12); J. Kolding (28); $\boldsymbol{S} t$. Terp (1), alm. ved levende Hegn i Angel! B ornh. Sandllugten ved Rønne (Baagøe). 
† S. tomentosa L. Bladene elliptiske, grovt saugtakkede, paa Underfladen hvidfiltede; Blomsterstanden en pyramideformet Top med længere Grene.

Kronbladene rosenrøde, mindre end hos foreg. $\frac{6}{2}-7$. h.

Forvildet i Ruderhegn (24)!

\section{Polygynia.}

\section{Rosa. Rose. $\left.{ }^{*}\right)$}

a. Spinosissina. Aarsskuddene tæt beklædte med Torne. Bagerfligene (oftest) hele.

668. R. pimpinellæfolia L. (Pimpinelle-R.) Fr. nov. p. 156 ; H. N. X, 52; R. spinosissima L. sp., H. 554; F. D. 398 .

Stongelen og Grenene (især de yngre) tæt beklædte med kortere og længere, rette eller svagt krummede Torne og Borster; Smaahladene rundagtigt-ovale, saugtakkede; Hybenet sammentrykt-kugleformet, kjødfuld-lederagtigt; Bageret vedblivende, dets Flige mod Modningen oprette og sammenstødende.

Lavere og med mindre Smaablade end de følg. Arter. Kronbladene bleggule eller hvide, Hybenet sortrødt, sildigt modnende. 6 . (Fr. 9). h.

I Sandklitterne paa Halve en langs Vesterhavet fra Skagen til Blaavand (H.) og paa de restlige Oer: Romo (16), Sylt, Amrom (H.); $S$.. Sandbakkerne ved Tibirke mod Arresø! forørrigt ikke funden paa Øerne. $\|_{1}$

*) Alle danske Arter af denne Slrgt have uligefinnede Blade med en i omtrent dens halve Længde tokløvet Bladskede. Et af de vigtigste Kjendetegn mellem Arterne er (efter Fries) at søge i Underbægerets (Hybenets) Beskaffenhed, idet dette snart er læderagtigt, snart kjødfuldt eller melet, snart tidligere, snart senere modnende. Behandlingen af denne vanskelige Slægt skylder jeg for en stor Deel Pastor M. T. Lange. 
$\dagger$ 669. R. cinnamomea L. (Mai-R.) H. 554; Fr. l. c. p. 153 ; F. D. 868 (R. fluvialis) og 1214 ; H. N. VII, 45-46.

Aarsskuddene med talrige, rette, de $x$ ldre Grene med faae, bøiede Torne (alm. parvise under Bladene); Smaabladene lancetformet-ovale, saugtakkede, paa Underfladen graaagtigt duunhaarede; Hybenet kugleformet, melet; Bagerfigene vedblivende, opret-sammenstødende.

Barken kanelbrun; Aarsskuddenes Torne smaae og tidligt affaldende, ofte 0 . Kronbladene rosenrøde, Hybenet tidligt modent, rodt. 5-6. (fr. 8). $\boldsymbol{h}$.

Findes paa flere Steder forvildet, f. Ex: $\boldsymbol{S}$. Frederiksberg! J. Dyrehavegaard ved Kolding (30), og dyrkes alm. (med fyldt Blomst) i Haver.

Anm. Den af H. fra Aalborg angivne R. cinnamomea (Beck) er, ifølge Expl. i Drej. Herb., $R$. lucida Ehrh., som hist og her findes plantet i Haver (M. T. Lange i Naturh. Foren. Vid. Medd. 1861 p. 6).

b. Canince. Aarsskuddene med færre Torne, Bægerfligene (oftest) fligede.

$\alpha$, Frugterne læderagtige, sildigt modne (sædv. i October); Tornene seglkrummede.

670. R. rubiginosa L. (Viin-R.) H. 556; Drej. n. 514; Fr. nov. p. 148 ; H. N. III, 41; R. suavifolia Lightf., F. D. 870.

Tornene stærke, seglkrummede, paa de unge Grene uligeformede; Smaabladene ovale eller rundagtigt-ægformede, dobbeltsaugtakkede, med udstaaende, kirtelbærende Takker, paa Underfladen og Bladstilken kirtelhaarede; Blomsterskjærmen oftest fleerblomstret; Blomsterstilkene rette, stivhaarede, Hybenet rundagtig-ovalt, kirtelbaaret eller glat; Bagerfigene tilbagebøiede, temmelig snart affaldende.

Bladene vellugtende (omtr. som Ebler), klæbe ved Tørringen fast til Papiret. Kronbladene mørk-rosenrøde. 6-7. $\zeta_{2}$.

$\beta$, horrida! Stængelen $\mathrm{i}$ hele sin Læugde beklædt med stærkere, mindre seglkrummede Torne.

Ved Gjærder, paa udyrkede Marker, hist og her i alle Provindser, men ikke overalt lige hyppig; sjeldnere i Klitter. $\boldsymbol{\beta}, \boldsymbol{S} \boldsymbol{j}$. Frederiks- 
vark (27)! Hellebak (Heiberg)! F. Nyborg (Lund); J. Svinekløy (Grønlund)! og Hjortels i Hanherred (Drej.).

671. R. inodora [Fr. Fl. hall. p. 85] (Lugtløs R.) H. N. III, 41.

Smaabladene langstrakt-ægformede eller elliptiske, skarpt saugtakkede med faae Kirtelhaar paa Takkerne og Underfladen, forøvrigt glatte, Bladstilkene tæt kirtelbaarede; Blomsterstilkene glatte, Hybenet glat, forøvrigt som foreg.

Bladene have en svag Lugt. Kronbladene hvide (?). 6-7. h.

Ved Gjærder og i Krat: $\boldsymbol{S} \boldsymbol{j}$. Aalsgaard ved Helsingør (12); paa Østenden af Lyø; Nyborgs Volde med foreg.? (12); Bor $n h$. Seiersgaarden ved Ronne (Hoff), Blykobbeaaen (14), Dynddalen ved Rø (Hjorth). *

Anm. Denne Art, som synes at variere meget, nærmer sig i Udseende meest folgende, i Characterer foregaaende Art.

672. R. canina L. (Vild R.) H. 556; Drej. n. 512; F. D. 555 og 1695 .

Stængelens Torne stærke, seglkrummede; Smaabladene elliptiske, jævne, skarpt enkelt saugtakkede med opret-tiltrykte Takker uden Kirtler; Hybenet ved Modenbeden opret, ovalt eller omvendt-ægformet, med efter Blomstringen tilbagebøiede, hurtigt affaldende Bagerflige.

Kronbladene lys-rosenrøde. 6-7. h. En meget foranderlig Art med Hensyn til Bladenes Form og Indskjæring, Takkernes Retning, Frugtens Form o. s. v. De vigtigste Former ere:

* genuina. Bladene glatte og jævne.

$\alpha$, nitida Fr. H. N. VI, 41. Bladene paa Underfladen frisk grønne, paa Overfladen glindsende.

$\beta$, opaca Fr. H. N. VIII, 45. Bladene paa Overfladen matgrønne, paa Underfladen blaagrønne.

** dumetorum H. N. VII, 43. (R. dumetorum Thuill.) Bladene rynkede, paa Underfladen eller begge Flader tiltryktduunhaarede, med mere udstaaende Takker paa Smaabladene. (Nærmer sig R. coriifolia).

*** collina H. N. VI, 42. (R. collina Jaeq., H. 558). Blomsterstilkene kirtlet-stivhaarede; Hybenet omvendt-ægformet, beklædt med enkelte Kirtelhaar, mindre læderagtigt og tidligere 
modent; Bægerfligene længere vedblivende. (Nærmer sig $\mathrm{K}$. tomentosa).

Ved Gjærder og i Kratskove alm. ulbredt $(\alpha$ og $\beta$ ), især meget hyppig paa Bornholm. ** sjeldnere: $\boldsymbol{S} j$. Hellebæk (12), Helsingør (11), Sandbjerg! Falst. N. Kirkeby, Onsløv, Torkildstrup (Koch); $\boldsymbol{F}$. Ollerup, Lyø (12), B or $n h$. ved Bodilsker (20); J. i Hedeegnene. *** paa Bakker, ikke alm., f. Ex $S j$. Hellebæk (12); Loll. Steensgaard (19); F. Ollerup (12); J. Akkedal og Vildsund i Thy (Dr.).

$\boldsymbol{\beta}$, Frugterne kjødfulde eller melede, tidligere modne. Stængelens og Grenenes Torne typisk rette (undtagen hos Nr. 673).

673. R. coriifolia [Fr. Fl. IHall, p. 85] (Stivbladet R.) H. 557 ; Fr. nov. p. 147 ; H. N. VI, 43.

Tornene stærke, seglkrummede, Smaabladene ægformede, enkelt saugtakkede med udstaaende Takker, læderagtige, rynkede, paa Underfladen (eller begge Flader) og Bladstilkene haarede; Blomsterstilliene meget korte, glatte; Hybenet næsten kugleformet, kjødfuldt, glat, med vedblivende, tilsidst oprette Bagerflige.

Kronbladene mørk-rosenrøde. 6-7. (fr. 8-9). $\boldsymbol{h}$.

Paa Marker og ved Gjærder, sjelden: $S j$. Hellebæk (12!), Helsingør (11)! Gurre (Hejberg), Kjøbenhavns Ladegaard ved Vandmøllen (9), Amager (8); Lull. Nakskov (19); $\boldsymbol{F}$. Nyborg (Lund); $\boldsymbol{J}$. Frederikshavns Kirkegaard (Drej. Herb.); $\boldsymbol{S} y \boldsymbol{l t}$ (Gronlund), Fohr (20). I*

Ann. Denne Art er nærmest beslægtet med R. mollissima, men deler de fleste Characterer med R. canina (dumetorum).

674. R. tomentosa [Sm. F]. brit, 2, 539] (Filthaaret R.) Koch Syn. II, 253; H. N. IX, 46; R. mollisima $\alpha$, Drej. n. 515 .

Tornene stærke, rette eller noget krummede; Smaabladene elliptiske, skarpt og dobbelt saugtakkede, med udstaaende Takker, paa begge Flader tiltrykt-duunhaarede; Blomsterstilkene rette, kirtlet-stivhaarede, Hybenet rundagtigt-aflangt, kjødfuldtlæderagtigt, med blaa Dug som let afgnides og let affaldende Kirtelhaar; Bagerfigene udstaaende, temmelig snart affaldende; Kronbladene i Randen glatte.

Bladene graagrønne. Kronbladene mørk-rosenrøde. 6-7. (fr. 9)· Һ̨. 
$\boldsymbol{\beta}$, alba (R. alba H. 558; F. D. 1215; R. eanina-alba Lge. Haandb. 1 Udg. S. 300). Kronbladene hvide.

I Hegn og Kratskove, ikke sjelden i de frugtbarere Egne af Landet. $\beta, \boldsymbol{F}$. Hofmansgave (4), Juelsberg (H.), Nyborg (Lund), mellem Ostrup og Dangstrup (19), Sørup (12); J. Orebro i Hanherred (16); $\boldsymbol{S} l$. Gjarder ved Haderslev (Gronlund)?

Anm. Nærmest beslægtet med R. canina (collina), men deler de fleste Characterer med R. mollissima. $\bar{\square}$

675. R. mollissima [Willd. Prodr. fl. Berol. n. 1237] (Hyben-R.) Fr. S. Veg. I, 174 ; H. N. VII, 42; R. villosa Linn. fl. Suec. \& herb. (ex C. Hartm.), H. 555 ; R. mollissima $\beta$ (R. mollis Sm.) Drej. n. 515; R. ciliatopetala Koeh 1. e.

Tornene rette; Smaabladene elliptisk-ovale eller omvendtægformede, dobbelt saugtakkede, tykke, paa begge Flader stærkt haarede, med ophøiede Nerver paa Underfladen; Blomsterstilkene rette, kirllet-stivhaarede; Hybenet næsten kugleformet, med stive Kirtelhaar, melet; Bagerfigene vedblivende, tilsidst sammenstødende; Kronbladene glatte eller "kiıtlet-randhaarede".

Biadene graaagtige, Kronbladene mørk-rosenrøde. 6-7. Frugterne $(8-9)$ høirøde, glindsende. $\mathbf{h}$.

$\boldsymbol{\beta}$, nemoralis! Bladene mere grønne og mindre haarede, Blomsterne enlige, Hybenet glat (Ligner R. cinnamomea).

$\gamma$, arenaria! Bladene meget smaae, Hybenet glat, ved Grunden afsmalnet, mindre end hos Hovedarten.

I Kratskove og ved Gjærder, ikke sjelden, hyppigst i de magrere Egne af Landet. $\beta$, i Skove: Bornh. Echodalen (20), Allinge! J. Haven i Vendsyssel! $\boldsymbol{\gamma}$, Jædderen ved Kjøge (9)!

Anm. Koch o. fl. Forff. angive Kronbladene som kirtlet-randhaarede, men hos os forekommer den oftest, om ikke altid, uden Randhaar.

676. R. pomifera [Herm. Ros. p. 16] (Spansk Hyben). Fr. nov. p. 150 ; Koch 1. e.; Drej. n. 516 ; Il. N. IX, 47; R. villosa pomifera H. 555 .

Smaaabladene oval-laneetformede, tynde og bløde; Hybenet beklædt med tykke Kirtelhaar; Kronbladene kirtlet-randhaarede; Frugterne meget store, melet-kjødfulde, paa nikkende Blomsterstilke; forøvrigt som foreg., inen i alle Dele større. 
Frugterne mørkrøde, Bladene blaagrønne, klæbe ved Torringen fast til Papiret. 6-7. (fr. 8-9). দ̆.

Ved Gjærder og omkring Byer, funden $\mathrm{i}$ alle Provindser, men sparsommere end foreg., og paa mange Steder forvildet fra Haver, hvor den ofte dyrkes paa Grund af de spiselige Frugter.

\section{Rubus. Klynger.}

a. Urteagtige, med ægformede Axelblade.

677. R. Chamæmorus L. (Multebær). H. 565 ; Drej. n. 517 ; F. D. 1 ; Whe. \& N. Es. Rubi germ. t. 49 .

Rodstokken krybende; Stanglerne (saavel de blomstrende som blonsterløse) oprette, 2-3-bladede; Bladene nyreformede, femlappede, med dobbelt-saugtakkede Lapper; Axelbladene tilvoxne til Stængelen; Blomsterne enlige og endestillede, tvebo; Bagerbladene under Blomstringen tiltrykte; Kronbladene rundagtige eller omvendt-ægformede.

$3-8$ " høi. Kronbladene hvide, Frugterne brandgule. $\frac{5}{2}-\frac{6}{1}$. 4.

I Tørvmoser, sjelden i Danmark og kun funden i det nordl. Jyll. (store Hammelmose i Vendsyssel, lille Vildmose, Tørsløv H., Ulsted N. for Hals (Grønlund) og i Nordsjalland: Helsingør ved Ladegaarden (21), mellem Orsholt og Gurre, paa Tuerne ved Gurre $S ø(11$ !).

678. R. saxatilis L. (Fruebær). H. 564; Drej. n. 518; F. D. 134 ; Whe. \& N. E. I. c. t. 9 .

De blomsterbarende Stangler oprette, de blomsterløse nedliggende eller krybende ; Bladene trekoblede, med rudeformet-ægformede, grovt og dobbelt saugtakkede Smaablade; Blomsterne $3-5$ samlede $\mathrm{i}$ en kortstilket Halvskjærm; Bagerbladene under Blomstringen tilbagerullede; Kronbladene oprette, linie-spadeformede.

Kronbladene hvide, meget mindre end hos foreg., Bær høirøde, sure. $6-7$.

I Skove, funden $\mathrm{i}$ alle Provindser, men sporadisk.

b. Buskagtige, med linie-lancetformede Axelblade.

aa. Idai. Stonglerne oprette, Bladene paa Aarsskuddene uligefinnede, Frugtsamlingen løsnes ved Modenheden fra Frugtbunden.

679. R. idæus L. (Hindbær). H. 560 ; Drej. n. 519; F. D. 788 ; Whe. \& N. Es. 1. c. t. 47 . 
Stangelen trind, beklædt med talrige Naalebørster; Bladene paa Aarsskuddene alm. med 5, paa de blomsterbarende Stcengler med 3, paa Underfladen sølvgraa-filtede, Smaablade; Blomsterstilkene 2-3-blomstrede, i Bladhjornerne eller halvskjærmformet samlede i Spidsen af Grenene; Kronbladene omvendt-ægformede, omtrent halvt saa lange som de ægformede, langt tilspidsede Bagerblade.

Stængelen overtrukken med en blaagraa Dug; Kronbladene hvide, Bær røde (ell. gule). 6 .

$\beta$, microphyllus Wallr. Bladene meget smaae, de nedre trekoblede, de øvre haandfligede.

I Skove og Krat meget alm., dyrkes i Haver (med større Frugter). $\beta, S j$. Holmegaardsmosen ved Broxø!

bb. Fruticosi. Bladene (typisk) fingrede, Frugtsamlingen fastvoxet til Fruytbunden*).

a. Genuini. Aarsskuddene næsten oprette eller i Spidsen svagt boiede, glatte, ikke duggede; Bladene paa begge Flader gronne; Blomsterstauden alm. enkelt; Bregerbladene paa Ryggen gronne, i Randen og paa Inderfladen hvidfiltede, langt tilspidsede.

680. R. suberectus (Anders. Trans. linn. soc. XI, p. 218 t. 16] (Opret K.) H. 563 ; Arrh. monogr. Rub. p. 19; F. D. 1992 ; H. N. VI, 44.

Aarsskuddene oprette, i Spidsen lidet bøiede, forneden trinde, foroven svagt kantede, med faae, svage og rette Torne;

*) Ved Undersøgelsen af denne Afdeling, hvis Arter fremtræde i saa stor Mangfoldighed, bør man lægge Mærke saavel til Aarsskuddene (de blomsterløse Stængler) som de blomstrende Stængler og Grene, da disse saavel i Gjennemsnit som i Henseende til Torne og Blade ere indbyrdes meget afvigende. De Dele af Planten, som afgive de mindst foranderlige Kjendetegn, ere Stængelens Gjennemsnit, Tornene, Blomsterstanden, Brgerbladene og de modne Frugter. Ved enhver Art har jeg søgt at angive det typiske Forhold uden at tage Hensyn til de tilfældigt afvigende, især de i Skygge forekommende Former, som ofte ere saa forskjellige fra Hovedarten, at de blive ukjendelige eller idetmindste vanskelige at henfore til en bestemt Art (Skyggeformerne have alm. tyndere og mere gronne Blade). 
Bladene tynde, tæt og alm. enkelt saugtakkede, med udstaaende Takker, 5-7-koblede, paa de blomsterborende Stangler 3-5. koblede, de nedre Smaablade næsten siddende; Blomsterstanden halvskjærmformet, faablomstret; Krorbladene omvendt.ægformede.

Kronbladene hvide eller blegrøde, Frugterne mørkrøde, glindsende, ofte feilslaaende. $6-7$.

$\beta$, fissus (R. fissus Lindl., Bab. man. 3 ed. p. 93 !) Aarsskuddene mindre oprette, med talrigere Torne; Bladene paa Blomsterstænglerne trekoblede, med kileformede, forneden heelrandede, foroven dybt saugtakkede Smaablade.

I Krat, ved Gjærder og paa udyrkede Marker, hyppig i Landets magre Egne, hror den ofte er den eneste forekommende Art, især paa Halvgen og i Nordsjælland. $\beta$, i Skove ved Rands pr. Fredericia!

681. R. plicatus [Whe. \& N. I. c. p. 15, t. 1] (Brombær). F. D. 2589 ; R. fruticosus L. Fl. Suec., Arrh. p. 23; Drej. n. 520 ; H. N. V, 51. (R. nitidus Whe. t. 4 hører til. samme Art).

Aarsskuddene oprette, i Spidsen bøiede, femkantede, med stærke, fjerne, paa Midten af Stængelen skjævt nedbøiede, foroven og paa de blomsterbærende Stængler seglkrummede Torne; Bladene femkoblede, foldet-rynkede, næsten læderagtige, glindsende, paa Overfladen næsten glatte, paa Underfladen duunhaarede eller tiltrykt-silkehaarede, Endebladet hjerteformet, de øvrige ægformede, tilspidsede, de 2 nedre kortstilkede, alle dobbelt saugtakkede, alm. med udstaaende Tænder; Blomsterstanglernes Blade 3-5-koblede, med ægformei elliptiske Smaablade; Blomsterstanden halvskjærmformet; Bagerbladene mod Frugtmodningen tilbagebøiede; Kronbladene rundagtigt-ovale eller omvendt-ægformede.

Kronbladene hvide ell. lys-rosenrøde, Frugterne sorte, glindsende, velsmagende, noget syrlige. $\frac{6}{2}-\frac{7}{1}$. (14 Dage tidligere end $R$. discolor, dumetorum o. fl. Arter).

$\boldsymbol{\beta}$, fastigiatus (R. fastigiatus Whe. 1. c. t. 2). Aarsskuddene udstrakte; Smaabladstilkene forlængede; Smaabladene og Bægerbladene meget langt tilspidsede. 
Ved Gjærder og i Udkanten af Skove, alm. paa Bornh., i Sjall. og i den sydlige Deel af Halveen, sparsommere i Fyen og det nordl. Jyll. til Aarhuus. $\beta$, i Skove: $S j$. Helsingor (27); J. Brondsted! $\boldsymbol{S} \boldsymbol{l}$. Gjærder ved Aabenraa!

Anm. R. fastigiatus Whe. er aabenbart en Form af R. plicatus, og ikke, som Sond. (fl. hamb. p. 272) antager, synonym med R. suberectus.

* 682. R. affinis [Whe. \& N. E. 1. c. p. 18, t. 3] (Skarptakket K.) Arrb. p. 25 ; H. N. VI, 45 ; R. plicatus** adfinis Lge. Haandb. 1 Udg. p. 305.

Aarsskuddene mere bøiede, femkantede med furede Sider; Smaabladene elliptisk-ægformede, paa de blomsterbærende Grene sammenknebne, skarpt og ofte dobbelt saugtakkede, med opadrettede Takker; Blomsterstanden forlænget, klase- eller topformet; Bugerbladene mindre langt tilspidsede, mod Frugt. modningen udstaaende, forøvrigt som foreg.

Krombladene hvide, Frugterne sorte. 7-8.

I Kratskove og ved Gjærder, micget sjeldnere end foreg.: $\boldsymbol{S}$. Hjulebækshuset ved Helsingør (9); J. Brøndsted ved Frederieia; $\boldsymbol{S}$. Aabenraa!

Anm. Denne Art er nærmest beslægtet med R. plieatus, med hvilken jeg tidligere havde forenet den, men de fleste Forfattere erklære den for en selvstæendig Art, $\mathrm{og}$ i flere Characterer staaer den nærved R. thyrsoideus, med hvilken den ogsaa i Fl. dan. er forvexlet: den danner saaledes et Overgangsled til den folgende Gruppe. De her fundne Expl. staae midt imellem den hos Whe. afbildede og de svenske Former, som ere betydeligt afvigende.

及, Discolores. Aarsskuddene udstrakte eller overhængende (med alm. stærke Torne), Bladene alm. graafiltede paa Underfladen, det nedre Par Smaablade stilkede; Blomsterstanden forlænget (Klase eller

Top); Bægerbladene overalt graafiltede (typisk kort tilspidsede).

re, Aarsskuddene glatte, femkantet-furede.

683. R. thyrsoideus [Wimm. Fl. v. Schles. p. 131] (Duskblomstret K.) Arrh. p. 28; H. N. III, 42; R. fruticosus Whe. t. 7 ; R. affinis Lbm. i F. D. 2539.

Aarsskuddene ved Grunden oprette, i Spidsen buekrummede, dybt furede, med 5 budte, fremstaaende Kanter, glatte, oned stærke, fjerne, forskjelligtformede Torne; Bladene fem- 
koblede, med ægformet-elliptiske, ved Grunden sammenknebne, paa Overfladen glatte, paa Underfladen filtede Smaablade; de blomsterbarende Grene haarede; Bladene trekoblede, med lancetformet-omvendt-ægformede Smaablade; Blomsterstanden forlænget, top- eller klaseformet; Bagerbladene mod Frugtmodningen nedbøiede; Kronbladene omvendt-ægformede.

Kronbladene hvide eller blegrøde. "Frugterne sorte, glindsende, velsmagende" (Arrh.). 7-8.

Følgende Former adskilles:

$\alpha$, candicans Bl. \& Fgh. ( $R$. fruticosus Whe.) Bladene paa Underfladen bvidfiltede, Endebladet æg-hjerteformet.

$\beta$, gracilis Godr. ( $\alpha$, oblongifolius Metsch i Linnæa 28, p. 125) Bladene paa Underfladen graagrønt filtede, Endebladet ægformet, Klasen sammenkneben, næsten enkelt.

Ved Gjærder og Skovkanter, især i de sydlige Egne af Landet, ikke alm.: B ornh. ved Allinge! Gudhjem, Randkleven (8), Nexø (11); $M e$ en red Liselund (Dr.); $\boldsymbol{S}$. Store Hareskor mellem Syvstjernen og Kulhusene (14), Gjorsløv Bøgeskov (9), $S l$. Veesriis ved Rylskov! $\beta$, Holbæk (Dr.)! $S l$. Aabenraa!

Anm. Til denne Art henføres desuden $R$. cordifolius Whe. t. 5 og $R$. rhamnifolius Whe. t. 6 , men disse Former ere ikke hidtil fundne i vor Flora.

$\beta \beta$, Aarsskudd€ne haarede (ikke kirtlede), kantede, men ikke furede.

684. R. vulgaris [Whe. \& N. E. l. c. p. 39 t. 14 (Skov-K.) Sond. f. hamb. p. 275 ; Metsch i Linnæa 28 p. 144; R. fruticosus F. D. 1163 ; H. N. X, 53 (R. Sprengelii) og XIII, 60 (R. umbrosus).

Aarsskuddene budt femkantede, mere eller mindre haarede eller tilsidst næsten glatte; med næsten rette Torne, femkoblede, paa begge Flader grønne, paa Overfladen næsten glatte, paa Underfladen blødt duunhaarede Blade; Smaabladene bredt ægformede, Endebladet kredsrundt-hjerteformet; Blomsterstanden klaseformet, næsten enkelt; Bagerbladene mod Frugtmodningen tilbagebøiede.

Kronbladene hvide eller blegrøde. "Frugterne store, sorte, velsmagendeu. 6-7. 
$\alpha$, umbrosus Whe. \& N. E. (Arrh. p. 31). Metsch I. c. p. 145 ; R. discolor ${ }^{*}$ umbrosus Fr., Lge. Haandb. 1 Udg. S. 308). Aarsskuddene med rette Torne, større og bredere, paa Underfladen grønne Smaablade.

$\beta$, carpinifolius Bl. \& Fgh. (Sond. I. c. p. 276 ; R. earpinifolius Whe. t. 13). Tornene noget bøiede, Smaabladene smalt ægformede, tilspidsede, paa Underfladen stundom graafiltede, Blomsterne større.

Paa skyggefulde Steder, ikke alm.: J. ved Brøndsted; Sl. Aabenraa, Flensborg!

Anm. 1. Denne Art har jeg tidligere betragtet som en Underart af $\mathbf{R}$. discolor, fra hvilken den i Characterer vanskelig kan sondres, skjøndt den i Udseende er meget forskjellig fra samme. Foruden de nævnte Former henfores (af Metsch l. c.) hertil endnu $R$. silvatieus Whe. t. 15 og $R$. villicanlis Whe. t. 17, men disse har jeg ikke med Sikkerhed kunnet erkjende i vor Flora.

Anm. 2. R. macrophyllus Whe. t. 12 (og dens Underart $R$. Schlechtendalii Whe. t. 11) forekommer uden Tvivl i vor Flora, og maa eftersøges. Den danner et forbindende Led mellem $R$. vulgaris og Gruppen Corylifolii.

685. R. discolor [Whe. l. c. p. 49 t. 20] (Forskjelligfarvet K.) F. D. 2414 ; H. N. VIII, 48; R. vulgaris * discolor Arrh. p. 32 ; R. fruticosus Sm. (L. herb.?, ikke Fl. Suec.)

Aarsskuddene skarpt kantede, tiltrykt-silkehaarede eller svagt haarede, med stærke, rette eller lidet bøiede Torne; Bladene fenkoblede, læderagtige, med elliptisk-ægformede, tilspidsede, paa Underfladen grøn- eller hvidfiltede, paa de blomsterbarende Grene trekoblede Smaablade; Blomsterstanden forlænget, med talrige krummede Torne; Bagerbladene efter Afblomstringen nedbøiede; Kronbladene onvendt-ægformede.

Stængelen alm. rødbruun; Kronbladene blegrøde eller hvide, Frugterne morkviolette, søde, med talrige Smaafrugter. 7.

Forekommer hos os især under følgende 2 Former:

$\boldsymbol{\alpha}$, genuinus (R. discolor Whe.) De blomsterbærende Grene zigzagbøiede, svagt haarede, Bladene tætsildende, ined kortere Bladstilke, paa Underfladen graa- eller hvidfiltede, med finere Aarer. 
$\beta$, pubescens Bl. \& Fgh. (R. pubescens Whe. t. 16). De blomsterbærende Grene tæt haarede, næsten rette, Bladene fjernere, med meget lange Bladstilke, paa Underfladen grønfiltede, med grovere Aarer.

Ved Gjærder og i Udkanten af Skove, bemærket $\mathbf{i}$ alle Provindser, men ikke i alle Egne lige hyppig; meest udbredt i det sydøstl. Jyll. Formen $\boldsymbol{\beta}$, er hos os hyppigere end $\boldsymbol{\alpha}$.

686. R. vestitus [Whe. l. c. p. 90, t. 33] (Rundbladet K.) R. discolor Drej. n. 522 (ex part.); R. leucostachys $\beta$, vestitus Bab. Brit. Rub. p. 15.

Aarsskuddene budtkantede, tret haarede af udstaaende Haar; Tornene stærke, rette; Bladene femkoblede, læderagtige, meget faste, paa Underfladen sølvglindsende af en tæa hvid eller guulgrøn Filt, Smaabladene næsten kredsrunde, pludseligt, men kort tilspidsede, skarptandede og noget bølgede i Randen; Blomsterstanden forlænget, udbredt og rigblomstret, med lange og spidse, næsten rette Torne, Bagerbladene efter Afblomstringen nedhængende; Kronblade som hos foreg.

Stærk og anseelig Væxt, Kronblade og Støvtraade mørk rosenrøde, sjeldnere hvide. Frugterne sortviolette, sødagtige, med smaae og talrige Smaafrugter. $7-8$.

$\beta$, viridis! Bladene paa begge Flader grønne, med lang. stilkede Smaablade, Tornene meget lange, rette; Blomsterstanden faablomstret, bladet indtil Spidsen.

Ved Gjarder. En af de hyppigste Rubus-Arter paa Halvoens Ostkyst, i det sydl. Fyen og især paa Thorseng, Langel. og Loll.! Falster red Gaabense! S $j$. Pedersborg ved Sorø! Moen! $\boldsymbol{\beta}, \boldsymbol{J}$. i Skove ved Dyrehavegaard pr. Kolding! $\boldsymbol{F}$. Veistrupgaard; L oll. Vesterborg (19); Falst. Lindeskoven ved Nykjøbing (14). (I Angel forekommer hyppigt den hvidblomstrede Form, som $\mathrm{i}$ det $\emptyset$ vrige Danmark er sjelden. Denne Form er ogsaa bemærket i Fyen ved Skaarup (14). 周

$\gamma \gamma$, Aarsskuddene beklcodte med talrige Haar, Kirtler og Naaleborster.

687. R. Radula [Whe. 1. c. p. 100 t. 39] (Børstehaaret K.) F. D. 2413 ; H. N. VIII, 47; R. vulgaris * Radula Arrh. p. 34 ; R. hirtus Drej. в. 525 (ex loc., non W. K.).

Aarskkuddene skarpt kantede, med flade, stribede Sider, faae, men stærke og rette Torne; Bladene femkoblede, Smaabladene 
tilspidsede, tæt og dobbelt tandet-saugtakkede, paa Underfladen graafiltede, Endebladet xg-hjerteformet, de øvige ærformetelliptiske; Bladstilkene og Nerverne paa Underfladen tæt beklædte med krumme Torne; de blomsterburende Grene kantede, tret kirtlet-haarede, med lange, rette Torne, som blive hyppigere op imod Spidsen, Blomsterstanden rigblomstret, forlænget, undertiden pyramideformet; Blomsterstilkene og de efter Afblomstringen nedbøiede Bagerblade beklædte med en tæt Filt og talrige Kirtelhaar; Kronbladene omvendt-ægformede.

Stærk og kraftig Væxt, let kjendelig fra de foreg. ved den rige Beklædning med Børster og Kirtelhaar, hvis øvre Deel tidligt affalder, medens den nedre Deel er vedblivende og gjør Stængelen ru at føle paa; Kronbladene hvide, sjeldnere blegrode; Frugterne sorte, glindsende, søde, med talrige Smaafrugter. 7-8.

$\beta$, Köhleri (R. Köhleri Whe. t. 25). Aarsskuddene svagt kantede; Bladstilkene og Blomstergrenene beklædte med talrigere Torne og Kirtler, Blomsterstanden indtil Spidsen bladbærende.

Ved Gjarder og i Randen af Skove meget alm. i Danmark. $\beta$, Gjærder ved Aabenraa!

Anm. Til denne Art høre R. rudis, R. Reichenbachii o. fl. af de hos Whe. 1. c. afbildede og beskrevne Arter, Ivilke jeg ikke engang som Former formaaer at adskille ved bestemte Kjendetegn.

$y$, Divergentes. Aarsskuddene svagt kantede eller næsten trinde, baarede, uden Dug eller Kirtler; Bladene 3-5-koblede, eens paa begge Arter Strngler, de nedre Smaablade kortstilkede eller stilklose; Blomsterstandens Grene udspilede; Bægerbladene langt tilspidsede.

688. R. Sprengelii [Whe. l. e. p. 33, t. 10] (Rødblomstret K.); H. 563 ; F. D. 1697 (Bladene t. 1696); H. N. XV, 49; R. Borreri Bell-Salt. (Bab. Brit. Rub. p. 16).

Aarsskuddene nedliggende og mangegrenede, budtkantede, med talrige, seglkrummede Torne; Bladene skarpt sangtakkede, paa begge Flader grønne og haarede, Nerverne paa Underfaden stærkt fremtrædende, alm. trekoblede, med ægformet, tilspidset Endeblad og skjavt-ægformede, tolappede Sideblade, sjeldnere femkoblede med de nedre Smaablade elliptiske og Bladstilkene af de 2 nedre Smaablade paa hver Side sammenvoxne; Bladene paa de blomsterbarende Stcengler trekoblede med rudeformet- 
elliptiske Smaablade, Blomsterstanden balvskjærmformet, med faablomstrede Grene, faae og svage Torne; Bagerbladene efter Afblomstringen udstaaende; Kronbladene omvendt-ægfornede.

Let kjendelig fra alle andre Arter ved Torne, Bladform og Blomsterstand. Kronbladene smukt og mørkt rosenrøde. Frugterne sorte, glindsende. $7-8$.

I Skove sjelden, især paa Øerne: $\boldsymbol{S} \boldsymbol{j}$. Hjortenæs Skov ved Sorø! Falst. Hanenor Skov (14); $\boldsymbol{F}$. Hverringe (H.); Sl. Ostenfeld pr. Husum (Didr.!), Aabenraa! Hunsby i Angel (28), Holtenau! og sandsynligviis flere Steder paa Ostkysten. 자

* 689. R. Arrhenii [Lge. Haandb. 1 Udg. S. 209 under R. Sprengelii].

Aarsskuddene trinde, med færre, svagere og mindre krumme Torne; Bladene paa begge Arter af Stængler femkoblede; Smaabladene tilspidsede, tæt og skarpt saugtakkede, Endebladet ægformet, de øvrige elliptiske (det nedre Par meget kortstilkede), Bladstilken og de paa Underfladen stærkt ophøiede, guulagtige Nerver haarede, forøvrigt næsten glatte; Blomsterne i Top med rigtblomstrede Grene; Kronbladene smaae, guulhvide, forøvrigt som foreg. (Frugterne ubekjendte).

I Marieskoven ved Flensborg (August 1846), Veesriis ved Rylskov i Angel! Uagtet jeg kun har fundet den paa disse faa Steder, kan jeg dog ved gjentagen Undersøgelse ikke andet end antage den for forskjellig saavel fra $R$. Sprengelii som fra $R$. hirtus, med hvilke den er meest beslægtet, og anbefaler den forøvrigt til nærmere Uudersøgelse. Med ingen anden af de her forekommende Arter kan den forvexles; kun $R$. scaber Whe. t. 32 har endeel Lighed med den, men denne Art afviger ved en tret Beklæduing af Kirtler paa Stænglerne, trekoblede Blade paa de blomsterbærende Stængler o.s.v.

$\delta$, Glandulosi. Aarsskuddene trinde, nedliggende, ofte rodslaaende, tæet beklædte med Kirtelhaar og smaae Torne; Blomsterstandens Greneudspilede; Brgerbladene langt tilspidsede, med talrige Børster og Kirtelhaar; Frugterne glindsende, sorte (ikke duggede).

690. R. hirtus [Waldst. \& Kit. Pl. rar. Hung. II, p. 150, t. 114] (Stivhaaret K.) H. II, 192; F. D. 2053! (ikke Drej.); Whe. t. 43.

Aarsskuddene stilkede, forneden trinde, foroven svagt kantede, tæt beklædte med forskjelligtformede Torne, Naalebørster, Haar og Kirtler; Bladene 3-5-koblede, paa Overfladen svagt, paa 
Underfladen tæt-haarede, graagrønne, med ægformet-elliptiske, langt, men ikke pludseligt tilspidsede Smaablade; de blomsterbarende Grene beklædte som Aarsskuddene, men med længere og stærkere Torne; Blomsterstanden forlænget, alm. bladet indtil Spidsen ( $R$. foliosus Whe. t. 28), med udstaaende Blomsterstilke; Bagerbladene grønne med hvid Rand, efter Afblomstringen udstaaende eller tilbagebøiede; Kronbladene smaae, omvendtægformede.

Kronbladene hvide. "Frugterne sorte, glindsende, med talrige Smaafrugter". 7.

I Skove, sjelden, og hidtil kun funden $\mathbf{i}$ de sydlige Dele af Halve en: Skamlingsbanken! Jels Skove (28), Lyksborg (12), Veesriis red Rylskov! 再

Anm. Til denne Art henhore endnu R. Menkei Whe. t. 22, $R$. apiculatus Whe. t. $24 \mathrm{og}$. Hystrix Whe. t. 41, hvilke Former dog ikke ere fundne hos os.

691. R. glaudulosus [Bell. App. fl. ped. 24] (Kirtelhaaret K.) H. 562 ; Arrh. p. 40 ; F. D. 1696 (undt. Bld.); H. N. V, 52 .

Aarsskuddene overalt trinde, tæt beklædte af Naalebørster, Kirtelhaar og meget svage Torne; Bladene trekoblede, paa begge Flader grøme, glindsende af tiltrykte Haar, med xgformetovale, pludseligt og langt tilspidsede, fiint saugtakkede Smaablade; Bladene paa de blomsterbarende Grene trekoblede, ned omvendt-xgformede, grovt saugtakkede, budte eller kort tilspidsede Smaablade (de øverste under Blomsterne alm. enkelte, ag-hjerteformede), Blomsterstanden kort, halvskjærmformet, med udstaaende Grene og Blomsterstilke; Bagerbladene grønne med en hvid Rand, efter Afblomstringen tiltrykte; Kronbladene smale, spadeformede.

Kronbladene hvide, Frugterne sorte, glindsende, velsmagende. Bladene har jeg stedse fundet trekoblede (i det sydlige Europa forekommer den ogsaa med femkoblede Blade). 7-8.

$\alpha$, genuinus Gren. \& Godr. fl. Fr. p. 542, (R. Bellardi Whe. t. 44). Bladene mørkgrønne, læderagtige, Stængelen bruun. 
$\beta$, umbrosus Godr., (R. Güntheri Whe. t. 21 ?). Bladene tynde, tilligemed Stænglerne lysgrønne; den blomsterbærende Stængels Blade med tilspidset-ægformede Smaablade, Blomsterstanden mere forlænget.

I Skove ( $\boldsymbol{\alpha}$, paa solaabne Pladser, $\boldsymbol{\beta}$, i Skygge), kun funden paa Halvøen: J. Mindstrup! Veile! Kolding (28); $\boldsymbol{S}$. hyppigere, f. Ex. Jels (12), Flensborg! Lylksborg (12), Veesriis ved Rylskov! Schnellmarker Skov ved Egernførde (16).

692. R. serpens [Gren. \& Godr. Fl. Fr. p. 538] (Krybende K.) R. cæsius $\varepsilon$, hispidus Whe. t. 46 .

Aarsskuddene ved Grunden trinde, foroven budtkantede, blaaduggede, beklædte med talrige Kirtelhaar og støre eller mindre, alm. rette Torne; Bladene trekoblede eller femkoblede med Bladstilkene af de 2 nedre Smaablade paa hver Side sammenvoxne, Smaabladene rynkede, paa Overfladen grønne, næsten glatte, paa Underfladen graagrønne, duunhaaret-filtede, skarpt og dobbelt saugtakkede; Blomsterstanden forlænget, 23-dobbelt sammensat, med halvskjærnformede Grene og talrigere og stærkere, ofte krumme Torne; Bagerbladene paa begge Sider graafiltede, efter Afblomstringen tiltrykte; Kronbladene omvendt-ægformede.

Ved Gjærder, sjelden: J. Kolding (28); $\boldsymbol{F}$. Ollerup!

Anm. De Expl. jeg har seet herfra, have alle en stærkt blaadugget Stængel, livilket ikke er Tilfældet med den fra Frankrig af Godr. beskrevne Art. Da den danske Form forøvrigt stemmer temmelig overeens med Bekr. (1. c.) og den citerede Fig. hos Whe., har jeg henfort den hertil; i Beklædningen staaer den mellem $I$. Radula og glandulosus, i Habitus ligner den $R$. dumetorum, Bladene minde om R. ccesius, men fra enhver af disse Arter er den saa afvigende at den ikke kan indordnes under nogen af dem. Frugterne ere mig ubekjendte: de beskrives sorte, glindsende (Godr.).

E. Corylifolii. Aarsskuddene fremliggende eller udstrakte, trinde eller svagt kantede, (uden Kirtler og oftest uden Haar, undertiden duggede); det nedre Par Smaablade stilkløse; Bægerbladene hvidfiltede, alm. kort tilspidsede.

* 693. R. Wahlbergii [Arrh. 1. c. p. 43] H. N. IX, 49; R. latifolius Bab.! R. corylifolius $\beta$, intermedius Wahlb.

Aarsskuddene nedbøiede, budtkantede, glatte, med forskjelligtformede, større og mindre, ofte stærke, Torne; Bladene 
femkoblede, Endebladet hjerteformet, de øvrige Smaablade ægformede, dybt og dobbelt tandet-saugtakkede, paa begge Flader grønne eller paa Underfladen hvidfiltede; $d \epsilon$ blomsterbarende Grene duunhaarede med stærke og talrige, oftest krumme Torne, store trekoblede Blade med rudeformet-xgformede, grovttandede Smaablade; Blomsterstunden en rigt.. blomstret Top, sammensat af korte halvskjærmblomstrede Grene, de nedre Greue fjerne, i Bladhjørnerne; Bagerbladene kort tilspidsede, udstanende fra den modne Frugt; Kronbladene rynkede, kredsrundt-ovale, smalere nedentil.

Kronbladene blegt rosenrøde ell. hvide, større end følg. og ofte i storre Antal, saa at Blomsten bliver halvfyldt (f. Ex. ved Hellebæk! Skaarup (19)! "Griflerne grønne", Frugterne mørkblaae, sure. 7 -8.

Ved Gjæerder: Sj. Kongens Møller! Helsingør (Dr.); Hellebæk! F alst. Gaabense! F. Skaarup (19), Svendborg! Staagerup (12); $\boldsymbol{J}$ Nebbegaard! $\boldsymbol{S} l$. Rylskov! og sandsynligviis ogsaa i de $ø$ vrige Provindser.

694. R. corylifolius [Sm. Fl. brit. 2, p. 542] (Hasselbladet K.) Drej. n. 524; F. D. 2538; Engl. Bot. 827; H. N. IX, 50 .

Aarsskuddene bueformigt nedbøiede, budtkantede eller næsten trinde, glatte eller svagt baarede, med ensformede, smaae og rette Torne; Bladene femkoblede, læderagtige, Smaabladene i Randen bølgede, paa Overfladen grønne, svagt haarede, paa Underfladen lysgrønnne, tæt duunhaarede, Endebladet bredt hjerteformet, de øvrige ægformede; de blomsterbarende Grene furede, duunhaarede, med smaae, næsten rette Torne; Blomsterstanden halvskjarmformet; Bager- og Kronblade som hos foreg.

Stængelen paa aabne Steder mørkrod; Bladene ofte meget store, $\beta$, grandifolia nob. (H. N. VII, 48), Smaabladene ligne Hasselblade; Kronbladene hvide; Griflerne gronne; Frugterne store, mørkviolette, saftfulde, men af vandet Smag. 7.

$\alpha$, genuinus! (R. corylifolius Arrh. p 16). Aarsskuddene budtkantede, ikke duggede, Kronbladene bredt omvendt-xgformede. 
$\beta$, pruinosus (R. pruinosus Arrh. p. 15; H. N. VII, 47). Aarsskuddene trinde, beklædte med en blaagraa Dug; Bladene 5-7-koblede; Kronbladene kredsrundt-ovale, bredere nedentil.

$\gamma$, appendiculatus! Blomsterstandens Grene forlængede, udspærrede, 1-3-blomstrede; Bægerbladene i Spidsen bladagtigt forlængede.

I Skove og Krat, ved Gjærder, en af de almindeligste Arter i Danmark, især paa Halvøens Østkyst. $\beta$, paa solaabne Steder ikke sjelden. $\gamma, \boldsymbol{S} j$. Brede (27); $\boldsymbol{J}$. St Lindholmsklipperne paa Bornh. (20)!

* 695. R. dumetorum [Whe. \& N. E. 1. c. p. 111, tab. 45 A] (Lund-K.) Metsch l. c. 111 (tildeels); R. nemorosus Hayne Arzn. 3, t. 10 ?, H. 561; Arrh. p. 45 (ikke Sond.); H. N. VI, 47.

Aarsskuddene nedliggende, trinde eller svagtkantede, alm. blaaduggede, med svage, ensformede, rette Torne; Bladene mindre læderagtige end hos foreg., 3-5-koblede, Endebladet ægformet, ved Grunden sammenknebet; Blomsterstanden faablomstret, balvskjærmformet; Bagerbladene tiltrykte til den modne Frugt; Kronbladene omvendt-ægformede, forøvrigt som foreg.

Adskilles fra foreg. ved de langstrakte, aldeles nedliggende Stængler, de tyndere Blade med mindre og anderledes formede Smaablade. Kronbladene livide eller blegrøde; "Grifferne blegrøde ; Frugterne sorte, syrlige med store, men faae Smaafrugter. 7-8.

a, glabratus Arrh. De blomsterbærende Grene og Bladenes Underflade svagt baarede.

$\beta$, tomentosus Arrh. (R. dumetorum $\beta$, tomentosus Whe. t. $45 \mathrm{~A})$. De blomsterbærende Grene duunhaarede, Bladene rynkede, paa Underfladen hvidtiltede.

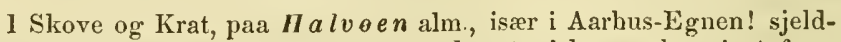
nere paa $\theta$ erne. $\alpha$, syues at være den typiske og hyppigst forekommende Form. $\boldsymbol{\beta}$, i Skove ved Haraldshund i Jyll.!

Anm. Gruppen Corylifolii er sikkert den vanskeligste af hele Slægten at bestemme, og det er i mange Tilfælde ikke let muligt at afgjøre, til livilken af disse tre Arter en given Form hører. Da imidlertid enhver af dem har $\mathrm{i}$ sine typiske Former et eiendommeligt Habitns, har jeg her vedligeholdt Adskillelsen, uden dog at ville lægge swerlig Vægt paa denne Sondring. Trertimod er jeg snarere tilborielig til, med Sonder (Fl. hamb. p. 284), Areschoug (Bot. Not. 1855 p. 31) 
o. Fl. at ansee R. Wahlbergii for en storre og mere ndviklet Form af $\mathbf{R}$. corylifolius, men med ligesaa god Ret troer jeg da at man bor foro R. dumetorum ind uuder samme Art, da man ogsaa af denne kan parvise talrige Overgangsformer til R. corylifolius. R. Wahlbergii danner, paa Grund af de starkere Torne, den kantede Stængel, forlangede Blomsterstand og udstaaende Bægerblade, et Mellemled til R. vulgaris, derimor nærner $\mathrm{R}$. dumetorum ved de vidtkrybende Aarsskud, den halvskjarmformede Blomsterstand og tiltrykte Bagerblade sig til $R$. casius. $R$. pruinosus Arrh. er neppe nogen selvstændig Art; de for den angivne Kjendetegn har jeg ikke fundet constante, og navnlig er Stængelens Overtrak med blaa Dug en Egenskab, som for en stor Deel afhaenger af Voxestedet og kan forekomme hos alle de 3 Former af Gruppen Corylifolii.

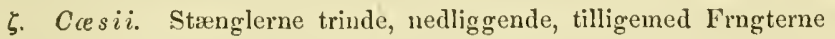
blaaduggede; Bregerbladene langt tilspidsede.

696. R. casius L. (Korbær-K.) H. 560 ; Drej. n. 523 ; Arrh. p. 50 ; Whe. t. 46 ; F. D. 1213.

Stcenglerne glatte, blaaduggede, tæt beklædte med korte og svage, let affaldende Torne; Bladene trekoblede, paa Underfladen graafiltede, Smaabladene skjavt agformede, grovt og dobbelt tandede, Endebladet alm. trelappet, Sidebladene tolappede; Blomsterstanden kort og faablomstret; Bagerbladene tiltrykte til den modne Frugt; Kronbladene ovale, i Spidsen indtrykte.

Krombladene hvide, Frugterne blaaduggede, af syrlig-vandagtig Smag. $6-7$.

$\boldsymbol{\alpha}$, umbrosus Wallr. Stængelen svagt beklædt, Bladene paa Underfladen grønne.

$\boldsymbol{\beta}$, agrestis Whe. t. 46 A. Stængelen tæt duunhaaret; Bladene læderagtige, paa Underfladen graafiltede.

$\gamma$, aquaticus Whe. t. 46 A. Bladene paa Overfladen glatte, paa Underfladen svagt haarede og grønne, Brgerbladene langt tilspidsede, Kronbladene onvendt-ægformede med lang Negl.

$\delta$, pseudo-idœus Whe. t. 46 B. (R. Idæus $\boldsymbol{\beta}$, canescens Metsch 1. c. p. 105). Bladene finnede; Blomsterne sædvauligt ufrugtbare.

Alm. udbredt i Danmark: $\boldsymbol{\alpha}$, i Skove; $\beta$, paa Marker og ved

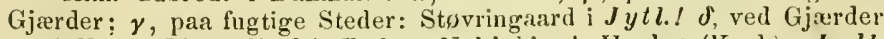
og i Krat: Sj. Vedbak! Fals $\boldsymbol{l}$. Nykjobing! Huulsø (Koch); Loll. 
Stokkemarke, Steensgaard, Engestofte; $\boldsymbol{F}$. i det sydøstlige alm. (19); J. Krybily (28) og Dyrehavegaard ved Kolding! Sl. Aabenraa!

\section{Fragaria. Jordbaer.}

697. F. vesca L. (Almindelig J.) H. 566; Drej. n. 526; F. D. 2235 .

Rodstokken udskyder Ranker; Bladene trekoblede, med rudeformet-elliptiske, dybt saugtakkede Smaablade; Blomsterstilkene tiltrykthaarede; Bogeret ved Frugtens Modenhed udstaaende eller tilbagebøiet.

Skaftet 6-8" høit, omtr. af Længde med Bladene, Kronbladene hvide, Frugterne hoirøde (sjeldnere livide), syrligt-krydrede. 5-6 (fr. $6-7$ ). 4 .

Alm. ved Gjærder, paa Bakker og i aabne Skove. Dyrkes i flere Afarter.

698. F. collina [Ehrh. Beitr. 7, p. 26] (Bakke-J.) H. 569 ; Drej. n. 527 ; F. D. 1389 ; H. N. VI, 49.

Bageret ved Modenbeden tiltrykt til den mørk-rosenrøde, søde Frugt, forøvrigt som foreg. 5-6. (fr. 6-7). ข.

Paa Bakker og i hojtliggende Skove, bemærket i alle danske Provindser, men sporadisk og ikke alm., hyppigst paa B or $n h$.

† 699. F. elatior [Ehrh. l. c. p. 23] (Spansk J.) H. 567; Drej. p. 183 ; H. N. VI, 48.

Blomsterstillienes Haar udstaaende; Bageret ved Modenheden ti'bagebøiet eller udstaaende, forøvigt som foreg., med Sliaftet længere end Bladene ( $1 / 2-1^{\prime}$ høit), Blomsterne større. (Ofte feilslaaer det ene Kjøn, saa at den bliver trebo. 5-6. (fr. $6-7) .4$.

Dyrkes alm. i Haver, og er derfra forvildet ved Gjærder og i Skove: S j. Fredensborg, Frederiksborg (15), Ruderhegn! Gjels Bakke (14), Kaningaarden (9), Jexgersborg Allee! Sondermarken! Philosopligangen ved Soro! Mo en ved Liselund! alm. i det gstl. Falst. (14); $\boldsymbol{F}$. Hvidkilde! J. Jungetgaard i Salling (16), Haraldslumd! $S$ l. Haderslev, Nyværk ved Slesvig (16), 乌usum (F. Müll.).

Anm. Foruden de foreg. dyrkes i Haver: $F$. virginiana (engelsk J.), F. grandiflora (Ananas-J.) o. fl. Arter. 


\section{Potentilla. Potentil.}

a. Bladene fingrede.

aa. Fragariastrum. Smaafrugterne ved Grunden haarede, Kronbladene hvide.

700. P. Hragariastrum [Ehrh. Herb. 146] (Jordbæragtig P.) P. Fragaria Sm., H. 577; Drej. n. 530; H. N. XIV, 54; Fragaria sterilis L., F. D. 1579.

Rodstokken krybende, med rankeformede blomsterløse $\mathrm{og}$ oprette eller opstigende blomsterbærende Grene; Bladene trekoblede, med omvendt-ægformede, fra Midten til Spidseu rundeller saugtakkede Smaablade; Blomsterne parvise eller enlige i Spidseu af Grenene; Frugtbunden haaret; Kronbladene omvendthjerteformede, lidet langere end Bægeret.

Hele Planten silkehaaret, Haarene paa Bladene tiltrykte, paa Bladstilke og Strengelen udstaaende. 5. य.

I Randen af Skove, paa Gresmarker, sporadisk og ikke alm.: $S j$. Høirup paa Stevns (Balslev), Ny Tappernoje (9), Krat ved Nysø (Stampe); Bornh. Buskegaard ved Romne (Hjorth), Skraenter ved Melsted Aa, Almindingen (Baagoe); Meen ved Marienborg (9); Falst. Stubbekjøbing (25) o. fl. Steder i det østlige (14); L oll. Nakskor $(9) ; \boldsymbol{F}$. Vindinge (E. C. Lange); $\boldsymbol{A} l \boldsymbol{s}$ ved Mintlerg (20); $\boldsymbol{S} l$. Haderslev (Gronlund), Sundeved (16, Aabenraa (Hempel), Grumtoft i Angel (12), Ballastbakken o. fl. St. ved Flensborg (12, 16), Grodersby, Kappel, Armæs (Lund); J. Koldiug (28), Thyrsbæk (10), Haraldslund (Meyer), Ebeltoft (Kyll.).

\section{bb. Smaafrugterne glatte, Kronbladene gule.}

a, T'erminales. Blomsterne flere samlede i Spidsen af en qvasteller halvskjærmformet Blomsterstand fra Spidsen af Stængelen eller Grenene.

ac, Blomsterstcenglerne sidestillede (udgaae fra Grunden af en midtstillet, ilike blomsterbcerende Bladrosette).

701. P. opaca L. (Matbladet P.) H. 573 ; Drej. n. 535 ; H. N. I, 51; F. verua F. D. 1648.

De blomsterbarende Stangler nedliggende, tilsidst opstigende; hele Planten tæt- og langhaaret af udstaaende Haar; Rodbladene 5-7-koblede, ined langstrakt-kileformede, næsten fra Grunden 
til Spidsen fliget-saugtakkede Smaablade; Yderbagerets Blade linieformet-ovale, kortere end de ægformede Bogerblade.

Stænglerne alm. rødlige. Kronbladene mindre end hos de 2 følg. 5. 4 .

Paa Græsmarker, Diger, i Randen af Skove: $S j$. i Egnen af Kjobenharn (f. Ex. Charlottenlund) og ved Roeskilde alm.! mellem Frederiksund og Havelse alm. (19), Slangernp, Næstved (H.), Lellinge ved Kjøge (16). Fra de øvrige Provindser har jeg ikke seet Expl. ${ }^{\sharp}$

702. P. verna L. (Vaar-P.) H. 573 (undt. Voxest.); Drej. n. 534 ; F. D. 2510 ; H. N. IV, 66.

De blomsterbarende Stangler opstigende eller nedliggende; Bladene 5-7-koblede; Smaabladene omvendt.ægformede eller kileformede, fra Midten til Spidsen dybt saugtakkede, med budte Takker, overalt beklædte med lange, rette Haar; Yderbagerets Blade ovale, omtrent af Længde med de ægformede Boegerblade.

Haarbeklædningen svagere end hos foreg., stærkere end hos følg., fra hvilken den desuden let adskilles ved Mangel af Stjernehaar. $\frac{5}{2}-\frac{6}{1}$. 2 .

Paa tørre Bakker, sjelden: J. Skovbakken ved Aalborg (Branth); F. Hindsholm ved Hals Gab (18); Moens Klint ved Dronningstolen o. fl. Steder! Sj. Refsnæs (15); Bornh. Arnager, paa Ostkysten alm. (20).

705. P. incana [Moench Meth. p. 249] (Graafiltet P.) H. N. III, 46; P. cinerea Koch Syn. p. 242, Lge. Haandb. 1 Udg., p. 355 (ikke Chaix), F. D. 2592.

Bladene 3-5-koblede, paa Underfladen tæt graafiltede af korte, stjerneformede Haar og tillige beklædte med lengere, udstaaende Haar; Smaabladene fra ovenfor Midten til Spidsen (eller kun i Spidsen) saugtakkede; Yderbagerets Blade linieformet ovale, kortere end de agformede Bagerblade; forøvigt som foreg., men blomstrer noget tidligere (5).

Frugterne var., saavel hos denne, som flere af de ørrige Arter, endog paa samme Plante, jævne eller rynkede. Kjendetegnene som hentes fra Smaafrugternes Beskaffenhed, ere derfor usikkre.

Paa tørre Bakker, sjelden: $S j$. Veirhøi! Bornh. LindholmsKlipperne i $R \oint \operatorname{Sogn}(20)$. 
Anm. Ifolge Fries (Bot. not. 1858 p. 33) og Billot (i Ferb. Fl. Gall. et Germ.) er vor Art forskjellig fra den sydeuropæiske $P$. cinerea Chaix.

\section{$\beta \beta$, Blomsterstonglerne udgaae fra Midten af en Bladrosette.}

704. P. collina [Wib. Fl. Werth. p. 267] (Bakke-P.) Koch Syn. II, 238; Fr. S. Veg. Sc. p. 171; F. D. 2591; P. sordida Fr. mant. 3, p. 43 ; H. N. VII, 49-50; P. Güntheri Pohl.

De blomsterbarende Stongler nedliggende eller opstigende, stærkt grenede, med eller uden sidestillede Bladrosetter ved Grunden; Bladene femkoblede, paa Underfladen tiltrykt-duunhaarede eller graafiltede; Smaabladene kileformede, omtrent fra Midten til Spidsen dybt saugtakkede, i Randen ikke tilbagerullede; Blomsterstanden quastformet; Yderbogerets Blade linielancetformede, kurtere end Brgerbladene.

Paa Bakker og torre Græsmarker: Bornh. ved Hammershuus (20)! Teign S. for Allinge, Arnager (Hjortlı). [F

Anm. Denne Art nærmer sig til foreganende Afdeling, naar den, hvilket oftest er Tilfældet, er forsynet med blomsterlose Bladrosetter; men disse ere ikke, som hos $\boldsymbol{\alpha} \alpha$, en Fortsattelse af Hovedaxen, men Begyndelse til nye Sideaxer.

705. P. argentea L. (Sølv-P.) H. 571; Drej. n. 536; F. D. 865 ; H. N. IV, 64 .

De blomsterbarende Stangler oprette eller opstigende; Bladene femkoblede, paa Underfladen (tilligemed Stængelen) hvidfiltede; Smaabladene kileformede, fra nedenfor Midten til Spidsen fjerfligede, i Randen tilbagerullede, Blomsterstanden qvastformet; Yderbagerets Blade budt lancetformede, kortere end Bægerbladene.

Bladene alm. paa Overfladen morkgronne, tiltrylit-liaarede, var. paa begge Flader graafiltede (P. arg. $\gamma$, impolita Lelın.; $I$. impolita Wahlenbg.). 6-8. 4.

Paa tørre, sandige eller kalkholdige Marker og Bakker, ved Grøftevolde o. s. v. alm. Afarten sjelduere, f. Ex. $\boldsymbol{S} j$. Sundbygster paa Amager (27); B or $n h$. Hammershuus (19), Ypernestad (Baagoe), Lindholmsklipperne (Hoff), L angel. Steengade (19); J. Haraldslund!

† 706. P. recta L. (Rank P.) H. 2, 194; F. D. 1820; H. N. XI, 46. 
Rodstokken vedvarende, Stoengelen $1-2^{\prime}$ høi, opret, lang: haaret, Bladene 5-7-koblede, med omvendt-ægformede, næsten. fra Grunden til Spidsen saugtakket-fligede Smaablade; Blomsterne i en endestillet Qvast; Bagerbladene ægformede, tilspidsede, af Længde med eller lidet kortere end de linie-lancetformede Yderbægerblade, Kronbladene store, bleggule.

Ved Gjærder, sandsynligviis forvildet: $\boldsymbol{S} \boldsymbol{j}$. Overdrev $\emptyset$ for Charlottenlund (14)! Groftevolde mellem Sorø og Krebshuset (Trojel); Bornh. Frydenlund og Vibegaard pr. Ronne (Hjorth, Hamann), Christiansø (Baagøe); $\hat{S} l$. Süderholz ved Husum (P. pilosa Willd.) F. Müll, F. V. Skjerninge (Kordt, forvildet fra Præstegaardens Have, bvor den i lang Tid dyrkedes)!

\section{yy, Enaarige T'cexter uden Bladrosetter ved Grunden af Stcengelen.}

707. P. norregica L. (Norsk P.) H. 574; Drej. n. 533\% F. D. $171 ;$ H. N. III, 45 .

Siangelen opret; Bladene trekoblede (eller Rodbladene 2-3parret-finuede); Smaabladene laneetformede eller oinvendt-æg. formede, næsten til Grunden dybt saugtakkede, langhaarede; med tiltrykte Haar; Blomsterne i en stærkt forgrenet Qvast; Yderbagerets Blade laneetformede, omtrent af Længde med de æg-lancetformede Bægerblade; Kronbladene omvendt-ægformede, kortere end Bægeret.

Planten af gron Farve, St:engelen langhaaret, med udstaaende Haar, noget ru. 6-7. $\odot$ eller $\odot$.

Ved sandige og grusede Sobredder, i fugtige Skove, sjelden og. sporadisk: $S j$. Frederiksborg Slotsgaard (12)! i de udtørrede Søer mellem Horsholm og Rudersdal (H.), Storedam ved Donse (23)! Jonstrup Vang (20), en sumpig Eng ved Bernstorf (Schum.); B ornh. ved. Veien mellem $\emptyset$. Larsker og Almindingen (20) og mellen $\emptyset$. Larsker og Clemensker (14). |*

Anm. Rodbladene ere stundom, men sjeldent, femkoblede eller finnede, men dette Forhold er, ifølge Lehm. (Rev. Pot. p. 200) ikke normalt, men grunder sig paa Dyrkning eller Forekomst i frodig Jordbund.

$\beta$, Axilliflora. Blomsterne enlige i Bladhjornerne. a๔, Blomsterne typisk firedeelte.

708. P. Tormentilla [Seop. Fl. carn. 1 p. 360] (Opret P., Tormentil). Drej. n. 531; Tormentilla erecta L., H. 578; F. D. 589 . 
Stconglerne grenede, oprette, opstigende eller udstrakte (ikke rodslaaende); Stangelbladene siddende eller kortstilkede, trekoblede, Rodbladene langstilkede, 3-5-koblede, Smaabladene kileformede, fra Midten til Spidsen saugtakkede; Axelbladene 3-5 fligede; Blomsterne langstilkede; Bagerbladene efter Afblomstringen udstaaende, kortere end Yderbægerets Blade; Frugterne svagt rynkede.

Rodstokken tyk, indvendig rød. Stængel og især Blomsterstilke meget fine, Rodbladene henvisnede ved Blomstringstiden. Var. meget i Henseende til Strengelens Retning, Bladene, Beharingen (tiltryktsilkehaaret ell. næsten glat) o. s. v., men er dog stedse vel adskilt fra den folgende Art. Tilfældigviis forekommer undertiden en femdeelt Blomst mellem de ørrige. \%.

Paa Enge, Lyngheder, i Skove o. s. v. alm. udbredt.

709. P. procumbens [Sibth. Fl. oxon. 162] (Fremliggende P.) Tormentilla reptans L., H. 579; F. D. 1217 og 1819 (Potent. nemoralis Nestl.); H. N. II, 51.

Stconglerne grcnede, udstrakte, ved Ledene ofte rodslaaende; Stangelbladene stilkede, 3-5-koblede; Rodbladene femkoblede, langstilkede; Smaabladene omvendt-ægformede, fra Spidsen til nedenfor Midten dylt-saugtakkede; Axelbladene hele eller fuatandede; Bćgerlladene efter Afblomstringen indbøiede, kortere end cller af Længde med Yderbægerets Blade; Frugterne rynkede.

Var. med femdeelte Blomster. Rodstokken tyndere, Bladene alm. mere silkehaarede end hos foreg. 7-8. 4 .

$\asymp P$. procumbenti-reptans [Lehm. Rev. Pot. p. 206] (P. mixta Nolte i Rehb. f. g. exs. n. 1743). Stænglerue meget grenede, rankeformigt udstrakte, ikke rodslaaende, Strngelbladene alm. femkoblede; Blomsterne fire- og femdeelte; Fugterne især foroven vortet-rynkede.

Ved Gjærder, paa Grasmarker og høie Enge, paa Østkysten af Halvoens sydlige Deel ikke sjelden: J. Nebbegaard! Fredericia (16), Kongsted! Morklolt (12), Seest! og iwær i slesv.; mod V. sparsommere: Rodding, Rosendal og Ostenfeld ved flusum (16), Fohr (20). Paa Øerne sjelden: $\boldsymbol{F}$. Skanrup, Keirup (19), mellem Hvidkilde $\mathrm{og}$ Rødskebølle (i2); Loll. red Sundby (Ǩoch); Falst. mellem Bregninge 
og Donnemose (14), paa Skrænter ved Næsgaard! $\boldsymbol{S}$. Galgebakken ved Soro (12), mellem Agershivile og Nærum (Blytt. i Drej. herb.), Fileværket! Bornh. Knudsker (Hjorth). $\asymp S l$. ved Wittensee (16). F

Anm. P. mixta Nolte er i Udseende meget forskjellig fra P: procumbens $\mathrm{og}$ næsten mere lig $\mathrm{P}$. reptans, men ved Udsad i den botaniske Have af Fro taget fra det Noltiske Voxested: Einfelder Søen i Holsteen, ere Planter fremkomne aldeles overeensstemmende med $\mathbf{P}$. procumbens. Der synes ikke at være nogen Tvivl om at det er en Bastardform af denne og følg., saaledes som NoIte og Lehm. antage, saameget mere som den kun yderst sjeldent bærer modent Frø.

\section{$\beta \beta$, Blomsterne femdeelte.}

710. P. reptans L. (Krybende P., Femfingerurt). H. 574 ; Drej. n. 532 ; F. D. 1164.

Stcengelen rankeformet, rodslaaende, oftest ugrenet; alle Bladene langstilkede, 5- (sjeldnere 3- eller 7-)koblede; Smacbladene omvendt-xgformede, næsten til Grunden saugtakkede; Blomsterne langstilkede; Yderbægerets Blade lancetformede, læugere end de ægformede, spidse Bogerblade; Frugterne fint punkterede.

Bladene paa Underfladen silkehaarede, paa Overfladen alm. næsten glatte. Kronbladene store. 6-8. 4.

Paa Agre, ved Veie og Gjarder o. s. v., alm. udbredt.

b. Anserina. Alle Bladene fjersnitdeelte.

711. P. anserina L. (Gaase-P.) H. 569; Drej. n. 529 ; F. D. 544 .

Stanglerne rankeformede, krybende; Bladene mellembrudtog mangeparret-fjersnitdeelte; Afsnittene elliptiske, fra Grunden til Spidsen dybt saugtakkede eller næsten halvfinnede, paa Underfladen tæt silkeliaarede, sølvglindsende; Axelbladene fligede; Blomsterne enlige fra Bladhjørnerne; Yderbagerets Blade lancetformede, ofte fligede, af Længde med eller kortere end de ægformede Bagerblade.

Bladenes Overflade var. graagtigt silkehaaret eller sjeldnere næsten grøn. Rodens Grene har jeg alm. fundet i Spidsen opsvulmede. 5-7. 4 .

$\boldsymbol{\beta}$, tenella Lge. Alle Plantens Dele finere og spædere, Bladstilken næsten ligelang med Pladen; Bladenes Afsnit 4-7 
Par, dybt og skarpt saugtakket-fjerfligede, ved Grunden sammenknebue, paa Overfladen glatte og $f_{1}$ isk grønne, paa Underfladen svagt tiltrykt-duunharede, Blomsterne meget smaae.

Alm. paa Græsmarker, ved Veie og Strandbredder. $\beta$, Nieblum paa $F_{\theta} h r(20)$ ! Denne Varietet, som ikke findes omtalt i Lehmanns Revisio Potent., er meget afvigende fra Hovedarten og endnu mere udmærket end den grønlandske Form (P. Egedii Wormskj.) som i flere Henseender synes at staae midt imellem den typiske og den her beskrevne Form.

\section{Comarum. Kragefod.}

712. C. palustre L. (Kjær-K.) H. 582; Drej. n. 528; F. D. 636 ; Potentilla palustris Seop., Lehm. Rev. Pot. p. 73.

Bladene uligefinnede med alm. 5 laneetformede, dybt saugtakkede Snaablade; Axelbladene tilvosne til Bladstilken, ved Grunden kræmmerhuusformigt omgivende Stængelen; Kronbladene omvendt.ægformede, tilspidsede, 3 Gange kortere end Bægerbladene.

Bladene paa Underfladen blaagronne, glatte eller i yngre 'Tilstand dumhaarede. Krone og Bæger bruunrode. (Bægerbladene ofte fligede). $6-7.4$.

I Tørvmoser og dybe Kjær alm. udbredt.

\section{Geum. Nellikerod.}

713. G. urbanum L. (Feber-N.) H. 579; Drej. n. 537; F. D. 672 .

Rodbladene lyreformet-fjersnitdeelte, med nedadtil aftagende Afsnit; Stcengelbladene trefligede eller -snitdeelte, med spidse, grovt-tandede Flige; Axelbladene haanäfligede; Blomsterne oprette; Bagerbladene under Blomstringen tilbagebøiede; Kronbladene rundagtige eller omvendt-æg formede, uden tydelig Negl, kortere end Bægerbladene; Frugtbunden siddende; Frohalen toleddet: det øvre Led ved Grunden duunhaaret, omtr. 4 Gange kortere end det nedre.

1-2' høi. Bxgerbladene grønne, Kronbladene gule. 6-8. 4. Ved Gjærder, i Skove og Krat meget alm.

714. G. intermedium [Ehrh. Beitr. 6, 143] (Høi N.) H. II, 195 ; Drej. 11. 538 ; F. D. 1874 ; H. N. VI, 90. 
Blomsterne nikkende; Bagerbladene under Blomstringen udstaaende; Kronbladene omvendt-ægformede, med kort Negl, omtrent af Længde med Bægerbladene; Frøhalens øvre Led ved Grunden langhaaret, forøvigt som foreg., men Blomsterne større, Kronbladene rødgule, sjeldnere lysgule.

$1^{1 / 2}-2^{\prime}$ løøi (høiere end følgende og kraftigere end foregaaende Art). 5-6. 2 .

I fugtige Skove og Krat, sporadisk: i $\boldsymbol{S}$ j. ikke sjelden; Falst. Riserup (Koch); Loll. Høibygaturds Skov (5); F. Hunderup Skov ved Odense! Søbo (24), St. Jørgensgaard (12), Skaarup (19)! J. Lundbykrat, Odstedgaard (12), Steenvad Molle ved Kolding (30); Sl. mellem Dyttebsl og Pommerby ved Gelting (Lund), Nyværk ved Slesvig (16); Lundsmark paa Als (20).

Anm. Denne Art danner et tydeligt Mellemled mellem foreg. og folg., men synes dog ikke, som flere Forff. antage, at være en ved Krydsning frembragt Bastardform, da foreg. neppe er udsprungen naar følg. har afblomstret. Skjøndt den vel oftest forekommer i faae Expl., har jeg dog ogsaa fundet den i Mwngde, f. Ex. i Krattet ved Aaen nedenfor Sorgenfri.

715. G. rivale L. (Eng-N.) H. 580; Drej. n. 539; F. D. 722 .

Rodbladene lyreformet- og mellembrudt-fjersnitdeelte; Stangelbladene trefligede med grovt tandet-lappede, næsten budte Flige; Axelbladene tandet-fligede; Blomsterne nikkende; Brgerbladene opret-tiltrykte; Kronbladene omvendt-hjerteformede med lang Negl, af Længde med Bægerbladene; Frugterne befæstede til en efter Afblomstringen forlænget Frugtholder; Frohalen to. leddet, det øvre Led langhaaret, over halvt saa langt som det nedre.

$1 / 2-1^{1 / 1} 2^{\prime}$ høi. 5-6. 4. Bægerbladene rødbrune, Kronbladene kjødfarvede, var. gule ell. hvidagtige. Desuden forekommer hyppigt en Misdannelse med store, dybt-fligede Brgerblade og topskydende Blomster (G. riv. hybridum H. 581).

Paa Enge og i fugtige Kratskove alm. udbredt. 


\section{3de Klasse. Polyandria (Mangehannede).}

\section{Orden. Monogynia (Enhunnede).}

\section{A. Kronen firebladet. $\psi$ eller $\odot$.}

a. Bægeret tobladet. $(1-3$. N. F. Papaveraceæ).

1. Papárer L. Kapselen ufuldstændigt mangerummet, opspringende ved Huller under det siddende, mangestraalede, vedblivende Ar. (Enaarige Væxter med hvid Mælkesaft).

2. Glaicium Tournef. Kapselen skulpeformet, ved en svampagtig Frøstol deelt i 2 Rum paalangs, opspringende ved Klapper fra oven; Arret tolappet, trekantet.piilformet. (Toaarig Urt med guul Mælkesaft).

3. Chelidónium L. Kapselen skulpeformet, enrummet, opspringende fra neden med 2 Klapper paalangs; 1 Griffel, tolappet Ar. (Vedvarende Urt med guul Mælkesaft).

b. Bægeret firebladet.

4. Actæáa L. Frugten et enrummet Bær med Frøene i 2 Rader paa en vægstillet Frøstol. (Verlvarende Urt. N. F. R anu culace $æ, d)$.

B. Kronen fembladet. $\boldsymbol{h}$.

5. Tilia L. Bægerbladene 5, ligestore, i Knopleiet sideliggende; Frugtknuden femrummet, ved Modenheden enrummet, enfrøet, nopspringende. (Træer med spredte Blade, Blomster skjærmformet Qvast og den fælles Blomsterstilk i sin halve Længde sammenvoxet med et aflangt Dækblad. N. F. Ti li a e e $)$.

6. Ileliảnthemum Tournef. Bxgerbladene 5, uligestore (de 3 indre større), i Knopleiet foldede; Frugten en treklappet Kapsel. (Halvbusk med modsatte Blade. N. F. Cist in ex). 
C. Kronen mangebladet. (Vandplanter med heelrandede Blade og enblomstrede Blomsterstilke. 7-8. N. F. Nymph æac ææ).

7. Nymphŕa L. Bægeret firebladet; Kronbladene uden Honninggjemmer; Frugtknuden mangerummet, mangefrøet; Arret siddende, mangestraalet; Frøene omgivne af en nætformet Frøhud.

8. Nuphar Sm. Bægeret fembladet, Kronbladene med Honninggruber paa Ryggen; Frøene uden Frøbud, forøvrigt som foreg.

Delphinium (13, 2).

\section{Orden. Di-Pentagynia (To-Femhunnede).}

A. Bægeret farvet, Frugterne Bællekapsler. (9-11. N. F. Ranunculaceæ, c).

9. Delphinium L. Bægeret fembladet, uregelret, det øvre Bægerblad med Spore; Kronen 1-4-bladet, de 1-2 øvre Kronblade med Spore; Bællekapslerne 1-3.

Anm. De i vor Flora forekommende Arter af denne Slægt have kun 1 Kronblad (med Spore) og alm. 1 Frugtknude.

10. Aconitum L. Bægeret fembladet, uregelret, det øvre Bægerblad (Hjelmen) hætteformet, Kronbladene 2, S-formede, med lang Negl; Bællekapslerne alm. 3.

11. Aquilégia L. Bægeret fembladet, regelret; Kronbladene 5, kræmmerhuusformede, med sneglehuusformet, indad. rullet Spore; Bællekapslerne 5.

Helleborus $(13,3)$.

B. Bægeret grønt, Frugten en Kapsel.

Hypericum. Støvdragere i 3 Bundter $(18,1)$.

Reseda (11,3). 


\section{Orden. Polygynia (Mangehunnede).}

A. Frugterne enfroede, nodagtige.

a. Bægeret farvet, Krone $0 .(12-14 . \quad$ N. F. Ranunculacex, a).

12. Anemóne L. (part.) Frugtbunden kugleformet eller halvkugleformet; Bægerbladene 5-10; Nødderne uden Striber eller Ribber, med kort, uforandret vedblivende Griffel. (Blom. sterne enlige, sjeldnere $2-3$ samlede, omgivne af et trebladet Svøb).

13. Pulsatilla Mill. Nødderne med en haaret Frøbale (den udvoxende Griffel) i Spidsen, forøvrigt som foreg.

14. Thalictrum L. Frugtbunden liden, skiveformet; Bægerbladene $4--5$, affaldende, Krone 0 ; Nødderne stribede eller ribbede paalangs, med kort, uforandret vedblivende Griffel. (Blomsterstanden mangeblomstret, uden Svøb).

b. Blomsterdxkket dobbelt. $(15-18$. N. F. Ra-

$$
\text { nuneulace } x, b) \text {. }
$$

aa. Bageret uden Spore.

15. Batráchium Wimm. (Fr. Mant. 3). Bægeret fembladet; Kronbladene 5, med en nøgen Honninggrube ved Grunden; Nødderne paatværs rynkede, opstigende, med skjær Griffel. (Kronbladene hvide med guul Negl, gule hos Nr. 741).

16. Ranúnculus L. (part.) Bægeret fembladet; Kronbladene 5 , med en af et Skjæl bedækket Honninggrube ved Grunden; Nødderne oprette, med endestillet Griffel, uden Tværstriber (jævne eller vortede); (Kronbladene gule).

17. Fíária Dill. Bægeret trebladet; Kronbladene (oftest) 8-10; Nødderne stumpe, med siddende Ar, forøvrigt som foreg.

bb. Bagerbladene med en Spore ved Grunden.

18. Ilyosúrus L. Frugtbunden kegleformigt forlænget, Kronbladene med en traadformet $\mathrm{Negl}$ og en rørformet Houninggrube ved Grunden af Pladen. 
B. Frugterne fleerfrøede, opspringende (Bællekapsler). (19-21. N. F. Ranunculaceæ, c).

a. Blomsterdækket enkelt.

19. Caltha L. Bægerbladene 5, farvede; Kronbladene 0 .

b. Blomsterdækket dobbelt.

20. Tróllius L. Bægerbladene i ubestemt Antal, farvede, hvælvede, affaldende; Kronbladene smaae, fladtrykt-tungeformede; Bællekapslerne stilkløse, talrige, i flere Kredse.

21. Eránthis Salisb. Bægeret affaldende, farvet, 5-8bladet; Kronbladene smaae, tolæbet-kræmmerhuusformede ; Bællekapslerne 5-6, stilkede, i 1 Kreds. (Blomsten tæt omgivet af et bladagtigt, dybt fliget Svøb).

+22 . Helléborus L. Bægeret vedblivende grønt (eller farvet), alm. fembladet; Kronbladene som hos foreg.; Bællekapslerne stilkløse, $3-10$ i en enkelt Kreds og ved Grunden lidet sammenvoxne.

\section{Monogynia.}

\section{Papaver. Valnue.}

a. Kapselen stivharet.

716. P. Argemone L. (Kølle-V.) H. 590; Drej. n. 541; F. D. 867 ; Rehb. ic. fl. g. III, tab. 14, fig. 4475 .

Bladene dobbelt fjersnitdeelte med linieformede eller smalt lancetformede, haarspidsede Flige; Støvtraadene oventil udvidede; Kapselen langstrakt kølleformet, med 4-6-straalet $A r$.

Stængel og Blomsterstilke tiltrykt-stivhaarede; Kronbladene højrøde med sortbruun Negl. 5-7. $\odot$.

\section{$\beta$, lejocarpum! Kapselen glat.}

Mellem Sieden, paa Groftevolde o. a. dyrkede Steder, alm. udbredt. $\beta$, i Omegnen af Kjøbenhavn (Kph. herb.).

b. Kapseleuglat.

717. P. dubium L. (Gjærde-V.) H. 591 ; Drej. n. 54\%; F. D. 902 ; Rchb. l. c. tab. 15, fig. 4477 . 
Bladene fjersnitdeelte, Afsnittene fjerfligede med lancetformede Flige; Blomsterstilkene, idetmindste foroven, tiltrykthaarede; Støvtraadene sylformede; Kapselen kølleformet med adskilte Straaler i Arret.

Bladene graagrønne, tilligemed Stængelen langhaarede af udstaaende Haar. Kronbladene mønierøde. Arrets Straaler flere end hos foreg., færre end hos følg. 6-7. $\odot$.

Ved Gjarder, paa dyrkede Steder alm.

718. P. Rhoeas L. (Korn.V.) H. 592; Drej. n. 542; F. D. 1580 ; Rehb. l. c. fig. 4470 .

Bladene fjersnitdeelte, med saugtakket-fligede Afsnit; Blomsterstilkenes Haar udstaaende; Stovtraadene sylformede; Kapselen halvkugleformet eller ouvendt-ægformet med afrundet Basis; under Frugłens Modenhed dække Arrets Straaler hinanden med Randene.

Stængel og Blade haarede. Kronbladene einoberrøde, sjeldnere hvide, større end hos foreg. $6-7 . \odot$.

\section{$\boldsymbol{\beta}$, strigosum. Blomsterstilkenes Haar tiltrykte.}

Mellem Sæden og ved Veie, sjeldnere end de foreg.: $\mathbf{S} j$. Amager (19), Flaskekroen, Gundersløvlolm! mod S. og V. hyppigcre (H.); L oll. Stokkemarke, Nakskov o. fl. St. (19); F. i den nordøstlige Deel alm, især paa Hiudsholm, ved Odense og Nyborg! $J$. mellem Frederikshavn og Sæby, Hasseriis (H.), Kalø (16), Ribe (16); Sl. Haderslev (21), Nyværk ved Slesvig (16). $\beta$, dyrket og stundom forvildet mellem Srden, f.'Ex. F. Nyborg med Hovedarten (19), Lehnshøi, Ollerup, Lindvads Molle (12).

† 719. P. somniferum L. (Opiat-V.) H. 593; Drej. p. 188 ; Rehb. l. c. tab. 17 , fig. 4481 .

Bladene bugtet-tandede, de øre med lijerteformigt omfattende, de nedre med smalere Basis; Stovtraadene oventil udvidede; Kapselen næsten kugleformet, med adskilte Straaler i Arret.

Hele Planten glat, blaagrøn. Kronbladene violette, røde eller hvide. $6-7 . \odot$.

Oprindelig indført fra Orienten og Sydeuropa, forekommer alm. dyrket $\mathrm{i}$ Haver og ofte forvildet omkring beboede Steder. 


\section{Glaucium. Hornskulpe.}

720. G. luteum [Scop. Fl. carn. I, 369] (Blaagraa H.) H. 590 ; F. D. 585 ; Rchb. l. c. tab. 11 , fig. 4468 ; H. N. $\mathrm{X}, 29$.

Bladene med omfattende Basis, fjerlappede; Lapperne bugtettandede; Kapselen meget lang, valseformet, knudret-ru, med piilformet $A r$.

Kronbladene gule. Hele Planten blaagraa. 7-8. (-).

Sandige Strandbredder, sjelden: J. Vestervig ved Limfjorden (H.), Harboøre (24), Dravet paa Thyholm! Ottesund (Nødskov), Lemvig (Kirchmann).

\section{Chelidonium. Svaleurt.}

721. C. majus I. (Almindelig S.) H. 588; Drej. n. 540; F. D. 542 ; Rehb. l. c. tab. 10, fig. 4466 .

Bladene fjersnitdeelte, med rundtakket-lappede Afsnit; Blomsterne i Skjærm; Støvtraadene oventil udvidede; Kapselen linieformet, trind-fladtrykt, glat.

Kronbladene gule; Bladene blaagrae; hele Planten indeholder en brandguul Mælkesaft. 5-8. ข.

$\beta$, crenatum (C. laciniatum Willd., H. 589; F. D. 676 og 2054 ; Rchb. I. c. fig. 4467). Afsnittene fjerfligede, spidse; Kronbladene indskaarne; Kapselen snoet.

Ved Gjærder og Mure, især omkring Byer: alm. paa $\theta$ erne, sjelden i det sydl. $J y l l$, f. Ex. Store Velling, Mørkholt (12), Kolding! Ribe (d'Origny). $\beta$, paa lignende Steder som Hovedarten, men sjeldneve: S $j$. Hørsholm, Holte, Virum (7), Dronninggaard (Petersen), Vangede (Hoff), Ordrup, Grofterne udenfor Østerport ved Kbhvn! Rosenborg Have (Schum.), Sorø! F. Middelfart, Viby, Harndrup, Odense (7); S a m s e (Jacobsen); J. Skive, Viborg, Mariager, Randers, Aarhus (7); $S l$. Haderslev, Rødding (7), Nyværk ved Slesvig (16).

\section{Actaea. Druemunke.}

722. A. spicata L. (Bær-D.) H. 587; Drej. n. 544; F. D. 498 ; Rehb. ic. fl. g. IV, 4739.

Bladene dobbelt trekoblede, Smaabladene dybt tredeelte eller trefligede med grovt saugtakkede Flige; Blomsterne i ægformede Klaser; Bagerbladene concave, længere end Støv- 
dragerne; Kronbladene omvendt-ægformede, af Længde med eller kortere end Støvdragerne.

1-2' høi. Bæger og Kronblade hvide, Bær sorte. 5-6. 4.

I Skove, ikke sjelden i Danmark.

\section{Tilia. Lind.}

723. T. grandifolia [Ehrh. Beitr. 5, 158] (Storbladet L.) H. N. XIV, 33, T. platyphyllos Scop., Rchb. ic. Al. g. VI, fig. 5139 ; T. pauciflora Hayne.

Aarsskuddene og Bladstilkene haarede; Bladene bredt og skjævt hjerteformede, næsten kredsrunde, kort tilspidsede, saugtakkede, paa Underfladen grønne og idetmindste langs Nerverne og i Nervevinklerne haarede; Dokbladet forneden skjævt afrundet; Qvasten 3--4-blomstret; Arrets Flige oprette; Kapselen kantet-ribbet, filtet, med haardt Frøgjemme.

Blomsterne bleggule og vellugtende, ligesom hos de folg. Arter. 6-7. 々.

I Skove. Vildvoxende har jeg fundet den paa Øen Flatø i Guldborgsund, andre Voxesteder ere mig ikke bekjendte. Plantes i Alleer, men sjeldnere end følg., f. Ex. Frederiksberg Allee, Søndermarken o. fl. St. omkring Kjøbeuhavu!

† 724. T. intermedia [DC. Prodr. 1, 513] Almindelig L.) Rebb. l. c. fig. 5138; T. europæa Sm., H. 596; T. vulgaris Hayne, Fr. S. Veg. Sc. 162 ; H. N. IX, 31.

Aarsskuddene og Bladstilkene glatte; Bladene skjævt hjerteformede:, tilspidsede, saugtakkede, paa Underfladen lysere, i Nervevinklerne skjæghaarede, forøvigt glatte; Dakbladet forneden smalt nedløbende paa Blomsterstilken; Qvasten mange(7-11)-blomstret; Arrets Flige tiltrykte; Kapselen jævn, omvendt-ægformet-kugleformet, filtet, med baardt Frøgjemme.

7. 万.

Alm. plantet i Alleer og Lystskove. Vildvoxende findes den neppe i Danmark.

725. T. parvifolia [Ehrh. 1. c. 159] (Smaabladet L.) Drej. n. 546 ; Rchb. I. c. fig. 5137 ; H. N. IX, 32; 'T. microphylla Willd., H. 598 ; T. europæa F. D. 553. 
Bladene mindre, paa Underfladen blaagraae, i Nervevinklerne tæt bruunt-skjæghaarede; Dakbladet forneden skjævtafrundet; Qvasten 5-7-blomstret; Arrets Flige udstaaende; Frugten pæreformet, vortet-ru, med tyndt Frøgjemme; forøvrigt som foreg. 7. $\boldsymbol{h}$.

I Skove, paa Bornh, Moen, Loll. og i Sydsjall. alm, i de andre Egne sjeldnere og sporadisk: $\boldsymbol{S} j$. Gyrstinge (12), Hornsherred, Jonstrup Vang (H.); F. Fænø ved Middelfart, V. Skjerninge; Thor seng (12); J. Rindsholm ved Viborg (Strandg.), Kidholm i Kolding Fjord (II.), Seem, Roager og Kloby Skove ved Ribe (16); $S l$. Rødding (16), Dravit Skov (Branth), Harrislev Enge, Flensborg, Husum (16). (Plantes sjeldnere end foreg.)

\section{Helianthemum. Soløie.}

726. Il. vulgare [Gärtn. fruet. 1. t. 76] (Almindelig S.) Drej. n. 545 ; Rchb. I. c. III, fig. 4547 ; Cistus Helianthemum L., H. 599 ; F. D. 101.

Halvbusk med opstigende Grene; Bladene modsatte, linieformet-ovale; heelrandede; Axelbladene lancetformede; Blomsterne i ensidig Klase med efter Afblomstringen tilbageboiede Blomsterstilke.

Kroubladene citıongule, undertiden med en brandguul Plet red Grunden, aabne sig kun i Solskin. 6-7. h.

Paa tørre, især lerede Bakker: paa Bornh, Meen og i Sjall., især den nordlige og vestlige Deel, alm; J. Aalborg (H.), Bjørnsholm (A. Lange), Hobro Skov og Bakkerne ved Hodalen (16). I de sydligere Egne af Halvøen, i Fyen og paa de øvige Øer er det mig ikke bekjendt at den er funden.

\section{Nymphaea. Nolikerose.}

727. N. alba L. (Hvid N.) H. 596 ; Drej. n. 547; F. D. 602 ; Rehb. 1. c. VII, 117.

Bladene flydende, ovalt-nyreformede eller kredsrunde, med dybt indskaarne Lapper ved Grunden, heelrandede; Kronbladene i flere Rækker, efterhaanden overgaaende i Støvdragerne, som ere tilvoxne til Frugtknuden næsten op til det 12-20-straalede $A r$.

Kronbladene hvide, store. 7-8. 4. 
I Aaer og Søer, alm., men ikke i alle Egne, f. Ex ikke bemarket paa Boruholm, hvor den dog tidligere skal have voxet $\mathrm{i}$ Borresø $\mathrm{i}$ Almindingen (efter Meddelelse af Cand. pharm. Baagøe, som atter har indplantet den paa Øen).

Anm. Proprietair Cordes til Pandum pr. Nibe har i 1861 med. deelt mig, at han $\mathrm{i}$ en Dam, "Sløien" ved Norre Bjerregaard i V. Hanlierred, $1^{1 / 2}$ Miil fra Aggersund, har for flere Aar siden fundet en Nymphæa, forskjellig fra N. alba ved mindre Blade (c. 4" brede), tyndere Bladstilke, himmelblaa Kronblade i faerre Rækker, smalere og under Blomstringen mindre udstaaende end hos hiin. Da Finderen kun har iagttaget denne Plante blomstrende een Gang og ilkke opberaret noget tørret Exemplar af Blomsten, er der endnu ikke tilstrælkkeligt Materiale forhaanden til Afgjorelse af det Spørgsmaal, om den paagjældende Plante er en tilfældig Form eller en constant Varietet af $\mathrm{N}$. alba eller mulig endog en fra deune forskjellig Art. (Exemplarer, meddeelte af Dyrlæge Hansen, ere nu indplantede $\mathbf{i}$ botanisk Have, og saavel disse, som torrede Expl. fru det angivne Yoxested, meddeelte af Adj. Grønlund, ndmærke sig ved flere Gange mindre Blade end N. alba).

\section{Nuphar. Aakande.}

728. N. luteum [Sm. i Sibth. Prodr. fl. graec. 1, 361] (Guul A.) Drej. n. 548; Rehb. 113; Nymphxa L., H. 594; F. D. 603 .

Bladene som foreg., Kronbladene i $1-2$ Rækker, Støvtraadene flade, Stovknapperne aflang.linieformede; Arret skjolılformet, beelrandet eller svagt rundtakket, med 10-20 Straaler, som ikke naae til Randen.

Kronbladene gule, have en eiendommelig og ikke ubehagelig Lngt. 6-8. 4 .

Forekommer paa samme Steder som foreg. og oftest i Selskab med denne. I enkelte Egne findes de adskilte. Mangler, ligesom hiin, paa Bornholm.

Anm. N. pumilum Sm., Rehb. 1. c. fig. 115; H. N. V, 21) som adskilles ved mindre Blade og Blomster, næsten firekantede Støvknapper, tistraalet og dybt titandet, tissidst lalvkugleformet $\mathrm{Ar}$, er funden i do tydske Hertugdømmer og maa soges paa 'lignende Localiteter som foreg. - Blade, fundue i Huul $\mathrm{S} \emptyset \mathrm{V}$. for Veile (10) synes at høro herhid, efter Beskrivelsen skal den ogsaa voxe ved Kjærgatard i Vendsyssel, men da jeg ikke har seet Expl. derfra, tor jeg ikke med Bestemthed anfore den som dansk. 


\section{Di - Pentagynia.}

\section{Delphinium. Ridderspore.}

729. D. Consolida L. (Korn-R.) H. 600 ; Drej. n. 549 ; F. D. 683 ; Rehb. ic. fl. g. IV, fig. 4669.

Stcengelen opret, med udspærrede Grene; Bladene haandsnitdeelte, dobbelt tredeelte, med linieformede Afsnit; Klaserne korte, faablomstrede; Dokbladene 3-4 Gange kortere end Blomsterstilkene; 1 glat Frugtknude.

Kronen blaa, sjeldnere hvid. 6-7. $\odot$.

Ukrud i Vintersæden, især paa høitliggende, torre Marker: hyppigst paa Bornh., Lolland, Falster og i Sydsjalland; i enkelte Egne sjelden, f. Ex. Jyll. S. for Aalborg og i det østl. Sjæll.

$\dagger$ D. orientale J. Gay [Desmoul. Cat. Dord. p. 12], $D$. Ajacis Lge. Hdb. 1 Udg. S. 326. Stongel og Grene oprette; Bladene 2-3-dobbelt haandsnitdeelte med smalt linieformede, rendede Afsnit; Klaserne tæt- og mangeblomstrede; Dakbladene længere end Blomsterstilkene; Frugtknuderne duunhaarede.

Kronen violet, rød ell. hvid. 7. $\odot$.

Dyrkes alm. i Haver som Siirplante, og forekommer derfra forvildet, f. E. F. i en Rrtemark ved Skaarup, Strandmarker ved Skaarupør (19).

\section{Aconitum. Stormhat.}

730. A. Napellus L. (Blaa S.) Drej. n. 550; Rehb. I. c. fig. 4700 ; H. N. VI, 23 ; A. neomontanum H. 601 ; F. D. 1698.

Bladene haandsnitueelte med spidse, fligede Afsnit; Blomsterne $\mathrm{i}$ Klase; Hjelmen halvkredsformet med en udstaaende Spids; Kronbladenes Negl bueformigt opstigende; Støvdragerne haarede; Frugtbladene i yngre Tilstand udstaaende; Frøene skarpt trekantede, rynket-foldede.

$1^{1 / 2}-3^{4}$ høi. Kronen blaaagtigt-violet. 7-8. ข.

Paa fugtige Steder i Skove, sjelden: J. Vuust i V. Hanherred (Grønlund)! $\boldsymbol{S} \boldsymbol{j}$. Hesttangs Mølle (Kyll., Nolt.!), Herlufsholm, Øerne i Sorø Sø.(H.). Paa det sidste Sted har jeg i de senere Aar søgt den forgjæeves. 


\section{Aquilegia. Akeleie.}

731. A. rulgaris L. (Almindelig A.) H. 602; Drej. p. 191 ; F. D. 695 ; Rehb. l. c. fig. $4729-30$.

Bladene paa Underfladen blaagraae, dobbelt trekoblede; Bismaabladene haandlappede, med budte, rundtakkede Lapper; Blomsterstilkene og Frugtknuderne kirtlet-duunhaarede; Bagerbladene ægformet-elliptiske, længere end Kronbladene.

2-3' høi. Bladene næsten glatte, Bæger og Kronblade alm. blaae, var i Henseende til Farve, Antal og Form. Monstrositeter med talrige Bregerblade, Kronen 0, (1, stellata) og talrige Kronblade uden Bæger (2, comiculata) dyrkes i Haver. 6-7. 4 .

Funden vildvoxende paa Klipperne ved Randkløveskaar (20) og ved Vestermarie (Baagøe) paa Bornh.! Paa de andre Steder, hvor den er funden, er den maaskee $\mathrm{i}$ ældre Tid udkommen fra Haver, hvor den dyrkes som Siirplante: $\boldsymbol{S} j$. Dragerup Skov ved Holbek (15), Søskoven ved Sorø! Jonstrup Vang, Hesttangs Mølle (14); Moens Klint (19); F alst. Lundeskole (14); F. Svendborg! J. Haraldslund ! Sl. Slotsvolden ved Gelting (16).

\section{Polygynia.}

\section{Anemone. Simmer.}

a. Hepatica. Rodstokken lodret ellerskjæv, S̀vøbets Blade udeelte, bægerlignende, tæt omgivende Blomsten.

732. A. Hepatica L. (Blaa S.) F. D. 610; Hepatica triloba Chaix, H. 602; Drej. n. 572; H. nobilis Rehb. 1. c. fig. 4642 .

Bladene langstilkede, trelappede, med budte, heelrandede Lapper; Bladstilken og Bladene i Randen og paa Underfladen silkehaarede; Svøbbladene ægformede.

Kronbladene blaa, sjeldnere røde eller hvide, Støvdragerne hivide; Bladene udvikles efter Blomsterne; men de ældre Blade hensidde uvisnede Vinteren over. $\frac{3}{2}-\frac{5}{1}$. 4 . alm.

I Skove, funden i alle Provindser, men ikke i alle Egne lige 
b. Anemone. Rodstokken vandret, Svøbets Blade haandsuitdeelte med fligede Afsnit, fjernede fra Blomsterne.

733. A. nemorosa L. (Hvid S.) H. 605 ; Drej. n. 571; F. D. 549 ; Rchb. l. c. fig. 4644 .

Rodbladene langstilkede, ligedannede med Svøbbladene, ofte 0 ; Svobbladene af Længde med eller kortere end den tiltrykt-duunbaarede Blomsterstilk, deres Stilk halvt saa lang som Pladen; Bagerbladene 6-8, glatte.

Skaftet stedse enblomstret. Blomsterne hvide eller rosenrøde. $\frac{1}{1}-\frac{5}{1}$. 4 .

I skyggefulde Skove, paa Enge mellem Krat, meget alm.

734. A. ranunculoides L. (Guul S.) H. 606; Drej. 11. 570 ; F. D. 140 ; Rehb. l. c. fig. 4643 .

Rodbladene som foreg.; Svobbladene meget kortstilkede (Stilken mange Gange kortere end Pladen), Blomsterstillien duunhaaret af udstaaende Haar, af Længde med eller kortere end Svobbladene; Bagerbladene alm. 5, udvendig duunhaarede.

Blomsterne gule, paa frodig Jord ofte 2-3 paa Skaftet. $\frac{4}{2}-\frac{5}{2}$. 2 .

I Løvskove, især paa fugtig Grund, ikke sjelden og funden i alle danske Provindser, men sporadisk og sparsommere end foreg. I*

$\asymp A$. ranunculoidi-nemorosa [Kze. i Rehb. D. Fl. p. 108] (A. nemorosa $\gamma$, sulfurea Pritz.), forskjellig fra A. nemorosa red Blomsterstilken, som er kortere end Svøbbladene og ved de svovlgule, paa Underfladen rødligt anløbne Bægerblade, fra A. ranunculoides ved Svøbbladenes Plade (kun lidet over dobbelt saa laug som den morkrøde Bladstilk) med dybere og skarpere fligede Afsnit, saut ved større og blegere Blomst, med næsten glatte Bægerblade, og (altid?) enblomstret Skaft.

Funden i Mængde paa Ellestubbe i Aaskoven ved Veistrup i Fyen (Rostrup)! Synes at være en Bastardform af de 2 andre Arter.

\section{Pulsatilla. Kobjelde.}

735. P. rulgaris [Lob. ic. 281] (Opret K.) H. 604; Drej. n. 573; Rehb. l. e. fig. 4657; Anemone Pulsatilla L., F. D. 153 . 
Rodbladene tredobbelt-fjersnitdeelte med linieformede Afsnit; Svolbladene stilkløse, ved Grunden sammenvoxne, haandformigt mangedeelte; Blomsterstilken opret; Bogerbladene oprette, dobbelt saa lange som Støvdragerne.

Hele Flanten silkehaaret, Haarene udstaaende. Blomsterne lysviolette. $4-5$. 4 .

I Kratskove, paa solaabne Græsmarker og Bakker: hist og her paa Halvoen, sjelden paa Øerne: $\boldsymbol{S}$ amso (2); $\boldsymbol{F}$. mellem Middelfart og Assens (Krabbe), Bederslev (H.); $\boldsymbol{S}$ j. Helsingo: (Drej.), Fredensborg (14), Charlottenlund!

736. P. nigrricans [Störk. Lib. Pulsat. 1771] (Nikkende K.) P. pratensis Mill.; H. 605; Drej. n. 574; Rchb. l. c. fig. 4655; H. N. 1, 34 ; Anemone I., F. D. 611.

Rod- og Sudbblade som foreg.; Blomsterstilken under Blomstringen bueformigt nikkende; Bagerbladene lidet længere end Støvdragerne, i Spidsen tilbagebøiede.

Beklædningen som hos foreg., Blomsten mørk-violet. 4-5. 4.

$\boldsymbol{\beta}$, schizocalyx! Bægerbladene fligede.

Paa sandige Bakker: alm. i Nordsjalland og de magrere Egne af $\boldsymbol{F} y e n$, sparsom i $\boldsymbol{S} y d v e s t-S j a l l$. og ikke bemærket paa Loll. Falst. eller Bornholm; paa II alvoen sjeldnere end foreg. (efter de Oplysninger jeg har kunnet erholde): Kokkedal, Fjerritslev og Norbjerg i Hanherred, Fiverlma paa Oland (16), ved Aalborg og N. Sundby i Mængde (Juel), Skandsen ved Aarhus (2), Horsens (Jørg.). $\beta$, Lappesteen ved Helsingør! **

Anm. Disse 2 Arter kunne kun med Sikkerhed adskilles under Blomstringen, og deres Fordeling i Landet, om hvilken ugiere Oplysninger kunde onskes, maa derfor iagttages om Foraaret.

\section{Thalictrum. Frestjerne.}

a. Blomsterue oprette.

737. T. flarum L. (Guul F.) H. 608; Drej. n. 567 ; F. D. 939 ; Relib. l. e. III, 4639 ; H. N. IX, 25.

Stcrngelen huul, furet; Bladene dobbelt finnede, Smaabladene kileformede eller omvendt-ægformede, i Spidsen 2-3-lappede eller hele, det nedre Par ofte med Smaanxelblade ved Grunden; Bladskedernes Ører spidst ægformede, bredere end selve Skeden; Blomsterne tæt samlede i en Halvskjærm eller Top; Støvdragerne 
oprette, med linieformede, budte Knapper; Frugterne elliptiske tiribbede.

Bladene paa Underfladen blegere, Blomsterne hvidgule, Støvdragerne gule. 7. 4 .

I fugtige Skove, paa Enge mellem Krat, ved Aabredder o. s. v., hist $\mathrm{og}$ her $\mathrm{i}$ alle danske Provindser, dog ikke overalt alm.

Anm. Den af Hornem. (p. 609) fra Bognæs Skov angivne $T$. elatum, der beskrives med en jævn Stæengel, høiere end hos foreg. og blaagraae Blade, er mig ubekjendt og maaskee har her en Feiltagelse fundet Sted, idetmindste have de af mig paa det nævnte Voxested fundne Expl. en furet Stængel og høre aabenbart til T. flavum. (T. elatum Jaeq. har desuden ogsaa en furet Stængel).

b. Blomsterne nikkende (Ingen Smaaxelblade).

738. T. simplex L. (Udeelt F.) H. 607 ; Drej. n. 568; Rehb. l. c. fig. 4631 ; H. N. III, 26 ; T. minus F. D. 244 ; T. dubium Schum. n. 483.

Rodstokken krybende; Stwngelen rank, udeelt, furet; Bladene dobbeit finnede, Smaabladene lancet-kileformede, hele eller 2-3-lappede (paa de nedre Blade omvendt-ægformede, 3-5lappede); de øvre Bladskeders Ører ægformet-aflange, tilspidsede, tiltrykte til Stængelen; Blomsterstanden klaseformigt sammenkneben (aflang eller pyramideformet), med faablomstrede Grene; Støvknapperne linieformet-ovale med en kort Braad; Frugterne elliptisk-ægformede, otteribbede.

Blomsterne af samme Farve, men, ligesom Frugterne, meget mindre end hos foreg. 7. 4 .

Paa tørre, udyrkede Marker, ved Gjærder, sporadisk og temmelig sjelden: B ornk. ved Olsker, Bodilsker (20), Aakirkeby (11), Knudsker, Nyker (1ljorth); $\boldsymbol{S} \boldsymbol{j}$. 'en Groft mellem Christiansholm og Flaskekroen! bag Flaskekroen (Sehum.!), Svogerslev Mose (19), Alindelille! Sævedø (17); Thorseng ved Stioul (9); F. Bjørnemose, Kogtved (12); Kejenæs paa $\boldsymbol{A}$ ls (20); J. Norbjerg, Aagaards Kalkbakker (16); Dybdal (!) og Blegkilde ved Aalborg (12), Aarupgaard ved Horsens (16). I *

739. T. minus L. (Liden F.) H. 607; Drej. n. 569; Fr. S. Veg. Sc. 135 ; F. D. 732 ; Rehb. 1. c. fig. 4627 ; H. N. VII, 23.

Rodstokken kort, lodret eller skjæv, beklædt med bladløse Skeder; Stangelen ikke buul, grenet, stribet, med bugtede Led- 
stykker; Bladene tredobbelt finnede, det nedre Par Smaablade større end de øvrige; Smaabladstilkene kantede, Smaabladene rundagtigt-kileformede, 3-5-lappede, paa Underfladen blaagraae; Bladskedernes Ører udstaaende, afrundede; Blomsterstanden udspærret, fjernblomstret; Støvknapperne linieformede, tilspidsede; Smaafrugterne "teenformede", fladtrykt-tveæggede, otteribbede.

Planten af blaagraa Farve. Var. i Henseende til Høiden $\left(1 / 2-3^{\prime}\right)$, Smaabladenes Form o. s. v. Blomsterne graae med violette Striber. 7-8. 4 .

Paa sandige Bakker og ved Strandbredder paa Havstokken, sporadisk og ilkke alm.: $\boldsymbol{S} j$. mellem Flaskekroen og Kjøge! Lappesteen ved Helsingør! 'Tibirke Bakker og Adserbo Overdrev! Adelersborg (Rafn), Nykjøbing (9), Saltbak og Vrøi N. for Kalundborg (Baagge)! Meen ved Ulfshale og Budsemark (Dr.); F alst, ved Grønsund! Bøtø (5)! Tromnæs (H.); $\boldsymbol{F}$. Holkenhavn (H.); Issehoved paa $\boldsymbol{S} a \boldsymbol{m s \boldsymbol { \theta }}$ (2); J. Frederikshavn (H.), Horne i Vendsyssel (Drej. herb.), Nørbjerg, Bulbjerg (16), Aalborg (H.), Boeslum Strand ved Ebeltoft (Ørting).

Anm. Store Expl. svare aldeles til T. maius Rehb. l. e. fig. 4629. Skjøndt Yderformerne ere saa afvigende, høre disse dog utvivlsomt til een Art, hvilket Overgange vise, som man seer dem f. Ex. ved Helsingør, hror den lave blaagraa Form findes paa den nye Havstok, medens Expl, teet ovenfor paa den ældre Havstok mellem Krat efterhaanden antage en mere grøn Farve og naae en Mands halve Høide.

? 740. T. flexuosum [Rehb. Ic. fl. germ. III, fig. 4628] (Bugtet F.) Fr. mant. 3, p. 47; S. Veg. Se. 136; H. N. VII, 24.

"Rodstokken krybende; Stangelen ved Grunden bladet; Bladskedernes Drer korte, tiltrykte, de ovre i Spidsen udstaaende, Smaabladenes Flige spidsere; Blomsterstanden forlænget, med udspærrede, fjernblomstrede Grene; Smaafrugterne elliptiske, fladtrykt-tveæggede, tiribbede, forøvrigt som foreg.

Frugterne mindre, mere regelmæssige end hos foreg. 7. $\psi$.

Paa Bakker, sjeldnere end foreg.: J. Jungbjerg N. O. for Aalborg (9); $\boldsymbol{F}$. ved Fyenshoved (27)! Osterven ved Nyborg (Lund); $S j$. Hyldemarkshusene ved Storebalt (Lund). (Maaskee hore nogle af Voxestederne fra foreg. herhid).

Anm. Flere af de angirne Kjendetegn, f. Ex. Smaabladenes Form, Ribbernes Antal o. s. v., forckomme mig foranderlige, og jeg har ikke varet istand til at adskille denne med Bestemtled fra foreg., hvorfor disse Arter anbefales til nærmere Undersøgelse og Dyrkningsforsøg. 


\section{Batrachium. Fropeber.}

a. Alle Bladene handdeelte.

741. B. sceleratum (L. Sp., under Ranunc.] (Tigger-F.) Ranunculus L., H. 613 ; Drej. n. 563; Lge. Haandb. 1 Udg. D. 735 ; F. D. 571 ; Rehb. l. e. fig. 4598.

Stcengelen opret, huul, grenet; Bladene dybt 3-5.deelte med rundtakket-lappede Afsnit, de øvre haandsnitdeelte med linieformede Afsnit; Bladskederne hindeagtigt ørede; Blomsterstilkene furede; Bagerbladene tilsidst tilbagebøiede, længere end de omvendt-xgformede eller ovale Kronblade; Frugtbunden kegleformigt forlænget, haaret; Frugtsamlingen kugleformet-oval ; Frugterne talrige, smaae, uden ophøiet Rand, i Midten fint rynkede, med utydelig Griffel.

Bladene glindsende, tilligemed Stængelen glatte eller noget duunhaarede, Kronbladene bleggule. 6-8. $\odot$.

Paa fugtige Steder, f. Ex. ved Grøfter, Søbredder og i Tørvmoser, alm. overalt i Danmark.

742. B. hederaceum [Fr. Mant. 3 p. 54] (Vedbendbladet F.) Ranunculus L., H. 622 ; Drej. n. 552; Gren.\& Godr. fl. Fr. p. 19 ; F. D. 321 ; Rehb. I. e. fig. 4573 ; H. N. II , 43.

Stcongelen trind, ved Leddene rodslaaende, krybende; Bladene nyreformede, budt femlappede; Frugtbunden glat; Kronbladene smalt kileformede, lidet længere end Bxgerbladene; Støvdragerne faae (omtr. 10); Frugterne glatte, overalt indtil den ophøiede Rand tværrynkede; Griffelen hurtigt affaldende.

Kronbladene hvide. 6-8. 4 .

I Kilder, Grofter og Bække: paa Halveen hist og her, paa Øerne meget sjelden: $\boldsymbol{F}$. Allesø (13), Lumby (18), Lunden ved St. Jørgensgaard (H.); Thors ved Svendborg (12). (I Sjæll. og paa de øvrige Øer $\emptyset$. for Fyen findes den neppe). 
b. Alle Bladene, eller idetmindste de nedre, haarformigt mangedeelte, de øvre ofte lappede. Frugtbunden haret.

aa. De svømmende (lappede) Blade typist tilstede.

743. B. peltatum [Fr. S. Veg. Sc. p. 141] (Skjoldbladet F.) H. N. XII, 48; Ranunculus Scbrank; R. aquatilis L. (tildeels).

Stcengelen budtkantet; de nedscnlete Blade langstilkede, børsteformigt-mangedeelte, Fligene uden Haar i Spidsen; Bladskederne uden Ører; de svømmende Blade altid tilstede, langstilkede, 3-5.lappede med rundtakkede Lapper, nyreformetkredsrunde; Kronbladene bredt omvendt-ægformede, dobbelt saa lange som Bægerbladene; Stovdragerne talrige, længere end Frugtsamlingen; Frugtbunden ægformet; Frugterne baarede eller glatte, budte, med en Braad af den vedblivende Griffel.

\section{6-8. ข.}

I stillestaaende og flydende Vand. J. Hanherred (16). Fra andre Steder i Danmark har jeg hidtil ikke seet Expl., som kunde henfores til denne Art.

744. B. heterophyllum [Fr. l. c. p. 140] (Forskjelligbladet F.) H. N. XI , 32; R. aquatilis L. (tildeels), H. 623; Drej. n. 553 (undt. Var.); Rehb. l. c. fig. 4576.

De nedsankte Blade børsteforinigt-mangedeelte med eet eller flere Haar i Spidsen af Fligene, kortstilkede eller stilkløse, omskedende, med orede Bladskeder, som $\mathrm{i} / 3$ af deres Længde ere sammenhængende med Bladstilken; de ovre, svommende Blade langstilkede, nyreformede, 3-5-lappede med rundtakkede Lapper, ofte 0 ; Blomsterstilkene af Længde med eller lidet længere end Bladene; Frugtbunden kugleformet, forøvigt som foreg.

5-7. 4. Blomsterstilkene udgaae alm. saavel fra Hjørnerne af de lappede som af de haardeelte Blade (hos foreg. kun fra de første). Var.

$\beta$, crassicaule Fr. (R. aquatilis F. D. 2416). Stængelen tyk, opblæst; Kroubladene store; Frugterne glatte. 
$\gamma$, succulentum (Koch). H. N. XI, 33. Ingen lappede Blade, de haardeelte Blades Flige tykke, saftrige.

Alm. i Damme, Søer og Grøfter $(\alpha \circ g$ og $; \gamma$, ved Randen af udtørrede Damme og Vandhuller.

745. B. confusum [Gren. \& Godr. Fl. Fr. I, 22 under Ranunc.] (Trefliget F.) H. N. XV, 28; Ranunc. Petiveri Koch Syn. II, 13; H. N. X, 18; R. tripartitus Nolte nov. p. 51; H. II, 201 (ikke DC); F. D. 1993; R. aquat. $\gamma$, Drej. p. 192.

De ovre Blade dybt trefligede, med kileformede eller omvendt-ægformede Flige; Blomsterstilkene meget længere end Bladene; Kronbladene smalt omvendt-ægformet-kileformede, neppe dobbelt saa lange som Bægerbladene; Griffelen længere; Frugtbunden ægformet-kegleformet, forøvrigt som foreg. 6-8. 4.

Paa lignende Steder som foreg., mindre hyppig, men bemærket hist og her $\mathbf{i}$ alle Provindserne.

? 746. B. hololeucon [Ranunc. ololeucos Lloyd Fl. Loir. inf. p. 3] (Sneehvid F.) R. Petiveri Coss. \& Germ. fl. Par. Atlas tab. 1 fig. 5-6; R. tripartitus $\beta$, obtusiforus DC.

Bladskedernes Ører store og brede, næsten til Grunden adskilte, tilligemed Bladene og Stængelens øvre Deel h́aarede; Kronbladene (Neglen indbefattet) heelt hvide, mere end dobbelt saa lange som de alm. tilbagebøiede Bugerblade; Griffelen kortere og tykkere, forøvrigt som foreg.

Bladene dybere deelte end hos foreg., næsten skjoldformede. 6-7. 4 .

Christians@ (Didr.)? Udenfor Floraen funden ved Neumünster. (16). Nærmere at eftersgge. 匇

bb. Alle Bladene borsteformigt mangedeelte.

747. B. trichophyllum [Chaix i Vill. Delph. I, p. 335 under Ranunc.] (Haarfliget F.) Gren. \& Godr. fl. Fr. I, 23 ; Ranunc. pantothrix Bertol., Rchb. 1. c. fig. 4576 ; H. N. IX, 27; R. pancistamineus Tauseh, Koch Syn. II, 433; R. aquat. phellandrifolius Schum. n. $502 \beta$; Drej. p. 192 ; F. D. 2357. 
Alle Bladenes Flige haarfine, forlængede, udspærrede; de nedre Blade stikede; Bladskederne ørede; Blomsterstilkene af Længde med eller lidet længere end Bladene; Kronbladene smalt omvendt-ægformede, neppe dobbelt saa lange som Bægerbladene, hurtigt affaldende; Stovdragerne 12-15, længere end Frugtsamlingen; Frugterne skarpkjølede, oftest haarede.

Ved de korte, efter Afblomstringen (endnu mere end hos de ørrige Arter) bueformigt nedbøiede Blomsterstilke, smaae Kronblade og faae Støvdragere let kjendelig fra de andre Arter. Var. tilfældigviis, men sjeldent, med lappede svømmende Blade. 6-8.

I Grofter og Brekke hist og her, f. Ex. S j. Flakkebjerg (Nielsen), Alindemagle (Lund), et Kjer mellem Bernstorf og Lundehuset! Valby (11), Bæk mellem Rudersdal og Fuursgen! Ledreborg (8), Bidstrupgaard, Korporalskroen (19); Billesborg ved Kjøge, Feddet ved Lindersvold (9); B ornh. ved Ronne (20), Stangebæk (Baagge); Mo en paa Havstokken (9); Falst. Skjoltrnp (14), N. Vedby, Gaabense, N. Grimmelstrup (Koch); L oll. ved Cypressegaarden (Panum), Slotø i Nakskov Fjord (19), Faursted Skov (5); $\boldsymbol{F}$. Hofmansgave (27); i det sydl. alm.; $\boldsymbol{J}$. Vendsyssel (alm. (12), Ranum ved Løgstor (8); S l. Marskgrofter ved Høier og Husum (16).

748. B. circinnatum [Fr. Mant. 3, p. 52] (Kredsbladet F.) H. N. IX, 29; Ranunculus Sibth., Drej. n. 554; F. D. 2236 ; Rchb. 1. c. fig. 4575 ; R. divaricatus Schrank; Gren. \& Godr. f. Fr. I, 25; R. pantothrix eapillaceus H. 623; R. aquatilis $\beta$, L. sp.

Stcongelen budt trekantet, hvid, gjennemsigtig, de nederste Blade kortstilkede, de øvre stilkløse, med korte, til alle Sider kredsformigt udspærrede Flige; Bladskederne alm. haarede, nden Ører; Blomsterstilkene meget langere end Bladene; Kronbladene 5, bredt omvendt-ægformede, 2-3 Gange længere end Bægerbladene, seent affaldende; Stovdragerne talrige, længere end Frugtsamlingen; Frugterne haarede, uden Kjøl. 6-8. 4.

I flydende og stillestaaende Vand, hyppigere end foreg. og bemærket $\mathrm{i}$ alle Provindser.

749. B. marinum [Fr. 1. c. p. 51] (Flydende F.) H. N. IX, 28; R. fluitans H. 623; Drej. n. 555 (efter de danske Voxesteder; ikke Lam.).

Stcengelen tyk, trind, hvid, gjennemsigtig, langstrakt-flydende ; 
Bladene stilkløse eller meget kortstilkede, med langstrakte, parallele Flige; Bladskederne orede; Blomsterstilkene længere end Bladeue; Blomsterknopperne lindseformigt fladtrykte; Kronbladene 5, omvendt-ægformede, omtrent dobbelt saa lange som Bægerbladene; Støvdragerne talrige, kortere end Frugtsamlingen; Frugterne glatte, skarpkjølede.

Den største og anseeligste af de danske Arter. 6-7. 2 .

I stærkt flydende Vand eller ved Havkysterne i Bralsvand, sjeldnere end de foreg.: $S \boldsymbol{j}$. Halleby $A$ a ved Udløbet i Tiissø! J. Rye Aa i Hanherred (16), Flade $S_{\emptyset}$ ved Agger! Ove S $\emptyset$ i Thy (Drej. herb.), Limfjorden ved Aalborg (Strandgaard), Viborg So (Drej lierb.), Gudenaa alm., Thorsted og Muldborg pr. Ringkjøbing (2), Nibs Aaen ved Ribe (16); St. Haderslev Fjord (8) og .Dam (Gronlund)! Slien, Wittensee (20).

Anm. F. D. 376 er forskjellig fra deme ved de korte Blomsterstilke, og er maaskee kun en Form af B. trichophyllum; men da nøiagtigere Analyser mangle, er dens Plads vanskelig at bestemme. B. fluitans (Lam.) Fr., K. fluviatilis Web., adskilt fra foreg. ved tydeligt stilkede Blade, 9-12 aflang.kileformede Kronblade, glat Frugtbund og Frugter uden Kjol, er neppe funden indenfor vor Flora.

\section{Ranunculus. Ranunkel.}

a. Bladene hele.

750. R. Lingua L. (Langbladet R.) H. 611 ; Drej. n. 557 ; F. D. 755 ; Rehb. 1. c. fig. 4597.

Stcongelen trind, huul, stivt opret, Bladene ved Grunden omskedende, linie-lancetformede, tilspidsede, fjerut og utydeligt tandede; Blomsterstillcene jævne; Frugterne ende i et bredt, sværdformet $\mathrm{Næb}$ (den vedblivende Griffel).

$2-3^{\prime}$ høi. Fra de nedre Led af Stængelen udgaae krandsformigt stillede Rodtrævler og Udløbere med langstilkede, æoformet-ovale eller æg-hjerteformede Blade. Stængel og Blade alm. tiltrykt-haarede. Kronbladene store. 7-8. 2 .

I Moser, Aaer og ved Søbredder, ikke sjelden i de danske Provindser (Paa Bornholm ikke benærket, Hoffi.).

751. R. Flammula L. (Nedbøiet R.) H. 610 ; Drej. n. 556 ; F. D. 575 ; Rchb. l. e. fig. 4595.

Stcongelen kantet, opstigende eller udstrakt, ved Grunden rodslaaende; Bladene lancetformede, de nedre ofte æg-lancet- 
formede, fjernttandede, de nedre langt-, de øvre kortstilkedu med omskedende Basis; Blomsterstillene furede; Frugterne ende $i$ en meget kort Griffel.

$1 / 2-1$ ' hoj. Ingen Udlobere. Forekommer undertiden i Vand med flydende Stangel. Bladene glatte eller svagt og tiltrykt-haarede. 6-8. ข.

$\boldsymbol{\beta}$, radicans Nolt. (intermedius Hartın.) Stangelen krybende, Bladene linie-laneetformede; Blomsterne mindre.

I fugtige Enge og Moser alm. $\beta$, paa fugtig Leergrund, f. Ex. S $j$. Gurre Sø; Falst. Nyby; Loll. Soholt (14); F. Hofmansgave (18), Ostergen ved Nyborg (Lund); $\boldsymbol{S} l$. (iram (I).

752. R. reptans L. (Krybende R.) H. 611; F. D. 108; H. N. $\mathrm{X}, 27$; li. Flammula $\beta$, Drej. p. 193 ; Rehb. l. e. fig. 4595 .

Stangelen trind, traadformet, grenet, nedliggende, med buekrummede Ledstykker; fra Leddene udgaae knippestillede Rodtrævler og enblomstrede Blonsterstilke; Bladene linieformede eller linie-lancetformede, heelrandede; Frugterne ende med en i Spidsen krumboiet Griffel.

Hele Planten spiedere, Blomsterne mindre end hos foreg., hvis Form $\beta$, den ligner, men fra livilken den ved Griffelens Form o. s. v. er vel adiskilt. 6-9. 4 .

Ved sandige og grusede Sobredder, sporadisk: $S \boldsymbol{j}$. Tiissø! Gurre Sø! Funrsøen ved Frederiksdals Molle! Emdrup (II.), Kattinge $S_{\emptyset}$ verl Roeskilde (15), Korporalskroen (F. D.), Gisselfeldt (II.); F alst. Botas (Benzon); Loll. Solsolt verl Maribo Sa! J. Skagen (Drej. herb.), V. Vandet So i Thy (Carst.), Flade So ved Agger, Haraldslund! Fiilsø! Rolfs Sø ved Varde $(30), \mathbf{S} l$. Seemülıle ved Rendsborg!

\section{b. Bladene haanddeelte.}

ac. Frugterne jarne.

a , Blomsterstilken trind; Frugtbumlen glat.

753. R. auricomus L. (Nyrebladet R.) H. 613; Drej. ฉ. 558 ; F. D. 665 ; Rehb. 1. c. fig. 4599.

Bladene nyreformede, glatte eller ranthaarede; Rodbladene stilkede, haandformigt deelte (lappede, fligede eller snitdeelte) med i Spidsen saugtakkede Flige, alle langstilkede, med Blad- 
skeder; Stangelbladene siddende, haandsnitdeelte, med linieformede, heelrandede eller saugtakkede, til alle Sider udstaaende Afsnit; Frugterne duunhaarede, kortstilkede, med hagekrummet Griffel.

$1 / 2-1^{\prime}$ hgi. Stængelen forneden violet. Planten glat, Blomsterstilke og Bager duunhaarede. Var. med hele, tandede Rodblade. Ofte mangle nogle eller alle Kronbladene. 4-5. 4 .

I Skove og Krat, paa Enge o. s. v. alm.

754. R. acris L. (Bidende R.) H. 620 ; Drej. n. 559; F. D. 2415 ; Rchb. l. c. fig. 4606 .

Rod- og Stcongelbladene stilkede, tiltrykt-silkehaarede, haandsnitdeelte eller haandfligede ined dybt saugtakkede eller fligede Afsnit; Frugterne glatte, siddende, flere Gange længere end den hagekrummede Griffel.

1-3' høi. Stængel og Bladstilke med tiltrykte, Bladskederne med udstaaende Haar. Var. i Henseende til Bladenes Indskjæring. 5-7. 4 .

$\beta$, Steveni Andrz. (Rehb. l. c. fig. 4605). Planten lavere, Bladfligene bredere, tæt silkehaarede.

$\gamma$, multifidus DC. (R. Boræanus Jord.) Planten høiere, Alle Bladenes Afsuit dybt fligede eller snitdeelte, med smale, linieformede Flige.

Pra Marker, høie Enge og ved Veigrøfter meget alm. $\beta$, paa Strandenge, f. Ex. Bognes Odde ved Roeskilde! Amager ved Kastrup! $\gamma$, hist og her med Hovedarten.

755. R. lanuginosus L. (Uldhaaret R.) H. 621; F. D. 397 ; Rehb. l. c. fig. 4609 ; H. N. X, 26.

Rod- og Stangelblade stilkede, tilligemed hele Planten uldhaarede af udstaaende eller nedadvendte Haar, dobbelt haandlappede med tandet-saugtakkede Lapper eller baandfligede med tandet-lappede Flige; Frugterne glatte, siddende, med en tilbagerullet, ved Grunden fladtrykt Griffel næsteu halvt saa lang som Frugten.

1-2' høi. Haarbeklædningen mere gunlagtig, Kronbladene mørkere gule end hos de øvrige Arter. 6. $\psi$. 
I høitliggende Skove paa Leergrund; kun funden i de vestlige Egne af Landet: $\boldsymbol{J}$. Riis Skov og Marselisborg Skov ved Aarhus ! Eltang, Kolding (2S); $S l$. Aarøsund (14), Christiansfeld, Hammelev, Haderslev (16), Langbjerg Skov (Rafn), Flensborg (12), Steenbjerghav Skov, Huusbyriis i Angel, Pulverholz (16), Klosterholz ved Slesvig (F. D.), Ellenberg og Lgitmark i Svansos (Lund), Sehested (20), Syderhöft ved Frederiksstad (F. Miill.); $\boldsymbol{F}$. Hindsgavls Skov nellem Middelfurt og Kongebroen! (I Sjall. og paa de ovrige Oer mangler den). 同

$\boldsymbol{\beta}$, Blomsterstilken furet; Frugtbunden haaret.

756. R. repens L. (Vandgrenet K.) H. $619 ;$ Drej. n. 562; F. D. 795; Relıb. l. e. fig. 4610.

Krybende Grene (Ranker) fra de nedre Bladhjørner; Bladene enkelt eller dobbelt haandsnitdeelte, Afsnittene fligede med saugtakkede Flige (de primære Afsnit stilkede); Bagerbladene tiltrykte eller udstaaende; Frugterne svagt indtrykt-punkterede, med lang, svagt bøiet Griffel.

Var. i Henseende til Beklædningen, Bladenes Indskjæring o.s. v. 5-7. ข.

Paa Enge, ved Grøfter o. s. v., meget alm.

757. R. polyanthemos L. (Mangeblomstret R.) H. 619; Drej. n. 561; F. D. 1700 ; Rchb. l. c. fig. 4607; H. N. $\mathrm{X}, 25$.

Rodstokken sammentrængt, uden krybende Grene; Bladene enkelt eller dobbelt haandsnitdeelte med figede Afsnit; Bagerbladene tiltrykte eller udstaaende; Frugtbunden stivt børstehaaret; Frugterne under Lupen svagt indtrykt-punkterede, med kort, bred, krumbøiet Griffel.

1-2' høi. 6-8. 4, Var. i Henseende til Bladenes Indskjæring:

$\alpha$, angustifolius. Bladene dohbelt snitdeelte, Afsnittene fligede med linieformede Flige; Stxugelen forneden og Bladstilkene tæt- og stivhaarede.

$\beta$, latifolius. Bladene haandfligede, med brede, tandetlappede Flige; hele Plantens Haarbeklædning svagere.

Paa hyie Enge saavel ved Stranden som inde i Landet, i Kratskove; sporadisk og ikke alm. ( $\beta$, især paa fugtige og skyggefulde, $\boldsymbol{\alpha}$, paa hoiere og solaabne Steder): $\boldsymbol{S} \boldsymbol{j}$. mellem Cliristiansholu og Flaskekroen! Kjøge (9); Thorseng ved Stioul (12), F. Ulriksholm, 
Odense (H.), Knudshoved (19); J. Krat ved Donneruplund! $\boldsymbol{S} \boldsymbol{l}$. Königsmark ved Husum (16), Slesvig (Esmarch); Loll. Lidsø i Rødbyfjord ! Falst. Nøisomhed, Klodskov (14), Grønsunds Færge! |*

758. R. bulbosus L. (Løgrodet R.) H. 617 ; Drej. n. 560 ; F. D. 551 ; Rehb. 1. c. fig. 4611.

Rodstokken løgformigt opsvulmet, uden Udløbere; Bladene haandsnitdeelte, med enkelt eller dobbelt fligede Afsnit; Boggerbladene under Blomstringen tilbagebøiede; Frugterne med kort, hagekrummet Griffel.

$1 / 2-1$ ' høi. $5-6.4$. alm.

Paa torre, især sandige Marker, ved Randen af Skove o. s. v.

6b. Frugterne knudret-vortede eller piggede.

759. R. Philonotis [Ehrh. Beitr. 2, 145] (Stivhaaret R.) H. 618 ; Drej. n. 565 ; F. D. 1459 ; H. N. VII, ż6; R. hirsutus Curt, Rehb. l. c. fig. 4617.

Stcengelen, især forneden, og Bladstilliene stivbaarede; Bladene dybt tredeelte, med enkelt eller dobbelt trelappede eller -fligede Afsnit; Blomsterstilkene furede; Bagerbladene under Blomstringen tilbagebøiede, af Kronbladenes halve Længde; Frugtbunden haaret; Frugterne fladtrykte med en Kreds af vorteformede Punkter indenfor den ophøiede Rand; Griffelen kort, næsten ret.

$1 / 2-1^{\prime}$ høi. 5-8. $\odot$.

$\beta$, parvulus (L.) $1-3$ " høi, mindre haaret, Stængelen $1-2$ blomstret.

Fnge og Marker paa Leer- og Kalkgrund, iswr i Nærheden af Havet: paa Bornh. og de øvrige Oer fra Moen til Fros samt i Sydsjell. alın, sparsommere i Nordsjall. og Fyen; paa Halvoen sjelden: J. Aarhus, Odstedgaard! S $\boldsymbol{l}$. Haderslev, Tonder (16), Oele i Angel (Lund), Pulverholz ved Slesvig (16), Eidersted (F. Müll.), Føhr (Groulund, $\beta$, paa Strandfælleder, f. Ex. paa Amager!

760. R. parviflorus L. (Smaablomstret R.) H. 622; Drej. n. 564 ; F. D. 1218 ; Rehb. l. c. fig. 4616 .

Bladene haandfligede med rundtakket-lappede Flige; Blomsterstilkene furede, modsatte Bladeve; Rronbladene linieformet-omvendt- 
ægformede, omtrent af Længde med de tilbagebøiede Bægerblade; Frugtbunden glat; Frugterne fladtrykte, paa hele Fladen indenfor den ophøiede Rand kortpiggede, med bred, krumbøiet Griffel.

Hele Planten haaret. 7. $\odot$.

Mellem Sæden, meget sjelden: $\boldsymbol{S} \boldsymbol{j}$. Dorothealyst (4); $\boldsymbol{F}$. Odense (H.), Lyø (M. Vahl). (Ikke iagttaget $\mathrm{i}$ de senere Aar).

761. R. arvensis L. (Ager-R.) H. 621; Drej. n. 566; F. D. 219 ; Rehb. 1. c. fig. 4614 ; H. N. VIII, 27.

Bladene enkelt eller dobbelt haandsnitdeelte, meà linielancetformede Afsnit; Blomsterstillene jævne; Bagerbladene tiltrykte til Kronen og lidet kortere end denne; Frugtbunden haaret, meget kort; Frugterne kredsstillede, fladtrykte med ophøiet Rand, paa begge Flader langtornede, med lang, i Spidsen svagt bøiet Griffel.

Stængel og Blade svagt haarede. Kronbladene bleggule. 5-7. $\odot$.

Ukrud mellem Kornet, især paa Kalk- og Leergrund: paa Bornh., Moen, Falst. og Loll. alm., paa Langel. og Thorseng hist og her (19); i de andre Provindser sporadisk: $\mathbf{S}$. Vordingborg (H.), Præsto (Dr.), Vindbyholt (9), 3 Nlilepælen mellem Kjøbenhavn og Kjuge (Dr.), Flakkeljerg (Nielsen) og Anedinge ver Skjelskor (22); F. Svendborg (H.), Nakkebglle (12); Sl. Haderslev (16), Tønning (F. Müll.). $\%$

\section{Ficaria. Vorterod.}

762. F. ranunculoides [Roth Fl. germ. 1, p. 622] (Smørblomst). Drej. n. 551 ; Rehb. 1. e. fig. 4572; Ranunculus Ficaria L., H. 612; F. D. 499.

Roden trævlet, med kølleformede eller pæreformede Knoller mellem Trævlerue; Bladene stilkede, hjerteformet-nyreformede; Rodbladene rundtakkede, Stcengellladene haandlappede.

Bladene glatte, glindsende, alm. med Løgknopper i Bladhjørnerue. Kronbladene glindsende gule. $\frac{3}{2}-\frac{5}{1}$. 4.

I Haver og Skove meget alm.

\section{Myosurus. Musehale.}

763. II. minimus L. (Liden M.) H. 355; Drej. n. 354; F. D. 406 ; Rehb. I. c. fig. 4569 . 
Talrige linieformede Blade og enblomstrede bladløse Slcafter udgaae rosetteformigt fra en meget forkortet Rodstok; St $v$ -

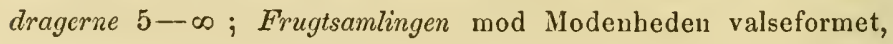
tilspidset; Frugterne talrige, tæt taglagte, trekantede med en kort Spids.

1-4" høi. 4-6. $\odot$.

Paa dyrkede, tørre, især lerede Marker alm.

\section{Caltha. Kabeleie.}

764. C. palustris L. (Eng-K.) H. 626 ; Drej. n. 577 ; F. D. 668 ; Rchb. 1. c. IV, fig. $471 \%$.

Stanglerne opstigende; Bladene bjerteformet-nyreformede, rundtakkede; Bagerbladene alm. 5, mørkgule, ovale, udstaaende; Ballekapslerne krandsstillede i alm. 1 Kreds.

$4-5$. భ.

Paa fugtige Enge, i Skormoser, Grofter o. s. v., meget alm.

\section{0. 'Trollius. Engblomne.}

765. T. europreus L. (Almindelig E.) H. 624; Drej. ฉ. 575 ; F. D. 133 ; Rchb. 1. c. fig. 4713.

Stcongelen opret; Bladene haandsnitdeelte med fligede Afsuit; Bogerbladene talrige, kredssunde, lysgule, lukkede omkring de linieformet-kileformede, safrangule Kronblade; Ballekapslerne i flere Kredse.

$1-1^{1 / 2} 2^{\prime}$ høi. En af vore smukkeste Markblomster. $\frac{5}{2}-6$. $\psi$.

Paa Enge og fugtige Steder i Kratskove: i de fleste Egne af Landet almindelig, i nogle Egne sjelden, f. Ex. Stevns (Balslev) og det nordl. Jyll. (12), mangler paa Bornholm (Hjorth) og i LollandFalst. (19)!

\section{Eranthis. Vinterblomme.}

$\dagger$ 766. E. hiemalis [Salisb. Trans. Linn. soc. 8, 503] (Guul V.) H. 625; Drej. n. 576; F. D. 1391 ; Rehb. 1. c. fig. $4 \pi 14$; Helleborus L.

Rodstokken knolleformet, frembringer 1 kredsrundt, stjernesnitdeelt Blad og enblomstrede Skafter; Bcgerbladene elliptiske 
eller ovale, citrongule; Kronbladene grøngule; Ballekapslerne fladtrykte, rynkede. 2-3. 4.

I Skove, sandsynligviis oprindelig forvildet fra Haver, sjeldeu: $\boldsymbol{S} \boldsymbol{j}$. Gl. Lellingegard (9), Fiurendal (Jacobsen), Antrorskov (H.), Orsløv ved Skjelskør (Nielsen)! Falst. ved Kraghave (14); F. Hofmansgave (18).

\section{+ Helleborus. Nyserod.}

$\dagger H$. viridis L. (Grøn N.) Rehb. 1. c. fig. 4718.

Stcongelen foroven grenet; Rodbladene langstilkede, fodsnitdeelte, med lancetformede, saugtakkede Afsnit; Stcngelbladene siddende, Bagerbladene udstaaende, grønne, Kronbladene halvt saa lange som Støvdragerne. $3-5 \quad 4$.

Forvildet, f. Ex. L oll. ved Skjelstofte; Falst. Riserup (Koch); Sj. Steensbøg Moller ved Vordingborg (19).

\section{4de Klasse. Didynamia (Tomiegtige).}

\section{Orden. Gymnospermia (Spaltefrugtede).}

De i denne Orden indeholdte Slægter hore alle, med Undtagelse af Nr. 21, til N.F. Labiata. De have modsatte Blade, Blomsterne i Qraster eller Nogler (tilsyneladende krandsstillede) i Bladhjorneme, tilsammen dannende Top eller Ax, tolabet Krone med heel eller tvedeelt Overlæbe, tredeelt Underlæbe; Stængelen oftest firekantet; Bladene havo en stærk og alm. behageligt krydret Lugt. Hos mange Arter af denne Familie fremtrade Blomsterne under en dobbelt Form (en Tilnærmelse til Tveboforholdet, ligesom det er 'Tilfæeldet med mange Asperifolice (S. 142), Primulacere (S. 146), Alsinacece (S. 311) o. fl.), nemlig den ene (ठ;) med storre Krone, længere Stovtraade og mere ndviklede Støvknapper, den anden ( $(+)$ med mindre Krone, kortere Stovtraade og mindre adviklede eller ganske feilslaaede

Støvknapper*).

A. Smaafrugterne 4 for Modenheden indlyyrdes adskilte Nødder; Blomsterne tilsyneladende krandsstillede.

AA. Bægeret titandet.

1. Marrúbium L. Kronens Overlæbe linieformet, tokløvet;

*) Uagtet begge disse Former forekomme omtrent lige hyppigt, er her i Regelen, saavel ved Slagts- som Artsbeskrivelser, taget 
Støvdragerne og Griffelen indsluttede i Kronen; Nødderne afstumpede med en trekantet Flade foroven.

BB. Bægeret regelm. femtandet.

a. Støvtraadene parallele.

aa. Kronens Overlabe forover hvalvet.

$\alpha$. Støvknappernes Rum opspringe paatværs ved Klapper.

2. Galeópsis L. Miảtfligen af Kronens Underlæbe budt eller udrandet, adskilt fra Sidefigene ved 2 opsvulmede Tænder; Nødderne oventil afrundede.

ß. Stovknappernes Rum opspringe ved Længderidser.

ณr. Nodderne oventil afrundede.

* Bronens Ror indrendig (red Stortradenes Indføinilig) med en Harkrands; Storkuaprummene i co axslen rel Linie udataande fra binanden.

3. Stachys L. Underlæbens Flige budte; de 2 nedre Støvdragere efter Bestørningen snoede, udadbøiede.

4. Ballóta L. Underlæbens Flige budte, Støvdragerne efter Bestørningen rette.

* Kronens Ror uden Harkrands; Storhnaprummene i Begrndelsen nasten parallele, sencre dannende en Vinkel indbyrdes.

5. Betónica L. Underlæbens Flige budte, Støvdragerne efter Bestørningen rette.

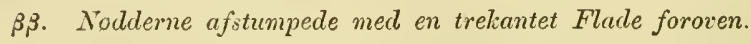

* Sidefligene al Krenens [inderlabe spidse (ctler 0); Nodderue i Spidsen glatte.

6. Lämium L. Underlæbens Sideflige smaae, tandformede eller 0 ; Strvknapperne haarede. (Kronen hvid eller rød).

7. Galeóblolon Huds. Underlæbens Flige alle spidse; Stovknapperne glatte. (Kronen guul).

Hensyn til den forste. Mertil bedes Begyndere at lægge Mærke for ikke at vildledes, jdet Beskrivelsen af flere Slagter kum passer par den forste, men ikke paa den sidste Form. 
- Daderlabeus Sideflige budte, Teidderne i Spidsen barede.

8. Leonúrus L. Blomsterkrandsene mangeblomstrede, danne et mellembrudt Ax; Brgerfligene tornede; Støvknappernes Rum divergerende.

bb. Kronens Overlabe plan, tilbageboiet eller 0.

$\boldsymbol{\alpha}$. Nødderne jævne.

9. Népeta L. Midtfligen af Kronens Underlæbe bvælvet, kredsrund; Støvknappernes Rum i en næsten ret Linie udstaaende fra hinanden.

10. Gléchoma L. Underlæben omvendt-hjerteformet, plan; Støvknappernes Rum danne en Vinkel indbyrdes, og ved deres Tilnarmelse til Gjenbostøvdragerne et Kors.

$\beta$. Nodderne grubet-punkterede.

11. Ajúga L. Kronens Ror indvendig med en Haar krands ved Stovdragernes Indføiningslinie, Overlæben kort utydeligt tokløvet; en Kirtel ved Grunden af Frugtknuderne.

12. Téucrium L. Kronens Rør indvendig nøgent; Overlæben synes at mangle, idet dens 2 Tænder ere bøiede henimod Underlaben, som derved synes femtandet.

b. Støvtraadene (efter Bestøvningen) bøiede fra hinanden foroven.

aa. Støvknappernes Rum parallele (Knapbaandet lige bredt).

13. Mentha I. Kronen tragtformet, firefliget, næsten regelret; Støvdragerne næsten ligelange. (Blomsterue $\mathrm{i}$ alsidige, endestillede Ax eller fjerntsiddende Krandse i Bladhjørnerne.

\section{bb. Stovknappernes Rum divergerende (Knapbaandet bredere nedentil).}

† 14. Elshóltzia Willd. Kronen firelappet, de 3 nedre Lapper indbyrues ligestore og næsten lige med den udelte Overlæbe, Støvknaprummene udspilede og tilsidst indbyrdes 
sammenflydende. (Blomsterne $\mathrm{i}$ ensidige $\mathrm{Ax}$ med toradede Dækblade).

15. Oríganum L. Kronen tolæbet, Underlæbens Lapper ligestore; Støvknaprummene adskilte, danne en Vinkel forneden. (Blomsterne $\mathrm{i}$ alsidige Ax med fireradede, taglagte Dækblade.

Stachys (s. Nr. 3).

\section{Bægeret tolæbet ${ }^{\star}$.}

a. Størtraadene divergerende,

aa. opadtil udadbøiede.

16. Thymus L. Bægerets Svælg lukket ved en Haarkrands, dets Overlæbe tretandet, Underlæben tofliget, ned opstigende, sylformede Flige; Støvknaprummene forneden divergerende.

(Mentha Pulegium).

bb. Stovtraadene opadtil indadbøiede og sammenstødende under Overleben.

17. Ícinos Noench. Blomsterne i $2-5$-blomstrede Knipper, omgivne af faae og korte Dækblade; Bægeret ved Grunden puklet, dets Svælg lukket ved en Haarkrands, dets Overlæbe trefliget, Underlæben tofliget, alle Bægerfligene sylformede; Kronens Rør ret, dens Overlæbe plan; Støvknaprummene foroven adskilte, forneden divergerende.

18. Clinopidium L. Blomsterne i mangeblomstrede Knipper, omgivne af et fælles mangebladet Svøb, dannet af børste-

*) Det tolæbede Bæger forholder sig omvendt mod Kronen, idet Overlaben er tredeelt, Underlæben todeelt. Flere af de med regelm. Bæger beskrevne Slægter vise en Tilnærmelse til det tolæbede Bæger, idet Bagertænderne ere uligelange, men af samme Form og med ligestore Mellemrum, (f. Ex. Glechoma, Nepeta, Leonurus Cardiaca). 
formede Dækblade; Bægerets Ror krumt, valseformet, Kronens Overlæbe næsten plan, forøvrigt som foreg.

$\dagger$ Melissa L. Blomsterne i 3-6-blomstrede Ḱnipper, omgivne af faae Dækblade; Bægeret ved Grunden ret, dets Rør klokkeformet, Overlæben tretandet med korte triangelformede Tænder, Underlæben tofliget; Kronens Rør opstigende, dens Overlæbe lidet hvælvet og med tilbagebøiede Spidser; Støvknaprummene eften Bestøvningen foroven sammenflydende, forneden udspilede.

b. Støvtraadene parallele.

19. Brunélla Tours. Bægeret ved Frugtmodenheden tillukt, dets Overlæbe tretandet, Underlæben todeelt, omfattet af Overlæbens indbøiede Rande; Kronens Rør med en Haarkrands, dens Underlæbe med budte Lapper; Nødderne jævne.

20. Scutellária L. Bægeret ved Modenheden tillukt, dets Læber udeelte, Overlæben med et skjoldformet Tilhængsel; Kronrøret uden Haarkrands; Nødderne smaagrubede eller punkterede, befæstede til en Frugtholder.

Leonurus Cardiaca' (s. Nr. 8).

B. Frugten for Modenheden udeelt, firerummet, tilsidst deelt i 4 Nodder. Blomsterne spredte.

21. Verbéna L. Bægeret femtandet; Kronen tolæbet; Blomsterne danne Ax. (N. F. Verbenaee $x$ ).

\section{Orden. Angiospermia (Kapselfrugtede).}

A. Blomsten oversædig.

22. Limmaa Gron. Bagerets Krave femdeelt; Kronen klokkeformet, næsten regelmæssig femdeelt; Frugtknuden trerummet, Frngten enrummet, enfrøet, uopspringende. (Krybende Halvbusk med modsatte Blade og toblomstrede Blomsterstilke. N. F. Caprifoliace $x)$. 
B. Blomsten undersædig.

a. Kronen regelret femdeelt.

23. Limosélla L. Bæger og Krone regelm. femfligede; Frugten enrummet, toklappet, mangefrøet. (Lav enaarig Dyndplante uden overjordisk Stængel. N. F. Scrophularinex, b).

b. Kronen uregelret, (tolæbet eller maskeret). aa. Kapselen torummet, med Frøstolen tilvoxet til Slillevaggen. ж. Støvknappernes Rum ved Grunden budte.

(«. Kronen maskeret*); Kapselen opspringende $i$ Spidsen eller paa Siden.

24. Linária Tournef. Kronen med en Spore ved Grunden; Kapselen opspringer ved Tænder i Spidsen eller paa Siden ved Laag. (N. F. Seropbularineæ, b).

25. Antirrhinum L. (part.). Kronen ved Grunden puklet; Kapselen skjæv, opspringer ved Huller i Spidsen. (N. F. Serophularineæ, b).

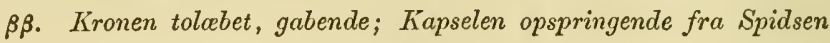
til Grunden.

26. Scrophulária L. Bægeret femdeelt; Kronen uregelm. krukke- eller kugleformet; Støvtraadene befæstede til Kronrørets Basis; Støvknapperne enrummede, opspringende ved en Tværspalte. (N. F. Serophularineæ, a).

27. Digitilis L. Bxgeret femdeelt; Kronen uregelm. klokkeformet; Støvtraadene befæstede til Kronrøret ovenfor Basis; Støvknapperne torummede, opspringende paalangs. (N. F. Serophularineæ, b).

$\dagger$ Mimulus L. Bægeret rørformet, femkantet og fem. tandet; Kronen tolæbet, med opret Overlæbe og udstaaende

*) Kronen kaldes maskeret, naar dens Underlæbe er forsynet med en opadrettet, alm. budt tolappet Fold (Ganen), som tillukker Svælget. 
Underlæbe; Støvknapperue torummede, med tilsidst sammenflydende Rum. (N. F. Serophularineæ, b).

及. Støvknappernes Rum ved Grunden tilspidsede.

ж«. Biegeret femtandet (eller tolcebet).

28. Pediculáris L. Bægeret opblæst; Frøene nætformigt grubede. (N. F. Scrophularinex, c).

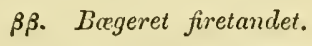

* Kapseleas Rum 1-2-froede.

29. Melimpyrum L. Bægeret rør- eller tragtformet, ikke opblæst; Frøene jævne, uvingede. (N. F. S crophularineæ, c).

*- Kapselens Rum mangefroede.

30. Rhinánthus L. Bægeret efter Afblomstringen blæreformig-opblæst; Kronens Underlæbe trelappet, med udeelte Lapper; Kapselen fladtrykt-vinget; Frøene jærne.

31. Euphrásia L. (part.) Bægeret ikke opblæst; Kronens Underlæbe trelappet, med tokløvede eller udrandede Lapper; Støvknappernes Rum med uligelange Tilhængsler ved Grunden; Griffelen indsluttet i Overlæben; Kapselen fladtrykt-hvælvet; Frøene riflede.

32. Odontites Pers. Bægeret ikke opblæst; Kronens Under]æbe trelappet, med udeelte Lapper; Støvknappernes Rum med ligelange 'Tilhængsler ved Grunden; Griffelen rager udenfor Overlæben; Kapselen hvælvet, næsten trind; Frøene riflede. $(30-32$. N. F. Seropbularineæ, c).

b6. Kapselen enrummet, med Frostolene befastede til Rygsømmen. (Snyltcplanter med farvede, skjolformede Blade: N. F. Orobanche $\alpha)$.

33. Lathráa L. Bægeret firefliget; den afblomstrede Krone heelt affaldende; Støvknapperne i Randen harede, en fri Kirtel ved Grunden af Frugtknuden. (Blomsterne i ensidige Klaser uned afrundede Dækblade).

34. Orobanche L. Bægeret til nedenfor Midten eller til Grunden todeelt (eller tobladet), med bele eller toklovede 
Flige; den afblomstrede Krone omkringskaaren ved Grunden, den øvre Deel affaldende, den nedre vedblivende. (Blomsterne i Ax med tilspidsede Dækblade).

\section{Gymospermia.}

\section{Marrubium. Marube.}

767. I. vulgare L. (Almindelig M.) H. 655 ; Drej. n. 600 ; F. D. 1036; Rchb. ic. fl. germ. XVIII, tab. 1224, fig. 1 .

Bladene ægformet-kredsrunde, rundtakkede, natformigt aarede og rynkede; Blomsterkrandsene adskilte, mange- og tætblomstrede, næsten kugleformede; Bageret med en Haarkrands i Svælget, dets Tænder sylformede, i Spidsen glatte, hagekrummede.

Hele Planten (især Stængelen og Bladenes Underflade) hvidfiltet; Kronen hvid. 7-9. $\%$.

Paa grusede Steder, især ved Gjærder omkring Landsbyer, sporadisk: hyppigere paa $\boldsymbol{B}$ or $n h$. end i de andre Provindser.

\section{Galeopsis. IIanekro.}

a. Ledstykkerne ikke opsvulmede under Ledene.

768. G. ochroleuca [Lam. Enc. 2, p. 600] (Guul H.) H. 650 ; F. D. 1650 ; Rehb. ic. fl. germ. XVIII, tab. 1228 , fig. 1 ; H. N. XII, 33 ; G. dubia Leers.

Stcengelen blødt duunhaaret af nedad tiltrykte Haar; Bladene æg-lancetformede, saugtakkede; alle Krandsene adskilte; Dakbladene linieformede, kortere end Bægeret, opret-tiltrykte, kort tornspidsede; Kronrøret 3 Gange lengere end Bægeret, Overlaben 2-3-tandet, Underlabens Flige rundtakkede.

Stængelen oventil og Bægeret kirtelhaarede. Kronen svorlguul med en citronguul Plet ved Grunden af Underlæben. 7-8. $\odot$.

Dyrkede, især sandige Marker, kun funden i Halve ens sydlige Deel: mellem Skudstrup og Vamdrup ved Kongeanen! Logumkloster, Marker N. for Rendsborg (16). (Mangler paa Oerne). 
769. G. Ladanum L. (Sand.H.) H. 619; Drej. n. 585; F. D. 1757; G. latifolia Hffm.; lichb. ie. fl. germ. XVIII, tab. 1228, fig. 3; G. Ladanm $\alpha$, latifolia Wimm.; Lge. Haandb. 1 Udg. p. 345; G. intermedia Vill., Gren. \& Godr. fl. Fr. II, p. 684 .

Stangelen blødt dumbaret af nedad tiltrykte Haar, Bladene elliptiske eller lancetformede, saugtakkede; alle Blomsterkrandsene adskilte; Dalbladene kortere end Biegeret, opret-tiltrykte; Bageret kirtelhaaret, dets Flige ligelange, kort tornspidsede, oprette; Kronroret dobbelt saa langt soin Bægeret, Overlaben svagt udrandet, Underlabens midterste Flig ndrandet, Sidefligene budte, heelrandede.

Stengelen, især foroven, kirtelhaaret. Kronen roseurod med en guul, rodstribet Plet ved Grunden af Underlæben. 7-8. $\odot$. Var. med smalere eller bredere Blade.

Ukrud mellem Srden, især alm. i sandige Egne.

770. G. angustifolia [Ehrb. Herb. 137] (Smalbladet H.) Rehb. 1. c. tab. 1229, fig. 1; G. Ladanum $\beta$, angustifolia Winm.; Lge. l. c.; G. Ladauum E. Bot. 884 .

Stcengclen blødt dumbaret af nedad tiltrykte Haar; Ble. dene linie-lancetformede, ved Grunden og i Spidsen forlængettilspidsede og heelrandede, i Midten fjernttandede eller nosteı heelrandede; de øvre Blomsterkrandse sammenhobede; Dakbladene udadbøiede, længere end Bregeret, langt toruspidsede; Bageret blodhaaret, ved Frugtmodningen opblrst, dets Flige uligelange, langt tomspidsede, tilsidst udstaaende; Kronen som foreg., men større, dens Overlæbe stærkexe hvælvet.

Ved dens Udseende og ved talrige Kjendetegn synes den at vare en fra foreg. vel adskilt Art. $7-8 . \odot$.

Mellem Sreden red Koster paa MIgen (28)! (I Sydeuropa er den lyppigere end foreg.) $\bar{\sharp}$

b. Ledstykkerne oventil opsvulmede, de ovre lirandse sammenbobede.

771. G. Tetrahit L. (AImindelig 11.) H. 649; Drej. H. 583 ; F. D. 1271 ; Rehb. 1. c. tab. 1231, fig. 1. 
Stcongelen stivhaaret af nedbøiede eller udstaaende Haar, under de stærkt opsvulmede Led tæt beklædt med Børster; Bladene ægformede eller elliptiske, tilspidsede, saugtakkede; Kronrørct omtrent af Længde med Bægeret, indtrykt paa Ryggen nedenfor Overlæben; Underlabens Midtflig plan, budt, næsten firekantet, fint rundtakket.

Strngelen oventil og Bægeret kirtelhaarede med oftest mørkrøde Kirtler, Kronen st $\varsigma$ rre, rod ( $\alpha$, rosea!) eller mindre, hvidguul, ved Grunden af Underlæben rodplettet ( $\boldsymbol{\beta}$, pallida!).

Pá dyrkede Steder, f. Ex. mellem Sæden, ved Gjærder o.s. v. aln.

Anm. Den i forrige Udg. optagne $G$. pubescens er kun en Afart af $G$. Tetrahit (G. Reichenbachii Reut?) med mindre opsvulmede Led, større og mørkere Kroner, hvis Rør er længere end Bægeret; den xgte G. pubescens Bess., som findes i Syd- og Mellemtydskland, forekommer neppe hos os.

* 772. G. bifida [Boenn. Fl. monast. p. 178] (T'vedeelt H.) Drej. p. 201; F. D. 2654 ; H. N. VII, 8; Rehb. l. c. tab. 1230 , fig. 1 .

Kronroret kortere end eller af Langde med Bageret, ikke indtrykt paa Ryggen; Underlabens Midtflig linieformet, i Spidsen tokløvet, med tilsidst tilbagerullet Rand, Bladene smalere (elliptiske), forøvrigt som foreg.

Kirtlerne paa Bægeret og Stængelens øverste Deel alm. gule. Kronen alm. mindre end hos Formen $\alpha$ af foreg., lysrød eller hivid med rode Aarer og en guul Plet ved Grunden af Underlæben. 7-8. $\odot$.

Forekomst som foreg. og ligesaa hyppig som hiin, af hvilken flere Forff. ansee den for en Afart.

773. G. rersicolor [Curt. Fl. lond. f. 6 t. 38] (Hampagtig H.) Drej. n. 584; Rehb. l. c. tab. 1231, fig. 3-4; G. canabina Roth, H. 650 ; F. D. 929 ; G. Tetrahit $\beta$, L.

Kronroret dobbelt saa langt som Brgeret, Underlabens Midtflig afrundet, fiint rundtakket, violet, den øvrige Krone svovlguul, over dobbelt saa stor som hos de 2 foreg., forøvrigt som disse.

Kirtlerne alm. røde. 7-8. $\odot$.

Mellem Sxdeu alm. udbredt. 


\section{Stachys. Galtetand.}

a. Udlobere fra Rodatokken. 4 .

774. S. silratica L. (Stor G.) H. 652; Drej. n. 590; F. D. 1102 ; Rehb. ie. fl. gernt. XVIII, tab. 1222, tig. 1.

Alle Bladene langstilkede, hjerteformede, grovt saugtakkede ; Krandsene sexblomstrede; Udloberne ikke tykkere inod Spilsen.

1'/2-2' hoji. Hele Planten laaden af udstalaende Haar. Kronen mork-brumurod (sjelduere skident violet) med hvide Aarer paa Underlahen; Brgeret og Kronens Overlabe kirtellaarede. Den har en nbelagelig, stinkende Lugt. $7-8$.

I Skove og Krat meget alm.

775. S. palustris I. (Smalbladet G.) II. 653 ; Drej. I1. 588 ; F. D. 1103 ; Rehb. 1. e. tab. 1211 , fig. 1.

Bladene lancetformede med afrundet eller svagt hjerteformet Basis, fint saugtakkede, de nedre kortstilkede, de ovre siddeude; Krandsene 6-12-blomstrede; Udloberne i Spidsen kolleformigt fortykkede.

$1-1^{1} / 2^{\prime}$ høi. Stængelen stivhaaret-rn af nedboicle Haar, Bladene 1) ødhrarede, paa Overfladen grome, paa Underfladen graagtige: Kronen lys-rosenrød, med hvide Aarer pan Underlæben; Overlæben og Brgeret dumbarede med fare Kirtelhar. Planten mindre stinkende end den foreg. 7-8.

$\beta$, canescens! (S. segetum IIagen). Bladene smalere, paa begge Flader graafiltede.

I Torvmoser, ved Grofter og paa dyrkede, især fugtige Marker alm. $\beta$, par mere tør Gruuil.

$\asymp$ S. palustri-sileatice [Schiede Pl. hybr. 43] (Tvivlsom G.) S. ambigua Sm., H. II, 206 ; Drej. n. 589 ; Lge. Haandb. 1 Udg. n. 749; F. D. 1877 ; Rehb. 1. e. tab. 1215.

Alle Bladene kortstilkede, æg-laneetformede med hjerteformet Basis, sang'akkede; Krandsene 6-8-blomstrede; $U d$ loberne som hos foreg. 
1-1 $1 / 2$ høi. Hele Planten haret, med nedbøiede Haar paa Stængelen; Kronen mørk rosenrød med hvide Aarer paa Underlæben. Den stærke, men nbehagelige Lugt har den tilfælles med S. silvatica. 7-8.

I Skove og paa dyrkede Steder meget sjelden: $\boldsymbol{S} \boldsymbol{j}$. Hellebaks Vang! en Groft ved Strandveien forbi Agershvile (Blytt); Lo ll. Nobbolle (19); J. Eskjær Slsov i Salling (Dr.); Haven i Vendsyssel (12)!

Anm. De fleste nyere Forfattere ansee denne Plante for en Bastardform af de 2 foregaaende Arter.

\section{b. Udløbere $0 . \odot$.}

776. S. arrensis L. (Ager-G.) H. 654; Drej. n. 587 ; F. D. 587 ; Rehb. 1. c. tab. 1212, fig. 1; H. N. IV, 12.

Alle Bladene stilkede, æg-hjertefurmede, budte, rundtakkede ; Krandsene 4-6-blomstrede; Bagertanderne af Længde med eller læugere end Kronrøret.

$1 / 2-3 / 4^{1}$ høi. Hele Planten stivhaaret, Hadrene paa Stængelen udstaaende. Kronen blegrød eller hvidagtig. 7-9.

Paa dyrkede Marker mellem Vaarsæden, i Haver o. s. v. et i flere Egne alm. Ukrud, især paa Bornh., i Sydsjall., paa Loll., Fals . $o g$ i Fyen, sjeldnere $\mathrm{i}$ det nordl. og vestl. Jyll. og Nordsjælland.

777. S. aumua L. (Enaarig G.) F. D. 2541 ; Rehb. I. c. tab. 1212 , fig. 2 .

Bladene lancetformet-ovale, rundtakket-saugtakkede, de nedre kortstilkede, de øvre næesten stilkløse; Krandsene 4-6blomstrede; Bageritanderne kortere end Kronrøret.

$1 / 2-3 / 4^{\prime}$ høi. Stængelen duunhaaret, Bægeret stivhaaret, Bladene næsten glatte. Kronen hvid med blegguul Underlæbe. 7-9.

Mellem Saden, paa sandige Marker, sjelden: Bornh. Ruthsker (Hjorth), Hasle (11)! Falst. i en Havremark mellem Brarup og Riserup (Koch)!

\section{Ballota. Tandbager.}

778. B. ruleralis [Swartz i Sv, bot. 489] (Almindelig T.) Fr. nov. p. 194 ; H. 655 ; Drej. n. 602; F. D. 1702; B. nigra L. fl. Suec., Fr. H. N. VII, 7; B. nigra var. ruderalis Relıb. l. c. tab. 1218 , fig. 3 .

Bladene æg-hjerteformede, grovt og uregelm. saugtakketrundtakkede, rynkede af de stærkt forgrenede, paa Underfladen 
ophøiede, paa Overfladen indtrykte Nerver; Bagret tragtformet eller næsten fladkravet, dets Tander jævnt udløbende i en lang, sylformet Spids.

Hele Planten haaret. Kronen rosenrød-lila med hvide Aarer, sjeldnere hrid (B. alba L. fl. Suec.). 7-9. I. Overlæben alm. heel, var.

$\beta$, nepetoides! Kronens Overlæbe tolappet, næsten plar.

$\gamma$, urticafolia (B. urticæfolia Ortm.) Rchb. I. c. fig. 4. Bladene dybt saugtakkede, uæsten lappede; Bægertændernes Spids længere end hos Hovedarten, stakformet.

Ved Gjarder, isæer omkring Byer, meget alm. - $\beta$, med Hovedarten ; $\gamma$, sjeldnere: Vedbæk!

* 779. B. foetila [Lam. Fl. Fr. II, p. 381] (Stinkende T.) Fr. nov. p. 195; Drej. n. 601 (undt. Voxest.); Rchb. ic. crit. VIII, 1041 ; H. N. XI, 18; B. nigra $\alpha$, foetida Koch og $\beta$, borealis (Schweigg.) Rehb. ic. fl. germ. XVIII, tab. 1218, fig. 1-2.

Bladene mindre og alm. mindre dybt tandede; Bageret fladkravet, med nætformig aarede, bredt ægformede, afrundede Tæuder, som pludselig ende $\mathrm{i}$ en kort Braad; forøvigt som foreg.

Har, ligeson foreg., men maaskee i noget hoiere Grad, en stinkende Lugt, omtr. som Staclyys silvatica. 7-9. \%. Kronen alın. af Farve som foreg., var.

$\beta$, alba (B. alba L. sp.) Kronen hvid, Bægertandernes Braad læugere end hos Hovedarten.

Sjelden i Danmark, og kun bemærket i Nærheden af Sohavne ( $\kappa$, paa Ballastpladser ved Nakskov (19); $\beta$ har jeg fundet jaa Lange Linie ved Kbh. tæet ved Indgangen fra Citadellet). Sandsyuligviis er den her (ligesom i Srerige) oprindelig indslabt med Ballast. At Hornem. (B. nigra - efter Beskr.) og Drej. angive denue som den i Danm. hyppigste Art, lidroser i hvert Fald fra en Feiltagelse. F. D. 673 (Mentha aquatica), som alm. henfores til B. foetida, er for slet til med Sikkerhed at kunne bestemmes. $\bar{F}$

Anm. Flere Forff. forene disse 2 Arter, og det kan ikke nægtes, at $B$. foetida $\beta$, alba $i$ Bægerets Form synes at danne en Overgang. Dr. Sonder (som har sendt mig en lignende hvidblomstret Form fra Hamburg') bemærker (Fl. hamburg. p. 335), at han endog pata samme Plante har fundet begge Bxgerformer. Imidlertid vil man, ved at sanmenligne den nordiske B. raderalis med den i Sydeuropa ene forekommende B, foetida, finde disse væesenlig forskjellige. Navnet B. 
nigra L., som bør beholdes naar man forener Arterne, kan ikke anvendes nuav de adskilles, fordi det deels er lidet betegnende, deels af Forff. anvendt paa begge Arteme, og sandsynligviis af Linné selv brugt collectivt.

\section{Betonica. Betonie.}

780. 1. officinalis L. (Læge-B.) H. 652 ; Drej. n. 586; F. D. 726 ; H. N. II, 23; B. stricta Ait., Rehb. ic. crit. VIII, 954; Stachys Betonica Benth., Rehb. ic. fl. germ. XVIII, tab. 1217.

Bladene aflang-xgformede med hjerteformet Basis, grovt saugtakkede eller rundtakkede, de nedre langstilkede, de øvre næsten stilkløse; Blomsterkrandsene danne et tæt Ax (de nedre Krandse stundom fjeruede fra de ovrige); Bagertanderne braadspidsede, med rgformet Basis; Kronens Overlabe budt, i Spidsen tilsidst tilbageboiet.

1.-2' høj. Hele Planten haaret (især Bægeret, Bladstilkene og Stængelen under Ledene). Kronen rosenrod, ndvendig hviduldet. 7-8. 2.

I Kratskove og paa hoie Enge sjelden: $\mathbf{S}$. Soplienberg (H.), Rygaard (Kyll.); Loll. Krat mellem Darket og Ottelund! Bjerremark, Rubjerggaard (5)! Lojitofte (14), Sringelen ved Nakskov (9); F. Skovgaarde (7); $S l$. Flensborg (25). *

\section{Lamiuns. Tvetand.}

a. Bladenc tilspidsede. ข.

aa. Kronroret krummet, med en Haarhrands indvendig $i$ Roret.

781. L. alhum L. (Dovnolde-T.) H. 546; Drej. n. 593 ; F. D. 594 ; Rehb. ic. fl. germ. XVIII, tab. 1205, fig. 1.

Stcengelen udeclt; Bladene $x g$-hjerteformede, grovt og uregelm. saugtakkede; Krandsene 10-20-blomstrede; Bagertonderne børsteformede; Haarkrandsen i Kronroret skraa.

1-1 $1 \frac{1}{2^{\prime}}$ høi. Kronen hvid, Underlabens Midttlig blegguul med en brum Plet ved Grunden, tolappet, Sidefligene ende $\mathrm{i}$ en spids Tand. $5-8$.

$\beta$, integrifolium Nolt. (Ians. Herb. 1028). L. parietarixfolium Benth. Bladene heclrandede, $x$ gformede, de ovre smalere. 
$\boldsymbol{\gamma}$, roseum Lge. Kronen rosenrød.

Ved (ijærder, omkring Byer o. s. v. meget alu. i de fleste Egne af Landet; sjelden par Falst. (Stubbekjøbing, 14, Kippinge, Koch), i det ostl. Lolt. (19), i det sydl. Fy en og paa Oerne deromikring (Vindeby par 'Thorseng, 12). $\beta$, Deetzbol i S iesv. (F. Müll.); $\gamma$, mellem Nykro og Veseby 0 . for Flensborg!

\section{I. maculatum L. (Plettet T.) H. 646 ; F. D. 1649 ;} Relib. 1. e. tab. 1205, fig. 3; H. N. XV, 18.

Stcungelen grenet; Bladene hjerteformede, uregelm. saugtakkede, med hvidgule Pletter paa Overfladen; Bogertonderne smalt sylformede, lidet kortere end Kronroret, som har en horizontal Haarkrands indvendig.

$1-1^{1} / 2^{\prime}$ hoi. Strengelen rodlig. Kronen rosenrod, med hvid-og rodstribet Underlæbe. $5-\mathrm{S}$.

Ved Gjærder meget sjelden: $\boldsymbol{S} l$. Vogelsang Skov (16). (I Holsteen paa flere Steder).

\section{Kronroret ret, med nogent Ror.}

† L. garganicum L. (Rehb. ie. fl. germ. XVIII, tab. 1207, fig. 2). Bladene hjerteformede, dybt og uregelm. dobbelt saugtakkede, rynkede og duunharede; Bægertænderne bredt sylformede, meget kortere end Kronrøret; Kronen skidenrød med sakformigt udvidet Svalg.

Forvildet ved Risingsminde pr. Odense (Lefolii)!

b. Bladene budte eller afrundede, sjellnerespidse (ikke tilspidsede).

aa. Kronroret oftest krummet, med en Haarkrands indvendig (ovenfor Basis).

783. I. purpureum L. (Rød T.) H. 647; Drej. n. 595; F. D. 523 ; Rehb. l. c. tab. 1204 , fig. 3 .

Bladene hjerteformede, uregelm. rundiakkede, alle stilkede; Bagertenderne omtrent af Lxengle med Bxgerraret.

${ }^{1}{ }_{2}-1$ ' løoi. Kronen rosenrod, sjeldnere livid. 4-9.

Paa dyrkede Steder overalt meget alın. 
bb. Kronrøret ret, indvendig nøgent.

784. L. incisum [Willd. Sp. 3, p. 89] (Fliget T.) H. 617 ; Drej. n. 594 ; F. D. 2358 ; Rchb. l. c. tab. 1204, fig. 4 ; H. N. X, 16; L. confertım Fr. S. Veg. Sc. p. 15 og 198.

Bladene uregelm. rundtakket-lappede eller indskaarne, de nedre hjerteformet-nyreformede, langstilkede, de øvre rudeformetægformede, kortstilkede med formeden udvidet Bladstill; de øvre Blomsterkrandse tæt samlede; Bogertcnclerne af Læugde med eller længere end Bægerrøret, sylformede, udstaaende, stivhaarede.

$1 / 2-3 / 4^{\circ}$ høi. Kronen rosenrød. Planten mørkfarvet, alm. rødligt anlgben. Flere af de angivne Kjendetegn variere, men ved sit hele Udseende er den nolssom forskjellig fra og kan ikke forvexles med foreg. (12). Fra folg. er den aldeles forskjellig.

Paa lignende Steder som foreg., hist og her $\mathrm{i}$ alle Provindser. $\bar{*}$

785. L. intermedium [Fr. Nov, p. 192] (Nyrebladet T.) H. 649 ; Drej. n. 596 ; F. D. 1701 (ikke god); Rehb. l. c. tab. 1204, fig. $1 ;$ N. N. I, 51.

Alle Bladene nyreformede, rundtakket-haandlappede, de nedre stilkede, de ovre næsten siddende eller omfattende med en kort, opblæst Bladstilk; Blomsterkrandsene adskilte; Bagertcenderne som hos foreg., længere end Røret.

$1 / 2-1$ ' høi. Kronen rosenrød, Overlæben snukt og mørkt purpurrød. 4-5 og 8-9.

Paa lignende Steder som de foreg., men sjelduere og sporadisk (paa enkelte Steder periodisk i Mængde): $\boldsymbol{S}$. Fortunen! Vibenshuus (Dr.) o. fl. St. i Kjøbenhavns Omegn! Ballerup (1), Roeskilde, Holbak (15); Falster! Loll. ved Rødby (H.); J. i det nordl. og nordvestl. alm.! Viborg (Feddersen), Hobro (16), Randers! Haraldslund! Hjortlund (12).

786. L. amplexicaule L. (Liden T.) H. 648; Drej. n. 597 ; F. D. 752 ; Rchb. 1. c. tab. 1204 , fig. 2.

Alle Bladene uyreformede, de nedre stilkede, rundtakkede, de øvre siddende og omfattende, haandlappede; Blomsterkrandsene adskilte; Bogeret blødt og graaagtig-duunhaaret; Tonderne 
kortere end Røret, før og efter Blomstringen sammeustødende i Spidsen.

$1 / 2-3 / 4^{\prime}$ høi. Krenen som foreg., med meget langt Rør. 5-8.

$\boldsymbol{\beta}$, clandestinum (Rehb. ic. crit. VIII, 950). Kronen liden, affaldende undsprungen, blomstrer tidligere end Hovedarten (4).

Ved Gjærder og mellem Sreden ikke sjelden.

\section{Galeobdolon. Barsvielg.}

787. G. luteum [Huds. Fl. angl. 258] (Gunl B.) H. 651; Drej. n. 598; H. N. II, 24; Galeopsis Galeobdolon L., F. D. 1272 ; Lamium Galeobdolon Crantz, Rehb. ic. Al. germ. XVIII, tab. 1206, fig. 3.

Stcongelen opstigende, duunharet af nedad tiltrykte Haar paa Kanterne, med Vandgrene fia Rodstokken; Bladene ægformede, saugtakkede; Bageret tragtformet, med bladagtigtgrønne, spidst triangelformede T'ander.

De ældre Blade hvidplettede. Kronen lysguul med morkere Underlæbe. $5-6.4$.

I Lovskove, alm. i de sydlige Egne af Landet omkring Ostersgen (f. E. Bornh., Loll. -Falst., Sydsjall., sydl. F. og Halvoens sydøstlige Skove). Sjelden mod N.: Sj. Hornbæk (20), Hellebæk! Egebæksvang! Frederiksborg, Fredensborg (Jørg.); Hørsholm (19). Holbæk (15), (mangler ved Kbhvn); F. Holkenharn, Ubberod, Vissenberg (H.); J. Lundbykrat (H.).

\section{Leonurus. Hjertespand.}

788. L. Cardiaca L. (Almindelig H.) H. 656 ; Drej. n. 599 ; F. D. 727 og 1756 ; Rehb. ic. fl. germ. XVIII, tab. 1233, fig. 2 .

Bladene alle stilkede, wxtformigt aarede, haandfligede, de gvre tre-, de nedre femfligede; Blomsterkrandsene siddende, tætblomstrede, adskilte; Brgeret glat, næsten tolæbet, med braadspidset-stikkende, uligelange Tander; Kronens Underlabe med aflang Midtflig, dens Rør indvendig forsynet med en Haarkrands.

2-3' høi. Kronen rosenrød, udvendig hvidfiltet, Underłæben hvidguul med rode Prikker. 7-8. 4.

Ved Gjærder, især omkring Landsbyer, alm. udbredt. 
789. I. Marrubiastrum L. (Stortandet H.) H. 656; F. D. 2653 ; H. N. XV, 19; Chaiturus Marrubiastrum Rehb. fl. exe. p. 317 , ic. fl. germ. XVIII, tab. 1233, fig. 1.

Bladene stilkede, aflange, saugtakkede, de øvre Blade (ved Blomsterne) lancetformede, heełrandede eller ovenfor Midten fjernt saugtakkede; Bogeret tiltrykt-duunhaaret, med braadspidsetstikkende Tonder; Kronens Midtflig rundagtig; Kronroret ind. vendig nøgent.

$1^{1 / 2}-2^{1 / 2} 2^{\prime}$ høi. Kronen lysrod, ndvendig filtet. 7-8. (.).

Ved Landshyer, kun fundet paa Loll.: Dannemarre (9), Harpelunde, Rolykke (19), Skovsbølle, Gloslunde, Alminde (14), Østofte, Errindlev (Rasmissen) og fl. St. (ialt noteret fra 14 forskjellige Voxesteder). 周

\section{Nepeta. Katteurt.}

790. N. Cataria L. (Almindelig K.) Il. 637; Drej. n. 591 ; F. D. 580 ; Rehb. 1. c. tab. 1242.

Bladene stilkede, æg.hjerteformele, dybt saugtakkede; Blomsterlurandsene stilkede; Dagertanderne sylformede; Nodderne jævie, glatte.

$1^{1 / 2}-2^{\prime}$ hoi. Hele Planten trt graafiltet. Fromen hivid med rorlpunkteret Underlæbe. 6-8. 4.

Ved Gjærder, især omkring Byer paa Gruns, men sporadisk, og i enkelte Egne ikke bentrket, f. Ex. Bomholm (Hoff).

$\dagger$. nuda L. Bladene aflang-hjerteformede, rundtakkede; Nodderne kundret-rue, i Spidsen duunhaarede.

Forvildet par en Høi ved Bidstrupgaard (tilligemed flere andre fremmede Planter).

\section{Glechoma. Korsknop.}

791. G. hederaceum L. (Vedbende-K.) H. 645; Drej. n. 592 ; F. D. 789 ; Rchb. 1. c. tab. 1241 , fig. 1-2; H. N. XI, 19 (var.).

De golde Stangler krybende, de blomsterbærende Grenc oprette eller opstigende; Bladene stilkede, med en Haarkiands ved Grunden af Bladstilken, nyreformede, rundtakkede; Krandsene 
dannede af kortstilkede, 3-5-blomstrede Nogler; Bagertanderne xgformede, sylspidsede, 3 Gange kortere end Roret.

Kronen blaaagtig, sjeldnere rod-violet med mørkrødprikket og hvidstribet Svælg. ( $q$ Formen har indsluttede, ikke korsstillede St $ø \mathrm{v}-$ dragere). $\frac{4}{2}-\frac{6}{1} \cdot 2$.

Ved Gjærder, i Randen af Skove o. s. v., meget almindelig.

\section{Ajuga. Laebelos.}

792. A. reptaus L. (Krybende L.) H. 635 ; Drej. n. 608 ; F. D. 925 ; Rehb. 1. c. tab. 1234 , fig. 3 ; H. N. IX, 15 .

Vandgrene fra Rodstokken; Bladene omvendt-ægformede eller ovale, rundbugtede; Rodbladene stilkede; de ove Dalbblade af Læengde med eller kortere end Blomsterne.

Var. svagthaaret eller næsten glat. Kronen blaa, sjeldent rød eller hvid. 5-6. $\%$.

I Lovskove (sjeldnere paa hoie Enge), oftest i Selskab med Galeobdolon, med livilken den ogsaa i Henseende til Fordeling i Landet stemmer overeens: Nords jall . sporadisk : Ledreborg, Rygaard (15), Fredensborg (Jørg.), Frederiksborg, Hørsholm! Søllerød (Petersen), Store Hareskov (14), Frederiksdal (H.), Lyugby (17), Frederiksberg Have (H.), mellem Valby og Flaskekroen, Voldgravene mellem Oster og Nørre Port (Krabbe), Cliarlottenlund ved Forsthaven (14)! Ordrups Mose ved Fuxveien! i $S y d-o g$ Vestsjall. alm., ligesaa paa de sydligere Øer og i Fyen; $\mathbf{S} a m s \theta(2) ; J$. i det nordl. sjelden: Viborg (Feddersen), Skyum Krat, Randers (H.), Haraldslund! i det sydøstl. alm. (Ikke bemærket paa Bornholm. Hoff).

793. A. pyramidalis L. (Pyranideformet L.) H. 633; Drej. n. 609 ; F. D. 185 ; Rehb. l. c. tab. 1234, fig. 2; H. N. XII, 34,

Rodstokken uden Vandgrene; Bladene som foreg., med korte Stilke; Blomsterkrandsene danne et pyramideformet Ax med fireradet stillede Dakblade, som alle ere meget læengere end Blomsterne.

Stængel og Blade trothaarede. Kronen lysblaa, mindre end hos foreg., sjeldnere hvid. 5-6. y eller $\odot$.

I høitliggende Skove, paa Bakker mellem Krat, Lyngheder, sporadisk og temmelig sjelden: $\boldsymbol{S} \boldsymbol{j}$. Asnæs Skov ved Kalundborg (Sinith), Helsingors Ladegaard (21), mellem Orsholt og Gurre, Hjørlunde Mark ved Slangerup, Jonstrup (H.), Greve (14); J. Hjørring (H.), Torslev 
Lgby), Overklitgaard og Agersted i Vendsyssel (16), Morsø (Schade), Skovsgaard Krat (Feddersen) og Margretelund ved Viborg (Morville)! Lyne Kro ved Varde, Hjerting (16); paa Bornh. flere Steder (H., 20).

\section{Teucriun. Kortlabe.}

734. T. Scordium L. (Løglugtende K.) H. 636; Drej. n. 610 ; F. D. 593 ; Rchb. l. c. tab. 1239, fig. 2 ; H. N. I, 17 .

Stcongelen opstigende, med Udløbere fira Rodstokken; Bladene stilkløse, linieformet-ovale, tandet-saugtakkede, de øvre nedenfor Midten heelrandede; Krandsene omtrent fireblomstrede.

$1 / 2-1^{\prime}$ høi. Planten haaret, har en løgagtig Lugt. Kronen lysrosenrod. $7-9.4$.

Paa fugtige Steder, især pan Leergrund, f. Ex. ved Randen af Grofter og Mergelgrave: $\boldsymbol{S} j$. en Groft bag Flaskekroen! Magleby paa Amager (15), Svenstrup ved Kjøge (Burs. herb), i Sydsjall., paa Falst., Loll. og Langel. hist og her; Sl. Fobislet ved Hadersler (II.). I Jyll. og de andre nordlige Egne af Landet mangler den. 7

† T. Chamadrys L. Rehb. I. c. tab. 1238.

Rodstoklien udsender traadformede, gule Udløbere; Stanglerne opstigende; Bladene kortstillede, æg-lancetformede, rundtakkede, paa Overfladen glindsende, paa Underfladen blaagraaduunhaarede; Krandsene 4-6-blomstrede, samlede til ensidige, endestillede Klaser.

Kronen rosenrsd. ל. 7-9.

Forvildet i Vemmetofte Dyrehave (Sünckenberg, Visby)! क

\section{Mentha. Mynte.}

a. M. genuinœ. Bægeret regelm. femtandet, med a abent Svælg; Kronens Overlæbe udrandet.

aa. Bladcne stilliløse, Stcengelbladene forskjellige fra Bladene ved Blomsterne; Blomsterkrandsene samlede til $A x$.

795. II. rotundifolia L. (Ruudbladet M.) F. D. 2542; Rehb. l. c. tab. 1282 ; H. N. IX, 12.

Bladene hjerteformet-ovale, i Spidsen afrundede, rynkede, tiltrykt-saugtakkede; Axene korte, tætblomstrede; Bageret ved 
Frugtmodenheden kugleformigt opblæst med lancet-sylformede, tilsidst sammenstødende Tonder.

$1-1^{1} / 2^{\prime}$ høi. Bladene hridfiltede af krnset Uld. Kronen lıvid, meget liden. 8-9. 4 .

Paa fugtige Steder, sjelden: Bornh. Ormebækken ved Pythuset, $1 / 4$ Miil S. O. for Ronne (21)! $S j$. Storehedinge (Visby)! 7

796. II. silrestris L. (Graa M.) H. 638 ; Drej. n. 581; F. D. 484 (slet) og 1932; Rchb. l. e. tab. 1283; H. N. I, 18.

Bladene ægformet-elliptiske, spidse, skarpt saugtakkede, ved Grunden afsmalnede (de nedre kortstilkede); Axene langstrakte, tætblomstrede (de nedre Krandse ofte adskilte); Bageret ved Frugtmodenheden opblæst med indsnøret Svælg og linie-sylformede, tilsidst sammenstødende Tunder.

$11 / 2-2$ ' hoi. Brgeret og Bladene paa Underfladen graafiltede, Kronen rød-lila, duunhaaret, storre end hos foreg. 8-9. थ. Bladene var. i Brede, Beklædning o.s.v.

Ved Aa- og Søbredder, i fugtige Skove, sporadisk og sjelden: $\boldsymbol{S} j$. ved Nordbredden af Esrom $\mathrm{S} \emptyset$ (21), Nøddebo (12), Fredensborg (Frevehen), Hørsholn (II.), Hesttangs Mølle (Schlichtkrull), Søndermarken (19), Svends Molle ved Valø (21), Bredebrks Molle verl Sparresholm(Lund); L oll. Soliolt Skov(5), Hamborgerskoven (Benzon); $\boldsymbol{F}$. Bjornemose (H.); J. Tange Brolnus (16), Williamsborg N. for Veile Fjord (H.), Lundeskov mellem Kolding og Vamdrup (16), Sl. Vedelspang (16), ved Eideren mellem Carlshïtte og Bargstedt!

797. I. virillis L. (Grøn M.) H. II, 204; F. D. 1876; H. N. VII, 9.

Bladene lancetformede, tilspidsede, fjernt, men skarpt sangtakkede; Blomsterkrandsene adskilte, danne et mellembrudt Ax; Bageret furet, dets Tander sylformede, rette, tilligemed de linieformede Dakblade randhaarede.

Bladene gronne. Hele Planten glat eller Stængel og Blade paa. Underfladen svagt haarede; Kronen lila, af Størrelse som foreg. 8-9. ข.

Ved Gjærder og Landsbyer, især paa fugtige Steder, sjelden: $\boldsymbol{S} j$. en Bæk ved Skotterup pr. Helsingor (9), Orholm (Drej. herb.), Broxø (Visly); Falst. Nykjobing; Loll. Vesterborg, Hillested (19), F. Ollerup! V. Skjerninge Molle! Assens (Kyll.); Sl. Dammen ved Iladerslev (N.)! Gram, Hoptrup (Gronlund); J. Lundeskov og Eistrup V. for Kolding, ved Skanderborg So (16); Ristrnp (H.), Ranum ved Logstør (8), Orlev i V. Hanherred (16); Christianso (Hamann)! * 
Anm. En var. canescens med graafiltede Blade, som efter Fr. findes i Srerige, har jeg ikke fundet lıos os. Alle Arterne i denne Slagt variere i Henseende til Beklædningen, men denne Art er, foruden dens typiske Mangel paa Haar, saa betydeligt forskjellig fra foreg., at de umuligt kume forenes. Den af Koch (Syn. p. 633) for M. viridis L. antagne Var. (glabra) af foreg., er (efter Beskr.) meget forskjellig fra den Ler forekommende M. viridis. (Snl. Fr. mant. 3 p. 56).

bb. Stcengelbladene stilkede, ensformede med Bladene ved

Blomsterne.

798. II. aquatica I. (Vand-M.) Fr. Nov. p. 182 ; F. W. A reschoug, Botan. Observ., ef. Bot. not. 1855 p. 20.

Stcengelen opret, med opstigende eller opret-aabue Grene; Bladene ægformede, elliptiske eller ovale, saugtakkede; Blomsterstilkene haarede; Bageret rør- eller tragtformet, furet, med tilspidset-triangelformede eller sylformede Tender; Kronen udvendig duunhaaret.

1-2' høi. Kronen lila. Var. betydeligt i Henseende til Bladenes Form, Beklædning, Blomsterstanden samt Støvdragernes og Griffelens indbyrdes Længde. 7-9. 4 .

Følgende Former kunne adskilles:

A. capitata Fr. Nov. p. 182; M. aquatica Drej. n. 580; Lge. Haandb. ed. 2, n. 790; Relib. l. c. tab. 1286; H. N. II, 25; M. hirsuta aquatica H. 640; Origanum vulgare F. D. 63. Bladene ægformede eller ovale, med kortere og mere tiltrykte Takker; Blomsterkrandsene faae, tat samlede til et Hoved uden Bladdusk i Spidsen; Støvdragerne oftest fremragende (ठ̋).

B. subspicata Aresch. I. c. p. 21 (cf. Fr. nov. p. 183), M. pyramidalis Lloyd fl. d'Ouest 344. Blomsterkrandsene flere, de nedre adskilte og ofte langstilkede, Bladene ved Blomsterne alm. siddende, de ovre danne ofte en Bladdusk; Støvdragerne alm. indsluttede ( $($ ).

C. verticillata Fr. Nov. p. 183, Aresch. 1. c. p. 21 ; M. sativa Fr. mant. 3, p. 57 ; Drej. 1. c. n. 579; Lge 1. c. n. 791 ; Rchb. I. c. tab. 1285 , 3 og tab. 1287; H. N. II, 26; II. hirsuta sativa H. 640 ; M. palustris Relıb. ic. crit. X, 1307. Bladene æg- 
lancetformede eller elliptiske, med skarpere Takker, Blomster. krandsene adskilte, med en Bladdusk i Spidsen; Støvdragerne alm. indsluttede (q).

Af denne Form forekomme følgende Afændringer:

$\alpha$, vulgaris. Hele Planten haaret og alm. stærkt grenet; Haarene paa Stængelen nedadvendte; Bladene æg-laneetformede eller elliptiske.

$\beta$, glabrata. Stængel og Blade meget svagt haarede eller næsten glatte.

$\boldsymbol{\gamma}$, brevifolia! Bladene korte og brede; Kronen meget svagt haaret; Stængelen, Bladene ved Blomsterne og Bægerne mørkviolet anløbne.

$\delta$, acutifolia (M. acutifolia Sm.). Rchb. I. c. tab. 1287, fig. 1. Bladene elliptiske eller lancetformede; Kronen meget stærkt haaret. Hele Planten alm. gron.

$\varepsilon$, latifolia Nolte (F. D. 2057; H. 640). Bladene bredt ægformede, dybt sangtakkede; Blomsterkrandsene fjerne.

I Grofter, Moser o. a. fngtige Steder (B. sjeldnere end A og C). A forekommer især ved Bredderne af selve Vandet, C i fugtige Enge eller endog par mere tør. Grund, begge ndbredte over hele Landet. Formen $\boldsymbol{\beta}$, Skjarhoved i Jyll! $\boldsymbol{\gamma}, \boldsymbol{S} \boldsymbol{j}$. Tryggersd Mose! J. Fanrholt i Vendsyssel! $\boldsymbol{S} \boldsymbol{l}$. Pobøl mellem F'lensborg og Husum! $\delta, \boldsymbol{S} j$. Hjnlebækshuset red Helsingør! J. (Kph. Herb.); $\boldsymbol{\varepsilon}, \boldsymbol{S} l$. Aabenraa!

Anm. De hos os almindeligt forekommende Former (A og C) af denne Art ere, saavel ved flere Characterer, som især ved Habitus saa forskjellige fra hinanden, at den almindeligt vedtagne Adskillelse i 2 Arter, M. aquatica og sativa, kunde synes tilstrækkelig berettiget, dersom ikke Formen $B$ dannede et tydeligt Overgangsled imellem dem, hrortil fremdeles kommer, at et af de viesenligste skjelnemarker, Mangel eller Tilstedevarelse af tomme Blade (Bladdusk) i Spidsen af Blomsterstanden, er funden at vare ikke eonstant. I Overeensstemmelse med Areschong (l. c) og efter at have seet Expl. af $\boldsymbol{M}$. pyramidata Lloyd, der er en øiensynlig Mellemform imellem dem, er jeg nu tilbøielig til at forene de forhen adskilte Arter. - Linués M. sativa synes at maatte henfores til de tvivlsomme Arter; til den i Norden og hele Nordeuropa almindelige Art kan den $i$ hvert Fald neppe henfores, da L. kun angiver den at voxe "in Europa australi".

799. I. gentilis L. (Eng-M.) H. 642; F. D. 736 (?) og 2655 ; H. N. VI, 13 ; M. pratensis Sole, Menth, britt. t. 17. 
Stcengelen opret med opret-aabne Grene; Bladene elliptiske eller æg-lancetformede, tilspidsede, skarpt saugtakkede; Bladene ved Blomsterne siddende; Dckbbladene nedhængende, længere end de unge Krandse; i Randen og paa Underfladen stivhaarede; Krandsene fjerne, smaae, tætblomstrede; Bageret lidet kortere end Kronen, rørformet-klokkeformet, med sylformede, randhaarede Tcender; Blomsterstilkene glatte.

Stængelen murkrød, med faae, nedadvendte Haar; Blomsterne neppe halvt saa store som hos foreg.; Kronen glat, blegrød-lila. 8-9. 4 .

$\boldsymbol{\beta}$, Agardhiana Fr. S. Veg. p. 13. M. sativa (Agardhiana) Fr. nov. p. 184 ; mindre haaret, Bladene større, bredt ægformede.

Faa fugtig Grund meget sjelden: J. Viborg (Drej. herb.); $S l$. Lyrskov (Jesser). $\beta$, Hjulebækshuset mellem Helsingør og Hellebæk! |*

800. M. arrensis L. (Ager-M.) H. 643; Drej. n. 578; F. D. 512 ; Rehb. 1. c. tab. 1289 , fig. 1.

Stcengelen fremliggende eller opstigende, med vandret udspilede eller opstigende Grene og underjordiske Udlobere, ved hvilke den overvintrer; Bladene xgformede eller elliptiske, spidse, tiltrykt-saugtakkede; Krandsene tæt- og mangeblomstrede; Bladene ved Blomsterne stilkede, Dakbladene kortere end Krandsene, bredere end hos foreg.; Bogeret klokkeformet, med ægformet-triangelformede, korte (ligesaa brede som lange) Tconder.

Kronen haaret, lila (lidet storre end hos foreg., mindre end hos næstforeg.). 7-9. 4. Forekommer i talrige Former, hvoraf følgende ere de eiendommeligste:

$\alpha$, vulgaris (Rehb. I. c. fig. 1). Bladene xgformede, Bladstilkene omtrent af Læugde med Blomsterkrandsene; Blomsterstilkene haarede.

$\beta$, parietaricefolia Beck (Rchb. 1. c. fig. 2). Svagthaaret; Bladene store, elliptiske, forneden heelrandede og afsmalnede i en Bladstilk, som er meget længere end Krandsene; Blomsterstilkene glatte.

$\gamma$, glabriuscula Koch (M. gracilis Sole Menth. britt. t. 16; M. arvensis aeuta Rchb. l. c. tab. 1286, fig. 5). Bladene elliptisk- 
lancetformede, tilspidsede, tilligemed Stængelen svagthaarede, Bladstilkene kortere end Krandsene, Blomsterstilkene glatte.

$\delta$, riparia Fr. nov. 189; H. N. II, 27. Stængelen lav, næsten opret, ugrenet; Bladene ægformede, tilligemed de tatsiddende Blomsterkrandse svagthaarede; Blomsterstilkene glatte. Hele Planten af en mørkrød Farve.

Paa Agre, løøie Enge, ved Grofter o.s. v. meget alm. Afarterne sjeldnere: $\boldsymbol{\beta}$, Bognæs Skov (Horn. Herb.); $\gamma, \boldsymbol{L}$ oll. ved Søllested (19); $\delta$, i Holsteen ved Einfelder-Søen! (ikke funden i det egenlige Danmark, meu anført fordi deu formorlenlig ogsaa forekonmer her).

b. Pulegium Mill. Bageret tolæbet, dets Svælg tilsidst lukket ved en Haarkrands; Kronens Overl sebe udeelt.

X 801. I. Pulegium L. (Polei-N.) H. 644; F. D. 1755; Rchb. 1. c. tab. 1290, fig. 2; Puleginm vulgare Mill., Koch Syn. II, 636.

Grenene talrige, fremliggende; Bladene ægformet-elliptiske, budte, utydeligt tandet-saugtakkede; Blomsterkrandsene alle adskilte; Bagerets Overlæbe med tilbagebøiede Tander.

Kroneme lila. 7-9. ข.

Paa fugtige, oversvømmede Steder: Falst. ved Korselitze (H.). Ikke senere gjenfunden. 闹

\section{Elsholtzia. Krydermynte.}

† 802. E. cristata [Willd. Sp. pl. 3, 59] (Ensidig K.) H. II, 207; Drej. p. 201 ; F. D. 2652; Rehb. l. e. tab. 1281; H. N. $\mathrm{V}, 8$.

Grenene og Bladstilliene ensidigt harede; Bladene stilkede, elliptiske, rundtakket-saugtakkede; Dokbladene kredsrundt-ægformede, pludseligt tilspidsede, randhaarede.

Kronerne smaae, blegt-lila. Planten har en eiendommelig og gjennemtræugende Lingt. 7-8. $\odot$.

Oprindelig indfort som Hareplante fra Siberien, forekonmer nu forvildet paa inange Steder omkring Byer og Haver. 


\section{Origanum. Merian.}

803. 0. vulgare L. (Almindelig M.) H. 657 ; Drej. 1. 582 ; F. D. 1581 ; Rchb. I. c. tab. 1262 , fig. 1 .

Bladene kortstilkede, elliptisk-ægformede, heelrandede eller ntydeligt tandede; Bogeret regelm. femtandet, dets Svælg lukket ved en Haarkrands; Blomsterne fleerbo.

Bladene grønne, næsten glatte, Kronerne røde, sjeldnere hvide (f. Ex. Riserup o. fl. St. paa Falst., Koch, 14, Præstø i Maribo S $\emptyset$, 19); Bæger og Dækblade alm. mørkviolette. 7-9. 4.

Ved Gjærder og i Kratskove: hyppig i Sydsjœll., paa Moen, Falst., Loll. og i det sydl. Fyen, sjeldnere i Nordsjell. (mangler t. Ex. ved Helsingør (21); paa Halvoen sporadisk, men ikke alm., paa Østkysten, mod V. sjeldnere, f. Ex. Hanstholm o. fl. St. i det nordvestlige Thy!

$\dagger$ O. Majorana L. (Have-M.) Rehb. 1. c. tab. 1263, fig. 3 ; Majorana Lortensis Moench. Bladene elliptisk-ovale, paa begge Sider graafiltede; Axene ovale med tæt taglagte Dækblade; Bægeret paa den ene Side til Grunden kløvet, forøvrigt heelt; Kronerne bvide. 7-8. $\odot$.

Dyrkes som Kryderurt i Kjøkkenhaver.

\section{Thymus. Tiniau.}

804. T. Serpyllum L. [Fr. nov. 195] (Smalbladet T.) H. 659 (undt. var. 2 og 4); Drej. n. 603; F. D. 1165; Rehb. 1. c. tab. 1266 ; H. N. V, 7 ; T. angustifolius Pers.

Stanglerne alsidigt haarede, regelmæssigt frekantede eller næsten trinde, de blomsterlose krybende og forlængede, de blomstrende opstigende; Bladene linieformet-kileformede eller omvendt-ægformede, ved Grunden randhaarede, paa begge Flader ophøiet-nervede; Blomsterkrandsene samlede til et Ax eller Hoved.

Kronen rød, sjeldnere hvid. 7-8. h. (Lav, ofte tueformigt sammentrængt Halvbusk). Var. i Henseende til Bladenes Form, Beklædning o. s. v.

Paa sandige Bakker og Lyngheder: alm. paa Bornh., Meens Klint, i det nordlige og nordøstlige $S$ jo $l l$. samt i den vestlige og mellemste Deel af Haivern. Paa Loll., Walst., i det sydl.og 
sydvestl. Sjall. ikke bemrerket. (I Fyen forekommer den kun paa de høiere Sandbakker $(12,24)$. Ia

805. T. Chamadrys [Fr. Nov. 197] (Bredbladet T.) Drej. n. 604 ; F. D. 2237 ; H. N. V, 6; T. Serpyllum vulgaris Rchb. 1. c. tab. 1267, fig. 1-2.

Stcenglerne alle opstigende, frekantede med 2 smalere og 2 bredere Flader, langs Kantcrne harede (og derved tilsyneladende toradet-haarede); Bladene ovale eller elliptiske, stilkede, paa Overfladen utydeligt nervede.

Kronen rod, sjeldnere hvid. Høiere, med større Blade end foreg. 7-8. Һ. Var.

$\alpha$, capitatus! Blomsterkrandsene samlede til et Hoved eller de nedre fjerne.

$\beta$, verticillatus! Blomsterkrandsene adskilte, danne et langstrakt, mellembrudt Ax.

Paa torre Marker og Bakker, ved Gjærder o s. v.: hyppig i Syd-og Vest-Sjall., paa Falster, Langeland, i Fyen og paa Halveens Ostkyst. Paa Loll. sparsom (f. Ex. Gronnegade, 5); forekommer sjeldent blandet med foreg. f. Ex. J. V. Velling (Dr.), Kalbygaard! $\varnothing$. Nykirke! Store Andst! $\boldsymbol{S} \boldsymbol{j}$. Kjøbenluavns Omegn! Paa Bornh. og $\mathrm{i}$ de vestlige Dele af Halvgen mangler den.

† T. vulgaris L. (Have-T.) Rchb. 1. c. tab. 1264. Stænglerne alsidigt duubarede; Bladene i Randen tilbagernllede, rgformede, de øvre lancetformede; Kronen hvid eller lila. 7-8. 万. Europa.

Dyrkes alm. i Kjøkkenhaver som Kryderurt; vildvoxende i Syd-

\section{Acinos. Voldtimian.}

806. A. thymoides [Moench Meth. 407]. Thymus Acinos L., H. 660 ; F. D. 814 og 1822 (var.); Calamintha Arinos Benth., Rchb. 1. c. tab. 1274, fig. 2 ; Drej. n. 605.

Stangelen fra Grunden af grenet, med opstigende Grene; Bladene agformet-elliptiske, saugtakkede; Krandsene adskilte; Blomsterstilkene enblomstrede; Bageret mod Frugtmodningen foroven sammensnøret, med opadbøiede Tander i Underlæben.

$4-8^{\prime \prime}$ høi. Kronerne violette. 6-8. $\odot$. 
Tørre Marker, Bakker og Grøftevolde, især paa Leer- og Kalk. grund, funden i alle Provindser, men sporadisk $0 \mathrm{~g}$ i de fleste Egne af Landet sparsom; hyppig i Omegnen af Aalborg (Branth), i $\mathbf{S} j$. omkring Frederiksværk og Roeskilde! samt paa M $\theta$ ens Klint!

\section{Clinopodium. Krandsborste.}

807. C. vulgare L. (Almindelig K.) H. 657; Drej. n. 606 ; F. D. 930 ; Calamintha Clinopodium Benth., Rchb. l. c. tab. 1274 , fig. 1 .

Rodstokken ndsender Udløbere; Stcongelen opret; Bladene ægformede, budte, fjernt og svagt saugtakkede; Krandsene 1-3, adskilte, den øvre endestillet; Svøbbladene stivhaarede, omtr. af Længde med Bægerne; Bagerroret tistribet, kirtelhaaret, ved Grunden ]øst tilleddet til de korte Blomsterstilke og hurtigt affaldende.

$1-1^{1} /_{2}^{\prime}$ høi, haaret. Kronen mørk-rosenrød, sjeldnere hvid, udv. duunharet, indv. med 2 haarede Langdestriber i Røret. 7-8. 4.

I Randen af Skove og Krat, ved Gjæerder, ikke sjelden; forekommer ofte i Selskab med Origanum vulgare, og er, ligesom denne, liyppigst i de sydlige Egne af Landet.

\section{$\dagger$ Melissa. Hjertensfryd.}

$\dagger$ M. officinalis L. (Læge-H.) Rehb. l. c. tab. 1261.

Stungelen opret; Bladene æegformede, afsmalnede i en Bladstilk der er kortere end Pladen, grovt saugtakkede; Blomsterstilkene nikkende.

1'/2-2' høi, mere eller mindre haaret. Kronerne hvide eller blegrode. Planten har en behagelig, citronlignende Lugt. 7-8.

Dyrkes som Kryderplante i Haver, og forekommer hist og her forvildet, f. Ex. Loll. Branderslev, Stokkemarke o. fl. St. (19).

\section{Brunella. Prunel.}

808. IB. rulgaris [Moench Meth. 414] (Almindelig P.) Prunella L., H. 663; Drej. n. 607 ; F. D. 910 ; Rehb. l. c. tab. 1223, fig. 2 .

Stonglerne opstigende; Bladene ægformede, budte, heelrandede eller tandede; Dokbladene nyreformede, kort tilspidsede; Brogerets Overlabe svagt tretandet, Tanderne kort af- 
stumpede, braadspidsede; Underlaben dybt totandet, med lancetformede 'Tæuder; alle Støvdragerne med en ret, tornformet Tand i Spidsen.

Kroneu blaaagtig-violet, sjeldnere rod eller livid. 7-8. 4.

Par Enge, i Skove o. s. v. alm.

809. B. grandiflora [Jacq. Fl. austr. 4, p. 40, t. 377] (Storblomstret P.) H. II, 209; F. D. 1933 ; Rchb. 1. c. tab. 1223, fig. 4; H. N. IV, 14.

Stcenglerne opstigende eller næsten oprette, Bladene aflangregformede, heelrandede eller ved Grunden tandede; Dakbladene nyreformede, tilspidsede; Bagerets Overlabe tretandet, med triangelformede, sylformigt tilspidsede, Underlaben dybt totandet med lancetformede T'ander; Stovdragerne med en kort, puklet Udvæxt i Spidsen.

Kronen violet, dobbelt saa stor som hos foreg. 7-8. 4 .

Paa Kalkbakker, sjelden: Dybdals Bakker ved Aalborg! 原

\section{Scutellaria. Skjolddrager.}

810. S. galericulata L. (Blaa S.) H. 661; Drej. n. 611; F. D. 637 ; Rehb. 1. c. tab. 1256, fig. 3.

Bladene æg-lancetformede, med hjerteformet Basis, fjernt og budt rundtakkede; Dakbladene omtrent af Størrelse med Stængelbladene; Blomsterne parvise i Bladhjørnerne, alle fjerne fra hinanden; Bogeret svagt og kort duunbaret.

Kronen blaa. 7-8. భ. Var.

$\beta$, hastoformis! Bladene med afstumpet Basis, den nedre Tand støre end de øvrige.

Paa Enge, i fugtige Skove og ved Aabredder alm.

? 811. S. hastifolia L. (Spydbladet S.) H. 662; F. D. 1822; Rehb. l. c. tab. 1256, fig. 1; H. N. IV, 13.

Bladene spydformede, heelrandede; Daklladene mindre end Stangelbladene; Blomsterne parvise $\mathrm{i}$ de avre liadhjorner, dannende en ensidig Klase; Bageret kirtlet-duunhaaret.

Kronen blaa eller violet. $7-8.4$. 
Paa Enge og ved Grofter. Angives fra $\mathbf{S}$. Omegnen af Kjobenhavn (Schum.), Kirkehyllinge i Hornsherred (Albrecht). Fra intet af disse Steder har jeg seet Expl.; muligviis kunde Var. af foreg., hvis Blade nærme sig Spydformen, være antaget for denne Art.

† S. altissima L. (S. comınutata Rehb. 1. c. tab. 1257, fig. 2); Bladene hjerteformede, dybt rundtakkede; Blomster i ensidige Klaser med ægformet-elliptiske Dakblade omtr. af det kirtelhaarede Bægers Længde; Kronen lysblaa med hvid Underlæbe.

I Mængde paa en Høi ved Bidstrupgaard, tidligere plantet.

\section{Verbena. Jernurt.}

812. V. officinalis L. (Lrge-J.) H. 638 ; Drej. n. 612; F. D. 528; Rchb. 1. c. tab. 1292 , fig. 2; H. N. $1,19$.

Bladene fjerfligede eller fjersnitdeelte (de nedre Flige storst), afsmalnede til en bred Bladstilk; Axene traadformede, samlede til en Top.

$1-2^{\prime}$ høi. Blomsteraxen og Bægeret kirtelhaarede. Kronen blegrod eller lila. 6-9. ข.

Ved Gjærder, især i og omkring Landsbyer, sporadisk og ikke alm., men funden i alle Provindser, hyppigst paa Loll., Falst. og Bornh.

\section{Angiospermia.}

\section{Linnaea.}

813. L. borealis L. (Nordisk L.) F. D. 3 ; Rehb. ic. ff. germ. XVII, tab. 1170.

Stcangelen langstrakt krybende og rodslaaende, halvbuskagtig; Bladene modsatte, ovale eller omvendt-ægformede, svagt saugtakkede; Blomsterstilkene spredte, oprette, oventil klæbrigt duunhaarede, med to sylformede Dakblade nedenfor de 2 hængende Blomster.

Kronerne hvide, i Svælget rødlige, vellugtende. 7-8. h.

I Norges og Sveriges Naaleskove hyppig; i Danmark knn funden mellem Lyng i Vinding Skov ved Landeveien mellem Vedelsbo og 
Salten Bro i Jyll. (29)! Tidligere har den sandsynligviis været funden ved Aarhus, ifølge haandskreven Angivelse ved et Expl. opbevaret i Brix's Herb. (!)

\section{Limosella. Dyndurt.}

814. L. aquatica L. (Liden D.) H. 684 ; Drej. n. 634 ; F. D. 69 ; H. N. XV, 23 ; Rehb. l. e. XX, tab. 1722, fig. 1.

Rodstokken med krybende Udlobere; Bladene langstilkede, lancet-spadeformnde, tilligemed de enblomstrede Blomsterstilke knippeviis udgazende fra Rodstokken og Udløbernes IJed.

Planten glat. Kronen hvidagtigt-kjødfarvet. $7-8 . \odot$.

$\beta$, minor (L. borealis Last.; L. aquatiea $\beta$, tenuifolia Rehb. l. c. fig. 2-3). Ingen Udløbere; Bladene smalt linieformede; Blomsterne meget smaae.

Paa lerede og dyndfulde, fugtige Steder, forekommer $i$ alle danske Provindser, men ikke alm. $\beta$, ved Bredden af en Dam S. for Horsholms Slotshave!

\section{Linaria. Torskemund.}

a. Blomsterne i Klase.

815. L. vulgaris [Mill. Dict. n. 1] (Hørbladet T.) Drej. n. 628 ; Rchb. I. e. XX, tab. 1685 , fig. 2 ; Antirrhinum Linaria L., H. 679 ; F. D. 982.

Stangelen opret, med Udløbere fra Rodstokken; Bladene talrige, spredte, linieformede eller smalt lancetformede, heelrandede, glatte; Klasen tætblomstret; Blomsterstilkene af Bægerets Længde; Kapselen oval, mere end dobbelt saa lang som Bxgeret, opspringende ved 4--6 Tænder i Spidsen; Froene kredsrunde, fladtrykt.vingede, i Midten knudret-rue.

1-2' høi, glat; Blomsteraxen og Blomsterstilkene var. kirtelhaarede eller glatte, Kroneu citronguul med orangefarvet Gane, floielshaaret Svælg, sjeldnere heelt blegguul. 7-9. 4 .

$\triangleleft$ Peloria. Kronen regelıet, med 5 Sporer, 5 Stovdragere, feilslaaende Frugtknude.

Paa torre Marker, ved Gjerder o.s. v., alm. $\triangleleft$ (en Monstrositet) Sj. ved Brondshøi (H.); F. Holkenhavn (Lund), Skjoldemose! J. Aalborg (12), Haraldslund! 
$\dagger$ L. genistaefolia Mill. 1. c. n. 14; Rehb. I. c. tab. 1686, fig. 1 .

Stcongelen opret; Bladene spredte, lancetformede, heelrandede, tilspidsede, stive, blaagraae; Blomsterstanden en af fjernblomstrede Klaser sammensat Top; Blomsterstilkene kortere end Bægerfligene; Frøene trckantede med ujævne Sider.

Hoiere end foreg., men med mindre Kroner (gule). 4.

Forvildet paa Gurre Slots Ruiner (Kjærschou!).

b. Blomsterne spredte i Bladhjornerne.

816. L. minor [Desf. Fl. atl. 2, 46] (Liden T.) Drej. n. 627 ; Rehb. 1. c. tab. 1682 , fig. 1; H. N. XI, 21; Antirrhinum minus L., H. 680 ; F. D. 502.

Stcengelen opret med opret-aabne Grene; Bladene laneetformede, bredest foroven, budte, heelrandede, de nedre modsatte, de øvre spredte; Blomsterstilkene 2-3 Gange længere end Bægeret; Sporen kortere end de uligelange, budt-linieformede Brogerfige; Kronens Svælg ufuldstændigt lukket af Ganen; Kapsclen oval, lidet kortere end Bægeret, opspringende ved 2 Tænder i Spidsen; Frøene aflange, furede paalangs.

$4-8$ " høi. Hele Planten kirtelhaaret. Kronen violet med blegguul Underlæbe. 7-8. $\odot$.

Paa tørre Marker mellem Sæden, især paa Leer- og Kalkgrund: Sj. hist og lier; paa Moen, Falst. og Loll. alm.; i de andre Provindser sjeldnere; J. Drastrup, Horup Mølle (H.), Aalborg (12); Sl. Nordskov ved Gelting, Nyverk ved Slesvig (16); Are (10).

817. L. spuria [Mill. Dict. n. 15] (Rundbladet T.) Rehb. 1. c. tab. 1680 , fig. 2 ; Antirrhinum spurium L., H. 678 ; F. D. 913 .

Stcenyelen fra Grunden af grenet, ined nedliggende Grene, Sidegrenene fine, meget længere end Hovedstængelen; de nedre Blade modsatte, de ovre spredte, alle bredsrundt-ovale eller æg-hjerteformede, budte med en meget kort Spids, heelrandede eller svagt rundbugtet-bolgede; Blomsterstilkene haarede, 1-3 Gauge længere end Bægeret; Sporen opadbøiet, spids, længere end de ægformede Bxgerflige; Kapsel og Fró som foreg. 
Stængel og Blade tæthaarede, med ofte klæbrige Haar. Kronen guul, med violet Overlæbe. 7-9. $\odot$.

Ukrudsplante mellem Sxden, sjelden og hidtil kun bemærket paa Lolland: Holmegaard ved Nakskov (19)! Dannemarre (14).

818. L. Elatine [Mill. 1. c. n. 16] (Spydb]adet T.) Drej. n. 626 ; Rehb. I. c. tab. 1680 , fig. 4 ; H. N. 1, 20 ; Antirrhinum L., H. 678 ; F. D. 426.

Stangelen fra Grunden af grenet, med nedliggende Grene; Bladene spredte, spydformede, spidse, heelrandede (paa den yngre Plante tandede); Blomsterstilkene glatte, traadfine, $3-\mathbf{4}$ Gange længere end Bregeret; Sporen tilspidset, næsten ret, længere end de lancetformede, tilspidsede Bagerflige; Kapselen kugleformet, opspringende paa Siden ved Laag; Frøene næsten kugleformede, nætformigt grubede.

Stængel og Blade haarede. Kronen guul, ved Grunden af Overlæben violet. 7-9. $\odot$.

Ukrud i Haver og paa Marker mellem Sæden, sporadisk og ikke alm.: B or $n h$. Marker ved Hlykobbegaarden! Hasle, Rø (Hjorth); $\boldsymbol{S} \boldsymbol{j}$. Tïisvilde (H.), Brøndshøi, Flaskekroen (Dr.), Amager ved Kastrup! mellem Valø og Billesborg, Gjorsløv i Stevns (9), Bjerre, Orsløv, Tjæreby (Nielsen) og Rude ved Skjelskis (17), Disagergaard ved Slagelse (16), Bjernede, Gyrstinge (12); Falst. og Loll. alm.; Ere (10); Thorseng (12); F. Hersnap og Dalby paa Hindsholm! Kjerteminde (Heiberg), Lunde ved Odense (18), Frangde (16), Rødekro ved Faaborg (Riise), Horne (H.); J. Odstedğ ard! Sl. Falkenberg red Slesvig (16). $\sharp$

† 819. L. Cymbalaria [Mill. 1. c. n. 17] (Lappet T.) Rehb. l. c. tab. 1680 , fig. 1 ; Antirhinum L., H. 677 ; F. D. 1220.

Stangelen krybende; Bladene nyreformede, femlappede, glatte; Blomsterstilkene mange Gange længere end Bageret; Frpene som hos foreg.

Kronen violet med guul Gane. 6-9. 4.

Paa Mure og Steendiger omkring Haver, sjelden: $\boldsymbol{S}$ j. Tommerpladseme ved Kjøbenhavn (Moller), Havegjærder ved Roeskilde (Thomsen), Kjøge Kirkemuur (12), Dronninggaard, Bagsvard (14); Sl. Murene af Slotshaven ved Gottorp (H.). lkke oprindelig indenlandsk. 可 


\section{Antirrhinum. Lovemule.}

820. A. Orontium L. (Langbægret L.) H. 680 ; Drej. n. 629 ; F. D. 941 ; Rehb. I. e. XX, tab. 1678 , fig. 2.

Bladene lancetformede, heelrandede, de nedre modsatte; Bagerfigene linieformede, længere end Kronen og mange Gange længere end Blomsterstilkene; Frugtknuden kirtelharet.

1/2-1' høi. Kronen rosenrød, sjeldnere hvid. 7-9. $\odot$.

Paa tørre Marker mellem Sæden, saavel paa Leer- som Sandgrund, bemærket i alle Provindser, men ikke alm. overalt, liyppigst paa Bornh., Loll., Falst. og de øvrige sydlige Øer.

\section{Scrophularia. Bruunrod.}

a. Venilia Don. Blomsterne i Knipper fra Blad. hjørnerne. Ingen Bistøvdragere. (Planten haret).

821. S. verualis L. (Vaar-B.) H. 682; Drej. n. 633 ; F. D. 411; Ceramanthe vernalis Rehb. 1. c. XX, tab. 1676. Bladene modsatte, hjerteformede, dobbelt-tandede, tilligemed Stængelen og Bladstilkene klæbrigt-kirtelhaarede; Knipperne 3-7-blomstrede; Bagerfligene omvendt-xgformet-lancetformede, budte, uden hindeagtig Rand, i Spidsen tilbagebøiede.

$1-2$ ' høi. Kronen grønguul. 5-6. $\odot$.

Ved Gjærder, især omkring Byer, ikke alm. $S j$. Classens Have, Frederiksberg Have tilvenstre fra Indgangen (H.)! Roeskilde alm.! Sorø! Kougsdal (16), Frydendal! Knapstrup (15), Holsteinborg (Nielsen); F. Maalø pea Hindsholm (12), Hverringe (Rafin), Odense (H.); $S l$. Nyværk og Værtshuset Berlin ved Slesvig (16),

b. Scorodonia Don. Blomsterne i endestillet Klase eller Top, dannet af Qvaster fra de øvre Bladhjørner. En gold Støvdrager befastet til Overlæben. (Planten glat.)

822. S. aquatica L. (Vand-B.) H. 682; Drej. n. 632 ; F. D. 507 ; H. N. XIV, 19; S. Ebrharti Steven., Koch Syn. II, 593; E. Bot. Suppl. t. 2875 ; S. alata Gil., Rehb. I. c. tab, 1672, fig. 1 .

Rodstokken krybende; Stangelen firekantet, tilligemed Blad- 
stilkene bredvinget; Bladene modsatte, xgformet-elliptiske, de nedre æg-hjerteformede, saugtakkede, de nedre Takker mindst; Qvasterne 7-9-blomstrede; Bagerfligene budte med en bred hindeagtig Rand; Bistovdrageren omvendt-nyreformet, svagt udrandet; Fapselen budt, med vedblivende Griffel.

2-4' høi. Kronen mørk rødbrum. 6-9. 4.

Ved Kildevæld, Aaer og Bække, hist og her: i Sjall. ikke alm., hyppigere i Fyen og paa de sydlige $\theta$ er.

Anm. S. Balbisii Horn. (S. aquatica Bab. Man. p. 233), som adskilles ved bredere, mere rnndtakkede Blade, Bistøvdrageren rundagtig-nyreformet, ikke udrandet, Kapselen spids-regformet, kunde muligviis ved noiere Indersogelse ogsaa findes i vor Flora. (Den mar soges paa lignende Steder som foreg.).

823. S. nodosa L. (Knollet B.) H. 681 ; Drej. n. 631 ; F. D. 1167 ; Rehb. 1. c. tab. 1674 .

Rodstokken knolleformigt opsvnlmet, bekladt med tandformede Skjæl; Stangelen firekantet, uvinget (hos større Expl. smalvinget); Bladene modsatte, ægformede eller æg-hjerteformede, dobbelt tandet-saugtakkede, de nedre Tænder størst; Qvasterne som hos foreg., Bogerfligene agformede, budte, med en smal hindeagtig Rand; Bistovdrageren omvendt-hjerteformetspadeformet, udrandet; Kapselen agformet, spids.

$1^{1} / 2-3^{\prime}$ høi. Blomsterstilkene violet kirtelhaarede. Kronen mork olivengron, Overlæben mørkbruun. 6-8. 4.

I Skove og Krat, ved Gjærder o. s. v. ikke sjelden.

\section{Digitalis. Fingerbolle.}

824. D. purpurea I. (Rød F.) H. 683; Drej. n. 630; F. D. 74 ; Rehb. I. c. XX, tab. 1688; H. N. X, 18.

Stangelen opret; Bladene spredte, æg-lancetformede, tandet. rundtakkede, paa Underfladen natformigt aarede og tilligemed Stangel og Bladstilke fint graafiltede, Blomsterne $\mathrm{i}$ ensidig Klase; Bagerfligene ægformede.

2-3' løi. Kronen rosenrød, sjeldnere hvid, indvendig mørkrødpunkteret. $6-8$. $\odot$.

I Skove: Sj. paa Derue i Gurre So (11), Krogerup Skov (9), Sollerød (Petersen); J. Thorstedlund Skov (Branth), Bjornsholm (8), 
Steenalt Skov (3), Serritslevgaard (Jørg.), Donneruplund! Kjærgaard Skov ved Ribe (H.); Sl. Gram (1), Sonderbrarup (Esmarch). (Paa flere af disse Steder og andetsteds forvildet, især omkring Haver, hvor den dyrkes som Siirplante).

\section{$\dagger$ Mimulus. Abeblomst.}

† 825. M. luteus L. (Guul A.) Bot. Mag. tab. 1501.

Stcengelen opret eller ved Grunden opstigende, Bladene modsatte, kredsrundt-ovale, bugtet-tandede, de nedre stilkede, de øvre siddende og halvt omfattende; Blomsterne modsatte i de øvre Bladhjørner; danne en kort Klase; Kronen dobbelt saa lang som Bægeret, gnul med storre eller mindre Pletter i Svælget.

1-11/2' hoj. Forneden glat, foroven ofte duunhaaret. 6-7. य.

Oprindelig fra det vestlige Amerika, dyrkes i forskjellige Former paa fugtig Grund i Haver. Forekommer forvildet i stor Mrengde langs Nordbredden af Viborg Sø, N. Vosborg! Bak ved Vestervig i Thy (Andresen)! F. Skaarup; Lo ll. Nakskov (19).

\section{Pedicularis. Troldurt.}

a. Kronen gabende; Kapselen skjævt æg formet, fladtrykt.

826. P. pälustris L. (Eng-T.) H. 671; Drej. n. 525 ; F. D. 2055 ; Rehb. 1. c. XX, tab. 1749 , fig. 2 .

Stangelen opret, fra Grunden af grenet; Bladene fjersnitdeelte med halvfinnet-lappede Afsnit, Lapperne rundtakkede; Bageret tolæbet, med lappede, kruset-tandede Læber; Fronens Over- og Underlæbe ligelange, Overlaben seglformigt krummet, med et kort Næb og paa hver Side af dette en sylformet Tand.

$1-1^{1 / 2} 2^{\prime}$ høi. Kronen rosenrød eller kjødfarvet. $5-7$. $\odot$ eller $\odot$. I fugtige Enge, Tyrvmoser og Kjær alm. ndbredt.

827. P. silvatica L. (Skov-T.) H. 672; Drej. n. 624; F. D. 225 ; Rehb. 1. c. tab. 1749 , fig. 1 og 1826, fig. $3-5$.

Stconglerne flere, de sidestillede opstigende eller nedliggende, den midterste kort, opret, med faae Blomster næsten fra 
Grunden af; Bludene som hos foreg.; Bregeret femtandet, Tænderne oventil bladagtige, tanderle; Kronen som bos foreg., men med længere Rør, Underlwben kortere end Overlaben.

Stænglerne 3-6" høie; Rodbladene rosettestillerle, lappede eller næsten hele, tidligt lienvisneude. Kronen rosenrød. 5-7. 4. (०)?)

I Hedemoser, fugtige Kratskove o. s. v., ikke saa alm. som foreg., hyppigst i Nordsjelland og paa Halvøen, mangler i enkelte Egne af Landet, f. Ex. paa Lolland-Falster.

b. Kronen lukket af de sammensluttende Læber, Kapselen nasten kugleformet.

828. P. Sceptrum carolinum L. (Storblomstret T.) H. 673 ; F. D. 26 ; Rehb. 1. e. tab. 1763 ; Sceptrum earolinum Rudb., Hartm. Skand. Fl. 5 Udg. p. 64.

Stcengelen opret, rank, ugrenet, faabladet; Bladene fjerlappede eller halvfinnede med rundtakket-lappede Flige; Blom. sterne krandsstillede, danne et idetmindste forneden mellembrudt Ax; Bageret femtandet med budte, rundtakkede Tænder; Kronens Overlæbe uden Næb, hietteformig boiet, udeelt, Underlæben trelappet.

1-2' høi. Krronen stor, bleggnul med Underlæbens Lapper i Spidsen rode. $7-8$. 4.

1 et hedeagtigt Pilekrat ved Kartoft Aa nær Skjærlund i Brande Sogn (Veile Aut) Th. Schigtz 1861!

\section{Melampyrum. Kofode.}

(Alle Arterne i denne Slrgt blive sorte ved Tørring).

a. Blomsterne alsidigt vendte.

829. I. cristatum L. (Firekantet K.) H. 667 ; Drej. n. 613 ; F. D. 1104 ; Rehb. 1. e. XX, tab. 1737.

Bladene linieformede eller linie-laneetformede, heelrandede; Dokbladene tilspidsede, ved Grunden hjerteformede, fliget-tandede, i 4 Rader, hvorved Axet bliver firekantet.

Kronen lysrod med hvidguul Underlabe; Dickbladene ved Gruuden rødviolette. (En Form med bleggnle Kroner, gunl Underlæbe og grønne eller grougule Dakblade forekommer sjeldnere). 6-8. $\odot$. 
I Skove og Krat, paa høie Enge, sporadisk, men funden $\mathrm{i}$ alle danske Provindser, hyppigst paa Bornh., i Fyen og paa Halveens Ostkyst, i de andre Egne ikke alm.

\section{M. árvense L. (Ager-K.) H. 668; Drej. n. 614;} F. D. 911 ; Rehb. l. c. tab. 1736 , fig. 1 .

Bladene lancetformede, i Randen tilbagerullede, ved Grunden bredere, spydformigt-tandet-fligede; Dakbladene $x$-lancetformede, spidse, halvfinnede, med sylformede Flige; Axet kegleformigt forlænget.

Stængel og Blade korthaarede. Kronen rod med en guul Plet paa Underlæben ved Svælget, Dækbladene rosenrøde. 7-8. $\odot$.

Paa Agre mellem Sæden, sjeldnere i Kratslsove: paa Bornh., Falst., Loll. og i Sydsjall. alm., forørigt sjelden: J. Elsegaards Strand ved Ebeltoft (Ørting), Fredericia! $S l$. Haderslev (16); L a ng el. ved Tranekjær (11); $\boldsymbol{F}$. Lundsgaard mellem Nyborg og Svendborg (F. Lange) o. fl. St. i det sydlige (12); $\boldsymbol{S} j$. Basnæs (Nielsen), de østlige Skrænter ved Tiissø (Lund), Reersø (Dr.), Refsnæs (15), Nexelø (Baagø), Odsherred (21), Gyrstinge Skov! Amager (1).

\section{b. Blomsterne ensidige.}

831. M. nemorosum L. (Blaatoppet K.) H. 669 ; Drej. n. 615 ; F. D. 305 ; Rehb. I. c. tab. 1735.

Bladene $x g$-lancetformede, heelrandede; Dakbladene ved Grunden piilformede, fliget-tandede; Blomsterne tætsiddende; Bogeret haaret med lancet-sylformede, udstaaende Flige af Længde med Røret, naaende Halvdelen af Kronen.

Korthaaret. Kronen guul med brandguul Underlæbe; Dækbladene blaae, sjeldnere hvide. $\odot$.

I Skove og Krat: paa Halvoen sjelden: J. Lundbykrat, Andruplund, Palsgaard (H.); Sl. Vonsbæk (7); F. Juelsberg Skov ved Nyborg (Heiberg); Falst. Vennerslund (Boye); i Sjall. hist og her alm.: paa de andre Øer ikke bemærket. Fै

832. II. pratense L. (Almindelig K.) H. 669 ; Drej. 1. 616 ; F. D. 2238 ; Rehb. l. c. tab. 1738 .

Bladene lancetformede med bredere Basis, de øvre tilligemed Drkbladene ved Grunden 1-3-fliget-tandede eller heelrandede; Blomslerne fjernede fra bverandre, vandret udstaaende; Bageret svagt duunhaaret eller glat, dets Tænder længere end 
Røret, der er 2-3 Gange kortere end Kronen; Kronens Underlacbe lige udstaaende.

Planten uæsten glat eller lidet ru. Kronen livid med gunl Underlæbe eller guul med blegguult eller lividt Rør; Dækbladene gronne. 6-7. $\odot$.

I Skove og Krat, paa Lyngheder: alm. udbredt.

833. II. silvaticum L. (Skov-K.) H. 670 ; F. D. 145; Rehb. 1. e. XX, tab. 1734, fig. 2.

Bladene smalt lancetformede, kortstilkede, alle heelrandede; Dokkbladenc eensdannede med Bladene, de ovre stundom med en enkelt Tand ved Grunden; Blomsterne fjerne, oprette; $B a$ gcret glat, med 'Tænder længere end Røret og næsten af Læugde med Kronen, hvis Underlabe er nedadbøiet.

Strengelen ensidigt haaret, Bladene paa Overfladen rue. Kronerne gule. Drkbladene grønne. 7-8. $\odot$.

I Skove og Krat: paa Halveen (isæer Ostkysten) hist og her; $\boldsymbol{F}$. Kratskov ved Lunde $\boldsymbol{N}$. for Odense $(4,18)$ ! Langeskovs Kro (16); $\boldsymbol{S} j$. Bggholm i Bromme Skov (Lund)! B ornh. ved Almegaard (19), Rønue, Knudsker, Pedersker (Hjorth), mellem Rø og Gudhjem (Baagøe). Paa de andre Oer ikke bemærket.

\section{Rhinanthus. Skjaller.}

834. R. major [Ehrb. Beitr. 6, 144] (Stor S.) R. Crista galli $\beta$, L. fl. Suec., H. 665 ; F. D. 981.

Bladene modsatte, linie-lancetformede med agformet Basis, rundtakket-saugtakkede; de ovre Dakblade lijerteformet-rudeformede, saugtakket-fligede; Axet mangeblomstret; Kronrøret bøiet; Overlaben i Spidsen totandet, med forlængede Tander; Griffelen rager udenfor Overlæben.

Dækblade og Bæger guulgronne; Kronen lysguul med violette Tænder paa Overlæben. 5-7. $\odot$. Var. glat og haaret, Bladenes Brede forskjellig. I Henseende til Frgene forekommer den hos os under 2 Former:

$\alpha$, platypterus Fr. Mant. 3, p. 60; H. N. VII, 11; Alectorolophus major $\beta$, glaber Rehb. l. c. XX, tab. 1739, fig. 2; Drej. n. 618. Froene omgivne af en bred, hindeagtig Vinge. $\beta$, apterus Fr. 1. e., H. N. X, 19; A. major $\alpha$, hirsutus 
Rchb. l. c. fig. 1; A. Reichenbachii Drej. n. 619. Frøene uvingede.

Paa Enge og Marker alm. udbredt; $\boldsymbol{\alpha}$, den hyppigste Form; $\boldsymbol{\beta}$, især mellem Sæden, f. Ex. J. i Vendsyssel hyppig (12), Eveldrup (Drej. Herb.); Ro paa Bornh.!

835. R. minor [Ehrh. l. c.] (Liden S.) H. 666 ; F. D. 2656 ; H. N. VII, 12 ; R. Crista galli $\alpha$, L. Al. Snec.; Alectorolophus minor Rchb. l. c. XX, tab. 1738; Drej. n. 617.

Bladene som foreg.; de dvre Dcelbblade hjerteformede, saugtakket-fligede; Axet kort, faablomstret; Kronrøret ret; Overlobens Tænder korte; Griffelen indsluttet i Overlaben; Froene omgivne af en bred hindeagtig Vinge.

Dækblade og Bæger skidengrønne, violet anlølone; Kronen bruunguul, med hvide eller violette Tænder paa Overlæben. 5-7. $\odot$.

Paa lignende Steder som foreg. og ligesaa alm. udbredt.

\section{Euphrasia. Oientrost.}

836. E. officinalis L. (Læge-Ø.) H. 66 т; Drej. n. 621 ; F. D. 1037 ; Rchb. I. c. XX, tab. 1731-32; Fr. S. Veg. Se. $195 ;$ H. IX, 17.

Stengelen budtkantet; Bladene ægformede, paa begge Sider 4-5-tandet-fligede; Dokbladene bjerteformet-triangelformede, sylformigt tandede; Kronens Svalg haaret; Underlaben langere end Røret; Overleben tilsidst tilbagebøiet; Kapselen omvendt. bjerteformet, udrandet.

Var. g]at eller haaret. Kronen hvid eller lila med morkere Striber og en guul Plet ved Grunden af Underlæben. 6-8. $\odot$.

Paa Enge, aabne Pladser i Skove o. s. v., alm. udbredt, forekommer paa de forskjellige Voxesteder under forskjellige Former uden bestemt Græudse.

* 837. E. parvillora [Fr. S. Veg. Sc. 195] (Smaakronet Ø.) H. N. IX, 18.

Bladene ægformede, saugtakkede, med $3-5$ Takker paa hver Side; Dakbladene æg-hjerteformede, tilspidset-tandede; Kronens Svcclg næsten glat; Underlaben af Rørets Længde, Overlaben tilsidst tilbagebøiet; Kapselen oventil afrundet, neppe udrandet. 
6-8. $\odot$. Kronen mindre $\mathrm{og}$ lysere end hos foreg., var. ligesom hiin; hyppigst forekommer den graaagtig-tathaaret. De meest udmærkede Former ere:

$\boldsymbol{\beta}$, imbricata Lge., F. D. 2657 (campestris Fr.?) Axene tætblomstrede, forlængede.

$\gamma$, curta Fr. H. N. II, 26; Rehb. 1. c. XX, tab. 1733, fig. 6. Axene korte, faablomstrede.

Paa torre Marker og høie Enge o. s. v. ikke sjelden: $\boldsymbol{\beta}$, paa Strandfelleder, t. Ex. Amager Fælled! Flaskekroen! F alst. Bøtø Fang (Koch). $\gamma$, pai torre Bakker.

Anm. Denne Art fortjener yderligere Opmerksomhed. Maaskee bør den ikke adskilles fra foreg., skjøndt den synes at have en ana$\log$ Udviklingsrække. Formen $\beta$, forekommer mig især udmærket.

838. E. gracilis [Fr. Fl. hall. p. 104; mant. 3, 62] (Spæd ø.) Drej. и. 620 ; H. N. II, 30 .

Stcengelen trind, stivt opret med tiltrykte Grene; Bladene ægformet-elliptiske, paa begge Sider tretakkede; Dakbladene ved Grunden kileformede, tilspidset-tandede; Kronens Svalg glat; Underlaben kortere end Røret, Overloben opret; Kapselen linieformet-aflang, afstumpet.

Spaed og tyndstrenglet; Kronen oftest violet, sjeldnere livid med mørkere Striber, mindre end hos foreg. 7-9. $\odot$.

Lyngheder og torre Bakker, alm. i Halvøens Hedeegne og paa B ornh.; paa de andre Øer sporadisk.

\section{Odontites. Rodtop.}

839. 0. littoralis [Fr, S. Veg. Sc. p. 196] (Strand-R.) H. N. XII, 37; O. verna Drej. n. 62\%; Bartsia Odontites $\beta$, littoralis Rchb. 1. c. XX, tab. 1727, fig. 2 .

Stongelen udeelt eller fargrenet; Bladene æg-lancetformede, budte, rundtakkede; de nedre Dithlade længere end Kronen; Kapselen længere eud Bægeret.

Bladene kjødfulde; Kronen smokt rod, udvendig dunet, større og morkere end hos folg. 6-7. $\odot$.

Paa Strandenge: i enkelte Egne ikke sjelden, f. Ex. langs Fjordene paa Halvoens Ostkyst (7, 28!); Agger (Drej. Herb.), Staby ved Nissum Fjord! Nordby paa Fano (1), Amrom (20)! St. Peter i Eidersted (F. Mïll.); $\mathbf{S}$. alm. omkring Lammefjorden! Flaskekroen! 
Vordingborg (29)! Reerso (21); Falst. p. fl. St. 14); L angeland ved Spodsbjerg (19); $\boldsymbol{F}$. Hofmansgave (18)!

840. 0. Tubra [Pers. Syn. 2, 150] (Mark-R.) H. N. XI, 22 ; O. serotina Drej. n. 623 (ikke Koch); Euphrasia Odontites L., F. D. 625 ; Bartsia Odontites Sm., H 664 ; Rchb. 1. c. $\mathrm{XX}$, tab. 1727, fig. 1 .

Stongelen fra Grunden af grenet; Bladene lancetformede, med smalere Basis, spidse, fjernt saugtakkede; Klasen før Udspringningen i Spidsen nikkende; Dokbladene kortere end Kronen; Kapselen af Længde med eller kortere end Bægeret.

Kronen skidenrød, udv. donet. 7-9. $\odot$.

$\beta$, pallida. Kronen hvid, ved Tørring blegrød.

Paa Kornagre mellem Sæden, i Landsbyer ved Gadekjær o. s.v. alm. udbredt; $\boldsymbol{\beta}$, meget hyppig i Egnen mellem Kolding og Aahenraa (hvor jeg ikke har bemærket den rodblomstrede Form)! Angel (16).

\section{Lathraea. Skjalrod.}

841. L. Squamaria [. (Bruun S.) H. 670 ; Drej. n. 635 ; F. D. 136 ; Rehb. 1. c. XX, tab. 1764.

Rodstokken beklædt med tykke, tandformede, taglagte Skijal, (underjordiske Blade); Skaftet bladløst eller med faae, ligesom Dolibladene, hindeagtig-skjwelformede Blade; Blomsterne i ensidig Klase; Kronens Overlæbe udeelt.

Hele Planteu rødlig, ved Tørring sort. Overlæben rosenrød, Underlaben hivid. 4-5. 4 .

I Slsove (Snylteplante paa Træerødder), funden $\mathrm{i}$ alle danske Provindser, men sporadisk og ikke alm.

\section{Orobanche. Gyvelqualer.}

842. 0. major L. (Stor G.) Fr. Mant. 3, 57; H. N. XII, 35 ; O. elatior Sutton, H. 685; Drej. n. 636; F. D. 1338 ; Rchb. l. c. XX, tab. 1794; O. stigmatodes Wimm., Koch Syn. II, 616. (?)

Bageret indtil nedenfor Midten tokløvet, med omtrent regelm. tvedeelte Flige, af Længde med det svagt bøiede Kronrør; Kronens Lœber parallele, Overlaben tolappet, ruud- 
takket-kruset, Underlceben tretandet; Stovtraadene befæstede lidet nedenfor Midten af Krourøret, $i$ den nedre Halvdeel kirtelhaarede indadtil; Griffelen opstigende, svagt haaret; Arret tolappet, med kugleformede, glatte Lapper.

1-4' høi, med tæt skjældækt, forneden meget tykt Skaft. Krowen rodviolet, udvendig kirtelhaaret, Arret violet. $\odot$.

Snyltende paa Rødderne af Centaurea Jacea og Scabiosa, sjeldenf: $\mathbf{S} j$. mellem Brondshøi og Søborghuns (Dr.)! Høie ved Bidstrupgaard (4)! Alindelille (27), Slijelskør (Nielsen), Borreby (Ehrenr.); S amso (28); J. Gudumlund (16).

843. 0. Cirsii [Fr. Mant. 3, 58] (Tidsel-G.) H. N. XI, 24 ; Rchb. 1. c. tab. 1832.

Dakbladene lidet længere end Kronen, de øvre danne en Dusk i Spidsen af Axet; Bageret indtil Grunden deelt i 2, til nedenfor Midten tokløvede Flige med uligelange, tilspidsede Tænder, neppe saa lange soin det bueformigt bøiede Kronrør; Kronen duunharet, gabende, med rmndtakket eller svagt udrandet Overlabe, Underlaben tilbagebøiet, trelappet med rundtakkede Lapper; Stovtraadene glatte, befæstede nær Grunden af Kronrøret; Griffelen i Spidsen bøiet, kun under det tolappede Ar svagt kirtelharet, forøvrigt glat.

1-2' høi, Axet mindre trtblomstret end loos foreg. Kronen bruunagtig med skidengnul Underlæbe, Arret violet. 8. $\odot$. Morch).

Snylteplante paa Cirsium oleraceum ved Hobro (Landinsp. J.

Anm. Den her i Landet fundne Plante afviger fra Beskrivelsen los Fries (l. c.) ved mndtakket (ikke todeelt) Overlæbe, men er forgvrigt neppe forskjellig fra den svenske Art. Den citerede Fig. los Reichenbach ligner ikke meget vor Plante.

844. 0. minor [Sutton Trans. linn. soc. 4, p. 179] (Liden G.) H. 686 ; Fr. Mant. 3, 59; F. D. 1219 ; Rehb. 1. c. tab. 1804.

Bageret indtil Grunden deelt i 2, fra en ægformet Basis pludseligt sylspidsede of omtrent til Nidten uregelm. tokløvede Flige, omtrent af Længde med det svagt boiede Kronror; Kronens Overlabe utydeligt tolappet, fremstaaende, Underlaben nedbøiet, med afrundede, ligedannede Lapper, begge Læberne aarede, bølget-rundtakkede; Støvtraadene befæstede nedenfor Midten af Kronrøret, foroven glatte, forneden haarede iudadtil; 
Stovlinapperne glatte; Griffelen bøiet, svagt haaret; Arret tolappet, med frastaaende Lapper.

4-10" hoi, Spædere og med mere faablomstret $A x$ end de to foreg. Kronen skidengunl, Arret rodt. angivet.

Snylteplante, sjelden: $\boldsymbol{F}$. Juelsberg Skov (4), Moderplanten ikke

845. O. Picridis [Vauch. Monogr. 60, 6. 12] (BittermælksG.) Rehb. I. c. XX, tab. 1796 .

Bageret dybt tvedeelt, med lancetformede, hele eller uregelm. trkløvede Flige, af Længde med eller længere end det svagt bøiede Kronror; Kronens Overlæbe udeelt, med foroven tilbagerullet Rand, Støvknapperne i Spidsen haarede, forøviigt som foreg. men alm. høiere af Vrext.

Snylteplante paa Picris hieracioides; her i Landet kun fundet paa Faxø Kalkbakker (23)!

Anm. De her fundne Expl. ere meget mindre end den i Sydenropa forekommende Form, saaledes som den er afbildet hos Rehb. Jeg har tidligere leuført den til $O$. minor, men er dog deels paa Grund af enkelte Characterer, deels paa Grund af Voxestedet, tillagielig til at antage dem for lienhorende til $O$. Picridis. Undersogelsen af disse Arter efter tørrede Exemplarer er forøvrigt meget ranskelig.

\section{Klasse. Tetradynamia (Firemrgtige).}

Hele denne Klasse hører til N. F. Cruciferce: Bager og Krone (oftest regelm.) firebladede, Frugten en Skulpe, som alm. springer op ved 2 Klapper, der løsne sig franeden og efterlade en hindeagtig Skillevæg (de vægstillede og indbyrdes sammenvoxne Frøstole), til hvilken Frøene ere befæstede i 2 Rækker paa hver Side. Vægsønmene staae ligefor Axen, Rygsømmene tillısire og venstre for samme. (De fleste udmærke sig ved skarp Smag).

\section{Orden. Siliculosa (Kortskulpede).}

A. Skulpen uopspringende,

a. smalvægget (Skillevæggene o: Afstanden mellem Vægsømmene, smalere end Afstanden mellem Ryg$\mathrm{s} ø \mathrm{~m} \mathrm{mene}$ ).

1. Sencbiéra Pers. Skulpen nyreformet eller udrandet, 
med storre Brede end Længde, torummet, Rummene uvingede, enfroede. (Kronbladene hvide). ${ }^{\circ} 0 *$ )

+ 2. Ísatis L. Skulpen flad, omvendt.segformet, vinget, enrummet, 1-2-frøet. (Kroubladenc gule). ${ }^{\circ} 0$

b. Skulpen bredvægget eller trind (Skillevæggen bredere end eller af samme brede som Afstanden melle m Rygommene),

aa. bestaaende af 1 Led (Blomsterne gule).

3. Néslia Desv. Skulpen kugleformet, enrummet, enfroet. $\circ 0$

4. Binias L. Skulpen agformet-afang, torummet med en skjæv Skillevæg, Ruminene enfrøede. oss

67. Skulpen deelt paatwers $i \dot{2}$ Led (Blomsterne rode eller hvide).

5. Cikile Tournef. Skulpen aflang; Rummene enfrøede, det øvre fladtrykt-firekantet, piilformet. $\circ$

6. Crambe L. Skulpens øv'e Led kugleformet, enfrøet, clet nedre lidet, tomt; Støvtraadene af de længere Støvdragere i Spidsen 2-3.tandede ( 0 : $1-2$ Tæunder foruden det forlængede Knapbaand). D)

B. Skulpen opspringende,

a. smalvægget.

aa. Rummene 1-2-frode.

7. Teeslália R. Br. Støvtraadene med Tilhæungsler ved Grunden; Skulpen vinget; Rummene tofroede. 0

8. Lepidium L. (part.) Støvtraadene uden Tilhæugsler; Skulpen alm. vinget; Rummene enfrøede. ${ }^{\circ}$

*) De efter Slægtsbeskrivelserne vedfsiede Tegn, som angive Forskjelligheder i Henseende til Frobladenes og Rodspidsens gjensidige Stilling, ere forklarese i den foran i Bogen meddeelte Oversigt over de naturlige Familier (Fam. Cruciferæ), hvortil her henvises. 
bb. Rummene fleerfroede.

9. Thlaspi L. (part.) Skulpen kredsrund-oval, dybt udrandet, vinget. $\infty$

10. Capsélla Medie. Skulpen omvendt-hjerteformet-triangelformet, uvinget. ${ }^{\circ} 0$

b. Skulpen bredvægget eller trind,

aa. dens Klapper forsynede med Rygnerve.

11. Camelina Crantz. Skulpen pæreformet med hvælvede Klapper; Griffelen ved Frugtmodningen todelelig, affaldende med Klapperne. (Kronbladene gule). ${ }^{\circ} 0$

12. Cochleària L. Skulpen elliptisk eller ægformet-kugleformet med hrælvede Klapper og fremstaaende Midtnerve; Griffelen ved Frugtmodningen udeelt, tilvoxet til Skillevæggen. (Kronbladene hvide). 0

13. Draba L. Skulpen elliptisk eller omvendt-ægformet, fladtrykt med svagt hvælvede Klapper og ikke fremstaaende Midtnerve; Griffelen 0. (Kronbladene hvide).

\section{bb. Klapperne uden Rygnerve.}

ж. Støvdragerne med tand- eller vingeformede Tilhxngsler ved Grunden.

14. Alýssum L. (part.) Kronbladene hele; Skulpen rundagtig, med 1-4-frøede Rum. (De kortere Støvdragere med børsteformede Tander ved Grunden). 00

15. Bertéroa DC. Kroubladene tokløvede; Skulpen oval, med 6-fleerfrøede Rum. (De længere Støvdragere ved Gruuden vingede). $\circ 0$

$\beta$. Støvdragerne uden Tilhængsler.

16. Subulária L. Bægerbladene ved Grunden lige (ikke pnklede); Skulpen oval, hvælvet, Klapperne budt kjølformede; Frøstrængene frie. o)

17. Laniria L. De 2 Bægerblade ved Grunden sækformigt udvidede; Skulpen oval-kredsrund eller elliptisk, fladtrykt; Frøstræugene tilvoxne til Skillevæggen. 
18. Nasturtium R. Br. (Fr.) Brgerbladene ved Grunden lige; Skulpen linieformet, elliptisk eller kugleformet, Klapperne hvælvede; Frostrængene frie. oo

\section{Orden. Siliquosa (Langskulpede).}

A. Skulpen uopspringende eller deelt patatæers.

19. Ríphanıs L. Skulpen ved Trærskillevægge afdeelt til en mangenervet Ledsknlpe, dannet af en forlænget Griffel; Skulpens Klapper meget smaae (eller 0 ), ved Frugtmodningen alm. utydelige ${ }^{*}$ ); Frobladene omvendt-nyreformede, dybt udrandecle. o)

B. Skulpen opspringende paalangs.

a. Arret tofliget, med oprette, i Spidsen sammenstødende Flige.

20. Hésperis L. Skulpens Klapper ennervede; Frøene $i$ een lige Linie; Frøbladene hele. ${ }^{\circ} 0$

b. Arret udeelt eller tolappet, med budte, frastaande Lapper.

aa. Skulpens Klapper nervelфse.

21. Dentária L. Skulpen fladtrykt med elastisk tilbagerullede Klapper; Frøstrængene brede; Frøene i een lige Linie; Frobladene hele, foldede. 00

22. Cardanine I. Skulpen fladtrykt, med elastisk tilbagerullede Klapper; Frøstrængene traadformede; Frøene i een lige Linie; Frøbladene liele, flade. oo

Nasturtium. Skulpen hvælvet $(15,1)$.

*) Den her meddeelte Berigtigelse til Slægtsınærkerne for Raphanus (ifølge hvilken Skulpens froberende Deel hidrører fra Griffelen, hrorimod dens Klapper, skjøndt de ikke indslutte Froe, men ere meget smaae under Blomstringen og oftest ukjendelige under Frugtmodningen, dog ere byggede aldeles som Klapperne hos de Korsblomstrede) skylder jeg Hr, Docent Didrichsens skarpe Blik og velvillige Meddelelso. Dette Exempel er ikke enestaaende i Familien, hvorfor Slagterue med uopspringende Skulper maa nærmere iagttages. 


\section{bb. Skulpens Klapper ennervede.}

. Griffelen kort.

«c. De 2 Rakker of Frue paa hver Side af Skillevoggen ordnede i een lige Linie.

23. Erýsímum I. (part.) Skulpen firekantet; Frøene aflange, jævne, Frøbladene hele. (Kronbladene gule). $\circ 0$

24. Barbaréa R. Br. Skulpen tveægget eller firekantet; Fraene fladtrykte, nætformigt-punkterede; Frøbladene bele. (Kronbladene gule). ${ }^{\circ}$

25. Arabis L. Skulpen fladtrykt-hvælvet; Frøene aflange eller ovale; Frøbladene bele. (Kroubladene hvide eller rødlige). $\infty *$ )

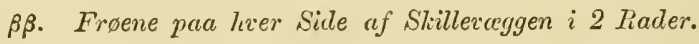

26. Turritis L. Skulpen tveægget-fladtrykt; Frøene smane, fladtrykte, Frøbladene hele. (Kronbladese hvide).

$\dagger$ Diplotáxis DC. Skulpen fladtrykt, med convexe Klapper; Frøene starre, aflange, jævne; Frobladene rundagtige, svagt udrandede. (Kronbladene gule). o)

\section{$\beta$. Griffelen forlanget.}

27. Brássica L. Skulpen trind; Frøene kuglerunde, jævne eller fint punkterede, ordnede i een lige Linie; Frobladene omvendt-lijerteformede, dybt udrandede. (Kronbladene gule). D)

cc. Skulpens Klapper 3-5-nervede.

28. Sinapis L. Skulpen trind, med forlænget Griffel; Frøene kuglerunde, i een lige Linie; Frøbladene omvendt. hjerteformede, dybt udrandede. (Kronbladene gule). ఏ)

29. Sisýmbrium L. (part.) Skulpen trind eller fladtrykttveægget, med kort eller ingen Griffel; Frøene $\mathrm{i}$ een lige Linie, aflange, fint punkterede; Frobladene hele. (Kronbladene gule). ${ }^{\circ}$

30. Alliária Andrz. Skulpen firekantet med kort Griffel; Frøene $i$ een lige Linie, aflange, stribede paalangs; Frobladene hele. (Kronbladene hvide). $\circ 0$

*) Hos Arabis Thaliana, som ifolge ennervede Klapper og ovrige Kjendetegn horer til denme Slægt, er Kimen oftest $\circ 0$. 


\section{Siliculosa.}

\section{Senebiera. Ravnefod.}

846. S. Coronopus [Poir. Enc. 7, 76] (Liggende R.) Drej. n. 641 ; Rchb. ic. fl. germ. II, fig. 4210 ; Cochlearia L., F. D. 202; Coronopus Ruellii Gärtn., H. 707.

Mangestæuglet, med nedliggende, til Jorden tiltrykte Strngler; Bladene enkelt eller dobbelt fjursnitdeelte med linieformede Afsnit; Blomsterstanden klaseformet, kortere end Bladene; Skulperne nyreformede, tilspidsede af den vedblivende Grifjel, nætformigt ryukede, i lianden straaleformigt stribede og takkede.

Stænglerne 2-6" lange. Kroubladene hride. 7-8. $\odot$.

Ved Strandbredder, paa Byggepladser, Gader og lignende Steder: ikke sjelden i Marskeguene paa Slesvigs Vestkyst (16); fra $J y l l$. og $\boldsymbol{F}$. ere ingen Voxesteder mig bekjendte, $\mathrm{i}$ de $ø$ vrige Provindser sporadisk: Sj. Finderup Præstegaard! Sorø Gader! Norrefælled v. Kbhvn! Tommerpladserne paa Christianshavn (Dr.), Amager Fælled, Kastrup! Nyord (9); F a lst. p. fl. St. (14); Loll. v. Keirup og Taars pr. Saxkjobing, Holmegard, Aunede (19); Bornh. alm.! Christiansg; Femern (H.).

\section{† 2. Isatis. Vaid.}

$\dagger$ 847. I. tinctoria L. (Farve-V.) Relub. l. c. fig. 4177.

Stcengelen opret, foroven halvskjærmformigt grenet; de nedre Blade lancetformede, fjernt tandede, Stængelbladene lancetformede, heelrandede, ved Grunden piilformigt onfattende; Blomsterstilkene traadfine, tykkere foroven, tilsidst nikkende; Kronbladene dobbelt saa lange som Bxgerbladene; Slkulperne jævne, 4-5 Gange saa lange som brede, med i Spidsen sammenflydende Vinger.

$1^{1 / 2}-3^{\prime}$ høi; blaagron. Kronbladene gule. 6-7. $\odot$.

B ornh. N. for Bobbeaaens Udlob (Hoff)! formodenlig indvandret.

\section{Neslia. Rundskulpe.}

848. I. paniculata [Desv. Journ. bot. 3, 162] ('Topblomstret R.) Drej. 11. 656 ; Rchb. I. c. fig. 4291 ; I1. N. XV, 36; Myagrum L., F. D. 204; lapistrum Gärtn., H. 692. 
Stangelen opret, mangebladet; Bladene lancetformede med piilformet, halvt-omfattende Basis, heelrandede eller utydeligt tandede, korthaaret-rue; Blomsterne i enkelte eller til en Top samlede Klaser*); Blomsterstillkene fine, udistaaende; Slkulpen nætformigt rynket.

$1 / 2-1 \frac{1}{1} 2^{*}$ hqi. Kronbladene gule. 6-7. $\odot$.

Ukrud mellem Kornet: paa Bornh., Heen, Falst., Loll. og Syds $\mathrm{j}$ all. alm., i de andre Egne sporadisk (Fra Jyll. har jeg ikke seet Expl.). |*

\section{Bunias. Takkeklap.}

† 849. B. orientalis L. (Orientalsk T.) H. 710 ; Drej. p. 216 ; F. D. 1651 ; L. Herb. IV, 79; Lælia Desv., Rchb. l. e. fig. 4162 .

De nedre Blade lyreformet-høvlformede, de ovre lancetformede, tandede; Blomsterne $i$ en enkelt eller flere til en Top samlede Klaser, med opret-aabne Blomsterstillke; Skulperne skjævt ægformede, knudret-tandede, med vedblivende Griffel.

2-4' họi. Bladene var i Indskjæring. Kronbladene gule. 6-8.

Paa Gresmarker omkring beboede Steder, oprindelig indført fra Rusland, men nu paa enkelte Steder alm., da den udbreder sig meget sterkt, f. Ex. Sj. Humlebæk (1), Fredensborg (Weilbach), Bastionerne mellem ø. og N. Port ved Kjøbenhavn! F. Rødkilde! Svendborg (H.)! Gudme (19); J. Horsens (13), Kolding (28); Sl. Haderslev (Gronlund), Flensborg (Stisgaard). |*

\section{Cakile. Strandsennep.}

850. C. maritima [Scop. Fl. carn. 2, 35] (Tykbladet S.) H. 709 ; Drej. 11. 637 ; F. I). 1168; Rehb. l. c. fig. 4158; H. N. III, 19; Bunias Cakile L.

Bladene fjersnitdeelte, med linieformede, budte, rendede, tandede Afsnit; Blomsterstilkene korte, tykke, udspxrrede.

Bladene kjødfulde, glatte. Kronbladene lysrøde, sjeldnere hvide, i Spidsen afrundede. 7--9. $\odot$.

*) Klasen er, ligesom hos de fleste Arter i deune Klasse, før Blomstringen halvskjærmformigt sammentrangt. 
$\boldsymbol{\beta}$, integrifolia Hornem. F. D. 1583. Bladene omvendt-ægformede, uregelret-budttandede eller rundtakket-lappede.

Ved Strandbredder paa den sandige llavstok, alm. udbredt. $\boldsymbol{\beta}$, J. Lenvig, Staby ved Nissum Fjord! mellem Ribe og Kjærgaard (H.), Sønderho paa Fanø (14); Sl. Hoier (Kph.), St. Peter og Ording i Eidersted (F. Müill.).

Anm. Formen $\beta$ er maaskee en egen Art, og maa derfor nærmere undersøges. Ninligviis løorer den til C. monosperm Lge. (deser. ie. ill. tab. 7) som udmarker sig ved fjerlappede Blade, Skulpens øvre Led ved Grunden afrundet (ikke piilformet), det nedre Led goldt, udrandede (oftest livide) Kronblade.

\section{Crambe. KJoftnaal.}

851. C. maritima L. (Strandkaal) H. 710 ; Drej. n. 638; F. D. 316 ; Rehb. l. e. fig. 4164 .

Bladene bugtet-fjerlappede med uregelret bolget-tandede Lapper; Blomsterstilliene opret-aabne, forlængede; Arret siddende.

2' høi. Hele Planten blaadugget, kjødfuld, glat. Kronbladene hvide. $6-7$. ข.

Paa den sandige Havstok, bemærket $i$ alle Provindser (undt. Bornh.), hyppigst ved Kysterne af Østersøen og paa enkelte Steder i Mængde, f. Ex. Veirø red Samsø (H.), Seierø (21), Sprogø! Erø (H.).

\section{Teesdalia. Flipkrave.}

852. T. undicaulis [R. Br. H. Kew. ed. 2, 83] (Nøgenstænglet F.) Drej. n. 639 ; Relıb. I. c. fig. 4189 ; H. N. 1, 31 ; Iberis L., H. 707; F. D. 323.

Bladene rosetteformigt samlede ved Grunden, lyreformetfjersnitdeelte; Stanglerne (alm.) flere, den midterste opret, bladløs, Sidestanglerne opstigende, med smaae, lancetformede Blade; Kronbladene uligestore, Skulpen oval-kredsformet, udrandet.

1-4" høi. Kronbladene hvide. 4-6. $\odot$.

Paa hoie og torre, isæer sandige Marker alm., sjeldnere paa Lolland-Falster end $\mathrm{i}$ de øvrige Egne.

\section{Lepidium. Karse.}

a. Skulpen vinget, udrandet.

aa. Blomsterstilkene ved Frugtmodningen tiltrykte. Frobladene trelappede.

853. L. satirum L. (Have-K.) H. 699; Drej. p. 217 ;

F. D. 1761 ; Rebb. l. c. fig. 4212 . 
Bladene enkelt eller dobbelt fjersnitdeelte, de nedre med tandet-lappede, de øvre med udeelte, linieformede Afsnit; Skulperne ovale, overalt vingede; Griffelen meget kort.

Plauten glat. Stængelen ofte overtrukken med en blaa Dug. Blomsterne smaae, Kronbladene hride. Bladene have en behagelig skarp Smag. 6-7. $\odot$.

Ukrud mellem Sæden, især Hørsæd, f. Ex. ved Kolding (28), Rantrum og Ostenfeld ved Husum (F. Müll.), Eidersted, Sandklitterne paa Romg (16)! B or $n h$. Fævagten ved Ronne (Baagøe). Forekommer desuden som forvildet omkring Haver, hvor den dyrkes som Salatplante. 7

bb. Blomsterstilliene ved Frugtmodningen udstaaende. Fróbladene hele.

854. L. ruderale L. (Stinkende K.) H. 700; Drej. n. 643 ; F. D. 184 ; Rchb. 1. c. fig. 1215.

Rodbladene fjerlappede, tidligt affaldende, de nedre Stcengelblade fjersnitdeelte, de ovre ndeelte, linieformede; Kronblade oftest 0; Støvdragere 2; Skulperne kredsrundt ovale, i Spidsen smalvingede; Griffelen utydelig.

Planten glat, meget grenet, ubehageligt og stærkt lngtende. 6-8. $\odot$.

Omkring Byer, især Kjøbstæder, paa Byggepladser, ver Mure, funden i alle Provindser sporadisk, i enkelte Egne hyppig, f. Ex. $\mathbf{S} \boldsymbol{l}$. paa Digerne i Marsken, i det sydl. Loll., S j. omkring Kbhvn.

855. L. campestre [R. Br. H. Kew. ed. 2, IV, 465] (Salomons Lysestage) Drej. n. 642; Rehb. I. c. fig. 4214; Thlaspi L., H. 701 ; F. D. 1221.

Rodbladene snart henvisnende, heelrandede eller bugtet-fjerlappede, omvendt-ægformede eller ovale, stilkede, Stcongelbladene tandede, piilformede, omfattende; Blomsterstilkene stive, vandret udspærrede eller nedboiede; Skulperne ægformede, i Spidsen bredvingede, vablet-punkterede; Griffelen kort.

Hele Planten graaagtig-duunhaaret, stivt opret, ${ }^{1 / 2}-1^{\prime}$ h høi, enkelt eller alm. i Spidsen grenet; Blomsterne smaae, Kronbladene hvide. 6-7. $\odot$.

Paa dyrkede Marker og ved Gjærder, paa Leer- eller Kalkgrund: paa $\boldsymbol{\theta}$ erne i de fleste Egne alm., sjelduere paa $\boldsymbol{H}$ alvoen, især mod S. og V. 
b. Skulpen uvinget, ikke udrandet.

856. L. Iatifolium L. (Bredbladet K.) H. 699; Drej. n. 644 ; F. D. 557 ; Rebh. l. c. fig. 4219 ; H. N. IX, 24.

Bladene saugtakkede, glatte, de nedre agformede eller elliptiske, langstilkede, de øvre æg-lancetformede, kortstilkede; Blomsterne i Top med txtblomstrede Greue og haarfine Blomsterstilke; Slulperne ovale, duunhaarede, Arret siddende. 7-8. 2.

Omtrent $2^{\prime}$ løi. Blomsterne meget smaae, Kronbladene hvide.

Ved Strandbredder i leret Marskbnnd: paa Oerne fra Moen til Ero ikke sjelden, i de andre Egne sparsom: Sj. Elhorn i Roeskilde Fjord (Kyll., Sehlichtkr.), Stalsgravene ved Norreport (Nielsen) og Tommerpladserne ved Kbhvu. (Dr.), Kastrup paa Amager! Tappernøie (H.) og Evenbro ved Præstos! Langelands Ostkyst (19); $\boldsymbol{F}$. Hofmansgave (H.), Bjornemose (12); J. Varde Aaes Udlob ved Hjerting (16); Sl. Hoptrup (28).

\section{Thlaspi. Pengeurt.}

857. T. arrense L. (Almindelig P.) H. 701; Drej. n. 640 ; F. D. 793 ; Rehb. l. c. fig. 4181.

Rodbladene omvendi-ægformede, stilkede, Stangelbladene elliptiske, med den piilformede Basis halvt-omfattende, tandede; Blomsterstillene udspærrede eller opstigende; Frdene stribetrynkede.

Hele Planten glat, ${ }^{1 / 2}-1^{\prime}$ hgi. Kronbladene hvide. 5-7. $\odot$. Paa Brakmarker og mellem Sæden et alm. Ukrud.

\section{Capsella. Ilyrdetaske.}

858. C. Bursa pastoris [Moench Meth. 271] (Almindelig H.) Drej. n. 645 ; Rehb. I. c. fig. 4229 ; Thlaspi L., H. 702 ; F. D. 729 .

Rodbladene lyreformet-tandede, halvfinnede eller fjersnitdeelte; Stangelbladene lancetformede, heelrandede eller tandede, med piilformet Basis; Blomsterstillene mod Frugtmodningen udspærrede.

2l $1 / 2-1^{\prime}$ hoi, mere eller mindre duunhaaret af stjerneformede Haar. 
Kronbladene hvide. 4-9. $\odot$. (Var. betydeligt i Henseende til Høiden, Bladenes Indskjæring o. s. v.).

Paa Marker, i Haver o. a. dyrkede Steder meget alm.

\section{Camelina. Dodder.}

859. C. foetida [Fr. Mant. 3, p. 70] (Hundehør) Myagrum sativum F. D. 1038.

Bladene lancetformede, heelrandede eller tandede, ved Grunden smalere, piilformede, duunhaarede; Blomsterstilkene mod Frugtmodningen slapt nedhængende; Skulperne omvendt-hjerteformede eller næsten kugleformede, punkterede, i Spidsen indtrylkte, med kort Griffel.

Kronbladene bleggule. $6-8$. $\odot$

Alm. Ukrud mellem Hor.

860. C. dentata [Pers. Syn. 2, p. 191] (Tandbladet D.) Fr. S. veg. Sc. p. 152 ; H. N. VII, 21 ; C. sativa dentata H. 691.

Bladene halvfinnede eller tandede, næsteu glatte; Blomsterstilkene mod Frugtmodningen aabent udstaaende; Skulperne omvendt-ægformede med en smal Rand, jævue, i Spidsen ikke udrandede; Griffelen længere; forøvrigt som foreg.

Kronbladene gule. Skulpens Klapper haardere end hos foreg. 6-7. $\odot$.

$\alpha$, pinnatifida (C. pinnatifida Horn. Hort. hafn. 2, p. 598; C. dentata F. D. 1824; Rchb. l. c. fig. 4294). Bladene dybt halvfinnede.

$\beta$, integrifolia (C. sativa Fr. Mant. 3 , p. 72 ; H. N. VII, 20 ; C. macrocarpa Heuff., Rchb. l. c. fig. 4294 b). Bladene heelrandede eller svagt tandede.

Forekommer som Ukrud mellem $\mathrm{H} \emptyset \mathrm{r}$ og anden Vaarsæd, men sjeldnere end foreg., f. Ex. $\alpha, \boldsymbol{F}$. Faaborg (15), Ringe; Stryno (12); J. Fjerritslev i V. Hanherred (Drej. Herb.), Gjeding (16), Leerbæk ved Veile (1), Fredericia (12), Kolding (28!); Sl. Rødding (16), Hø: r (Branth). $\beta, S j$. Tikjøb! Marker ved Lyngby S $ø$ ! F alst. N. Grimmelstrup (Koch), Stubbekjobing (14); aln. paa Bornholm!

861. C. silrestris [Wallr. Sched. crit. p. 347] (Smaaskulpet D.) Fr. Mant. 3 p. 68 ; C. sativa $\alpha$ silvestris Fr. 1 v. 
ed. 2, p. 199; C. sativa Rehb. 1. e. fig. 4292 ; Brassica eampestris F. D. 550 (tildeels, slet Fig.).

Stangelen udeelt eller faagrenet, med oprette Grene, tætog mangebladet; Bladene elliptiske eller lancetformede, ved Grunden piilformigt oufattende, fjernt og utydeligt tandede, korthaaret-rue; Klasen tætblomstret, Blomsterstilliene mod Frugtmodningen oprette; Skulperne pæreformede, haarede, fiint punkterede, med en bred, fladtrykt Rand og længere Griffel end hos foreg.

Kronbladene gule. Hoiere end de 2 foreg. Arter, men med mindre Skulper og Frøe. Formen microcarpa DC. (C. microcarpa Andrz., Rchb. 1. c. fig. 4293, er den hos os forekommende). 6-7. $\odot$.

Paa Græsmarker, hidtil kun funden paa faa Steder i Danmark: $\boldsymbol{S} \boldsymbol{j}$. Marker ved Landbohøiskolen! Falst. S. Kirkeby, Ournpgaard (Koch)! F. Seden ved Odense (12).

\section{Cochlearia. Kokleare.}

862. C. danica L. (Dansk K.) H. 704; Drej. n. 648; F. D. 100 ; Rehb. I. e. fig. 4257 ; H. N. IV, 35 .

Stconglerne nedliggende eller opstigende; Rodbladene langstilkede, hjerteformet-spydformede, Stcengelbladene kortstilkede, æg-triangelformede eller rudeformede, 3-5-lappede; Kronbladene omtrent af Bægerbladenes dobbelte Længde; Sliulperne ægformede eller ovale, med kort Griffel.

Kronbladene hvide. 5-6. $\odot$ (Bladene hos denne og de folg. Arter glatte, kjodfulde, af en behagelig, skarp Smag).

$\boldsymbol{\beta}$, integrifolia Drej. Bladene rundagtige, heelrandede.

Ved Strandbredder i Sandet og mellem raaden Tang, ikke sjelden. $\boldsymbol{\beta}$, med Hovedarten, f. Ex. Aalliolm i Isefjorden (Nolt.).

863. C. anglica L. (Engelsk K.) H. 704; Drej. n. 649; F. D. 329 ; Rehb. 1. c. fig. 4258 ; H. N. XIV, 31 og X, 35 (var.).

Stcongelen opstigende eller opret; Rodbladene lingstilkede, ægformet-ovale, ved Grunden afrundede; Stangelbladene stilkløse, halvt-oinfattende, elliptiske eller rudeformede, bugtettandede; Kronbladene omtrent af Bægerbladenes tredobbelte Længde; S'kulperne elliptiske med middelstor Griffel.

Uaandb. i den danske Flora. 
Kronbladene hvide. Frøene omtr. dobbelt saa store som hos de andre Arter. 5-6. $\odot$.

Ved Strandbredder, sjeldnere end foreg. og følg., f. Ex. Sj. Bisserup ved Skjelskør (Nielsen), Ourø (15), Oxholm i Isefjorden (9), Dragør (H.), Saltholm! Moen ved Noret (27); Falst. ved Grønsund, Kalvøs i Guldborgsund (14), Nykjøbing (29), Tjæreby Fang (14); L oll. Bjerremark (5)! Saltvig (19); Fre ved Ourehoved (12); $\boldsymbol{F}$. Svendborg (H.), Hofmansgave (18)! J. Estruplund (H.), Holmene i Randers Fjord (7), Horsens Fjord (Jørgens.); Kolding Fjord (28); $S l$. Lyksborg (Hansen), Husum o. fl. St. i Marsken og paa Halligerne (N.). *i]

Anm. Denne Art beskrives alm. med forlænget Griffel, men hos de af mig undersøgte Expl. er Griffelen kun lidet længere end hos foreg. $\mathrm{og}$ folg. (omtr. $1 / 6$ af den fuldvoxme Skulpes Læengde). Mellem Arterne $\mathrm{i}$ denne Slæegt er det vanskeligt paa Papiret at drage nogen fast Græudse, og stundom synes de ogsaa i Naturen at sammenflyde, da næsten alle de angivne Kjendetegn ere Forandring underkastede (f. Ex. dyrket i bot. Have af Frø fra Saltholm viser C. anglica sig kun forskjellig fra $C$. officinalis ved noget storre Kronblade og Frøe), men de have $\operatorname{dog} \mathbf{i}$ vild Tilstand hver sit eiendommelige Udseende, og i deres typiske Former ere de meget forskjellige.

864. C. officinalis L. (Læge-K.) H. 703; Drej. n. 650; F. D. 135 ; Rchb. l. c. fig. $4260 ;$ H. N. XIII, 50.

Stanglerne oprette eller opstigende; Rodbladene langstilkede, spydformet-nyreformede; Stangelbladene stilklose, halvtomfattende (dc nedre ofte kortstilkede), ægformet-elliptiske eller rudeformede, bugtet-tandede eller lappede; Kronbladene omtr. dobbelt saa lange som Bægerbladene; Skulperne oval-kugleformede, med kort Griffel.

Alm. høiere, men spæedere, med mindre Kroner, Skulper og Frøe end foreg. Kronbladene hvide. 5-6. ๑.

Ved Strandbredder, funden $\mathrm{i}$ alle danske Provindser, men ikke overalt alm. Meget udbredt og hyppig omkring Isefjorden!

\section{Draba. Gjaslingblomst.}

865. D. verna L. (Vaar-G.) H. 693; Drej. n. 646; F. D. 983 ; Rchb. 1. c. fig. 4234 ; Erophila vulgaris DC.

Bladene rosetteformigt samlede ved Grunden, elliptiske eller lancetformede, i Spidsen tandede; Skafterne bladløse; Blomsterstilkene længere end de elliptiske Skulper; Kronbladene omtr. til Midten tokløvede. 
1-6" høi. Kronbladene hvide. 3-5. $\odot$

$\beta, \operatorname{prccox}$ Stev. (Rehb. 1. c. fig. 4233; H. N. IV, 34). Skulperne ovale.

Paa torre Marker, Groftevolde o. s. v., meget alm.

866. D. incana L. (Hvidgraa G.) H. 696 ; F. D. 130; Rehb. I. e. fig. 4249 ; H. N. V, 14.

Bladene ved Roden og paa de blomsterløse Bladknipper rosettestillede, Stangelbladene talrige, spredte $\left({ }^{2} / 5\right)$, saugtakkede, lancetformede eller de øvre ægformede; Blomsterstilkene kortere end de lancetformede, tilsidst snoede Skulper; Kronbladene udrandede.

4-10" hoi, graaagtig af stjerneformede Haar. Kronbladene livide. $5-6$. 4 .

Paa tørre Steder, især paa Kalkgrund, kun funden i den nordlige Deel af $\boldsymbol{J} y \boldsymbol{l l}$.: Lerup i $\emptyset$. Hanherred (Dr.), Korsø og Blis Kalkbakker i Thy (23)! Dybdals Bakker og Sohngaardsholm ved Aalborg (Beck).

\section{Alyssum. Krognaal.}

867. A. calycinum L. (Stivbægret K.) H. 697 ; Drej. n. 647 ; F. D. 1704 ; Rehb. 1. c. fig. 4269 ; H. N. $1,29$.

Stconglen fra Grunden af grenet, med opstigende Grene; Bladene tætsiddende, heelrandede, de nedre omvendt-ægformede, de øvre lancet-spadeformede; Blomsterne i valseformede, mangeblomstrede Klaser fra Spidsen af Grenene; Bagerbladene vedblivende, i Spidsen skjæghaarede, omtrent halvt saa lange som den kredsrunde, hvælvede, i Spidsen indtrykte, i Rauden smalt vingede Skulpe.

3-8" høi. Hele Planten hvidgraa af stjerneformede Haar. Kronbladene bleggule (i visnet Tilstand hvide). $\frac{5}{2}-\frac{6}{1}$. $\odot$.

Paa torre Marker og Bakker, ved sandige Søbredder og mellem Sæden, sporadisk, men funden $\mathrm{i}$ alle Provindser og er $\mathrm{i}$ de senere Aar bleven temmelig almindelig udbredt.

\section{Berteroa. Klovplade.}

868. B. incana [DC. Syst. 2, p. 191] (Graa K.) Rehb. 1. c. fig. 4284 ; Alyssum L., H. 697 ; F. D. 1461 ; H. N. I, 30; Farsetia R. Br., Lge. Haandb. 1 Udg. Nr. 832. 
Stængelen opret eller opstigende, foroven grenet, med oprette Grene; Bladene lancetformede; Skulpen fladtrykt-hvælvet, ikke udrandet, med lang Griffel.

$1-1^{1} / 2^{\prime}$ høi. Hele Planten graa af stjerneformede Haar. Kronbladene hride. 5-8. ข.

Paa torre Steder, især ved Veie og Byer, sjelden: J. Randers ved Kirkegaarden og Veiene $\emptyset$. for Byen! S l. Hadersler (Grønlund), Sundeved (16); F. Faaborg (H.); B ornh. Klemensker (Hjorth), N. for Rønne! 降

\section{Subularia. Sylblad.}

869. S. aquatica L. (Vand-S.) H. 692; F. D. 35 ; Rebb. 1. c. fig. 4232 ; H. N. VI, 20.

Bladene sylformede, heelrandede, tæt samlede ved Grunden; Blomsterskafterne bladløse, udstrakte eller opstigende; Kronbladene smaae, heelrandede.

$1 / 2-2^{\prime \prime}$ høi. Roden trævlet, med hvide Trævler. Kronbladene hvide, paa Blomsterne under Vandet $0.7-8 . \odot$.

Ved Aa- og Søbredder (over og under Vandet) sjelden: J. Skjern Aa ved Løuborg! Ørnsø ved Ribe (6)!

\section{Lunaria. Sakbager.}

870. L. rediviva L. (Vedvarende S.) H. 708; F. D. 2241 ; Rehb. 1. c. fig. 4290.

Bladene hjerteformede, tilspidsede, fint og skarpt tandede; Skulperne lancetformet-elliptiske, spidse; Froene nyreformede, dobbelt saa brede som lange.

$1^{1 / 2} \rightarrow 2^{\prime}$ høi. Kronbladene hvide eller blegt lila. 6-7. 4 .

Paa fugtige Steder i Skove, sjelden: J. Aaen ved Greis Mølle! Veile (4); B or $n h$. Store Fos i Rø Sogn (Baagøe)! F

† 871. L. biennis [Moench Meth. 126] (Toaarig S.); F. D. 1880 ; Rehb. 1. c. fig. 4289 ; L. annua L., H. 708 ; Drej. p. 218.

Bladene hjerteformede, spidse, grovt tandede; Skulperne ovale, budte; Frøene hjerteformetkredsruude, ligesaa lange som brede. 
1-1 $1 / 2^{\prime}$ høi. Kronbladene violette eller hvide. 5-6. $\odot$.

Forvildet omkring Haver, hvor den dyrkes son Sïrplante.

\section{Nasturtium. Brondkarse.}

a. Kronbladene hvide.

872. N. Armoracia [Fr. Mant. 3, 65] (Peberrod.) H. N. VIII, 21; Cochlearia L., Rehb. l. c. fig. 4262; Armoracia rusticana Fl. wett., H. 705; Drej. n. 651.

Rodbladene langstilkede, regformet-ovale, rundtakkede; Stcrngelbladene siddende, lancetformede, de ovre heelrandede, de mellemste sangtakkede, de nedre halvfinnede; Skulperne ovale eller elliptiske*), meget kortere end de oprette Blomsterstille.

Roden lang, tapformet, Rodbladene meget store. $2-3^{\prime}$ høi. Kronbladene luvide. Frøene modnes sjeldent eller aldrig hos os. 6-7. 4 .

Paa Stryno (som det synes, vildroxende: 12); Sl. Tǿnning (F. Müll.). Dyrkes i Haver og paa fugtige Marker, og forekonmer derfra forvildet.

873. N. officinale [R. Br. H. Kew. ed. 2, IV, 110] (Almindelig B.) Drej. n. 668 ; Rehb. 1. c. fig. 4359 ; H. $\mathbf{N}$. XV, 33; Sisymbrium Nasturtium L.; H. 716; F. D. 690.

Stangelen fra en nedliggende Rodstok opstigende; Bladene lyreformet-fjersnitdeelte, med 2-4 Par rundagtigt-ægformede, rundbugtede eller heelrandede Afsnit; Skulperne linieformede, trinde, opstigende, af Længde med eller længere end de nedboiede Blomsterstilke.

Fra Stængelens nedre Bladhjørner udgaae knippestillede Trævlerødder. Kronbladene hvide. 6-7. 2. Var. meget i Henseende til Høiden, Smaabladenes Størrelse of Form o.s. v.

*) Skulpens Form hos Arterne i denne Slægt danner en Overgang fra denne til folg. Orden, og nogle af Arterne hore derfor strængt taget til Siliquosa. At adskille de kortskulpede i en egen Slægt (Roripa Bess., cf. Gren. \& Godr. Al. Fr.) fra de langskulpede, er unaturligt, da idetmindste alle Arterne med gule Ḱronblade ere saa nar beslægtede, at de nødvendigriis maa forenes i een Slægt. 
$\boldsymbol{\beta}$, siifolium (Rchb. 1. c. fig. 4361). Stængelen tyk og meget høi, Afsnittene store, æg-lancetformede.

$\gamma$, microphyllum (Rchb. 1. c. fig. 4360). Stængelen tyndere og lavere, Afsnittene kortstilkede, meget smaae.

Ved Bredderne af Bække, Kilder og Grøfter, hist og her, men ikke overalt lige alm. $\beta$, i selve Vandet; $\gamma$, paa mere tor Grund, f. Ex. $S j$. Svinninge! J. Kolding (28).

b. Kronbladene gule (Brachyolobus DC.), aa. langere end Bagerbladene.

874. N. amphibium [R. Br. ]. c.] (Vand-Peberrod). Rehb. I. c. fig. 4363 ; Sisymbrium L., H. 717 ; F. D. 984 (ikke god); Brachyolobus Drej. n. 652 .

Bladene lancetformede, de nedsænkte fjersnitdeelte, de nedre ovenfor Vandet stilkede, halvfinnede, de ovre siddende, med halvt-omfattende Basis, saugtakkede; Skulperne elliptiske, lidet længere end Griflerne, 2-3 Gange kortere end de udspilede eller nedbøiede Blomsterstilke.

Bladene var. i Indskjæring. 6-7. 4 .

I Bæklse, Grøfter og Kjær alm.

875. N. silrestre [R. Br. l. c.] (Langskulpet B.) F. D. 1881 ; Rehb. I. c. fig. 4368 ; H. N. XI, 35 ; Sisymbrium L., H. 716 ; Brachyolobus Drej. n. 654 .

Alle Bladene stilkede, fjersnitdeelte, med elliptisk-lancetformede, paa de øvre Blade linieformede, saugtakkede Afsnit; Slculperne linieformede, fladtrykt-tveæggede, af Længde med eller længere end de udstaaende Blomsterstilke; Griffelen meget kort.

7-8. 4.

$\beta$, rivulare (Rcbb. I. c. fig. 4365). Bladenes Afsnit smale, linieformede, Griffelen længere.

Ved Randen af Bække og Grøfter, sjelden og kum funden i de sydligere Egne af Landet: Bornh. Læsaaen red Limensgade! Grødby Aa ved Boderne! Nexø (20); Loll. Nakskov (19); F. Ølstedgaard (24)! Sl. Süderholz og Rødemis ved Husum (F. Müll.), Süderstapel (16). - $\beta$, Høireby og Raahave paa Loll. (5)! 
876. N. anceps [Wablenb. mser, sec. Fries; Rchb. Bot. Zeit. V, 1, 295] (Treægget B.) Rehb. l. c. fig. 4364; H. N. VI, 18; Sisymbrium Wahlenb., H. 718; Brachyolobus Drej. n. 653 ,

De nedre Blade lyreformet-fjersnitdeelte; Skulperne tveægget-fladtrykte, linie-lancetformede, af Blomsterstilkenes halve Længde, 2-3 Gange længere end Griffelen, forøvrigt som foreg. og var., ligesom denne, i Henseende til Bladenes Indskjæring. 7-8. ข.

Paa fugtige Steder, sjelden: $\boldsymbol{J}$. Ribe (d'Origny)! $\boldsymbol{S} l$. Aabenraa (Hempel), Skovlund Aa mellem Flensborg og Læk, Husum (20), Hollingsted (Didrichsen)! Treyaholm ved Trenefloden (Jesseu), Rendsborg (28); Hummelmai paa $\boldsymbol{A} l \boldsymbol{s}$ (20)! (Saavel denne som foreg. angives af Horn. som ikke sjeldne, livilket maa beroe paa en Feiltagelse). F*

\section{bb. Kronbladene af Langde med Bagerbladene.}

877. N. palustre [DC. Syst. II, 191] (Kjær-B.) Rebb. l. e. fig. 4362 ; H. N. VI, 19; Sisymbrium Leyss., H. 717 ; F. D. 409 (S. islandicum) og 931; Brachyolobus Drej. n. 655.

Bladene lyreformet-fjersnitdeelte med elliptiske, tandede Afsnit, de ovre ved Grunden øreformet-halvtomfattende; Slculperne opblæste, linieformet-ovale, opstigende, af Længde med de udspilede eller nedbøiede Blomsterstilke; Griffelen meget kort.

Hele Planten morkgrøm, ofte bruunagtigt anløben. Kronbladene skidengule. $6-8$. $\odot$.

Paa fugtige Steder, f. Ex. ved Randen af Gadekjær og Grøfter, meget alm.

\section{Siliquosa.}

\section{Raphanus. Reddike.}

878. R. Raphauistrum L. (Kiddike). H. 731; Raphanistrum segetum Baumg., Drej. u. 658; Rehb. l. c. fig. 4172; Sinapis arvensis F. D. 678.

Bladene lyreformet-halvfinnede eller -snitdeelte; Bogerbladene tiltrykte, Skulpen halsbaandformigt indsnøret paatværs 
og tilsidst furet paalangs, flere Gange længere end Blomsterstilken, dens Klapper altid tilstede, men meget smaae og mod Frugtmodningen utydelige.

Planten blaagrøn, mere eller nindre stivhaaret af ved Grunden kirtelformigt opsvulmede Haar; Kronbladene bleggule. 6-7. $\odot$.

Alm. Ukrud i dyrket Jord, især mellem Vaarsæden.

Anm. Ved de angivne Kjendetegn skjelnes den let fra Sinapis arvensis, med hvilken den lhar nogen Lighed og stundom bliver forvexlet.

$\dagger R$. sativus L. (Have-R.) Rehb. 1. c. fig. 4175. De nedre Blade lyreformede, de øvre ægformet-elliptiske, tandede: Skulpen trind, kegleformigt tilspidset, svagt eller ikke indsnøret, lidet længere end Blomsterstilken, dens Klapper suart (endog paa samme Plante) 0 , snart tydelige og mod Frugtmodningen tilvoxende.

Kronbladene violette eller hivide. 6. $\odot$.

Dyrkes i Kjokkenhaver formedelst den spiselige Rod, og forekommer forvildet.

\section{IIesperis. Aftenstjerne.}

879. II. matronalis L. (Vellugtende A.) Drej. n. 669; Rchb. 1. c. fig. $4377-78$; H. inodora L., H. 724 ; F. D. 921 og 924.

Rodbladene lancetformede; Stongelbladene ægformet-elliptiske, tilspidsede, tandede; Kronbladene omvendt-ægformede, budte eller svagt udrandede; Blomsterstillene udstaaende, flere Gange kortere end den opstigende, valseformet-knudrede Slculpe.

Bladene rue. Kronbladene violette eller hvide, vellugtende. 6-7. 4 .

I Kratskove og ved Gjærder, sjelden: $\boldsymbol{S} \boldsymbol{j}$. Helsingør, Taarbæk, Springforbi (H.); $\boldsymbol{F}$. Fjellebro (Kyll.), Ulriksholm, Vissenberg, Hindsgavl (H.); J. Blegkilde ved Aalborg (Branth), Viborg (16), Frysenborg (2), Jensgaard (Kyll.), Gjærder ved Kolding! Forekommer desuden hist og lier forvildet ved Haver, hvor den dyrkes som Siirplante. F

Ann. Den dyrkede Form (H. matronalis L.) er (efter Koeh) ikke væsenligt forskjellig fra den vilde (H, inodora $L$.) undtagen deri, at den sidste kun lugter om Natten.

\section{Dentaria. Tandrod.}

880. D. bulbifera L. (Løgbærende T.) H. 711 ; Drej. n. 665 ; F. D. 361 ; Rehb. 1. c. fig. 4318. 
Rodstokken vandret, tandet af hvidagtige, kjødfulde Skjæl; de nedre Stongelblade fjersnitdeelte med lancetformede, saugtakkede Afsnit, de øvre bele, lancetformede, saugtakkede; sorte Logknopper i Bladhjørnerne.

Kronbladene lys-rosenrøde, kun faa Blomster frembringe Frugt. $5-6$. 4 .

I hqitliggende Skove, sporadisk og temmelig sjelden: $\mathbf{S} j$. Bjørnstrup paa Refsnæs (15), Benzonslund (H.), Jægerspriis (Kyll.). Egelund ved Hillered (A. Rafn), Sorø (7), Vintersbølle (29); M Klinteskov! Falst. ved Hesnæs (14), Kraghave, Flatø i Guldborgsund (29); Loll. paa Borgy og Lindo i Maribo So (5); F. Trolleborg (Oppermann;; $\boldsymbol{J}$ Oland i Limfjorden (Drej. Herb.), Osted (Brix), Clausholm (7), Kah (13), Palsgaard (H.), Veile! Refstrup (30), Kolding (28); $S l$. paa flere Steder i Skovene, især paa Østkysten.

\section{Cardanine. Springklap.}

a. Bladstilken med piilformede $\varnothing$ rer ved Grunden.

881. C. injpatiens L. (Ǩronløs S.) H. 713; Drej. n. 662 ; F. D. 1339 ; Rehb. 1. c. fig. 4302 .

Bladens mangeparret-fjersnitdeelte; Afsnittenc paa de nedre Blade agformet-elliptiske, halvfinnede, paa de øvre lancetformede, tandet-fligede eller paa den opadvendte Rand heelrandede; Blomsterstilkene opret-aabne; Skulperne opstigende.

$1 / 2-1^{1 / 1} 2^{1}$ høi. Kronbladene hvide, omtrent af Bægerbladenes Langde, oftest $0.5-6$. $\odot$.

Paa fngtige Steder i Skove, sjelden: $J$. Øland i Limfjorden (Aaby), Anlaget ved Veile (30)! Greisdalen (16), Kidholm i Kolding Fjord (2s); F. Ølstedgaard (24)! Falst. (Heerforths Herb.); Hoens Klinteskov (Freuchen).

b. Bladstilken uden Ører.

aa. Kronbladene dobbelt saa lange som Bagerbladene, med smal, opret Plade.

882. C. parviflora L. (Smaablomstret S.) H. II, 218; Rehb. l. c. fig. 4301 ; H. N. III, 21.

Bladene mangeparret-fjersnitdeelte, alle Afsnittene ligestore, heelrandede, paa de nedre Blade ovale, paa de ovre linieformede; Rodbladene faae, Stangelladene talrige; Skulperne opstigende, paa næsten retvinklet udstaaende Blomsterstillie. 
Planten finere og spædere end de følg., Blomsterne meget smaae, hvide. 6-7. $\odot$.

Paa fugtige, oversvommede Steder, meget sjelden: $\boldsymbol{S} \boldsymbol{l}$. Aabenraa (N.). $F$

883. C. intermedia [Horn. Oec. Pl. p. 714] (Rosettebladet S.) F. D. 1762 (ikke god); C. hirsuta L., Drej. p. 322 ; Rchb. I. c. fig. 4304 ; C. hirsuta a, campestris Fr. nov. p. 201 ; H. N. III, 20.

Alle Bladene faaparret-fjersnitdeelte; Rodbladene talrige, rosetteformigt samlede, med kredsrundt-ægformede, rundbugtede Sideafsnit og større, kredsrundt-nyreformet Endeafsnit; Stcengelbladene faae, mindre end Rodbladene, med ligestore, linie-lancetformede Afsnit; Stcenglerne opstigende, ofte udstrakte, med rette Ledstykker; Blomsterstilkene opret-aabne, 3-4 Gange kortere end de oprette Skulper, de øverste Skulper meget længere end den blomstrende Deel af Klasen; Støvdragerne oftest 4 .

Forekommer hos os oftere glat end haaret, hvorfor Navnet hirsuta synes mindre passende og Linné har muligviis derunder tillige indbefattet folg. Art. 2-6" høi. Kronbladene hride. 4-5. $\odot$.

I Tørvmoser og ved (ijærder, især i løs Turv- eller Sandjord, sporadisk: J. Tandrup $\mathrm{i}$ Thy (Drej. Herb.), Hald og Hjarbæk ved Viborg (Morville), Fusing Vasehuus (3), Fiskergaarden ved Randers (Selmer)! Skanderborg (16), Kolding (28); Sl. Cliristiansfeld, Aabenraa (N.), Flensborg (Hansen), Husum (F. Müll.); Als ved Sonderborg (20); i Fyen alm.! Langel. ved Tranekjær; Falst. ved Seminariet (H.), S. Kirkeby (Koch), Bregninge (14); Moen ved Ulfssund (9); $S j$. Haverup og Steenstrup ved Sorø! Mose mellem Nærum og Søllerød!

884. C. silratica [Link i Hoffm. phytogr. Blätt. 1, 50] (Skov-S.) Koch Syn. II, 46; Rehb. I. c. fig. 4303; C. impatiens F. D. 735 ; C. hirsuta H. 713 (undt. Var.).

Stangelen opstigende eller opret, med zigzagbøiede Ledstykker; Rodbladene faae og tidligt henvisnende; Stcrngelbladene talrige, alm. større end Kodbladene, forøvrigt som foreg., men med flere Par større og bredere Afsnit; Blomstersiilkene udstaaende, 2-3 Gange kortere end de opstigende Skulper, af hvilke de øvre neppe naae høiere end Blomsterne. 
Væxten kraftigere $(4-8$ " høi), oftest haaret, med blegere grønne Blade og forholdsviis miudre Blomster end foreg. Kronbladene hvide. 5-6. $\odot$ eller 4 .

$\beta$, clandestina Fr. Nov. p. 203 ; H. N. VII, 18 . Kronbladene meget smaae eller 0 , med senere Blomstringstid.

Paa fugtige Steder i Skove, sporadisk og ikke alm.: J. Borglum Klosterskov (Gronlund)! Rold Skov (8), Randrup (Feddersen)! V. Velling, Lindum (Drej. Herb.), Linaa Storskov (16), Ostbirk (2), Veile, Hoien, Trelde Skov (12)! mellem Kolding og Vamdrup (16)! S l. Jels (12), Gram (Reimers), Rodding (16), Haderslev (Gronlund), Aabenraa, Hoist, Slesvig (N.), Flensborg (12), Süderholz og Ostenfeld ved Husum (F. Müll.); A ls i Sonderborg Skov (20); $\boldsymbol{S}$. Nyrupgard ved Sorø! Teglstrup Hegn! Haımermølleskoven, Skovsborg (12), Hareskoven (26)! Grasholmen ved Christiansø (Didrichsen)! - $\beta$, ved Kolding (28)!"

Anm. C. hirsuta $\beta$, silvestris Fr. nov. 202 horer efter Bekrivelsen ("caulis 1-2-pedalis, vix flexuosus, fol. in exspitem densum collecta") neppe herhid, men er muligviis en usadvanlig høi Form af foreg. Art. Links Beskrivelse af C. silvatica passer aldeles til den her forekommende Plante, men Cit. af F. D. ere urigtige (tab. 148 fores til C. silvatica, t. 735 til C. hirsuta). Imidlertid er Navnet baade passende og tilstrækkeligt forklaret ved Kochs Beskrivelse og Afbildningen hos Rehb. At den er en fra foreg. vel adskilt Art forekommer mig utvivlsomt.

\section{bh. Kronbladene 3 Gange langere end Bageret, med bred, udstaaende Plade.}

885. C. amara L. (Vandkar'se). H. 715 ; Drej. n. 663 : Rebb. 1. c. fig. 4305 .

Stangelen opstigende eller opret, ined Udløbere fra Grunden, kantet-furet, bladet indtil Spidsen; Bladene faaparret-fjersnitdeelte, med bugtet-tandede, paa de nedre Blade ovale, paa de ovre elliptiske eller lancetformede Sideafsnit og større Endeafsnit; Støvdragerne af Kronbladenes Længde, med violette Stovknapper; Griffelen forlanget, sylformet.

$1-1^{1 / 2}{ }^{\prime}$ høi. Kronbladene hvide, paa aabne Steder svagt lila-stribede. $5-6$. 4 .

$\boldsymbol{\beta}$, hirta W. Gr.; C. hirsuta F. D. 148 ; C. h. silvatica H. 714. Stængel og Blade harede, Blomsterstilkene glatte.

$\boldsymbol{\gamma}$, minor Lge. Spædere og lavere end Hovedarten $\left(4-6^{\prime \prime}\right.$ høi) med tæthaarede Blade og meget smaae Bladafsnit, Kronbladene violette.

I Moser, ved Kilder og Bække, ikke sjelden. $\beta$, paa skyggefulde Steder; $\gamma$, Viborg (Feddersen)! 
886. C. pratensis L. (Engkarse). H. 714 ; Drej. n. 664 ; F. D. 1039 ; Rehb. l. e. fig. 4308.

Stcongelen opret, trind, foroven svagt stribet, det øvre Ledstykke forlænget og Klasen derved fjernet fra Bladene; alle Bladene fjersnitdeelte, med heelrandede eller rundbugtede, paa de nedre Blade rundagtig-ovale, paa de øvre lancetformede Sideafsnit og større Endeafsnit; Støvdragerne af Kronbladenes halve Længde, med gule Støvknapper; Griffelen kort, (neppe saa lang som Skulpens Brede).

$1-1^{1} / 2^{\prime}$ høi. Kronbladene lila, sjeldnere hvide. 5-6. భ. Forekommer undtagelsesviis med Udløbere, og var. desuden i Henseende til Afsnittenes Form o. s. v.

$\beta$, dentata Schult. (Rehb. I. c. $\beta$ ). Bladafsnittene bugtettandede.

$\gamma$, parviflora Bot. Foren. Catal. $1845(\Longleftarrow \gamma$, angustifolia Mortens. Mscr.?) Bladafsnittene smalt linieformede, Blomsterne mindre.

d. gynocrates Didr. Støvveien langt fremragende, stilket, dens Stilk mindst af Kronbladneglens Længde (bos den typiske Form er Støvveien ustilket).

Paa Enge o. a. fugtige Steder meget alm. $\boldsymbol{\beta}$, ved Bredden af Sollerod So! Gram (Reimers); $\gamma$, Nordsjalland (24)! Bornh. ved Rønne (Hjorth); \&, hyppig paa alle Engene langs Ladegaardsaaens Løb, funden 1863 at Doc. Didrichsen!

\section{Erysimum. Iljorneklap.}

887. E. cheiranthoides L. (Gyldenlak-H.) H. 722 ; Drej. n. 670 ; F. D. 731 (slet) og 923 ; Rchb. l. c. fig. 4383.

Bladene lancetformede, fjernt rundbugtet-tandede eller næsten heelrandede, alle kortstilkede; Blomsterstilkene $2-3$ Gange længere end Bægeret, mod Frugtmodningen vandret udspærrede, halvt saa lange som den fuldvoxne, opstigende Slculpe.

Skulpen (ligesom den øvrige Plante) med faae, tregrenede Haar. 6-8. $\odot$.

I dyrket Jord, især mellem Sæden, funden i alle danske Provindser $\mathrm{og}$ ikke sjelden: hyppigst paa de sydlige Øer.

888. E. hieraciifolium L. (Rankskulpet H.) H. 722; Drej. n. 671 ; F. D. 229 ; Rehb. I. c. fig. 4388 ; H. N. VIII, 19 ; E. strictum Fl. Wett., Koch Syn. II, 55. 
Bladene lancetformede, saugtakket-taudede, de nedre stilkede, de øvre siddende; Blomsterstilkene af Længde med Bægeret, mod Frugtmodninger oprette, 3-4 Gange kortere end den fuldvoxne, opret-tiltrykte Skulpe.

Skulpen og Bladene tret beklædte med tregrenede Haar. Kronbladene storre end hos foreg. 6-7. $\odot$.

Paa Bakker o. a. tørre Steder: kun funden paa Moen, hvor den forekommer flere Steder paa Storeklint! \&

\section{Barbarea. Vinterkarse.}

889. B. stricta [Fr. mser. 1819, S. Veg. I, 146] (Rankskulpet V.) H. N. VI, 16; Relub. l. c. fig. 4355 ; B. parviflora Fr. nov. p. 207.

De nedre Blade langstilkede, udeelte, rnndbugtede, ovale eller øreformede med ovalt Endeafsnit, de mellemste kortstilkede, ovale, rundtakkede, Bladstilken ved Grunden pilformigt udvidet, de øvre siddende med piilformet Basis, elliptiske eller omvendtægformede, bugtet-tandede eller oreformede; Kronbladene 1/2 Gang længere end Bægeret; Skulperne tiltrykte, tveægget-firekantede.

Kronbladene kortere, smalere og blegere gule end hos følg. Art. 5. $\odot$.

Paa fugtige Steder, sjelden: $\boldsymbol{S}$. mellem Kalundborg og Lerchenborg (Baagøe)! Kjøng og Barrit Moser ved Vordingborg (28); J. Hansted Mose (2), alm. ved Ribe (d'Origny)! Enge ved Kolding Aa (28)! Sl. Oxenrad (Gronlund), Heilsminde, Broager (28), Haderslev Dam (8), Gram (1), Almdorf N. for Husum ( $\mathrm{F}$. Mülli.).

890. B. vulgaris [R. Br. H. Kew. ed. 2, IV, p. 109] (Almindelig V.) Fr. nov. p. 205; Drej. n. 666; Rehb. l. c. fig. 4356 ; Erysimum Barbarea L., H. 720 ; F. D. 985.

De nedre Blade lyreformet-fjersnitdeelte med rundagtigthjerteformet Endeafsnit; de ovre Stangelblade bugtet-balvfinnede med oreformigt omfattende Basis; Kronbladene dobbelt saa lange som Bageret; Skulperne oprette, tveægget-firekantede.

Bladene have en skarp, men ikke behagelig Smag. 6. 4 .

$\beta$, arcuata (Rehb. I. c. fig. 4357 ; H. N. Xll, 49). Blomsterstilkene udstaaende, Skulperne bueformigt opstigende. 
Paa Græsmarker og ved Gjærder, ikke sjelden, men sporadisk. $\beta$, med Hovedarten, f. Ex. $S j$. Kirke-Værløse (14), Bregentved (12); Moen ved Borre! F alst. Øverup (14); J. Kolding (28).

891. B. precox [R. Br. I. c.] (Tidlig V.) Fr. nov. p. 206 ; Mant. 3 , 75 ; H. N. I, 28 ; Rehb. I. c. fig. 4358 ; Drej. n. 667 ; Erysimum Sm., H. 721; F. D. 1759 ; B. vulg. acidula Hartm.

De nedre Blade lyreformet.fjersnitdeelte, med oval-nyreformet eller ægformet Endeafsnit og talrige Sideafsnit; de фvre Stcongelblade lyreformet-halvfinnede eller -snitdeelte med linieformede Sideafsnit; Kronbladene dobbelt saa lange som Bægeret; Skulperne opret-aabne, budt-firekantede.

"Bladene have en behagelig, skarp, karseagtig Smag“. (Fr.). 5-6. $\odot$.

Paa lignende Steder som foreg., men sjeldnere: $\boldsymbol{S} \boldsymbol{j}$. paa Vesterfælled! Nysø, mellem Præstø og Kallehave (H.), Ørsløv ved Skjelskør (Nielsen); Loll. Hellinge (19); J. ved Viborg Sø (Morville), Kolding (28); Sl. Gram (1), Bukhavn ved Kappel o. fl. St. (N.). (Om alle de angivne Voxesteder høre til denne, tor jeg ikke med Bestemthed paastaae, da den ofte er vanskelig at kjende fra foreg.). $\bar{₹}$

\section{Arabis. Gaasemad.}

a. Stængelbladene talrige, med halvt omfattende Basis; Kronbladene med opret, omvendt-ægformetlinieformet Plade.

892. A. hirsuta [Scop. Fl. carn. 2, 30] (Stivhaaret G.) Drej. n. 660 ; Rchb. l. c. fig. 4342 ; H. N. XII, 50; Turritis L., H. 726 ; F. D. 1040.

Stcongelen opret; Rodbladene kortstilkede, omvendt-ægformetlancetformede, fjernt og svagt saugtakkede; Stcengelbladene siddende, med hjerteformet Basis, saugtakkede; Skulperne tiltrykte til Stængelen, fladtrykte, mange Gange længere end 'de oprette Blomsterstilke; Klapperne med en tydelig Midtnerve, knudrede af de fremstaaende, tydeligt vingede Frøe.

$1 / 2-1^{\prime}$ høi. Stængelen ved Grunden stivhaaret, alle Bladene haarede af grenede Haar. Kronbladene hride. 5-6. 4. 
Paa Bakker, især paa Leer- eller Kalkgrund, ved Gjærder, sjeldnere paa tórvholdige Enge: bemserket i alle Provindser, men sporadisk og ikke alm.

b. Stæugelbladene faae, ikke omfattende; Kronbladenes Plade omvendt-ægformet, udstaaende.

893. A. arenosa [Scop. 1. c. 2, 32] (Sand-G.) Drej. n. 659 ; F. D. 1760 ; Rehb. l. c. fig. $4 \hat{3} 22$; H. N. VII, 15 $\log \mathrm{X}, 34$ A. sueciea - biennis); Sisymbrium arenosum L., H, 718 .

Stcongelen grenet; Rodbladene rosetteformigt samlede, lyreformet-fjersnitdeelte eller halvfinnede; Stangelbladene kortstilkede, lancetformede, saugtakket-fligede, de ovre næsten heelrandede; de 2 Bagcrblade ved Grunden puklede; Blomsterstilkene opretaabne; Skulperne opstigende; Klapperne med svag Midtnerve, knudrede af de fremstaaende, svagt vingede Frøe.

4-10" høi. Stængelen stivhaaret; Bladene tæt beklædte med grenede Haar. Kronbladene hvide eller lila. 5-7. $\odot$.

Paa sandige eller kalkholdige Bakker, sjelden: $\boldsymbol{S}$ j. Stevns Klint (9), Tappernøie (17); Moens Klint alm.!

Anm. Mellem den Plante, som under Navn af A. suecica-biennis er fremstillet i H. N. (I. e.) og vore Expl. fra Møen formater jeg ikke at see nogensomhelst Forskjel. Strengelen har hos vor ligesaa mange Blade og Skulperne findes snart opret-aabne, snart udstaaende.

\section{A. Thaliana L. (Almindelig Gr.) H. 725; F. D.} 1106; Sisymbrium Thalianum Gay, Drej. n. 674; Conringia Rebb. 1. c. fig. 4380 .

Stangelen grenet; Bladene lancetformede, fjernt-tandede; Rodbladene rosetteformigt samlede, kortstilkede; Stongelbladene siddende, ofte heelrandede; Bagerbladene ikke puklede ved Grunden; Blomsterstilkene udstaaende; Skulperne opstigende, linieformede, med jævne, svagt ennervede Klapper; Frøene uvingede.

$2-8$ " høi. Stængelen forneden stivhaaret; Bladene mere eller mindre haarede af grenede Haar. Kronbladene hvide, mindre end hos foreg. 4-5. $\odot$.

Paa dyrkede, torre Marker alm. udbredt. 


\section{Turritis. Taarnurt.}

895. T. glabra L. (Glat T.) H. 726; Drej. n. 661; F. D. 809 ; Rehb. I. c. fig. 4346; Arabis perfoliata Lam.

Stangelen stivt opret, de nedre Blade stilkede, lancetformede, tandede eller halvfinnede, rue af tregrenede Haar, de ovre piilformigt omfattende, heelrandede, glatte; Skulperne tiltrykte til Stængelen, mange Gange længere end de oprette Blomsterstilke.

$1^{1 / 2}-3^{\prime}$ høi. Hele Planten blaadugget. Kronbladene guulhvide. $6-7$. $\odot$.

Paa Marker, ved Grøftevolde o. a. tørre Steder alm.

\section{$\dagger$ Diplotaxis.}

$\dagger$ D. tenuifolia [DC. Syst. II, p. 632] Rehb. l. c. fig. 4420; Sisymbrium L.

- Bladene glatte, fjersnitdeelte eller dybt halvfinnede, med fjerne, linie-lancetformede, budte Flige; Klasen fjernblomstret, efter Afblomstringen meget forlænget; Bcogerbladene under Blomstringen vandret udstaaende, halvt saa lange som Kronbladene; Skulperne opstigende, omtrent af Længde med de opretaabne Blomsterstilke.

Stængelen ved Grunden halvbuskagtig. Kronbladene bleggule. 7-9. थ.

Paa Grunsdynger ved Fordinghorg (A. Lange)! formodenlig hidført med Ballast.

\section{Brassica. Kaal.}

a. Blomsterstanden under Blomstringen en forlænget Klase, Støvdragerne næsten ligelange.

896. B. oleracea L. (Almindelig K.) F. D. 2056 ; Rehb. l. c. fig. 4438 .

Bladene blaagrønne, glatte; de nedre lyreformet-snitdeelte, stilkede, de ovre $æ g$-lancetformede med omfattende Basis; Bugerbladene opret-tiltrykte; Støvdragerne alle oprette; Froene jævne.

Kronbladene bleggule. $6-7 . \odot$ 
I vild Tilstand forekommer den ved Strandbredder og er fundet red Kramnitze paa $\boldsymbol{L}$ oll. (9). (Fig. i F. D. er tegnet efter Expl. fra den ikke under vor Flora lorrende $O$ Helgoland). I Haver dyrkes den under en Mangde Afiendringer og forekommer undertiden tilfxldigt forvildet $i$ Nærlseden af Dyrkningsstedet. त

b. Blomsterstanden under Blomstringen halvskjærmformet; de 2 Støvdragere meget kortere end de øvrige.

897. B. Nåpus I.. (Raps). H. 728; Drej. p. 226 ; Rehb. 1. c. fig. $4435 \gamma ;$ H. N. XIV, 29.

Bladene blaagraae, glatte, de nedre stilkede, lyreformethalvfinnede, de ovre lancetformede med piilformigt omfattende Basis; Bagerbladene oprette eller tilsidst noget udstaaende; de 2 kortere Sløvdragere opstigende, de langere oprette; Skulperne udstaaende; Frone svagt punkterede.

Kronbladene smukt gule. $5-6 . \odot$ eller $\odot$.

$\alpha$, oleifera biennis. Toaarig, med stærk Rod (Vinterraps).

$\boldsymbol{\beta}$, oleifera annua (H. N. X, 32). Enaarig, med tynd Rod (Sommerraps).

$\boldsymbol{\gamma}$, rapifera Metzg. Toaarig, med tyk og kjødfuld Rod (Kaalrabi).

Findes som vild i Slesvigs Marskegne (efter H.). Formerne " $\operatorname{og} \beta$, især den forste, dyrkes som Olieplanter, dog i større Maalestok for end un; $\gamma$, dyrkes sonı Foderplante. I de Egne, hvor den dyrkes, torekommer den hyppigt forvildet.

898. B. campestris L. (Ager-K.) H. 727; Drej. n. 678; F. D. 550 (slet); Rehb. I. c. fig. 4434 ; H. N. IX, 21.

De nedre Blade fjernt-stivhaarede, de øvre glatte, tilspidsetægformede, med hjerteformigt omfattende Basis; Bageret tilsidst vandret udstaaende; Blomsterstilliene vandret udspilede; Sluulperne opstigende, forøvigt som foreg.

Kronbladene smukt gule. $6-7 . \odot$ eller $\odot$.

$\beta$, esculenta Gren. \& Godr. B. Rapa L., Rehb. 1. c. fig. $4437(\beta)$; H. N. IX, 22. Roden tyk, kjødfuld (Hvidroe).

Alm. Ukrnd i Vaarsæden, dog ikke lige hyppig overalt, mangler f. Ex. i flere Egne af Fyen. Roen, som efter de nyere Forfatteres 
Mening kun er en ved Dyrkning frembragt Form af Agerkaalen, dyrkes alm. i Have og Mark og forekommer derfra tilfældigt forvildet.

$\dagger$ 899. B. lanceolata [Lge. Haandb. 2 Udg., p. 447, F. D. 2658] (Smalbladet K.)

Alle Bladene stilkede, de nedre elliptiske, bugtet.halvfinnede eller tandede, de øvre lancetformede, heelrandede eller tandede; Bagerbladene oprette, tilsidst udstaaende; Skulperne noget fladtrykte, med Kjøl paa Ryggen, tilligemed Blomsterstilkene opretaabne; Frøene grubet-punkterede.

Bladene paa Overfladen grønne, paa Underfladen blaagraae. Kronbladene gule. $\odot$ eller $\odot$.

Denne Plante, som er aldeles forskjellig fra de andre mig bekjendte Arter af denne Slægt, og i flere Henseender lig $E$. Richeriz Vill. (hvilken dog bl. a. er forskjellig ved dens Varighed) har jeg i flere Aar fundet forvildet paa Gjødningspladser udenfor Kjøbenhavn. (I den senere Tid har jeg ikke bemærket den).

900. B. nigra [Koch D. Fl. 4, 713] (Senep-K., Sort Senep). Drej. n. 679 ; Sinapis L., H. 730 ; F. D. 1582; Rchb. l. c. fig. 4427 ; L. Herb. IV, 80.

Alle Bladene stilkede, de nedre lyreformet-snitdeelte med lappet Endeafsnit, de øvre lancetformede, heelrandede eller med en enkelt Tand red Grunden; Bagerbladene udstaaende; Blomsterstilkene oprette; Skulperne tiltrykte til Blomsteraxen, fladtryktfirekantede; Frøene grubet-punkterede.

Frgene mindre end hos de foreg., af skarp Smag. 6-7. $\odot$.

Paa dyrket Jord, f. Ex. ved Veie, mellem Vaarsæden, ikke sjelden, især hyppig paa Øerne. Dyrkes desuden alm. i Have og Mark for Frgenes skyld.

\section{Sinapis. Senep.}

901. S. arrensis L. (Ager.S.) H. 729; Drej. n. 676 ; F. D. 753 ; Rchb. 1. c. fig. 4425 .

Bludene ægformede tller elliptiske, grovt og uregelm. tandede, de nedre orede eller lyreformede; Bagerbladene under Blom :ingen tilbagebøiede; Skulperne valseformede, knudrede, med trenervede Klapper, meget længere end de opret-aabne Blomsterstilke; Griffelen af Længde med eller kortere end 
Skulpen, kegleformigt-firekantet, treribbet med lige Afstand mellem Ribberne indbyrdes og Randeu.

Stæengelen stivhaaret, Bladene, især de nedre, haarede, var. glat. Froene sorte. 5-7. $\odot$.

$\alpha$, vulgaris. Skulperne glatte.

$\beta$, hispida Sond. (S. arvens. b. Schkuhriana l. c. fig. 4426 b; S. orientalis Schk.?) Skulperne stivhaarede af korte, nedbøiede Haar.

Meget alm. Ukrud paa Brakmarker og mellem Vaarsæden overalt i Danmark. $\beta$, hist og her paa samme Steder som Hovedarten.

902. S. alba L. (Guul S.) H. 730; Drej. n. 677; F. D. 1393 ; Rehb. l. c. fig. 4424 ; H. N. VII, 13.

Blanene fjersnitdeelte (de nedre lyreformede), med rundtakket-lappede Afsnit; Bagerbladene under Blomstringen udspærrede; Blomsterstilkene efter Afblomstringen vandret udstaaende, ligelange med Skulperne (Griffelen fraregnet); Skulperne opstigende, valseformede, stivhaarede, knudrede, med femnervede Klapper; Griffelen længere end Skulpen, fladtryktsværdformet med 3 imod Midten tæt samlede og fra Randen fjernede Ribber.

Planten stivharet. Frøene lysgule, skarpe af Smag. 6-8. $\odot$.

Mellem Sæden og ved Gjærder sporadisk og ikke alm., men funden i alle Provindser. Dyrkes paa Grund af de skarpe Frøe.

\section{Sisymbrium. Gabeklap.}

903. S. officinale [Scop. F]. carn. 2, p. 26] (Rank G.) Rchb. 1. c. fig. 4401 ; Erysimum L., H. 720 ; F. D. 560; Chamæplium Wallr., Drej. n. 675.

Bladene høvlformet-fjersnitdeelte med spydformet Endeafsnit; de ovre spydforwede; Grenene stivt udspærrede; Skulperne fra en bredere Basis sylformigt tilspidsede, tæt tiltrykte til Blomsteraxen, flere Gange længere end de tykke Blomsterstilke; Skillevaggen uden Nerver.

Planten rank og stiv, mere eller mindre haaret og noget ru. Kronbladene smaae, men langere end Bregerbladene. 6-7. $\odot$.

Ved Veie, Mure og Ryddepladser, især i Nærheden af Byer: ikke sjelden, i størst Mrngde paa Bornholm! 
† S. Irio L. (Glatbladet G.) H. 719; Rchb. I. c. fig. 4408.

Bladene som hos foreg.; Shulperne knudrede, bueformigt opstigende, 3-4 Gange længere og kun lidet tykkere end de udstaaende, meget tynde Blomsterstilke; Skillevaggen uden Nerve; de øvre Skulper naae op over den blomstrende Deel af Klasen.

Bladene glatte. Stængelen var. glat eller haaret. Kronbladene smaae, bleggule. 7-8. $\odot$.

Fæstningsmure paa Christiansø (18)! sandsynligviis indført.

† S. Loeselii L. (Stivhaaret G.) Rchb. I. c. fig. 4409 .

Bladene Jyreformet-halvfinnede eller -fjersnitdeelte med vandret udstaaende, lancetformet-elliptiske eller linie-lancetformede, heelrandede eller bugtet-tandede Flige; Endefligen spydformet; Skulperne opstigende, dobbelt saa lange som de næsten vandret udstaaende Blomsterstilke, i yngre Tilstand ikke naaende den blomstrende Deel af Klasen.

Stængelen $1-1^{1} / 2^{\prime}$ høi, opret, tilligemed de nedre Blade stivhaaret. Kronbladene gule, større end hos foreg. og følgende. 6-7. $\odot$.

Christiansø (Baagøe)! formodenlig indvandret.

904. S. Sophia L. (Finbladet G.) H. 719; Drej. ฉ. 672; F. D. 528 ; Rchb. l. c. fig. 4405 .

Bladene dobbelt fjersnitdeelte med linie-lancetformede Afsnit; Grenene opret-aabne; Blomsterstilliene udspærrede; Skulperne opstigende, traadformet-valseformede, noget knudrede; lidet længere og tykkere end Blomsterstilkene; Skillevaggen med 1 eller flere Nerver.

Var. duunhaaret eller næsten glat. Kronbladene gule, kortere end Bægerbladene. 6-7. $\odot$.

Alm. i hele Landet ved Byer, i Haver o. a. dyrkede Steder.

\section{Alliaria. Logurt.}

905. A. officinalis [Andrz, i DC. Syst. 2, 489] (Skov-L.) Rehb. J. c. fig. 4379 ; Erysimum Alliaria L., H. 722 ; F. D. 935 ; Sisymbrium Alliaria Scop., Drej. n. 673. 
De nedre Blade langstilkede, nyreformede, rundtakkede, de orre kortstilkede, ljerteformede, tandede; Skulperne opretaabne eller opstigende, mange Gange længere end de tykke, udstaaende Blomsterstille.

Planten ved Grunden duunhaaret, foroven glat. Bladene have, naar de gnides, en lggagtig Lugt. Kronbladene hvide. 5. (-).

I Skove og Krat, ved levende Hegn, alm. udbredt.

\section{6 $6^{\text {de }}$ Klasse. Monadelphia (Enknippede).}

\section{Orden. Pentandria (Femhannede).}

1. Linum L. Bxger og Krone fembladede; 5 Grifler; Frugten en femrummet, ved en Skillevæg fra Rygsømmen ufuldstændigt tirummet, tifrøet Kapsel. (N. F. Lineæ).

Lysimachia. 1 Griffel med udeelt $\operatorname{Ar}(5,1)$.

Erodium. 1 Griffel med $5 \mathrm{Ar}$; fendelelig Spaltefrugt $(10,1)$.

Geranium pusillum $(10,1)$.

\section{Orden. Decandria (Tihannede).}

2. Óxalis L. Bæger og Krone regelm. fembladede; 5 lange og 5 korte Støvdragere; 5 Grifler; Frugten en femklappet, mangefrøet Kapsel, opspringende elastisk ved Ridser; Frøene omgivne af en Frøhud. (N. F. Oxalideæ).

Geranium. 1 Griffel med 5 Ar; femdelelig Spaltefrugt. $(10,1)$.

Ononis

Ulex

Sarothamnus

Genista

Cytisus

Anthyllis

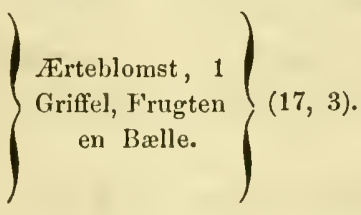

\section{Orden. Polyandria (Mangelannede).}

3. Altháa L. Yderbægeret 6-9-fliget; Bægeret femdeelt; Kronblade 5; Frugten mangedelelig Spaltefrugt med nødagtige 
Smaafrugter, ordnede krandsformigt onkring den midtstillede Griffel.

4. Malva L. Yderbægeret trebladet, forøvrigt som foreg. (3-4. N. F. Malvace $)$.

\section{Pentandria. \\ 1. Linum. IJr.}

906. L. catharticum L. (Vild H.) H. 353 ; Drej. n. 351 ; F. D. 851; Cathartolinum pratense Rehb. ic. fl. germ. VI, fig. 5153.

Bladene modsatte, elliptiske, de nedre ovale eller omvendtagformede; Blomsterne i Qvast; Bogerbladene elliptiske, tilspidsede, kirtlet-randhaarede, balvt saa lange som Kronbladene, omtrent af Længde med Kapselen; Frøene oval-halvmaaneformede, blege.

1/4-1' høi. Kronbladene smaae, hvide med guul Negl. 6-8. $\odot$.

$\beta$, condensatum M. Lange, Ledstykkerne af Længde med eller kortere end Bladene.

Paa Euge, især med tørvholdig Bund, i Kratskove o. s. v.; alm. ndbredt. $\boldsymbol{\beta}, \boldsymbol{F}$. Midskov paa Hindsholm (12).

† L. usitatissimum L. (Sæd-H.) Rehb. l. c. fig. 5155 .

Bladene spredte, lancetformede; Bagerbladene ægformede, svagt randhaarede uden Kirtler; Frøene omvendt-ægformede, brune, glindsende.

$1-1^{1} \frac{1}{2}$ høi. Kronbladene blaae. 7-8. $\odot$.

Alm. dyrket. 


\section{I. Decandria.}

\section{Oxalis. Gjogemad.}

a. Ingen overjordisk Stængel. Kronbladene (hvide eller rødlige) 3-4 Gange længere end Bageret; Frøene stærkt furede paalangs, med svagere Tværstriber.

907. 0. Acetosella L. (Suurkløver). H. 509; Drej. n. 695 ; F. D. 980 ; Rehb. ie. fl. germ. V, fig. 4898.

Rodstokken vandret, med tandformede Skjæl af de vedblivende Bladpuder; Bladene trekoblede; Smaabladene omvendthjerteformede, duunhaarede, især paa Underfladen; Blomsterstilkene længere end Bladene, med 2 skjælagtige, forneden sammenvoxne Dakblade ovenfor Midten; Kronbladene omvendtægformede, svagt udrandede.

Kronbladene hvide med røde Aarer. De senere Blomster kronbladlose, de tidligst udsprungne ofte ufrugtbare. $4-5$. ข.

$\boldsymbol{\beta}$, lilacina! Kronbladene lila med violette Aarer.

I Løvskove, paa Muldjord, meget alm. $\beta, S j$. Ledreborg! Ravnsholt Skov, Store Hareskov (14), Søllerød (Kyll.); Bornh. Rønne, Almindingen (Hjorth); Moens Klint (5); Falst. paa fl. St. (14); L angel. ved Lindelse (12); F. Groftebjerg (A. Lange), Skaarup (19)!

b. Den overjordiske Stængel grenet; Kronbladene gule, af $\mathrm{B}$ ægerets dobbelte Længde; Frøene riflede paatværs.

908. O. stricta L. (Rank G.) H. 510; Drej. n. 696; Rehb. l. e. fig. 4895 ; O. eorniculata F. D. 873 .

Rodstokken kort, bueformigt opstigende, med kjødfulde Udlobere, som overvintre, medens Hovedaxen bortdøer; Stcengelen opret, de nedre Grene korte; Bladene som hos foreg., men med mindre, glatte eller i Randen svagt duunhaarede Smaablade; Axelblade 0 ; Blomsterstilkene 2-3-blomstrede, med smaae, sylformede Dakblade ved Grunden af de mod Modningen opretaabne Smaablomsterstilke.

$1 / 2-1^{\prime}$ høi. Blomsterne meget mindre end hos foreg. 7-8. 4. 
Ved Gjærder, især omkring Byer, Jkrud i Haver og mellem Sæden, ikke alm. og sandsynligviis oprindelig forvildet: $\boldsymbol{S}_{\boldsymbol{j}}$. Refsnæs (15), Frederiksværk! Ramløse (Rafn), Gurre (9), Tikjob! Hellebæk! Helsingør, Fredensborg (Dr.), Nøddebo, Frederiksborg (H.), Rudergaard (Thomsen), Aldershvile (14)! Ørholm! Lyngby! Classens Have (19), Nysø (H.), Sorø alm.! Munkebjergby (Lund), Høve, Flakkebjerg (Nielsen); M $\boldsymbol{H}$ en ved Liselund (12) og Marienborg; L oll. Aalholm (H.); $\boldsymbol{F}$. V. Skjerninge! $\boldsymbol{S} \boldsymbol{l}$. Nyværk ved Slesvig (16), Owschlag (20).

909. 0. corniculata L. (Nedliggende G.) H. 510; F. D. 1753 ; Rchb. 1. c. fig. 4896.

Ingen Udlobere; Stungelen kort, de nedre Grene forlængede, nedliggende og rodslaaende; Bladstilkene og Bladenes Underflade duunhaarede; Axelbladene tilvoxne til Bladstilken; Blomsterstilkene 1-5-blomstrede, med imod Modningen tilbageboiede Smaablomsterstilke, forøvrigt som foreg. $6-9$. $\odot$.

Forekommer sjeldent som Ukrud, oprindeligt indtus. med Sæd fra Syd-Europa: Sl. Gelting, Slotsvolden ved Husum, alm. i Haver og ved Gjærder omkring Garding i Eidersted (16); B ornh. i Haver (Rafn).

\section{Polyandria.}

\section{Althrea. Stokrose.}

910. A. officinalis L. (Læge-S.) H. 741 ; Drej. n. 701 ; F. D. 530 ; Rebb. ic. fl. germ. V, fig. 4849 .

Stcengelen opret; Bladene xg-hjerteformede, de nedre fem-, de øvre trelappede, med grovt-tandede Lapper; Blomsterstilliene mangeblomstrede, i Bladhjørnerne, flere Gange kortere end Bladene; Yderbagerets Flige linie-lancetformede, kortere end: Bægeret.

Hele Planten blødt hvidfiltet, 2-3' høi. Kronen rosenrød. 7-9. 4 .

Ved Strandbredder ikke alm. og kun funden i de sydlige Egne af Landet: $\boldsymbol{J}$. Strandklinter ved Fredericia (12)! $\mathbf{S} l$. Bæverør ved Gelting (16); Baagø ved Assens (Kyll.); F. Gyldensteen (18), Thorseng mellem Bregninge og Vemmenæs (H.); Langel. ved Rudkjøbing og Magleby (H.); Loll. Færgelandet ved Nakskov! Dueholm (9), Aalholm (H.), Blangs (19); Falst. ved Vennerslund (H.), Oureloved, Lindeskoven (Koch), Vaalse, 'Tjareby Fang (14)! II e en (H.); Sj. mellem Christiansholm og Flaskelkroen (forvildet)! 


\section{Malva. Katost.}

a. Stængelbladene dybt fligede eller snitdeelte, Blomsterne enlige i Bladbjørnerne.

911. II. moschata L. (Moskus-K.) H. 743; Drej. p. 231 ; F. D. 905 ; Rehb. 1. c. fig. 4841 ; H. N. X, 37 .

Stangelen opret, haaret af udstaaende og oftest enkelte Haar; Bladene kredsrundt-nyreformede, de nedre haandlappede, de фvre haandsnitdeelte med enkelt eller dobbelt fjerfligede Afsnit; Blomsterstilke og Bager stivhaarede; Yderbagerets Blade linie-laneetformede; Smaafrugterne jævne, tæt duunhaarede.

$1-1^{1} / 2^{\prime}$ høi. Bladene have, naar de gnides, en svag Moskuslugt, dog forekomme de ogsaa ulugtende. Kronen rosenrød eller hrid. 7-9. 4 .

I Krat $o g$ ved Gjærder, funden $\mathrm{i}$ alle Provindser, men ikke alm. og især ved beboede Steder, sandsynligviis oprindelig indført. $\bar{\varpi}$

912. II. Alcen L. (Rosen-K.) H. 742; Drej. n. 697; F. D. 1882 ; H. N. XIV, 34 ; M. exeisa Rehb. l. e. fig. 4842 b.

Stcengelen opret, haaret af tiltrykte, knippestillede Haar; Bladene hjerteformede, Rolbladene haandlappede, Stcongelbladene dybt haandfligede eller -snitdeelte med tandede eller halvfinnede Flige; Blomsterstilke og Bager graafiltede; Yderbugerets Blade ægformede; Smaafrugterne glatte, svagt rynkede paatvæers.

$1^{1 / 12}-2^{4}$ høi. Kromerne rosenrøde, større end hos foreg. 7-8. 4.

$\beta$, fastigiata (M. fastigiata Cavan.). H. N. XIII, 51 ; M. Alcea Rehb. 1. c. fig. 4842 a. Graagtig af tiltrykte Stjernehaar; de mellemste Stængelblade femfligede, de øvre trefligede, med faatandede eller næsten bele Flige.

Ved Gjærder og i Kratskove, forekommer i alle danske Provindser, men sporadisk og ikke alm. $\boldsymbol{\beta}, \boldsymbol{S} \boldsymbol{j}$. ved Classens Have! Skjelskør (Nielsen); Falst. ved Vaalse (14); Loll. Juellinge (19); Thorseng ved Lundby med Hovedarten (12); $S l$. ved Egerufordei Krat paa Veien til Louisenlund (16). 
b. Bladene lappede, Blomsterne knippestillede i Bladhjørnerne.

aa. Blomsterstilkene efter Afblomstringen oprette.

913. H. silvestris L. (Alunindelig K.) H. 741; Drej. n. 698 ; F. D. 1223 ; Rehb. J. c. fig. 4840 .

Stangelen opret eller opstigende, tilligemed Blad-og Blomsterstilke samt Bægeret stivhaaret af udstaaende Haar; Bladene nyre-hjerteformede, de nedre (budt-) 5-7-, de øvre (spidsi-) 3-5-lappede, Lapperne tandet-rundtakkede; Yderbagerets Blade lancetformede; Kronbladene omvendt-hjerteformede, dybt udrandede, 3 Gange længere end Bægeret; Smaafrugterne glatte, synkede paatværs, skarpkantede.

2-3' høi. Kronen rødviolet, sjeldnere hvid (Bringe i Sjæll., 14). 7-9. $\odot$. Danmark.

Ved Gjærder og Veie, omkring Byer, alm. i de fleste Egne af

Anm. M. mauritiana L. Alle Bladene budt femlappede, Bladstilke og Blomsterstilke glatte, Kronbladene mørk carmoisinrøde, er funden forvildet paa Glacierne mellem Østerport og Kastellet (19).

$M$. nicceensis All. Bladene nyreformede, budt 5-7-lappede; Blomsterstilkene efter Afblomstringen oprette eller udstaaende, stivhaarede; Smaafrugterne harede, nætformigt rynkede, med ophoiet Rand; Kronbladene knap dobbelt saa lange som Bægeret, blegblaa eller lila. Forvildet ved Kastrup Molle paa Amager (19). (Tidligere paa Pladsen ved Thorvaldsens Museum)!

\section{bb. Blomsterstilkene efter Afblomstringen nedadbøiede.}

914. II. vulgaris [Trag., Fr. nov. p. 219] (Rundbladet K.) Drej. n. 699 ; Rehb. I. c. fig. 4836 ; H. N. VIrI, 34 ; M. rotundifolia L. (tildeels), H. 742; F. D. 721.

Stangelen opstigende eller fremliggende; Bladene langstilkede, nyreformede, haandlappede, med 5-7, tandet-rundtakkede, Lapper; Yderbogerets Blade linie-lancetformede, kortere end det med Stjernehaar og længere Randhaar beklædte Bager; Kronbladene kileformede, udrandede, 2-3 Gange længere end Bægeret; Smaafrugterne jævne, i Randen afrundede.

Kronbladene lila eller hivide med røde Aarer. 6-9. $\odot$ eller $\odot$. Ved Gjærder, Veje, Rendestene o. s. v. meget alm. 
915. I. borealis [Walln. i Liljebl. Sv. Fl. ed. 3, 374] (Smaablomstret K.) Drej. n. 700; II. rotundifolia L. fl. Suec., Fr. nov. p. 218 ; Rehb. I. c. fig. 4835 ; H. N. VIII, 33; M. pusilla Witb., H. T42; F. D. 1825.

Stangelen fremliggende eller opstigende; Bladene bredt nyreformede, laandlappede med 5-7 korte, saugtakket-rundtakkede Lapper; Yllerbagerets Blade linie-lancetformede, af Længde med det randhaarede Bager; Kronbladene svagt udrandede, af Længde med Bægeret; Smaafrugterne nætformigt rynkede, skarpkantede.

Kronbladene hvide med sragt Anstrog af lila, meget mindre end hos foreg. 6-8. $\odot$.

Ved Strandbredder, paa Diger omkring Byer, ikke sjelden og iagttaget $i$ alle danske Provindser, men forekommer især i Strandegnene.

\section{7de Klasse. Diadelphia (T'oknippede).}

\section{Orden. Hexandria (Sexhannede).}

1. Iunária L. (part.). Bægeret tobladet, affaldende; Kronen uregelm. firebladet, 2 ydre Kronblade, livoraf det ene med Spore, og 2 indre, sammenstødende; Frugten enfrøet, uop springende.

2. Corýdalis DC. Bæger- og Kronblade som foreg., (Bægerbladene ofte 0 ). Frugten en fleerfrøet, i 2 Klapper opspringende Kapsel. (1-2. N. F. Fumariaceæ).

\section{Orden. Octandria (Ottehannede).}

3. Polýgala L. Bægeret fembladet, med 2 indre, større og 3 ydre, mindre Blade; Kronen uregelret; Støvdragerne forneden sammenvosne med Kronbladene; Frugten en torummet Kapsel med enfrøede Rum; Frøene hængende, haarede, med en trelappet Frøhud ved Grunden. (N. F. Polygaleæ). 


\section{Orden. Decandria (Tihannede).}

(Bægeret femtandet eller femfliget, alm. tolæbet; Kronen uregelw. iembladet (Erteblomst): det ørre Blad (Fanen) større, de 2 mellemste indbyrdes ligestore (Vingerne), de to nedre sammenvoxne (Kjølen); Frugten en Bælle; Bladene for det meste sammensatte, med Axelblade ved Grunden. (4-21. N. F. Leguminosæ $\alpha$, Papilionaceæ).

A. Alle Støvtraadene sammenvoxne $\mathrm{i}$ eet Bundt. $(16,2)$.

a. $B æ g$ eret tolæbet.

4. Ulex L. Bægeret til Grunden todeelt, Overlæben utydeligt to-, Underlaben tretandet; 2 Drkblade i Form af et Yderbxger ved Grunden; Griffelen traadformet, opstigende; Bællen opblæst, af Længde med Bægeret. (Bladene enkelte, tornformede, Grene og Smaagrene tornspidsede).

5. Cenista I. Bægerets Overlæbe til Grunden tvedeelt, Underlæben tretandet; Griffelen sylformet, opstigende; Bællen længere end Bægeret. (Bladene enkelte, ikke tornformede).

† 6. Cýtisus L. Bægerets Overlæbe totandet, Underlaben tretandet; Griffelen sylformet, i Spidsen bøiet, med skjævt Ar; Bællen længere end Bægeret. (Bladene trekoblede).

7. Sarothámnus WVimm. Griffelen sneglehuusformigt indrullet, i Spidsen udvidet, med hovedformet Ar, forøvrigt som foreg.

b. $B æ g$ get femdeelt.

8. Ononis L. Bægeret femfliget, vedblivende, ved Frugtmodningen aabent; Bællen siddende eller kortstilket, fremragende udenfor Brgeret. (Bladene erkelte eller trekoblede).

9. Anthýllis L. Bxgeret uregelm. femtandet, vedblivende, opblæst, ved Frugtmodningen lukket; Bællen stilket, indsluttet af Bægeret (Bladene uligefinnede).

B. De 9 Støvtraade sammenvoxne, den tiende fri.

a. Bællen tværdelelig (Ledbælle).

10. Ornithopus L. Blomsterne i Skjærm; Bællen halsbaandformet, indsnøret ved Leddene, Tværrummene enfrøede (Bladene uligefinnede). 
b. Bællen opspringende paalangs eller uopspringende.

aa. Bladene uligefinnede.

11. Onobrýchis Tournef. Bællen enrummet, enfrøet, uopspringende, nætformigt-rynket (Blomsterne i Klase; Bladene mangeparrede).

12. Astrágalus L. Bællen ved den indbøiede Rygsøm ufuldstændigt torummet, fleerfrøet (Blomsterne i Ax eller Hoved; Bladene mangeparrede).

† Phaséolus L. Bællen opspringende, fleerfrøet, enrummet eller indsnøret ved ufuldstændige Skillevægge mellem Frøene; Griffelen sneglehuusformigt snoet (Blomsterne i lilase; Bladene sammensatte af et Par Sidesmaablade og et Endeblad, med Smaaaxelblade ved Grunden).

\section{Bladene ligefinnede.}

13. Vícia L. Girffelen traadformet, noget fladtrykt, mod Spidsen overalt haaret eller paa Yderfladen under Arret skjæghaaret, forøvrigt glat; Bællen med et kortere eller længere Næb paa Grund af den bueformigt opstigende Rygsøm (Bladene oftest mangeparrede, Endebladet omdannet til en Slyngtraad eller Braad).

14. Errum L. Griffelen trind, traadformet, mod Spidsen overalt haaret; Bællen faafrøet, i Spidser afrundet, nden Næb (Endebladet omdannet til en Slyugtraad).

15. Pisum L. Griffelen ved Grunden knæbøiet, paa Yderfladen udbulet, paa Inderfladen trekantet-kjølet; Arret fladtrykt fra Siden, paa Inderfladen haaret; Navlen langagtigoval (Endebladet omdannet til en Slyugtraad; Axelbladene større end Smaabladene).

16. Láthyrus L. (part.). Griffelen bueformigt opstigende eller snoet, oventil fladtrykt fra Ryggen og i Spidsen paa Inderfladen haaret, paa Yderfladen glat; Navlen langagtig-oval (Endebladet omdanuet til en Slyngtraad). 
17. Orobus L. Bladene ende med en kort Braad; Bællen opspringende i snoede Klapper; Navlen linieformet, forøvrigt som foreg.

\section{cc. Bladene trekoblede.}

$\boldsymbol{\alpha}$. Kronen fribladet, affaldende efter Afblomstringen; Bællen læugere end Bægeret.

* Boellen mangefrøet.

18. Lotus L. (part.). Kjølen tilspidset i et Næb; Griffelen knæbøiet-opstigende, overalt traadformet og tyndere end Arret; Bællen trind, linieformet, ret, opspringende $\mathbf{i}$ snoede Klapper. (Blomsterne i Hoved eller Skjærm).

19. Tetragonólobus Scop. Griffelen bueformigt opstigende, i Spidsen under Arret udvidet; Bællen firekantet, paa Kanterne vinget, forøvrigt som foreg. (Blomsterne enlige eller parviis).

20. Melicágo L. Kjølen budt; Griffelen tyndere end Arret; Bællen seglformet eller sneglehuusformigt snoet, kun opspringende i den ene Søm eller uopspringende. (Blomsterne i Hoved eller kort Klase).

21. Trigonella L. Kjølen budt; Griffelen traadformet; Bællen fladtrykt, mere eller mindre bøiet. (Blomsterne enlige eller 2-3 samlede; hos udenlandske Arter ofte i Skjærm eller Hoved).

\section{** Ballen faafrøet.}

22. Melilótus Tournef. Kjølen budt; Bællen rundagtig: ægformet, 1-2-frøet. (Blomsterne i Klase).

(Medicago lupulina L. - Ballerne alm. enfrøede).

$\boldsymbol{\beta}$. Kronen sambladet, vedblivende $\mathrm{i}$ visnet Tilstand efter Afblomstringen; Bællen kortere end Bægeret.

23. Trifólium L. Kronens nedre Deel sambladet og sammenvoxet med Støvtraadenes Bundt; Bællen faafrøet. (Blomsterne i Hoved eller Skjærm). 


\section{Ilexandria.}

\section{Fumaria. Jordrog.}

916. F. capreolata L. (Kilattrende J.) H. 750 ; Drej. n. 702; Hammar Monogr. Fum. p. 24 tab. V; F. D. 2359; Rehb. ic. f. germ. III, tab. 4, fig. 4456 ; H. N. XIII, 47.

Stcengelen klattrende ved Hjælp af de snoede Bladstilke; Bladene finnede med trekoblede Smaablade; Bismaabladene dybt tredeelte, med kileformede, 2-3-lappede Afsnit, Lapperne ovale; Smaablomsterstilkene efter Afblomstringen bueformigt tilbagebøiede; Bcegerbladene brede, ægformede, tandede, halvt saa lange som Kronen; Frugterne kuglerunde, jævne.

Planten blaagraa. Var. med opret-aaljne Blomsterstilke, Kronbladene hvide eller lovidgule, i Spidsen mørkrøde. 6-9. $\odot$.

Paa dyrkede Marker og ved Gjærder, sjelden: J. i Mængde ved Horsens i Korn- og Kartoffelmarker (Dr. (?) nu forsvunden (2); $\boldsymbol{S} l$. Haveukrud ved Gram (20), Steengjærder ved Aschan pr. Egernførde, Wyk paa Folır (16); Meen (H.). ${ }^{*}$

917. F. officinalis L. (Læge-J.) H. 749; Drej. n. 703; Hamm. l. e. p. 1, tab. I; F. D. 940 ; Rehb. 1. e. tab. 3 , fig. 4454 .

Stcongelen opret (sjeldnere svag, med snoede Bladstilke); Bladene som foreg., men med bredere eller smalere lancetformede, spidse Lapper; Blomsterstilkene efter Afblomstringen opret-aabne; Bagerbladene agformede, tilspidsede, 1/3 af Kronens Længde, bredere end Blomsterstilkene; Frugten kugleformet, i Spidsen indtrykt, næsten omvendt-nyreformet, knudret-rynket.

Planten lidet blaagraa. Kronbladene mindre end hos foreg., rosenrøde, i Spidseu mørkrøde, de ydre med grøn Midtnerve. 5-8. $\odot$. Var. i Henseende til Blomstens Størrelse og Farve, Bagerbladene. (hele eller tandede), Lappernes Form 0. s. v., og desuden:

$\beta$, minor Hamm. l. c. p. 3 (F. offic. $\beta$, tenuiflora $1 \mathrm{Udg}$., ikke Fr.). Lapperne budte, Klaserne faablomstrede, med mindre Blomster; Planten mere blaagraa.

$\gamma$, floribunda Hamm. (F. officinalis $\beta$, [densiflora Parl.). Bladfligene sualere, Klaserne tætblomstrede; Blomsterne mørkere. 
Paa dyrket Jord i Have og Mark alm. - $\beta$, især red Gjærder og paa skyggefulde Steder. $\gamma$, som ved Dyrkningsfors $9 g \mathrm{i}$ bot. Have er gaaet tilbage til Hovedarten, er funden i Fye $n$ red Veistrup (19).

918. F. Yaillantii [Lois. Not. p. 102] (Smalfiget J.) Hamm. I. c. p. 8, tab. II; Rchb. l. c. tab. 1, fig. 4452 ; H. N. III, 25.

Stcengelen svag, meget grenet, med oprette eller klattrende Grene; Bladene som foreg., men Afsnittene 2-3-Aligede, med linieformede, spidse Flige; Bagerbladene meget smaae, mange Gange kortere end Kronen, smalere end de efter Afblomstringen oprette eller udspærrede Smaablomsterstilke; Frugten kugleformet, i yngre Tilstand med en svag Spids, knudret-rynket.

Hele Planten blaagraa; Kronbladene hvide eller blegrøde, i Spidsen mørkrøde, mindre end hos foreg. 6-8. $\odot$.

Paa dyrkede Marker, meget sjelden: $J$. mellem Sæden paa Aagaards Kalkbakker (16).

\section{Corydalis. Laerkespore.}

a. Capnoides DC. Rodstok 0; Stæugelen mangebladet; Klaserne modsatte Bladene; 2 Frøblade.

919. C. claviculata [DC. Fl. fr. 4, 638] (Klattrende L.) Rchb. l. c. tab. 5, fig. 4457 ; H. N. XIII, 46; Fumaria L.; H. 751 ; F. D. 340 .

Stangelen svag, klattrende; Bladene finnede; Smaabladene alm. 2-3-koblede med elliptiske eller ovale, heelrandede $B$ smaablade, de yderste omdannede til Slyngtraade; Dakbladene æg-lancetformede, lidet længere end de meget korte Smaablomsterstille; Griffelen affaldende.

Bladene meget tynde, paa Underfaden blaagraae. Kronerne smaae, hvide eller bleggule. 6-7. $\odot$.

Mellem Buske, især paa fugtig, tørvholdig Grund: $\boldsymbol{S} \boldsymbol{j}$. Skamstrup (Drej. Herb.), V. for Helsingør mellem Rubus (21)! Klosterriis ved Hornbak! Horserød Hegn (15), Skorhusene i Gribs Skov nærved Esron! Moen ved Askeby (Olufsen); i Fyen ikke sjelden; paa Halvoens Ostkyst sporadisk: Steenalt Skov (H.), Nebbegaard ved Veile Fjord! Christiansfeld (H.), mellem Drey og Lyksborg (16). 궁 
b. Bulbocapnos Bernh. Rodstokkenknollet; Stængelen faabladet; Klasen endestillet; 1 Frøblad.

aa. Knollen heel, skjaldakt, med knippestillede Rodtravler; ingen Rodblade, men et skedeformet Blad uden Plade ovenfor

Stangelens Basis.

920. C. fabacea [Pers. Syn. 2, p. 269] (Liden L.) H. 748; Drej. n. 705; T. Fries bot. not. 1854 p. 40 ; F. D. 1394 ; Rebb. 1. c. tab. 7, fig. 4460 ; H. N. 30 ; Fumaria bulbosa $\beta$, L.

Bladene dobbelt-trekoblede; Bismaabladene 2-3-fligede eller -snitdeelte, med kort braadspidsede eller næsten spidse Flige; Klasen kort, faa-, men txtblonstret, for og efter Blomstringen nikkende; Dakbladene ægforınet-elliptiske, bele, kortere end Blomsterne; Sporen næsten ret; Griffelen under Blomstringen opstigende; Kapselen æg-lancetformet, 3 Gange længere end de oprette Smaablomsterstille.

2-6" høi. Var. (men sjeldent) med indskaarne Dækblade; Kronbladene violetrode. 4. 4 .

I Lovskove, alm. udbredt. [*

921. C. pumila [Host, Fl. austr. 2, p. 304] (Kortstilket L.) T. Fr. I. c. p. 40 ; Rehb. l. c. fig. 4461 ; H. N. VIII, 26 ; C. Halleri H. 749 ; Drej. n. 706 ; F. D. 1224 ; C. Lo. belii Tausch.

Bladene som hos foreg., men med bredere og mere budte Flige; Klasen tæt, mangeblomstret, opret eller tilsidst nikkende; Dokbladene bredt-kileformede, fingerdeelte, af Lxngde med eller længere end Blomsterne; Bregerbladene 0; Sporen i Spidsen lidet bøiet; det sporeløse ydre Kronblad uden Pukkel ved Grunden; Griffelen opstigende; Kapselen $x g$-lancetformet, 3 Gange længere end de tilsidst udadbøiede Smanblomsterstilke.

3-8" høi. De ydre Kronblade rodviolette, de indre livide eller bleggule. 4-5 (idetmindste 8 Dage senere end foreg.). 4 .

$\beta$, latiloba! (C. grandifolia Mortens. mser.) Smaabladene og Dækbladenes Flige meget brede, I)xkbladene langere end Blomsterne; det sporelose ydre Kronblad pulilet ved Grunden. 
I Krat og Løvskove med foreg., men sjeldnere: $\boldsymbol{S}$. Egebæksvang (21)! Charlottenlund, Fortunen, Sorgenfri! Bidstrupgaard (20) Dragerup Skov ved Holbæk (15), Asnæs (Smith!); F. Hofmansgave: (H.); J. Haraldslund (1), Ulsund ved Ringkjøbing (16); $S l$. Haderslev, Nyvark (16); L oll. ved Nakskov (Kisky); Bornh. Almindingen (20), Almegaard (Hoff), Seiersgaard ved Rønne (Zahrtmann), Ypernestad Fiskerleie, Lindholmsklipperne (Baagøe). $\quad \boldsymbol{\beta}, \boldsymbol{F}$ alst. ved Abelvig og. Grønsund (14). I*

Anm. I Egebæksvang ved Helsingør har jeg fundet en Form forskjellig fra foreg. ved Blomsterstilkene over halvt saa lange som Kapselen. Om denne horer til C. laxa Fr. (mant. 3, 86, T. Fr. 1. c. p. 39 , H. N. VIII, 25), som beskrives med tætblomstret, nikkende Klase, Drkblade af Blomsternes Længde, Blomsterstilkene næsten saa lange som Kapselen, Sporen ret, Griffelen ikke kuæbøiet), kan jeg formedelst Mangel af Blomster-Expl. ikke afgjøre.

922. C. solida [Sm. Engl. F]. 3, p. 353] (Langstilket L.) Fr. mant. 3 , 85 ; S. veg. Sc. 145 ; T. Fr. 1. c. p. 39 ; H. N. XI, 34 ; C. digitata Pers., Rebb. l. c. fig. 4462 ; Fumaria bulbosa $\gamma$, L. sp. $(\alpha$, Fl. Suec.); Bulbocapnos Haller Drej. Bot. not. 1842 p. 34 .

Bladene som hos foreg., men med smalere Flige; Klasen opret, forlænget, mangeblomstret; Dakbladene dybt fingerdeelte, kortere end Blomsterne; Bogerbladene 0 eller tidligt affaldende; Sporen i Spidsen bøiet; det sporeløse ydre Kronblad i Spidsen udrandet, med en skarp Kjøl paa Ryggen, som naaer heelt ud til Indskjæringen, ved Grunden puklet; Griffelen fra en knæbøiet Basis opstigende; Smaablomsterstilkene fine, tilsidst udbøiede, af Længde med den lancetformede Kapsel.

$3-8$ " høi. Kronbladene violet-røde, de indre hvide med rode Striber. 4 (tidligere end foreg.). 4.

I Kratskove meget sjelden: $S l$. Gram forvildet (A. Rafn)! Husum, Tønning (F. Müll.). ॠ.

bb. Knollen tilsidst huul, med spredte Rodtravler, uden Skjol; intet skedeformet Blad, men 2-flere fuldt udviklede Blade frot Rodstokken.

923. C. cava [Schweigg. \& Kört. Fl. erlang. 2, p. 44] (Huulrodet L.) Drej. n. 704; H. N. I, 33; C. bulbosa Pers. H. 747 ; Rchb. 1. c. tab. 8, fig. 4463; Fumaria bulbosa L. Sp. $(\gamma$, Fl. Suec. $)$, F. D. 605. 
Stangelbladene som hos de foregarende; Rodbladene langstilkede; Klasen forlænget, under og efter Afblomstringen opret; Dakbladene elliptiske eller ægformede, hele, kortere end Blomsterne; Bagerbladene meget smaae, tidligt affaldende; Sporen i Spidsen tyk, buekruinmet, det sporeløse ydre Kronblad i Spidseu udrandet, med en skarp Kjøl paa Ryggen, som ikke naaer til Indskjæringen; Griffelen opstigende; Smaablomsterstillkene 2-3 Gange kortere end den modne Kapsel.

1/2-1' høi. Kronblidene røde, rødviolette eller hvide. 5. 4.

I Lørskove paa Iøs Muldjord, funden i alle Provindser, men i mange Egne ikke alm., hyppigst i Sydsjælland, Fyen og paa de sydlige Øer.

\section{Octandria.}

\section{Polygala. Malkurt.}

924. P. vulgaris L. (Almindelig M.) H. 751; Drej. n. 707 ; F. D. 516 ; Rebb. ic. crit. I, 52-53; ie. fl. germ. VIII, tab. 1344 fig. 1 ; H. N. XIV, 32 b.

De nedre Blade elliptiske, de фvre længere, laneetformede; Klaserne endestillede, mangeblomstrede; Dokbladene 3 (det ene større), affaldende ved Afblomstringen; de 2 storre Bagerblade elliptiske, trenervede, med i Spidsen sammenstødende Nerver, Sidenerverue udadtil forgrenede, med sammenløbende Grene; Kapselen omvendt.hjerteformet; kortere og oftest smalere end de storre Bægerblade.

6-7. 4. Var. i Henseende til Blomsternes Storrelse og Farve (blaa, røde og hvide), Bægerbladenes Længde og Brede i Forhold til Kapselen o.s. v. Den meest afvigende Form er:

* oxyptera (Rchb. ic. crit. I, 47-49; ic. fl. germ. I. e. fig. 1. Stanglerne talrige, nedliggende; Klasen ensidig; de storre Bagerblade smalere end Kapselen.

Hovedarten forekommer meget alm. paa udyrkede Græsmarker, Bakker og solaabne Steder i Skove; * paa Lynglieder og Overdrev ikke sjelden, især paa Halvøen. 
925. P. depressa [Wenderoth Schrift. d. Ges. z. Marb. p. 1, t. 1] (Spæd M.) Drej. i Krøy. Tidsskr. I, p. 226: Rehb. ic. fl. germ. XVIII, tab. 1347, fig. 1; P. serpyllacea Whe.; P. vulgaris * depressa Fr. Mant. 2; Lge. Haandb. 1 Udg. p. 405.

Stanglerne talrige, fine, nedliggende, med oftest modsatte Grene; de nedre Blade modsatte, bredt elliptiske eller omvendtægformede; Klaserne faa-(4-6-) blomstrede; fra de ovre Bladhjørner udgaae Blomstergrene, der naae meget bøiere end den endestillede Klase (som derved bliver tilsyneladende sidestillet), forovrigt som foreg.

Ved de lavere og finere Stængler, frisk grønne, noget kjødfulde Blade og faae, men store, smukt blaae Blomster let kjendelig fra foreg. 7-9. 4 .

I Lyngmoser mellem Sphagnum, sjeldnere end foreg. og kun bemærket paa Halvoen: J. Vuust i V. Hanherred (Gronlund)! Møgelkjær ved Viborg (Feddersen)! ved Eveldrup (Dr.)! Thorsted pr. Ringkjøbing! Sl. Gram (8)! Marieskoven ved Flensborg!

926. P. amara L. (Bitter M.) H. 752 ; Gren. \& Godr. A. Fr. I, p. 196; F. D. 1169 ; H. N. III, 14; P. uliginosa Rehb. ic. crit. I, $40-41$; ic. fl. germ. XVIII, tab. 1348, fig. 2-3.

Rodbladene rosetteformigt samlede, omvendt-ægformede, afrundede, Stangelbladene elliptisk-omvendt-ægformede; Klaserne endestillede; Dakbladene som hos foreg.; de 2 større Bagerblade elliptiske eller omvendt-ægformede, trenervede, med neppe sammenstødende Nerver, Sidenerverne udadtil forgrenede, med ikke sammenløbende Grene; Kapselen omvendt-lijerteformet, bredere, men lidet kortere end eller af Længde med de større Bægerblade.

Planten lavere, Kronen mindre end hos de foreg., mørkeblaa, sjeldnere blegt mælkeblaa. Bladene af bitter Smag (dette er dog kun i ringe Grad Tilfældet med den sjællandske Plante). 5-6. य.

Paa Enge og Kalkbakker, sjelden: $\boldsymbol{S} \boldsymbol{j}$. Engen V. for Leersøen (mellem Uttersløv Mølle og Lygten)! J. Silstrup ved Thisted (Jacobsen)! Blegkilde (1I. Valıl), Dybdal og Klarupgaard ved Aalborg (Dr.). I 


\section{Decandria.}

\section{Ulex. Tornblad.}

927. U. europsus L. (Opret T.) H. 756; Drej. n. 708; F. D. 608 .

Grenene udspærrede, stikkende; Bladene naaleformede, furede, endende $\mathrm{i}$ en stikkende Torn; Blomsterstilkene kortere end Bægeret, med 1 smalere Drkblad ved Grunden og 2 bredere, ægformede Dækblade foroven; Vingerne længere end Kjolen, lidet kortere end Fanen; Bageret og Ballen tilligemed Blomsterstilke og Grene uldhaarede.

4-7' høi Busk. Kronerne gule, langs Kjølens Rand silkehaarede, forevrigt glatte. 10-11. Ђ.

Ved Gjærder, især paa sandig Jordbund, sporadisk og ikke alm.: Bornh. ved Rønne Citadel! Seiersgaard ved Rønne (Hjorth); $\mathbf{S} j$. Fredenshorg (Jørg.), Charlottenlund (Dr.); M Falst ved Bøtø; Loll. ved Taars pr. Saxkjøbing (5); F. Gribsvad! Minnendal! Assens (H ), Hindsgavl (28); J. Thaarupgaard ved Viborg (Drej. Herb.), Steenalt Skov (H.), Randers, Mattrup (16), Rathlousdal (Jørg), Houer! Veile (H.), Bredstrup (12), N. for Hjerting (16); Als ved Augustenborg (H.); $S$ l. Haderslev (16), Hgibjerg ved Arrild (Fabr.-Mïller), Aabenraa (Grønlnnd), Egernførde, Friederichsruhe ved Rendsborg (16), Mildsted red Husum (F. Müll.), Sylt (F. D.), Føhr (H.). Paa flere af disse Steder synes den oprindelig at være plantet som Hegn. \#

\section{Genista. Visse.}

a. Stængelen tornet af tilspidsede Grene (Blomsterne udvikles af Biknopper ved Siden á tornede Grene).

928. G. anglica L. (Engelsk V.) H. 755 ; F. D. 619 ; H. N. XIII, 63 .

Bladene lancetformede, tilligemed Grenene glatte; Axelblade 0 ; Dakbladene bladagtige, længere end Blomsterstilkene; Ballerne lancetformede, opblæst-trinde, næsten valseformede, glatte, med 6-10 Frøe.

. Kronbladene gule. 5-7. 々. 
Paa Lyngbakker og i Hedemoser: paa Halvoen*) hyppig; i Fyen ved Hindsgavl (12), Middelfart (18), Verringe, Vissenberg (H.). Paa de øvrige Øer ikke bemærket. 周

929. G. germanica L. (Tydsk V.) H. 755 ; F. D. 1826 ; H. N. XIII, 64.

Bladene oval-lancetformede, tilligemed Grenene baarede af udstaaende Haar; Axelblade 0; Dakbladene sylformede, kortere end Blomsterstilkene; Ballerne rudeformet-elliptiske, fladtrykte, uldhaarede, 3 -5-frøede.

Kronbladene gule. 6-7, h.

Paa Lyngheder, sjelden og kun funden paa Halvøen: J. Nørholm (H.), Tinnet og Vonge i $\emptyset$. Nykirke Sogn! Sl. Oxenvad (12). F

b. Stænglernetornløse (Blomsterne eller de blomsterbarende Grene udvikles af Hovedknoppen i Bladhjørnerne).

930. G. tinctoria L. (Farve-V.) H. 754; F. D. 526; H. N. V, 46.

Stangelen opret, med opstigende Grene; Bladene lancetformede, glatte, i Randen svagt haarede; flade; Axelbladene smaae, sylformede; Blomsterne i Klaser i Spidsen af de enaarige Grene; Kronbladene og Ballen glatte.

Kronbladene gule. 7-8, $\boldsymbol{h}$.

Paa Lyngheder, Bakker, Græsmarker, ved Veie : alm. paa $\boldsymbol{H}$ alvoen; i Fyen ved Hindsgavl, Vissenberg (H.)! Mangler paa de פvrige Øer. $¥$

931. G. pilosa L. (Haaret V.) H. 754; F. D. 1225; H. N. I, 46.

Stanglerne fremliggende eller opstigende, knudrede; Bladene omvendt-ægformede, budte, med indrullet Rand, tilligemed Grenene tiltrykt-silkehaarede; Axelbladene smaae, tandformede; Blomsterne enlige eller $2-3$ samlede, omgivne af et Bladknippe, spredte eller $\mathrm{i}$ afbrudte Klaser langs opad de toaarige Grene; Fane og Kjol tilligemed Bællen silkehaarede.

*) Hverken denne eller de øvrige Arter af Genista bemærket i Vendsyssel (12). 
Kronbladene gule. 5-7.

Lyngheder og sandige Bakker: paa Halvøen ikke sjelden mod 7. og S. Mangler paa Øerne.

\section{Cytisus. Guldregn.}

† 932. C. Laburum L. (Almindelig G.) Jacq. Fl. austr. tab. 380 .

Bladene langstilkede, trekoblede; Smaabladene elliptiske, paa Underfaden tiltrykt-silkehaarede; Blomsterne i mangeblomstrede, nedhængende Klaser.

Træ med glat Bark. Kronbladene gule med mørkbrune Striber paa Fanen. 5-6. $\zeta$.

Dyrkes alm. i Haver og stundom i Hegn, forekommer hist og her forvildet, f. Ex. Sj. Hornbæks Plantage! Frederiksdals Skov! Falst. Nykjobing (Koch).

\section{Sarothamuus. Gyvel.}

933. S. scoparius [Koch Syn. I, 152] (Kost-G.) Drej. n. 709; Spartium scoparium L., H. 752; F. D. 313; Sarothamnus vulgaris Winm.

Stangelen opret, med riisformede, stive, kantede Grene; Bladene trekoblede, (paa de yngre Grene enkelte), med lancetformede, paa Underfladen tiltrykt-silkehaarede Smaablade; Blomsterne 1-2 i Bladhjørnerne; Ballerne fladtrykte, randhaarede.

2-3' høi, storblomstret, Kronbladene mørkgule. 5-6.

Paa Bakker og Lyngheder, alm. paa Halvoen S. for Limfjorden; paa Øerne sporadisk: $\boldsymbol{F}$. Fuaborg (H.); Falst. Bregninge (14), Korselitze, Lindeskoven, Bøtø Fang (Koch); $\mathbf{S} j$. omkring Helsingør alm.! Fredensborg (Jørg.), Smidstrup (15), Farum (1), Strandveien ved Charlottenlund! Mo ens Lilleklint!

\section{Ononis. Krageklo.}

934. 0. campestris [Koch \& Ziz Cat. pal. 22] (StrandK.) Fr. S. Veg. Sc. 162 ; H. N. X, 44; O. spinosa $\beta, L$. (tildeels), Koch Syn. II, 173; L. Herb. 1X, 166; O. spin. $\alpha$, glomerata Schum. n. 605; H. 757; O. procurrens Drej. n. 711 (ifølge Voxest. og Beskr. for en Deel, ikke Wallr.). 
Strengelen opret eller opstigende, tilligemed de tornede Grene ensidigt kirtlet-duunharet; Bladene enkelte eller trekoblede; Smaabladene linie- eller lancetformet-ovale, skarpt saugtakkede, næsten glatte; Axelbladene æg-lancetformede; Blonusterne enlige i Bladhjornerne, de ovre samlede til en Kla:e; Bcellerne af Længde med eller længere end Bægeret; Frøene 2-4, rupunkterede.

Kronerne rosenrøde med hvid Kjøl. 7-9. $\zeta_{\text {. }}$.

Paa Strandenge og Marker (hos os kun funden i Nærheden af Havet); i Fgnene omkring Ostersøen ikke sjelden og især alm. paa de sydlige Oer fra $\boldsymbol{F}$ alster til $\boldsymbol{A} \boldsymbol{r} \boldsymbol{\theta}$ ! Ved Kysterne af Vesterhavet og Bælterne sporadisk: $S$ l. Husum (16); F. Kjerteminde (9); $\boldsymbol{S}$ j. Reers (11), Kalkbrænderiet, Amager, Flaskekroen! I d onordligere Egne (omkring Kattrgattet) ikke bemærket.

Anm. Det linneiske Navn O. spinosa er tvivlsomt og for størsteDelen at henføre til følg. Art, hvorfor jeg med Fries har optıget det ældre Kochske Navn, (for vor Floras Vedkommende vilde Navnet O. littoralis være meest passende). Drej. har (fl. exc. p. 235) sammenblandet Charactererne for denne og følg. Art, hvorfor hans Beskrivelse ikke kan benyttes.

935. 0. repens L. (Mark-K.) O. arvensis (L., tildeels), Sm. Engl. Fl.; Fr. S. Veg. Se. p. 162; H. N. X, 46; O. spinosa L. (tildeels), H. 757; Drej. n. 710 (tildeels); F. D. 783 ? O. procurrens Wallr.

Rodstokken krybende; Stonglerne nedliggende eller opstigende, alsidigt haarede af klæbrige Haar; Grenene oftest tornede; Bladene enkelte eller de nedre trekoblede, Smaabladene bredt ovale, saugtakkede, kirtelhaarede, især paa Underfladen; Axelbladene bredt ægformede; Blomsterne enlige i Bladhjørnerne; Ballerne kortere end Bægeret, 2-4-frøede; Frøene som hos foreg.

Kronerne som foreg. 7-8. Ђ马. En meget foranderlig Flante, dens vigtigste Former ere:

$\beta$, mitis (O. spinosa $\alpha$, L. Sp. II; H. N. X, 45). Grenene uden Torne, Blomsterne ofte parviis samlede.

$\gamma$, spinosissima! Tornene stærke, ofte grenede; Bladenerundagtigt-ovale, tilligemed Blomsterne mindre end bos $\alpha$. 
Ved Gjærder, paa Heder og saavel dyrkede som udyrkede Marker, alm. udbredt i Danmerk. $\boldsymbol{\beta}$, med Hovedarten, sjeldnere; $\boldsymbol{\gamma}$, paa Sandbakker: J. Kollerup N. V. for Aarhuus! $\mathbf{S} j$. Beks Kro ved Tiisso! B ornh. Hammershuus (Hamann), Sandvig!

936. 0. hírcina [Jacq. Hort. vind. I, 40, t. 93] (Stinkende K.) Drej. n. 712 ; F. D. 1584 ; H. N. X, 47; O. arvensis Retz. (Linn. herb.); H. 758.

Stcrngelen opret eller opstigende, tilligemed de tornløse Grene alsidigt klæbrig-laaden; Bladene trekoblede, Smaabladene elliptisk-ovale, saugtakkede; Axelbladene ægformede; Blomsterne parviis i Bladhjørnerne, samlede til Klaser i Spidsen af Stængelen og de ovre Grene; Ballen kortere end Bægeret, 4-5frøet, Frøene som hos foreg.

Større $\mathrm{i}$ alle Dele end de foreg. Hele Planten stærkt klæbrighaaret, af ubehagelig Lugt. Kronerne som hos foreg. Var. med enkelte Blade. 7. h.

Paa hoie Enge og ved Gjærder, funden $i$ alle Provindser, men i mange Egne sporadisk og ikke alm. Hyppig paa Bornh.! i Lollands vestlige Deel! og i Jyll. N. for Liimfjorden. |**

\section{Anthyllis. Rundballe.}

937. A. vulneraria L. (Guul R.) H. 758; Drej. n. 713 ; F. D. 988 ; H. N. X, 48 ; L. Herb. III, 57.

Bladene uligefinnede, Smaabladene linieformet-ovale eller elliptiske, Endebladet større end Sidebladene; Blomsterne i 2 tæt samlede Hoveder $\mathrm{i}$ Spidsen af Stængelen, omgivne af fingerdeelte Diekblade.

4-10" høi. $\frac{5}{2}-7$. 4. Stænglerne og Bladene paa Underfladen. tiltrykt-silkehaarede; Bægeret filtet, var. hvidt, næsten sølvglindsende og (især i Spidsen) rødviolet; Kronerne lysere eller mørkere gule, var.

$\beta$, maritima (A. maritima Sehweigg.) Høiere, mere grenet og silkehaaret, med $3-4$ Blade paa Stæugelen og bleggule Blomster.

$\gamma$, rubriflora DC. H. N. XIV, 57. Kronerne mørkt høirøde, Stænglerne alm. lavere og mere udstrakte.

Paa tørre, sandige og kalkholdige Marker og Bakker, ved Veie o. s. จ. alm. $\beta$, J. Klitterne ved Fjaltring! $S l$. Klitterne ved Eider- 
sted (F. Müll.); $\gamma$, Bornh. langs Østkysten fra Bobbe-Aaen til Randkløveskaar $(20)$ !

\section{Ornithopus. Fugleklo.}

938. 0. perprsillus L. (Liden F.) H. 772 ; Drej. n. 735; F. D. $730 ;$ H. N. II, 49 ; L. Herb. II, 40.

Mangestænglet; Stanglerne udstrakte ; Bladene 6-12parrede med ovale Smaablade; Blomsterstilkene længere end Bladene, 2-4-blomstrede; Ledballerne seglformigt krummede, Ledene stribede paalangs.

3-10" høi; Stænglerne fine; Kronerne smaae, hvide med røde Striber. 6-7. $\odot$.

Paa tørre, sandige Marker, alm. paa Halveen; i Fyen hist og her i Bakkepartiet fra Middelfart til Svendborg; Thorseng ved Bregninge! Langel. mellem Steengade og Tranekjær (12); længere mod $\emptyset$. sjelden: $\boldsymbol{S} j$. Munkebjergby (Lund), Præstø (H.).

\section{Onobrychis. Esparsette.}

† 939. O. satira [Lam. Fl. fr. 2, p. 652] (Foder-E.) Drej. p. 242 ; Hedysarum Onobrychis L., H. 773; F. D. 2243.

Bladene mangeparrede, med elliptisk-ovale eller lancetformede, braadspidsede Smaablade; Axclbladene hindeagtige, sammenvoxne og modsatte Bladet, med ægformede, sylspidsede Flige; Blonsterne i kilaser; Bagerroret kort, Bægertænderne sylformede (den nedre kortere end de øvrige), længere end Kronens Vinger; Ballen omvendt-ægformet, med kjølformet, tornet-tandet Rygsøm.

$1-2^{\prime}$ høi. Kronerne rosenrøde med mørkere Striber. 6-7. 4.

Har stundom været dyrket som Fodervæxt, og er derfra forvildet, f. Ex. $\boldsymbol{S}$ j. Kalundborg, Amager (H.), Stevns Klint ved Mandehoved (9); Moens Klint S. for Graaryg (Lütken); Falst. Næsgaurd (Koch); L oll. Vesterborg (Nielsen); Sl. Egernforde (20). $\$$

\section{Astragalus. Astragel.}

940. A. Janicus [Retz. Obs. 2, p. 41] (Dansk A.) A. hypoglottis H. 777; Drej. n. 734; Lge. Haandb. 1 Udg. Nr. 903 ; H. N. XI, 49; L. Herb. I, 15 (ikke L.); A. arenarius F. D. 614 . 
Rodstokken grenet, med udstrakte eller opstigende Stangler; Bladene 8-12-parrede, Smaabladene paa de nedre Blade ægformet-ovale, udrandede, paa de фvre lancetformede; Axelbladene forneden (omtrent til Midten) sammenvoxne og modsatte Bladet; Blomsterstilken længere end det stottende Blad, oventil tilligemed Dakbladene og Bageret tiltrykt-haarede af sorte Haar; Bællerne æg-hjerteformede, langhaarede, rette og stilkede ved en kort Frugtholder, som under Blomstringen er halvt saa lang som Frugtknuden.

Stænglerne 2-6" lange. Kronen blaa eller violet. 6-7. 4 .

Paa Strandenge, Marker og Bakker, især i Nærheden af Havet: i $S j$. hist og her mod $N$. ng hyppigst omkring Isefjorden fra Roeskilde til Odsherred! i Sydsjell. og de andre Provindser sparsom: $\boldsymbol{F}$. Hindsholm, Hals ved Hofmansgave, Munkebo Bakke (H.)! J. Houer red Veile (10), Fjedsted Bakker ved Ribe (H.). 用

Ann. Den hidtil almindelige Mening, at A. danicus Retz. skulde vare synonym med $A$. hypoglottis L. kan jeg ikke tiltræde. Den linnéiske A. hypoglottis beskrives nemlig "leguminibus replicatis compressis, acumine reflexo" og siges at ligne meget $A$. prentaglottis, hvilket aldeles ikke passer paa vor Plante. Den angives desuden kun fra Spanien, men A. danicus, som voxer i England, Danmark og enkelte Egne af Tydskland, mangler i Frankerig og er efter alle de mig bekjendte Data ikke funden i Spanien. Dersom altsaa denne Plante ikke har været nkjendt af Linné, turde den snarere af ham være indbefattet under $A$. arenarius, idet han angiver denne fra England, hvor den (efter Bab.) ikke findes, og desuden citerer som synonym Raj. Angl. t. 12 f. 3 , der aldeles utvivlsomt fremstiller A. danicus.

† 941. A. Cicer L. (Rundbællet A.) Jacq. Fl. austr. t. 251 ; L. Herb. 1X, 168.

Stonglerne opstigende; Bladene 10-16-parrede, med lancetformet-ovale, kort braadspidsede Smaablade; Axelbladene frie, lancetformet-sylspidsede eller de øvre forneden sammenvoxne og modsatte Bladet; Blomsterstilken (kortere end det tilsvarende Blad) tilligemed Dakblade og Bager tiltrykthaarede af sorte Haar; Ballerne rette, opblæste, æg-bjerteformede, sorthaarede, næsten stilkløse; Frugtholderen meget kort eller 0.

$1-1^{1} / 2^{\prime}$ hgi. Kronerne bleggule. 6-7. 4 .

Paa Kjøbenharns Glacis mellem Nørre- og Vester-Port ved Teglgaardsbroen (26)! formodenlig forvildet. 同 
942. A. glycyphyllos L. (Sødbladet A.) H. 775; Drejn. 733 ; F. D. 1108.

Stconglerne udstrakte eller opstigende; Bladene 5-6-parrede, med rundagtigt-ovale, budte Smaablade; Axclbladene frie, ægformede, tilspidsede; Blomsterstilken glat, kortere end det støttende Blad; Bollerne linieformede, i Gjennemsnit trekantede, glatte, bueformigt krummede, tilsidst sammenslyngede, befæstede til en Frugtholder, som under Blomstringen er $1 / 6$ af Frugtknudens Længde.

Planten næsten glat, $1 \frac{1}{2}-3^{\prime}$ høi. Bladene have en bitters $\phi d$ Smag, omtrent som Lakrits. Kronerne skidengule. 6-7. 4 .

I aabne Skove og Krat, ved Gjæerder og Randen af Græsmarker, alm.

\section{† Phaseolus. Bonne.}

$\dagger$ Ph. multiflorus [Willd. Sp. 3, p. 1030] (Pralbønne).

Stangelen slyngende; Smaabladene ægformede; Blomsterstilkene længere end Bladene; Ballerne nedhæugende, seglformede, rue.

Var. med høirøde og hvide Kroner. Frøene violette med sortagtige Pletter. 7-8. $\odot$.

Dyrkes i Haver.

$\dagger$ Ph. vulgaris [Savi Mem. 3, p. 14] (Almindelig B.).

Stcrngelen lidet slyngende; Smaabladene ægformede; Blomsterstilkene kortere end Bladene; Bcellerne nedhængende, rette, næsten glatte.

Kronerne hvide eller lila. Frøene mindre end hos foreg., var. i forskjellige Farver. 7-8. Var.

$\beta$, nanus (Ph. nanus L.). Stængelen lav, ikke slyngende. Dyrkes i Haver og paa Marker i flere Afarter.

$\dagger$ Ph. compressus [DC. Prodr. II, 392] (Snittebønne).

Stongelen slyngende; Bcellerne fladtrykte; Froene hvide, større og mere fladtrykte end hos foreg., forøvrigt som denne.

Kronerne hvide. 7-8. $\odot$.

Dyrkes alm. i Haver. 


\section{Vicia. Vikke.}

a. Ervilia. Griffelen fladtrykt fra Ryggen, i Spidsen svagt men alsidigt haret.

aa. Axelbladene halvt piil- eller spydformede, nosten heelrandede.

943. V. Orobus [DC. Fl. fr. 5, p. 577] (Lyng-V.) Drej. n. 742 ; H. N. VII, 41; Orobns silvaticus L., H. 763; Vicia cassubica F. D. 98.

Rodstokken kort, uden Udløbere; Stconglerne oprette eller opstigende; Bladene mangeparrede, endende med en kort Braad; Smaabladene æg-lancetformede, braadspidsede; Blomsterstilken (tilligemed Klāsen) lidet længere end det støttende Blad; Ballerne lancetformede, 3-6-frøede, graabrune.

Hele Planten haaret. Kronerne hvide med rødviolette Aarer. 6-7. ข.

Paa Lyngbakker og i Kratskove', især i Hedeegne: i Jyll. hist og her, men ikke alm.; $S l$. Kolsnap (Gronlund), Froslev Molle, Slesvig (16); Sj. Roeskilde, Brede Bakker (Dr.), mellem Lynghy og Frederiksdal (Hornem. Herb.) Den har i mange Aar forgjæeves været eftersøgt paa de fra Sjælland angivne Voxesteder. *1

944. V. cassubica L. (Kassubisk V.) H. 767; Drej. ᄁ. 743 ; F. D. 1395 ; H. N. IlI, 40 ; L. Herb. II, 35.

Rodstokken med krybende Udlobere; Stconglerne oprette eller opstigende; Bladene mangeparrede, ende med en Slyngtraad; Smaabladene linieformet-ovale med bredere Basis, braadspidsede; Blomsterstilken lidet kortere end det stottende Blad; Ballerne korte, elliptiske, 1-2-frøede, graabrune.

Stænglerne og Bladene, især de nedre, duunharede. Kronerne violette med hvidagtig $\mathrm{Kj}$ øl. $\frac{6}{2}-\frac{7}{1}$.

I Kratskove: hyppig i Almindingen o. fl. St. paa Bornh.! ikke sjelden i Kbhvns Onjegn! i de andre Egne sporadisk: $S j$. Jægerspriis (19), Kongsøre Skov i Odsherred (H.); F. Lykkesholm (H.); J. Agdruplund i Vendsyssel (9), Lundbykrat (H.), Skatskov red Eveldrup (Dr.); $S t$. Midsunde (16). I*

bb. Axelladene halvmaaneformede, tandede.

945. V. silvatica L. (Skov-V.) H. 767; Drej. n. 745; F. D. 277. 
Stcongelen svag, klattrende; Bladene 6-8-parrede med en Slyngtraad; Smaabladene ægformet-ovale, budte eller svagt udrandede, kort braadspidsede; Axelbladenes Tænder langt sylspidsede; Klaserne efter Afblomstringen længere end det støttende Blad; Ballerne linie-lancetformede, sorte.

Bladene glatte, tynde, smukt grønne. Kronerne hvide med lila Aarer. 7-8. 4 .

I skyggefulde Løvskove, funden i alle Provindser, men sporadisk.

b. Cracca, Griffelen fladtryktfra Siden, i Spidsen alsidigt $t æ$ tharet.

946. V. Cracca L. (Muse-V.) H. 768; Drej. n. 744; F. D. 804 ; L. Herb. VIII, 148.

Stcengelen svag, klattrende; Bladene 8-10-parrede, med oval-lancetformede, paa begge Flader tiltrykt-silkehaarede Smaablade; Axelbladene halvt-spydformede, heelrandede; Klaserne mangeblomstrede, paa nikkende Blomsterstilke af Længde med eller lidet længere end det støttende Blad; Bagerets nedre Tænder kortere end Røret; Fanens Plade og Negl ligelange, Vingerne sammenstødende; Bcellerne linie-lancetformede, 6-9frøede, pludseligt sammendragne til en Frugtholder, som er kortere end Bægerrøret.

Kronerne blaaagtigt-violette, sjeldent hvide. 6-8. 4 .

$\beta$, leptophylla (Fr. Fl. Hall., H. 768). H. N. VII, 42; Smaabladene linie-lancetformede, meget smale.

Ved Gjærder, paa dyrkede Marker og i Kratskove alm. $\beta$, paa Enge, især ved Stranden, f. Ex. $\boldsymbol{S} \boldsymbol{j}$. Tryggerød Mose! Vesterfælled! Falst. Bøtø Fang (Koch), Jyll. Nebbegaard!

947. V. tenuifolia [Roth Fl. germ. 1, p. 309] (Tyndbladet V.) Fr. nov. p. 230; H. II, 232; F. D. 2177; H. N. XIII, 61 ; L. Herb. II, 36.

Stangelen stiv, bugtet mellem Ledene, lidet klattrende; Bladene 10-14-parrede; Smaabladene linie-lancetformede, paa Underfladen haarede af udstaaende Haar, forøvrigt, ligesom Stængelen, tiltrykt-haarede eller glatte; Axelbladene heelrandede, 
de nedre halvt-spydformede, de øvre linieformede; Klaserne mangeblomstrede, paa oprette Blomsterstilke, som ere meget længere end det stottende Blad; de nedre Bagertander kortere end Roret; Fanens Plade næsten dobbelt saa lang som Neglen, Vingerne frastaaende; Bcllen lancetformet, 6-8-frøet, efterhaanden afsmalnet i en Frugtholder af Længde med Bægerrøret.

Hoiere end foreg., med større, vellugtende Blomster; Kronerneblaae, Vingerne blegere. 6-8. 4 .

Ved Gjærder og i Krat, sporadisk og ikke alm.: Ébelo (A. Meyer)! $\boldsymbol{F}$. Dalby paa Hindsholm (12), mellenı Odense og Skibhuse (19); $\boldsymbol{S}$. Kulbjerg paa Tudsenæs (15), Strandkanter ligeoverfor Reers (14), Bognæsgararden ved Roeskilde! Bidstrupgaard! Ermelundsskoven (Benzon)! Gjerdrup, Basnæs, Borreby (Nielsen); M o en ved Liselund, Sømark og paa Aborrebjerget! Stege Nor (9); fialst. Riserup, Blæsbjerg Molle (Koch), mellem Gundsler og Stubbekjøbing! [\%

948. V. villosa [Roth 1. e. 2, p. 182] (Duunhaaret V.) H. 769 (undt. Voxest.) ; F. D. 2599; H. N. IV, 61; L. Herb. IX, 167.

Stangelen svag, klattrende; Bladene omtrent otteparrede; Smaabladene oval-lancetformede, tilligemed Stængelen uldhaarede; Axelbladene halvt-spydformede, større end hos de foreg.; Klaserne mangeblomstrede, af Længde med eller lidet kortere end det stottende Blad; de nedre Bagertander sylfurmede, længere end Roret; Fanens Plade 1/2 Gang kortere end Neglen; Ballerne rudeformet-elliptiske, fladtrykte, 3-6-frøede, pludseligt sammendragne til en Frugtholder af Længde med Bægerrøret.

Kronerne store, blaaagtigt-violette, med blegere Vinger. 6-7. $\odot$

Paa dyrkede Marker mellem Sæden, meget sjelden. De eneste danske Expl. som jeg har seet, ere samlede paa Hasseløen mellem Lolland og Fal ter (Koch, Lütken)! og ved Vesselsminde N. for Kjobenhavn (19)! samt paa Marker ved Valby (Heiberg). Den angives af Hornem. fra Fyen (Einsiedelsborg, Hofmansgave, Svendborg) og Moen, men de Expl. fra det sidstnævnte Voxested, som opbevares i Hornemans Herb., høre til V. tenuifolia, Expl. fra Svendborg til en Form af V. Cracea, |* 
c. Vicia s. s. Griffelen fladtrykt fra Ryggen, i Spidsen paa Yderfladen skjægharet, forørigt glat.

aa. Blomsterne $i$ en 3-10-blomstret Klase, Ballerne stillede. 4. 949. V. dumetorum L. (Krat-V.) H. 766; Drej. n. 746; F. D. 1464 ; L. Herb. VIII, 147.

Stongelen klattrende, kantet, næsten vinget; Bladene faa(4-5) parrede; Smaabladene ægformede, budte med en Braad; Axelbladene halvmaaneformede, med sylspidsede Tænder; Klaserne 6-10-blomstrede, længere end det støttende Blad; Bcogertcenderne korte, triangelformede, de nedre lidet længere end de øvre.

Glat og frisk grøn. Kronerne mørk-rosenrøde, de modne Bæller gunlbrune. 7-8.

I Skove og Krat, sjelden: $\boldsymbol{S}$ j. Eshønderup (H.), Boserup Skov! Ledreborg, Korsør Skov (H.), Basnæs (Nielsen)! Falst. mellem Buske i Korselitze Have (Koch); F. Maglehgi ved Lykkesholm, Einsiedelsborg (H.), Nisbyhoveds Skov ved Odense! J. Lundbykrat (3), Hadsund ved Hobro (9). F.

950. V. sepium L. (Gjærde-V.) H. 771; Drej. n. 739; F. D. 699 ; L. Herb. VIII, 146.

Rodstokken med Udlobere; Stcenglerne opstigende og klattrende; Bladcne 5--8-parrede; Smaabladene oval-ægformede, budte ined en Braad, aftage i Størrelse mod Spidsen af Bladet; Axelbladene halvt-piilformede, tandede; Klaserne 3-5. blomstrede, kortstilkede, meget kortere end det støttende Blad; Bagertcenderne sylformede, de nedre meget længere end de øvre.

Planten af mat grøn Farve, mere eller mindre haaret; Kronerne skident rode eller violette, sjeldnere hvide. Bællerne ved Modenheden sorte (alm. komme kun 1-2 Bæller i hrer Klase til Modenhed). $\frac{5}{2}-\frac{7}{1}$.

I Skove og Krat, ved levende Hegn, alm. udbredt.

3b. Blomsterne 1-i, nasten siddende, i Bladhjornerne. Ballerne stilklose 0: uden Frugtholder. $\odot$.

a. Bladene ende med en Slyngtraad; Froene jærne, runde.

951. V. sativa L. (Forler-V.) H. 769; Drej. n. 738; F. D. 522 ; L. Herb. V, 90 . 
Bladene 5-7-parrede; Smaabladene ovale eller omvendtagformede, udrandede med en Braad i Indskjæringen; AxelBladene halvmaneformede, tandet-fligede, med en sort Plet i Spidsen; Bcegertanderne ligestore, lancet-sylfurmede, af Længde med Røret; Bollerne oprette, flade, duunhaarede; Frøene fladtrykt-kugleformede.

Fanen violet, Vingerne røde. 6-7. Erter.

Dyrkes som Sædart og forekommer som Ukrud, f. Ex. mellem

952. V. angustifolia [Roth l. c. I, 310] (Smalb]adet V.) H. 770 ; Drej. n. 737 ; F. D. 1310 ; H. N. XII, 56; L. Herb. III, 55 .

Bladene 3-5-parrede; Smaabladene paa de nedre Blade omvendthjerteformedv eller ovale og i Spidsen indtrykte med en Braad i Indskjæringen, paa de ovre linieformet-ovale; AxelBladene halvt-piilformede, tandet-fligede, med en alın. lysere Plet mod Spidsen; Bagertanderne ligestore, sylformerle, kortere end Roret; Ballerne udstaaende, trind-fladtrykte, i moden Tilstand sorte, næsten glatte; Froene kuglerunde.

Mindre og spædere end foreg. Kronerne smukt og mørkt purpurxøde. $5-6$.

$\beta$, segetalis (Thuill.) Smaabladene paa de øvre Blade linie-lancetformede. Sæden.

I Krat, ved Gjarder og paa dyrket Jord alm. - $\beta$, især mellem

$\beta$, Bladene ende med en Braad; Frøene tærniugformede, rue.

953. V. lathyroides I.. (Vaar-V.) H. 770; Drej. n. 736; F. D. 58 ; L. Heıb. III, 56 ; H. N. XIV, 55.

Bladene 2-3 parrede; Smaabladene omvendt-lijerteformede eller oinvendt-ægformede, i spidsen udraudede og sadvanligt braadspidsede; Axelbladene halvt-piilformede, heclrandede; Blonsterne eulige; Bargertinderne ointrent ligestore, sylformede, kortere end Roret; Ballerne glatte.

Strenglerne 2-4" lange, oftest flere og nedliggende. Paa kraftige Expl. forlenges stundom Braaden i Blartets Spidse og antager Form af en Slyngtraad. Blomsterue smaae, rodviolette. 4-5. 
Paa græsklædte Marker og Bakker, især paa sandig Jordbund, ikke sjelden, men ofte overseet paa Grund af dens Lidenhed.

d. Faba. Griffelen i Spidsen paa Yderfladen skjæghaaret; Bællen tyk, svampagtig-puklet; Frøene aflange, fladtrykte paa Siderne.

$\dagger$ V. Faba L. (Hestebønne). Sturm D. Fl. b. 32; Faba vulgaris Moench.

Bladene 1-3-parrede, ende med en Braad; Smaabladene ovale eller elliptiske, budte; Axelbladene balvmaaneformede, tandede; Blomsterne 2-5 samlede $\mathrm{i}$ en kort Klase, meget kortere end Bladet; Baggertcenderne uligestore; Ballen duunhaaret.

Kronerne hride med en sort Plet paa Vingerne, Fanen ofte rydlig anløben og med sorte Striber. Bællen ved Modenheden sort, Frøene blegbrune. 6-7. $\odot$.

Dyrkes $\mathrm{i}$ flere Afarter deels paa Marker som Fodervæxt og deels i Haver (nnder Narn af valsk Bønne).

\section{Ervum. Lindse.}

954. E. hirsutum L. (Laaden L.) H. 772; F. D. 639; Vicia hirsuta Koch Syn. 1, 191; Drej. n. 740; L. Herb. VIII, 149.

Bladene 6-8-parrede; Smaabladene linieformede eller ovallinieformede, afstumpede eller indtrykte med en Braad; Axelbladene tandet-fligede; Blomsterstilkene 2-6-blomstrede; Bagertwnderne omtrent ligestore, sylformede, af Længde med eller længere end Roret; Bollerne elliptiske, tofrøede, tilligemed. Bladene duunhaarede.

Kronerne smaae, blaaggtigt hvide. $5-7 . \odot$. alm.

Paa Grøftevolde, tørre Marker og Bakker, mellem Sæden o. s. vø,

955. E. tetraspermum L. (Tadder-L.) H. 771; F. D. 95 ; Vicia Moench, Drej. n. 741 ; L. Herb. IV, 73.

Bladene 3-5-parrede, Smaabladene oval-linieformede, budte med en Braad; Axelbladene halvt-piilformede, heelrandede; 
Blomsterstilkene 1-2-blomstrede; Bagertcenderne uligestore, de øvre triangelformede, de nedre sylformede, kortere end Røret; Ballerne linieformet-ovale, firefrøede, tilligemed Bladene glatte.

Kronerne lidet større end hos foreg., hvide med lila Fane. 6-7. $\odot$.

Paa dyrkede Marker mellem Sæden, ved Gjerder, paa Bakker: sporadisk og hyppigere $\mathrm{i}$ de sydlige end $\mathrm{i}$ de nordlige Egne af Landet. (sjeldnest i Jyll.).

\section{Pisum. Ert.}

† 956. P. arrense L. (Graae Erter). H. 759; Drej. p. 247; Sturm D. Fl. h. 4.

Bladene 1-3-parrede, med omvendt-ægformet-elliptiske Smaablade; Axelbladene balvt hjerteformede, ved Grunden tandede, næsten ligesaa lange som de 1-2-blomstrede Blomstersitilke; Kronens Fane lila, grønligt stribet, Vingerne røde; Frøene kañîede, graagrønne med brune Punkter. 6-7.

Dyrkes som Sædart og forekommer hyppigt som Ukrud mellem anden Sæd, især mellem de alm. Aerter.

$\dagger$ †. sativum L. (Gule $\mathbb{E}$.) Drej. p. 247.

Kronbladene hvide; Frøene kugleformede, gule, forøvrigt som foreg. 6-7. $\odot$. forvildet.

Dyrkes alm. i Mark og Have, forekommer stundom tilfældigt

\section{Lathyrus. Fladballe.}

a. Kroubladene gule.

957. L. Aphaca L. (Bladløs F.) Horn. i Krøy. Tidsskr. 1, 461 ; F. D. 2245.

Stcongelen kantet, uvinget; Bladene heelt omdannede til en Slyngtraad (uden Smaablade); Axelbladene piilformede, kortere end de enblomstrede, ovenfor Midten leddede Blomsterstilke; Bagertenderne linie-lancetformede, næsten ligestore, meget læangere end Roret; Brellen seglformigt krummet; Frøene jævne.

Hele Plauten glat, blaagrøn. 6-7. $\odot$. 
Paa dyrket Jord meget sjelden: $\boldsymbol{F}$. Dæmningerne ved Næsbyhoveds Skov udentor Odense! (Ikke funden i de senere Aar. Angives af Kyll. fra Falster). 政

958. L. pratensis L. (Guul F.) H. 764; Drej. n. 747; F. D. 527 ; L. Herb. VI, 113.

Stangelen firekantet med uligestore Sider; uvinget; Bladene med 1 Par elliptisk-lancetformede, grundnervede Smaablade ug endende $\mathrm{i}$ en grenet Slyngtraad; Axelbladene skjævt piilfornede; Blomsterne i Klase paa en Blomsterstilk som er længere end Bladene; Bogertonderne sylformede, uligestore, omtrent ligelange med Røret; Frøene jævne.

6-7. ข. Var. i Henseende til Blomsternes Retning i Klasen (ensidige eller næsten alsidige), Beklædningen (næsten glat, tiltryktsilkehaaret eller tæt-duunhaaret), Smaabladenes Størrelse o.s.v. (Sml. Drej. i Krøy. 'Tidsskr. II, 282).

Ved Gjærder, paa Enge og fugtige Steder i Skove alm. Den starkt duunhaarede Form (villosus Dr.) sjeldnere og især paa høitliggende, solaabue Steder.

b. Kronbladene røde eller violette (undtagelsesviis hvide).

aa. Stangelen kantet uden Vinger.

959. L. tuberosus L. (Knollet F.) H. 763; Drej. n. 748; F. D. $14 t 33$; H. N. 1,50 .

Rodstokkens Grene knolleformigt opsvulmede; Stangelen firekantet; Bladene enparrede, Smaulladene ovale, budte med en kort Braad; Axelbladene halvt.piilformede, tilspidsede; Blomsterstilken meget længere end Bladet; Klasen 2-6-blomstret; Borgertanderne uligestore: de øvre kort triangelformede, de mellemste æg lancetformede, den nedre sylformet, af Længde med Røret; Ballerne glatte, hvælvede; "Frøene svagt knudrede, med meget kort Navle."

Kronerne rosenrøde, vellugtende; Rodknollerne spiselige. 7-8. 4.

Paa Marker og ved Gjærder, sjelden: $\boldsymbol{S}$ j. Kastelsvolden ved Kjobenhavn (Schunı, 29)! Bidstrupgaard ved Roeskilde. (Paa det sidste sted, hvor den endnu findes, har den voxet fra ældgammel Tid, da Expl., sanilede der, allerede findes i Bursers Herbarium)! [* 
960. L. maritimus [Fr. Fl. Sean. p. 106] (Strand-Art). Drej. n. 749 ; H. N. II, 50; Pisum L., H. 759; F. D. 338; L. Herb. II, 37.

Stcengelen trekantet, nedliggende; Bladene 4-5-parrede; Smaabladene elliptiske eller ovale, budte eller lidet spidse og ined en kort Braad, Axelbladene spydformede, meget større end hos foreg., Blomsterstillken omtrent af Længde med Bladet; Klasen 4-8blomstret; Bo'gertonderne uligestore: de øvre triangelformede, den nedre linie-laneetformet, længere end Roret; Ballerne fladtrykte, først duunhaarede, tilsidst glatte; Frøene jævne, Navlen omgiver omtrent $1 / 3$ af Frøet.

Planten blaagrøn; Bladstilkene alm. bueformigt tilbagebøiede; Kronerne violetrøde. 7-8. 4. Var. i Henseende til Smaabladenes Form, Beklædningen (alm. glat, sjeldnere duunhaaret: - velutinus Fr.) o. s. v. En meget afvigende Form er

* acutifolius Bab. Stænglerne tynde; Bladstilken udstaaende (ikke bøiet); Smaabladene elliptisk-lancetformede, spidse, meget mindre end bos Hovedarten; Bægertænderne længere tilspidsede; den nedre i Spidsen alm. tilbagebøiet.

Ved sandige Strandbredder, ikke alm.: J. Lokken (9), Hanstholmen (Dr.), Ringkjøbing (1), Klitter ved Filsø (16); St. Sylt, Føhr (N.), Amrom (16); $\boldsymbol{E}$ r $\theta$ paa Halen og Dreiet ved Marstal (H.); Fals $\iota$. mellem 'Iromnæes og Hesnæs! o. fl. Steder langs Kysten af Ø-tersøen (Koch), Bøtø (Benzon); S $j$. Skjelskør (H.), Nykjøhing, Holbæk (Bursers Herb.): Bornh. Hammershuus (19), Hasle (11), Rønue (8)! * J. i Klitterne vęd Agger (Dr.)! Harboøre (H.), Klitter ved Fjaltring! $S l$. Nieblum paa Fohr (20).

bb. Stængelen vinget.

961. L. palustris L. (Kjær-F.) H. 766; Drej. n. 750; F. D. 399 ; L. H. II, 38 .

Bladene 2-3-parrede, Smaabladene lancetformede, spidse eller budte med en Braad; Axelbladene halvt-piilformede; Bladstilken rendet, med en smal, ophoiet Rand; Blomsterstilken længere end Bladet; Bcegertonderne uligestore: de øvre kort triangelformede, den nedre lancet-sylformet, lidet kortere end Roret; ved et afrundet Indsnit adskilt fra de mellemste; Griffelen retvinklet opstigende; Frøene jævne, Navlen omgiver omtrent $1 / 4$ af Frøet. 
Kronerne violet-blaa. 6-8. 4. Var. i Henseende til Axelbladenes Størrelse og Smaabladenes Brede $(\alpha$, latifolius, med bredt lancetformede eller ovale, $\beta$, ensifolius, med smalt lancetformede, næsten linieformede Smaablade), samt Smaabladenes Antal (Expl. med 1 Par Smaablade fundne i Omegnen af Kbhavn. Koch).

I Moser og paa fugtige Enge, bemærket i alle danske Provindser, men sporadisk og paa flere Steder periodisk forsvindende.

\section{L. silvestris L. (Skov-F.) H. 765; Drej. n. 751;} F. D. 325 .

Bladene enparrede; Smaabladene lancetformede, tilspidsede i en Braad; Bladstilken vinget, med smalere Vinger end Stængelen; Axelbladene halvt-piilformede, smalere end Stængelen; Blomsterstilken under Blomstringen lidet længere end Bladet; Bagertunderne uligestore: de øvre ægformede, sylpidsede, den nedre sylformet, lidet kortere end Røret, adskilt fra de mellemste ved et afrundet Iudsnit; Griffelen bueformigt opstigende, snoet; Frøene jævne, Navlen omgivende det halve Frø.

Kronerne rosenrøde, sjeldent hvide. 7-8. 4. Var. i Henseende til Smaabladenes Brede:

$\boldsymbol{\beta}$, platyphyllus (Retz.) F. D. 785 ; L. latifolius H. 765 (ikke L.), Smaabladene elliptiske (3-4" lange), budte med en Braad eller spidse (ikke tilspidsede); Stængelen bredvinget.

$\gamma$, stenophyllus! Smaabladene lancet-linieformede, $1^{1} / 2-2^{\prime \prime}$ lange, Stængelens Vinger smalere.

I Kratskove og ved Gjærder ikke sjelden. $\boldsymbol{\beta}, \boldsymbol{S}$ j. Holbæk (27), Kjøge! Falst. ved Næsgaard (H); Loll. i Strandsandet ved Rødby (Müll. i F. D.); F. Krat ved Lunde pr. Odense (18), St. Jørgensgaard (12). $\gamma$, Tüisvilde (27).

963. L. heterophyllus L. (Bredvinget F.) H. N. IV, 62.

Bladene 1-2 parrede; Smaabladene lancetformet-elliptiske, spidse eller budte med en Braad; Bladstilkens Vinger lige saa brede som Stængelens; Axclbladene af Brede med eller bredere end Stængelen; Bagertanderne uligestore: de øvie kort triangelformede, den vedre sylformet, længere end Røret, ved et skarpt Indsnit adskilt fra de mellemste lancetformede; "Frøene knudretrue, Navlen neppe $1 / 3$ af Frøets Omkreds ", forøvrigt som foreg. 
Bladene paa Underfladen blaagrønne. Kronerne rosenrøde. 7-8. 4 .

Gjærder ved Raahave paa Loll. (5)! andre danske Voxesteder ere mig ikke bekjendte. [न

\section{Orobus. Glatbaelle.}

a. Stængelen vinget.

964. 0. tuberosus I. (Knollet G.) H. 761 ; Drej. n. 752 ; F. D. 781 ; L. Herb. VIII, 151 ; Lathyrus macrorrhizus Wimm., Lge. Haandb. 2 Udg. S. 481.

Rodstokken krybende, ved Ledene knolleformigt opsvulmet; Stcongelen opstigende; Bladene 2-3-parrede, med oval-lancetformede Smaablade; Axelbladene halvt piilformede, naaende op over det nederste Bladpars Basis.

6-10" høi. Bladene glatte, paa Underfladen glandsløse, blaagraae; Kronerne rødviolette. 5-6. 4.

$\beta$, tenuifolius (Roth). H. N. V, 49. Smaabladene linieformede.

Paa Lyngbakker, i Krat og Skove alm.; ikke bemærket paa Loll., F a lst., det sydlige Fyen og Smaaøerne $(14,12 !)$ - $~ \beta$, meest paa solaabne Steder.

\section{b. Stængelen kantet, uvinget.}

965. 0. niger L. (Sort G.) H. 762 ; Drej. n. 754 ; F. D. 1170 ; L. Herb. VIII, 150; Lathyrus niger Wimm., Ige. l. c. p. 482 .

Stangelen opret, grenet; Bladene 4-7-parrede; Smaabladene ovalt-elliptiske, braadspidsede, paa Underfladen mat blaagraae; Axcluladene sylspidsede, de ovre linie-lancetformede, de nedre halvt piilforınede, naaende op til det nedre Bladpars Basis.

1-2' høi, glat, bliver sort ved Tørring. Kronerne røde, Fanen med mørkere Aarer. 6-7. 4 .

I Skove og Krat, hist og her i alle Provindser, men ikke alm.

966. 0. rernus (Vaar-G.) H. 761; Drej. и. 753; F. D. 1226 ; L. Herb. IV, 74 ; Lathyrus vernus Wimm.; Lge. I. c. 
Stcengelen opret, udeelt, formeden firekantet, foroven trekantet: Bladene 2-3-parrede; Smaabladene ægformede eller elliptiske, tilapidsede, svagt randhaarede, paa Underfladen grønne, glindsende; Axclbladene balvt piilformede (storre end bos foreg.) ikke waaende til det nedre Bladpar.

${ }_{1 / 2}^{\prime}-1^{\prime}$ høi. Kronerne røde eller violette, efter Afblomstringen: blaakgtig-grønne. 5. 4.

I skyggefulde Løvskove, funden i alle Provindser, men sporadisk. og ikke alm. i*

\section{Lotus. Kjallingtand.}

967. L. uliginosus [Scbkuhr Handb. 2, p. 412, t. 211 ] (Sump-K.) F. D. 15ะ1; H. N. XV, 56; L. corniculatus silvaticus H. 789; L. major Scop., Drej. в. 729; L. Herb. VI, 115.

Stangelen opret, ved Grunden opstigende, huul ; Smaabladene omvendt-xgformede; Axelbladene bredt og skjævt ægformede, budte; Blomsterne i et 5-12-blomstret Hoved; Bagertenderne sylformede, før Udspringningen tilbagebøiede; Kronens Vinger svagt buede nedadtil, bredere end den jævnt opstigende $K_{j} \phi l_{\text {. }}$

Bladene paa Underfladen blaagraae, var. glatte og haarede (Blomsterstilkene stundom 1-2-blomstrede). Kronerne gule, blive grønne red Torring. $7-8.4$.

I fugtige Enge og Moser, ved Randen af Kilder og Bække, ikke sjelden paa $\| a l v e e n$, i Fyen, Loll-Falst. og det restlige $S j \propto l l$; sparsommere i de nordlige og gstlige Egne af sjæll.

968. L. corniculatus L. (Almindelig K.) H. 788; Drej. n. 728 ; F. D. 991 ; L. Herb. VI, 114.

Stanglerne fremliggende; Smaabladene omvendt-xgformede; Axelbladene skjævt ægfornet-elliptiske eller halvt-ægformede; Blomsterhovedet 4-6-blomstret; Bagertanderne fra en ægformet Basis kort sylspidsede, før Udspringlingen tiltrykte; Vingerne starkt buede nedadtil, bredere end den retvinklet opstigende Kjol.

Bladene paa Underfladen blaagronne, Kronerne af Farve soms foreg., ofte med Anstrog af Orange eller Høirødt, blive grønne ved: Tør ring. 6-7. 2. Alm. glat eller svagt haaret. 
$\boldsymbol{\beta}$, villosus (Thuill.) Hele Planten graaagtig af en tæt Haarbeklædning.

$\gamma$, carnosus Pers. H. N. XV, 55. Bladene saftrige.

Paa Græsmarker, Bakker og ved Veie alm. $-\beta$, paa tørre Bakker og Lyngheder, sjeldnere; $\gamma$, ved Strandbredder.

969. L. tenuis [Kit. i Willd. H. berol. 2, 797] (Smalbladet K.) L. corniculatus angustifolius H. II, 235; F. D. 1995 ; L. tenuifolins Rchb., H. N. XII, 58; L. Herb. VI, 116.

Stcenglerne oprette, opstigende eller nedliggende; Smaa. bladene linie-lancetformede eller linieforınede, bredere foroven; Axelbladene linie-lancetformede; Blomsterstilkene fine, med $\overline{3}--5$ Blomster-i Hovedet; Vingerne smalere end den retvinklet opstigende Kjol, forøvrigt som foreg., men Stænglerne tyndere og mere grenede.

6-7. ข.

Paa Strandenge, hist og her paa Øerne. Fra Halvøen er intet Voxested mig bekjendt.

\section{Tetragonolobus. Kantballe.}

970. T. maritimus [Roth Fl. germ. I, p. 323] (StrandK.) Drej. n. 730 ; L. Herb. VI, 117 ; Lotus marit. L., H. 788; F. D. 800 ; H. N. IV, 59 ; T. siliquosus $\beta$, maritimus Ser.

Stanglerne fra en traagtig, grenet Rodstok opstigende; Smaabladene omvendt-ægformede eller rudeformede; Axelbladene skjævt ægformede, ved Grunden tilvoxne til Bladstilken; Blomsterstilken 2-3 Gange længere end det stottende Blad, med 1 endestillet Blomst omgivet af et trekoblet Dokblad med linielancetformede Smaablade.

Blomsterstilke, Bægertænder og Bladene i Randen og paa Underfladen haarede; Bladene noget kjødfulde, paa Underfaden blaagraae. Kronerne bleggule. 6-7. 4 .

Paa Strandenge: har sin største Udbredelse langs Kysterne af Store Bxlt og Østersøen (i det vestlige og sydvestlige Sjæll. samt paa Smaaøerne): $S j$. Guiben (1), Saltbæk paa Refsnæs (15), Kalundborg (H.), Drosselbjerg, Stillinge (Lund), Øerne og Kongebroen ved Korsør, Skjelskør, Basnæs, Holsteinborg, Fiurendal (H)! Bornh. Hanmeren (Hjorth), mellem Sandvig og Allinge (Hoff), paa en Eng ved Rise (Rafn); Rønne (Hjorth), Randkleven (8)! F alst. Ourehoved 
(Koch); L oll. Bjerremark (5); FFr ved Marstal (H). Ved de øvrige Have sjelden: $\boldsymbol{J}$. Lokken ved Vesterhavet (H.). [*

Anm. Den hos os udelukkende i Nærheden af Stranden forekommende Form er kun ved noget mere kjødfulde Blade forskjellig fra den i det Indre af Europas Fastland voxende Hovedart, T. siliquosus (L.), og er neppe engang som Afart at adskille derfra.

\section{Medicago. Sneglebrelle.}

a. Falcago Rchb. Bællen opspringende, fladtrykt, seglformigt bøiet eller sneglehuusformigt snoet, i Midten a aben.

971. I. sativa L. (Foder-Lucerne). H. 789; Drej. p. 241 ; F. D. 2244 ; H. N. VII, 37 ; L. Herb. V, 91.

Stonglerne oprette; Smaabladene ovenfor Midten saugtakkede, i Spidsen udrandede med en Braad, paa de nedre Blade omvendt-ægformede, paa de øvre linieformet-kileformede; Axelbladene langt sylspidsede, ved Grunden æg-hjerteformede, tandede; Blomsterstilken længere end det støttende Blad, Blomsterstanden klaseformet; Bocllen sneglehuusformigt-snoet, tiltrykt-haaret.

$1-1 \frac{1}{1} 2^{\prime}$ høi. Kronerne lila med violette Striber. 7-9.

Dyrket hist og her som Fodervæxt og, forvildet derfra, findes den nu paa flere Steder som vildvoxende, f Ex. Bornh. ved Rabekkegaard (Hoff), Moen, Amager (H.); $S j$. Brondbyoster (19), Glacierne mellem N. og Ø. Port ved Kjøbenhavn! mellem Charlottenlund og Skovshoved (Dr.)! Skovsborg (15), Adelersborg! Kalundborg (H.), Korsor! Falst. S. Kirkeby, Uggerløse (Koch), Nykjøbing (19); F. Hofmansgave (18), Nyborg Vold '(H.); J. Aagaards Kalkbakker (16); Sl. Sundeved (Nolt).

972. I. falcata L. (Segl-S.) H. 790; Drej. n. 732; F. D. 233 ; H. N. VII, 40; L. Herb. V, 92.

Stunglerne opstigende; Smaabladene linieformet-kileformede; Axelbladene xg-lancetformede, sylspidsede, de nedre hindeagtige, tandede; Klaserne korte, halvskjærmforınede; Ballen seglkrummet med eoneav Bugsøm; forøvrigt som foreg.

$1 / 2-1 \frac{1}{2} 2^{\prime}$ høi. Kronerne gule. 7-8. ข.

Paa sandige eller kalkholdige Marker og Bakker, ved Gjærder: paa Burnh. alm., i $S j$. og paa Moen hist og her; sjeldnere i de andre Provindser: $\boldsymbol{F}$. ved Nyborg (24); J. Aalborg, mellem Grenaa og Scheel, ved Ebeltoft (H.). 
b. Lupulina Gren. \& Godr. Bællen uopspringende, nyreformet, i Spidsen sneglehuusformigt suoet og i Midten lukket, uden Torne.

973. II. lupulina L. (Humleagtig S.) H. 791; Drej. घ. 731 ; F. D. 992 ; L. Herb. IV, 76.

Smaabladene omvendt-ægformede eller omvendt-hjerteformede; indtrykte med en Braad, ovenfor Midten tandede eller næsten heelrandede; Axelbladene ægformede, sylspidsede, tandede eller heelrandede; Blomsterne i ovale, tæt- og mangeblomstrede Ax; Ballerne nætformigt aarede, glatte eller tiltrykthaarede, suoede i $1 \frac{1}{2}$ Ongang.

${ }^{1 / 4}-1^{\prime}$ høi. Kronerne gule, smaae, alm. enfrøede, i moden Tilstand sorte. Ligner en Trifolium af Afdelingen a. 6-9. $\odot$.

$\beta$, Willdenowiana (Boenn.). Bællerne beklædte med udstaaende, kirtelbærende Haar.

Ved Veie, paa høie Enge og Jerede eller kalkholdige Marker, meget alm. $-\beta$, hist og her, mindre almindelig end Hovedarten.

c. Spirocarpus DC. Bællen uopspringende, kredsrund, sneglebuusformigt sammenrullet, beklædt med Torne, som udgaaedeelsfra Rygsømmen, deels

fra en ophøiet Nerve indenfor Randen.

974. II. minima [Lam. Dict. 3, p. 636] (Liden S.) H. 791 ; H. N. 1, 47; M. polymorpha $\mu$, minima L., F. D. 211.

Fleerstænglet, med oprette eller opstigende Stongler; Smaabladene omvendt-ægformede, mod Spidsen tandede, indtrykte med en Braad; Axelbladene ægformede, sylspidsede, heelrandede eller tandede; Blomsterne $\mathrm{i}$ et $2-5$-blomstret Hoved; Ballerne kugleformede, dannede af $3-5$ Vindinger uden Længdeaarer, men med 2 Rækker af $\mathrm{i}$ Spidsen hagekrummede Torne.

2-8" høi. Hele Planten mere eller mindre tæt duunhaaret. Kronerne gule, lidet storre end hos foreg. Bællen fra det foreg. Aar, hvoraf Planten er fremspiret, findes alm. fasthæftet til Roden endnu under Blomstringen. 5-6. $\odot$.

Paa tørre, isier sandige Bakker, sjelden i Danmark: Bornh. paa Skrænterne langs Stranden fra Boderne til Pythuset! Hammershuus 
(H.); Meen paa Troldkonehøiene i Borre Sogn (Holst); $\boldsymbol{S}$ j. Refsnæs hist og her paa Sandmarker (15), Skrænterne ved Beks Kro N. for Tiissø! Hyldemarkshusene ved Storebalt (Lund); $\boldsymbol{F}$. Klintebjerg pr. Odense (N. E. Hofm. Bang)! Samse ved Maarup Vig (2).

$+M$. maculata Willd. Smaabladene omvendt-hjerteformede, bruunplettede, Axelbladene fliget-tandede, Bællen med Længdeaarer og bøiede, ikke hagekrummede Torne.

Findes undertiden forvildet, f Ex. i flere Aar paa Pladsen udenfor Thorvaldsens Museum! Kastrup Mølle paa Amager (Branth)!

\section{Trigonella. Bukkehorn.}

975. T. ornithopodioides [DC. Fl. fr. IV, p. 50] (Fugleklo-B.) Trifolium L., F. D. 368; Melilotus H. 779 ; Medicago. Fr. Mant. 3, p. 93.

Stanglerne talrige, udstrakte; Smaabladene omvendt-hjerteformede, tandet-saugtakkede; Axelbladene lancet-sylformede, hindeagtige; Blomsterstilken $\Sigma-3$ blomstret, kortere end det støttende Blad; Ballen budt linieformet, svagt seglformet, med convex Bugsøm, rynket paatværs, baaret.

$2-5 "$ høi. Kronbladene rødlig-hvide. 7. $\odot$.

Meget sjelden: Sandmarker i den nordlige Deel af $\boldsymbol{S} y \boldsymbol{l t}$ (F. D.) $\emptyset$ stkanten af Christiansø(H.) Paa det sidste Sted søgt forgjæves i. de senere Aar. 요

\section{Melilotus. Steenklover.}

976. II. alba [Lam. Dict. 4, p. 63] (Hvid S.) M. vulgaris Willd., H. 779 ; Drej. n. 725; F. D. 1 i05; H. N. VI, 35 ; L. Herb. V, 93.

Stangelen opret, grenet; Smaabladene omvendt-ægformede eller ovale, afskaarne eller budte, fjernt-saugtakkede; Axelbladene børsteformede, heelrandede; Klaserne forlængede; Kronens Vinger og Kjol af lige Længde, kortere end Fanen; Ballerne uden Frugtholder, omvendt-ægformede, budte med en Braad, nætformigt rynkede, glatte, 1-2-frøede; Bugsømmen budtkjølet.

2-4' høi. Planten har (ligesom de øvrige Arter i Slægten), en stærk og efter Tørringen vedholdende Lugt (omtr. som Trigonella Foenum græcum ellex Heracleum). Kronerne hvide, "lugtløse". De: modne Bæller graabrune. 7-9. ๑. 
Ved Strandbredder, Veie, omkring Byer, især i Nærheden af Stranden, sporadisk og ikke alm., men funden $i$ alle Provindser.

977. II. officinalis [Willd. Enum. hort. berol. 2 p. 790] (Lrge-S.) H. 777; Drej. n. 726; H. N. VI, 32-33; Trifolium Melilot. off. L., F. D. 934 ; M. macrorrhiza Pers., Koch Syn. II, 182.

Stangelen opret, grenet; Smaabladene omvendt-ægformede, budte, de ørre linieformet-ovale eller kileformede, indtrykte, alle fjurnt saugtakkede; Axelbladene børsteformede; heelrandede; Klaserne forlængede; Fane, Vinger og Kjol af lige Isængde; Ballerne red en kort Frugtholder stilkede, omvendt-ægformede, spidse, med skarp kjølformet Bugsøm, nætformigt rynkede og duunhaarede, alm. tofrøede.

2-3' høi. Kronerne gule, "lugtende". De modne Bæller sorte, meget større end hos de ørrige Arter. 7-9. $\odot$.

Ved. Strandbredder, Veie og paa Marker ikke sjelden.

978. II. arrensis [Wallr. Sched. 391] (Mark-S.) H. N. VI, 34; M. officinalis Lam. diet. 4, p. 63; Koch Syn. II, 182; M. Petitpierreana Rehb.

De nedre Blades Smaablade omvendt-xgformede eller ovale, de ovre oval-lancetformede, alle tandet-saugtakkede; Klaserne forlængede, mindre tætblomstrede; Vingerne kortere end Fanen, Jængere end Kjolen; Ballerne kortstilkede, glatte, med budtkjølet Bugsøm, rynkede paatværs, forøvigt som foreg.

1-2" høi. De modne Bæller gronbrume, tilligemed Blomsterne mindre end hos foreg. Kronerne bleggule, sjeldnere hvide, "vellugtende". 7-9. $\odot$.

Ран Marker, sjelden: $\boldsymbol{J}$ Ferslev og Scheelsminde ved Aalborg (Branth)! Sj Kalundborg (Baagøe)! Marker ved Kjøbenliavns Assistenskirkegand! Falst. ved Korselitze og Karleby (Rasmussen)! Riserup, Bıgninge (14), s. Kirkeby, Ourupgaard, Kringelborg (Koch). Den hvidblomstrede Form ved Bagsvard (19). Sandsynligviis indtort med fremmed sæd.

979. II. dentata [Pers. Syn. 2, 348] (Strand-S.) H. 778; Drej. n. 727 ; F. D. 1883 ; H. N. X, 49 ; L. Herb. I, 16; Trifolium dentatum Waldst. \& Kit. pl. rar. hung. I, p. 41 t. 42 (den første Kilde til Arten). 
Stcongelen opstigende eller opret, ofte fra Grunden af grenet; Smaabladene elliptisk- eller lancetformet ovale, fiint og tæt saugtakkede; Axelbladene sylformede med børsteformede Tænder ved Grunden; Klaserne kortere og mere tætblomstrede end hos de foreg.; Vingerne kortere end Fanen, længere end Kjolen; Ballerne uden Frugtholder, omvendt-ægformede, svagt rynkede, glatte.

Lavere $\left(1-1^{1} / 2^{4} h ø i\right)$ og finere, med meget mindre Blomster end de foreg. Kronerne gule, de modne Bæller sortbrune. 7-9. $\odot$.

Ved lerede $\mathrm{gg}$ dyndfulde Strandbredder, paa Strandenge, ikke alm. og fornemlig i de sydlige Egne (omkring Bælterne og Østersøen): Sl. Haderslev (16); Femeru; Are (N.): Dreje (12); F. Hofmansgave (1), Koholm ved Svendborg (12); Thor seng ved Vemmenæs (12); Loll. Nakskov Fiurgeland! Flatø i Guldborgsund! Falst. Vaalse, N. Vedby (Koch), Hesnæs, Nykjøbing, Bøtø (14)! S $\boldsymbol{j}$. Avedore (26), Flaskekroen ved Kalkovnen! Kastrup paa Amager (Dr.)! Holbæk (15), Reersø (Dr.), Korsør! Skjelskør! [\%

\section{Trifolium. Klover.}

a. Chronosemium DC. Smaabladenes Sideaarer udeelte; Kronbladene gule, efter Afblomstringen hindeagtigt vedblivende; Vinger og Kjøl bedækkede af den hvælvede og nedadbøiede Fane; Bællen med en Frugtholder.

aa. Axelbladene randhaarede; Griffelen 4-6 Gange kortere end Boellen.

980. T. filiforme [L. Sp. pl. 1088, ex descr., loc. nat. et synon. Raj.] (Faablomstret K.) Sm. fl. brit. 1404; E. Bot. 1257 ; Gren. \& Godr. fl. Fr. I, p. 422; T. micranthum Viv.; Lge. Haandb. 1 Udg. n. 941.

Stanglerne nedliggende; Smaabladene onvendt-ægformede eller kileformede, rynket-nervede, i Spidsen svagt tandede og afskaarne eller udrandede, det midterste siddende; Axelbladene*).

*) Axelbladene hos Trifolinm-Arterne ere i omtr. deres halve Længde tilvoxne til Bladstilken. Ved Beskrivelsen af disse er her taget. Hensyn til de midterste paa Stængelen, da de øvre, (under Blomsterstilkene) ofte have en fra hine meget afvigende Form. Blonster- 
elliptiske (bredest paa Midten); Blomsterstilkene traadfine, noget bøiede, af Længde ined eller lidet Iængere end det støttende Blad, 3-6-blomstrede; Fanen jævn, Vingerne oprette.

Stænglerne 2-4" lange. Kronerne bleggule, meget smaae. 6-7. $\odot$.

Paa Strandenge, meget sjelden: J. Steensballesund ved Horsens (Mygind)! Loll. vell Gottesgabe (19), Bjerremark (5)! Fra andre Steder er den mig ikke bekjendt.

981. T. minus [Sm. Fl. brit. 1403] (Traadstænglet K.) E. Bot. 1256 ; T. filiforme DC., H. 78i; Drej. n. 724; Lge. Haandb. 1 Udg. n. 942 ; F. D. 1707; H. N. II, 48 og IX, 54 ; L. Herb. I, 20 (ikke L.); T. procumbens L. Sp. (tildeels), Gren. \& Godr. 1. e. 423.

Stconglerne nedliggende eller opstigende; Smaabladene omvendt-ægformede eller omvendt-hjerteformede, i Spidsen svagt tandede og udrandede. det midterste stilket; Axelbladene xgformede; Blomsterstilkene fine, længere end Bladene, med 8-12hlomstrede, noget fladtrykte Hoveder; Fanen utydeligt stribet, Vingerne oprette.

Stænglerne 3-10" lange; Kronerne lysgule, visnede blegbrune. 5-8. $\odot$.

Paa Græsmarker, tørre Enge, Bakker o. s. v. alm. udbredt.

982. T. procumbens [L. Fl. Suec. (excl. syn. Raj.); Sm. Fl. brit. 792] (Udstrakt K.) H. 787; Drej. n. 723; F. D. 796; H. N. IX, 53; L. Herb. IV, 78; T. agrarium Poll., Gren. \& Godr. l. c. 423 (ikke L.).

Stcenglerne opstigende eller udstrakte, med udstaaende Grene, Smaabladene omvendtægformede eller omvendt-hjerteformede, ophoiet-nervede, fra Spidsen til Midten tandede, udrandede, dei midterste stilket; Axelbladene halvt-ægformede; Blomsterstilkene rette, udstaaende, alm. Jængere end Bladene,

standen er hos alle Arterne for Enlieds Skyld og fordi en skarp Grændse er vanskelig at drage, benevnt et Hoved, skjondt den hos nogle Arter ved Axens Forlangelse strængt taget er et Ax (f. Ex. Nr. 988), hos andre (f. Ex. Nr. 984-86) en Skjærm. 
med halvkugleformede, tilsidst ovale, tæt- og mangeblomstrede Hoveder; Fanen med ophøiede Striber, dobbelt saa lang som Bællen; Vingerne udstaaende.

Hovederne meget større end hos foreg., mindre end hos følg. Kronerne smukt gule, i visnet Tilstand blegbrune. 6-8. $\odot$. Var. i Henseende til Stænglernes Længde, Beklædning (glat eller duunhaaret), og

$\boldsymbol{\beta}$, campestre Schreb. ( $\boldsymbol{\alpha}$, majus Koch Syn.) Stænglerne næsten oprette, Blomsterstilkene af Længde med Bladene. Kronen mørkere guul.

Ved Veie, paa Marker o.s. v. alm. $\beta$, med Hovedarten sjeldnere. bb. Axelbladene glatte; Griffelen omtrent af Langde med Ballen. 983. T. agrarium L. (Humle-K.) H. 786; Drej. n. 722; F. D. 558 ; H. N. IX, 52; L. Herb. I, 19; T. aureun Poll., Gren. \& Godr. I. c.

Stangler og Grene oprette; Smaabladene rudeformet-omvendtægformede, opbøiet-nervede, fra Midten til Spidsen tandede, afskaarne eller svagt-udrandede, alle siddende ; Axelbladene lancetformede, sylspidsede, af Længde med Bladstilken; Blomsterhovederne først halvkugleformede, tilsidst ovale; Fanen med ophøiede Striber, dobbelt saa lang som Bællen; Vingerne udstaaende.

$1 / 2-1^{\prime}$ høi, bleggrøn. Kronerne smukt guldgule, tilsidst blegbrune. 7-9. $\odot$.

$\beta$, brevipes Drej. Grenene opret aabne, Smaabladene ovallancetformede, Blomsterstilkene kortere end det stottende Blad.

Ved Veie og paa Græstnarker: i det nordøstlige Sjall. hist og her, sjeldnere i de andre Egne af Landet: $\boldsymbol{S} \boldsymbol{j}$. Holbak (15), Gyrstinge? Borgd red Soro! Magleby paa Stevns (5); Fulst. Halskor Vunge (Liitken); Loll. Mageltving (Rasm.); F. Skovlyst ved Svendborg (19), Kirkeby (12), Trolleborg! J. Ugilt i Vendsyssel (Gronlund); Sl Rødding, Husum (16). $-\beta$, ved Teglbrænderiet mellem Farum og Slangerup (16). $\quad$ *

Anm. 1. T. spadiceum L. (H. 786; H. N. III, 37) adskilt fra foreg ved de wvre Blade modsatte, Bægertænderne langhaarede, Blonisterne tilsidst sodfarvede, er ikke hidtil funden i vor Flora, men derimod i Holsteen.

Anm. 2. Da de Linneiske Skjelnemærker ikke ere de samme som nu benyttes til Adskillelsen at de 4 foreg. Arter, og efterat de 
fleste Forff. ere enige $\mathrm{i}$ at ansee den under Nr. 980 opførte som en egen Art, er der yttret Tvivl om Anvendelsen af de linneiske Navne T. agrurium, procumbens og filiforme. Trifol. agrarium $\mathrm{L}$ synes baade ifølge Limnés Beskrivelse, de anførte synonymer og ifølge Expl. i Limnés Herbarium (ef. C. Hartm. i Vet. Ac handl. 1851, p. 287) utvivlsomt at være den med dette Navn hidtil almindelig benæunte Art, og til den foreslaaede Forandring i Navnet for denne Art forekommer der mig ikke at være nogeusomhelst Grund. Linnés T. filiforme synes ganske at stemme overeens med $T$. micranthum Viv., saavel naar der tages Hensyn til Beskr. ("planta vix spithamaea profert pedunculos vix capillo aut seta equina crassiores et in capitulis tantum 3 v. 5 flosculos distinctos, magis manifeste pedicellatos " etc.) som til Synonymer (Raj. Angl. t. 14 f. 4); den angives desuden kun fra England, men $T$. minus Sm., som forend Adskillelsen af $T$. mieranthum alınindelig antoges for ' $T$. filiforme L. er ikke sjelden i Norden og kunde neppe være ubekjendt for Linné. Grunden til den indtraadte Usikkerhed i Nomenclaturen synes at være den, at Linné har indbefattet under Navnes T. procumbens baade T. minus Sm. og den Art, som almindelig tillagges Navnet procumbens. Men da det er vanskeligt, om ikke nmuligt, at udfinde hvilken af de 2 Arter Linné oprindelig har tæent paa ved det formeentlig collective Navn, har jeg beholdt dette for den som Traditionen har tillagt det, ag derimod anvendt Smiths Navn T. minus, som ikke er Trivl underkastet, for den anden Art.

b. Smaabladenes Sideaarer grenede; B allen uden Frugtholder; Kronbladene hvide eller røde.

aa. Blomsterne forsynede med Dalblade; Bagerets Svalg nøgent; Griffelen jount boiet, opstigende.

* Trifoliastrum DC. Blomsterne stilkede; Bægerets Rør ikke opblæst.

984. T. montanum L. (Bjerg-K.) H. 785; Drej. n. 714; F. D. 1172 .

Stangelen opret eller opstigende; Smaabladene lancetformede, epidse, med talrige og fremspringende Aarer mod Randen, kirpt og hvast saugtakkede; Axcllladene lancet-sylformede, jævnt og langt tilspidsede; Blonsterhovedet tæt, før Udspringningen s...udrykt, under Blomstringen kugleformet, tilsidst ovalt, paa Blomsterstilke fra de øvre Bladhjurner; Smaablomsterstilkene 1/3 af Bægerrorets Længde, efter Afblomstringen tilbagebriede; Bagertanderne sylformede, de to ovre kortere end den nedre; "Ballen enfrøet".

Rodstokken tyk, træagtig. Stængelen, de yngre Blades Underflade og Brgeret haarede. Kronen hvid. 7. 4.

llaandb, i dell dauske Flora. 
Paa Græsmarker og Bakker, sjelden: B or $n h$. mellem Aakirkeby og Limensgade! Arnager (H.), Ringeby (Hamann); $\boldsymbol{S}$ j. Nymølle (26), en Hoi bag Flaskekroen (Dr.), $\emptyset$. for Flaskekroen 1863 (14), mellems Skillingskroen og Kjøge Kro (M. Vahl i F. D.). ¡

985. T. hylbrilum L. (Fladhoved-K.) H. 779; F. D. 1706 ; H. N. VII, 36 ; L. Herb. VIII, 152.

Stcengelen opstigende eller opret; Smaabladene ovale eller rudeformet-omvendt-ægformede, budte, med ophøiede Aarer i Randen, fiint og mere eller mindre tæt saugtakkede; Axelbladene æg-lancetformede, jævnt sylspidsede, stribede; Blomsterhovedet rundagtigt, efter Afblomstringen fladtrykt, paa Blomsterstilke fra de øvre Bladhjorner; Smaablomsterstilkene efter Afblomstringen: tilbagebøiede, de indre 2-3 Gange lengere end Bægerrøret; Bageret randhaaret; Tandtrne sylformede, de 2 øvre lidet langere end den nedre; "Ballen tofrøet".

Hele Planten glat. Kronen forst hvid, senere smukt rosenrød, 7-8. ข.

Paa Græsmarker, ikke almindelig og maaskee fra forst af indført med fremmed Sad: $S j$. Marianelund ved Gurre, Tikjøb! Bringe, Herløv (14), Strandbredder ved Kalkbræuderiet! Marker bag Flaskekroen! Roholte i Sydsjælland! Bredderne af Sorø $S_{\emptyset}$ ! F alst. Riserup, N'æsgaard (14), Korselitze (Koch); F. Midskov paa Hindsholm! Ollerup, Sorup (12); J. Ornsø ved Silkeborg (12), Horsens (16); $S l$. Flensborg (16), Huusby i Angel! Kappel (Lund, Slesvig (Esmarch). |*

986. T. repens L. (Hvid K.) H. 780 ; Drej. ฉ. 715 ; F. D. 990 ; L. Herb. V, 96.

Stangclen krybende; Smaabladene kredsrund-ovale eller omvendt-ægformede, skarpt og tæt saugtakkede, budte eller udrandede; Axelbladene hindeagtige, $x g$-lancetformede, pludseligt tilspidsede; Blomsterhovedet først fladtrykt, siden rundagtigt, paa meget lange Blomsterstilke fra Bladhjornerne, de indre Smaablomsterstilke af Længde med Bægerrøret; Bagertcenderne glatte, lancetformede, de 2 øre langere, tilsidst tilbagebøiede; Baller 3-4-frøet; Kronbladene hvide, tilsidst ofte kjødfarvede, forøvigt som foreg.

Blad- og Blomsterstilke undertiden dumnharede, Planten forøvrigt glat; Bladene have ofte en bleg eller bruun, halvmanneformet Plet paa Midten. 6-8. 4. En Misdannelse ( $\triangle$ phyllantlum!) med Bæger- 
blade og Frngtknurler omdannede til Blade, de ovrige Blomsterdele mere eller mindre forvandlede, forekommer ikke sjeldent, og især i fugtige Sommere.

Paa Enge og Græsınarker, overalt alm.

** Fragarioides. Blomsterne siddende (i Hoved); Bægerrorets Rygside med de 2 orre Tænder efter Blomstringen hindeagtigt-

- opbliest.

987. T. fragiferum L. (Jordbær-K.) H. 785 ; Drej. n. 716 ; F. D. 1042 ; H. N. XI, 50; L. Herb. V, 97.

Stangelen krybende; Smaabladene omvendt-ægformede eller ovale, budte eller udrandede, mod Randen ophoiet-nervede, tæt og skarpt saugtakkede; Axelbladene hindeagtige, forneden rørformigt sammenvoxne, fra en lancetformet Basis langt sylspidsede; Blomsterhovedet paa en meget lang Blomsterstilk fra Bladhjornerne, under og efter Blomstringen kugleformet, omgivet af et mangebladet $S v \emptyset b$ af Bægerets Længde; $B \propto x$ gercts øvre, opblæste Deel nætformigt-rynket, haaret; Ballen 1-2-frøet.

Glat eller svagt haaret. Kronen kjødfarvet. 7-8. 4:

Paa Strandenge alm., sjeldnere ved Bredden af Færskvandssøer og ved Veie inde i Landet, f. Ex. Si. Leersøen! alm mellem Glostrup og Herstedøster (12), Tjustrup S $\emptyset$, Sor bjerg (Nielsen).

† T. resupinatum L. (Omvendt K.) (Sturm D. Fl. h. 16).

Stcenglerne grenede, med nedliggende eller opstigende Grene; Smaabladene rudeformet-elliptiske eller omvendt-ægformede, saugtakkede; Blomstcrhovedet fladtrykt, efter Afblomstringen kugleformet, med 10-12-deelt, meget kort $S v \phi b ;$ opadvendte Blomster; lironen rosenrød, vellugtende, forøvigt som foreg. $7-9$.

Er oprindelig indfort fra Italien med Ho, der havde tjent til Indpakning af Thorvaldsens Arbeider; har silen den Tid i flere Aar voxet i Mængde pra Hadserne omkring Thorvaldsens Museum og er senere fundeu ved Kastrup Molle paa Amager (Branth). 司 
bb. Blomsterne uden Dakblade, siddende ( $i$ Hoved); Griffelen $i$ Spidsen hagekrummet.

* Lagopus. Hovederne deels endestillede, deels sidestillede (fra Bladhjørnerne); Kronen omtr. af Bægerets Længde, blegrød eller hvid. $\odot$.

988. T. arvense L. (Hare-K.) H. 783; Drej. n. 717 ; F. D. 724 ; L. Herb. I, 18.

Stcangelen opret, med oprette eller udspilede Grene; Smaabladene linieformet-kileformede, i Spidsen udrandede, utydeligt tandede; Axelbladene hindeagtige, stribede, den frie Deel børsteformet; Blomsterhovederne ovale, tilsidst valseformede, ved en Blomsterstilk fjernede fra det støttende Blad; Bageret tæt laadent, uden ophøiet Ring i Svælget, Tanderne børsteformede, næsten ligestore, længere end Røret og Kronen.

Hele Planten blødhaaret, Axet graaagtigt af de tæthaarede Bægere; Kronen meget liden, hvidagtigt-kjødfarvet. $7-8$.

Paa tørre, især sandige Marker og Bakker alm. udbredt.

989. T. striatum L. (Stribet K.) H. 784 ; Drej. n. 721; F. D. 1171 ; H. N. XV, 54; L. Herb. VI, 118.

Stcengclen opstigende eller opret; Smaabladene paa de nedre Blade omvendt-hjerteformede, paa de ovre omvendt-ægformede eller kileformede, ovenfor Midten svagt saugtakkede; Axelbladene stribede, ægformede, den frie Deel triangelformet, pludseligt syldspidset; Blomsterhovederne ægformede eller ovale, stilkløse (๖: tæt omgivne af det støttende Blad); Bagerroret tæt uldhaaret; Svolget indsnøret af en bruskagtig Ring; Tonderne braadspidsede, mod Spidsen næsten glatte, tilsidst udstaaende, (den nedre længere end de øvrige), kortere end Røret og af Længde med eller lidet kortere end Kronen.

Planten haaret. Kronen blegrød. 6-7.

$\beta$, strictum Drej. Stængelen rank, Smaabladene rudeformet-elliptiske.

Paa dyrkede og udyrkede Marker, saavel paa Leer- som Sandgrund, ikke sjelden: hyppigst paa Halveens $\boldsymbol{\theta}$ stkyst, i Fyen og sydl. og vesil. S $j$ all. $-\beta$, paa Marken mellem Charlottenlund og Oresundet (Dr.), Mannehøiene paa Møen (17). 
** Eutriphyllum DC. Alle Blomsterhovederne endestillede, (i Spidsen af Hovedstængelen og Grenene); Kronen meget længere end Bægeret, purpurrød (undtagelsesviis hvid). 4.

990. T. pratense L. (Rød K.) H. 781; Drej. ๖. 719; F. D. $989 ;$ L. Herb. V, 94.

Stangelen opstigende, udeelt eller grenet, med retts Ledstykker; Smaabladene ovale eller omvendt-ægformede, heelrandede eller svagt tandede, i Spidsen indtrykte eller budte med en Braad; Axelbladenes frie Deel xgformet, pludseligt tilspidset i en børsteformet Spids; Blomsterhovederne enlige eller 2 samlede, tæt omgivne af det støttende Blad; Bagerrøret tinervet, duunhaaret, Svcelget indsnøret af en bruskagtig, haaret ling, Tanderne randhaarede, de 4 øvre omtrent ligestore, lidet kortere end Røret, den nedre lidet længere end Røret, ikke naaende op til Vingerne; Bcellen opspringende paatværs.

Bladene have alm. en halvmaaneformet Plet paa Midten. Kronen rosenrød, sjeldnere hvid. 5-9.

$\beta$, sativum Schreb. Større i alle Dele og mere grenet; Blomsterbovedet stundom ved en Stilk fjernet fra det støttende Blad.

$\gamma$, parviflorum Bab. Blomsterhovederne aflange, ved en Stilk fjernede fra det støttende Blad, Blomsterne stilkede, mindre end hos Hovedarten; Bægertænderne af Længde med eller længere end Kronen.

Paa Enge og Græsmarker, alm. vildvoxende og dyrket som Foderraxt $(\beta)$ over hele Landet. $\gamma$, (en meget afvigende Form) sjeldnere: $\boldsymbol{S}$ j. Hellebæks Teglværk! Grøndal og Lundehunsmosen ved Kbhavn! Hjortenæs ved Sorø! $\boldsymbol{F}$. Nielstrup (12).

991. T. medium L. (Bugtet K.) H. 782; Drej. n. 718; F. D. 662 (T. alpestre) og 1273 ; L. Herb. V, 95; T. flexuosum Jaeq.

Stcrngelen grenet, med zigzagbøiede Ledstykker ; Smaabladene elliptiske eller lancetformede, mod Randen mangegrenet-nervede og heelrandede eller utydeligt saugtakkede; Axelbladenes frie Deel lancetformet, jæunt sylspidset; Blomstcrhovederne enlige, mod Blomstringen ved en Stilk fjernede fra det stattende Blad; 
Bcegerrøret næsten glat; Svcelget med en Haarkrands; Ballen opspringende paalangs, forøvrigt som foreg.

Kronen mørk rosenrød eller violetrød. Hovederne alm. større, men mindre tætblomstrede end hos foreg. og følg. 6-7.

$\boldsymbol{\beta}$, strictum Hartm. Stængelen mere rank, Bladene mere duunhaarede.

Paa Græsmarker, Bakker, ved Veie og i Randen af Skove alm. udbredt. $-\beta$, i Skygge.

992. T. alpestre L. (Skov-K.) H. 783; Drej. n. 720; H. N. XIII, 62, L. Herb. I, 17.

Stangelen rank-opret, alm. udeelt, med rette Ledstyklier; Smaabladene smalt lancetformede, mod Randen fint- og mangegrenet-nervede, Nerverne udløbende $\mathrm{i}$ hvasse, men meget korte Takker; Axelbladenes frie Deel sylformet, jæunt tilspidset i en lang, børsteformet Spids; Blomsterhovederne ofte 2 samlede, tæt omgivne af det beskyttende Blad; Bagerroret tyvenervet, uldhaaret, de 4 øvre Tander omtrent ligestore, lidet kortere end Røret, den nedre næsten dobbelt saa lang som Røret; forøvrigt som foreg.

Kronen rosenrød, sjeldnere hvid med rød Kjøl. 6-7.

I hoitliggende skove temmelig sjelden: Sj. Ledreborg! Boserup! Bidstrupgaard! Hvedstrup (8), Slangerup (H.), mellem Søsum og Knardrup, Ballerup, Jonstrup (14), Hareskoven, Fredriksdal (H.), Nymolle! Kjoge Aas (9)! J. i Aalborg-Egnen (12), Aarslev (H.). F*

\section{8de Klasse. Polyadelphia (Fleerknippede).}

\section{Orden. Polyandria (Mangehannede).}

1. Hypéricum L. Bæger og Krone fembladede; Stovtraadene ved Grunden sammenvoxne i 3 Bundter; 3 Grifler; Frugten en treklappet Kapsel. (N. F. Hyperieineæ). *)

*) Alle vore Arter af denne Slægt have modsatte, mere eller mindre gjennemsigtigt punkterede Blade og gule Kronblade, som ofte 


\section{Polyandria.}

\section{Iypericum. Perikon.}

a. Stingelen fladtrykt-tveægget.

993. H. humifusum L. (Liggende P.) H. 795; Drej. n. 755 ; F. D. 141 ; Rehb. ic. fl. germ. VI, fig. 5176 ; H. N. I, 35 .

Stanglerne talrige, nedliggende; Bladene ovale, med gjennemsigtige Punkter i Vidten og spredte sorte Kirtler mod Randen; Blomsterne i en faablomstret Qvast; Bagerbladene hee]randede eller fjernt-tandede, med sorte Punkter mod Randen paa Underfladen, de tre oval-linieformede, budte med en Braad, de to kortere, laneetformede; Støvdragerne I5-20; Griflerne kortere end Kapselen.

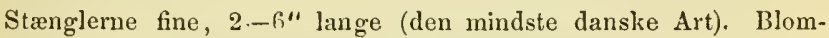
sterne aabne sig kun i Solskin. 6-8. य.

Paa Bakker og torre Marker, ikke sjelden i de fleste Egne af Landet. $¥$

994. II. perforatum L. (Prikbladet P.) H. 794; Drej. n. 756 ; F. D. 1043 ; Rehb. 1. c. fig. 5177.

Stangelen opret; Bladene elliptiske eller ovale, med talrige gjennemsigtige Punkter og faae sorte Kirtler; Blomsterne i rigtblomstrede Qvaster fra Spidsen af Strengelen og Grenene; Bagerbladene ligestore, lancetformede, spidse, heelrandede eller i Spidsen svagt tandede, med sorte Punkter paa Underfladen; Stovdragerne $\infty$; Grifterne læugere end Kapselen.

1-2' høi. Kronbladene med sorte Punkter og Streger i Randen. 7-8. 4 .

$\beta$, angustifolium Gaud. Bladene linieformede, med færre sorte Punkter.

tilligemed Blade og Bægerblade ere forsynede med sorte Kirtler. Den alm. Adskillelse i Arter med eller uden Kirtler i Randen af Brgerbladene er ikke heldig, da idetmindste H. humifusum alm. har sorte Kirtler i Randen, uagtet den angives uden disse, og Forskjellen saaledes ikke er skarp. 
Ved Randen af Veie, paa Diger, Græsmarker o. s. v. meget alm.g. ogsaa i Hedeegne. -- $\beta$, sjeldnere, f. Ex. Sj. Brede Bakker! F alst. Korselitze Skov (Koch); Loll. ved Steensgaard (19); Bornh. Hammershuus (Baagøe).

b. Stængelen firekantet.

995. H. quadrangulum L. [Fr. Nov. p. 237] (Firekantet P.) H. N. XI, 37; Rehb. 1. c. fig. 5178; H. dubium Leers, H. 794 ; H. tetragonum (Fr.) Drej. n. 758.

Stcengelen opret, skarpt firekantet, uvinget; Bladene ovale, budte, med faae (eller ingen) gjennemsigtige Punkter og sorte Kirtler: Blomsterstanden en Top, dannet af faablomstrede Qvaster fra Spidsen af Stængelen og de øvre Grene; Bagerbladene ægformet-ovale, budte, heelrandede, under Blomstringen udstaaende; Kronbladene elliptisk-ovale, budte, med talrige sorte Punkter.

1-2' høi. 7-8. 2.

Ved Veie, paa Græsmarker og tørre Enge alm.

996. II. tetrapterum [Fr. Nov. p. 236] (Firevinget P.) Drej. n. 757 ; Rehb. l. e. fig. 5179 ; H. N. VII, 29; H. quadrangulum H. 793 ; F. D. 640.

Stangelen opret, firekantet-vinget; Bladene ovale, budte, med talrige gjennemsigtige Punkter og en Række af sorteKirtler mod Rauden; Blornsterstanden en tæt Halvskjærm, dannet af mangeblomstrede Qvaster fra Spidsen af Stængelen og de øverste Grene; Bagerbladene laneetformede, tilspidsede, heelrandede, under Blomstringen oprette, efter samme i Spidsen tilbagebøiede; Kronbludene laneetformede, med faae (eller ingen) røde Punkter.

Stængelen $1-2^{\prime}$ høi, ofte rødlig. Kronbladene blegere gule og mindre end hos foreg. 7-8. 4 .

Ved Bredderne af Aaer, Kilder og Grofter: ikke sjelden paa Halvoens Ostkyst, Fyen og de sydlige $\boldsymbol{\theta} e r$ (Burnh. indbefattet), i Sjall. og det nordlige og vestlige Jyll.

\section{c. Stængelen trind.}

997. H. montaum L. (Bjerg-P.) H. $795 ;$ Drej. n. $760 ;$ F. D. 173 ; Rehb. 1. e. fig. 5187. 
Stangelen opret; Bladene siddende, ægformede eller ovale, de øvre med, de nedre uden gjennemsigtige Punkter; Blomsterne i Halvskjærm eller kort Klase, dannet af trt-, men faablomstrede Qvaster; Bargerbladene lancetformede, spidse, med stilkede, sorte Kirtler i Randen; Frøene valseformede, under Lupen fint punkterede.

1-2' høi. Bladene glatte, ofte paa Underfladen rue, var. bredere og smalere, spidse og budte. 7-8. $थ$.

I hoitliggende Skove og paa Bakker mellem Krat, funden $\mathrm{i}$ alle Provindser (med Undtagelse af Lolland og Falster), men sparsom og sporadisk.

998. II. pulchrum L. (Smuk P.) H. 796; Drej. n. 759; F. D. 75 ; Rehb. I. c. fig. 5185 ; H. N. VII, 30 .

Stcongelen opret; Bladene budte, i Randen tilbagerullede, gjennemsigtigt-punkterede; Stongelbladene æg-hjerteformede, siddende og omfattende; Bladene paa Grenene ovale, meget kortstilkede; Blomsterne $\mathrm{i}$ en forlænget Klase, dannet af faablomstrede Qvaster; Bagerbladene omvendt-ægfornede, budte, med sorte, utydeligt stilkede Kirtler i Randen; Frøene valseformede, svagt halvmaaneformigt bøiede, under Lupen fiint punkterede.

Stængelen $1-1^{1} \frac{1}{2}{ }^{4}$ høi, of e rødligt anløben; Bladene glatte, paa Underfladen blaagraae. Kronbladene smukt gule med sorte Kirtler i Randen og alm. brandgule Striber i Spidsen. 7-8. 4.

I høie Skove og paa Lyngbakker: alm. paa Halveen; paa Øerne sjelden: $\boldsymbol{F}$. Hindsgavl (12), Svanninge Bakker, Ilvidkilde (H.); $\boldsymbol{M} \theta$ ens Klint (H.); $\boldsymbol{S} j$. Helsingør (!), alm. ved Hellebrek, Tikjøb! Krogenberg Hegn (Weilbach), Frederiksberg (Dr.)! Bornh. i Almindingen!

999. H. hirsutum L. (Laaden P.) H. 795; Drej. n. 761; F. D. 802 ; Rehb. 1. c. fig. 5189 ; H. N. XI, 48.

Stcengelen opret, tilligemed de agformet-ovale, kortstilkede, gjennemsigtigt-punkterede Blade haaret; Blomsterstanden en forlænget Klase eller Top, dannet af mangeblomstrede Qvaster; Bagerbladene lancetformede, spidse, randhaarede af kortstilkede, sorte Kirtler; Frøene valseformede, under Lupen vortet-punkterede. 
$1^{1 / 2}-3^{\prime}$ høi. Kronbladene bleggule med faae sorte Kirtler i Randen. (Ved Beklædningen let kjendelig fra alle de øvrige Arter). 7-8. 4 .

I Slove og Krat, funden i alle Provindser; hyppig paa Østkysten af Halvoen, i Fyen og paa de mindre $\theta$ er; i Sjall. sparsom.

\section{9de Klasse. Syngenesia (Rörhannede)。 *)}

\section{Orden. S. crqualis (Lige Sambo).}

Blomsterkurvene eenskjønnede (alle Blomsterne $\Varangle$ ).

I. Semiflosculosæ. Alle Blomsterne i Kurven med tungeformede Kroner; Kurvbladene bladagtige; Planten indeholder Mrlkesaft. (N. F. Synanthereæ, a, Cichorace $x)$.

A. Fnokken 0 eller hindeagtig.

1. Lámpsana L. Blomsterleiet nøgent; Kurvdækket toradet, den indre Kreds $8-10$-bladet, med under Frugtmodningen oprette Kurvblade, den ydre Kreds meget kort; Skalfrugterne svagt tyvestribede, med ingen eller utydelig Fnok (Kronerne gule).

*) Alle de i denne Klasse indeholdte Planter høre til N. F. Synanth e reæ. Blomsterne ere tæt samlede $\mathrm{i}$ en lovedformet Blomsterstand (B lomsterkurv), paa en kort, ofte skiveformet Axe (Blomsterleiet) og omgivne af krands- eller spiralstillede Dækblade (Kurvdækket, dets enkelte Blade Kurvbladene). Bægeret sammenvoxet med Fingtknuden, dets Krave fjer-eller haarformet (Fnok), sjeldnere hindeagtig eller 0 ; Kronen regelm. femtandet eller tungeformet, enten eens hos alle Blomsterne i Kurven eller de ydre (Randblomsterne) forskellige fra de indre (Skiveblomsterne). Støvdragerne 5 med sammenvoxne Støvknapper; Frugten en Skalfrugt beklædt med den redblivende Fnok. 
2. Arnóseris Gärtn. Blomsterleiet afdeelt i Rum med hindeagtigt tandet Rand; Kurvdækket enradet, mangebladet (ned faae, korte Skjæl ved Grunden), under Frugtmodningen kugleformigt tillukt; Skalfrugterne femkantede, tistribede, med kort, bindeagtig, faatandet Fnok. (Kronerne gule).

3. Cichórium L. Blomsterleiet afdeelt i Rum med børsteformigt tandet Rand; Kurvdækket toradet, i den ydre Kreds 5 , i den indre 8 Blade; Skalfrugten fladtrykt-kantet, fiint stribet; Fnokken dannet af en kort, hindeagtig, fryndset Rand (Kronerne blaae, røde eller hvide).

B. Fnokken haarformet $(0$ : Straalerne udeelte, alm. fiint saugtakket-rue).

a. Bægerrøret forlænget udover Skalfrugten i Form af et $\mathrm{N} æ b$ nedenfor Fnokken.

4. Taráxacum Hall. Kurven mangeblomstret; Blomsterleiet nøgent; Kurvbladene i $2-3$ Kredse, i den indre Kreds længere; Skalfugten trind, svagt sammentrykt, ribbet; Ribberne foroven (henimod Nrbet) skjælformigt piggede.

5. Lactúca L. (part.) Kurven faablomstret; Blomsterleiet nøgent; Kurvbladene i $2-3$ Kredse, i den ydre Kreds meget korte, Skalfrugten fladtrykt, med jævne Ribber; Fnokken sneehvid.

b. Skalfrugterne uden $\mathrm{N} x$ b (eller svagt indsnørede mod Spidsen),

aa. fadtrykte.

6. Sonchus L. Blomsterleiet nogent; Kurvdakket efter Afblomstringen ved Grunden udvidet, med taglagte (spiralstillede) Kurvblade; Skalfrugten ribbet paalangs og ofte svagt stribet paatværs; Fnokken blød, sueehvid.

bb. Skalfrugterne $i$ Gjennemsnit ncesten trinde.

7. Crepis L. Blomsterleiet grubet med svagt haarettaudet Rand, uden Avner; Kurvbladene toradede, den ydre 
Kreds kortere; Skalfrugten 10-20-stribet, med jævne Striber, lidet bredere ved Grunden og $\mathrm{i}^{\circ}$ Midten end i Spidsen (foroven. afstumpet eller svagt afsmalnet), med blød, sneehvid Fnok.

8. Arácium Neck. Blomsterleiet grubet, uden tandet Rand; Kurvdakket under Blomstringen valseformet, med toradede, i den ydre Kreds kortere Kurvblade; Skalfrugten tistribet, med jævne Striber, lidet bredere ved Grunden og $i$ Midten end i Spidsen; Fnokken skjør, skidenguul.

9. Ilieráciun L. (part.) Blomsterleiet grubet, med svagt tandet Rand; Kurvdækket taglagt; Skalfrugten tiribbet, med jævne Ribber, ligebred overalt eller smalere ved Grunden; Fnokken skjør, guulhvid eller skidenguul.

C. Fnokken fjerformet (o: Straalerne med tydelige Sidegrene).

a. Skalfrugten med $\mathrm{N} æ b$.

10. Hypochæris L. Blomsterleiet beklædt med hurtigt affaldende, linieformede Avner; Kurvbladene spiralformigt taglagte; Skalfrugten stribet paalangs, og langs Striberne ru. (Bladene tandede).

11. Tragopógon L. Blomsterleiet grubet, Gruberne med en ophøiet Rand; Kurvdækket toradet med ligelange, ved Grunden sammenvoxne Kurvblade; Skalfrugten af Randblomsterne ribbet paalangs og, især foroven, langs Ribberne pigget. (Bladene heelrandede).

b. Skalfrugten uden $\mathrm{N} x$ (eller svagt indsnoret i Spidsen).

aa. Fnolkens Sidestraaler indvavede $i$ hinanden.

12. Scorzonéra L. Kurvbladene spiralformigt taglagte, de ydre brede, de indre i Randen hindeagtige; Blomsterleiet fint vortet, uden Avner; nogle af Fnokkens Straaler længere, i Spidsen ikke fjerede. (Bladene heelrandede). 


\section{b6. Fnokkens Sidestraaler frie.}

๙. Randblomsternes Fnok kort, hindeagtig, tandet.

13. Thrincia Roth. Kurvdækket taglagt; Skalfrugten i Spidsen indsuøret, oventil ru; Fnokken sneehvid.

B. Fnokken eens hos Rand- og Skiveblomster.

14. Leointodon L. (part.) Kurvdækket taglagt; Skalfrugten i Spidsen indsnøret, riflet paatværs eller lidet ru; Fnokken skjør, skidenguul, vedblivende, dens Straaler frie, alle eens eller en ydre Kreds kortere, baarformede.

15. Picris L. De ydre Kurvblade taglagte, tilbagebøiede, de indre meget længere og indbyrdes ligelange, oprette; Skalfrugten indsnøret i Spidsen, riflet paatværs; Fnokken blød, sneehvid, affaldende, dens Straaler ved Grunden sammenhængende.

(Hypochceris glabra var.).

II. Capitata. Alle Kronerne rørformede; Kurvbladene alm. stive, Kurven mere eller mindre kugleformet. Ingen Mrlkesaft (N. F. Synanthereæ b, Cyuarex).

A. IKurvbladene $\mathrm{i}$ Spidsen hagekrummede.

16. Lappa Tournef. (Árctium L.). Blomsterleiet beklædt med børsteformede Avner; Støvknapperne med traadformede Tilhængsler ved Grunden; Fnokkens Straaler i flere Kredse, korte, haarformede, affaldende.

B. Kurvbladene spidse, alm. stikkende.

a. Fnokken harformet, ru.

17. Serrátula L. Blomsterleiet beklædt med Avner; Kurvdækket ægformet med taglagte, spidse, ikke tornspidsede Kurvblade; Støvknapperne uden Tilhængsler; Fnokken vedblivende, dens Straaler frie, i flere liredse, den indre Kreds længere end de øvrige. 
18. Onopórdon L. Blomsterleiet afdeelt i flere Rum meä hindeagtigt tandet Rand; Kurvdækket kugleformet med taglagte, tornspidsede Kurvblade; Støvtraadene glatte, Støvknapperne uden Tilhængsler; Fnokkens Straaler forneden sammenvoxne til en Ring, tidligt affaldende.

19. Círluus L. (part.). Blomsterleiet beklædt med Børster eller Haar; Kurvdækket kugleformet eller aflangt; Støvtraadene haarede; forøvigt som foreg.

(Centaurea decipiens) 19, 3.

b. Fnokken fjerformet.

20. Cirsium Tournef. Blomsterleiet beklædt med Børster eller Avner; Kurvdækket taglagt; Støvtraadene frie, Støvknapperne uden Tilhængsler; Skalfiugten glat; Fnokkens Straaler enkelte, ved Grunden sammenvoxne til en Ring.

21. Silybum Gärtn. Støvtraadene sammenvoxne; Fnokkens Straaler med meget korte Sidegrene; forøvrigt som foreg.

22. Carlíma L. Blomsterleiet beklædt med fligede Avner; Kurvbladene taglagte, de ydre oprette, stikkende, de indre udstaaende, hindeagtigt-raslende; Støvtraadene frie, Støvknapperne med hver 2 traadformede og fjerede Tilhængsler ved Grunden; Fnokken grevet, med fjerede Grene; Skalfrugten tæu beklædt med tiltrykte Haar.

III. Discoidece. Alle Kronerne rørformede; Kurven. valseformet, med urteagtige eller hindeagtige Kurvblade. Ingen Mælkesaft (N. F. Synanthereæ c, Eupatoriace $æ)$.

23. Bidens L. Blomsterleiet beklædt med skjælagtige Avner; Kurvbladene i 2 Kredse, den ydre Kreds udstaaende; Arrene lancetformede; Skalfrugten fladtrykt; Fnokken dannet af 2-5 Børster eller Stak med nedadvendte Smaatorne.

24. Enpatórium L. Blomsterleiet nøgent; Kurvdækket faabladet, taglagt; Arrene meget lange, traadformede; Skal- 
frugten stribet eller kantet, med haarformet, mangestraalet Fnok.

(Artemisia maritima) 19, 2.

\section{Orden. S. superflua (Overflodig Sambo).}

Blomsterne i Kurven forskjelligkjønnede (i Randen $q$, i Skiven $\Varangle$ \%

I. Discoidece. Alle Kronerne rorformede (undtagen hos Nr. 26). N. F. Synantherex c, Eupatoriaceæ.

A. Kurvbladene i 1 eller 2 líredse (i den ydre Kreds mindre).

25. Petasites Gäitn. Fleerbo (den ene Plante $(\not)$ bærer Kurve med $\Varangle$ Blomster i Skiven og falae $q$ Blomster i Randen, den anden ( $q$ ) med $q$ Blomster i Randen og faae $\delta$ Blomster eller golde ఫ Blomster i Skiven)*). Blomsterleiet nøgent; $\Varangle$ Blomsterne skjævt afskaarne, næsten tungeformede, $\hat{\delta}$ og $\not{q}$ Blomsterne femtandet-røformede; Fnokken haaret. (Blomsterkurvene klaseformigt saulede).

26. Tussiligo L. (part.)**). Enbo: Randblomsterne $q$ i flere Kredse, med tungeformet Krone. Skiveblomsterne $\Varangle$ med rorformet, femtandet krone, forøviigt som foreg., men Blomsterkurven enlig, endestillet.

(Senecio vulgaris) Enbo (II).

B. Kurvdækket taglagt.

a. Fuokken 0 eller avneformet.

27. Artemísia L. Blomsterkurvene kugleformede eller ægformede; Blomsterleiet nøgent eller haaret; Skivekronerne

*) Hos $\Varangle$ Planten af $P$. officinalis lar jeg fundet Skiveblomsterne $q$ og frugtbare, Randblomsterue $\Varangle$ ufrugtbare, med kort Griffel og ofte firekløvet Kroue.

**) Denne Slægt hører ifølge den kunstige Iuddeling til den følgende Afdeling (Radiatæ), men paa Grund af dens noie naturlige Slægtskab med Petasites har jeg anført den ved Siden af denne. 
rørformede; Randkronerne traadformede; Skalfrugterne fladtrykttrekantede, uden Fnok (Blomsterstanden en Top).

28. Tanacétum L. Blomsterkurvene fladtrykt-halvkugleformede; Blomsterleiet nøgent, med ophøiede Vorter; Skivekronerne femtandede, Randkronerne tretandede; Skalfrugterne femkantede; Fnokken dannet af en svag Hindekant (Blomsterstanden en Halvskjærm).

29. Cótula L. Blomsterkurv og Blomsterleie som foreg.; Skivekronerne fretandede, Randblomsterne kronløse; Støvdragerne med bornformede Tilhængsler i Spidsen; Skalfrugterne fladtrykt-vingede, uden Fnok; Randblomsternes Frugter stilkede, Skiveblomsternes siddende. (Blomsterkurvene enlige i Spidsen af Grenene).

(Matricaria discoidea) II.

(Anthemis Cotula $\beta$, disciflora) II.

b. Fnokken haarformet.

30. Gnaphálium L. Kurvbladene hindeagtigt-raslende; Skivekronerne rorformede, femtandede, Randkronerne traadformede, i Spidsen udvidede, 3--5-tandede; ingen Blomster mellem Kurvbladene; Arret tokløvet saavel hos Rand- som Skiveblomsterne; Fnokken hos alle Blomsterne eens.

31. Antennária Gärtn. Trebo: Den ene Plante (ठే) bærer golde $\Varangle$ Blomster, den anden $(q)$ frugtbare $q$ Blomster. $\widehat{o}$ : Kronerne rørformede; Arret udeelt; Fnokkens Straaler i Spidsen kølleformigt udvidede. $q$ : Kronerne traadformede; Arret tokløvet; forøvrigt som foreg.

32. Filágo L. (Fr. Nov. p. 267). Kurvbladene urteagtige eller kun $\mathbf{i}$ Randen hindeagtige; $\mathbf{i}$ den yderste Kreds 5 ligestore; Skivekronerne rørformede, firetandede, Randkronerne traadformede, i Spidsen udvidede, 4-5-tandede; 1 eller flere Rækker Blomster uden Fnok mellem de øvre Kronblade.

(Inula Conyza) II. 
II. Radiatce. Skivekronerne rørformede, Randkronerne tungeformede. (N. F. Synantherer d, Radiatæ).

A. Fnokken 0 eller hindeagtig.

a. Blomsterleiet uden Aver.

aa. Kurvbladene ligelange.

33. Bellis L. Skiveblomsternes Ar i Spidsen fladtrykte; Skalfrugterne fladtrykte med en smalvinget Rand, uden Fnok.

\section{bb. Kurvbladene taglagte.}

34. Chrysinthemum L. (part.). Kurvdækket halvkugleformet; Blomsterleiet hvælvet eller fladt, ikke huult; Skiveblomsternes Skalfrugter trinde, stribede, Randblomsternes trekantede eller mangefurede; Fnokken 0 eller i Form af en svag Hindekant.

35. Matricária L. (part., Fr. Mant. 3, 114). Kurvdækket under Blomstringen fladt; Blomsterleiet kegleformet eller hvælvet, mod Frugtmodningen indvendig huult; Skiveblomsternes Skalfrugter trekantede, forøvrigt som foreg.

b. Blomsterleiet beklædt med Avner eller Skjæl.

36. Ánthemis L. Blomsterkurven flad eller halvkugleformet; Straaleblomsterne talrige, med aflang Krave; Skalfrugterne trinde eller fladtrykt-firekantede, med en svag Hindekant istedetfor Fnok.

37. Achilléa L. Blomsterkurven valseformet; Straaleblomsterne faae $(4-10)$ med rundagtig Krave; Skalfrugterne fladtrykte, uden Fnok.

† Galinsóga liuiz \& Pav. Blomsterkurven halvkugleformet; Straaleblomsterne faae (4-5) med rundagtig Krave; Skalfrugten kantet, tiltrykt-haaret, Fnokken hindeagtig, med oventil fryndsede Flige.

Haundh, i den danske Floro. 


\section{B. Fnokken haarformet.}

a. Kurvbladene taglagte, uligelange (Skiveblowsternes Ar fladtrykte, paa Inderfladen ha arede).

aa. Stovknapperne med haarformede Tilhangsler ved Grunder.

38. Ínula L. Blomsterleiet nøgent, punkteret; Straaleblomsterne talrige, eensfarvede med Skiveblomsterne (gule).

bb. Støvknapperne uden Tilhangsler.

«. Straale- og Skiveblomsterne eensfarvede (gule).

39. Solidigo L. Blomsterkurvene valseformede; Blomsterleiet nøgent, grubet; Straaleblomsterne faae; Skalfrugterne trinde.

$\beta$. Strate- og Skiveblomsterne forskjelligfarvede.

40. Erigeron L. Blomsterleiet grubet, uden Avner; Straaleblomsterne talrige, i flere Kredse, de indre ofte med traadformet eller ingen Krave; Skalfrugterne fladtrykte, med enradet, mangestraalet Fnok.

11. Aster L. (part.) Blomsterleiet grubet, Gruberne omgivne af en tandet Rand; Straaleblomsterne talrige, i 1 Kreds, alle tungeformede; Skalfrugterne fladtrykte, med fleerradet; mangestraalet Fnok.

b. Kurvbladene i 1-3 Kredse (med indbyrdes: ligelange Blade i hver Kreds).

aa. Skiveblomsternes Ar fadtrykte, paa Inderfladen haarede.

† Stenáctis Cassin. Kurvbladene i 2 Kredse; Blomsterleiet med fine (kun under Lupen synlige) Avner; Straaleblomsterne i 2 Kredse (forskjelligfarvede fra Skiveblomsterne); Skalfrugterne fladtrykte; Fnokken bos Skiveblomsterne toradet (den ydre Kreds kort), hos Straaleblomsterue enradet. . 
bb. Shiveblomsternes Ar trinde, $i$ Spidsen udvidede og penselhaarede.

ж. Skiveblomsterne med, Straaleblomsterne uden Fnok.

42. Dorónicum L. Blomsterleiet grubet, mellem Gruberne finthaaret; Kurvdækket fladt eller halvkugleformet, dets Blade i 2-3 Kredse; Skalfrugterne næsten trinde, furede.

B. Alle Blomsterne nden Fnok.

43. Senécio L. Blomsterleiet grubet, mellem Gruberne finthaaret; Kurvdækket valseformet eller klokkeformet, dets Blade i 2 Kredse, den ydre Kreds kortere (Kurvbladene i Spidsen brandplettede; Stængelbladene spredte).

44. Cineríria L. Blomsterleiet nøgent; Kurvdxklset valseformet, dets Blade i 1 Kreds (ikke brandplettede), forøvrigt som foreg.

45. Áruica L. Blomsterleiet grubet, Grubernes Rand finthaaret; Kurvdækket valseformet, med 2 Kredse af ligelange Kurvblade; Straaleblomsterne red Grunden af Kraven forsynede med 5 ikke sammenvoxne golde Støvdragere (Stængelbladene modsatte).

Tussilago (I).

\section{Orden. S. prustranea (Unytlig Sambo).}

Skiveblomsterne ధॄ, Randblomsterne kjønsløse.

46. Centauréa L. Blomsterleiet beklædt med Børster eller Avner; Kurvdækket xg- eller kugleformet, dets Blade taglagte, med hindeagtige, ofte fryndsede eller tornede Tilhængsler; Skivekronerne rørformede, Randkronerne uregelm. tragtformede; Griffelen under Arret udvidet; Fnokken haarformet eller 0 .

$\dagger$ Helianthus L. Blomsterleict fladt eller lidet hvælvet, beklædt med skjælformede Anner; Kurvdækket dannet af taglagte, gronne Kurvblade, Skivekronerne rorformede, Randkronerne tungeformede; Griffelen valseformet, ikke udvidet; 
Skalfrugten kantet-fladtrykt; Fnokken dannet af 2-flere affaldende Borster.

† Rudbéckia L. Blomsterleiet kegleformet; Kurvbladene toradede, udstaaende; Skalfrugteu firekantet, bredere foroven, Fnok 0 eller kort, uregelmæssigt tandet, forøvrigt som foreg.

(Bidens cernua radiata). $(19,1)$.

\section{Orden. S. necessaria (Nodvendig Sambo).}

47. Caléndula L. Randkronerne frugtbare med tungeformede Kroner og tofligede Ar; Skiveblomsterne $\Varangle$ ufrugtbare med rorformede Kroner og kugleformede Ar; Skalfrugterne forskjelligformede (alm. baadformede), uden Fnok.

\section{Orden. S. segregata (Scerskilt Sambo).}

48. Échinops L. Blomsterkurvene enblomstrede, med taglagt Kurvdække; mange Kurve samlede i et kugleformet Hoved; Fnokken kort, borsteformet.

\section{Orden. Monogamia (Sarbo).}

Impatiens

Lobelia

$\left.\begin{array}{l}\text { Lobelia } \\ \text { Solanum }\end{array}\right\}$ Blomsterne ikke samlede i en Blomsterkurv. $(5,1)$.

\section{Syugenesia aqualis.}

\section{Lampsana. Ilaremad.}

1000. L. communis L. (Almindelig H.) Lapsana comm. H. 827 ; Drej. n. 762 ; F. D. 500 ; Rehb. ic. fl. germ. XIX, tab. 1353. Stangelen opret, foroven grenet og dannende en sammensat Halvskjærm*); de nedre Blade lyreformet-fjersnitdeelte, Stcengelbladene bugtet-tandede; Blomsterkurvene faablomstrede.

Mere eller mindre haret, Haarene ofte med rode Kirtler. 7-8. $\odot$. Ved Veigrøfter, i Haver, Skove o.s.v., meget alm.

*) Den alm. saakaldte Halvskjærm hos en stor Mængde Arter i denue Familie er strængt taget en Qvast, idet den øvre Kurv 


\section{Arnoseris. Svineøie.}

1001. A. pusilla [Gärtn. Fruct. 2, p. 355 t. 157] (Liden S.) Hyoseris minima L., H. 825 ; F. D. 201; Rehb. 1. e. XIX, tab. 1354, fig. 1 ; H. N. II, 17.

Bladene omvendt-ægformede, tandede, rosetteformigt samlede ved Grunden; Stonglerne flere fra Grunden, bladløse, udeelte eller 1-2.grenede; Grenene med et skjælformet Dakblad ved Udgangspunktet fra Stængelen, forneden traadsmale, opadtil efterhaanden tykkere og under Blomsterkurven hule.

$2-10^{\prime \prime}$ hoi. Kronerne gule. 7-8. $\odot$.

Dyrkede Marker par let, sandig Grund: paa Halve en hyppig i Hedeegnene, paa Øerne temmelig sjelden: $\boldsymbol{F}$. Strib, Assens (H.), Kirkeby! Thorseng verl Bregninge (12); Langel. ved Steengade (19); Loll. mellem Kjettinge og Gronnegade (5); Falst. Bregninge Molle, Halskov (14); $\boldsymbol{j}$. Skaaninge By ved Jægerspriis, mellem Ørsholt og Louisenlyst oved Helsingør (21); Bornh. Arnager! o. fl. St. (H.).

\section{Cichorium. Cikorie.}

1002. C. Intybus L. (Almindelig C.) H. 827; Drej. n. 763 ; F. D. 907 ; Rehb. l. c. XIX, tab. 1357, fig. 2.

Stcengelen opret, med stive Grene; de nedre Blade halvtomfattende, høvlformet-balvfinnede med tandede Flige, de qvre laneetformede med piilformet omfattende Basis, heelrandede; Kurvene $1-3$, siddende eller kortstilkede, $\boldsymbol{i}$ hvert af de ørre Bladhjørner.

Stængelen og Bladene haaret-rue. Kurvbladene ofte kirtelhaarede. Kronerne blaae, sjeldnere livide eller lila. 7-9. 4 .

Ved Veie og Gjærder, paa udyrkede Marker: alm. i de fleste Egne, men aftager eller forsvinder i de magrere Egne, savnes $f$. Ex. omkring Helsingør (21) og er sjelden i det Indre af Halvøen: J. Skjærhoved! $S l$. Rødding, Husum (16).

\section{Taraxacum. Malkebotte.}

1003. T. officinale [Web. Prim. fl. Hols. p. 56] (A]mindelig M.) Drej. n. 781 ; T. off. $\alpha$, genuinum Koeh, Lge.

udvikles forst og derpan efterhaanden de i Ordenen nedenfor samme, men da de nedre Grene alm. 'overgaae de øvre i Laengde, nare de sædvanligt lige Høide foroven. 
Haandb. 1 Udg. S. 447; Rehb. I. c. XIX, tab. 1404 ; Leontodon Turaxacum L., H. 812 ; F. D. 574.

Roden tapformet; Bladene alle samlede ved Grunden, høvlformet-balvfinnede eller tandede; Skafterne oprette eller opstigende, blad]øse, trinde, hule, med en enlig Kurv i Spidsen; de ydre Kurvblade tilbagebøiede, lancetformede, foroven afrundede, uden eller med en svag Pukkel i Spidsen; Skalfrugten grønlig-graa, foroven stærkt pigget.

Kronerne gule. 5-9. ข. Var. betydeligt i Henseende til Bladenes Indskjæring, Beklædning o. s. v. Ukrud.

Paa Græsmarker, i Haver, ved Veie o. s. v., overalt et almindeligt

1004. T. erythrospermum [Andrz. i Bess. Fl. podol. II, n. 1586] (Kambladet M.) F. D. 2594 ; T. offic. $\beta$, glaucescens Koch Syn. II, 492, Rchb. I. c. tab. 1405, fig. 1; Lge. l. c. S. 448 ; T. off. $\beta$, arenarium Drej.; L. Tarax. 3 , obliquus Fr. nov. p. 245 ; H. N. XIII, 31 ; L. corniculatus Kit.

Bladene mellembrudt- og høvlformet-snitdeelte med langstrakt-triangelformede, kamagtigt tætsiddende Afsnit; de ydre Furvblade æg-lancetformede, vandret udstanende, de indre linieformede, med udvidet, afrundet Spidse og en Pukkel umiddelbart nedenfor samme; Skalfrugten rødbruun (eller graabruun), forøvrigt som foreg.

Planten blaagraa, alle dens Dele mindre og finere end foreg. Var. med de ydre Kurvblade tiltrykte. 5-6. ข.

Paa Lyngheder, tøorre Marker og Sandbakker, ikke alm., nıen bemærket $i$ alle Provindserne.

1005. T. palustre [DC. Fl. Fr. IV, p. 45] (Eng-M.) T. off. I, palustre Fr. I. c., H. N. XIII, 29, Lge. S. 448; L. p)alustris Sm., F. D. 1708 og (L. obliquus) 1935; T. off. $\varepsilon$, lividum Koch.

Bladene bøvlformet-snitdeelte, med fjerne, smalt-linieformede eller korte triangelformede Afsnit; Skaftet nedbøiet eller op. stigende; de ydre Kurvblade ægformede, tiltrykte, de indre uden Pukkel i Spidsen; Skalfrugten grønlig-bruuw, foroven svagt pigget. 
Aldeles glat og næsten glindsende, Skaft og Bladstilke ved Grunden rodviolette. 5-6. 4 .

Paa Enge, især Strandenge: $\boldsymbol{S} \boldsymbol{j}$. Helsingør (Heiberg), Frederikssund, Bognæs (19), Kattinge (14) og Hersløv red Roeskilde! Engen ved Leersøen! Amager (27), bag Flaskekroen (Dr.); B or $n$ h. ved Listed Fiskerleie (Baagøe)! Ronne (19); Loll. ved Ulsløv Sø (Koch)! Bukkehave Molle paa Thorseng (12); J. alm. ved Ranum (8), Hobro (16); Sl. Strandenge ved Flensborg, Langballe Aa i Angel (16).

Anm. Ifolge Hr. Rostrups Iagttagelse gaaer Skalfrugten hos denne Art jæevnt over $\mathrm{i}$ Nabet, hvis nedre farvede Deel er $1 / 3$ af Frugtens Liengde, hos de 2 foreg. Arter er Overgangen fra Skalfingten til Nabet mere pludselig og dettes farrede Deel kun $1 / 4$ af Frugtens Længde.

\section{Lactuca. Laktuk.}

a. Næbet halvt saa langt som eller af lige Længde med Skalfrugten. Blomsterne gule.

1006. L. muralis [Fresenius Taschenb. 1832, p. 481] (SkovL.) Prenanthes L., H. 812 ; F. D. 509 ; Mycelis Rehb. ic. A. germ. XIX, tab. 1417; Drej. n. 783.

Bladene med vinget, ved Grunden piilformigt-øret Bladstilk, høvlformet-snitdeelte, med kantede eller grovt tandede Afsnit; Blomsterne i en Top med traadfine, faablomstrede Grene; Kurvbladene i 2 Kredse: den indre Kreds fembladet, mange Gange langere end den ydre; Blomsterkurvene omtrent femblomstrede; Skalfrugtens Næb flere Gange kortere end Fnokken.

Bladene glatte, mat-blaagronne. Kurvbladene alm. rodbrune. Kronerne gule, Skalfrugten morkbrnun. 7-8. $\odot$ eller 4 .

Paa løs Muldjord i Løvskove, alm. udbredt.

1007. L. Scariola L. (Tornbladet L.) H. 811 ; Drej.n. 782 ; F. D. 1227 ; Rehb. l. c. XIX, tab. 1421, fig. 1; H. N. VIII, 4.

Bladene tværsstillede, siddende, med piilformet Basis, høvlformet-halvfinnede, (de øvre hele), i Randen tornet-tandede, paa liygnerven tornede; Toppen pyramideformet, med mangeblomstrede Grene; Blomsterturvene mangeblomstrede, med taglagte Kurvblacle; Skalfrugtens Nob af Længde med Fnokken.

Kronerne gule. Skalfrugterne blegbrune. 7-8. ๑).

Ved Veigrofter omkring Byer og beboede Steder: $\boldsymbol{S} \boldsymbol{j}$. i Kbharns Omegn alm., f. Ex. hist og her par Voldene, langs Veien til Lunde- 
huset! Amager (Dr.), forøvrigt sjelden: Magleby, Skjelskør (Nielsen), Vordingborg; $\boldsymbol{F}$. ved Odense Kanal (H.); J. Diger ved Ribe (6).

$\dagger$ L. sativa L. (Salat) Rchb. 1. c. tab. 1421, fig. 3. Adskilt fra foreg. ved bredere, mindre indskaarne, ikke tværsstillede Blade alm. uden Torne, Blomsterne $i$ en halvskjærmformet Top, dyrkes i Kjøkkenhaver og forekommer stundom forvildet omkring disse.

b. Næbet meget kort. Blomsterne lila. (Mulgedium C ass.).

$\dagger$ L. Plumieri Gren. \& Godr.; Sonchus L.; Mulgedium DC., Rehb. 1. c. XIX, tab. 1416 ; Stcengelen opret, stribet, glat, blaadugget; Rodbladlene store, høvlformet-fjersnitdeelte med spydformet Endeafsnit og vinget Bladstilk; Stcengelbladene omfattende Stængelen med afrundede Ører; Blomsterkurvene talrige i Halvskjærm; Kurvbladene taglagte, glatte. 7-8. 4.

Forvildet red Nykjøbing paa Falster (Lütken)! (Vildroxende i Syd-Europa).

$\dagger$ L. macrophylla (Sonchus macrophyllus Willd.). Stængelen foroven, Bladenes Underflade og Kurvbladene tæt stivhaarede af alm. kirtelbærende Haar; Rodbladene meget store, hjerteformede eller lyreformede med bjerteformet Eudeafsnit; Kurvene større, høiere af Væxt, forøvrigt som foreg. 7-8. 4.

Paa Bakken ved Søllerød Kro, forvildet (Petersen, 15)! (Vildvoxende i Nordamerika).

\section{Sonchus. Svinemalk.}

a. Blomsterstilkene og Kurvbladene kirtlet-børsteha arede. 4.

1008. S. palustris L. (Kjær-S.) H. 808; Drej. n. 787 ; F. D. 606 (S. arvensis) og 1109; Rchb. ic. XIX, tab. 1414.

Stcengelen i Spidsen skjærm- eller halvskjærmformigt grenet, med qrastblomstrede Grene; Bladene i Randen fiint tornettandede, ved Grunden piilformigt omfattende med nedadvendte Ører, de nedre høvlformede, de øvre hele; Skalfrugterne furede paalangs og svagt riflede paatrærs.

$4-8^{4}$ høi. Rodstokken uden Udlobere. Kronerne lysgule. 7-8. 
Ved Aaer og Grofter, især i Strandegne, hvor Saltvandet af og til gaaer op i Grofterne, sjeldnere ved Frrskvandssøer og Bredderne af selve Havet: paa Malvoens Gstkyst alm. ved Fjordene fra VeileFjord til Eiderkanalen! paa Oerne sporadisk: $\boldsymbol{F}$. Middelfart (12), Langensø (13), Odense Kanal, Ulriksholm, Hverringe (H.), Christiansminde ved Svendborg! Thorseng og Langel. ikke sjelden (12); L oll. Gottesgabe (19), Fuglsang Slots Ruiner; Falst. iklke sjelden $\bmod$ V. (14); $\boldsymbol{S} j$. Vordingborg (14), Lindersvold (H.), Holsteinborg, Basnas, Borreby (Nielsen), Parnas ved Soro (Bredsd.), Kastellet og Kirsebærgangene ved Kbhavn (II.), Arre Sø (Rafn).

1009. S. arrensís L. (Ager-S.) H. 809; Drej. n. 786; Rehb. l. e. XIX, tab. 1412.

Rodstokken med Udløbere; Stcengelen i Spidsen skjærmeller halvskjærmformigt grenet, med 1 eller faae til en Qvast samlede Kurve paa Grenene; Bladene høvlformede, halvfinnede eller bugtede, ved Grunden hjerteformigt omfattende med tilbagebøiede Ører, i Randen grovt tornet-ta:ıdede; Skalfrugterne stribede paalangs og svagt riflede paatværs.

2-4' høi. Kronerne morkgule. 7-8. Var:

$\boldsymbol{\beta}$, integrifolius! F. D. 2543. Bladene hele, linieformede, fint tandede, Stxngelen med 1 eller faae Kurve.

$\gamma$, lavipes Koch. (maritimus Retz.) Blomsterstilkene glatte, Kurvbladene svagt kirtelhaarede eller glatte.

Almindeligt og meget besværligt Ukrud paa Marker mellem Sæden, ved Veie o. s. v. - $\beta$, i Sandklitter ved Skagen (Drej.) og Fjaltring! $\gamma$, hist og her, især ved Strandbredder.

b. Kurvbladene typisk glatte. $\odot$.

1010. S. asper [Vill. Fl. delph. 3 p. 158] (Ru S.) Drej. n. 785 ; F. P. 843 ; Rchb. I. e. XIX, tab. 1410 , fig. 2 ; S. oleraceus asper H. 810 .

Blomsterstanden skjxrmformet; Bladene hele eller høvlformet-bugtede, ved Grunden hjerteformigt ornfattende med tilbagebøiede Ører, i Randen tornet-tandede med uligestore Tænder; Skalfrugterne smalt vingede, jævne, stribede paalangs.

$1-2^{\prime}$ høi. Bladene alm. Iæderagtige, ofte glindsende. Kronerne gule, paa Underfladen rodlige. 6-9.

$\beta$, inermis Bischoff, Rehb. l. e. XIX, tab. 1411; Bladene høvlformet-fjersnitdeelte eller halvfinnede, med frerre og ikke tornede 'Trncler. (Ligner i Udseende følg. Art.) 
Paa dyrket Jord i Haver, ved Gjærder og mellem Sxden, ikke sjelden. $\beta$, list og her med Hovedarten.

1011. S. oleraceus L. (Almindelig S.) H. 809 ; Drej. n. 784 ; F. D. 682 ; Rehb. 1. c. XIX, tab. 1410 fig. 1.

Bladene høvlformet-halvfinnede eller -fjersnitdeelte, ved Grunden piilformigt omfattende med lige udstaaende $\varnothing$ rer, i Randen grovt tandede; Skalfrugterne uvingede, stribede 'paalangs og riflede paatværs; forøvrigt som foreg.

1-2' høi. Bladene mere slappe, matgronne eller blaagraue. Kronerne bleggule. Var. ined kirtelhaaret Kurvdække. 6-9.

Paa dyrket Jord alm., især et besværligt Ukrud i Haver.

\section{Crepis. Ilogeslijag.}

a. Stængelen bladbærende (Crepis DC., Fr.).

1012. C. biennis L. (Toaarig H.) H. 824 ; Drej. n. 769 ; F. D. 1997 ; Rchb. ic. f. germ. XIX, tab. 1439 ; H. N. II, 5. Stcengelen opret, i Spidsen halvskjærmformigt grenet; $\mathrm{Bla}$ dene høvlformet-halvfimmede, i Randen flade; Stangelbladene med oreformigt omfattende Basis; Kurvbladene linie-lancetformede, paa Inderfladen silkehaarede, de ydre udstaaende, de indre tiltrykte; Griflerne gule; Skalfrugterne 13-16-stribede, skident straagule, i Spidsen uden Nab.

Stængelen furet, $1-3^{\prime}$ hoi, tilligemed Bladene mere eller mindre stivhaaret. Kurvene meget storre end hos de folg. 6-7. $\odot$.

Ved Veie og paa Marker, især paa Leer- og Kalkgrund, liist og her i alle Provindser, især hyppig i Roeskilde-Egnen, Syd-og Vestsjalland, sydl. Fyen, Loll., Falst. og Bornh.

1013. C. tectorum L. (Tag-H.) H. 823 ; Drej. n. 770 ; Rehb. I. c. XIX, tah. 1442 (1452).

Stcengelen opret, omtrent fra Midten halvskjærmformigt grenet; Rodbladene lancetformede, høvlformet-halvfinnede eller tandede, Stangelbladene linieformede, heelrandede, med tilbagerullet Rand og piilformigt halvt-omfattende Basis; de ydre Kurvblade linieformede, udstaaende, de indre lancetformede, tiltrykte, paa Inderfladen tiltrykt-haarede; Griflerne grønligt brune; Shal- 
frugterne kastaniebrune, tistribede, i Spidsen afsmalnede til e t kort, ru Næb.

Stængelen 1-2' høi, furet, dunnhaaret. Kronerne gule. 6-8. $\odot$.

$\beta$, segetalis Roth, H. N. II, 6 ; C. strieta Sehultz, H. 824 . Bladene heelrandede eller svagt tandede, Grenene stivt oprette, fine, en- eller faablomstrede.

Paa dyrkede Marker mellem Sæden, ved Veie, alm. udbredt. (Navnet, som er hentet fra dens tilfæeldige Forekomst paa Huustage, er mindre passende). $\beta$, med Hovedarten. I*

1014. C. virens L. (Grøn H.) Drej. n. 768; F. D. 2544 ; Rehb. l. e. XIX, tab. 1441 (1451).

Stangelen opret eller opstigende, grenet, ofte fra Grunden af; Rodbladene høvlformet-snitdeelte, balvfinnede eller tandede; Stcengelbladene linie-laneetformede, i Randen flade, heelrandede eller især mod Grunden fliget-tandede og piilformigt omfattende; Kurvbladene alle tiltrykte, de ydre linie-børsteformede, de indre linic-laneetformede, paa Inderfladen glatte; Griflerne gule; Skalfrugterne skident blegbrune, tistribede, jævne, uden Næb.

Bladene frisk gronne, tilligemed Stængelen næsten glatte. Kronerne gule. 7-9. $\odot$. Var. betydeligt i Henseende til Høiden, Stængelens Retning, Bladenes Form og Indskjæring. De meest iøinefaldende Former ere:

$\beta$, elatior Drej. $\mathbf{1}^{\mathbf{1} / 2}-2^{\prime}$ høi, opret, de nedre Blade høvlformet-snitdeelte, de øvre linieformede, ved Grunden fligede.

$\gamma$, capillaris Fr. ( $\alpha$. multieaulis Kph. i Drej. fl. exe.) F. D. 2545 ; C. diffusa DC. Lav og spæd, med oftest talrige, nedliggende Stængler, traadfine Blomsterstilke.

Ved Gjærder, paa Marker o. s. v., ikke sjelden i de fleste Egne af Landet, især hyppig paa Ostkysten af Halvoen (omtrent fra Randers mod S.) og i Fyen. Ikke bemærket paa Bornh.! og i det nordlige Jyll. (Dr.). - $\beta$, med Hovedarten, paa frodig Jordbund. $\gamma$, paa torre Marker (er ofte, men ikke altid, frembragt ved Hovedstængelens Afhugning). 7

b. Stængelen bladløs (Intybus Fr.)

1015. C. premorsa [Tauseh, Bot. Zeit. II, 1, p. 79] (Afbidt H.) Drej. n. 767 ; Rehb. 1. c. XIX, tab. 1444 (1454); 
Hieracium præmorsum L., H. 819; F. D. 942 ; Intybus Fr., Lge. Haandb. 1 Udg. n. 971 ; H. N. XIII, 28.

Rodstokken nedentil afbidt; Stcongelen et udeelt og bladløst, duuubaaret Skaft; Rodbladene oval-lancetformede, jæunt nedløbende i Bladstilken, fjernt og utydeligt tandede, duunharade; Blomsterkurzene i Klase, de nedre Blomsterstillie 2-3blomstrede, de ovre enblomstrede; Skalfrugterne oliveubrune, linieformede, lidet afsmalnede imod Spidsen.

\section{$1-1 \frac{1}{1} 2^{\prime}$ høi. Kronerne bleggule. 6. 4.}

Paa Enge og i Moser, ikke alm.: $\boldsymbol{S} j$. Grøndal og Lundehuusmosen red Kjøbenhavn! Kjoge Aas mod Lellinge (9), Bidstrupgaards Mose! Hareskoven ved Ballerup (H.), mellem Knardrup og Bringe, Jonstrup Vang (14)! J. Aalborg (Strandg.), Lundsgaard nellem Skive og Viborg, Hodal Mglle ved Hobro (16). |*

\section{Aracium. Ornegie.}

1016. A. paludosum [Monn. Ess. p. 73] (Kjær-Ø.) Drej. n. 771 ; Hieracium L., H. 821 ; F. D. 928 ; H. N. XII, 7; Crepis Moench, Koch. Syn. II, 506; Rchb. ic. XIX, tab. 1463.

Stongelen opret; Rodbladene stilkede, lancetformede, mod Grunden halvfinnet-tandede; Stangelbladene med hjerteformigtøret Basis, omfattende, æg-lancetformede, tilspidsede, skarpt tandede; Blomsterkurvene i en faablomstret Halvskjærm; Kurvbladene tiltrykte, sort-kirtelliaarede.

1-2' høi, glat, mørkgrøn. Kronerne gule. 6-7. 4 .

Paa Enge og i fugtige Skove, alm.

\section{Ileracium. Ilogeurt*).}

a. Pilosella. Skalfrugterne meget smaae, med fine, ligelange Straaler i Fnokken. (Udskyde i Regelen

bladbærende Vandgrene fra Rodstokken).

aa. Blomsterkurven entig $i$ Spidsen af Stangelen, Kronerne paa Overfladen gule, paa Underfladen rodstribede.

1017. II. Pilosella L. (Haarrig H.) Fr. Symb. Hierac.

*) Til Undersøgelse af denne paa Grund af Arternes Mangfoldighed og Foranderlighed yderst vanskelige Slægt maa især benyttes 
p. 2 ; Epier. 1. 10 ; H. 816 ; Drej. n. 772 ; F. D. 1110 ; Rehb. ic. H. germ. XIX, tab. 1468; H. N. VI, 4; L. Herb. VIII, 155.

Bladene omvendt-xgformet-lancetformede, graagronne, paa begge Flader stivhaarede og paa Underfladen hvidgraae af en tæt stjerneformet Duun; Skaftet bladlost; de ydre Kurvblade budte, de indre spidse.

Skaftet $2-8^{\prime \prime}$ høit, tilligemed Vandgrenene stivhaaret, desuden ofte oventil, ligesom Kurvbladene, beklædt med sorte Kirtelhaar. Blomsterkurvene meget storre end hos de andre Arter af Afdelingen a. 5-7. 4. Var. med Vandgrenene omdannede til bladede Blomsterstængler, uden Vandgrene og

$\beta$, pilosissimum (Vaill.) Fr. Symb. p. 3. Rodstokken stærkt udviklet, Skaft og Vandgrene korte, tæt beklædte med stive, ved Tøring rustbrune Haar.

Ved Gjærder, paa torre Græsmarker og Balker meget alm. -

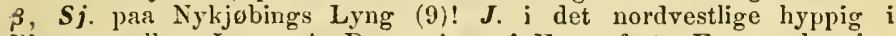
Pletter mellem Lyngen! De øvrige af Fr. anfurte Former har jeg ikke fundet hos os.

b6. Blomsterkurvene $i$ Regelen flere, qvast- eller halvslijurmformigt samlede $i$ Spidsen af Stangelen. Kronen ensfarvet paa begge Flader.

a, Rodstokken krybende, med forlængede Vandgrene; luurvbladene budte.

1018. I. Auricula L. (Lancetbladet H.) Fr. Symb. p. 14, Epicr.p. 19; H. 817 ; Drej. n. 773; F. D. 1111 ; Rchb. 1. c. XIX, tab. 1475 , fig. 2; H. N. VI, 6 og XI, 14.

Bladene lancetformede, i Spidsen bredere og bulte, heelrandede, nøgne*), glatte, ved Gruuden randhaarede, blaagtigt

Fries "Symbolæ ad historiam Hieraciorum" og "Epicrisis generis Hieraciorum" Ups. 1862 (i Forening med de i II. N. indeholdte Original-Exemplarer). Blandt de talrige Arter, som ere heskrevue i disse vigtige Værker, er det muligt at endnu flere end de her anforte ville findes hos os, skjondt Danmark er forholdsviis fattigere paa Hieracier end de tilgræendsende Bjerglande.

*) Udtrykket nogen bruges i demne Slægt for at betegne Mangel af den stjerneformede Duun, glat om Mangel af længere Haarbeklsedning. 
duggede; Skaftet alm. enbladet; Halvskjormen dannet af $2-5$ Blomsterkurve; alle Kurvbladene budte; Griffelen guul.

Vandgrenene mod Spidsen stivhaarede, paa kraftige Expl. ofte i Spidsen blomsterbærende; Skaftet $1 / 3-1^{\prime}$ h sit, nedentil næsten glat, foroven beklædt med Haar, sorte Kirtler og stjerneformet Duun (Paa smaae Expl. forekommer ofte kun $1 \mathrm{Kurv}$, paa store stundom flere end 5 og $2-3$ Blade paa Skaftet (H. dubium H. 817). Kronerne guldgule. $6-7.4$.

Paa Bakker, Græsmarker og høie Enge, alm. udbredt, dog neppe saa alm. som foreg.

1019. 1. pratense [Tausch, Bot. Zeit. 11, 1, p. 56] (Eng-H.) . Fr. Symb. p. 19, Epicr. p. 23; F. D. 2660; H. N. VI, 10; H. collinum Rchb. I. c. XIX, tab. 1477 (ikke Gochn.).

Rodstokken vidtkiybende; Rodbladene bredt lancetformede eller omvendt-ægformede, budte, fjernt og svagt tandede, frisk grønne, uøgne, i Randen og paa Underfladen, især langs Nerverne, stivhaarede; Skaftet 1-2-bladet, langhaaret; Halvskjormen qvastforwet, med talrige smaae Blomsterkurve; alle Kurvbladene budte, alm. sort-kirtelharede; Griffelen guul.

Vandgrenene kortere eller længere, stundom rodslaaende; Skaftet $1_{2}-1 \frac{1}{2^{\prime}}$ hyjt, især forneden beklredt med lange, hvide Haar, imod Spidsen tillige med stjerneformet Duun; Kronerne gule. 6 . ข.

Paa knge. Kun funden her i Landet paa "Ryerne" mellem Lundehuset og Strandveien ved Kbhavn (Rostrup 1857)! |*

$\dagger$ 1020. Il. aurantiacum L. (Pomeransfarvet H.) Fr. Symb. p. 23, Epicr. p. 24 ; H. 819 ; F. D. 1112 ; Rehb. l. c. XlX, tab. 1474 ; H. N. X, 9 .

Skaftet fleerbladet, forneden tæt- og langhaaret; Rodbladene omvendt-ægformede, Stangelbladene lancetformede, alle Bladene frisk grønne, heelrandede eller svagt tandede, stivhaarede; Halvskjarmen med 3-10 Kurve; alle Kurvbladene budte; Griffelen: bruun.

Forekommer stundom uden Vandgrene. Skaftet $1 / 2-1 \frac{1}{1}{ }^{\prime}$ h hit, Kurvene stgrre og færre end hos foreg., rar. i Hens. til Kronernes Farve (alm. høirøde, sjeldnere orange eller gule). Kurvbladene sorte, tilligemed den $\emptyset$ vre Deel af Stængelen stivhaarede af alm. sorte Haar; 
Haarene paa Bladene og Strengelens nedre Deel skidengule eller rustfarvede. $6-7$. 4 .

En Bjergplante, som neppe har sit Hjem her, men forekommer stundom forvildet, f. Ex. $\$ j$. Græsmarker ved Noddebo (A. Rafn)! Charlottenlund (H.), Karlsberg ved Valby! J. Hatting ved Horsens (Jørg.), S l. Stapelholm (Forehhammer), mellem Schwabstedt og Bergenhusen (F. Müll.).

$\boldsymbol{\beta}$, Rodstokken sammentræengt; Vandgrene korte eller 0 ; de indre Kurvblade spidse eller tilspidsede.

1021. II. cymosum L. (Qvastblomstret H.) Fr. Epicr. p. 35-36; H. N. XIII, 12 og 14; H. 818; Drej. n. 774; F. D. 810 (var.); H. glomeratum macilentum Fr. Symb. p. 39, Lge. Haandb. 2 Udg., p. 518; H. Nestleri Vill., Rehb. l. e. XIX, tab. 1486 (H. poliotrichum) og tab. 1485 (H. cymigerum Rchb.).

Skaftet 3-6-bladet, beklædt med tæt stjerneformet Duun, faae sorte Kirtelhaar og længere Haar; Bladene lange, linielancetformede, svagt tandede, stivhaarede og graaagtigt duunhaarede, især paa Underfladen; Halvskjormen sammensat, qvastformet, med mange, smaae, paa Grenene tæt sammenhobede Kurve; Griffelen guul.

Skaftet $1-3^{\prime}$ høit; Rodstokken ofte uden Vandgrene; Kurvbladene stivhaarede og graafiltede. Har de mindste Kurve af alle danske Arter i denne Slrgt. Kronerne gule. 6-7. 4.

Paa Skranter og Bakker mellem Krat, sjelden: $S j$. Strandklinterne mod Oresundet mellem Taarbæk og Strandmollen! Stevis Klint ved 'Tommestrup $(16,28) ! \boldsymbol{F}$. Lund sguards Klint ved Kjerteminde (A. Lange); SEbelo (H.).

b. Pulmonarea Koch. Overvintre ved Bladrosetter, hris vedblivende Blade tilligemed de $i$ folgende Aar udviklede Rodblade ved Grunden omgive Stængelen (pbyllopoda Fr.). Kurvbladene i afbrudte Spiraler (॰: næsten toradede); Fnokkens Straaler stive, uligeiange.

1022. If. murorum L. (Muur-H.) Fr. Symb. p. 108; Epicr. p. 91 ; H. 820 ; Drej. n. 775 ; Rchb. 1. c. X1X, tab. 1519-20.

Rodbladene talrige, frisk gronne, bjerteformede eller xgformede, tandede, med storre, nedadvendte eller udspxrrede 
Tænder ved Grunden; Stcongelen en- eller faabladet; Kurvene i en fra det øvre Stæugelblad fjernet Halvskjærm med opstigende Grene; Kurvbladene tilspidsede, grøune med sorte Wirtelhaar; Griffelen bruunagtig eller grønlig guul; Fnokken næsten hvid.

1-2' høi. Bladene blødhaarede eller næsten glatte, nøgne. Kronerne gule, deres Tænder glatte. $\frac{6}{1}-\frac{7}{1}$. 2. Var. betydeligt i Henseende til Bladformen, Stængelbladenes Antal, Beklædningen o. s. v. De i vor Flora meest afvigende Former ere:

$\alpha$, silvaticum L. Sp., Fr. Epicr. p. 91, H. murorum $\alpha$, Fr. Symb. p. 108; H. N. II, 7. Bladene langstilkede, meget tynde og slappe, tandede $\mathrm{i}$ forskjellig Dybde.

$\beta$, rotundatum (H. rotundatum Kitaib.) Stængelen ofte bladløs; Rodbladene hjerteformede, næsten heelrandede.

$\gamma$, subccsium Fr. Epicr. p. 92 ; H. murorum * incisum Fr. Symb. p. 110 ; H. incisum Koch, Rehb. l. c. XIX, tab. 1521 fig. 2 ; F. D. 2598 (H. cæsium). Bladene ved Grunden dybt tandede, blege, nesten blaagronne; Kurvbladene graafiltede, uden Kirtler. (Har nogen Lighed med H. cæsium).

I Skove og Krat ikke sjelden: $\beta$, Marselisborg Skov ved Aarhus! $\gamma$, Stevns og Moens Klint!

1023. H. integrifolium [Lge. Haandb. 2 Udg. p. 520] (Ovalbladet H.) F. D. $2661 ;$ H. vulgatum * integrifolium Fr. Symb. p. 117; Lge. Haandb. 1 Udg. p. 456; H. rotum. datum Hans. Herb. Nr. 1234 (ikke Kit.) H. murorum integrifolium H. N. XII, 23.

Rodstokken langstrakt, krybende; Rodbladene talrige, langstilkede, med langhaarede Bladstilke, onvendt-ægformet-ovale eller bredt elliptiske, heelrandede eller ntydeligt tandede; Stangelen 1-5.bladet; Halvskjarmens Grene opstigende, tilligemed Kurvdækket beklædte med graae stjerweformede Duun og sorte Kirtelhaar; Kurvbladene budte; Griffelen olivenbruun; Fnokken skident hvid.

1-2' høi. Bladene frisk gronne, i Randen og paa Underfladens Nerver langhaarede, nggne. Kronerne gule, i Spidsen randhaarede. 7. 2. 
I Kratskove, sjelden, og kun funden paa Halveen: J. Smidstrup Krat i Gadbjerg Sogn ved Veile, Steenvad Mølle ved Kolding (30)! Paaby Krat ved Kolding (28)! 世

Anm. Denne Art forekommer mig at være saa forskjellig baade fra H. murorum og fra H. vulgatum, at den med god Grund kan opstilles som egen Art. Fra hiin adskilles den ved en alm. fleerbladet Stængel og skident guulhvid Fnok, fra denne ved talrige Rodblade og en olivenfarvet Griffel, fra begge ved den eiendommelige Bladform, budte Kurvblade og i Spidsen randhaarede Kroner. (Dette sidste Kjendetegn findes dog ikke hos de norske Expl., som forøvigt aldeles ligne vore). I Habitus liguer den meget den sydemopæiske Crcpis succiscefolia Tausch. En Form af denue har været benævnt Hierac. integrifolium (Hopp.), men da den hører til en anden Slægt, turde dette Navn, som synes det meest passende for vor Art, overfores paa denne uden Frygt for Forvexling.

1024. II. casium [Fr. Nov. ed. I, p. 76, Symb. Hierac. p. 112] (Blaagrøn H.) H. N. XII, 19; Rchb. l. c. XIX, 1524 fig. 2 .

Bladene æg-lancetformede eller elliptiske, dybt tandede, ved Grunden afsmalnede, blaagrønue, haarede eller næsten glatte, paa Underfladen svagt beklædte med stjerneformet Duun; Rodbladene talrige; Stcengelen en-faabladet; Halvslijwrmens Grene opret-aabne, duunhaarede, uden Kirtler; Kurvbladene, især de ydre, budte, graafiltede; men med faae Kirtler; Griffelen mørk blyfarvet eller olivenbruun; Fnokken skident guulhvid.

$1 / 2-1^{1} / 2^{\prime}$ høi. Bladene ofte plettede, alm. fastere end hos de 2 foreg. Arter. I Skygge tabe de undertiden den blaagtige Farve. Kronerne gule, deres Tænder glatte. 6-7. 4. Var.

$\beta$, nemorum Fr. H. N. XII, 20. Bleggrøn, med tyndere Blade; Kurvbladene graafiltede med enkelte Kirtelhaar, Bladenes Filt spindelvævagtig, let affaldende.

$\alpha$, paa aabne Bakker, i Kratskove, isar paa Klippegrund, ikke alm.: Bornh. ved Hammershuus! Hoen s Klint i Selskab med var. $\gamma$ af foreg., men sjeldnere end denne. $\boldsymbol{J}$. i det østlige Vendsyssel alm. (12), Silkeborg Vesterskov! Sl. Nygaard Skov ved Haderslev (8), Lonisenlund ved Egernforde (20)! $\beta$, i Sliove, hyppigere end Hovedarten og maaskee ligesaa almindelig som 11 . murorum, med hvilkeu den let kan forvexles.

Anm. Denne Art er, ligesom H. murorum og vulgatum, meget foranderlig i sine Former, og enkelte af disse (hvis Besteminelse ofte foraarsager Vanskelighed) nærme sig til H. nurorum, andre til H. palleseens eller saxifragum. Formen H. murorum $\gamma$ har jeg tidligere, i Overeensstemmelse med Prof. Fries's Bestemmelse, henfort til denne. 
1025. I rulgatum [Fr. Nov. p. 258, Symb. p. 115] (SkovH.) H. N. II, 8-10, XIII, 22-23; Rchb. I. c. XIX, 1526; H. silvaticum Lam., Gren. \& Godr. fl. Fr. II, p. 375.

Bladene lancetformede eller elliptiske, skarpt tandede, haarede, nøgne; Rodbladene faae; Stcngelen fleerbladet; Halv. skjurmens Grene opret-aabne, tilligemed Kurvdakket graafiltede og ofte sort-kirtelbaarede; Kurvbladene smale, spidse; Griffelen guul; Fnokken skident bvid.

$1-3^{\prime}$ høi. De nedre Rodblade og Stængelen ved Grunden ofte rødviolette. Kronerne gule, med glatte Tænder. $\frac{6}{2}-\frac{8}{1}$. \%. Forekommer i forskjellige Afændringer i Henseende til Bladformen, Beklædningen, Stængelbladenes Antal o. s. v. De vigtigste hos os forekommende Former ere:

$\boldsymbol{\beta}$, angustifolizm Fr. Bladene smale, lancetformede, svagt haarede; Stængelbladene alm. talrigere end hos Hovedarten.

$\gamma$, latifolium Fr. Bladene bredt elliptiske, tilligemed Bladstilke og Stængler langbaarede; Stængelbladene faae.

$\delta$, ramosum Fr. in litt. (non H. ramosum W. K.) Stængelen næsten fra Grunden af grenet, mangebladet, bvashaaret$\mathrm{ru}$; Bladene lancetformede, dybt (næsten fliget-) saugtakkede, langhaarede; Halvskjærmen bladbærende.

I Skove og Krat, sjeldnere paa aabne Steder, den hyppigste Art i Danmark af Afdelingen b. Formen $\gamma$, er temmelig hyppig, især i Skove, $\beta$, sjeldnere; $\delta$, en meget afvigende Form, som efter Beskr. af H. ramosum W. K., nærmer sig endeel til denne, har jeg fundet mellem Vedbæk og Tryggerød og i Frederiksdals Skov.

Anm. Som en alm. Regel for Afæendringerne i denne Art angiver Fr. at den alın. paa aabne Pladser faaer smalere Blade og talrigere Stængelblade, men i Skygge er mere bred- og faabladet, medens det Modsatte er Tilfaldet ned H. murorum.

1026. H. anfractum [Fr. i Vet. Ac. Forhandl. 1856 p. 148] (Bugtẹt H.) F. D. ined.; M. T. Lange i Naturb. Foren. vid. Medd. 1861 p. 9.

Stangelen faa $(2-3)$-bladet, zigzagbøiet; Bladene stilkede, smalt lancetformede, skarpt og ofte dobbelt saugtakket-tandede, paa Underfladen langs Midtnerven baarede, forøvigt næsten glatte; Halvskjormens Grene udspærrede, fine; Kurvene smane, 
Kurvbladene spidse, graadunede og mere eller mindre beklædte med sorte Haar og Kirtler; Kronens Tænder glatte, Griffelen gronlig-guul; Skalfrugterne mindre og med mere hvid'Fnok end hos foreg.

Bladene alm. blaaagtig-gronne, ofte rodplettede, Rodbladene tidligt henvisnende. Kronerne gule. 7-8. 4.

I Hornbreks Plantage ved Helsingør (12)!

w. Accipitrina Koch. Overvintre med lukkedeKnopper, som udvikle en fleerbladet Stængel; Rodbladene ikke udviklede, de nedre Stængelblade tidligt henwisnende (aphyllopoda Fr.). Kurvbladene $\mathrm{i}$ u afbrudte Spiraler (regelm. taglagte); Fnok som foreg.

1027. . Il. tridentatum [Fr. S. Veg. Sc. p. 6; Symb. p. 171] (Tretandet H.) H. N. III, 4; XII, 14; Rchb. I. c. XIX, 1531, fig. 1-2; H. murorum silvaticum F. D. 1113 ; H. rigidum $\beta$, tridentatum Griseb. 1. c. p. 47 .

Stcengelen huul, stivt opret; Bladene paa Midten skarpt-, men faatanc'ede (omtr. 3 Tænder paa hver Side), de nedre elliptiske, kortstilkede, de ovre æg-lancetformede, Bladene fortsættes indtil Grunden af Halvskjærmen; Grenene oprette, tynde; Kurvene smaae, efter Afblomstringen nedenfor Midten sammenknebne, med graafiltede, svagt haarede og sjeldent kirtelhaarede, grønne, i Randen blegere Kurvblade (de ydre budte, tilbagebøiede, de indre spidse, tiltrykte); Griffelen olivenbruun; Fnokken næsten hvid.

1-2' høi. Kronerne gule. 7. 4. Var.

$\beta$, angustifolium Fr., H. rigidum Rchb. I. c. tab. 1531, fig. 1. Stængelen høiere, Bladene smalere og mindre haarede.

$\gamma$, integrifolium $\mathrm{Fr}$. in litt. Bladene linie-lancetformede, de nedre budte, næsten heelrandede, de øvre langt tilspidsede, med faae og fjerne Tænder.

I Skove, ikke alm., f. Ex. Sj. Ordrup, Bernstorf (27)! J. Viborg (Morville)! Stovringgaard! $\boldsymbol{\beta}, \boldsymbol{S} \boldsymbol{j}$. Hornbreks Plantage! J. Silkeborg (12); Sl. Egernførde (20)! $\gamma$, i Silkeborg Vesterskov! 
Anm. Fig. i Fl. dan. 1113 henfores alm. til H. vulgatum, men: paa Grund af de dybt tretandede Blade, Mangelen af Rodblade og: især det taglagte Kurvdække maa jeg antage at den snarere er tegnet. efter Expl. af $\mathrm{H}$. tridentatum.

1028. H. gothicum [Fr. Symb. p. 121] (Gothisk H.) Fr. Epicr. p. 114; H. N. II, 12-14 (H. boreale var.); H. tridentatum asperum (Fr.?) Lge. Haandb. 2 Udg. p. 522; H. vulgatum irriguum Rehb. 1. c. XIX, 1527 (ikke Fr.).

Stcongelen stivt opret, ikke huul; Bladene lancetformede,. fra Midten til henimod Grunden tandede eller fliget-saugtakkede(med 3-5 Tænder paa hver Side), de nedre kortstilkede (stundom vedblivende), Bladene fortsættes jævnt aftagende indtil Gunden af Halvskjærmen; Grenene stive, oprette; Kurø. bladene nøgne, sortgrønne (i tørret Tilstand næsten sorte), med en Række sorte Kirtelhaar paa Ryggen, de ydre brede og. budte, de indre linieformede, næsten spidse; Griffelen i frisk Tilstand guul, tøret bruunagtig; Fnokken skident guulhvid.

1-4' høi. Kronerne mørkere gule end hos foreg. og de to efterfolgende Arter. Stængelen ofte rødligt anløben. 7-8. 4 .

Paa Bakker og i solaabne Krat, temmelig alm. udbredt paa Halvgen, ikke sjelden i Nordsjall. og paa Bornh.

Anm. Denne Art er ikke lidet foranderlig og kan let forvexles med smalbladede Former af foreg. og efterfolg.; med H. vulgatum og H. boreale har den kun fjernere Lighed. Her i Landet er den smalbladede Form ( $\beta$, angustijolium Fr.) den fremtræedende, lovorimod jeg ikke har bemærket den liredbladede ( $\boldsymbol{c}$, latifolizm $\mathrm{Fr}_{\mathbf{r}}$ ), medmindre de under $H$. rigidum med Trivl anførte Voxesteder skulde tilhøre denne. Fra $H$. rigidum adskilles den ved spadere Stangel og mere oprette Grene, mindre Kurve, spidsere og mere tiltrylste Kurvblade o.s. v., fra 11 . triclentatum ved en alm. lıviere, mere ru og fastere (ikke huul) Strengel, mindre sammenknebne Kurve uden Filt men med Kirtler paa Ryggen af Kurvbladene, norkere gule Kroner og hele Plantens morliere Farve. Mellenformer ere dog yderst vanskelige at henfore ned Sikkerhed til nogen bestemt af disse 3 Arter. Til saadame tvivlsomme Former ere maaskee at henregue $H$. tridentatum asperum og H. rigidum subgothicum Fr. Symb.

? 1029. H. rigidum [Hartm. Skand. Fl. ed. I, p. 300] (Rank H.) Fr. Symb. p. 173; H. N. 1X, 3; XII, 13; F. D. 2597. 
Stcengelen ikke huul, stivt opret; Bladene lancetformede, i Midten skarpt-, men faa- (omtrent 3-) tandede, siddende, de nedre kortstilkede; Bladene fortsættes indtil Grunden af Halvskjærmen; Grenene udstaaende; Kurvene storre end hos foreg., efter Afblomstringen ved Grunden budte, med budte, tiltrykte, eensformigt grønne, ved Tørring sorte Kurvblade; Griffelen guul eller bruun; Fnokken skident guulhvid med rustfarvet Anstrøg.

Stgl. 2-4' høi, alm. ru, ved Grunden rodlig; Bladene alm. mere tætsiddende end hos toreg. Kurvdækket $\mathrm{i}$ Begyndelsen beklædt med Duun, som hurtigt forsvinde, samt med vedblivende sorte Haar og Kirtler. Kronerne gule. 7-8. 4.

I Skove og Krat, paa Bakker, sjeldnere end foreg.: Sjall. (det speciclle Voxested erindrer jeg ikke, Expl. bestemte af Lector Lindeberg)! J.Marselisborg!(?) Skatskov ved Eveldrup (Dr. herb.),(?) Egekrat ved Karup Aa (Feddersen)? (Dens Forekomst her i Landet bør næermere iagttages. Efter Prof. Fries's Meddelelse er det trivlsomt on den findes i Danmark, men i Symb. Hierac. p. 174 anfører han den blandt de danske Planter (H. rigidum subgothicum), men denne Form er sandsynligviis $\mathrm{nm}$ forenet med H. gothicum).

1030. II. boreale [Fr. Nov. ed. I, p. 77; Symb. p. 190] (Bredbladet H.) H. 821 ; Rehb. l. e. XIX, 1541; H. N. XI, 10 ; XII, 12.

Stangelen opret, ikke huul, mangebladet; Bladene ægformede eller elliptiske, fra Grunden til Midten tandede, de nedre med smalere Basis (eller kortstilkede), de ovre siddende (paa bredbladede Former halvt omfattende), naaende til Grunden af Blomsterstanden, hvis Grene ere stivt oprette, samlede til en halvskjærinformet Top; Blomsterstilkene oventil tykkere og beklædte med skjælformede Blade; Kurvbladene brede, budte, tiltrykte, mørkgrøne, ved 'Tøring sorte, nøgne, uden Kirtelhaar og næsten glatte; Griffelen grønlig-guulbruun.

2-4' høi, Stængelen alm. ru, var. haaret eller glat. Har af alle danske Arter $\mathrm{i}$ denne $\Lambda$ fdeling de bredeste Blade, men disse var. forøvrigt i Brede, Form og Indskjæring. Kroneme bleggule. 8-9. य.

I hoitliggende Skove, ikke sjelden par Ostkysten af Halvoen: pata Derne sporadisk: F. Ebelø, Ulriksholm (18), Egebjerg (en meget bredbladet Form)! Thuro (12), Loll. temmelig alm. (19)! F alst. hist og her (14)! $\boldsymbol{S}$. Springforbi! Charlottenlund! Viborggaard pr. Nestved (Visby)! :Steensby Viøller ved Vordingborg (19). En smalbladet Form ( $\beta$, angusti- 
folium Fr. H. N. XI, 10) er funden paa Falster ved Korselitze og Hallerup (Koch)!

Anm. Fr. bemærker, at jo færre Blade denne Plante har, destor smalere ere de, og omvendt, medens det Modsatte finder Sted hos H. umbellatum. Den ved Egebjerg i Fyen samlede Form er meget udmærket ved en næsten mandsliøi Stængel, tætsiddende, brede, hjerteformede Blade, som tilligemed Stængelen ere beklædte med stjerneformet Duun. Den sildige Blomstringstid, de ved Grunden bredere Blade, blegere Kroner og især Kurvdakket adskille tilstrækkeligt $\mathrm{H}_{\text {. }}$. boreale fra de ovrige her i Landet forekommende Arter.

1031. H. umbellatum L. (Smalbladet H.) Fr. Symb. p. 177; H. 822 ; Drej. n. 777 ; F. D. 680 og 872 (H. sabaudum); H. N. IX, 1; Rehb. l. e. XIX, 1533.

Stangelen ikke huul, tætbladet; Bladene siddende, linieformede eller lancetformede, heelrandede eller svagt tandede, med tilbagebøiet Rand; Blomsterstanden skjærm- eller halvskjærmformet med udstaaende Grene; Blomsterstilkene oventil tykkere; Kurvbladene ensfarvet-mørkgrønne, ved Tørring sorte, tilligemed Blomsterstilkene beklædte med hurtigt affaldende, stjernehaaret Duun, forovrigt glatte, de ydre i Spidsen udspærrede eller tilbagebøiede, de indre oprette; Griffelen guul (i tørret Tilstand grønlig-bruun).

1-3' høi. Var, i Henseende til Beklædning, Bladenes Form og Indskjæring. Af de hos Fr. nævite Former forekomme hos os:

$\boldsymbol{\beta}$, filifolium Fr., Rchb. 1. e. 1534, fig. 2. Bladene meget lange, smalt linieformede, heelraudede. Planten glat.

$\gamma$, humile Schum. Fra Rodstokken udgaae talrige smale, rosettestillede Blade, og faabladede, 3-6" lange Stængler med: enlige Blomsterkurve.

$\delta$, coronopifolium (Gmel.) Fr. Bladene smale, dybt tandede eller fjerfligede.

$\varepsilon$, duncnse Reynier ( $\beta$, villosum! i Bot. Foreu. Catal. Bladene bredt lancetformede, tandede, tilligemed den opstigende: eller fremliggende Stængel rue og stivhaarede.

Ved Gjerder, i Krat og paa ndyrkede Marker meget alm. $\beta$, paa Lyngheder og i Sandklitter: J. Skagen, Eveldrup (Drej. Herb.), 'Thorsted pr. Ringkjøbing! Rome (16; A $m$ rom (Jessen); $\gamma$, i Sand: Thurseng ved Bregninge (12)! Falst. (14); Rome (Nolt); $\mathcal{J}, J$. Flyvesandet ved Skagen (Drej.), Brøndersløv (Gronlund); Thorseng 
(12); $\boldsymbol{S}$. Helsingør (27); $\boldsymbol{\varepsilon}$, ved sandige Strandbredder: $\boldsymbol{J}$. Skagen (Drej. herb.), Hanstholm! Hvide Bjerge ved Veile Fjord! Samso (Jacobs.); F. Knudshoved (19); Loll. Bredfjed ved Rødby Fjord! $\boldsymbol{S} j$. Adserbo Overdrev ved Frederiksværk! B or $\boldsymbol{n}$ h. Rønne, Klause Mølle!

\section{Ilypochaeris. Kongepen.}

a. Stængelen glat; Fnokken toradet med børste. formede (ikke fjerede) Straaler i den ydre Kreds. (Euhypocharis $D u b y$ ).

1032. H. glabra L. (Glat K.) H. 826 ; Drej. n. 780; F. D. 424 ; Rchb. ic. A. germ. XIX, tab. 1398 ; H. N. II, 16.

Bladene alle samlede ved Grunden, bugtet-tandede eller høvlformede; Kurvbladene glatte, ligesaa lange som Blomsterne; Randblomsternes Skalfrugter uden eller ined meget kort Næb.

Stænglerne alm. flere, $1 / 3-1$ ' lange, oprette eller nedliggende, grenede; Bladene glatte eller bekladte med faae, spredte Haar. Kronerne gule. $7-8$. $\odot$.

Paa tørre, sandige Bakker: hist og her i det nordligste Jyll. (Dr), Nordsjell. og især alm. paa Bornh.! I de sydlige Egne af Halvgen, Fyen og Sydsjall. sjeldnere; Loll. Bregneholt (19); paa F alst. ikke bemærket.

1033. H. radicata L. (Almindelig K.) H. 826 ; Drej. n. 779 ; F. D. 150 ; Rehb. 1. c. XIX, tab. 1397; H. N. XIV, 10.

Bladene samlede ved Grunden, bugtet-tandede eller høvlformet-halvfinnede, rue; Kurvbladene glatte, i Spidsen paa Rygnerven stivbaarede; Blomsterne længere end Kurvdækket; alle Skalfrugterne med Næb.

1-2' høi. En- eller fleerstænglet, Stænglerne alm. grenede. Kurvene flere Gange større end hos foreg. Kronerne gule, udvendig gronlig-brune. 7-8. ข.

Ved Veigrøfter, paa Græsmarker o. s. v. meget alm.

b. Stængelen stivharet-ru, Fnokken enradet, alle Straalerne fjerede. Achyrophorus Scop.).

1034. H. maculata L. (Plettet K.) त. 825 ; Drej. n. 778 ; F. D. 149 ; Rchb. I. c. XIX, tab. 1396 ; Achyrophorus maculatus Scop. 
Stcongelen udeelt eller faagrenet; Bladene tandede, rue; Kurvbladene stivhaarede, ovenfor Midten filtet-randhaarede, kortere end Blomsterne; alle Skalfrugterne med Næb.

1-2' høi, alm. enstænglet; Stængelen ofte 1-2-bladet; Bladene alm. uregelmæssigt bruunplettede, Blomsterkurvene færre (1-3), men større end hos foreg. Kronerne gule. 6-7. थ. Vár.

$\beta$, Mülleri Lge. (Leontodon hirtum F. D. 901). Bladene halvfinnede, med lancetformede, budte Flige. Stængelen fra Grunden af grenet, Grenene opstigende, beklædte med talrige, linieformet-skjælformede Blade; Kurvene mindre (Maaskee en egen Art).

Paa Skov- og Lyngbakker, forekommer i alle danske Provindser, men sporadisk og $\mathrm{i}$ enkelte Egne sjelden ( $\mathrm{i}$ det cydlige Fyen kun bemærket paa Svanninge Bakker (15). $\boldsymbol{\beta}, \boldsymbol{S} j$. Drosselbjerg paa Skrænter mod Storebælt (Lund)! I. olland (O. F. Müller).

\section{Tragopogon. Gedeskjag.}

$\dagger$ 1035. T. porrifolius I. (Porrebladet G.) H. 806; F. D. 797 ; Rehb. ie. fl. germ. XIX, tab. 1387 ; H. N. X, 3.

Bladene fra en bred, omfattende Basis efterhaanden linieformigt afsmalnede, stirt oprette; Grenene kølleformigt opsvulmede under Blomsterkurvene; Kurvbladene 8, længere end de ydre Kroner; Skalfrugterne af Randblomsterne skjælformigt piggede.

Kronerne violette. 6-7. $\odot$.

Ved Gjærder og paa Marker, især omkring Byer, sporadisk og temmelig sjelden: $\boldsymbol{J}$. Aalborg (Strandg.), Kolding (28!); $\boldsymbol{S}$ l. Husum (16); F. Hvidkilde (12), Svendborg (19); $S j$. Rute, Haarsløv, Tjæreby (Nielsen) og Ørsløv ved Skjelskør! Holsteinborg (22); Loll. Vintersborg, Engestofte, Saxkjøbing (19), Nakskov (F.D.); F alst. Stubbekjøbing (Rasm.), Maglebrænde (14), Veggerløse (Koch)!, Nykjøbing, Moseby (H.); Bornh. Kanegaard ved Rønne (21), Rønne Vang (Hjorth). Er matskee ikke oprindelig indeulaudsk, men forvildet fra Dyrkning i tidligere 'Tid. $\$$

$\asymp T$. pratensi-porrifolius [Rostr. mscr.]. De ydre Kroner i Kurvene bruunviolette, de indre gule.

Formodenlig en Bastardform af foregaaende og efterfølgende og fuuden i Selskab med disse: $\boldsymbol{F}$. Hvidkilde (12); Loll. Vesterborg (19). 
1036. T. pratensis L. (Eng-G.) H. 805 ; Drej. n. 789; Fr. nov. p. 240 ; F. D. 906 ; Rchb. l. c. XIX, 1389, fig. 1.

Bladene fra en bred, oufattende Basis jæunt linieformigt afsmalnede, oprette eller i Spidsen nedbøiede; Grenene under Blomsterkurvene lidet opsvulmede; Kurvbladene 8, omtrent af Længde uned de ydre Kroner; Randblomsternes Skalfrugter knudret-rue, ligelange med Næbet.

Blomsterne kun aabne on Formiddagen. Kronerne gule. 6-7. $\odot$.

$\hat{f}$, tortilis Mey. chl. Hanov., Rehb. l. e. fig. 2. Bladene snoede, i Rauden bølget-krusede.

Ved Veie, paa Marker og høie Enge, alm. udbredt. $-\boldsymbol{\beta}$, med Hovedarten.

1037. T. minor [Fr. Nov. p. 241] (Smaablomstret G.) H. N. XV, 6; Rehb. l. c. XIX, tab. 1390, fig. 2.

Bladene fra en bred, omfattende Basis pludseligt linieformede, meget smalt og langt tilspidsede, slapt nedhængende; Kurvbladene omtrent dobbelt saa lange som de ydre Kroner; Skalfrugtens $\mathrm{Nab}$ kortere end selve Frugten; forøvrigt som foreg., men alm. lavere af Væxt.

6-7. $\odot$.

Paa lignende Steder som foreg. og, idetmindste i Sjall., iklke sjelden.

Anm. Denne Art har ved Dyrkning i vor botaniske Have bevaret et fra den foreg. Art forskjelligt Udseende, men Characteren som hentes fra Kronernes og Kurvbladenes indbyrdes Lengdeforhold, maa benyttes med Varsomhed, da Kronernes Lanode hos T. pratensis er meget forskjellig, snart længere (grandiflorus Fr.), snart betydeligt kortere end Kurven (brachyglossus Fr.).

\section{Scorzonera. Skorzonere.}

1038. S. humilis L. (Lav S.) H. 806 : Drej. n. 788; Rebb. ic. fl. germ. XIX, tab. 1383 ; H. N. VII, 3; L. Herb. Ill, 59.

Rodstokken foroven skjældækt, med talrige, stilkede, heelrandede Blade; Skaftet 1-3-blomstret, med 1-3 smalt linieformede Blade; Kurvbladene $1 / 2$ Gang kortere end Kronen; Skalfrugterne stribede, med jævne Striber. 
Skaft og Bladstilke beklæedte med en løs UId, som let afgnides. Kronerne gule. 5-6. 4. Forekommer under 2 Former:

$\alpha$, latifotia (F. D. 816, slet). Bladene elliptiske eller bredt lancetformede.

$\beta$, angustifolia (F. D. 1653). Bladene linieformede eller lancet-linieformede.

Begge Formerne, mellem hvilke ingen skarp Grændse kan drages, forekomme hist og her $\mathrm{i}$ alle Provindser, almindeligst paa $\boldsymbol{H}$ alve en og Bornholm: $\boldsymbol{\alpha}$, paa høie Enge og aabne Steder i Skove; $\beta$, paa tørre Steder, f. Ex. Lyngbakker.

† S. hispanica L. (Spansk S.) Rchb. l. c. XIX, tab. 1384. Stangelen fleerbladet; Bladene elliptiske eller lancetformede, tilspidsede, de ydre Kurvblade triangel-ægformede; Stalfrugterne piggede, forøvrigt som foreg.

Kronerne gule, vellugtende (som Vanille). 5-7. $\odot$.

Dyrkes i Haver paa Grund af den spiselige Rod, og forekommer tilfældigt forvildet, f. Ex. S $j$. Tommerup paa Amager (19), Engen mellem Peblingesøen og Farimagsveien! J. Viborg (Feddersen).

\section{3. 'Thrincia. Ilundesalat.}

1039. T. hirta [Roth. Cat. bot. 1, p. 98] (Haaret H.) H. N. XIII, 32; Apargia Sm., H. 814; F. D. 1827 ; Rchb. ic. fl. germ. XIX, tab. 1365.

Bladene rosetteformigt samlede ved Grunden, linie-lancetformede, tandede eller hovlformede, mere eller mindre haarede af i Spidsen alm. tokløvede Haar; Skafterne flere, bladløse, enblomstrede; Blomsterkurven før Udspringningen nikkende.

Kurvbladene var. haarede eller glatte; Bladene var. i Henseende til Indskjæring og Beklædning. Kronerne gule, paa Underfladen grauagtigt-røde. 7-9. 4 .

Paa tørre ('Hræsmarker og Bakker, sjelden: J. Haraldslund! Fjeldsted Bakker (H.); F. Ulriksholm (H.); Loll. Aalholm! $S j$. Vesterfalled (19). $\rightarrow$

Anm. Leontodon hirtus L., som alm. citeres til denne Art, beskrives med udeelte Haar og Kronerne gule paa Underfladen, hvorfor den neppe kan høre lierhid. Koch antager Leont. Villarsii Lois. for den linneiske L. hirtus. 


\section{Leontodon. Lovetand.}

1040. L. hispidus L. (Stivhaaret L.) F. D. 862 ; Rehb. ic. XIX, tab. 1368-69; H. N. VII, 4; Apargia Host, H. 813; Drej. n. 765 ; L. hastilis Koch Syn. II, 481.

Stcongelen furet, bladløs, i Spidsen udvidet, før Blomstringen nikkende, alm. udeelt; Bladene tandede eller høvlformet-balvfinnede, tilligemed Skaft og Kurvdække mere eller mindre stivbaarede af 1-3-kløvede Haar; Frokkens Straaler i 2 Kredse, den indre fjeret, den ydre kortere, ru.

Bladene var. i Indskjæring og Behaaring. Den glatte Form ( $L$. hastilis L.) er saavidt mig bekjendt, ikke funden hos os. Ligner foreg., men er i alle Dele storre. Kronerne gule. 6-9. 4 . ndbredt.

Paa høie Enge, ved Randen af Veie o. a. udyrkede Steder alm.

1041. L. autumnalis L. (Høst-L.) Rehb. l. c. XIX, tab. 1366, fig. 2-3; Apargia Willd., H. 815; Drej. n. 764; F. D. 1996; Oporina Don.

Stangelen grenet (sjeldnere udeelt), Grenene oprette, i Spidsen udvidede og beklædte med skjælformede Blade; Rodbladene glatte eller svagthaarede af ugrenede Haar; Fnokkens Straaler alle fjerformede.

Kronerne gule. 7-10. \%. Var. betydeligt i Henseende til Bladenes Indskjæring, Kurvdækkets Beklæedning o. s. v. Blandt de mange Former udhæves:

$\beta$, salinus Aspegr. (integrifolius Bot. For. Cat.!) Bladene heelrandede eller med faae og utydelige Tænder; Kurvbladene glatte.

$\gamma$, curonopifolius (Bot. For. Cat.!) Bladene enkelt eller dobbelt fjersnitdeelte med smalt linieformede Afsnit; Kurvdækket beklædt med løs, hvidagtig Duun.

$\delta$, nigro-lanatus Fr. (Apargia Taraxaci Sm., H. 815 ; F. D. 1523 ; Hieracium Taraxaci L., Leontodon Lois. Rehb. l. c. fig. 1). Stængelen alm. udeelt, Blomsterkurven storre, med sorthaarede Kurvblade.

Meget alm. paa Enge, Græsmarker, ved Veie o. s. v., spiller især en betydelig Rolle paa vore Syltenge, paa hvilke Formen $\beta$, lige- 
ledes forekommer (f. Ex. ved Lillestrand i $\boldsymbol{J} y \boldsymbol{l l}$.!). $\boldsymbol{\gamma}$, paa tørre Marker og Overdrev iklse sjelden; $\delta$, paa Øerne i Vesterhavet: F $a n \theta, \mathrm{S} y l t, \operatorname{R\theta m} \theta$ (N.); Bornh. (H.), Christiansø (Didrichsen).

\section{Picris. Bittermalk.}

1042. P. hieracioilles L. (Rubladet B.) H. 807 ; Drej. n. 766 ; F. D. 1522 ; Rehb. ic. fl. germ. XIX, tab. 1375 ; H. N. $1,8$.

Stcongelen opret, bladet, i Spidsen halvskjærmformigt grenet; Bladene elliptisk-lancetformede, bugtet-tandede; Stcongelbladene halvt-omfattende; Kurvbladene $\mathrm{i}$ de ydre Kredse udstaaende eller tilbagebøiede.

Stængelen $1^{1 / 2}-3^{\prime} h \emptyset \mathrm{i}$, tilligemed Bladene stivhaaret-rn, Kronerne gule. $7-8$. $\odot$.

Ved Randen af Veie, i Kratskove, bemærket $\mathrm{i}$ alle Provindser, (undt. Bornh.), ikke sjelden, men sporadisk. 周

\section{Lappa. Burre.}

a. Kurvbladene indvævede $i$ en spindelværagtig Filt.

aa. Blomsterstanden halvskjormformet (Grenene forlangede).

1043. L. tomentosa [Arctium toment. Scbk. Handb. 3, p. 49] (Filtet B.) Drej. n. 794; Rchb. jc. fl. germ. XV, tab. 811, fig. 2.; A. Bardana Willd., H. 829; A. Lappa $\beta$, L., F. D. 642 og 2423 B.

Bladene budte, heelrandede eller svagt tandede, de nedre hjerteformede; Blomsterkurvene før Udspringningen ægformetpyramideformede, efter samme kugleformede, tæt hvidfiltede; de ydre Kurvblade udstaaende, fra en bredere, grøn Basis sylformede, i Spidsen hagekrummede, guulbrune, de indre oprette, linieformede, i Spidsen mørkrøde, budte eller krusede (ikke hagekrummede).

$2-4^{4}$ høi. Kronerne mørk rosenrøde, Støvdragerne blaae. 7-8. $\odot$.

$\beta$, denudata! (L. tomentosa var. F. D. 2423 A). Kurvbladene uden Filt.

Ved Veie og omkring Byer: i Sjall. meget alm. (den hyppigste Art); hist og her paa Bornh., Loll.-Falster og Als! alm. paa Hindsholm! meget sjelden i de gvrige Egne af Fyen (Vibeltsdal ved Svendborg! Trede (12) og paa U alvoen: hist og her mellem Aalborg (Dr.) og Nibe (12), Randers (7), ved det nye Veianlæg S. for Horsens, 
Veile, Flensborg, Hyrup, Huusby (12), Husum! $\beta$, Sj. Snekkesteen (Grønlund), Kjøbenhavns Volde! Orslev og Bjerre ved Skjelskør (Nielsen)! *

\section{bb. Blomsterstanden klaseformigt forlanget (Grenene korte).}

1044. L. minor [Arctium miuus Schk. I. c.] (Liden B.) Drej. n. 793 ; F. D. 2662 ; Rehb. l. c. XV, tab. 811 , fig. 1; H. N. XIII, 6; A. Lappa L. (tildeels) H. 829 (val. minus).

Bladene grovt tandede, spidse eller budte, de nedre bjerteformede; Blomsterkurvene for Udspringningen xgformede, efter samme nedtrykt-kugleformede, tyndt filtede; alle Kurvbladene sylformede, hagekrumınede, de ydre udstaaende, grønne, i Spidsen skidengule, de indre oprette, lidet bredere, heelt grønne.

Hele Planten graagrøn, lavere $\left(1^{1} / 2-2^{1} / 2^{\prime}\right)$ og mere sammentrængt end de øvrige Arter; Kurvene neppe mere end halvt saa store som hos følgende. Kronerne blegrøde; Støvdragerne lila. 7-8. $\odot$.

Ved Veie og Gjærder, især omkring Byer, meget alm., især i Landets magrere Egne, hvor den ofte er den eneste forekommende Art.

1045. L. intermedia [Aret. intermed. Lge. mser. (1843), Haandb. 1 Udg. n. 1000] (Skov-B.) F. D. 2663; Rchb. 1. c. XV, tab. 812, fig. 1 ; A. Lappa $\beta$, majuscula Hartm. Skand. fl. ed. 4 p. 260 (?); Lappa minor ${ }^{*}$ campestris Fr. S. Veg. Sc. p. 5.

Bladene spidse, fjernt og svagt tandede, de nedre hjerte. formede; Blomsterkurvene store, tyndt filtede, før Udspringningen rundagtige, efter samme ægformede; alle Kurvbladene hagekrummede, de ydre nedbøiede, sylformede, grønne, i Spidsen skidengule, de méllemste udspærret aabne, de indre oprette, lancetformede, i Spidsen morkrøde; Skalfrugterne mere end dobbelt saa store som hos foreg.

Hele Planten nørkgrøn, Stængelen ofte rødlig. Høiere end de ørige Arter $\left(3-5^{\prime}\right)$, men tillige af slankere Væxt. Kroneme rosenrøde, Støvdragerne blaae. Var. med livide Kroner og alle Kurvbladene grønne med skidengule Spidser. 7-9. $\odot$.

Paa skyggefulde Steder saavel i Skove og Krat som ved levende Hegn, iklke sjelden i Danmarks Skovegne (Ostkysten af Halvøen og paa (Jerne).

Anm. Denue Art, som jeg i flere Aar lar jagttaget og adskilt, er nærmest beslagtet med foreg., og Mange ville kun ansee den for en 
Skovform af denne. Da den imidlertid afviger ikke lidet, saavel red flere Characterer som især ved et forskjelligt Habitus, og da denne Forskjellighed har vedligeholdt sig ved gjentagne Udsædsforsıg i den herværende bot. Have, har jeg ingen Tvivl om dens Ret til at opstilles som en egen Art. (Om Schkuhr har kjendt og indbefattet denue under sin A. minus, har jeg ikke kunnet udfinde, men at han fortrinsviis skulde have tænkt paa den, anseer jeg ikke for rimeligt paa Grund af dens stedse høie Væxt).

b. Kurvbladene glatte (uden Filt).

1046. L. major [Schk. l. c. (Arctium)] (Glat B.) Drej. n. 792 ; F. D. 2424 ; Arctium Lappa L. (tildeels), H. 828; Lappa officinalis All., Kehb. l. c. XV, tab. 812, fig. 2.

Bladene hjerteformede, spidse eller budte, paa Overfladen grønne, paa Underfladen svagt filtede; Blomsterstanden halv. skjærmformet; Blomsterkurvene i yngre Tilstand kugleformede, tilsidst noget nedtrykte; alle Kurvbladene linieformede, grønne, i Spidsen guulbrune, hagekrummede, de ydre tilbagebøiede, de mellemste og indre oprette.

3-4' høi og kraftig af Væxt. Kronerne violetrøde, Støvdragerne blaae. 7-9. $\odot$.

$\beta$, subtomentosa Lge. Bladene paa Underfladen tret hridfiltede, Blomsterkurvene uden eller med meget svag Filt, Kurvbladene violetbrune. (Kunde muligviis antages for en Bastardform af L. major og I. tomentosa, dersom den ikke forekom paa Steder hvor sidstnævnte aldeles ikke findes).

Ved Veigrøfter, omkring Byer: alm. i Landets frugtbare Egne (den hyppigste Art i Fyen og paa $\theta$ stkysten af Halveen), men bliver sjeirlnere eller forsvinder aldeles paa den magrere Jordbund (mangler f. Ex. aldeles ved Helsingor (21) og i Jyllands Hedeegne!). $\beta$, hist og her med Hovedarten, men sjeldnere: f. Ex. Sj. Esrom! F. Svendborg, St. Jørgensgaard!

\section{Serratula. Skjaer.}

1047. S. tinctoria L. (Engeskjær). H. 830 ; Drej. n. 791 ; F. D. 281 ; Rchb. l. e. XV, tab. 802 .

Stangelen opret, i Spidsen halvskjærmformigt grenet; Lladene lancetformede eller elliptiske, tilspidsede, skarpt sang- 
takkede, varierende i Indskjæring mellem hele og lyreformetfjersnitdeelte, med i Dybde tiltagende Indsnit mod Bladets Basis.

Bladene ofte lidet rue paa Underfladen; Planten forøvrigt glat; Kurvbladene i Spidsen brune, Kronerne mørkrøde, sjeldent hvide (14). 7-8. 4.

Paa høie Enge, sjeldnere i Kratskove: meget alm. paa Bornh.! ikke sjelden par L oll.! paa Falst. og i $\boldsymbol{S}$. hist og her (ikke alm.); længere mod V. sjelden: Thorseng ved Stionl (9), $\boldsymbol{F}$. Vesteraaby! Lunde pr. Odense (18); J. Aarhus (H.); $\boldsymbol{S} l$. Ellenberg ved Slien (Lund). $\overline{7}$

\section{Onopordon. Aselsfoder.}

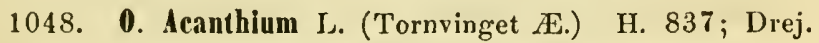
n. 795 ; F. D. 909 ; Rehb. I. c. XV, tab. 813.

Stangelen opret, bredvinget af de nedløbende Blade; Bladene elliptiske, tandede eller bugtet-lappede, Nerverne i Blade og Vinger ende i Torne; Kurvbladene filtede, lancet-sylformede, de ydre udspilede.

$3-5^{\prime}$ høi. Hele Planten tæt beklædt af en hvidgraa, spindelrævagtig Filt. Kurvene store. Kronerne rosenrøde. 7-8. (-).

Paa Diger og ndyrkede Pladser omkring Byer, især Kjøbstæder, funden hist og her $\mathrm{i}$ alle Provindser, men iklse alm.

\section{Carduus. Tidsel.}

a. Blomsterkurvene aflang-valseformede.

1049. C. tenuiflorus [Curt. Fl. Lond. f. 6, t. 55] (Tyndblomstret T.) H. 833 ; F. D. 2058 ; Rchb. ic. fl. germ. XV, tab. 865 .

Stangelen tornet-vinget; Stangelbladene nedlobende, bugtetlappede, med tornet-tandede Lapper; Kurvene 2-flere sammen. hobede i Spidsen af Stængelen og Grenene, mindre og smalere end hos de folgende Arter.

$2-3^{\prime}$ høi. Bladene paa Underfladen graafiltede; Kurrbladene bleggronne og næsten glatte. Kronene lysrgd-vinlette. 7-8. (?) (?)

Sjelden og hidtil kun funden par Digerne i Sydslesvigs Marskegne: Hnsum (N.), Rødemislıof, Papenburg, Steenslusen ved Süderstapel (16), Eidersted (F. Müll.). 叉 
b. Blomsterkurvene ægformede eller rundagtige. aa. Kurvbladene ikke indsnørede.

1050. C. crispus L. (Kruset T.) H. 833 ; Drej. n. 802 ; F. D. 621 ; Rehb. 1. c. XV, tab. 880 , fig. 1 ; H. N. XI, 4 (var.)。

Stcongelen opret, tornet-vinget; Bladene paa Overfladen grønne, næsten glatte, paa Underfladen hvidfiltede, bugtettandede, lappede eller halvfinnede, $i$ Bugterne randhaarettornede; Tanderne ende $\mathrm{i}$ en stærkere Torn; Kurvene rundagtige, enlige eller sanımenhobede paa korte, tornet-vingede eller i Spidsen nøgne Blomsterstilke; Skalfrugterne under Lupen riflede paatværs og utydeligt stribede paalangs.

Bladene meget foranderlige i Henseende til Indskjæringen. Kronerne mørk- eller violet-røde. 6-9. $\odot$. Var.

$\boldsymbol{\beta}$, ochroleucus! Kronerne hvidgule.

Ved Gjæirder, omkring Byer, alm. udbredt, undtagen pac $\boldsymbol{B}$ ornholm, hvor den er sjelden: Ronne Vang (Hjorth). $\beta, S j$. Lygteveien udenfor Kjøbenhavn! S l. Haderslev (Gronlund)!

Anm. C. crispus $\beta$, polyanthemus Godr. (C. multiflorus Gand., Koch Syn. II, 459), Rchb. XV, 880, tig. 2, med halvfinnede, paa Underfaden uldhaarede eller spindelværfiltede Blade, ægformede, $3-5$ tæt sammenhobede Kurve, Skalfrugterne fiint stribede paalangs og utydeligt riflede paatværs, vil muligviis ogsaa findes $i$ vor Flora. Den danner ligesom et forbindende Led mellem foreg. $\mathrm{og}$ folg. og forekommer mig at have noget Udseende af en Bastardform.

\section{C. acanthoides L. (Tornstanglet T.) H. 832;} Drej. n. 803 ; Rehb. l. c. XV, tab. 873 ; H. N. XI, 3.

Stcrngelen tæt tornet-vinget; Bladene graaagtige, næsten glatte eller paa Underfladens Nerver haarede, dybt halvfinnede eller fjersnitdeelte med tredeelte eller bugtet-lappede Afsnit; Lapperne ende $\mathrm{i}$ en lang og stærk Torn; Kurvene rundagtige, enlige eller sammenhobede paa korte, tornet-vingede Blomsterstilke; Skalfrugterne under Lupen tydeligt riflede paatværs.

Kurvbladene alm. i Spidsen tilbageboiede, sjeldnere rette. Let kjendelig fra foreg. ved den forskjellige Beklædning og de talrigere, meget stærkere, straagule Torne. Kroverne smulst purpurrøde, men ogsaa af denne forekommer en Form med hvidgule Kroner ( $\beta$, ochroleucus l). 7-9. $\odot$. 
Ved Veie og omkring Byer: paa Bornh.og i de fleste Egne af $S j$ all. meget alm., paa Samse (Jacobs.); $\boldsymbol{F}$. hyppig paa Hiulsholm! I det ovrige Fyen, paa Loll.-Falst. og de mindre Oer ikke bemærket; par II alvoen er den mig km bekjendt at være funden ved Haderslev (16). $\quad \beta, S j$. Verebro Noller (14); B or $n h$. (Hoff)! En Form med talrigere og langere, naesten guldgule Torne ( $\gamma$, horridus!) er funden ved Gjærder i Ramløse i Nordsjæll. (Schiitz)!

$\asymp$ C. crispo-acanthoides! Bladene paa Underfladen hvidfiltede; Tornene svagere, Kroneme violetrøde, forøvrigt som foreg. og uden Tvivl en Bastardform mellem denne og C. crispus.

Mellem Hovedarterne ved Brøndshøi og Strandveien nærved Kalkbrænderiet!

bb. De mellemste Kurvblade nedenfor Midten indsnørede, tilligemed de ydre tilbageboiet-udstaaende.

1052. C. nutans L. (Nikkende T.) H. 832 ; F. D. 675 ; I'ehb. ic. fl. germ. XV, tab. 877 ; H. N. VII, 5.

Stcongelen tornet-vinget; Bladene dybt halvfinnede, graagrønne, paa Overfladen haarede eller næsten glatte, paa Underfladen langs Nerverne uldhaarede; Blomsterlurvene enlige, paa forlængede, uvingede, i Spidsen nikkende Blomsterstilke; Kurv. bladene ved Grunden agformede, ovenfor Indsnøringen tornspidset-sylformede; Skalfrugterne tydeligt stribede paalangs, svagt riflede paatværs.

Væxten lavere, Blomsterkurvene mere end dobbelt saa store som hos foreg. Kronerne morkt purpurrode. 7-8. $\odot$.

Ved Veigrofter og Randen af Marker, meget sjelden i Danmark: Falst. S. Kirkeby (Koch); F. Dalby paa Hindsholm! mellem Peirup og Holstenshuus! Skaarup (19); Stryno (Glahn); Sl. Hoirup 1 Miil V. for Christiansfeld (12), mellem Hestebjerget og Nyværk ved Slesvig (16); J. 'Thisted (Jacobsen)!

$\asymp$ C. crispo-nutans Koch (Sond. Fl. Hamburg. p. 237). C. acanthoides Gren. \& Godr. fl. Fr. II, p. 231 (ikke L.).

Forskjellig fra $C$. nutans ved høiere og mere grenet Stængel, 1-3-blomstrede, indtil Spidsen tornet-vingede Blomsterstilke, mindre Kurve og smalere Kurvblade; fra C. crispus ved fjersritdeelte, paa begge Flader grønne Blade, som i Randen tilligemed Stæugelens Vinger ere stærkere tornede; 
meget større, noget nikkende Blomsterkurve, nedenfor Midten indsnørede, i Spidsen stikkende Kurvblade.

I Selskab med Hovedarterne ved Skaarup (19) og Dalby paa Hindsholm!

\section{Cirsium. Bladhoved.}

a. Stængelen tornet-vinget af nedløbende Blade. (.

1053. C. lanceolatum [Seop. Fl, carn. 2, p. 130] (Laneetbladet B.) Drej, n. 797; Nägeli i Koch Syn. p. 989; Rehb. ic. fl. germ. XV, tab. 826 ; Carduus L., H. 831; F. D. 1173.

Bladene dybt halvfinnede; Fligene dybt todeclte, med lancetformede Smaaflige og fremstaaende, i en stærk og spids Torn endende Nerver, paa Overfladen tiltrykt-stivbaaret-rue, paa Underfladen bvidfiltede; Blomsterkurvene enlige eller 2-3 samlede, rundagtigt-ægformede, tæt filtede; Kurvbladene ndstaaende, laneetformede, endende $\mathrm{i}$ en lang og spids Torn.

2-4' høi, med store Kurve. Kronerne rosenrøde, sjeldnere hvide. 7-8. Var. i Henseende til Bladenes Indskjæring, Kurvenes Form og Antal paa Grenene o. s. v. Følgende afvigende Former (som af Rchb. ansees for adskilte Arter) høre uden Trivl herhid:

* nemorale Nägeli l. c. p. 990 (C. nemorale Rehb. fl. germ. exc. p. 286 ; ie. fl. germ. XV, tab. 826). Bladene mindre dybt deelte, paa Underfladen spindelvævfiltede; Kurvene næsten kugleformede.

** Drejeri (C. Drejeri Rchb. ic. fl. germ. XV, tab. 827). Stængelens Vinger bredere; Bladene kortere og mindre dybt deelte, paa Overfladen kort-stivbaarede, paa Underfladen graafiltede; Kurvene nedtrykt-kugleformede, de indre Kurvblade forliengede.

Ved Gjærder og paa udyrkede Steder meget alm. i hele Landet. * Meen (Fries); Slesvig (Rchb.). *** Moens Klint! Hjermesler og Thise i Vendsyssel, Korsøgaard ved Hobro (Drej.).

\section{$\asymp$ C. oleracso-lanceolatum [J. Vahl mser.].}

Stcengelen kantet-furet, overalt klæbrig duunhaaret; Bladene halvt nedløbende, fjersnitdeelte med 2-3-fligede Afsnit; Fligene lancetformede, svagt tornspidsede, paa Overfladen næsten 
glatte, paa Underfladen svagt graafiltede; Blomsterkurvene i en mangegrenet Halvskjærm, paa forlængede, duunhaarede Blomsterstilke; Kurvbladene næsten glatte, svagt tornspidsede; Kronbladene skident røde.

Ved Kongekilden i Ordrups Krat med Hovedarterne (27)!

1054. C. palustre [Scop. l. c. p. 128] (Kjær-B.) Drej. n. 796 ; Näg. l. c. p- 990 ; Rehb. l. c. XV, tab. 831 ; Carduus L., H. 833; Carduus acanthoides F. D. 1341.

Bladene fjersnitdeelte eller halvfinnede, med lancetformede, 2-3-fligede, tornet-tandede Afsnit, paa Overfladen spredthaarede, paa Underfladen graafiltede; Blomsterkurvene sammenhobede $\mathrm{i}$ Spidsen af Stængelen og de ovre Grene, svagt filtede, efter Udspringningen ægformede; Kurvbladene æg-lancetformede, tiltrykte: med en kort, udstaaende Braad.

Strengelen $3-5^{\prime}$ høi, alm. bruunagtig. Kronerne rødviolette, sjeldnere hvide. $7-8$.

$\beta$, putatum Nägeli 1. c. (C. Chailleti Gaud.). Bladene halvt nedløbende, paa begge Flader næsten ensfarvede; Kurvene enlige, paa uvingede, forlængede Blomsterstilke.

I Tørvmoser, Kjær og fugtige Enge alm. udbredt. $-\beta$, som har et meget afvigende Udseende, men kun er en ved Hovedstæengelens Afhugning frembragt Form, har jeg fundet ved Leersøen udenfor Kbhvn.

b. Bladene ikke nedløbende. ข.

\section{aa. Kronens Krave spaltet til Midten.}

$\asymp$ C. palustri-oleraceum [Näg. 1. c. p. 999]. Rehb. 1. c. $\mathrm{XV}$, tab. 846 .

Stangelen kantet-furet; Bladene omfattende, dybt halvfinnede med lancetformede, 2-3-lappede, tornet-tandede Flige, paa Underfladen lidet filtede; Blomsterkurvene flere samlede $\mathrm{i}$ Spidsen af Stængelen og de øvre Bladhjøruer, kortstilkede, med smaae, lancetformede, tornet-saugtakkede Dcelbblade; Kurvbladene lancetformede, ved en mod Spidsen fremstaaende Nerve pa: Ryggen tornspidsede. 
Kronerne hvidgule, Støvdragerne i Spidsen og Griflerne lila-røde. (Ligner i Bladformen og de smaae Blomsterkurve C. palustre, ved Stængelen og de ikke nedlobende Blade samt Blomsternes Farve C. oleraceum. 7 -8.

Paa Mosegrund med Hovedarterne, sjelden: $\mathbf{S} \boldsymbol{j}$. Tryggerød Mose ved Vedbæk (et Expl.)! Raavaddam, Bidstrupgaard (19). En Form med balvt nedløbende Blade funden ved Tonder (Branth).

1055. C. oleraceum [Scop. l. c. p. 124] (Grøn B.) Drej. n. 798 ; Nägeli l. c. p. 995 ; Rchb. 1. c. XV, tab. 834; Cnicus L., F. D. 860 ; Carduus Vill., H. 837.

Stcengelen trind, furet, bladet indtil Spidsen og oventil grenet; Bladene lysgrønne, glatte eller svagt haarede, med omfattende Basis, de nedre halvfinnede eller fjersnitdeelte med hele, lancetformede, tornet-saugtakkede Flige, de ovre hjerteformede, tornet-sangtakkede eller fligede; Blomsterkurvene tæt omgivne af flere xgformet-elliptiske, lys guulgrønne Dackblade; Kurvbladene jævnt sylformet-tornspidsede; Kronens Krave lidet længere end Røret.

$3-5^{\prime}$ høi. Kronerne bleggule; Støvdragerne skident violette. Ved den svage Behaaring, lysgronue Farve og de forskjelligfarvede Dækblade let kjendelig fra de פvrige Arter. 7-8.

Paa Enge og i fugtige Skove: i de fleste Egne alm., men ikke overalt: (sjelden paa Falster (Moseby (5), Liselund, Korselitze, Ravnsø (Koch), Næsgaard, Bregninge, Bellinge (14)) og Loll. (Egholm, Hunseby (5); ikke bemærket i V. Hanherred (12) eller paa Bornholm! i*

$\asymp$ C. oleraceo-acaule [Hampe i Linnæa 1837 p. 1] Näg. 1. c. p. 1010 ; C. acauli-oleraceum Rehb. I. c. XV, tab. 858 ; C. decoloratum Koch Syn. I, p. 398; Carduus rigens La Chen., H. II, 243.

Stangelen grenct; Bladene paa Overfladen svagt, paa Underfladens Nerver tret duunhaarede; Stangelbladene lancetformede, siddende (ikke omfattende), halvfinnede, med trelappede Flige, Lapperne ægformede, tornet-tandede; Blomsterkurvene enlige, omgivne af $2-3$ lancetformede, med de ovre Blade ensfarvede Dakblade; Kurvbladene lancetformede, jævnt, men kort tornspidsede: Kronens Krave som hos foreg. 
1-1 $1 / 2^{\prime}$ høi. Kronerne bleggnle eller svagt rødlig-gule. Ligner foreg. i Henseende til Blomsterkurvene og den forlengede, grenede Stængel, folg. i Bladene og Dækbladene. 7-8.

Forekommer med Hovedarterne, men sjelden, og sadvanligviis kun faae Expl.: S j. Hesttangs Molle, Jonstrup Vang (14), Griesvaenget red Skjelskır (Nielsen)! $\boldsymbol{J}$, eu Groft ved Veien mellem Kolding og Stest! St. en Skoveng ved Aabenraa (Bargum).

1056. C. acaule [All. Fl. ped. I, p. 153] (Kortstienglet B.) Drej. n. 800 ; Näg. 1. e. p. 993 ; Rehb. I. e. XV, tab. 840 ; Carduus L., H. 836 ; F. D. 1114.

Den overjordiske Stangel udeelt, sædvanlig meget kort eller 0 ; Bladene kortstilkede (ikke omfattende), paa Underfladeus Nerver dumbaarede, lancetformede, halvfinnede eller fjersnitdeelte, med ægformede, 3-4-lappede, tornet-tandede Flige; Blomsterkurven omgivet af $1-3$ laneetformede, med de øvrige Blade ensfarvede Dakblade; Kurvbladene æg-lancetformede, budte, pludseligt og kort tornspidsede; Kronens Rør længere end Kraven.

Kroneme smakt og morkt rosenrøde, sjeldent livide. 7-8. Var.

$\beta$, caulescens F. D. 1884. Stængelen forlænget (indtil 1' høi), fra Grunden til Spidsen bladet.

Paa hoie Enge, græsklædte Bakker og Overdrev, ikke sjelden. $\beta$, med Ifovedarten, men sjeldnere og oftest i Skygge eller paa frodigere Jordbund.

1057. C. heterophyllum [All. 1. e. p. 152, t. 34] (Forskjelligbladet B.) Drej. n. 801 ; Näg. I. e. p. 993; Rehb. I. c. $\mathrm{XV}$, tab. 838 ; Carduus L., H. 835 ; F. D. 109.

Stcenyelen opret, filtet; Bladene paa Overfladen morkgronue, glatte, paa Uuderfaden tæt sølvlivid-filtede, i Randen fiint tornet-saugtakkede; Rodbladene stilkede, laneetformede, hele eller halvfinnede; Stangelbladene fra en bred lijerteformet Basis jævnt og langt tilspidsede, linie-laneetformede, de ovre bele, de nedre halvfinnede; Blomsterkurven enlig, ved en uøgen Blomsterstilk fjernet fra det ovre Blad og uden Dxkblade; Kurvbladene laneetformede, budte, kort tornspidsede; Kronens Rør og Krave outrent ligelange. 
Stængelen 2-4t høi, udeelt eller sjeldnere med 2-flere Grene og 1 Kurv paa hver Green. Kronerne smukt purpurrøde. 6-7.

I Skove paa Leergrund: i Halveens østlige Skovegne ikke sjelden, sparsommere mod V., f. Ex. Skjærhoved! Norholm (H.), Ribe (16); paa Øerne sjelden: $\boldsymbol{F}$. Krat ved Lunde pr. Odense, Østrupgaards Skov (18); L oll. Bjerremark (5); $\mathbf{S}$. Slangerup, Hareskoven mod Ballerup (H.), Jonstrup Vang!

\section{bb. Kronens Krave spaltet til Grunden. (Breea Less.).}

1058. C. arrense [Scop. 1. c. p. 126] (Agertidsel) Drej. n. 799; Näg. 1. c. p. 995 ; Rehb. 1. c. XV, tab. 842 ; Serratula L., F. D. 644 ; Carduus Curt., H. 834.

Stangelen grenet (de nedre Grene blomsterløse), i Spidsen halvskjærinformet med $2-5$ nøgleformigt sanmenhobede Kurve i Spidsen af Grenene; Bladene hele eller bugtet-halvfinnede med tornet-tandede Flige; Blomsterkurvene ægformet-valseformede, filtede, med tiltrykte, ægformigt tilspidsede og i Spidsen ud. staaende Kurvblade; Kronrøret i Spidsen bøiet.

Bladene var. glatte eller paa Underfladen filtede. Kurvene mindre end hos de foreg. (undtagen Nr. 1054). Blomsterne ofte tveboe (det ene Kjøn ( $\hat{\sigma}^{*}$ med ufrugtbare Blomster, større Kroner, hvis Rør er omtrent dobbelt saa langt som Kraven, det andet Kjøn (q) med mindre Kroner, Kronroret 4 Gange længere end Kraven, svagt udviklede Støvdragere. Kronerne skident violette eller lila-røde, sjeldent hvide. 7--8. Var.

$\beta$, horridum W. \& Gi. Bladene halvfinnede, i Randen bølgede, tæt og stærkt tornede.

$\gamma$, mite Koch. Bladene bugtet-tandede, de øvre hele, svagt tornede.

$\delta$, integrifolium W. \& Gr., Fr. H. N. XIV, 9. Alle Bladene heelrandede eller svagttandede, paa Underfladen tæt hvidfiltede.

$\varepsilon$, semidecurrens Lge. Stængelens Ledstykker foroven tornede af de halvt nedløbende Blade; Grenene meget talrige og langstrakte; Blomsterkurvene enlige i Spidsen af forlangede Blomsterstilke.

Paa dyrkede Marker mellem Sxeden et meget almindeligt og besværligt Ukrud. Afarterne med Hovedarten, men sjeldnere: $\delta$, Kj $\boldsymbol{~}$ benhavns Glacier mellem Nørre- og Vesterport! J. Hjørring (Grønlund)! $\varepsilon$, Klitter paa Sydenden af Amroin (20)! En Form med hvide Kroner paa fialst. ved Holgershaab (Koch)! 


\section{Silybum. Solvblad.}

$\dagger$ 1059. S. marianum [Gärtn. fruct. 2, p. 378, t. 162] (Marietidsel). Drej. p. 259; Rebb. l. c. XV, tab. 882 ; Carduus L., H. 835.

Stangelbladene omfattende, i Randen bølgede, tornet-tandede, de nedre bugtet-halvfinnede, de øvre hele; Kurvbladene med ægformet, tornet-randhaaret Basis og udstaaende, sylformet, i en lang Torn udløbende Spidse; Kronroret meget lengere end Kraven.

2-4' høi. Bladene gronne med hvide Pletter og Striber. Kurvene meget store. Kronerne violette. 7-8. $\odot$.

Omkring Byer, oprindelig forvildet fra Haver: J. Randers (H.), Lovskal (3), Aarlus (16), Hatting ved Horsens (Jørg.): $S l$. Haderslev (Nielsen), Hesteberger Koppel ved Slesvig (Esmarch), Husum (16); $F$. Bogense, Ulriksholm (H.), Assens (Kyll.), Faaborg (24); Me en ved Stege (Dr.); $\boldsymbol{S}$. Stillinge (Lund).

\section{Carlina. Bakketidsel.}

1060. C. vulgaris L. (Almindelig B.) H. 838; Drej. n. 790 ; F. D. 1174 ; Rebb. 1. \& XV, tab. 742.

Stcongelen stivt opret, tætbladet, udeelt eller i Spidsen balvkjarmformigt grenet; Bladene bugtet-halvfinnede eller tandede, i Randen tornede, paa Underfladen filtede; de ydre Kurvblade lancetformede, dobhelt halvfinnede, tornede; de indre linieformede, hindeagtigt-hvidgule, nedenfor Midten raandhaarede.

$1-1^{1 / 2^{\prime}}$ høi. Kronerne rødgnle, Støvdragerne gule. 7-8. ().

Paa Bakker og udyrkede Steder, ikke sjelden i Danmark, især paa Leergrund.

\section{Bidens. Brondsel.}

1061. B. tripartita L. (Fligbladet B.) H. 839; Drej. n. 805 ; F. D. 2178 ; Rehb. l. c. XVI, tab. 941.

Bladene modsatte, stilkede, fjersnitdeelte med lancetformede, saugtakkede Afsuit (de $1-2$ nedre Par Afsnit større og derved 3-5-deelte); Blomsterkurvene oprette, i halvskjarmformet Qvast, først næsten valseformede, efter Aflolomstringen nedtrykt-halvkugleformede, indeholdende 40-60 Blomster; de ydre Rurv- 
blade 6-8, lancetformet-spadeformede, tæt tornet-randhaarede, de indre Kurvblade smalt rgformede, pludseligt udløbende $\mathrm{i}$ en budt Spidse; Avnerne linieformede, trenervede, kun naaeude til Grunden af Fnokken; Kronen halvt saa lang sum Bægerrøret; Skalfrugterne kileformede, brune, rynket-vortede, med alm. 2 Borster i Fnokken.

$1^{1 / 1 / 2}-2^{\prime}$ høi. Planten mørkgrøn, ofte bruunagtigt anløben. Kronerne guulbrune. $\frac{7}{2}-9$. $\odot$. Var.

$\beta$, minor. Lavere $\left(2-6^{\prime \prime}\right.$ høi), med udeelte, lancetformede, saugtakkede Blade.

Ved Bredder af Moser og Gadekjær, i Dynd o. s. v. meget alm. $\beta$, paa mere tør Jordbund, sjeldnere.

1062. B. platycephala [Ørsted i Ind. sem. bort. haun. 1859 , p. 27] (Fladhoved-B.) Ørd. i Naturh. Foren. vid. Medd. 1862 , p. 312 , tab. 3 .

Bladene modsatte, kortstilkede eller de ovre siddende, i Forhold til Plantens Størrelse hele eller ved Grunden dybt 3-5-deelte, Afsnittene lancetformede, fjernt og ikke dybt saugtakkede; Blomsterkurvene i en halvskjærmformet Qvast eller enlige i Spidsen af Stængelen, før og efter Blomstringen stærkt nedtrykte (Breden meget større end Høiden), indeholdende 100-150 Blomster; de ydre Kurvblade 10-12, lancetformede, kort og fjernt tornet-randharede, de indrc æg-lancetformede, spidse; Avnerne smalt linieformede, alm. ennervede, naaende til Midten eller Spidsen af Fuokken; Kronen firetandet, af Længde med Bægerrøret; Skalfrugterne graaggtig-olivenbrune, bredt omvendt-ægformede, jævne, med 2-3 Børster i Stakken.

$1 / 2-1^{1} / 2^{\prime}$ høi. Hele Flanten gunlgrøn, Stængelen forneden ofte rødlig, Kronerne gule. Frugterne flere Gange mindre end hos foreg. Art. $\frac{8}{1}-9$ (alm. 8-14 Dage senere end foreg., men tidligere end følg.).

Ved Randen af Søer, Damme og Torvgrave, hidtil kun bemærket i S jall. sporadisk, nen paa nogle Steder i Mængde: Bredderne af St. Jørgens $S_{g}$ (Orsted)! Dam mellem Taarbak og Strandmøllen! Tikjøb! Rostgaards Dain ved Hellebæk!

Anm. I Udseende har den endeel tilfælles med følg., i Characterer staaer den nærmere ved foreg. Art, men er væsenlig forskjellig fra begge og kan neppe antages for en Bastardform, bl. a. fordi den 
stedse bærer rigeligt spiredygtigt Frø. Narmest er den beslægtet med $B$. radiata Thuill. (B. fastigiata Michalet), men denne synes dog (efter Expl. dyrkede i bot. Have) at vare tilstrakkelig adskilt ved en morkere gron Farve, høiere, oventil kirtelharet Stængel, ved Bladafsnittene, som have tahigere og mere udstanende Sideanrer, flere og spidsere Takker, ved de kortere og smalere ydre Kurvblade og ved sildigere Blomstringstid $(9-10)$.

1063. B. cernua L. (Nikkende B.) H. 839 ; Drej. n. 806 ; Rehb. I. c. XVI, tab. 941.

Bladene modsatte, siddende eller kortstilkede, ved Grunden næsten sammenvoxme, lancetformede, fjernt, men skarpt og alm. dybt saugtakkede; Blonsterkurvene enlige eller i klaseformet Blomsterstand, nikkende, fladtrykt-halvkugleformede, indeholdende T0-100 Blomster; de ydre Kurvblade lancetformede, kort og fjernt randhaaret-takkede, de indre ovale eller bredt agformede, budte; Avnerne lancet-spadeformede, alm. femnervede, naaende omtr. til Midten af Frokken; Kronen halvt saa lang som Bagerrøret; Skalfrugterne omvendt-agformet-kileformede, sortbrune; Fnoklien lysere, alm. dannet af 3-4 Børster.

1-2' høi. Planten frisk grøn, foroven kirtelhaaret, Blomsterne lys-brunngule. $\frac{8}{2}-9$. $\odot$. Var.

$\beta$, radiata F. D. 841 ; Coreopsis Bidens L. Randkronerne tungeformede, kjønsløse, gule.

$\gamma$, minima (L.) F. D. 312. Dværgform (1-2" høi), Blomsterkurven enlig, alm. opret (uden eller med tungeformede Randkroner).

Ved Randen af Damme og Torvmoser, alm. udbredt. $\boldsymbol{\beta}$, hist $\mathrm{og}$ her nred Hovedarten. $\gamma$, paa mere tor Grund og ved grusede Sobredder ikke sjelden.

\section{Eupatorium. Ijortetrost.}

1064. E. canmabinum L. (Hampagtig H.) H. 840; Drej. n. 804 ; F. D. 745 ; Rehb. 1. c. XVI, 892.

Bladene inodsatte, kortstilkede, dybt 3-5-deelte, med lancetformede, sangtakkede Afsnit, det midterste storst; Kurvene smaae, valseformede, faablomstrede, talrigt samlede $i$ en tæt Halvshjarm; Kurvbladene budte. 
Stængelen opret, 2-4' høi, tilligemed Bladenes Underflade duun. haaret. Kronerne blegrode. 7-9. 4 . udbredt.

Ved Søbredder, paa Enge mellem Krat, i fugtige Skove, alm.

\section{Syngenesia superfIua.}

\section{Petasites. Ilestehov.}

1065. P. officinalis [Moench Meth. p. 568] (Pestilensurt). Drej. n. 807; Tussilago Petasites L., H. 856; F. D. 842 ; H. N. I, 7; P. vulgaris Desf., Rehb. l. c. XVI, tab. 901.

Bladene bredt hjerteformede med afrundede Lapper ved Grunden, i Randen uregelm. tandede, paa Underfladen graaagtigt uldhaarede; $\not{\zeta}(T$. Petasites L.): Klasen ag-valseformet; Kurvbladene $\mathrm{i}$ den indre Kreds budte; Arrene korte, rgformede: \& (T. hybrida L.): Klasen pyramideformet; Blomsterkurvene $1 / 2$ Gang mindre; Kronerne traadformede; Arrene linieformede.

Bladene ofte meget store (Stilken inftil $4^{4}$ lang, Pladen indtil $1^{1} 2^{\prime}$ i Gjennemsnit). Blomsterne fremkomme, som hos de ovrige Arter, f $\Leftrightarrow r$ Bladene paa et med rødlige Skjæl (Bladskeder) beklædt Skaft. De nedre Skeder have ofte en svag Begyndelse til en Plade. $\Varangle$ er hos os langt hyppigere end o. Kronerne rosenrode. 4-5. 4 .

Ved Aa- og Søbredder, i sumpige Skcve, ikke sjelden, men sporadisk: hyppigst i $S y d s j a l l$, paa $\theta$ erne og i det sydl. Fyen, hvor den ofte følger Aaløbene $\mathrm{j}$ lange Strukninger og aldeles beklæder disses Bredder med Udelnkkelse af al anden Vegetation, f.Ex. Aaen mellem V. Aaby og Rødkilde i Fyen!

1066. P. albus [Gärtn. fruct. 2, p. 406] (Hvidblomstret H.) Drej. n. 808 ; Rehb. 1. c. XVI, tab. 899 ; Tussilago L., H. 855 ; F. D. 524 ; H. N. II, 3 .

Bladene nyreformede, med afrundede Lapper ved Grunden, skarpt og uregelm. tandede, mellem de større Tænder bugtetudrandede, paa Underfladen hvidgraa-filtede; Kurvbladene i den indre Kreds smale, spidse; $\Varangle(T$. alba L.): Klasen kort, ægformet, næsten halvskjærmformet; Arrene linie-lancetformede, tilspidsede; $\{$ ( $T$. ramosa Hopp.): Klasen forlænget, med fleer- 
blomstrede Blomsterstilke; Kronerne traadformede, Arrene korte, linieformede.

Bladene mindre end hos foreg. Kronerne guullivide. 3-4. 4 .

I fugtige Skove paa Leergrund, ved Søbredder: J. Rold Skov (8), Odder, Rathlousdal (Aabye), Lundum Molle ved Horsens (2), Brandbjerg (28), og derfra mod $\mathrm{S}$. hist og her $\mathrm{i}$ de østlige Skove paa Halvoen; paa Øerne meget sjelden: $\boldsymbol{S} j$ Sorø? (H.), Petersværft (West), Nusgaard ved Dronninggaard (20). *

1067. P. spurius [Rchb. Fl. exe. p. 279] (Hvidbladet H.) Rehb. I. c. XVI, tab. 897; Tussilago Retz., H. 857; F. D. 1828 ; H. N. II, 4 .

Bladene triangelformet-piilformede eller hjerteformede, med 2-3-lappede, udadtil udspilede, indadtil indbøiede Lapper ved Grunden, i Randen fiint og næsten regelm. tandede, paa Overfladen bleggrønne, paa Underfladen sneehvidt og fløirlsagtigt filtede; Klasen kort, tilsidst ofte halvskjærmformet; Kurvbladene i den indre Kreds brede, budte; $\$$ : Kronerne udvidede foroven, (næsten tungeformede); Arrene korte, ægformede; $\Varangle:$ Arrone budt-tungeformede.

Kronerne hvide eller blegrøde. 4-5. 4.

Ved sandige Bredder af Havet (eller Indsøer), sjelden i Danmark (og ikke i alle Aar blomstrende): Bornh. ved Arnager (H.), fra Sosa-Odden til Pythuset (Lotze), Hasle (20); F alst ved Grøusund! Hesnæs (14); Stubbekjøbing (25), Giabense! $\boldsymbol{S} j$. Langebæk Skov (West).

\section{Tussilago. Folfod.}

1068. T. Iarfara L. (Almindelig w.) H. 854; Drej. n. 809 ; F. D. 595 ; Rehb. l. c. XVI, tab. 904.

Bladene nyreformet-ljjerteformede, grovt og bugtet-tandede, med mindre Tænder mellem de støre; Blomsterkurven efter Afblomstringen nikkende; Randkronerne smalt tungeformede.

Blomsterne udvikles, ligesom hos foreg. Slagt, før Bladene; Skaftet $1 / 2-1$ ' hosit, beklædt med skjælformede Blade og tilligemed Bladenes Underflade overtrukken af en hvid Uld, som let afguides. Kronerne gule. $3-4$ (5-fr.) ข.

Paa leret Jordbund, meget alm. i Danmark. 


\section{Artemisia. Bynke.}

a. Absinthium Tournef. Hlomsterleiet haret.

1069. A. Absinthinm L. (Malurt). H. 844 ; Drej. n. 811 ; F. D. 1654 ; Rehb. l. c. XVI, tab. 1029.

Stongelen opret; Bladene 2-3-dobbelt fjersnitdeelte, med budt-lancetformede Afsnit; Blomsterkurvene kugleformede eller halvkugleformede, nikkende; Kurvbladene ligelange, de ydre linieformede, i Spidsen hindeagtige, de indre budte, med bred, hindeagtig Rand.

Hele Planten sglvglindsende graa af fine og tæt-tiltrykte Silkehaar, har en stærk Lngt og bitter Smag. Kronerne guulagtige. 7-8. ข.

Ved Randen af Marker og Veie, omkring Landsbyer: meget alm. paa Bornh. og Loll., temmelig alm. langs Kattegattet N. f. $\mathrm{Ny}-$ kjobing i Odsherred (14), i de øvrige Provindser sporadisk og temmelig sjelden.

b. Blomsterleiet nøgent.

aa. Seriphidium Bess. Alle Kronerne ఫ̧, med en slijov

Basis befastcde til Frugtknuden.

1070. A. maritima L. (Strand-Malurt). H. 842; Drej. n. 814 ; F. D. 1655 ; H. N. IV, 4.

Stanglerne opstigende eller oprette; Bladene 2-3-dobbeit fjersnitdeelte, med smalt linieformede, budte Afsnit; de nedre Stangelblade med Ører ved Grunden; Blomsterliurvene æg-valseformcde; Kurvbladene omvendt-ægformede, de ydre kortere, filtede, de indre i Randen hindeagtige.

De golde Stængler danne Tuer. Bladene mere eller mindre sølvgraa-filterle, have en behagelig krydret Lugt og en mildt bitter Smag. Kronerne rødgule. Var. i Henseende til Grenenes og Blomsterkurvenes Retning: 8-9. 4 .

$\alpha$, typica. Grenene i Spidsen nikkende, Blomsterkurvene oprette.

$\beta$, gallica (A. gallica Willd., F. D. 2119 ; Rehb. 1. c. XVI, tab. 1034). Grene og Blomsterkurve oprette.

$\gamma$, salina Koch, Rchb. 1. c. XVI, tab. 1039 (A. salina Willd.). Grene og Kurve hængende. 
Ved Strandbredder, især paa feed og leret Marskbund, funden i alle Provindser (undt. Bornh.), men i de fleste Fgne ikke alm.; hyppigst i Slesvigs Marskegne og paa Oerue i Ostersøen (f. Ex. i det sydl. Loll.). De 3 Former roxe i Selskab med liverandre og synes at være omtr. lige almindelige.

\section{bb. Abrotanum Tourn. Randkronerne 오.}

1071. A. campestris L. (Mark-B.) H. 842; Drej. n. 812; F. D. 1175 ; Rehb. 1. c. XVI, tab. 1036.

Stcenglerne opstigende; Bladene enkelt eller 2-3-dobbelt fjersnitdeelte med linieformede, kort braadspidsede Afsnit; Stongelbladene med Yrer ved Grunden; Blomsterkurvene ægformet-kugleformede, oprette eller nikkende; Kurvbladene ægformede, glatte; med lindeagtig Rand, de ydre kortere.

De blomsterløse Stængler danne Tuer, de blomsterbærende tynde, riisformede, ofte rødbrune. Planten næsten ulugtende. Kronerne rødlige. 8-9. थ. En i Henseende til Stænglernes Retning, Bladformen og Kurvenes Størrelse meget foranderlig Art. Var. desuden glat eller duunhaaret af tilsidst affaldende Haar og

$\beta$. sericea Fr. Bladene sølvglindsende af en tæt, vedblivende Filt.

Paa torre, sandige Marker, ikke sjelden i de fleste Egne af Landet. $\boldsymbol{\beta}$, i Sandklitter og paa Strandskrænter, f Ex. Sj. Hellebæk, Stevns Klint alm! fialst. Ulslov Strand (Koch); Loll. paa Bredfjed i Rødby Fjord! B ornh. Sandfugtsstrækningen ved Rønne!

1072. A. vulgaris L. (Graa B.) H. 844 ; Drej. n. 813 ; F. D. 1176 ; Rehb. 1. e. XVI, tab. 1038.

Stangelen opret; Bladene dobbelt fjersnitdeelte med spidst lancetformede (hele, saugtakkede eller fligede) Afsnit, paa Under fladen hvidfiltede; Stcengelbladene med Ører ved Grunden; BlomsterJurvene oprette eller lidet nikkende, æg-valseformede; Kurvbladene filtede, i Randen hindeagtige, de ydre kortere.

Bladene hàre en svagt krydret, ikke behagelig Lugt. Kronerne rodgule. 7-6. 4 .

Ved Veigryfter, i Randen af Skove, omkring Byer o. s. v., meget alm.

\section{Tanacetum, Regnfang.}

1073. T. vulgare L. (Almindciig R.) H. 841; Drej. n. 810 ; F. D. 871 ; Rehb. I. c. XVI, tab. 996. 
Stcengelen opret: Bladene enkelt eller dobbelt fjersnitdeelte, med linie-lancetformede, sangtakkede Afsnit; Blornsterkurvene i Halvskjærmen naae ligehøit.

2-3' høi. Bladene have en stærk, krydret Lugt. Kronerne gule. $\frac{7}{2}-9.4$.

Ved Gjærder og Veigrøfter, alm. i de fleste Egne: hyppigst paa Loll. - Falst., sparsomt i Halvoens Hedeegne.

\section{Cotula. Fiirkloft.}

1074. C. coronopifolia L. (Fligbladet F.) H. 874 ; F. D. 341 ; Rehb. I. c. XVI, tab. 998 ; H. N. XIV, 6.

Stcongelen fra Grunden af grenet, med svage, opstigende Grene; Bladene omfattende, lancet-linieformede, halvfinnede; Blomsterkurvene enlige, i Spidsen af Grenene.

$3-6$ " høi, glat; Grenene ofte rødagtige. Kronerne gule. 7-8. $\odot$.

Paa dyndfuld, leret Grund, saavel inde i Landet som paa Strandenge, hidtil kun funden paa faae Steder i Danmark: J. Harbogre (24); Thorseng i den sydlige Deel alm., især ved Gadekjær i Byerne (H., 12!,; $\operatorname{Ar} \theta$ (Riise i Kph. Herb.). 网

\section{Gnaphalium. Evighedsblomst.}

a. Helichrysum Gärtn. \& Blomsterne i Randen i e en Kreds.

1075. G. arenarium L. (Guul E.) H. 845 ; F. D. 641 ; Rehb. I. c. XVI, tab. 950 ; H. N. II, 1 ; Helichrysum DC., Drej. n. 820.

Stcengelen opstigende eller opret; Rodbladene spadeformede, budte; Stangelbladene linie-lancetformede; Blomsterkurvene i en endestillet, af flere Nøgler tæt sammensat Halvskjærm.

$1 / 2-1$ ' høi, hele Planten graafiltet. Kronerne stærkt gule, Kurvbladene citrongule (sjeldnere brandgule med høirøde Spidser eller hvide). 7-9. 4 .

Sandige Marker og Bakker, funden i alle Provindser, men ikke overalt: hyppigst i Nordsjall. og paa Bornh. [\$

b. Gnaphalion Koch. + Blomsterne i flere Kredse.

aa. Blomsterkurvene nøgleformigt samlede $i$ Spidsen af Grenene. $\odot$.

1076. G. luteo-album L. (Guulbvid E.) H. 846 ; F. D. 1763 ; Rchb. l. e. XVI, tab. 947 ; H. N. I, 1. 
En-fleerstænglet, med nedentil udeelte Stangler, Hovedstængelen opret, Sidestænglerne opstigende eller nedliggende; Bladene halvt oinfattende, i Randen bolgede, de nedre lancetspadeformede, budte, de фvre lancet-linieformede, spidse; Skalfrugterne ru-punkterede.

'1/4-1' høi, hele Planten hvidgraa-filtet. Kronerne kjødfarvetgule, Kurvbladene solvglindsende straagule. $7-8$.

Paa sandige Overdrev, meget sjelden og kun funden $\mathrm{i}$ de sydligste Provindser: B or $n$ h. ved Veie i Sandstrækningen mellem Pythuset og Stampen! Røune (Hjortl); Sl. Sorgvold N. for Rendsborg (16).

1077. (. uliginosum L. (Sump-E.) H. 849 ; Drej. n. 817 ; F. D. 859 ; Rehb. l. c. XVI, tab. 948 .

Stcengelen fra Grunden af grenet, de nedre Grene opstigende; Bladene lancetformede, med størst Brede foroven, spidse, heelrandede eller svagt bølgede, tilligemed Stængelen graafiltede; Skalfrugterne jævne; Fnokkens Straaler 8-12.

$3-6^{\prime \prime}$ høi. Kurvbladene olivengronne med hindeagtig, straaguul Rand. Kronerne guulagtige. 7-8.

Pa: fugtige Agre, i sumpig Grund alm. ndbredt.

* 1078. G. nudum [Hoffm. Bot. Tasch. 1791, p. 292] (Glat E.) F. D. 2474 ; H. N. XII, 6; G. uliginosum $\gamma$, glabrum Koch Syn. II, 400; Rehb. ic. crit. VIIl, 999.

En-fleerstæuglet, med svage, udstrakte, udeelte eller grenede Stangler; Bladene linieformede, spilse, heelrandede, tilligemed Stxuglerne glatte, grønne; Skalfrugterne korthaaretrue (eller jævne?), med 6-10-straalet Fnok.

Stænglerne 1-2" lange. 7-ל.

Ved Sø og Aabredder, paa fugtige Overdrev, sjelden: Amager Fælled; Borgsum og Klaus Limbaks Borg paa Fohr (20). Fit

Anm. Ved dens tinere og mere udstrakte Strengler, smalere, aldeles gronne og glatte Blade sant fierre, til en kort og tret Klase samlede Kurve i spidsen af stængleme let kjendelig og saa forskjellig fra foreg. at den synes at fortjene P'lads som en egen Art. Expl. fra det angivne Voxested saavelsom fra Geesthacht i Lanenborg (livor jeg samlede den i Mrengde i Selskab med foreg. uden Overgange) have rue Skaltrugter, hvorimod koch (l. e.) beskriver dem jxvne. Dette Kjendetegu synes altsaa at viere forauderligt, hvilket muligviis ogsaa gjælder om $G$. pilulare Wahlenb. (H. N. X, 2), som $\mathbf{i}$ andre Henseender er laugt mere lig G. uliginosum. 
bb. Blomsterkurvene $i$ Nogler fra Bladhjornerne, danne en bladet, axformet Klase. 4.

1079. G. silvaticum L. (Rank E.) H. 847 ; F. D. 1229 ; Relrb. ic. fl. germ. XVI, tab. 949; G. rectum Sin., Drej. n. 818 .

Stangelen opret eller ved Grunden opstigende; Rodbladene lancetformede; Stongelbladene linieformede, spidse; Skalfrugterne korthaaret-rue; Fnokken mangestraalet.

Stængel og Blade graafiltede, de sidste ofte paa Overfladen glatte; Kurvbladene grønne, i Randen hindeagtige, i Spidsen brune. $7-8$.

Paa Bakker, Lyngheder, i Krat og Randen af Skove alm.

\section{Antennaria. Kattefod.}

1080. A. dioeca [Gärtn. fruct. 2, p. 410, t. 167] (SandK.) Drej. n. 819 ; Rchb. l. c. XVI, tab. 951; Gnaphalium L., H. 846 ; F. D. 1228.

Bladene paa de blomsterløse, krybende Sidestangler omvendt-ægformede eller spadeformede, budte, paa den oprette Blomsterstangel linie-lancetformede, spidse, tiltrykte; Blomsterstangelen udeelt, med $4-6$ Kurve samlede til en tæt, kort Halvslijorm i Spidsen.

Kurvbladene og Kronerne rosenrøde eller hvide. Bladene paa Overfladen grønne, paa Underfladen hvidfiltede. Var. $\beta$, hyperborea (D. Don), med Bladene filtede paa begge Flader. 5-6. $\psi$.

Paa sandige Marker, Bakker og Lyngheder alm. $\boldsymbol{\beta}$, Bornh, ved Rønne (19), flere Steder i Bodilsker Sogn (Baagøe)!

\section{Filago. Musenrt.}

a, Oglifa Cass. Kurvbladene budte, efter Frugtens Modenhed udbredte i Stjerneform.

1081. F. minima [Fr. Nov. p. 268] (Liden M.) Drej. n. 815 ; H. N. I, 3; F. montana F. D. 1276 (ikke L.); Gnaphalium montauum Willd., H. 850 ; Oglifa minima Rehb. 1. c. XVI, tab. 946.

En-fleerstæuglet; Stanglerne oventil gaffeldeeltc med opret- 
aabne Grene; $3-5$ Kurve samlede i ende- og axelstillede Nogler; Bladene tiltrykte, lancet-sylformede, spidse; Kurvene femkantet-kugleformede, med budte, i Randeı glatte Kurvblade; Skalfrugterne jæevne eller under Lupen hvidt punkterede.

Spædere og lavere $\left(2-6^{\prime \prime}\right.$ høi), mindre stærkt graafiltet end den følg. 7-8. $\odot$.

Paa sandige Marker og Bakker alm.

1082. F. arrensis L. [Fr. 1. c. 267] (Ager-M.) Drej. n. 816 ; F. D. 1275 ; F. montana-arvensis H. N. I, 2; Gnaphalium arvense Willd., H. 851 ; Oglifa arvensis Cass., Rchb. l. e. XVI, tab. 946 .

Stangelen fra Grunden af grenet, med 3-7 nøgleformigt samlede Kurve i Spidsen af de oprette Grene; Bladene lancetformede, budte; Kurvbladene budte, overalt filtede; Skalfrugterne under Lupen hvidt punkterede.

4-8" høi, hele Planten tæt hvidfiltet. $7-8 \odot$.

Paa tørre, især sandige Marker og Bakker ikke sjelden. क

Anm. Den ægte F. montana L. (Fr.), som især er kjendelig ved Grene beklædte med Nøgler fra Grunden af, og fra hvilken foreg. kun er eu lidet afvigende Form, er saavidt mig bekjendt, ikke funden i Danmark.

b. Gifola Cass. Kurvbladene braadspidsede, efter Afblomstringen ikke stjerneformigt udbredte.

1083. H. germanica L. (part.) (Hvidgraa M.) Drej.n. 817; Rchb. l. c. XVI, tab. 945, fig. I; H. N. VI, 3; Gnaphalium Willd., H. 850 (part.); F. canescens Jord. fragm. 3, p. '201, tab. 7 A.

Stangelen oventil gaffeldeelt, med $20-30$ Kurve samlede i axel- eller endestillede, kugleformede Hoveder; Bladene smalt lancetformede, i Randen bølgede; Kurvbladene forneden filtede, i Spidsen glatte, straagule, hindeagrigt-braadspidsede; Skalfrugterne hvidt punkterede.

1/3-1' høi. Stængelen enkelt eller med opstigende Grene ved Grunden. Hovederne større og med talrigere Kurve end hos de foreg. Hele Planten beklædt med en hvidgraa Filt. "Svagt lugtende" (G. E. Sm.). 7-8. $\odot$. 

sjelden.

Paa torre Marker og Bakker, ved Randen af Veie o. s. v., ikke

* 1084. F. apiculata [G. E. Smith, Phytol. II (1846), p. 575] (Guulgraa M.) F. lutescens Jord. l. c. tab. 7 B; Rchb. l. c. fig. II; Filago germ. L. (part.); Gnaphalium germanicum F. D. 997.

Bladene bredere lancetformede, overalt beklædte med guulgraa eller graagrøn Filt; 15-20 Kurve i Hovederne; Kurvbladene i Spidsen mere eller mindre purpurrøde, forøvrigt som foreg.

"Lugter omtrent som Regnfang" (Sm.) 7-8. $\odot$.

Paa sandige Marker og Bakker: Bornh. alm.! Sj. Sterns Klint (14), Kjøge, Borød ved Sorø! Langel. ved Steengade (19); J. Ødstedgaard! Synes at være udbredt over hele Landet, men noget mindre alm. end foreg., fra hvilken den forekommer mig vel adskilt.

Anm. Navnet F. germanica L. er saavel hos Linné som de fleste senere Forff. collectivt, og indbefatter baade denne og foreg. Art, hvorfor det neppe vil være muligt at paavise, om L. har havt nogen af disse særligt for Øie ved sin Beskrivelse. Jeg har imidlertid med de engelske Botanikere beholdt det almindelige Navn for den almindeligst forekommende Art.

\section{Bellis. Tusindfryd.}

1085. B. perennis L. (Almindelig T.) H. 868 ; Drej. n. 836 ; F. D. 503 ; Rehb. l. c. XVI, tab. 918.

Bladene udgaae rosetteformigt fra en meget forkortet Rodstok, omvendt-ægformede eller spadeformede, rundtakkede eller rundbugtede; Blomsterkurvene enlige i Spidsen af Skafterne; Kurvbladene budte, ved Grunden sammenvoxne

Skafterne 2-3" lange. Skivekronerne gule, Randkronerne hvide eller røde. Afandringer med lutter tungeformede (1, liguliflora) og lutter rorformede Kroner (2, tubuliflora) dyrkes i Haver. Slsalfrugten haaret og Kronrøret ved Grunden stundom beklædt med Haar, hvorved Frugten faaer Udseende af at være forsynet med en Fnok. 1-12. 4.

$\beta$, caulescens! (B. hybrida Ten. ?) Rodstokken udsender flere forlængede, overjordiske Grene med langstilkede Blade; Skafterne $1 / 2-1$ ' lange.

l'aa side Græsmarker og høie Enge meget alm. $\boldsymbol{\beta}$, i Skove, f. Ex. Ruderhegn (19)! Jonstrup (14). 


\section{Chrysanthemum. Oxcoie.}

a. Chrysanthemum Tournef. Alle Krouerne gule; Randblomsternes Skalfrugter 3-4-kantede med 2 skarpt fremstaatende Vinger, Skiveblomsternes trinde, stribede.

1086. C. segetum L. (Guul O., Onde Urter). H. 869 ; Drej. n. 837 ; F. D. 995 ; Rchb. I. c. XVI, tab. 986.

Stangelen udeelt eller faagrenet; Kurvene enlige i Spidsen af Stængelen og Grenene; Bladene lancetformede, ved Grunden tandede, i Spidsen fligede, de øvre med omfattende Basis; Kurvbladene rundagtigt-ovale, med en bred, hindeagtig Rand; Skalfrugterne uden Hindekant.

Hele Planten glat, blaagrøn. 7-8. $\odot$.

Et besværligt Ukrnd i Kornmarker, især i Vaarkornet, overalt i Danmark (under forskjellige Benærnelser), kun mindre hyppig hvor et bedre Agerbrug har udryddet den.

b. Leucanthemum Tournef. Skivekronerne gule, Straalekronerne hvide; alle Skalfrugterne trinde, de ydrefurede, de indre stribede.

1087. C. Leucanthemum L. (Hvid O., Præstekrave). H. 869 ; Drej. n. 838 ; F. D. 994; Leucanthemum vulgare Lam.; Tanacetum Leucantbemum Sehultz bip., Rehb. 1. c. XVI, tab. 988.

En-fleerstænglet, Stanglerne udeelte eller faagrenede, med enlige Kurve i Spidsen; de nedre Blade stilkede, omvendtægformede, rundtakkede, de фvre siddende, linie-laneetformede, ved Gıunden fjersnitdeelte, i Spidsen fliget-saugtakkede; Kurvbladene xg-lancetformede, grønne med bruun Indfatuing og smal, hvid-hindeagtig, uregelm. tandet Rand; Straalekronerne linieformet-ovale, af Længde :sed eller langere end Skiven; Skalfrugterne (typisk) nden Hindekant.

Lugtløs. 6-7. 4. Bladene alm. glatte, var. i Beklædning og og Indskjæring:

$\beta$, coronopifolium Hartm. Alle Bladene fjersnitdeelte eller dybt halvfinnede, med sreformigt omfattende liasis. 
$\gamma$, hirsutum Hartm. Stængel og Blade tæt beklædte med kort, kruset Uld.

Forekommer desuden med skjævttandet Hindekant paa Skalfrugten - auriculatum etc. Peterm.

Paa (iræsmarker og ved Veje, meget alm. $-\beta, \operatorname{og} \gamma$, med Hovedarten, men sjeldnere.

1088. C. Parthenium [Pers. Syn. 2, 462] (Matrem.) Drej. n. 839 ; Pyrethrum Sm., H. 870 ; Matricaria L., F. D. 674 ; Tanacetum Schultz bip., Rehb. 1. c. XVI, tab. 992.

Bladene stilkede, fjersnitdeelte med agformede, fjerlappede Afsnit; Stangelen oventil halvskjærmformigt grenet, med udspærrede Grene; Kurvbladene linie-lancetformede med hvidhindeagtig, duunhaaret Rand; Straalekronerne rundagtigt ovale, kortere end Skiven; Skalfrugterne med meget kort Hindekant.

Stængel og Blade kort-dıunhaarede; Planten stærkt lugtende. 7-8. 4 .

Paa Grøftevolde, især omkring Haver og Landsbyer, funden hist og her i alle Provindser, men ikke alm. (Dyrkes ofte i Haver, især en Var. med lutter tungeformede Kroner).

$\dagger$ C. corymbosum L. (Tanacetum corymbosum Schultz bip., Rchb. l. c. XVI, tab. 993). Bladene dobbelt fjersnitdeelte med linie lancetformede, fliget-saugtakkede Afsnit; Kurvene i Halvskjærm med oprette Grene; Randlkronerne linieformet-ovale, længere end Skiven; Skalfrugterne med tydelig Hindekant. 7-8.

Forvildet paa en $\mathrm{H} ø$ i ved Bidstrupgaard!

\section{Matricaria. Kamille.}

1089. II. inodora [L. Fl. Suec. 2, p. 765] (Lugtløs K., Baldersbraa). Fr. mant. 3, 115; Chrysanthemum inodorum L. Sp., Drej. n. 840 ; F. D. 696; Pyrethrum Sm., H. 871; Tripleurospermum Schultz bip.; Chamæmelum Vis., Rchb. 1. c. XVI, 985.

Stangelen opret, oventil halvskjærmformigt grenet; Bladene dobbelt fjersnitdeelte, med traadformet-børsteformede Afsnit; Kurvbladene linieformet-ovale, budte med en bruunt-hindeagtig, ujævu Rand; Blomsterleiet halvkugleformet, under Blomstringen 
heelt; Straalekronerne udstaaende; Skalfrugterne brune med 3 tykke, blege Ribber paa Inderfladen, paa Yderfladen hvælvede, stribede paatværs, med 2 Kirtler under den svagt tandede Hindekant.

Uden eller med meget svag Lugt. Randkronerne hvide, Skivekronerne gule. Misdannelser med lutter tungedannede Kroner eller med lutter rurformede Kroner og topskydende Kurve findes undertiden. 6-10. $\odot$ (eller $\odot)$.

* salina Wallr. (Pyrethrum inodorum var. F. D. 1936; Tripleurospermum maritimum Koch Syn. II, 1026). Stængelen udstrakt, fra Grunden af grenet, ofte rodlig; Bladenes Afsnit kjødfulde.

* borealis Hartm. (M. inod. ambigua Fr.). Vedvarende, Kurvbladene større, med bred, sortbruun Rand.

Par Groftevolde, Agre og omkring Byer, i de fleste Egne alm. og ofte et besvarligt Ulirud, især omkring Kjøbenhavn i stor Mæengde. * ved Strandbredder, ikke sjelden. ** B or $n h$. Klipper ved Hammershuus $(8)$ !

Anm. Alt hrad jeg har seet fra Danmark under Navn af Matricaria maritima horer til Var. * af for eg., fra hvilken (ifølge Fr. l. c.) den exte linneiske $M$. maritima (H. N. VII, 1, XII, 2) skal adkkilles især ved hvidhindede, heelrandede Kurvblade, storre og tyk kere Frugter sant bredere ng kortere Bladafsnit. Da demne findes i Sverige ved Kysterne af Kattegattet indtil Kullen, kunde den muligviis ogsaa forekomme ved de nordlige danske Kyster.

1090. I. Chamomilla L. (Vellugtende K.) H. 872 ; Drej. n. 841 ; F. D. 1764 ; Rchb. l. c. XVI, tab. 997.

Stangel og Blade som bos foreg.; Kurvbladene oval-linieformede, budte, med en hvid hindeagtig, heel Rand; Blomsterleiet kegleformet, efter Blomstringen huult; Straalekronerne mod Afblomstringen nedbængende; Skalfrugterne blege, budt femkantede og femstribede, uden Hindekant.

Kronernes Farve som hos foreg., som den er meget lig, men fra hvilken den, foruden de angivne Kjendetegn, let adskilles ved mindre Kurve og især ved en stærk og ret bchagelig Lugt. $6-10$. $\odot$.

Ved Veie og mellem Sæden, men især onkring Byer paa leret og gjødet Jordbund, funden i alle Provindser, men ikke lige hyppig oreralt, og i enkelte Egne (f. Ex. i det sydlige Fyen og paa Smaagerne, 12) aldeles ikke tilstede. En Forn med lutter tumgedannede Kroner findes i Ilornemanns Herb., sanlet ved Kalkbrænderiet, S. for Flaskekroen. 
† M. discoidea [DC. Prodr. VI, 50] (Skiveblomstret K.) Chamomilla discoidea J. Gay, Cotula matricarioides Bong.

Glat, skidengrøn, Bladenes Afsnit bredere og kortere end hos de foreg.; Kurvene kortstilkede; Kurvbladene ovale, budte, med en bred, hvid-hindeagtig Rand; Blomsterleiet kegleformet, tilsidst huult, ingen tungeformede Randkroner; Skivelkronerne firetandede; Skalfrugterne blege, større end hos foreg., mindre end hos næstforeg., med en meget smal Hindekant. 7-9. $\odot$.

En fra det vestlige og nordvestlige Amerika indvandret Plante, som $\mathrm{i}$ de senere Aar er funden forvildet paa flere Steder $\mathrm{i}$ Europa omkring Byer. Her er den iagttaget 1861-64 ved Rendestene langs Sortedamsveien ved Kbh. (Ørsted)!

\section{Anthemis. Gaaseurt.}

a. Maruta Cass. Avnerne pa Blomsterleiet liniebørsteformede, spidse.

1091. A. Cotula L. (Stinkende G.) I. 873; Drej. n. 846 ; F. D. 1179 ; Maruta Cotula Cass., Rehb. l. c. XVI, tab. 1000 .

Stcengelen opret, furet; Bladene 2-3-dobbelt fjersnitdeelte med linie-sylformede Afsnit; Blomsterleiet kegleformet; Skalfrugterne trinde, knudret-stribede med en rundtakket Rand foroven.

Bladene var. tiltrykt-duunhaarede eller næsten glatte. Har en stærk, men ubehagelig Lugt. Skivekroneme gule, Straalekronerne hvide. 6-9. $\odot$.

\section{$\boldsymbol{\beta}$, disciflora! Alle Kronerne rørformede.}

Ved Veie, Gadekjær og lignende noget fugtige Steder omkring Landsbyer, ikke sjelden, især meget hyppig paa Lolland! $-\boldsymbol{\beta}, \boldsymbol{J}$. ved den nye Landevei $S$. for Horsens! $S j$. ved Veien mellem Herløv og Husum (14); Bornh. Bodilsker (Baagøe).

b. Avnerne lancetformede, braadspidsede.

1092. A. arrensis L. (Ager-G.) H. 872; Drej. n. 845; F. D. 1178 ; Rehb. l. c. XVI, tab. 1004 ; H. N. XV, 1.

Stcongelen opret eller opstigende, stribet; Bladene dobbelt fjersnitdeelte, med linie-lancetformede Afsnit; Blomsterleiet kegle- 
formet; Kurvbladene med en hindeagtig, uregelm. tandet Rand; Slaklfrugterne firekantede, javnt stribede, Randblomsternes med en tydelig, bølget-ujævn, Skiveblomsternes med en svag, heelrandet Hindekant foroven.

Bladene tiltrykt-silkehaarede, have en svag, men ret behagelig Lugt*). Randkronerne hvide, Skivekronerne gule. Forekommer, ligesom foreg., uden Straalekroner ( $\boldsymbol{\beta}$, disciflora M. T. Lange i Naturh. Foren. vid. Medd. 1861 p. 10). 6-8. $\odot$.

Par Grøftevolde, i Kornagre o. a. dyrkede Steder, alm. udbredt. $\boldsymbol{\beta}, \boldsymbol{F}$. Ollerup (12)!

1093. A. tinctoria L. (Farve-G.) H. 874 ; Drej. n. 844 ; F. D. 741 ; Rehb. l. c. XVI, tab. 1010 ; H. N. VI, 1.

Bladene enkelt eller dobbelt fjersnitdeelte, med halvfinnede eller saugtakkede Afsnit; Blomsterleiet halvkugleformet; Slaalfrugterne fladtrykt-firekantede, smalt vingede, paa begge Sider femstribede, med en skarp Rand foroven.

Stængel og Blade, især paa Underfladen, duunhaarede. Alle Kro. nerne gule. $\frac{6}{2}-9$. 4 .

$\beta$, discolor Fr. Straalekroverne hvide, Bladene næsten glatte.

Paa tørre Bakker og Diger, sjelden: $\boldsymbol{S} \boldsymbol{j}$. Ankersmedbakken ved Helsingør (Dr.), Gjærder ved Rudersdals Kro, Veien mellem Lyngby og Viintappergaarden! mellem Herløv og Husum (14); F. Svendborg (H.); $\boldsymbol{J}$. Viborg (Morville). $-\beta$, mellem Hovedarten ved Ruders-

\section{Achillea. Rollike.}

1094. A. Ptarmica L. (Nyse-R.) H. 875 ; Drej. n. 842 ; F. D. 643 ; Rehb. l. c. XVI, tab. 1014 .

Bladene lancet-linieformede, skarpt og ru-saugtakkede; Blomsterkurvene i en Halvskjærm i Spidsen af Stængelen, de enkelte Blomsterstilke tykkere foroven, flere Gange langere

*) Denne og flere af de foreg. Arter forvexles ofte og bringes iflæng til Apotheket nnder Navn af Kamilleblomster. Fornden de angivne Slægts- og Arts-Kjendetegn skjelnes de let ved liden $\emptyset$ velse paa Lngfen, som hos hver af de paagjældende Arter er eiendommelig. 
end Kurven; Straaleblomsterne omtrent 8-10, af Længde med eller længere end Kurvdækket.

Stængelen foroven duunhaaret, Bladene alm. glatte, Kronerne hvide. 7-8. น.

Paa Enge, ved Grøfter, alm. i de fleste Egne af Danmark. (Paa Falst. temmelig sjelden).

1095. A. Millefolium L. (Almindelig R.) H. 875; Drej. n. 843 ; F. D. 737 ; Rehb. 1. c. XVI, tab. 1026.

Bladene i Omrids lancetformede, 2-3-dobbelt fjersnitdeelte, med linieformede, spidse Afsnit; Kurvene samlede i Spidsen af Stængelen til en tæu Halvskjærm; Smaablomsterstilkene omtrent af Længde med Kurven; Straaleblomsterne 4-6, af Kurvdækkets halve Længde.

Halvskjærmen indeholder flere, men mange Gange mindre Kurve end hos foreg. Kronerne livide, sjeldnere rosenrøde (F. D. 1937). 7-9. น. Var. i Henseende til Beklædningen: duunhaaret eller næsten glat og

$\beta$, lanata Koch. Stængel, Blade og de meget korte Grene i Halvskjærmen filtet-uldhaarede.

$\gamma$, magna Sond. fl. Hamburg. p. 466, høi og kraftig, Bladene bredere, tredobbelt fjersnitdeelte med ægformede Flige, bredere Midtnerve, Halvskjærmen meget stor og udbredt.

Paa Græsmarker, ved Veie og i Krat meget alm. - $\beta$, paa tørre, solaabne Bakker sjeldnere: $\boldsymbol{S} \boldsymbol{j}$. mellem Hellebæk og Helsingør (Heiberg); B ornk, ved Allinge og Rømersdal! $\boldsymbol{\gamma}, \boldsymbol{F}$. Svendborg (14).

\section{† Galinsoga.}

$\dagger$ G. parviflora [Cav. Ic. III, p. 41, t. 281]. Viborgia Acmella Roth.

Bladene modsatte, stilkede, ægformede, saugtakket-tandede; Kurvene smaae, paa meget lange Stilke, som danne en fjernblomstret Halvskjærm; Straaleblomsterne hvide, kortere end Kurvdækket, Skivekronerne gule; Skalfrugten sort, omvendt-kegleformet, omtrent dobbelt saa lang som den hvide hindeagtige Fnok.

$1-1 \frac{1}{1}{ }^{4}$ h $\varphi$, glat eller foroven (sjeldnere overalt) haaret. $7-8.2$.

Oprindelig fra Amerika, funden forvildet hist og her, f. Ex. $\boldsymbol{S}$ j. ved Sorø (Lund); $\boldsymbol{F}$. Hofimansgave (18)! 


\section{Inula. Alant.}

a. Conyzoides. Randkronerne trekløvede, af L $\mathrm{L}$ ngde med Kurvbladene, ikke udstraalende.

1096. I. Conyza [DC. Prodr. 5, p. 464] (Trekløft.A.) Rehb. 1. c. XVI, tab. 923 ; Conyza squarrosa L., H. 852 ; F. D. 622 .

Bladene elliptisk-lancetformede, svagt saugtakkede, paa Overfladen duunharede, paa Underfladen kort, men tæet graafiltede, de nedre stilkede; Blomsterkurvene nøgleformigt samlede i Spidsen af Grenene og dannende en sammensat Halvskjærm; Kurvbladene i Spidsen tilbagebøiede, randhaarede; Skalfrugterne trinde, ovenfor Midten stivhaarede, med enradet Fnok.

$1-2^{\prime}$ høi. Kronerne gule. Kurvbladene røulige, med grøn Rygnerve og Spidse. 7-8. $\odot$.

Paa tørre, udyrkede Bakker, sjelden: J. Vosnæsgaard (28)! $\boldsymbol{F}$. Fyenshoved (Schouw, Hofm. Bang)! Assens (Kyll.).

b. Randkronerne tungeformede, udstralende.

aa. Pulicaria Gärtn. Fnokken toradet, den ydre Kreds kort, ved Grunden sammenvoxet til en Krands.

1097. I. pulicaria (Loppe-A.) H. 865; F. D. 613; Pulicaria vulgaris Gärtn., Drej. n. 829 ; Rehb. J. c. XVI, tab. 933 ; P. dysenterica H. N. XV, 2.

Bladene lancetformede, forneden smalere, med afrundet, halvt omfattende Basis, duunhaarede, i Randen bølgede; Blomsterstanden qvastformet; Kurvene halvkugleformede; Siraalekronerne lidet længere end Kurvbludene; Skalfrugten dunnhaaret; den ydre Fnok borsteformigt fliget.

${ }^{1 / 2}-1^{\prime}$ høi. Stængelen oventil og Blomsterkurvene tæthaarede. (Randkronerne meget smaae). 7-9. $\odot$.

Ved Gadekjær, Randen af Veie, især omkring Byer, sporadisk og i de fleste Egue ikke alm., hyppigst paa de sydlige Øer, i Sydsjall. og det sydl. Fyen. 用

1098. I. dysenterica L. (Strand-A.) H. 865 ; F. D. 410 ; Pulicaria Gärtn., Rchb. 1. c. XVI, tab. 933 ; H. N. XIII, ‘. 
Bladene elliptiske eller lancetformede, med hjerteformet eller piilformet-omfattende Basis, i Randen svagt tandede, paa Overfladen korthaarede, paa Underfladen graafiltede; Blomsterkurvene balvskjærmformigt samlede i Spidsen af Stængelen; Straalekronerne meget længere end Kurvbladene; Skalfrugten haaret; den ydre Fnok meget kort, takket.

$1-1^{1} / 2^{\prime}$ høi. Beklædning som hos foreg. Kurvene over dobbelt: saa store som hos foreg., meget mindre end følg. 7-9. थ.

Ved Grofter og andre fugtige Steder, især paa Leergrund og stedse i Nærheden af Havet: ved Kysterne af Østersøen ( 0 : de sydlige Øer fra Møen til Als, sydl. Fyen og Slesvigs Østkyst) ikke sjelden; sjelden i $S j .:$ Vordingborg (29)! Korsør (1:3), Holbæk (15)! Eriksholm (Feddersen) og i det nordlige Fyen: Hofmansgave (H.), Rørbæk, Odense! (I $\boldsymbol{J} y \boldsymbol{l} l$. ikke bemærket). T)

\section{bb. Inula. Fnokkens Straaler $i$ een Kreds.}

«, Skalfrugterne haarede.

1099. I. Britanica L. (Soløie-A.) H. 864 ; Drej. n. 831 ; F. D. 413 (slet); Rchb. 1. c. XVI, tab. 926 ; H. N. IV, 5.

Bladene lancetformede, heelrandede eller fjernt tandede, paa begge Flader haarede, de nedre stilkede, de ovre med en bredere, hjerteformet Basis omfattende; Kurvene enlige $\mathrm{i}$ Halvskjærm fra Spidsen af Stængelen; Kurvbladene spidse, hvidfiltede.

$1-1 \frac{1}{2} 2^{\prime}$ h $ø$ i. Stængelen og især Grenene bvidiltede, Bladene var. j Beklædning, Kurvbladene i Længde. 7-9. ข.

Strandenge og Overdrev i Nærheden af Strandkysterne: paa de sydlige Øer fra Falster til Frø hist og her ikke sjelden; i de andre Provindser sparsommere: Sj. Amager ved Kastrup og flere Steder! Flaskekroen (Drej.), alm. ved Skjelskør (Nielsen), Korsør (Lund), Reersø (Dr.), Rørby pr. Kalundborg (Baagøe), Lammefjorden ved Adelersborg (Rafis); F. Langø paa Hindsholin! Kjerteninde! Odense Fjord (H.), Østergen ved Nyborg (Lund); J. True ved Aarhus (2), Ødstedgaard! S $l$. Aabenraa (Rafn), Langlballe Aa i Angel (H.), Slieminde (16), Kappel (Lund), Svansø (2S), Fredriksort, Femern (16); Midlum paa Føhr (20)! (I det nordl. Jyll. og paa Boruh. er den ikke fundeu). 席

Anm. Hornemanns Navn "brittanisk Alant" er upassende, da den ikke forekommer i Storbritanien. Artsnavnet "Britanica " hidrorer fra en i Oldtiden omtalt Lægeplante af dette Navn ( som af Fortolkerne har veret overfort paa forskjellige Planter, hvorefter Navnet af Linné benyttedes saavel for en Rumex-Art son for ver Plante. 
$\boldsymbol{\beta}$, Skalfrugterne glatte.

1100. I. salicina L. (Pilebladet A.) H. 866; Drej. n. 832 ; F. D. 786 ; Rehb. l. e. XVI, tab. 928.

Bladene lancetformede (alle med størst Brede paa Midten), omfattende, heelrandede eller svagt tandede og i Randen rue, glatte eller paa Underfladen svagthaarede, med ophøiede Nerver paa Underfladen; Kurvene enlige eller i en faablomstret Halvskjærm; Kurvbladene spidse, randhaarede.

$1-1^{1}{ }^{1}{ }^{4}$ høi. Stængelen glat eller forneden haaret, Grenene glatte. 7-8. 4 .

Paa høie Enge, ved Gjærder og i Kratskove, især paa Kalkgrund: fra Slesv. er intet bestemt Voxested mig bekjendt, forøvrigt findes den hist og her, men ikke alm., i alle de andre Provindser, paa $\boldsymbol{B}$ ornh. meget hyppig paa Engene. |*

1101. I. Helenium L. (Almindelig A.) H. 684; Drej. n. 830 ; F. D. 728; Corvisartia Helenium Mérat, Rchb. l. c. XVI, tab. 921.

Rodbladene lancetformede, stilkede; Stangelbladene æg-hjerteformede, halvt omfattende; alle Bladene grovt og dobbelt tandede, paa Underfladen hvidfiltede; Blomsterstanden halvskjærmformet; de ydre Kurvblade ægformede, de indre linieformede, indsnorede paa Midten, mod Spidsen bredere, budte, med fryudset-tandet Rand; Slialfrugterne firekantede.

3-4' høi. Blomsterkurvene meget store. 7-8. 4.

Paa fugtig Grund omkring Landsbyer 0 . a. beboede Steder, hist og her i alle Provindser, hyppigst paa Loll.-Falster! Paa de fleste Steder formodenlig forvildet fra Dyrkning i ældre Tid som en anseet Lægeplante, dog er den funden i $\boldsymbol{S} j$. paa Stigsnæs ved Skjelskør (14) og J. paa Kalkbakker S. for Haraldskjær (9), som det synes vildvoxende.

\section{Solidago. Gyldenriis.}

1102. S. Virga aurea L. (Almindelig G.) H. 862 ; Drej. n. 833 ; F. D. 663 ; Rehb. I. c. XVI, tab. 911.

Bladene elliptiske eller lancetformede, nedentil afsmalnede $i$ en vinget Bladstilk, de nedre saugtakkede, de øvre ofte heelrandede; Blomsterlurvene paa længere eller kortere Grene fra Bladbjornerne, danne en forlænget, enkelt eller sammensat Klase med oprette Grene. 
Planten næsten glat. Var. i Henseende til Høiden, Bladenes Brede og Grenenes Længde o. s. v. 7-9. ข.

I Kratskove, paa udyrkede Bakker, Diger o. s. $\nabla$. i de fleste Egne af Landet alm., sjeldnere i det sydvestl. Sj. (17) og Loll.-Falst.!

$\dagger$ S. canadensis L. Bladene smalt lancetformede, heelrandede, Blomsterstanden en Top, sammensat af bueformigt udstaaende, enlige Klaser; Kurvene mindre.

Forvildet fra Haver, f. Ex. i Charlottenlund! F. Svendborg (19).

\section{Erigeron. Bakkestjerne.}

† 1103. E. canadensis L. (Kanadisk B.) H. 852; Drej. p. 269 ; F. D. 1274 ; Rehb. I. c. XVI, tab. 917.

Stcongelen stivhaaret-ru; Bladene linie-lancetformede, stivhaarede, især i Randen; Rodbladene noget bredere foroven, i Spidsen svagt tandede; Blomsterstanden en forlænget Top, sammensat af mangeblomstrede Klaser paa oprette Grene; Kurvbladene glatte, i Spidsen randhaaret-saugtakkede.

Stzengelen grøn. Kurvene meget mindre, men talrigere end hos følg. Straalekronerne hvidgule. 7-8. $\odot$.

Oprindelig indført fra Nordamerika, forekommer nu paa enkelte Steder som Ukrud, f. Ex. Sj. Helsingør (H.), Hellebæk! Christiansholm ved Kbhaval (Baagve), Nestved (Dr.); F alst. Bregninge (Hansen); Loll. Stokkemarke (19); Thorseng ved Breguinge! F. Hofmansgave (18), Svendborg (H.); Sl. Haderslev (16), Flensborg! Rendsborg (20)

1104. E. acris L. (Bitter B.) H. 853; Drej. n. 835; F. D. 2595 (var.); Rchb. 1. c. XVI, tab. 917.

Stcongelen duunbaaret; Bladene linie-lancetformede, heelrandede, haarede; Rodbladene omvendt-ægformet-lancetformede; Blomsterstunden en enkelt eller lidet sammensat Ḱlase; Grenene opret-aabne eller opstigende, med 1-3 Kurve; Kurvdakket graafiltet.

Stængelen alm. rødbruun. Straalekronerne lila, af Længde med eller lidet længere end Skivekronerne. 7-8. $\odot$ eller $\%$.

* strictus! Alle Bladene omvendt-ægformet-lancetformede; Grenene stivt oprette, danne en Halvskjærm; Kurvbladene 
svagere haarede, hvorved deres violetbrune Farve bliver synlig (som hos Hovedarten næsten skjules af den tæite Filt).

Paa tørre, isæer sandige Marker, Bakker og Diger, alm. udbredt. * paa Bastionerne mellem N. og $\varnothing$. Port ved Kjøbeubavn!

Anm. Maaskee hører Formen *, som ved gjentagne Udsædsforsog i bot. Have har bevaret sit Udséende, til F. a. - serotinus Fr. mant. 3, 107, som er mig ubekjendt. - Fig i F. D. 874, som af Flere henfores til E. acris, hører efter Fr. og Lund (Christianias Fl. p. 21) ikke herhen, og har ogsaa kun liden Lighed med vor.

$\dagger E$. speciosus [DC. Prodr. V, 284]. Stenactis speciosa Lindl. Bot. Reg. tab. 1577.

Stangelen opret, $1^{1} / 2-2^{\prime}$ høi, glat eller foroven svagt liaaret, de nedre Blade stilkede, spadeformet-linieformede, de mellemste ng øvre siddende og halvt omfattende, tungeformet lancetformede, alle heelrandede, fiint randbaarede; Blomsterstanden en Halvskjærm, dannet af faae, store, før Udspringningen nikkende Kurve; Kurvbladene langt randhaarede, Randkronerne i meget stort Antal, linieformet-traadformede, Iysviolette. 7-8. 4.

Forvildet i stor Mængde paa Gurre Slots Ruiner! (Oprindelig hjemmelørende i Californien).

\section{Aster.}

1105. A. Tripolium L. (Strand-A.) H. 861 ; Drej. n. 834 ; F. D. 615 ; Rehb. l. c. XVI, 907 ; L. Herb. IX, 169.

Bladene linie laneetformede, heelrandede eller svagt saugtakket-rue, kjødfulde; Blomsterstanden halvskjærmformet, med oprette Grene; Kurvbladene budte, tiltrykte.

1-2' høi, hele Planten glat. Straalekronerne violette, Skivekronerne gule, tilsidst rødbrune. (Var. med hvide Straalekroner). $8-9$.

Paa saltholdig Jordbund i Dynd, Leer og Slik, alm. ved Danmarks Kyster, især i Marskegnene. (Den hvidblonstrede Form er iagttaget ved Nyborg (Lund), Ribe (30).

1106. A. salignus [Willd. Sp. pl. 3, p. 2040] (Pilebladet A.) H. II, 251 ; F. D. 2475 ; H. N. XIII, 1.

Bladene laneetformede, fiint saugtakkede, paa Overfladen henimod Randen rue; Blomsterstanden en Top med halvskjærın- 
formede, opret-aabne Grene; Kurvbladene spidse, oventil udstaaende.

Straalekronerne lila eller hvide, Skivekronerne gule. 7-8. 4.

Forekommer forvildet, især omkring Haver og Byer, f. Ex. $\boldsymbol{S}$ j. mellem Egelund og Fredensborg (Jørg.), Farumgaard (14)! Pesthuset ved Kjobenhavn! ved Sorø So (12); Falst. Stubbekjøbing (19); $\boldsymbol{J}$. Eng ved Nonmolle ved Viborg (Feddersen); $\boldsymbol{S} l$. Eiderens Nordbred ved Rendsborg (16). 用

Stenactis. Smalstraale.

$\dagger$ 1107. S. annua [N. Es. Ast. p. 273] (Enaarig S.) Rehb. 1. c. XVI, tab. 912 ; Aster annuus L., H. 861 ; F. D. 486 ; Stenactis bellidiflora A. Braun, Lge. Haandb. 1 Udg. S. 488.

De nedre Blade elliptiske eller omvendt-ægformede, grovt, men fjernt saugtakkede, de övre lancetformede, næsten heelrandede; Blomsterstanden halvskjærmformet.

Blade, Grene og Kurvdække haarede, Randkronerne smalt linieformede, hvide eller lila, Skivekronerne gule. 7-8, $\odot$.

Tilfældigt forvildet omkring Haver: $\boldsymbol{S} \boldsymbol{j}$. Frydenlund (H.), Næsgaard ved Dronninggaard (14)! Flommen ved Sorø (Bredsd.); S $l$. Gottorp (Hornem. Herb.). ॠ

\section{Doronicum. Gemserod.}

$\dagger$ 1108. D. Pardalianches L. (Hjertebladet $G$ ) Jacq. Fl. austr. t. 350 ; Rehb. I. c. XVI, tab. 955.

Rodstokken med krybende, i Spidsen knolleformigt opsvulmede Udløbere; Bladene hjerteformede, tandede; Rodbladene langstilkede, de nedre Stungelblade stilkede med øreformigt omskedende Bladstilk, de ovre siddende, omfattende; Stcongelen med een eller faae Blomsterkurve i Spidsen; Kurvbladene sylformigt tilspidsede.

$1^{1 / 3}-2^{\prime}$ høi. Planten haaret. Kronerne gule. 5-6. ข.

Oprindelig en Bjergplante, som nu forekommer forvildet paa flere Steder: $\mathbf{S}$ j. Skjelskør (Nielsen), Plantagen ved Sorø Akademihave! Næsgaard ved Dronninggaitrd (19); F. Brobygaard (18); J. Bjørnkjær i Vendsyssel (Juel), Fusing Slkov (Selmer), Lillerup ved Horsens (E. H. Lange), Bygholm (Jørg.); $\boldsymbol{S} l$. Gram (6), Nyværk ved Slesvig! 7 


\section{Senecio. Brandbager.}

a. Randkronerne rorformede eller tungeformede med tilbagerullet $\mathrm{Krave.}$

1109. S. vulgaris L. (Almindelig B.) H. 857; Drej. n. 821 ; F. D. 513 ; Rehb. l. c. XVI, tab. 959.

Bladene halvfinnede eller fjersnitdeelte, de ovre med oreformet-omfattende Basis; Afsnittene tandede; Blomsterkurvene i en nikkende, alm. tætblomstret Halvskjærm; Kurvbladene $i$ den ydre Kreds talrige, tiltrykte, stærkt brandplettede, meget kortere end de indre; alle Kronerne rørformede; Skalfrugterne tiltrylktduunharede.

${ }^{1 / 2}-1^{\prime}$ høi. Bladene var. glindsende, næsten glatte og løst filthaarede. $3-10$. $\odot$.

$\beta$, radiatus Koch (S. denticulatus F. D. 791)*). Randkronerne tungeformede.

Paa dyrlset Jord, især i Haver og paa sandige Marker meget alm. $\boldsymbol{\beta}$, i Strandsandet paa Lolland (F, D.); J. Skagen (Drej. Herb.), Sandklitter paa Oerne i Vesterliavet: Fan $\boldsymbol{\theta}, \boldsymbol{M}$ a $\boldsymbol{n} \boldsymbol{\theta}, \boldsymbol{S} \boldsymbol{y} \boldsymbol{l t}$ (N.)!

1110. S. silvaticus L. (Skov-B.) H. 858 ; Drej. n. 822 ; F. D. 869 ; Rebb. 1. c. XVI, tab. 960 .

Bladene fjersnitdeelte, med lialvfinnede eller tandede $A f$ snit; Blomsterkurvene i en opret Halvskjærm; de ydre Kurvblade faae, tiltrykte, svagt brandplettede, meget kortere end de indre; Randlironerne tungeformede; Skalfrugterne tiltrykt-duunhaarede.

${ }^{1 / 2}-2{ }^{\prime}$ høi. Stængelen, især oventil, og Bladene, isæer paa Uuderfladen, dunnharede, ofte lidt klæbrige. Kurvene længere og smalere end hos foreg. 7-8. $\odot$.

*) Uagtet Fries (Mant. 3, 104) og Koch (Syn. II, 1026) henfore F. D. 791 til S. silvatiens, kan jeg dog ikke tiltræde denne Anskuelse, men maa, paa Grund af dens Mangel paa Haar og de talrige ydre Kurvblade, med Nolte (nov. p. 7) antage den for en Var. med Straalekroner af S. vulgaris. Former af denne sidste, som aldeles ligne den afbildede Fig. i Udseende (dog uden Straale. kroner) fandt jeg i Strandsandet ved Ronne paa Bornh. 
Paa torrre, aabne Steder i Skove, sandige Marker, Heder (især efterat Lyngen er afbrendt), ikke sjelden.

1111. S. riscosus L. (Klæbrig B.) H. 858; Drej. n. 823; F. D. 1230 (ikke god, ligner mere foreg.); Rchb. 1. c. XVI, tab. 960 .

Bladene fjersnitdeelte, med tandet halvfinnede Afsnit; Blomsterstanden en opret Halvskjærm; de ydre Kurvblade 6-8, udstaaende, svagt brandplettede, omtrent halvt saa lange som de indre; Randkronerne tungeformede; Skalfrugterne glatte.

$1-1 \frac{1}{1}{ }^{\prime}$ høi, klæbrig-kirtelhaaret. Kurvene større, men færre i Halvskjærmen end hos de foreg. 7-10. $\odot$.

Ved sandige Strandbredder, paa Ryddepladser, sløifede Steder ornkring Byer, især paa sandig Grund, ikke alm.: Bornh. Hasle Skandse (20), Rønne, Christiansø (Baagøe); $S j$. paa den sandige Havstok mellem Hornbæk og Helsingør almindelig! Snekkesteen (Grøulund), Birkerød (H.); i Kbhavn hyppig efter Ildebranden, nu sparsommere (f. Ex. omkring ('niversitetet). A mager ved Götchens Batteri (Dr), Bisserup (Drej. Herb.); Falst. Stubbekjøbing; Loll. mellem Krønge og Søholt (Rasm.); Fre (10).

b. Jacobaa Moench. Randkronerne tungeformede, med fladt udstaaende Krave.

aa. Bladene fjersnitdeelte eller dybt halvfinnede.

+1112 . S. vernalis [Waldst. \& Kit. pl. rar. Hung. I, p. 23, t. 24] (Vaar-B.) Rehb. l. c. XVI, tab. 959.

Rodbladene stilkede, omvendt-ægformede, bugtet-grovttandede, Stangclbladene linie-lancetformede med oreformigt-omfattende Basis, bugtet-halvfinnede med ægformede, budte, kruset-tandede Lapper; de ydre Kurvblade 6--10, tiltrykte, stærkt brandplettede, ointr. 4 Gange kortere end de indre; Skalfrugterne tiltrykt.haarede, med hvid, blød, vedblivende Fnok.

$1 / 2-1$ ' høi. Stængel og Blade beklædte med kruset, spindelvævagtig hvid Uld. Ifølge Varigheden og Bladformen hører den nærmere til foreg. Afdeling, fra hvilken den adskilles ved større og udstaaende Randkroner. Kronerne gule. 5-6. $\odot$.

Dyrkede Marker i Landets sydligere Egne, sporadisk og formodenlig indført med fremmed Sæd: "alst. S. Kirkeby (Koch)! Bornh. Teign S. for Allinge, Bakkegaard i Ruthsker Sognl, Fævagten ved lionne (Baagge)! Almegaard i Knudsker Sogn (Hoff)! Nyker (Zahrtmann). 
1113. S. erucrefolius L. (Smalfliget B.) H. 859 ; F. D. 1885 ; Rehb. ic. erit. IV, tab. 516 ; H. N. I, 4.

Bladene fjersnitdeelte, med linieformede, $\mathrm{i}$ Randen tilbage. rullede, tandede eller (mere eller mindre dybt) halvfinnede $A f$ snit, det nedre Par Afsnit heelrandede, oreformigt omgivende Stængelen; de ydre Kurvblade flere, tiltrykte, omtrent halvt saa lange som de indre; alle Skalfrugterne haaret-rue, med vedblivende, mangestraalet Fnok.

Bladene paa Underfladen lost uldhaarede, var. betydeligt i Henseende til Indskjæringerne og disses Brede. Kronerne gnle. 8-9. 4.

Paa Græsmarker eg ved Veie, sporadisk og temmelig sjelden: $\boldsymbol{J}$. Randrup og Viskum 6 . for Viborg (Morville); $\boldsymbol{S} t$. Angel, Gottorp Slotsvold, Dreisprung ved Husum (16), Nordstrand (N.), Fredriksstad, Süderstapel (F. Müll.); F. Seden (12), Gjierder mellem Hessum og Skeby! o. fl. Steder N. for Odense Fjord (4); L angel. Finglsbolle; Loll. Veilo (19), Loitofte, Aalstrup, Christianssæde (14), Bjerremark, Grønnegade (5); B ornh. Ø. Larsker!

1114. S. Jacobrea L. (Eng-B.) H. 859; F. D. 944; Rebb. ic. fl. germ. XVI, tab. 964; Jacobæa vulgaris Moeneb, Drej. n., 824.

Rodbladene og de nedre Stangelblade lyreformet-fjersnitdeelte, stilkede, de ovre fjersnitdeelte med aflang-laneetformede, tandede eller halvfinnede Afsnit og mangedeelte, omfattende Orer ved Grunden; de ydre Kurvblade 2-4, meget kortere end de indre; Randblomsterne med faastraalet, affaldende Fnok og glatte Skalfrugter; Skiveblomsterne med mangestraalet, vedblivende Fnok, duunhaarede Skalfrugter.

Bladene glatte eller ved Grunden hviduldede. Kronerne gule. 7-9. 4 .

Paa Enge og ved Veigrøfter alm. udbredt.

1115. S. aquaticus [Huds. Fl. angl. 366] (Vand-B.) H. 860 ; F. D. 784 ; Rchb. I. e. XVI, tab. 965 ; H. N. III, 2; Jacobra aquatica Drej. n. 825.

De nedre Blade stilkede, hele eller lyreformede med et ægformet, rundtakket eller tandet Endeafsnit, de ovre siddende eller kortstilkede, lyreformet-snitdeelte, med rundtakket-lappet 
Endeafsnit, linieformede, skjæve, tandede Sideafsnit og ørethalvomfattende Basis; alle Skalfrugterne glatte; forovrigt som foreg.

Halvskjærmens Grene mere slappe, Kurvene større, men færre og: fjernere end hos foreg. Kronerne gule. 7-9. $\odot$. (4)

$\beta$, pinnatifidus Gren. \& Godr. (S. pratensis Richt., Rchb. ic fl. germ. XVI, p. 38; S. barbareæfolius Ruhb. l. c. tab. 965 (ikke Krock.). Høiere, med længere Grene; de nedre Blade lyreformet-fjersnitdcelte, de øvre dybt fjersnitdeelte.

Ved $\mathrm{S}$ ø- og Aabredder, Gadekjær, i fugtige Skove: alm. paa Halvoen, især den vestlige Deel, i det sydlige Fyen og paa Oerne (undt. Falster: 14); sparsommere i $S j$ jell. (især $\bmod N$ og ø.). $\beta$, paa flere Steder i Lolland (19); $S l$. Angel (Frglich i Hornem. Herb.).

\section{bb. Alle Bladene hele, saugtakkede.}

I116. S. paludosus L. (Kjær-B.) H. 860 ; F. D. 385 ; Rchb. I. c. XVI, tab. 974; H. N. II, 2; Jacobæa paludosa Drej. n. 826.

Bladene siddende, linie-lancetformede; de ydre Kurvblade omtrent 10, halvt saa lange som de indre; Straaleblomsterne 12-15; Skalfrugterne glatte eller svagt duunhaarede, med skidenguul Frok.

Stængelen 4-6' hoi, huul, uldhaaret; Bladene glatte eller paa Underfladen uldhaarede. Kronerne gule. 7-8, 4.

I Aaer og Moser, sjelden i Danmark: $\boldsymbol{S} \boldsymbol{j}$. en Aa ved Beldringe (Schum.); J. ved Langby Kro (Beck); $\boldsymbol{S} l$. Eiderens Nordbred ved Rendsborg! $\overline{\$}$

† 1117. S. saracenicus L. (Saracenisk B.) H. 861 ; F. D. 2059 ; Rehb. I. c. XVI, tab. 970 ; Jacobæa sarracenica Drej. p. $26 \bar{i}$; S. salicetorum Godr.

Bladene lancetformede, de øvre siddende, de nedre afsmaluede til en kort Bladstilk, ved Grunden heelrandede; de ydre Kurvblade omtr. 5, over halvt saa lange som de indre; Straalekronerne 7-8; Skalfrugterne glatte; Fnokken luvid.

Rodstokken krybende, Stængelen $3-5^{\prime}$ høi, heel, tilligemed Bladene glat. Kronerne gule. 8-9. 4 . 
Oprindelig indvandret, forekommer omkring Haver og dyrkede Steder: $S j$. et Gjarde mellem Hillergd og Fredensborg! Dronninggaard $(9,14)$, Frederiksberg Have, Søndermarken (Dr.), ved Leersøen (19), Ledreborg (Thomsen), Gisselfeld (Smith); Sh Nyvierk red Slesvig (16).

\section{Cineraria. Fuolurt.}

1118. C. palustris L. (Almindelig F.) H. 863 ; Drej. n. 827 ; F. D. 573 ; H. N. I, 5; Seneeio palustris DC., Rchb. l. c. XVI, tab. 978 .

Bladene lancetformede, i Randen bølgede, de nedre saugtakket-fligede, stilkede, de ovre heelrandede eller tandede, halvt omfattende; Halvskjormen grenet; Skalfrugterne kantede, glatte.

Stængelen hunl, 2-4' høi, hele Planten klæbrig-haaret af leddede Haar. Kronerne gule. 6-7. $\odot$.

I Torvmoser og dybe Kjær, alm. udbredt. F

1119. C. campestris [Retz. Prodr. fl. Scand. ed. I, p. 159] (Mark.F.) H. 863 ; F. D. 1177 ; C. alpina $\gamma$, L., Fr. H. N. I, 6; Senecio campestris DC., Rehb. 1. c. XVI, tab. 978.

Rodbladene omvendt-ægformede eller lancetformet-ovale, rundbugtede eller næsten heelrandede, sammendragne til en kort Bladstilk; Stcengelbladene lancetforınede, svagt tandede, de øvre linie-lancetformede, heelrandede, siddende; Halvskjormens Grene udeelte; Skalfrugterne stivhaarede.

$1 / 3-1$ ' høi. Stængei og Blade i yngre Tilstand beklædte med en løs, hvid Filt, som let afgnides. Kronerne gule. 6-7. ข.

Paa aabne Kalk- og Kridtbakker, kun funden paa Halvoen: Thy (16), Aalborg, Horsekjier Riis (H.), Mergelbakker ved Hodal Mulle pr. Hobro, Raasted Dalen ved Randers (16)! Randers (M. Vahl).

\section{Arnica. Volverlei.}

1120. A. montana L. (Bjerg-V.) H. 866; Drej. n. 828; F. D. 63 ; Rehb. 1. c. XVI, tab. 958.

Rodbladene oval-lancetformede eller omvendt-ægformede, med 2 stærke Nerver paa hver Side af Mlidnerven, heelrandede eller bolgede i Randen; Stcongelbladene modsatte, siddende; Blomsterkurvene store, enlige i Spidsen af den udeelte ellér faagrenede Stcengel; Skalfrugterne stivhaarede. 
1-2' høi. Stængelen og Kurvbladene klæbrig-haarede af brune Kirtelhaar, som meddele Planten en stærk Lugt. Kronerne orange. 6-7. $\%$.

Paa Lyngheder, høie Enge, Skorbakker: paa Halveen alm., i Fyen hist og her, aftagende i Hyppighed mod $\varnothing . ;$ i Sjall. sjeldnere: Odsherred, Antvorskov (H), Horsebøg ved Sorø! Landlyst (14), Hammermollen o. fl. Steder ved Helsing ør (21), Donze (28), Fredensborg, Kudergaard, Ballerup (H.), Jonstrup Vang (14), Bagsværd! (Paa B ornh., Loll. og Falst. ikke bemærket. |*

\section{Syngenesia frustranea.}

\section{Centaurea. Knopurt.}

a. Skalfrugterne uden Fnok.

1121. C. Jacea L. (Almindelig K.) H. 878; Drej. n. 847 ; F. D. 519 ; Rehb. 1. c. XV, tab. 754 .

Bladene lancetformede eller linie-lancetformede, heelrandede, tandede eller ved Grunden øreformigt fligede; Kurvbladene med rundagtigt-ægformede, hule, bredt hindeagtige Tilhongsler i Spidsen; Randblomsterne kjønsløse, meget større end Skiveblomsterne.

Stængel og Blade haaret-rue. Kurvbladene lysere eller mørkere brune; Kronerne smukt violetrøde, sjeldnere hvide. 7-9. 4. Var. betydeligt i Henseende til Stængelens Forgrening, Bladformen, Beklædningen og Kurvbladenes Indskjæring. De vigtigste Former ere:

$\boldsymbol{\alpha}$, genuina. Alle Kurvbladenes Tilhængsler beelrandede eller uregelm. spaltede.

$\beta$, cuculligera Rehb. 1. c. XV, tab. 754. Kurvbladenes Tilhængsler kappeformigt udhulede, næsten alle heelrandede.

* fuscescens! Tilhængslerne brune.

** argyrolepis! Tilhangslerne hvid - hindeagtige, sølvglindsende, Kronerne stundom hvide. (Ligner C. alba L.)

$\boldsymbol{\gamma}$, lacera Koch. Tilhængslerne paa de indre Kurvblade uregelm. spaltede, paa de ydre regelm. fryndset-fligede; Bladene linieformede. 
$\delta$, laciniata M. T. Lange (Naturb. Foren. vid. Medd. 1861 p. 11). Bladene halvfinnet-fligede.

Paa høie Enge, udyrkede Steder, alm. udbredt. $-\beta^{*}$, Østervold ved Kjøbenhavn! Sorø (12); ** S j. Tikjøb! J. Aarbus (Mohr)! $\gamma$, Falst. Riserup (Koch); Loll. Søllested (19); ved Blykobbeaaen paa Bornholm! J. Lille Vildmose ved Gudumlund! $\delta, \boldsymbol{F}$. $\emptyset$. Skjerninge (12).

1122. C. decipiens [Thuill. Fl. Paris. ed. 2, p. 445] (Mørkskjællet K.) Rchb. l. c. XV, tab. 759; C. nigrescens Gren. \& Godr. fl. Fr. II, 241, DC. prodr. VI, 571, Lge. Haandb. 2 Udg. S. 563 (ikke Willd.); C. Jacea var. capitata Koch \& Ziz.

Bladene lancetformede, heelrandede eller bugtet-tandede, Kurvbladene med rundagtigt-ægformede, sortbrune, fryndsetrandbaarede Tilhwngsler; Fryndserne omtrent af Længde med selve Tilhængslens Brede, de $2-3$ øvre Kredse af Tilhængsler fjernede fra de øvrige; alle Blomsterne $\Varangle ;$ Randkronerne lidet større end Skivekronerne.

Stængel og Blade haaret-rue. Kronerne violetrøde. 7-8. 4 .

Ved Gjærder, sjelden: $\boldsymbol{S} j$. S. for Lillehedinge i Sterns (1860)! F. Skaarup (19)! 菏

Anm. 1. Fra foreg. let kjendelig ved de sortbrune, mindre hule Kurvblade med længere Fryndser, ved alm. frugtbare Randblomster; fra $C$. nigra L. ved Mangel af Fnok, kortere Fryndser og de Kurvblades større Afstand fra de nedre. Efter Koch forekommer den hyppigst med større Straaleblomster (C. Jacea $\varepsilon$, commutata Koch Syn.), dette er ikke Tilfældet med de af mig fundne Expl., som henhore til den Form, der er kaldet C. Jacea rar, capitata Koch \& Ziz. Ifølge Prof. A. Brauns velvillige Meddelelse er den i Willdenows Herbarium opbevarede $C$. nigrescens den samme Plante, som senere er kaldet C.transalpina Schleich. og ikke, som jeg tidligere efter Decandolles, Grenier \& Godrons Autoritet havde antaget, den her beskrevne Plante, hvorfor det tidligere anvendte Navn maa forandres.

Anm. 2. C. nigra L. (F. D. 996 ; Rchb. 1. c. XV, tab. 761), som findes saavel i Norge som $i$ det sydligere Europa, har hidtil ikke været angivet fıa Danınark. Til en af denue Arts talrige Former hører dog muligviis den af M. T. Lange (Naturhist. Foren. vid. Medd. 1861 , p. 11) under Navn af C. Jacea var. (?) beskrevne Form, som ifølge Beskrivelsen og navnlig paa Grund af de med en kort Fnok forsynede Frugter ikke synes at henhore til nogen af de ovenfor beskrevne Arter. Den er funden ved Veien mellem Jellinge og Greis i Jyll. (12) og maa nærmere eftersøges. 
b. Skalfrugterne fnokbærende.

1123. C. phrygia L. (Fjeret K.) H. 876 ; F. D. 520 (ikke god); Rehb. l. e. XV, tab. 764; H. N. XIII, 4; C. austriaca Willd.

Bladene elliptiske eller $æ$-lancetformede, heelrandede eller fjernt tandede; Kurvbladene ved Grunden lancetformede, med langt sylspidsede, tilbagekrummede, haarformigt-fryndsede Tilhangsler; Fnokken neppe 1/3 af Skalfrugtens Læugde.

Stængel og Blade korthaaret-rue. Kronerne rodviolette. 7-8. 4 .

Ved Gjærder og i Kratskove: paa Halve en, især dens sydlige og østlige Egne ikke sjelden! i Fyen sporadisk: Gremmelykke! Kjærsgaurd (H.), Langensø (13), Hunderup ved Odense, Lykkesholm, Ringe (H.), V. Hirsinge (24), Grønnerup! Svendborg(H.). I Sjæll. $o g$ paa de øvrige Øer mangler den. $|*|$

1124. C. Scabiosa L. (Stor K.) H. 878; Drej. n. 849; F. D. 1231 ; Rehb. 1. c. XV, tab. 774 .

Bladene enkelt eller dobbelt fjersnitdeelte, med lancetformede, tandede eller heelrandede Afsnit, der ofte ende i en bruskagtig Spids; Kurvdckket kugleformet; de ydre Kurvblade ægformede, fryndset-randhaarede, de indre xg-lancetformede, sortgrønne, med ægformede, sortbrune, børsteformigt-fligede Tilhœngsler; Fnokken af Længde med Skalfrugten.

Kurvene stgrre end hos de ovrige Arter. Kronerne violette, sjeldnere hvide. Var. i Henseende til Beklæduing. 7-9. 2.

I Krat, ved Gjærder og Veie, alm. i de fleste Egne af Landet.

1125. C. Cyanus L. (Kornblomst). H. 877; Drej. n. 848 ; F. D. 993 ; Rehb. 1. c. XV, tab. 768 .

Bladene lancet-linieformede, heelrandede eller med en enkelt Tand ved Grunden; Kurvdakket ægformet, med ægformede eller æg-lancetformede, foroven i Randen mørkbrune, børsteformigt saugtakkede Kurvblade; Fnokken af Længde med Skalfrugten.

Stængel og Blade, især paa Underfladen, filtede. Kronerne himmelblaa (i Haver dyrkes stundom hvide, røde eller violette Afændringer). 6-7. $\odot$.

Alm. Ukrudsplante i Vintersæden. 
† C. montana L. (Rehb. 1. e. XV, tab. 771). Stcenglerne oprette; Bladene lancetformede, nedløbende, løst filtede; Blomsterkurvene enlige med xgformede, i Randen sortbruunt-fryndsede Kurvblade, himmelblaa Kroner; Fnokken meget kortere end Skalfrugten. 6.4 .

Dyrkes bist og her som Siirplante i Haver, og er funden forvildet ved gl. Kongevei og Ryssensteens Bastioner ved Kjobenhavn (Heiberg), Svenstrup! $\boldsymbol{F}$. Svindinge (Letli).

\section{$\uparrow$ Helianthus. Solsikke.}

$\dagger$ H. tuberosus L. (Jordæble). Rchb. 1. c. XVI, tab. 940.

Bladene tilspidsede, saugtakkede, rue, de nedre æg-hjerteformede, de øvre elliptiske; Stangelen foroven halvskjærmformigt grenet, med oprette Blomsterkurve.

Kronerne gule; spiselige Rodknoller. 10-11 (blomstrer sjeldent hos os). 4 .

Dyrkes i Haver som Surrogat for Kartofler.

\section{Rudbeckia.}

$\dagger$ R. fulgida [Ait. H. Kew. ed. I, 3, p. 251] Bot. mag. 1996.

Stxngelen hvashaaret, grenet eller udeelt; Bladene laneetformede eller elliptiske, heelrandede eller svagt tandede, stivhaxret-rue; Blomsterkurvene enlige i Spidsen af Stængelen eller Grenene; Kurvbladene grøune, lidet kortere end de orangegule Straalckroner ; Skiveblomsterne sortrøde, tæet samlede i Halvkugleform. 7-8.

Dyrkes stundom i Haver som Siirplante, indfort fra Nordamerika. Funden i de senere Aar par flere Steder i Landet: $\boldsymbol{J}$. Græsmarker i Torslev Sogn (8)! Viborg (Feddersen), Heder ved Hobro (Joh. Møreh)! Bornh. (Hoff)!

\section{Syngenesia necessaria.}

\section{Calendula. Morgenfrue.}

$\dagger$ 1126. C. officinalis L. (Lxge-M.) H. 879 ; Rchb. ic. A. germ. XV, tab. 890 . 
Rodbladene stilkede, omvendt-ægformede; Stcongelbladene siddende, elliptisk-lancetformede, svagt tandede; Skalfrugterne halvmaaneformede, paa Ryggen tornet-knudrede.

Kronerne brandgule. 7-9. $\odot$.

Forekommer hist og her forvildet som Ukrud i og omkring Haver.

\section{Syngenesia segregata.}

\section{Echinops. Tidselkugle.}

1127. E. spharocephalus L. (Fligbladet T.) H. 880 ; Drej. p. 272 ; F. D. 2179 ; Rehb. ic. fl. germ. XV, tab. 734 .

Stangelen opret, trind, furet; Bladene halvfinnede, medtornet-tandede Flige; Kurvene lancetformede; de ydre Kurvblade talrige, børsteformede, halvt saa lange som de indre, lancetformede, børsteformet-ranchaarede.

$2-4^{\prime}$ høi. Stængelen oventil tæt Iıvidfiltet; Bladene paa Overfladen klæbrigt-duunhaarede, paa Underfaden Invidfiltede. Hovederne gratagtigt sølvglindsende. Kronerne blate. 7-8. 4.

Paa Marker og ved Veie, sjelden: $\boldsymbol{S} j$. Asnres Skov ved Skovriderboligen (Smith), Snedinge, Holsteinlıorg (H.)! Glænø (17); $\boldsymbol{F}$. Landeveien mellem Nyborg og Odense ved Birkende! J. Engelsholm (forvildet? 12)

\section{0de Klasse. Gynandria (Ilunbo).}

\section{Orden. Monandria (Enhannede).}

Alle Slægterne i denne Orden $(1-16)$ høre til N. F. Orchideæ: Blomsten damnet af et sexbladet Biomsterdække i 2 Kredse: i den ydre Kreds 3 ligestore Blade (de 2 sidestillede, det tredie nedadvendt, men ved Blomstens Dreining opadvendt), i den indre Kreds 2 ligestore, sidestillede Blade, det tredie opad- (ved Dreiningen nedad-) vendte (Læben) af forskjelligt Udseende fra de $s$ vrige, ofte med en sporeformet Tillıængsel; 1 torummet Stavknap fasthæeftet til Arret og ved denne Sammenvoxning dannende en Griffelstotte; Støvet i Masser (1-2 i hrert Rum), ofte ved en stilkformet Basis (Støvholderen) befæstede til en Kirtel; Arret ender ofte $i$ et Næb mellem: 
Stovknappens Rum; Frugten undersadig Kapsel. (Blomsterne i Ax -iler Klase).

A. Stovknappen heelt tilroxet til Stovveien (1-2 Knoller fra Rodstokken).

a. Læben forsynet med en Spore.

aa. Støvknappens Rum ved Grunden sammenstødende, med et Nab mellem Rummene.

1. Orchis L. (part.). Læben fliget; Støvknappens Rum ved Grunden forenede $\mathrm{i}$ en fælles torummet Pung; Støvmasserne adskilte (med hver sin Støvholder); Knollerne udeelte eller haanddeelte.

2. Auacámptis Rich. Læben fliget; Støvknappens Rum ved Grunden forenede $i$ en fæelles enrummet Pung; Støvholderne ved Grunden sammenvoxne (Knollerne udeelte).

3. Gymmalénia R. Br. Læben fliget; Støvknappens Rum uden Pung; Støvholderne adskilte (linollerne haunddeelte).

66. Stovknappens Rum ved Grunden adskilte.

4. Platanthéra Rich. Læben udeelt; Sporen lang, traadsmal; Støvknappens Rum uden Pung (Knollerne udeelte).

5. Coeloglóssum Hartm. Laben fliget; Sporen kort, sækformet; Støvknappens Rum uden Pung (Kuollerne haanddeelte).

$$
\text { b. Laben uden Spore. }
$$

6. Ilermínium R. Br. Blomsterdækket klokkeformigt tillukt; Læben fliget, ved Grunden stundom puklet (Antydning af en Spore); Frugtknuden snoet; Støvmasserue uden Pung, en kirtelformet Tilhængsel paa hver side af Nabet (Knollerne udeelte).

7. Ophrys L. (part.) Blomsterdækkets Blade ndstaaende; Læben figet, lappet eller tandet; Frugtknuden ikke snoet; Støvmasserne hver indesluttede i sin Pung (Knollerne udeelte). 
B. Stovknappen fri (kun med sin nedre Deel tilhæftet til Arret).

a. Læben med en Spore (Rodstokken uden Knoller, koralformig grenet).

8. Epipógon Gmel. (Epipogi um Sw.). Blomsterdækket med opadvendt, i Midten dybt indskaaren (toleddet) Læbe; Frugtknuden ikke snoet; Støvmasserne 2, udeelte, kornede, ved 2 forlængede Støvholdere befæstede til en fælles Kirtel. (Bladene skjælformede).

$$
\text { b. Læben uden Spore, }
$$

aa. $i$ Midten dybt indskaaren (toleddet). Rodstokken uden Knoller, Roden trcevlet.

9. Cephalanthéra Rich. Frugtknuden stilkløs, snoet; Griffelstøtten uddragen; Støvmasserne til Grunden todeelte, kornede, uden Støvholder og Kirtel.

10. Epipictis Rich. Frugtknuden stilket, ikke snoet; Griffelstøtten kort, Læbens yderste Led ved Grunden puklet; Støvmasserne til Grunden todeelte, kornede, uden Støvholder befæstede til en fælles Kirtel.

\section{bb. Laben uleddet,}

$\alpha$, lappet eller fliget. Rodstokken koralformigt grenet eller krybende, med Trævlerødder, uden Knoller.

11. Listéra R. Br. Læben 2-3-fliget; Griffelstøtten forlænget ud over Støvknappen; Støvmasserne kølleformede, kornede, til Grunden todeelte, uden Støvholder befæstede til en fælles Kirtel (Bladene 2, modsatte, med udviklet Plade).

12. Neóttia (L.) Læben tofliget; Griffelstøtten naaer ikke udover Støvknappen; Støvmasserne kølleformede, kornede, til Grunden todeelte, uden Støvholder befæstede til en fælles Kirtel (Bladene spredte, skjæl- eller skedeformede, uden Plade).

13. Corallorhiza R. Br. Læben trelappet, ved Grunden sammenhængende med Blomsterdækkets 2 ydre Sideblade; Støvknappens Rum tværdeelte i 2 Smaarum, med 2 kuglerunde, 
voxagtige Støvmasser i hvert Rum (Bladene spredte, skjælformede uden Plade).

$\beta$, Læben udeelt eller svagt tandet. Rodstokken med 1-3 Knoller.

14. Spiránthes Rich. Perigonbladene ved Grunden sammensluttende og dannende en ret Vinkel med Frugtknuden, i Spidsen tilbagebøiede; Læben nedadvendt, ved Grunden huul, i Spidsen rundtakket; Griffelstøtten kort, med 2 Tænder bagtil og en paa hver Side af Støvknappen; Støvknappen vedblivende, Støvmasserne kølleformede, kornede, dybt todeelte, uden Støvbolder befæstede til en fælles Kirtel.

15. Stirmia Rchb. Perigonbladene udstaaende, Lxben opadvendt, beelrandet eller tandet; Griffelstøtten uddragen, bøiet, oventil tovinget; Støvknıppen affaldende; Rummene adskilte, med 2 runde, voxagtige Støvmasser i bvert.

16. Malixis $\mathrm{Sw}_{\mathrm{w}}$ (pärt.) Griffelstøtten kort, ret, med 2 Tænder foroven; Støvknappen vedblivende, Støvmasserne kølleformede, roxagtige, i Spidsen todeelte; forørigt som foreg.

\section{Orden. Hexandria (Sexhannede).}

17. Aristolóchia L. Blomsterdækket enkelt, sambladet, med skraat afskaaren Krave; Støvknapperne siddende, danne en sexlappet Krands omkring det straaleformede Ar; Frugten en sexrummet, mangefrøet, undersædig Kapsel (N. F. A r i s t ol o c h i e æ).

\section{Monandria.}

\section{Orchis. Gjogeurt.}

a. Knollerne*) udeelte, kuglerunde eller ovale. aa. Laben dybt trefliget, den midterste Flig tolappet, alm. med en Tand $i$ Indskjoringen.

1128. 0. fusea [Jacq. Fl. austr. 4, t. 307] (Storkronet G.) O. purpurea Huds., Rubb. ic. Fl. germ. XIII-XIV, tab. 378;

*) Knollerne hos Slægten Orchis (o. fl. Slagter i denne Familie) 2: den ene fremskyder det indevarende Aars Stængel, den anden indeholder Knoppen til Blomsterstangelen for det folgende Aar. 
O. militaris $\beta$, L., H. 885 ; Drej. n. 852 ; F. D. 1277 ; H. N. $\mathrm{X}, 61$.

Bladene elliptiske; Dakbladene hindeagtige, mange Gange kortere end Frugtknuden; de ydre Perigonblade forneden sammenvoxne, foroven sammenstødende i Form af en Hjelm; Labens Sideflige linieformede, udrandede eller takkede, Midtfigen omvendt-hjerteformet med afrundede, uregelmæssigt rundtakkede Lapper og en Tand i Indskjæringen; Sporen ikke halvt saa lang som Frugtknuden.

$1-2^{\prime}$ høi. Hjelmen mørk purpurrød med brune Punkter; Læben hvid eller lysrød med ophøiede, mørkrøde Punkter. 5-6. 4.

I Skove og Krat paa Kalkgrund meget sjelden: M $\boldsymbol{\theta}_{\boldsymbol{1}}$ en i Mængde paa Store- og Lilleklint! J. Trelde Sliov ved Fredericia (!)

1129. 0. ustulata L. (Rulæbet G.) H. 885 ; Drej. n. 853 ; Rehb. ic. fl. germ. XIII-XIV, tab. 368 ; H. N. XV, 65; Ophrys anthropophora F. D. 103.

Bladene lancetformede; Dakbladene hindeagtige, over halvt saa lange som Frugtknuden; de ydre Perigonblade frie, foroven sammenstødende til en halvkugleformet Hjelm; Labens Sidefige og den dybt kløvede Midtfigs Lapper linieformede, i Spidsen rundtakkede eller udrandede; Sporen $1 / 3$ af Frugtknudens Længde.

$1 / 2-1^{\prime}$ høi. Axet tætblomstret, valseformet, Blomsterne meget. mindre end hos foreg., Hjelmen mørk purpurrød, Læben hvid med fløielsagtigt ophøiede, purpurfarvede Punkter. 6-7. 4 .

Paa høie Enge og Bakker, især paa Kalkgrund, sporadisk og temmelig sjelden: $\boldsymbol{J}$. Engskrænter ved Aagaards Kalkbakker (16), Buderupholm (H.), Blegkilde ved Aalborg (Branth), Horsens (Jørg.); F. Hunderup (H.); $\boldsymbol{S}$. en Klint ved Tudienæs, Tiisvilde (H.), Skullerupholm (Weilbach), Herthadalen (Sommerfeldt), Alindelille (20), Søllerød, bag Flaskekroen, Kjøge Aas (Dr.), Gjorsløv (d'Origny), Præstø (H.), Rosenfeldt Teglværk (29), mellem Ravnstrup og Nestved (20), Herlufsholm (H.), Søllerød Skov ved Rude nærved Fiurendal (22); $M_{\theta}$ en paa Aborrebjerget o. fl. St.! F alst. ved Stubbekjøbing (25)! Bønuit (Koch); B ornh. Rønne, Aakirkeby, Bodilsker (20), Randkleven (8).

bb. Laben trelappet, med korte, brede Lapper, den midterste svagt udrandet.

1130. 0. IIorio L. (Grønstribet G.) H. 883; Drej. n. 855 ; F. D. 253 (slet); Rehb. 1. c. tab. 363 ; H. N. I, 66. 
Knollerne kuglerunde; Bladene lancetformede, de nedre udbredte, de øvre tiltrykte; Dakbladene farvede, af Læugde med Frugtkuuden; de ydre og $\bar{z}$ indre Perigonblade budte, sammenstødende foroven til en Hjelm; Labens Midtfig svagt udrandet; Sporen vandret udstaaende eller opadbøiet, lidet kortere end Frugtknuden.

4-10" høi. Perigonbladene med grøne Aarer, carmoisinrøde eller violette, sjeldnere hvide, 5-6. 4 .

Paa høie Enge og udyrkede Marker, ikke sjelden, dog mindre hyppig end folg. og $\mathrm{i}$ adskillige Egne ikke bemærket: hyppigst $\mathrm{i}$ det sydl. og vestl. Sjall. samt par M $\boldsymbol{M}$ en.

1131. 0. mascula L. (Tyndaxet G.) H. 884 ; Drej. n. 856 ; F. D. 457 ; Rchb. 1. c. tab. 390 .

Knollerne ovale; Bladene omvendt-ægformet-laneetformede; Dakbladene farvede; af Længde med Frugtknuden; Blomsterdakkets ydre Sideblade ægformede, spidse, foroven udadbøiede, det øvre budt eller spidst, længere end de af samme bedækkede 2 indre Sideblade; Lobens Midtfig udrandet (ofte med en Tand i Indskjæringen); Sporen vandret eller opadbøiet, lidet længere end Frugtknuden.

$1 / 2-1^{\prime}$ hoi. Bladene alm. bruunplettede; Perigonbladene violetrøde, uden gronne Aarer, Læben dybere lappet end hos foreg. Blomsterne have alm. en sødlig Lugt. 5-6. 4.

Paa løøie Enge, i Skove og Krat, meget alm. (En Var. uden Spore funden paa Loll. ved Ourebygaard (Rosenørn Lehn)!

b. Knollerne aflange, bele eller i Spidsen

$$
2-3 \text {-deelte. }
$$

1132. 0. sambucina L. (Bredlxbet G.) H. 886; Drej. ฉ. 854 (bis); F. D. 1232 ; Rehb. 1. c. tab. 412 ; H. N. XIV, 65.

Bladene onvendt-ægformet-lancetformede; Dakbladene hindeagtigt farvede, de nedre bladagtige, fleernervede, længere end Frugtknuden og omtrent af Længde ined Blomsterne; de ydre Perigonblade udstaaende; Laben svagt trelappet; Sporen nedadbøiet, af Længde med Frugtknuden.

4-10" høi. Var. med gule og violet-lysrøde Blomster. 5-6. 4. 
Paa Bakker mellem Krat, sjelden: $\boldsymbol{J}$. Sønderskovgaards Krat i Ø. Hanherred (16), Estruplund (3), Aarslev (H.), Brabrand Mark (2), Lynghakker red Agrie (13); $\boldsymbol{S} \boldsymbol{j}$. en Høi ved Slagelse (H.), Vordingborg (11); B ornh. Hammershuns, Lindholms Klipper, Nexø, Vældensby (20)! Almegaard ved Rønne (Hjorth) o. fl. St. (Baagøe).

Anm. I flere Henseender, f. Ex. ved Dækbladene og især ved de snart hele, snart i Spidsen deelte Knoller danner denne Art en Overgang mellem foreg. og følg. Atdeling.

c. Knollerne dybt haanddeelte. (D rkbladenetrenervede, bladagtige, Sporen nedadrettet, kortere end Frugtknuden).

1133. 0. majalis [Rehb. ic. crit. VI, p. 7, tab. 770] (Mai-G.) F. D. 2664 ; O. latifolia L., Fr. mant. 2, 53 ; H. 886 (part.); Dr. n. 855 ; Rebb. ic. fl. germ. XIII-IV, tab. 402.

Stcongelen buul, 4--6-bladet; Bladene udstaaende, lancetformede eller elliptiske, med størst Brede paa Midten, de фvre naae omtrent til Axets Basis; de nedre Dakblade længere, de ovre kortere end Blomsterne; Blomsterdakkets ydre Sideblade opstigende; Laben omvendt-hjerteformet, trelappet, Sidelapperne rundtakkede, den midterste spids; Støvmasserne alm. bleggule.

Bladene alm. med mørkbrune Pletter. Blomsterne violet-røde sjeldnere blegrøde eller hvide. $\frac{5}{2}-\frac{5}{1}$. 4 .

Paa fugtige Enge, ikke sjelden i Danmark, dog ikke i alle Egne lige almindelig.

1134. 0. incarnata L. [Fr. Mant. 3, 140] (Kjødfarvet G.) Drej. p. 275 ; F. D. 266 (O. latifol.) og 2476 ; Rebb. I. c. tab. $397-99$; H. N. VII, $65-66$; O. angustifolia W. \& Gr., O. latifolia Rafn D. Fl. I, 376.

Stangelen huul, 4-6-bladet; Bladene opret-tiltrykte, sværdformet.]ancetformede, med storst Brede ved Grunden og en kappeformigt sammentrukken Spidse, de øvre naae op over Axets Basis; alle Dakbladene l:engere end Blomsterne; Blomsterdokkets ydre Sideblade tilsidst (næsten parallelt) tilbagebøiede; Laben omvendt ægformet, utydeligt trelappet (med alm. nedbøiede Sidelapper); Støvmasserne alm. blaagrønne.

Bladene uplettede. Blomsterne kjødfarvede, sjeldnere rødviolette eller hvide. Efter Doc. Didrichsens Iagttagelse ere begge Knollerne 
i Blomstringstiden hos denne Art livide, hos foreg. derimod den ældre Knol bruun (lederfarvet). 6 (blomstrer omtr. 8 Dage senere end foreg.) य. Var. (ligesom foreg.) med smalere ( $\curvearrowleft$, angustifolia) eller bredere Blade (latifolia Fr. l. c.) og desuden:

$\beta$, hamatodes Rehb. 1. c. XIH-XIV, p. 51, tab. 398, med tæt og fint brunnplettede Blade, morkere Blomster.

I dybe Moser med Hrengedyad, paa fugtige Enge, ikke sjelden, og i mange Egne (f. Ex. omkring Kbhavn) liyppigere end foreg. Fnrekommer snart i Selskab med, snart adskilt fra biin. $\beta$, Ladegaarden ved Kjobenhavn (I. Vahl jun.)!

Anm. Saavel fordi begge Arterne variere bred- eller smalbladede, som fordi Navnene O. angustifolia og latifolia have været saa yderst forskjelligt auvendte, har jeg foretrukket de valgte Navne, som efter den critiske Undersøgelse over disse Arter af Prof. Fries (l. e.), sml. med Fig. hos Relhb., ikke kunne være udsatte for Misforstaaelse. Arterne selv ere ofte vanskelige nok at adskille, og man finder (skjøndt. sjeldent) Former, der have Kjendetegn tilfelles med begge. En saadan Form er den ovenfor nævnte $\beta$, som endeel ligner den $\mathbf{i}$ det nordlige Skandinavien forekommende 0 . cruenta Müll. F. D. 876, hvilken af Rchb. (l. e.) ogsaa lienregnes til O. inearnata.

\section{0. maculata L. (Plettet G.) H. 887 ; Drej. n. 856} (bis); F. D. 933 ; Rehb. 1. c. tab. 407.

Stcongelen heel, 6-10-bladet; de nedre Blade bredt, de mellemste smalt lancetformede, de фvre linieformede, det øverste ikke naaende Axets Basis; Axet tætblomstret; de nedre Dakblade af Længde med, de фvre kortere end Blomsterne; Blomsterdakkets Blade tilspidsede, de ydre Sideblade udstaaende; Laben flad, omvendt-nyreformet, tydeligt trelappet.

Bladene plettede. 6-7. 4. Var. betydeligt i Henseende til Høiden, Bladenes Brede og Blomsternes Farve (alm. blegt rosenrøde eller lila med morkrøde Pletter og Striber).

$\beta$, concolor! Bladene uplettede; Blomsterdækket sneehvidt uden Pletter.

I Skove, Tørv- og Hedemoser, paa Lyngbakker o. s. v., meget alm. - $\boldsymbol{\beta}$, red Aborre S $\emptyset$ paa Møen! $\boldsymbol{S} j$. Grasvænget ved Skjelskør (Nielsen); J. Norup ved Veile (30).

\section{Anacamptis. Ilorndrager.}

1136. A. pyramilalis [Rich. Mem. mus. d'hist. nat. 4, p. 55] (Pyranideaxet H.) Rehb. 1. c. tab. 351 ; Orchis L., H. 883 ; Drej. n. 854 ; F. D. 2113 ; H. N. VI, 57. 
Knollerne 2, rundagtige, udeclte; Bladene lancet-linieformede, de фvre skedeformigt sammenrullede; Axet tætblomstret; Doxtbladene farvede; Laben trelappet med 2 Folder ved Grunden og heelrandede Lapper; Sporen traadformet, af Længde med eller længere end Frugtknuden.

8-15" høi. De fleste Blade ere visnede naar Blomstringen begynder. Blomsterne smnkt og mørkt purpurrøde. 7. భ.

I aabne Skove paa Kalkgrund, sjelden: Meen paa Storeklint! Aborrebjerget! Krat ved Kjelby (Mørch); $\boldsymbol{S}$. Alindelille Fredskov!

\section{Gymnadenia. Traadspore.}

1137. G. conopsea [R. Br. i H. Kew. ed. 2, V, 191] (Langaxet T.) Drej. n. 857; Rehb. J. e. tab. 422; H. N. IX, 67 ; Orchis L., H. 888; F. D. 224.

Knollerne 2, haandformigt deelte; Bladene linie-lancetformede; Axet valseformet, forlænget; de ydre Perigonblade udstaaende; Lceben trelappet med budte, ligestore Lapper; Sporen traadformet, spids, bøiet, næsten dobbelt saa lang som Frugtknuden.

$1-11^{1}{ }^{\circ}$ høj. Blomsterne mørk rosenrøde. $\frac{6}{2}-\frac{7}{1}$.

Par Enge: sporadisk paa Øerne, hyppigst paa Bornh. (20) og i det nordlige Fyen (4); paa Halvoen sjeldnere: $\boldsymbol{J}$. Teglgaardsholm mellem Varde og Henne (H.).

1138. G. albida [Rich. 1. c. p. 57] (Hvid T.) Rehb. 1. c. tab. 419 ; H. N. XIV, 66; Satyrium I., H. 890 ; F. D. 115 ; Habenaria R. Br., Drej. n. 862.

Knollerne til Grunden deelte i tyndt kegleformede Trævler (som giver Udseende af en knippeformet Trævlerod); de nedre Blade omvendt-ægformede, de фvre lancetformede; Axet valseformet; de ydre Perigonblade sammenluttende til en rundagtig Hjelı; Laben dybt trefliget, den midterste Flig storst; Sporen budt, ret eller svagt bøiet, 3 Gange kortere end Frugtknuden.

6-10" høi. Axet næsten ensidigt; Blomsterne hvidgule. 7.4.

Paa Bakker og tørre Enge, sporadisk og temmelig sjelden, især paa Øerne: $\boldsymbol{J}$. Lindenborg, Torslev (H.), mellem Thostrup og Tovelstrup, Eveldrup (Dr.), V. Velling, Meilgaard, Grenaa, Kals (H.), Donneruplund! Fredericia (H.), Bakker S. for Kolding Aa (7); $S l$. Arrild 
Hede (20), Breeklum (F. Müll.), Schanendal og Lyngheder nær Mølledammen ved Husum (16); $\boldsymbol{S} j$. Bakker mellem Hjortekjærshuset $o g$ Nymolle! Brede (Dr.); Bornh. Rytterknægten (Lotze), Bodilsker (20), Klemensker (19)!

\section{Platanthera. Fladknap.}

1139. P. solstitialis [Drej. I. c. n. 850, cf. Kröy. Tidskr. IV, p. 45] (Vellugtende F.) Rehb. l. c. p. 120; P. bifolia Rich. (part.), H. N. VI, 62; Orchis bifolia H. 882 (part.); F. D. 235 .

Knollerne udeelte, elliptiske eller kegleformede; ovenfor de 2-3 nedre skedeformede Blade (uden Plade) 2 tætsiddende, tilsyneladende modsatte Blade med lancetformet-omvendt-ægformet Plade, de $2-4$ derpaa følgende spredte, meget mindre, linie-lancetformede; Sporen traadformet, meget længere end Frugtknuden; Støvknappens Rum parallele; "de golde Støvdragere kugleformet-nyreformede".

8-12" høi. Blomsterne vellugtende. De ydre Perigonblade hride, de indre (tilligemed Læben og Sporen) i Spidsen grøngule. 6-7. थ. Drej. (Krøy. Tidskr. l. e.) adskiller følgende Former:

$\alpha$, latiflora (F. D. 2360 ; Rchb. l. c. tab. 428 (laxiflora). Blomsterdækkets 2 indre Sideblade tilspidsede, opstigende og i Spidsen sammenstødende; Griffelstøtten foroven afrundet.

$\beta$, densiflora (F. D. $2361 \mathrm{a}-\mathrm{h}$; Rchb. l. c. tab. 428, fig. 2 og 429, fig. 4 ; P. brachyglossa Rchb. ic. crit. IX, tab. 1144). De to indre Sideblade budte, i Spidsen sammenstødende; Griffelstøtten afstumpet eller udrandet.

$\gamma$, patula F. D. 2361 i. De to Sideblade budte, frastaaende; Griffelstatten budt.

Paa Bakker og høie Enge, findes i alle Provindser, hyppigst paa Halvoen, i Fyen, paa Moen og Bornh., sparsommere $\mathrm{i}$ det vestl. Sjall., par $\boldsymbol{I}$ oll $\mathrm{ng} \boldsymbol{F}$ alster. Formen $\beta$, synes at vere den almindeligste; $\boldsymbol{\alpha}$, sjellnere, f. Ex. $\boldsymbol{S} j$. Kjøhenhavns Omegn (Drej.), Jonstrup Vang (14), Gyrstinge (19); $\gamma, S j$. ved Flaskekroen (Drej.).

1140. P. chlorantha [Custor i Rehb. Mössl. Hand̉b. 2, p. 1565] (Groulig F.) Drej. n. 851; F. D. 2362 ; H. N. VI, 61; P. montana Rebb. I.' c. tab. 430; Orchis bifolia Crantz et plur. autt. (part.). 
Sporen traadformet, i Spidsen fladtrykt-kølleformet, omtrent dobbelt saa lang som Frugtknuden; Stovknappens Rum forneden divergerende; "de golde Stovdragere store, omvendt-ægformede" ; forøvrigt som foreg.

$10-15^{\prime \prime}$ høi. Blomsterne mindre tætsiddende, men større end hos foreg., af svagere Lugt (idetmindste om Dagen), deres Farve som foreg., men ved den store Saftplet (Arrets frie Deel) have de et mere grønligt Udseende. 6-7. 4 .

Paa Enge òg mellem Krat, ikke sjelden, og i $S j a l l$. hyppigere end foreg.

Anm. Navnet $O$. bifolia L. indbefatter begge Arter og kan derfor ikke citeres som Synonym til nogen af dem. Det Samme gjælder om Navnet Platanthera bif. Rich., der alm. anvenrles paa den forste Art. For denne har jeg derfor beholdt det Navn, som af Drej. er tillagt den $\mathrm{i}$ den ovenfor citerere klare og udforlige Afhandling, $\mathrm{i}$ hvilken en nøiagtig Beskrivelse og Synonymik af de 2 Arter er givet. Det af G. Rchb. for P. chlorantha fo: etrukne Navn P. montana (efter Orchis montana Schmidt) er ikke heldigt, da denne Art netop hyppigst findes paa Enge, hiin paa Bakker.

\section{Coeloglossum. Poselarbe.}

1141. C. viride [Hartm. Skand. Fl. ed. I, p. 329] (Grøn P.) H. N. XV, 66 ; Satyrium L., H. 890 ; F. D. 77 ; Himantoglossum Drej. n. 858; Platanthera Lindl., Rchb. l. c. tab. 434.

Knollerne dybt haanddeelte; Bladene elliptiske eller lancetformede; Perigonbladene budte, sammenstødende til en Hjelm; Laben linieformet, tretandet, den midterste Tand meget kort.

4-10" høi. Blomsterne skident guulgrønne med rødligt Anstrøg. 6-7. 4 .

Paa hoie Enge og græsklædte Skrænter, sporadisk og sjelden: $\boldsymbol{J}$. Orsted (3), Brabrand (Viborg); $\boldsymbol{S} j$. en Klint ved Tudsenæs (H.), Charlottenlund (Kyll.); Falst, ved Stubbekjøbing (25)! Bornh. ved Rønne (20).

\section{Ilerminium. Pukkellabe.}

1142. Il. Ilonorchis [R. Br. I. c. p. 191] Grøn P.) Drej. n. 859 ; Rchb. I. c. tab. 415 ; H. N. XI, 66 ; Ophrys L., H. 895 ; F. D. 102.

Knollen kugleformet; Bladene lancetformede; Axet linieforme:; de indre Perigonblade ved Grunden svagt trelappede; Laben dybt trafliget, Fligene linieformede, den midterste størst. 
3-6" hoi. De nye Knoller (1-2) dannes i Spidsen af vandrette Udløbere, fjernede fra Moderknollen, og meget mindre end denne. Alm. 2 storre Blade nedenfor Midten og 1-2 mindre høiere oppe par Stæugelen. Blomsterne gronne. 6-7. 4.

I Enge og Moser: funden i alle danske Provindser, men sporadisk og ikke alm., forekommer sjeldnere paa Bakker (f. Ex. Møeus Klint!).

\section{Ophrys. Flueblonist.}

1143. 0. Illyodes L. (Bruunlæbet F.) H. 896; Drej. n. 860 ; F. D. 1398; H. N. XV, 67; O. muscifera Huds., Rchb. J. c. tab. 447 .

Knollerne 2, kugleformede; Bladene oval-lancetformede; Axet forlænget, fjernblomstret; de 3 ydre Perigonblade ovale, de 2 indre kortere, linieformet-traadformede; Luben trekløvet, med linieformede Sideflige og tolappet Midtflig.

1-1 $1 / 2^{\prime}$ høi. Læben mørk bruunrød, fløielshaaret, med Undtagelse af en glat, firekantet, blaangtig Plet i Midten. Blomsterne have i Form Lighed med Fluer (ligesom overhovedet Blomsten hos flere Arter af deune Familie ligner Insekter). Planten bliver sort ved Torring. 6. 4 .

I aabne Skove paa Kalkgrund: kun funden i Alindelillo Fredskov i Sjall., hvor den voxer i Mæugde.

\section{Epipogon. Knalabe.}

1144. E. aphyllum [Swartz Sv. bot. 512, Epipogium] (Bladløs K.) Rehb. l. c. tab. 468; H. N. XV, 68; Satyrium Epipogium L., H. 892; Limodorum Epipogium Sw., F. D. 1233 og 1399; Epipogium Gmelini Rich., Drej. n. 873 (Epigogium).

Rodstokken koralformigt grenet, ofte med lange, traadfine Udløbere; Stcengelen ved Leddene omgivet af korte Bladskeder uden Plade; forøvrigt bladløs; Klasen faablomstret; Blomsterne hængende, hvorved Sporen bliver opadvendt; de ydre og 2 indre Perigonblade linie-lancetformede, næsten ligelange; Laben trelappet, de to Sidelapper afrundede, den midterste spids, bjerteformet, rundtakket, med 2 Rækker takkede Vorter langs nedad hver Side; Frugtknuden næsten kugleformet. 
Planten af en lysbruun, gjennemsigtig Farve. Blomsterne have en stærk Lugt. Læben bleg med violette Pletter, de øvrige Perigonblade bleggule. 8 . $\psi$.

I skyggefulde Skove paa raadent Træ, meget sjelden: $\mathbf{S} \boldsymbol{j}$. Gyrstinge Skov (Albrecht); Meens Klint $(4,9,28)$ ! Synes jkke at komme til Udvikling $i$ alle Aar. lik

\section{Cephalanthera. Skovlilie.}

a. Blomsterue røde, Frugtknuden duunharet.

1145. C. rubra [Rich. Ann. Nus. IV, p. 60] (Rød S.) Drej. n. 864; Rclib. 1. c. tab. 464; Serapias L., H. 901; F. D. 345 ; Epipactis All., H. N. VIII, 66.

Bladene sværdformet-lancetformede; Dakbladene længere end Frugtknuden; alle Perigonbladene spidse; Labens yderste Led ægformet, tilspidset.

1' høi. Blomsterne rosenrøde, Læben hvidguul med ophøiede Striber. $\frac{6}{2}-7$. 4 .

I Skove par Kalkgrund, sjelden: Moens Storeklint alm.! $\boldsymbol{S}$ j. Alindelille Fredskov! Gyrstinge Slov (Albr.)! Braaby Vesterskov og Tuel Skov ved Sorø (7); J. Buderupholm (Beck); $\boldsymbol{S} l$. Graasteen (Freuchen).

b. Blomsterne hvide, Frugtknuden glat.

1146. C. grandiflora [Bab. Man. p. 296] (Hvidguul S.) H. N. XIV, 70; Serapias grandiflora L. (part.) Scop., H. 900; Epipactis pallens Sw., F.D. 1400; Ceplalanthera pallens Rich., Drej. n. 865 ; Lge. Haandb. 1 Udg. n. 1097; C. Lonchophyllum Rehb. 1. c. tab. 471 .

Bladene ellipiske eller ægformede; Dakbladene længere end Frugtknuden; alle Perigonbladene budte; Labens ydre Led æg-hjerteformet.

1. høi. Blomsterne hvide, Læben med gule, ophøiede Striber. $6-\frac{7}{1}$. ข.

I Skove paa Kalkgrund, sjelden: Mo ens Klint i Mængde! Sj. Kjøge Aas (9), Ledreborg Dyrehave (15), Alindelille Fredskov! Gyrstinge, Braaby Vesterskov (7). 7.

1147. C. ensifolia [Rich. l. c.] (Sværdbladet S.) Drej. n. 866 ; H. N. XIV, 69 ; Epipactis Sw., Serapias Sm., H. 900 ; S. grandiflora F. D. 506; Ceph. Xiphophyllum Rchb. l. c. tab. $4 \div 0$. 
Bladene sværdformet-laueetformede, de ovre linieformede; Dokbladene (undtagen de $1-2$ nederste) meget kortere end Frugtknuden; de ydre Perigonblade spidse, de indre budte; Labens yderste Led budt, af større Brede end Længde.

1 ' høi. Blomsterne sneelıvide med en guul Plet $\mathrm{i}$ Spidsen af Laben. $\frac{5}{2}-\frac{7}{\mathrm{~T}}$. 4 .

I Skove, temmelig sjelden: $\boldsymbol{B}$ or $\boldsymbol{n} \boldsymbol{h}$. Hollendergaarden i Olsker Sogn (Baagge), Almindingen (20), Almegaard ved Rønne (Hjorth); $\boldsymbol{S}$. Udby (Badstïb.), Valo, Kjøge Aas (9), Aldershvile, Gjels Skov, Dronninggaard (H.), Alindelille og Kastrup Skove (20)! Alsted Skov, Glums Osterskov! Dragerup Skov ved Holbæk (15); F. Hverringe (H.), Hallenskov ved Svendborg (11), Kogtved (E. C. Kragh)!

\section{Epipactis. Iluullabe.}

a. Læbens yderste Led budt, med en enkelt Pukkel ved Grunden; det inderste Led toviuget. Krybende Udlobere fra Rodstokken. (Arthrochilium Irm.)

1148. E. palustris [Crantz Stirp. "austr. 462] (Sump-H.) Drej. n. 870 ; Rchb. l. e. tab. 483; H. N. XIV, 68; Serapias Seop., H. 899 ; S. longifulia L.; Helleborine latifolia F. D. 267.

De nedre Blade bredt, de ovre smalt lineetformede; Blomsterne nikkende; de ydre Perigonblade æg-lancetformede; Labens ydre Led hjerteformet eller nyreformet, rundtakket; Frugtknuden duunhaaret.

${ }^{1 / 2}-1^{\prime}$ høi. De ydre Perigonblade blegbrune, de indre og Læebens inderste Led hvide med røde Striber, det ydre Led hvidt. 7. 4.

I vaade Enge og Moser, forekommer hist og her i alle danske Provindser.

b. Læbens ydre Led spidst, med en Pukkel paa hver Side forneden, det inderste Led uvinget. $\mathrm{Ud}]_{ø b}$ ere 0. (Euepipactis $[\mathrm{r} \mathrm{m}$.)

1149. E. latifolia [All. Fl. ped. 2, p. 152] (Bredbladet H.) Drej. n. 871 ; H. N. XIV, 67; Serapias L., H. 898; Epipaetis Helleborine 4 viridans Crantz, Rehb. 1. c. tab. 488. Bladene*) bredt ægformede, spidse, langs Nerverne fint

*) Da Bladene hos Arterne i denne Slægt ere meget forskjellige i Farve, Storrelse og indbyrdes Afstand paa forskjellig Hoide af 
duunhaaret-rue, tætsiddende (omtrent 2-3 Gange længere end Ledstykket ovenfor samme); Klasen tætblomstret, alsidig, Blomsterne under og efter Blomstringen udstaaende; Perigonbladene spidse, aabne, længere end den klæbrigt duunbaarede Frugtknude; Lobens yderste Led bredt hjerteformet, tilbagebøiet, dets Pukler jævne, i Gjennemsnit rundagtige.

1-2' høi. Stængelen opadtil klæbrig-haaret. Bladene mørkgrøune (de nedre omskedende uden Plade, de øvre æg-lancetformede). Blomsterne gronne, alm. indvendig skident violetrøde. $\frac{7}{2}-8$. $थ$.

1 Skove, red levende Hegn o. a. skyggefulde Steder: alm. paa Halve ens Østkyst, i det sydl. Fyen og paa $\boldsymbol{\theta}$ erne, sparsommere i $S j \in l l$.

1150. E. microphylla [Swartz Vet. Ac. Handl. 1800 p. 232] Serapias Ehrh.; S. latifolia F. D. 811; Epipactis Hellcborine 1, microphylla og 3 , varians (viridiflora Irm.) Relub. 1. c. tab. 484 og 487.

Bladene ægformede eller elliptiske, tilspidsede, glatte, fjerntsiddende (af Længde med eller 1/g-1 Gang længere end Ledstykket ovenfor); Klasen ensidig, faablomstret; Blomsterne efter Blomstringen vedhængende; Perigonbladene tilspidsede, lukkede, kortere end den glatte Frugthnude; Labens yderste Led æghjerteformet, tilspidset, dets Pukler i Gjennemsnit kantet-krusede.

$1-1^{1} 12^{\prime}$ høi. Hele Planten næsten glat. Foruden de angivne Mærlser let kjendelig fra foreg. ved spædere Væxt, smalere og friskgronne Blade. Blomsterne har jeg stedse fundet gronne eller med et svagt rødligt Anstrøg; Læben i Randen hvidagtig. $\frac{7}{2}--8$. 2 .

I skyggefulde og fugtige Lovskove: i Sjall. hist og her og i mange Egne hyppigere end foreg; $i$ de andre Provindser sparsommere: Mo ens Klinteskov (14); Falst. Gnldborg (19), Hanenov Skov (Koch); Loll. Sæbyholm o. fl. Sṫ. (19); F. Skaarup, Svendborg (19), Faaborg (12), Vissenberg! Bornh. i Almindingen ved Gamleborg! J. Rugtved i Vendsyssel (12), Ø. Velling, Randers (Drej. Herb.), Urup ved Horsens (2); $\boldsymbol{S} l$. Veesriis ved Rylskov (12).

1151. E atrorubens [Hoffm. Bot. Tasch. 1801, p. 182, under Serap. latif.] (Rødblomstret H.) Drej. n. 872; E. rubiginosa Gaud., Koch Syn. II, 801 ; E. media Fr. mant. 2, p. 54;

Stængelen, er her stedse, naar ikke andet udtrykkelig er næunt, Tale om de midterste og meest fuldkomment udviklede Blade. 
H. N. VIII, 65; E. Helleborine 2, rubiginosa Crtz., Rch 1. c. tab. 485 ; Serapias microphylla H. 899 ; S. latifoliaatrorubens H. II, 260 ; F. D. 1938.

Bladene æg-lancetformede eller elliptiske, tilspidsede, sværdformigt tilbagebøiede, langs Nerverne fintharet-rue, tætsiddende (3-5 Gange længere end Ledstykket ovenfor); Klasen ensidig, tætbloinstret; Blomsterne opret-udstaaende, efter Blomstringen nikkende; de ydre Perigonblade aabne, tilspidsede, duunharede; Lobens yderste Led omvendt-nyreformet, meget kort tilspidset, med tilbagebøiet Spids, dets Pukler i Gjennemsnit kantetkrusede; Frugtknuden klæbrig-duunhaaret.

$1 / 2-1$ ' høi. Rodtrævlerne tæthaarede. Stængelen foroven ligesom Blomsterstilkene klæbrigt haarede, Bladene morkt og noget bruunagtigt grønne. Blomsteme smukt $\circ g$ mørkt rosenrøde. $\frac{6}{2}-7$. 4 .

I Skove paa Kalkgrund: Moens Klint meget alm.! Saavidt mig bekjendt, det eneste Voxested i Danmark.

Anm. Fries anforer (l. c.) Afendringer ( $\boldsymbol{\alpha})$ med hride og $(\boldsymbol{\beta})$ med grønne Blomster. Disse ere mig ubekjendte; men skjøndt denue Art altsaa, ligesom de foreg., kan forekomme af forskjellig Farve, har dog enliver Art (idetmindste i vor Flora) en typisk Grundfarve, nemlig hos demne mork rosenrod, hos foreg. gron og hos næstforeg. skident violet, hvorfor Navnet atrorubens synes mig meget passende, og det er derfor her belioldt, saa meget mere som det er det ældste (om end som Varietetmavn). Flere Botanikere, og senest Irmisch (Limnæa XVI, 449; sml. Rchb. l. e. p. 141-44) have forenet den med E. latifolia. Jeg har i vor Flora stedse fundet dem vel adskilte, f. Ex. ogsaa ved forskjellig Blomstringstid, og jeg har derfor vedligeholdt Adskillelsen. Jeg anseer det for salare vanskeligt $\mathrm{og}$ ofte beroende paa Godtbefindende, at afgjore, livorvidt en Plante skal ansees for en Art eller en constant Underart, og troer det derfor rigtigere i en Localflora at adskille end at forene for meget. E. microphylla, som tidligere af Irmisch (l. c.) ligeledes forentes med E. latifolia, ansees nu af sanme Forf. (Beitr. z. Biol. u. Morphol. de Orcli.) for en god Art, adskilt foruden de den fremskyder lutter blomsterbærende, og ikke, som de 2 andre Arter, tillige blomsterløse Stangler.

\section{Listera. Fliglabe.}

1152. L. ovata [R. Br. l. c. p. 201] (Egbladet F.) Drej. n. 868; Rehb. l. c. tab. 479; Ophrys L., H. 893; F. D. 137 .

Rodstokken krybende, med talrige spredte Trævlerodder; Skaftet opret, med 2-3 Blauskeder ved Grunden og 1 Par 
modsatte, ovale eller ægformede Blade nedenfor Midten af Stængelen; Klasen forlænget, mangeblomstret; Perigonbladene hjælmformigt sammensluttende, de ydre ægformede, spidse, de 2 indre linieformede; Laben tokløvet (uden Sideflige), med udeelte, linieformede, næsten parallele Lapper.

Stængelen $1-1^{1 / \frac{1}{}} 2^{\prime} h \dot{\text { i }}$, foroven duunharet; Blomsterne grønne med guulgrøn Læbe, lugte svagt af Moskus. 5-6. 4.

I sumpige Skove, paa Enge mellem Krat, ikke sjelden.

1153. L. cordata [R. Br. l. c.] (Hjertebladet F.) Drej. n. 869 ; Rehb. l. c. tab. 480 ; Ophrys L., H. 894 ; F. D. 1278 .

Bladene hjerteformede, omtrent paa Midten af Stængelen; Klasen kort, faablomstret; Perigonbladene aabne, de 3 ydre xgformede, de 2 indre budte, linieformet-ovale; Laben trefliget med korte, opadboiede, linieformede Sidefige, den midterste Flig tokløvet med linieformede, divergerende Lapper; forøvrigt som foreg.

$4-6^{\prime \prime}$ høi. Stængelen glat. Blomsterne bruunlig-grønne eller kobberfarvede. 5-6. 4 .

I Skove, især Naaleskove, meget sjelden: $\boldsymbol{J}$. Stagsted Skov i Vendsyssel (Branth), Gjesing N. for Aarhus (Lynglyy); $S_{j}$. Hornbæks Plantage (17!), Frederiksberg Have (MI. Vahl, nu forsvunden).

\section{Neottia. Fuglerede.}

- 1154. N. Nidus avis [Rich. l. c.] (Guulbruun F.) Drej. n. 867 ; Rehb. I. c. tab. 473 ; Ophrys L., H. 892 ; F. D. 181.

Rodtravlerne talrige, korte, knippeformigt sammenslyngede; Stcengelen beklædt med brune Skeder uden Plade, forøvrigt bladløs; Klasen mangeblomstret; Blomsterstilkene kortere end Dækbladene (eller 0); Perigonbladene omvendt-ægformede, budte; Labens Flige budte, divergerende.

$1 / 2-1^{\prime}$ høi. Blomsterne, ligesom hele Planten, bleg-bruunagtige. 6-7. 2.

I skyggefulde Løvskove, funden i alle Provindser og ikke sjelden, men sporadisk.

Anm. Den almindelige Anskuelse, at denne Art skulde leve som Snylteplante paa Træernes Rødder, modsiges udtrykkelig af Irmisch (Beitr. z. Biol. u. MIorphol. der Orchideeu). 


\section{Corallorhiza. Koralrod.}

1155. C. virescens [Drej. i F. D. tab-2363] (Skov-K.) C. innata R. Br., Drej. n. 863 ; Rehb. J. c. tab. 490 ; Ophrys Corallorhiza L., H. 893 ; F. D. 451.

Rodstokken koralformigt grenet; Stcengelen jævn, omgivet af 3-4 Skeder uden Plade, forøvrigt bladlos; Klasen faablomstret; Laben aflang-firekantet, udrandet, forøvrigt udeelt med en budt Tand ved Grunden paa hver Side; Griffelstotten bueformigt indbøiet; Frugtknuden stribet.

2-6" høi. Blomsterne grønne, Læeben hvid med purpurrøde Punkter. $\frac{5}{2}-\frac{6}{2}$. 2 .

I Lovskove, meget sjelden: Moens Khinteskov, f. Ex. bag Maglevandsfaldet! $\boldsymbol{S} \boldsymbol{j}$. Krat ved Tibirke!

* 1156. C. ericetorum [Drej, i F. D. tab. z364] (Lyng-K.); Rchb. l. c. tab. 491.

Rodstokken koralformigt grenet; Stangelen stribet, omgivet af omtrent 3 omskedende Blade uden Plade, forøvrigt bladløs; Klasen faablomstret; Laben aflang, trelappet, den midterste Lap udrandet; Griffelstøtten opret, S-formigt bøiet; Frugtknuden rund. takket-vinget.

2-4" høi. Blomsterne guulgrønne med rodligt Anstrøg, Læben hvid med purpurrode Pletter. $\frac{5}{2}-\frac{6}{1}$. $\psi$.

Paa Lyngheder ved Kjøge Bugt $1 / 2$ Miil $N$. for Skillingskroen, mellem Callnna vulg. og Salix repens, i Miengdo 1838! Hornbæks Plantage (20). [ ⿷匚

Anm. Reichenbach (1. c. p. 160) anseer denne Plante for en ved Forskjellighed i Voxested frembragt Afart af foreg.

\section{Spiranthes. Skrueax.}

1157. S. autumnalis [Rich. l. e.] (Høst-S.) Drej. n. 861; Rchb. 1. c. tab. 474; Ophrys spiralis L., H. 894 ; F. D. 387.

Knollerne (alm. 2) langstrakt ægformede eller pæreformede, filtede, udgaaende fra en meget kort Rodstok med et Blomsterskaft og et sidestillet Bladknippe i Spidsen; Rodbladene æglaneetformede eller elliptiske; Stcongelbladene omskedende, uden eller med en kort, sylformet Plade; Axet ensidigt, spiralformigt snoet; Laben omvendt-ægformet, huul, rundtakket. 
$4-6^{\prime \prime}$ bøi. Stængelen foroven duunhaaret. Blomsterne gronlig. hvide. $9-10$. 4 .

Paa Græsmarker, sjelden: $\boldsymbol{S} l$. Aabenraa (Oeder), Langbjerg Bakker (Rafn); Sj. Steenved Overdrev ved Kjelsbjergene, en Høi ved Præst $\oint$ (H.); Falst. ved Nresgaard (Olufsen), mellem Øverup og Kraghave (14)! B ornh. ved Gaasebækken, nordre Teglværk, Baggeaaen, Terkels Mølle (Rafn), Rønne (8), mellem Rønne Castel og Pythuset (IIoff), Fynegaard, Kanegaard og Buskegaard i Knudsker Sogu (Hjorth). 虾

\section{Malaxis. Iljertelabe.}

1158. II. paludosa [Swartz Vet. ac. handl. 1800 p. 235] (Sump-H.) H. 897; Drej. n. 874 ; Rehb. I. c. 494 ; H. N. XIV, 71; Ophrys L., F. D. 1234.

Rodstokken forlæuget, næsten lodret, bærende 2 løgformede Knoller, den ældre forneden, beklædt med visnede Blade, den yngre ovenfor Jorden, dannet af $2-3$ Bladskeder og $2-3$ xgformede Blade; indenfor det øvre af disse en løgformigt opsvulmet Axedeel med et femkantet Skaft i Spidsen; Axet tætblomstret; de ydre Perigonblade ægformede, spidse; Laben æghjerteformet, spids, heelrandet, halvt saa lang som de ydre og af Længde med de indre (oval-linieformede) Perigonblade.

1-3" høi. Blomsterne grønne, meget smaae. 7-8. 4.

I Tørv- og Hedemoser mellem Sphagnum, temmelig sjelden: J. Klitterne i Thy, Viborg, F'nsing Vasehuus, $\emptyset$. Velling (7), V. Velling (3), Riis Mose mellem Horsens og Skanderborg (13), O. Nykirke! Nebbeguard! Søviggaard N. V. for Varde (30), Ribe (6); Sl. Rødding (7), Flensborg, 'Tolkvade So ved Slesvig (16), Eidersted (F. Müll.); $S j$. Dybendal ved Munkebjergby (Lund), Aamosen (7), Tepri og Lyngby Moser (H.)! Kjgge Aas (9), Holmegaardsmosen! Loll. Birket (9); Falst. Lidstrup Lyng (Koch), Horreby Lyng!

\section{Sturmia. Mygblomst.}

1159. S. Loeselii [Rebb. ic. crit. $\mathrm{X}$, tab. 1286] (Tr. kantet M.) Rehb. I. c. tab. 492; Malaxis Sw., H. 897; Drej. n. 875 ; H. N. VI, 65 ; Ophrys Loeselii L.; O. paludosa F. D. 877 .

Rodstokken kort, vandret, nedsender haarede Rodtrævler og bærer 2 Knopper ved Siden af hinanden: den xeldre knolleformigt opsvulmet, omgivet af visnede Blade (og ofte med det forrige Aars 
Blomsterskaft i Spidsen), den yngre ved Siden af hiin, med 3 Bladskeder forneden og 2 oval-laneetformede Blade foroven; indenfor det øvre Blad en svagt opsvulmet Axedeel med et trekantet Skaft i Spidsen; Axet faablomstret; de ydre Perigonblade linieformede, bolgede eller snoede, de indre traadformede; Lœben omvendt-ægformet, budt, heel eller 3-5-tandet, rundtakket, meget bredere end de øvrige Perigonblade.

3--6" hoi. Bladene glindsende, tilligemed Blomsterne guulgronne. Den ældre Knol alm. ribbet af de visnede Bladskeders Karbundter. Stundom findes endnu Rester af en tredie Knol (fra det næstforeg. Aar) tilbage. 6-7. 4 .

I dybe Moser og Hængedynd mellem Mosser, sporadisk og ikke alm.: $\boldsymbol{S}$. Mose mellem Strandmgllen og Rarvaddam! Lyngby Mose (H.), Lundehunsmosen! Bidstrupgaards Nose! Værebro Moller (14), Bromme (Lund), Flommen ved Soro! Loll. Birket 9), F. Birkende, Hofmansgave (II.); J. Hillerslev Eng i Thy (Dr.), Gjellerup Eng ved Brabrand S $\$$ (2); Sl. Pulverholz ved Slesvig (16).

\section{II exandria.}

\section{Aristolochia. Slangerod.}

1160. A. Clematitis L. (Hjertebladet S.) IH. 902; F. D. 1235 ; Rebb. ic. Al. g. XII, tab. 1340.

Bladene stilkede, hjerteformede, heelrandede, med fiint forgrenet Aarenæt; Blomsterne knippeformigt samlede i Bladhjørnerne; Blomsterdakket kræmmerhuusformet, ved Grunden kugleformigt opsvulmet.

1-2' høi. Blomsterne gule. 7-8. 2.

Ved Gjærder omkring Byer, sjelden, og formodenlig i ældre Tider indført: J. Aalborg (H.), Viborg (Dr.), Mariager (7), Orsted, Veile (H.), Kolding! Kirkegaarden ved Ribe (6); Falst. Nykjøbing Slots Ruiner $(9) ; \mathbf{S} j$. Vemmetofte Dyrehave forvildet (Visby). 


\section{$21^{\text {de }}$ Klasse. Monoecia (Enbo).}

\section{Orden. Monandria (Enhannede).}

A. Frugterne bæragtige (Urteagtige Væxter).

1. Arum L. Blomsterne samlede paa en i Spidsen nøgen Kolbe med $\hat{o}$ Blomsterne ovenfor og adskilte fra $q$ Blomsterne; Kolben omgivet af et sammenrullet Hylster. (N. F. Aroide $æ$ ).

Calla. Kolben heelt beklæedt af Blomster, Hylsteret fladt udbredt $(6,1)$.

B. Frugterne tørre (Nødder eller. Hindefrugter). Urteagtige Væxter.

a. 1 Griffel for hver Frugtknude.

2. Zostéra L. $\delta$ og $q$ Blomsterne i 2 Rækker paa den ydre Side af en linieformet Kolbe, omgivne af et fælles, i Spidsen bladagtigt Hylster; 0 Blomsterne bestaae af en enkelt Stovdrager, $q$ af en enkelt Frugtknude med forlænget Griffel og z Ar. (N. F. Fluviales, a.)

3. Najas L. Blomsterne enlige i Bladbjørnerne, bver omgivet af et sambladet, tandet eller fliget Hylster, $\hat{\delta}$ : enkelt Blomsterdækike, 1 firerummet Støvknap; $q$ : Griffelen 0 eller meget kort, med utydeligt tolappet Ar. (N. F. Fluviales, b.)

4. Zanuichéllia L. Begge Kjøn omgivne af et fælles Hylster; $\widehat{\delta}$ : uden Blomsterdække, 1 Støvdrager; 우: Blomsterdækket klokkeformet; 3-6 Frugtknuder med tydelig Griffel og skjoldformet Ar. (N. F. Fluviales, c).

Lemna $(21,2)$.

$$
\text { b. } 2-3 \text { Grifler (eller } \mathrm{Ar} \text { ). }
$$

5. Callítriche L. Blomsterne i Bladhjørnerne, omgivne af 2 hindeagtige Dækblade; 2 lange, traadformede Ar; Frugten firefrøet, nopspringende eller tilsidst deelt i 4 Smaafrugter. (Vandplante med modsatte Blade. N. F. Callitrichineæ). 
6. Euphórbia L. Blomsterne (i Greenvinklerne) i en Blomsterkop med et sambladet, 3-10-Jappet Hylster (Kopdække); $\hat{o}$ Blomsterne flere $\mathrm{i}$ en Kreds, hver bestaaende af 1 nøgen Støvdrager tilleddet til en Blomsterstilk og omgivet af et Dækblad; 9 Blomsten enlig i Midten, stilket, nøgen; 3 Grifler; tredelelig Spaltefrugt (Springfrugt) med toklappede, enfrøede Smaafrugter. (Urter med Mrlkesaft, spredte eller modsatte Blade. N. F. Euphorbiaceæ.)

C. Frøene nøgne i aabne Frugtblade (Træagtige Væxter med naaleformede, spredte eller (paa en forkortet Green) knippestillede Blade; Blomster i Rakler: ô Raklen omgivet af skjælformede Dækblade, indsluttende talrige enhannede, nøgne Blomster; $q$ Raklen med talrige, spiralstillede, affaldende Dxkblade, $0 \mathrm{~g}$ indenfor hvert af disse 1 tilsidst træ- eller læderagtigt udvoxende Frugtblad (Kogleskjæl), som i Forening danne en Kogle). (T-10. N. F. Coniferæ, Abielineæ.)

a. ô Raklen grenet.

7. Pinus L. (part.) Kogles' ;ællene i Spidsen tykkere og forsynede med et kantet, træagtigt Skjold; Bladene 2-5 knippeformigt samlede, vedblivende.

b. Tokakndeelt.

8. Ábies Link. Koglerne oprette, Kogleskjællene læderagtige, mod Spidsen tyndere, alm. kortere end de tilspidsede Drkblade og tilligemed disse affaldende ved Modenheden; Bladene spredte, stilkede, fladtrykte, vedblivende.

9. Pícea Link. Koglerne hængende; Dækbladene tidligt henvisnende, kortere end de vedblivende, jævne, læderagtige, mod Spidsen tynçere Kogleskjæl; Bladene spredte, siddende, firekantede, veỏblivende.

10. Larix DC. Kogleskjællene som hos foreg., fra Begyndelsen kortere end de tidligt henvisnende Dxkblade; Bladene talrige, knippestillede, slappe og fade, affaldende. 


\section{Orden. Diandria (Tohannede).}

11. Lemna L. Bladløse, svømmende Planter; Rodtrævlerne med en Rodhætte $\mathrm{i}$ Spidsen; $\hat{\sigma}$ og $\$$ Blomster omgivne af et fælles hindeagtigt Hylster; Blomsterdække $0 ; 1-2$ Støvdragere; 1 Frugtknude (N. F. Lemnaceæ.)

\section{Orden. Triandria (Trehannede).}

a. Bladene parallelnervede.

12. Typha L. Blomsterne tæat samlede i valseformede Ax (eller Kolber), tิ ovenfor $\nmid$ Axet; Blomsterne omgivne af flere Børster; Støvtraadene sammenvoxne; Frugten stilket, nødagtig (med hindeagtigt Frøgjemme); Arret udeclt. (N. F. Ту p h aceæ.)

13. Spargánium L. Blomsterne tæt samlede i kugleformede Hoveder ( $\widehat{\sigma}$ ovenfor $\$$ ); Blomsterne omgivne af $3-5$ Skjæl; Støvtraadene frie; Frugten siddende, steenfrugtagtig (med svampagtigt Mellemlag); Arret udeelt. (N. F. Typhace æ.)

14. Carex L. Blomsterne i ellkelte eller sammensatte Ax, hver Blomst omgivet af et Dækskjæl; $\{$ : Blomsterdækket sambladet, krukkeformet, omgivende den siddende, nødagtige Frugt; $2-3 \mathrm{Ar} ; \hat{o}$ : Blomsterdække 0; Støvtraadene frie (N. F. Cyperaceæ, b.)

b. Bladene fjernervede.

15. Amarántus L. Blomsterdækket enkelt, 3-5-deelt; 3 Ar; Frugten enfrøet, uopspringende*) Hindefrugt; Frøets Kim kredsformigt ongivende Frøhviden. (N. F. A marantace æ.)

*) Hos de fleste udenlandske Arter i denne Slægt er Hindefrugten trærsopspringende; mange have 5 Støvdragere. 


\section{Orden. Tetrandria (Firehannede).}

a. Blomsterdxkket dobbelt.

16. Littorélla Berg. $\hat{o}$ : Blomsterne stilkede; Bægeret dybt firedeelt; Kronen firefliget; $q$ : Blomsterne stilkløse; Brgeret trebladet; Kronen sambladet, hindeagtig, med svagt firetandet Krave; Griffelen forlænget, udeelt; Frugten nødagtig. (N. F. Piantagineæ.)

b. Blomsterdækket enkelt eller 0 .

aa. Urteagtige Vaxter. Arret penselformet. (N. F. Urticacex.)

17. Urtica L. $\hat{\delta}:$ Blomsterdækket firedeelt; $q$ : Blomsterdxkket firedeelt i 2 ydre, mindre. og 2 indre, storre Flige; Frugten nodagtig, omgivet af det vedblivende, hindeagtige Blomsterdække. (Haarene indeholde en brændende Vædske.)

Parietaria. 하 og $f$ Blomsterdækket firedeelt, o firetandet, klokkeformet. (Haarene ikke brændende). $(4,1)$.

\section{bb. Traagtige Vaxter. 2 traadformede $A r$.}

18. Alnus Tournef. Blomsterne af begge Kjon i Rakler, som ere tilsyne om Efteraaret. $\hat{o}$ : Rakleskjællene udeelte, med 4-5 Biskjæl omgivende 3 Blomster; Blomsterdxkket enkelt, firefliget; $q$ : Rakleskjællene udeelte, toblomstrede; 1 Frugtknude med $2 \mathrm{Ar}$; Frugten Nød, ongivet af de vedblivende, tilsidst træagtige Rakleskjæl. (Knopperne stilkede, omgivne af et enkelt Kuopskjæl. N. F. B etulineæ.)

19. Bétula L. (part.) ỡ Raklerne synlige om Efteraaret; Rakleskjællene skjoldformede med 2 Sidelapper og indsluttende 2-3 Biskjæl: Støvdragerne $8-12$ (॰: 4 for hvert Biskjæl); $q$ Raklerne om Efteraaret indsluttede i Knoppen; Skjallene trelappede, 2-3-blomstrede, ved Frugtmodningen affaldende; Vingefrugt. (Knopskjællene taglagte. N. F. Betuline æ.)

† Morus L. Blomsterne af begge Kjøn i Ax; 今ే: Blomsterdækket dybt firedeelt; $\$$ : Blomsterdakket firebladet, med parviis modsatte Perigonblade (de ydre størst); Frugten en Nød, 
omgivet af det vedblivende og tilsidst kjødfulde Blomsterdække, hvorved Frugtknuden faaer Udseende af et Bær. (N. F. M oreæ.)

Corylus $(21,6)$.

\section{Orden. Pentandria (Femhannede).}

a. Blomsterdækket enkelt. Frugten nødagtig.

20. Átriplex L. ơ og $\Varangle:$ Blomsterdækket 3-5-deelt; 3-5 Støvdragere; $q$ : Blomsterdækket tobladet eller todeelt, fladtrykt, omsluttende (ikke sammenvoxet med) Frugten; 2 Grifler; Frugten uopspringende Hindefrugt, Frøets Skal hornagtig. (N. F. Salsolaceæ).

21. Hảlymus Wallr. ㅇ: Blomsterdækket fladtrykt, i hele sin Længde sammenvoxet, omsluttende Frugten og foroven udløbende i 2 hornagtige Flige; Frøets Skal hindeagtig; forøvrigt som foreg. (N. F. Salsola ceæ).

Quercus. Frugten Nød, omgivet af en Skaal $(21,6)$.

Xanthium. Støvtraadene sammenvoxne; Frugten Skalfrugt (21, 7).

b. Blomsterdxkket dobbelt; Frugten ${ }^{\circ}$ Br.

Bryonia (21, 8).

\section{Orden. Hex-Polyandria (Sex-Mangehannede).}

a. B lomsterdækket dobbelt.

22. Sagittária L. Bæger og Krone trebladede; $\widetilde{\sigma}$ : Støvdragerne $\infty$; $ᄋ$ : Frugtknuderne $\infty$, oversædige paa en kugleformet Frugtbund; Griffelen kort ; Arret haaret; enfrøede, nødagtige Fleerfoldfrugter. (N. F. Alismaceæ, b.)

23. Ilyriophýllum L. $\widehat{\delta}$ : Bægeret firedeelt; Kronen firebladet, affaldende; Støvdragerne 8; $q$ : Bageret firetanảet, affaldende; Krone 0 eller firebladet, affaldende; 4 siddende Ar; Frugten undersædig, firedelelig Spaltefrugt. (N. F. Halorrha g e $æ$.) 
b. Blomsterdækket enkelt (eller 0 ).

\section{aa. Urteagtige Vaxter.}

24. Ceratophýllum L. $\lesssim$ og $\$$ : Blomsterdækket uregelm. 8-12-fliget med tandede Flige; $\widehat{o}:$ Støvknapperne omtr. 12, siddende, i Spidsen hornede; $\nmid$ : 1 Frugtknude med sylformet Griffel; Frugt fri, enfrøet Nød (Vandplante med Blomsterue i Bladhjornerne). (N. F. Cer a tophylleæ.)

25. Potérium L. Bægeret regelm. firedeelt, ved Grunden omgivet af $3-4$ affaldende Drkblade; Krone 0 ; $\hat{0}$ : Støvdragerne $20-30$, med lange, fine Støvtraade; $9: 2-3$ Frugtknuder med traadformet Griffel og penselformet Ar; Frugten 2-3-rummet Skalfrugt o: 2-3 Nødder tæt omgivne af Bægerrøret (Vedvarende Urt med Blomster i Hoved, foroven $q$, forneden $\widehat{\sigma}$, i Midten ofte $\not{\zeta}$ Blomster). (N. F. Ros a ee 2, a.)

$\left.\begin{array}{l}\text { Arum } \\ \text { Calla }\end{array}\right\}$ Blomster i Kolbe, omgivet af et Hylster $(21,1)$.

b6. Traagtige Vaxter med Blomsterne i Rakler (25-28.

$$
\text { N. F. Cupulifer } \alpha \text { ). }
$$

ж. Ar eller Grifler 2, Støvdragerne befæstede paa Rakleskjællene, med en Haardnsk i Spidsen af Støvknappen; Skaalen bladagtig, dannet af et fliget Drekblad eller Hylster; Frugtknuden torummet, med eet $\mathrm{Eg}$ i hvert Rum.

26. Carpínus L. Begge Kjon i Rakler. ઠૈ: Støvdragere omtrent 12, befæstede ved Grunden af de udeelte Rakleskjæ]; Biskjæl 0; $q$ : Blomsterue parviis, omgivne af 2 hele, affaldende Dækblade; Frugt uødagtig, beklxdt med det efter Afbiomstringen tilvoxende, tandede, oversædige Blomsterdække og omgivet af et bladagtigt og vedblivende, tilsidst trefliget Hylster.

27. Córylus L. $\widehat{\sigma}$ : Blomsterne i Rakler; 1 udeelt Rakleskjæl; Støvdragerue omtrent 8, befæstede paa Midten af de tofligede Biskjæl; $q$ : Blomsterne i Hoved; Frugten Nod, beklædt af det vedblivende, svagt tandede, oversædige Blomsterdække og omgivet af et bladagtigt fliget Hylster.

Betula. Vingefrugt $(21,4)$.

Hnandb, i den danske Flora. 
B. Ar eller Grifler 3-7, Støvdragerne befæstede i et Blomsterdække, med glatte Størknapper; Frugtkuuden trerummet, med 2 Ag $\mathrm{i}$ hvert Rum; Frugten heelt eller tildeels omgiret af flere med den udvidede Blomsteraxe sammenvoxne Dækblade i Form af en Skaal.

28. Vagus L. đ̊: Raklen kugleformet, langstilket, hængende; Blomsterdækket klokkeformet, 8-10 Støvdragere; ㅇ: Skaalen firefliget, toblomstret; Blomsterdækket oversædigt, 3-5 fliget: 3 Grifler, Frugterne trekantede Nodder, heelt omgivne af Skaalen, som er beklæxdt med traadformede Fryndser.

† Castánea Tournef. đ̃: Raklen forlænget, kortstilket, opret; Blomsterdxkket hjulformet; $10-15$ Stovdragere; $q$ : Skaalen firefliget, treblomstret; Blumsterdækket oversædigt, 5-7-lappet; 5-7 Grifler; Frugterne ægformede Nødder, heelt omgivne af den tæet piggede Skaal.

29. Quercus L. శే: Raklen forlænget, hængende; Blomsterdxlket hjulformet; $8-10$ Støvdragere; + : Skaalen udeelt, enblomstret; Blomsterdækket oversædigt, svagt tandet; 3 sid. dende Ar; Frugten en oval, trind Nod, ved Grunden omgivet af den kopformede, med taglagte Skjæl beklædte Skaal.

$\gamma$. Ar 2; Stovdragerne befæstede til et Blomsterdække; Frugteme uden skaalformede Drekblade.

† Juglans I. Â: Blomsterne i Rakler; Blomsterdækket 2-6 fliget; + : Blomsterne $2-3$ sanmen; Blomsterdækket firedeelt, oversædigt; Frugten Steenfrugt. (N. F. Juglan$\mathrm{d} e x$.)

\section{Orden. (Monadelphia (Enknippede).}

30. Xánthinm L. đ̂: Flere Blomster omginne af et mangebladet Svab; Blomsterdækket sambladet, femtandet; 5 Støvdragere; $+: 2$ blomster omgivne af et dobbelt Srøb: det ydre dybt 5-s deelt, det indre $\mathrm{i}$ Spidsen tohornet og omgivende de modnende Skalfrugter; Blomsterdækket oversædigt, dannet af en ineget svag, skraa Rand, som undertiden paa den ene Side lober ud $\mathrm{i}$ en tradformet Flig; 2 Ar. (N. F. A mbrosiex). 


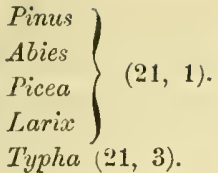

\section{Orden. Polyadelplia (Fleerlinippede).}

31. Bryónia L. Bæger og Krone femfligede; f⿱: Støvdragere 5, sammenvoxne i 3 Bundier (2. 2. 1.); \&: Frugten et 3-6-frøet, undersædigt Bar. (Vedvarende Ur't med klattrende Stængel. N. F. Cucurbitace ).

\section{Monandria.}

1. Arum.

1161. A. maculatum L. (Dansk Ingefær). H. 960 ; Drej. n. 949 ; F. D. 505 ; Rchb. ic. fl. germ. VII, fig. 8 .

Rodstokken knolltt; Bladene piilformede; Hylsteret længere end den i spidsen nogne, kolleformede, violetbrune, ovenfor Støvdragerne med snoede Traade beklædte Kolbe.

Bladene hos os alm. uplettede. Bær høirode. 5-6 (fr. 7). ข.

I fugtige Skove: J. Aalborg (H.), Kalø (13), Aarhus, Palsgaard (H.), derfra mod S. ikke sjelden paa Halvgens Ostkyst, Oerne fial Als til Moen, det sydl. Fyen og sydsjæll.; i Nordsjælland sparsom: Odsheried (H), Agersvold (16), Dronninggaard (14), Kuliavn bag Vesterbro, Rosenborg Have, Kastelsvolden (H.); Bornh. ved St Jons Kapel (Hjorth), Helligdommen i Røe Sogn (Hoff), Slammebjergs Skov ved $\operatorname{Nex}(20)$. ॠ

\section{Zostera. Baendeltang.}

1162. Z. marina L. (Hav-B.) H. 6 ; Drej. n. 877; F. 1). 15 ; Rehb. ic. fl. germ. VII, fig. 4; H. N. XV, 83.

Bladene linieformele, (omtrent $2^{\prime \prime}$ brede), 3-5-nervede; Kolbens Stilk opadtil bredere; Frugterne stribede paalangs.

Bladene meget lange, overalt ligebrede, olivengronne, $6 \rightarrow 8$. 4 . 
$\beta$, angustifolia F. D. 1501 ; Rchb. I. c. fig. 3, H. N. VI, 70; Z. nana Roth (efter Cit. af F. D. og Caulin.). Rodstokken tyndere, Bladene smalere, omtrent $1^{\text {"' }}$ brede, trenervede, med utydelige Sidenerver; Kolbestilken længere, forneden meget tynd.

Paa Sandbund i Havet overalt ved de danske Kyster, især paa dybere Vand. $\beta$, med Hovedarten, men sjeldnere.

Anm. Formen $\beta$, maa nøiere unders $\varnothing$ ges; efter flere Forfatteres Mening er den en egen Art (cf. Durieu de Maisonneuve, not. pl. de Girond. p. 77).

1163. Z. minor [Nolt. i Rehb. l. c. VII, p. 2 t. 2] (Dværg-B.) Z. Noltei H. II, 107; F. D. 2041; Z. nana Koch Syn. II, 783 (ikke Roth); H. N. XI, 70.

Bladene smalt linieformede (neppe $1^{\prime \prime}$ brede), ennervede; Kolbens Stilk traadformet, ligebred overalt; Frugterne jævne.

Meget lavere og finere, med kortere Blade end foreg. 7-8. 4 .

Paa Sandbund i Salt- og Brakvand, især i Fjordene hvor Vandet ikke er dybt, og fornemlig $i$ de vestligere Egne: J. Liimfjorden ved Aalborg (Dr.), Løgstør, Sebbersund (8)! mellem Fanø og Jylland (16), Føhr (20), Rømø, Sylt, Amrom (N.), Eidermundingen (F. Mlüll.); Aargsund (8) og derfra mod S. i alle Fjordene paa Slesvigs Østkyst; F. Falsled Bugt (15), Skaarupgr (19)! Loll. ved Ravnsby (19); F alst. Guldborgsund N. for Klodskov (14).

\section{Najas. Najade.}

1164. N. marina L. (Kufrøet N.) H. II, 279; F. D. 2121; N. major Roth, Koch Syn. II, 783; N. monosperma Willd., H. $955 \mathrm{og}$ (Caulinia fragilis) 911.

Bladene krandsstillede $\left({ }^{1} / 3\right)$, linieformede, skarpt tandede, omskedende, med heelrandet Skede; Frugterne punkterede.

Bladene frisk grønne, Skederne rødlige. 8-9. $\odot$.

I Salt- og Brakvand, sjelden og kun bekjendt fra Slesvig: Noret ved Nordskov i Angel $(16,28)$ ! i Slien 1 Miil $\varnothing$. for Slesvig (Frolich, Suhr). |*

\section{Zannichellia. Vandkrands.}

1165. Z. palustris L. (Kjær-V.) H. 911; Fr. Nant. I, 16 ; F. D. 67 ; H. N. XV, 76. 
Bladene linie-traadformede, krandsstillede $(1 / 3) ;$ Frugterne $3-5$, siddende eller med en fælles, kort Stilk, tilspidsede i en vedblivende Griffel af lidet over Frugtens balve Længde.

7-9. ข. Var.

$\alpha$, repens (Boenn.) Rehb. VII, fig. 20. Stængelen ved Ledene rodslaaende.

$\beta$, major (Bocnn.) Rehb. l. c. fig. 24. Planten større, med opret Stængel og bredere Blade.

I Færsk-og Saltrand, ikke sjelden: $\alpha$, især i Damme og Vandhuller med grundt Vand.

* 1166. Z. pedicellata [Fr. Mant. I, 18; 3, 135] (Stilkfrugtet V.) F. D. 2610 ; H. N. III, 66; Z. pedunculata Rehb. l. c. fig. 21 .

Frugterne 3-4, tydeligt stilkede med falles Stilk og særegne Smaastille; Griffelen fiin, af Frugtens Længde; forøvrigt som foreg.

Alm. spædere end foreg., men forekommer ogsaa $i$ en storre Form. Frngterne have en hindeagtig, rundbugtet, tilsidst tandet $\mathrm{Kj} \emptyset \mathrm{l}$ paa Rygsømmen og stundom tillige paa Bugsømmen (i sidste Tilfælde Z. gibberosa Relıb. VII, 22). 7-8. 4 .

Paa lignende Steder som foreg. og ligesaa hyppig. \$

* 1167. Z. polyearpa [Nolte Nov. fl. Hols. p. 75] (Mangefrugtet V.) Fr. Nant. I, 17; F. D. 2609; Rchb. l. c. fig. 23; H. N. VI, 69 (Z. palustris) og X, 66 .

Frugterne 4-6, siddende, halvmaaneformede, ved Grunden budte; Griffelen kort, ointrent $1 / 4$ af Frugtens Læugde.

7-8. 4.

$\beta$, tenuissima Fr. Spædere, med omtrent 4 Frugter.

Voxested som de foreg., men sjeldnere: L oll. Steensgaard; Fatst. mellem Stubbekjøbing og Liselund (19)! Stesvig (N.)? $\boldsymbol{\beta}, \boldsymbol{J}$. Havnen ved Sæby (12); $\boldsymbol{j}$. Esrom $\mathrm{S} \emptyset$ ved Fredensborg (Heiberg), Hvedstrup (8), Gadekjær i Himmel $\omega \mathrm{v}$ pr. Roeskilde (15)! Orsl $\varrho \mathrm{v}$ o. H. St. ved Skjelskør (Nielsen)! L oll. Bollesminde (19). [*

Anm. De her beskrevne Arter af Zannichellia hore efter afd. J. Gays Undersøgelse alle til een Art, $Z$. brachystemon Gay, fra hvilken den i det sydlige og vestlige Europa forekoumende Z. macrostemon Gay adskilles ved meget lange Støvtraade, større og frerummedo Støvknapper. 


\section{Callitriche. Vandstjerne.}

a. Pseudocallitriche Hegelmaier (monogr. Callitr.) Hele Planten nedsænkt under Vandet. Alle Bladkrandsene adskilte; Drkblade 0; Smaafrugterne adskilte ved et dybt Indsnit og en smal Skillevæg.

1168. C. autumnalis L. (Høst-V.) H. 910 ; Drej. n. 882 ; F. D. 2120 ; Rehb. V, fig. 4749 ; H. N. IV, 83.

Alle Bladene ennervede, linieformede, med bredere Basis, i Spidsen udrandede; Ledstykkerne korte; Arrene meget lange, tilbagebøiede, tidligt affaldende; Frugternes Kjøl hindeagtigt vinget.

Bladene af en reen og mork grøn Farve. 7-9. 4.

I Soer og Aaer hist og her, ikke alm., f. Ex. Sj. Aaen ved Raavaddam! Frederilisdals Møllebæe (Dr.), Emdrup Sø, Ladegaardsaaen, Damhuussøen (9), Jonstrup (14), Flommen red Sorø (12), Ondløse! $\boldsymbol{F}$. Egense ver Hofmansgave (4); J. Toihushaven ved Randers (7), Haraldslund! $S l$. Jels $\mathrm{S} \emptyset(\mathbf{1 6})$.

b. Eucallitriche Hegelm. 1. c. De øvre Bladkrandse samlede til en paa Vandets Overflade svømmende Rosette*); Blomsterne (alm.) omgivne af D ækblade; et svagt Indsnit og en bred Skillevag mellem Smaa-

$$
\text { frugterne (C. verna L.). }
$$

1169. C. verna [Kützing i Linnæa VIl, p. 175] (Smaafrngtet V.) Drej. n. 881; Rchb. l. c. fig. 4746.

De nedre Blade linieformede, med smalere Basis, de pvre omvendt-ægformede, trenervede; Dakbladene svagt bøiede; Arrene oprette, affaldende ved Frugtmodningen; Frugterne omvendt-hjerteformede eller ovale, udrandede (Længden større end Breden), Smaafrugterne hvælvede, med skarp, meget smalvinget $K j \phi l$.

*) De til denne Afdeling hørende Arter ere typisk Vandplanter med langstrakte Stxengler og (med Undtagelse af den endestillede Bladrosette) nedsænkte Blade. Paa fugtig Jordbund, som i Sommerens Løb udtørres, forekomme imidlertid af alle Arterne Former med korte Ledstykker og krybende Strengler, som i Udseende ere yderst forskjellige fra Hovedformerne, men dog have de væsenlige Characterer tilfælles med disse. 
Bladeue (ligesom hos de folg.) lysere og mere mat gronne end hos foreg. Forekonmer undertiden i flydende Vand med lntter linieformede, i Spidsen indtrykte eller ndrandede Blade (C. verna tenuifolia H. 910). Paa Steder, lyvor Planten knu af og til oversvommes af Vandet, bliver den lavere af Vaxt, meget grenet, rodslaaende $o g$. med mindre Blade (var. minima Hopp. og caspitosa Schultz) Rehb. 1. c.

I Færskvand (Bække, Grøfter og Moser), hist og lier.

1170. C. hamulata [Kïtz. i Kooch Syn. ed. 1, p. 246] (Bredfrugtet V.) Rehb. 1. c. fig. 4749 ; H. N. XV, 64.

Alle Bladene smalere ved Grunden, de nedre linieformede, de ovre omvendt-ægformede; Dokbladene smale, seglkrummede; Arrene meget lange, iilbageboiede, tilligt affaldende; Frugterne kredsrund-uyreformede, i Spidsen svagt udrandede (Breden større end Længden), Smaafrugterne fladtrykte, med skarp, næsten retvinklet, smalvinget $\mathrm{Kj}$ jol.

Paa lignende Steder som foreg.: Christiansø (Didr.)! S $l$. Husum Mølledam (F. Müll.). Andre Voxesteder ere mig ikke bekjendte, men den vil sikkert, ved ngiere at eftersgges, findes list $\mathrm{og}$ her.

1171. C. stagnalis [Seop. Fl. carn. 2, 151] (Storfrugtet V.) Drej. n. 879 ; Rehb. 1. c. fig. 4747 ; H. N. XV, 63; C. verua repens H. 910 ; F. D. 129 og 1741 (C. verna).

Alle Bladene omverdt-ægformede, 3-5-nervede; Datbladene brede, svagt krummede, sammenstødende mod Spidsen; Arrene vedblivende, opret-aabne, tilsidst tilbageboiede; Frugterne nasten kredsrunde (Længde og Brede omtrent lige), i Spidsen udrandede, Smaafrugterne fladtrykte eller hvalvede, med skarp, bredvinget Kjøl.

\section{$5-8$. 4.}

I Kjer og Grofter, paa dyudfulde, oversvømmede Steder. Synes at være deu liyppigste Art i Danmark.

Anm. 1. De 3 sidstnrevnte Arter, som efter Vandets forskjellige Dybde og orrige Beskaffenhed fremtrade under sata yderst forskjellige Former, fortjene noiere Undersgelse saavel i Henseende til Characteremes Bestandighed som til deres Forckomst og Uibredelse i vor Flora. De enkelte Voxesteder, som jeg for liver af disse med nogenlunde Sikkerhed kunde angive, har jeg ikke anfort, da jeg formoder, at de alle ved nermere Undersogelse ville hefindes at vare udbredte over den hele Flora. 
Anme. 2. C. platycarpa Küt\%. (Rchb. I. c. fig. 4748, Lge Haandb. 2 Udg. S. 594) er eiter Hegelmaier (1. c. p. 59) kun en Form af C. stagnalis med de nedsænkte Blade smalere og Frugterne mere flade og derved næsten parallele. Paa Steder, som kun til visse Tider af Aaret ere oversvommede, bliver Plauten krybende, grenet, med kortere Ledstykker og mindre Blade (var. minor Rchb. 1. c).

\section{Euphorbia. Vortemalk.}

a. StængeJbladene spredte $(\% / 5)$.

aa. Froene rynket- eller grubet-punkterede. $\odot$.

๙. Blomsterstandens forste Forgrening en femgrenet Skjærm, med qvastformigt tredeelte Grene; Kopdækkets Lapper rundagtige, heelrandede.

1172. E. Helioscopia L. (Kilebladet V.) H. 530 ; Drej. n. 885 ; F. D. 725 ; Rehb. ic. fl. germ. V, fig. 4754.

Bladene kileformede eller omvendt-ægformede, ovenfor Midten saugtakkede; Smaafrugterne jævne; Frøene nætformigt grubede, næsten kugleformede.

$3-8^{\prime \prime}$ høi; hele Planten gunlgrøn, Dækbladene gule. Smaae Expl. ofte ugrenede. 5-9. $\odot$.

Almindeligt Ulsud paa dyrkede Steder, især mellem Sæden.

ß. Blomsterstanden 2-4-grenet med gjentaget-gaffeldeelte Grene;

Kopdekkets Lapper tohornet-lialvmaaneformede.

1173. E. exigua L. (Liden V.) H. 529; Drej. n. 883 ; F. D. 592 ; Reluh. 1. c. fig. 4777, H. N. I, 52.

Bladene siddende, linieformede, heelrandede; Dalcbladene ved Grunden af Smargrenene $x g$-lancetformede med skjævt hjerteformet Basis; Smaafruyterne jævne eller ved Grunden utydeligt rue, med skarp, uvinget $K$ jol; Frøene ovale, knudretrynkede.

$2-6^{\prime \prime}$ hoi. Bladene var. spidse, budte med en Braad eller stumpt afskaarne. Skjærmen er paa store Exp]. stundom femgrenet. 7-9. $\odot$.

Ukrud mellem Sæden: alm. paa de sydlige Øer fra Lolland til Ero; i Fyen paa Hindsholm! Fraugde (16), Holkenhavu, Orbak (Lund); Sjall. $\bmod \mathrm{V}$. og S. list og lier, sparsommere mod N. og O.: Glostrup (24), mellem Herlov og Husum, Eiby og Rødoure (14), Kalkbrenderiet bag Flaskekroen! Amager (1), Roeskilde alm. (15), Kjøge (9), Stevns! Bornh. Hasle (Zahrtm.); J. Ukrud i Haver ved Aalborg (Klitsch)! * 
1174. E. Peplus L. (Stilkbladet V.) H. 528; Drej. n. 884 ; F. D. 1100 ; Rehb. l. e. fig. 4773.

Alle Bladene heelrandede; Stangelbladene kortstilkede, de nedre ovalt-kredsrunde, de ovre omvendt-ægformede; Dakbladene skjævt triangel-ægformede; Smaafrugterne med en dobbelt, smalvinget $\mathrm{Kjol}$; Frone ovale, i begge Ender afstumpede, med 2 Længdefurer paa Inderfladen og 4 Rækker Gruber paa YderAladen.

$6-10^{\prime \prime}$ høi. Planten mørkgrøn, ofte rødligt anløben. 7-8.

Paa dyrket Jord, især i Haver, et alm. Ukrud.

Anm. E. segetalis L. (Relib. 1. c. fig. 4780) angives med Tvivl fra $\boldsymbol{B} \cup \cdot \boldsymbol{r} \boldsymbol{h}$. af Hornemann. Den kjendes ved linieformede Blade, nyre formet-rudeformede Drkblade, femgrenet Blomsterstand med gaffeldeelte Grene $o g$ paatvers parallelt furede Frøe. (Har forgjieves vaeret eftersggt af Alle, som senere have besggt Øen).

\section{Frone javne. 4.}

1175. E. Esula L. (Laneetbladet V.) H. 530; F. D. 1270 ; Rehb. 1. e. fig. 4791 ; H. N. IV, 68.

Bladene laneetformede eller linie-laneetformede; Blomsterstanden mangegrenet med gjentaget-gaffeldeelte Grene; Dokbladene ved Grunden af Smaagrenene triangel-nyreformede, budte med en Braad; Kopdceklkets Lapper tohornede; Smaafrugterne paa Ryggen svagt ru-punkterede.

1-11/2' høi. Planten lys- og guulgron, Dakbladene gule. 6-7.

Forekommer hist og her omkring dyrkede Steder, oprindelig forvildet, f. Ex. J. Horsens (Jorgensen), 'Thyrshak (10); $\boldsymbol{S} l$. Nyvark ved Slesvig (16); $\boldsymbol{A} r \boldsymbol{r}_{\theta}$ verl AEroskjøbing (10); $\boldsymbol{F}$. Diemunger ved Hofmansgave (18); Loll. mellem Maribo og Refahale (19); $\boldsymbol{S} j$. Glacierne udenfor Osterport ved Khhatvn (26); B ornh. (Rafn).

b. Stængelbladene korsiis-modsatte (1/9. 1/4).

$\dagger$ E. Lathyris L. (Rchb. l. e. fig. 4783). Bladene linieformet-ovale, de øvre ved Grunden lijerteformede; Blomsterstanden alm. firegrenet med gjentaget-gaffeldeelte Grene; Dokbladene agformede; Kopdalikets Lapper tohornede; Smuafrugterne i modeu Tilstand rynkede; Froene nxtformigt aarede. 5-7. $\odot$. 
Forvildet omkring Haver, f..Ex. Holmdrup i Fyen (19); Østofte i Loll. (H.); Falst. Stubbekjøbing (Benzon)! 周

\section{Pillus. Fyr.}

1176. P. silvestris L. (Almindelig F.) H. 972; Drej. p. 305 ; Rehb. ic. fl. germ. XI, fig. 1127.

Naalene halvtrinde, rue, 2 sammen i hvert Kinippe; Koglen før Nodeubeden ægformet-kegleformet.

Middelhøit Tre med ujærn Bark. Koglen 11/2-2" lang, modnes i det andet og affalder $\mathrm{i}$ det tredie Aar efter Blomstringen.

Alm. plantet i Skove, forekommer hist og her forvildet i Moser, f. Ex. Sj. Lynghy Mose (28), Rudehegn! F alst. Horreby Lyng (Koch). Har $\mathrm{i}$ en tidligere Periode været vildvoxende i Daumark, hvilket de talrige Fyrrelevninger i Tørvmoserne vidne om.

$\dagger$ P. Strobus L. (Weymouths F.) Drej. p. 305.

Naalene 5 i hvert Knippe; Koglen valseformet, 5-6" lang. Hoit og slankt Træ med glat Bark. 5. 万.

Forekommer hist $\mathrm{og}$ her i Plantager, indfort fra Nordamerika. Fi

\section{Abies. Adelgran.}

$\dagger$ A. pectinata [DC. Fl. fr. 3, p. 276] (Almindelig 赵.) Drej. p. 305; Rchb. l. c. fig. 1139 ; P. Picea L.; Abies vulgaris Poir.

Naalene toradede (og Grenene derved fladtrykte), i Spidsen budt-udrandede, morkgronne med 2 hvide Striber paa Underfladen; Storknappernes Rum opspringende paatværs; Koylesijocllene affaldende, budte.

Hyit Træ. Barken hvidagtig, glat. Koglen omtrent 8 "lang. 5. Ћ.

Plantet ligesom foreg., men sjeldnere. (Vildroxende forekommer den især i Alperne og Pyrenæerne).

\section{Picea. Gran.}

$\dagger P$. excelsa [Link i Linnæa v. 15, p. 517] (Rød G.) Pinus Abies L., H. 971; F. D. 193; Abies excelsa Poir. Drej. p. 305 ; Rchb. l. c. fig. 1138.

Naalene alsidigt vendte, sylspi isede, heelt grønne; Støvknappcrnes Rum opspringende paalangs; Kogleskjollene vedblivende, i Spidsen gnavet-tandede. 
Hoit Tra med ujævn Bark. Koglen omtr. 6" lang. 5.

Alm. som plantet Træ i Skove og Plantager, ikke oprindelig indenlandsk, men hjemmelıørende i Norges, Sveriges og Tydsklands Bjergegne. Funden forvildet i Moser i Nyrup Hegn ved Helsingør (Heiberg).

\section{Larix. Laerlietrae.}

$\dagger$ L. europaca [DC. Fl. fr. 3, p. 27'7] (Almindelig L.) Drej. p. 305 ; Rehb. 1. e. fig. 1137 ; Pinus Larix L.

Naalene paa de forlængede Grene enlige, spredte, paa de forkortele Grene talrige, knippestillede, med en rorteformet Knude i llidten; $\hat{\sigma}$ og $q$ Raklerne lings opad de forlængede Grene; Koglen opret, xgformet, med budte, vedblivende Slijol; Dalibladene tilspidsede, vedblivende, men ved Modningen kortere end Kogleskjællene.

Høit 'Træ. Barken afskaller i tynde Plader. Koglen omtrent 1 " lang. 5. h.

Almindelig plantet i Naaleskove. (Dens Fædreland er Sibiricu, Karpatherne og Alperne). $\overline{i k}$

\section{Di a nd ria.}

\section{Lemna. Andemad *).}

a. Staurogeton Rehb. Løvet starkt forgrenet, dets Plader langstrakte, tynde og uæsten hindeagtige, jævit afsmalnede i en længere Stilk.

1177. L. trisulea L. (Korsbladet A.) H. 912; Drej. n. 4 ; F. D. 1586 ; Staurogeton Rehb. ic. H. germ. VII, fig. 19.

Rodtravlerne enlige; Lovets Plader lancetformet-elliptiske, budte eller kort braadspidsede, skjæve, under Lupen fint randhaaret-tandede.

Iysgron, storre end de følg., ligger største Delen af Aaret under Vandet. 5-6. 4 .

I stillestanende Vaud almindelig, men sjeldent blomstrende (Charlottenlund 1863, Didrichsen).

*) Flere vesenlige Berigtigelser til Arternes Beskrivelse i denne Slæcht skyldes $\mathrm{Hr}$. Professor Steenstrups velvillige Meddelelse. 
b. Lemnœ genuinœ. Løvet svagere grenet, dets Plader ovale eller kredsrunde, tykkere (med udviklede Lufteellelag, der holde dem flydende paa Vandets Overflade), pludselig overgaaende i en kort, traadsmal Stilk.

1178. L. polyrrhiza L. (Stor A.) H. 913 ; Drej. n. 5; F. D. 1589 ; Spirodela Schleid., Rehb. l. c. fig. 17.

Rodtrovterne knippeformigt samlede; Lovets Plader kredsrunde, flade eller kun paa Overfladen svagt hvælvede.

Løvet større end hos do 2 følgende Arter, paa Underfladen rødagtigt. $6-7.4$.

I Vand, ikke sjelden, dog mindre hyppig end den folgende, og meget sjeldent blomstrende.

1179. L. minor L. (Liden A.) H. 913 ; Drej. n. 6 ; F. D. 1587 ; Rehb. l. c. fig. 15.

Rodtravlerne enlige; Løvets Plader oval-kredsrunde, svagt hvælvede eller paa begge Sider næsten fladtrykte.

Den mindste af Arterne, omtrent af Størrelse som et Lindsefro, lysgron. $5-8$. $थ$.

Denne Art varierer betydeligt i Henseende til Løvpladernes Størrelse og de 'pa sammes Underflade forekommende luftfyldte Cellers Udvikling. En meget afvigende Form er

* tenella (Stp. i Lge. Haandb. 1 Udg. S. 599). Løvpladerne mindre og smalere, fladtrykte paa Over- og Underfladen (som Følge af de luftfyldte Cellers ringe Størrelse).

I Aaer, Damme og Søer, meget alm. og ofte i stor Mængde. Formen * forelsommer deels alene, deels blandet med den typiske Form, som da gjerne hedækker den, fordi den formedelst de større luftfyldte Celler ligger hoiere paa Vandet. Den er fundet i $\boldsymbol{S}_{j}$. ved Horsholm, Suusaaen ved Herlufsholm (23)! $\boldsymbol{F}$. i Skaatup Seminarinms Have (19); J. Ribe Aa (23); Sl. Satrup Mose i Augel! og anbefales til yderligere Efters øgning.

\section{L. gibha L. (Tykbladet A.) H. 913; Drej. n. 7;} F. D. 1588 ; Rehb. I. c. fig. 16; Telmatophace Schleid.

Rodtravlerne enlige; Løvets Plader omvendt-ægformede, afrundede, paa Underfladen halvkugleformigt hrælvede. 
Lovet ofte rødagtigt, paa Underfladen formedelst de store luftfyldte Celler svampagtigt hrælvet og næsten gjennemsigtigt. 6-8. $\psi$.

$\beta$, major Koch (Falst. Veget. p. 37) dobbelt saa stor som Hovedarten, med kortere Rodtrævler.

I Grave og Damme, funden $\mathbf{i}$ alle Provindser, men ikke saa hyppig som de ovrige Arter. $\beta$, F alst. i en Dam ved Riserup (Koch)!

\section{Ill. Triandria.}

\section{Typha. Duunhammer.}

1181. T. latifolia L. (Bredbladet D.) H. 914; Drej. n. 890 ; F. D. 645 ; Rehb. 1. c. IX, fig. $747-48$.

Bladene bredt linieformede; Axene valseformede, ô unid. delbart ovenfor $\&$ Axet; Støvtraadene efter Bestøvningen 2-4 Gange længere end Støvknapperne; Arret skjævt ægformet, med den farvede Spidse ragende frem over det børsteformede Blomsterdakke.

5-6' høi. Var. i Henseende til Bladenes Brede og Axets Tykkeise. 7. $\psi$.

I Tørvmoser og ved Aabredder, alm. udbredt.

1182. T angustifolia L. (Smalbladet D.) H. 914 ; Drej. n. 889 ; F. D. 815 ; Rebb. l. c. fig. 745 .

Bladene smalt linieformede, ved Grunden rendede; $\delta$ Axet fjernet fra $\$$; Stovtraadene efter Bestøvingen 1/2 Gang længere end Støvknapperne; Arret sinalt linieformet, ragende langt frem over Børsterne.

4-6' høi; Bladene 2-4"“ brede. Afstanden mellem Axene er forskjellig. 7. 4 .

Voxested som foreg., funden i alle Provindser (undt. Bornh.), men sjeldnere og kun i enkelte Egne i storre Mrngde eller endog fortrængeude hiin. 


\section{Sparganium. Pindsviinknop.}

a. Stængelen udeelt; $\hat{\delta}$ Hovederne under Blomstringen nasten ligestore med $q$.

1183. S. minimum [C. Bauh., Fr. S. Veg. Se. II, p. 560] (Spæd P.) H. N. XII, 78; S. natans H. 916; Drej. n. 886; F. D. 260 ; Rehb. l. c. fig. 749 (ikke L.)

Stcengelen svag; Bladene svømmende, langstrakt og smalt linieformede, budte, flade, ved Grunden omskedende; Blomsterhovederne ( 1 ô tidligt affaldende, $2-3$ o) siddende (eller det nedre kortstilket) i Bladlijørnerne; Frugterne ustilkede; Griffelen kort, tilligemed det vedblivende, aflange, skjævt afskaarne $\mathrm{Ar}$ 1/4 af Frugtens Længde.

Lysgrøn, ofte mere langstrakt, men altid spæedere end følgende. Ved de budte, smale og svømmende Blade let kjendelig fra de andre Arter. 7. 4.

I Torvmoser, forekommer i alle danske Provindser, men sparsommere end de folgende Arter.

$A n m$. Den i det nordlige Skandinavien forekommente rgte $S$. natans L. (Fr. l. c., H. N. XilI, 76) adskiller sig (efter F'r.) ved bredere Bladskeder, flere 0 Hoveder og omtr. 5 o Hoveder, det nedre ofte langstilket, stilkede Frugter. Den findes neppe i Dantnark.

1184. S. simplex [Huds. Fl. angl. ed. 2, p. 401] (Rank P.) H. 916 ; Drej. n. 887 ; F. D. 932 ; Rehb. l. c. fig. 750 ; H. N. XV, $79 ; \mathrm{S}$. erectum $\beta, \mathrm{L}$.

Stangelen rank-opret; Bladene linieformede, spidse, forneden trekantede med flade Sider, ved Grunden omskedende, i Spidsen flade med en Kjøl paa Underfaden; $\delta$ Blornsterhovcderne 4-flere, siddende; 9 Hovederne 3-4, stilkede, Stitkene (med Undtagelse af den nedre) forneden sammenvoxue med Stængelen og derved udgaaende fra Midten af Ledstykket (iklse fra Bladvinklen); $\$ Blomsterne kortstilkede; Griffelen forlænget, af Lxngde med det linieformede $A r$ og tilligemed dette ligesaa lang som eller lidet længere end Frugten.

$1-1^{1 / \frac{1}{}}$ h høi. 7-8. य.

I Søer, Kjær og Bække alm. udbredt. 
b. Stangelen foroven grenet; 0 Hovederne meget mindre end $q$.

1185. S. ramosum [Huds. l. c.] (Grenet P.) H. 915; Drej. n. 888 ; F. D. 1282 ; H. N. XV, 77-78; S. erectum $\alpha$, L., Rehb. l. c. fig. 751 .

Bladene linieformede, budte, forneden skarpt trekantede med hule Sider, ved Grunden omskedende, mod Spidsen flade med en Kjøl paa Underfladen; Grencne udgaae fra Bladhjørnerne, længere end Ledstykket ovenfor, med $1-3$ siddende o Hoveder, talrige og tætsiddende $\hat{o}$ Hovcder; $\$$ Blomsterne siddende; Griffelen kort, tilligemed det linieformede $A r$ kortere end Frugten.

Hoiere end foreg. $\left(2-3^{\prime}\right)$, med meget mindre $0^{7}$ Hoveder. Mørkgrøn, de nedre Bladskeder og Frugterne ved Grunden violetrøde. 7-8. ข.

Paa lignende Steder som foreg., meget alm.

\section{Carex. Star. $\left.{ }^{*}\right)$}

A. Monostachyce. 1 enkelt Ax i Spidsen af Straet.

a. Trebo.

1186. C. diorca L. (Tvebo-S.) H. 917; Schum. n. 759; Drej. n. 891 ; F. D. 369 ; Rehb. ic. Al. germ. VIII, 522; Andersson Cyp. Scand. t. III, f. $10 ;$ H. N. 86 .

*) Carex-Arterne maae undersøges naar Frugterne have naaet deres fuldkomne Udvikling, og de her givne Beskrivelser, f. Ex. af Smaaaxenes Form, de enkelte Deles relative Langde o.s. v., gjalde, naar intet Andet er navnt, deme Nilstand. Hvad der i Beskrivelserne er betegnet $s \cap m$ "Frngten "jalder egenlig det Nodiden tæt omgivende og vedblivende Blomsterdakke (perigynium). De fra Formen af Skedens Munding og af Skedehinden (stavel den frie, mod Bladpladen vendte, som den forreste, med Skedens Forside sammenvoxede Deet) hentede Kjendetegn ere af ikke ringe Vigtighed for Arternes indbyudes Adskillelse, ag bor derfor noiere mdersoges og beskrives. Jeg lar til en Begyulelse i nærvarende Udgave beskrevet disse Forhold for saa mange Arter, som jeg har kumnet undersgge i levende Tilstand. 
Rodstokken udskyder Udløbere; Straaet opret, jævnt; Bladene traadsmale, børsteformigt sammenrullede, Bladskedens Munding kredsrund, Skedehindens frie (mod Pladen vendte) Deel kort afskaaren $\mathrm{i}$ en Bue, den forreste Deel afiundet og ligelang med den bageste Deel, vedblivende og langt fremragende udenfor Skeden; Dakskjallene ægformet-ovale, budte; 2 Ar; Frugterne ægformede, mangenervede, foroven i Randen rue, tilsidst vandret udstaaende.

4-6" høi. ơ Axene linieformede, $q$ (under Blomstringen) ovale. Frugterne mørkbrune. 5-6. ข. Var.

$\beta$, isogyna Fr. Mant. 3,153 ; H. N. XV, 86. Axet for-

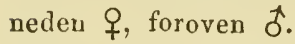

$\gamma$, scabriuscula Hartm. Straaet høiere, oventil ru.

I raade Enge, Hængedynd, ikke sjelden. $\beta, S j$. ved Raavaddam (19); J. Eveldrup (Drej. Herb.). $\quad \boldsymbol{y}$, er angivet fra Danmark, men uden bestemt Voxested.

b. Enbo. Axet foroven ô, forneden + .

1187. C. pulicaris L. (Loppe-S.) H. 918 ; Schum. n. 770; Drej. n. 892 ; F. D. 166 (slet) og 2516 ; Rchb. l. c. fig. 524 ; And. l. c. III, 7; H. N. XIII, 87.

Straaene oprette, jævne, tueformigt samlede, uden Udløbere; Bladene børsteformigt sammenrullede, Skedemundingen og Shedehinden som hos foreg., men Skedebindens forreste Deel mindre fremragende udenfor Skeden; Dakskjallene ægformede, spidse: $\widehat{\sigma}$ Blomsternes vedblivende, $q$ Blomsternes affaldende; 2 Ar; Frugterne elliptiske, tonervede, jævne, tilsidst nedhængende.

2-6" høi. Axet under Blomstringen lancetformet. Frugterne faee, glindsende brune. 5-6. 4.

I Torrmoser og fugtige Enge, hist og her i alle Provindser,. men sjeldnere end foreg.: hyppigst paa Ulvoen.

1188. C. pauciflora [Lightf. Fl. scot. p. 543 ; t. 6 f. 2] (Faablomstret S.) H. 919 ; Drej. n. 893 ; Rehb. 1. c. fig. 526; And. III, 2; H. N. XI, 82; C. leucoglochin Ehrb., Schum. n. 771 ; F. D. 1279 . 
Rodstokken skjævt opstigende, med Udløbere; det øvre Stangelblad smalt linieformê, paa Overfladen rendet, de nedre meget korte; Axet faablomstret (1-2 우, $3-5$ 우 Blomster); + Dakskjullene tilspidsede, affaldende; $3 \mathrm{Ar}$; Frugterne sylformede, langt tiispidsede, jævne, tilsidst nedhængende.

2-6" høj. Frugterne blegt straagule, let affaldende. 6. ข.

I Torv- og Hedemoser mellem Splıagnum, sjelden: J. Frederikshavn, Hasselriis, Svendstrup, Vesterkjær, Slumstrup (H.), Horbylund V. for Silkeborg, Ø. Nykirke! $\boldsymbol{S} j$. Bidstrupgaard (H.), Bagsværd, Fredriksdal (M. Vahl).

B. Homostachya. 1 sammensat Ax i Spidsen af Straaet (Smaaxene nærmere eller fjernere fra hinanden, alle [eller nogle] androgyne 0 : sammensatte af of $0 \mathrm{~g}$ 우 Blomster.

a. Schelhammeria Moench. Smaaxene samlede til et Hoved, omgivet af et $2-5$-bladet $S v ø b$.

$X$ 1189. C. cyperoides L. (Fladax-S.) H. 925; Drej. n. 894 ; F. D. 1465 ; Rchb. 1. c. fig. 576; And. IV, 42.

Straaene tueformigt samlede fra en sammentrængt Rodstok, budt trekantede med plane Sider, jævne, foroven lidt rue; Hovedet rundagtigt; de ydre Svobblade meget lange; Smaaaxene forneden $\delta ;$ Dakskjollene langt tilspidsede, tilligemed Frugtens forlængede, tokløvede $N \propto b$ i handen tornet-saugtakkede; $2 A r$.

Hele Planten gron. 7. 2.

I en ndtorret Dam ved Frederikshorg, fumden i Mængde af Holboll, formodenlig indfort med Indpakning og $\mathrm{i}$ mange Aar søgt forgjeves; gjenfunden 1852 (Kñekenborg)! men senere atter forsvunden. 网

b. Vignea Koch. Smaarane samlede til et forlænget, fortløbende eller afbrudt Ax. 2 Ar.

aa. Acroarrhena $\mathrm{Fr}$. Smacaxene foroven $\hat{0}$.

a. Chordorrhizece. Rodstokken vidtkrybende; Axene brunagtige, enkelt sammensatte.

1190. C. incurra [Lightf. Fl. scot. p. 544, t. 24, f. 1] (Krumstænglet S.) II. 920 ; F. D. 432 ; Rchb. 1. c. fig. 533; And. III, 12 ; H. N. XIV, 85. 
Straaet budtkantet, jævnt, krumbøiet, kortere end eller af Længde med de børsteformigt sammenrullede Blade; Skedemundingen kredsrund, Skedehindens frie Deel kort afskaaren, bueformet eller udrandet, dens forreste Deel svagt udrandet, naaende udover Skeden; Axet rg-kugleformet, med tæt sammenbobede Smaaax; 우 Axskjollene bredt xgformede, budte med en Braad, kortere end de ægformede, opblæste, nerveløse, i et jævnt, skjært afskaaret Næb tilspidsede Frugter.

2-6" høi. 6-7. 4 .

Ved sandige Strandbredder, meget sjelden: Løkken i det nordvestlige $\boldsymbol{J} y \boldsymbol{l l}$. (Lyngby).

1191. C. chordorrhiza [Ehrh. i Linn. suppl. 414] (Mangegrenet S.) H. 921 ; Drej. n. 895 ; F. D. 1408 ; Rehb. I. c. fig. 535; And. III, 14; H. N. IX, 85.

Rodstokken skjævt opstigende, mangegrenet; Straaene rette, jævne, forneden trinde og stribede, foroven budt trekantede, meget længere end de smalt linieformede, rendede Blade; Skedemundingen oval, Skedehindens frie Deel bueformigt afrundet, dens forreste Deel svagt udrandet, tidligt sønderreven, naaende udover Skeden; Axet ægformet, med tæt sammenhobede Smaaax; Frugterne ægformede, opblæste, tydeligt mangenervede, pludseligt udløbende $\mathrm{i}$ et næsten jævnt $N a b$, ligelange med de ægformede, spidse Dakstijal.

Høiere end foreg. $\left(1 / 2-1^{\prime}\right)$, med mindre Ax. Den største Deel af Planten nedsænkt mellem Sphagnum o, a. Moseplanter. 6. थ.

I dybe Moser med Hængedynd, sjelden: $\boldsymbol{S} \boldsymbol{j}$. Dronninggaard (H.), Lyngby Mose! $S l$. Oxager Mose i Angel $(16,28)$. W

1192. C. disticha [Huds. Fl. angl. 403] (Toradet S.) And. III, 15; H. N. XI, 81; C. intermedia Good., H. 922; Schum. n. 782; Drej. n. 896; F. D. 1343 (ungt Expl.); Rehb. I. c. fig. 552 .

Rodstohilen vandret eller skjævt opstigende; Straaene rette, trekantede, med rue Kanter; Bladene linieformede, flade; Skedemundingen $x$ gformet-oval, Skedehindens frie Deel bred, bruunthindeagtig, budt udløbende i Midtnerven, dens forreste Deel 
vedblivende, dybt udrandet, lidet fremragende udenfor Skeden; Axet forlænget, med toradet stillede og tæt samlede, ovale Smaaax, de nedre og øvre $\$$, de midterste $\delta^{\star} ;$ Fingterne ægformede, mangenervede, foroven smalvingede, jærnt udløbende i et ru, tokløvet $N_{c} b$, længere end de ægformede, tilspidsede Doekskjol.

1-2' høi. En Misdannelse med store, hindeagtigt opblæste og bøiede Frugter er ikke sjelden. 5-6. 4.

I Moser, vaade Enge og Grøfter alm.

1193. C. arenaria L. (Sand-S.) H. 921 ; Schum. n. 783; Drej. n. 897 ; F. D. 1766 ; Rehb. I. c. fig. 551 ; And. III, 16 ; H. N. XIII, 86; L. Herb. VII, 140.

Rodstokken vandret med talrige og langstrakte Udløbere; Straaene trekantede, forneden jævne, foroven rue, mod Frugtmodningen i Spidsen nikkende; Bladene smalt linieformede, tilsidst indrullede; Skedemundingen kredsrund, Skedehindens frie Deel kort afskaaren, bruunt-hindeagtig, under Lupen fint randhaaret-fryudset, dens forreste Deel vedblivende, naaende udover Skeden; Axet forlænget, med ægformet-elliptiske Smaaax, de øvre $\hat{\delta}$, de midterste androgyne, de nedre $q$, ofte adskilte; Frugterns ægformede, tydeligt nervede, i Rauden bredvingede og lang1 tilspidsede i et sangtakket-ru, dybt tokløvet Næb, ligelange med eller kortere end de xg-lancetformede, tilspidsede Dakkskjol.

Rodstokken ofte favnelang, tat beklædt med visne Bladskeder. Straene $1 / 2-1^{\prime}$ hoie, foroven et langt Stykke bladløse, nedenfor Midten tætbladede; Drkskjællene blegbrune med gron Rygnerve. 5-6. य.

Paa Sandmarker og i Sandklitter, hyppig i de fleste Egne og kun sjelfnere i de frugtbare Dele af Litudet (f. E. i Fyen).

Anm. Den beskrives alm. med de androgyne Smaaax i Spidsen $\sigma^{*}$, forıeden $\$$; men paa mange Expl. som jeg har undersogt, fandt jeg det modsatte Forhold at finde Sted.

B. Paniculatce. Rodstokken sammentrangt; Axene brunagtige, alm. dobbelt sammensatte; Frugterne opret-aabne.

1194. C. teretiuscula [Good. Trans. Linu. soc. 2, p. 163, t. 19, f. 3] (Trindstænglet S.) H. 925; Schum. n. 786; Drej. 
n. 903 ; F. D. 1886 ; Rehb. l. c. fig. 572 ; And. III 22; H. N. VI, 79.

Rodstokken kort, skjævt krybende, fremskyder i liden Afstand fra binanden flere forneden trinde, foroven trekantede og rue Straae med convexe Sider; Bladskedens Munding kredsrund; Skedehindens frie Deel lige afskaaren, dens forreste Deel ligesaa og langt fremragende udenfor Skeden; Axet enkelt eller dobbelt sammensat, med kortgrenede eller siddende, tæt samlede (eller de nedre fjerne) Smaaax; Frugterne xgformede, paa Kyggen hvælvede, ved Grunden svagt stribede, forøvrigt nerveløse, efterhaanden afsmalnede $\mathrm{i}$ et tokløvet, $\mathrm{i}$ Randen ru-saugtakket $N a b$, længere end de ægformede, spidse Dakskjocl.

Omtrent $1^{\prime}$ høi. Bladene smale, blaagrønne. Dækskjællene graabrune med bred hindeagtig Rand. 5-6. 2 .

I Tørvmoser og Kjær, alm. udbredt.

1195. C. paraloxa [Willd. Act. acad. berol. 1794, p. 39, t. 1] (Langaxet S.) H. 925; Drej. n. 902; F. D. 1887; Rchb. l. e. fig. 573 ; And. III, 23; H. N. VI, 78; C. appropinquata Schum. n. 785.

Straaene tueformigt samlede, skarpt trekantede med convexe Sider, foroven rue; Skedemundingen kredsrund, Skedehindens frie Deel meget kort og lige afskaaren, dens forreste Deel udrandet, ikke fremragende udenfor Skeden, tidligt sønderreven; Blomsterstanden en sammentrængt Top med sammensatte, tydeligt stilkede Grene; Frugterne ægformede, paa Ryggen hrælvede, tydeligt nervede, pludseligt udløbende i et tokløvet, i Randen ru-saugtakket $N w b$; Dakskjollene ægformede, spidse, kortere end Fragten.

$1 \frac{1 / 2}{2}-2^{1} / 2^{\prime}$ høi. Adskilt fra foreg. og følg. ved mindre blaagronne Blade og ved de nedre Bladskeder, som opløses i lange sortbrune Trævler og omgive Tuerne. Dækskjællene brune med smal hindeagtig Rand, og Axene derved for Blomstringen brune. 5-6. 4 .

Paa fugtige, især torvlıoldige Enge, ikke sjelden, og sandsynligviis udbredt $i$ alle danske Provindser. 
1196. C. paniculata L. (Top-S.) H. 924; Sehum. n. 784 ; Drej. n. 901 ; F. D. 1116 ; Rehb. I. c. fig. 574 ; And. III, 21 ; H. N. X, 81 .

Stracene tueformigt samlede, skarpt- og ru-trekantede med 2 concave og en plan Side; Skedemundingen kredsrund, Skedehindens frie Deel meget kort, bueformet (næsten utydelig), dens forreste Deel lige afskaaren, vedblivende, lidet fremragende udenfor Skeden; Blomsterstanden en dobbelt sammensat Top med forlængede, tydeligt stilkede Grene; Frugterne æyformede, paa Ryggen hvælvede, ved Grunden svagt stribede, forøvrigt nerveløse, efferlaanden afsmalnede i et tokløvet, i Randen ru-saugtakket $N w b$, af Længde med de ægformede, tilspidsede Dakiskijal.

Af Hoide med foreg., men kraftigere; Stængelen, især ved Grunden, tykkere, Bladene bredere, blatgronne. Dækskjællene graabrmne med bred, hvid-hindeagtig Rand, hvorved Toppen i yngre 'Tilstand filaer et graaagtigt glindsende Udseende. 5-6. 4. Forekommer hyppigst med stærkt forgrenet, ofte pyramideformet Top, men var.

$\beta$, simplicior And. (Cyp. Seand. p. 67). Blomsterstanden et sammenknebet, enkelt-sammensat $A x$ med fjerne, siddende eller meget kortstilkede Smaaax.

I Moser og Kjier meget alm. $\beta$, med Hoverlarten, sjeldnere, f. Ex. Flommen ved Sors! Falst. ved ldestrup (Koch).

$\gamma$. Muricatce. Rodstokken sammentrængt; Axene grønlige, Frugterne udspærrede, Iængere end Dækskjælleue.

1197. C. dirulsa [Good. 1. c. p. 160] (Mellembrudt S.) H. 924 ; Drej. I. 900 ; F. D. 1280 ; Rehb. l. e. fig. 570 ; And. III, 20; H. N. VI, 80 (C. paniculata simplex).

Straaet fiint, trekantet, foroven ru, lidet nikkende; Skedemundingen kort og afiundet, Skedehindens frie Deel meget kort, udrandet, dens forreste Deel ikke forlænget udover Skeden, med tykkere Rand og vedblivende uforandret; Axet forlænget, mellembrudt; de nedre Smaaax fjerntsiddende, ofte stilkede, sammensatte og med et Diekblad ved Grunden; Dakskjollene ægformede, braadspidsede, hvid-hindeagtige med grøn Rygnerve; Frugterne æg.kegleformede, plan-convexe, nerveløse, til- 
spidsede i et tokløvet, randhaaret-ru $N a b$, uden svampagtigt Cellevæv indvendig; Nødden næsten siddende.

$1-1^{1 / 2^{\prime}}$ høi, frisk grøn. 6-7. 4. Tar.

$\beta$, intermedia (C. virens Lam., C. muricata $\beta$, virens Koch, And. III, 18; Lge. Haandb. 2 Udg. p. 607; F. D. 2608). Smaaaxene mindre fjerne, kun de nedre adskilte.

I skyggefulde Skove, sjeldnere ved Gjærder, sporadisk og ikke alm., men funden $\mathrm{i}$ alle danske Provindser. $\beta$, hist og her paa lignende Steder som Hovedarten.

1198. C. muricata L. (Spidskapslet S.) H. 923; Schum. n. 776 ; Drej. n. 899 ; F. D. 1526 ; Rehb. l. c. fig. 561 ; And. III, 19; H. N. IX, 84.

Straact opret; Skedemundingen aflang, Skedehindens frie Deel længere, budt udløbende i Midtnerven, dens forreste Deel naaende udover Skeden, i Randen meget tynd og tilsidst sønderreven; Smaaaxene tætsiddende og stilkløse, danne et fortløbende eller kun lidet afbrudt Ax; Dakskjollene bruunthindeagtige med grøn Rygnerve; Frugterne svagt nervede ved Grunden, mere vandret udspærrede, ved Grunden indvendig svampagtigt fortykkede; Nodden ved en forlænget Frugtholder fjernet fra Perigyniets Basis; forøvrigt som foreg.

Omtrent $1^{\prime}$ høi. 6-7. \%. Hyppigt forekommer en Var. (eller rettere Misdannelse) med store, hindeagtigt opblæste og krumbøiede Frugter.

Almindelig over hele Landet: $\boldsymbol{\alpha}$, ved Gjærder, paa Græsmarker og hoie Enge; $\beta$, i Slygge.

Ann. C. divulsa $\beta$, intermedia har tidligere snart været henfort som Afart til denne, suart opstillet som en egẹn Art (C. virens Lam.), men omhyggelige Undersøgelser af Durieu de Maisonneuve (Bull. soc. bot. Fr. VI, 621) have godtgjort, at den er en kun lidet fra C. divulsa afvigende Form.

1199. C. rulpina L. (Ræve-S.) H. 922; Schum. n. 781; Drej. 11. 898 ; F. D. 30 ; Rehb. l. e. fig. 564 ; And. III, 17; H. N. IX, 83 .

Straaet opret, skarpt og ru-trekantet, med concave Sider; Skedemundingen ægformet, Skedehindens frie Deel kort, med indbøiet Rand, budt udløbende i Midtnerven, dens forreste 
Deel udrandet, vedblivende, lidet fremragende udenfor Skeden. Axet tat, dobbelt sammensat, med stilkløse, tretsiddende eller ved Grunden lidet adskilte Smaaax; Dokskijallene xgformede, langt braadspidsede, bruunt-hindeagtige med grøn Rygnerve, lidet kortere end de xgformede, plan-eonvexe, svagt 5-7nervede, i et tokløvet, ru-saugtakket Nab tilspidsede Frugter.

$1^{1 / 2}-3^{\prime}$ hoi. Kraftigere og med bredere Blade end de foreg. 6-7. 4. Var.

$\beta$, nemorosa (Rehb. l. c. fig. 563 ; C. nemorosa Rebent., H. 923). Axet forneden mellembrudt, med forliengede Dækblade; Dakskjællene blegere.

Paa vaade Enge, i fugtige, lerede Grofter, alm. $\boldsymbol{\beta}$, en Skyggeform (analog med $\beta$, at næstforeg. Art), sjeldnere end Hovedarten.

\section{b2. Hyparrhenæ. Smaaaxene forneden $\hat{\sigma}$.}

a. Contiguce. Smaarene tætsiddende eller de nedre lidet adskilte, i Regelen længere end de hindeagtige Dækblade.

ка. Frugterne vandret udsparrede.

1200. C. stellulata [Good. l. c. p. 144] (Stjerneaxet S.) H. 928 ; Sebum. n. 772 ; Drej. n. 905 ; Rehb. I. e. fig. 560 ; And. IV, 37 ; H. N. X, 84; C. murieata F. D. 284 (ikke god).

Straaene tuefurmigt samlede, oprette, trekantede, joviue eller foroven lidet rue; Skedemundingen oval-kredsrund, Skedehindens frie Deel tynd, kort afskaren og afrundet, dens forreste Deel vedbliveude, lige afskaaren og fremragende uleufor Skeden; Smaaaxene 3-5, rundagtige, lidet adskilte; Dokslijollene ægformede, budte, brune med hindeagtirr Rand, meget kortere end de bredt ægformede, tydeligt nervede, $i$ et laugt, tokløvet, ru-saugtakket $N w b$ tilspidsede Frugter.

4-10" høi. Bladene smalt linieformede, trisk grønne. Ved de stjerneformigt udspærrede Frugter let kjendelig fra alle Arter i deuue Afdeling. $5-6.4$.

Paa fugtige Euge, alm. 


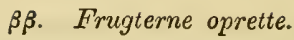

1201. C. Ieporina L. (Hare-S.) Drej. n. 906; Rehb. 1. c. fig. 554 ; And. IV, 26 ; H. N. VIII, 80; C. ovalis Good., H. 926 ; Schum. n. 778 ; F. D. 1115.

Stracene tueformigt samlede, oprette eller opstigende, budttrekantede, jævne eller oventil lidet rue, foroven et langt Stykke bladløse, forneden tætbladede; Bladskcdens Munding trekantet-ægformet, Skedehindens frie Deel kort afskaaren, hvidhindeagtig, dens forreste Deel udrandet, vedblivende, langt fremragende udenfor Skeden; Sinaaaxene 4-6, ovale eller omvendt-ægformede; Frugterne ægformede, fladtrykte med en hindeagtig-vinget Rand, tydeligt nervede, tilspidsede $i$ et tokløvet, ru-saugtakket $N_{c e b}$, af L:engde med eller kortere end de lancetformede Dakskijal.

$1 / 2-1^{\prime}$ høi. Bladene faste, rendede. Det nedre Dækblad stmdoin bladagtigt, af Længrle med Axet. Drkskjællene bruun-hindeagtige med grøn Rygnerve. 6-7. 4. Var.

$\beta$, argyroglochin (Rehb. l. e. fig. 555; H. N. VIII, 77; C. argyroglochin H. 927 ; F. D. 1710). Bladene længere og slappere, Smaaaxene fjernere, omvendt-ægformede, Dækskjællene hvid-hindeagtige med gron Rygnerve.

Paa høie Enge, Græsgange og ved Veie, alm. - $\beta$, i Skove, sjeldnere: $\boldsymbol{J}$. Haven i Vendsyssel (12); $\boldsymbol{S}$. Gurre Vang! Kongens Møller! Sonderslioven ved Sorø!

1202. C. elongata L. (Forlænget S.) H. 929; Schum. n. 780 ; Drej. n. 907 ; F. D. 1236 ; Rehb. I. e. fig. 565; And. IV, 32 ; H. N. X, 83 .

Straaene tæt tueformigt samlede, oprette, slappe, ru-trekantede med plane Sider; Skedemundingen xgformet, Skedehindens frie Deel meget kort afskaaren (i Form af en svag Rand), budt udløbende i Midtnerven, dens forreste Deel udrandet, tynd hindeagtig, tidligt søuderreven, lidet fremragende udenfor Skeden; Smaaaxene 6-10, afvexlende eller i 3 Rader, lidet adskilte (især de nedre), elliptisk-valseformede; Dakskjallene ægformede, budte med en meget kort Braad, omtrent 
balvt saa lange som de lancetformede, fladtrykt convexe, paa begge Sider mangenervede, i et kort, ru, utydeligt tokløvet Nab tilspidsede Frugter.

1-2' høi. Bladene lange, gunlgrønne; Drkskjællene brune med hvid-hindeagtig Rand og grøu Rygnerve. Var. med et bladagtıgt forlænget Dækblad ved Grunden af det nederste Smaaax. 6. 4 .

I Moser og fugtige Skove, hist og her, ikke almindelig.

1203. C. canescens L. (Kortkapslet S.) Drej. n. 908; F. D. 285 ; Rchb. I. e. fig. 546 ; And. IV, 39 ; H. N. XI, 80 ; C. curta Good., H. 927 ; Schum. n. $973-74$ (C. eurta og canescens).

Rodstokken sammentrængt, med korte Udløbere; Straaene i Tuer, oprette, trekantede med eoncave Sider, mod Spidsen lidet rue; Skedcmundingen bredt ægformet, Skedehindens frie Deel kort, indbøiet, budt udløbende i Midtnerven, dens forreste Deel næsten lige afskaaren, tynd og tidligt sønderreven, neppe fremragende udenfor Skeden; Smaaaxene 5-8, oval-kølleformede, afvexlende eller treradede, de nedre adskilte; Dakskjollene bredt ægformede, braadspidsede, kortere end de taglagt-tiltrykte, xgformet-elliptiske, convexe, svagt nervede, i et kort, utydeligt udrandet $N \alpha b$ tilspidsede Frugter.

Omtrent 1' løøi. Hele Planten blaagrøn. Dækskjællene straagule med gron Rygnerve. 6-7. 4 .

$\beta$, tenuis O. F. Lang (Linnæa 185 I, p. 538). Spædere, med mere rue Straa, smalere og slappere Blade, Smaaxene neppe halvt saa store som hos $\alpha$, det nedre ofte omgivet af et bladagtigt Dækblad.

I fugtige Skove, alm. udbredt. $\boldsymbol{\beta}, \boldsymbol{S} \boldsymbol{l}$. Marieskoven ved Flensborg! Wittensee (20)!

Anm. Formen $\beta$, er ikke lidet afoivende fra Hovedarten og i Udseende langt mere lig den nerbeslægtede C. vitilis Fr. (C. Persoonii Sieb), saa at hvis den ikke afveg fra denue ved mindre dybt udrandede Frugter, livilket angives son det vigtigste Skjælnemærke mellem C. canescens og C. vitilis, vilde jeg uden Betænkning have henfort den til sidstnevnte, nanseet at deune er en alpinsk P'lante. Den slesvigske Form danner altsaa et forbindende Led mellem de 2 Arter, og jeg anbefaler den til narmere Undersggelse i den frie Natur. 
1204. C. brizoides L. (Bævre-S.) H. II, 270; F. D. 2180 ; Rehb. l. c. fig. 548 ; And. III, 24.

Rodstokken med Udløbere; Straaene oprette, skarpt og rutrekantede; Axet kort, toradet, med omtrent 5, tætsiddende, elliptisk-lancetformede, bueforıigt udbøiede Smaaax; Frugterne æg-lancetformede, nervelose, fra Grunden til Spidsen randhaaretrue, tilspidsede $\mathrm{i}$ et tokløvet $N a b$, lidet længere end de lancetformede, spidse Dakskjoel.

Omtrent $1^{\prime}$ høi. Dækskjællene straagule. 6-7. 4.

Paa Enge og i fugtige Skove, meget sjelden: Sl. Borby og Sehested ved Ekeruförde (F. D.). Angives fra Sjællaud, funden af Vahl og schum. (Euum. n. 779), men da Beskrivelsen ikke er god og intet Expl. findes hrerlen i Vahls Hler Schumachers Herb., maa denne Angivelse ansees for tvivison. 周

B. Remotce. Dækbladene, idetmindste det nedre, bladagtige, forlangede, (meget langere end det tilhørende Smaakx), de nedre Smaax langt fjernede fra hinanden.

1205. C. remota L. (Axelblomstret S.) H. 928; Schum. n. 775 ; Drej. n. 904 ; F. D. 370 ; Rehb. I. c. fig. 556 ; And. IV, $40 ;$ H. N. VII, 82.

Rodstokken tueformigt sammentrængt; Straaene tynde, i Spidsen nikkende, forneden jævne, foroven meliem Smaaxene zigzagbøiede, rue; Skedemundingen kredsrund, Skedehindens frie Deel temmelig bred, opret, hvid-hindeagtig, i Spidsen udrandet, dens forreste Deel vedblivende, langt fremragende udenfor Skeden; Smaaaxene 5-8, enkelte, omvendt-ægformede, afvexlende, de $3-4$ nedre fjerne, med Dakblade længere end Straaet; Dakskjallene ægformede, spidse, sølvglindsende eller straagule med grøn Rygnerve, kortere end de ægformede, fladtrykte, nervede, i Spidsen saugtakliet-rue og i et tokløvet Nab tilspidsede Frugter.

1-2' høi. Bladene smale, frisk gronne. 6-7. 4.

I fugtige Skove, almindelig. 
1206. C. Boenninghauseniana [Weihe Bot. Zeit. 9, 2, p. 743] F. D. 2300; Relib. l. c. fig. 568; And. IV, 41; H. N. $\mathrm{X}, 82$.

Rodstolikn tueformet; Straaene rette, ru-trekantede; Skedemundingen og Skedehinden som hos foreg.; Smaaaxiene 8-12, afvexlende, lancetformede, de $3-4$ nedre fjerne, det nederste sammensat, med et Dakblad kortere end eller af Længde med Straaet, de derpaa folgende uden Dxkblade og efterhaanden mindre sammensatte, de ovre tætsiddende, enkelte, tilsidst bueformigt udbøiede; Dakskjocllene agformede, spidse, guulbruunhindeagtige med grøn Rygnerve, af Længde med de ag-laneetformede, plan-convexe, stribede, fra Grunden randhaaret-rue og i et tokløvet Nab tilspidsede Frugter.

2-3' høi. Danner tætte 'Tuer med lange og stærke Rodtrevler. Straaene forneden tykkere, Bladene bredere end hos foreg., blaagronne. 7. 4 .

$\boldsymbol{\beta}$, subpaniculata! Bladene bredere, de nedre Smaax paa forlængede, dobbelt sanmensatte Grene i Form af en Top, det nederste Drkblad meget kort.

Ved Randen af firgfter o. a. fugtige Steder i Skove, sjelden: $J$. Fusing Skov (3)! Sj. Philosophgangen ved Soro! Braaby Vesterskov (7)! Valy (?) og derfra indplimtet i botanisk Have! - $\beta$, med Hovedarten ved Soig! $\pi$

Anm. O. F. Lang (1. c. p. 492) har fremsat den Formodning, at C. Boeminghauseniana skulde vare en gold Form af C. paniculata, fordi han ikke har fundet den med modne Frugter. Denne Miening behover neppe nogen særlig Gjendrivelse; den er limmelvidt forskjellig, saavel i Characterer som Voxested, fra C. paniculata og horer utvivlsomt til samme Gruppe som C. remota og C. axillaris. Ifølge Fries (Bot. not. 1858 p. 129) er den kun en Form af den sidstnævirte Art. Begge disse Arters sjeldne Forekomst og den Omstændighed, at de næsten stedse ere fundue ined golde Frugter, har foranlediget flere Botanikere til at frakjende dem Ret som selvstendige Arter, og senest har Duval-Jouve (Bull. soc. bot. Fr. XI, 15) fiemsat den Anskuelse, at C. axillaris skulde vare en steril Form af C. remota, hvorimod Crepin antager den for en Bastarl af C. remota og vulpina. C. axillaris er mig for lidet bekjendt til at jeg tor have nogen Mening herom, men hval C. Boenuingh. anqaaer, kan jeg tilføie, at jeg isar hos Formen $\beta$ har fundet talrige fuldmodne og spiredygtige l'rugter, hvorfor jeg ingenlundo er tilboielig til at antage denne for en blot gold Form. 
C. Heterostachyce. कै $0 \mathrm{~g}$ $q$ Axene adskilte fra hinanden ${ }^{\star}$ ).

a. Distigmatico (Fr. Bot. not. 1845 ), med 2 Ar. aa. Straaene samlede $i$ tatte Tuer, de nedre Bladskeder med optrcevlet Noet.

1207. C. stricta [Good. l. c. p. 196] (Stivtoppet S.) H. 933 ; Schum. n. 802 ; Drej. n. 912 ; F. D. 2548 ; Rehb. 1. c. fig. 583 ; And. VI, 60; H. N. VIII, 73.

Straaene oprette, skarpt trekantede, rue, med faae eller ingen Straablade; Bladene ved Torring i Randen tilbagerullede; Skedemundingen xgformet, Skedehindens frie Deel temmelig bred, indbøiet, hindeagtig (hvid eller blegbruun), spidst udløbende $\mathrm{i}$ den dybt rendede Midtnerve, dens forreste Deel dybt udrandet, meget tynd og tidligt sønderreven, fremragende udenfor Skeden; Dakbladene stivt oprette, kortere end Straaet, uden Skeder, men med 2 Ører ved Grunden; ô Axene 1-2; 올 Axene 2-3, siddende eller kortstilkede, oprette, langstrakt.valseformede; Frugterne elliptisk-ovale, fladtrykte, tydeligt nervede, tilspidsede i et kort, ikke udrandet Nob, tidligt affaldende.

$2-3^{\prime}$ høi, blaagrøn og meget stiv, danner store og tætte Tuer, de bladløse Skeder talrige, med stærkt Trævlenæt. I Spidsen af o Axene findes næsten altid $\sigma^{\pi}$ Blonister, hrorved Axene blive tilspidsede. Var. betydeligt i Bladenes Brede, Axenes Antal, Form og gjensidige Afstand, Dækskjællenes og Frugternes Farve o.s. v. 5-6. 4 .

I Torvmoser og Kjær meget alm.

1208. C. csespitosa L. [Fr. Mant. 3, 156] (Tue.S.) Rehb. 1. c. fig. 582 ; And. VI, 59; F. D. 2547 ; H. N. VIII, 78;

*) Arterne i denne Afdeling have typisk Ax med adskilt Kjøn, men hos nogle ere $i$ Regelen, hos andre undtagelsesviis, enkelte af Axene androgyne (Nr. 1214 har saaledes i Regelen et androgynt Endeax, hos Nr. 1207, 1211, 1212, 1220 o. Al. ere de grre $q A x$ næsten altid i Spidsen $\left.0^{\pi}\right)$. Flere Arter $\mathrm{i}$ denne Afdeling tindes stundom med sammensatte $O A x$, hrorved de fare et meget forandret Udseende. Denne ilisdannelse liar jeg bl. A. iagttaget hos Nr. 1227, 1230, 1231, 1232, 1236 og 1239. 
C. pacifiea Drej. n. 911 ; C. tenuis Schum. n. 791; C. Drejeri Lang.

Straaene oprette, skarpt og ru-trekantede, 3-5-bladede; de nedre Blade meget korte, de dvre ikke saa lange som Straaet; Bladene ved Torring i handen tilbagerullede; Dakbladene smaae, kortere end Straaet, det nedre bladagtigt, med 2 Ører ved Grunden, de ovre skedeformede med en Spids; $\widehat{\delta}$ Axet alm. 1, ㅇ Axene 2-3, sildende eller kortstilkede, tat samlede, ovale eller kort valseformede; Frugterne agformet-elliptiske, nerveløse, paa begge Sider convexe, budte, med et meget kort, ikke udrandet $N a b$, længere end Drkiskjallene.

$1 / 2-1^{1} / 2^{\prime}$ høi, danner tætte Tuer med lange, frisk gronne Rodblade med møıbrune Skeder ved Grunden; Trævlenættet svagere end hos foreg., men dog tydeligt tilstede (hvilket ikke sees af Fig. i Fl. dan). Var. i Henseende til of Axenes Antal og Form, Dækskjællenes Form og Farve. 4-5. 2.

I'Torrmoser og paa Enge: $\boldsymbol{S}$ j. ikke sjelden i det nordøstlige! F. Nielstrup (12); J. Thy (23), Hodalen o. fl. St. red Hobro (16), Randers, Mariager (7), O. Velling (Dr.), Haraldslund! $S l$. Husum (16). Fra andre Egne er den mig ikke bekjendt.

* 1209. C. turfosa [Fr. Bot. not. 1843, p. 104] (Tørv-S.) And. VI, 58; H. N. X, 75 .

Straaene theformigt samlede, med eller uden Udlobere ved Grunden og meget svagt Trævlenxt ved de nedre Bladskeder; Bladene ved Tøring tilbagerullede; Frugterne nerveløse, i torret Tilstand fiintstribede, forøvrigt ligesom følgende, med hvilken den er nær beslægtet, og fra hvis var. $\gamma$, jeg navnlig ikke formaaer med Sikkerhed at adskille tørrede Exemplarer.

I Torvmoser, ikke sjelden i Sverige, men findes ogsaa, saavidt jeg af torrede Expl. kan skjonne, her i Landet ( $\boldsymbol{j}$. Dyrehaven! Aldershvile (9), Linnge ved Soro! $F$. Ollerup (12)) og maackee vil den ved nærmere Eftersogning findes paa flexe Steder, men den maa undersøges i levende Tilstand. F

bb. Rodstolkien med kortere eller langere Udløbere; Bladskederne uden Trovlencet.

1210. C. rulgaris [Fr. Mant. 3, p. 153] (Almindelig S.) And. V, 52; Relıb. l. c. fig. 580-81; H. N. VIII, 76; C. 
cæspitosa Good., H. 932; Sehum. n. 792; Drej. n. 910; F. D. 1281 og 2478.

Straaene tueformigt samlede, skarpt trekantede, forneden tæt beklædte med Blade, som næsten naae Straaets Længde; Skedemundingen ægformet, Skedehindens frie Deel kort afskaaren, budt udløbende i Midtnerven, dens forreste Deel afrundet eller næsten lige afskaaren, tynd, tidligt sønderr even, neppe naaende ndenfor Skeden; Bladene ved Tørring indrullede; Dakbladene bladagtige, uden Skede, men med 2 Ører ved Grunden, det nedre omtrent naaende Spidsen af $\hat{\circ}$ Axet; 0 Axene 1-2; \& Axene 2-4, siddende eller kortstilkede, oprette, valseformede; Frugterne oval-elliptiske, udadtil hvælvede, indadtil flade, mangenervede, med et kort, udeelt $N \propto b$, længere end de budte Dakskijol.

5-6. 4. En yderst foranderlig Plante. Blandt de talrige Afændringer i Henseende til Høiden, Voxemaaden, $q$ Axenes Form og Stilling, Frugternes og Dækskjællenes Farve o.s. v., maa fremhæves:

$\boldsymbol{\beta}$, stolonifera Hartm. Udløberne langstrakte; Straaet kort, noget krumbøiet.

$\gamma$, juncella $\mathrm{Fr}$. (H. N. X, 76). Udløbere 0, Bladene smale, børsteformigt sammenrullede, Axene fjerne, tynde og langstrakte.

$\delta$, tenuis Hartm. Bladene flade, smale og slappe, $q$ Axene fjerne, de nedre tydeligt stilkede.

Enge og Moser, meget alm. over hele Landet. - $\beta$, pra mere tor Grund, f. Ex. Overdrev; $\gamma$, i Hedemoser, sjeldnere: J. Estrup (12) og Faurholt i Vendsyssel! Hørbylund V. f. Silkeborg! Bornh. Poulsker $(20) ! \delta$, i fugtige Skove; $\boldsymbol{S}$. Dyrehaven! J. Haldum skov ved Frysenborg!

? C. aquatilis [Wahlenb. Fl. lapp. p. 246] (Vand-S.) F. D. Suppl. t. 33 ; Rehb. I. e. fig. 587; And. V, 54; H. N. III, 77.

Straaene oprette, budtkantede, jævne; Bladene i tørret Tilstand med iuchullet Rand; Dekbladene bladagtige, naae ud over Straaet, det nederste med en kort Skede; $\hat{\sigma}$ Axene $1-3$, o Axene 3-4, oprette, kølleformet-valseformede, de nedre tydelint stilkede; Frugterne smaae, tæt og regelmæssigt stillede, 
ovale, nerveløse, budte, med et meget kort, udeelt Nobb, lidet langere end Dakskjallene.

Et Expl. af deune Art findes i M. Valls Herb. med Angivelse af at være samlet $i$ Danmark, men nden Voxested (efr. Drej. i Krøy. Tidsskr. III, 422). Maa nærmere eftersigges, da dens langt nordligere Voxekreds gior dens Forekomst her i Landet tvivlsom.

Anm. C. tricostata Fr. Mant. 3, 152, And. V, 55 ; H. N. X, 75 (var.) kunde muligviis ogsaa findes $\mathrm{i}$ vor Flora. Deu beskrives med et høit (omtr. 2'), ru Straa, lange Dcelblade, Bladene flade eller ved Torring lidet tilbagerullede, $\{$ Axene $3-4$, valseformede, Frugterne tret taglagte i 8 Rader, trenervede, budte med en kort Spids. Den maa søges ved Aabredder o. a. fugtige Steder. Om C. obtusata Schum. (n. 804) horer herheu, er ikke let at afgjore, da intet Expl. er opbevaret $\mathrm{i}$ hans Herbarium, og Beskrivelsen ikke er tilstrækkeligt betegnende.

1211. C. trinervis [Degland i Lois. Fl. gall. ed. 1, II, p. 731 (Klit-S.) Drej. Symb. Caricol. tab. 7; Fr. S. Veg. Se. II, 561; Kze. Riedgr. t. 1, f. 2; F. D. 2665 ; C. frisica H. Koch i Flora 1846, p. 273.

Rodstoliken krybende; Straaet kort (3-8") og stivt, ved Grunden tæt ongivet af henvisnede Bladskeder, opret, budttrekantet, jovnt; Bladene tretsiddende, rendede, ved Tørring indrullede, i Spidsen trekantede; Dakbladene længere end Straaet, øreformigt-omskedende; $\nmid$ Axene 3 eller flere, tat samlede, valseformede; Frugterne rgformet-elliptiske, fint punkterede, 3-7-nervede, af Længde med de budte, ofte braadspidsede Dakskjoel.

Ved Slesvigs vestlige Strandbredder (Nolte), Sandklitter paa Rømø (16)! og Sylt (F. Müll.). N

Anm. De af mig undersøgte Expl. afvige fra Beskr. (hos Kumze 1. c.) ved Endeaxet i Spidsen $q$, de $2-3$ derpaa folgemle androgyne (i Spidsen $0^{7}$ ), de $2-3$ nederste $\$$, Frugterne elliptiske, med 7 Nerver (3 stærkere, 4 svagere), men stemmer forøvrigt alleles overeens med Beskr. og Afbildn. saivelsom med Expl. fra Frankrigs Vestkyst, hvor den er almindelig. Den er en god Art, beslagtet deels med C. acuta, deels med C. aquatilis, nen ved de reulede Blade og tydeligt nervede Frugter forskjellig fra begge, og i Udseende mere lig C. vulgaris.

121\%. C. acuta L. (Spidsaxet S.) H. 934; Schum. n. 803; 
Drej. n. 913 ; F. D. 2247 ; Rchb. l. c. fig. 584; And. V, 56 ; H. N. VIII, 74.

Straaet i Spidsen nikkende, skarpt og ru-trekantet; Bladene flade, i Randen tilbagerullede; Skedemundingen skjævt ægformetkredsrund, Skedehindens frie Deel kort afskaaren, bruun-hindeagtig, dens forreste Deel skjæv; Daklladene naae op over Straaet, bladagtige, det nedre uden eller med en kort Skede og 2 korte Ører ved Grunden; ô Axene 2-3, 우 Axene 3-4, langstrakt valseformede, under og efter Blomstringen nikkende, liet nedre kortstilket, de ovrige siddende; Frugterne fastsiddende, oval-elliptiske, paa begge Sider hvælvede (eller næsten kugleformede), utydeligt nervede, ende i et kort, ikke kløvet $N a b$; Dakskjæellene spidse, omtrent af Frugternes Længde.

$1^{1} / 2-3^{\prime}$ høi. Bladene alm. brede, ofte blaagromne. 5-6. Var. med fjerne eller tætsiddende $ᄋ A x$, samt i Henseende til Dækskjæl lenes og Frugtemes Form og Farve. $q$ Axene ofte i Spidsen o, var.

$\triangleright$ anomala. Alle Axene $\hat{\delta}$, bueformigt nikkende.

Ved Bredderne af Søer og Aaer, i Kjær, forekommer i alle danske Provindser. $D$ ved Bredderne af Peblingesøen ved Kbhavn!

* 1213. C. prolixa [Fr. Mant. 3, 150] And. V, 57, H. N. $\mathrm{X}, 74$.

Rodstokken uden eller med korte Udløbere; Bladene bredere, slappe, frisk grønne; 9 Acene adskilte, langstrakt valseformede, tilsidst hængende; Frugterne let affaldende, ægformede, fladtrykt-convexe, tydeligt nervede, kortere end de tilspidsede Dekksijol; forøvigt som foreg.

Paa lignende Steder som foreg.: $\boldsymbol{S} \boldsymbol{j}$. Leire (12), Sorø! $\boldsymbol{F}$. Høirup Molle (12); J. Eveldrup (Drej. herb.). Jeg har tidligere fundet den paa flere Steder, som jeg ikke nu erindrer; jeg skulde næsten formode, at den her i Laudet ikke er sjelden, men paa Grund af den foreg. Arts store Foranderlighed lian den let forvexles med denne, som den i Udseende har megen Lighed med, skjøndt den i flere Characterer nærmer sig mere til C. strjeta.

Anm. C. cemulans Drej. n. 909 (tildeels): med et kølleformet o $A x$; + Axene fjerne, xgformet-ovale; Dukbladene brede, længere end Straaet o. s. v., er en eiendommelig Form, som har en fjern Lighed med C. acuta, men hverken kan forhindes med denne eller nogen anden mig bekjendt Art. Saalænge som imidlertid kun et 
enkelt, ikke fuldstændigt Expl. foreligger, bor den neppe optages som egen Art i Floraen. (Af Drej. blev den forenet med en aldeles forskjellig Form: efr. C. paludosa). Grøfter ved Røiels Bom (Drej., 11).

\section{b. Tristigmatica (Fr.), med 3 Ar.}

aa. Frugten uden eller med meget kort Nab.

$\alpha, 1$ endestillet androgynt Ax. Frugterne fiint ru-punkterede.

1214. C. Buxbaumii [Wahlenb. Vet, ac. handl. 1803, p. 163] H. 943 ; Drej. n. 914 ; F. D. 1406 ; Rehb. I. c. fig. 589 ; And. VI, 65; H. N. VIII, 79; C. polygama Schk. Riedgr. tab. Gg. (1801); C. subulata Schum. n. 793.

Straaene skarpkantede, lidet rue, forneden omgivne af Skeder med optrævlet Næt; Skedemundingen langagtig-ægformet, Skedehindens frie Deel temmelig bred, indbøiet, spidst udløbende i Midtuerven, dens forreste Deel meget tynd, tidligt sønderreven, det nedre Dakblad omtrent af Længde med (lidet kortere eller længere end) Straaet; Endeaxet kølleformet, foroven $q$; o Axene 2-3 ovale, oprette, kortstilkede eller næsten siddende, det nedre fjernet fra, de øvre tæt ved Endeaxet; Frugterne elliptisk-ovale, budt-trekantede, tydeligt nervede, budte, med et meget kort, svagt udrandet $N a b$, omtreut af Længde med (længere eller kortere end) de braadspidsede Daklskjoel.

$1 / 2-2^{\prime}$ høi. Bladene alm. blaagrønne, Skederne rødlige. Frugterne blege, Dækskjællene sortbrune eller mørkt rødbrune, og Axene derred brogede. 6.4 .

I Tørvmoser, meget sjelden: $\boldsymbol{S} \boldsymbol{j}$. en Mose ved Farum (M. Vahl). Siden den Tid liverken funden der eller andetsteds i Landet.

$\beta, 1$ endestillet o Ax. Frugterne jævne (ikke punkterede).

1215. C. limosa L. (Dynd-S.) H. 945; Schum. n. 797 ; Drej. n. 915 ; F. D. 646 ; Rehb. 1. c. fig. 592 ; And. VII, 73; H. N. $\mathrm{X}, 71$.

Rodstokken skjært opstigende, med Udløbere; Straaene skarpt trekantede, med smale, rendede Blade, meget kortere end Straaet; Skedemundingen ægformet, Skedehindens frie Deel temnelig bred, hvid-hindeagtig, budt udløbende i Midtnerven, 
dens forreste Deel udrandet, fremragende udenfor den slappe, indfoldede Skede, der foroven er smalere end Bladpladen, Dakbladene traadformede, rendede, ved Grunden oreformigt omfattende, kortere end Straaet; $\hat{o}$ Axet linieformet; $q$ Axene 1-2, ægformet-elliptiske, langstilkede, mod Frugtmodningen hængende; Frugterne omvendt-ægformet-ovale, fladtrykt-trekantede, svagt nervede, med en meget kort, udeelt Spids, omtrent af Længde med de elliptiske, tilspidsede Dockskjoel.

$1 / 2-1^{\prime}$ høi, blaagrøn. Dækskjællene glindsende rødbrune. 5-6. ข.

I dybe Moser med Hængedynd, ikke alm.: S j. Bøllemosen ved Hillerød (Knæckenborg), Sondersøen ved Varløse (14), Ruderhegn! Lyngby Mose! Fre (10); J. Estrup i Vendsyssel (12), Sjgrring og V. Vandet i Thy (Carst), Vildsted Eø ved Løgstor (8)! Aalborg, Eveldrup (Drej. Herb.), Moser ved 'Tostrup So, alm. mellem Viborg og Skive (16), Moser ved Østbirk (2), Ribe (28); $S l$. Schirnau ved Eideren (20).

1216. C. pallescens L. (Bleg S.) H. 947 ; Schum. n. 795; Drej. n. 917; F. D. 1050; Rchb. l. c. fig. 617; And. VII, 78 ; H. N. XII, 84 (var.).

Rodstokken tueformet, uden Udløbere; Straaene foroven skarpkantet-rue; Bladene fiinthaarede og rue; Skedemundingen omvendt-ægformet, Skedehindens frie Deel temmelig bred, opret, hvid-hindeagtig, budt udløbende i Midtnerven, dens forreste Deel langt fremragende udenfor Skeden med 2 Ører og mellen disse en spids Indskjæring; Dukbladene længere end Straaet, med meget korte Skeder; $\hat{\sigma}$ Axet lancetformet; + Axene $2-3$, ovale, tætblomstrede, stilkede, mod Frugtmodningen nikkende; Frugterne ovale, budte, uden $N a b$, paa begge Sider convexe eller utydeligt trekantede, svagt stribede, omtrent ligelange med de ægformede, spidse Dakskjal.

${ }^{1 / 2}-1^{\prime}$ høi. Hele Planten guulgrøn. ơ Axet straaguult; $ᄋ$ Dækskjællene hvidhindede eller blegbrune med grøn Rygnerve. (En tilfældig Form med Dækbladene ved Grunden rynkede paatværs: $C$. undulata Kunze, Rehb. l. e. fig. 618, er neppe engang at ansee for en Afart). 5-6. 4 .

Paa høie Enge og i Skove, ikke sjelden.

1217. C. strigosa [Huds. Fl. Angl. II, p. 411] (Tyndaxet 
S.) H. 944; F. D. 1237 ; Rehb. 1. c. fig. 602 ; And. VIII, 99 ; H. N. XI, 74.

Rodstoklien tueformet, med korte Udløbere; Straaene budtkantede, jærne; Bladene brede, flade; Dukbladene bladagtige, langt omskedende, ountrent naaende Spidsen af Straaet; $q$ Axene $3-5$, smalt linieformede, fjernblomstrede, alle fjernede fra hverandre, mod Frugtmodningen hæugende, de nedre langstilkede; Doklislijollene æg-lancetfornede, spidse, hvid-hindeagtige med grøn Rygnerve, kortere end de elliptiske, nervede, trekantede, i et skjævt afstumpet, ndeelt Næb tilspidsede Frugter.

$1-2^{\prime}$ høi, frisk grøn. 5-6. 4.

I Skove, meget sjelden og kun bekjendt fra $S l$ : Kobbermglleskoven ved Flensborg (H.), Pulverholz og Louisenlund ved Slesvig (16). F

1218. C. maxima [Scop. Fl. carn. II, p. 229] (Kjæmpe-S.) C. pendula Huds.; Hans. Herb. n. 248; Rchb. I. c. fig. 604 ; C. Agastachys Ehrh.

Rodstokken tueformet; Straaene skarpkantede, oventil lidet rue; Bladene brede, flade, i Randen og paa den kjolformede Rygnerv? rue; Skedemundingen æg-lancetformet, Skedehindens frie Deel temmelig bred, indboiet, tilspidset udlobende i Mlidtnerven, dens forreste Deel vedblivende, udrandet, neppe fremragende udenfor Skeden; Dakbladene bladagtige, langt omskedende, naaende omtrent til Spidsen af Straaet; $q$ Axene $4-5$, langstrakt valseformede, tætblomstrede, bueformigt hængende, alle fjernede fra hveraudre; Dcekskjollene lancetformede, tilspidsede, brune med grøn Rygnerve, kortere end de smaae, elliptiske, trekantede, nerveløse, $\mathrm{i}$ et kort, udrandet Næb tilspidsede Frugter.

Høi $\left(2-3^{\prime}\right)$ og bredbladet, Bladene blaagrønne, Frugterne forholdsviis smaae. $6-7$. $\psi$.

I fugtige Skove, ved Bredderne af Vandløb, meget sjelden. Prof. Nolte har meddeelt mig at den er funden i Nærheden af Kobbermollen ved Flensborg (Hansen). 用

1219. C. panicea I. (Hirse-S.) H. 947; Schum. n. 796; Drej. n. 916 ; F. D. 261 ; Relsb. 1. c. fig. 607 ; And. VII, 76; H. N. IX, 75 (var.); L. Herb. VIII, 144. 
Rodstokken med Udløbere; Straaet stribet, næsten trindt, jæunt (ikke ru); Bladene brede, i Randen og paa Rygnerven lidet rue, forøvrigt jævne; Skedemundingen kredsrund-hjerteformet, Skedehindens frie Deel kort, indbøiet, meget tynd og gjennemsigtig, dens forreste Deel kort afskaaren, meget tynd og tidligt sønderreven; Dakbladene langt omskedende, af Længde med eller kortere end det tilharende $\mathrm{Ax}$, meget kortere end Straaet; $\delta$ Axet lancetformet; 오 Axene 1-3, linie-valseformede, fjernblomstrede, stilkede, oprette; Frugterne ovale med et kort $N a b$, paa begge Sider convexe, svagt nervede, lidet længere end de ægformede, budte eller lidet spidse Dakskjacl.

$1 / 2-1^{\prime}$ høi, blaagrøn. Dækskjællene kastaniebrune med hvid hindeagtig Rand og guulgrøn Midtnerve. 5-6. 4. Var.

$\beta$, sublivida Hartm.? Straaet fiint, Bladene meget smale, Frugterne og Axene mindre, det øvre $q A x$ naaer ligesaa høit som $\hat{o}$ Axet.

Paa fugtige Enge, meget alm. $\beta$, Enge ved Sorø!

$\boldsymbol{\gamma}$. $\sigma^{\pi}$ Axene flere. Frugterne ru-punkterede.

1220. C. glauca [Scop. Fl. earn. II, p. 223] (Blaagrøn S.) Drej. n. $93 \mathrm{i}$; Rehb. l. e. fig. 648 ; And. VII, 79; H.N. IX, 76; C. recurva Huds., H. 949 ; Schum. n. 801 ; F. D. 1051.

Rodstokken udskyder Udløbere; Straaet opret, jævnt, Bladene flade, i Randen og paa Underfladens kjolformede Midtnerve rue; Skedemundingen næsten kredsrund, Shedehindens frie Deel temmelig bred, afrundet, opret, bruun-hindeagtig, dens forreste Deel udrandet, tynd, lidet fremragende udover Skeden; Dokbladene bladagtige, det nedre kort øreformigt-omfattende, omtrent af Straaets Længde; $f$ Axene alm. 2; $q$ Axene ovalvalseformede, tætblomstrede, stilkede, mod Frugtmoduingen hængende; Frugterne omvendt-xgformede eller ovale, budte, med et meget kort, vorteformet $N a b$, paa begge Sider eonvexe, paa de 2 Rande svagt haarede, omtrent ligelange med de ægformede, spidse Dakkskjol. 
$1 / 2-1^{\prime}$ høi, blaagrøn. 6-7. 4. Var. med $1 O^{7} \mathrm{Ax}$ og med $q$ Axene i Spidsen androgyne, samt

B, sphcerostachya Lge., F. D. 2666 (C. thuringiaea Scbk. Handb. 4, p. 184 tab. Ppp!) 1 कै Ax; 3-5 siddende, næsten kngleformede $q$ Ax.

I lerede Grofter, ved Kildevæld, paa Enge og fugtige Steder i Skove, alm. $\beta$, i stor Mængde paa en Eng mellem Raavaddam og Strandmollen 1840 ! (senere ikke gjenfunden).

$\delta, 1 \sigma^{\pi}$ Ax. Frugterne duunharede.

ac. Dcekbladene med meget kort eller ingen Skede; Bladene rue $i$

Randen af opadvendte Smatorne.

- Rodstokien (ueformet, uden I'dlabere.

1221. C. montana L. (Bakke-S.) Drej. n. 928; F. D. 1769 ; Rehb. 1. e. fig. 633; And. VII, 85; H. N. VI, 72; C. collina Willd., H. 937.

Straaene talrige, tynde, oprette, foroven lidet rue, bladløse og kun ved Grunden omgivne af faae og korte Stcongelblade samt tætte Bladknipper med lange Blade; Dakbladene hindeagtige, omfattende og skraat afskaarne, i Spidsen udrandede med en sylformet Spids i Indskjæringen; $q$ Axene 1-2, ægformet-ovale, tætsiddende ; Frugterne omvendt-ægformetelliptiske, nervede, med et meget kort, svagt udrandet $N a b$, længere end de budte, kort braad̉spidsede Dakskjocl.

$1 / 2-1$ ' høi, frisk grøn, de nedre Bladskeder morkrøde, langs Midten nætformigt optrævlede. Bladene fra foregaaende Aar blive henvisnede siddende paa Planten og ere længere end de unge Straa. Dækskjællene og de hindeagtige Dælbblade mørkt rødbrune. 5-6. 4 .

I hoitliggende Skove og paa Bakker mellem Krat; er mlg knn bekjendt fra Halvoen og Nordsjelland: $J$. Aagarards Veirmolle i V. Hanherred (16), Dybdals Bakker ved Aalborg (Dr.), Hobro, Mariager Klosterskov (16), Fusing Slov (Dr.), Haraldslund (Estrup); Sl. Rødding (16); $\mathbf{S}$. Boserup! Jonstrup Vang! Hareskoven (Aabye), Gjels Skov! Fuglevad Molle (9), Nymolle (1), Charluttenlund!

1222. C. pilulifera L. (Kugleaxet S.) H. 937; Schum. n. 788; Drej. n. 927; Rchb. I. e. fig. 631; And. VII, 82; H. N. XII, 85 ; C. filiformis Poll., F. D. 1018 (ikke L.)

Straaene tynde, tilsidst krumbøiede, foroven lidet rue, et langt Stykke bladløse, ved Grunden med faae tætsiddende 
Blade og omgivne af talrige Bladlinipper; Skedemundingen kredsrund, Skedehindens frie Deel meget kort afskaaren, dens forreste Deel svagt udrandet, ikke naaende udover Skeden; det nedre Dakblad med 2 korte Ører ved Grunden, bladagtigt, linie-. eller sylformet; + Axene 2-3, næsten kugleformede, mere eller mindre txtsiddende; Dakskjallene ægformede, sylspidsede ved en udløbende Midtnerve, omtrent ligelange med de ovalkugleformede, nerveløse, fiinhaarede, meget kortnæbede Frugter.

$1 / 2-1^{\prime}$ høi. Dækskjællene blegbrune med grøn Midtnerve. Alm. omgivet af visne Blade ved Grunden ligesom foreg. 6-7. 2. Var.

$\beta$, longebracteata! Det nedre Dxkblad meget langt, Axene blege, det nedre ofte adskilt fra de øvige.

Paa tørre Bakker, aabne Steder i Skove o. s. v., alm. udbredt. $\beta$, i Skygge.

\footnotetext{
** Rodstokken med [dlobere.
}

1223. C. ericetorum [Poll. Fl. palat. 2, p. 580] (LyngS.) Drej. n. 929 ; F. D. 1765 ; Rchb. l. c. fig. 636; And. VII, 83 ; H. N. VII, 75 ; C. ciliata Willd., H. 937.

Straaet jevnt, tilsidst noget bøiet; det nedre Dakblad meget kort, braadspidset, hindeagtigt omfattende; $q$ Axene 1-2, tætsiddeude, ovale; Doekskjollene omvendt-ægformede, afrundede, randhaarede, med hvid-hindeagtig Rand og ikke udløbende, bruun Midtnerve, kortere end de oval-rundagtige, nerveløse, meget kortnæbede Frugter.

$1 / 4-1 / 2^{\prime}$ høi. Bladene brede, korte og stive, næsten aldeles jærne. Axene have et graaagtigt gliudsende Udseende. 5-6. 2.

Paa tørre, solaabne Bakker og Lyngheder paa Halvøen hist og her, paa Øerne sjeldnere: $\boldsymbol{S} \boldsymbol{j}$. Nedre Draby i Homsherred (19), Blæsenborg Kro ved Ledreborg (20!), Brinkerne i Frederiksdals Skov mod Fuursøen! Brede (Dr.), Ørliolm (7); B ornh. Helveds- og Paradiisbakkerne ved Nexø (20). |*

1224. C. præecox [Jacq. Fl. austr. V, p. 23, t. 446] (VaarS.) H. 936; Schum. n. 787; Drej. n. 930; F. D. 1527; Rehb. 1. c. fig. 634 ; And. VII, 84; H. N. XI, 72.

Straaet jævnt, opret; Skedemundingen næsten kredsrund, Sledehindens frie Deel kort, buefornet, dens forreste Deel lige 
afskaaren, tynd, ikke naaende udover Skeden; det nedre Dakblad kort, bladagtigt, sylformet, omfattende eller kort omskedende; + Axene $1-3$, siddende eller kortstilkede, valseformet-elliptiske; Dakskjollene ægformede, tilspidsede eller budte, bruunagtige med grøn, udløbende Nerve; Frugterne omvendtægformet-ovale, nerveløse, med et kort, svagt udrandet $N a b$, af Dækskjællenes Længde.

1/3-1' høi, Bladene brede, i Randen rue, forøvrigt jævne. Ved de brune Ax og ikke randhaarede Dækskjæl let kjendelig fra foreg. Det nedre Dækblads skede stundom forlænget. 5. 4. sjelden.

Pą tørre Marker, Bakker; ved Randen af Veie o. s. v., ikke

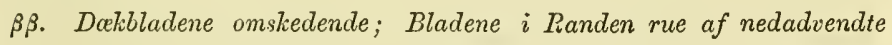
Smaatorne.

1225. C. digitata L. (Fingeraxet S.) H. 940 ; Sebum. n. 784; Drej. n. 926 ; F. D. 1466 ; Rehb. l. e. fig. 699 ; And. VII, 88 ; H. N. XI, 7 I.

Rodstokken tueformet, uden Udløbere; Straaene talrige, jævne, ved Grunden med skedeformede Blade uden eller med meget kort Flade samt tætte Bladknipper; alle Dakbladene omskedende, skjævt afskaarue, hindeagtige; + Axene 2-3, stilkede, oprette, tilsidst fjernblomstrede; Dockskjocllene oinvendtægformede, budte eller udrandede med en meget kort Braad, glindsende brune med hindeagtig Rand og grøn, ikke udløbende Midtnerve; Frugterne omvendt-ægformede, med et meget kort Nab, ligelange med Dxlsskjællene.

$6-8^{\prime \prime}$ hoi, de nedre Bladskeder rode. $q$ Axene naae ved Stilkens Forlængelse op til eller ud over $\sigma^{\prime \prime}$ Axet, hvorved Blomsterstanden faaer et fingerformet Udseende. 5-6. 4 .

Skorbrinker, især paa Leer-eller Kalkgrund, sporadisk og iklse alm.: J. Palstrup ved Viborg, Himmelbjerget (7), Yding Skov ved Skanderborg, Skaadeklint ved Aarhus (2), Brandbjerg (28), Greis Mølle (12); Sl. Kodding, Gram (1). Kobbermglleskoven ved Flensborg, Dyrehaven ved Slesvig (16); $\boldsymbol{S}$ j Alindelille Fredskov! Ledreborg (12), Kattinge ved Roeskilde! Frederiksdals Skov paa Bakkerne mod fuursøen! Brede (Dr.), Lellinge Skov ved Kjøge! Moens Klint alm.! Bornh. i Almindingen og i Skove ved Bobbe- og Kobbe-Aaen (20). 
b6. Frugtens Nab forlanget, mere eller mindre dybt tolløvet.

$$
\text { a. } 1 \text { o Ax. }
$$

«. $\subsetneq$ Axene kortstilkede, under Modenheden oprette.

1226. C. flava L. (Guul S.) H. 938; Schum. n. 789; Drej. n. 918 ; F. D. 1047 ; Rehb. 1. c. fig. 654 ; And. VII, 93 ; H. N. XIII, 82.

Straaene tæt tueformigt samlede, uden Udløbere, jævne, oprette; Bladene flade eller rendede, med kjølformet Midtnerne paa Underfladen; Skedemundingen skjævt oval, Skedehindens frie Deel temmelig kort, i Randen ujævnt bølget, afrundet, dens forreste Deel udrandet eller skraat afskaaren, naaende udenfor Skeden, Dukbladene kort omskedende, bladagtige, meget længere end Straaet, tilsidst tilbagebøiede; + Axene $2-4$, tæt ved ô Axet og indbyrdes tæt samlede, kortstilkede (det nedre ofte fjernet fra de øvrige og langstilket), oval-kugleformede; Fruyterne ægformede, opblæste, nervede, tilspidsede i et tilbagebøiet, lidet ru $N a b$ af Perigyniets Længde, længere end de budte Daclsslijal.

Omtrent $1^{\prime}$ høi, guulgrøn, $\sigma^{\prime \prime}$ Axet straaguult. 5-6. 4 .

* lepidocarpa (C. lepidocarpa Tausch, Kze. Suppl. Riedgr. t. 13 f. 2 ; H. N. X, 70). Spædere, med mindre, fra $\delta$ Axet fjernede, rundagtig-ovale $q A x$; Frugterne mindre, Næbet kortere end Perigyniet, mindre bøiet.

I Moser og paaa fugtige Enge. * er hos os meget hyppigere end Hovedarten,

Anm. De Kjendetegn, som ere anførte for C. lepidocarpa, ere neppe tilstrækkelige til at adskille demne som en særegen Art.

1227. C. Oederi [Ehrh. Calam. n. 79] H. 939; Drej. n. 919 ; Rehb. 1. c. fig. 652 ; And. VII, 92 ; H. N. V, 85; L. Herb. VIII, 142 ; C. divisa F. D. 371 ; C. flava $\beta$, Schum. n. 789 .

Stractene i trtte Tuer; Bladene smale, rendede, tilsidst i Randen indrullede; Skedemundingen kredsrund-rgformet, Skedehindens frie Deel kort, budt, dens forreste Deel lige afskaaren, lidet fremragende udenfor Skeden; $q$ Axene mindre, rundagtig. 
ovale; Frugterne smaae, ægformet-elliptiske, med svagere Nerver, tilspidsede $\mathrm{i}$ et næsten ret, ru $\mathrm{N} b$ af lidet over Perigyniets Længde; forøvigt som foreg.

2-9" høi. 5-7. En meget foranderlig Plante. Dværgformen ( $\beta$, pygmaa Anders. 1. e. p. 25) med Straene meget lave, kortere end de golde Bladknipper, er C. demissa F. D. 1342. En mere afvigende Form er:

* oedocarpa Anders. p. 25. Dxkbladene opret-aabne, omtrent af Længde med Straaet; $\widehat{\delta}$ Axet ved en tydelig Stilk fjernet fra de indbyrdes adskilte, agformet-ovale $q$ Ax; Frugterne med stærkere Nerver og læengere Næb.

Meget alm. ved Søbredder, paa oversvømmet Sandgrund og paa Torvjord, især hvor Gronsvaren nylig har været afskaaren. * (en meget afvigende Form, som synes at danne en Overgang til C. fulva - eller efter Andersson til C. speirostachya), er sjeldnere: $\boldsymbol{S} \boldsymbol{j}$. Hellebæks Vang! Teglstrup Hegn (15), O1drups Mose! Longs Almanak ved Sorg! Falst. ved Pandebjerg (Estrup)! Langel. ved Tranekjær (12).

1228. C. extensa [Good. l. e. p. 175] (Udspilet S.) H. 939; Drej. n. 920 ; F. D. 1709; Rehb. l. c. flg. 655 ; And. VII, 91 ; H. N. III, 72.

Rodstoliken tueformet, uden Udløbere; Stradene oprette, jærne; Bladene børsteformigt indrullede; Dakbladene meget længere end Straaet; tilsidst bueformigt udspilede, det nederste kort omskedende, de øvrige uden Skede; 올ene 2-4, ovale, tæt samlede og siddende (eller det nedre lidet fjernet fra de øvrige og kortstilket); Frugtcrne elliptiske, nervede, med et lige, jævnt (ikke ru) $\mathrm{Nab}$, omtrent ${ }^{1 / 3}$ af Perigyniets Lrengde; Dakskjollene ægformede, braadspidsede, kortere end Frugterne. $1 / 2-1$ ' hoi og stiv, noget blatagron. 6-7. य. Var.

$\beta$, pumila Anders. 1. c. p. 26. Strataene meget lave (1-2"), noget bøiede, kortere end de seglformigt krummede Blade.

Paa Strandenge: hist og her (ikke alm.) red Kysterne af Østersøen ou Oresundet: A $/ s$ ved Igenlaf (20); $S l$. Gelting Birk (28) og Baveror (16)! Slieminde ved Jlasholm (Jessen); Femern (16); Loll. ved Nakskor Fjord (19; ; F lst. Gronsunds Nor mellem Oureby og Nesby! Saltholm (Schlichtkrull); Christianso (H). - - $\frac{\beta}{2}$, i Vaudhuller ved Hammeren paa Hornholm! $\boldsymbol{F}$. ved Fyenshoved!

Anm. De af mig paa Falster samlede Expl. afrige red bredere, i frisk Tilstand næsten flade Blade, det nedre Drkblad langt om- 
skedende; Næhet langere (næaten af Perigyniets Længde). Maaskee horer denne til Formen C. Balbisii Spreng., Rehb. 1. c. fig. $655 \beta$.

1229. C. distans L. (Fjernaxet S.) F. D. 2434 ; Rehb. l. c. fig. 622 ; And. VIII, 96 ; H. N. VII, 76; C. binervis H. 942 ; Drej. n. 983.

Rodstoklien tueformet, uden Udløbere; Straaene jævne; Bladene flade; Skedemundingen næsten kredsrund, Skedehindens frie Deel kort: budt, noget bølget, dens forreste Deel vedblivende, fremragende udenfor Skeden i Form af et aflangt, budt, Bladpladen modsat Øre; $\hat{\sigma}$ Axenes Skjæl skident straagule; $q$ Axene 2-3, fjerne, alle stilkede (det nedre ofte langstilket), valseformet-ovale, omgivne af bladagtige, langt omskedeude Dakblade, der ere længere end de til samme hørende og næsten naae det følgende Ax; Dukslijcllene xgformede, budte med en kort Braad af den udløbende, grønne Nerve; Frugterne længere end Dækskjællene; ægformede, budt-trekantede, nervede, tilspidsede i et lidet ru (tilsidst jievnt), paa den indre Side af Spaltningen smaatornet-ru $N a b$.

$1 / 2-1 \frac{1}{1} 2^{\prime}$ høi. Bladene korte, mat- og bleggrønne, med alm. talrige og meget fine rode Punkter paa Bladskeden. Det nedre \& Ax udgaaer ofte nærved Grunden af Straaet. 6-7. 4 .

Paa Strandenge og Overdrev nærved Havet, funden $\mathrm{i}$ alle danske Provindser, men sporadisk og iklse alm.

Anm. Drejer (l. c.) beskriver Perigyniets Næb som "jærnt", hvilket jeg ogsaa har fundet paa aldre Expl, formodenlig paa Grund af at de rue Fremragninger, som i yngre Tilstand stedse ere tilstede, tidligt forsvinde. - Den ægte C. binervis Sm. er eu aldeles forskjellig Plante, som ikke er funden og neppe findes i Danmark.

1230. C. Hornschuchiana [Hoppe i Flora 1824, p. 599] (Skedestilket S.) Drej. n. 922; Rchb. l. c. fig. 621; And. VIII, 95; C. speirostachya Sin. Engl. Fl. (1828); F. D. 2249 og 1049 (C. distans); H. N. VI, 73; Lge. Haandb. 1 Udg. n. 1178 ; C distans Wablenb., H. 941 (ikke L.); C. biformis $\beta$, fertilis Schultz i Flora 1841, p. 54.

Rodstokken udskyder korte, bueformigt opstigende Udløbere; Skedehinden som hos foreg., men med et mere kort afskaaren, Bladpladen modsat Øre; $\hat{\delta}$ Axenes Dakiskjal glindsende rodbrune med 
bvid-hindeagtig Rand og grøn Rygnerve; $q$ Ax'ene 2-3, fjerne, alle stilkede, ægformet-ovale, omgivne af langt omskedende, bladagtige, smale Dakblade, der ere lidet længere end det tilharende og ikke naae det følgende + Ax; Dwkskjollene rgformede, spidse, brune med hvidhindet Rand og grøn, næsten udløbeude Rygnerve; Frugterne længere end Dækskjællene, skjævt ægformede, opstigende, par begge Sider convexe, nervede, tilspidsede i et ru Nceb uden Smaatorne i Spaltningen.

1/2-1' høi. Bladene korte, af blaagrøn Farve. Forekommer ofte med $2 \sigma^{\circ}$ Ax. 6-7. 4 .

I Enge og Torvmoser, hist og her, forekommer i de fleste Egne af Danmark, men hyppigst paa Halvøen.

* 1231. C. fulva [Good. l. c. p. 177] (Bruunguul S.) H. 942 ; Drej. n. 921 ; F. D. 2435 og 1768 (?); Rehb. l. c. fig. 620 ; And. VIll, 94 ; H. N. V, 86 ; C. biformis a, sterilis Schultz 1. c.

Rodstolken udskyder nieget korte, svagt opstigende eller næsten rette Bladknipper; Straaet ru; Dakbladene bredere, det nedre af Længde med Straaet eller idetrnindste naaende ô Axet; Frugterne med ret Næb; forøvrigt som foreg., men Bladene længere, mere frisk grønne; + Dækskjællene rødgule.

$1-1^{1 / 2^{\prime}}$ høi. 6-7. 4 .

Faa Enge mellem Buske, sjeldnere end foreg.: J. Estrup i Vendsyssel (12), Koustrup i Thy (Dr), Jehjerg mellem Struer og Holstebro (16), Haraldslund! Odder (Aabye); Sl. Rødding (7), Gram (Reimers), Husum (16); F. Otterup og Norup Moser (18), Ballen ved Ø. Skjerninge (12); Sj. Sorø! mellem Ronnede og Kjøge(Dr.), Mose mellem Ravaddam og Strandmollen!

Anm. Nogle Forff. (Selultz l. e., ef. Lang i F'lora 1847) ansee denne for en ved forandret Voxested frembragt Form af foreg., Andre for en Bastardform af C. flavi og Hornschuchiana. Mod den sidste Mening strider det, at deu ogsaa findes i Egue hvor den sidsturevnte ikke forekommer. Uagtet den Omstrudighed, at den altir (?) findes med golde Frugter, vidner imod dens Berettigelse som en egen Art, optages den dog indtil videre her som en saadan, forli den stedse har et fra foreg. temmelig forskjelligt Udseende. Overgangsformer har jeg ikke seet. - Fig. i F. D. 1768 er tegnet efter et Have Exemplar, opkommet af Fro fra Norge, og har et meget forskjelligt Udseende fra den vildvoxende.

$\beta \beta$. + Axene lanystilkede, nod Frugtmodningen hengende.

1232. C. silvatica [Huds. l. c.] (Skov-S.) H. 948; Schum. 
n. 799 ; Drej. n. 925 ; F. D. 404 ; Rchb. l. c. fig. 603 ; And. VIII, 100 ; H. N. VII, 81; L. Herb. VIII, 143; C. Drymeja Ehrh.

Rodstokken sammentrængt, med bueformigt opstigende Bladknipper; Straaet forneden jævnt, foroven ru; Skedemundingen skjævt ægformet, Skedehindens frie Deel hvid-hindeagtig, indbøiet, budt udløbende i Midtnerven, dens forreste Deel dybt udrandet, vedblivende, naaende udover Skeden; Dakbladene bladagtige, langt omskedende, af Længde med eller kortere end Straaet; $q$ Axene $3-4$, linieformede, fjernblomstrede, alle fjernede fra hinanden og langstilkede, med traadformede Axstilke; Dokskjollene lancetformede, langt tilspidsede, paa Ryggen og i Spidsen saugtakket-rue, hindeagtige med grøn Rygnerve, næsten af Længde med de elliptiske, nerveløse, i et langt, tókløvet, jærnt $N a b$ tilspidsede Frugter.

1-1 $1 \frac{1 / 2^{\prime}}{}$ høi; i Henseende til Bladene og Plantens Farve meget lig C. strigosa, men ved Frugter og Dækskjæl aldeles forskjellig fra denne. 6-7. 4 .

I skyggefulde Lørskove, alm. udbredt.

1233. C. Pseudocyperus L. (Knippeaxet S.) H. 949; Schum. n. 800 ; Drej. n. 924 ; F. D. 1117; Rehb. l. c. fig. 657 ; And. VIII, 111 ; H. N. XI, 75.

Rodstokken tueformet, uden Udløbere; Straaet skarpt trekantet med rue Kanter; Skedemundingen langagtig-ægformet, Skedelindens frie Deel temmelig kort, spidst udløbende i Midtnerven, dens forreste Deel svagt udrandet, tynd, tidligt sønderreven, lidet fremragende udenfor Skeden; Dakbladene bladagtige, naae langt ud over $\delta$ Axet, de nedre med en kort, de øvre uden Skede; $\$$ Axene $3-6$, tætsiddende, valseformede, tætblomstrede, alle langstilkede; Dockskijcllene sylformede, langt tilspidsede, fra Midten til Spidsen randhaaret-rue, af Længde med eller længere end de bueformigt-bøiede, nervede, i et langt, dybt tokløvet, jævnt $N a b$ tilspidsede Frugter.

$1^{1} / 2-2^{\prime}$ h $ø$ i, stor og smuk Starart, hele Planten frisk grøn, Bladene brede, meget rue, de nedre Bladskeder med optrævlet Nat. 6-7. భ. 
I dybe Moser og ved Sobredder, ikke sjelden; i enkelte Egne af Jyll. sparsom, f. Ex. omkring Randers og Aarhus.

\section{B. O' Axene i Regelen flere. ace. Frugterne glatte.}

1234. C. resicaria L. (Blære-S.) H. 952 ; Schum. n. 807 ; Dréj. n. 933 ; F. D. 647 ; Rechb. l. e. fig. 658 ; And. VIII, 107 ; H. N. XIV, 81.

Rodstokken krybende; Straaet skarpt trekantet med rue Kanter; Bladene flade, frisk grønne; Skedemundingen langagtigægformet, Skedehindens frie Deel kort, spidst udløbende i Midtnerven, dens forreste Deel bueformet, vedblivende, lidet fremragende udenfor Skeden; Dakbladene bladagtige, det nedre omtrent naaende Spidsen af Straaet, dets skede meget kort, Dieformet; $1-3$ ơ $A x$; + Axene $2-4$, elliptiske eller ovale, de nedre stilkede, mod Modenheden nikkende; Dakskjallene æglaucetformede, tilspidsede, jevne, meget kortere end de opretaabne, opblæst-ægformede, nervede, i et tokløvet $N a b$ tilspidsede Frugter.

1-2' høi. Hele Planten frisk gron, de nedre Bladskeder nætformint optrævlede. 5-6. భ. Var. i Henseende til $q$ Axenes Form og Axstilkenes Længde.

I Moser og ved Søbredder, alm. i Danmark.

1235. C. ampullacea [Good. l. c. p. 207] (Tosnablet S.) H. 952 ; Schum. 808 og 809 (C. obtusangula); Drej. n. 932; F. D. 2248 ; Rehb. l. e. fig. 659 ; And. VIII, 106; H. N. $\mathrm{X}, 73$.

Rodstokken krybende; Straaet budt trekantet med jærue Kanter (foroven mellem Axene lidet rue); Bladene blaagrønne, rendede, med indrullet Rand; Sliedemundingen kredsrund eller omvendt-hjerteformet, Skedehindens frie Deel kort, udrandet, blegbruun-hindengtig, dens forreste Deel bueformet, lidet fremragende udenfor Skeden; + Axene 2-4, valseformede, oprette eller de nedre nikkenủe, paa kortere eller længere Stilke; Dakskjallene spidse (ikke tilspidsede); Frugterne nasten kugleformetopblaste, udspærrede; forøvrigt som foreg. 
$1 / 2-1^{\prime}$ høi. Let kjendelig fra foreg. ved den mere blaagrønne Farre og de mere guulagtige $q$ Ax. Frugterne mindre, men mere kugleformede. 6. (omtrent 8 Dage senere end foreg.). $\psi$.

$\beta$, robusta Sond. Fl. hamburg. p. 505, 3-4' høi, med bredere og mere flade Blade, $3-5 \hat{f} \mathrm{Ax}$, $\$$ Axene tykkere (ofte i Spidsen $\widehat{\sigma}$ ), større Frugter.

I Torv- og Herlemoser, Enggrøfter o. s. v., meget alm. $\beta$, Klingstrup Molledam i Fyen (14)!

1236. C. riparia [Curt. Fl. Lond. IV, t. 60] (Tykaxet S.) H. 951 ; Scluum. n. 806 ; Drej. n. 935 ; F. D. 1118 ; Rehb. I. c. fig. 647 ; And. VIII, 110; H. N. IX, 78.

Rodstoklien med krybende Udløbere; Straaet skarpt trekantet, oventil ru; Bladene flade; Skedemundingen rundagtig. ægformet, Skedehindens frie Deel temmelig bred, opret, budt udløbende i Midtnerven, dens forreste Deel udrandet, tynd, ikke fremragende udenfor Skeden, som er nætformigt optrævlet langs Midten; de nedre Dokblade kort omskedende, naaende op til eller ud over Spidsen af Straaet; $\hat{o}$ Axene 2-5, tykke; ㅇ Axene 3-4, elliptisk-valseformede, de nedre langstilkede, mod Modenheden nikkende, de фvre kortstilkede, oprette; Dakskjollene rg-lancetformede, langt tilspidsede, i Spidsen saugtakket-rue, omtrent ligelange med de ægformede, paa begge Sider convexe, mangenervede, i et kort tokløvet $\mathrm{Nab}$ tilspidsede Frugter.

2-4' høi (en af de storste danske Carices), Bladene brede (indtil $\left.1 / 2^{\prime \prime}\right)$. O og $ᄋ$ Axenes Dækskjæl brune. 6-7. 4 .

$\beta$, gracilescens Hartm. (Anders. l. c.). Straaet mere ru, Bladene snalere, $\Varangle$ Axene forlængede, oprette; Frugternes $\mathrm{Næb}$ mere dybt kløvet.

I dybe Moser og Kjær, ved Aa- og Søbredder: funden i alle Provindser (undt. Bornh.), men ikke alm. - $\beta$, Ordrups Mose ved Kbhavu!

1237. C. paludosa [Good. 1. c. p. 202] (Kjær-S.) H. 951; Schum. n. 805 ; Drej. n. 934 ; F. D. 1767 (et ungt Expl.); Rehb. l. c. fig. 644 ; And. VIII, 109; H. N. IX, 77, 
Straaet skarpt trekantet, ru; Skedemundingen langagtigægformet, Skedehindens frie Deel temmelig bred, brum-hindeagtig, budt udlobende i Midtnerven, dens forreste Deel udrandet, tynd og tidligt sønderreven, lidet fremragende udenfor Skeden; of Axene 1-2; $\$$ Axene 2-4, oprette, det nedre kortstilket, de øvre siddende; Frugterne ægformet-elliptiske, budt trekantede; de nedre Bladskeder nætformigt optravlede; forøvigt som foreg., fra hvilken den desuden kjendes ved smalere og mere rue Blade, færre og tyudere Ax.

2-3' høi og stiv, blaagrøn, meget $r u$ 6. 2. Var. med 2 og $3 \mathrm{Ar}$, samt $\mathrm{i}$ Henseende til Antal og Form af Axene, Dækskjællenes Lrengde o.s.v. De meest afvigende Former ere:

$\beta$, spadicea Roth ( $\beta$, elongata Schum. 1. e.; C. Kochiana DC., Rchb. l. c. fig. 651). \& Axene længere og tyndere, alle stilkede, tilsidst udstaaende; Dxkskjellene langt og hvast tilspidsede, lidet langere end Frugteme; Bladene alm. smalere.

$\gamma$, depauperata Lge. (Bot. not. 1849 p. 165); C. æmulans Drej. (tildeels). 1 kølleformet $\hat{o} \mathrm{Ax}, 3$ ovale eller rundagtige $\mathrm{OAx}$; Bladene smalere; oftest $2 \mathrm{Ar}$.

Paa lignende Steder som foreg, men mere alm. udbredt. $\beta$, Skoven mellem Ermelund og Ordrups Mose! $\gamma$, paa udtorret Mosebund: $\boldsymbol{F}$. Rodkilde (12); $\boldsymbol{S} \boldsymbol{j}$. ved Lyngby $\mathbf{S} \emptyset$ ! Ørholm! ved Fuxveien indenfor Dyrehavegjærdet!

Anm. Den under $\gamma$, anforte Plante, som synes at være en ved et mere tort Voxested frembragt, i Delenes Ansal og Størrelse reduceret Form, er af Drej. (l. c p. 291) forenet med C. cemulans, men er aldeles forskjellig fra det Expl., hrorpaa hiin Arts Beskrivelse fornemmelig var grundet (cf. p. 688 Anm.).

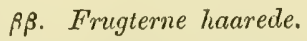

1238. C. filiformis L. (Traad-S.) H. 950 ; Sehum. n. 790 ; Drej. n. 936 ; F. D. 379 (C. hirta) og 1344; Rebb. 1. c. fig. 643 ; And. VIII, 103 ; H. N. 1X, 79.

Rodstokken krybende; Straact budtkantet, javnt, oventil lidet ru; Bladene og Dekbladene traadformigt indrullede, glatte, paa Overfladen rue; Dækbladene længere end Straact, uden Skede, det nedre ined korte Ører ved Grunden; के Axene 1-2, linie-laneetformede, med glatte, lancetformede, spidse 
Dækskjæl; $q$ Axene 2-3, siddende eller det nedre kortstilket, lancetformede eller elliptisk-valseformede, oprette; Dakskjallene tilspidset-lancetformede, brune med hvidguul Rygnerve; Frugterne elliptiske, opblæste, med et kort, dybt tokløvet Nobl.

$1^{1 / 1} / 2-3^{\prime}$ høi, tynd og rank, lettest kjendelig' ved de traadsmale, sammenrullede Blade. De nedre Bladskeder med Trævlenæt. 6-7. 4 .

I dybe Kjær og ved Søbredder, hist og her, men ikke alm. Fra B or $n h$. har jeg ikke seet Expl.

1239. C. hirta L. (Haaret S.) H. 953 ; Sehum. n. 810 ; Drej. n. 937 ; F. D. 425 (ungt Expl., Axet Tab. 379 tilvenstre); Rchb. l. e. fig. 628; And. VIII, 101.

Rodstokken vidtkryhende; Straaet skarpt trekantet, jævnt; Bladene flade, tilligemed Skederne haarede; Skedemundingen kredsrund, Skedehindens frie Deel kort, tyk og i Spidsen u'l randet, tilligemed den forreste Deel randhaaret; Dakbladene b]: 1 agtige, omskedende, omtrent af Læungde med Stranet; $\hat{\delta}$ Axeme 1 -2, lancetformede, med omvendt-ægformede, i Randen og paa Ryggen haarede Dækskjæl; + Axene 2-3, elliptiske eller lancetformede, oprette, stilkede; Dakskjollene æg-lancetformede, langt tilspidsede, i Spidsen randhaaret-rue, hindeagtige, i Midten grøune, omtrent femnervede; Frugterne ægformede, tilspidsede i et langt tokløvet $N a b$.

${ }^{4} / 2-1^{1 / 2^{\prime}}$ høi. Graaagtig af den tætte Beklædning. 6-7. భ. Var.

$\beta$, sublavis Horn. F. D. 1711 ; C. hirtæformis Pers. Hele Planten, undtagen Frugterne, glat, grøn.

Meget hyppig, saavel paa torre son oversvommede Steder, især paa Sandgrund. $-\boldsymbol{\beta}$, ved Strandbredder og paa fugtige Steder: $\mathbf{S} \boldsymbol{j}$. en Groft ved Frederiksdal! F a lst. paa flere Steder (14); Loll. Steensgaard (19); $d l s$ ved Søuderborg (H.).

\section{Amarantus. Amarant.}

$\dagger$ 1240. A. Blitum L. (Fremliggende A.) H. 957; F. D. 2246 ; Rchb. ic. crit. V, 663 ; H. N. I, 55; Euxolus viridis Moq Tand. i DC. Prodr. XIII, 2, 273.

Stconglerne fremliggende; Bladene afvexlende, langstilkede, 
æg-rudeformede, budte, i Spidsen indtrykte; Blomsterne nøgleformigt samlede i Bladhjornerne og i Spidsen af Stængelen dannende et bladlast $\mathrm{Ax} ; 3$ Dalulade ved Grunden af Blomsterdækket, omtrent halut saa lange som dette.

Bladene var. plettede. Blomsterne gronlige. 7-9. $\odot$.

Ukrudsplante i Haver o. a. dyrkede Steder, formodenlig indført med Urtefro og hidtil kun funden paa faae Steder: $\boldsymbol{S} j$. Fredensborg Slotshave (9), Amager ved Götchens Batteri! Haver i Classens Vænge (Benzon) o. fl. St onkking Kbhavn (Didr., 12); Me en ved Stege (H); F a lst. Overup, Nykjøbing (14); Loll. Nakskov i Haver og paa Gader $(9,19)$; B or $n h$. Ukrud i Haver i Ronne (8). $\overline{\$}$

\section{Tetrapdria.}

\section{Littorella. Strandbo.}

1241. L. lacustris L. (Liden S.) H. 954; Drej. n. 940; Rehb. ic. fl. germ. XVII, 1116 ; Plantago uniflora F. D. 170.

Bladiene meget smalt linieformede, rendede, ved Grunden omskedende, tiligemed de enblomstrede Blomsterstillc adgaaende fra Rodstokken; Stovtraadene lange, haarfine.

1-2" bøi. 6-7. 4 .

Ved Sobredder, især par sandig Grund: paa Bornholm og i Halvoens Hedeegne ikke sjelden, paa Øerne sparsom: $\boldsymbol{F}$. Hals ved Hofmancgave (H.); $\boldsymbol{S}$. Nykjøbing (H.), Rørvig (Schum.), Skarritsø! Tjustrup Sø (Weilb.), Frederikssund (H), Gurre Sø (11), Donze (II.), Ruderhegn (26), Emdrup, Damhuset (H.); Loll. Maribo Sis (Kóoh), Borg $\emptyset$, Heirede $\mathrm{S} \emptyset$ (Kherre Wichfeld). Paa Falst. skke bemærket.

\section{Urtica. Nalde.}

1242. U. urens L. (Brænde-N.) H. 957; I)rej. 11. 941; F. D. 739 ; Rchb. ic. fl. germ. XII, fig. 1320.

Bladene modsatte, ovale eller elliptiske, fliget-saugtakkede; Blomsterne enbo, i parviis stillede Nogler fra Bladhjørnerne; Nøglerne kortere end Bladstilken.

$1 / 2-1$ ' høi, frisk gron. 6-9. $\odot$.

I dyrket Jord, især i Haver, et almindeligt Ukrud. 
1243. U. dioeca L. (Trebo-N.) H. 958 ; Drej. n. 942 ; F. D. 746 ; Rehb. 1. e. fig. 1324 .

Rodstokikn kryhende; Bladene modsatte, æg-hjerteformede, langt tilspidsede, skarpt saugtakkede; Blomsternøglerne samlede i grenede $A x, 2-3$ fra hvert Bladhjørne, hængende, langere end Bladstilken. Trebo.

1-3' høi. Bladene var. bredere eller smalere, paa unge Skud ofte dybt haandfligede, af morkere og mere mat gron Farve end foreg. $7-8$. $\psi$.

Ved Gjærder, i Skove og paa 'andre udyrkede Steder alm. En Form med de nedre Ax $Q$, de mellemste og $ø$ rre $\mathrm{i}$ Spidsen $\sigma^{*} \mathrm{og}$ $\zeta(\beta$, polygama!) har jeg fundet ved Kalkbrienderiet .N. for Kbhrn.!

Ann. Begge Arter ere beklædte med Brændeborster, som red Berøring udgyde en brændende Satt i Huden.

\section{Aluus. Ri.}

1244. A. glutinosa [Gärtu. fruet. 2, t. 90] (Rød Æ.) H. 955 ; Drej. n. 939 ; F. D. 2301 ; Rchb. I. c. Xll, fig. 1295 ; Betula Alnus $\alpha$, glutinosa L.

Bladene rundagtige, ved Grunden kileformede, i Spidsen budte eller udrandede, nregelm. tandet-saugtakkede, rynkede, i Vinklerne mellem Aarerne paa Underfladen dnnede, forovrigt glatte, paa begge Flader grøne, klabrige; + Raklerne ovale.

Høit Træ med rodguult Ved og mørk graabruun, tidligt revnende Bark. ${ }_{2}^{3}-4$. (fr. 8-9). h.

I fugtige Slsove og Moser, alm. udbredt.

1245. A. incana [DC. Fl. fr. 3, 304] (Graa E.) H. 956; Drej. n. 938; F. D. 2302; Rehb. I. e. fig. 1291; Betula Alnus $\beta$, incana $L$.

Bladene ægformede, spidse, dobbelt saugtakkede, rynkede, paa Underfladen overalt graagtigt duunhaarede; $q$ Raklerne ovale, længere end hos foreg,, men paa kortere Stilke.

Barken graa, glat, Vedet mere hvidt end hos foreg. 3 (mindst 14 Dage tidligere end hos foreg.). (fr. S-9). $h_{2}$.

Plantes ikke sjeldent; forekommer desuden stundom i Udkanten af Skove og Moser, nen sjeldnere end foreg. if. Ex. mellem Bagsvard og Joustrup!) og er sandsyuligviis ikke vildvoxende i Daumark. is 


\section{Betula. Birk.}

1246. B. verrucosa [Ehrh. Beitr. 6, 98] (Vorte-B.) F. D. 2549 ; Fr. S. Veg. Se. p. 211 ; B. alba L. (tildeels), Koch Syn. II, 760 ; B. odorata Rehb. l. e. fig. 1288 (ikke Bechst.)

Bladene $æ g$-triangelformede eller rudeformede, langt tilspidsede, grovt og dobbelt saugtakkede; $q$ Rakleskjollene langstilkede, med bredt triangelformet, tiltrykt Mlidtflig og halvmaaneformet tilbagebøiede Sideflige; Frugten med en Vinge dobbelt saa bred som det elliptiske Fro og naaende op til Spidsen af Griflerne.

Hoit Træ. Barken hvid, hos det gamle Træ bruun, revnet, Grenene tynde, ofte hiengende $(\boldsymbol{\beta}$, pendula), de unge alm. rue af talrige gjennemsigtige Vorter. 4-5 (fr. 7-8).

I Skove og Torvmoser: paa Bornh. og i enkelte Egne af Halve en ilke sjelden i Skovene, sparsommere paa $\theta$ erne.

1247. B. odorata [Bechstein Diana I, p. 74 t. 1] (Klabrig B.) Hentze i Bot. Zeit. 1848, p. 107; B. alba L. (Fr.), F. D. 1467 ; Retıb. l. e. fig. 1282 ; B. glutinosa Wallr., Fr. S. Veg. Se. p. 212 , ef. p. 5.56 ; H. N. II, 54.

Bladene agformede, spirlse, enkelt eller dobbelt og mere fint-saugtakkede; 9 Rakleslijallene ko:tstilke le ined en udstaaende Midılig, Sidefigene afrundede, lige udstanende; Frugtens Vinger bredere end (ihke dobbelt saa brede som) det omvendt-ægformede Fro og kun lidet lingrere end dette.

Hoit Træ med hvid Bark, Gremene tylkkere end hos foreg. (sjeldnere hængende), Knopperne og de unge Blade klabrige. 4-5. (fr. 7-8). Var.

$\beta$, tiliafolia Læstad. (Nya bot. Not. 1856, p. 106 t. 3 f. 9). Bladene store, (omtrent af Storrelse som Bladene af Tilia parvifolia) rundagtig-hjerteformede, næsten til Grunden rundtakket-saugtakliede.

* pubescens (B. pubescens Ehrh., H. II, 284 ?). Lavere, oftest buskagtig, Bladene og de unge Grene duunharede; \& Raklerne kortstilkede, oprette, Rakleskjællenes Midtlig for- 
længet, Sidefligene afrundede, noget bueformigt tilbagebøiede; Frugtens Vinger naae næsten op til Griflernes Spidse.

** carpathica (B. earpatbica Willd., Hentze l. c. p. 108; B. carpath. $\gamma$, bereynica Rchb. I. e. fig. 1286). Bladene elliptisk-rudeformede, indtil nedenfor Midten skarpt og dobbelt saugtakkede; de frugtbærende Rakler kortstilkede, oprette; Kakleskjællene længere stilkede, med skjævt afrundede Sideflige; forøvigt som Hovedarten.

Hovedarten liyppigt plantet i Skove, sjeldent vildvoxende: $\boldsymbol{S}$. Helsingør! Holmegaardsmosen! $\beta$, Tibirke Mose! - * ikke sjelden i Moser og fugtige Kratskove. ** i Skovene ved Silkeborg!

Anm. Birkearternes rette Begrændsning er endnu langt fra at være klar, og om Synonymien ere de fleste Forff. uenige. Ogsaa om Arternes Begrændsning ere Meningerne yderst forskjellige, idet Nogle adskille mange flere end de her nævnte Former som egne Arter, Andre derimod forene alle disse tilligemed B. verrueosa under det linnéiske Navn $B$. alba. Den udforlige Beskrivelse af $B$, odorata Bechst., som er meddelt af Hentze (l. c.), passer aldeles paa den Art, som alm. er kaldt B. glutinosa. De under * og ** anførte Former ere meget forskjellige fra Hovedarten, og muligviis virkelige Arter. * pubescens nærmer sig i Henseende til Frngterne I3. verrueosa; den maa ikke forvexles med de mige eller buskagtige Expl. af B. odorata, som have en stærk Haarbeklædning. Behaaringen kan overhovedet neppe benyttes til Adskillelse mellem Arterne, da ogsaa B. verrucosa forekommer haaret $\mathrm{i}$ ung 'Tilstand.

\section{Morus. Morbartra.}

† M. alba L. (Hvidt M.) Rehb. ic. fl. germ. XII, fig. 657.

Bladene ægformede, grovt saugtakkede eller lappede; o Axene af Længde med eller kortere end Blomsterstilkene; Blomsterdalkets Blade i Randen glatte; den boragtige Frugtstand ved Mlodenheden hrid eller blegrød, af vandagtig Smag. $5-6$.

Oprindelig hjemmehørende i Orienten, dyrkes i de senere Aar hist og her som Aæringsplante for Silkeorme.

† M. nigra L. (Sort M.) Rehb. 1. c. fig. 658.

Bladene hjerteformede, nindre dybt saugtakkede, men mørkere og mere rue end hos foreg.; $q$ Axene meget langere end Blomsterstilkene eller næsten siddende; Blomsterdukkets 
Blade randhaarede; Frugtstanden ved Modenheden sortrød, velsmagende.

Høiere og med større Frugter end foreg., frembringer her i Landet kun sjeldent ơ Ax. 6. (Fr. 8-9). Ћ.

Dens Hjem er Orienten, den plantes hyppig i Haver paa Grund af dens spiselige Frugter.

\section{Pentandria.}

\section{Atriplex. Mielde. *)}

a. Dichospermum Dumort. Fleerbo: + : Blomsterdakket tobladet, Frugten lodret; $\not$ : Blomsterdxkket $3-5$-deelt, Frugten vandret.

$\dagger$. hortensis L. (Have-M.) H. II, 151; Westerlund Sv. Atripl. p. 29 ; Schk. Handb. t. 349.

*) Begrændsningen af Arterne i denne Slægt er forbunden med ikke faa Vanskeligheder, deels fordi de kun med nogenlunde Sikkerhed kunne bestemmes naar Frugterne og Blomsterdxkket ere fuldvorne (hvilket hos os sædvanligt indtræffer fra Slutningen af August til September), deels fordi Organerne ere saa foranderlige og Formerne som Folge deraf saa mangfoldige, at det vilde vare let at opstille ligesaa mange Arter som man har Exemplarer i sit Herbarium. De vigtigste Kjendetegn hentes fra $q$ Blumsterdækket, Frugten og Frotet samt Bladenes Form og Indskjering, men da selv intet af disse Organer er aldeles constant indenfor hver eukelt Art, er en fyldestgjorende Beskrivelse af de typiske Arter og deres meest eiendommelige Udviklingsformer saare vauskelig. At andre Botanikere, som have beskjæftiget sig med denne Slægt, have følt lignende Vanskeligheder, deron vidue de hyppige Uovereensstemmelser eller endog Modsigelser i Beskrivelsen af de med samme Navn betegnede Arter eller Afarter hos forskjellige Forfuttere. Jeg er tilbojelig til at troe, at flere af de afvigende Former ere frembragte ved Krydsning mellem de forskjellige Arter, som ofte voxe i Mrngde samlede i store Strækninger langs vore Kyster, men da jeg ikke er saa heldig at have havt Leilighed til at anstille Forsøg, hvormed jeg kunde bestyrke eller be- 
Stcongelen opret; Bladene muurskeeformede eller hjerteformede, tandede, de øvre aflang-spydformede; de frugtbærende Blomsterdakker rundagtig-ægformede, heelrandede, nætformigt aarede.

Hele Planten lysgrøn, undertiden findes en Var. med blodrøde Blade. 7-8. $\odot$.

Dyrkes i Haver og forekommer undertiden forvildet, f. Ex. $S \boldsymbol{j}$. Helsingør (Heiberg)! F. Østerøen o. fl. St. ved Nyborg (Lund).

$\dagger$ A. nitens [Rebent. Fl. Neomarch. p. 126]. Westerlund l. c. p. 29 ; Schkuhr Handb. t. 348 .

Bladene triangel-spydformede, dybt tandede eller forneden bugtet-lappede, paa Overfladen mørkgrønne, paa. Underfladen sølvglindsende af tiltrykte Skjæl; de frugtbærende Blomsterdakker ægformede, kort tilspidsede; forøvrigt som foreg.

\section{7-8. $\odot$.}

Vild i det sydøstlige Europa, funden forvildet i Loll. ved Maribo og Taars Firgegaard (19)!

b. Enbo. $q$ Blomsterdækket mere eller mindre dybt tokløvet; Frugten lodret.

aa. Obionopsis Lge. Stovknapperne gule. $q$ Blomsterdakket ved Frugtmodningen fra Grunden til Midten bruskagtigt, omtrent til Midten todeelt.

1248. A. arenaria [Woods, Bab. Man. ed. 3, p. 271] (Sølvbladet M.) A. laciniata H. 288; Engl. Bot. t. 165; F. D. 1284 ; A. crassifolia Gren. \& Godr. A. Fr. III, 10; Lge. Haandb. 1 Udg. n. 1199 (undt. synon.); A. rosea Mloq. i DC. prodr. XIII, 2, p. 92 (tildeels), Rafn 2, 236? A. rosea-arenaria Westerlund l. c. p. 82 .

vise denne Formodning, henleder jeg de danske Botanikeres Opmærksomhed paa dette Punkt, som ikke vil være uden Betydning med Hensyn til Arternes Bestemmelse. Ved Bearbeidelsen af Atriplex-Slægten i nærv. Udgave har jeg benyttet $C$. A. Westerlund, Bidrag till kännedomen af Sveriges Atriplices, Lund 1861, et Arbeide, der indeholder flere værdifulde Iagttagelser. 
Stanglerne udbredte eller opstigende, kantede, uden affarvede Striber*), med udspilede Grene; Bladene æg-murskeeformede, budt- og rundbugtet-tandede, stundom nasten trelappede, de nedre modsatte, budte, de ovre spredte, lancetspydformede, ổ Blomsterne tæet samlede $\mathrm{i}$ Ax foroven, + Blomsterne adskilte, knippestillede eller enlige i Bladbjørnerne;

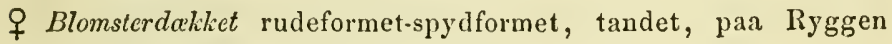
vortet; "Frøcne ujarne, glands]øse".

Bladene kjodfulde, (tilligemed Stængelen) graangtige, især paa Underfladen, af en tæet Belilædning med hvidgraae Skjæl. 8-9. $\odot$.

$\beta$, parvifolia (A. rosea $\delta$, parvifolia Moq. 1. e.). Spad og udstrakt, med meget smaae, rundagtige, svagt rundbugtede eller heelrandede og minulre kjødfulde Blade.

Ved Strandbredder, sjelden: J. Røddal ved Limfjorden (Beek). Blaavands-Huk (28)! Sonderhoe paa Fanø (14)! Fohr (M. Vahl, Nolt. Sehiøtz!); $\boldsymbol{F}$ alst. ved Gjedserodde (H.); $\mathbf{S}$. Frederikssund (Ratin)? $\beta$, Diger ved Husum! i:

Anm. Den her beskrevne og i Fl. dan. 1284 aflildede Plante, som synes at vaere almindelig udbreit langs det vestlige Europas Kyster, har været henført til forskjellige Arter, uden at det, saavidt jeg skjønmer, endnı er godtgjort, on den henligrer til nogen af clisse, eller om den ikke rettere man ansees for en sierskilt Art, hvilkut jeg anseer for rimeligt. I saa Fald bor den formeentlig beholde det af de nyere eugelske Botanikere brugte Navn A. arenaria. Jeg lar tidligere med Grenier \& Godion o. Fl. henfort dentil A. crassifolia Mey., men denne altaiske Plante afviger, ifolge Ledebours Athilıning og Expl. i Hornemanns Herbarium, narnlig vel de mindre og axformigt sammentrængte O Blomster; altfor megret fra vor Art til at kumne forenes med denne. ${ }^{+}$Den ved Hallands og Bolnusläns Kyster voxende $A$. crassifolia Fr. er forskjellig sarvel fria Meyers og Ledebours Plante som fra den her omhandlede; Expl. fra Dr. Lindeberg tilliore tolgende Afleling og stemme aldeles overeens med anthentislie Expl. af $A$. Babingtonii tra England, meddeelte af Babington. Af de aeldre engelske Botanikere, af Hornem. o. Fl. er vor Plante henærnt A. laciniata L. Sp., (ikke Fl. snee.), men dette (sandsynligviis collective) Navn anvendes, 1 almindeligt paa en syd- og gsteuropaisk Plante, som er forskjellig ved mere opret Stængel, længere, smalere og mere spidst fligede Blade, mindre og paa Ryggen sjeldent vortede Blomsterdakker, som ere mere tat samlede $\mathrm{j}$ nellembrudte $\mathrm{Ax}$ uden mellemliggende Blade (ef. H. N. XIV, 59). Nærmest forekommer den mig at vare beslægtet med A. rosea L., hvortil Fl. dan. 1284 ogsan citeres af Moquin (1. c.), og muligviis er den (saaledes som Westerlund l. c. antager), en Strandform af denne meget polymorplie Plante, skjoudt

*) Hos alle (?) Arter af Atdelingen bb er Stangelen forsynet med stærke affarvede Længdestriber. 
den ikke stemmer nøie overeens med nogen af de hos Moq. anforte Varieteter og skjondt de Expl. af den typiske A. rosea som jeg har sammenlignet, deels fra Sverige, deels fra det sydlige Europa, ere betydeligt forskjellige, f. Ex. ved en mindre skjældælst Stæugel og Blade, mindre Blomsterdækker, glindsende Frøe o.s. v. Den ægte A. rosea findes neppe i Danmark, thi de af Rafn anforte Voxesteder ere tvivlsomme.

6b. Teutliopsis Dumort. Stфvknapperne for Bestøvningen oftest rode. $\quad$ o Blomsterdwkket bladagtigt, til nedenfor Midten eller nasten til Grunden todeelt.

1249. A. Babingtonii [Woods i Bab. Man. ed. 3, p. 270] (Tykbladet M.) Lindeberg nov. fl. Suec. p. 22, t. 2; Westerlund 1. e. p. 39 ; A. rosea Bab. Monogr. Atripl. p. 13, E. B. Suppl. t. 2880 (ikke L.); A. crassifolia Fr. mant. 3, 163; S. Veg. Scand. p. 201 (ikke C. A. Mey. eller Godr.); H. N. $\mathrm{X} 1 \mathrm{~V}, 60$.

Stcengelen udstrakt eller opstigende, bugtet, med udspilede Grene, i yngre Tilstand beklædte med hvidgraae Skjæl; Bladene xg-triangelformede, bugtet-tandede med $1-2$ større Lapper ved Grunden (og derved ofte spydformede); $\{$ Blomsterdakket tykt og kjødfuldt, til lidet nedenfor Midten todeelt, dets Flige rudeformet-ægformede med en kort Spids, svagt tandede og paa Ryggen vortede; Frøene ujævne, glandsløse.

8-9. $\odot$. Danner i flere Henseender et Overgangsled mellem foreg. Afdeling $\mathrm{og}$ de folgende Arter, $\mathrm{j}$ Habitus især lig A. hastata $\beta$, salina. Bladene oftest afvexlende, tykke $\mathrm{gg}$ kjødfulde, alm. beklædte ned Skjæel eller Meel, var.

$\beta$, virescens Lge. Større og kraftigere, med næsten grønne Blade og mere tandet Blomsteriakke.

Ved Strandbredler: $\boldsymbol{S}$ j. Hellebæk! Flaskekroen! Ostkysten af Amager (Lindeberg)! J. Toftlands Klint paa Fohr? (20). $\quad \boldsymbol{\beta}$, Strandbredder paa Avernako (12)! Dragor paa Amager! Hornbak! Sandsynligviis vil den ved nærmere at efterspores findes paa flere Steder.

1250. A. hastata L. [Fr. Mant. 3, 162] (Spydbladet M.) Rafn. II, 238; H. 288 (undt. var. 3); F. D. 1286; A. latifolia Wahlenb., Drej. n. 302.

Stangelen opret eller nedliggende; de nedre Grone ud- 
spilede; Bladene spydformede, med vandret udstaaende Lapper, tandede, de ovre lancetformede, heelrandede; Blomsternoglerne samlede til forneden mellembrudte Ax; \& Blomsterdnkket uæsten til Grunden todeelt, dets Afsnit triangel-murskeeformede, heelrandede eller svagt tandede ved Grunden; Frøene gliudsende.

Var. gron eller graaagtig. 7-9. $\odot$. De mærkeligste Former af denne meget foranderlige Art ere:

$\boldsymbol{\alpha}$, deltoides Mloq. 1. c. p. 94 (A. deltoidea Bab. I. e., E. B. Suppl. t. 2860). Bladene ofte modsatte, triangelformede med nedadvendte Lapper ved Grundeu, bugtet-tandede eller næsten heelrandede; Blonsterdækket større end Frugterne, dets Afsnit æg-triangelformede, flade, paa Ryggen vortede.

$\beta$, salina (Wallr. s. A. patula; A. oppositifulia DC., Koeh i Sturm D. Fl. h. 79; A. hastata 2, macrotheca Rafn 1. c.?). Bladene modsatte, kjødfulde, heelrandede eller faatandede, Planten beklædt med Skjæl og derved graagtig.

$\gamma$, prostrata (A. prostrata Bouch., H. II, 151, A. hast. $\gamma$, uriangularis Moq. 1. c.). Stænglerne tyndere, ofte nedliggende; Bladene triangel-spydformede, heelrandede eller faatandede; Blomsternøglerne adskilte, Blonsterdækket meget større end Frugterne, dets Afsnit æg-rudeformede, tilspidsede, eonvexe, uden Vorter paa Ryggen.

$\delta$, platysepala Guss. (Westerlund 1. c. p. 45). Stængelen opret, meget grenet, Blomsternoglerne faablomstrede og langt adskilte, Blomsterdæklket meget fladt, dets Afsnit triangelspydformede, forøvrigt som foreg.

$\boldsymbol{\varepsilon}$, microcarpa Koeh (A. mierosperma W. Kit., Drej. n. 301 ; A. hastata microtheea Rafn II, 239; H. 289; A. ruderalis Wallr., Koch i Sturm D. Fl. h. 79). Bladene tandede eller næsten heelrandede, ofte modsatte; Blomsternoglerne danne tæette Ax; + Blomsterdikket lidet større end Frugterne, dets Afsuit xg-lancetformede, eonvexe, beclrandede eller tandede, med Vorter paa Ryggen; Frugterne meget smaae.

Ved Strandbredder (isaer $\beta$ ) og paa dyrkede, gjodede Steder omkring Byer alm. Formen $\mathcal{J}$, er fundeu pia strandbredden ved Krudttaarnene paa Amager (Lindeberg)! Kastrup! 
1251. A. calotheca [Fr. Mant. 3, 164] (Skjøubægret M.) H. N. VIII, 45; A. hastata 3, ealotheca Rafn II, p. 240; H. 289 ; F. D. 1638; A. laciniala L. fl. Suee. (tildeels, ikke I. Sp.); A. hastata Sm., Drej. n. 304 ; Rehb. ic. crit. I, fig. 33.

Stangelen opret eller opstigende; de nedre Grene udspilede; de nedre Blade spydformede, dybt bugtet-tandede, med opadvendte Tænder ved Grunden, de фvre lancet-spydformede; Blomsternøglerne danne mellembrudte Ax; Blomsterdakket næsten til Grunden todeelt, dets Afsnit triangelformede, tilspidsede, dybt fligede med sylspidsede Flige, paa Ryggen ophøiet-nervede (ikke vortede); Frøene glandsløse.

Alm. storre og kraftigere af Væxt end de følg. Var. graagtig eller beklæedt med hridgraa Skjæl. Frøene alm. storre end hos foreg., mindre end hos følg., og, især hos Formen «, smaae i Forhold til Blomsterdækket. 8-9. $\odot$. Følgende Former kunue adskilles:

$\alpha$, macrosepala! ( $\beta$, maerotheea Moq. l. c., ikke Rafn). Bladene store, grome, ofte dybt fligede, endog halvfinnede; Blomsterdækkets Afsnit større.

$\beta$, microsepala! ( $\gamma$, microtheca Moq. l. c., ikke Rafn). Bladene tilligemed den øvrige Plante alm. melede, Blomsterdækket mindre.

$\gamma$, parvifolia! Stærkt melet, Bladene smare og smale, mindre dybt fligede. (Har Udseende af en Bastardform mellem A. ealotheca og A. prostrata).

Ved Strandbredder: alm. i de fleste Eqne i Danmark. $\beta$, er den hyppigste Form; $\gamma$, har jeg fundet ved Kalkbrænderiet og Flaskekroen; $\alpha$, paa oversvommet Marskbund længere fra Havet. |;

* 1252. A. longipes [Drej. Fl. exe. n. 303] (Stilkblomstret M.) A. stipitata var. longipes Westerlund l. e. p. 54.

Stangelen opret, med opstigende Grene; de nedre Blade forlænget-spydformede med opadvendte Lapper, næsten heelrandede, de $\emptyset v v^{\prime} \in$ g-lancetformede, heelrandede; Blomsternoglerne i mellembrudte Ax; Blomsterdoekket ofte langstilket, med ægformet-spydformede, heelrandede eller fligede, paa 
Ryggen ophøiet-nervede (ikke vortede) Afsnit; Frøene store, glindsende.

7-9. $\odot$.

$\beta$, muricata (A. patula $\gamma$, murieata Ledeb., A. stipitata $\alpha$, genuina Westerlund 1. c. p. 53. Bladene tykkere, i Randen uregelm. tandede, Blomsterdækkets Afsuit store, triangel-spydformede, med ofte lange Flige ved Grunden.

Paa Marker (Drej.) og ved Strandbredder (!) i Selskab med de andre Arter ikke sjelden omkring Kjøbenhavn, f. Ex. ved Flaskekroen, ved Kalkbrænderieı! paa Amager! J. Sebbersund ved Limfjorden (8)! $\boldsymbol{\beta}$, paa Vesterfælled!

Anm. De af mig samlede Expl. stemme aldeles overeens med Beskrivelsen hos Drej., som dog selv yttrer T'vivl om denne Arts Bestandiglied. Jeg er inidlertid tilboielig til at ansee den for en vel adskilt Art, nærmest beslægtet med foreg. og følgende, men ved flere Kjendetegn sila forskjellig fra begge, at jeg ikke kan forene den med nogen af disse. Fra hiin adskilles den ved smalere, næsten heelrandede Blade og storre, glindsende Frøe, fra denne ved storre, ofte dybt fliget Blomsterdakke og storre Froe, fra begge ved de langstilkede Blomster. Fries henforer den til A. deltoidea Bab. 1. e., som efter Beskrivelsen og de i E. Bot. afbildede Exemplarer er meget forskjellig fra vor Art, og nærmest beslægtet med A. hastata. Jeg seer ikke nogen Grund til at ombytte det Drejerske Artsnavn med det nyere $A$. stipitata Westerlund, som har omtrent samme Betyduing. Den af mig under $\beta$, anforte Form (som Westerlund anseer for Hovedformen, og som synes hyppigere i Sverige), er hos os, saavidt jeg har bemurket, sjeldnere end den æote A. longipes Drej., og jeg er tilbovielig til at ansee den for en Bastardform mellem denne og A. ealotheca.

1253. A. patula L. (Svine-M.) Rafn II, 241; H. 290; Drej. n. 306 ; F. D. 1285; H. N. VIII, 53 (ikke Bab.).

Stongelen opret eller opstigende; de nedre Grene udspilede; Bladene spydformet-lancetformede, de ovre linie-laneetformede, heelrandede; Blomsternoglerne tæt samlede i stivt oprette, kortgrenede $\mathrm{Ax} ; \uparrow$ Blomsterdakket næsten til Grunden todeelt, dets Afsnit spydformet-rudeformede, paa Ryggen ofte vortede; Frøene glindsende.

Bladene eensfarvet gronne. 7-9. $\odot$. Ilandt de talrige under denne Art henhorende Former nævnes f $s$ lgende:

$\alpha$, genuina (Westerlund l. e. p. 56). Bladene triangelformede eller æg-lancetformede med spydformet Basis og ud. 
staaende eller opadrettede Lapper ved Grunden, forøvrigt alm. beelrandede.

$\boldsymbol{\beta}$, erecta (A. ereeta Huds., H. II, 152; Sturm D. Fl. h. 79). Stængelen opret, med opstigende Grene; Bladene alm. tandede, æg-lancetformede med lange opadrettede Lapper ved Grunden; Blomsterdækket lidet større end Frugten, paa Ryggen vortet, hvidmelet.

$\gamma$, oblongifolia (Waldst. \& Kit. pl. rar. Hung. 3, t. 221 ; Westerlund 1. c. p. 56; A. angustifolia F. D. 2226). Stængelen opret, Bladene xg-lancetformede, de nedre spydformede, med opadrettede Lapper ved Grunden, de øvre linie-lancetformede, heelrandede; Blomsterstanden i Spidsen nikkende, med adskilte Nøgler, Blomsterdækkets Afsnit rudeformede, heelrandede, paa Ryggen svagt vortede.

$\delta$, angustifolia (A. angustifolia Sm., Drej. n. 299; H. II, 150). Strngelen ofte nedliggende, Bladene heelrandede, de nedre lancetformede, de ovre linieformede.

Alm. paa dyrkede Steder omkring Byer, mellem Sæden (især $\delta$ ), sjeldnere ved Strandbredder. $\beta$, sjeldnere end de $\omega$ vrigere Former: Ordrup, Kjgbenhavn! $\boldsymbol{F}$. Nyborg (Lund).

cc. Exomidea Westerlund l. c. p. 59. Støvknapperne gule. Blomsternoglerne adskilte, tatblomstrede, indsunkte $i$ en tat Meel (som nasten har Lighed med Filt), Bladene linieformede (ikle spydformede).

1254. A. littoralis L. (Strand-MI.) Rafn II, 241; H. 291; Drej. и. 298; F. D. 1287 ; H. N. V, 58.

Stcongelen opret, med oprette eller tilsidst udspærrede Grene; Bladene linieformede eller smalt lancetformede, heelrandede eller svagt tandede (uden større Lapper ved Grunden); Blomsternøglerne danne mellembrudte Ax; + Blomsterdckkets Afsnit triangelrudeformede, tilspidsede, i Randen tandede og paa Ryggen vortede; Frøene glindsende.

Planten alm. lividmelet. Blomsterdækkets Form meget forskjellig, oftest ere Afsuittene meget langt tilspidsede, med tilbageboiet Spidse. 7-9. $\odot$. 
* serrata Moq. 1. c. (A. serrata Hnds., A. marina Rafn 243; Bab. man. ed. 2, p. 258; Koch i Sturm 1. c. h. 80 ; H. N. V, 59). Bladene bredere, tandede; Blomsterdækliets Afsnit triangel-hjerteformede, nasten budte.

Ved Straudbredder, meget alm. * sjeldnere end Hovedarten.

\section{Ilalynus. Kilebager.}

1255. 11. pedunculatus [Wallr. Sched, erit. p. 117] (Stilket K.) Drej. n. 305 ; H. N. I, 57 ; Atriplex L., Rafn 2, p. 244; H. 291 ; F. D. 304 (ikke god).

Stcengelen urteagtig; Bladene omvendt-ægformede, budte, heelrandede, spredte eller de nedre modsatte; $\$$ Blomsterdaklet ved Modenheden omvendt-hjerteformet med en Tand i Indskjæringen, paa tilsidst forlængede, udspærrede Blomsterstilke.

Hele Planten blaagraa af en tæt Beklædning med Skjæl, 1/2-1' høi. 7-9. $\odot$.

Ved Strandbredder paa Leer-eller Marskbund; funden i alle Provindserne (undt. Bornh.), men ikke alm.

1256. II. portulacoides [Wallr. ]. c.] (Stilkløs K.) Atriplex L., H. II, 150; F. D. 1889; H. N. XIV, 61; Obione portulacoides Moq.

Stangelen buskagtig, opstigende; Bladene modsatte, omvendt-ægformet-lancetformede, heelrandede; de frugtborende Blomsterdakk $r^{*}$ ustilkede, trelappede, paa Ryggen vortede.

Hele Planten, ligesom foreg., beklædt med lividgraae Slkjæl. 7-8. 万.

Ved Strandbredder, sjelden og hidtil kun funden paa Slesvigs Vestkyst, hvor den efter Nolte er liyppig ndenfor Marskdigerne (f. Ex. Husum) og paa Halligerne (f. Ex. Beenshallig), Gating paa $F_{\theta} h r(20)$ ! Amrom (Jessen). 周

\section{Ilex-Polyandria.}

\section{Sagittaria. Piilblad.}

1257. S. sagittafolia L. (Spids P.) H. 962 ; Drej. n. 943 ; F. D. 172 ; Relıb. ic. fl. g. VII, 94. 
Bladene langstilkede, spidse, piilformede med forlængettriangelformede, spidse Grundlige; Skaftet bladløst, med krandsstillede Blomster foroven, dannende en fjernblomstret Klase.

$2-3^{\prime}$ høi. Rodstokken skyder fra de nedre Bladhjørner Udløbere, hvis knolleformigt opsvulmede Spidse løsrives fra Moderplanten og $\mathrm{i}$ det følgende Aar danner en ny Plante. De tidligst udviklede og under Vandet nedsænkte Blade ere baandformede. Kronbladene hvide med rød Negl. 7. 4.

I Aaer og Søer, hyppigst i de store Aaer paa II alve ens Vestkyst, sparsommere paa $\theta$ erne. (Paa Loll., Falst. og Bornh. ikke bemærket).

\section{Myriophyllum. Tusindblad.}

1258. III. spicatum L. (Axblomstret T.) H. 961; Drej. n. 945 ; F. D. 681 .

Bladene krandsstillede, børsteformigt kamdeelte med alm. modsatte Flige; Blomsterne i Krandse, danne et mellembrudt, før Udspringningen opret $\mathrm{Ax}$; de nedre Dakblade indskaarne, af Længde med eller lidet Jængere end Blomsterkrandsene, de øvre kortere, heelrandede.

Stængelen, som hos de følg., flydende. Støvknapperne før Bestøvningen rode. 7-8. 4 .

I Færsk- og Brakvand, alm., og kun i enkelte Egne ikke tilstede, f. Ex. Sydvest-Sjæll. (17).

1259. I. alterniflorum [DC. Fl. fr. V, 529] (Haarfliget T.) Drej. n. 944 ; F. D. 2061 ; H. N. IV, 82.

Bladene krandsstillede, haarformigt kamdeelte, med alm. afvexlende Flige; Dakbladene som hos foreg.; Blomsterne i et mellembrudt, for Udspringringen nikkende $A x$, dannet foroven af afvexlende $\hat{\sigma}$ Blomster, forneden af $2-3$ halvt krandsstillede $\subsetneq$ Blomster.

Finere $o g$ spædere end foreg. og $f \circ] \mathrm{g} .7-8$. 2 .

I Søer, Bække og Tørvgrave, sjeldnere end de andre Arter: J. Vadum i Vendsyssel! alm. i Varde-Egnen (30), Fiilsø! i Kongeaaen og 'Torvgrave i Nærheden af samme mellem Skodborg og Kolding (2S), Si. Husum Mølledam (F. Müll.); $S j$. Gurre So (11); Burnh. en $\mathrm{S} \emptyset$ i Almindingeu! 
1260. II. rerticillatum L. (Krands-T.) H. 962; Drej. n. 946 ; F. D. $1046(\beta)$.

Bladene krandsstillede, børsteformigt kamdeelte, med alm. modsatte Flige; alle Dakbladene kamdeelte, længere end de regelmassige, i Spidsen tret samlede Blomsterkrandse, som danne et opret, forneden mellembrudt $\mathbf{A x}$.

Alm. mere frisk grøn end de foreg. Støvknapperne gule. 6-8. 4. Var.

$\alpha$, pinnatifidum Wallr. (M. vertieillatum DC.) Drkbladene mange Gauge længere end Blomsterkrandsene.

$\beta$, pectinatum Wallr. (II. pectinatum DC.) Dækbladene lidet længere end Blomsterkrandsene, hrorved disse danue et Ax.

I Søer, Damme og Grøfter alm.

\section{Ceratophyllum. Ilornblad.}

1261. C. oxyacanthum [Chamisso i Linnæa 1829, p. 504] (Tornet H.) Drej. n. 948 ; C. demersum L., H. 961; F. D. 2000 ; H. N. IX, 63.

Bladene haandsnitdeelte, dobbelt gaffeldeelte, med omtrent 4 bruskagtigt tandede Flige; Frugten med 2 tilbagebøiede Torme ved Grumden og en vedblivende Griffel af Frugtens Langde (eller længere) i Form af et Horn i Spidsen.

7-9. భ. Var. med Tornene ved Grunden indskræunkede til korto Vorter (C. apiculatum Cham.).

I Soer og Damme, alm. i Danmark.

1262. C. muticum [Cham. l. c.] (Tornløs H.) Drej.n. 947; C. submersum L., H. 961 ; Nolt. nov. p. 75 ; F. D. 510 (ikke god); H. N. IX, 64 .

Bladene krandsstillerle, tredobbelt gaffeldeelte, med 5-8 finere og svagere tandede Flige; Frugten ved Grunden vortet, uden Torne, med et Horn (af len vedblivende Griffel) i Spidsen, som er meget kortere end selve Frugten.

Bladfligene finere og mere oprette end hos foreg. 6-7. ข.

Paa lignende Steder som foreg., men meget sjeldnere: $\boldsymbol{S} \boldsymbol{j}$. Roes- 
kiJde (Nolt.), mellem Hredstrup og Heringeløse (15)! Bøgelund og Bisserup ved Skjelskør (Nielsen, 14)! Halst. Stubbekjøbing (19); L oll. Nakskov, Slotg (19); $S$ l. Husum (F. Müll.), Frederiksstad (F. D.).

\section{Poterium. Bibernelle.}

1263. P. dictyocarpum [Spach, Ann. Sc. nat. 1846, p. 34] (Blodstillende B.) Gren. \& Godr. fl. Fr. I, 562; P. Sanguisorba L. (part.), H. 963 ; F. D. 1939 ; H. N. VII, 52.

Stangelen kantet; Bladene uligefinnede med modsatte, ægformet-ovale, dybt saugtakkede Smaablade; Blomsterhovedet ovalt eller kugleformet; Skalfrugten beenhaard, nætformigt rynket, aflang med 4 budte, svagt vingede Kanter.

1-2' høi. Stænglerne var. oprette, opstigende eller nedliggende, dens nedre Deel og Bladene glatte eller dnumhaarede. 6-7. 4 .

Paa Kalkgrund, sjelden: J. Aagaards Kalkbakker (16), Aalborg (Brix), Dyhdal! N. Sundby (12), Dal Hede (Branth), Viborg (H.). Tøilunshaven ved Randers (7); Bornh. ved Lxesaaen og mellem Vældensby og Arnager (19), Pythuset (14), Havskrænter mellem Baunolde og Horsemyreodde (Hjorth). Forvildet forekonmer den ved Qvintus udenfor Kjøbenhavn (Hauberg)!

\section{Carpinus. Avnbog.}

1264. C. Betulus L. (Almindelig A.) H. 969 ; Drej.n. 951 ; F. D. 1345 ; Rchb. ic. fl. germ. XII, fig. 1296.

Bladene elliptisk-xgformede, tilspidsede, rynket-fjernervede, skarpt og dobbelt saugtakkede; Hylsterets Midtflig forlænget, saugtakket eller heelrandet, Sidefigene spidse; Nodden ægformet, stribet; Størknapperne i Spidsen skjæghaarede.

Høit Træ med lys askegraa Bark. 5 (blomstrer samtidigt med Løvspringet. Frngterne modnes 7-8). h.

I Skove: paa Halveen og i Nordsjalland sparsom, i Fyen. Sy dsjelland og paa de sydlige 0 er temmelig hyppig, især i Mrngde par Burnholm, hvor den træder istedetfor Bøgen.

\section{Corylus. Ilassel.}

1265. C. Arellana L. (Alınindelig H.) H. 970 ; Drej. n. 952 ; F. D. 1468 ; Rehb. l. c. fig. 1300.

Bladene æg-bjerteformede eller rundagtige, tilspidsede, 
dobbelt tandede; Griflerne purpurrø de; Hasen klokkeformig-aaben, i Spidsen uregelmæssigt fliget.

Buskagtig, sjeldnere middelstort Træ, Bladstilkene og de unge Grene alm. kirtelharede. Noddens Form meget forskjellig. 3-4. (blomstrer for Løvspringet. Frugterne modnes 8-9).

I Kratskove alm.; forekommer desuden overalt plantet ved levende Hegn og i Harer formedelst dens spiselige Frugter.

+ C. tubulosa Willd. (Lamberts-N.) Rehb. l. c. fig. 1301 . Hasen bladagtigt forlænget ud over den xgformede, fladtrykttilspidsede Nød.

Dyrkes i Haver.

\section{Fagus. Bøg.}

1266. F. silvatica L. (Almindelig B.) H. 965 ; Drej. n. 953 ; F. D. 1283 ; Rehb. l. c. fig. 1304 ; H. N. I, 59.

Bladene ægformet-elliptiske, spidse, utydeligt bølget-tandede, i Randen og paa Nerverne silkelaarede; Axelbladene lancetformede, bruun-hindeagtige, hurtigt affaldende; Skaalen beklædt med Blødpigge.

Frøbladene nyreformede, kjødfulde, paa Underfladen hvide. 5. (fr. 8-9). 万.

Det almindeligsto Tra i de danske Skove, mangler par Bornh. (plantet paa nogle faa Steder) og i IIalveens Hedeegne. (Kun i Vendsyssel har jeg fundet Bogen paa Hedebakker, hvor den, blandet med Bærreasp, danner lavt Krat).

\section{$\doteqdot$ Castanea. Kastanietro.}

+ C. vulgaris [Lam. Diet. I, p. 708] (Agte K.) C. vesea Gärtn., Rchb. 1. c. fig. 1305 ; Fagus Castanea L.

Bladene lancetformede, tilspidsedc, skarpt saugtakkede, med strerkt fremstaaende Nerver; Knopskjallene glatte, Skaalens Pigge lange og stikkende, Nødden bruun glindsende, ved Grunden blegere og glandsløs.

Høit Tra med glatte og glindsende, affaldende Bladc. 6 (fr. 9-10). 万.

Indført fra Sydemopa, dyrkes hist og her i Haver og taaler godt vort Clima, men Frugterne modnes sjeldent her. 


\section{Quercus. Eg.}

1267. Q. pedunculata [Ehrb. Arb. n. 77] (Stilk-E.) H. 963; Drej. n. 954; Rubb. l. c. fig. 1313 ; Q. foemina F. D. 1180 ; Q. Robur $\alpha$, L.

Bladene meget kortstilkede eller næsten siddende, fjerlappede med bjerteformet Basis; Knopskjallene regelm. taglagte i 5 Rader. + Blomsterstilkene ved Hodenheden mange Gange længere end Bladstilkene.

Hoit Træ med glatte, ọm Vinteren alm. affaldende Blade. 5 (fr. 8-9). h.

Almiudelig $\mathrm{i}$ de danske Skove. De i Jyllands Hedeegne saa hyppige lave Egekrat (Fur) bestaae i Regelen af denne Art.

1268. Q. sessiliflora [Sm. Fl. brit. 3, 1026] (Vinter-E.) H. 965 ; F. D. 2667 ; Q. Robur $\beta$, L., Rehb. l. c. fig. 1309.

Bladene stilkede med afrundet eller tilspidset Basis, de frugtbarende Blomstersiille af Længde med eller kortere end Bladstilkene (stundom 0); Frugterne kortere, tykkere og mere afrundede; forøvrigt som foreg.

Bladene blive lenvisnede siddende paa Træet om Vinteren. 5. (fr. 8-9). 万.

I Skove og Krat, sjeldnere end foreg. og kun i enkelte Egne: J. Buderupholm (H.), Hall (Strandgaard), Silkeborg! i sknvene paa og omkring Himmelbjerget hyppig og den eneste Art, Rorbæk ved Veile (12); $s ;$. Dys ehaven mellem Klampenborg og Eremitagen (1 Træe, formodenlig plantet); (ilænø (Nielsen, 14)! Futst. (H.); Bornh. den hyppigste Ligeart i Almindingen! I vore Torvmosers æuldre Lag har Prof. Steenstrup (Vid. Selsk. Skr. 9, p. 53) kun fundet Levninger af denne Art.

Juglans. Valnodtrce.

† J. règia L. Schk. Handb. tab. 302. Bladene vellugtende, uligefinnede; Smaabladene 3-4 Par, ovale, næsten heclrandede; Steenfrugten oval-kugleformet; Stenen toklappet.

5 (fr. 10). h.

Dyrkes alm. i Haver og onkring beboede Steder paa Grund af de spiselige Frugter. 


\section{Honadelphia.}

\section{Xanthium. Braadfro.}

$X$ 1269. X. strumarium L. (Skreppeagtig B.) H. 959; Drej. n. 955 ; F. D. 970 ; Rehb. ic. fl. germ. XIX, fig. 1576 .

Bladenc trenervede, hjerteformede eller nyre-hjerteformede, grovt og uregelm. tandet-lappede (alm. trelappede); flere halvkugleformede ơ Blomsterhoveder i Spidsen af Stængelen; $\$$ Blomsterne samlede til siddende eller kortstilkede Nøgler i Bladhjørnerne; Frugterne duunhaarede og bekliedte med stive, i Spidsen hagekrummede Torne.

Blomsterne gronne. 7-9. $\odot$.

I Narheden af Byer og beboede Steder; tidligere funden sporadisk i Danmark, f. Ex. $\boldsymbol{S} \boldsymbol{j}$. (Græse (Kyll.), Amigerport og Salpeterværket udenfor Osterport ved Kbhavm, Kjøge (H.); M o en red Stege; Falst. ved Nykjøbing (H.). I de senere Aar er den hverken funden paa de anforte Steder eller andensteds, og er maaskee nu aldeles forsvunden af Floraen.

\section{Polyadelphia.}

\section{Bryonia. Galdebar.}

1270. B. alba L. (Eubo-G.) H. 974; Drej. n. 956; F. D. 813 ; Rchb. ic. fl. germ. XIX, fig. 1620 .

Stcongelen klattrende ved Hjælp af Slyngtraade; Bladene rue, hjerteformede, haandlappede, ined 5 grovt tandede Lapper; Bageret af $q$ Blomsten af Langde med Kronen; Arret glat.

Blomsterne guulgrønne, Bær sorte. 6-8. 4.

Ved Gjærder, isser omkring Byer, funden i alle danske Provindser, men sporadisk og ikke alm. Ved Tonder forekommer en Var. med mørkgrønne Bær (Branth).

1271. B. lioeca [Jacq. Fl. austr. 2, t. 199] (Trebo-G.) H. 975 ; F. D. 1830 .

Stangelen som foregaaende; Bladene rue, hjerteformede, 
haandfligede med omtrent 5, heelrandede eller faatandede Flige; tvebo; $\Varangle$ Bageret af Kronens halve Længde; Arret haaret.

Bladfligene alm. smalere end hos foreg., Blomsterne skidengule, Bær høirøde. 6-8. 2 .

Ved Gjærder, sjelden: J. aln. omkring Ribe (6); Slesvig(16); F. Sanderumgaard, Faaborg (H.). 用

\section{2de Klasse. Dioecia (Tvebo).}

\section{Orden. Monandria (Enhannede).}

Najas (21, 1).

Salix purpurea $(22,2)$.

\section{Orden. Diandria (Tohannede).}

1. Salix L. " $\hat{\delta}$ og $q$ Blomsterne i Rakler; Blomsterne omgivne af 1 Rakleskjæl og 1-2 Kirtler; $ే$ : Støvdragere 1-8; $q$ : 1 Frugtknude med 1 Griffel og 2 hele eller tokløvede Ar; Frugten toklappet, mangefrøet Kapsel; Frøene med Frøuld ved Grunden. (T'ræer eller Buske med affaldende Blade; Knopperne omgivne af 1 enkelt eller 2 kappeformigt sammenvoxne Knopskjæl. N. F. Salicineæ).

Fraxinus. Fr. Vingefrugt $(2,1)$.

\section{Orden. Triandria (Trehannede).}

2. Émpetrum L. Blomsterne i Bladhjørnerne; Bæger og Krone trebladede; $q$ : Arret straaleformet; Frugten et fleerfroet Bær. (Halvbusk med stedsegrønne Blade. N. F. Empetreæ).

Salix amygdalina $(22,2)$.

Carex dioeca $(21,3)$.

Valeriana dioeca $(3,1)$.

\section{Orden. Tetrandria (Fïrehannede).}

a. Urteagtige Vxxter.

Urtica dioeca $(21,4)$. 
b. Buskvæxter.

aa. Blomsterne enlige $i$ Knipper, Frugten baragtig.

3. Hippophäe L. $\delta$ : Blomsterdxkket tobladet, med $\mathrm{i}$ Spidsen sammenhængende Blade; $q$ : Blomsterdækket tofliget, tilsidst kjødfuldt og omgivende Frugten (et falsk Bær); Arret udeelt, l'nieformet. (Busk med Vedtorne og skjældækte Blade. N. F. Elæagneæ).

4. Viscum L. §: Blomsterdækket firedeelt, Støvknapperne siddende paa Blomsterdakkets Flige; $q$ : Bægeret en svag, oversædig Rand; Kronen firebladet; Griffelen 0; Arret afstumpet*). (Suyltevæxt med knippestillede Blomster $\mathrm{i}$ Vinklerne If gaffeldeelte Grene. N. F. Loranthacex).

Rhammus catharticus $(5,1)$.

Salix cuspidata $(22,2)$.

bb. Blomsterne $i$ Rakler, Frugten nodagtig.

5. Myrica L. ठ̊: Blomsterne nøgne; 4-6 Støvdragere befæstede ved Grunden af Rakleskjællene; skjælformet, 2-4-fliget; 1 Frugtknude med 2 traadformede Ar. (N. F. Myricè $)$.

\section{Orden. Pentandria (Femhannede).}

a. Urteagtige Væxter. (6-7. N. F. Urticacea, b). 6. Ilimulus L. §: Blomsterne i grenet Klase (Top); Blomsterdækket femdeclt; Størdragerne oprette; $q$ : Blomsterne i Rakle med 2-3-blomstrede, urteagtige Rakleskjæl; Blomsterdækket skjælformet, to lange traadformede Ar; Frugten nødagtig. (Slyngende Væxt med haandfligede Blade).

† Cúnnabis L. đ̊: Blomsterne i korte Klaser, 오: Blomsterne knippestillede i Bladhjørnerne; $\delta$ : Blomsterdækket femdeelt: Støvdragerne hængende; $q$ : Blomsterdakket spaltet i

*) Efter Schleiden har Viscum et nøgent $A \mathrm{Eg}$ (uđen Frogjemme), omgivet af den kjødfuldt tilvoxende Frugtbund; efter J. Agardh o. Fl. en eller flere nggne Kimsxkke (uden AEghinder) i Spidsen af Egstolen, men indsluttede af et Frogjemme. Det synes derfor endnu tvivlsomt, om denne Familie i det naturlige System skal heuregnes til de Nogenfrøede. 
den ene Side og indhyllende den nødagtige Frngt; 1 kort Griffel og 2 traadformede Ar. (Opret Væxt med fingrede Blade).

\section{b. Træagtige Væxter.}

7. Juniperus L. $\hat{\sigma}$ : Blomsterne i Rakler; Støvknapperue befæstede til Underfladen af skjoldformede Rakleskjæl; 오: Blomsterne $\mathrm{i}$ en kort Rakle, de nedre Rakleskjæl tomme, de 3 øre ved Grunden sammenvoxne, tilsidst kjødfuldt tilvoxende og omsluttende de 3 \& Blomster (dannende et falsk Bær). (Busk eller lavt Træ med stedsegrønne Blade. N. F. Coniferæ, b, Cupressine $æ$ ).

Ribes alpinum $(5,1)$.

Salix pentandra $(22,2)$.

6. Orden. Hex-Polyandria '(Sex-Mangehannede).

a. Træagtige Væxter.

aa. Blomsterne $i$ Rakler.

8. Pópulus L. Blomsterne af begge Kjøn i Rakler, med saugtakket-fligede Rakleskjæl; $\widehat{0}: 8-30$ Støvdragere befæstede paa en skaalformet Udvidelse af Frugtbunden, $q$ : 1 Frugtknude (ved Grunden omgivet af en Skaal ligesom $\widehat{\sigma}$ ) med to fligede (sjeldnere 3-4-lappede) Ar; Frugten toklappet Kapsel *); Frøene talrige, med Frøuld ved Grunden. (Træer med affaldende Blade, sammentrykte Bladstilke og spiralformigt taglagte Kropskjæl. (N. F. Sali c in ex).

Salix pentandra $(22,2)$.

Slyrica $(22,4)$.

\section{bb. Blomsterne $i$ Klase eller Halvskjarm.}

Acer. Todelelig Vingefrugt $(8,1)$.

*) Var. med 3-4-klappet Kapsel (Rostr.). 
b. Urter.

aa. Blomsterdakket undersadigt.

9. Mercuriảlis L. Blomsterdakket enkelt, tredeclt, grønt; o : 9-12 Stovdragere; + : 2 Bistøvdragere, 1 torummet Frugtknude med 2 næsten siddende Ar; Frugten tolelelig Spaltefrugt med enfrøede, toklappede Smaafrugter (Hindefrugter). (N. F. Euphorbiaceæ).

Rumex Acetosa og Acetosella (6, 3).

Melandrium vespertinum og diurnum $(10,4)$.

Irubus Chamcemorus $(12,3)$.

bb. Blomsten oversadig. (11-12. N. F. Hydrocharidea).

10. Stratiotes L. Bager og Krone trebladede; talrige

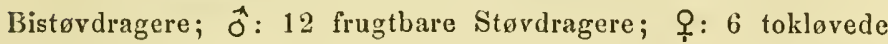
Grifler, Frugten sexrummet, mangefrøet, uopspringende. (Vand. plante med linieformede Blade).

11. Ilydrochíris L. (Bæger og Krone trebladede; $\hat{\delta}: 9$ Stovdragere, 3 ufrugtbare Grifler; $q$ : 3 traadformede Bistovdragere og 3 kjodfulde Skjæl, 6 tokløvede Grifler, Frugten sexrummet, mangefrøet, uopspringende. (Vandplante med nyreformede Blade).

\section{Orden. Monadelphia (Enlnippede).}

† 12. Taxus L. Begge Kjøn udgaae fra Bladlijørnerne; § Raklerne smaae, kugleformede, med taglagte Skjæl ved Grunden og flere forneden soileformigt sammenvoxue Støvdragere med skjoldformede, 5-8-rummede Støvknapper; 9 flere taglagte tomme Dækskjæl ved Grunden af et endestillet nogent Asg, det modne Frø omgivet af den kjodfuldt tilvoxende, skaalformede Frøkappe. (Træ med naaleformede Blade. N. F. Couiferæc, Taxineæ).

\section{Orden. Syngenesia (Rorhannede).}

$\left.\begin{array}{l}\text { Antennaria } \\ \text { Petasites }\end{array}\right\}(19,2)$. 


\section{I. (II) Diandria. \\ 1. Salix. Piil $\left.{ }^{\star}\right)$.}

a. Amerina Fr. (Skjørpile). Raklerne stilkede, med bladet Stilk, udvikles samtidigt med Bladene, oftest hængende; Rakleskjællene eensfarvede; Blomsterne (idetmindste $\hat{\sigma}$ ) med 2 Kirtler ved Grunden (undt. Nr. 1278) og de nederste i Raklen først udspringende; Støvknapperne gule; "Arrenes Flige rettede tilhøire og venstre (0: parallelt med Axenu)**).

aa. Fragiles. Traagtige med skjore Grene, affaldende \& Rakleskjoel (undt. hos Nr. 1275).

1272. S. pentandra L. (Laurbær-P.) H. 980; Fr. Mant. 1, p. 41 ; Drej. n. 957 ; F. D. 943 ; Rehb. ie. fl. germ. XI, fig. 1268 ; H. N. IX, 60 .

*) Pilearterne maa undersøges deels om Foraaret under Blomstringen, deels senere paa Aaret naar Bladene ere fuldkomment udviklede, til hvilken Tid ogsaa Axelbladene fosrst kunne tydeligt erkjendes, medens disse ofte paa de yngre Grene ere ufuldkomne eller endog aldeles ikke tilstede. Størdragernes Antal er hos de fleste Arter 2, og kun naar et andet Autal findes, er dette udtryklkeligt nævnt i Beslrivelserne. En stor Deel af de her anforte Pile ere ikke oprindeligt indenlandske, men da det om mange er vanskeligt at afgjøre, hvorvidt de ere vildvoxende eller ikke, ere alle Arter, som ikke ere fundne i Moser o. a. udyrkede Steder og altsaa øiensynligt tilhøre vor Flora, betegnede med $\dagger$. Blandt disse blive nogle plantede overalt og ere at betragte som acclimatiserede. Flere Arters fremmede Herkomst antydes ved at Spidserne af de unge Grene bortfryse om Vinteren, eller derved at kun det ene Kjon findes hos os. (Efter Fries forekomme af de nordligere Arter mod disses Sydgrændse kun $\varnothing$, af de sydlige mod Nordgrændsen kun 우). De fleste dyrkede Pile, selv de som efter deres Natur have en høi Stamme, sees her i Landet næsten altid kun som Buske, fordi Grenene afkappes og benyttes til Gjærder, Kurve o. s. v. Ved Revisionen af denne Slægt har jeg havt god Hjæelp af Hr. Seminarielærer Rostrup, som i de senere Aar merl Opmærksomhed har iagttaget de danske Pilearter og meddeelt mig mange værdifulde Bemærkninger om disse.

**) De her anforte Kjendetegn, som ere hentede fra Raklernes forskjellige (centripetale eller centrifugale) Udspringning, har jeg ved 
Bladene agformet-elliptiske, spidse, fiint og kirtlet-saugtakkede med flere Kirtler ved Grunden af Pladen, mørkgrønne, glatte; Støvdragerne 5-7, med forneden haarede Støvtraade; Kapselen glat, kortstilket; Stilken to Gange længere end Kirtlerne; Griffelen af Middellangde, Arrene i Spidsen tokløvede.

Busk eller lavt 'Træ. Silavel Grene som Blade glindsende, glatte. $\frac{5}{2}-\frac{k}{1}$ (den sildigst blomstrende af de danske $\mathrm{Pil}_{\mathrm{e}}$ ). $\boldsymbol{h}$.

I Moser og fugtige Kratskove ikke sjelden.

Anm. Axelbladene beskrives som "rette, ægformede ; jeg har km yderst sjelden fundet disse tydeligt udviklede (knn hos meget storbladede vilde Skud) og selv da som megret smaae, kirtelignendo Legemer, livorfor jeg har udeladt disses Beskrivelse blandt Kjendetegnene par Arten.

1273. S. cuspidata [Schultz Fl. Starg. Suppl. p. 47] (Firehannet P.) F. D. 2487; H. N. XV, 61; S. Meyeriana Willd.; Rehb. 1. c. fig. 1266 ; S. fragili-pentandra Wimmer*).

Bladene lancetformet-elliptiske, tilspidsede; Axelbladene halvt hjerteformede, skjæve; Stovdragerne 3-4; Kapselens Still 3-4 Gange liengere end Kirtlerue; Arrene udrandede; forøvrigt som fureg., men høiere af Væxt og blomstrer omtrent 8 Dage tidligere.

Ved Gjærder: $\boldsymbol{S} \boldsymbol{j}$. ved Leersøen (19), forhen ved gl. Kongevei! F. Vildroxende i Moser par Hindsholm, ved Nielstrup og ved Ifegn $i$ det sydlige ikke sjelden, hist og her i det sydl. og ostl. Jyll. (12). 9 Planten er ikke funden hos os, men stundom findes enkelto androgyne Rakler paa $\sigma^{*}$ Planten. 7

$\dagger$ 1274. S. fragilis L. (Skjør-P.) H. 983; Fr. Mant. 1, p. 42 ; Drej. ฉ. 958 ; F. D. 2484 ; Rehb. l. c. fig. 1264; H. N. I, 60 og XV, 62 a.

Heeraarige Undersøgelser fundet constante los idetmindste et stort Antal Arter, og jeg er ved Andres samstemmende Meddelelser bestyrket $\mathrm{i}$ den Formening, at dette Forhold hensigtsmassigt kan benyttes til Arternes Adskillelse. Bemærkningerne om Arrenes forskjellige Retning ere mig meddeelte af Mr. Rostrup. Disse Forhold anbefales til yderligere Undersøgelse.

*) Prof. Wimner har i Fl. v. Schles. p. 474 o. flg., i flere senero Athandlinger (sml. Andersons nya bot. Not. 1849 p. 178) og i sin Exsiccatsamling ("Salices exsiceatæ*) sogt at bevise en stor Mrngde Pilearters lrybride Herkomst. Uden at gaae ind paa en 
Grenene næsten retvinklet udspærrede; Bladene bredt laneetformede, tilspidsede, saugtakkede, guulgrønne, paa Underfladen matgrønne; Axelbladene halvt hjerteformede; Støvtraadene glatte eller svagt haarede ved Grunden; Kapselen glat, stilket; Stilken 2-3 Gange saa lang som Kirtlerne; Griffelen af Middellængde, Arrene tokløvede.

Høit og hurtigt voxende Træ. Grenene (i Vinllerne) meget skjøre; Bladene glatte, i yngre Tilstand ofte silkehaarede. Blomstrer omtr. 14 Dage senere end foreg. $\left(\frac{5}{2}\right)$. Var.

* pendula (Ser.). S. Russeliana Sm.; Rchb. l. e. fig. 1265 (S. albo-fragilis); Grenene tyndere, mindre skjøre, tilsidst nikkende; Bladene smalere, silkehaarede; Axelbladene længere tilspidsede, Raklerne mindre og tyndere; Støvtraadene ved Grunden uldhaarede; Kapslerne mindre.

Ved Gjærder, omkring Byer ikke sjelden, synes at mangle $\mathrm{i}$ det sydlige Fyen og pat Smaaverne deromkring (12). (Egenlig vildvoxende har jeg ikke fundet den her i Landet). * som i Udseende nærmer sig endeel til S. alba, og som maskee er en egen $\Lambda \mathrm{rt}$, forekommer sjeldnere plantet.

1275. S. viridis [Fr. Nov. p. 283] (Grøn P.) F. D. 2486; H. N. 1,61 .

Grenene oprette (i en Vinkel mod Stammen af omtr. $60^{\circ}$ ); Bladene smalt lancetformede, tilspidsede, glatte, de yngre paa Underfaden blaagraae; Axelbladene meget smare, ægformede (eller 0); Raklerne oprette eller udstaaende; Rakleskjallene oftest vedblivende; Stфvtraadene ved Grunden haarede; Kapselen glat, stilket; Stilken mod Frugtmodningen dobbelt saa lang som Kirtelen, Griffelen kort; Arrene ndrandede.

Middelhoit Træ. De unge Grene glatte, rødbrune. Bladene smalere, morkere grønne end hos foreg., fra hvilken den endog i bladløs Tilstand

nærmere Undersøgelse af dette Spørgsmaal, som ikke her vilde have sin rette Plads, skal jeg kun i Almindelighed bemærke, at jeg ilske kan antage den Anskuelse i hele sin Udstrækning for holdbar, ifolge hvilken omtrent Halvdelen af vore Pilearter skulde være Bastarlformer. For Fuldstændigheds Skyld har jeg angivet de Wimmerske Navne blandt Synonymerne for hver af de formeentlige hybride Arter. 
er let kjendelig ved meget tyndere, mere oprette Grene, samt ved mindre Knopper. (Hos 9 Blomsterne har jeg kun fundet 1 Kirtel). $\frac{4}{2}-5$.

Ved Gjarder, omkring Byer o.s. v., neget alm. og i de fleste Egne hyppigere end foreg. I Moser ved Helsing hr har jeg fundet den, som det synes, villwoxende. [*

† 1276. S. alba L. (Hvid P.) H. 994; Fr. 1. c. p. 44; Drej. 1. 959 ; F. D. 2552 ; Rehb. l. c. fig. 1263 ; H. N. 1, 62.

Grenene oprette; Bladene smalt lancetformede, tilspidsede, saugtakkede, paa begge Flader tiltrykt-silkehaarede; Axelbladene meget smaae, laneetformede (eller 0); Raklerne bueformigt krummede; Stovtraadene ved Grunden uldharede; Kapselen glat, meget kortstilket; Stilken kortere end Kirtelen; Griffelen meget kort; Arrene udrandede.

Hosit 'Træ. De unge Grene graafiltede. \& Blomsterne have, ligesom foreg., kun 1 Kirtel. $\frac{5}{2}$. Var.

$\beta$, coerulea Koch. (S. coerulea Sm., Engl. Bot. 2431). Bladene lange, linie-lancetformede, paa Underfladen blaaduggede, tilsidst glatte.

$\gamma$, vitellina koch. (S. vitellina L.?). Grenenes Bark smukt rødbruun, Rakleskjællenc msnuierødc.

Ved Landsbyer og Gjærder ikke sjelden: $\beta$, i Leersøen (19); $\gamma$, ved Overdrevskroen mellem Roeskilde og Ringsted!

bb. Amygdalina. Buskagtige, med seigere Grene og vedblivende $\&$ Rakleskjal.

1277. S. amygdalina 1. (Mandel-P.) Fr. Mant. 1, p. 42 ; Drej. n. 960 ; F. D. 2558 ; Rehb. 1. c. fig. 1256-60; H. N. III, 5 ; S. triandra L., H. 980.

De unge Grene kantet-furede; Bladene kortstilkede, æglancetformede, tilspidsede, sangtakkede, glatte; Axelbladene store, halvt lijerteformede, takkede; Ralileskjollene i Spidsen glatte; Stovdragerne 3; Kapselen glat, stilket; Stillen 2-3 Gange læugere end Kirtlerne; Griffelen meget kort; Arrene udspærrede, udrandede.

Ved de store, allerede para de unge Grene kjendelige Axelblade let at adskille fia de foreg. 5. Var. i Bladformen og:

$\alpha$, concolor. Bladene paa begge Flader grønne. 
$\beta$, discolor. Bladene paa Underfladen blaagraae.

Ved Gjærder og Plantninger, hist og her (ikke alm.), sjelden i Noser: J. Vendsyssel (H.), ved Kolding Aa (28), $\boldsymbol{S} \boldsymbol{j}$. en Mose ved Grøndal mellem Kbhavn og Brøndshøi! Leersøen (19). (Formen $\boldsymbol{\alpha}$, er her i Landet den hyppigste, tvertimod hvad der er Tilfældet i Sydeuropa, og $\sigma^{\top}$ er hos os meget sjeldnere end of).

+ 1278. S. undulata [Ehrh. Beitr. 6, p. 101] (Bølgebladet P.) H. 980 ; Fr. l. c. p. 62 ; Drej. p. 307 ; F. D. 2550 ; Rclib. I. c. fig. 1261 ; H. N. III, 55; S. triandraviminalis Wimm.

De unge Grene trinde eller svagt kantede; Bladene linielancetformede, langt tilspidsede, i Randen saugtakkede og svagt bølgede; Axelbladene halvt hjerteformede, tilspidsede, takkede; Rakleskjallene uldhaarede; Støvdragerne 3; Kapselen duunhaaret eller glat, stilket, med 1 Kirtel ved Grunden, Stilken dobbelt saa lang som Kirtelen; Griffelen forlæuget; Arrene tokløvede.

Bladene i yngre Tilstand duunhaarede, ældre glatte. Rakleskjællene stundom i Spidsen affarvede (røde). 5.

Ved Gjærder: $\boldsymbol{S}$ j. Kbhavn ved Stadsgravene, gamle Kongevei, Iygten! Valby, Lundehuset (19); $\boldsymbol{J}$. Vendsyssel og Thy (Viborg). Kun Q Planten er funden her i Landet. $\$$

b. Vetrix (Baandpile). Grenene langstrakte, Raklerne siddende, udvikles før Bladene; Rakleskjællene $i$ Spidsen forkjelligfarvede, 1 Kirtel.

aa. Pruinosa. Yderbarken overtrukken af en blaaagtig Dug, Inderbarken citronguul. Støvknapperne for Bestøvningen brandgule, efter samme skidengule. (De ovre Blomster $i$ ô Raklen udspringe forst).

$\dagger$ 1279. S. acutifolia [Willd. Sp. p]. 4, p. 668] (Blaadugget P.) Fr. l. c. p. 46 ; F. D. 2602; H. N. VIII, 58 og $\mathrm{XIV}, 63$; S. pruinosa Wendl., Rehb. l. c. fig. 1255 ; S. caspica hortul.

Grenene mørkt violetbrune, om Efteraaret $\operatorname{og} \mathrm{i}$ tørret Tilstand) blaaduggede; Bladene linic-lancetformede, langt tilspidsede, saugtakkede, glatte og glindsende; Axelbladene lancet- 
formede, tilspidsede; Kapselen glat, nasten siddende; Griffelen forlænget; Arrene linieformede, udeelte.

Funden som vildvoxende ( $\left.\sigma^{*}\right)$ i Leersoens udtørrede Bassin (19). Plantet forekommer den list $\mathrm{og}$ her, dog ikke almindelig og stedse kun $\sigma^{*}$, f. Ex. $S j$. ved Stadsgravene udenfor Norreport i Mængle! Frederiksberg, Vedbak (19); J. Ostergaard og Nasby ved Logstør (12); Bornh. ved Hanmershuus (19). 3-4 (den tidligst blomstrende af alle hos os forekommende Pile).

bb. Purpurea. Yderbarken uden Dug, Inderbarken citronguul, Stovknapperne for Bestøvningen rodgule, efter samme sorte. (De ovre Blomster $i$ ơ Ralilen udspringe forst; "Arrenes Flige rettede for-og bagtil o: lodret paa Axen (I).

1280. S. purpurea L. (Purpur-P.) H. 984; Fr. 1. c. p. 63 ; Drej. n. 961 ; F. D. 2554 ; Rehb. l. c. fig. 1230; H. N. II, 56 ; S. monandra Hoffm.

Buskagtig; Bladene lancetformede, foroven bredere, tilspidsede, svagt saugtakkede; Axelblade 0; 1 Støvdrager dannet af 2 sammenvoxne Støvtraade med 1 (firerummet) eller 2 (torummede) Støvknapper; Kapselen uldbaaret, siddende, med Kinelen naaende op over dens Basis; Griffelen kort, Arrene udrandeda.

De unge Grenes Yderbark alm. mørkrød, sjeldnere guulbruun eller graaghtig, Grenene, især paa ơ Expl., ofte i Spidsen henvisnede efter Vinterkulden. Bladene glatte eller i yngre Tilstand silkehaarede, blive sorte ved Torring. Rakleskjallene i Spidsen sorte. 4-5. Var.

a, gracilis Gren. \& Godr. (S. purpurea Sm.). Lav Busk. Bladene paa Underfladen blaagraae, Raklerne meget tynde; Griffelen meget kort, Arrene korte, xgformede.

$\beta$, Hclix (S. Helix L.). Rchb. l. c. fig. 1232. Grenene opret-aabne, Bladene bredere, pas begge Sider ensfarvede; Griffelen lrengere, med linieformede Ar.

$\gamma$, Lambertiana (Sm.) Rehb. 1. c. fig. 1235. Hoierc af Væxt, med bredere Blade, tykkere Rakler, forøvigt som $\beta$.

Forekommer hyppigt plantet, især ved Gjærder, og dyrkes faa flere Steder til Brug ved Kurveflatning. $\boldsymbol{\beta}$, Lundehuusmosen (19); $\gamma$, ved Sorø S $s$ !

1281. S. rubra [Huds. Fl. angl. p. 428] (Rød P.) Fr. 1. c. p. 63 ; F. D. 2555 ; Rehb. l. c. fig. 1236 ; H. N. $\mathrm{X}, 60$. 
Høi Buskvæxt; Bladene langstrakt-lancetformede, tilspidsede, glatte eller duunhaarede, i Randen tilbagerullede og svagt saugtakkede, Axelbladene linieformede; Raklerne lingere og tykkere; Støodragerne 2, sammenvoxne til Midten; Griffelen forlænget; Arrets Flige udeelte, linieformede; forøvrigt som foreg.

Høiere end foreg.; ligner i Characterer S. purpurea, i Udseende S. viminalis, og ansees af Wimm. l. ç. for en Bastardform mellem disse 2 Arter (S. purpureoviminalis). 4-5.

Sjelden: $\boldsymbol{S} \boldsymbol{j}$. i Langholrusmosen ved Dronninggaard (9), Valby! Ryerne mellem Lundehuusmosen og Strandveien $(19) ! S \boldsymbol{~}$. Fresendelf ved Trenen (F. Müll.).

cc. Viminales. Buskagtige med lange riisformede Grene. Yderbarken uden Dug, Inderbarken grønlig-hvid. ("Arrets Flige rettede for- og bagtil 0: lodret paa Axen ").

† 1282. S. mollissima [Ehrh. Beitr. 6, p. 101] (Blød P.) H. 93; Fr. l. c. p. 62 ; F. D. 2604 ; H. N. I, 65 .

Bladene langstrakt lancetformede, tilspidsede, utydeligt saugtakkede, paa Overfladen gronne, paa Underfiaden blødhaaretgraafiltede; Axelbladene xgformede, spidse (eller 0); Raklerne kortstilkede eller næsten siddende; Rakleslijcllene langhaarede; de nedre Blomster i Raklen udvikles først; Kapselen tæthaaret, næsten siddende; Griffelen forlænget; Arrets Flige tokløvede, under Blomstringen af Længde med Rakleskjællenes Haar.

Grenene glindsende, glatte, bruungule; Rakleskjællene under Blomstringen røde, i Spidsen mørkere, senere rustgule. 4-6.

SjeIden: $S j$. Kongens Enghave nær gl. Pesthuus (9), Utterslev, Ryerne mellem Lundehuset og strandveien $(19) ! f$. j det sydlige paa flere Steder mellem Faaborg og Svendliorg (f. Ex. V. Skjerninge (12)! $S \iota$. ved Bredderne af Eideren N. for Rendsborg! Tønning, Süderholz (F. Müll.). Saavidt uig bekjendt er $\sigma$ Planten ilke funden her i Landet.

Anm. Den hos Rchb. (1. c. fig. 1250) afbildede Plante af dette Navn afviger fra den her beskrevue ved langstilkerle Kapsler og indtil Midten sammenvoxne Stovtraad:. Denue Atbildning horer derfor neppe til den af Fries, Koch o. Fl. beskrevie Art, saameget mindre som Rehb. anseer sin Plante for en Bastarl af $\mathrm{S}$. purpurea og caprea, hnilket aIdeles iklse kan passe paa de Expl. jeg har seet, som snarere minde or $\mathrm{S}$. lanceolata eller undulata end om S. caprea. 
Wimm. 1. c. antager S. mollissima for en Bastard af S. undulata og S. viminalis.

$\dagger$ 1283. S. viminalis L. (Baand.P.) H. 994; Fr. l. c. p. 61; Drej. n. 962 ; F. D. 2485 ; Rchb. l. c. fig. 1248; H. N. I, 64 .

Bladene linie-laneetformede, spidse, heelrandede med tilbagerullet Rand, paa Overfladen graagronne, paa Underfladen silkehaarede og solvglindsende; Axelbladene linieformede; Raklerne tæt samlede, næsten siddende, de øvre Blomster i ô Raklen udspringe først; Kapselen hvidfiltet, næsten siddende, Griffelen forlænget; Arrets Flige linieformede, udeelte, fremragende oven. for Rakleskjællenes Haar.

Ved de meget smale og stedse i Randen tilbagerullede Blade let kjendelig fra de ørrige Arter. Spidsen af Grenene bortfryser ofte om Vinteren. Efter Wimmer (Sehles. Fl. p. 479) forekomme Arrene, endog paa samme Plante, snart hele, snart kløvede, hvilket ogsaa Hr. Rostrup har bemærket at være Tilfaldet hos os. $\frac{4}{2}-\frac{5}{1}$.

Meget alm. ved Gjærder overalt i Danmark.

† 1284. S. stipularis [Smith Fl. Brit. 1069] (Langbladet P.) F. D. 2668; Engl. Bot. 1214 ; Rehb. l. e. fig. 1249.

Bladene langstrakt lancetformede, tilspidsecie, svagt bolgetrundtakkede eller heclrandede (de æeldre uden tilbagerullet Rand), paa Overfladen grønne, tilsidst næsten glatte, paa Underfladen graafiltede; Axelbladene store, halvt lijerteformede, tilspidsede, bølget-saugtakkede, af Længde med eller længere end Bladstilken; Raklerne siddende; Rakleskjællene rødbrune, beklædte med lange, hvide Haar, som naae til Spidsen af Griffelen; Kapselen hvidfiltet, næsten siddende (Kirtelen længere end Kapselstilken); Griffelen kortere end Arrets linieformede, forlængede, udeelte Flige.

Grenene hridgraa-filtede. Har Lighed med S. viminalis og S. acuminata; ved kıaftigere Viext, bredere og svigere filtede Blade og tykkere Rakler forskjellig fra hiin, ved smalere Blade, lysere Rakleskjæl, kortere Kapselstilk og længere Ar fra denne, og ved de meget store Axelblade let kjundelig fra begge. $\frac{4}{2}-5$.

Ved Gjarder, sjelden og kun $\mathrm{Q}: \mathbf{S}$. Lygten, Lundehunsmosen (19)! Hornbaks Plantage (Heiberg)? 
+ 1285. S. acuminata [Sm. Fl. brit. 3, 1088 (ikke Hoffm. eller Koch)] (Spidsbladet P.) Engl. Bot. 1434; F. D. 2669; H. N. XI, 60; S. dasyelados Wimm.

Bladene elliptisk-lancetformede, tilspidsede, i Randen bølgede, fjernt og utydeligt saugtakkede (med i yngre Tilstand ved Grunden tilbagerullet Rand), paa Overfladen sortgrønne, tæt, men korthaarede, paa Underfladen blaagraa-filtede; Axelbladene halvt hjerteformede, tilspidsede; Raklerne siddende, de ovire Blomster udspringe først; Rakleskjollene næsten heelt sortbrune, beklædte med lange, hvide Haar, som naae op til Spidsen af Griffelen; Kapselen hvidfiltet, kortstilket, dens Stilk ligelang med Kirtelen; Griffelen af Længde med det udeelte eller udrandede Ars Flige.

Grenene meget tykkere end hos foreg. og følg., tilligemed Knopskjællene tæt beklædte med en sortgraa Filt. Raklerne tykke og meget laadne af de lange og tatsiddende Haar. Original-Expl. af $S$. dasyclados Wimm. stemme aldeles overeens med vor Plante. S. acuminata Rehb. l. c. fig. 1252 hører neppe herhid. $\frac{4}{2}-5$.

Ved Gjærder, sjelden: $\boldsymbol{S} j$. mellem Gl. Kongevei og FalkoneerAlleen ved Kbharn! Lundehuusmosen (19), Strædet ved Sorg! Loll. Steensgaard (19). (Paa alle disse Steder kun O).

† 1286. S. lanceolata [Fr. Nov. p. 283, Mant. 1, p. 61 (ikke Ser. eller Sm.)] (Lancetbladet P.) Drej. n. 963; H. N. I, 63 og II, 59; S. Smithiana (Koch?) H. II, 303; F. D. 2551 ; Rchb. l. c. fig. 1251; Lge. Haandb. 1 Udg. n. 1230 ; S. affinis Gren. \& Godr.; S. viminali-caprea Wimm.

Bladene lancetformede, spidse, heelrandede eller svagt bølget-tandede, paa Overfaden gragrønne, paa Uuderfladen silkehaarede og solvglindsende; Axelbladene halvt piilformethjerteformede; Raklerne siddende, alm. buekrummede, de nedre Blomster udspringe først; Kapselen graafiltet, kortstilket; Stilken af Længde med Kirtelen; Griffelen af Middellængde; alm. kortere end det tokløvede Ars linieformede Flige.

Høiere end de 3 foreg., stundom træagtig. Grene og Knopskjæ] næsten glatte. Arrene ere snart kløvede, snart hele. Saavel disse som Griffelen og Kapselstilken ere af forskjellig Længde. $-\frac{5}{1}$. Var. 
$\alpha$, acuminata IVimm. (S. acuminata Koch, ikke Hoffm. eller Sm.). Bladene med afruudet Basis, paa Underfladen tæt hvidfiltede; Griffelen og Arrets Flige længere.

$\beta$, capraformis Wimm. Bladene lancetformede, mod begge Ender afsmalnede, svagere filtede; Griffel og Ar korte.

Alm. ved Gjærder (en af de hyppigst plantede Pilearter her i Landet, hvor jeg dog stedse kun har fundet $q$ Expl.).

Anm. Navnet S. Smithiana Willd. har været meget omtvistet og forskjellig anvendt. Gren. \& Godr. anvende dette Navu paa en Form af S. Seringeana Gaud., S. lanceolata Ser. (ikke Fr.), som ikke hidtil er bemærket i vor Flora, men som muligviis kunde findes her. For vor Art har jeg foretrukket Navnet S. lanceolata Fr., som er mindre udsat for Forvexling.

c. CapreaFr. Grenene korte, knudrede; Raklerue siddende eller tilsidst stilkede, udvikles forend

(hos Nr. 1290 samtidigt med) Bladeue.

aa. Cinerascentes (Graavidier). Griffelen 0 eller meget kort, "Arrets Flige rettede for- og bagtil o: lodret paa Axen". Bladene rynkede, tathaarede. (Forekomme typisk som lave Iracr).

1287. S. cinerea L. (Graa P.) H. 992 ; Fr. l. c. p. 54; Drej. n. 965 ; F. D. 2601 ; Rehb. 1. c. fig. 1222; H. N. VII, 59 ; S. acuminata Hoffm.

Grenene og Knopshjollene graafiltede; Bladcne elliptiske eller omvendt-ægformet-lancetformede, spidse, paa begge Flader graagrønne, par Overfladen dunnharede, paa Underfladen filtede, svagt bolget-saugtakkede; Axelbladene nyreformede; Ralilerne siddende, valseformede (de ovre Blomster i ô Raklen udspringe forst); Kapselen hvidfiltet, langstilket, Stilken 4 Gange længere end Kirtelen; Arrets Flige agformede, tokløvede.

4-5. En Misdannelse med androgyme Rakler forekommer af og til. Bladene i Form meget foranderlige: $\boldsymbol{\beta}$, aquatica (Sm.), H. 992; Rchb. l. c. fig. 1223, har omvendt-ægformede, kort tilspidsede Blade, næsten af samme Form som Bladene hos S. aurita. En Var. lejocarpa, med glatte Kapsler, er funden i Lundeluusmosen (19).

I Moser og fugtige Kratsliove, meget alm.

Anm. I Selskab med S. cinerea og hastata samlede jeg 1858 paa flere Steder i det nordlige Jyll. (f. Ex. Broust, Fjerritslev) en 
Form, som synes at være frembragt ved Krydsning mellem de 2 nævnte Arter (S. cinereo-hastata). Bladene ere ovale eller bredt-elliptiske, budte eller med en meget kort Spids, saugtakkede, paa Overfladen svagthaarede, paa Underfladen (især i ung Tilstand) graafiltede, rynkede; Axelbladene store, hjerteformede, svagt saugtakkede. Da Blomster og Frugter manglede, er jeg dog endnu i Tvivl om dens rette Plads, og maa anbefale den til nærmere Undersøgelse i Blomstrings tiden.

1288. S. caprea L. (Vidie-P.) H. 993; Fr. l. c. p. 54; Drej. n. 966 ; F. D. 245 ? (slet) og 2603; Rchb. 1. c. fig. 1224.

De aldre Grene og Knopskjollene glatte; Bladene bredt elliptiske, ovale eller ægformede, spidse, svagt rundtakkede, i yngre Tilstand paa begge Flader graafiltede, ældre paa Overfladen glatte og grøne; Axelbladene nyreformede; Raklerne tykke, ovale eller æg-valseformede (de nedre $\hat{\delta}$ Blomster udspringe først); Kapselen hvidfiltet, langstilket, Stilken 4-5 Gange længere end Kirtelen; Arrets Flige tokløvede.

Bladene var. betydeligt i Form (fra elliptiske til næsten hjerteformede eller kredsrunde), Randeu snart heel, snart rundtakket. Forekommer undertiden med tydeligt stilkede $\$$ Rakler paa en bladet Stilk. $4-\frac{5}{1}$.

I Moser og Skove alm. udbredt. Som høit Skovtræ forekommer den hyppigst paa Bornholm.

1289. S. aurita L. (Øret P.) H. 989; Fr. 1. c. p. 55; Drej. n. 964 ; F. D. 2600 ; Rchb. l. c. fig. 1220 ; H. N. VII, 60 .

Knopslijxllene glatte; Bladene omvendt-ægformede, spidse eller budte med en kort, tilbagebøiet Spids, tandet-rundtakkede, nætformig-aarede og rynkede, paa Overfladen duunhaarede, paa Underfladen blaagraa-filtede; Axelbladene halvt-nyreformede; Raklerne ovale (de nedre $\widehat{\delta}$ Blomster udspringe først); $q$ Raklerne kortstilkede, med bladet Stilk; Kapselen hvidfiltet, stilket, Stilken 2-3 Gange længere end Kirtelen; Arrets Flige udrandede eller tokløvede.

Lavere af Væxt end de foreg., med spædere Grene og alm. mindre Blade, som var. i Formen (men altid med størst Brede ovenfor Midten). 
Rakleskjællene i Spidsen rodbrune, hos de 2 foreg. Arter sortbrume. 4-5 (lidet senere end foreg.).

$\beta$, fimbriata! Bladene dybt og spidst fryndset-tandede, med uligestore, bølgede $o g$ i Randen tilbageboiede Tænder.

I fugtige Engo or Moser, sumpige Sliove alm. $\beta$, ved Udkanten af Danstrup Hegn merved Landlyst pr. Fredensborg!

b6. Virescentes (Gronvidier). Buskagtige, med idetmindste de aldre Blade glatte; Griffelen forlanget. (De ovre Blomster $i$ ô Raklen udspringe forst).

1290. S. hastata L. (Spydbladet P.) H. 982; Fr. l. e. p. 48; Drej. n. 967 ; F. D. 1238; Rehb. I. e. fig. 1213; H. N. III, 53.

De unge Grene hvidfiltede; Bladene elliptiske, ægforınede eller æg-hjerteformede, fiint saugtakkede, glatte, paa Underfladen blaagraae og fiint aarede; Axelbladene store, halvt hjerteformede, sangtakkede; Raklerne stilkede med bladet Stilk, udvikles samtidigt med Bladene*); Rakleskjollene kruset-uldhaarede; Kapselen glat, stilket, Stilken omtrent dobbelt saa lang som Kirtelen; Arrets Flige tokløvede, "rettede for- og bagtil ( lodret par Axen)".

Bladeue forandre ikke deres Farve ved Tørring. Herved, sant ved de store Axelblade og fir. Begyndelsen stilkede Rakler let kjendelig fra folg.

I Moser, især paa Hedegrund, paa Halvoen hist og her, men ikke alm.: J. Hanherrederne, Thy (Dr.), Vendsyssel alm.! Nykjøbing p. M. (28), lille Vildmose! Eveldrup, (Dr.), Ostrup Krat ved Randers (7), Aarslev (H.), Urup, Lundum, Hansted (2), Skjern! paa Oerne sjeldnere: $S j$. Tibirke IIose mod Arreso! Himmelor ved Roeskilde (8), Langholmsmosen ved Dronninggaard (H.), Leersøen (19).

*) Denne Art afviger ved stilkede Rakler og samtidig Udvikling af Blade og Blomster fra de wrrige Arter i samme Afdeling (c), men kan paa Grund af naturligt slegtskab ikke adskilles fra deune. En kunstig Gruppering af Pilearterne er paa Grund af de foranderlige Forhold hos mange Arter neppe mulig. Jeg har derfor i det Vasenlige fulgt den ypperlige naturlige Anordning, som er givet af Fries. 
1291. S. nigricans [Sm. Trans. Linn. soc. 6, 120] (Sortagtig P.) H. 981 ; Fr. l. c. p. 52 ; F. D. 2553 ; Rechb. 1. c. fig. 1217 ; H. N. V, 62 og VIII, 62 ; S. phylicæfolia $\beta, L$., F. D. 1053 .

Høi Busk; de yngre Grene rød- eller sortagtige med hvidgraa-duunhaaret Beklædning; Bladene omvendt-ægformet-elliptiske eller smalt agformede, sangtakkede, paa Underfladen blaagraae, under Lupen fint hvidpunkterede, med silkehaaret Midtnerve, forøvrigt alm. glatte; Axelbladene halvt hjerteformede med ret Spids, kirtlet-saugtakkede; Raklerne ulvikles førend eller samtidigt med Bladene; $\hat{\sigma}$ Raklerne siddende, $q$ forst kort, tilsidst tydeligt stilkede, Rakleskjollene langhaarede; Kapselen langt tilspidset, stilket, med en Stilk 3-4 Gange længere end Kirtelen; Arrets Flige tokløvede eller udrandede, "rettede tilhøire og venstre (э: parallelt med Axen)".

Bladene var. betydeligt i Formen (fra ægformede til lancetformede, i frisk Tilstand grønne, tørrede blive de sorte og meddele Papiret, hvori de opbevares, en sort Farre. O Raklerne var. fia forlænget valseformede til oval-kugleformede; Kapslerne snart glatte (lejocarpa), snart mere eller mindre filthaarede (eriocarpa Koch). Knopskjællene har jeg alm. fundet haarede hos 9 , ofte glatte hos $0^{*}$. $4-5 . \quad$ h.

I fugtige Enge, sjelden i Danmark: Vildroxende har jeg fundet den i Flommen ved Sorø ( $Q$ ), plantet ved Gjærder mellem FalkoneerAllen og gamle Kongevei udenfor Kbhrn ( $\left.0^{7}\right)$. I Leersøens udtørrede Bassin findes begge Kjon (19).

ee. Argentew (Solvidier). Lave Buskvexter med (oftest) underjordisk Stamme, almindelig silkehaarede Blade; Griffelen hiort, "Arrets Flige rettede for-og bagtil, o: lodret paa Axen".

1292. S. ambigua [Ebrh. Beitr. VI, p. 103] (Lav P.) Koch Syn. II, 753; F. D. 2670 ; Rehb. 1. c. fig. 1243 b.; S. incubacea (L.?) Fr. mant. 1 p. 66 ; S. plicata Fr. fl. Hall. p. 148; H. N. XI, 64; Lge. Haandb. 1 Udg. n. 1235; S. aurito-repens Wimm.

Stongelen lav, buskagtig; Bladene omvendt ægformet-elliptiske, spidse med tilbagebøiet Spidse, i Panden tilbagerullede, 
fjernt tandede eller heelrandede, paa Overfladen nedtrykt-, paa Underfladen fiint og ophoiet-aarede, silkehaarede; Axelbladene halvt rgformede; de frugtborende $q$ Rakler kortstilkede med bladet Stilk; Kapselen silkehaaret, stilket, Stilken 2-3 Gange længere end Kirtelen; Arrets Flige næsten siddende, udrandede.

Var. i Bladenes Form og Beklædning (paa Overfladen dunnhaarede eller glatte, paa Underfladen alm. silkehaarede). Forekommer under 2 Former: den ene (S. spathulata Willd. efter Wimm.) hoiere (med kortere og bredere Blade, nærmer sig mere $\mathrm{S}$. aurita, den anden ( $S$. ambigua Elurh., W.) med smalere Blade og lavere Stængel, staaer nærmere S. repens. $4-5$.

I Moser og fugtige Skove: $\boldsymbol{S} \boldsymbol{j}$. Pedersborg ved Sorø! Hornbæks Plantage, Hammermølleskoven og Lappen ved Helsingor (Heiberg), Hareskoven mellem Kulhusene og Frederiksdal! Leersøen (19).

Aum. Denne Art danner et Nellemled mellem S. aurita og repens, og ligner denne i Udseende, hiin i de fleste Charaeterer, hvorfor den af Wimmer ansees for en Bastardform af disse 2 Arter. Navnet S. incubacea L., som af Fr. har været overfort paa -denne, er meget omtvistet af Forff., og jeg har derfor foretrukket at betegne denne Art ved det Ehrhartske Navı. Hartm. søger S. incubacea L. i S. repens; Smith (efter Linn. Herb.) i S. angnstifolia; S. incnbacea Hornem. p. 391 er ntvivlsomt en Form af S. repens.

1293. S. repens L. (Krybende P.) H. 990 og S. incubacea 991 ; Fr. I. c. p. 65 ; Drej. n. 968 ; F. D. 2489 ; Rehb. I. c. fig. 1239 ; H. N. VI, 55; L. Herb. IX, 165.

Stangelen krybende med udstrakte eller oprette Grene; Bladene fra lancetformede til kredsrunde, heelrandede med tilbagsebøiet Rand og Spidse; Axelbladene lancetformede (eller 0); Raklerne valseformet-ovale, under Blomstringen siddende, efter samme kortstilkede, med bladet Stilk, udvikles for Bladene; Kapselen glat eller haaret, med en Stilk 2-3 Gange langere end Kirtelen; Griffelen meget kort; Arrets Flige tokløvede.

4-5. En yderst foranderlig Plante i Henseende til Bladenes Form og Beklædning, Raklernes Form, Kapselens Beklædning o. s. v• Blandt de talrigste Former nævnes som de vigtigste:

$\beta$, fusca Sm., Rchb. I. c. fig. 1240 ; S. fusca L. (part.) Grenene ofte forlængede; Bladene elliptiske eller ovale; Kapselen filtet.

$\gamma$, argentea (Sm.); F. D. 2605 ; Rclub. 1. c. 1243 ; S. are- 
naria L.; S. fusca H. 991; Bladene ovale eller kredsrunde, paa begge Flader (eller idetmindste paa Underfaden) tæt og tiltrykt silkebaarede, sølvglindsende; Kapselen filtet.

d, lejocarpa Koch; Rehb. l. c. fig. 1241. Bladene glatte eller paa Underfladen silkehaarede; Kapselen glat.

I Torvmoser og Enge, paa fugtig Hede- og Sandgrund, alm. Af $\beta$, har jeg fundet en udmærket Form i Jægersborg Allee mellem Ordrup og Charlottenlund (svarende til Fig. 1240 hos Rchb. og foruden de anførte Kjendetegn mærkelig ved tilsidst langstilkede Rakler); $\gamma, j$ Klitter, f. Ex. J. alm. i Klitterne ved Vesterhavet; $\boldsymbol{S} \boldsymbol{j}$. ved Tiisvilde: o. fl. St. i Nordsjall. (19); B ornh. alm.! $\delta$, med Hovedarten, f. Ex. $\boldsymbol{S} j$. Lappen ved Helsingør (Heiberg), Heder mellem Flaskekroen og Kjøge! Lundehunsmosen! $\boldsymbol{F}$. Skaarup (19).

\section{S. rosmarinifolia L. (Rosmarinbladet P.) H. 991;} Fr. l. c. p. 64 ; Drej. n. 969 ; F. D. 2556 ; Rehb. l. c. fig. 1242 ; H. N. VI, 56.

Stcongelen krybende, med langstrakte, oprette Grene; Bladene linieformede eller linie-lancetformede, flade, med ret Spidse, Raklerne ægformet-rundagtige, forøvigt som foreg. 5 .

I Moser, meget sjeldnere end foreg.: $\boldsymbol{S}$ j. Lyngby Mose (2S)! Lundehutusmosen! Leersøen (19), Ordrups Mose mod Ermelund!

* 1295. S. angustifolia [Wulf. i Jacq. Coll. 3, p. 48] (Smalbladet P.) Fr. l. e. p. 65 ; F. D. 2557 ; Rchb. 1. c. fig. 1238 ; H. N. II , $60 ; \mathrm{V}, 65$; S. repenti-viminalis Wimm. Schles. Fl. p. 483 .

Høi Busk med overjordisk Stamme og opstigende Grene; Bladene stivt oprette, langstrakt-linie-lancetformede; Axelbladene lancetformede; Raklerne ovale, tilsidst kort valseformede; Kapselens Stilk kortere (lidet længere end Kirtelen); Griffelen længere; forøvrigt som foreg.

I Henseende til Bladene ligner den S. viminalis, i Characterer staaer den forørrigt meget nær S. rosmarinifolia. Planten er mig for lidet bekjendt til at jeg tør have nogen Mening om, hvorvidt den, som Wimmer antager, er en Bastardform af $\mathrm{S}$. viminalis og repens, en Formodning, som dens overalt sjeldne Forekomst maaskee dog kunde bestyrke. Koeh (Syn. II, 755) bemærker om denne og de 2 foreg. Arter: "ægre hæ species describuntur, quæ vivæ non difficile distinguuntura. $\frac{4}{2}-\frac{5}{1}$. 
Ved Veien i Frederiksborg store Dyrehave (9), Leersøen (19)! Andro Voxesteder i Danmark ere mig ikke bekjendte. $\bar{i}$

†? 1296. S. Doniana [Sm. Engl. Fl. IV, p. 213] Engl. Bot. Suppl. 2599; S. purpureo-repens WVimm.

"Lav Busk $\left(3-6^{\prime}\right)$ med overjordisk Stamme og oprette Grene; Bladene lancetformede cller omvendt-ægformet-lancetformede med ret Spidse, fjernt saugtakkede, paa Overfladen glindsende, paa Underfladen silkehaarede; Axelbladene linieformede; Raklerne siddende, tilsidst kortstilkede; ठै Stovtraadene sammenvoxne; $q$ Kapselen filtet, dens Stilk næsten dobbelt saa lang som Kirtelen; Griffelen kortere end Arrets udrandede, korte Flige."

Fra S. purpurea, som den meget ligner, adskilles den (foruden de angivne Kjendetegn) ved efter Bestøvningen brungule (ikle sorte) Støvkuapper. Den er mig kun bekjendt af Beskrivelse og Afbildn. i E. B.

Funden ved Slesvig (Jessen, ef. Sond. Fl. hamb. p. 534).

\section{II. (III) Triandria.}

\section{Empetrum. Krakling.}

1297. E. nigrum L. (Revlingbær). H. 996; Drej. и. 970 ; F. D. 975 ; Rchb. l. c. V, fig. 4810 .

Stanglerne fremliggende; Bladene krandsstillede eller tret spiralstillede $\left({ }^{3} \varepsilon\right)$, smalt oval linieformede, budte, laderagtige, morkgrome med lysere Midinerve paa Underfladen; Arret nistraalet; Froene 6-9.

Lynglignende Halpbusk med næsten naaleformede Blade. Kronen morkrød, Bærrene sorte. 5. T.

I Torvmoser og paa Lyngheder: paa Halvoen meget alm. i Hedeeguene, sjeldnere $\mathrm{i}$ de frugtbare Egue mod 0 . og paa Øerne: $\boldsymbol{F}$. Hals ved Hofmansgave (H.); $\mathbf{S}$. Aamosen (15), onkring Nykjobing $\mathbf{i}$ Odsherred og i det nordøstl. alm.! Lynghy Mose! Kjøge (9), Holmegardsmosen! L oll. Stokkemarke, Karlely verl Nysted (19); F a tst. Iorreby Lyng (H.), Lidstrup Lyug (Koeli); Bornh. ikke sjelden i Hoilyngen! 


\section{III. (IV) Tetrandria.}

\section{Illippophaё. Tidse.}

1298. H. rhamnoides L. (Sand-T.) H. 999: Drej. n. 972; F. D. 265 ; Rehb. 1. c. XI, fig. 1165 .

Bladene lancet-linieformede, heelrandede, paa Underfladen solvglindsende, paa begge Flader beklædte med hvidgraae, stjerneformede (Blomsterdækket med rustfarvede) Slijal; $\delta$ Blomsterne i korte, alm. fireradede Ax ved Grunden af de unge Grene.

Busk med stærke Vedtorne. Bærrene gule. 5-6. $\zeta$.

Strandklitter (paa Leer eller Kalk) og Sandklitter, i den nordl. og nordvestl. Deel af Jyll. alm., sjeldnere mod S. (Rijs Skov ved Aarhus!) og paa Øerne! $\boldsymbol{F}$. Vedelsborg (H.); Sj. Refsnæs (19), Lerchenborg, Stevns Klint (H.); Mo ens Klint i stor Mængde; F alst. mellem Korselitze og Gronsund (H.) og mellem Tromnæs og Bøtø (Koch); B ornh. (H.)

\section{Viscum. Fugleliim.}

1299. V. album L. (Misteltein). H. 997; Drej. n. 971; F. D. 1657 .

Grenene trinde, leddede, gjentaget-gaffeldeelte; Bladene modsatte, lancetformet-tungeformede, budte, 3-5-nervede, heelrandede; Blomsterne 3-5 nøgleformigt samlede i Greenvinklerne.

Bladene stedsegrønne, læderagtige, Blomsterne guulgrønne, Bær hvide. 4-5. Ћ.

Snyltende Busk paa Træstammer, især Ebletræer, ikke alm.: Sj. store Elmue ved Lindersrold (Mørch)! Petersværft (H.); Loll. Soesmark (5), Oureby (Rosenorn Lehn); J. Trelde Skov ved Fredericia (H.); $\boldsymbol{S} l$. Bockholt ved Arnæs (16), Husum paa Pæretræer (F. Müll.).

\section{Myrica. Pors.}

1300. II. Gale L. (Mose-P.) H. 998; Drej. n. 973; F. D. 327 ; Relıb. 1. c. XI, fig. 1277.

Bladene lancetformede med størst Brede ovenfor Midten, fra Midten til Spidsen saugtakkede; Raklerne ovale, siddende 
tæt sammen i Spidsen af Grenene; Rakleskjcellene bredt-ægformede med en kort Spids, bruun-hindeagtige.

Lav Busk. Blomsterue udvikles før Bladene. Vellugtende af en harpixagtig Saft, som udskilles i Form af Draaber fra Blade og Rakler. 4-5. h.

I Moser, især i Hedeegne: alm. i den vestlige og midterste Deel af Halveen, sjeldnere mod 0 . og paa Øerne: $\boldsymbol{F}$. Sanderumgaard, Rønninge (H.); $\boldsymbol{S}$. Tiisvilde! Frederiksværk, Gilleleie, Nykjobing (H.), Aanısen (15), mellem Munkebjergloy og Eskildstrup So (Lund), Bromme ved Sors (7), Særløse (20) og Skov-Hastrup ved Roeskilde (15), Holmegaardsmosen! Falst. Systofte (Koch); Loll. S $\xi$ holt (H.), Alsø (5); Bornh. ved Snogebæk (Lotze), Dueodden (Hjorth).

\section{IV. (V) Pentandria.}

\section{Humulus. Ilumle.}

1301. II. Lupulus L. (Almindelig H.) H. 999; Drej. n. 974 ; F. D. 1239 ; Rehb. ic. fl. germ. XII, fig. 1326.

Stcongelen slyngende, svagt kantet og paa Kanterue ru af hagekrummede Børster; Bladene modsatte, rue, haandlappede, med tilspidsede, saugtakkede Lapper; Axelbladene ovale eller ægformede, hele eller i Spidsen tokløvede.

Blomsterne gronne. o Raklerne (Humlekopper) vellugtende, af bitter Smag. 6-7. 2 .

I Skove og ved Gjærder, alm. $q$ Planten dyrkes.

\section{Cannabis. Hamp.}

$\dagger$ C. sativa L. (Almindelig H.) Rehb. 1. e. XII, fig. 1325.

Bladene rue, haandsnitdeelte, med lancetformede, tilspidsede, saugtakkede Afsnit. $7-8 . \odot$. $\odot$.

o Planten storre og morkere end $\sigma^{*}$. Blomsterue gronne.

Dyrkes som IIandelsplante. 


\section{Juniperus. Ene.}

1302. J. communis L. (Almindelig E.) H. 1007; Drej. n. 975 ; F. D. 1119 ; Rehb. l. c. XI, fig. 1141.

Bladene krandsstillede ( $1 / 3)$, linie-sylformede, stikkende, paa Overfladen rendede; paa Underfladen kjølede; Frugten (Enebær) kugleformet, sortagtig, overtrukken med blaggraa Dug.

5-6 (Frugterne modnes først $\mathrm{i}$ det andet Aar). $\boldsymbol{Z}$.

Paa Lyngheder og torre Bakker: forekommer oftest buskagtig, men danner flere Steder i det midterste $\boldsymbol{J} y / l$. Skove; hyppig $\mathrm{i}$ de magre Egne af Halvgen, i $N$ ordsjall., paa $\boldsymbol{M}_{\theta}$ ens Klint og $\boldsymbol{B}$ or $n h$., i de øvrige Egne sjelden, og mangler i de mere frugtbare og dyrkede Dele af Landet.

\section{V. (VI) II ex-Polyandria.}

\section{Populus. Poppel.}

a. Leuce Duby. Rakleskjællene randha arede; $8 \mathrm{St} ø$ vdragere; Arrets Flige smale; de unge Grene (idetmindste hos unge Planter) filtede eller harede.

$\dagger$ 1303. P. alba L. (Sølv-P.) H. 1001; Drej. n. 978; F. D. 2182 ; Rehb. ic. fl. germ. XI, fig. 1272 ; H. N. XIII, 69. Bladene ag-hjerteformede, bugtet-tandede, paa de unge Grene hjerteformede eller ovale med hjerteformet Basis, 3-5lappede, alle Bladene paa Underfladen og Smaagrenene sneehvidt filtede (med vedblivende Filt); $q$ Rakleslijollene lancetformede, saugtakkede; Arrene todeelte; Knopperne filtede.

Høit Træ. 4-5. 万.

Alm. plantet omkring beboede Steder, sjeldnere i Skove og maaskee ikke oprindeligt vildvoxende.

† 1304. P. canescens [Sm.? Koch Syn. II, 759] (Graa P.) H. 1002 ; Drej. n. 979 ; F. D. 2183 ; P. hybrida 11. Bieb., Rchb. l. c. fig. 1271.

Bladene rundagtigt-ægformede, alle bugtet-tandede, paa Underfladen tilligemed Smaagrenene og Knopperne bvidgraa- 
filtede, tilsidst glatte; + Ralieslijcellene lancetformede, saugtakket-Higede; Arrene 2-3-deelte.

Høit The. 4-5. 万.

Omkring Byer og beboede Steder med foreg. $\bar{i}$

Anm. Forekommer stundom enbo (med ơ og ㅇ Rakler paa samme Træ), med androgyne Rakler eller med de nedie Blomster i Raklerne ఫ, (4-8 Støvdragere mellem Skaalen og Kapselen (Didr., Rostr.)).

1305. P. tremula L. (Bævre-Asp). H. 1002; Drej. n. 977 ; F. D. 2184 ; Rehb. 1. c. fig. 1274.

Bladene ægformet-kredsrunde, tandet-rundtakkede, glatte; Knopperne klæbrige, glatte; Grenene glatte, hos det unge Træ eller paa Rodskuddene haarede; $q$ Rakleskjellene omvendt-xgformede, dybt haanddeelte; Arrene uregelm. 3-4-lappede.

Træ af Middelstørrelse. Bladstilken vender Kanten (den smaleste Side) mod Pladen hos alle Poppelarter; men da Stilken hos denne er fladere end hos de ovrige, bevæges Bladene let af Vinden, hvilken Egenskab den skylder sit Navn. 4-5. 万.

* villosa (Lang) P. canescens (Sm.) Rehb. I. e. fị. 1273. Bladene paa begge Flader eller paa Underfladen tiltrykt-silkehaarede, tilsidst glatte; "Arrene frekløvede".

I Skove og Krat, alm., ogsaa i Hedeegne, danner f. Ex. i Halvøens Hedestrakninger ofte Kratpartier (alene eller i Selskab med andre 'Træarter). * sjeldnere, f. Ex. S $\boldsymbol{j}$. Soro Sonderskov! Cliarlottenlund! Falst. Taaderup (14). (Rehb. anseer demne for en egen Art og henfører til den Narnet P. caneseens Sm. Da jeg ikke tor antage det for afgjort, om det Kjendetegn, som hentes fra Arrene, er bestandigt eller ikke, da den liele wvrige Plante er aldeles lig. P. tremula, og da navnlig Bladenes Behaaring er et ingenlunde paalideligt Mrrke, maa jeg ansee den kun for en simpel Varietet)

b. Aegiros Duby. Rakleskjællene glatte, Stovdragerne $12-30$; Arrets Flige kredsformet-nyreformede; alle Smangrenene glatte.

$\dagger$ 1306. P. monilifera [Ait. Hort. Kew. ed. 1, 3, p. 407] (Kanadisk P.) Drej. p. 312.

Grenene udstaaende, de yngre kantet-furede; Bladcne triangelægformede, kort tilspidsede, saugtakkede, de yngre i Randen svagt duunhaarede.

Hoit Træ. 4-5. Һ. De unge Blade rodlige. 
Plantes alm. omkring Byer og i fugtige Skove, oprindelig indfort fra Nordamerika. $O$ Planten er her i Landet meget sjelden: 1 Tra ved Svanholm paa gl. Kongevei (19).

† 1307. P. nigra L. (Sort P.) H. 1003; Drej. n. 976 ; Rchb. l. c. fig. 1275 ; H. N. XII, 64.

Grenene udstaaende, de yngre trinde; Bladene triangel-ægformede, langt tilspidsede, i Randen glatte, saugtakket-tandede.

Høit Træ. 4-5. h. Løvspringet 8-14 Dage tidligere end hos foreg., de yngre Blade frisk grønne.

Paa lignende Steder som foreg., men sjeldnere. Jeg har aldrig fundet den vildvoxende, men jden er sandsynligviis indfort fra SydEuropa. (Den æuldste og største Poppel i Danmark, ved Herlufsholm, er et Expl. af denne Art).

$\dagger$ 1308. P. pyramidalis [Rozier i Lam. dict. 5, 235] (Pyramide-P.) Drej. p. 312 ; P. dilatata Ait.

Grenene opret tiltrykte; Bladene rudeformede, kort tilspidsede, i Randen glatte, saugtakkede, nedenfor Midten heelrandede.

Høit Træ. (Af nogle Forff. henført som Var. til foreg., men ved de mindre og mere rudeformede Blade og især ved dens rank-pyramideformede Væxt yderst forskjellig fra hiin). 4-5. $\mathbf{~}$.

Plantes ofte omkring beboede Steder, oprindelig indfort fra Orienten eller Sydeuropa.

† 1309. P. balsamifera L. (Balsam-P.) Duham. II, t. 50. Blaclene ægformede, tilspidsede, fiint og tiltrykt-saugtakkede, de yngre og især Knopperne stærkt klæbrige, vellugtende.

5. 万.

Plantes som de foreg., ikke sjelden, indfort fra Amerika.

\section{Mercurialis. Bingelurt.}

1310. I. perennis L. (Vedvarende B.) H. 1004; Drej. n. 980 ; F. D. 400 ; Rchb. 1. c. V, fig. 4804.

Rodstokken krybende; Stangelen udeelt; Bladene æegformetelliptiske, rundtakket-saugtakkede, ruhaarede; $q$ Blomsterne langstilkede.

Planten faaer ved Torring et mørkblaat eller violet Anstrøg. o Planten mørkere end $\sigma^{\circ}$. Blomsterne grønne. 4-5. ข.

I skyggefulde Lovskore, meget alm. 
1311. II. annua L. (Enaarig B.) H. 1005; Drej. n. 981; F. D. 1890 ; Rehb. l. c. fig. 480 l.

Stcongelen opret, grenet med korsviis modsatte Grene $(\mathbf{1} / 2.1 / 4) ;$ Bladene xgformede eller ægformet-elliptiske, saugtakkede, glatte; of Blomsterne kortstilkede eller siddende.

Planten lysere gron end foreg. Blomsterne gronne. 7-8. $\odot$.

Ukrud i Haver, ikke alm.: $\boldsymbol{S}$ j. Marienlyst ved Helsingør (Holbøll), Kongens Have ved Frederiksborg (A. Rafu), Kirsebærgangen ved Norre-vold (19), Universitetsgaarden (Heiberg), Rosenborg Have (Schum.); ๑. fl. St. omkring Kbhavn; J. Aalborg (H.); Sl. Husum (F. Müll.); Bornh. (H.).

\section{Stratiotes. Krebsklo.}

1312. S. aloides L. (Aloebladet K.) H. 1.006; Drej. n. 983 ; F. D. 337 ; Rehb. 1. c. VII, 111.

Bladene rosetteformigt samlede ved Roden, linie-sværdformede, kjolede, i Randen tornede; Skaftet fladtrykt, med 2 Blornsten omgivende Hylsterblacle i Spidsen, forøvirigt bladløst.

Fra Rodstokken udgaae lange og talrige Rodtrævler samt Udlobere med en Knop i Spidsen, der tilsidst løsrives fra Moderplanten. Planten for og efter Blomstringen nedsænkt under Vandet. Kronbladene hvide. $7-8$. น.

I Torvmoser, Sser og Brkke: hyppig paa Halvoen, især i Aaer og Marskgrofter mod V., sparsommere paa $\Theta$ erne (i det sydlige Fyen og paa Smaaøerne mangler den. (Jeg har kun fundet of Planter hos os, og maaskee forekonmer o Planten ikke i vor Flora. Sml. Nolte Stratiotes u. Sagittaria p. 31).

\section{Hydrocharis. Frobid.}

1313. II. Morsus rane L. (Vand-F.) H. 1005; Drej. n. 982 ; F. D. 878 ; Rehb. I. e. VII, fig. 112.

Stcengelen svsmmende, med forlnngede Ledstykker, fro Ledene udgaae Rodtravler og langstilkede, kredsrundt-nyreformede, heelrandede Blade; $\hat{0}$ Blomsten omgivet af $1-2$ hylsterformede Docklalade.

Kronen hvid. Overvintrer ved Endeknopper fra Udløbere ligesom foreg. 7-8. 4 .

I Torvgrave, Søer og Aaer, alm. overalt i Danmark. 


\section{VI. (VII) II on adelphia.}

\section{$X$ 12. Taxus. Taxtrae.}

$X$ 1314. T. baccata L. (Almindelig T.) H. 1008; Rchb. 1. e. XI, tab. 538; F. D. 1240 .

Bladene toradede, kortstilkede, i Spidsen alm. krumbøiede, Alade, spidse, stedsegrønne; Frøkappen høirød, meget saftfuld (hrorved Frøet faaer Lighed med en Steenfrugt).

Busk eller lavt Træ. Bladene mørkgrønne, blegere paa Underfladen. 4-5 (Frugten modnes i October). $\mathfrak{h}$.

Dyrkes stundom i Haver og Lystskore. Findes vildvoxende i alle Nabolandenes Bjergskove, men ikke i Danmark; om den tidligere har været vildvioxende her i Landet, er tvivlsomt (Kyll. angiver den at voxe wudi en Skov ved Fjelderup").

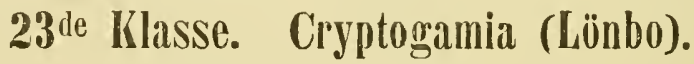

\section{Orden. Filices (Bragner).}

Sporehusene (Kapsler, som indeholde en Mrngde smaae, frie Sporer) samlede i Frugthobe (sori) paa Bagsiden af det oftest 1-flere Gange finnetdeelte $\mathrm{L} \emptyset \mathrm{v}$ eller hos nogle (ved Bladkjødets Forsvinden) paa Bagsiden af den tilbageblivende Nerve og dennes Forgreninger. (Løvet i Knoptilstanden sueglehuusformig indrullet, udgaaende fra en underjordisk Rodstok, og ofte, isæ̉r ved Grunden, beklædt med hindeagtige

Skjæl (Avmer).

a. Kapslerne omgivne af en leddet Ring. Frugthobene paa Bagsiden af Løvet, aa, omgivne af et hindeagtigt Shjal (Sloret, indusium). $\alpha$, Frugthobene linieformede eller aflange.

1. Asplénimu L. (part.) Frugthobene rette eller krum. mede, omgivne af et enkelt Slør, som er fasthæftet ved den ydre og aabner sig paa den indre Side*) (Løvet snitdeelt).

*) Brægnerne maa undersøges medens Frugterne endnu befinde sig paa et yngre Udviklingstrin; i ældre Tilstand forstyrres ofte For- 
† 2. Scolopéudrium Roth. Frugthobene rette, parallele, i Retning med Lovets Sideaarer; 2 og 2 samlede og fra hver Side omgivne af et Slør, tilsidst sammenfldende. (Lovet heelrandet).

$\beta$, Frugthobene kredsrunde. (Løvet fjersnitdeelt).

3. Aspidium R. Br. Sløret kredsrundt, skjoldformet og befæstet i Midten af de rundagtige Frngthobe.

4. Lastráa Presl. Sløret nyreformet, forøvrigt som foreg.

5. Cystopteris Bernh. Sløret rundt eller xegformet, befo:stet med Randen til de rundagtige Frugthobe, tidligt affaidende.

bb. Frugthobene omgivne af Lovets tilbagerullede Rand (et ucegte Slør).

$\boldsymbol{\alpha}$, de frugtbærende og golde $\mathrm{L} ø \mathrm{v}$ eensformede.

6. Pteris L. Frugthobene uafbrudt fortlobende langs Rancien af det $2-3$ Gange fjersnitdeelte Løvs secundære eller tert:ære Afsnit.

$\beta$, de frugtbærende og golde $L ø v$ forskjelligformede.

7. Blechnum L. Løvet fjersnitdeelt med heelrandede Afsuit; Frugthobene i 2 parallele Rækker langs Afsnittenes Midtnerve, bedækkede af de indbøiede Rande.

8. Struthiópteris Will. Løvet fjersnitdeelt med halvfnnede Afsnit; Frugthobene bedække Afsnittenes grenede Sidenerver og tilsidst deres hele Underflade, (i Begyndelsen skjulte af Afsnittenes lige indtil Nidtnerven tilbagerullede Bladsubstans, tilsidst frie, idet Randen udbredes og spaltes fjerrormigt).

\section{cc. Frugthobenc uden Slor.}

9. Polypódium L. (part.). De frugtbærende og golde Løv eensformede, fjersnitdeclte eller trekoblede; Frugthobene kredsrunde, spredte eller i regelmæssige Rakker.

holdet, idet deels Sloret falder af, deels Frugthobene sammeuflyde og saaledes tabe deres oprindelige Form. 
b. Kapslerne uden Ring, i enkelte eller grene Ax paa samme Stængel som (men af forskjelliz Udseende fra) de golde Løv.

aa. Kapslerne noetformigt stribede, kortstilkede.

10. Osmúnda L. (part.) Kapslerne kugleformerio, toklappede, i grenede Ax. (Det golde Løv dobbelt fjel nite'(clt).

bb. Kapslerne uden Striber, siddende.

11. Botrýchium Sw. Kapslerne adskilte, i grentede Sx. (Det golde Løv deelt).

12. Ophioglóssum L. Kapslerne sammenhær grexilc ijed deres Sider, toradet ordnede til et ensidigt, enkeit $A$. (bet golde Løv heelrandet).

\section{Orden. Lycopodiacece (Ulvefoddei).}

Bladene taglagte, skjæl- eller sylformede, Frugterne ol f ringe 1 Klapper, siddende enlige i Blaḍjornerne eller samlede th $A x$ or omgivne af Dækblade forskjellige fra Stængelbladsne.

13. Lycopódium L. (part.). Frugterne (Spori?huse) crsartede, i Form af rundagtige eller nyreformede, (0)klarp ite,

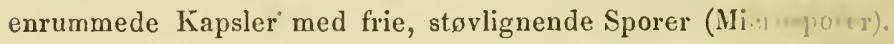

14. Selaginélla Spring. 2 Slags Frugter: nogle $m$ b is foreg., andre 3-4-klappede med 3-4 større Sporer (Marro. sporer), sorn ere næsten kugleformede og forsynede mea is Spidsen sammenløbende Striber.

\section{Orden. Isoëtece (Brasenurter).}

15. Isoëtes L. Sporehusene rundagtigt-ovale, w grim af en uopspringende Hinde og indsænkte $i$ de linitriur $A$ Blades udvidede Basis; de i de indre Blades Skeder in Iuttec Sporehuse indeholde et meget stort Antal mindre Spare: lif crosporer), de $\mathbf{i}$ de ydre Bladskeder indsluttede et riugure Antal større, sphærisk-triangelformede (Macro-) Sporer. 


\section{Orden. Rhizocarpece (Rodfrugtocexter).}

16. Pilulária L. Bladene linie-børsteformede, for Udviklingen sneglehuusformigt sammenrullede; Frugterne paa Rodstokken ved Bladenes Basis, kortstilkede, kugleformede, firerummede og i udviklet Tilstand freklappet-opspringende, indeboldende talrige Sporehuse, hvoraf de nedre indslutte 1 større (Macrospore), de ovre mange smaae (Micro-) Sporer.

\section{Orden. Equisetacece (Padderokker).}

17. Equisétum L. Stængelen leddet, med en tandet Skede ovenfor bvert Led, udeelt eller med krandsstillede Grene; Sporehusene kredsformigt ordnede i Form af Lapper paa Underfladen af kortstilkede, skjoldformede Forgreninger af den fælles Frugtaxe, bvorved der dannes en endestillet, axformet Klase.

\section{Orden. Characece (Krandsnaalvaxter). *)}

Vandplanter med leddede Stængler, uden ægte Blade, men med st eller mindre, fra Ledene krandsformigt udgaaende Grene, hvilke enten forgrene sig paa samme Maade som Hovedaxen eller i Spidsen opIøses i Straaler; to Slags Formeringsorganer, enten paa samme eller forskjellige Planter (Enbo eller Tvebo): 1, kugleformede Antheridier af rød Farve, indeholdende Spiraltraade og 2, Sporehuse af oftest aflang Form, indeholdende 1 Spore og omgivne af 5 spiralformigt snoede Celler, hvis frie Ender i Sporehusets Spidse danne en tandet Krone.

18. Nitélla Ag. Stænglernes Ledstykker encellede, jævne, i tørret Tilstand hindeagtige (kun undtagelsesviis incrusterede);

*) Uden at tage Hensyn til Sporgsmaalet om Characeernes Plads i Systemet, som har været meget omtvistet (de fleste Botanikere ere tilboielige til at stille dem i Nxrheden af Algerne), har jeg efter Opfordring fra forskjellige Sider og tillige af Hensyn til at vi i den danske botaniske Litteratur savne saagodtsom al Veiledning til at bestemme de her forekommende Arter af en talrig og eiendommelig Familie, fundet mig foranlediget til at forsoge en kort Fremstilling af denne og en Beskrivelse af de Arter, som efter livad jeg har kunnet erfare, findes i Danmark. Jeg tor haabe, at den derved bevirkede Forogelse af Haandbogens Onfung ikke vil blive misbilliget, hvis det maatte lyklies mig derved at lette Huandb. i den dauske Flora. 
Grenene krandsstillede, i Spidsen straaleformigt eller gaffelformigt deelte, uden Svob eller Bracteer ved Grunden af Krandsgrenene eller Straalerne; Antheridierne (hos de enboe Arter) ovenfor Sporehusene i Straalernes eller Smaagrenenes Gaffeldelinger; Sporehusenes Krone opret, tidligt affaldende, dannet af en dobbelt Række Celler ( 2 i hrer af de 5 Flige).

19. Chara Vaill. (Ag.). Stænglernes Ledstykker oftest dannede af en større central og flere mindre peripheriske Celler (og derved stribede), incrusterede, skjøre *) og uigjennem-

Studiet af en Plantefamilie, til hvis Undersøgelse der i Tørvmoser, Mergelgrave og ved vore Kyster findes rigeligt Materiale. Bestemmelsen af Arterne er ofte forbunden med Vanskelighed, idet den samme Art par forskjellige Alderstrin og paa forskjellige Voxesteder antager meget forskjellige Skikkelser, og i en kortfattet Beskrivelse at meddele nøiagtige Kjendetegn er derfor en vanskelig Opgave, som jeg ikke tor tiltroe mig at have løst overalt fyldestgjørende. Jeg havde hellere ønsket at oppebie den bebudede Monographi af Prof $A$. Braun, og tillige at undersøge i den frie Natur de danske Characeer i længere Tid end jeg hidtil har været istand til, men jeg har paa den anden Side troet ikke at burde opsatte til en usiklser Fremtid Meddelelsen af de Optegnelser jeg lıar indsamlet. Da Familieu hidtil har været saa lidet paaggtet hos os, anseer jeg det for utvivlsomt, at der i vor Flora vil findes adskillige Arter foruden de her nævnte. Ved Arternes Beskrivelse har jeg især benyttet Tallmanns njörsöl till en system. uppställning af växtfamiljen Characece" Stockh. 1853 saint de nyere Arbeider af Wahlstedt: (Skand. Arterne af Characeæ, Lund 1862) og Nordstedt (Skandinaviens Characeer, Bot. Not. 1863); og foruden Hornemanns o. fl. Herbarier, samt hvad der velvillig er mig meddeelt fra forskjellige Egue af Landet, har jeg havt god Hjælp af en rig Samling Characeer, som Prof. A. Braun har havt den Godhed at meddele mig tilligemed sin Bestemmelse af flere har fundne tvivlsomme Arter.

*) Characeerne maa undersøges i frisk Tilstand eller opbevarede i Spiritus; tørrede ere de vanskelige at undersøge, fordi deres fine Dele sammentrykkes og Frugterne let affalde og tillige fordi de tildeels ere meget skjøre, især de Arter som ere overtrukne (incrusterede) af et tykt Lag kulsuur Kalk, der kun ved chemisk Belıandling kan fjernes. (De fleste Arter have i levende Tilstand en stærk og meget ubehagelig Lugt). 
sigtige (sjeldnere encellede, gjennemsigtig-bindeagtige uden Incrustation); Grenene krandsstillede, med 1-2 Rækker naaleformede Celler (Svøb) ved Grunden, deres Axe gjentagne Gange leddet, med krands- eller halvkrandsstillede Forgreninger ("Bracteer") udgaaende fra Ledene; Autheridierne (hos de enboe) udenfor Bracteerue, nedenfor eller ved Siden af Sporehusene, som i Spidsen bære en vedblivende, af 5 enkelte Celler dannet, ofte stjerneformigt udbredt Krone.

\section{Filices.}

\section{Asplenium. Radelov.}

a. Athyrium Roth. Frugthobene aflange, bøiede (Lovet dobbelt fjersnitdeelt, dets Afsuit tiltage i Størrelse mod Midten).

1315. A. Filix foemina [Bernh. i Schrad. n. Journ. V, p. 2] (Mangefinnet R.) Polypodium L.; Aspidium Sw., H. II, 360 ; Athyrium Roth, Drej. n. 991 ; F. D. 2436.

Løvet i Omrids elliptisk; Afsnittene lancetformede, tilspidsede; de secundare Afsnit halvfinnede eller fjersnitdeelte med i Spidsen tandede Flige; Sløret fryndset, med Tilhæftuingspunktet mod Randen af de secundære Afsuit; Frugthurene talrige, tilsidst rundagtige.

1-2' høi. Løvets Skaft kantet, nedentil beklædt med Avner. Var. betydeligt i Henseende til Størrelse, Løvets Indskjæring o. s. v. 7-9. 4 .

I Skove og ved Steengjærder, alm. Danmark.

b. Asplenium s.s. Frug thobene linieformede, rette. aa. Løvet fjersnitdeelt, med rundtakkede Afsnit, de midterste storst.

1316. A. Trichomanes L. (Rundfinnet R.) H. II, 363; Drej. n. 987 ; F. D. 119. 
Løvet i Omrids linie-lancetformet; Afsnittene skjævt ægformet-ovale, budte; Skafterne glatte, i ældre Tilstand sortbruunt-glindsende, paa Overfladen rendede med smal hindeagtig Rand.

4-6" høi. (En af vore mindste, men smukkeste Brægner). 6-10. थ.

I Klipperidser og mellem Stenene i Steengjærder, sporadisk og ikke alm.: B or $n h$. hist og her i Granit-Terrainet! Sj. Ravnsholms Hegn (13), Hillerød Skandsebakke (Knæckenborg), Birkerød (H.), Kirkeværløse, Farum (14), mellem Nærum og Søllerød (Petersen), Rudersdal! Hareskoven, Fuglevad Mølle (H.), Lundtofte (24), Ermelundsskoven mod Lyngby (Dr.), Sonnerupgaard (H.), Grydebjerg ved Sorø! Langebæk ved Kallehave (Rosenørn-Lehn); Falst. Ourupgaard (Koch), Idestrup (Krebs); F. Svindinge! Ørbæklunde! Hundstrup! J. Fredrikshavn (H.), Torslev i Vendsyssel (Branth), Bæklund ved Viborg (Morville), Hald Bøgeskov (Strandgaard); $\boldsymbol{S} l$. Sundeved (H.), Dybbøl Bjerg (16); Als ved Adserballig (10).

bb. Løvet dobbelt fjersnitdeelt, Afsnittene tiltage $i$ Størrelse nedadtil.

1317. A. Adiantum nigrum L. (Sort R.) H. II, 365; F. D. 250 ; H. N. X, 98 .

Løvet glindsende grønt, i Omrids smalt og tilspidset-triangelægformet, dobbelt- (i Spidsen enkelt, ved Grunden ofte tredobbelt) fjersnitdeelt; de secundœre Afsnit rudeformet-elliptiske, ved Grunden heelrandede, i Spidsen saugtakkede; Sløret heelrandet.

6-10" høi. Løvskafterne nedentil glindsende mørkbrune. 6-9. 4.

I Ridser af Granitklipperne paa Bornholm hist og her: Hammershuus, Kleven (2U)! Nørre Borgdal (8), Rø! Gudbjem (H.), Svanike (11).

1318. A. Ruta muraria L. (Muurrude). H. II, 365; Drej. n. 989 ; F. D. 190 ; H. N. XIV, 97.

Løvet mat grønt, i Omrids bredt og budt triangel-ægformet; de secundcere Afsnit omvendt-ægformede, med kileformet, beelrandet Basis, i Spidsen lappet-rundtakkede eller næsten beelrandede; Sløret fryndset.

2-4" høi. (Smaae Expl. ere alm. kun enkelt fjersnitdeelte). Løvskafterne grønne, sparsomt beklædte med Avner. 6-9. 2 .

I Klipperidser og Steengjærder, sjelden: $\boldsymbol{B}$ or $n h$. i Almindingen (F. D., Rafn); $\boldsymbol{S}$. Kronborg Mure (21); J. Viborg Domkirke (Morville); 
A ls paa Sønderborg Slotsmuur (20)! $S \boldsymbol{l}$. Beftoft og Nustrup Kirkemure (Kyll.), Nieblum Kirke paa $F_{\theta} h r(20)$ !

cc. Lovet fingerformigt-gaffeldeelt med lancet-linieformede Afsnit.

1319. A. septemtrionale [Sw. Synops. filic. 75] (Nordisk R.) H. II, 364 ; Drej. n. 988; Acrostichum L., F. D. 60.

Lovet langskaftet, ovenfor Midten 1-\% Gange uregelmæssig gaffeldeelt; Afsnittene foroven spidst og dybt $2-3$-fligede, beelt bedækkede af Frugthobene.

4-6" høi. Lørskafterne tilsidst ved Grunden mørkbrune. 6-10. 4.

Paa lignende Steder som foreg., sjelden: $\boldsymbol{B}$ or $n h$. ; Granitterrainet hist og her (f. Ex. Bobbeaaen, Lehnsgaard, Norre Borgdal (8), Gudhjem (11), Kleven (20); Sj. Pæleveien i Gribs Skov! Rudeliegn mod Dumpedals Molle! Farumgaurd (Morch); Jonstrup Vang (14), Fuglerad lílle (Schum.); J. Frederikshavn (H.), Torslev og Hørby Kirkemure i Vendsyssel (Lgby).

\section{Scolopendrium. Miltbragne.}

1320. S. officinarum [Sw. Syn. fil. 89] (Hjortetunge). H. II , 366 ; Drej. n. 990; H. N. X, 99; Asplenium Scolopendrium L.

Lovet laneet-tungeformet, spidst, med hjerteformet Basis, heelrandet eller bølget, længere eud Skaftet; de 2 samlede Frugthobe sammenflyde tilsidst til een. .

Løvskafterne og Midtnerven beklædte med Avner. De unge Løv hjerteformede. $7-8$. 4 .

Angives fra Dronninggaard af Kyll., men er siden hans Tid ikke funden der. I Skoven paa den sydlige Skraaning af Aborrebjerget (Møen) har Hr. Exam. polyt. Hamann fundet et Par Exemplarer.

\section{Aspidium. Skjoldbragne.}

1321. A. angulare [Kit. i Willd. Sp. T, 25T] (Tornfliget S.) F. D. 2559; H. N. XIII, 96 ; Polystichum Presl.; Aspidium aculeatum Sw. (Polypodium L.); Aspid. aculcatum $\beta$, Swartzianum Koch Syn.

Lovskaftet og Lovets Midtnerve tæt beklædte med brune, xgformede, tilspidsede Avner, Løvet dobbelt fjersnitdeelt, ligesom de primare Afsnit i Omrids lancetformet, tilspidset, de 
secundare Afsnit skjævt ægformet-rudeformede eller halvt spydformede (med en øreformet Flig ved Grunden af den fra Løvets Axe bortvendte Side), braadspidset-tandede, det nederste i den øre Rad af hvert Hovedafsnit størst.

De unge L $\emptyset$ v paa Underfaden beklædte af fiuere Avner. (Ved den tætte Bekladning og Smaaafsnittenes Form let kjendelig fra vore andre Brægnearter). 7-8. 4.

Paa Græsholmen ved Christiansø (Didrichsen 1849)! Bornh. Steilebjerg red Hammerhuus (Zahrtmann); $\boldsymbol{S}$. Frederiksdals Skov (Kjærschou)!

Anm. Den i Sydeuropa almindelige A. lobatum Sw. (Polypodinm Huds.); A. aculeatum $\alpha$, vulgare Doell., som er forskjellig fra den her forekommende Form ved smalere og stivere $L \emptyset v$ med mindre dybt deelte Afsnit, hvis secundære Afsnit (med Undtagelse af det nedre Par) mangle den øreformede Flig ved Grunden, forenes af de fleste nyere Forfattere, vistnok med Rette, med A. angulare Kit., og for begge disse Former vil i saa Fald Fællesnavnet $\boldsymbol{A}$. aculeatum (L.) Doell. rettest blive at anvende.

\section{Lastraea. Mangelov.}

1322. L. Thelypteris [Presl Pteridogr. p. 76] (Kjær-M.) Polypodium L., F. D. 760 ; Aspidium Sw., H. II, 358; Drej. v. 998; Polystichum Roth, Koch Syn. II, 97 7.

Rodstokken vandret-krybende; Lovet fjersnitdeelt (de 1-2 nedre Par Afsnit mindre end de ovrige), med linie-laneetformede, nærmest Axen fjersnitdeelte, mod Spidsen halvfinnede Afsnit og budte, heelrandede eller rundbugtede (paa de frugtbærende Løv i Randen tilbagerullede og derved tilsyneladende spidse) Flige; Frugthobene i Forgreningerne af Fligenes todeelte Sideaarer, daune 2 parallele, tilsidst sammenflydende Rækker midt imellem Fligenes Rand og Midtnerve.

$1 \cdots 1 \frac{1}{1} 2^{4}$ høi, Skaftet meget skjørt, glat; Løvet mat-blaagrønt, med faae $\mathrm{ng}$ korte, kun under Lupen synlige Haar paa Underfladen, forøvrigt glat. (Frugtbærende Expl ere temmelig sjeldne). 7-8. భ.

I Moser og fugtige Enge alm. udbredt.

1323. L. Oreopteris [Presl 1. e.] (Bjerg-M.) Polypodium Ehrb., F. D. 1121; Aspidium Sw., H. II, 359; Drej. n. 997.

Rodstokken tueformigt sammentrængt; Løvet fjersnitdeelt; Afsnittene jærnt aftagende i Størrelse fra Midten imod-begge 
Ender, linie-lancetformede, tilspidsede (de nedre korte, triangelformede), halvfinnede med budte, heelrandede eller rundbugtede, i Randen plane eller kun lidet tilbagerullede Flige; Frugthobene i 2 Rækker tæt indenfor Randen af Fligene og naaende næsten til Spidsen af disse; Sløret tidligt affaldende.

2-3' høi. Skaftet sparsomt beklædt med Avner, Løvets Underflade med spredte, kun under Lupen synlige Kirtler. 7-8. 4.

Ved Steengjærder og i høitliggende Skove, sporadisk og sjelden: J. Frysenborg Skuv (Dr.), Skove S. for Veile-Fjord (12)! S l. Huusby (28, Flensborg (1); $S$ j. Fredenslorg (Herb. H. Hafn.), Skandsebaklken ved Hillerød (Knæckenhorg), Birkerød (H.), Gjærder mellem Nærum og Søllerød! Hvide Overdrev ved Særløse pr. Roeskilde (15), Sparresholm (Lund); Bornh. Hammershuus (8), Almindingen (20).

1324. L. Filix mas [Presl 1. c.] Almindelig M.) Polypodium L.; Aspidium Sw., H. II, 360; Drej. n. 995.

Rodstokken tyk, tueformet, næsten lodret; Lovet fjersnitdeelt; Afsnittene lidet aftagende i Størrelse nedenfor Midten, lancetformede, fjersnitdeelte (i Spidsen halvfinnede), med afrundede eller afstumpede, rurdtakkede, i Randen ikke tilbagebøiede Flige; Fligenes Sidenerver svage, gaffeldeelte; Frugthobene i 2 Rækker fra Grunden til Midten af Fligene, nærved disses Midtnerve; Sloret vedblivende.

2-4' høi. Løvene kredsformigt samlede i Spidsen af Rodstokken, glatte eller beklædte med faa Avner paa Underfladen, Skaftet mere eller mindre tæt beklædt med bruunt-hindeagtige Avner. 6-8. 4 .

$\beta$, erosa Doell (Aspid. ero:um Schk. crypt. IV, t. 45). Afsnittene og deres Flige fjernere fra hianden, Fligene uregelmæssigt og dobbelt saugtakkede eller fjerlappede, med saugtakkede Lapper.

$\gamma$, lepidota Lge. Løvskaftet indtil Spidsen og Nerverne paa Løvets Underflade tæt beklædte med Avner.

I Skove og ved Steengjærder meget alm. $-\beta$, ved Kjølstrup i Fyen (18)! J. Gudumlund pr. Aalborg! Bornh. i Almindingen (Baagøe)! S $l$. Morgenstern ved Husum (Didr.)!

1325. L. cristata [Presl l. c. p. 77] (Budtfinnet M.) Polypodium L., Aspidium Sw., H. II, 359 ; Drej. n. 996 ; F. D. 1591 ; H. N. IX, 98. 
Rodstokken sammentrængt; Løvet fjersnitdeelt, i Omrids smalt (lancetformet eller linie-lancetformet); Afsnittene kun lidet aftagende i Størrelse fra Midten, triangel-ægformede, fjersnitdeelte (i Spidsen og hos de ufrugtbare Løv halvfinnede), med afrundede, braadspidset-saugtakkede, i Randen ikke tilbagebøiede Flige; Fligenes Sidenerver tydelige, fleerdeelte; Frugthobene i 2 Rækker fra Grunden til Spidsen af Fligene; Sloret vedblivende.

- $1^{1 / 2}-2^{1}$ høi. Skaftet paa det frugtbare Løv temmelig langt, beklædt med spredte Avner, 6-7. 4 .

Paa Tuer og mellem Krat i Torv- og Hedemoser, sporadisk og ikke alm.

1326. L. spinulosa [Presl l. c. excl. *] (Skarpfinnet M.) Polypodium Müll. fl. Fredriksd., F. D. 707; Aspidium Sw., H. II, 361 ; Drej. n. 994 ; H. N. XIII, 97.

Rodstokken sammentrængt; Lovet i Omrids æg-lancetformet, dobbelt fjersnitdeelt, det nedre Par Afsnit kortere end de øvrige; de secundare Afsnit ægformet-elliptiske, spidse, fra Grunden braadspidset-saugtakkede med indboiede Takker (eller halvfinnede med braadspidset-saugtakkede Flige); Frugthobene (mindre end hos foreg.), i 2 Rækker fra Grunden til henimod Spidsen af de secundære Afsnit.

1-3' høi, mørkgrøn. 7-9. ข. Lørskaftet i forskjellig Grad beklædt med hindeagtige Avner, var. desuden i Henseende til Indskjæringens Grad, Atsnittenes og Fligenes Form 0. s. v. Flere Former ere opstillede som egne Arter, blandt disse:

* dilatata (Presl) Aspidium dilatatum Sw., H. II, 362; F. D. 759 (Polypod. Dryopteris, ikke god) og 1346 (Aspidium Filix mas). Løvet mørkere grønt, større end hos Hovedarten, triangel-ægformet (det nedre Par Afsnit af Længde med eller længere end de øvrige), tredobbelt fjersnitdeelt med saugtakket-halvfinnede, eller dobbelt fjersnitdeelt med balvfinnede Smaaafsnit.

I Skove, især paa fugtig Grund, ved Steengjærder o. s. v. alm. * sjeldnere: Bornh. i Almindingen! Falst. hist og her (14); $S j$. Jonstrup Vang, Fuursøens Sydstrand (14), Høsterkjøb, Hammermøllen, 
Dragerup Skov ved Holbæk (15), Feldskoven ved Sorø! Hæsede Skov ved Gisselfeld (Jacobsen); B or $n h$. Dynddalen ved Rø (Hjorth), Kleven ved Klemensker, Rønne (Hoff)! $\boldsymbol{J}$. Aalborg (Strandg.), i stor Mængde ved N. Vosborg! S $\iota$. Haderslev, Heils (Gronlund).

Anm. De Kjendetegn, der angives for at adslille * som egen Art, forekomme mig foranderlige og ikke tilstrakkelige til at den kan ansees for mere end en Form af $\mathbf{L}$. spinulosa.

\section{Cystopteris. Bagerbragne.}

1327. C. fragilis [Bernh. i Schrad. n. Journ. v. 1, p. 2, pag. 26] (Skjør B.) Drej. n. 992; Polypodium L., F. D. 401; Aspidium Sw., H. II, 362.

Løvet i Omrids lancetformet eller elliptisk (det nederste Par Afsnit lidet kortere end de øvrige), dobbelt fjersnitdeelt; de nedre secundare Afsnit halvfinnede eller fjersnitdeelte med spidse eller budte, saugtakkede eller tandede Flige; Frugthobene uordenligt spredte, især henimod Randen af de secuudxre Afsnit, tilsidst næsten sammenflydende.

1/2 -1' høi, Skaftet skjørt, alm. kortere end Løvet, forneden rødligbruunt, med faae Avner; Lovet fint, lysgrønt, var. i Heuseende til Afsnittenes Form og Indskjæring. 6-7. భ.

I Steengjærder: paa Halvøen sjelden: J. Frederikshavn (Drej.), Horby i Vendsyssel (12); daa Oerne sporadisk og ikke alm.: $\boldsymbol{F}$. Orbæklunde, Peirup (12); Vornies p. Thorseng (12); Sj. Alsted (Frk. E Povelsen) og Haverup red Sorø! Kongsdal! Odinshøi (Heiberg), Mærkerup, Kirkeværløse, Jonstrup (14), Rudersdal, Brede, Fredriksdal, Kulhusene! Vemmetofte (9); F a ls $t$. Ourupgaard (Koch), Næsgaard, Halskov (14); Loll. Saxkjøbing (Benzon), Musse (5); Meens Klint (Mørch); Bornh. Listed Fiskerleie (Baagøe) o. fl. St. (19!).

1328. C. montana [Bernh. J. c.] (Bjerg-B.) Drej. n. 993 ; F. D. 2250 ; Aspidium Sw., H. II, 363; H. N. III, 96.

Lovet i Omrids triangelformet, tredobbelt fjersnitdeelt; Afsnittene stilkede, det nederste Par Afsnit længere end de øvige, med meget større nedadvendte end opadvendte secundare Afsnit; de tertiure Afsnit halvfinnede med tandede (eller fjersnitdeelte med halvfinnede) Flige; Frugthobene uordenligt spredte.

1/2-1' høi, Skaftet læengere end Løvet, med faae, spredte Avner, Løvet meget fiint deelt, i Omrids næsten ligt P. Dryopteris. 6-7. 4 . 
I en udtørret Ellemose ved Knapstrup i $S j \notin l l$. (4), det eneste bekjendte Voxested i Danmark.

\section{Pteris. Ornebragne.}

1329. P. aquilina L. H. II, 367 ; Drej. n. 999 ; F. D. 2303.

Lovet tredobbelt fjersnitdeelt med stilkede Afsnit; de tertiore Afsnit oval-linieformede, budte, heelrandede, rundbugtede eller ved Grunden med 1-3 Par Flige (eller dobbelt fjersnitdeelt med fra Grunden til Spidsen halvfinnede Smaaafsnit).

1-6' h Det nederste Par Afsuit meget større end de øvrige, ofte af Længde med Hovedaxen, hrorved Lovet bliver trekoblet; Løvet i yngre Tilstand paa Underfladen ofte duunhaaret, ældre glat, læderagtigt, med stærkt fremtrædende Nerver. Karbundterne i Skaftets underjordiske Deel danne i Tværsnit en flakt Ørn. 7. 4.

I Skove, paa Heder mellem Krat o.s. v. meget alm.

\section{Blechnum. Kambragne.}

1330. B. Spicant [Roth fl. germ. 3, p. 44] Osmunda L., F. D. 99; Lomaria Desv., Drej. n. 1000 ; Blechnum boreale Sw., H. II, 366 .

Løvet i Omrids langstrakt-lancetformet, fjersnitdeelt, med bueformigt-opadbøiede, heelrandede, paa de golde Løv tætsiddende, bredt linieformede, budte, paa de frugtbærende fjerne, smalt linieformede, spidse Afsnit; de nederste Afsnit af de golde Løv meget korte, budt ægformede.

8-12" høi. 7-8. 4.

I Skove, især paa fugtig Grund mellem Mos og Stene, sporadisk og fortrinsviis i Hedeegne: paa Halve $\boldsymbol{n}$ ikke sjelden, sparsommere paa Øerne: $\boldsymbol{F}$. Kongebroen ved Middelfart (12); $\boldsymbol{S} \boldsymbol{j}$. Birkerød, Rudergaard, Fredriksdal (H.), Særløse ved Roeskilde (20), Sparresholm (Lund), Gisselfeld (H.), B ornh. Ngrre Borgdal (8), Almindingen (25), Maidalen i Helgenesbakkerne (Baagøe).

\section{Struthiopteris. Strudsvinge.}

1331. S. germanica [Willd. Enum. hort. ber. p. 1071] H. II, 371; S. europæa Drej. n. 1001; Osmunda Struthiopteris L., F. D. 169 . 
Det ufrugtbare $L \rho v$ i Omrids elliptisk-lancetformet, fjersnitdeelt, Afsnittene aftage efterhaanden i Størrelse fra Midten af, halvfinnede med heelrandede, seglformigt udadbøiede, budte eller kortspidsede Flige (det nederste Par Flige i hvert Afsnit tiltrykte til Hovedaxen), det frugtborende $L \phi v$ langskaftet, lancetformet, fjersnitdeelt med linieformede, først sammenrullede, tilsidst fladt udbredte Afsnit.

Rodstokken tyk, kugleformigt sammentrængt, de ufrugtbare Løv yderst, $i$ en tragtformet Kreds (2-3' høie), de frugtbare Løv i Midten, morkbrune. 8-9. 4 .

Paa fugtige Steder i Skove: i det nordøstl. S $j$ a ll. (fra Hammermøllen og Egebæksvang ved Helsingør til Fredriksborg og Bloustrød!) hist og her, ofte i stor Mrngde; i de andre Egne af Landet sjelden: $\boldsymbol{S} \boldsymbol{j}$. Skorsborg (15), Charlottenlund! Skjoldnæsholm, Gisselfeld (H.), Sparresholm (Dr.), Christianslund ved Ronnede (Fru Brun), Langebæk ved Kallehave (Rosenøru Lehn); $\boldsymbol{F}$. Holkenhavn, Hvidkilde, Vissenberg (H.), Høisholt i Tommerup Sogn (24). Paa Halvgen er det mig ikke bekjendt at den er funden. i*

\section{Polypodium. Engelsød.}

1332. P. vulgare L. (Almindelig E.) H. II, 354; Drej. n. 984 ; F. D. 1060.

Løvet fjersnitdeelt, med afvexlende, linieformede, budte, heelrandede eller svagt rundbngtet-tandede Afsnit; Frugthobene i 2 Rækker langs Afsnittenes Midtnerve.

Rodstokken tyk, krybende, tæt beklædt med brune Skjæl; Løvet mørkgrønt, tilligemed Skaftet glat; Frugthobene store, med brandgule Kapsler. 6-10. 4 .

Ved Steengjærder, i aabne Skove 0. s. v. meget alm.

1333. P. Phegopteris L. (Duunhaaret E.) H. II, 355; Drej. n. 985 ; F. D. 1241.

Lovet i Omrids triangel-ægformet, dobbelt fjersnitdeelt; Afsnittene modsatte, lancetformet-tilspidsede, duunhaarede, jævnt aftagende i Længde mod Spidsen, det nederste Par nedadvendte; de secundare Afsnit linieformet-ovale, budte, de nederste Par paa begge Sider af Hovedaxen indbyrdes sammenvoxne; Frugthobene i 2 Rækker langs Randen af de secundære Afsnits nedre Deel. 
Rodstokken tynd, krybende, tilligemed Skafterne af de unge Løv beklædt med faa brune Avner. Løvet blegt og mat gront; Frugthobene smaae, med skidenbrune Kapsler. 6--S. 4 .

I Skove, især paa fugtig Grund, sporadisk: paa Halvoens Østkyst og i S jall. hist og her, paa de ovrige Øer sjelden: Mo en (12); Falst. Herslebslund (Rasm.), Bregninge (14); F. Lakkendrup (19), Ravnholt (A. Lange), Otterup (18); Bornh. i Klippeterrainet mod N. V. (Bargøe).

1334. P. Dryopteris L. (Tredeelt E.) H. II, 356 ; Drej. n. 986 ; F. D. 1943.

Løvet i Omrids bredt triangel- eller muurskeeformet, trekoblet, glat; Smaabladene dobbelt fjersnitdeelte, de secundære Afsnit forneden fjersnitdeelte, i Midten halvfinnede og i Spidsen tandede eller bele; Fligene linieformet-ovale, budte, heelrandede eller svagt rundtakkede; Frugthobene i 2 Rækker langs Randen af de secundære Afsnit.

Rodstokken tynd, krybende, sort, beklædt med faae brune Avner, Skafterne næsten glatte, glindsende, tilsidst sorte, Løvet blaagrønt, Frugthobene smaae, med blegbrune Kapsler. 6-8.

I hoie Skove: ikke sjelden paa Bornh., i Sjall. og paa Østkysten af Jyll. Pra de Skjoldemose (12), Langkildegaard, Glorup (19), Ravnholt (A. Lange); Falst. Bregninge (14).

\section{Usmunda. Kongebragne.}

1335. 0. regalis L., H. II, 372 ; Drej. n. $1002 ;$ F. D. 217 ; H. N. XII, 98.

Lovet dobbelt fjersnitdeelt; de secundare Afsnit linie-lancetformede med æg-hjerteformet, ofte toøret-lappet Basis, heelrandede eller med svagt saugtakket Rand af de talrige og stærke, heelt udløbende Nerver; Frugterne samlede i Spidsen af Løvet til en dobbelt finnet Top, sammensat af linieformede Ax.

$3-5^{\prime}$ høi. (Ved Grunden af det ufrugtbare Lovs Afsnit findes ofte nogle Rækker af Frugter, i Spidsen af de frugtbærende Grene ofte fladt udbredt Lov). $6-8$. 4 .

I fugtige Skove, Overdrev og Torvmoser mellem Krat, sporadisk og temmelig sjelden: $\boldsymbol{S}$. Helsingor (H.), Frydenlund (11), Søer i Ruderhegn $\varnothing$. for Landevejen til Hørsholm! Søllerød (Dr.), Feddet ved Lindersvold! F. Holkenhavn (F. D.), Skaarup (19), Græsholms- 
skoven ved Svendborg (H.), Rødskebølle (12), Moser N. for Ollerup! Trolleborg, Bommelund (24); Sl. Jels (7), Dravit Skov (Rafn), Marieskoven og Sollie ved Flensborg (16); Lolt. ved Stokkemarke (19), Søholt (5), Karleby ved Nysted (19); F alst. Horreby Lyng, Virket (14); Bornh. ved Borre So (F. D.), Olene (14).

\section{Botrychium. Maanerude.}

1336. B. Lunaria [Sw. Syn. fil. p. 171] (Almindelig M.) H. II, 369; Drej. n. 1003 ; Osmunda L., F. D. 18 (venstre Fig.).

Det ufrugtbare L $\phi v$ udgaaer omtrent fra Midten af Skaftet, i Omrids oval-hjerteformet, fjersnitdeelt; Afsnittene vifteformetbalvmaancformede med kileformet, heelrandet Basis, i Spidsen bele, rundbugtede eller rundtakket-lappede.

$2-6^{\prime \prime}$ høi. Skaftet ved Grunden omgivet af brune Skeder. Undertiden findes Frugter i Spidsen af det golde Lovs Áfsnit ligesom hos foreg. 4 .

* rutaceum Fr. nov. p. 289 ; B. matricariæfolium A. Braun, Koch Syn. II, 972; F. D. 18 (høire Fig.)? Det ufrugtbare Løv triangel-ægformet, fjersnitdeelt, med halvfinnede Afsnit.

Pua Græsmarker, Bakker og Lyngheder, sporadisk og ikke alm., hyppigst har jeg fundet den paa Moens Klint. * paa lignende Steder som Hovedarten, men meget sjeldnere: $S j$. Lyngheder mellem Kjøge og Kjøbenharn! Moen (H.); Bornh. ved Hammeren (19).

Anm. Formen * betragtes af flere Forff. som egen Art, men uagtet den i Udseende er temmelig afvigende fra B. Lunaria, er den dog neppe andet, end en Form af denne med i høiere Grad indskaaret Løv, hvilket Overgansformer (fra Møen) have overtydet mig om.

1337. B. rutæfolium [A. Braun i Doell Rhein. Fl. p. 24] (Stilkbladet M.) Koch Syn. II, 972; B. rutaceum Sw. (part.), H. II, 370 (excl. loc. nat.); B. matricarioides Willd., Fr. nov. p. 288 ; H. N. III, 99 ; F. D. 18 (øvre Fig.).

De ufrugtbare $L \varnothing v$ alm. 2, det nedre (overvintrende fra forrige Aar) omskedende, det ørre tilvoxet til Basis af Skaftet, i Omrids bredt triangel-hjerteformede, trekoblede med enkelt eller dobbelt fjersnitdeelte Smaablade; Afsnittene bredt-ægformede, budte, heelrandede eller rundtakkede.

$2-4$ " hoi. 6-7. 4 . 
Paa Lyngbakker og sandige Overdrev, meget sjelden: Falst. Bøtø (Benzon); $\boldsymbol{S}$. Tiisvilde (27), grusede Bredder N. O. for Gurre Sø (14), Bagsværd (Benzon)! l*

\section{Ophioglossum. Slangetunge.}

1338. 0. vulgatum L., H. II, 369; Drej. n. 1004; F. D. 147 .

Det ufrugtbare $L \phi v$ ægformet-elliptisk eller hjerteformet, heelrandet, befæstet lidet ovenfor Midten af det nedentil meget tynde Skaft; Axet linieformet.

4-10" høi. Rodstokken ofte knolleformigt opsvulmet, Rodtrævlerne $\mathrm{i}$ frisk Tilstand gule, Løvet frisk grønt, glindsende. 6-7. 4 .

Paa Enge, især i Nærheden af Stranden, fugtige Steder i Skove, funden $i$ alle danske Provindser, men sporadisk og ikke almindelig.

\section{Lycopodiacex.}

\section{Lycopodium. Ulvefod.}

a. Frugterne i Hjørnerne af Stængelbladene.

1339. L. Selago L. (Otteradet U.) H. II, 350; Drej. n. 1005 ; F. D. 104.

Stconglerne oprette eller opstigende, flere Gange gaffeldeelte med ligehøie Grene; Bladene tiltrykt-taglagte eller tilsidst udstaaende, i 8 Rækker, lancet-ægformede, tilspidsede, læderagtige.

$4-8$ " høi, glindsende mørkgrøn. I Spidsen af Grenene udvikles ofte flere Rækker af fladtrykte Knopper, som, løsrevne fra Moderplanten, spire til nye Planter. 6-8. 4.

I Hedemoser, sandige Overdrev ved Kildevæld, sporadisk og ikke alm.

b. Frugterne omgivne af $D$ ækblade forskjellige fra Stængelbladene og samlede til Ax.

aa. Axene siddende.

1340. L. inundatum L. (Krybende U.) H. II, 352; Drej. n. 1006 ; F. D. 336 ; H. N. XV, 97. 
Stangelen krybende, tiltrykt til Jorden, grenet, de frugtbarende Grene oprette; Bladene slappe, linie-traadformede, tilspidsede, paa Hovedstængelen ensidigt opadrettede, paa de frugtbarende Grene alsidigt spredte, opret-tiltrykte; Dakbladene ved Grunden udvidede, forøvigt ligeformede med Stængelbladene; Axet valseformet, omtrent af Længde med og tykkere end den frugtbærende Green.

\section{7-8. 4.}

Hedemoser og fugtige Overdrev: paa Halvoen hist og her, paa Øerne sparsom: $\boldsymbol{F}$. Hals ved Hofmansgave (H.); F alst Horreby Lyng (Koclı), Bøtø (Benzon); $\boldsymbol{S} \boldsymbol{j}$. 'Tiisvilde, Rudersdal (H.), Heder ved Kjøge Bugt (15), Kjøge Kro (9), Dybendal ved Muukebjergby (Lund); Bornh. ved Hammeren (19), Plantagen N. for Ronne (8).

1341. L. annotinum L. (Femradet U.) H. II, 351; Drej. n. 1007 ; F. D. 127.

Stangelen langstrakt, krybende, mangegrenet; Gronene oprette eller opstigende, Bladene stive, paa Hovedstængelen i 5, paa Grenene i 8 Rækker, ndspærrede eller tilbagebøiede, lancet-sylformede, tilspidsede, fjernt saugtakkede; Dakbladene bredt ægformede, langt tilspidsede, med hındeagtig, gnavet-tandet Rand forneden; Axet valseformet, tyndere og meget kortere end den frugtbærende Green.

\section{7-8. 4 .}

I hoitliggende Skore og paa Lyngheder: ikke sjelden paa $\boldsymbol{I I}$ alv$\theta e n$, mindre hyppig paa Øerne: $\boldsymbol{F}$. Flintholm (12); $\boldsymbol{S}$. Hornbæks Plantage (12)! Skoven ved Marianelund (21), Gurre (14), Danstrup Hegu! Gribs Skov! Gjels Skov (1), Rudelıegn (19), Mose i Dyrehaven mod N. (7), Kollekolle (13), Jonstrup Vang, Store Hareskov (14), Roeskilde (Albrecht); Moens Storeklint (9); F alst. Abelvig Skov, Horreby Lyng (14); Bornh. Almindingen (20).

Ann. L. alpinum L. (F. D. 79), ved heelrandede, fireradet-tiltrykte Plade forskjellig fra foreg., ved siddende $A x$ fra de folg., angives at vare funden i Egnen af Hjorring (Drej. i Krøy. Tidsskr. II, 191) men da denne Angirelse beroer paa et enkelt Expl. fra et Herbarium, maa jeg indtil videre ansee denne Fjeldplantes Forekomst i vor Flora for trivlsom, saa meget mere som en Forvexling med L. Chanıcyparissus, der ofte har stor Lighed med hiin, kunde antages at have fundet Sted.

\section{bb. Axene stilkede.}

1342. L. complanatum L. (Flad U.) H. II, 351; F. D. 78 (slet) og 2671. 
Stcengelen krybende; Grenene opstigende, gaffeldeelt-mangegrenede; Smaagrenene vifteformigt udspilede, fladtrykte, paa den indadvendte Side lidet concave eller næsten plane, med ophøiet Midtlinie, paa den udadvendte Side convexe; Bladene (paa Smaagrenene) fireradede, sylformede, heelrandede, paa de flade Sider tiltrykte (det indadvendte meget mindre end det udadveudte), paa de skarpe Sider ligestore, i Spidsen udstaaende; Axstulkene gaffeldeclte, med 2-4 Ax samlede; Dokbladene rundagtigtæg-hjerteformede, svagt tandede, jævnt tilspidsede $i$ en ved Modenheden tilbagebøiet Spids.

Frisk grøn. 7-8. 4 .

Paa Lyngheder, sjelden: J. Hørby (12), Torsler og Allerup Bakker (Branth) i Venḋsyssel, Mors (II.), i Viborg Amt hyppig (7), Eveldrup (Dr.), Mariager (7), Ø. Nykirke! Skjærhoved (12), Nørup, Førstballe ved Veile $(30) ; S l$. (H.); $S j$. Tiisvilde Indhegning (H.).

1343. L. Chamacyparissus [A. Braun i Doell. Rhein. Fl. p. 36] (Cypresbladet U.) Koch Syn. II, 970; F. D. 2ミ72; L. sabinæfolium Rupr.; H. N. XIII, 100 (neppe Willd.).

Stangelen underjordisk krybende; Smaagrenene knippeformigt samlede; Bladene alle tiltrykte, de til hinanden svarende paa de flade Sider omtrent ligestore; Axstilkene gaffeldeelte, med 2-8 Ax samlede; Dakbladene muurskeeformet-hjerteformede, tandede, pludseligt tilspidsede $\mathrm{i}$ en længere Spids; forøvrigt som foreg.

Mat og blaaagtig grøn, Grenene mindre fladtrykte end hos foreg. 7-8. 4.

Lyngheder: J. Viborg (Morville), Vorde ved Viborg (Feddersen)! Thorsted pr. Ringkjøbing, Randbøl Hede! Holsted mellem Kolding og Varde (14); $S l$. Arrild Hede (12); $\boldsymbol{S j}$. Svenstrup (J. Hofm. Bang); Bornh. i Almindingen (25)! 原

Anm. Jeg anseer den uden Betænkning for en fra foreg. vel adskilt Art, hvorom saavel de angivne Kjendetegn som Iagttagelse af deres forskjellige Habitus $\mathrm{i}$ levende Tilstand har overbeviist mig. Matskee hore dog nogle af Voxestederne fra foreg. til denne, da der fra flere af disse Steder savnes Expl. for at kunne afgjøre dette.

1344. L. claratum L. (Almindelig U.) H. II, 349 ; Drej. n. 1008 ; F. D. 126.

Stcongelen krybende, mangegrenet; Grenene opstigende, næsten trinde; Bladene spredte, i mange Rækker, udstaaende, 
med indbøiet, i et Huar endende, Spidse, lancet-linieformede, fjernt tandede; Axene parviis samlede, paa en fælles, tæt skjældrekt Axstillk; Dakbladene bredt xgformede, tandede, haarspidsede og udstanende.

Planten lysgron (Sporerne bekjendte under Navn af Hexemeel). 7-8. 4 .

Paa Lyngheder, i højitliggende Skove: alm. i Nordsjall. og paa H alvoen, sparsom i Sydsjell., Fyen og paa de mindre Øer.

\section{Selaginella. Dvarg-Ulvefod.}

1345. S. spinulosa [A. Braun l. c. p. 38] H. N. XI, 100 ; Lyeopodium selaginoides L., H. II, 352; F. D. 70.

Stangelen nedliggende, med opstigende Grene; Bladene spredte, udstaaende, lancetformede, tilspidsede, i Randen tornet-tandede; Axene langstrakt-kølleformede, enlige i Spidsen af Grenenc; Dckbladene af Form med (men noget større end) Stængelbladene.

Spæd Væxt med smukt grønne Blade og tilsidst guldgule Ax. 7-8. 4.

I Hedemoser og fugtige Steder mellem Klitterne, kun funden i det nordvestlige Jylland: Aagaard i V. Hanherred (16)! Taabøl (Andresen)! Hillerslev og Klitmgller i Thy (23), Kjærgaard (A. Lange)! Løgstør (Dr.), Bjørnsholm, Thorstedlund (8)!

\section{Is ö̈tex.}

\section{Isoëtes. Brasenfode.}

1346. I. lacustris L. [D. R.] (Sortgrøn B.) H. II, 248 ; F. D. 191 ; Rehb. ic. fl. germ. VII, 1; H. N. XI, 99.

Rodstokken sammentrængt, i ældre Tilstand med 2 Længdefurer, og derved tolappet, forøvrigt udeelt, med knippestillede Rodtrcevler; Bladene twt samlede, linieformede, halvtrindt-firekantede, paalangs firerummede, sortgronne, stive, alm. oprette; Macrosporerne meelagtigt hvide, tegnede med nætagtigtbølgede Ujævnheder paa Overfaden. 
Bladene $3-7 "$ lange, uden Spalteaabninger. 7-9. ข.

$\beta$, falcata! Lavere $\left(1-1 \frac{1}{1} g^{\prime \prime}\right.$ høi) med stærkt seglformigt tilbagekrummede Blade, lysbrune Macrosporer, forørrigt som Hovedarten.

I Søer med Sandbund (under Vandet), meget sjelden: J. Lyskjær Sø i Orum Klit i Thy (Andresen)! S $l$. Tolkvade $\$ \emptyset$ (Jessen, 16)! Angives desuden at være funden i en Dam i Frueskov ved Bagsværd (O. F. Müller), men da dette ikke senere har bekræftet sig, kan muligviis en Forvexling have fundet Sted, f. Ex. med Littorella, som, naar den voxer under Vandet, ikke er ulig Isoëtes. $\boldsymbol{\beta}$, Store $\emptyset \mathrm{x}-\mathbf{S} \emptyset$ i Rold Skov ved Hobro (J. Mørch)!

1347. I. echinospora [D. R. i Bull. soc. bot. Fr. 1861, p. 164] (Guulgrøn B.) A. Braun, 2 deutsche Isoëtes-Arten, p. 7.

Bladene guulgrønne, slappe, langt og fint tilspidsede, alm. bueformigt tilbageboiede; Macrosporerne piggede og forsynede med punktformede, spidse (men meget skjøre og let affaldende) Ujævnheder paa Overfladen; forøvigt som foreg.

Bladene alm. kortere end hos foreg. (2-6"). 7-9. 4 .

I Søer med Dynd- og Gruusbund; voxer under Vandet ligesom foreg., hidtil kun fundet paa faae Steder: J. Porssø i Hvidberg Sogn (Thy) Andresen 1863 ! $S j$. Gurre Sø 1864 (14)!

\section{Rhizocarpea.}

\section{Pilularia. Pilledrager.}

1348. P. globulifera L., H. II, 347 ; F. D. 223 ; H. N. $\mathrm{XV}, 98$.

Rodstokken krybende, traadformet; Frugterne omtrent af Størrelse som et Frø af Vicia sativa, ndvendig bruunfiltede.

7-8. 4 .

I Lyngmoser, Søer og Vandhuller, sjelden: Bornh. alm. i smaae, om Sommeren udtorrede Søer i Høilyngen! $S \boldsymbol{j}$. Søen mellem Lyngby og Frederiksdal (F. D.), Nykjøbing (H.); J. Vang i Vendsyssel (Dr.), 'Tolbøl Klit i Thy (Andresen)! Kjær 0 . for Vildsted (8)! Paderup Mose ved Randers (7); Ornsø ved Ribe (Fabricius - Müller); $S \boldsymbol{l}$. Jels Sø (7), Tolker Mose ved Slesvig (Jessen); F $\theta h \mathrm{r}$ p. fl. St. (20). 


\section{Equisetacex.}

\section{Equisetum. Padderokke.}

a. Vernalia A. Braun. De frugtbærende og golde Stængler forskjellige: hine ugrenede, ikke grønne, tidligt fremskydende og efter Sporernes Udtøm melse henvisnende, disse grenede, grønne og senere udviklede.

1349. E. arrense L. (Almindelig P.) H. II, 342; Drej. n. 1013 ; F. D. 2001 .

Det frugtburende Slaft gjennemsigtig-guulbruunt, med fjerne, klokkeformet-tragtformede Skeder, der i Spidsen ere klovede i 8-10 tilspidset-lancetformede Tænder; den golde Stangel stribet-furet, krandsgrenet; Grenene firekantede med firetandede Skeder; Tanderne ennervede, sylformet-tilspidsede, grønne med hvidagtig Rand.

Rodstokken langstrakt og vidtkrybende, ved Ledene ofte knolleformigt opsvulmet. Grenene rue, opret-aabne eller udstaaende, alm. uden Smaagrene. 4-5. భ.

$\beta$, serotinum Mey. Chlor. hanov. p. 666. De grenede Stængler i Spidsen axbærende. (Frugtbærende i Juli-Aug.).

$\gamma$, decumbens Mey. 1. c. p. 667 (E. arv. $\gamma$, arenarium Mortens. Mser.). De frugtbærende Skafter meget korte (2") udvikles samtidigt med de golde, som ligeledes ere korte, talrige og nedliggende, G:enenes Skeder alm. femtandede.

$\delta$, nemorosum A. Braun i Doell. Rhein. Fl. p. 27, den golde Stængel høiere $\left(1^{1} / 2-2^{\prime}\right)$ og tykkere, ved Grunden bleg, de 6-7 nedre Skeder uden Grene, Grenene lange, vandret udstaaende eller hrengende.

Paa dyrkede Marker, ved Veigrøfter o.s. v., især paa Leerorund, meget alm. - $\beta, S \boldsymbol{j}$. Bakker ved Nymolle! $\gamma$, paa Sandgrund: $\boldsymbol{S} \boldsymbol{j}$. en sandig Bakke ved Bringe (14)? J. Klitter ved Agger i 'Thy! $\delta, S j$. Hornbæks Plantage! ved Bagværd Sø (Heiberg)!

Anm. 1. De golde Stængler og nogle af Afarterne kunne forvexles med E. palustre, men demne ad-killes foruden ved det forskjellige Voxested og de ovenfor angivne Kjendetegn tillige derved at Stæengelens indre Rum ere alle ligestore, medens tos E. arvense det midterste er storst. 
Anm. 2. Om den af $\mathrm{Hr}$. Seminarielærer Mortensen fundne meget eiendonmelige Form med Rette er henført til E. arvense decumbens, om den henhorer til en anden af de talrige Former, hvorunder denme Art optræder, eller om den endog er hidtil ubeskreven, tor jeg ikke afgjore. Paa Grund af V'oxestedet, dens lave Vext o. s. v. har jeg foreløbig lenfort den til den nærnte Form, men denne er (efter Doell, Fl. von Baden, I, p. 59) hidtil ikke funden med Frugt.

1350. E. Telmatrja [Ehrh. Beitr. 2, p. 160, 1783], (Elfenbeens-P.) H. II, 343; Drej. n. 1014; F. D. $1469(\beta)$; E. maximum Lam. Fl. Fr. I, p. 7 (1778); E. eburneum Roth, Catal. bot. 1, p. 128 (1797).

Det frugtborende Skaft bruunagtigt, med tatsiddende, tragtformede, 20-30-tandede Skeder; Tanderne børsteformet-sylspidsede; den golde Stangel hvidagtig-gjennemsigtig, glindsende, med talrige, krandsstillede, furet-ottekantede Grene; Skederne 4-5-tandede med tonervede, sylspidsede Tænder.

Den frugtbærende Stængel tyk, 1/2 -1 ' høi, med omtr. 2" lange $\mathrm{Ax}$, den golde Strengel smukt elfenbeenshvid, $3-6^{\prime}$ h $q \mathrm{i}$, med rue Grene. 5-6. ข.

$\beta$, serotinum. Den grenede Stængel i Spidsen axbærende. $6-7$.

I fugtige Skovdale, ved Randen af Grøfter og Bælke, især paa Leer- og Kalkgrund, ikke sjelden i Skovene paa Halvgens Østkyst, mindre hyppig paa Øerne: $\boldsymbol{F}$. Middelfart (1), Lundsgaards Klint ved Kjerteminde (24), Hvedholm (H.), Magaard! Falst. ved Tronnies! Bregninge (med var. $\beta, 14) ;$ M e en ved Maglevandsfaldet $i$ stor Mængde! S $\boldsymbol{j}$. Haraldsted Skov ved Kilden (Aabye), Ledreborg (H.)! Egebreksvang $(21) ! \beta$, sjeldnere: paa $M$ o en med Hovedarten! F alst. (Koch); $\boldsymbol{F}$. Hvedholn (H.), Lundsgaards Klint (Heiberg); J. Rydhave ved Holstebro (Schmidt)! $\boldsymbol{S} l$. Haderslev (Gronlund).

b. Subvernalia A. Braun. De frugtbærende Stængler (idetmindste foroven) brune, udvikles omtrentsamtidigt med de golde (grøne), Frugtaxet efter Sporernes Udtommelse benvisnende, men selve Frugtskaftet vedblivende og tilsidst grenet.

1351. E. umbrosum [Willd. Sp. pl. 5, p. 3] (Lund-P.) H. II, 344 ; Drej. n. 1615; F. D. 1770 ; E. pratense Ehrh.; H. N. VI, 99.

Det frugtbarende Sliaft med fjerne, dybt stribede, hvid- 
grønne Skeder; spaltede til Milten i 10-15 smalt sylspidsede, sortbrune Tander; Grenene nilspilede eller bueformigt nedbøiede, alm. ugrenede, 3-4-kamtede med 3-4-tandede Skeder; Tanderne agformede, spidse, ennervede, Nerven forsvindende nedenfor Spidsen.

$1 / 2-1 \frac{1}{1} 2^{\prime}$ høi, Stængel og Grene rue; Stængelens Furer dybere end hos folg. 5. 2. Var.

$\beta$, ramulosum! De nedre Grene meget lange, med krandsstillede Sinaagrene.

I fugtige og skyggefulde Løvskove, par Skovenge, sporadisk, men ikke sjelden. $\boldsymbol{\beta}$, pai Enge ved Skjerumbro mellem Lemvig og Ringkjøbing!

1352. E. silraticum L. (Skov-P.) H. II, 344; Drej. n. 1016 ; F. D. 1182.

Det frugtbarende Skafts Skeder tragtformede, grøn- og brunnstribede, i Spidsen 5-6-lappet-tandede, med budt-ægformede, rødbrune Tander; Grenene opret-aabne, vandrette eller neảbøiede, firekantede, med trekantede Smaagrene og 3-4-tandede Skeder, hvis Tander ere sylformede, ennervede, med Nerven udløbende til Spiđsen.

1-2' həi, mindre ru end foreg. 5. 4 .

I Skove, paa Skovenge og side Marker, alm. udbredt.

c. Aestivalia A. Braun. De frugtbærende og golde Stiongler eensartede (grønne), henvisnende mod Vinteren, Frugtaxet budt.

1353. E. palustre L. (Kjær-P.) H. II, 345; Drej. n. 1010 ; F. D. 1183.

Stongelen grenet, dybt $6-8$-furet, indvendig afdeelt $i$ flere ligestore Rum; Skederne 6-8-tandede, med triangelformede, sylspidsede, i Spidsen brune, i Randen bredt-hindeagtige Tander; Grenene 5-6-furede, med 5-6-tandede Skeder.

Planten næsten jævn, $1 / 2-2$ ' hoi. 6-7. ฯ.

$\beta$, polystachyon. Alle Grenene i Spidsen axbærende.

$\gamma$, arenarium Fr. Stængelen ved Grunden nedliggende, Grenenes skeder dybt og tilspidset-tandede. 
$\delta$, tenue Doell, Rhein. Fl. p. 29 (E. prostratum Hoppe). Stænglerne talrige fra Grunden, ofte nedliggende.

Paa slette Enge, ved Kildevæld og i Moser alm. og ofte et skadeligt Ukrud. $\beta$, med Hovedarten, men sjeldnere; $\boldsymbol{\gamma}$, paa sandige Marker, ikke alm.: $\boldsymbol{J}$. ved Haraldslund! $\boldsymbol{\delta}, \boldsymbol{J}$. Hjallerup i Vendsyssel!

\section{E. limosum L. (Dynd-P.) H. II, 345; Drej.} n. 1012; H. N. XI, 98; E. limosum a, linnæanum Doell, Bad. Fl. 1, p. 64 .

Stangelen ugrenet eller faagrenet, i frisk Tilstand svagt, i tørret dybt stribet, indvendig huul (enrummet); Skederne 1020-tandede; Tanderne smalt sylformede, i Spidsen sortbrune med en meget smal, hindeagtig Rand; Grenene 5-6-furede, med 5-8-tandede Skeder.

$1-2^{\prime}$ høi, i alle Dele større end foreg., jævn, Stængelen og Skederne forneden glindsende. 5-6. 4.

$\beta$, polystachyon Lejeune Fl. Spa, p. 274. De øvre Grene axbærende.

* fluviatile. H. II, 345 ; E. fluviatile L. Fl. Suec., Drej. n. 1011 ; F. D. 1184; H. N. XI, 97; E. liınosum b. verticillatum Doell, Bad. FI. 1, p. 64. Stængelen mangegrenet; Skedernes Tænder bredt sylformede, tilligemed Skedens øverste Rand sortbrune.

I Kjær, ved Sø- og Aabredder alm. $\boldsymbol{\beta}$, Gilleleie (Heiberg)! * I Aaer og Søer hist og her.

Anm. De fleste nyere Forff. ere enige i, ikke at adskille E. fluviatile som Art fra $\mathrm{E}$. limosum. Blandt de talrige og foranderlige Former som denne Art frembyder, er det vistmok let at udsondre nogle, som ere $\mathrm{i}$ høi Grad forskjellige indbyrdes, men Grenenes Antal og Længde samt Tændernes Form forekomme mig idetmindste at være uden bestemt Grændse.

d. Hiemalia A. Br. De golde og frugtbærende Stængler eensartede, stedsegrønne og vedvarende om Vinteren; Frugtaxet spidst.

1355. E. hiemale L. (Skavgræs). H. II, 345; Drej. n. 1009 ; F. D. 1409.

Skafterne ugrenede, 14-20-furede, rue; Skederne korte, 
valseformede og tæt sluttende omkring Stcengelen, sorte eller hvide med en sort Rand forneden og foroven; Tanderne meget korte, budte med en hurtigt affaldende Spids.

$1-3^{\prime}$ høi. Fra alle de foreg. let kjendelig ved de rue Striber, som ridse Neglen. 6-7. 4 .

I fugtige Skove, ved Kildevæld paa Sandgrund, sporadisk og ikke alm., men funden i alle de danske Provindser.

1356. E. variegatum [Schleich. Cat. pl. belv. p. 2†] (SandP.) F. D. 2490 .

Skafterne ugrenede eller ved Grunden faagrenede, 6-8furede, rue; Skederne korte, forneden grønne, i Midten sorte, i Spidsen udvidede, hvidhindede med $6-8$ korte, spidse, vedblivende eller affaldende (i Midten sorte, i Randen hvidhindede) Tonder.

$1 / 2-1 '$ høi og meget finere end foreg. 7-8.

Paa fugtige Steder i Sandegne: Det eneste Expl. jeg har seet fra Danmark findes $\mathrm{i}$ Drejers Herb. under Navn af $E$. palustre arenarium, samlet i Klitterne i Thy.

\section{Characex.}

\section{Nitella. Glandstraad.}

a. Nitellavera. Grenene*) opløses ved deres første Deling i flere eller frere ligestore, symmetrisk ordnede Straaler.

aa. Krandsgrenene 2-3 Gange deelte, Smaagrenene forsynede med Led, Endeledstykket braadspidset.

1357. N. tenuissima [Rabenh. Cryptog. Fl. p. 196] (Spæd

G.) Wallm. monogr. p. 18 ; Coss. \& Germ. Atl. f. Paris, tab.

*) For at opnaae saavidt muligt faste Benærnelser for Characeernes talrige Forgreninger liar jeg anvendt folgende Udtryk for disse: Hovedstcengelens forste, krandsstillede Forgreninger benævnes i begge Slægter Hoved- eller Krandsgrene (og der skjelnes mellem de golde og frugtbærende Grene, der ofte ere indbyrdes forskjellige), 
41 F.; Chara tenuissima Desv., A. Braun i Flora 1835, I, p. 53 ; Rebb. ic. erit. VIII, 1065-68.

Enbo, med traadfine Stcengler, Krandsgrenene 6-8, korte, tæt og næsten kugleformet sammenhobede, tre Gange deelte; Straalerne i første og anden Deling 6-7, Smaagrenene 3-5, med et enkelt Led og et tilspidset, omtrent dobbelt saa langt som bredt Endeledstykke; Sporehusene meget smaae, ovale, 6-9stribede, med kort, afstumpet Krone.

Fiin og meget spæd (2-3" høi), oftest lysgrøn, stundom incrusteret. Ved de tret og kugleformigt sammenhobede Grene og yderst smaae Frugter let kjendelig fra de følgende Arter.

I Færskrand. Angives fra Dinmark (Wallm.), men intet Voxested er mig hekjendt. Hornemann anforer fremdeles fra Danmark "N. Alexilis batrachosperma", men da der intet Expl. findes $\mathrm{i}$ hans Herbariuin, tør jeg efter den korte Beskrivelse (H. II, 676) ikke have nogen begrundet Mening om der med denne menes $N$. tenuissima eller den regte $N$. batrachosperma A. Br. (Rehb. 1. c. fig. 1070). 同

1358. N. gracilis [Ag. Syst. Alg. p. 125] (Fiin G.) Wallm. l. e. p. 19 ; Coss. \& Germ. 1. c. t. 41 , E.; Wahlstedt Skand. Char. p. 1; Chara gracilis Sm., A. Br. l, c. p. 53 ; Engl. Bot. 4140 ; Rebb. ic. erit. fig. 1069; H. N. VII, 100; Nitella flexilis b. gracilis H. II, 676 .

Enbo, med tyude, bøielige Stongler, $6-7$ længere, ikke tæt sammenhobede, 2-3 Gange deelte Krandsgrene; Straalerne i alle Delinger 3-4; Smaagrenene med 2-3 Led; Endeledstykket braadspidset, $2-3$ Gange saa langt som bredt; Sporehusene forholdsviis store, femstıibede, næsten kugleformede, med utydelig Krone.

disses yderligere Forgreninger benævnes hos Nitella Straaler af forste, anden Deling o. s. v. og Straalerne af sidste Deling særligt Smaagrene. Hos Chara kaldes Hovedgrenenes krandseller halvkrandsstillede Forgreninger (efter Wallm.) Bracteer. Stundom udgaaer indenfor Hovedgrenenes Krandse en eller anden storre Green; disse Grene, hvis Forgreningsmaade alm. er eensartet med Hovedstængelens, ere betegnede med Navnet Vinkelgrene. 
$2-6^{\prime \prime}$ hoi, lys- eller guulgron, Grenene meget fine, men ved de angivne Kjendetegn adskilles den let fra foreg.

I Færskvand. Angives fra Danmark (Hornem., Wallm.), men jeg kan intet specielt Voxested anfore.

1359. N. mucronata [Kütz. Phyc. germ. p. 256] (Braadspidset G.) Wallm. l. c. p. 25 ; Chara mucronata A. Braun l. e. p. 52 ; H. N. XII, 100; Chara flexilis Rchb. l. c. fig. 1071 .

Enbo; Stcenglerne langstrakte, bøielige og gjennemsigtige; Krandsgrenene 6-8 uligelange, 1-2 Gange deelte (de golde Grene undertiden udeelte); Straalerne i første Deling 3-4, i anden Deling 2; Smaagrenene korte, med et enkelt Led og budt, braadspidset Endeledstylke; Sporehusene ovale, 7-8-stribede, med kort Krone.

Høi (indtil over $1^{\prime}$ ), mørkere eller lysere grøn og glindsende, med boielige og temmelig lange Grene; Sporehusene mindre end hos foreg. I'ar.

$\beta$, heteromorpha A. Br. 1. c., Coss. \& Germ. l. c. t. 40, D, 4-5. De frugtbærende Krandse tæt sammentrængte i Spidsen af Hovedgrenenc eller af Vinkelgrene fra Hjørnerne af de golde Grene; Straalerne talrigere, men kortere.

$\gamma$, flabellata Coss. \& Germ. 1. c. t. 40, D, 1-3; N. flabellata Kütz., A. Braun, Wallm., Lge. Haandb. 2 Udg. p. 697. Finere end Hovedarten, med Krandsgrenene oftest 3 Gange deelte, længere og alm. talrigere, Smaagrene. (Efter Nordstedt, Skand. Charac. p. 37 er den kun en Form af Ch. mucronata og ikke en selvstændig Art).

Hovedarten forekommer uden Trivl i Danmark, og angives herfra af Wallm. $\beta, \mathrm{i}$ Aaen ved Have Molle pr. Ringsted (Aaby)! $\gamma, \mathrm{i}$ den botaniske Haves Parker! $\boldsymbol{F}$. Hals ved Hofmansgave (E. Hofm.Bang)! $¥$

bb. Krandsgrenenc engang deelte eller ulleelte med en Knobøining $i$ Delingens Sted; Smaagrenene uden Led.

$$
a, \text { enb? }
$$

1360. N. flexilis [Ag. l. c. p. 124] (Bøielig G.) Wallm. l. c. p. $3 \hat{3}$; H. JI, 675 (undt. varr. a-h); Chara flexilis 
Bruzel., A. Braun 1. c. p. 50 (neppe L.); Nitella Brongniartiana Coss. \& Germ. l. c. t. 40, C, $1-2$; N. furculata Rchb. Mössl. Handb., Nordstedt, Skand. Char. p. 35.

Stangelen lang, bøielig, glindsende; Krandsene fjerne; Krandsgrenene 6, omtrent af lige Tykkelse med Stængelen, 2-3-deelte eller udeelte; Smaagrenene lange, budte eller spidse (ikke braadspidsede); Sporehusene tilsidt næsten kugleformede, syvstribede, deres Krone kort, med i Spidsen sammenstødende Tænder.

Lysere eller mørkere grøn og olieagtigt glindsende, ved Tørring oftest sort. Af denne, ligesom af flere andre Arter, forekommer undertiden en Form af afvigende Udseende (nidifica) med Vinkelgrene, hris Ledstykker ere forkortede og Krandsgrenene flere Gange deelte.

I Færskvand, sjeldnere i Havet, ikke alm.: $\boldsymbol{S}$ j. Dronninggaard (11)! Ordrup Mose! Raavaddam (Aabye).

* 1361. N. procera [Wallm. 1. c. p. 32] (Høi G.)

Stor og kraftig, med 10-12 meget lange, trestraalede Grene i de nedre (golde) Krandse; de ovre, frugtbærende Krandsgrene 4-5, deelte i 2-3 Straaler; Sporehusene storre, stundom 2 samlede, forøvrigt som foreg., med hvilken den er nær besłægtet.

Grimmerup Mose i Angel (Wallm.). 图

$$
\beta, \text { trebo. }
$$

1362. N. syucarpa [Kütz. l. c. p. 256] (Tvebo-G.) Chara syncarpa Thuill., A. Br. l. c. p. 51; Rehb. l. c. fig. 1073-77; N. flexilis d. syncarpa Wallr., H. II, 675.

Krandsene fjerne, med 8-9 udeelte eller 2-4-straalede Grene; Smaagrenene tilspidsede; $\widehat{0}$ : Antheridierne snart enlige i Vinklerne af Smaagrenene, snart flere tæt samlede $\mathrm{i}$ et endestillet Hoved; : Sporehusene 2-3 samlede nedenfor Straalernes Delinger eller fra Midten af de udeelte Straaler, 5-6-stribede.

$\mathrm{H} \emptyset \mathrm{i}$ (indtil over $1^{\prime}$ ), smukt grøn. Saavel Antheridier som Sporehuse sidde ofiest flere samlede enten paa de øvre Krandsgrene eller hyppigere paa de talrige forlsortede Vinkelgrene. Ved det adskilte Kjøn let kjendelig fra $N$. flexilis, med hvilken den ofte har været 
forvexlet. Den forekommer under meget forskjellige Former, der af Flere ansees for særegne Arter. Af disse findes hos os:

* pseudoflexilis A. Br. (N. atrovirens Wallm. 1. c. p. 35 ; N. opaca $\beta$, atrovirens Wahlstedt 1. c. p. 7 ; N. syncarpa var. Smithii Coss. \& Germ. 1. c. t. 39, 7-12. Større og mørkere grøn, alm. glindsende, ikke incrusteret; Stængelens Ledstykker kortere end Krandsgrenene; Sporehusene enlige eller 2 samlede.

** capitata Coss. \& Germ. 1. c. t. 39, 1-6; Chara capitata N. E., Nitella Ag., Wallm. I. c. p. 37. Spxdere, bleggrøn, ofte incrusteret, med længere Ledstykker; Sporehusene alın. 3 samlede; Antheridierne ofte hovedformigt samlede par meget korte Vinkelgrene og alm. indhyllede i Sliim.

I Færskvand, hist og her, f. Ex. F. Veistrup (19)! J. i Mergelgrave ved Eveldrup (Drej.)! Haraldslund! $S j$. Gurre Sø (14!) golde Exemplarer (?) ** Kjobenhavns Omegn (Hornem., Aabye)!

b. Tolypella A. Br. Hovedgrenenes Axe forlænget udover den forste Deling, ved de 1 - 3 nedre Led forsynet med mindre Grene, som faae Lighed med Bracteer ("falske Bracteer"); Smagrenene forsynede med Led.

1363. N. intricata [A. Braun!] (Mangefrugtet G.) Chara intricata Trentep., Chara polysperma A. Br. l. c. p. 56 ; Ganter. Oesterr. Char. p. 12, tab. I, 3; Nitella Kütz., Wallm. I. c. p. 41 ; Chara fasciculata Amici.

Enbo; Krandsgrenene $8-10$; de nedre Grene golde, forlængede, deelte; Smaagrenene bestaae af flere Led og et tilspidset Endeledstylile; de frugtbcrende Grenes Axe fortløbende i 2-3 Led og ved hvert Led forsynet med 3-5 langstrakte, enkelte eller deelte mindre Grene (falske Bracteer); Antheridierne stilkede, tilligemed talrige Sporehuse tæt samlede ved Grenenes nedre Led eller ved Grunden af Hovedgrenene; Sporehusene ovale, 10-12-stribede, gjennemsigtige, med kort, afstumpet Krone.

Stor (over 1') og stærlkt forgrenet; de frugtbærende Grene tæt sammenhobede, forneden incrusteret og i torret Tilstand graaagtig. 
Udmærket og let kjendelig ved Smaagrenenes talrige Led, de mange tæt sammenhobede Frugter og den tidlige Fructification (4-5). Den har Lighed med Slægten Chara ved Incrustation og Forgreningsmaade.

I Leergrave ved Næsbyhoved pr. Odense (Lgby i Horn. Herb.)!

1364. N. Stenhammariana [Wallm. 1. c. p. 43] (Fuglerede-G.) Chara Stenhamınariana Wallm. add. ad Liljebl. Sv. Fl. ed. 3 ; H. N. XV, 100; Conferva nidifica F. D. 761; Chara nidifica Bruzel., Ch. flexilis c. nidifica H. II, p. 675 ; Nitella flexilis (Chara L.) Nordstedt 1. c. p. 39.

Enbo; Krandsgrenene 6-8; de nedre Grene golde, udeelte; de frugtbarende Grene og Vinkelgrenene med sammentrængte Ledstykker, ved de $1-2$ nedre Led forsynede med 3-4 udeelte, uligelange falske Bracteer; Smaagrenene (stundom tillige Hovedaxens og Hovedgrenenes Ledstykker) bestaae af flere Led, med budt Endeledstykke; Sporehusene 2-flere samlede, tilsidst kugleformede, 7--8-stribede, kastaniebrune, med spids Krone; Antheridierne enlige, ovenfor eller ved Siden af Sporehusene.

Lavere end foreg, $\mathrm{i}$ frisk Tilstand lysgrøn, torret sortgrøn, glindsende, ikke incrusteret. Ved de udeelte Grene og falske Bracteer samt ved budte Endeledstykker desuden kjendelig fra foreg. - Fructificerer senere paa Sommeren (7-9).

I Salt- og Brakvand: $\boldsymbol{S}$ j. Kallebodstrand ved Kbhavn? (Aabye, ufuldst. Expl.); $\boldsymbol{F}$. Odense Fjord ved Hofmansgave (Hofm. Bang)! mellem Loll. og Falst. (Müll.), Rødby Fjord (19)! «

\section{Chara. Krandsnaal.}

a. Lychnothamnus Rupr. Stænglernes Ledstykker encellede, jævne, Antheridierne ved Siden af Sporebusene. (Gjennemsigtige og boielige, uden Incrustation)*).

1365. Ch. alopecuroides (Delil., var. Wallrothii A. Br.) (Rævehale-K.) H. N. XV, 99; Ch. papulosa Wallr.; Ch. Wallrothii Rupr.; Nitella flexilis e, barbata H. II, 676.

*) Denne Afdeling danner i flere Henseender en Overgang fra Slægten Chara til Nitella. Flere Forff. have derfor', da der ogsaa blandt 
Enbo; Stanglerne stivt oprette, med 5-8 Grene i Krandsene og ved Grunden af disse et forskjelligt Antal (4-13) forlængede, udstaaende eller tilbagebøiede Svobblade; Krandsgrenene indadbøiede, $3-5$ leddede, med $5-6$ forlængede, naaleformede Bracteer ved hvert Led og indenfor hvert af disse enlige Antheridier og ovale, 11-stribede, gjennemsigtige Sporehuse med utydelig Krone.

$2-8^{\prime \prime}$ høi og spæd, glindsende og smukt grøn, ikke incrusteret. Stængelens nedre Ledstyklker follængede, de øvrige forkortede, med duskformigt sammentrængte Krandse. I Habitıs ikke ulig Ch, crinita.

I Salt- og Brakvand, sjelden: J. Øen Røn i Limfjorden (Aabye)! F. Odense Fjord ved Ulriksholm (H. 4, 18!). |*i!

b. Charæ genuina. Stængelens Ledstykkerstribede eller furede af flere parallele Celler, der som et Barklag omgive en støre Celle i Midten; Antheridierne nedeufor Sporehusene.

aa. Strigosa. Stangelen behladt med flere eller farre Borster eller Vorter (hveranden Rakke af Stangelens Striber (Hovedstriberne) med, hveranden (de secundcere Striber) uden Børster*).

$$
\propto \text {, Enbo. }
$$

ce, I torret Tilstand graaagtige, incrusterede, slijore.

* Fo etidac. Stanglerae mindre dibt stribede, sragt bekladte med hornede Vorler, sjeldnere med Borster; Krandşrenenes Budeledslyhiber og Bracteerne budte.

1366. Ch. foetida [A. Br. l. c. p. 63] (Stinkende K.) Wallm. l. c. p. $76-78$; Coss. \& Germ. 1. c. tab. 37 (ex part.), Ch. vulgaris pl. autt., H. N. VI, 100 (dextr.).

Stanglerne forlængede, med 8-10 Grene i Krandsene, dens Ledstykker stribede, Hovedstriberne beklædte med vorteformede Ujævnheder, sjeldnere med Børster, mindre fremragende

foreg. Slrgt findes Arter, som have flere Characterer tilfalles med Chara, vedligeholdt den tidligere Forening af Slægteme.

*) De med Børster beklædte Striber ligge undertiden dybere og ere mindre fremtrædende end de ovrige, og ere derfor ved Torring ofte ukjendelige. 
end de secundære; Svøbet kort eller 0; Grenene opstigende, 5-6-leddede, med Bracteer af ulige Længde; Sporehusene ovale, 13-stribede, med opret, temmelig kort Krone.

Graagrøn, i tørret Tilstand askegraa, og i Regelen stærkt incrusteret, meget stinkende. Af denne meget forskjellige Arts talrige Former forekomme her:

$\alpha$, vulgaris A. Br. (Ch. vulgaris $\alpha$, Wallr., Kütz.; $\mathrm{Ch}$. foetida Walm. l. c. p. 76; Coss. \& Germ. 1. c. fig. 1-4). Bleggrøn, med tynde Stængler; Grenenes øverste Ledstykker uden Barklag; de indadvendte Bracteer 4 (2 af Frugternes Længde, 2 længere), de udadvendte 2 meget korte.

$\beta$, longibracteata A. Br., Coss. \& Germ. 1. c. fig. 7 ; (Ch. longibracteata $\alpha$, Wallm. 1. c. p. 77 ; Ch. vulgaris b. foliosa Horn. 676). Langstrakt, Grenene længere, med Barklag indtil Spidsen; de 2 inderste Bracteer meget lange (4 Gange Sporehusets Længde).

$\gamma$, brevibracteata A. Br. Stængelen lavere, de 2 længste Bracteer neppe dobbelt saa lange som Sporehuset.

$\delta$, subhispida A. Br. 1. c., Coss. \& Germ. l. c. fig. 6 . Stængelen foroven beklædt med Børster; Grenenes øverste Ledstykker uden Barklag.

\section{$\boldsymbol{\varepsilon}$, munda A. Br. ined. Uden Incrustation.}

I Færskvand almindelig, (især $\beta$ ). Formerne $\gamma$, og $\delta$, forekomme hist og her (f. Ex. Hofmansgave); $\varepsilon$, F. Hofmansgave (18); J. Eveldrup (Drej. i Hornem. og Aabyes Herb.).

* 1367. Ch. contraria [A. Br. Schweitzer Char. p. 135] Wallm. l. c. p. 76 ; Wahlst. 1. c. p. 15 ; Ch. foetida var. hispidula \& densa (?), Coss. \& Germ. 1. c. fig. 5 \& 8.

Stængelens periferiske $R ø r$ beklædte med fine Vorter eller længere Børster, de med Ujævnheder beklædte Striber (Hovedrørene) mere fremragende end de secundære Rør, og derved synlige ogsaa i tørret Tilstand; 4 Bracteer lidet længere end Sporehusene, forøvrigt som foreg., men spædere, med alm. kortere og ved Frugtmodningen indbøiede Grene.

I Færskvand: $\boldsymbol{F}$. Hasmark Mose ved Hofmansgave (18!); J. Flade S $\emptyset$ ved Agger! (Expl. bestemte af Prof. A. Braun). (W 
* Hispida. Stængetens Ledstyhiker dybl furede, alm. bekladto med langere Berster; Girenenes Endeledslykker og Bracleerne spidse.

1368. Ch. hispida [L. (?), Sm. fl. britt. 1, 5] (Stivhaaret K.) Wallm. I. c. p. 80 ; A. Br. l. e. p. 66 ; H. II, 677 (exel. varr.); F. D. 154 (?), Coss. \& Germ. l. e. tab. 38, B. 1-2; Ch. spinosa Rupr., Nordst. 1. e. p. 47.

Stangelen høi, tyk og kraftig, med spiralformigt bøiede Striber; Hovedrørene mindre fremragende end de secundære, beklædte med lange og sylspidsede, spredte eller knippestillede, nedadvendte Borster; Krandsgrenene 8-10, i Frugttilstanden opret-aabne, med et $S v \rho b$ dannet af 2 Rækker Torne nedenfor hver Krands; fra hvert af Grenenes 4-8 Led udgaae 8-10 tilspidsede Bracteer, hvoraf de $3-5$ indre ere længere, de 2-4 ydre kortere end Sporehusene (de ydre Bracteer ofte meget smaae eller 0); Sporehusene store, 10-13-stribede, med stor, opret-aaben Krone.

Den største og anseeligste Art, i frisk Tilstand mat lysgrøn, torret graaagtig, sædvanlig incrusteret og temmelig skjør. Af dens forskjellige Former maa følgende særskilt nævnes:

$\beta$, gymnoteles $\mathrm{A}$. Br. Stængelen mindre incrusteret, næsten uden Børster, Grenenes $2-3$ ovre Ledstykker meget lange, uden Barklag.

$\gamma$, micracantha A. Br., Wahlstedt 1. e. p. 27 ; Nordst. I. c. p. 47; Ch. equisetina Kütz. Stængelen grov, med faae og korte Børster, Krandsgrenenes ovre Ledstykke budt baand. formet uden Barklag og Inerustation (en oftest steril Form).

En af de almindeligste Arter, især i Færskvand. $\beta$, i Moser ved Kjøbenhavn! Sortedams $\emptyset$ (Aabye). $\gamma$, J. Vildsted $\mathrm{S}_{\varphi}(8)$ ! Loll.. i Tørvgrave ved Birket (19)! Avernakø (12)!

1369. (. polyacantha [A. Braun ined.] (Mangetornet K.) Wahlst. l. e. p. 29 ; Nordst. 1. c. p. 48 ; Ch. hispida var. pseudocrinita Coss. \& Germ. l, e. t. 38 B. 3; H. N. XIV, 100.

Langstrakt, men alm. tyndere end foreg., meget skjør og stærkt incrusteret; Stcengclens Hovedrør mere fremragende end de secundære, tæt beklædte med lange og spidse Børster, som paa Ledstykkernes ovre Deel ere nedadvendte, paa den 
nedre Deel opadvendte; Krandsgrenene 7-9, korte, med alm. 7 Led, hvorfra udgaae $6-8$ indbyrdes omtr. ligelange Bracteer; alle længere end de ovale, 13-stribede, sortblnae eller blyfarvede Sporehuse.

I Færskvand, sjelden: $\boldsymbol{S}$. Bidstrup ved Roeskilde (Nordstedt)! L oll. Mose ved Birket (19)!

$\beta \beta$, Mindre stijøre, stagt eller aldeles ikike incrusterede og $i$ tørret Tilstand grøne (Baltica).

1370. Ch. horrida [Wallm. ined.] (Pigget K.) Wah]stedt 1. c. p. 24 ; Nordst. l. c. p. 49 ; Ch. hispida $\gamma$, echinata Lge. Haandb. 2 Udg. p. 704; Ch. baltica fastigiata Wallm. monogr. p. 86 ; H. N. XIV, 99.

Grøn, næsten uden Incrustation; Stangelen langstrakt $\left(1 / 2-1^{\prime}\right)$, lidet grenet, furet-stribet; de secundore Rør fremstaaende, Hovedrørene ved Tørring nedsænkte, med stærke, knippestillede Børster, som paa Ledstykkernes øvre Deel ere nedadvendte, forneden opadvendte; Krandsgrenene 10-13, fjerne, fine, lange, stivt oprette; Bracteerne 6-8, omtr. ligelange og længere end det tykke, ovale, tilsidst sortbrune Sporehuus.

I Salt- og Brakvand: Hofmansgave indenfor den store Dæmning (27)!

Ann. Denne Art', som i Udseende har endeel tilfælles med Ch. hispida og polyacantha, synes at danne et Mellemled mellem disse og Ch. baltica. Da den er visenligt forskjellig fra begge disse Grupper, har jeg med de nyere svenske Monographer af Characeerne opfort den som en egen Art.

1371. Ch. intermedia [A. Braun ined.]. Nordst. 1. c. p. 50.

Stangelen høi, tyk og kraftig, stærkt stribet; Hovedrørene mere fremtrædende end de secundære, med̀ faae og korte Børster; Krandsgrenene 6, bestaaende af 5 Led; de nedre Ledstykker korte, med Barklag, de 2-3 ovre Ledstykker uden Barklag, med en tilleddet Braad i Spidsen; de indre Bracteer. lidet kortere eller længere end de store, ægformede Sporehuse. 
Skjør og stierkt incrusteret. Danner efter Wallm. et Mellemled mellem Ch. hispida"og foetida, og forekommer nuder 2 Former:

$\alpha$, papillosa A. Br., Wahlst. 1. c. p. 22 , Ch. papillosa Kütz., Wallm. 1. c. p. 80. Lavere (omtr. 1/2 ${ }^{\circ}$, og med færre Børster, Krandsgrenene omtr. 6, iudbøiede. (Ligner i Udseende $\mathrm{Ch}$. contraria og $\mathrm{Former}$ af $\mathrm{Ch}$. foetida).

$\beta$, aculeolata A. Br., Wahlst. 1. c. p. $22, \mathrm{Ch}$. aculeolata Kütz. Høiere (1') med flere og længere Børster, Krandsgrenene $7-9$, oprette. (Ligner Ch. Liljebladii og $\mathrm{Ch}$. hispida $\gamma$, micracantha).

$\alpha$, I Slien ved Klensby Nor (20)! Expl, bestemte af Prof. A. Braun. $\beta, J$. Vildsted Sø $(8)$ ! [*

1372. Ch. Liljebladii [Wallm. 1. c. p. 86] Wahlst. 1. c. p. 19; Ch. distans Wallm. olim.

Stcengelen grov og langstrakt, med mange og fine periferiske Rør, Hovedrørene meest fremtrædende; Ledstylkerne meget forlængede, de nedre uden, de øvre med flere eller færre, knippestillede eller spredte, opret-aabne Borster; Krandsgrenene $9-12$, kortere end Ledstykkerne, med 2 Riekker nedbøiede Svølblade ved Grunden; Grenenes Led 5-6, det nedre Ledstykke kort og tykt, Endeledstylket kort, kegleformet, uden Barklag, de øvrige traadformede, med Barklag, de 1-3 nedre Led frugtbærende, med omtr. 8 Bracteer, de indre længere, de ydre kortere end Sporehusene; de øvre Led golde, med færre Bracteer; Sporehusene aflang-valseformede, 10-15stribede, med stor og udbredt Krone; Antheridierne store.

Af Størrelse som Ch. hispida, men meget finere, kun lidet incrusteret, og ved Stængelens talrigere, finere Striber, færre, mere opadvendte Børster og en lys, men frisk gron Farve adskilt fra hiin.

"I Guldborgsund mellem Lolland og Kjeldsø, i saa stor Mængde at den hindrer Seiladsen" (Viborg (?) 1792 i Hornem. Herb., Expl. bestemte af Wallı.). I Nakskov Fjord i Mrngde (19)! 㔷

1373. Ch. baltica [Fr. Nov. p. 289] (Østersøisk K.) Wallm. 1. c. p. 85 (undt. var. $\gamma$ ) ; F. D. 2311 ; H. N. IX, 100; Ch. hispida a. baltica H. II, 677. 
Stcongelen dybt furet, beklædt med talrige og stærke, nedadvendte, enlige eller 3-flere knippeviis samlede Børster; Krandsgrenene omtrent 9, meget kortere end Ledstykkerne, med 2 Rækker Svøbblade ved Grunden; Grenenes Led 5-7, de 3 nedre Ledstykker frugtbærende, de $1-3$ øvre uden Barklag; Bracteerne talrige, krandsstillede; Sporehusene næsten kugleformede, i yngre Tilstand hvide, tilsidst sorte, 8-10-stribede, med kort, aaben Krone.

Skjør, men alm. uden Incrustation. Dens vigtigste Kjendemærker fra Ch. hispida ere ovenfor angivne. Ch. aspera er trebo og desuden adskilt ved en fiint stribet Stængel, meget finere Børster og en guulgraa Farve. Med andre Arter kan den neppe forvexles. Folgendo Former adskilles:

$\alpha$, genuina (Ch. baltica $\beta$, humilis Wallm. 1. c.) Lav, mørk- eller guulgrøn, Grenenes øverste Ledstykke meget udvidet, fladtrykt; de ydre Bracteer af Længde med, de indre længere end Sporehusene.

$\beta$, firma Wahlst. l. c. p. 18 (Ch. firma Ag.) Ontrent $1^{\prime}$ lang, stiv og noget incrusteret, graagrøn eller bruunagtig, de 1-3 ørre Ledstykker smale, de ydre Bracteer kortere end, de indre af Læungde med Sporehusene.

I Saltvand: Øresund ved Kysterne af Saltholm i Mængde! Kallebodstrand ved Amager (Aabye); Store Bælt ved Korsør (4), Reersø (11); L oll. i R Hornem. Herb., men uden Angivelse af Voxested. ⿷匚

* 1374. Ch. Nolteana [A. Br. l. c. p. 62] (Mørkgrøn K.) Wallm. l. c. p. 84 .

Stangelen kraftig, stribet, i Spidsen forsynet med faae, fjerne og korte Børster, forneden nøgen; Krandsgrenene 8-12, længere end Ledstykkerne, med meget korte Svøbblade ved Grunden; Grenene 5-6-leddede, de $1-3$ nedre Ledstykker kortere, og (ligesom Hovedstængelen) omgivne af Barkceller; de øvrige Ledstykker uden Barklag, længere og tykkere (af Hovedstængelens Tykkelse), indsnørede ved Ledene; Endeledstykket kort og tilspidset; Bracteerne faae, korte og uligelange, de ydre meget korte eller 0; Sporehusene blege, med kort, aaben Krone. 
Omtr. $1 / 2^{\prime}$ høi, mørk olivengrøn, glindsende, uden Incrustation. En af vore sjeldneste $\mathrm{ng}$ eiendommeligste Characeer, som i Udseende har Lighed med Former af den sydeuropæiske $C h$. scoparia Bauer. Prof. Braun, som tidligere antydede dens Slægtskab med Ch. hispida gymnoteles, har meddeelt mig, at han nu er tilbøielig til at forene den med Ch. baltica. Ogsaa Wahlstedt og Nordstedt (l. c.) forene saavel denne Art som Ch. Liljebladii med Ch. baltica; jeg har imidlertid beholdt disse adskilte, fordi de forekomme mig i høi Grad ioinefaldende, saavel i deres ydre Udseende som i flere Characterer.

Slesvig (Nolt.), i Slien ved Louisenlund (20)! [w

$$
\boldsymbol{\beta} \text {, Trebo. }
$$

$\boldsymbol{\alpha}$, Asperœ Wahlst. Stcengelen fin, oftest incrusteret, Børsterne fine, talrige og enlige.

1375. Ch. aspera [Willd. Berl. Mag. III, 298 (Hvas K.) A. Br. l. c. p. 71 ; Wallm. l. c. p. 94 ; Coss. \& Germ. l. c. t. 38, D; H. N. III, 100; Ch. hispida (L. fl. Suec.) Nordstedt l. c. p. 44 ; F. D. 1940 ; Ch. hispida €. aspera H. II, 679.

Stanglerne talrigt samlede, stivt oprette, tynde, fiint stribede, beklædte med flere eller færre, fine og sylspidsede, vandrette, foroven nedbøiede, formeden opadvendte Borster; Krandsgrenene 7-8, oprette (i Spidsen lidet ind-eller indadboiede), kortere end Strengelens Ledstykker, ved Grunden oingivne af 2 Rækker Suфbblade, 4-8-leddede med forlængede Ledstykker; Bracteerne 6-8 uligelange (de to indre dobbelt saa lange som, de mellemste af Lrengde med og de ydre kortere end Frugterne); Sporehusene oval-kugleformede, $10-$ 11 -stribede, voxgule, med tydelig, budt Krone.

Var. i Henseende til Grenenes Længde og Antal af Led, Børsternes Beskaffenhed o. s. v. Følgende ere de mærkeligste Former:

$\alpha$, maritima (Wallm. I. c. 95). Nindre skjør og alm. ikke incrusteret, tæt beklædt med Børster, der alın, ere lidet længere end Stængelens Gjennemsnit.

1. pallida! Bleg- eller guulgrøn.

2. nigricans (Ch. hispida d. nigricans Horn. J. c.). Hele Planten af en sortgrøn Farve. 
$\beta$, leptophylla A. Br. Grøn, ikke incrusteret, med tynde Stængler og haarfine Grene, faae, fjerne og svage Torne.

$\gamma$, stagnalis (Wallm. l. c.). Spædere og mere eller mindre langstrakt, med længere Grene og færre Børster. Oftest incrusteret, meget skjør og af graaagtig eller lys spanskgrøn Farve.

$\delta$, aculeolata (Wallm. 1. c. p. 96), Ch. hispida c. curta Horn. 1. c., Ch. curta Nolt. mscr. i Horn. Herb. (?). Stærkt incrusteret, skjør og lys askegraa, med meget korte Børster; Grenene korte, med indbøiet Spidse.

Horer til de hyppigste Arter i Danmark, deels i Salt- eller Brakvand $(\alpha)$, deels i Færskvand $(\beta$ og $\gamma)$. $\alpha$ 2, Brakvand ved Amager (27); $\beta, J$. Vildsted S $\oint$ red Løgstør (8)! $\boldsymbol{F}$. Brakvand ved Hofmansgave (18)! $\delta$, Gyrstinge $\mathrm{S} \varnothing$ (Aabye)!

Anm. Ch. fragilis er enbo, og desuden let kjendelig ved Stængelens Mangel paa Børster. Ch. hispida, med hvis mindre Former den har nogen Lighed, er ogsaa enbo, ligesom Ch. baltica, hvilken den staaer nærmest, men som ved flere ovenfor anforte Kjendemærker er tilstrækkelig adskilt. Med andre Arter kan den iklse forvexles. Wallm. og Nordstedt ansee denne Art for Linnés Ch. hispida.

$\beta \beta$, Crinita Wahlst. Gronne, uden Incrustation, hvasse af talrige, fine, krands- eller knippestillede, udsparrede Børster.

1376. Ch. crinita [Wallr. Ann. bot. 190, tab. 3] (T:ethaaret K.) A. Braun 1. c. p. 70; Ganter. 1. c. p. 14, tab. II, 8; H. N. VIlI, 100; C. bispida b. crinita Horn. I. c. p. 678 .

Stonglerne talrigt samlede, oprette, tynde og fine, tæt beklædte med talrige, vandret udspilede, haarfine Børster (der ere mere end dobbelt saa lange som Stængelens Tværsnit); Krandsgrenene 8-10, opret-aabne eller tilbagebøiede, 4-6leddede, ved Grunden omgivne af en dobbelt Række Svøbblade (den øvre Rakke opad-, den nedre nedadbøiet); Bracteerne omtrent 8: de 6 ydre ligelange og meget fine (mere end dobbelt saa lange som Sporehusene), de 2 indre meget korte; Sporelusene svagt 10-13-stribede; tilsidst sortagtige, med kort og afstumpet Krone.

Mørkgrøn, af et meget sirligt Udseende. Dens spæde Væxt, 
talrige og lange Børster o. s. v. gjøre den let kjendelig fra de øvrige Arter. Exemplarer med Antheridier ere yderst sjeldne. - Man adskiller 2 Former:

$\alpha$, genuince (Ch. crinita Wallm. l. c. p. 91 ; Ch. crinita $\alpha$, leptosperma A. Br. l. c. 71). Høiere, med forlængede Ledstykker (længere end Krandsgrenene), lysere, i torret Tilstand graaggtig-gren; Sporehusene elliptisk-ovale.

$\beta$, condensata (Ch. condensata Wallm. l. c. p. $92 ;$ Ch. crinita $\beta$, pachysperma A. Br.; Ch. canescens Lois.). Lavere, med forkortede Ledstykker (kortere end Krandsgrenene), mørkgrøn, tørret olivenfarvet; Sporehusene kugleformerle.

I Salt- eller Brakvand, sjeldnere i Fæerskvand, ikke alm. i Danmark : $\alpha, \boldsymbol{J}$. Norsminde Fjord (Aabye)! $\boldsymbol{F}$. Hofmansqave (18)! $S j$. Glæn $\sigma$ ved Skjelskor (14)! Oresundet ved Amager (Aabye)! $\beta$, Hofmansgave (4)! Baage (Liebm. Herb.)! Loll. Nakskov Fjord ved Lienlund (19)! Sj. Kallebodstrand!

$\gamma \gamma$, Ceratophyllce Wahlst. Tykstcenglede, $i$ levende Tilstand oftest rodlige, med faae (eller ncesten ingen) liorte, cegformede, opblceste

Borster.

1377. Ch. ceratophylla [Wallr. Ann. bot. p. 192] (Hornbladet K.) A. Braun 1. c. p. 65 ; Ch. tomentosa $\beta$, ceratophylla Wahlenb., H. II, 677.

Stcongelen stiv og tyk, mci spiralformede Hovedrør *), svagt beklædt med korte og brede Børster; Krandsgrenene 6-8, aabne eller udspilede, ved Grunden omgivne af 2 Rækkker Svobblade, 3-6-leddede; Endeledstykket (eller de 2-3 øvre Ledstykker) nden Barklag; Bracteerne krandsstillede, ligelange, lorte, brede og spidse; Sporchusene lidet kortere end Bracteerne, 13-15-tribede, med udbredt Krone; Antheridierne store.

Skjør og incrusteret, forneden mørkgrøn, foroven teglsteensrød, - torret Tilstand graangtig. Ved de brede og korte Bracteer, den tykke Stængel o. s. v. let kjendelig fra de øvrige Arter. Med Ch. hispida og Ch. foetida, hrormed nogle af dens Former have Lighed, san den paa Grund af Kjømnets Fordeling paa 2 Planter og de eienRommelige brede, blæreformede Børster ikke forvexles. Den er

*) Stængelen har, ifølge Wahlstedt, ingen secundære Rør. 
iøvrigt en meget foranderlig Art, og hos os forekomme især 2 Former:

$\alpha$, macroptila A. Br. (?) Ch. ceratophylla Wallr. Stængelen langstrakt, med flere og længere Børster; Grenene og de talrige Bracteer langere, udstaaende.

$\beta$, microptila A. Br. (Ch. latifolia Willd., F. D. 1656 (ठ̋)). Stængelen kortere ( $2-3^{\prime \prime}$ lang), med faae Børster, kortere og mere oprette Grene og Bracteer og et meget bredt, forlæuget Endeledstykke.

* tomentosa (Ch. tomentosa L. (?), Wallm. l. c. p. 89 ; F. D. 1911 (ठే): H. N. V, 100); Stængelen tyndere, med forlængede Ledstykker, Grenene og Braeteerne længere, udstaaende; i frisk Tilstand orangefarvet eller grøn, i tørret Tilstand frisk grøn, næsten uden Incrustation.

I Færskvand, temmelig sjelden: $\boldsymbol{\alpha}, \boldsymbol{F}$. Egense ved Hofmansgave (18)! $\boldsymbol{\beta}, \boldsymbol{S} \boldsymbol{j}$. Gyrstinge S $\boldsymbol{\phi}$ (Aabye), Fuursøen (Lgby, Vahl!); J. Vildsted Sø ved Logstor i Mængde (S)! * hyppigst i Brak- eller i Saltvand: $\boldsymbol{F}$. Einsiedelsborg (F. D., Hofm. Bang)!

Anm. Wallmamn adskiller Ch. tomentosa og Ch. ceratophylla, hrorimod disse sammenfattes under een Art af $A$. Braun, og denue lorening af de 2 Former til een Art bekræftes yderligere i en udforlig Fremstilling af Wablstedt (1. e. p. 34). Efter de Expl. jeg har seet, má jeg ausee den Ansliuelse, at de ere Modificationer af samme Art, frembragte ved forskjelligt Voxested, for fuldstandig begrumdet, i modsat Fald burde Ch. latifolia, som er endeel afvigende fra de ovrige Former, ogsaa sondres som en egen Art. Mellem de forskjellige Former synes desuden ikle at være nogen skarp Grændse. Da de linneiske Navne i denne Slægt ere saa lidet sikkre og da tilmed Navnet Ch. tomentosa er lidet betegnende, har jeg foretrukket det uyere Wallrothske Navn for den samlede Art.

\section{6b. Inermes. Stangelen uden Børster langs Striberne.}

1378. Ch. fragilis [Desv. i Lois. not. p. 126] (Skjør K.) A. Braun 1. c. p. 68 ; Wallm. 1. c. p. 101; Coss. \& Germ. 1. c. t. $38, \mathrm{C}$; Ch. vulgaris (L. part.) H. II, 676 .

Enbo; Stonglerne tynde, fiint stribede ; Krandsgrenene 7-10, alm. kortere end Stængelens Ledstykker, i frugtbærende Tilstand opret-tiltrykte eller bueformigt indbøiede, med en dobbelt Række af smaae og tiltrykte (stundom utydelige) Svøbblade; Grenenes Led $6-10 ;$ Bracteerne fine og tilspidsede, hurtigt 
affaldende, de ydre meget smaae eller 0 , de indre af forskjellig Længde; Sporehusene ovale eller ægformet-elliptiske, 13-15-stribede, med lang, opret Krone.

Meget skjør, for det meste frisk gron og uden Incrustation. I Udseende narmer den sig meest $\mathrm{Ch}$. foetida, men ved de meget finere Stængler, de tidligt affaldende Braeteer, hvorved Grenene (især de golde) synes nøgne o. fl. Kjendetegn adskilt fra denne. Fremtræder især under nedenstaaende Former, mellem hvilke dog neppe lader sig drage nogen skarp Grændse:

$\boldsymbol{\beta}$, Hedwoigii (Ch. Hedwigii Bruzel.; Ch. vulgaris a. Hedwigii Horn. l. c.; H. N. VI, 100 (venstre Pl.). Større, blaagrøn, ofte incrusteret; de indre Bracteer af Sporehusenes Længde.

$\gamma$, pulchella (Ch. pulchella Wallr.; Ch. vulg. c. pulchella Horn. l. c., H. N. XII, 99). Finere, oliven- eller graagrøn, uden Incrustation; Krandsgrenene lengere, med talrige Led; de indre Bracteer lidet kortere end Sporehusene.

$\delta$, capillacea (Ch. capillacea Wallm.; Ch. fragilis $\beta$, longibracteata Rabenh., A. Br.). Meget fiin, frisk grøn uden Incrustation; Krandsgrenene lange (ofte længere end Lecstykkerne, de indre Bracteer ofte meget længere end Sporehusene.

$\varepsilon$, barbata Ganterer (Ch. frag. var. foliolata Hartm.). Bracteerne lange, Grenene lange og fine, med tydelige, ofte meget lange Svøbblade; har undertiden Spor af Børster i Form af Vorter paa Strngelen.

* annulata (Ch. annulata Wallm., Lge. Haandb. 2 Udg. p. 710). Lav, tueformet, mørkgrøu, mindre skjør, med færre Krandsgrene, korte og talrige $(15-20)$ Ledstykker paa Grenene og sortgrønne, ringformigt indsuørede Led, uden Bracteer (oftest gold).

I Færskvand, en af de almindeligste Arter i Danmark. Formen $\varepsilon$, symes at være sjeldnere: $\boldsymbol{F}$. Torvgrave ved Mynderup (12)! * (en eiendommelig Form, som jeg tidligere med Wallm. optog som selvstændig Art, men som af A. Bram og de ovrige nyere Forff. ansees for en Form af Clı. fragilis) er funden i $S$ l. i Slien ved Lonisenlund $(20) !$ S $j$. Gurre S $q !$ (Yaa begge Steder uden Frugt.) 


\section{Rettelser og Tillæg,}

som bedes bemærkede før Brugen af Bogen.

Side 2 Lin. 12 tilføies: Ørslør ved Skjelskør (14).

- $6-14-$ Egebæks Vang (ürsnlund), Munkevangen i Gribs Skov ved Esrom l

$-9-14-$ Lerchenborg (Smith), Holsteinborg (Nielsen)! (forma $\iota$, gracilis).

$-17-23-$ Aalholm (Mgller).

$-18-23-$ Hald $\mathrm{s}$ ( (Feddersen).

$-33-4$ - Tjæreby, Ørsløv, Basnæs (Nielsen), Lerchenborg (Suith).

$-30-9-$ Vildated ved Løgstor (8)!

- - 2 f.n. - Malle ved Løgstør (8)!

-40 - 4 f.n. - Karup paa Alheden (Feddersen).

$-44-5-$ Arentoft ved Tonder (Branth).

$-45-17-$ Bogelunde, Stubberup og Snedinge ved Skjelskgjr (Nielsen).

$-48-13-$ Kjærmoser N. for Vildsted Sø ved Løgstør (8)!

$-50-17-$ Brøndshøi!

-51 efter Lin. 5 tilføies:

Anm. Den her beskrevne Plante er funden i de fleste Lande af Europa, men overalt, som det synes, sporadisk og temmelig sjelden, og er neppe nogetsteds iagttaget med moden Frugt, hvilket bekriefter den Anskuelse, som allerede A. Braun (Flora 1844) har udtalt, at den skulde være en Bastardform af Lolium perenne og Festuca pratensis, og hvormed flere nyere Forskeres Undersøgelser stemme overeens (sml. Crepin, not. s. pl. crit. de la Belg. IV, p. 53, Focke og Ascherson i Bot. Zeit. 1864). 
Unægtelig synes denne Mening, ifølge hvilken Planten matte opfores enten under Lolium (som L. pratensi-perenne Syn. L. festucaceum Lk.) eller nnder Festuca (som F. perennipratensis, Syn. F. elongata Ehrh. Beitr. VI, 133) at liave mere for sig end dens Indordning enten under Brachypodium (Fries) eller især under Glyceria (Gren. \& Godr.), fra hvilke Slægter den i flere Henseender er væsenlig forskjellig. If $₫$ lge Ascherson (Bot. Z. 1864, p. 25) maa det tidligere anvendte $\mathrm{N}$ ivn for denne Plante (F.loliacea) være at henfore ikke til Huds., men til Curtis, Koch o. fl. Forff., idet den Hndsonske Plante af dette Navn maa antages at være en axblomstret Form af Glyceria fluitans ( $\beta$, triticea Fr.) $\mathrm{og}$ at fremdeles rimeligviis Grenier \& Godr. have havt den samme Form for Oie ved deres Glyceria loliacea, idet de beskrive dens Frugt som stemmende med Glyceria-Frugter, medens ingen andre Forfattere have iagttaget modne Frugter hos Lolium festucaceum Link.

Side 52 Lin. 8 f. n. tilføies: $\boldsymbol{S}$. Dyrehaven ved Skjelskør (Nielsen)! $J$. Lundbrek ved Nibe (8)!

- 59 - 2 f. n. "ikke bemærket paa Bornh." rettes til: Bornh. Lelinsklint (Hjorth).

- 60 - 20 tilføies: Oryza clandestina (Web.) A. Bram, Verhandl. d. bot. Vereins f. Brandenb. 2, 195.

- - $\quad 3$ f. n. **k) forandres til: I vort Clima blomstrer den saa seent paa Aaret, at Toppen stundom ikke naaer sin fulde Udvikling. I Sommeren 1862 fandt jeg dog ved Hellebæk Exemplarer, paa hvilke den endestillede Top var fuldt ndtraadt af Skeden, og hvor der blandt mange golde Blomster fandtes enkelte, kjendelige ved en morkere Farve, i hvilke Frugten var fuldmoden. Foruden den endestillede Top findes der i de gvre og mellemste Bladskeder skjulte eller kun med den sverste Spidse fremragende Blomsterstande, og disses Blomster ere stedse lukkede, med ufuldkomneSt $\rho$ vknapper, som kun sparsomt ndvikle Blomsterst $\iota v$, men dog i Regelen bære fuldt udviklede Frigter (sml. DuvalJouve i Bull. soc. bot. Fr. 1863, Walz og Ascherson i Bot. Z. 1864).

- 62 Lin. 11 tilføies: Brede Bakker (Sehütz).

- $65-18$ - Tonder (Branth).

- $74-18$ - Sylt (28)!

- 84 efter nederste Linie tilføies: $\delta$, divaricatum! Topgrenene udsparret-aabre.

- 85 Lin. 3 tilføies: $\delta$, Sorø (Nielsen)!

- $88-13$ t. n. tilføies: Ranum ved Løgstør (8)! 
Side 90 Lin. 13 tilføies: Jonstrup Vandmølle (14)!

- $93-10-$ Teglstrup Hegn, Store Hareskov (14).

- $101-17-$ Ballerup (14).

- 104 nederste Linie tilføies: Kalkbakker ved Smakmølle pr. Løgstør (8)!

- 112 Lin. 18 tilføies: Frederiksdal (14).

- 119 - 7 f.n. - $\quad S j$. Gurre, Smørumøvre, Vensløv ved Skjelskør (14)!

- 122 - 20 - J. Næsby ved Løgstør (8)!

- 124 - 3 - i Gurre Vang meget almindelig!

- $127-.12$ - Randrup Krat ved Viborg (Feddersen).

- 134 - 11 f.n. -- Tjustrup Sø (Nielsen)!

- 136 - 4f.n. - Bringe (14), Borreby (Nielsen)!

- 139 efter Lin. 3 f.n tilføies:

$\gamma$, dichotomus Wall. (Sched. crit. p. 67;? P. flabellatus Bab.?). Stængelen noget fladtrykt, Bladskederne store, oppustede, tveæggede, med bred, hindeagtig Raud; Bladene korte, flade, kort og pludseligt tilspidsede, alm. trenervede, paa de golde Grene vifteformigt udstaaende; Axet kort og faablomstret, med tætsiddende Krandse. Passer nogenlunde til Babingtons Beskrivelse af $P$. fabellatus, og er muligviis en egen Art, forskjellig fra $P$. zosteraceus ved kortere Blomsterstilke, tætsiddende Blomsterkrandse og meget kortere Blade med større Skeder, fra $P$. pectinatus ved en fladtrykt Stængel, flade, trenervede, kortspidsede Blade.

- 140 Lin. 3 tilføjes: $\boldsymbol{S j}$. Gadekjær i Haarslør ved Skjelskør (14)!

J. Brakvand ved Nibe Fjord (8)!

- " efter Lin. 4 tilføies: $\gamma$, i Østersøen ved Omø (Nielsen, 14)!

- " Lin. 24 tilføies: Søndersøen ved Jonstrup (14)!

- $159-5$ - Bjørnsholm (8)!

- 160 - 3 f.n. - Faartoft ved Tlisted (Jacobsen), Ladegaarden red Aalborg (Branth).

- $168-1$ - Kantbager.

- $\quad 12$ - Sl. Bov (Petersen).

- 169 - 6 f.n. - I Foraaret 1864 har Hr. Nielsen dog samlet P. elatior ved Skjelskør, hvor han hidtil havde søgt den forgjæeves. (I Overeensstemmelse hermed maa den ovenstaaende Anmærkning forandres. 
Side 177 Lin. 6 tilføies: 7-8. $\odot$.

- 190 - 2 f.n. Krat mellem Karup og Resen (Feddersen).

- $177-10$ tilføies: 7-8. $\odot$.

- $210-7$ f. n. tilføies: $\boldsymbol{J}$. Smaaholme ved Nibe og Sebbersund $(8)$ !

- 212 - 13 tilføies: Edelgave i Ledøie Sogn (14).

- 217 - 13 - Ukrud i Haver ved Tonder (Branth).

- $219-8$ f. n. nordvestlige rettes til nordøstlige.

- $220-2$ f. n. Skove rettes til Hove.

- 231 - 12 f. n. tilføies: Høier (Branth).

- $236-22$ tilføjes: 7-8. 4.

- $240-8$ - Refsnæs (15).

- $248-15$ - Draved Skov (Branth).

- 266 - 2 - almindelig langs alle Bredder af Gurre Sø (paa Gruus)!

- 273 - 4 f. n. tilfsies: Bredderne af Hald Sø (Feddersen).

- 287 - 1 f. n. - Store Hareskov (14).

- 289 efter Lin. 10 f. n. tilfoies:

$\gamma$, littorcllafolium Mortens. mser. Bladene (alle med Undtagelse af de $1-2$ yngate) linieformede, jæunt tilspidsede (omtrent som hos Littorella lacustris) o : Bladstilken er fladt udbredt og Bladpladen mangler.

- "Lin. 7 f. n. tilføies: $\gamma$, Tjustrup 'Sø ved Sorø (14)!

- 303 - 8 f. n. - almindelig ved Tønder (Branth).

- 319 - 2 f. n. - Aborrebjerget paa Møen (Baagøe)!

- $3 \ldots 1-7$ tilføies: $S j$. Horubæks Plantage!

- " - 12 f. n. tilfsies: I.oll. ved Knuthenborg ('Thaning).

- 324 - 16 tilfoies: Hogild Mose ved Karup Aa (Feddersen).

- $329-10$ - Nørbjerg Kalkbakke i V. Hanherred (8)!

$-353-6-7-9$.

- $"-20-7-8 . \odot$.

- " - 12 f. n. tilføies: $\mathbf{S} j$. Maaløv (14), Høragre ved Tikjøb i Mangde!

- 355 - 21 tilføies: Nymølle (14)!

- " nederste Linie tilfoies: $S j$. Nybglle (14)!

-. 358 Lin. 1 tilføies: Mørkegaard ved Qvistgaard Station (15), Nyrup, Danstrup Hegn!

- " efter Lin. 13 tilføies: Prof. A. Braun, som ifølge min Anmodning har undersøgt $S$. lividum i Willdenows Herbarium, har meddeelt mig, at denne Plante, saavidt det af de $i$ Herbariet opbevarede maadelige Exemplarer kan skjønnes, er forskjellig fra vor; Namet S. lividum, som forst af Drejer er brugt for denue, maa derfor opgives. Jeg maa 
altsaa indtil videre antage den for en Form af S. Fabaria Koch (S. purpureum Tausch), thi til $S$. purpurascens Koch (saaledes idetmindste som jeg jopfatter denne) kan den neppe henhøre.

Side 362 Linie 3 tilføies: Heder ved Tjele pr. Viborg (Feddersen).

- $365-4-$ S -4 ndersøens Nordskræent (14).

- $373-5 \quad-\quad$ Krat ved Gurre $S \varnothing(14)$ !

- $374-5$ f.n. $6-7$ rettes til $7-8$.

- 408 - 12 f.n. tilføies: Hedebakker mellem Resen og Karup (Feddersen).

- 413 - 14 f.n. - Skovgaard ved Viborg (Feddersen).

- $423-1$ f.n. - Holsteinborg, Stubberup, Basnæs, Glænø (NieIsen).

- 424 - 7 f.n. - Høier, List (Branth).

- $435-15$ tilføies: og i Henseende til Kronens Læber. (Ved Tikjøb har jeg fundet en Form med 4-5. tandet Overlæbe og alle Underlæbens Flige rundtakkede).

- $443-23-$ Asmild Klosters Have (Feddersen).

- $446-2$ - Lindum Skov, Møgellkjær (Feddersen).

- 448 efter Lin. 8 tilføies:

$\dagger$ M. piperita L. (Peber-MI.) forvildet ved St. Jørgensgaard i Fyen (12).

- 449 Lin. 23 tilfgies: $\varepsilon, J$. Barmer ved Nibe Fjord (8)!

$-450-13-S j$. forvildet i Haver ved Tikj

$-451-8-\beta$, J. Kjettrup i $\varnothing$. Hanherred (8)!

- $\quad-\quad$ - 9 (ikke funden i det egenlige Danmark o.s. v.) rettes til: $S_{j}$. Bredderne af Gurre $S_{\wp}$ (paa Gruusbund)!

- 453 - 18 tilføies: Aalholm (Møller).

$-457-2$ f.n. tilfoies: Slettestrand i V. Hanherred (8)!

- $467-3$ f.n. - Logstør (8)!

- $469-15$ efter "tokløvede" tilføies (eller hele).

- " $\quad-23$ brunagtig rettes til violetbrun eller skidenguul med violet Anstrgg.

- 12 tilføies: O. Cirsii oleracei Caspary (Schr. der Phys. Ges. z. Königsberg, 2 Jahrg. p. 46 t. 1).

- $477-21$ - ved Kysterne af Omø i stor Mængde (Nielsen, 14).

- 478 - 9 - Omg(14).

- $484-18$ - Porskjær i Taabel Hede ved Agger (Andresen).

- $493-14$ f. n. tilføies: Bisserup ved Skjelskør (Nielsen)! 
Side 503 Lin. 19 tilfsies: $\boldsymbol{S}$. Store Hareskov (14); Loll. Aalholm (Moller).

- 512 - 4 f.n. - Granskov ved Sølyst N. for Esrom Sø!

- 521 - 1 f. n. - Slettestrand i V. Hanherred (8)!

- 528 - 15 tilføies: Glænø ved Skjelskør (Nielsen).

- 537 - 5 f.n. tilføies: 'Torvmose i Asnæs Skov (Smith)!

- 541 - 8 f.n. - Nylijøbing paa Falster ('Trojel).

- 597 - 5 tilføies: Aagerup (Smith).

- $705-10$ - Rudby Gader (Benzon)!

- 782 - nederste Lin. tilføies: Vildsted So ved Løgstør (8)! 


\section{Register}

over

de i Haandbogen indeholdte Arters og Varieteters Navne.

(De med Cursio trykte Navne ere Synonymer.)

Abies, 653.

$x$ excelsa Lam., 666.

pectinata $\mathrm{DC} ., 666$. vulgaris Poir., 666.

Acer, 292.

campestre L., 300. platanoides L., 300. Pseudoplatanus L., 500 .

Achillea, 561 .

Millefolium L., 616.

" $\beta$, lanata Koch, 616.

" $\gamma$, magna Sond., 616.

Ptarmica L., 615.

$\times$ Achyrophorus maculatus Scop., 583.

Acinos, 430.

thymoides Moench, 453.

Aconitum, 402 .

y. Napellus L., 410.

x neomontanum H., 410.

A corus, 243.

Calamus L, 272.

Acrostichum septemtrionale L., 757.

A ctæa, 401 .

×. spicata L., 406.

A d о ха, 293.

$x$ moschatellina L., 306.

A egopodium, 152.

Podagraria L., 218.

" $\beta$, subsimplex, 219.

Aesculus, 290.

X Hippocastanum L., 290.

A ethusa, 153.
Aethusa Cynapium L., 224.

" $\beta$, pygmæa, 224.

" segetalis Boenn., 224.

Agraphis nutans Link, 249.

A grimonia, 358.

$\times$ Eupatoria L., 360.

$x$ odorata Mill., 360.

Y procera Wallr., 360.

A gropyrum, 23.

x acutum DC., 54.

" $\beta$, macrostachynm, 54.

" $\quad$, microstachyum, 54.

$y$ adfine Dethard., 54.

adfine Drej., 53.

$x$ caninum R. S., 56. " $\beta$, gracilius, 56 . juncenm Beauv., 52. littoreum Drej., 56. obtusiusculum Lge., 53. pungens R. \& Sch., 55. repens Beauv., 55.

" $\beta$, arundinaceum Fr., 56.

" $\gamma$, firmum, 56 .

" $\delta$, littorale Bab., 56.

strictum Deth., 53 .

Agrostem ma, 311 .

$\times$ Githago L., 342.

Agrostis, 25.

- alba L., 73.

" $\beta$, coarctata Blytt., 74.

" $\delta$, gigantea Rchb., 74.

- $y$, maritima Mey., 71.

" $\varepsilon$, vivipara Rchb., 74. 
Agrostis arundinacea L., 71.

$X$ canina L., 72.

capillaris F. D., 73.

y coarctata Schum., 70.

flava F. D., 74.

gigantea Roth, 74.

maritina Lam., 74.

pumila L., $7 \overline{\text {. }}$.

t mubra H., 72.

silvatica L., 74.

Spica venti L., 72.

stolonifer $u \alpha$, L., 73.

stolonifera $\beta$, L., 74.

" decumbens Rafn, 74.

tenella Hoffm., 75.

$\times$ vulgaris With, 73 .

"$\delta$, punila F. D., 73.

- $\beta$, stolonifera, 73 .

- $\gamma$, tenella, $7 \pi$.

Aira, 27.

\&, vivipara, 73 .

aquatica L., S5.

coerulea L., 84.

$x$ caspitosa L., 79.

" $\beta$, pallida, 79

* $\quad \delta$, stolonifera, 79 .

" $\gamma$, vivipara, 79.

canescens L., 79 .

caryophyllea L., 80.

cristata L., 77.

+ flexuosa L., 78.

glauca Schrad., 77.

pracox L., 80.

uliginosa Whe., 78.

IVibeliana Sond., 79.

Airopsis, 27

tearyophyllea Fr., 80.

xprecox Fr., 80.

A jug a , 429.

X pyramidalis L., 445.

* reptans L., 445.

Allucea nutans Rehb., 258.

Alchemilla, 10 S.

+ Aphanes Leers, 126.

arvensis Scop., 126.

montana Willd., 126.

vulgaris L., 125.

" $\beta$, subsericea Koch, 126.

Alectorolophus hirsutus Rchb., 465 .

major Richb., 465.

minor Rehb., 466.

Reichenbachii Drej., 466.

A lisma, 244.

natans L., 259.

y Plantago L., 2 \$8.
Alisma Plantago $\gamma$, graminifolium Elirh., 289.

" $\beta$, lanceolatum With., 289.

» $\delta$, latifolium Lge., 289.

ranunculoides L., 289.

" $\gamma$, littorellæefolium Mort., 795.

" $\beta$, repens, 289.

repens Cav., 289.

Alliaria, 474.

$x$ officinalis Andrz., 500 .

Alli um, 242.

acutangulum Schrad., 257.

angulosum Nolt., 257.

arenarium Sm., 253.

arenarium Fr., 254.

Xascalonicum L., 255.

carinatum L., 256.

$\times$ Сера L, 255.

fallax R \& S., 257.

" * serotinum, 257.

+Kochii Lge. 254.

montanum Schmidt, 256.

$x$ oleraceum L., 255.

" $\boldsymbol{\beta}$, canaliculatum Fr., 256.

Porrum L., 253.

sativum L., 254.

Schoenoprasum L., 256.

Scorodoprasum L., 253.

" $\beta$, minus Fr., 253.

senescens IV. Gr., 257.

sphærocephalum L., 255.

uisinum L., 257.

vineale L., 254.

" $\alpha$, capsuliferum Koch, 254.

" $\beta$, compactum 'Thuill, 254.

" $\gamma$, purpureum Koch, 254.

Alnus, 655 .

₹. glutinosa Gürtn., 706 .

X incana DC., 706.

A lopecurus, 25.

$x$ agrestis $L, 65$.

$x$ fulvus Sm., 60 .

geniculatus L., 65.

nigricans Horn., 65.

pratensis L., 65.

Alsine, 311 .

marina Drej., 536.

media L., J41.

- decastemon, 342.

rubra Wlilbg., 535.

tenuifolia Whllbg., 337.

" $\beta$, viscosa, $3 \overline{5} 7$.

viscosa Sclireb., 337.

Alsinella marina F. D., 334, 336. 
Alsinella rubra Sw., 333. viscosa Hartm., 357.

Althæa, 50l.

Xofficinalis L., 504.

A lyssum, 472 .

calycinum L., 483. incanum L., 483.

Amarantus, 654. Blitum L., 704.

Amelia media Alef., 320. " minor Alef., 320 .

Ammoplila arenaria Lk., 67. baltica Lk., 68.

Anacamptis, 633.

Ypyramidalis Rich., 639.

An agallis, 146.

$\checkmark$ arvensis L., 185.

- coerulea, 185.

X coerulea Schreb., 185.

Anchusa, 143 .

X arvensis M. B., 166.

Yofficinalis L., 166.

Andromeda, 309 .

* polifolia L., 322.

Anemone, 403.

Y Hepatica L., 411. nemorosa L., 412.

" $\gamma$, sulfurea Pritz., 412.

pratensis L., 413.

Pulsatilla L, 412.

ranunculoides L., 412.

ranunculoidi-nemorosa Kze., 412.

Anethum, 154 .

Y graveolens L., 227.

Angelica, 154

$X$ Archangelica H., 228.

Xlittoralis Fr., 228.

X silvestris L., 228 .

Antennaria, 560 .

Y dioeca Gärtn., 605.

$x$ " $\beta$, hyperborea Don., 608.

Anthemis, 561 .

$x$ arvensis L., 614.

" $\beta$, disciflora, 615 .

Cotula L., 614.

" $\beta$, disciflora, 614.

tinctoria L., 615 .

" $\beta$, discolor Fr., 615.

A nthericum, 242.

Liliago L., 259.

ossifragum L., 259.

ramosum L., $2 j 8$.

" $\beta$, Pseudo-Liliago Lge., 259.

Anthoxanthum, 25.

* odoratum L., 64 .
Anthoxanthum odoratum $\gamma$, laxiflorum, 64.

" $\beta$, majus, 64.

" $\alpha$, vulgare, 64.

Anthriseus, 155.

$x$ Cerefolium Hoffm., 251 .

$X$ silvestris Hoffm., 252.

x vulgaris Pers., 231 .

Antliyllis, $5(18$.

maritima Sclıweigg., 521.

×Vulneraria L., 521.

" $\beta$, maritima, 521.

" $\gamma$, rubriflora, 521 .

Antirrhinum, 452 .

Cymbalaria L., 459.

Ellatine L., 459.

Linaria L., 457.

minus L., 458.

$x$ Orontium L., 460.

spurium L., 455.

Apargia autumnalis Willd., 587.

hirta Sm., 586.

hispida Host., 587.

Taraxaci Sm., 587.

Apera Spica venti Beanv., 72.

Aphanes arvensis L., 126.

Apium, 152.

* graveolens L., 218 .

inundatum kichb., 217.

Ptroselinum L., 218.

repens Relib., 217.

Aquilegia, 402 .

* vulgaris L., 411 .

Arabis, 474 .

y arenosa Scop., 495.

+hirsuta Scop., 494.

perfoliata Lam., 496.

suecica-biennis Fr., 495.

Thaliana L., 495.

Aracium, 556 .

$\times$ paludosum Monn., 572.

Arbutus uva ursi L., 322.

Archangelica, 155.

$\times$ littoralis Fr., 228.

officinalis Hotfm., 229.

Arctium, 557.

Lardana Willd., 588.

intermedium Lge., 589.

Lappa L., 585-90.

" majuscula Hartm., 589.

majus Schk., 5y0.

minus Schk., 589.

tomentosum Sclik., 585.

Arctustaphylos, 509 .

officinalis IV. \& Gr., 322. 
Arctostaphylos Uva ursi Spr., 322.

Arenaria, 311.

marginata DC., $5 \overline{3} 6$.

marina F. D., 335.

media F. D., J31.

peploides F. D., 337.

rubra L., 33.

1 $\beta$, marina, $\bar{\jmath} 56$.

serpyllifolia L., 3.57 .

" $\beta$, glutinosa, 335 .

- $\alpha$, scabra, 5.58 .

tenuifolia F. D., $5 \bar{\jmath} 7$.

trinervia L., 358.

Aristolochia, 635 .

Clematitis L., 651.

Armeria, 157.

campestris $\gamma$, Hofmanni, 239.

" $\beta$, Fochii, 239 .

elongata Drej., 259.

* maritima Willd., 259.

purpurea Koch, 259.

xulgaris Willd., 239.

- $\quad \alpha$, elongata, 259.

" $\gamma$, humilis, 259 .

" $\quad \beta$, purpurea, 259.

Armoracia rusticana fl. wett., 485.

Arnica, 562 .

$x$ montana L., 627.

Arnoseris, 555 .

pusilla Gärtn., 565.

Arrhenatherum elatius M. K., 85.

Artemisia, 559.

× Absinthium L., 604 .

+ campestris L., 605.

- $\beta$, sericea Fr., 605.

gallica Willd., 604.

+ maritima L., 604 .

" $\beta$, gallica, 604 .

" $\gamma$, salina, 604 .

salina Willd., 604.

$x$ vulgaris L., 605 .

A rum, 652.

x maculatum L., 659.

Arundo arenaria L., 67.

baltica Flïgg., 68.

Calamagrost is L., 70.

Epiqejos L., 68.

neglecta Ehrh., 70.

Phragnites L., 84.

Pseudophragmites Nolt., 60.

silvatica Schrad., 71.

stricta Timm., 70.

As a rum, 355.

+ europium L., 359.

Asclepias Vincetoxicum L., 212.
Asparagus, 241.

$\gamma$ officinalis L., 247.

As perugo, 142.

procumbens L., 160.

Asperula, 106.

y odorata L., 112.

y tinctoria L., 113.

A spidium, 751 .

aculeatum Doell., 75 S.

aculeatum Sw., 757.

- $\beta$, Swartzianum, 757.

" $\alpha$, vulgare, $75 \mathrm{~S}$.

angulare Kit., 757.

cristatum Sw., 759.

dilatatum Sw., 760 .

erosum Schk., 759.

Filix foemina Sw., 755.

Filix mas Sw., 759.

fragile Sw., 761 .

montanum Sw., 761.

Oreopteris Sw., 758.

spinulosum Sw., 760.

Thelypteris Sw., 758.

Asplenium, 750 .

Adiantum nigrum L., 756.

XFilix foemina Berruh., 755 .

₹ Ruta muraria L., 756 .

Scolopendrium L., 757.

* septemtrionale Sw. 757.

Trichomanes L., 755.

Asprella oryzoides Lam., 60.

Aster, 56:.

annuus L., 622.

salignus Willd., 621 .

* Tripolium L., 621.

Asterocephalus Columbaria Wallr., 110.

suaveolens Wallr., 110.

Astragalus, 509.

arenarius F. D., 522.

Cicer L., 523.

danicus Retz, 522.

glyeyphyllos L., 524 .

hypoglottis L., 523.

hypoglottis pl. autt., 522.

Astrantia, 151.

$x$ major L., 216 .

Athamanta Libanotis L., 22.).

Oreosclinum L., 225.

Athyrium Filix foemina Rotl, 755.

Atriplex, 6.56 .

angustifolia Sm., 716.

arenaria Woods, 710 .

" $\beta$, parvifolia, 711 .

Babingtonii Woods, 712. 
Atriplex Babingtonii $\boldsymbol{\beta}$, virescens, 712. calotheca Fr., 714.

" $\alpha$, macrosepala, 714.

- $\beta$, macrotheca, 714 .

- $\beta$, microsepala, 714 .

" $\gamma$, microtheca, 714 .

" $\gamma$, parvifolia, 714 .

crassifolia Fr., 712.

crassifolia Gren. \& Godr., 710. crassifolia C. A. Mey., 711.

deltoidea Bab., 713.

erecta Huds., 716.

hastata Sm., 714 .

bastata L., 712.

" $\gamma$, calotheca, 714.

" «, deltoides, 713.

- 2, macrotheca, 713 .

- $\beta$, microcarpa, 713.

- $\beta$, microtheca, 713 .

" $\delta$, platysepala Guss., 713.

- $\gamma$, prostrata, 713 .

" $\gamma$, salina, 713 .

- $\gamma$, triangularis, 713.

hortensis L., 709.

laciniatc L. fl. Suec., 714.

laciniata F. D. 710.

latifolia Whlbg., 712.

littoralis L., 716.

"* serrata, 717.

Jongipes Drej., 714.

" $\beta$, muricata, 715 .

marina L., 717.

microsperma W. K., 713.

nitens Rebent., 710.

oppositifolia DC., 713.

y patula L., 715.

" $\delta$, angustifolia, 716.

- $\beta$, erecta, 716 .

" $\propto$, genuina Westerl., 715.

" $\delta$, muricata Ledeb., 715.

n $\gamma$, oblongifolia W. K., 716 .

pedunculata L., 717.

portulacoides L., 717.

prostrata Bouch., 713.

rosea Bab., 712.

rosea L., 710.

- $\beta$, arenaria Westerl., 710.

• $\delta$, parvifolia Moq., 711.

serrata Huds., 717.

" $\delta$, parvifolia Moq., 711.

muderalis Wallr., 71 .

stipitata Westerl, 715.

"var. longipes Wester].,

Atropa, 144.
XAtropa Belladonna L, 167. physaloides L., 168.

Avena, 27.

caryophyllea Web., 80.

xelatior L., 83.

" $\beta$, typica, 83.

" $\alpha$, vulgaris, 83 .

y fatua L., S1.

flavescens L., 80.

flexuosa M. K., 78.

Chybrida Peterm., 81.

internedia Lindgr., 81.

y orientalis Schreb., 82.

procox Beauv., 80.

pratensis L., 82.

pubescens L., 83.

sativa L., 82 .

strigosa Schreb., 82.

Avenella flexuosa Bluff, 78.

\section{B.}

Baldingera arundinacea .Fl. wett., 63.

Ball ota, 428 .

alba L., 439.

foetida Lam., 439.

" $\quad \beta$, alba, 439 .

nigra L., 438-39.

" $\boldsymbol{\beta}$, borealis, 439.

" $\alpha$, foetida, 439 .

$\times$ ruderalis $\mathrm{Sw} ., 4.3 \mathrm{~S}$.

" $\quad \beta$, nepetoides! 439.

- $\gamma$, urticæfolia, 439 .

urticcefolia Ortm., 439.

B arbarea, 474 .

parviflora Fr., 493.

præcox R. Br., 494.

stricta Fr., 493.

vulgaris R. Br., 493.

" $\beta$, arcuata, 493.

" $\gamma$, acidula Hartm., 494.

Bartsia Odontites Sm., 467.

- $\beta$, littoralis Rehb., 467.

Batracbium, $40 \overline{3}$.

circinnatum Fr., 419.

confusum (Gren. \& Godr.), 418.

fluitans (Lam.), 420.

hederaceum, Fr., 415.

heterophyllum Fr., 417.

" $\beta$, crassicaule Fr., 417.

" $\gamma$, succulentum Koch, 418 . hololeucon (Lloyd), 418.

marinum Fr., 419.

peltatum Fr., 417.

$\times$ sceleratum (L.), 416 . 
Batrachium trichophyllum Chaix, 418.

Bellis, 561.

hybrida 'Ten., 610.

x perennis L., 610 .

" $\beta$, caulescens, 610 .

Berberis, 240.

X vulgaris L., 244.

Berteroa, 472 . incana DC., 485.

Berula angustifolia Koch, 221.

Beta, 149.

Cicla L., 204.

maritima L., 204.

$x$ vulgaris J., 204.

$\times$ " $\iota$, Cicla, 204.

* $\beta$, rapacea, 204.

Betonica, 428 .

$\times$ officinalis L., 440 .

stricta Ait., 440.

Betula, 655 .

alba L., 707.

Alnus a, L., 706.

- $\beta$, incana L., 706.

carpathica Willd, 70 S.

glutinosa Wallr., 707.

x odorata Bechst., 707.

v $\beta$, tiliæfolia, 707.

"* carpathica, 708.

$\times$ " * pubescens, 707 .

odorata Rehb., 707.

pubescens Ehrh., 707.

$\times$ verrucosa Ehrh., 707.

Bidens, 558.

$\times$ cernua L., 601 .

* $\gamma$, minima, 601.

$\times \quad$ " $\beta$, radiata, 601,

minima L., 539.

platycephala Ørst., 600 .

tripartita L., 599.

" $\beta$, minor, 600 .

B] echnum, 751 .

boreale Sw., 762.

$\times$ Spicant Roth, 762.

B litu m, 149.

x Bonus Henricus Mey., 209.

botryoides Drej., 20 S.

capitatum L., 207.

glaucum Koch, 209.

x rubrum Rehb., $20 \mathrm{~S}$.

$x$ virgatum L., 20 S.

Blysmus compressus Panz., 44. mufus Paliz. 44.

Borrag o, 145.

$y$ officinalis L., 165.
Botrychium, 752.

x Lunaria Sw., 765.

"* rutaceum Fr., 765.

matricaricefolium Braun, 765.

matricarioides Willd., 765.

rutaceum Sw., 765.

rutæfolium Braun, 765.

Brachyolobus amphibius All., 486.

anceps Drej., 487.

palustris Drej., 487.

silvestris Drej., 486.

Brachypodium, 23.

gracile Beauv., 51.

- $\beta$, majus, 52 .

loliaceum Fr., 51.

pinnatum Beauv., 52.

silvaticum R. S., 52.

Brassica, 474 .

$\times$ campestris L., 497.

" $\beta$, esculenta Gren. \& Godr., 497.

lanceolata Lge., 495.

Napus L., 497.

* $\beta$, oleifera annua, 497.

" $c$, oleifera biennis, 497.

" $\gamma$, rapifera, 497.

nigra Koch, 498.

oleracea L., 496.

Rapa L., 497.

Richeri Lge., 498.

Briza, 28.

media L., 85.

Bromus, 29.

arenarius Thom., 101.

arvensis L., 99.

arvensis F. D., 99.

asper Murr., 103.

commutatus Schrad., 100.

erectus Huds., 103.

giganteus L., 97.

gracilis Schum., 52.

hordeaceus Whlbg., 101.

inermis Leyss., 114.

littoreus Retz, 86.

mollis L., 101.

" $\beta$, lejostachys, 101.

- $\gamma$, pygmæus, 101.

nanus Weig., 101.

pinnatus L., 52.

pratensis Ehrh., 100.

racemosus $\mathrm{L}_{\mathrm{s}}, \mathrm{100}$.

$x$ secalinus L., 99.

serotinus Beneken, 103.

silvaticus Juss., 52.

sterilis L., 102. 
Bromus tectorum L., 102. triflorus L., 98.

Brunella, 431.

$\times$ grandiflora Jacq., 455. vulgaris Mönch., 454.

Bryonia, 658.

x alba L., 723.

dioeca Jacq., 725.

Bulbocapnos Halleri Drej., 514.

Bulliarda, 109. aquatica DC., 127.

Bunias, 471.

Cakile L., 476.

$x$ orientalis L., 476.

Bunium Carvi M. B., 219.

Bupleurum, 152. rotundifolium L., 217. tenuissimum L., 216

Butomus, 308.

$\gamma$ umbellatus L., 308.

c.

Cakile, 471. maritima Scop., 476.

" $\beta$, integrifolia Horn., 477. monosperma Lge., 477.

Calamagrostis, 25. arenaria Roth, 68.

× arundinacea Roth, 71.

baltica Hartm., 68.

Epigejos Roth, 68 .

" $\beta$, glauca, 69 .

glauca M. B., 69.

gracilis Schum., 70.

Halleriana DC., 69.

lanceolata Roth, 70.

Langsdorfii Trin., 69.

neglecta Ehrh., 70.

* $\beta$, geniculata Fr, 71.

nutans Saut., 69.

phragmitoides Lge., 69.

rubicunda Blytt., 69.

silvatica DC., 71.

stricta Spreng., 70.

Calaniintha Acinos Benth., 455. Clinopodium Benth., 454.

Calendula, 564.

$\therefore$ officinalis L., 631 .

Calla, 245.

x palustris L., 272.

Callitriche, 652.

autumnalis L., 662.

hamulata Kïtz., 662.

ptatycarpa Kütz., 6li4.
Callitriche stagnalis Scop, 665 . verna L., Kütz., 662.

" cæspitosa Schultz, 665.

" minima Hopp., 663.

" repens H., 663 .

" teriuifolia H., 663.

Calluna, 1292 .

$\chi$ vulgaris Salisb., 302.

$n$, pubescens Koch, 302.

Caltha, 404 .

- palustris L., 426.

Calystegia sepium R. Br., 175.

Camelina, 472.

dentata Pers., 480.

" $\beta$, integrifolia, 480.

n $\alpha$, pinnatifida, 480 .

$\gamma$ foetida Fr., 480.

microcarpa Andrz., 481.

pinnatifida Horn., 480.

sativa Fr., 480.

n $\beta$, dentata Horn., 480.

- $\alpha$, silvestris Fr., 480.

sativa Rchb., 481.

silvestris Wallr., 480 .

n $\beta$, microcarpa DC. 481.

Campanula, 146.

Cervicaria I.., 190.

x glomerata L., 190.

hederacea L., 190.

x latifolia L., 189.

patula L., 188.

* persicæefolia L., 187.

n $\quad \beta$, calycida, 187.

rapunculoides L., 189.

Rapunculus L., 187.

rotuudifolia L., 188.

" $\delta$, calycida! 188.

" $\gamma$, paiviflora! 188.

- $\beta$, stricta Schum., 188.

Trachelium L., 189.

Cannabis, 725 .

† sativa L., 745.

Capsella, 472.

Bursa pastoris L., 479.

Cardamine, 473 .

amara L., 491.

" $\beta$, hirta W. \& Gr., 491.

- $\gamma$, minor Lge., 491.

hirsuta L., 490.

" $\alpha$, campestris Fr., 490.

" $\beta$, silvestris Fr., 491.

hirsuta F. D., 491.

hirsuta Horn., 490.

- silvatica H., 491.

impatiens L., 489. 
Cardamine intermedia Horn., 490. parviflora L., 495.

x pratensis L., 492.

" $\beta$, dentata Koch, 492.

" $\delta$, gynocrates Didr., 492.

" $\gamma$, parviflora Bot. For., 492. silvatica Link., 490.

" $\beta$, clandestina Fr., 491.

Carduus, 558 .

$*$ acanthoides I., 592.

acanthoides Gren. \& Godr., 593. acaulis L., 597.

areensis Curt., 598.

crispo-acanthoides Lge., 593.

crispo-nutans Koch, 593.

jerispus L., 592 .

" $\gamma$, ochrolencus, 592.

" $\beta$, polyanthemos Godr., 592 . heterophyllus L., 597.

lanceolatus L., 594.

marianus L., 599.

multiflorus Gaud., 592.

f nutans L., 593.

oleraceus Vill., 596.

palustris L., 595.

rigens La Chen., 596.

tenuiflorus Curt., 591.

Carex, 654 .

$x$ acnta L., 687.

aemulans Drej., 685, 703.

Agastachys Ehrh., 691.

ampullacea Good., 701.

$\beta$, robusta Sond., 702.

appropinquata Schum., 676.

aquatilis Whlbg., 686 .

x arenaria L., 675.

argyroglochin Horn., 680.

axillaris Good., 683.

Balbisii Spr., 698.

Liformis $\beta$, fertilis Schultz, 698. «, sterilis Schultz, 699.

binervis Horn., Drej. 698.

× Boenninghruseniana Whe, 68.5 .

* $\beta$, subpaniculata! 653 .

brizoides L., 682.

Buxbaumii IVhlog., 689.

cespitosa L., 684 .

cespitosa Good., 686.

canescens L., 681 .

" $\beta$, tenuis Lang, 681 .

chordorrhiza Ehrh., 674.

ciliata Willd., 694.

collina Willd., 693.

curta Good, 681.

teyperoides L., 687.
Carex digitata L., 695. dioeca L., 671.

" $\beta$, isogyna Fr., 672.

" $\gamma$, scabrinscula Hartm., 672.

dista:1s L., 698.

distans Walıleub., 698.

disticlia Huds., 674.

divisa F. D., 696.

divulsa Good., 677.

" $\beta$, intermedia, 678.

Drejeri Lang, 685.

Drymeja Ehrl., 700.

elongata L., 680 .

ericetorum Poll., 694.

extensa Good., 697.

" $\beta$, pumila, 697 .

filiformis L., 703 .

filiformis Poll., 695.

flava L., 696.

* * lepidocarpa, 696.

frisica H. Koch, 687.

fulva Good., 699.

glauca Scop., 692.

" $\beta$, spliærostachya Lange, 693.

hirta L., 704.

" $\beta$, sublævis Horn., 704.

hirtceformis Pers., 704.

Horuschuchiana Hopp., 698.

incurva Lightf., 675.

intcrmedia Good., 674.

Kochiana DC., 7 ()3.

lepidocarpa Tausch., 696.

leporina L., 680.

" $\beta$, argyroglochin, 680 .

leucoglochin Ehrh., 67-2.

limosa L., 689.

maxima Scop., 691.

montana L, 693.

muricate L., 678.

" $\boldsymbol{\beta}$, virens 678 .

nenırosa Rebent., 679.

obtusangula Schum., 701.

obtusata Schum., 687.

Oederi Ehrh., 696.

"* oedocarpa And., 697.

ovalis Good., 6SII.

pacifica Drej., 685.

pallescens L., 690 .

paludosa Good., 702.

" $\gamma$, depauperata! 703 .

" $\beta$, elongata Sclıum., $70 \overline{3}$.

" $\beta$, spadicea Roth, 703.

panicea L., 691.

" $\beta$, sublivida Hartm., 692. 
Carex paniculata L., 677.

" $\beta$, simplicior, 677.

paradoxa Willd., 676.

pauciflora lightf., 672 .

pendula Huds., 691.

pilulifera L., 693.

n $\beta$, longebracteata! 694.

polygama Schk., 689 .

præcox Jacq., 694.

prolixa Fr., 688.

Psendocyperus L., 700.

pulicaris L., 672.

recurva Huds., 692.

remota L., 682 .

riparia Curt., 702.

„ $\beta$, gracilescens, 702.

silvatica Huds., 699.

speirostachya Sin., 698.

stellulata Good., 679.

stricta Good., 684.

strigosa Huds., 690.

subulata Schum., 689.

tenuis Schum., 685.

teretiuscula Good., 675.

thuringiaca Schk., 695.

tricostata Fr.. 687.

trinervis Degland., 687.

turfosa Fr., 685.

undulata Kunze, 690.

vesicaria L., 701.

virens Lam., 678.

vulgaris Fr., (iS5.

" $\gamma$, juncella Fr., 686 .

n $\beta$, stolonifera Haitm., 686.

" $\delta$, temuis Hartm., 686.

vulpina L., $67 \mathrm{~S}$.

" $\beta$, nemorosa, 679.

Carliua, 558.

vulgaris L., 599.

Carpinus, 657.

$\times$ Betulus L., 720 .

Carum, 152.

+ Carvi L., 219.

Cistanea, 658 .

vesca Gärtn., 721.

$\times$ valgaris Lam., 721.

Cat abros a, 28.

aquatica Beauv., 85.

" $\beta$, subtilis Hook, 85 .

Cathartolinum pratense Rchb., 502.

Caucalis, 155.

Anthriscus H., 250.

daucoides L., 2.50.

nodosa Scop., 230.

scandicina Rotl, 231.
Caulinia fragilis Willd, 660.

Centaurea, 565 .

Cyanus L., 630.

decipiens Thuill., 629.

Jacea L., 628.

var. capitata Koch, 629.

" $\beta$, cuculligera, 628.

" $\gamma$, lacera, 628 .

" $\delta$, laciniata, 629.

montana L., 631 .

nigra L., 629.

nigrescens Gren. \& Godr., 629.

nigrescens Willd., 629.

phrygia L., 630.

$x$ Ssabiosa L., 630 .

Centaurium Frythroa Rafn, 177. inapertum Rafn, 176.

vulgare Rafn, 177.

Centinodium aviculare Rchb., 278.

Centunculus, 107.

minimus L., 123.

" $\beta$, simplex, 123.

simplex Horn., $12 \overline{3}$.

Ceplialanthera, 634 .

ensifolia Rich., 644.

grandiflora Bab., 644.

Lonchophyllum G. Rehb., 644.

pallens Rich., 644.

rubra Riclı, 644.

Xiphophyllum G. Rchb., 644.

Centhalaria pilosa Gren.\&Godr., 111.

Ceramanthe vernalis Rehb., 460.

Cerastium, 512 .

aquaticum L., 349.

arvense L., 348.

brachypetalum Desport., 347.

glomeratum 'Thuill., 347.

glutinosum Fr., 546.

glutinosum Relib., 546.

macilentum Aspegr., 347.

ovale Pers., 547.

pumilum Curt., 545.

" $\beta$, abortivum Lge., 346. semidecandrum L., 346.

" $\beta$, viscidum Fr., $\mathbf{3} 46$.

strigosum Fr., 347.

tetrandrum Curt., 345.

triviale Link., 348.

viscosum L., 347.

viscosum Hor'u., 546.

viscosum Sm., 548 .

vulgatum L., 348.

" $\beta$, holosteoides Fr., 548 .

vulgatum Relib., 347.

Cerasus avium DC., 366. 
Cerasus caproniana DC., 565. Padus DC., „6ö.

Ceratopliyllum, 657. apiculatum Cham., 719. demersum L., 719. muticum Cham., 719. oxyacanthum Cham., 719. submersum L., 719.

Cerefolium sativum Bess., 231.

Chærophyllum, 155. sativum Lam., 251. silvestre L., 2.52.

temulum L., 2.3:.

Chatospora ferruginea Relib., 55. Chaiturus Marrubiastminehb, 444. Chamcenelum inodorum Vis., 612.

Chamænerium, 291. angustifolium Scop., 294.

Chamoeplium officinale Wallr., 499. Chamomilla discoidea Gay., 614.

Chara, 754 . alopecuroides Del. c., 780 . annulata Wallm., 791. asperd Wild., 787.

" $\delta$, aculeolata, 7S8.

- $\beta$, leptophylla, 788.

" $\alpha$, maritima, 787.

" $\gamma$, stagualis, 785.

baltica Fr., 78. .

" fastigiata Wallm., 784.

- $\beta$, firma. 786 .

" $\beta$, hamilis, 7S5.

canescens Lois., $7 \mathrm{~S} 9$.

capillacea Wallm., 791.

capitata N. E., 779.

ceratophylla Wallr., 789.

" $\alpha$, macroptila, 790 .

" $\beta$, microptila, 790 .

"* tomentosa, 790.

conáensata WVallm., 789.

contraria A. Br., 782.

crinita Wallm., 789.

crinita Wallr., 788.

" $\beta$, condensata, 789 .

- $\alpha$, leptospermia, 789 .

- $\beta$, pachysperma, 789 .

curta Nolt., 758 .

distans Wallm., 785.

equisetina Kïitz., 78..

fasciculata Amici, 779.

firma Ag., 786.

flexilis L. (Bruzel.), 777.

" nidifica Horn., 750.

flexilis Rchb., 777.

foetida A. Br., 781.

" $\gamma$, brevibracteata, 782.
Chara foetida $\beta$, longibracteata, 792 .

* $\varepsilon$, munda, 782 .

1) $\delta$, sublispida, 782 .

" $\alpha$, vulgaris, 782.

fragilis Desv., 790 .

* annulata, 791 .

1 $\varepsilon$, barbata, 791 .

" $\delta$, capillacea, 701 .

* $\beta$, Hedwigii, 791.

n $\gamma$, pulchella, 791 .

gracilis Sm., 776.

Medwigï Bruzel., 791.

hispida (L.?) Sm., 785.

* aspera H., 787.

" baltica H., 785.

" crinita H., 788.

" curta H., 788.

" $\gamma$, echinata! 781.

" $\quad \beta$, gymnoteles, 78.3 .

" $\gamma$, micracantha A. Br., 783.

" nigricans $\mathrm{H}$., 787 .

" pseudocrinita Coss., 783.

horrida Wallm., 784.

intermedia A. Br., 784.

intricata Trentep., 779.

latifolia Willd., 790.

Liljebladii Wallm., 785.

longibracteata Wallm., 782 .

mucronata A. Br., 777.

nidifica Bruzel, 780.

Nolteana A. Br., 786

papillosa Kütz., 785.

papulosa IVallr., 750.

polyacantha A. Br., 78.5.

polysperma A. Br., 779 .

putclella Wallr., 791.

spinosa Rupr., 783.

Stenhammariana Wallm., 780.

syncarpa Thuill., 778.

tenuissima Desv., 776 .

tomentosa L., 790.

" $\beta$, ceratophylla, 789.

Wallrothii Rupr., 780 .

vulgaris $\alpha$, Wallr., 791.

"L. (part.), 790.

" b, foliosa Horn., 7S2.

"Hedxoigï Horn., 791.

" pulchella, 791 .

Chelidonium, 401 .

laciniatrm Willd., 403.

majus L., 406.

n $\beta$, crenatum, 406.

Chenop o dina, 149 .

maritina Moq., 210.

" $\beta$, erecta, 210.

- $\gamma$, vulgaris, 210 . 
Chenopodium, 149.

album L., $2(15$.

- $\gamma$, glomerulosum, 206.

" $\beta$, viride, 206.

Bonus Henricus L., 209.

Botrys L., 206.

botryoides Sm., 205.

ficifolium Sm., 206.

glaucum L., 209.

hybridum L., 204.

maritimum L., 210.

murale L., 205.

olidum Curt., 207.

opulifolium Schrad., 206.

polyspermum L., 207.

" $\beta$, acutifolum, 207.

rhomibifolium Mühl., 205.

rubrum L., 208.

" $\varepsilon$, crassifolium, $20 \mathrm{~S}$.

" $\delta$, glomeratum, 208.

urbicum L., 205.

" $\beta$, intermedium Koch, 205. viride L., 206.

Vulvaria L., 207.

Chilochloa Boehneri Beauv., 67.

Chimaphila uniflora Fr. 319.

Chrysanthemum, 561 .

corymbosum L., 612.

inodorum L., 612.

Lencanthemum L., 611.

* $\beta$, coronopifolium, 611.

" $\gamma$, hirsutun, 612.

Parthenium Pers., 612.

segetum L., 611 .

Chrysosplenium, 293.

alternifolium L., 505 .

oppositifolium L., 505.

Cicendia, 1117.

filiformis Rchb., 123.

Cichoritum, 555 .

Intybus L., 565 .

Cicuta, 152.

virosa L., 220 .

$\mathrm{C}$ iner aria, 563.

alpina $\gamma$, L., 627.

campestris Retz, 627.

palustris L., 627.

Circæa, 2.

alpina L., 5.

" major H., 6.

alpino-lutetiana Mey., 6.

intermedia Ehrh., 6.

lutetiana L., 6.

" intermedia Whlbg., 6.

lutetiano-alpina Mey., 6.
Cirsium, 558.

acaule All., 597.

- $\quad \beta$, caulescens, 597.

acauli-oleraceum Rchb., 596.

arvense Scop., 598.

$" \quad \gamma$, horridum, 598.

- $\delta$, integrifolium, 598.

" $\quad \beta$, mite, 598.

" $\varepsilon$, semidecurrens! 598.

Chailleti Gaud., 595.

decoloratum Koch, 596.

Drejeri Rchb., 594.

heterophyllum All., 597.

lanceolatum Scop., 594.

" ** Drejeri, 594 .

* nemorale, 594.

nemorale Rchb., 594.

oleraceo-acaule Näg., 596.

oleraceum Scop., 596.

oleraceo-lanceolatum J.Vahl, 594.

palustre Scop., 595.

" $\beta$, putatum Näg., 595.

palustri-oleraceum Näg., 595 .

Cistus Helianthemum L., 408.

$\mathrm{Cla}$ di um, 22.

germanicum M. K., 48.

Mariscus R. Br., 47.

Clinopodium, 450 .

vulgare L., 454.

Chicus oleraceus L., 596.

Cni dium, 153 .

venosum Koch, 224.

Cochlearia, 472 .

x anglica L., 481.

Armoracia L., 485.

Coronopus L., 475.

$x$ danica L., 481.

$\beta$, integrifolia DC., 481.

officinalis L., 482 .

Coeloglossum, 633.

viride Hartm., 642.

Colchicum, 244.

- autumnale L., 287.

Comarum, 364 .

palustre L., 399.

Conferva nidifica F. D., 780.

Conium, 156.

maculatum L., 253.

Conringia Thaliana Rchb., 495.

Convallaria, 241.

bifolia L, 125.

- majalis L., 247.

- multiflora L., 247.

Polygonatum L., 247.

verticillata L., 247. 
Convolvulus, 145.

* arvensis L., 175.

sepium L., 175.

" $\beta$, coloratus! 176.

Conyza squarrosa L., 617.

Corallorhiza, 654 .

ericetorum Drej., 649.

innata R. B., 649.

virescens Drej., 649.

Coreopsis Bidens L., 601.

Coriandrum, 156.

+ sativum L., 233.

Cornus, 107.

- sanguinea L., 124.

x suecica L., 123.

Coronopus Piuellii All., 475.

Corrigiola, 156.

hittoralis L., $2 \overline{5} \mathbf{3}$.

Corvisartia Helenium Mérat, 619.

Corydalis, 507.

bulbosa Pers., 514.

$\checkmark$ cava Schw. \& K., 514.

claviculata Pers., 512.

digitata Pers., 514.

fabacea Pers., 513.

grandifolia Mort., 513.

Halleri F. D., 513.

laxa Fr., $5 \mathrm{l} 4$.

Lobelii Tausch, 513.

pumila Host, 513.

" $\beta$, latiloba! 515 .

solida Sm. 514.

Corylus, 657.

Avellana L., 720.

tubulosa Willd., 721 .

Corynephorns, 27.

$\Varangle$ canescens Beauv., 79.

- $\beta$, maritimus Gren. \& Godr., S0.

Cotoneaster, 362.

$\times$ vulgaris Lindl., 331.

Cotula, 560

coronopifolia L, 606.

matricarioides Bong., 614.

Crambe, 471.

$\times$ maritima L., 477.

Crat $\mathfrak{a u s}, 362$.

Aria «, L., 369.

" $\beta$, L., 569 .

monogyna Jacq, 367.

" $\beta$, denudata Schnm., 367. oxyacantha L., 367.

oxyacanilia Jacq., 367 .

punctata Ait., 368.

torminalis L., 368 .
Crepis, 555.

$y$ biennis L., 570 .

diffusa DC., 571.

paludosa Mönch, 572.

præmorsa 'Tausch, 571.

stricta Schultz, 571.

tectorum L., 570.

" $\beta$, segetalis Roth, 571.

virens L., 571.

" $\gamma$, capillaris Fr., 571.

" $\beta$, elatior Drej., 571.

" $\alpha$, multicaulis Kph., 571.

Critanus Falcaria Rehb., 220.

Crocus, 20.

vernus L., 34.

Cucubalus Behen L., 329.

maritimus Lam., 330.

Otites L., 331.

viscosus L., 332.

Cus cuta, 150 .

densiflora Soy.-Will., 213.

Epilinum Whe., 213.

Epithymum Murr., 214.

" $\beta$, Trifoliz Choisy., 214.

europæa L., 213.

" $\beta$, nefiens Fr., 214.

Ligustri Aresch., 214.

major DC., 213.

minor DC., 214.

Schkuhriana Pfeiff., 214.

Trifolii Bab., 214.

Cydonia, 565.

vulgaris Pers., 371.

Cynanchum vincetoxicum R. Br., 212.

Cynoglossnm, 143.

Lappula Wallr., 161.

Lofticinale L., 161.

Oniphalodes L., 161.

Cynosurus, 30 .

cristatus L., 105.

Cyperus, 21.

flavescens L., 35.

fuscus L., $\mathbf{3 5}$.

Cystopteris, 751 .

- fragilis Bernh., 761.

montana Bernh., 761.

Cytisus, 508 .

Laburnum L., 519.

\section{D.}

Dactylis, 29. adbreviata Bernh., 104. glomerata L., 104. 
Dactylis glomerata $\beta$, adbreviata Drej., 104.

" $\gamma$, lobata Drej., 104.

Daphne, 292.

Mezereum L., 304.

Datura, 144.

Stramoniun L., 171.

Da u cus, 155.

$\times$ Carota L., 229.

Delphinium, 402. Ajacis autt., 410 .

Consolida L., 410 , orientale I. Gay., 410.

Dentaria, 473 .

- bulbifera L., 4 SS.

Deschampsia ccespitosa Beauv., 79 . Thuillieri Gren. \& Godr., 78.

Dianthus, 510 .

Armeria L., 326.

barbatus L., 527.

Carthusianorum L., 527.

deltoides L., 328 .

" $\beta$, glaucus, 328.

glaucus L., 328.

prolifer L., 326.

- superbus L., 329.

" $\beta$, cæspitosus Drej., 329.

$\gamma$, micropetalus Lge., 329.

Dichostylis fluitans Rehb., 40.

Digitalis, 432.

purpurea L., 461.

Digitaria, 24.

ciliaris Koel., 62.

filiformis Koel., 61.

glabra, 61.

hrumifusa Pers., 61.

sanguinalis Scop., 62.

" $\beta$, ciliaris Gren. \& Godr., 62.

" ", genuina, 62.

Digraphis, 24.

, arundinacea Trin., 63.

Diplotaxis, 474. tenuifolia DC., 496.

Dipsacus, 106 .

"pilosus L., 111. silvestris Mill., 112.

Doronicum, 565 .

Pardalianches L., 622.

Draba, 472.

incana L., 483.

verna $L ., 4 \mathrm{S2}$.

Drosera, 156.

anglica Huds., 256.

intermedia Hayme, 237.
Drosera longifolia L., 256.

" $\beta$, obovata, 236.

obovata M. K., 236.

$\therefore$ rotundifolia L., 236.

" $\quad \beta$, bracteata Lgby., 256.

E.

Echinochloa, 24.

- Crus galli Beauv., 63.

Echinops, 564 .

- sphærocephalus L., 632.

Echinopsilon hirsutum Moq., 210.

Echin osperm um, 143.

Lappula Lehm., 161.

Echium, 142.

+ vulgare L., 158.

Elatine, 293.

Alsinastrum L., 307.

Hydropiper L., 307.

" $a$, gyrosperma, 307 .

- $\boldsymbol{\beta}$, orthosperma, 307 .

Eleocharis, 21 . acicularis R. Br., 38 . multicaulis Sm., $5 \mathrm{~S}$.

$\checkmark$ palustris R. Br., 57. uniglumis Lk., 37.

Elsholzia, 429. cristata Willd, 451.

Ely mus, 23. arenarius L., 60 .

" $\beta$, minor, 60 .

caninus L., 56 .

europceus L., 59.

Empetrum, 724.

Y nigrum L., 743.

Eudymion, 241.

nutans Dumort., 249.

Enodium, 28.

coerulcum Gand., S4.

" $\beta$, altissimum Lk., 84 .

" $\delta$, divaricatum Lge., 793.

" $\gamma$, viviparum, 84 .

Epilobium, 291.

angustifolium L., 294.

hirsutum L., 298.

" $\beta$, micranthum! 299.

hirsutum $\beta$, L., 298.

montanum L., 295.

nudum Schum., 294.

palustre L., 295.

parviflom Schreb., 295.

pubescens Roth, 298.

" $\quad \beta$, subglabrum Koch, 298.

purpureun Fr., 297.

rivulare Whlbg., 298. 
f Epilobium roseum Schreb., 294. roseo-pubescens Lge., 299. tetragonum L, 297.

" $\beta$, obseurum Schreb., 297. virgatum Fr., 296.

Epijactis, 6.54 .

atrormbens Hoffm., 645.

ensifolia Sw., (j44.

Helleborine 1 , microphylla, 645.

"2, mbiginosa, 646.

" 3, varians, 645.

"4, viridans, 645.

latifolia All., 645.

media Fr., 645.

micropliylla Ehrh., 646. pallens Sw., 644.

- palustris Crtz., 645. rubiginosa Gaud., 646. rubra All, 644. viridiflora Inm., 646.

Epipogium Gmelini Rich., 645.

Epipogon Gmel., 631. apliyllum Sw., 645.

Equisetum, 753 .

arvense $L$., 771 .

" $\gamma$, decumbens Mey., 771.

" $\delta$, nemorosum Braun, 771.

" $\beta$, serotinum Mey., 771.

eburneun Roth, 772 .

fuviatile L., 774.

hiemale L., 774.

+ limosum L, 774.

* * fluviatile H., 774.

" $\beta$, polystachyon, 774.

palustre L., 775 .

، $\gamma$, arenarium, 775.

" $\boldsymbol{\beta}$, polystachyon, 775 .

tenue Doell., 774.

pratense Elirl., 773.

silvaticum L., 775 .

Telmateja Ehrl., 772.

" $\beta$, serotimum, 772.

$\chi$ umbrosum Willd., 772.

" $\beta$, ramulosum, 775 . variegatum Sclıl., 775.

Erauthis, 404 .

+ hiemalis Salisb., 426.

Erica, 29:.

$\times$ Tetralix L., 50 ? vulgaris L, 502 .

Erigeron, 562 .

-acris L., 620 .

" $\beta$, strictus, 620 .

canadensis L., 621!

- speciosus DC., 62!
Eriophorum, 21.

$x$ alpinum L., 47.

angustifolium Roth, 46 .

gracile Koch, 45.

latifolium Hopp., 46.

polystachyon L. $(\boldsymbol{\alpha}, \boldsymbol{\beta}), \underline{46}$.

n $\gamma, 45$.

triquetrum Hopp., 45.

vaginatum L., 47.

Erodium, 509 .

- cicutarium L'Her., 319. pimpinellafolium Willd., 519.

Erophila vulgaris DC., 482.

Ervum, 509 .

hirsutum L., 5.50.

×tetraspermum L., 530.

Eryngium, 151.

campestre L., 215.

maritimum L., 215.

Ery sinum, 474 .

Alliaria L., 500.

Barbarea L., $49 \bar{\jmath}$.

t cheiranthoides L., 492.

* hieraciifolium L., 492.

officinale L., 499.

pracox Sm., 494.

strictum Fl. Wett., 492.

Erythrea, 145.

Centanrium Pers., 177.

linarifolia Pers, 177.

" minor Hartm., 177.

littoralis Fr., 177.

pulcliella Fr., 176.

ramosissima Pers., 176.

Esmarchia cerastoides Rchb., 345.

Eunnymus, 107.

- europaus L., 124.

E upatorium, 558 .

+ cannabinum L., 601 .

Euphorbia, 655 .

Esula L., 665.

x exigua L., 66 4.

* Helioscopia L., 664.

Latliyris L., 665.

Y Peplus L., 665.

segetalis L., 665.

Euplirasia, $4 \overline{3} \overline{3}$. gracilis Fr., 467.

Odontites L, 468.

officinalis L., 466.

parviflora Fr., 466.

" $\beta$, curta Fr., 467.

" c, imbricata, 467 .

Luxolus viridis Moq., 704.

Exacum filiforme Willd., 123. 


\section{F.}

Faba vulgaris Mönch, 530.

Fagopyrum, 295.

esculentum Moench, 306.

tataricnm Gärtn., 305.

Fagus, 658.

Castanea L., 721.

silvatica L., 721.

Falcaria, 152.

Rivini Host, 220.

Farsetia incana R. Br., 485.

Fedia dentata Wallr., 32

eriocarpa Rchb., 33. olitoria Vahl, 32.

Festuca, 29.

arenaria Osb., 95.

arundinacea Liljebl., 76.

arundinacea Schr., 96.

aspera M. K, 105.

borealis M. K., 76.

bromoides L., 98.

decumbens L., 77.

dumetorum L., 95.

duriuscnla L., 94.

" $\beta$, cæsia Fr., 94.

elatior L., 96.

elatior Sm., 96.

elonguta Ehrl., 793.

erecta Wallr., 103.

fluituns L., S8.

gigantea Vill., 97.

" $\beta$, triflora, 97.

glauca F. D., 95.

glanca Lam., 94.

gracilis Moench, 52.

hirsuta F. D., 95.

littorea Whlbg., 96.

" $\beta$, pauciflora Hartm., 97.

loliacea Hnds., 51.

loliacea F. D., 95.

nemiorum Leyss., 95.

o vina L., 93.

- $\gamma$, glauca Fr., 94.

- $\beta$, tenuifolia, 94.

vinnata Moench, 52.

pratensis Huds., 96.

" $\beta$, pseudololiacea Fr., 96. - rubra L., 94.

" $\beta$, arenaria Fr., 95.

" - cresia Fr., 95.

- $\propto$, genuina, 95.

- $\beta$, dumetorum, 95.

sabulicola L. Duf., 95.

sciuroides Roth, 98.
XFestuca silvatica Vill., 97. speciosa Schreb., 104. tenuifolia Sibth., 94.

Ficaria, 405 .

$\times$ ranunculoides Moench, 425 .

Filago, 560.

apiculata Sm., 610.

arvensis L., 609.

canescens Jord., 609.

lutescens Jord., 610.

xermanica L., 609.

minima Fr, 608 .

montana L., 609.

montana F. D., 608.

Flnminia, 26.

4 arundinacea Fr., 76.

Fragaria, 364 .

collina Ehrh., 592.

Kelatior Ehrh., 592.

x grandiflora Ehrh., 392.

sterilis L., 393.

* vesca L., 392.

virginiana Ehrh., 392.

Fraxinus, 2.

- excelsior L., 4.

Fritillaria, 241.

Meleagris L., 249.

Fumaria, 507.

bulbosa $\alpha, \gamma$, L., 514.

bulbosa $\beta$, L., 513.

capreolata L., 511.

claviculata L., 512.

officinalis L., 511 .

" $\beta$, densiflora Parl., 511.

" $\gamma$, foribunda Hamm., 511.

" $\beta$, minor Hamm., 511.

Vaillantii Lois., 511.

G.

Gagea, 242.

arvensis Schult., 251.

lutea Schnlt., 252.

minima Schult., 251.

spathacea Schult., 250 .

stenopetala Relıb., 252

" $\beta$, bifolia Koch, 252 .

Gaīanthus, 240.

* nivalis L., 245.

Galeobdolon, 428 .

x luterum Huds., 443.

Galeopsis, 428 . angustifolia Ehr., 435.

* bifida Boenn., 436.

cannabina Rotlı, 436. 
Galeopsis dubia Leers., 434. Galeobdolon L., 443. intermedia Vill., 435.

- Ladanum L., 455 .

- $\beta$, angustifolia W. Gr., 435.

" $\alpha$, latifolia W. Gr., 435.

latifolia Hoffm., 435.

ochroleuca Lam., 434.

pubescens Bess., 436.

Reichenbachii Reut., 436.

$\gamma$ Tetrahit L., 435.

" $\beta$, L., $4 \mathfrak{3} 6$.

versicolor Curt., 436.

Galinsoga, 561 . parviflora Cav., 616.

Galium, 107.

Aparine L., 118.

n $\gamma$, confertum Westerlund, 119.

- $\quad \gamma$, infestum W. K., 119.

" $\gamma$, marinum, 119.

" $\beta$, tenerum, 119.

Bocconi All., 116.

- boreale L., 113.

n hyssopifolium, 115.

* latifolium, $11 \mathrm{j}$.

decolorans Gren. \& Godr., 115.

elatum Thuill., 114.

elongatum Presl., 117.

eminens Gren., 116.

erectum Huds., 115.

- $\beta$, rigidum, 115.

glaucum F. D., 114.

hercynicum Weig., 117.

infestum W. K., 119.

insubricum Gaud., 114.

lave Thuill., 116.

$\times$ Mollugo L., 114.

- $\beta$, ochroleucum, 114.

" $\gamma$, umbrosum, 114.

palustre L., 117.

pusillum sm., 116.

saxatile L., 117.

$\times$ silvaticum L., 114.

silvaticum Drej., 114.

y silvestre Poll., 116.

" «, glabrum Schrad., 116.

- $\beta$, hirtum Koch, 116.

" $\quad$ supinum Gaud., 116.

spurium L., 119.

- $\beta$, Vaillanti, 119.

tenerum Schleich., 119.

tricorne With., 119.

uliginosum L., 118.

Vaillantii DC., 119.
Galium verum L., 115.

$\gamma$, altissimum, 116.

* $\beta$, effusum, 115.

" $\delta$, littorale Lge., 116.

Genista, 508 .

anglica L., 517.

germanica L., 518.

pilosa L., 518.

tinctoria L., 518.

Gentiana, 145.

Amarella L., 177.

campestris L., 178.

Centaurium L. $(\boldsymbol{\alpha}, \beta), 176-77$.

filiformis L., $12 \overline{5}$.

germanica L., 178.

lingulata Ag., 178.

Pneumonanthe L., 178.

pulchella Sw., 176.

uliginosa Willd., 178.

Geraui um, 508 .

cicutarium L., 319.

$\times$ columbinum L., 317 .

- dissectum L., 317.

lividum L'Herit. 315.

lucidum L., 318.

molle L., 317.

palustre L., 313.

phæum L., 515.

" $\quad \beta$, lividum Koch, $\mathbf{3} 15$.

pratense L., 514 .

pusillum L., 316.

pyrenaicum L., 315.

robertianum L., ふ18.

- $\beta$, rubricaule H., 318.

rotundifolium L. Sp., 316.

rotundifolium L. fl. Siı, 316.

- $\beta$, minus Fr., 316.

sanguineum L., 313.

silvaticum L., 314.

viscidulum Fr., 316.

G e u m, 364 .

intermedium Ehrh., 399.

rivale L., 400 .

* hybridum Horn., 100.

x urbanum L., 599.

Githago segetum Desf., 342.

Gla u c i um, 401 .

Yluteum Scop., 406.

Gla ux, 148.

maritima L., 102.

Glerhoma, 429.

$x$ hederaceum L., 444.

Glyceria, 28.

airoides Rchb., 85.

aquatica Presl., 85. 
Glyceria aquatica Whlbg. 87. arundinacea Fr., 76.

Catabrosa Kl. \& R., 85.

distans Whlbg., 86.

" $\beta$, pulvinata, 87.

fluitans M. K., 88.

" $\alpha$, acutiflora Doell., 88.

- $\delta$, obtusiflora Sond., S7.

- $\beta$, triticea Fr., 88.

loliacea Gren. \& Godr., 51.

- maritima M. K., 85 .

" $\beta$, anomala Lge., 86 .

plicata Fr., 87.

- $\beta$, triticea, 88 . spectabilis M. K., 87 .

Gnaphalium, 560 .

arenarium L., 606.

arvense Willd., 609.

dioecum L., 6018.

germanicum Willd., 609.

luteo-album L., 606.

montanum Willd., 608.

nudum Hoff'm., 607.

rectum $\mathrm{Sm}, 60 \mathrm{~S}$.

silvaticum L., 608.

y uliginosum L., 607. y, glabrum Koch, 607.

Gratiola, 3.

$\checkmark$ officinalis L., 17.

Gymnadenia, 633.

albida Rich., 640.

conopsea R. Br., 640.

Gypsophila, 310 .

muralis L., 328.

serotina Rehb., 325.

Vacearia Sibth., 325.

\section{II.}

Habenaria albida R. Br., 640 .

Halianthus, 311 .

peploides Fr., 357.

Haloscias, 155 .

scoticum Fr., 223.

Halymus, 656 .

- pedunculatus Wallr., 717. portulacoides Wallr., 717.

Hedera, 148. Helix L., 201.

Hedysarum Onobrychis L., 522.

Heleocharis Beothryon Drej., 39.

Heleochloa aquatica Fr., 87. distans Drej., 86.
Helianthe mum, 401.

Y vulgare Gärtn., 408.

$\mathrm{Heli}$ anthus, 5 fis.

tuberosus L., 631.

Helichrysum arenarium DC., 606.

Helleborine latifolia F. D. 645.

$\mathrm{Helleb}$ orus, $\mathbf{4}(19$. hiemalis L., 426.

$x$ viridis L., 427.

Heloseiadi um, 152. inundatum Koch, 217. repens Koch, 217.

Hepatica nolilis Rchb., 411. triloba Chaix, 411.

Heracle u m, 154. sibiricum L., 226.

* australe Hartm., 226.

- Sphondylium L., 226.

t " $\boldsymbol{\beta}$, elegans Koch, 226.

He rmininm, 655 .

- Monorchis R. Br., 642.

Herniaria, 149.

$\times$ glabra L., 205.

" $\beta$, subciliata Bab., 203.

hirsuta L., 203.

Hesperis, 475.

inodora L., 488.

$y$ matronalis L., 488.

Hi er a c u m, 556 .

aufractum Fr., 578.

- aurantiacum L., 574.

Auricula L., 575.

boreale Fr., 581.

" $\beta$, angustifolium Fr., 582.

eæsium Fr., 577.

" $\beta$, nemorum Fr., 577.

collinum Rehb., 574.

cymigenum Rchb., 575.

cymosum L., 575 .

dubium H., 574.

glomeratum macilentum Fr., 575.

gothicum Fr., 580.

incisum Koch, 576.

integrifolium Lge, 576.

murorum L., 575.

" $\gamma$, incisum Fr., 576.

- integrifolinm H. N., 576.

" $\beta$, rotundatum Kit., 576 .

" silvaticum L., 576.

" silvaticum F. D., 579.

" subcrsium Fr., 576.

Nestleri Vill., 575.

paludosum L., 574.

Pilosella L., 572.

" pilosissimum Fr., 573. 
Hieracium poliotrichum Rchb., 575. prcenorsum L., 572.

pratense 'Tausch, 574. ramosum IV. \& K., 578. rigidum Hartm., ว $\$ 0$. " $\beta$, tridentatum, 579. rotundatum Kit., 576. sabaudum F. D., 532. silvaticum Lam., 578. Taraxaci L., 587. tridentatum Fr., 579.

, $\beta$, angustifolium Fr., 579.

" $\beta$, asperum Fr., 580.

" $\gamma$, integrifolium Fr., 579. $\rightarrow$ umbellatum L., $5 \$ 2$.

" $\delta$, coronopifolium, 582.

, $\varepsilon$, dunense, 582 .

1) $\beta$, filifolium, 582.

" $\gamma$, humile, 582 .

- $\beta$, villosum, 582.

$\checkmark$ vulgatum Fr., 578.

" $\beta$, angustifolium Fr., 758.

$\therefore$ integrifolium Fr., 576.

" irriguum Rchb., 580.

- $\gamma$, latifolium Fr., 578.

" $\delta$, ramosum Fr., 578.

Hierochloa, 26.

borealis, R. S., 75.

Himantoglossum viride Drej., 642.

Hippoglossum maritimum Hartm., 159.

Hippophä, 725.

rhamnoides L., 744.

Hippuris, 1.

vulgaris L., 2.

" $\beta$, fluitans Lilj., 2.

$\mathrm{Holcus}, 26$. avenaceus Scop., 83.

lanatus L., 76 .

mollis L., 76 .

odoratus L., 75 .

Holos te $u \mathrm{~m}, 30$. umbellatum L., 105.

Hoskenya peploides Ehrh., 337.

Hordeum, 23.

distichon L., 58.

liexastichon L., 58.

maritimum With, 58.

murinum L., 59.

polystichum Doell., 57.

$\beta$, liexastichon Doell., 58.

" $c$, vulgare Doell., 57.

pratense Huds., 58.

secalinum Schreb., 58.

silvaticum Huds., 59.
Hordeum vulgare L.. 57.

Hottonia, 146.

palustris L., 153.

Humulus, 72.5.

* Lupulus L., 745.

Hyacinthus botryoides L., 249.

non scriptus L., 249.

Hydrocharis, 727.

Morsus ranæ L., 749.

Hydrocotyle, 151.

- vulgaris L., 215.

Hyos cyamus, 144. agrestis Kit., 171.

niger L., 170.

" $\beta$, agrestis $\mathrm{Fr}, 171$.

Hyoseris mininza L., 565 .

Hypericum, 550 .

dubium Leers., 552.

* hirsutum L., 553.

humifusum L., 551.

montanum L., 552.

perforatum L., 551.

" $\beta$, angustifolium, 551.

pulchrum L., $55 \overline{\text { s. }}$

quadrangulum L., 552.

quadrangulum F. D., 552.

tetragonum (Fr.), 552.

$\times$ tetrapterum Fr., 552.

Hypochoeris, 556 .

glabra L., $585 \overline{.}$

+maculata L., 583.

" $\beta$, Mülleri Lge., 584. radicata L., 585 .

I.

Jacobaa aquatica Drej., 625. paludosa Fl. wett., 626. sarracenica Moench, 626. vulgaris Moench, 625.

Jasione, 147. montana L., 191.

" $\beta$, littoralis Fr., 191.

Iberis nudicaulis L., 477.

Ilex, 109.

* Aquifolium L., 127.

" $\beta$, integrifolia, 127.

Illecebrum, 148. verticillatum L., 202.

Impatiens, 147.

$\rightarrow$ Noli tangere L., 198. parviflora DC., 199.

Imperatoria, 154.

$\times$ Ostruthium L., 225. 
Intybus premorsus Fr., 572.

Inula, 562.

Britannica L., 618.

Conyza DC., 617.

dysenterica L., 617.

Helenium L., 619.

pulicaria L., 617.

salicina L., 619.

Iris, 20.

Pseudacorus L., 34.

spuria L., 34.

Is atis, 471.

tinctoria, 475 .

Is o ëtes, 752.

echinospora DR., 770.

lacustris L., 769 .

$\mathrm{Juglans}, 65 \mathrm{~S}$.

regia L., 722 .

Juncus, 242.

acutiflorus Ehrh., 263.

" $\beta$, macrocephalus Koch, 263.

alpinus Vill., 265.

" $\beta$, rariflorus, 265.

anceps Laharp., 265.

articulatus L., 264.

" $\beta$, subatratus, 264.

atratus Krock, 265.

atratus H. N., 264.

atricapillus Drej., 264.

" $\alpha$, congestus, 264.

" $\beta$, sparsiflorus, 264.

balticus Willd., 262.

* inundatus, 262.

bottnicus Whlbg., 267.

4 bufonius L., 268 .

- $\beta$, fasciculatus K., 268.

bulbosus L., 266-67.

" maritimus H., 267.

campestris L., 272.

capitatus Weig., 269.

communis Mey., 261.

compressus Jacq., 267.

conglomeratus L., 260.

diffusus Hopp., 261.

effusus $L ., 261$

- $\beta$, compactus Leight., 261.

- $\gamma$, prolifer Sond., 261.

filiformis L., 262.

Gerardi Lois., 267.

glaucus Ehrh., 261.

insularis Viv., 269.

inundatus Drej., 262.

lagenarius Laharp., 264.
Juncus lamprocarpus Ehrh., 264.

" $\delta$, multiflorus, 264.

- $\gamma$, pauciflorus, 264.

" $\beta$, repens, 264.

maritimus Lam., 260.

nigricans Rehb., 265.

nigritellus D. Don., 264.

obtusifloı us Ehrh., 263.

pilosus $\alpha$, L., 270.

pilosus $\delta$, L., 270.

pygmæus Thuill., 269.

repens Nolt., 264.

repens Req., 264.

retroflexus Rafn., 265.

silvaticus Reich., 263.

squarrosus L., 266.

subuliflorus Drej., 261.

subverticillatus Wulf., 266.

supinus Moench, 266.

" $y$, fluitans, 266.

- $\beta$, repens, 266.

- $\gamma$, terrestris, 266.

Tenageja Ehrh., 268.

tenuis Willd., 267.

triandrus Rchb., 269.

uliginosus Roth, 266.

ustulatus Hopp., 265.

Juniperus, 726.

communis L., 746 .

\section{K.}

Knautia, 106.

y arvensis Coult., 110.

- $\beta$, campestris, 110.

Kochia, 150.

$f$ hirsuta Nolt., 210.

Koeleria, 27.

cristata Pers., 77.

glauea DC., 77.

\section{L.}

Lactuca, 555 .

macrophylla, 568 .

muralis Fresen., 567.

Plumieri Gren. \& Godr., 565.

sativa L., 568 .

Scariola L., 567.

Latia orientalis Desv., 476.

L a mi u m, 425.

album L., 440.

- $\beta$, integrifolium, 440.

- $\gamma$, roseum Lge., 441. 
Lamium amplexicaule L., 442. " $\beta$, clandestinum, 442 . confertum Fr., 442. Galeobdolon Crantz., 443. garganicum L., 441. incismm Willd., 442. intermedium Fr., 442. maculatum L., 441. parietaricefolium Benth., 440.

- purpureum L., 441.

Lampsana, 554 .

7 comnunis L., 564.

L a p p a, 557. intermedia Lge., 589.

major Gärtn., 590.

* $\beta$, subtomentosa Lge., 590. minor DC., 589.

* campestris Fr., 589. officinalis All., 590.

Y tomentosa Lam., 588 " $\beta$, demudata Lge., 588.

Lapsana communis L., 564.

Larix, 653 .

7 europæa DC., 667.

Laserpitium, 155.

+ latifolium L., 229.

i $\quad \beta$, asperum, 229.

- $\gamma$, tennissimum Lo'e., 229.

Lastræa, 751 .

+ cristata Presl., 759. dialatata Presl., 760. Filix mas Presl, 759. " $\beta$, erosa, 759. - $\gamma$, lepidota Lge., 759.

+ Oreopteris Presl., 758. + spinulosa Presl., 760 . " * dilatata, 760 . Thelypteris Presl, 758.

L a thræa, 435 . Squamaria L., 468.

Lathyrus, 509. Aphaca L., 531.

theterophyllus L., 534. latifolius H., 534. macrorrhizus Wimm., 535. maritinus Fr., 5j̄̄. " $\quad \beta$, acutifolius Bab., 533. niger Wimm., 535. palustris L., 533.

- pratensis L., 532 . - $\beta$, villosus Drej, 532. silvestris $\mathrm{L} ., 534$.

- $\beta$, platyphyllus, 534.

- $\gamma$, stenophyllus Lge., 534. tuberosus L., 532.
Lathymes vernus Wimm,, 535.

Leersia, $2 \vec{\pi}$.

x oryzoides Sw., 60.

Lemna, 654 . gibba L., 668. " $\beta$, major Koch, 669. minor L., bitis. - * tenella, 668 . polyrrhiza L., 668 . trisulca L., 668. L e ontodon, 557.

+ autumnalis L., 587. " $\gamma$, coronopifolius, 587.

" $\delta$, nigro-lanatus, 587 .

" $\beta$, silinus, 587.

corniculatus Kit., 566.

hastilis L., 5 S7.

lirtus L., 586.

hivtus F. D., 584.

$\times$ hispidus L., 587.

obliquus F. D., 566.

palustris Sm., 566.

Taraxaci Lois., 587.

Taraxacum L., 566.

- 3 obliquus Fr. 566.

" 1 palustris Fr., 566.

Le onurus, 429.

X Cardiaca L., 443.

Marrubiastrum L., 444.

Lepidium, 471.

campestre R. Br., 478.

latifolium L., 499.

ruderale L., 478.

sativum L., 477.

Lepigonum, 311.

fasciculare Lönmr., 356.

lejospermum Kdbg., 335.

"c, cymosum, 335.

" $\beta$, racemosum, 3.35 .

marinum Wahlb., 336.

" $\beta$, fasciculare, 336 .

medium Fr., 335.

neglectım Kindb., 334.

Nrubrum Fr., 553.

" $\beta$, arenarium, 334

" ce, campestre Feuzl., 534.

" $\beta$, pingue Fenzl., 334

- $\quad \beta$, radicans Kdbg., 334.

salinum Kdbg., 535 .

salinum kr., 335.

Lepturus, 22.

filiformis Trin., 48.

" $\alpha$, strictus Lge., 49.

× $\beta$, subcurvatus I Lge., 49. incurvatus Drej., 48.

Huandb, den danske Flora. 
Lepturus incurvatus Trin., 49.

Leucanthemum vulgare Lam., 611.

Leucojum, 240.

* rstivum L., 246.

Levisticum, 154.

$y$ officinale Koch, 227.

Libanotis, $15 \overline{3}$.

montana All., 225.

vulgaris DC., 223.

Ligusticum Levisticum L., 227. scoticum L., 223.

Ligustrum, 3 .

X vulgare L., 7 .

Lilium, 241.

x bulbiferum L., 250.

Martagon L., 250.

Limnant $\mathrm{l}$ e $\mathrm{m} \mathrm{nm,} 145$.

nymphoides Hffg. \& Lk., 179.

Limnochloa alpina Drej., 47. cospitosa Rehb., 40.

Limodorum Epipogium Sw., 643.

Limosella, 432 . aquatica L., 457 .

" $\beta$, minor, 457. borealis Less., 457.

Lin aria, 432.

- Cymbalaria Mill., 459. Elatine Mill., 459. genistafolia Mill., 458. minor Desf., 458. spuria Mill., 458.

× vulgaris Mill., 457.

Linnæa, 431.

$x$ borealis L., 456 .

Linum, 501. catharticum L., 502.

v $\beta$, condensatum M. Lange, 502.

Radiola L., 127.

usitatissimum L., 502.

Listera, 634.

cordata R. Br., 648.

ovata R. Br., 647.

Lithospermum, 142.

* arvense L., 159.

officinale L., 158.

Littorella, 655 .

lacustris L., 705.

Lobelia, 146.

Dortmanna L., 186.

L o liu m, 22.

arvense H., 50.

arvense With., 51.

Bouchéanum Kith., 50. festucaceum Link., 51.
Lolium Halleri Gmel., 50.

italicum A. Br., 50.

$>$ Linicola Sond., 50.

y perenne L., 49.

" $\gamma$, aristatum, 50 .

n $\alpha$, vulgare, 50 .

" $\beta$, tenue H., 50.

$\times$ temulentum L., 50 .

tenue L., 50.

Lomaria Spicant Desv., 762.

L on icera, 147.

* Periclymemum L., 191.

Y Xylosteum L., 191.

Lotus, 510.

corniculatus I., 556 .

" anqustifolius H., 557.

" $\gamma$, carnosus Pers., 537.

- silvaticus H., 556 .

" $\beta$, villosus Thuill., 537.

major Scop., 536.

maritimus L., 537.

tenuifolius Rchb., 537.

\% tenuis Kit., 537.

uliginosus Schk., 536.

Lnnaria, 472.

anmua L, 484.

(biennis Moench, 484. rediviva $L ., 484$.

Luzula, 242.

X albida DC., 271.

campestris DC., 272.

" $\beta$, erecta, 271.

" $\beta$, pallescens, 271.

congesta Lej., 271.

erecta Desv., 271.

Forsteri DC., 270.

maxima DC., 270.

multiflora Lej., 271.

" $\gamma$, congesta, 271.

" $\beta$, pallescens, 271.

pilosa Willd., 270.

" $\beta$, simplex, 270.

silvatica Gaud., 270.

vernalis DC., 270.

Lyehnis, 312 .

dioeca $\alpha$, L., 345.

dioeca $\beta$, L., 343.

diuma Sibth., 343.

Flos cuculi L., 344.

pratensis Rafn, 343.

silvestris Rafn, 343.

Viscaria L., 344.

Lycium, 144.

barbarum L., 170.

vulgare Dun., 170. 
Lycopodinm, 7.52 . alpinum L., 767. annotintum L., 767. Chamæcyparissus $\mathrm{Br} ., 768$.

7 clavatum L., 768 . complanatum L., 767. inundatum L., 766. scibincefolium Willd, 768. selaginoides L., 768 . Selago L., 766 .

Lycopsis arrensis L., 166. Ly copus, 3 .

$x$ europeeus L., 7.

Ly s ima chia, 146.

T nemorum L., 185 .

x nummularia L., 184. punetata Jacq., 184.

y thyrsiflora L., 185.

+ vulgaris L.. 181.

L y thr $11 \mathrm{~m}, 358$.

x Salicaria L., 359.

M.

Majanthemum, 108.

*. bifolium DC., 125.

Convallaria Web., 125.

Majorana hortensis Mch., 452.

Mala clitum, 312 .

f aquaticum Fr., 349.

" $\boldsymbol{\beta}$, saxatile Fr., 349 .

II alaxis, 655 .

Loeselii Sw., 650.

paludosa Sw., 650 .

Malus silvestris Mönch., 370 .

Malva, 502 .

$\times$ Alcea L., 505.

$\beta$, fastigiata, 505 .

borealis Wallm., 507.

excisa Rchb., 505.

fastigiata Cav., 505.

mauritiana L., 506.

moschata L., 505.

nicteensis All, 506.

pusilla With, 507.

rotnudifolia L., Fr., 506, 507.

silvestris L., 506 .

vulgaris Fr., 506.

Marrubium, 427 . vulgare L., 451.

Maruta Cotula Cass., 614.

Matricaria, 561.

y Chanomilla L., 613.

discoidea DC., 614.
Matricaria inodora L., 612. " ambigua Fr., 615.

"*: borealis Hn., 613 . * salina, 613.

maritima L., 615 .

Parthenium L., 612.

Medicago, 510 .

B falcata L., 558 .

* lupulina L., 559.

" $\beta$, Willdenowiana, 539.

maculata Willd., 540.

× minima Lam. 539.

omithopodioides Fr., 540.

polymorpha $\mu$, minima L., 539.

K sativa L., 538.

M el ampyrum, 452 .

arrense L., 464.

cristatum L., 465.

nemorosum L., 464.

pratense L., 464.

silvaticum L., 465.

Melandrium, 311.

$\times$ diurnum Fr., 343.

1 $\beta$, expallens, 343.

noctiflorum Er., 344.

vespertinum $\mathrm{Fr}$, 343.

" $\gamma$, coloratum Rostr., 34.5.

- $\beta$, laciniatum Lge., 545.

Melica, 26.

coevulea L., 84.

$X$ nutans L., 75 .

$x$ uniflora Retz, 75 .

Melilotus, 510.

$x$ alba Lam., 540.

- arvensis Wallr., 541.

dentata Willd., 541.

macrorrhiza Pers., 541.

officinalis Willd., 541.

officinalis Lam., 541.

ornithopodioides H., 540.

Petitpierreana Rehb., 541.

vulgaris Willd., 540.

Melissa, 430 .

officinalis L., 454.

Mentha, 429.

acutifolia Sm., 449.

aquatica L., 448.

"A, capitata Fr., 448.

- B, subspicata Aresch., 448.

- C, verticillata Fr., 448.

" $\delta$, acutifolia, 449.

" $\gamma$, brevifolia, 449.

1) $\beta$, glabrata, 449 .

1) $\varepsilon$, latifolia, 449 .

- $\quad c$, vulgaris, 449. 
Mentha arvensis L., 450.

" $\gamma$, glabriuscula, 450 .

1 $\beta$, parietariæfolia, 450 .

" $\delta$, riparia, 451. gentilis L., 449.

" $\beta$, Agardhiana, 450. gracilis Sole, 450.

hirsuta aquatica H., 448. "sativa H., 448.

palustris Rchb., 448.

pratensis Sole, 449.

Pulegium L., 451.

pyramidalis Lloyd., 448.

rotundifolia L., 446 .

sativa L., 449.

sativa Fr. 448, 450.

silvestris L., 447.

viridis L., 447.

Menyanthes, 145.

nymphoides L, 179.

trifoliata L., 179.

Mercurialis, 727.

$\lambda$ annua L., 749 .

perennis L., 748 .

Mertensia maritima Don., 159.

Mespilas Cotoneaster L., 368. monogyna IVilld., 567.

Oxyacantha Gärtn., 367. oxyacanthoides Thuill., 367.

Microcala filiformis Lk., 125.

Milium, 26.

effusum L., 74.

Mimulus, 452.

1 luteus L., 462.

Moehringia, 311.

$\gamma$ trinervia Clairv., 358.

Molinia coerulea Mönch, 84.

littoralis Host, 84.

Moneses grandiftora Salisb., 319.

Monotropa, 292.

glabra Beruh., 301.

hirsuta Nolt., 501.

Hypophegea Wallr., 301.

Hypopitys Wallr., 501.

- $\quad \beta$, glabra, 301.

" ce, hirsuta, 501.

Montia, 20.

fontana L., 53.

" $\beta$, major F. D., 3.5.

lamprosperma Cham., $5 \overrightarrow{5}$.

minor Gmel., 35.

rivularis Gmel., 55.

Morns, 655.

$x$ alba L., 708 .

nigra L., 708.
Mulgedium Plumieri DC., 568.

Muscari, 241.

× botryoides Mill., 249.

Myagrum paniculatım L., 475. sativun L., 480.

Mycelis muralis Rehb., 567.

Myosotis, 145.

$x$ arvensis L., $16 \overrightarrow{3}$.

caspitosa Schultz., 164.

collina Hoffm., 163.

hispida Schl., 165.

intermedia Link, 163.

Lappula L., 161.

laxiflora Rchb., 165.

lingulata R. S., 164.

$\beta$, radicans Lge., 164.

palustris With., 165.

" $\beta$, laxiflora, 165.

" $\gamma$, strigulosa, 165.

repens Don, 165.

scorpioilles $\alpha$, arvensis L., 163.

" $\beta$, palustris, 165.

silvatica Hoffm., 161.

sparsiflora Mik., 163.

strigulosa Rclib., 165.

stricta Link, 162.

versicolor Pers., 162.

Myosnrus, 403 .

minimus L., 425 .

Myrica, 725 .

$\times$ Gale L., 744.

Myriophyllum, 656. alterniflorum DC., 718. pectinatum DC., 719 .

spicatum L., 718 .

verticillatum L., 719.

" $\beta$, pectinatum, 719 .

" $\alpha$, pinnatitidum, 719 .

Myrrhis, 156.

7 odorata Scop., 233.

Myrtillus silvaticu.s Drej., 303.

uliginosus Drej., 503.

\section{N.}

Najas, 652.

major Roth, 660 .

marina L., 660 .

monosperma IVilld., 660.

Narcissus, 241.

* poëticus L., 246.

Psendonarcissus L., 246.

Nardus, 22.

+ stricta L., 48. 
Narthecium, 242.

$\times$ Ossifragum Huds., 259.

Nasturtium, 473.

t. amphibium R. Br., 486. anceps Rchb., 487.

- Armoracia Fr., 485.

officinale $\mathrm{R}$. Br., 485.

- $\gamma$, micropliyllum, 486 .

" $\beta$, siifolium, 486 .

palustre DC., 487.

silvestre R. Br., 486.

$\beta$, rivulare Rehb., 486.

Naumburgia thyrsiflora Drej., 183.

Neottia, 634 .

Nidıs avis Riclı., 648.

Nepeta, 429 .

- Cataria L., 444. nuda L., 444.

Neslia, 471.

x paniculata Desv., 475 .

Nicundra, 144. physaloides Gärtn., 168.

Nitella, 753.

atrovirens WalIm., 779.

Brongniartiana Coss. \& Germ., 778.

capitata Ag.. 779.

flabellata Kütz., 777.

flexilis Ag., 777.

- e, barbata, 780 .

1) batrachosperma, 776.

- h, gracilis, $\mathbf{7 7 6}$.

- d, syncarpa, 778.

furculata Rchb., 778.

gracilis Ag., 776 .

intricata A. Br., 779.

mucronata Kuitz., 777.

" $\gamma$, flabellata, 777.

" $\beta$, heteromorplia, 777.

opaca $\beta$, atrovirens Wahlst., 779. polysperma Kütz., 779.

procera Wallm., 778.

Stenhammariana Wallm., 780.

syncarpa Kütz., 778.

"** capitata, 779 .

* * psendoflexilis, 779.

tenuissima Rabenlı, 775.

Nuphar, 402.

X luteum Sm., 409. pumilum Sm., 409.

Nymplıa, 402.

F alba L., 408.

lutea L., 409.
0.

Obione portulacoides Moq., 717.

Odontites, $4 \vec{\jmath} \vec{s}$.

littoralis Fr., 467.

rubra Pers., 468.

, $\beta$, pallida, 468.

serotina Drej., 468.

verna Rchb., 467.

Oenanthe, 153 .

conioides (Nolt.), 223.

$\times$ fistulosa L., 221.

fluviatilis Colem., 223.

Lachenalii Gmel., 222.

Phellandrium Lam., 222. pimpinelloides Sm., 222.

Oenothera , 291 .

K biennis L., 299.

muricata Murr., 399.

Oglifa arvensis Cass., 609.

minima Relsb., 608.

Omphalodes, 145.

\&verna Moench, 161.

Onobrychis, 509 .

+sativa Lam., 522.

Ononis, 508.

arvensis L., 520.

arvensis Retz., 521.

feampestris Koch \& Z., 519.

hireina Jaeq, 521 .

procurrens WVallr., 520.

+ repens L., 520.

" $\beta$, mitis, 520.

- $\gamma$, spiuosissima, 520.

spinosa L., 520.

spinosa re, $\beta$, L., 519-20.

" $\alpha$, glomerata Schum., $51 y$.

Onopordon, 558.

Acanthium L., 591.

Ophioglossnm, 752 .

vulgatum L., 766.

Ophrys, 633.

anthropophore k. D., 636.

corallorhiza L., 649.

cordata L., 648.

Loeselii L., 650.

Moñorchis L., 642.

muscifera Huds., 643.

nyyodes Sw., 643.

Nidis avis L., 648.

ovata L., 647.

paludosa L., 650.

spiralis L., 649.

Oporina autumenalis Doll., 587.

Orchis, $63 \overline{3}$.

angustifolia IV. Gr., 638. 
Orchis bifolia L., 611. conopsea L., 640.

fusca Jacq., 635.

incarnata L., 633.

* $\beta$, hæmatodes, 639 .

latifolia L., 638.

latifolia F. D., 638.

4 maculata L., 639.

" $\beta$, concolor, 639.

majalis Rehb., 638.

mascula $L, 637$.

militaris $\beta$, L., $6 \overline{5} 6$.

+ Morio L., 636. purpurea Huds., 635. pyranidalis L., $6 \mathbf{3} 9$. sambncina L., 637.

* ustulata L., 636.

O $x$ i g a $\mathrm{n} \mathrm{m}, 450$.

* Majorana L., 452.

- vulgare L., 452.

Ornithogalum, 242.

arvense Pers., 251.

luteum L., 252.

minimum $\mathrm{L}, 251$.

nutans L., 258.

pratense H., 252.

spathaceum Hayn, 250.

stenopetalum Fr., 25\%.

x umbellatum L., 258.

Ornithopus, 508.

perpusillus L., 522 .

Orobanche, 4.j.

Cirsii Fr., 469.

Cirsii oleracei Casp., 796.

elatior Sutt., 568.

major L., 468.

minor Sutt., 469.

Picridis Vauch., 470.

stigmatodes Wimm., 468.

Orobus, 510 .

- niger L., 535.

silvaticus I,, 525.

tuberosus L., 535.

vernus L., 535.

Osmund a, 752 .

Lunaria L., 765.

- regalis L., 76.4 .

Spicant L., 762.

Struthiopteris L., 762.

Oxalis, 501 .

Acetosella L., 503.

* $\beta$, lilacina, 503 .

corniculata L, כ04.

stricta L., 505 .

Oxycoccos palustris Pers., 50 t.
P.

Panicum, 24.

ciliare Retz., 62.

Crus galli L., 63.

glabrum Gand., 62.

glaucum L., 61 .

$\times$ miliaceum L., 62.

sanguinale L., 62.

sanguinale Poll., 61.

verticillatum L., 61 .

viride I., 61.

Papaver, 401.

XArgemone L., 404.

- $\beta$, lejocarpum, 404.

$\times$ dubium L., 404.

Rhoeas L.; 405.

" $\beta$, strigosum, 405.

x somniferum L., 405.

Parietaria, 108.

y erecta M. K., 125.

officinalis L., 125.

Paris, 293.

₹ quadrifolia I., $\mathbf{3 0 6 .}$

Parnassia, 157.

palustris L., 257.

Pastinaca, 154.

Xsativa L., 226.

" $\beta$, silvestris, 227.

Pedicularis, 433 .

palustris L., 462.

Sceptrum Carolinum L., 463. silvatica L., 462.

Peplis, 240.

Portula L., 245.

Petasites, 559.

albus Gärtn., 602.

officinalis Mönch., 602 .

spurius Rehb., $60 \overrightarrow{3}$.

vulgaris Desf., 602.

Petroselinum, 152. hortense Rchb., 218.

+ sativum Hoftim., 218.

Peuced anum, 153.

Oreoselinum Mönch., 225.

Ostruthium Koch, 225.

palustre Mönch, 225.

Phalaris, 25.

arundinacea L., 63.

$\times$ canariensis L., 63 .

oryzoides L., 60.

phleoides L., 67.

Phaseolus, 509.

x compressus DC., 524.

xmultiflorus Willd, 524 . 
Phaseolus uanus L., 524.

$\chi$ vulgaris Savi, 524 . " $\beta$, namis, 521.

Phellandrium aquaticum L., 222. conioides Nolt., 223.

Philadel plus, 562 .

$x$ coronarius L., 366.

Phleum, 25.

$x$ arenarium L., 67.

$\times$ Boehmeri Wib., 67. nodosum L., 66. phalaroides Koel., 67.

of pratense L., 66. - $\beta$, vodosum, 66.

Phragmites, 28.

* communis Trin., 84 . " $\gamma$, flavescens, 84 . n $\beta$, repens, 84 .

Physalis, 144.

X Alkekengi L., 167.

Phyteum a, 147.

x spicatum L., 190.

Picea, 653.

* excelsa Link., 666.

Picris, 557.

hicracioides L., 588.

Pilularia, 675. globulifera L., 753 .

Pimpinella, 152.

y magua L., 219. nigra Willd., 220).

Saxifraga L., 219.

- " dissectifolia Wallr., 220.

Pinguicula, 5 .

y valgaris L., 17.

Pinus, 653.

Abies L., 666.

Larix L., 667.

Picea L., 666.

భ silvestris L., 666.

Strobus L., 666 .

Pis $11 \mathrm{~m}, 509$.

- arvense L., 5.3.

maritinum L., 535.

$\times$ sativum L., 531.

Plantago, 107.

$<$ Coronopus L., 122.

$\quad \beta$, pygmra, 122.

intermedia Gil., 120.

$\times$ lanceolata L., 121.

- $\beta$, eriophylla Dene., 121. major L., 120.

" * intermedia, 120.

$\beta$, minima, 120.

$\gamma$, pubescens, 120.
Plantago maritima L., 122.

" $\beta$, dentata, 122 .

" $\gamma$, pygmaa, 122.

media L., 121.

uniflora F. D., 705.

Platanthera, 633.

bifolia Rich., 641.

brachyglossa Rehb., 641.

6 chlorantha Cust., 641.

montana Rchb., 641.

solstitialis Drej, $\mathbf{6 4 1 .}$

" $\beta$, densiflora, 641 .

* $\alpha$, latiflora, tíl.

" $\gamma$, patula, 641.

viridis Lindl., 612.

Po a, 28.

alspersa Drej., 90.

angustifolia L., 90.

annua L., 88.

aquatica L., $8 S$.

arenaria Rafn, 77.

bulbosa L., 90 .

" $\boldsymbol{\beta}$, vivipara, 90 .

Chaixi Vill., 92.

compressa L., 95.

costata Schum., 92.

decrumbens Scop., 77.

distans L., 86.

$\rightarrow$ fertilis Host., 89 .

fluitans Scop., 88.

hybrida Gand., 91.

maritima Huds., 86.

nemoralis L., 89.

" $\quad y$, firmula Gaud., 89.

* " $\boldsymbol{\beta}$, subuniflora Rchb., 89.

" $\alpha$, vulgaris Koch, 89 .

palustris F. D., 89 .

palustris Roth, 90.

pratensis L., 92.

" $\gamma$, angustifolia Rehb., 92.

* $\boldsymbol{\beta}$, humilis Rehb., 92.

serotina Ehrh., 89.

silvatica Poll., 97.

sudetica Schrad., 92.

sudetica Hänk., $9 \mathrm{l}$.

sudetica *, remota Fr., 91.

trivialis L., 91.

" $\beta$, multiflora Relib., 91.

Polemonium, 145.

coeruleum L., 176.

Polygala, 507.

amara L., 516.

depressa Wend., 516.

oxyptera Relıb., 515.

serpyllacea Whe., 516. 
Polygala uliginosa Rehb., 516. vulgaris L., 515.

$$
\text { " * depressa, } 516 .
$$

Polygonatum anceps Mönch, 248. multiflorum Mönch, 248. verticillatum Mönch, 248.

Polygonum, 243. amphibium L., 274.

$$
\text { " ce, natans, } 274 .
$$

" $\beta$, terrestre, 274. aviculare L., 278.

" $\delta$, angustifolium, 278.

" $\varepsilon$, depressum, 278.

n $\gamma$, erectum, 278.

" $\beta$, littorale, 278.

" $\varepsilon$, prostratum, 278.

Bistortal L., 273.

Convolvulus L., 278.

dubium Stein, 277.

dumietorum L., 279.

Fayopyrum L., 306.

Hydropiper L., 277.

incanum DC., 275.

intermedium Ehrl., 277.

Xlapatiifolium L., 274.

" $\gamma$, incanum, 275.

" $\beta$, pallidum Fr., 275.

" $y$, nodosum Fr., 275.

$\delta$, procumbens Sond., 275.

laxifiorum Whe., 277.

laxum E. Bot, 275.

minus H., 276.

mite Sclurk., 277.

mite autt., $27 \%$.

nodosum Pers, 275.

pallidum Witl., 275.

- Persicaria L., 275.

" biforme Whlbg., 276.

pusillum Lanl., 276.

strictum All., 276.

" , elatum Fr., 276.

- $\beta$, pusillum Fr., 276.

tataricum L., 305.

viviparum L., $27 \bar{\jmath}$.

Poly podium, 751. aculeatum L., 757.

cristatum L., 759.

Dryopteris 'L., 764.

Filix foemina L., 755.

Filix mas L., 759.

fragile L., 761 .

Oreopteris Ehrh., 758.

Phegopteris L., 763.

spinulosum Müll., 760 .
Polypodium Thelypteris L., 758. vulgare L., 763 .

Polystichum angulare Presl., 757. Thelypteris Roth, 758.

Populus, 726.

talba L., 746.

balsamifera L., 748.

canescens Sm., 747.

canescens Rchb., 746.

dilatata Ait., 748.

hybrida M. B., 746.

Y monilifera Ait., 747.

7 nigra L., 748.

pyramidalis Roz., 745 .

tremula L., 747.

* villosa, 747.

Potamogeton, 109.

acıminatum Schum., 133.

acutifolius Link., 136.

caspitosus Nolt., 157.

coloratus Horn., 150.

compressus Oed., 137.

compressus $\mathrm{Fr}$., 136.

crispus L., 135.

" $\beta$, gemmifer, 135.

curvifolius Hartm., 131.

decipiens Nolt., 133.

densus L., 135.

fasciculatus Wolfg., 140.

filiformis Pers., 140.

flabellatus Bab., 139, 794.

fluitans Roth, 128.

- $\quad \beta$, rivularis, 129.

fluitans H., F. D., 131.

Friesii Rupr., 157.

gracilis Fr., 135.

gramineus L., 152.

" «, graminifolius Fr., 152.

" $\beta$, heterophyllus Fr., 132.

" $\beta$, Zizii Koch, 133.

gramineum Schum., 132.

heterophyllus Schreb., 132.

Hornemanni Mey., 150.

lucens L., 133.

" $\beta$, acuminatus, 133.

" angustifolius H., 131.

" $\beta$, heterophyllus Fr., 133.

" $\beta$, minor Nolt., 133.

marinus L., 140.

" $\beta$, fasciculatus, 140 .

monogymus 1. Gay, 139.

mucronatus Schrid., 137.

natans $L ., 128$.

" $\beta$, fluviatilis Fr., 128.

- $\beta$, prolixus, 128. 
Potamogeton nitens Web., 151. " $\beta$, heterophyllus, 131.

" $\alpha$, salicifolius, 131. oblongus Viv., 129. obtusifolius M. K., 137. parnassicefolius Sclurad., 130. pectiuatus L., 139.

" $\gamma$, dichotomus Walhr., 794.

" $\gamma$, flabellatus, 139.

" $\boldsymbol{\beta}$, scoparius, 159. perfoliatus L., 134. plantagineus Ducr., 130. polygonifolius Pourr., 129.

" $\alpha$, angustifolius, 130 .

1 $\beta$, amphibius, 130. prælongus Wulf., 131. pusillus L., 138.

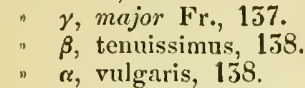
rufescens Schrad, 131. rutilus IVolfg., 157. serrulatus Schrad., 135. serratum Schum., 131. setaceum Schum., 140. sparganifolius Læestad., 129. trichoides Cham., 158.

Zizii M. K., 153 . zosteraceus Fr., 139. zosteræfolius Schum., 136.

Potentilla, 364 . anserina L., 398.

" $\boldsymbol{\beta}$, tenclla, 398. argentea L., $\mathbf{3} 95$. - $\gamma$, impolita, 395. cinerea, 394.

+ collina Wib., 395.

Egedii Wormskj., 399. Fragaria Sm., 393.

Fragariastrum Ehrl., 393. Güntheri Pohl., 395. impolita Wahlenb., 395. incana Moench, 394. mixta Nolt., 397.

nemoralis Nest., 397.

* norvegica L., 396.

1 opaca L., 393. palustr is Scop). 399. pilosa Willd., 396. procumbens Sibth., 397. procumbenti-reptans Lehm., 397. recta L., 395.

reptans L., 398. sordida Fr., 395.

X Tormentilla Sibth., 396.
Polentilla verna F. D., 393.

verna L., 394.

Poterium, 657. dictyocarpum Spach, 720.

Sanguisorba L., 720.

Prenanthes morralis L., 567.

Primula, 145.

acaulis Jacq., 182.

brevistyla DC., 182.

elatior Jacq., 181.

" $\beta$, acaulis Fr., 182.

" $\boldsymbol{\beta}$, decipiens Sond., 181.

" macrocarpa Personn. 181. farinosa L., 1 SO.

grandiflora Lam., 182.

" $\beta$, caulescens, 182.

officinalis Jacq., 150.

" $\beta$, subacaulis Doell., 181. officinali-elatior Muret., 181.

silvestris Scop., 182.

Tommasinii Gren. \& Godr., 181. unicolor Nolt., 181.

variabilis Goupil., 182.

veris $\gamma$, acaulis L., 182.

" $\beta$, elatior L., 181.

" $r$, officinalis L., 181.

vulgaris Huds., 182.

Prunella grandiflora Jacq., 455. vulgaris L., 454.

Prunus, 362.

avium L., 366.

Cerasus L., 365.

domestica L., 565.

fruticans Whe., 364 .

insititia L., $\mathbf{3} 65$.

insititia Drej., 364.

Padus L., $366^{\circ}$

spinosa L., 364.

" $\beta$, coxtanea W. Gr., 364.

Psamma, 25.

arenaria R. S., 67.

baltica R. S., 68.

Pteris, 751.

aquilina L., 762.

Pulegium vulgare Mill., 451.

Pulicaria dysenterica Gärtı., 617. valgaris Gïrtu., 617.

Pulmonaria, 142. angustifolia $\mathrm{L}$., 160. angustifolia F. D., 160.

azurea Bess., 160.

maritima L., 159.

ofticinalis L., 159.

Pulsatilla, 403 .

- nigricans Störk., 415. 
Pulsatilla nigricans $\beta$, schizocalyx, 413. pratensis Mill., 413.

vulgaris Mill., 412.

Pyrethrum inodorum Sm., 612. * $\beta$, salinum Wallr., 613.

Parthenium Sm., 612.

Pyrola, 509.

chlorantlua Sw., 321.

media Sw., 320 .

minor L., 320.

rotundifolia L., 521 .

" $\beta$, arenaria Koch, 321.

secunda L., 320 .

uniflora L., 319 .

Pyrus, 362.

acerba DC., 371.

$x$ communis L., 370.

" $\boldsymbol{x}$, Achras Wallr., 370.

" $\boldsymbol{\beta}$, Pyraster Wallr., 370.

Cydonia L., 371.

Malus L., 370.

$\kappa$, austera Wallr., 371.

$\boldsymbol{\beta}$, mitis Wallr., 371.

torminalis Ehrh., 368 .

\section{Q.}

Quercus, 658.

foemina F. D., 722.

pedunculata Ehrh., 722.

Robur $\kappa, L, 722$.

1 $\beta$, L., 722 .

sessiliflora $\mathrm{Sm}$, 722.

\section{R.}

Radiola, 109.

linoides Gmel., 127.

millegrana Sin., 127.

Ranunculus, 403 .

acris L., 42 .

* $\gamma$, multifidus, 422 .

" $\beta$, Steveni, 422 .

aquatilis L., 417.

aquatilis $\beta$, L., 417.

" $\beta$, phellandrifolius Schum., 418.

arvensis L., 425 .

auricomus L., 421.

Borceanus Jori., 422.

bulbosus L., 424 .

circinnatus Sibth., 419.

divaricatus Schrk., 419.

Flammula L., 420 .
Ranuoculus Flammula $\beta$, intermedius, 421.

- $\beta$, radicans, 421.

Ficaria L., 425.

fuitans H., 419.

fluitans Lam., 420.

fluviatilis Web., 420.

hederaceus L., 416 .

hirsutus Curt, 424.

lanuginosus L., 422.

Lingua L., 420.

pantothrix Bert., 418.

" capillaceus DC., 419.

parviflorus I.., 424.

parvulus L., 424.

paucistamineus Tansel, 418.

peltatus Schrk., 417.

Petixeri Koch, 418.

$x$ Philonotis Ehrh., 424.

" $\beta$, parvulus, 424.

polyanthemos L., 423.

" $\alpha$, angustifolius, 423.

" $\beta$, latifolins, 423 .

repens I., 423.

reptans L., 421.

sceleratus L., 416.

tripartitus Nolt., 418.

" $\beta$, obtusiflorus DC., 418.

Raphanistrum segetum Batmg., 4 S7.

Raph anus, $47 \bar{\jmath}$.

Raphanistrum L., 487.

sativus L., 498.

Rapistrun paniculutum Gärtn., 475.

$R$ eseda, 358.

luteola L., 361 .

Rh amnus, 148.

catharticus L., 199.

Frangula L., 199.

Rhinanthus, 45.5.

Crista galli a, 466 .

, $\beta$, L., 465.

major Eluh., 465.

- $\beta$, apterus Fr., 465 .

" $\propto$, platypterus Fr., 465.

minor Ebrls., 466.

Rhyncospora, 21.

alba Vahl, 37.

fusca Vahl, 36.

Ribes, 148.

alpinum L., 201.

Grossularia L., 200.

^ $r$, pubescens, 200.

- $\beta$, glandulosum, 200.

$x$ nigrum L., 200.

rubrum L., 201. 
Ribes rubrinı $\beta$, lencocarpon, 201. Uva crispa L., 200.

Ros a, $56 j$. alba F. D., 377.

canina L., 375.

" alba, 377.

"** collina, 375 .

" * dumetormm, 375.

" e, nitida Fr., 375.

- $\beta$, opaca Fr., 375. ciliato-petala Koch, $\mathbf{5} 77$.

$x$ cinnamomer L., 574.

collina Jacq, $\mathbf{3 7 5}$.

coriifolia Fr., 376 .

x clumetorum Thuill., 375.

fuvialis F. D., 574 .

inodora Fr., 375.

* lucida Ehrh., 374.

mollis Sm., 377.

x mollissima IVilld., 377.

" $\gamma$, arenaria, 377.

" $\beta$, nemoralis, 377 .

pimpinellafolia L., $37 \overline{5}$.

pomifera Herm., 377.

rubiginosa L., 374 .

- $\beta$, horrida, 374.

spinosissima I., 373.

suavifolia Lightf., $\mathbf{3 7 4}$.

* tomentosa 5 m., 576 .

" 8 , alba, 377.

villosa L., 377.

" $\beta$, pomifera, 577 .

Rottboellia filiformis Roth, 48. incurvata Cav., 49.

incurvata antt. scand., 48.

Rudbeckia, 564 .

fulgida Ait., 631 .

Rubia, 107.

$x$ tinctorum L., 120.

$\mathrm{Rubus}, 363$.

affinis Whe., 381.

apiculatus Whe., 387.

Arrhenii Lge., 386.

Bellardi Whe., 387.

Borreri Bell -Salt., 385.

$\alpha$ cxsius L., 391.

" $\beta$, agrestis Whe., 391.

" $\gamma$, aquaticus Whe., 391 .

" $\varepsilon$, hispidus Whe., 388.

" $\delta$, pseudo-idiens Whe., 591.

" $\lessdot$, umbrosus Whe., 391.

carpinifolius Whe., 38.).

Chamamorns L., $37 \mathrm{~S}$.

cordifolius Whe., 382.

corylifolius Sm., 389.
Rubus corylifolius $\gamma$, appendiculatus, $\overline{3} 90$.

$\checkmark \quad \beta$, grandifolius! $\mathbf{3 8 9}$.

" $\beta$, intermedius, 388.

" $\beta$, pruinosus, $\bar{\jmath} 90$.

discolor Whe., 383

" $\alpha$, geminus, 383.

- $\beta$, pubescens, 384 .

* * umbrosus, 383.

dumetorum Whe., 390.

* a, glabratus Arrh., 390.

" $\beta$, tomentosus Whe., 390.

fastigiatus Whe., 380 .

fissus Lindl., 380 .

foliosus Whe., 387.

fruticosus Arrh., 380.

fruticosus Whe., 581 .

glandulosus Bell., 387.

" $\beta$, umbiosus Gorlr., 358.

Güntheri Whe., 388.

livitus Drej., 3S4.

$\times$ hirtus W. K., 386.

Hystrix Whe., 387.

idæus L., 378.

" $\beta$, canescens, 391.

$\quad \beta$, microplyyllus Walls., 379.

Köhleri Whe., 385.

latifolius Bab., 588.

leucostachys $\beta$, vestitus Bab., 384.

macrophyllus Whe., 385.

Menkei Wlie., 387.

nemorosus Науn, 390.

nitidus Whe., $3 S 0$.

plicatus Whe., $5 \mathrm{SO}$.

."** adfinis, 581.

" $\beta$, fastigiatus, 380 .

pruinosus Arrh., 390.

pubescens Whe., 384.

$x$ Radula Whe., 584.

" $\beta$, Köhleri, 385.

rhamnifolius Whe., 382.

rudis Whe., 385.

saxatilis L., 378.

scaber Whe., 386.

Schlechtendalii Whe., 385.

$\times$ serpens Gren. \& Godr., 388.

silvaticus Whe, 35..

Sprengelii Whe., 585.

.* Arrhenii! 386.

suberectus And., 379.

* $\beta$, fissus, 380 .

$x$ thyrsoideus Winm., 351 .

" $\alpha$, eandics' is, 382.

" $\beta$, gracilis, 382 .

" $\alpha$, oblongifolius, 382. 
Rubus umbrosus Whe., 383. vestitus Whe., 384. n $\boldsymbol{\beta}$, viridis, 384 . villicaulis Whe., 385 . vulgaris Whe., 382 .

$\beta$, carpinifolius, 383.

«, numbrosus, 385.

* discolor Arrh., 383.

* Radula Arrh., 384.

Wahlbergii Arrh., 388.

Rumex, 345 .

Acetosa L., 286.

Acetosella L., 287.

acutus L., $28 \tilde{.}$.

acutus H., 284.

aquaticus $\beta$, Drejeri Sond., 281. conglomeratus Nurr., 284.

conspersus Hartm., 283.

crispus L., 282.

cristatus Wallr., 283.

divaricatus L., 284.

divaricatus Fr., 284.

domesticus Hartm., 281.

, latifolius Hartm., 281.

Friesii Gren. \& Godr., 284.

Helolapathrm Drej., 281.

heterophyllus Schultz., 280.

Hippolapathum Fr., 280.

* Helolapathum, 280.

Hydrolapathum Huds., 279.

longifolius DC., 282.

maritinus L., 286.

maximus Schreb., 280.

Nemolapathim Ehrh., 284.

Nemolapathum Wallr., 285.

nemorosus Schrad., 285.

$\beta$, sanguineus, 285.

$\alpha$, viridis, 285.

obtusifolius L., 284.

divaricatus, 284.

obtusifolius Wallr., 284

palustris Sm., 285.

pratensis M. K., 285.

propinquus Aresch., 282.

sanguineus L., 285.

silvestris Wallr., 284.

Ruppia, 109.

brachypus I. Gay, 141.

muritina L., 141.

rostellata Koch, 141.

spiralis L., 140.

s.

Sabulina viscosa Rclıb., 337.

Sagina, 312.
Sagina apetala L., 350 .

n $\beta$, decumbens F. D., 350.

ciliata Fr., 550.

depressa Sihultz, 350.

erecta F. D., 350 ).

maritima Don., 350.

nodosa Torr. \& Gray., 352.

" $\beta$, moniliformis Lge., 352 .

procumbens L., 351 .

" $\beta$, crassifolia Nolt., 351 .

n $\gamma$, spinosa Gibs., 351.

stricta Fr., 349.

$\beta$, maritima Fr, 350 .

subulata 'Torr. \& Gr., 251.

Sagittaria, 656 .

$\times$ sagittrefolia L., 717.

Salicornia, 2.

biennis Afz., 5 .

" radicans Fr., 5 .

$X$ herbacen L., 4.

" c, erecta F. D., 5.

" $\beta$, patula F. D., 5.

radicans $\mathrm{Sm} ., 5$.

Salix, 724.

acuminata Sm., 736 .

acuminata Hoffm., 737.

acuminate Koch, 737.

acutifolia Willd., 732.

affinis Gren. \& Godr., 736.

y alba L., 731.

- $\beta$, coerulea, 731 .

" $\gamma$, vitellina, 731 .

albo-fragilis Rchb, 750 .

ambigua Ehrh., 740.

amygdalina L., 731.

* " a, concolor, 731 .

ү $\beta$, discolor, 732 .

angustifolia IVulf., 742.

arenaria L., 741.

aurita L., 738 .

- $\beta$, fimbriata Lge., 739

aurito-repens Wimm., 740.

caprea L., 738.

caspica hort., 732 .

cinerea L., 737.

$\beta$, aquatica, 737.

cinereo-hastata? 738 .

coerulea Sm., 731.

X cuspiclata Scluultz, 729.

dasyclados Wimm., 736 .

Doniana Sm., 745.

fragili-pentandra Wimm., 729.

fragilis L., 729.

" pendula, 730 .

fusca L., 741 . 
Salix hastata L., 739 .

Helix 1., 735.

incubacea Fr., 740.

incubacea H., 741.

X lanceolata Fr., 736.

- $\propto$, acuminata, 737.

* $\quad \beta$, capreformis, 737.

Meyeriana Willd., 729.

mollissima Ehrh., 734.

monandra Hoffm., 733.

nigricans Sm., 740 .

pentaudra L., 728.

phylicafolia $\beta$, F. D., 740.

plicata Fr., 740.

pruinosa Wendl., 732.

purpurea L., 733.

" $\alpha$, gracilis, 733.

- $\beta$, Helix, 733.

- $\gamma$, Lambertiana, 753.

purpureo-repens IVimm., 743.

purpureo-viminalis Wimm., 734.

repens L., 741.

" $\gamma$, argentea, 741.

" $\beta$, fusca, 741 .

" $\delta$, lejocarpa, 742.

repenti-viminalis Wimm., 742 .

rosmarinifolia L., 742.

x rubra Huds., 733.

Russeliana Sm., 730.

Smithiana Willd., 737.

spathulata Willd., 741.

stipularis Sm., 755.

triandra-viminalis WVimm., 732.

triandra L., 731.

undulata Ehr., 752.

viminalis L., 735.

viminali-caprea Wimm., 736.

viridis Fr., 730 .

vitellina L.. 731.

Salsola, 149.

hirsuta L., 210.

$\times$ Kali L., 210.

Salvia, $\bar{j}$.

pratensis L, 7 .

Sambuens, 156.

Ebulus L., 2.55.

nigra L., 25 .

" $\beta$, laciniata, 234.

racemosa L., 235.

Samolus, 146.

Valerandi L., 186.

Sangu is orba, 108

officinalis L., 126.

Sanicula, 151.

$x$ europæa L., 216.
Saponaria, 310.

$x$ officinalis L., 325 .

Vaccaria L., 325.

Sarothamus, 508.

$x$ scoparius Koch, 519.

valgaris Winm., 519.

Satyrium albidem L., 640.

Epizogium L., 643.

virille L., 642.

Saxifraga, 310.

$\times$ granulata L., 324.

Hirculus L., 323.

tridactylites L., 324.

Scabios a, 106.

arvensis L., 110.

canescens IV. K., 110.

× Columbaria L. 110.

suaveolens Desf., 110

Succisa L., 111.

Scaudix, 155.

Anthriscus L., 231.

Cerefolium L., 231.

odorata L., 233.

x Pecten Veneris L., 232.

Sceptrum Carolinum Rudb., 463.

Sched onorus, 29. asper Fr., $10 \bar{s}$.

- erectus Fr., 105.

$x$ inermis Fr., 104.

serotinus Rostr., $10 \overline{3}$.

sterilis Fr., 102.

tectorum Fr., 102.

Scheuchzeria, 244.

palustris L., 287.

Schoberia na aritima Mey., 210.

Schoeu us, 21.

albus L., 37.

compressus L., 44.

ferrugineus L., 35.

fuscus L., 36.

Mariscus L., 48.

nigricans L., 36 .

rufus Huds., 44.

Scirpus, 21.

acicularis L., 38 .

Bacothryon Ehrh., 39.

bifolius Wallr., 45.

crespitosus L., 40.

Caricis Retz., 44.

carinatus Sm., 42 .

Duvalii Hopp., 42.

fluitans L., 40.

glaucus Sm., 41.

Holoschoenus F. D., 42.

lacustris L., 41. 
Scirpets lacustris $\beta$, glauceıs Fr., 42. maritimus L., 43 .

" $\beta$, monostachys, 43.

" $\gamma$, macrostachys, 45 .

" $\delta$, sphærostachys, 43.

multicaulis Sm., 35.

nanus Spr., 39.

palustris L., 37.

- $\beta$, minor Horn, 37.

parvulus R. S., 39.

pauciflorus Lightf., 39.

1) $\boldsymbol{\beta}$, minor Blytt., 39.

Pollichii Gren. \& Godr., 42.

pungens Vahl, 43.

Rothii Hopp., 43.

rufus Schrad., 44.

1) * bifolius, 45 .

setaceus L., 41 .

silvaticus L., 44.

Taberuæmontani Gm., 41.

- $\beta$, monostachys Lge, 45.

trigonus Nolt., 42.

triqueter L., 42.

uniglumis M. K., 37.

Scleranthus, 309.

anuutus L., 323.

" $\beta$, biennis Fr., 323.

perennis $\mathbf{L}, 323$.

Scolochloa festucacea Link, 76.

Scolopendrin m, 751.

officinarum Sw., 757.

S corzonera, 556 .

$<$ hispanica L., 586 .

humilis L., 585 .

" $\boldsymbol{\beta}$, augustifolia, 586.

" ce, latifolia, 586.

Scrophularia, 432 .

alata Gil., 460 ).

aquatica L., 460.

Ballisii Horn., 461.

Ehrharti Stev., 460.

nodosa L., 461.

vernalis L., 460 .

Scutellaria, 451 .

altissima L., 456 .

commutata Rehb., 456.

galericulata L., 455 .

- $\beta$, liastæermis, 455 .

hastifolia L., 455.

Secale, 25.

cereale L., 57.

Sedum, 512 .

acre L., $\mathbf{5 5 5}$.

" $\beta$, sexangulare Godr., 355.

album L., 554 .
Sedum boloniense Lois., 354.

Ycruciatum Desf., 354.

Fabaria Koch, 358.

Forsterianum Rehb., 355.

lividum Drej., 357.

maximum Sut., 356.

monregalense Balb., 354.

purpurascens Koch, 357.

reflexum L., $\mathbf{3 5 6 .}$

reflexum F. D., 356.

rupestre L., 556 .

* $\alpha$, glaucum, 356 .

" $\beta$, viride, 356.

sexangulare L., 355.

sexangulare DC., 555.

×Telephium L., 356.

* $\boldsymbol{\beta}$, purpureum F. D., 357.

Telephium Rchb., 357.

Selaginella, 752.

spinulosa A. Br , 769.

Selinum, 154.

$\gamma$ Carvifolia L., 227.

lineare Schum., 224.

palustre L., 225.

silvestre L., 224.

silvestre F. D., 225.

Sempervivu m, 559 .

tectorum L., 561 .

Senebiera, 470 .

* Coronopus Poir., 475.

Senecio, 563 .

aqnaticus Huds., 625.

" $\beta$, pinnatifidus, 626 .

barbarecefolius Rchb., 626.

campestris DC., 627.

denticulatus Miill., 623.

erucrefolius L., 625.

Y Jacobæa L., 625.

paludosus L., 626.

palustris DC., 627.

pratensis Richt., 626.

salicetorum Godr., 626.

saracenicus L., 626 .

silvaticus L., 625.

vernalis W. \& K., 624 .

viscosus L., 624.

vulgaris L , 623.

" $\beta$, radiatus Koch, $62 \bar{j}$.

Serapias ensifolia Sm., 644.

grandiflora Scop., 644.

latifolia L., 645.

- $\boldsymbol{\beta}$, atrorubens, 647.

longifolia L., 645.

microphylla Ehrh., 646.

palustris Scop., 645. 
Serapias rubra L., 644.

Serratula, 557. arvensis L., 598

$\times$ tinctoria L., 590 .

Setaria, 24.

gliuca Beauv., 61. verticillata Beauv., 61.

y viridis Beauv., 61. m

Sherardia, 106.

$x$ arvensis L., 112.

Silene, 310.

alglica L., 352.

- Armeria L, 330. gallica L., 352.

+ inflata Sm., 329.

y " $\beta$, petræa, 330 .

infracta Bess., 332.

y maritima IVith, 330 .

noctiflora L., 314.

$x$ nutians L., 33 l.

Otites Sm., 351.

quinquerulnera L., 332.

Saponaria Fr., 325 .

silvestris Rehb., 332.

viscosa Pers., 532.

Sily b um, 55 S.

marianum Gärtı., 599.

Sinap is, 474 .

alba L., 499.

* arvensis L., 498.

$\quad \beta$, lispida, 499.

" b, Schkuhriana, 499.

nigra L., 498.

orientalis Schk., 499.

Sison inundatum L., 217.

Si s y m b r i $\mathrm{m}, 474$.

Alliaria Scop., 500.

amphitiume L., 486.

anceps Whllog., 487.

arenosum L., 495.

Irio L., 500 .

islandicum F. D., 487.

Loeselii L., 500 ).

Nasturtium L., 485.

ofticinale Scop., 499. palustre Leyss., 487.

silvestre L., 486 .

\. Soplia L., 500.

tennifolium L., 496.

Thalianum Gay, 495.

Sium, 152.

angustifolium L., 221.

Falcaria L., 2201.

latifolium I., 221.

nodiflorum F. D., 221.
Sirm repens Jacq., 217.

Solanum, 144.

× Dulcamara L., 169.

" $\delta$, laciniatum, 170.

" $\gamma$, marinum, 170 .

- $\beta$, tomentosum, 170.

humile Beruh., 169.

miniatum Bernh., 169.

* nigrum L., 168.

- humile, 169.

" miniatum Rchb., 169.

" villosum F. D., 169.

tuberosum L., 168.

villosuin Lam., 169.

Solidag $0,562$.

$x$ canadensis L., 620 .

$\times$ Virga anrea L., 619.

Sonchus, 555.

arvensis L., 56 S.

" $\beta$, integrifolius Lge., 569 .

" $\gamma$, lievipes Koch, 569 .

asper Vill., 569.

" $\beta$, inermis Bisch., 569.

macrophyllus Willd., 568.

maritimus Retz., 569.

Yoleracens L., 570.

` asper H., 569.

palustris L., 568.

Plumieri L., 568.

Sorbus, 365.

7) Aria Crtz., 368.

ancuparia L., 370.

" $\beta$, integerrima, 370 .

fennica Kalm., 369.

hybrida L. fil., 369.

intermedia H., 369.

scandica Fr., 369.

torminalis Crtz., 368.

Sparganium, 654 .

erectum L. $(\alpha-\beta), 670-71$.

mininum Fr., 670 .

natans autt, 670 .

natans L, 671).

ramosum Huds., 671.

simplex Huds., 670.

Spartium scoparium L., 519.

Spergella nodosa Rchb., 352.

subulata Rehb., 351.

Spergula, 312.

$x$ arvensis L., 352.

" $\beta$, sativa, $35 \bar{j}$.

" $\alpha$, vulgaris, $35 j$.

arvensis Rehb., 353.

laricina F. D., 351.

maxima Whe., 353. 
Spergula Morisonii Boreau, 353. nodosa I., 352.

pentandra L, 354 .

pentandra autt. Scaud., 353.

subulata Sw., 351.

vernalis Willd., 353.

Spergularia mura Pers., 333.

" $\boldsymbol{\beta}$, pinguis, $\mathbf{3 3 4}$.

Spiræa, $\mathbf{j 6 3}$.

denudata Hayne, 572.

x filipendula L., 371 .

salicifolia L., 372.

tomentosa L., 373.

ulmaria L., 372.

" $\beta$, concolor! 372.

" $\alpha$, discolor Koch, 372.

Spiranthes, 635.

autumualis Rich., 619.

Spirodela polyrrhiza Schleid., 668.

St achys, 428 .

anzligua Sm., 437.

annua L, 438.

arvensis L., 438.

Betonica Bentl., 440.

palustris L., 437.

" $\beta$, canescens, 437.

palustri-silvatica Schied., 437.

segetum Hagen, 437.

silvatica L., 457 .

Statice, 157.

Armeria L., 240.

Armeria F. D., 235.

Behen Drej., 257.

bahusiensis Fr, 238.

elongata Hoffm., 239.

Limonium L., 237.

rariflora Drej., 238.

" $\beta$, borealis Fr., 238.

$n \alpha$, danica Fr., 238.

Staurogeton trisulcum Relıb., 667.

Stellaria, 311.

crassifolia Elırh., 339.

, $\boldsymbol{\alpha}$, elodes M. B., 339.

" $\beta$, brevifolia Rafn, 339.

glauca With., 340.

gramiuea L., 541.

" $\alpha$, grandiflora, 341.

- $\beta$, parviflora, 311 .

- $\gamma$, spathulata, 341 .

Holostea L, 359 .

media Sm., 341.

" $\gamma$, apetala, 342.

- $\beta$, neglecta, 342.

* $\alpha$, vulgaris, 342.

nemorum L., 312.
Stellaria neglecta Whe., 342. palustris Retz., 340.

" $\quad$, glauca, 340 .

- $\beta$, viridis, 340 .

uliginosa Murr, 310.

Stenactis, 562 .

annua Cass., 622.

bellidiflora A. Br., 622.

speciosa Lindl., 621.

Stenhammaria, 142. maritima Rchb., 159.

Stratiotes, 727.

aloides L., 749 .

Struthiopteris, 751.

europcea Drej., 762.

germanica Willd., 762.

Sturmia, 635.

Loeselii Rchb., 650.

Suceda maritima Dumort., 210.

Subularia, 472 .

aquatica L., 484.

Suce is a, 106.

$x$ pratensis Mönch, 111.

Sym phy tum, 1.43.

y officinale L., 166.

orientale L., 167.

patens Sibth, 167.

Syringa, 3 .

vulgaris L., 8.

\section{T.}

Tanacetum, 560 .

corymbosum Schultz, 612.

Leucanthemum Schultz., 611.

Parthenium Schultz, 612.

vulgare L., 605.

Taraxacum, 555 .

erythrospermum Andrz., 566. officinale Web., 565.

* $\beta$, arenarium Drej., 566.

" $\beta$, glancescens, 566 .

" $\varepsilon$, lividum, 566.

" $\gamma$, palustre, $566^{\circ}$. palustre DC., 566.

Taxus, 727.

Y baccata L., 750.

Teesdalia, 471 .

nudicaulis R. Br., 477.

Telmatophace gibba Schld., 668.

Tenageja Vaillantii 'Thuill., 268.

Tetragonolobus, 510 .

maritimus Roth, 537.

siliquosus Roth, 537. 
Tetragonolobus siliquosus $\beta$, maritimus Ser., 537.

Teucrium, 429.

1 Chamædrys L., 446.

Scordium L., 446.

Tha lietrum, 403 .

dubium Schum., 414.

elatum H., 414.

* flavam L., 415.

flexuosum Rchb., 415.

majus Rchb., 415.

minus L., 414.

simplex L., 414.

Thelaia chlorantha Alef., 321. intermedia Alef., $\mathbf{3} 21$. rotundifolia Alef., 321.

Thesium, 148.

ebracteatum Hayn., 202.

" $\beta$, subbracteatum, 203. pratense $H_{\text {., }} 202$.

Thlaspi, 472 .

arvense L., 479.

Bursa pastoris L., 479.

campestre L., 478.

Thrincia, 557.

hirta Roth, 586 .

Thymus, 430.

Acinos L., 453.

angustifolius Pers., 452.

Chamædrys Fr., 453.

" $\alpha$, capitatus, 453 .

" $\beta$, verticillatus, 453.

Serpyllum L., 452.

" $\beta$, vulgaris Rchb., 453.

vulgaris L., 453.

Thysselinum palustre Hoffm., 225.

Tilia, 401.

europcea Sm., 407.

grandifolia Ehrh., 406.

intermedia DC., 407.

microphylla Willd., 407.

parvifolia Ehrh., 407.

pauciflora Hayn., 407.

platyphyllos Scop., 407.

vulgaris Hayn, 407.

Tilloea aquatica Lam., 127. prostrata Schk., 127.

Tiniaria Convolvulus Drej., 278. dumetorum Drej., 279.

Fordylium Anthriscus L., 230. nodosum L., 250.

Torilis, 155.

× Anthriscus Gm., 230.

X nodosa Gärtn., 230.

Tormentilla erecta L., 396.
Tormentilla reptans L., 397.

Tragopogon, 556.

minor Fr., 585.

porrifolius L., 584.

pratensis L., 585 .

n $\beta$, tortilis Mey., 585.

pratensi-porrifolius Rostr., 584.

Trapa, 107.

natans L., 124.

Trichera arvensis Schrad., 110.

Trientalis, 260.

europæa L., 291.

Trifolium, 510.

agrarium L., 544.

" $\beta$, brevipes, 544.

agrarium Poll., 543.

alpestre L., 530 .

arvense L., 548.

aureum Poll., 544.

dentatum W. K., 541.

filiforme DC., 543.

filiforme L., 542.

flexuosum Jacq., 549.

fragiferum L., 547.

hybridum L., 546.

medium Is., 549.

" $\beta$, strictum Htm., 550.

Melilotus officinalis L., 511.

micranthum Viv., 542.

minus Sm., 545.

montanum L., 545.

ornithopodioides L., 540.

pratense L., 549.

" $\gamma$, parviflorum Bab., 549.

- $\quad \beta$, sativum Sehreb., 549.

procumbens L., 543.

, $\beta$, campestre, 544 .

" $\alpha$, majus, 544.

repens L., 546 .

" phyllanthum, 546 .

resupinatum L., 547.

spadiceum L., 544.

striatum L., 548.

" $\beta$, strictum Drej., 548.

Triglocli in, 244.

maritimum L., 288.

palustre L., 288.

Trigonella, 510.

ornithopodioides DC., $\mathbf{5 4 0 .}$

Triodia, 26.

decumbens Beauv., 69.

Tripleurospermum inodor. Schultz, 612.

maritimum Schultz., 613.

Trisetum, 27. 
Trisetum flavescens Beauv., 80 .

Tritionm, 23.

acutum DC., 54.

acutum Fr., 53.

cestivum L., 57.

adfine Deth., 54.

caninum Schreb., 56 .

hebestachyum Fr., 53.

hibernum L., 57.

junceum L., 53.

laxun Fr., 54.

littoreum Schum., 54.

repens L., 55.

". $\beta$, maritimum Koch, 56 .

strictum Deth. 53.

turgidum L., 57.

vulgare Vill., 56.

" $\ll$, xstivum, 57.

" $\beta$, hibernum, 57.

Trollius, 404.

europæus L., 426.

Tulipa, 241.

Xilvestris L., 250.

Tunica prolifera Scop., 326.

Turritis, 474 .

glabra L., 496.

hirsuta L., 494.

Tussilago, 559.

alba L., 602.

Farfara L., 603.

hybrida L., 602.

Petasites L., 602.

ramosa Hopp., 602.

spuria Retz., $60 \overrightarrow{3}$.

Typha, 654 .

angustifolia L., 669.

latifolia L., 669.

\section{U.}

Ulex, 508.

europæus L., 517.

Ulmus, 150.

campestris H., 211.

* campestris Sm., 211.

" $\beta$, suberosa, 212.

effusa Willd, 212.

montana Sm., 211.

pedunculata Foug., 212.

suberosa Ehrh., 212.

Urtica, 655.

dioeca L., 706.

urens L., 705.

Utricularia, 4.
Utricularia Bremii Heer., 19. intermedia Hayn., 18.

major Schmid, 18.

minor L., 19.

neglecta Lehm., 18.

pulchella Lehm., 19.

vulgaris L., 17.

\section{V.}

Vaccaria pyramidata Fl. Wett., 325.

V a c cinium, 292.

Myrtillus L., 303.

× Oxycoceos L., 304 .

Yuliginosum L., 303.

" $\beta$, macrocarpum Drej., 303.

Vitis idæa L., 303.

Valeriana, 20.

anqustifolia Tausch., 51 .

y dioeca L., 50.

Locusta a, olitoria, 32.

n $\delta$, dentata, 29.

officinalis L., 31 .

" $\beta$, angustifolia, 31.

1) $\beta$, minor Koch, 31.

olitoria F. D., 32.

sambucifolia Mik., 31 .

Valerianella, 20.

dentata Poll., 32.

eriocarpa Desv., 33.

Morisonii DC., 32.

" $\beta$, dasycarpa Rchb., 32.

" $\alpha$, lejocarpa Koch, 32.

olitoria Poll., 32.

" $\beta$, lasiocarpa Rchb., 32.

Verbascum, 144. adulterinum Koch, 174.

Blattaria L., 174.

collinum Schrad., 174.

cuspidatum Schrad., 172.

Ly chnitis L., 173.

nigro-lychnitis Schied., 175.

nigro-thapsus Fr., 175.

nigrum L., 173.

" $\beta$, thyrsoideum Koch, 173. phlomoides Drej., 172.

phlomoides L., 171.

Schiedeanum Koch, 175.

Schraderi Mey., 172.

thapsiforme Schr., 172.

" $\beta$, cuspidatum, 172.

thapsiformi-nigrum Schied., 174.

thapso-nigrum Schied., 174.

Thapsus L., 172. 
Verbena, 431. officinalis L., 456.

Veronica, 3 . agrestis $\mathrm{L}$. (Fr.), 10. " $\beta$, calycida, 10 . agrestis F. D., 9.

* Anagallis L., 16. arvensis L., 11 .

พ Beccabunga L., 16. Buxbaumii Ten., 9.

Chamedrys L., 15.

" $\beta$, parviflora, 15.

( hederæfolia L., 8 . " $\beta$, umbrosa Mort., 8. latifolia L., 14.

$\checkmark$ longifolia L., $1 \overrightarrow{5}$. maritima F. D., 13.

y montana $\mathrm{I}_{\lrcorner .}, 15$.

officinalis L., 14.

" $\beta$, decolorans, 15.

opaca Fr., 10.

parmularia Poit., 16.

peregrina L., 12.

$\checkmark$ persica Poir., 9.

polita Fr., 9.

pseudo-Chamcedrys Jacq., 14.

scutellata L., 15.

" $\beta$, villosa Schum., 16.

x serpyllifolia L., 12.

spicata L., 12.

" $\beta$, integrifolia, 13.

triphyllos L., 11 .

verna $L ., 11$.

versicolor (Fr.), 10.

Viborgia Acmella Roth, 616.

Viburnum, 156.

y Opulus L., 254.

\& $\beta$, roseum R. \& S., 234.

Vicia, 509 .

yangustifolia Roth, 529.

" $\beta$, segetalis, 529.

cassubica L., 525 .

Cracca L., 526.

- $\quad \beta$, leptophylla Fr., 526.

dumetorum L., 528.

Faba L., 530 .

hirsuta Koch, 5.50.

lathyroides L., 529.

Orobus DC., 525.

sativa L., 528 .

segetalis 'Thuill., 529.

sepium L., 528 .

silvatica L., 525.

tenuifolia Roth, 526.

tetrasperma Koch, 530.
Vicias villosa Roth, 527.

Villar,ia nymphoides Vent., 179.

Viucar 146.

minot L., 186.

Vincetox ic um, 150.

officinale Mönch, 212.

Viola, 147.

arenaria DC., 195.

arvensis Murr., 198.

$f$ canina L., 195.

" $\beta$, lucorum Fr., 196.

" $\gamma$, minor, 196.

" silvatica H., 195.

" $\quad \beta$, sabulosa Rchb., 196.

× epipsila Ledeb., 192.

ericetorum Schrad., 195.

flaricornis Sm., 196.

hirta L., $19 \bar{s}$.

lactea Nolt., 196.

lancifolia Thore, 196.

mirabilis L., 194.

nemoralis Kütz., 196.

x odorata L., 194.

$\gamma$ * $\beta$, alba, 194.

palustris L., 192.

persicafolia Schreb., 197.

pratensis M. K., 197.

punila Vill., 197.

Riviniana Rehb., 195.

Ruppii Rchb., 196.

sabulosa Bor., 198.

scanica Fr., 192.

Y silvatica Fr., 195.

* $\beta$, macrantha Fr., 195.

silvestris Kit., 195.

* stricta Horn., 196.

" $\beta$, humilis, 196.

tricolor L., 197.

* $\beta$, angustifolia, 198.

" $\varepsilon$, arvensis, 198.

- $\delta$, arenaria, 195.

- $\gamma$, hortensis, 198.

" $\zeta$, syrtica, 198.

" , vulgaris, 198.

uliginosa Schrad., 193.

Vis caria, 312.

purpurea Wimm., 344.

$\mathrm{Viscum}, 725$.

album L., 744.

Vulpia, 29.

bronoides Link., 98.

myuros Gmel., 98.

pseudo-myuros Rchb., 98.

sciuroides Gmel., 98. 
W.

Wahlenbergiahederacea Rchb., 190. Waldschmiedia nymphoides Web., 179.

\section{$\mathbf{X}$.}

Xanthium, 658. strumarium L., 723.

\section{$\mathbf{Z}$.}

Zannichellia, 652. brachystemon Gay., 661. gibberosu Rchb., 661.
Zannichellia macrostemon Gay., 661.

palustris L., 660 .

n $\beta$, major, 661 .

- $\alpha$, repens, 661 .

pedicellata Fr., 661 .

pedunculata Rchb., 661. polycarpa Nolt., 661 .

" $\beta$, tenuissima, 661 .

repens Boenn., 661.

Zostera, 652 .

marina L., 659.

$\beta$, angustifolia, 660 .

minor Nolt., 660.

nana Koch, 660.

nana Roth, 660.

Noltei Horn., 660. 


\title{
Alfabetisk Fortegnelse
}

\author{
over \\ de danske Plantenavne.
}

(Slagtnavnene ere trykte med opretstaaende Typer, de meest bekjendte og i Folkesproget optagne Navne for enkelte Arter med Cursiv).

A.

Aakande, 409.

Abeblomst, 462 .

Abild, 370.

Aftenstjerne, 488 .

Agermaane, 560 .

Agertidsel, 598.

Akeleie, 411 .

Alant, 617.

Amarant, 704.

Andefod, 207.

Andemad, 667.

Angelik, 228.

Arum, 659.

Arve, 185.

Ask, 4.

Asparges, 247.

Aster, 621.

Astragel, 522.

Avnbog, 720.

Avnknippe, 417.

Axelbcer, 368.

B.

Baandpile, 752.

Bakkestjerne, 620.

Bakketidsel, 599.

Ealdersbraa, 612.

Baldrian, 50.

Barsvælg, 443.
Bede, 204.

Beenbræk, 259.

Beenved, 124.

Berberisse, 244.

Betonie, 440.

Bibernelle, 720 .

Bingelurt, 74 ?

Birk, 707.

Bitterblad, 123.

Bittermalk, 588 .

Bjørneklo, 226.

Blaabcer, 303.

Blaahat, 110.

Blaastjerne, 112.

Blaatop, S4.

Bladhoved, 594.

Blommetrce, 365.

Blærebæeger, 167.

Blærerod, 17.

Blcere-Smelle, 329.

Boghvede, 305.

Bokar, 112.

Braadfro, 723.

Brandbæger, 623.

Brasenfode, 763 .

Bridurt, 203.

Bromber, 380.

Brudelys, $30 \mathrm{~S}$.

Bruskbæger, 202.

Bruunrod, 460.

Brcendencelde, 705.
Brændeskjærm, 224.

Brøndkarse, 485.

Brondsel, 599.

Bukkeblad, 179.

Bulkketorn, 170.

Bukkehorn, 540.

Bulmeurt, 170 .

Bunke, 78.

Burre, 588.

Byg, 57.

Bynke, 604 .

Bxegerbrægne, 761.

Bækarve, 307.

Bændeltang, 659 .

Bcevreasp, 747.

Bævregræs, 85.

Bog, 721.

Bølle, 303.

Bønne, 524.

C.

Centunkel, 123.

Christtorn, 127.

Cikorie, 565.

\section{D.}

Dansk Ingefer, 659.

Desmerurt, 306.

Dild, 227. 
Djævelsbid, 111.

Dodder, 480.

Druemunke, 406.

Dueurt, 294.

Duunlammer, 669.

Dværgbunke, 80.

Dværgulvefod, 769 .

Dyndurt, 457 .

Dovncelde, 440.

\section{E.}

Edderkopurt, 258.

Eg, 722.

Ene, 746.

Engblomme, 426.

Engelshigrces, 239.

Engelsød, 763.

Engeskijor, 590.

Engkarse, 492.

Entian, 177.

Esparsette, 522.

Evighedsblomst, 606 .

\section{F.}

Faareleger, 239.

Falsl Jasmin, 366 .

Femfingerurt, 398.

Festgres, 75.

Fiirkløft, 606 .

Fürling, 349 .

Fingerax, 61.

Fingerbolle, 461.

Föoringras, 66.

Fireblad, 306.

Fladax, 35.

Fladbælle, 531.

Fladkıap, 641.

Fladstjerne, 539 .

Fliglæbe, 647.

Flipkrave, 477.

Flitterax, 74 .

Flok, 176.

Flueblomst, 643 .

Fløielsgrces, 76.

Fnokurt, 627.

Fodangel, 230.

Foldfros, 229.

Forglemmigei, 160.

Fredløs, 183.

Fruebcer, 378.

Frytle, 270.

Frobid, 749.

Fropeber, 416.
Frøstjerne, 413.

Fuglegraes, 341.

Fuglekirsebcertrce, 366.

Fugleklo, 52?.

Fugleliim, 744.

Fuglemælk, 258.

Fuglerede, 648.

Fyr, 666.

Følfod, 603.

\section{G.}

Gaasefod, 204.

Gaasemad, 494.

Gaaseurt, 614 .

Gabeklap, 499.

Galdebær, 725.

Galnebær, 167.

Galtetand, 457.

Gedeblad, 191.

Gederams, 294.

Gedeskjæg, 584.

Gemserod, 622 .

Gifttyde, 220.

Gipsurt, 325.

Gjæslingblomst, 482.

Gjøgemad, 503.

Gjogeurt, 635 .

Glandsfrø, 63.

Glandstraad, 773.

Glatbælle, 535.

Gran, 666 .

Gulddusk, 18 ว.

Guldhavre, 80.

Guldregn, 519.

Guldstjerne, 250.

Gulerod, 229.

Guulax, 64 .

Gyldenriis, 619.

Gyvel, 519.

Gyvelqvæler, 468.

\section{H.}

Halvsvøb, 224.

Hamp, 745.

Hanekro, 434.

Hanespore, $6 \tilde{3}$.

Haremad, 564.

Haregre, 216.

Hassel, 720.

Havgræs, 140.

Havre, 81 .

Hedelyng, 302 .

Heire, 99 .
Heiresvingel, 102.

Hestebønne, 530.

Hestegræs, 76 .

Hestehov, 602.

Hestekastanie, 290.

Hestetunge, 159.

Hindbcer, 378.

Hindebæger, 237.

Hindeknæ, 555.

Hirse, 62.

Hjelme, 67.

Hjertelæbe, 650 .

Hjertensfiryd, 454 .

Hjertespand, 443.

Hjorterod, 223.

Hjortetrøst, 601.

Hjortetunge, 757.

Hjulkrone, 165.

Hjørneklap, 482.

Hornblad, 719.

Horndrager, 659 .

Hornnød, 124.

Hornskulpe, 406.

Humle, 745 .

Hundegræs, 104.

Hundehor, 480 .

Hundesalat, 586.

Hundetunge, 161.

Hunllæbe, 645 .

Huulsvob, 232.

Huuslgg, 361 .

Hvede, 56.

Hvene, 72.

Hvidblomme, 246.

Hvidroe, 497.

Hvidtorn, 367.

Hyld, 234.

Hyrdetaske, 479.

Hogebartrce, 366.

Høgeskjæg, 570.

Høgeurt, 572.

Hønsebar, 123.

Hønsetarm, 345.

Hør, 502.

Horsilke, 213.

\section{J.}

Jernurt, 456 .

Jordbær, 392.

Jordbærspinat, 207.

Jordrgg, 511.

Jordable, 631.

Jødekirsebcer, 167. 
$\mathbf{K}$.

Kaal, 496.

Kaalrabi, 497.

Kabeleje, 426.

Kalmus, 272.

Kambregne, 762.

Kambunke, 77.

Kamgraes, 105.

Tiameelblomster, 615.

Kamille, 612.

Tianariegrces, 63.

Kantbælle, 537.

Karse, 477.

Kartebolle, 111.

Kartoffel, $16 \mathrm{~S}$.

Kastanietræe, 721.

Katost, 505.

Kattefod, 608.

Kattehale, 559.

Katteskjæg, 48.

Katteurt, 444.

Keiserkrone, 249.

Kiddilee, 457.

Kilebæger, 717.

Kirsebcertrce, 565.

Kjælderlıals, 504.

Kjollingtand, $5 \tilde{5} 6$.

Kjomper, 120.

Kjornld, 45.

Klaseskj:erm, 221.

Klinte, 342.

Klokke, 187.

Klokiehyacinth, 249.

Klynger, 378.

Kloftnaal, 477.

Kløver, 542.

Kløvkrone, 349.

Kløvplade, 483.

Knavel, 525.

Knopurt, 628.

Knælæbe, 643

Kobjælde, 412.

Kodriver, 180.

Koføde, $46 \overline{3}$.

Kogleax, 39 .

Kolleare, 481.

Kommen, 219.

Kongebrægne, 74.

Kongelys, 171.

Kongepen, 583.

Konval, 247.

Koralrod, 649.

Korbor, 391 .

Koriander, 233.
Kornblomst, 650.

Kornel, 123.

Korsknop, 444.

Kortlæbe, 446.

Kragefod, 599.

Krageklo, 519.

Krandsbørste, 454.

Krandsnaal, 780.

Krap, 120.

Krebsklo, 749.

Krognaal, $48 \vec{\jmath}$.

Krop, 32.

Krumhals, 166.

Krydermynte, 451.

Kræge, 364.

Krrekling, 743.

Kulsukker, 166.

Korvel, 23 ].

L.

Laktuk, 567.

Lambertsnød, 721.

Langnab, 232.

Leverurt, 237.

Liguster, 7.

Liimurt, 329.

Lilie, 250.

Lilielionval, 247.

Lind, 407.

Lindse, 550 .

Linnæea, 456.

Lobelie, 186.

Lostilk, 22.5.

Lucerne, $53 \mathrm{~S}$.

Lungeurt, 159.

Lyng, 302.

Læbel 6 s, 445.

Læerkespore, 512.

Lærketræ, 667.

Løg, 253.

Løgurt, 500.

Lon, 300 .

Løvefod, 125.

Løvemule, 460.

Luvetand, 587.

Løvstikke, 227.

\section{II.}

Maanerude, 765.

Maiblomst, 125.

Malurt, 604.

Mandstro, 215.
Mangeløv, 758.

Mannagrces, 58.

Marehalm, 60.

Marietidsel, 599.

Narube, 454 .

Matrem, 612.

Meelbærris, 522.

Merian, 452.

Mesterrod, 225.

Miliegraes, 74.

Miltbrægne, 757.

Milturt, 305 .

Mistel, $\mathbf{3 6 8 .}$

Misteltein, 744.

Mjødurt, 37I.

Morbærtre, 708.

Morgenfrue, 631.

Multebcer, 578.

Mmne, 190

Musehale, 425.

Museurt, 608.

IIuurmude, 756.

Mygblomst, 650 .

Mynte, 446.

Mysike, 112.

Mysse, 272.

Mælde, 709.

Mælkebøtte, 565.

Mælkurt, 515.

Mærke, 221.

N.

Naadesurt, 17.

Naalebæger, 202.

Najade, 660.

Narcis, 246.

Natlys, 299.

Natskyage, 168.

Naur, 300.

Nellike, 526.

Nellikerod, 399.

Norel, 357.

Nyserod, 427.

Nabfro, 36.

Nælde, 705.

Nokkerose, 408.

\section{0.}

Onde Urter, 611.

Oxetunge, 166.

Oxeøie, 611. 
P.

Paaskelilie, 246.

Padderokke, 771.

Pastinak, 226.

Peberrod, 4 S5.

Pebertrce, 304.

Pengeurt, 479.

Perikon., 551.

Persille, 218.

Pestilensurt, 540.

Pibeved, 366.

Pigfres, 161.

Pigæble, 171.

Piil, 728.

Piilblad, 717.

Pilledrager, 770 .

Pimpinelle, 219.

Pindselilie, 246.

Pindsviinknop, 670.

Poppel, 746.

Pors, 744.

Poselabe, 642.

Potentil, 393.

Pragtstjerne, 348.

Pralbønne, 524.

Prunel, 454.

Prcestekrave, 610.

Pnkkellæbe, 642.

Paretrce, 570.

\section{Q.}

Qvalkved, 234.

Qvan, 228.

Qvik, 52.

Qvæde, 371.

Qvæsurt, 126.

R.

Radel $ø$ v, 755.

Raigræs, 49.

Randfro, 230.

Ranunkel, 420.

Rapgræs, 88.

Raps, 497.

Rapuntzel, 190.

Ravnefod, 475.

Reddike, 487.

Regnfang, 605.

Revlingbar, 743.

Ribs, 201.

Ridderspore, 410.

Riisgres, 60.
River, 160.

Roe, 497.

Rose, 373.

Rosmarinlyng, 322.

Rottehale, 66 .

Rug, 57.

Rundbælle, 520.

Rundskulpe, 475 .

Runkelroe, 204.

Rævehale, 65.

Rødbede, 204.

Rødkna, 257.

Rødtop, 467.

Røllike, 615.

Røn, 368.

$\mathrm{Rør}, 68$.

Rørgres, 63.

Rørsvingel, 76.

S.

Safran, 34.

Salat, 568.

Salomons Lysestage, 478.

Salomons Segl, 248.

Salturt, 4.

Salvie, 7.

Samel, 186.

Sanct Hansurt, 356.

Sandkryb, 202.

Sandskjæg, 79.

Sandvaaner, 337.

Sanikel, 216.

Seglblad, 220.

Seline, 227.

Selleri, 218.

Senep, 498.

Simmer, 411.

Singrøn, 186.

Siren, 8.

Siv, 260.

Skabiose, 110.

Skarntyde, 233.

Skavgraes, 774.

Sliedeknæ, 273.

Skeeblad, 288.

Skjaller, 465.

Skjoldbrægne, 757.

Skjolddrager, 455.

Skjælrod, 468.

Skjæne, 35.

Skjær, 590 .

Skjæermax, 61.

Skjærmlille, 217.
Skorem, 255.

Skorzonere, 585.

Skovarve, 338.

Skovlilie, 644.

Skovmcerke, 112.

Skovstjerne, 291.

Slirueax, 649.

Skræppe, 279.

Slaaentorn, 364.

Slangehoved, 158.

Slangerod, 651.

Slangetunge, 766 .

Smalstraale, 622 .

Snelle, 329.

Smorblonst, 425.

Sneebolletrae, 254.

Snegleballe, 538.

Snerle, 175.

Snerre, 115.

Snittebønne, 524.

Snylterod, 301.

Sodaurt, 210.

Solbar, 200.

Soldug, 256.

Solsikke, 631 .

Solgie, 405.

Sommerraps, 497.

Spansk Hyben, 577.

Spansk Korvel, 233.

Spergel, 352.

Spidsgal, 105.

Spidshale, 48.

Springbalsamin, 198.

Spring fro, 198.

Springklap, 489.

Springkuap, 125.

Sqvalderkaal, 218.

Star, 671.

Stedmodersblomst, 197.

Steenbræk, 325.

Steenfrø, 158.

Steenkløver, $5 \mathbf{4 0 .}$

Steenurt, 354 .

Steffensurt, 5 .

Stjerneskjærm, 216.

Stiklielsbcer, 200.

Stilkax, 51 .

Stokrose, 504.

Stolthenrik, 209.

Storkenæb, 313.

Stormhat, 410.

Storskjærm, 225.

Strandarve, 337.

Strandgaasefod, 210. 
Strandbo, 705.

Strandkaal, 477.

Strandmalurt, 604.

Straudsennep, 476.

Strandert, 5.5.5.

Strudsvinge, 762.

Suktertop, 249.

Sumpstraa, 57.

Sucurlilover, 503.

Svalerod, 212

Svaleurt, 406.

Srinemælk, 568 .

Svinerie, 565.

Svingel, 93.

Srovlrod, 225.

Sværdlilie, 34.

Sværtevæld, 7.

Sylblad, 484.

Syre, 286.

Sæbeurt, 325.

Sækbæger, 484.

Sodgræs, 85.

Sødskjærm, 233.

Solvblad, 599.

Solvpoppel, 746.

\section{T.}

Taarnurt, 496.

Tagrør, 84.

Takkeklap, 476.

Tandbæger, $4.5 \mathrm{~S}$.

Tandbrlg, 77.

Tandrod, $48 S$.

Tangurt, 210.

Taxtræ, 750 .

Tidløs, 287.

Tidse, 744 .

Tidsel, 591.

Tirlselkugle, 632.

Timian, 452.

Timotheigrces, 66.

Tjarenellike, 344 .
Tornblad, 517.

Torskemund, 457.

Traadspore, 640 .

Tranebcer, 304.

Tranehals, 519.

'Trehage, 288.

Troldurt, 463.

Trævlekrone, 544 .

'T'ulipan, 250.

Tusindblad, 718.

Tusindfryd, 610.

Tnsindfr

Tusindgylden, 176.

'Treblad, 359 .

Tvetand, 440 .

Tyttebcer, 303.

'Treppegras, 85.

Torstetrce, 199.

U.

Ulvefod, 766.

\section{V.}

Vaarforglemmigei, 161.

Vaid, 475.

Valbirli, 300.

Valmue, 404.

Valnodtræ, 722.

Valst: Bønne, 530.

Vandarve, 33.

Vandax, 128.

Vandlarse, 491.

Vandkrands, 660 .

Vandkryber, 245.

Vandnavle, 215.

Vandpeberrod, 486.

Vandrollike, 183.

Vandspiir, 2.

Vandstjerne, 662.

Van, 561 .

Vedbende, 201.
Veibred, 120.

Vibefedt, 17.

Vibereg, 249.

Vidie, 757-58.

Vikke, 525.

Vild Persille, 224.

Vild Rosmarin, 322.

Vinterblomme, 426.

Vintergjaek, 245.

Vintergrøn, 319.

Vinterkarse, 493.

Vinterraps, 497.

Viol, 192.

Visse, 517.

Voldtimian, 453.

Volverlei, 627.

Vortemelk, 664.

Vorterod, 425.

Vrietorn, 199.

Væselhale, 98.

Y.

Ypern, 211.

E.

Abletrce, 370.

Edelgran, 666.

El, 706.

Alm, 211.

Arenpriis, 8.

Atretrce, 300.

Art, 551.

Aselsfoder, 591.

$\boldsymbol{\theta}$

Oientrøst, 466.

Oruebræone, 762 .

Orneøie, 572. 



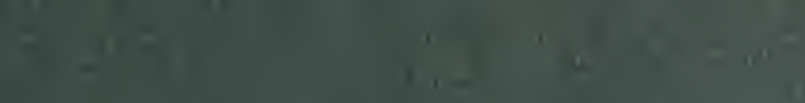

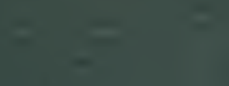

$$
\begin{aligned}
& =2 \\
& =-1
\end{aligned}
$$

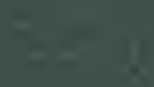

1

1

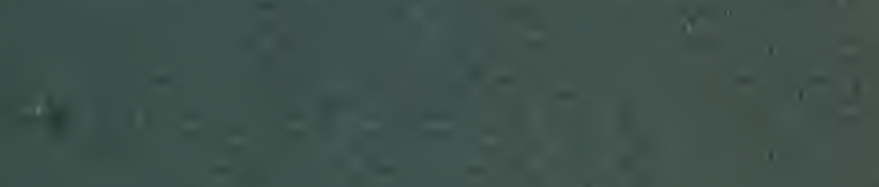

$\sqrt{3}$

$$
1+20
$$

$=$

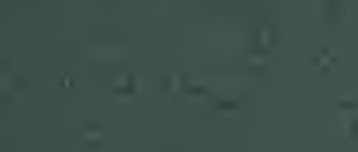

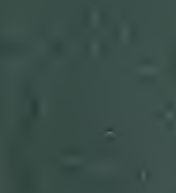

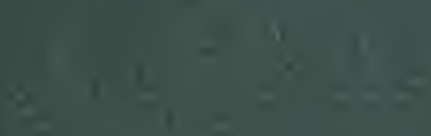

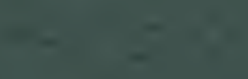

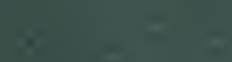

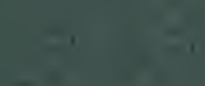

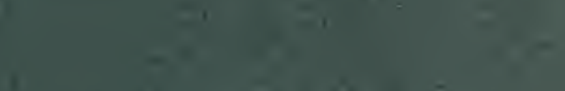

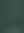

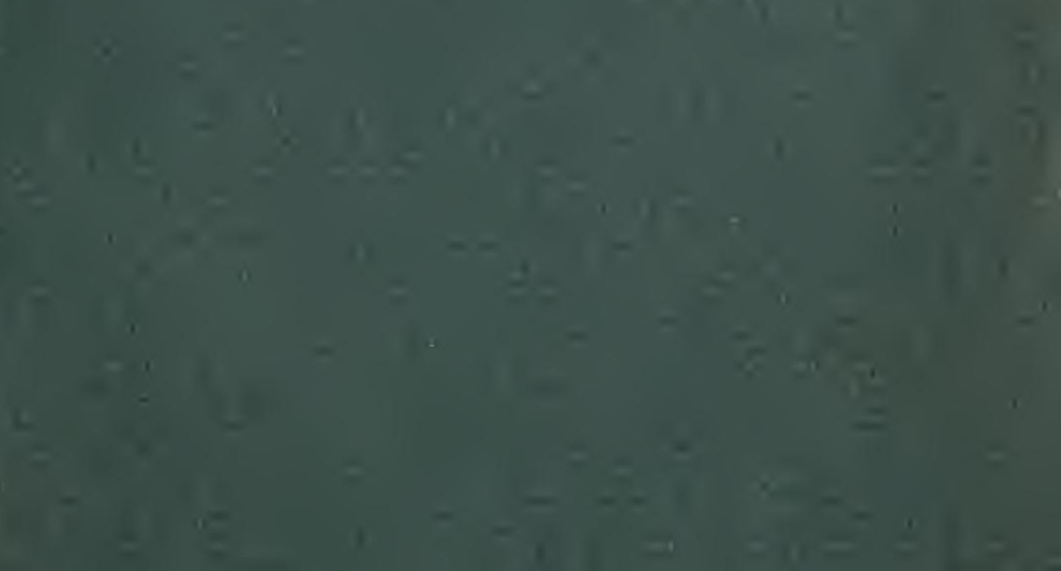





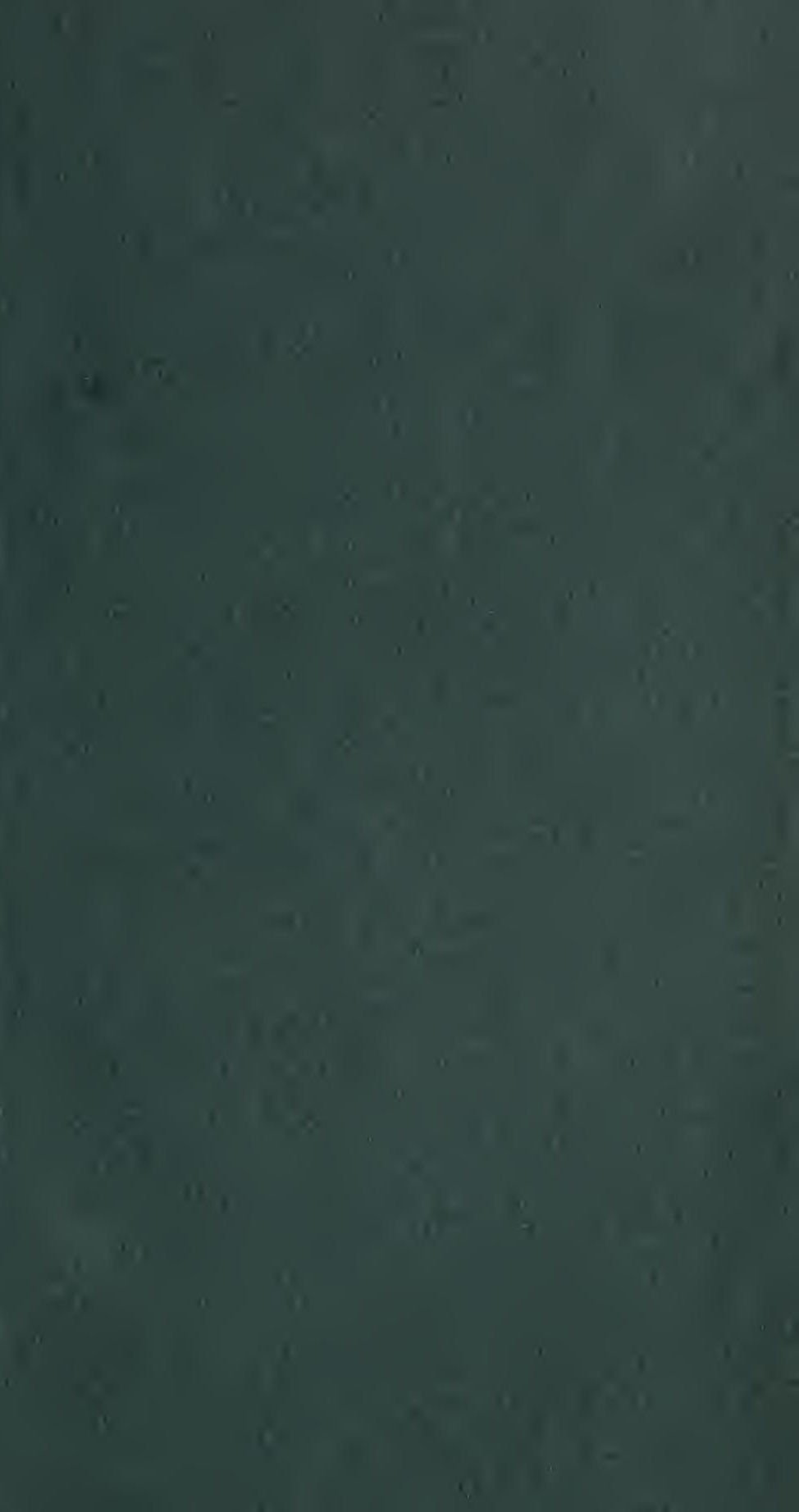





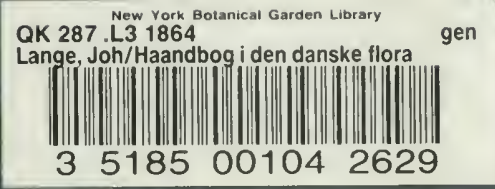


W

H.

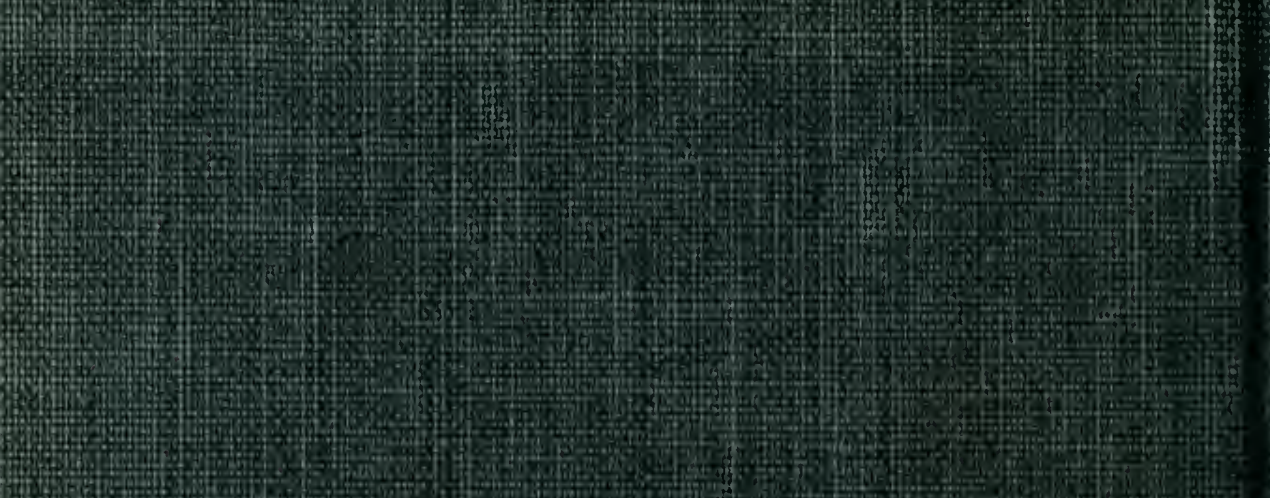

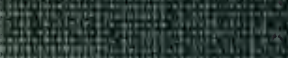

19.

(1)

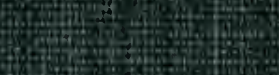

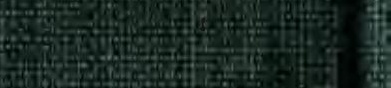
3.

3. 20. Soficin (1)

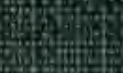

H.

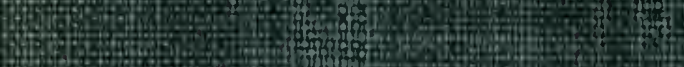

6.

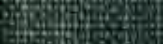

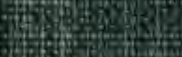

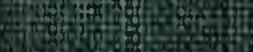

(1)

ares.

Q

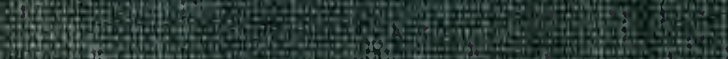

20.

4 (2)

Q7.

(3)

(2) 3.

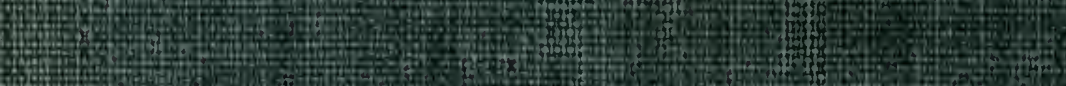
3.4. s.t. 8. 7) 3. 